






\title{
BOTANY OF CALIFORNIA.
}

\author{
VOL. I.
}



(UNIFORM WITH THE PUBLications OF THE)

GEOLOGICAL SURVEY OF CALIFORNIA.

J. D. Whitney, State Geologist.

B $\mathrm{O}$

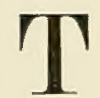

A

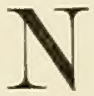

Y.

VOLUME I.

P O L Y P E T A L $A$,

By W. H. BREWER ANd SERENO WATSON.

G A M O P E T A L A,

BY ASA GRAY.

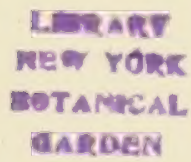

CAMBRIDGE, MASS.

WELCH, BIGELOW, \& CO, UNIVERSTTY PRESS.

1876 . 


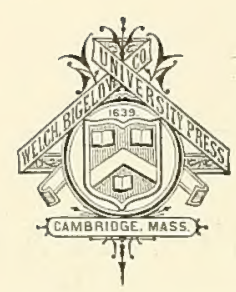


Names of the gentlemen by the aid of whose contributions the publication of this volume has been secured:-
LELAND STANFORD.
R. B. WOODWARD.
D. O. MILLS.
WILLIAM NORRIS.
LLOYD TEVIS.
JOHN O. EARL.
J. C. FLOOD.
HENRY PIERCE.
CHARLES MCLAUGHLIN.
OLIVER ELDREDGE.

S. CLINTON IIASTINGS. 



\section{LHERART \\ WEE YORK \\ INTRODUCTION.

$7 \mathrm{HE}$ Act of the Legislature, passed in 1860, authorizing a geolngical Survey of the State of California, required, among other things, a "full and scientific description of its botanical productions." In accordance with this requisition, the material necessary for such a description was assicluously collected by the Geological Corps, whenever and wherever it was possible to carry on this work in addition to the other more pressing duties of the Survey proper. During the years from 1860 to 1864, the botanical cullecting was entirely under the charge of, and mostly performed by, Prufessur W. H. Brewer. It was under his supervision that the bulk of the materiul was accumulated, the elaboration of which has formed the basis of the present volume. Professor Brewer having left California in 186t, no firther continuous and systematic collecting was attempted by the Surey. Mr. H. N. Bolander was, however, engaged for a few months in 1866 and 1867 in making a more thorough botanical cxploration of portions of the Sirrra Nevada than had before been possible; and he also male a trip through the Coast Ranges, north of the Bay of San Francisen, in which he was assisted from the funds of the Survey, then, as always, entirely inalequate to a vigorous prosecution of the work in all its branches. I)r. J. Cr. Conper. Zoulogical Assistant of the Survey, during a winter spent at Furt Mfohitre, and on the way thither and back, made important additions to the hutanical cullections. On the return of l'rofessor lirewer to the least, in 1864, arrancements were commenced for working up the collections, with a view to the publication of a Flora of California, or a systematic descrigtion of the plants growing spontaneously over that wile area of between 150,(100) and $16(1),(1) 11)$ square miles.* The total number of species thus includerl wats costinated an

- In point of fnet, in the present volume the botnny of the whole castern slope of the Sierm Nevada, and of the runges adjacent to it on the enst, from. Arizona to Northern Nevada, amb of Southern Oregon, has been fully worked up, and a considerable number of species inchulul which have not yet been found within the borders of the State of California, although many of them, in all probability, will be. 
two thousand, and it was thought that the work of determining and describing them would not occupy more than a year or two. The co-operation of distinguished specialists throughout the country was secured, and various portions of the collections placed in their hands to be worked up. It is, however, at the Herbarium of Harvard University, and under the supervision of Professor A. Gray, that most of the material has thus far been elaborated. The collections made by the Survey were there arranged by Professor Brewer, and the new species of the Polypetaloe and Gamopetalce were described by Professor Gray in various communications made to the American Academy of Arts and Sciences, and published in their Proceedings.*

In this work it was necessary that the material which had accumulated during the many years in which California had been botanically explored by various Government expeditions, both American and foreign, and by numerous private collectors, should be passed under review. It was equally necessary that the mass of literature already accumulated in relation to this Flora, and scattered through hundreds of volumes, which in many cases are "not to be obtained except with great difficulty, should be thoroughly examined. Much the largest portion of this material, both of books and plants, was accessible at the Herbarium in Cambridge; and, where the collections in this country were deficient, both Dr. Gray and Dr. Engelmann were enabled to supply deficiencies and make the necessary comparisons, during visits to Europe, and especially to the great storehouse of the world's botany at Kew. While this work of description and comparison went on, much new material was constantly coming in, chiefly through several zealous private collectors, who of course had to send their plants to Cambridge for determination. Thus it happened, that, as the amount of material to be worked over was constantly increasing, so the time required for the work was also greatly expanded. The Survey not being able to pay any one for devoting his whole time to this investigation, the year 1874 had been reached and the printing had not been begun. The Legislature of 1873-74 put an end to the work by refusing any further appropriations for the Survey, and the present volume would have remained unpublished, had it not been for the generosity of a few citizens of San Francisco, who came forward and placed in the hands of the late State Geologist a sum sufficient 
to insure the publication of one rolume of the Flora of California. The names of these gentlemen will he found on the prage following the title. As snon as possible alter this munificent act, an arramement was made with Mr. Serenn Watsun, late Butanist of the Fortieth I'alallel surery, to umble-

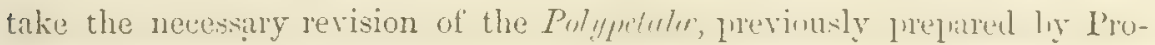
fessor Iirewer, lut which neeled still further elichoration. l'mofésur (imay, in accorlance with previous arrangement, wats realy with the finnentuler, and, to insure greater uniformity, all the ordinal chindeters of the volume have also heen written ly him. There has heen no interruption in the work since the necessary funds were raised for its contiuuance. It is not necessilly to insist on the reatsons why the greparation of this volume lias imvired a much larger amount of labor aud of time than was originally expected. Intanints will not fail to alpreciate the mannitule of the task thus umbertaken, and will recounize the great differene between a work like the present one and even the most complete of the hotanicil reports which have hitherto accompaniel or formed a part of the reports of Corremment experlitions. It only remains for me to thank those who have contrihutent to this rolume cither intellectually or pecunialyily, and to expess my sincere rencet that the Lenisliture of Conlifurnial hals just aljourned withunt laving male any frovision for the continuance of the Botany, or for bringing before the world

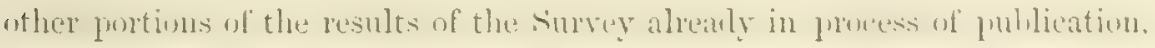
or nearly realy for it, at the time the work was suspemedel ly the Lewislature of $1873-7 \pm$.

Should the means be secured for the publication of the second rolume

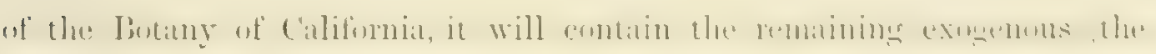

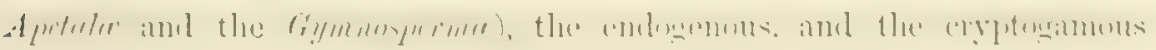
orders. It is proposed also to add an accented list of generic names with their derivations; and a chronological list of botanical collectors on the west coast of America, together with an index to the genem and species of the entire Flora, and a glossary of the botanical terms used.

J. D. WITXEY.

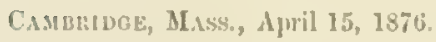




\section{$\mathrm{NOTE}$.}

THE following Keys are designed to facilitate the reference of any plant to its proper Order; and it is hoped that the one may so supplement the other that in most cases little difficulty will be found. A synopsis is likewise given of the genera under each order, and of the species in most of the larger and more difficult genera.

All the more important synonymy is eited, including references to the principal figures. The geographical range is indicated as nearly as our present knowledge permits, but the habitats of many of the rare or local species will doubtless be much extended as the State is more thoroughly explored. Additional species will also be discovered, and the descriptions of the known species here given may prove in some cases to be defective or erroneous. Information in regard to any additions or corrections is solicited for an appendix to the second volume, or for a future supplement.

It has not been possible to give here, introductory to the Flora, that preliminary botanical instruction which is necessary to its use. To supply the need, a brief Introduction to Systematic Botany will probably be included in the volume which is to follow, and reference may be made meanwhile to the ordinary text-books upon the subject, such as Gray's "Lessons in Botany." 


\section{ANALITICAL ARTIFICIAL KEY TO THE ORDERS AND ANOMLLOUS GENERA IN THIS VOLUME.}

Divisio: I. POLYTETALE : calyx and corolla both present; the latter of separate petals.

A. Stamens numerous, at least more than 10 and more than double the number of the petals,

1. Hypogynons, i. e. on the receptacle free from the ovary and calyx.

Pistils few to nany distinct carpels, or rarely only one.

Calyx mostly deciduous : juice of herbage colorless.

Calyx early deciluons : juice yellowish.

Calyx persistent : leaves peltate.

Pistil a single simple carpel, forming a pock.

P'istil compound: cells, placentae, or stigmas more than one.

I'ctals more numerous than the sepals,

Indefinitely numerous, small, and persistent: aquatic.

Just twice as many ( $\$$ or 6 ), and both usually caducous.

Five to 16 and more numerous than the persistent sepals.

Rasuscelaces, 1.
Platystemon in PAPAVERACE, 5.

NYMPILACEX, 3. Acacia in Legumisoses, 31.

Petals of the same number as the sepals,

Four, and both decidnous.

Four or less, but cleft, and calyx persistent.

Five, and the calyx persistent.

Sepals valvate in the bud: stamens monadelphous.

Sepals imbricated in the bud.

Leaves opposite, entire, pellucid-punctate.

Leaves alternate, not pellucid-punctate, plane.

Corolla ephemeral : two outer sepals small and bret-like. CISTACEx, 10.

Corolla gamopetalous, tubular: sepals round. Fouquiera in TAMAliscrive. 17.

Leaves all radical, hollow pitchors.

NrMphiace.5, 3.

PAPAVERACE, 5.

Portulacaces, 16.

Cappatidoaces, 8 .

RESEDACEA, 9.

Milivace.e, 20.

HYPERICACEE, 19.

2. Perigynous or epigynous, borne on the (either free or adnate) calyx.

Leafless mostly prickly fleshy plants: ovary 1-celled.

Leufy fleshy plants, with 3 or more cells to the ovary.

Leafy Heshy herbs, witl 1-celled ovary.

Not Hesliy.

Leaves opposite, simple: sepals and petals numerous.

Leaves oprosite, simple: sepuls and petals 4 or 5.

Leaves alteriate, with stipules.

Leaves alternate, without stipules.

(arpels 2 or more, superior, becoming follicles.

Ovary inferior, with 3 or more purietal placentre.

Fluwers manly direcious : petals minte or nono.

Flowers perfect : petals conspicuous : leaves rough.

Cactackis, 43.

FicoInEe, 44.

Portulacice.e, 16.

Calfeastucken, 33.

Saitfracictie, 34.

ROSACE. 32.

Crossosoma in RAsticulacter, 1.

DATISCACF, 42.

I.ASACEN, 40.

B. Stamens 10 or less, or if more not exceeding twice the number of the petals, or sepals when the petals are wanting.

1. Ovary or ovaries superior or mainly so (but sometimes enclosed in the calyx-tubo).

* Pistils more than one nul clistinct.

Pistils of just the same number as petals and as sepuls.

Leaves simple, fleshy.

Leuves pinuate, (Siyles partly unitul.)

CrasertancFin, 35.

Pistils not correspomiling in number with pretals or sepals.

Stanusis borne on the receptacle.

Nitumens lorne out the anlyx.

stipules persistent : leaves altermate.

stipules cadueous: leaves opposite, complouml,

sitipules none or indistinet. 
* * Pistil only one,

* Simple, i. e. of one carpel, as shown by the single style, stigma, and cell (the latter sometimes with a false division in Astragalus).

Anthers opening by uplifted valves or transversely.

Bereeridace 2.

Anthers opening lengthwise or at the top.

Flowers irregular, or leaves twice pinnate : fruit a legume. Legumos 31.

Flowers irregular: leaves simple.

POLYGalaceE, 12.

Flowers regular.

Leaves opposite, punctate.

Leaves alternate, not punctate, mostly stipulate.

Fruit a drupe or akene.

Fruit a coriaceous follicle.

Cneoridium in Rutaces, 25.

ROSACEE, 32 .

Glossopetalon in SAPINDACE 29.

+ + Pistil compound, as shown by the number of cells or placentie, styles or stigmas.

Ovary 1-celled, with (2 to 4 or rarely more) parietal placentæ.

Petals (long-clawed) and teeth of long-tubular calyx 4 or 5 .

Petals and sepals or lobes of the cleft calyx 5 .

Corolla irregular; lower petal spurred.

Corolla regular or nearly so.

Styles or sessile stigmas entire.

Styles 3, each 2-parted: placentæ 3.

Petals 2 , but persistent sepals 4 : flower irregular.

Petals 4, but hract-like sepals 2 : flower irregular.

Petals 4 or 6 : sepals half as many, caducous.

Petals and sepals each 4 : stamens 6.

Frankentacex, 13.

VIOT,ACE $E, 11$.

SAXifragace, 34.

Droserace

RESEDACE.E, 9.

FUMARIACE $6,6$.

PAPaVerace. 5 . 5.

Capparidacer, 8.

Ovary and pod 2-celled : 2 placentie parietal: stamens tetradynamous. CrUCIFEr., 7.

Ovary and capsule 1-celled, several - many-seeded on a central placenta,

Truly so, the partitions wanting or very incomplete.

Sepals 2 : leaves often alternate.

Sepals or calyx-lobes 5 or sometimes 4 : leaves all opposite.

Here may be sought the apetalous

Apparently so; the partitions at length vanishing.

Stipules between the opposite leaves.

No stipules.

Ovary and fruit 1-celled with a single seed on a stalk from the base.

Shrubs: styles or stigmas 3 : fruit drupe-like.

Herbs : fruit a utricle.

Style at most 2-cleft: stipules scarious.

Styles 5 : calyx scarious.

Ovary more than 1-celled : seeds attached to the axis, or base, or summit.

Flowers very irregular: ovary 2-celled : cells 1-seeded.

Flowers regular or nearly so.

No green foliage.

Folinge pellucid-punctate : strong-scented shrubs.

Monotroper, \&c., in ERTCACEe, 54.
RUTACEe, 25.

Foliage not pellucid-punctate.

Anthers opening by terminal pores or chinks at the end.

Anthers opening lengthwise.

Stamens as many as the petals and opposite them, i. e. alternate with the calyx-lobes,

These valvate in the bud.

These small or obsolete: petals valvate.

Stamens when just as many as petals alternate with them.

Strong-scented shrnb: leaves opposite, 2 -foliolate.

Strong-scented herbs: leaves lobed or compound.

Herbs, not strong-scented.

Ovules 1 to 4 in each cell.

Leaves all simple and entire.

Leaves all opposite, compound, and leaflets entire.

Leaves alternate or opposite, the latter with divisions ог leaflets not entire.

Portulacaceer, 16.

Caryophyllacex, 14. Glaux in Primulacee, 57.

Elatinacee, 18.

LYTHRACE, 37.

Anacardiacee, 30.

ILLECEBRACE $2,15$.

Plumbaginace $5,56$.

Polygalace 12.

ERICACE正, 54 .

Orules numerons,

Stameus on the calyx : style 1.

Stamens on the calyx : styles 2 or 3 .

Stamens on the receptacle : leaves opposite, simple.

Cells of the ovary as niany as the sepals, 2 or 5 .

Rhamiceie, 27.

Vitacex, 28.

ZYGOPHYLIACE. 23.

Geraniaceie, 24.

LINACEE, 22.

ZYGOPHYLIACE E, 23.

Geraniace $\mathbb{E}, 24$.

LXTHRACEE, 37.

SAXifragacee, 34.

Cells fewer than the sepuls, 3 .

Molligo in FrCOIDEE, 44 .

Elatinace.e, 18 
Shrubs or trees with opposite simple leaves,

Pinnately veined, not lobed.

Palmately veined, lobed.

Shrubs or trees with alternate lobed lenves.

Shrubs or trees with opposite cornjound leaves.

Stamens 4 to 8.

Stamens 2 or rarely 3 .

2. Ovary and fruit inferior or mainly so.

Tendril-bearing herbs : flowers monoecious or dioecious.

A yuatic herbs: flowers dioecious or monardrous.

Shrubs or herbs, not tendril-bearing nor dicecious, nor umbelliferous.

Stamens as many as the small or unguiculate petals and opposite them : calyx valvate.

Stamens if of the number of the petals alternate with them.

Styles 2 to 5 , distinct or united below.

Fruit a few-seeded pome.

Celastrace $\varepsilon_{2}, 26$

SAIISDACEA, 29.

Steiculiace.e, 21

SAYINDACE $E, 29$.

OLEACE.E, 59.

Fruit a may-sceded (or rarely 3-5-celled 3-5-seeded) capsule. SAXIFRAGACE $\boldsymbol{A}_{3} 34$ Fruit a 1-celled many-seeded berry.

Style 1, undivided : stigmas 1 to 4 .

Flowers in cymes or a glomerate cluster.

Flowers racemose, spicate, or axillary.

Ovary 1-celled: herbage scabrous.

Ovary 2-5-, mostly 4-celled.

Herbs: flowers in unbels: styles 2 : fruit dry.

Herbs or shrubs: flowers in umbels: styles 4 or 5 : fruit berry-like.

RIIANACEE, 27.

ROSACEE, 32.

Ribes in SAXIFIAGACE., 34

CoIsacex, 47.

LOASACE $x, 40$.

ONAGRACER, 39

UMBELLYFER $x, 45$.

Araliace $x, 46$.

DIVISION II. GAMOPETALE : petals more or less united into one piece.

A. Ovary inferior, or at least largely so.

Stamens more numerous than the lobes of the corolla, 8 or 10 ,

Distinct and free from it, or mearly so.

Monadelphous on its tube.

Stamens as many as the lobes of the corolla (5 rarely 4), syngenesious.

Flowers in an involucrate head.

Flowers separate, racemose or spicate.

Stamens as many as the corolla-lobes, or at least 4, distinct,

Nearly or quite free from corolla : leaves altermate: no stipules. Stamens distinct.

Stamens more or less united.

Inserted on the corolla : leaves opposite or whorled,

With stipules, or else in whorls, quite entire.

Without stipules, opposite.

Stamens only 3, fewer tlan the lobes of the corolla.

Leaves opposite: stamens distinct.

Leaves alternato: stamens often united.

ERICACF. 54.

STYRACACE 5 , 58.

Composite, 51.

LOBELIACE. 52

Campanthaces, 53.

Nemacladus in Loblisces, 52.

RuBICE. 49 .

Capirifoliace.e, 48.

VALTRIANACF, 50

Cucuibitacese, 41.

B. Ovary superior (free), or mainly so.

1. Stamens more numerous than the lobes of the corolla.

Pistil single and simple: leaves compound.

Pistils several and simple: leaves simple, fleshy.

Pistil compound, with 3 styles.

LEGUMTNOSE, 31.

Crassulack.

Pistil compound, with one undivided style.

Ovary 3-10-colled : stamens distinct.

Ovary partly or at length 1-colled: stamens monadelphous.

Fouquiern in TAMARISCIXE. 17.

2. Stamens as many as the divisions of the corolla and opposite them.

Styles 5: ovary and fruit 1-ovuled, 1-seeded.

Stylo 1: ovary and capsule several-many-seeded.

Ericucfofi, 54.

STYRACACFE, 58.

PIIMBACIXACFef, 56.

P'IRIMULACF. 57.

3. Stamens as many as the lobes of the corolla and altemate with them, or fewer.

- No green herbage.

Corolla rogular : stamens froo : seeds very many and minuta.

Corolla regular: stamens in its throat: fruit $10-20$-colled.

Mosotrop: 1, :if.

LFNsOACE. 65.

Corolla iregular : atamens didynnunous: 
* * With ordinary green herbage.

* Corolla regular or nearly so : stamens not didynamous.

Corolla scarious and veinless : stemless herbs.

Plantagixacem, 75.

Corolla more or less veiny.

Stamens 2 or 3 , but parts of corolla 4 or 5 .

Stamens 5, sometimes 4 , as many as the corolla-lobes.

Pollen in solid waxy masses : fruit a pair of follicles.

Pollen in powdery grains.

Ovaries 2 : fruit a pair of follicles.

Ovary 4 -lobed, forming 4 separate or separable seed-like nutlets.

Orary single and entire.

Style 3-cleft at apex : capsule 3-celled : corolla convolute.

Styles or stigmas 2 or 1 .

Ovules and seeds at most 4, large, with large embryo and little or no albumen : peduncles axillary.

Ovules few or numerous : embryo small, in albumen.

Leaves all opposite or whorled and entire: capsule

1-celled: corolla convolute in the bud.

OLEACEF, 59.

ASCLEPIADACEE, 61 .

Apocynace.e, 60 .

BorRaginaCEe, 65.

Polemoniacez; 63.

Convolvulaces, 66 .

Leaves alternate, 3 -foliolate : leaflets entire : corolla in-

duplicate : flowers racemose. Menyanthes in Gentianace $2,62$.

Leaves various, mainly alternate.

Styles 2, or 1 and 2-cleft (except in Romanzoffia) : capsule 1 - 2-celled.

Style only 1 : stigma usually 1 : capsule or berry 2-celled, or rarely more, many-seeded.

See also Verbascum \& Limosella in

HYdROPHYLAACE, 64.

SOLANACEx, 67 .

SCrophulariace $\boldsymbol{x}, 68$.

+ * Corolla irregular : stamens (with anthers) only 4 and didynamous, or 2 : style 1 .

Ovary and capsule 2-celled, few-nany-secded.

Seeds small, mostly indefinite : embryo small in copious albumen. Scrophulariaces, 68.

Seeds larger in proportion, filled by the flat embryo.

Numerous in a long capsule, winged, on a partition which separates from the valves.

Few, on hooked processes of the placenta.

Ovary and capsule 1-celled, with many-seeded placentre in the axis. "

Ovary 4-parted, in fruit as many seed-like nutlets.

Ovary undivided: fruit splitting into 2 or 4 one-seeded nutlets (or

berry-like with as many stones).

BigroNiacex, 71.

ACANTHACEE, 72.

LENTIBULARIER, 70.

LABIATEE, 73.

VERBENACEX, 74.

\section{Apetalods Forms in Polypetalous and Gamopetalous Orders.}

Carpels several or numerous and distinet: stamens hypogynous. Raxunculacre, 1. Carpels single and simple: calyx. also wanting.

Carpels 1 or 2, rarely 3 , distinct and free: stamens on the calyx. Rosaces, 32.

Carpel single and simple: stamen eprigynous. Hippuris in HaLoragex, 38.

Carpels combined into a compound ovary, which is

One-celled and $1-2$-ovuled.

Herbs with scarious stipules.

Shrubs without stipules.

Two-four-celled, with one or at most two ovules in each cell.

Aquatic herbs.

Terrestrial herbs, 2-seeded.

Shrubs or trees,

With alternate simple leaves and fleshy fruit.

With opposite compound or lobed leaves, and

Single 1-celled 1-seeded samara for fruit.

A pair of samaras.

One-celled and many-ovuled : herbs.

Placentre 3, parietal : ovary inferior.

Placentæ 2, parietal : ovary partiy superior.

Placenta I, central or basal : leaves mostly opposite.

Style and stigna one.

Styles or at least stigmas 3, or rarely more.

Two-five-celled and many-ovuled.

Herbs, with free calyx and green herbage.

Herbs, with adrate calyx and green herbage.

Herbs destitute of green herbage.

Shrub, with alternate lobed leaves.
ILLICEBRACE 15.

Pistacia in ANACARDIACE, 30.
Lepidium in CRUCIFERE, 7 .

RHAMNACE 27.

Fraxinus in OLFACE 2 , 59.

Acer \& Negundo in SaPindace 29.

DATISCACEE, 42.

Saxifiagace $2,34$.

Glaux in Primulace 5 , 57.

Caryophyllaceie, 14.

Frcordex, 44.

Lndwigia in ONAGRACE $\boldsymbol{N}_{3} 39$

Allotropa in ErICACEd, 54.

Sterculiace 21. 


\section{SYNOPTICAL KEY TO THE ORDERS, \&C.}

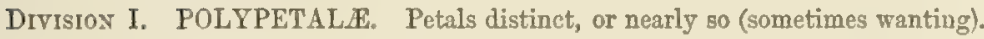

A. Stamens hypogynous (free both from the calyx and from the superior ovary).

* Carpels solitary or distinct.

* Sepals and petals deciduous (rarely persistent in No. 1). Leaves alternate (opposite in climbers), or radical : stipules none.

1. Ranunculaceæ, p. 2. Sepals ( 4 or more), petals (as many and alternate with them, when present), stamens (usually numerous), and earpels ( 1 to many) all distinct and free. Fruit akenes or follicles (in Actoca a solitary berry). Mostly herbs.

2. Berberidacez, p. 14. Parts of the flower in threes, in opposite ranks, distinct (sepals and petals wanting in Achlys, and stamens 9). Carpel solitary (a berty in Berberis). Anthers opening by valves. Perennial herbs or shrubs, with compound leaves.

Carpels several, soon distinct, becoming linear torulose several-seeded pods. Sepals 3 : petals 6 : stanens many. Annual ; leaves entire, mostly opposite. Platystemos in Paparcracca.

Carpel solitary, becoming a spinose pubescent 1 -seeded nut. Flowers irregnlar": sepals and petals, 5 : stamens 4. Pubescent shrubs, with simple leaves. KRAMeris in Polygalacea.

$$
\text { + + Sepals persistent; petals deciduous. }
$$

Carpel solitary, becoming a globose drupe. Flowers 4-merous. Smooth shrub, with opposite entire pungent leaves. CNeornIus in Rulacce.

Carpel solitary, becoming a few-to many-speded 2 -valved or indehiscent pod. Flowers 5-merous : stameas 10 or many. Small trees, with bipinnate leaves and small flowers in. spikes or heads. MrMose. in Leguninosec.

Follicles several. Fleshy plants, with stamens nearly hypogynous. Crassticaces.

Follicles 2. Anthers attached to the stigma. Herbs; leaves opposite, entire. AschepIADAcEs. $\div+\div$ Sepals and petals persistent.

Carpels becoming indehiscent 1 -2-seeded pods. Sepals and petals 3 or 4 : stamens many. Per. ennial aquatic, with peltate leaves. Brasesia in Nymphacacca.

* Ovary compound, with parietal placente or seeds covering the cell-walls. + Capsule many-celled, indehiscent. Sepals and patals persistent.

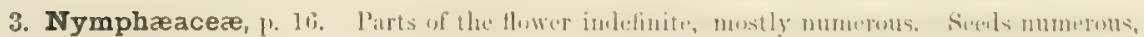
covering the walls of the cells. Perennial aquatic, with cordate entire leaves and solitary flowers.

+ + Valves separating from the persistent placentre. Sepals (2 or 4) and petals deciduous. ++ Sceds albuminous.

5. Papaveracea, p. 18. Sepals 2 or 3 , caducous : petals twice as many, alike : stamens numerous. Capsule 2 - several-valved, 1-celled (several-celled in Romneya). Herbs (very ravely shrubby), with mostly alternate leuves, no stipules, and often colored juice.

6. Fumariacea, p. 23. Flowerg very irregular: sepuls 2 , small : petals 4 , in dissimilar pairs : stamuns 6, diadelphous. Poul-eelled, 2-valved, several-many-seeded. Perennial herbs, with alternate dissected leaves and no stipules.

$$
\text { t+ ++ Seeds without albumen. Flowers regular. }
$$

7. Cruciferæ, p. 25. Sepals and petals 4 : stamens 6 , tetmdynmmous (mrely 4,2 , or none). Pod 2-celled, 2-valved, 2-nany-seeded (rarely 1-celled and indehiscent). Herbs, with alternate lenves and no stipules.

8. Capparidacee, p. 49. Sepals end petals 4 : stamens 6 or moro, nearly equal. Porl 2.valved, 1 - 2-celled, 1-several-seedul. Mostly anuum! horbs (Isomeris shrubby), with alteruate compound leaves, often stipulite. 
+++ Capsule 1 celled, several-carpelled, the valves not separating from the placente. Calyx persistent.

* Flowers irregular.

9. Resedaceæ, p. 53. Sepals 4 : petals 2 or 4, cleft or entire: stamens few to many. Capsule 3-6-beaked, many-seeded. Herbs; leaves alternate, entire ; stipules glandular.

11. Violacea, p. 54. Sepals and petals 5: anthers 5, coherent: style 1, clavate. Capsule 3-valved, many-seeded. Low herbs, with alternate or radical stipulate leaves.

$$
+++ \text { Flowers regular. Stipules none. }
$$

10. Cistaceæ, p. 54. Sepals and petals 5, two of the sepals minute : stamens many : style 1. Capsule 3-valved, few-many-seeded. Herbs or woody at base; leaves entire, alternate.

36. Droseraceæ, p. 212. Flowers 5-merous, but styles 3, 2-parted. Capsule 3-valved, manyseeded. Low marsh herbs ; leaves radical, reddish, entire, beset with gland-tipped hairs.

13. Frankeniaceæ, p. 60. Stamens 4 to 7 : style 2-4-sleft. Capsule 2-4-valved, enclosed in the tubular furrowed 4-5-lobed calyx. Low woody-based herbs, with opposite entire leaves and small flowers.

Flowers 5-merous: stamens indefinite: styles 3. Capsule 3-valved. Low herbs, with opposite entire punctate leaves. Hypelicum in Hypericacece.

Flowers 4-merous : petals united at base, bearing a broad gland. Capsule 2-valved, few-manyseeded. Smooth biennials, with opposite or whorled leaves. Frasera in Gentianacea.

*** Ovary compound (of 2 to several carpels), with central placentæ. Stamens mostly strictly hypogymous. Sepals persistent.

+ Flowers very irregular.

12. Polygalaceæ, p. 58. Capsule compressed, narrowly winged, 2-celled, 2-seeded. Stamens 6 to 8 , united; anthers 1-celled, opening at the top. Low woody-based perennials, with alternate entire leaves, and no stipules.

* Flowers regular. Capsule 1-celled, with free central placenta. Leaves entire.

++ Embryo eurved around central albumen.

14. Caryophyllaceæ, p. 61. Flowers mostly 5-merous: petals sometimes none : stamens 10 or fewer: styles 3 to 5 , the capsule opening by as many or twice as many valves. Seeds numerous. Herbs, rarely woody at base, with opposite leaves, and mostly no stipules.

15. Illecebraceæ, p. 71. Fruit a 1-seeded utricle included in the calyx. Petals none: stamens perigynous : style bifid. Low herbs, with opposite leaves, scarious stipules, and sessile axillary flowers.

16. Portulacacæ, p. 73. Capsule 2-3-valved or circumscissile. Sepals 2 (4 to 8 in Levisia): petals 2 to 5 or more: stamens few or many: style 2-3-cleft. Seeds few or many. Succulent herbs, with opposite or alternate or radical leaves, often stipulate.

+* + Embryo straight in albumen. Petals united at base : stamens opposite them.

Utricle 1-seeded, enclosed in the scarious calys. Flowers 5-merous. Perennial acaulescent maritime herbs. Plumbáginace. .

Capsule 5-valved, few-many-seeded. Flowers mostly 5-merous : style 1. Herbs with mostly opposite leaves, or acaulescent. Some Primulace.

+++ Flowers regular. Ovary 2 - several-celled.

* Capsule not lobed nor winged.

(a.) Stamens distinct or nearly so, not fascicled.

4. Sarraceniaceæ, p. 17. Capsule 5-celled, 5-valved, many-seeded. Sepals and petals 5, persistent : stamens many : style 5-lobed. Acaulescent marsh perennials, witl pitchershaped leaves and solitary flowers.

18. Flatinaceæ p. 79. Capsule 2-5-celled, many-seeded. Flowers 2- or 5-merous: styles distinct. Low annuals, with opposite leaves, membranous stipules, and axillary flowers.

22. Linaceæ, p. 88. Capsule 2-5-valved, 4-10-celled and -seeded. Flowers 5-merous : styles 2 to 5. Low herbs, with entire opposite or alternate leaves, often with stipular glands, and panicled flowers.

Capsule 3-celled, several-seeded. Flowers 5-merous: petals none: styles 3. Prostrate annual, with entire verticillate leaves and axillary flowers. MoLLdGo in Ficoidcce.

Capsule 5-celled, several seeded. Low herbs, with sour juice and alternate or radical 3-foliolate leaves. Oxalis in Geraniacere.

Capsule 5-10-celled, many-seeded. Stamens 10, rarely fewer; anther-cells opening by a terminal pore or chink. Sealy-bracted herbs without green foliage (or Ledum an evergreen shrub, with alternate exstipulate leaves)。 Some ERICACE巴. 
Capsule woody, 5-celled, 5-seeded. Flowers 5-merous. Seeds minged. A leafless spinose shrub. Canotra in Rosacea.

Ovary 3-celled: fruit it larese leathery 3-valrul 1 -seeded poul. Trees, with opposite dicitate serrate leaves, no stipules, and showy panicled irregular flowers. Esculus in Sapindacca.

(b.) Stamens clustered in fascicles or united into a tube.

19. Eypericaceæ, p. So. Stamens numerous in 3 sets. Capsule 3-cellel, many-seeded. Sepals and petals 5 : styles 3 . Perennial herbs, with opposite entire punctate leaves, no stipules, and yellow cymose flowers.

20. Malvacea, p. 81. Stamens numerous, united into a tube : anthers 1-celled. Carpels either in a ring, 1 -few-seeded and at length separating, or forming a 5 - 10-celled many-seeded capsule. Calyx ralvate : petals 5, united at base. Herbs or shrubs, with alternate stipulate leaves.

21. Sterculiacea, p. 87. Stamens 5, united into a tube : anthers 2-celled. Capsule 4-5-celled, few-seeded. Flowers 5-nerous: calyx imbricate : petals none. Shrub, with alternate leaves, and showy flowers.

t+ Fruit lobed or winged. Seeds 1 or 2 in the cells, pendulous : albumen little or none.

23. Zygophyllacez, p. 91. Capsule 5-10-lobed, -celled, and-seeded. Flowers 5-merous : stamens 10: style 1 , short : sepals mostly deciduous. Herbs or shrubs, with opposite stipulate compound leaves (leaflets entire), and solitary fiowers.

24. Geraniacea, p. 92 . Capsule 5-parted, -celled, and-seeded. Flowers 5-merous : stamens mostly 10 : styles coherent to an axis, at length separating from it. Herbs, with lobed

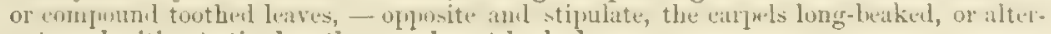
nate and without stipules, the carpels not beaked.

25. Rutacea, p. 96. Fruit 2-celled, an orbicular samara or didymous capsule. Flowers 4 -merous: style 1. Shrubs, with aromatic dotted alternate leaves, and no stipules.

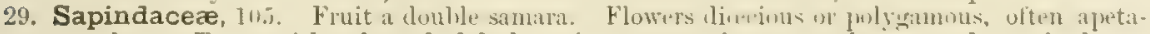
lous. Trees, with palmately lobed or pinnate opposite serrate leaves, and no stipules.

Fruit a simple samara, usually 1 -celled and 1 -seeded. Flowers 4 -merous, perfect or diocious: petals often none: stamens often $2:$ style 1. Trees, with opposite pinnate leaves, and no stipules. Fraxivus in Oleacea.

* * Orary compound, with central placente. Stamens upon a more or less perigynous disk. Flowers mostly polygamous or diocious. Calyx persistent or the limb deciduous. Cells 1 - few-seeded. Seeds mostly erect or ascending and albuminous.

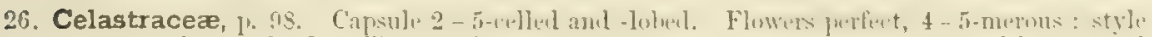
very short. Seeds arillate. Shrubs, with simple opposite pinnately veined leaves, and no stipules.

27. Rhamnacea, p. 99. Fruit berry- or drupe-like, or dry, 1-4-celled. Calyx ralvate, the 1 or 5 lobes alternate with as many stamens, deciduous: petals often none: style $2-4$. cleft or lobed. Shrubs, with simple alternate or opposite leaves, and small stipules.

28. Vitacea, p. 105. Fruit a 2 -celled $2-4$-seeded beny. Flowers $4-5$-merons : calyx mi. nute: petals valvate: the stamens opposite them. Wooly vines, climbing by tendrils: leaves alternate, lobed.

30. Anacardiacea, p. 109. Drupes 1-celled, 1-seeded. Flowers mostly 5-merous : stigmas 8. Shrubs, with milky resinous juice, alternate simple or compound leaves, and no stipules. Albumen little or none.

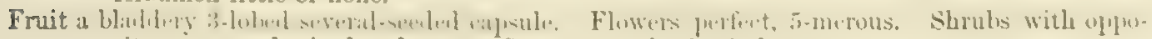
site compound stipulate leaves. STAPIYLEA in Sapinalncca.

B. Stamens perigynous (upon the calyx), or epigynous.

- Orary superior or nearly so. (See last group.)

+ Carpels solitary or distinet. Seed very marely albuminons.

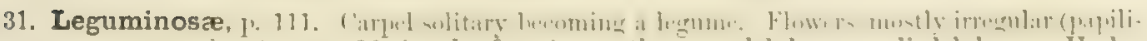
onmeres): stamens 10 (mrely fewer), mostly monulelphous or dimlelphous. Herbs, shrubs, or trees, with alurrante stipulate simple or compound leaves.

32. Rosacee, p. 164. (arpels one to muny, becoming akenes or sometimes 1 - 2-sumlexl drupms (or coherent with the ealyx into a 2 -several-(eelled pone). Flowers regular, mustly 5-merous, or the stumens usually numerous. Herbs, shrubs, or trees, with alterinati mostly stipulnte simple or compound lenves.

33. Calycanthacea, p. 190 . Carpels numerous, beroming akenus within a hollow reveptacle Si'puls, petals, and stamens indefinite. Aromatic slurubs, with opposite entine leaves, and no stipules. 
Carpels 2 to 5 , becoming many-seeded follicles. Seed albuminous. Sepals and petals 5 , persistent: stamens many. Smooth shrubs, with alternate entire leaves, and no stipules. Crossosoma in Ranunculaceo.

Flowers 5-merous: carpels fewer than 5. Low acaulescent herbs. SAxirRAGA in Saxifragaceo. Flowers 3-7-merous. Thick fleshy herbs, with simple alternate leaves. Some Crassulace..

Carpel solitary, becoming an ovoid 1-2-seeded follicle. Flowers 4-merous. Low spinescent shrubs, with alternate entire stipulate leaves. GLossopetalon in Sapindacere.

\pm+ Carpels more or less united. Seeds mostly albuminous. Leaves simple : stipules none.

34. Sazifragaceæ, p. 192. Carpels 2 to 5, forming a 1-celled or 2-5-celled many-seeded capsule, or nearly distinct. Flowers 5-merous: stamens rarely numerous: styles 2 to 5 , usually distinct. Herbs or shrubs; leaves alternate (opposite in Hydrangece) or radical.

35. Crassulaceæ, p. 208. Carpels 3 to 5, becoming 1 -many-seeded follicles, distinct or connate at base. Flowers 3 - or 5-merous: stamens nearly hypogynous. Thick fleshy plants, mostly herbs, with altermate or opposite leaves.

37. Iythraceæ, p. 213. Capsule 2-4-celled, many-seeded, enclosed in the tubular or campanulate calyx. Flowers 4- or 6-merous: style 1. Herbs, with entire mostly opposite leaves, and axillary flowers. No albumen.

Fruit a 1-2-seeded utricle, included in the calyx. Style 2-cleft. Low herbs, with opposite entire leaves. ILLECEBRACEE.

Carpels 2, with distinct styles, enclosed in the at length fleshy calyx and becoming berry-like. Small tree, with alternate serrate evergreen leaves and minute stipules. HETEnomeles in Fosacer.

Capsule 3-5-celled, many-seeded, cireunascissile. Flowers 5-merous : petals none : styles 3 to 5. Fleshy herbs, with opposite entire leaves. Sesurium in Ficoidece.

Capsule 2-celled, several-seeded, adnate at base to the calyx. Flowers irregular : petals, as well as filaments, somewhat united. Slender annual, with alternate leaves and milky juice. NeMracianus in Lobeliacere.

Fruit fleshy, becoming dry, 3-valved, 1-celled and 1-seeded. Petals about 5, united at base : stamens 10, monadelphous : style 1. Shrub, with alternate entire leaves. STrracaces..

$$
\text { * * Ovary wholly inferior. }
$$

+ Fruit with central placentæ. Herbs, with few stamens, not trailing, and flowers not in umbels : stipules none.

38. Halorageæ, p. 214. Fruit jodehiscent and nut-like, 1-4-celled and -seeded. Seeds suspended, albumanous. Aquatic herbs, with verticillate or opposite leaves, and inconspicuous often apetalous sessile axillary flowers.

39. Onagraceæ, p. 216. Capsule 2- or 4-celled, sometimes indehiscent, mostly many-seeded. Flowers 2-4-merous : style 1 : calyx valvate. Herbs, rarely woody at base, with mostly alternate leaves; flowers often showy. No albumen.

Capsule 1-celled, 1-seeded. Flowers 5-merous: style 1. Seed suspended, exalbuminous. Perennial herbs, with simple alternate tenaciously scabrous leaves. PETALonrx in Loasacer.

* + Fruit fleshy, indehiscent. Tendril-bearing herbs. Stamens few.

41. Cucurbitaceæ, p. 238. Flowers monoecious or dicecious, often gamopetalous. Fruit 1 several-celled. Leaves alternate, palmately veined or lobed, without stipules. Seeds without albumen.

+ + + Fruit with parietal placentx, several-many-seeded. Stamens many (except in $R$ ibes). Stipules none.

+ Herbs, not fleshy. Capsule 1-celled.

40. Loasaceæ, p. 235. Flowers perfect, conspicuous : style 3-5-cleft: placentre as many. Leaves rough with tenacious hairs, simple.

42. Datiscacea, p. 242. Flowers mostly diceious : petals minute or none : styles 3. Leaves smooth, pinnately compound.

Fruit a berry. Flowers $4-5$-merous: styles 2 to 4 , more or less united. Shrubs, often spiny, with simple altemate palmately veined and lobed leaves. Grossulacess in Saxifragacea.

$$
\text { \# ++ Thick fleshy plants. Capsule } 1 \text {-several-celled. }
$$

43. Cactacea, p. 24. Fruit fleshy, 1-celled. Sepals and petals numerous. Leafless prickly perennials, sometimes woody.

44. Ficoidea, p. 250. Capsule 3-5-celled. Sepals few, mostly 5. Unarmed herbs, with mostly opposite leaves. 
++++ Fruit indehiscent, dry or berry- or drupe-like, 2-(rarely $3-5$-) celled, the cells with one suspended seed. Ovary with an epigynous disk (wanting in G'arryra).

*+ Flowers in umbels. Herbs, mostly with aiternate and componnd lenves.

45. Umbelliferæ, p. 252. Carpels and styles 2 : fruit dry. Umbels mostly compound.

46. Araliaceæ, p. 273. Carpels and styles 4 or 5 , forming a berry-like fruit. Umbels panicled.

++ Flowers in cymes or aments. Shrubs (rarely herbaceous) with opposite entire leaves.

47. Cornacez, p. 274. Drupes baccate, 1-2-celled. Flowers perfect and cymose, or dicecious and in aments, 4-5-merous : petals valvate, distinct: style 1.

Baccate drupes containing 1 to 5 seed-like nutlets. Flowers perfect, cymose, 5-merous : petals imbricate, united. Shrubs with simple or pinnate leaves. SAMBuces in Caprifolincere.

Fruit a benry or drupe, containing 2 to 5 thin 1 -2-celled carpels or nutlets: ovaries 2 in each carpel, ascending. Flowers 5-merous: stamens 10 or 20 : petals imbricate, distinct. Shrubs or trees, with simple alternate stipulate leaves. Posicese in Rosacea.

Drvisiox II. Gajopetal.t. Petals unitul ahove their base (very rarely wanting). Calgx generally persistent (sometimes minute).

\section{A. Orary inferior.}

* Filaments and anthers distinct. Leaves opposita.

48. Caprifoliaceæ, p. 277. Fruit a $1-5$-celled, 1 -few-seeded berry or capsule. Stamens 4 or 5 : style 1 or none. Shrubs (one low creeper), with simple or pimuate leaves and 110 stipules. Seet albuminous.

49. Rubiaceæe, 10.281. Fruit dry, indehiscent, 2-4-celled, 2-4-seeded. Flowers regular, 4-5-merous : style 1 , entire or cleft. Shubs with capitate flowers, or herbs with flowers mostly eymose; leaves entire, opposite aud stipulate, or verticillate. Seed albuminons.

50. Valerianaceæ, p. 286. Ovary 3-celled, becoming a 1-celled 1-seeded akene-like firuit. St:zmens 3, fewer than the corollin-lobes. Flowers imegular. Herbs, with opposite simplet or pimnate leaves, without stipules. Albumen none.

* Anthers or filaments (5) united into a tube around the 2-cleft or entire style. No stipules.

51. Compositæ, p. 288. Fruit an akene. Flowers in an involucrate heal: calyx reduced to a pajpus or wanting: filaments mostly distinct. Albumen none.

52. Lobeliacez, p. 443. Capsule 1 -2-celled, many-seeded, more or less inferior. Flowers irregular, scattered or racemose : filaments united; anthers sometimes distinct. Herbs, with alternate simple leaves. Seeds albuminous.

\section{* * Stamens distinct. Leaves alternate, without stipules.}

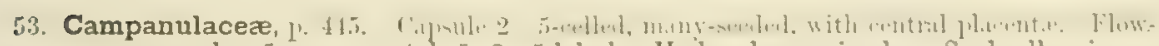
ers regulur, 5-nerous: style 1, 2 -5-lobed. Herbs; leaves simple. Seets albuminons.

Berry many-seeded, 4-5-celled. Flowers regular, 4-5-merous : anthers opening by temimal pores : style 1. Shrubs, with simple leaves. VAcervius in Liricacece.

Fruit fleshy, indehiseent. Flowers moncecious or diocions : stamens commonly uniled. Tendrilbearing trailing herbs. CucunBtTAcE.s.

B. Ovary superior or nearly so, compound. (Stipules none.)

- Corolla regular. Stamens not didynamous.

$$
+ \text { Fruit } 5 \text { - many-celled. }
$$

54. Fricaceæ, p. 448. Fruit berry-like or enpsular, 5-10-celled, 5-many-seeded, with central $(1: 11, y$ [ terminal pore or chink. Shrubs, with simple nlternate lenveg (olposite in R'ulmia), or siraly bracted herbs without green folinge.

55. Lennoacea, p. 464. Fruit drupaceons, $12-20$-celled and-semed. Parts of the flower 5 to 10: style 1 : anthers opening lengthwise. Fleshy sealy herbs, without grven luerkage

$$
++ \text { Fruit } 1-4 \text {-celled. }
$$

++ Fruit 1-celled, with a central hasal placeuta.

56. Plumbaginaceæ, p. 465. Cansule a 1-sepded utricle inclosed in the senrions cnlyx. Flowers 5-merous: petals neurly distinct. Mfuritime meauldesent herhs, with entive leatses.

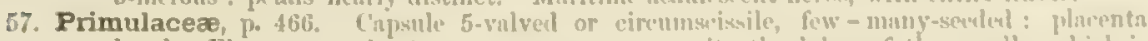

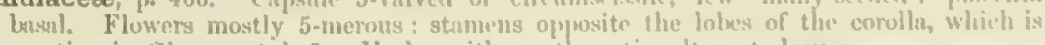
wanting in Glauz: style 1. Herbs, with unostly entire alternate leavess 
58. Styracea, p. 470. Fruit fleshy, becoming dry, 3-valved, 1-seeded. Calyx truncate : petals 4 to 8 , nearly distinct: stamens 10 , monadelphous: style 1 . Shrub, with alternate entire leaves.

59. Oleacex, p. 471. Fruit a simple samara, usually 1-celled and 1-seeded (or a 2-celled drupe or capsule). Flowers 4-merous, perfect or diøeious: petals often none: stamens usually 2 : style 1. Shrubs or trees, with opposite pinnate or simple leaves.

+* Carpels 2, nnited by their styles or stigmas, becoming distinct follicles with numerous comose seeds. Perennial herbs, with milky juice, and opposite entire leaves : flowers 5-merous.

60. Apocynacex, p. 472. Corolla convolute in the bud. Anthers nearly free : pollen powdery.

61. Asclepiadacea, p. 474. Corolla and calyx nearly valvate. Anthers attached to the stigna: pollen in waxy masses.

++++ Fruit 1-celled : placentre 2, parietal (sometimes united in the axis).

62. Gentianacez, p. 478. Capsule septicidal, few-many-seeded. Flowers 4-5-merous : style 1 or none; stigmas 1 or 2 . Glabrous herbs, with simple and opposite or 3 -foliolate and alternate leaves : inflorescence not scorpioid.

64. Hydrophyllaceæ, p. 501. Capsule loculicidal, few-many-seeded. Flowers 5-merous : styles 2, usually more or less distinct. Herbs (Eriodictyon shrubby), often rough-hairy, with alternate (rarely opposite) often compound leaves, and mostly seorpioid infiorescence.

$$
++++++++ \text { Fruit } 2-4 \text {-celled, with central placentæ. }
$$

75. Plantaginaceæ, p. 610. Capsule 2-celled 2-few-seeded, circumscissile. Flowers 4-merous: stamens 2 or 4 : style 1 : cololla scarious. Acaulescent herbs.

66. Convolvulacea, p. 532. Capsule 2-celled, 1-4-seeded, 2-valved or circumscissile. Flowers mostly 5-merous : styles 1 or 2 . Herbs, mostly twining, with alternate leaves, or parasitic and without green herbage.

65. Borraginaceae, p. 518. Ovary 4-celled and mostly 4-lobed, maturing usually as many 1-seeded nutlets. Flowers 5-merous : style single. Herbs, mostly rough-hairy, with alternate (or the lower opposite) entire leaves, and scorpioid inflorescence.

63. Polemoniaceæ, p. 485. Capstule 3-celled, 3-many-seeded, loculicidal. Flowers 5-merous : style 3-cleft. Herbs (rarely woody at base), with opposite or altermate simple or compound leaves.

67. Solanacea, p. 537. Fruit a berry or capsule, 2-celled (rarely more), many-seeded. Flowers 5-merous: style siniple: corolla valvate or plaited in the bud. Herbs (rank-scented) or shrubs, with alternate simple or pinnate leaves.

Capsule didymous, mostly 2-parted, cireumscissile, 2 -4-seeded. Stamens 2 or 3 : style 1 . Nearly herbaceous, with mostly opposite sessile leaves. Mexodora in Oleacea.

Capsule 2-celled, many-seeded. Flowers 5-merous : style single: corolla imegular, imabricate. Herbs with alternate leaves and racemose flowers. VEliBascum in Scrophulariacea.

Capsule imperfectly 3-celled, several-seeded. Flowers 5-merous : stamens 10 or more : styles 3. Seeds thim, winged or comose. Small spinescent trees. Fouquiera in Tamariscince.

* * Flowers irregular. Fertile stamens 4 and didynamous, sometimes 2.

+ Fruit capsular, 1-2-celled : style 1 .

t+ Seeds albuminous.

68. Scrophulariaceæ, p. 546. Capsule 2-celled, with central placentæ, few-many-seeded. Corolla imbricated. Herbs or sometimes woody, with alternate or opposite leaves.

69. Orobanchaceæ, p. 583. Capsule 1-celled, 2-valved, with 2-4 parietal placentæ, manyseeded. Parasitic herbs, without green foliage: scales alternate.

$$
++t+\text { Seeds without albumen. }
$$

70. Lentibulariea, p. 586. Capsule 1-celled, with central placentæ, bursting irregularly, manyseeded. Stamens 2 ; anthers 1-celled. Floating herbs, with capillary dissected leaves.

71. Bignoniaceze, p. 586. Capsule (linear) 1-2-celled, 2-valved, with numerous winged and tulted seeds. Slirubs, with linear entire opposite or alternate leaves.

72. Acanthacee, p. 587. Capsule clavate, 2-celled with central placentre, 4-seeded: seeds on hook-like processes of the placentr. Stamens mostly2. Herbs ol shrubs; leaves opposite.

$$
+ \text { + Fruit of } 2 \text { or } 4 \text { distinct ol united 1-seeded nutlets. }
$$

73. Labiata, p. 589. Ovary 4-lobed around the 2-cleft style, forming as many distinet nutlets. Stamens 4 or 2. Mostly aromatic herbs or woody at base, with square stems, and opposite simple lenves.

74. Verbenaceæ, 1) 607. Ovary not lobed, 2-4-celled; fruit splitting into as many nutlets. Stamens 4 : style 1 . Herbs or shrubby, rarely aromatic ; leaves opposite or whorled. 


\section{B O T A N Y}

\section{OF \\ C A L I F O R N I A.}

\section{Series I. PHENOGAMOUS or FLOWERING PLANTS.}

Plants bearing true flowers, that is, having stamens and pistils, and producing seeds which contain an embryo.

\section{Class I. DICOTYLEDONOUS OR EXOGENOUS PLANTS.}

Stems consisting of a pith in the centre, of bark on the outside, and these separated by one or more layers of fibrous or wooly tissute, which, when the stem lives from year to year, increases by the adlition of new layers to the outside next the bark. Embryo usually with two opposite cotyledons, or rarely with several in a whorl.

\section{Subchass I. ANGIOSPERMA.}

Pistil consisting of a closed ovary which contains the orules and forms the fruit. Cotyledons two.

\section{Division I. POLYPETALE.}

Floral envelopes consisting usually of hoth calyx and corollat the peetals met united with each other, in some cases wauting. 


\section{ORDER I. RANUNCULACE开.}

Herbaceous or somewhat shrubby plants, with colorless and usually acrid juice; distinguished by the polyandrous and often polygynous flowers; the numerous stamens hypogynous (perigynous in Crossosoma); the sepals, petals, stamens, and few or numerous (in Actcea solitary) pistils all distinct and free. Sepals very commonly colored and petaloid. Petals in many wanting or in the form of nectaries. Anthers short. Seeds solitary or several, with minute embryo in firm-fleshy albumen. Foliage various: stipules none.

An order of 31 genera, several of which are numerous in species, widely distributed over the world, but nost largely represented in the northern temperate and frigid zones. Several are used in medicine; some (like Aconite) are acrid poisons ; and many are cultivated for ornament.

Our thirteen gevera belong to six tribes, which need not be recapitulated, as their characters may be more easily apprehended from a simple key.

\section{Synopsis of Genera.}

* Sepals petal-like, valvate-induplicate in the bud, deciduous : leaves all opposite.

1. Clematis. Half-woody, climbing by the petioles. Petals none or minute. Fruit a head of hairy-tailed akenes.

* * Sepals petal-like or sometimes greenish, imbricated in the bud, deciduous: herbs.

* Carpels numerous, 1-ovuled, in fruit becoming akenes.

++ Leaves on the stem opposite or whorled on or below 1-flowered peduncles.

2. Anemone. Sepals 4 to 20 , petal-like. Petals none. Akenes in a head.

$$
++++ \text { Leaves all alternate. }
$$

3. Thalictrum. Flowers mostly diocious, panicled. Petals none. Akenes several in a head.

4. Myosurus. Flowers pelfect, solitary on a scape. Sepals spurred at base. Petals slender. Akenes very numerous in a long slender spike.

5. Ranunculus. Flowers perfect. Sepals not spurred. Petals generally broad and conspicuous (rarely minute). Akenes numerous in a globular or oblong head. + + Carpels few; several-ovuled, becoming follicles (pods) in fruit.

$$
\text { ++ Flowers regular. }
$$

6. Caltha. Petals none: leaves simple and round-reniform: carpels 5 to 12.

7. Isopyrum. Petals none: leaves termately compound : carpels 3 to 6 .

8. Aquilegia. Petals 5, all spurred backward: leaves ternately compound : carpels 5.

$$
+++ \text { Flowers irregular. }
$$

9. Delphinium. Upper sepal produced backward into a spur : carpels 1 to 5 .

10. Aconitum. Upper' sepal arched into a hood: carpels 3 to 5.

$$
\text { * + + Carpel one, many-ovuled, in fruit a berry. }
$$

11. Actæa. Sepals caducous: petals small. Leaves ternately compound. Raceme short.

* * * Sepals herbaceous, imbricated in the bud, persistent : petals conspicuous : carpels few, becoming many-seeded follicles in fruit: leaves alternate.

12. Pronia Herbs, with compound leaves. Seeds not arillate.

13. Crossosoma. Shrubs, with simple entire leaves. Seeds arillate. Stamens perigynous.

\section{CLEMATIS, Linn.}

Sepals 4 (sometimes more in foreign species), colored and petal-like, valvate in the bud. Petals none or small. Pistils numerous: styles persistent, and (in our species) becoming long feathery awns in fruit. Akenes numerous, in a head. Half-woody climbers or perennial herbs, with opposite leaves.

A genus of abont 100 species, belonging to temperate and warm climates of both hemispheres. Many have much beauty, and a few are cultivated for ornament. Our species are long, woody (or half-woody) vines, climbing by the petioles, with compound leaves and showy flowers. 


\section{§1. Petals none. - Clematis proper.}

1. C. ligusticifolia, Nutt. Nearly glabrous : stems elongated (sometimes 30 feet long): leaves 5-foliolate; leaflets broadly ovate to lanceolate, $1 \frac{1}{2}$ to 3 inches longr, acute or acuminate, 3-lobed and coarsely toothed, rarely entire or 3-parted: flowers diocious, paniculate: sepals thin, silky, white, 4 to 6 lines long : akenes pubescent ; tails 1 to 2 inches long. - Torr. \& Gray, Fl. i. 9.

Var. Californica, Watson. Leaves silky-tomentose beneath, often small.

The typical form ranges from Oregon to the Saskatchewan and New Mexico, entering California on the northeast; the variety from San Diego to the Sacramento, and to Arizona.

2. C. lasiantha, Nutt. 1. c. Silky tomentose: stems elongated, stout: leaflets 3 , ovate, 1 to 11 inches long, acute, coarsely toothed or 3-lobed or the terminal 3 -parted : flowers dicecious, solitary, on rather stout 1 -2-bracted peluncles: sejals obtuse, thickish, 6 to 10 lines long: akenes pubescent.

Santa Barbara to Napa Co, and in the Sierra Nevada to Plumas Co., Mrs. M. E. Pulsifer Ames.

3. C. pauciflora, Nutt. 1. c. Somewhat silky-pubescent: stems more slender, short-jointed: leaves short and fascicled; leaflets 3 to 5 , only 3 to 9 lines long, cuneate-obovate to cordate, mostly 3 -tnothed or lobed : Howers solitary or few and panicled, on slender pedicels: sepals thin, 4 to 6 lines long : akenes glabrous.

San Diego, Nullall, Cooper, Cleveland.

C. Drummonni, Torr. \& Gray, a similar species, but with long-petioled and not fascicled leaves, - leaflets laneeolate to orate, long-acuminate and 3 -lobed; akenes pubescent, with tails 2 to 4 inches long, - probably enters S. E. Califoraia from Arizona and Sonora.

\$2. Some of the outer filaments enlarging to small spatulate petals. - ATRAGEXE, DC.

4. C. verticillaris, DC. A slender climber, almost glabrous: leaves ternate; leaflets ovate or subcordate, pointed: flowers solitary, bluish-purple, 2 or 3 inches across: the outer stamens enlarging to narrow petals.

Shaded rocky places in mountains, Cape Mendocino (Douglas); east to Maine, and north to British America. Leaflets 2 inches long, commonly entire; but sometimes those on sterile stems are $1-3$-toothed or lobed. Peduncles 3 to 6 inches long, the flower commonly nodding.

\section{ANEMONE, Linn.}

Sepals 4 to 20, colored and petal-like, imbricated in the bud. Petals none. Pistils numerous: style shurt: stirma lateral. (voule suspunded. Akenes in a head, compresserl, pointed, or enling in longr featbery awns. - Erect perennial herbs with lubed or divided leaves, which are all ralical excrpt those which form an involucre, usually some distance below the flower.

Sipecies athout 70 , mostly belonging to the mountains of the north temperate anul aretie zenes. Of the 15 North American species half a dozen are also found either in the Old World or in the Audes of South America.

\section{* Styles long and hairy, at length forming plumose tails. - Pulsatilla, Tourn.}

1. A. occidentalis, Watson. More or less silky-viltus, alpime : stmes stout,

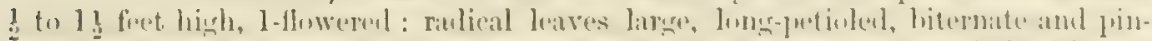
nate, the hateral primary divisions nearly sessile, the staments pinnatifid with marrow laciniately toothed lobes: involucral leaves similar, nearly sessile about the nidelle of the stem: sepals 6 or 7,6 to 9 lines long, white or purplish at base:

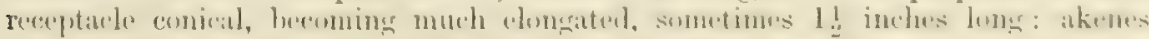

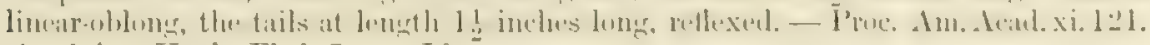
A. alpina, Hook. Fl. i. 5, not Linn.

Mt. Shasta (Brewur); Lassen's Peak (Lemmon); and northward to the British boundary. Perhans it is also the A. alpina of arctic collectors from kotzebue Sound and the Gulf of st. 
Lawrence. It differs from A. alpina of Europe and the Caucasus in its more finely and narrowly dissected leaves, with the lateral primary divisions not long-petiolulate, and in its lengthened receptacle, which in the Old World species is small and hemispherical, even in fruit.

* Styles short and nearly naked, not becoming elongated. - ANEMONE proper.

+ Carpels very numerous, in a close head, densely villous.

2. A. multifida, DC. Alpine or subalpine, somewhat silky-villous: stems 3 to 15 inches high, 1-3-flowered : radical leaves long-petioled, nearly semicircular in outline, ternate, the sessile divisions deeply lobed with cleft linear segments : involucral leaves similar, shortly petioled : sepals 5 to 8 , red or whitish, 4 to 6 lines long, villous externally: receptacle oblong, the head in fruit globular to oblong, 5 to 12 lines long: akenes very densely woolly, ovate-oblong, with a straight beak.

Sierra Co. (Lemmon) ; on the Columbia (Douglas); and frequently in the mountains eastward, ranging to the Saskatchewan, Lake Superiol, and N. New York. Also South American.

\section{++ Carpels fewer, pubescent only: stems 1-flowered.}

3. A. nemorosa, Linn. Smooth or somewhat villous: stems from a slender rootstock, 3 to 12 inches high, without radical leaves : involucre of three petioled ternate leaves, the divisions cuneate-oblong to ovate, incisely toothed or lobed, or the lat eral ones 2-parted, about an inch long : peduncle equalling the involucre: sepals 4 to 7, oval, white or pinkish : akenes 12 to 20, oblong, 2 lines long, with a hooked beak.

Under redwoods near the coast (Bigelow, Bolander); Sierra Co. (Lemmon); and northward to the British Boundary. It is conmon on the eastern side of the continent, in Europe and N. Asia. Popularly known as Wood-Anemone.

A. Deltoidea, Hook. Fl. i. 6, t. 3, A., is a closely allied species in Oregon. It is 10 to 15 inches high, slender: radical leaves trifoliolate; leaflets rhomboid, serrate : involucre of rhomboid or rhomboid-ovate and undivides leaves on very short petioles, serrate and sometimes 3-lobed. It has not yet been found in California.

\section{THALICTRUM, Tourn.}

Sepals 4 to 7, either greenish or petal-like, imbricated in the bud. Petals none. Pistils 4 to 15. Orule suspended. Akenes in a head. - Perennial herbs with alternate leaves which are 2 or 3 times ternately compound; the leaflets stalked. Flowers in corymbs or panicles.

A genus of about 50 species, belonging mostly to northern cliniates. They are of delicate and graceful habit. Our species are dicecious, and not abundant.

1. T. Fendlexi, Engelm. Diœeious: leaves $2-3$-ternate; the leaflets usually more or less 3-lobed, sometimes toothed or cut at the apex into several lobes, the base entire, and varying in shape from cordate to cuneate: sepals broadly ovate: filaments very numerous, slender: anthers pointed: carpels 5 to 15 , compressed, oblique, with about three ribs on each side, sometimes reticulated. - Pl. Fendl. 5.

Rocky or shaded places, Napa Valley and southward; New Mexico and the Rocky Mountains. The whole plant is smooth, ereet, 12 to 30 inches high. Flowers in a terminal panicle. Leaflets 6 to 9 lines long and about as wide.

T. occidextale, Gray, Proc. Am. Acad. viii. 372, from Oregon to Montana, is very like T. Fendleri, except in the akenes, which are nearly half an inch long, narrow, long-acuminate, and less curved than in that. Perhaps to be found in N. California.

\section{MYOSURUS, Linn. MoUSE-TAIL.}

Sepals 5, spurred at the base. Petals 5, linear, on a slender claw, with a pit at its summit. Stamens 5 to 20. Akenes very numerous, crowded on a long and slender spike-like receptacle. Seed suspended. - Very small annual herbs, with a tuft of linear or spatulate entire radical leaves, and solitary flowers on simple scapes. 
A small genus of only two or three species, widely dispersed over the globe. They are known by the English name of Mouse-tail, from the very long and narrow receptacle of the flower, densely covered with the small akenes, the whole very like a mouse's tail.

1. M. minimus, Linn. Receptacle in fruit slender, 1 or 2 inches long: akenes blust.

Wet places in Sacramento Valley (Hartweg), and alkaline soil near Livermore Pass (Brcucer); east to Kentucky; also Australia, Northern Europe, and Asia. A small annual, 2 to 6 inches high, with a tuft of narrow radical leaves which are usually shorter than the naked scapes. Each scape is but one-flowered, but the receptacle is so long and slender that it seems very like a scaly spike 9 to 18 lines long, with the small sepals, petals, and stamens spreading from the base. Although so widely spread, it is apparently nowhere an abundant plant.

2. M. aristatus, Benth. Receptacle in fruit oblong or linear, 2 to 8 lines long: akenes long-beaked.

In the shade of sage-brush, Carson and Sierra Valleys to Utah; also Chili. A small plant, less than two inches high.

\section{RANUNCULUS, Linn. Crowfoot. Buttercer.}

Sepals usually 5. Petals 3 to 15 , each with a small scale or pit at the base inside. Pistils numerous. Akenes in a head, usually flattened, beaked with the persistent style. - Herbs, mostly perennial, of somewhat viried habit. Flowers either solitary or somewhat corymbed. Leaves various.

A genus of about 160 species, inhabitants of all parts of the world, but most abundant north of the tropics. Mlost of the species are acrid, and some are poisonous. The name Crowfoot was originally applied to species with lobed or divided leaves, and Buttcrcup to those with yellow flowers, but both names are now more loosely used.

\$1. Aquatic herls, commonly perennial, but sometimes annual, with the submersed leaves, if any, finely divided: petals white, with a pit at the base, the claw yellow: akenes transwersely wrinkled. - Batrachuм, DC.

1. R. hederaceus, Linn., var. (ilabrous: stems floating, 6 to 12 inches long: leaves commonly all tluating, 3 to 8 lines wide, deeply 3-lobed, truncate or cordate at the hase; the lobes equal, oval or oblong, the lateral ones usually with a broat noteh in the apex; submersed leaves none, or rulimentary and resembling adrentitious roots: peduncles opposite the upper leaves, thicker than the petioles, 6 to 8 lines long: sepals a line long : petals 2 lines, whovite-oblong : stamens commonly 6 (5) to 9): akenes commonly + ( 1 to 6$)$, about a line loug : receptacle smouth. $-R$. hydrocharis, var. Lobbii, Hiern.

In shallow water, Marin Co. (Bigelove), and Russian River (Bolcnder); and Oregon (Lobb), the var. Lobbii (R. hydrocharis, var. Lobbii), Hiem, in Seemann's Jour. Bot ix, 66, t. 11t. The description is for this variety only, which is confined to the Pacific const. There is much ilifficulty in determining the species of this section; as many as 75 have been deseribed, but authors differ widely as to their limitations. Hiern, after a long examination, unites all under one aggregate species, arranging them under 35 main varieties.

2. R. aquatilis, Linn, var. trichophyllus, Chaix. Stems long and cuarsely filiform, growing in water: leaves all submersed and cut into numerous capillary segments which are 4 to 10 lines long: peduncles 1 or 2 inches long: flowers 3 to 5 lines in diameter: akenes numerons in a close gholular heal, which

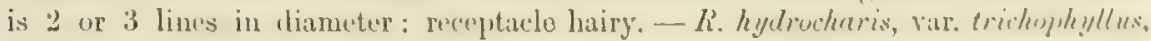
Hiern, l, c.

Vill. cospitosus. Strms short, growing in mul: stements of leabes lipulate, a line or more long: Howers 2 or 3 lines in diameter. $-R$. hydrocharis, var. caspilosus, Hiern, 1. c.

The first form is rather common in ponds and streams; the second is much more rare. Long Valley, Mendocino County (Kellogg), Sunoma, Brever. Both formsextenl to the Eastern States; also to Europe, Asia, and Australia. 
\$2. Terrestrial herbs, with the leaves all undivided: sepals large and petal-like: petals minute, with a nectariferous pit at the base of the blade: akenes smooth, tapering. - Aphanostemia, St. Hilaire.

3. R. hystriculus, Gray. Glabrous : the scape-like stem 6 to 10 inches, usually 1-flowered and leatless: leaves broadly cordate or reniform, about 5-lobed, deeply crenately toothed: sepals 5 to 6 , white and petal-like, 4 to 5 lines long, deciduous: petals inconspicuous, consisting of a minute fleshy blade (having a nectariferous pit at its base) raised upon a narrow claw of twice its length, the whole scarcely 2 lines long: akenes 2 to 3 lines long, slender and tapering to a long hooked beak, and forming a compact ovate head. - Proc. Am. Acad. vii. 328.

Foot-hills of the Sierra Nevada, Forest Hill and Newcastle (Bolander), and near Placerville, Rattan. This little plant has more the look of an Anemone than a Ranunculus, but the fruit distinguishes it. The scapes are rarely 2 -flowered, and sometimes bear a single leaf. The minute petals are probably yellow. Root faseicled-fibrous. Leaves 1 or 2 inches long, on petioles three times as loug.

\section{\$3. Terrestrial herbs, with the leaves compound: sepals somewhat petal-like: petals with a scale at the base: akenes vesicular and margined or winged at the base.}

4. R. Andersonii, Gray. Stems 3 to 6 inches high, 1-flowered: radical leaves palmately 2-ternate; leaflets petiolulate, laciniately lobed: flowers about an inch in diameter; petals obovate or nearly orbicular, deep pink ; sepals nearly as long, glabrous, persistent, somewhat petaloid, pink on the margin: akenes 4 to 5 lines long, bladdery, obovate, compressed, with a narrow ventral wing and a dorsal margin, glabrous, mucronate, with very short subulate recurved style. - Proc. Am. Acad. vii. 327 ; Watson, Bot. King. 6 , t. 1 .

Sierra Valley (Lemmon), near Carson Valley (Anderson), east to Salt Lake, Watson. The plant is either wholly glabrous or somewhat ciliate on the dilated petioles and on the segments of the leaves. Stems commonly seape-like and leafless, but sometimes with a small divided leaf or bract a short distance below the flower. Leaves somewhat fleshy, an inch or more long and wide, on petioles 2 inches long. A truly remarkable species.

\$ 4. Terrestrial herbs, but often growing in wet places, mostly erect: sepals green and herbaceous: petals yellow, with a scale at the base: akenes neither wrinkled nor hispid. - Ranunculus proper.

\section{* All the leaves undivided, the margins entire.}

5. R. Flammula, Linn., var. reptans, Gray. Glabrous throughout: stems filiform, creeping and rooting at the joints, 4 to 10 inches long: leaves mostly lanceolate and acute at each end, entire: flowers 4 (2 to 5) lines in diameter: petals broadly obovate, one half longer than the sepals: akenes few, in a small globular head, plump, smooth; beak very short and curved. - R. reptans, Linn.

Moist places from the sea-level to 6,000 feet altitude. The species has a wide range on both continents. A creeping plant, in wet places, and quite variable in size. Leaves 1 to $1_{\frac{1}{2}}^{\frac{1}{2}}$ inches long, the lower ones on long petioles, the upper ones usually somewhat clustered at the joints, varying from linear to oblong in shape. The head is of rather few earpels, commonly but 2 lines in diameter.

6. R. alismafolius, Geyer. Smnoth throughout: stems nearly or quite erect, 10 to 16 inches high, rather stout: leaves broadly lanceolate, entire, blunt at apex: flowers 6 to 9 lines in diameter : petals broadly obovate, conspicuously nerved, nearly twice as long as the sepals: akenes smooth, slightly flattened, pointed with a nearly or quite straight heak, crowded in a compact, ovate head.-Benth. Pl. Hartw. 295.

Var. alismellus, Gray. Stems slender, erect, 6 to 8 inches high: lower leaves elliptical: petioles sparincly pilose : flowers 5 to 6 lines in diameter : petals about 6 . - Proc. Am. Acad. rí. 327. 
Wet places. The first form in several localities at lower altitudes, by various collectors. The var. at Lake Tenaya and Mt. Dana (Brewer), Ostrander's, Bolander. The species ranges to New England, British America, and Europe. The most characteristic distinction between this and $R$. Flammula is the straight style and long straight beak; but so far as relates to the California forms, the most olwious difference is that this has usually ereet stems and larger flowers, while that has creeping stems.

7. R. Lemmoni, Gray. Villous at base: stems 6 to 10 inches high, sparinuly branched: leaves narrowly lanceolate, 3 to 4 inches long, the radical on long petioles: flowers few, long-peduncled, half an inch bruad, bright yellow: sejals villous, somewlat frersistent: heads glubose, 3 to $t$ lines broad : akenes turcill, jubescent. submembrantceons, $1 \frac{1}{2}$ to 2 lines long; beak very short, subulate, incurved. - Proc. Am. Acad. x. 68.

Sierra Valley, J. G. Lemmon.

§. R. trachyspermus, var. Lindheimeri, Engelm. Smooth throughout: stems slender, erect, 8 to 10 inches high: lower leaves oval, upper ones lanceolate or linear, all entire: flowers 2 lines in diameter: heads of fruit oblong: akenes granulately roughened. - Pl. Lindh. i. 3 ; Torr. Pacif. R. Rep. iv. 62.

This has only been found (by Dr. Bigelonc) in Napa Valley, and more specimens are needed for satisfactory determination. The species otherwise is known only from Texas.

* Radical lewves undivided; stem leaves, if any, toothed or lobed: glabrons perennials.

9. R. Cymbalaria, Pursh. Glabrous: flowering stems nr scipes leafless, 3 to 6 inches ligh, l to $\mathbf{i}$-Howered: leaves thickish, broally ovate or orate-cordate, coarsely crenate, clustered at the root and at the joints of the loner filiform ronting runners; petals yellow, 2 lines long and longer than the green sepals: the mature akenes a line long, striate-veined on the sides, enlitring upwarls; apex blunt, with a short oblique beak; head compact, oblong; 3 to 6 lines long.

Wet saline soils (Bolandcr) and in similar places eastward to the Atlantic; also Europe and Asia.

10. R. glaberrimus, Hook. Glahrous: stems 3 to 6 inches high, 1-3-fowereel: madical leaves broally oval, either entire or with 3 large blunt teeth at the apex; cauline leaves cuneate at the base, 3-cleft to the middle: petals oval, yellow, 3 to 4 lines long: sepals oval, not reflexed, half as long as the petals: akenes plump or

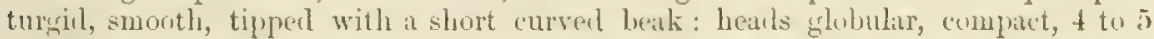
lines in diameter. - Hook. Fl. i. 12, t. 5 .

Washoe Mountains (Andcrson) and northward in subalpine situations to Oregon and Idaho.

11. R. oxynotus, (iny. Mlpime, clabrus, cespituse, with thick fibrons roots: stems stout, 4 to 6 inches high, decumbent at base, 1 -3-flowered : leaves crowded,

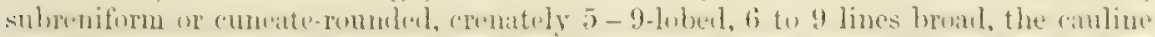

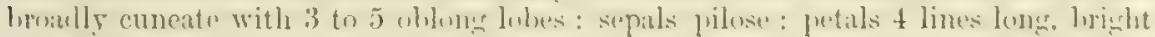

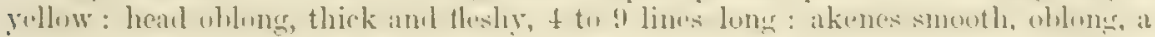
line long, carinate on the back, ancuminate with the curved suhulate style. - Pruce. Am. Acad. x. 68 .

Near snow on the central Sierra Nevada, at 10,000 to 11,000 feet altitudo; Wood's Penk and peak above Sonora Pass (Brciecr) ; Mount Stanford, Sierra Co. (Lcmmon). Near $R$. nivalis, differing in its cespitose habit and less deeply lobed radical leares.

* * * Some or all the leaves ternately compound: stems branching, several-flowered: roots mostly a fascicle of thickened fibres: flowers bright yellow.

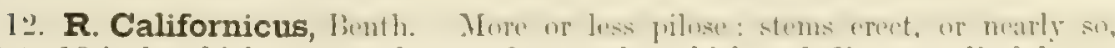
12 to 18 inches high: root a cluster of somewhat thickened fibres: raclical lenves commonly pinuately ternate, the leaflets lacinintely cut into 3 to 7 lobes or parts, which are usually linear: flowers 5 to 10 lines in diameter: petals usually 10 to 14 narrowly obovate: sepals shorter than the petals, reflexed: akenes nearly 2 lines

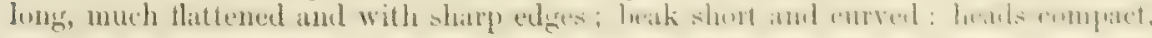


ovate or globular. - Pl. Hartw. 295. R. dissectus, Hook. \& Arn., Bot. Beech. 316. R. acris, var., Torr. \& Gray, Fl. 1. 21. $R$. delphinifolius? ib. 659 (not HBK.).

Var. canus. Softly canescent throughout.- $R$. canus, Benth. Pl. Hartw. 294.

This is by far the most eommon and abundant speeies in the State, and is particularly abundant in the coast ranges, where low grassy hills are often yellow with the shining flowers in early spring. This species is very variable in most of its parts. The pubescence varies with the locality, and also with the year ; the plant being more hairy in dry years. The leaves vary greatly in the degree of their division; they are sometimes simply 3-lobed, sometimes dissected into numerous linear divisions, and are found in every intermediate gradation. The flowers are usually bright sulphur-yellow, but are sometimes found quite pale. $R$. canus, Benth., is thought by Professor Gray to be probably $R$. occidentalis, Nutt.; but the fruit is unknown.

13. R. repens, Linn. More or less hairy : stems ascending, usually not more than 10 to 15 inches long, and in the typical form often forming long runners : roots a cluster of somewhat thickened fibres: radical leaves variously ternately divided; the leaflets either sessile or stalked, and variously laciniately cut or divided : flowers 6 to 10 lines in diameter; petals usually 5 to 7 , obovate and longer than the spreading sepals: akenes flattened, margined, $1 \frac{1}{4}$ lines long, the stout beak nearly half as long: heads compact and globular.

This variable species stands between $R$. Californicus and $R$. macranthus, its varieties passing into those species by a complete succession of forms. The connecting forms, however, are not Californian. The species is rare here, and it is questionable whether the typical form has yet been found in the State. It really belongs more eastward. The two others mentioned, while more limited in range, are vastly more abundant here. It extends across the continent and to Europe.

14. R. macranthus, Scheele. More or less hairy with spreading hairs : root as in the last: stems stout, erect, 2 to 4 feet high : radical leaves $1-2$-ternately divided; the leaflets laciniately toothed or lobed : flowers 14 to 18 lines in diameter: petals commonly 5 or 6 , broadly obovate, deep shining yellow, twice as long as the closely reflexed sepals: akenes flattened, but hardly margined, $1 \frac{1}{2}$ lines long; the subulate beak nearly as long; crowded into an ovate-globose head. - Watson, Bot. King. 9.

Moist soils from Oregon to Nevada and Texas. In this State near the coast. This is the largest and stoutest of all our species; is sometimes over 5 feet high (Kellogg), and also has the largest flowers. As in the other species of this section, the leaves are very variable as to division and pubescence. Specimens from Texas are more hairy, and the petals are more numerous and narrower than in ours.

15. R. Nelsonii, var. tenellus, Gray. Sparingly pilose : stems ereet, $1 \frac{1}{2}$ to 2 feet high, rather slender: radical leaves either trifoliolate, with the leaflets cuneate at the base and laciniately 3 to 5 -cleft, or else simply cleft and with the divisions again cut into lobes : petals usually 5,1 to 3 lines long, exceeding the hairy, strongly reflexed sepals: akenes a full line long, flattened, with a short stout curved beak: heads globular, 3 lines in diameter. - Proc. Am. Acad. viii. 374. R. tenellus, Nutt. ; Torr. \& Gray, Fl. i. 23.

Sierra Nevada near Yosemite, Bolander. The typical form is a more robust plant, the simple radical leaves often 3-4 inches in diameter. It ranges from Oregon to Alaska. Our variety has a more slender habit, the radical leaves two inches or so in diameter, the peduncles quite slender and 1-4 inches long. The small flowers easily distinguish it from the other species of this group.

§. Akenes hispid-roughened: annual: otherwise as in \$ 4.-ECHINELLA, DC.

16. R. hebecarpus, Hook. \& Arn. Somewhat pilose, with spreading hairs : stems ascending, slender, 6 to .18 inches high: lower leaves ternate or 3-parted; the leaflets cuneate at base, and 2 to 3-lobed; upper ones more divided: petals 5, a line or less long: sepals hairy, about equalling the petals : akenes few in a head, a line or less long, rounded, flat, the sides rough with short scattered hairs: heads globular, 2 lines in diameter. - Bot. Beech. 316. R. parviflorus, var., Torr. \& Gray, Fl. i. 25. 
Tar. pusillus. Stems very slender or filiform, weak and ascending or procumbent, 3 to 6 inches long: leaves reniform, crenately 5-lobed or parted.

Coast-ranges and foot-hills of the Sierra Nevada. This species is easily recognized by its slender habit, minute flowers, and roughened akenes. Like our other annuals it is very variable, and at first sight some of the forms seem strikingly unlike others.

In addition to the preceding species, $R$. fascicularis, Muhl, has been reported from the State, but Professor Gray (Proe. Am. Acad. viii. 373) thinks the species is not found west of the Rocky Mountains. "What has been so called from Califoruia is probably $R$. Californicus, Benth."

R. Chrlessis, DC., occurred in the collections of Captain Beechey's voyage, from California (Bot. Beech. 134). The species has procumbent stems, hispid petioles, cordate-orbicular, $3-5$-lobed leaves, the lobes dentate. This species has not been found in the State since, and it is probable that the specimen may have got into the Californian collection from the Chilian, or else that the species was once introduced but failed to survive.

R. MuRicatus, L., a low coarse annual species from Europe, with large very rough akenes, and flat stout recurved beaks, has been reported from "the streets of San Francisco" (Bolander's Catalogue, 3).

\section{CALTHA, Linn.}

Sepals 5 to 12, decillous, colored, and looking like petals. Petals none. Stamens numerous. Pistils 5 to 12, each with sereral orules, becoming follicles in fruit, which at ripening are sprealing, Hattenel, and sereral-secled. - Glabrous peremnial herbs, with broad cordate undivided leaves.

A small genus of about 9 species, belonging to the cooler parts of both hemispheres.

1. C. leptosepala, DC. Stems erect, 1 -flowerel and scape-like, 3 to 12 inches high, and exceeding the leaves; leaves all radical, cordate.

Swamps near head of King's River, at 8,000 feet (Brewer), near Lassen's Peak, Lemmon; also alpine stations from New Mexico and the Rocky Mountains to Alaska. Californian specimens have the leaves 2 or 3 inches across, cordate-orbicular, margins nearly entire; sepals greenishwhite, 6 to 10 lines long, and 4 or 5 lines broad, and rather blunt. Rocky Mountain specimens have sepals usually narrower, often bluish; the leaves orate, cordate, and more or less crenate. Sometimes the stems bear a second and smaller flower, and the species appears to pass into C. biflora.

\section{ISOPYRUM, Linn.}

Sepals usually 5, white and petal-like, decicluous. Petals, in our species none (in foreign species 5, minute). Stamens 10 to 40 . Pistils usually 3 to 6 , hut indetinite; becoming follicles in fruit, which are sereral-seederl, oblong or ovate, and pointerl with the persistent style. - Simoth, slenter herbs, with 2 -3-ternately compound leaves, and axillary or terminal flowers.

Species 7, belonging the North Temperate zone of both continents.

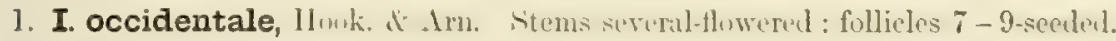
- But. Becch. 316.

Near Forest Hill, on light soil among shrubs (Bolander), (where Douglas found it is not stated). A glabrous herb, 6 to 10 inches, branching above, its delieate habit suggesting Thalidrum. Root of thickenerl fibres. Leaflets 4 to 8 lines long and cut into 2 or 3 broad, blunt lobes, glaucous beneath. Flowers 6 to 9 lines in diameter, white. Follicles or pods 6 lines long and 2 wide, flattened, obliquely pointed, transversely veined.

\section{AQUILEGIA, Tourn. Colcmbise.}

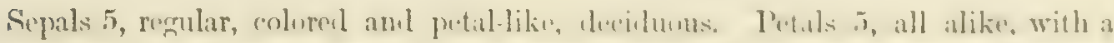
short, sprealing lip, and pruluevl backwarks into a long tubular spur. Stamens numerous, the outer ones long and exserted, the inner ones renlued te thin scoles.

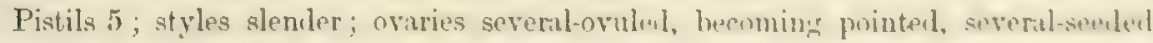


follicles in fruit. - Glabrous perennial branching herbs, with $2-3$-ternately compound leaves, the leaflets lobed. Flowers showy, terminating the bränches.

Many species have been described, which some authorities now reduce to half a dozen or less. They belong mostly to the cooler parts of the northern hemisphere.

1. A. truncata, Fisch. \& Mey. Stems 1 to 2 feet high : flowers 1 to $2 \frac{1}{2}$ inches in diameter, red tinged with orange or yellow: sepals spreading or reflexed : petals truncate, the very short limb not at all produced; spurs thick and blunt, 6 to 9 lines long. - Ind. Sem. Petrop. 1843, 8. Regel, Sert. Petrop. 1852, t. \& fol. 11. A. Canadensis, Torr. Pacif. R. Rep. iv. 62. A. Californica, Lindl.; Gray, Proc. Am. Acad. vii. 328. A. eximia, Van Houtte, Fl. Serres, 1857, t. 1188.

Shady places by streams. Very variable as to size, foliage, and color of flowers. A variety near New Idria has silvery margins to the leaves.

A. FORMOSA, Fisch., of Oregon and eastward, is very similar, but has the limb of the petals longer and produced upward on the outer side.

2. A. carulea, James. Stems 1 to 2 feet high, sparingly branched: leaflets usually sessile: flowers blue or white, very large, the sepals spreading 2 to 3 inches: petals longer than the stamens and style; spurs slender, and $1 \frac{1}{2}$ to 2 inches long. Long's Exped. ii. 15. A. leptocera, Nutt. Jour. Acad. Phil. vii. 9. A. macrantha, Hook. \& Arn. Bot. Beechey, 317, t. 72.

On wooded slopes in the Sierra Nevada at 8,000 to 12,000 feet (Brewer, Bolander), rare in this State, to the Rocky Mountains, where it is very abundant.

\section{DELPHINIUM, Tourn. LARKSPUR.}

Sepals 5, colored and petal-like, very irregular, the upper one prolonged backwards at the base into a long spur. Petals 2 to 4, irregular; when 4 the upper 2 developed backwards into a spur which is enclosed in the spurs of the calyx. Stamens many. Pistils 1 to 5 . Fruit of 1 to 5 dehiscent, many-seeded follicles. Erect herbs, with palmately-cleft, lobed, or dissected leaves, and racemose flowers.

The species of this genus are variable in so many directions that it is difficult to satisfactorily limit or define them. Accordingly, some authors recognize 100 or toore species, others 40 or less. They all belong to the north temperate zone. Our species are all perennials, with showy flowers, some of great beauty.

* Flowers blue, purple, or violet, or at least not red.

+ Mostly low: roots a cluster of thick Aleshy fibres or tubercles.

1. D. simplex, Dougl. Canescent throughout with a fine short somewhat woolly pubescence, rarely nearly glabrous: stem stout and strict, rather tall, 1 to $2 \frac{1}{2}$ feet high, leafy: leaves all much dissected, with linear obtuse lobes, on stout ereet petioles: racemes usually dense and many-flowered, the pedicels often short and nearly erect: flowers small, blue, varying to nearly white or yellowish; sepals 4 to 5 lines long, usually about equalling the stout straight spur, rarely much spreading: ovaries and capsule pubescent. - Hook. Fl. i. 25.

In the Coast Ranges from San Diego northward to Washington Territory and Idaho ; Knight's Ferry, Bigelow. Much resernbling $D$. azureum of the eastern plains, which differs in its less strict habit, and looser racemes of larger and more open flowers.

2. D. variegatum, Torr. \& Gray. Pubescent with straight spreading or often reflexed hairs, the pubescence above sometimes tomentose or rarely nearly wanting, sometimes tomentose throughout or short and appressed: stems 1 to 2 feet high, sparingly leafy: leaves all dissected with oblong or linear, obtuse or acutish lobes: flowers large, on long pedicels in a short open raceme, deep blue or rarely white; sepals broad, spreading, 6 to 10 lines long; the spur usually comparatively short and stout; upper petals not purple-veined (in dried specimens) : ovary and capsule pubescent. - Fl. i. 32. 
In the Coast Ranges from Santa Barbara (Brercer) to Punta de los Reyes, Biyclow. A frequent and showy species, varying in its colors. Distinguished from $D$. dccomum, to which it bas usually been referred, by its hairy ovaries, leaves all dissected, and greater pubescence.

D. Menziesix, DC., is a similar species, glabrous below, at least at the very base, pubescent above with spreading hairs, especially the inflorescence: flowers large, deep blue; the upper petals veined with purple; the spur long and slender. - From Puget Sound to Montana and the Blue Mountains of Oregon, apparently not entering Califormia. Reported also from Kotzebue Sound. The D. Mensicsii of the Colorado Flora is D. BICoLor, Nutt. (D. Menzicsii, var. Utahense, Watson, Bot. King Exp. 12), very similar and perhaps only a variety, but it has uniformly smaller flowers and is glabrous throughout (including the ovaries), or occasionally somerhat tomentose-pubescent.

3. D. decorum, Fisch. \& Mey. More or less pubescent with sprending hairs, but usually nearly glalorous: sten 6 to 15 inches hish : lower leaves 5 -lobed, straringly toothed, the upper with narrow linenx divisions: Howers larse, deep blue, long-pedicelled in an upen raceme; sepals broat, 6 to 9 lines long; spreading; spur usually long and narrow: ovary and capsule glabrous. - Torr. \& Gray, Fl, i. 661. D. patens, Benth. Pl. Hartw. 296.

Tar. Nevadense, Watsun. Scarcely differing hut in the smaller flowers and leaves often all linear-lobed. - D. Menziesii, Watson, I. c., excl. var.

In the Coast Ranges from Santa Barbara (Brewcer, and perhaps from San Diego, Parmy) to Mendocino Co. The variety is found in the central Sierra Nevada, and is frequent on the mountains and foot-hills of W. Nevada. Often glabrous excepting the ciliate bracts and somewhat villous flowers.

4. D. depauperatum, Nutt. Perhaps only a form of the last rariety, with the ovaries pubescent. Most of the specimens, however, are very slender and fewflowered, the lower leaves reniform in outline, 3-5-parted, the rather broad lobes entire or few-cleft. The pubescence of the infloreseence is usually straight and spreading. - Torr. \& Gray, Fl. i. 33. Watson, Bot. King Exp. 12.

In the Sierra Nevada from the hearl of the Kern (Rothrock) to the Blue Jountains, Oregon, and eastward in the mountains of Nevada (Walson).

\section{++ Stout and tall: root perennial but not tuberous.}

5. D. Californicum, Torr. it Gray. Stems nearly or quite smonth below: leaves laree, 3 to 5 cleft, the divisiuns variously lobed: racene strict, close-flewered above: pedicels and flowers densely velvety pubescent. - Torr. \& Gray, Fl. i. 31. D. exaltatum, Hook. \& Arn. Bot. Beechey, 317.

Dry soils near the const. Stems stout, 2 or more feet high. Lower leaves 3 to 5 inches in diameter, usually deeply 5-eleft, the divisions cuneate at base and laciniately toothed or lobed. Flowers commonly a light but dull blue, often more or less tinged with violet.

6. D. scopulorum, firiy. Stems tall, snooth or fullerulent : lower leaves on

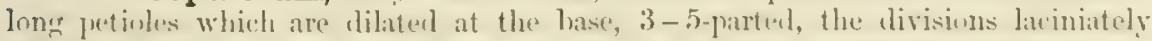
Jober, the lobes sharp-pointed: raceme rather striet: dluwer's springly pilose without. - Pl. Wright. ii. 9.

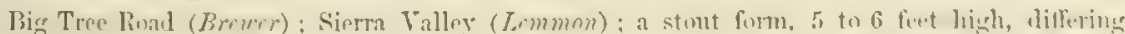
from that prevalent in the mountains of C'olumulo in the less narrowly divident leaves atme nearly glabrous inflorescence. It is still less like $D$, clatum, yar. (?) occidculalc, of the monntnins enst-

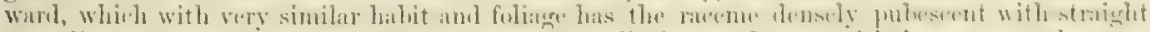

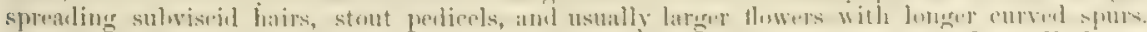
The pubescence in D. scopulomem is shorter, more woolly and appressed, and the pedicels are slender.

7. D. trollifolium, Gray. Glabrous thromethont or sliethely villous: leates

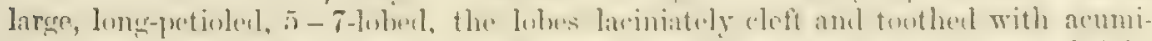

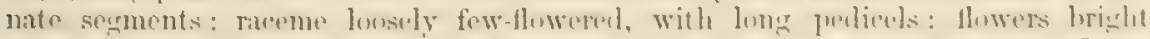

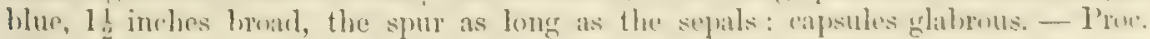
Am. Acad. viii. 275.

Oregon, Hall. Specimens collected by Kcllogg in Mendocino Co. seem referable to this speries. 
* * Flowers red.

8. D. nudicaule, Torr. \& Gray. Smooth or slightly villous : stem $\frac{1}{2}$ to $\dot{2}$ feet high or more: leaves mostly near the base of the stem, 1 to 3 inches in diameter, 3-5-lobed, the lobes more or less deeply 3-7-toothed with broad obtuse mucronulate segments: flowers 1 to $1 \frac{1}{4}$ inches long, including the straight spur, which is longer than the sepals, usually light scarlet with more or less of orange; sepals but little spreading; petals usually ciliate or somewhat villous: carpels pubescent or smooth. - Fl. i. $33 \& 661$; Hook. Bot. Mag. t. 5819.

Var. elatius, Thompson. The taller form with more leafy stems, the flowers with rather longer and more slender spurs than in the typical state. - Garden, iii. 477. D. sarcophyllum, Hook. \& Arn. Bot. Beechey, 317.

In the Coast Ranges from Mendocino Co. to San Francisco; Plumas Co., Mrs. Pulsifer Ames.

9. D. cardinale, Hook. Tall and stout, nearly glabrous: leaves large, 5-7lobed nearly to the base, the divisions deeply 3-5-cleft with narrow long-acuminate segments: flowers as in the last, but larger and more open, bright scarlet with yellow centre, petals somewhat hairy: carpels smooth. - Bot. Mag. t. 4887; Torrey, Bot. Mex. Bound. 30, t. 2. D. coccineum, Torrey, Pacif. R. Rep. iv. 62.

Apparently confined to the mountains of S. California; Los Angeles (Wallace) to San Diego.

10. ACONITUM, Tourn. Monkshood.

Sepals 5, colored and petal-like, very irregular ; the upper one arched into a hood or helmet. Petals 2 to 5 ; the upper 2 with long claws and irregular spur-like blades concealed within the hood; the lower 3 either very minute or obsolete. Pistils 3 to 5 . Fruit of 3 to 5 dehiscent, many-seeded follicles. - Herbs with palmatelylobed leaves.

Species 18 , mostly belonging to the mountains of the Northern Hemisphere. Some (all ?) of them are poisonous.

1. A. Fischeri, Reichenb. Leaves palmately 3-5-cleft ; the divisions broadly cuneated, and laciniately toothed or cut into acute lobes : flowers in a loose terminal raceme, often somewhat panicled: follicles usually 3. - Ill. Sp. Aconiti Gen. fol. i. 22. A. nasutum, Hook. Fl. Bor.-An. I., 26. A. Columbiunum, Nutt.; 'Torr. \& Gray, Fl. i. 34.

Moist places in the Coast Ranges north of Clear Lake, the Sierra Nevada at 4 to 8,000 feet ; also the Rocky Mountains, Alaska, Kamtschatka, and Siberia. Stems smooth below and either smooth or with short pubescence above. Leave 3 to 5 inches in diameter. Specimens from near the coast are identical with the Siberian plant, the stems 2 to $3 \mathrm{f}$ (et high, sometimes weak at the base, either smooth or sparingly pubescent above, the flowers blue or purple. In the Sierra Nevada and eastward a larger form occurs, 3 to 6 feet high, more pubescent above, the sepals larger and pale blue or white, and the petals smaller. Rather rare.

\section{ACT声A, Linn. Baneberry.}

Sepals 4 to 6 , nearly equal, petal-like, falling off early. Petals 4 to 10 , small. Stamens numerous. Pistils single; stigma sessile, 2-lobed. Fruit a many-seeded berry. Seeds smooth, flattened, packed horizontally in 2 rows. - Perennial herbs, with 2-3-ternately compound leaves. Root usually tuberous or thickened. Flowers in a terminal short raceme.

Species perhaps 2, belonging to the cooler regions of the Northern Hemisphere.

1. A. spicata, Linn., var. arguta, Torr. Fruit either white or red, in a loose more elongated raceme. - A. arguta, Nutt.; Torr. \& Gray, Fl. i. 35.

Shady ravines of the Coast Ranges north of San Francisco. Rare in this State, but a widely spread species, extending north to Alaska, east to New England and Canada; also to Japan; Siberia, and Northern Europe. A smooth herb with graceful habit, 1 to 2 feet high. The stem 
bears one or two leaves which are really ternately decompound, but very often each terminal division is stalked and again ternately divided, while the lateral ones are sessile and only tootlied or lobed, thus making the last division pinnately j-fuliolate. Leatlets 1 to 2 inclues long, doubly or unequally serrate. In our variety the raceme is short and eapitate in flower, becoming 3 to 5 inches long in fruit; the pedicels slender, the lower ones scattered and 9 to 16 lines long. Fruit either white or red.

\section{P无ONIA, Linn.}

Sepals 5, herbaceous, persistent, imbricated in the bud. Petals 5 to 10. Stamens numerous, inserted on a fleshy disk. Pistils 2 to 5 . Fruit of 2 to 5 leathery, several-seeled follicles. - Perennial herbs with ternately or pinnately compound leaves and showy flowers.

Species 3 to 6 , according to the different riews of different authorities, all belonging to the Northern Henisprere. Several oriental species (or at least varieties) are in conmon cultivation for their ornamental flowers.

1. P. Brownii, Dougl. Leaves thick, 1-2-ternately compound, the leaflets ternately and pinnately lobed: follicles 3 to 5. - Hook. Fl. Bor.-Am, i, 27. P. Californica, Nutt.; Torr. \& Gray, Fl. i. 41.

San Bernardino to Vancouver and Western Utah, but rare east of the Sierra Nevada. Stems 10 to 18 inches high, smooth, striate, erect when growing but gradually bending over until ruaturity, when the follicles rest on the ground. Leaves glancous benenth, either glaucous or glabrous above. Sepals green, sometimes quite unequal in size. Petals scarcely larger than the sepals, thick and leathery, dull, dark red. Follicles very leathery, smooth, erect, 1 to $1 \frac{1}{2}$ inches long. This plant endures a great range of station and climate, from wet to very dry soils and from the hot plains of Southern California to near the confines of perpetual snow on the mountains.

\section{CROSSOSOMA, Nutt.}

Sepals 5, orbicular, imbricated in the bud, unequal, persistent, scariously margined, united at base into a short turbinate tube. Petals 5 , not clawed. Stamens numerous (12 $\left.\left.t_{1}\right) 30\right)$, inserted with the petals in 2 or 3 irregular series upon the simewhat thickened base of the ealyx, persistent: anthers attached dorsally a little alove the base, dehiseing lungitudinally down the sides. Carpels 2 to 6 , distinct, sessile upon a short stipe, coriaceous, fullicular, many-seeded. Seels in 2 rows, with a large fringed arillus, globose-reniform, black ant shinine : embryo strungly enrvel in the thick fleshy albumen and nearly as long, the narrowly obloug cotylentons excedling the rimlicle. - Simoth shruhs with alternate simple entire mucronulate leaves, and solitary flowers terminating the branchlets.

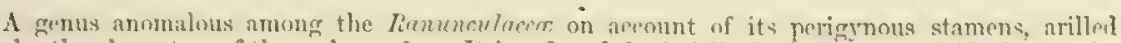
seeds, the churacters of the embryo, \&c. It is referred doubtfully by Bentham and Hooker to the Dilleniacca. The following are the only known species.

1. C. Californicum, Nutt. I stout diffuse shruh, 4 fert high, with whitish woml and gray bitter bark: leaves oblong, 1 to 3 inchus lomer attenuate to a very

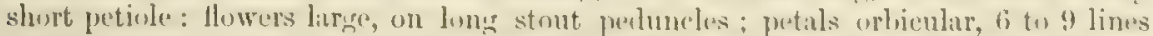

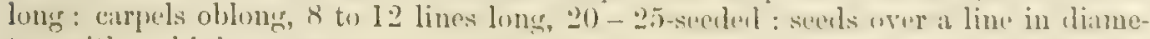
ter, with a shining crustaceons texta, covereal with the hown fring of the arillus. - Pl. Gamb. 150, t. 22 ; Torr. Pacif. R. Rep. iv. t. 1, fig. 1, only.

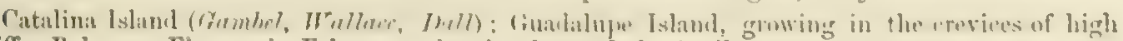
eliffs, Palmer. Flowers in February, ripening its seeds in April ; stamens 25 to 30.

2. C. Bigelovii, 1 atson. Low and more slender: leaves latucuns, 3 to 6 lines

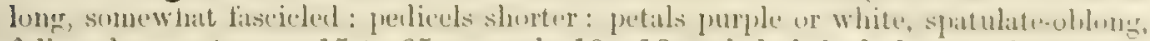
6 lines long: stamens 15 to 25 : carpels $10-12$-secled, $\frac{1}{2}$ inch long. - Proc. Am. Acad. xi. 122. C. Californicum, Torr. in Pacif. R. Rep. iv. 63, t. 1, excl. fig. 1.

Cañons near the mouth of Bill Williams River (Bigelono); east of Så Beranalino, Parry. 


\section{ORDER II. BERBERIDACE两。}

Shrubs or herbs, mostly with compound or divided alternate leaves, and no stipules; the flowers all perfect, with the parts distinct and hypogynous, remarkable for having the bracts, sepals, petals, and stamens (in ours six) before each other instead of alternating (an anomaly which comes from there being two whorls of each, three pieces in a whorl), and the 2-celled anthers opening by uplifted valves, hinged at the top. - Calyx and corolla imbricated in the bud, deciduous, both usually colored. Pistil one, simple, i. e. of a single earpel: style short or none. Seeds anatropous, with a small or minute embryo in copious firm-fleshy or horny albumen. - Achlys is a most exceptional genus, having no calyx nor corolla, and 9 or more stamens.

A small order of a dozen genera (and half as many more of the Lardizabulea appended to it, not here taken into view), of which only Berber is is numerans in species, most of the others having only one or two species each, chiefly natives of temperate regions, and of the northern hemisphere, with a few in S. America. The juice is watery, but the inner bark and wood of the Barberry yellow. No active properties, except in Podophyllum of the Atlantic States, the root of which yields podophyllin, a powerful cathartic. The fruits, when berries, are innocent and edible, but sometimes acid.

* Flowers complete : stamens 6, mostly short.

1. Berberis. Flowers yellow, in clustered racemes. Fruit a few-seeded berry. Shrubs with rigid leaves, in ours odd-pinnate.

2. Vancouveria. Flowers whitish, in a raceme or panicle. Fruit a follicle. Herb, with ternately compound leaves all radical.

* * Flowers naked : stamens 9 or more, slender.

3. Achlys. Flowers spicate on a scape, without bracts, sepals, or petals. Herb, with only radical 3-parted leaves.

\section{BERBERIS, Linn.}

Sepals 6 , petal-like, with 3 or 6 closely appressed bractlets in 1 or 2 rows. Petals 6, opposite the sepals, usually 2-glandular at base. Stamens 6. Carpel 1: stigma circular and peltate. Fruit a berry, with 1 to 3 erect seeds. - Smooth shrubs with yellow wood, pinnate or fascicled simple leaves, yellow flowers in clustered bracteate racemes, and oblong or globose acid berries.

A genus of about 50 species, belonging to both continents, but largely S. American. In Bcrboris proper, of which B. vulgaris, Linn., the common Burbcrmy, is the type, the primary leaves are reduced to mere spines, in the axils of which are fascicles of actual simple leaves with jointed petioles. All our species belong to the section Mahonia, Nutt., which has evergreen unequally pinnate leaves, sessile spinulosely dentate leaflets, and dark blue globose berries.

\section{* Leaflets pinnately veined.}

1. B. repens, Lindl. A low somewhat procumbent shrub, less than a foot high : leaflets 3 to 7 , ovate, acute, not acuminate, 1 to 21 inches long, not shiny aboxe: racemes few, terminating the stems, 1 to $1 \frac{1}{2}$ inclies long. - Bot. Reg. t. 1176. B. Aquifolium, Pursh, mainly, and of numerous authors.

"Throughout the State," extending nortliward to British Columbia and eastward to Colorado and New Mexico.

2. B. Aquifolium, Pursh. A shrub 2 to 6 feet high: leaflets usually 7, but often more, the lower pair distant from the stem, ovate to oblong-lanceolate, $1 \frac{1}{2}$ to 4 inches long, acnminate, green and shining above, sinuately dentate with numerous spinose teeth: racemes $1 \frac{1}{2}$ to 2 inches long, clustered chiefly in the subterminal axils; fruit nearly globose. - Lindl. Bot. Reg. t. 1425. 
Frequent in Oregon and northward, where it is known as the "Oregon Cirape," and ripurtill sonthward in the coast ranges even to Monterey. Pursh's description and figure belong mainly to $B$. repens.

3. B. pinnata, Lag. Tery much like tha last species, but the leaves more

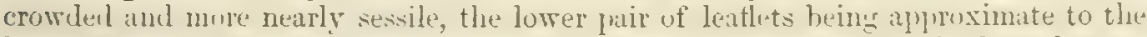
hase of the petiole ; leaflets usually 5 to 7 : ricemes more freyuestly lateral upon the branches; fruit oblong-ovoid, 4 lines long. - Gen. \& Spec. 14. Mahonia fascicularis, DC. ; Deless. Icon. Sel. 2. 2, t. 3.

Hills about San Francisco Bay and southward to San Diego, thence east to New Mrexico. Fruit fleasint to the taste and known to the Mexiens as Lrür wmarilla. There has always been much confusion and is still some uneertainty respecting this species and its allies. Lagasea's

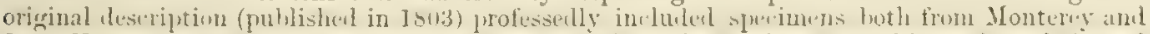

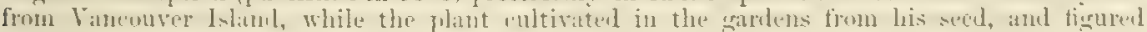
under this name, appears to have been wholly the Oregon form, which Pursh afterwards included with the low $B$. repens in his description and figure of $B$. Aquifolium. Humbolut and Bonpland afterward applied the nume $B$. pinnala to a Mexican plant, figured by them, and DeCandolle at length included all, the Mexican, Californian, and Oregon together, under the name Mahonia fascicularis. The question of synnymy is most conveniently solved by retaining what has become the ordinary application of the mames, $B$. fuscicularis being limaited to the Mexican species, which seems distinguishable from the Californian B. pinnate by its more numerous, more ncuminate, and less shining leallets.

\section{* Leaflets palmately nerved.}

4. B. nervosa, Purh. Stems simple, but a few inches high; petioles and peduncles springing from the apex, acempanied by dry glumaceus righlly acuminate bracts: leares 1 to 2 feet loms of 11 to 17 ovite acminate leatlets: ratcemes elongated; parlicels shrit : fruit larger than in the preceling species, 3 to 4 lines in diameter, - Fl. 219, t. 5, excluding flowers. Hook. Bot. Mag, t. 3949. Mahonia glumacea, DC.

Near the coast from Monterey to Vancouver Island.

\section{VANCOUVERIA, Morren \& Decaisne.}

Sepals 6 , obovate, reflexed, caducous with the 6 to 9 oblong membranaceous lraretlets. Potals 6 , shurter than the sepals and oplosite them, linear-spatulate, nectary-like, reflexed. Stamens 6. Carpel 1, the stigma slightly dilated, cupshaped: ovules 10 or less, in 2 rows upon the ventral suture. Capsule debiscing

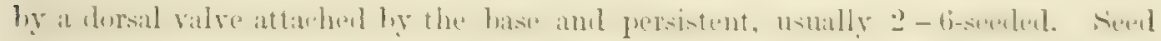

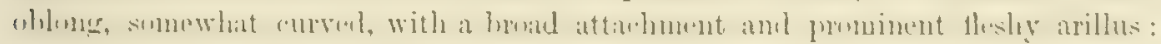

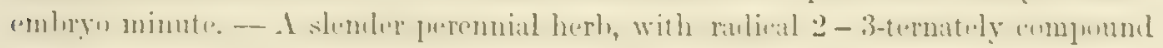
leaves, and white flowers in au open paniculate raceme upon a naked scape.

A genus of a single species, seareely separable from Epinediun of the Old World.

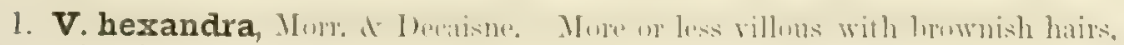
1 to 2 feet high: root creeping: leares diffuse, long-petioler ; the leatlets 1 to 2

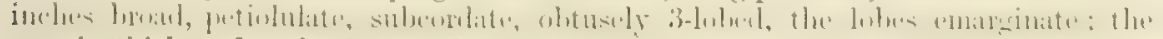
margin thickened and often undulate: scape exceeding the leaves: peclicels elon-

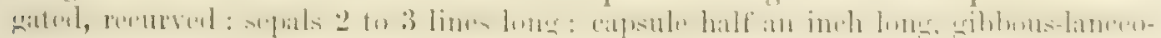
late, with a slender benk : arillus 2-loberl, more than half covering the seed. - Ann. Sei. Nat. 2 ser. ii. 351. Epimedium hexandrum, Hook. Fl. i. 31, t. 13.

Shady woods near the const from Santa Cruz to Vancouver Islund. The characters of the fruit and seed are those of Epimalium.

\section{ACHLYS, DC.}

Sepals and petals none. Stamens 9 , in 3 rows; filaments slender, the outer

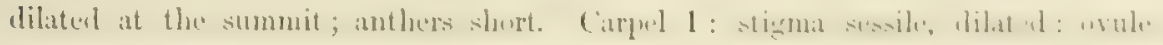


solitary, erect. Fruit pulpy, becoming dry, indehiscent, reniform, the rounded dorsal portion subcartilaginous, the ventral side strongly concave, membranaceous, with a fleshy central ridge. Seed erect, straight : embryo very small. - A smooth perennial herb, with radical trifoliolate leaves, the flowers crowded in a naked spilie terminating the scape.

A second species in Japan closely resembles the following.

1. A. triphylla, DC. Root ereeping : leaf on petioles a foot long or more, solitary from a scaly base, the leaflets broadly euneate, 3 to 5 inches long, palmately nerved, the outer margin irregularly and coarsely sinuate: scape solitary, equalling the leaf; spike 2 to 3 inches long; flowers small, white, fragrant : fruit 2 lines long. Syst. ii. 35. Hook. Fl. i. 30, t. 12.

Shady woods near Mendocino (Bolander) and northward to Vancouver Island. Sometimes known as May-Apple.

\section{ORDER III. NYMPH画ACE再.}

Aquatic perennial herbs, with horizontal trunk-like rootstocks or sometimes tubers, which have rather an endogenous than exogenous internal structure; the leaves peltate or deeply cordate and involute from both margins in the bud; solitary axillary perfect Howers on long peduncles; ovules remarkable for being on the back or sides of the carpels (instead of the ventral edge); embryo small at base of fleshy albumen enclosed in a fleshy bag! Stamens numerous. - Comprises almost half as many suborders as genera.

The Water-Lilies, and their relatives, of few species and wide geographical dispersion, comprise 8 genera under three suborders. The Water-Shield is the type of the first, Water-Lilies of the second, and the Nelumbium or Indian Lotus, the sole genus of the third (Nelumbonece), which differs from the character of the rest in the great embryo without albumen, and the nut-like earpels separately immersed in hollows of a top-shaped receptacle. To this belongs the Nelumbo of Eastern America and the Indian Lotus or Sacred Bean of Asia. There are no true Water-Lilies (Nymphoea) in North America west of the Mississippi region, but one Nuphar reaches California; where also the Water-Shield is a solitary representative of the first suborder, Cabombece. The two genera are briefly contrasted thus :

1. Brasenia. Pistils 4 to 18 in a cluster, pod-like, 1 -2-seeded. Leaves on slender stems, entíre, centrally peltate.

2. Nuphar. Pistil many-celled, many-seeded, free, Leaves all from the rootstock, deeply cordate.

\section{BRASENIA, Schreber. WATER-SHIELD.}

Sepals and petals nearly alike, narrowly oblong, dull purple, bypogynous, each 3 or sometimes 4, persistent. Stamens 12 to 18 , hypogynous: filaments slender: anthers oblong-linear. Carpels 4 to 18, distinct, tipped with a linear and one-sided large stigma, ripening into a kind of indehiscent 1 -2-seeded pods. $-\mathbf{A}$ single species.

1. B. peltata, Pursh. Leaves floating ( 2 to 4 inches long), elliptical and centrally peltate on the slender petioles, which are alternate on the filiform ascending stems, bright green above, reddish-brown beneath: flower small, half an inch long. - Gray, Gen. Ill. t. 39.

In Clear Lake (Bolander) and Pit River (Brewer) ; thence to Puget Sound. Known at few Pacific stations, while from Canada to Texas it abounds, extending to Cuba. It also occurs in Japan, Eastern India, Australia, and at one known station in tropical Western Africa! The stems and stalks are coated with a clear jelly. The "tuberous" rootstocks are collected by the Californian Indians for food. 


\section{NUPHAR, Smith. YelLow PoND-LiLT.}

Sepals 5 to 12, thick, ronndish, persistent, free, colored (generally yellow) within, partly green outside. Petals and stamens short-and numerous, hypogynous, densely crowled around the ovary, at length recurving, persistent; the former sometimes resembling sterile stamens, sometimes more dilated and conspicuous, but always small. Filament very short: anther truncate at aper, the two linear cells adnate, introrse. Ovary oblong or ovate, 8-20-celled, its truncate top occupied by the 8 -20-radiate stigma, ripening (usually above water) into an ovoid or flask-shaped indehiscent fruit with a firm rind and a fleslyy or pulpy interiur; the cells wanyseeded. No arillus to the oval seeds. - Herbs of shallow waters ( 4 or 5 species of the northern temperate zone), sending up large and mostly rather leathery cordate leaves (either upright or floating) and stout 1 -flowered peduncles from a long and thick trunk-like creeping rootstock in the mul beneath: flowering all summer.

1. N. polysepalum, Engrelm. Larger than the Atlantic 1 . advent: leaves 6 to 12 inches long and three fourths as wide, rounded alove, cleeply cordate at base: sepals 8 to 12 : petals 12 to 18 , dilated and unlike the stamens, vellow, often tinged with red: fruit globular, 2 inches long or less. - Trans. St. Louis Acad. ii. 282. N. advena, Newberry in Pacif. R. Rep. vi. 67.

Rare south of Mt. Shasta, more abundant thence to British Columbia and east to and beyond the Rocky Mountains. Klamath Marsh is half covered with the floating leaves, and the large seeds form an important article of food among the Indians, who collect great quantities for winter use. "The seed tastes like that of Brooni-Com, and is apparently very nutritious." This species has the largest fruit and fowers of any of the genus, some of the flowers being 5 inches in diameter and borue ou seapes 1 or 2 feet high. The leaves are floating if there be sufficient water, otherwise erect.

\section{ORDER IV. SARRACENIACE正.}

Bog-plants with pitcher-shaped or tubular and hooded leaves, and perfect polyandrous hypogynous flowers, the persistent sepals, petals, and cells of the ovary each 5 (with one exception). Fruit a many-seeded capsule. Embryo small in lleshy alhumen. - Represented in the Atluntic Lnited stattes by several species of Surrecenie, in the muntains of Cuima ly the little-knuwn apetalus Ueliemphora, in California by tho peculiar genus,

\section{DARLINGTONIA, Torr.}

Calyx without bracts, of 5 imbricaterl narrowly oblonge sepals, persistent. Potals 5, ovate-(b)lone, erect, with a small ovate tip answering to the hlule, and a larer ohlonge lower portion answering to the claw. Stamens 12 to 15 in a single row :

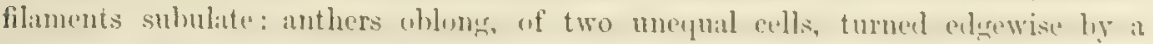
twisting of the likment, so that the smaller cell finces the ovary. (Jvary somexhat

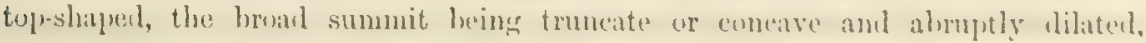

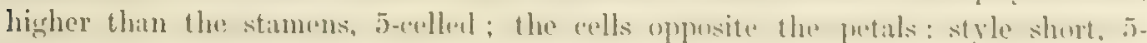

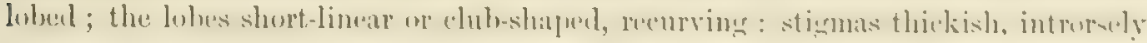

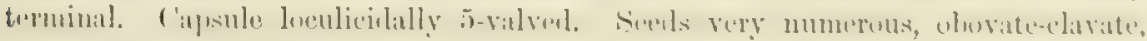
thickly beset with soft slender projections. $-\mathbf{A}$ single species.

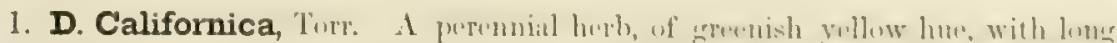

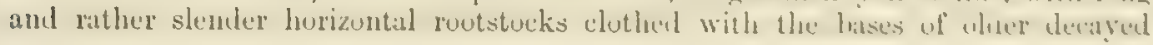


leaves; these tubular, gradually enlarging upwards to a vaulted ventricose hood, which terminates in a 2 -forked deflexed appendage under which is the contracted rounded orifice, the ventral edge winged: scape bearing several membranous scaly bracts, the upper ones crowded near the nodding purplish flower. - Smithsonian Contrib. vi. 4, t. 1, \& Bot. Wilkes Exped. 221.

Mountain swamps and borders of brooks, at 1,000 to 6,000 feet, from Truckee Pass to the borders of Oregon; first collected near Mount Shasta, by $W$. D. Brackenvidge of the Wilkes Exploring Expedition party, with foliage and vestiges of fruit, and next in blossom by $D r$. $G$. $W$. Hulse. The "pitchers" are 18 to 34 inches high, and an inch or less in diameter, except near the top, tapering downward, and spirally twisted about half a revolution, the twist being most often to the left. Expanding near the summit it is vaulted into an inflated sac or hood 2 to 4 inches across, with a circular opening an inch or less in diameter on the under side. The dome of this hood is spotted with large thin translucent areolæ, which are usually colored somewhat orange or yellow. A wing 2 to 4 lines wide runs along the inner side of the pitcher, clasping the rootstock below and entering the orifice above. At the upper and outer edge of the orifice, a blade or appendage arises which is narrow at its base, but rapidly widens and divides into two equal and divergent lobes. It is something like a fish-tail in shape, sureading 3 or 4 inches, pointing downward, and beset with short and sharp stiff hairs, all pointing toward the orifice, the lobes twisted outward about half a revolution. The green of this blade is variously blotehed with red and yellow. The interior of the pitcher is polished above, but the lower part is beset with stiff sharp slender transparent hairs pointing downwards at a sharp angle. Within and about the orifice and on the colored "fish-tail" there is a sweet secretion very attractive to insects. A line of this honey has sometimes been found to extend along the wing from the orifice down to the ground. The base of the pitcher contains a clear secreted liquid. This whole contrivance constitutes one of the most curious natural fly-traps known. An insect roaming over the outside soon finds the wing like a fence to guide him to the orifice, and a line of honey enticing him that way. The blade at the opposite side is mottled and gayly colored to catch the eye and fancy of the flying insect. The lobes are so twisted that he may alight on the outside and by travelling along the blade find himself within. It is a broad and open road at first, curving and narrowing as the two lobes converge, and leading directly into the orifice. Moreover, the sharp bristles in the path all pointing one way make that the natural direction to travel, and the honey sweetens the path where the dangerous opening yawns above the narrowed way. The "honey pastures" just within the orifice now tempt him, and are next visited. When satiated and he would leave, the translucent areolæ above, like numerous lighted windows in the roof, entice him away from the darker door in the floor by which he entered. The captive sees no way of escape, and from the shape of the pitcher and the needle-like hairs pointing ever downwards, his destruction is sure. By this elaborate contrivance he was first attracted to the plant, then enticed within, then imprisoned and ultimately consigned to the lake in the bottom of the pit. From the experiments of $D r$. Hooker, and from some interesting homologies, it is not difficult to believe that this liquid digests the insect for the nourishment of the plant. The fragmentary remains of dead insects in great variety are always found in the mature healthy leaves, often filling the tube to the height of several incles and tainting the air with their decay. From the observations of the entomologist Edwards, it seems that more species of flies are caught than of other insects. But bees, hornets, butterflies, dragon-flies, beetles, grasshoppers, \&c., and even snails are entrapped. For fuller details of the behavior of this "insectivorous plant," see Proc. Am. Assoc. 1874, B, 64, and Proc. Calif. Acad. 1875. The secretion upon the edge of the wing was detected by Mrs. 7i.. M. Austin, of Butterfly Valley.

The plant is gregarious, and the hoods and blades are strikingly conspicuous when seen in the bright sunshine of their places-of growth, strongly suggesting the unromantic name Calf's Head, by which the local mountaineers know it.

\section{Order V. PAPAVERACE画.}

Herbaceous plants, in one instance shrubby, usually with milky or orange-yellow juice, of narcotic or also acrid properties; the flowers perfect, with sepals, petals, and stamens hypogynous and not in fives; the former 2 or 3 and caducous (falling when the corolla opens) ; the petals twice as many, in two sets, and early deciduous; the stamens indefinite ; the pistil with a 1-celled ovary with parietal placentæ, in fruit capsular; the seeds numerous or several, anatropous, with a minute embryo in copious albumen. - Leaves mostly alternate, destitute of stipules. Peduncles 
usually 1 -flowered and the flower-bud drooping before expansion. Petals imbricaterl and commonly crumpled in the bud. Valves of the capsule in most cases separating from the slender placentre, which remain as a kind of frame. - Dendromecon is the sole shrublyy plant of the orler. Plutystemon is exceptiunal in haring the sereral carpels all distinct, or at least early separating, and formiug as many turulose porls, and the upper leaves are disposed to be opposite or in whorls. Eschscholtzia has the two sepals united into a calyptra which falls off whole, atnd the juice is colorless ; it is nearly so in Romneya, in which the capsule is streral-celled, more truly than in a poppy, by the placentre reaching the centre. And Arctomecon has persistent petals!

An order of 17 genera and alout 50 speries, mostly inhabitants of the temperate and warm parts of the northern hemisphere. Many have showy flowers, and are cultivated for ormament. Opium is derived from the milky juice of the poppy (mostly $P$. somniforum, Linn.), and several other species have reputed medicinal value.

Papaver sominiferca, Limn., extensively cultivated for opium, and familiar in gardens as an ommental annual, is not unlikely to oceur spontaneously in some places. P. RHG.As, Linn., the Com Poppy of Europe, might also have been expected in grain-fields, but it has not been reported. The genus is known by the radiate sessile crown of stigmas, forming a cap over the summit of the ovary and capsule, the latter opening only by pores under the margin of the crown.

* Herbs : sepals 2 or 3 and distinct.

+ Annuals, with entire leaves, the uppermost opposite or whorled.

1. Platystemon. Filaments very broad. Carpels few to many, in a circle, distinct or soon becoming 50, forming as many slender torulose pods, tipped with the linear stigmas.

2. Platystigma. Filaments slightly dilated or fliform. Ovary with 3 placentre, tipped with 3 broad and flat or linear stigmas, becoming a 3 -valved capsule.

$$
++ \text { Perennials, with lobed or toothed leaves, all alternate. }
$$

3. Romneya. Sepals 3, winged. Stigmas several, oblong. Capsule bristly, several-celled, several-valved trom the top. Leaves divided.

4. Arctomecon. Sepals mostly 2 : petals 4, persistent. Stigma thickish, 4-6-lobed. Capsule smooth, 1-celled, 4-6-valved at the top. Leaves few-toothed.

+++ Annuals, with lobed or divided leaves. (Papaver would belong here.)

5. Argemone. Stigma 3-4-lobed, almost sessile. Capsule bristiy or prickly. Leaves simple, prickly-toothed.

6. Meconopsis. Stigma 4-8-lobed on a club-shaped style. Capsule unarmed and smooth. Leaves pinnately divided, unarned.

* * Shrub with entire leaves or nearly so.

7. Dendromecon. Stigmas 2, short and erect on a short style. Capsule linear, grooved, 2-vulved.

- * Annual herbs : sepals completely nnited into a zarrow pointed cap (ealyptra), which falls off entire from a dilated top-shaped receptacle.

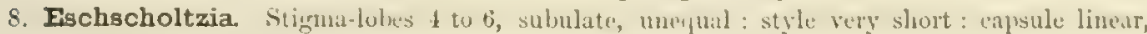
grooved, 2-valved.

\section{PLATYSTEMON, Benth.}

Supals 3. Petals 6. Stamens many, with thattened filaments and linear anthers.

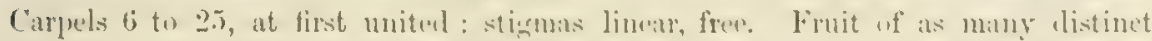

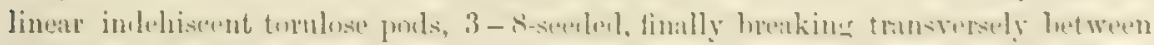

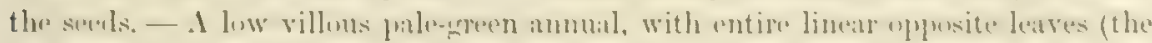
lower alternate), and long-peduncled yellow flowers.

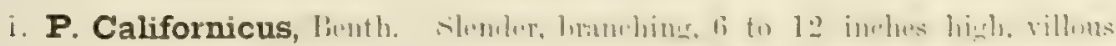
with sprealing hairs: leaves 2 to 4 inches long, sessile or clasping, brondly linear, obtuse: peduncles 3 to 8 lines long, erect: the sepals villous; petals pale yellow

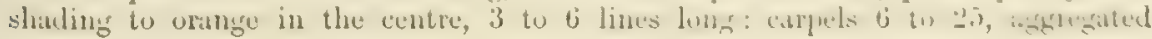


into an oblong head, smooth or somewhat hairy, 5 to 10 lines long, beaked with the linear persistent stigmas, the 1-seeded divisions a line long: seeds smooth. Trans. Hort. Soc. 2 ser. 1. 405. Hook. Bot. Mag. t. 3579 \& 3750.

Very common in early spring on the lower hills and in the valleys from Mendocino County to S. California, and also eastward through Arizona to S. Utah. Sometimes ealled Cream-Cups.

\section{PLATYSTIGMA, Benth.}

Sepals 3 (rarely 2). Petals 4 to 6 . Stamens few to many, with narrow filaments and oblong or linear-oblong anthers. Ovary 3-angled, oblong or linear: stigmas 3, distinct, ovate to linear. Capsule 1-celled, 3-valved, dehiscent to the base, manyseeded. Seeds small, smooth and shining. - Low slender annuals, resembling Platystemon in habit, with pale-green entire opposite or verticillate leaves, and long-peduncled pale-yellow flowers. Only the following species.

* Capsule ovoid-oblong: stamens many; anthers linear-oblong; filaments dilated: stigmas broad: villous, short-stemmed. - Puatrstigma proper.

1. P. lineare, Benth. Somewhat villous with spreading hairs, 6 to 12 inches high, the stem usually very short and leafy: leaves linear, 1 to 3 inches long: peduncles erect: flowers an inch or less in diameter: capsule half an inch long. Traus. Hort. Soc. 2 ser. i. 407. Hook. Bot. Mag. t. 3575.

Valleys and low bills from Salinas Valley to Oregon ; common in early spring.

* Capsule linear: stamens few; anthers oblong; filaments filiform: stigmas narrow: glabrous, long-stemmed. - Meconeli. (Meconella, Nutt.)

2. P. Californicum, Benth. \& Hook. Tery slender, with long-jointed dichotomous stems: leaves ovate-spatulate to oblanceolate or the upper ones linear, $\frac{1}{2}$ to 1 inch long, acute: flowers 3 to 12 lines broad: stamens 10 to 12 : capsule marrowly linear, 9 to 15 lines long. - Gen. Pl. i. 51. Meconella Californica, Torr. in Frem. Rep. 312.

Central California, San Mateo to Sonoma counties, and eastward to the foot-hills of the Sierra Nevada.

P. OReganum, Benth. \& Hook, a smaller plant with smaller flowers, 4 to 6 stamens, and shorter capsules, inhabiting Oregon and Washington Territory, may be looked for in Northern California.

\section{ROMNEYA, Harrey.}

Sepals 3, with a broad membranaceous dorsal wing. Petals 6. Stamens very numerous, with filiform filaments thickened above, and oblong anthers. Ovary oblong, densely setose, more or less completely several-celled by the intrusion of the many-ovuled placentas : stigmas free, oblong, fleshy. Capsule completely 7-11celled, dehiscing to the middle, the valves separating by their margins from the firm persistent placentas. Seeds numerous, finely tuberculate. - A smooth stout perennial, with colorless bitter juice, pinnately cut or divided alternate leaves, and very large white flowers.

1. R. Coulteri, Harv. Leaves glaucous, thickish, petioled, 3 to 5 inches long, the lower ones pinnatifid, the upper ones pimnately eut or toothed; the petioles and margins often sparingly ciliate with rigid spinose bristles: flowers white, sometimes nearly 6 inches in diameter; petals broadly obovate: filaments half an inch long, purple at base : eapsule oblong, 1 to $1 \frac{1}{2}$ inches long, obscurely many-angled, hispid with appressed bristles and crowned with the persistent stigmas : seeds black, a line or less long. - Lond. Jour. Bot. iv. 74, t. 3. 
Borders of streams near' San Diego. The plant is probably several feet high, the stems erect, branching and flexuous, but whetlier entirely herbaceous or half woody at the base has not been definitely stated.

\section{ARCTOMECON, Torrey.}

Sepals mostly 2. Petals 4, persistent. Stamens numerous, with filaments slightly thickened upward, and linear anthers. Ovary smuth, 4 -6-carpelled, with nerve-like placentas, rather few-oruled: style very short: stigmas 4 to 6 , short and thick. Capsule obovoil, l:rellerl, $4-6$-angled, dehiscent above, the 4 to 6 valves separating from the tirm persistent plarental ribs. Seeds fer, shining, very finely lined longitudinally. - A low somewhat hairy biennial or perennial; with alternate leaves, few-toothed at the apex, and rather large white flowers.

1. A. Californicum, Torr. Erect am somewhat cespitose, the stems 4 to 12 inches high, more or less villous below with long bristly hairs, nearly glabrous above: leaves long-cuneate or oblanceolate, 1 to 2 inches long, 3 -several-toothed (sometimes lobed) at the apex, or the upper entire, crowded at base; the teeth bristle-tipued : jetals oblung-oril to orbicular, 6 to 10 lines long: carsule 3 to 5 lines lung: seerls nearly straight, 1t lines lung. - Frem. Rey. 312, t. 2. Parry, Am. Naturalist, ix. 139.

Discovered by Fremont on the banks of a creek in sterile soil near the southeastern border of the State, but probably in Nevada. It has since beeu collected only by Parry in S. Utah.

\section{ARGEMONE, Linn.}

Sepals 2 or 3, spinosely beaked. Petals 4 to 6 . Stamens numerous, with filiform filaments and linear anthers. "Wary oblong, with 3 to 6 uerve-like placentas: stigmas nearly sessile, dilatul, muliating. Capsule ollung or ovoil, prirkly, 1-celled, opening at the tol, the 3 to 6 valves separating from the firm parietal ribs. Seeds

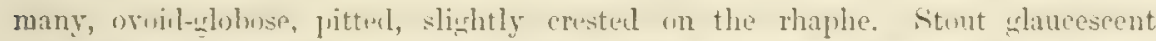
anmuls; with sinuately pinnatifil prickly-touthed leaves, large white or yellow short-pedicelled flowers, and yellow juice.

A genus of about half a dozen species, all natives of the warmer parts of America.

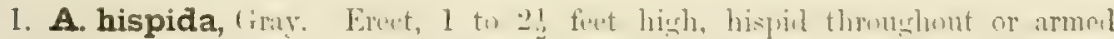
with rigil bristles or jrickles: leaves 3 to 6 inches long, tho lower attenuate to a winged petiole, the upper sessilo or auriculate-clasping: flowers white, 2 to 4

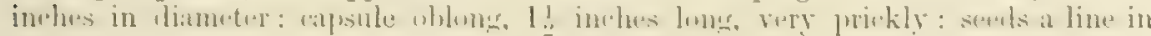
dimeter.-Pl. Fendl. 5. A. munita, Dumand \& Hilgard, Pacif. R. Rep. v. 5, t. 1. A. Mexicana, var. hispida, Torrey, Bot. Mrex. Bound, 31.

Dry hillsides and valleys through Central California, and enstward to Colorado and New Mexico. In Southern California it is known as Chicrlole. The foliage is pale but not spotted.

A. Mrxicana, Linn., is very similar but is smoother, the leaves aro blotcher with white, and the flowers are usually yellow. It is native from Texas and Northern Mexico to Central America, but as a weed has spread to ahnost all warm countries and may have reached Southern California.

\section{MECONOPSIS, Viguier.}

Sepals 2. Petals t. Stamens numerons, with filiform filaments amb whinnes anthers. Ovary 1-celled; placentas 4 to 8 , nerve-like or somewhat intruded: style

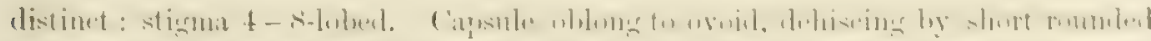

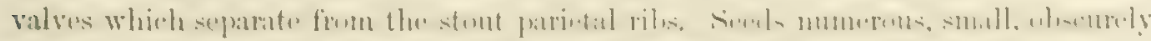

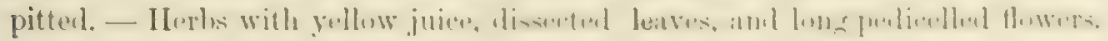

A genus of 8 species, 6 of which belong to the Himalayn megion, and 1 to Western Europe. 
1. M. heterophylla, Benth. Annual, smooth, slender, 1 to 2 feet high : lower leaves long-petioled, pinnately divided, the segments oval to linear and 2 to 12 lines long; upper leaves sessile, the segments usually narrow : flowers scarlet to orange, the petals 2 to 12 lines long; peduncles elongated: capsules smooth, obovate-oblong or top-shaped, truneate, narrowed below, 6 to 8 lines long, strongly ribbed; the persistent style a line long. — Trans. Hort. Soc. 2 ser. : i. 408. Hook. Ic. Pl. t. 272. M. crassifolia, Benth. 1. c.

A very variable species, in dry soils from San Diego to Clear Lake, flowering in early summer.

\section{DENDROMECON, Benth.}

Sepals 2. Petals 4. Stamens numerons, with short filiform filaments and linear anthers. Ovary linear, with 2 nerve-like placentas: style short: stigmas 2, short and erect. Capsule linear, nerved, 1-celled, dehiscent the whole length by 2 valves separating from the placental ribs, many-seeded. Seeds oblong or globose, finely pitted, carunculate. - A smooth branching shrub ; with alternate vertical entire thick and rigid leaves, and showy yellow flowers. The only truly"woody plant belonging to the order.

1. D. rigidum, Benth. A shrub 2 to 8 feet high, with many slender branches and whitish bark: leaves ovate to linear-lanceolate, 1 to 3 inches long, very acute or mucronate, sessile or nearly so, twisted upon the base so as to become vertical, reticulately veined, the margin rough or denticulate: flowers bright yellow, 1 to 3 inches in diameter, on pedicels 1 to 4 inches long: capsules curved, attenuate above into the short stout style, $1 \frac{1}{2}$ to $2 \frac{1}{2}$ inches long: seeds large, $1 \frac{1}{2}$ lines long. Trans. Hort. Soc. 2 ser. i. 407. Torrey, Bot. Mex. Bound. t. 3. D. Harfordii, Kellogg, Proc. Calif. Acad. v. 102.

Dry rocky hills of the Coast Ranges from San Diego to Clear Lake, most abundant south of Point Conception; Santa Rosa Island, Harford. Very variable in its foliage and in the size of the flowers, but all the forms seem referable to a single species.

\section{ESCHSCHOLTZIA, Cham.}

Sepals coherent into a narrow pointed hood, decidnous from within a dilated topshaped torus. Petals 4. Stamens numerous, with short filaments and linear anthers. Ovary linear, with 2 nerve-like placentas: style very short: stigmas divided into 4 to 6 linear unequal divergent lobes. Capsules elongated, strongly 10-nerved, 1-celled, dehiscent the whole length by 2 valves separating from the placental ribs, many-seeded. Seeds globose, reticulate or rough-tuberculate. Smooth glaucous slender annuals; with colorless bitter juice, finely dissected alternate petioled leaves, and bright orange or yellow flowers.

The very variable Califormian plant, first collected by Chamisso, and published by him in 1820 , has since been described under numerous names, and has usually been considered as affording basis for 4 or 5 or more distinct species; but the differences in habit, foliage, and flowers seem to be of too little moment or too inconstant for a recognition of more than varieties among the various forms. There are indications, however, that the seeds may afford characters upon which some of the following varieties may be re-established as species. Mature fruiting specimens are at present too rare in our collections to permit a positive determination of the question.

1. E. Californica, Cham. Usually 1 to $1_{2}^{1}$ feet high and rather stout, branching: flowers large, 2 to 4 inches in diameter, usually brilliant orange in the centre; torus dilated and often broadly rimmed: capsule $2 \frac{1}{2}$ inches long, curved : seeds two thirds of a line in diameter, reticulated; rhaphe obscure. - Hor. Phys. Berol. 73, t. 15. E. crocea, Benth. 
Var. Douglasii, fray. Rather mnre slender and the leares more finely diviled; flowers smaller, 1 to 2 inches in diameter, more yellow; torus with a narrower limb or simply turbinate: seed tuberculate; rhaphe well marked. - E. Dounlusii, Benth. Pl. Hartw, 296.

Var. hypecoides, Gray. Still more slender, 4 to 12 inches high, the stems leafy : Howers 1 to 1 inch in diameter, with cylindrical torus: capsule 11 inches long. - E. hypécoides, Benth. Trans. Hort. Soc, 2 ser, i. 408.

Var. caspitosa, Brewer. Stems very short : leaves mostly subradical, shorter than the scape-like peduncles; the lobes narrowly linear, acute: flowers $\frac{1}{2}$ to an inch broad: torus cylindrical: capsule $1 \frac{1}{2}$ to 2 inches long: seeds more densely tuberculate. - E. caspitos $\alpha$ and tenuifolia, Benth. 1. c.

Sunny exposures, particularly valleys and low hills, throughout the State and to Washington Territory, often in great abundance. The typical form seems confined to Califomia. Some of the latter reduced forms are found eastward through Arizona to New Mexico and S. Utah, but rurely. This is the most conspicuous flower of the State flora, and sometimes large areas are made painfully brilliant by its intense glow in the bright sunshine. The color varies from deep orange to light sulphur-yellow, or even pure white. The larger-flowered varieties are common in cultivation under various names.

2. E. minutiflora, Watson. Slender, branching, a foot high: flowers 3 lines in diameter or less: torus without border: capsule $1 \frac{1}{2}$ inches long, very narrow: seeds smaller (hardly half a line in diameter), nenrly smooth. - Proc. Am. Acad. xi. 122. E. Califomica, var. tenuifolia, Gray in Bot. Ives Colorado Exp. 5, in part. E. Californica, var. hypecoides, Watson, Bot. King Exp. 14.

Peculiar to the interior basin, ranging from Northwestern Nevada (Watson) to Sitgreaves Pass in Western Arizona (Nevberry) and Southern Utah, Parry.

\section{Order VI. FUMARIACE无.}

Tender herbs, with watery and bland juice, dissected compound leaves, and perfect irregular hypogynous flowers with the parts in twos, except the diadelphous stamens, which are 6 ; the ovary and capsule one-celled with two parietal placente. Sieels, dece, as in Papaverarrie, to which, heiner a small group of about 6 igenera, it has been united. Like that order, the petals are double the number of the sepals, viz. four in two series. The main characters are given under the genera.

1. Dicentra. Corolla fattened, heart-shaped or 2-spurred at tho base.

2. Corydalis. Corolla 1-spurred at the base.

\section{DICENTRA, Borkh.}

Sepals 2, small and scale-like, sometimes caduens. Corolla flattenet and cordate, at least at hase, of 2 pairs of petals; the outer pair larerer, saccate or spurreel at hase, the tips sprealing; the inner murh narrower, spom-shaped, mostly carinate or crested on the batek the small hollowed tips lishty miterl at the aprex. the fwo forming a cavity which contains the anthers aml stirma. Stamens b, in two sets. viz. there before each of the outer pretals and slightly athering to their hase, their

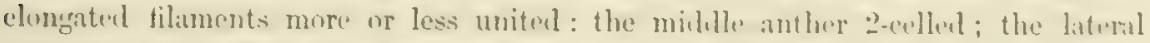

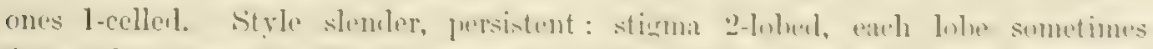

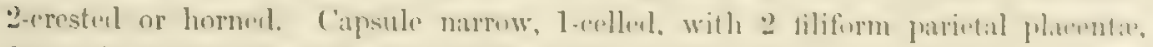

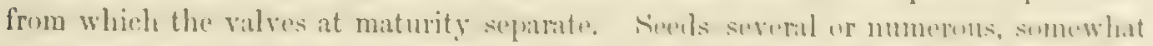
reniform, with or without a rest. - Porennials, sometimes with tuberifirons ar

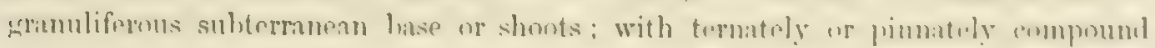


or decompound leaves, wholly glabrous, and racemose or paniculate flowers; the corolla often withering-persistent.

A genus of about a dozen species, divided between North America and Eastern Asia with the Himalayas; one large and showy species from Northern China, D. spectabilis, now common in gardens.

\$1. Flowers on a scape: filaments lightly united: seeds shining, with a loose caruncle or crest at the hilum.

1. D. formosa, DC. Leaves and scapes from the apex of thickish and almost naked creeping rootstocks, a span to a foot or two in height; the former twice or thrice ternately compound; the ultimate divisions narrow and incisely pinnatifid: flowers compound-racemose at the summit of the naked scape : corolla rose-colored, ovate-cordate, with short spreading tips to the larger petals. - Fumaria formosa, Andr. Bot. Rep. vi. t. 393.

In the Sierra Nevada at 3,000 to 9,000 feet, and through Oregon to Fraser River. A graceful plant; the scapes rather later than the leaves. Base of the corolla sometimes deeply, sometimes slightly cordate. Nearly related to D. eximia of the Alleghanies.

2. D. uniflora, Kellogg. Leaves and scape from a fasciculate fleshy root surmounted by a bulb-like cluster of fleshy grains, 3 to 5 inches high: the blade of the former ternately or somewhat pinnately divided, broadly or narrowly ovate in outline, glaucous; the 3 to 7 divisions pinmatifid into a few linear-oblong or spatulate lobes: scape 2-3-bracted, l-flowered: corolla flesh-colored, narrowly oblongcordate; the two outer petals tapering above, at length recurved-spreading. - Proc. Calif. Acad. iv. 141 ; Porter in Hayden Rep. 1872, 760.

Sierra Nevada in the alpine region, near Cisco and northward, Kellogg, Lemmon. Also in the Wahsatch Mountains above Ogden and northward, Chadbourne, Coulter, \&c.

D. Cucullaria, DC., of Eastern North America, occurs in the woods of Oregon, and may extend to the borders of California. It is distinguished by its simple or nearly simple raceme of cream-colored flowers, with the sacs of the onter petals extended into divergent spurs.

\$ 2. Flowers long and narrow, compound-racemose or panicled on a leafy stem: filaments diadelphous nearly to the top: seeds dull, crestless. - CHRYsocapros, Torr.

3. D. chrysantha, Hook. \& Arn. Pale and glancous, 2 to 4 feet high : leaves twice pinnate, the larger a foot long or more; the divisions cleft into a few narrow lobes: racemose panicle terminal, a foot or two long: sepals caducous: corolla linear-oblong or clavate, bright golden-yellow, over half an inch long, the base slightly cordate : capsule oblong-ovate or narrower. - Bot. Beechey, 320. t. 73 ; Torr. Bot. Mex. Bound, 32. Capnorchis chrysantha, Planchon, Fl. Serr. viii. 193, t. 820 .

On arid hills, \&c., from Lake Co. to San Diego. Plant of stiff and rather coarse habit, but the flowers brilliant.

\section{CORYDALIS, Vent.}

Corolla one-spurred at the base on the upper side, deciduous. Otherwise mainly as in Dicentra.

A rather large genus, of wide geographical distribution, most abundant in the Old World, only a single and a rare species known in California. Two others are not unlikely to occur on the northern border, viz.

C. AUREA, Willd., var. occtDextAlis (otherwise called C. montanc), Engelm., a low biennial species with golden yellow blossoms.

C. Scovleri, Hook. Fl. t. 14. of the woods of Oregon, a thick-rooted perennial, with one or two large 3 or 4 times pinnate leaves on the stem, and loose spreading racemes of long-spurred rose-colored flowers, - to which the following is somewhat related.

1. C. Caseana, Gray. Perennial, pale and slightly glaucous, branching, 2 or 3 feet high : leaves twice or thrice pinnate; leaflets obovate or oblong, nearly sessile 
(ahout half an inch in length), snme of them more or less confluent : racemes erect, densely many-flowered, 3 to 5 inches long : corolla white or eream-color with bluish tips; the straight spur half an inch loug, horizontal or ascending, very obtuse, exceeding the rest of the flower: capsule oval or oblong, turgid, tipped with a slender style : seeds shining, crestless. - Proc. Am. Acad. x. 69.

Moist and shady ravines in the Sierra Nevada, near Truckee (Bolander): thence to Plumas Co., E. L. Case (for whom it is named), Lemmon, \&c. Also in S. Colorado, Brandegre.

\section{ORDER VII. CRUCIFER尼.}

Herbs, with a pungent watery juice, cruciform corolla, tetradruamons stamens, a 2-celled pod (silicle) with 2 parietal placentie, and an embryo filling the seed, with cotyledons (accumbently or incumbently) apulied against the molicle. - Flurers perfect, hypogynous. Calyx of 4 seprals, decicluous. I'etals 4 , usually with narrowed base or claw, and the lamina spreading, so forming a cross, rarely wanting. Stamens 6 , two of them inserted lower down on the receptacle and shorter than the other four. Ovary 2-celled hy a partition which stretches across frum the placenta, rarely 1-celled by its abortion. Style undivided or none: stigma entire or 2-lobed. Fruit the peculiar capsule or pod named a silique, or when short a silicle; the 2 valves falling away from the placenta and partition, which persist, forming whit is called a replum, in a ferw genera indehiscent. Ovules few or numerous, sometimes solitary, campylotropous. Seeds with a smooth coat; albumen none. Cotyledons either accumbent (i. e. applied edcewise to the ralliche) (or incumbent (i. e. with the radicle against the back of one of them), nsmally pline, sometimes (as in Mustarl) folded or wrapyed aromd the raticle. Flowers generally in racemes and the perlieds without any bract. Leaves alternate, without stipules : no glandular pubescence.

A large family, comprising about 175 genera, and between one and two thousand knomn species, distributed over all parts of the world, but few in the tropics, and most in the temperate and colder regions. Nearly all are innocent, except for the excessive pungency or acridity of the seeds of Mlustard and the root of Horse-radish; ; several furnish condiments; and Cabbage, Tumips, \&e., are staple articles of food. The order is so strietly natural that generic distinctions are difficult.

I. Pod regularly dehiscent, 2-valved.

- Pod strongly compressed parallel with the broad partition: cotyledons accumbent.

+ Pod short; valves nerveless or faintly 1-nerved: flowers white or yellow.

1. Platyspermum. Pod large, orbicular, 8 -12-seeded; valves flat, nerveless. Seeds broally winged. Dwarf glabrous annual, with 1-flowered scapes: flowers stuall, white.

2. Alyssum. Pod small, orbicular, $2-4$-seeded; valves convex, nerveless. Seeds wingless, Canescent, hranching : flowers racemoso.

3. Draba Pod ovate to oblong or linear, few-many-secded; valves flat or convex Seeds wingless. I sow : flowers racemose.

$$
++ \text { Porl elongated. }
$$

++ Valves nerveless; replum thickened: seedls wingless: flowers whito or rose-enlor, mostly large : leaves all petioled : stems usually from running rootstocks or smnll tubers.

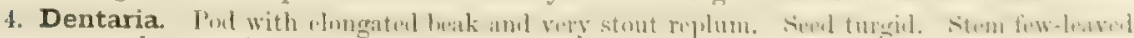
near the summit: raceme short: glnbmis.

5. Cardamine. Pod moderately beaked or pointed, less stout. Seed more flattened. Stems leafy, with elongated racemes.

++ \$+ Valves 1-nerved; replum thin : secls flat, often rringed or margined : flowers whito to purple (yellow in one species of Cheiranthres): leaves entire or toothed, the cauline sessile : root perpendiculur.

6. Arabis. Anthers short, scarcely emnrginate at hase. Petals with a flat blade aud claw. Calyx short or narrow, rarely colored. Seeds in 1 or 2 rows. 
7. Streptanthus. Anthers elongated, sagittate at base. Petals often without a dilated blade, more or less twisted or undulate, the claw channelled. Calyx dilated and usually colored. Seeds in one row.

8. Cheiranthus. Petals with a broad flat limb and long claw. Calyx large, not colored. Seeds in one row, not margined.

* * Pod terete or 4-angled, slightly or not at all compressed : seeds not margined; cotyledons incumbent or more or less oblique.

+ Pod long-linear (1 to 4 inches); ; valves 1 -nerved : seeds in 1 row, oblong, somewhat flattened; cotyledons mostly more or less oblique : anthers linear. Stout biennials or perennials.

4. Flowers white to purple : anthers sagittate.

9. Caulanthus. Petals with a broad claw, somewhat dilated above and undulate, little longer than the broad sepals, usually purple. Filaments included. Stigma nearly sessile, somewhat 2-lobed. Pod sessile, 3 inches long or more.

10. Thelypodium. Petals with narrow claw and flat linear to rounded limb, much exceeding the narrow sepals, white or rose-color. Filaments often exserted. Style short; stigma mostly entire. Pod shorter, sessile or short-stipitate.

$$
++++ \text { Flowers yellow. }
$$

11. Stanleya. Pod somewhat terete, long-stipitate. Stigma sessile, entire. Anthers not sagittate, spirally coiled. Leaves petioled, entire or pinnatifid.

12. Erysimum. Pod 4-angled, sessile. Stigma 2-lobed. Anthers sagittate, not coiled. Leaves narrow, entire or repandly.toothed.

\% + Pod linear, mostly less than an inch long, more or less 4-angled; valves 1-3-nerved: seeds globose to oblong, smaller and less flattened, in one row (except one species of Siymbrium): anthers oblong to linear-oblong: flowers yellow (white in Smelowskia) : at least the lower leaves pinnatifid.

13. Brassica. Pod nearly terete, with a long stout beak. Seed globose; cotyledons infolding the radicle. Anthers long, sagittate.

14. Barbarea. Pod pointed, somewhat 4-angled. Seeds oblong; cotyledons nearly accumbent. Anthers short, oblong. Leaves lyrately pimnatifid. A smootl marsh perennial.

15. Sisymbrium. Pod nearly terete, short-pointed or obtuse. Seeds small, oblong; cotyledons incumbent. Anthers linear-oblong, sagittate. Mostly annual, often with finely dissected leaves.

16. Smelowskia. Pod short, 4-angled, pointed at each end. Flowers white or pinkish. Alpine perennials with narrowly pinnatifid leaves; otherwise as Sisymbrium.

+++ Pod oblong-cylindric to globose; valves strongly convex, nerveless: seeds in 2 rows; cotyledons accumbent.

17. Nasturtium. Pod oblong or short-linear. Flowers white or yellow. Smooth or somewhat hispid.

18. Vesicaria. Pod orate to globose. Seed flattened. Flowers yellow. Densely stellatecanescent.

* * * Pod more or less obcompressed, i. e. flattened contrary to the partition, which is narrower than the valves: seeds not winged.

* Valves 1-nerved or obtusely carinate, not winged : cells sereral-seeded : cotyledons incumbent : flowers white (or yellow in Tropidocarpum).

19. Subularia. Pod ovoid, slightly obcomapressed. A dwarf stemless aquatic, smooth, with tufted subulate leaves.

20. Tropidocarpum. Pod linear, often 1 -celled by the disappearance of the narrow partition. Slender hirsute annuals with pingatifid leaves and axillary flowers.

21. Capsella. Pod obcordate or oblong, much compressed, many-seeded; valves carinate. Nearly smooth annuals.

* + Valves acutely carinate or winged : cells few- $(1-5-)$ seeded : cotyledons accumbent and flowers white (or in Lepidium cotyledons mostly incumbent and in one species the flowers yellow).

22. Lyrocarpa. Pod fiddle-shaped, flattened, somewhat acutely carinate; cells 5-seeded. Pubescent annuals.

23. Thlaspi. Pod cuneate-oblong; valves sharply carinate; cells $2-4$ seeded. A smooth alpine perennial ; leaves entire.

24. Iepidium. Pod orbicular or obovate, 2-winged at the summit; cells 1 -2-seeded.

+++ Valves inflated, nerveless: cells several-seeded : cotyledons accumbent : flowers yellow. 
25. Physaria. Pod didymous; colls nearly globular. Stellate-canescent perennials, with entire leaves.

II. Pod of 2 indehiscent cells, separating at maturity from the persistent axis.

26. Senebiera. Cells small, globose, rugose or tuberculate. Sced turgid; cotyledons incumbent. Flowers white, minute, in racemes opposite to the pinnatifid leaves.

27. Biscutella. Cells flat, nearly orbicular, Seeus Hat. Flowers rather large. Stigma dilated or conical, nearly sessile.

III. Pod indehiscent, 1-celled or transversely jointed.

28. Thysanocarpus. Pod small, plano-conrex, orbicular, winged or margined, 1-seeded. Slender anutuals.

29. Raphanus. Pol elongated, terete or necklace-form, attenuated abore, sereml-seeded. Coarse introduced annuals or biennials.

\section{PLATYSPERMUM, Hook}

Pod orbicular, flat, with flat nerveless valves and hyaline partition. Seeds few, orbicular, flit and broally marrined with a thin wing; cotyledons accumbent. Sepals equal, spreading. Petals oborate, scarcely clawed. - A low delicate annual; with ralical simple or pinnatiful leaves, and several slender 1-flowered scapes; flowers small, white.

1. P. scapigerum, Hook. Glabrous: leaves usually runcinately pinnatificl: scapes 2 to 3 inches high : flowers erect or nodding: pod 8-12-seeded. - Fl. i. 68, t. 18 .

On dry hillsides in the shade of larger plants, in early spring; of short duration. Sierra Co. (Lemmon); Steamboat Springs, Nevada (Watson); and northward to the Columbia.

\section{ALYSSUM, Tourn.}

Pod oval or orbicular, compressed; ralves convex and nerveless. Seeds 1 or 2 in each cell; cotyledons accumbent. Sepals equal. Petals white or yellow. Longer filaments often toothed. - Low heris, stellate-canescent, mostly with siwple leaves.

A large genus of the Eastem Continent, a few of its species widely naturalized weeds or realily escaping from cultivation.

1. A. calycinum, Linn. Anuual, loranching from the runt, the stems mustly

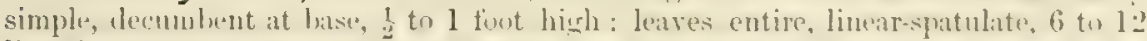

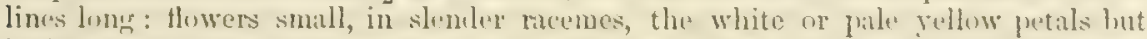

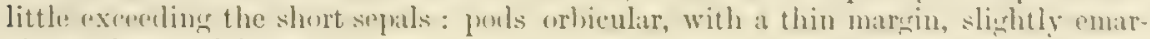

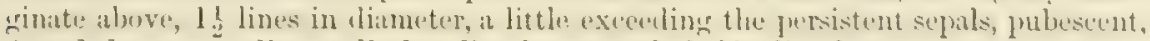
4-seeded, on spreacling pedicels a line long: style half a line long.

A native of Southern Europe, sparingly naturalized about the Bay of San Francisco.

2. A. maritimum, Linn. Teremial, somewhat cameserent with appresionl silliy

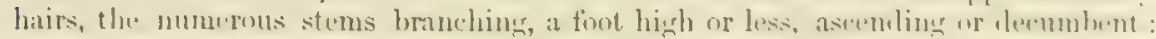

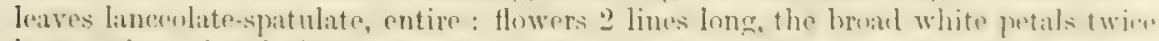

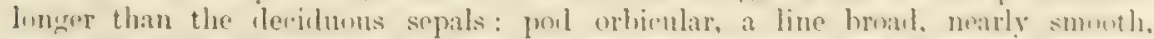

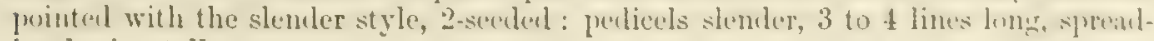
ing horizontally.

Often cultivated for its fragrant flowers under the name of Swece Alyssum. Native about tho Mediterranean; sparingly naturalized near Oakland.

\section{DRABA, Linn.}

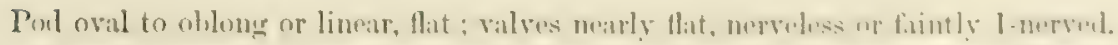
Seeds few to many, in 2 rows in ench cell, wingless; cotyledens acrumbent. Shepals 
equal. Filaments mostly flattened, without teeth. Anthers rounded or oval. Low annual or perennial herbs; with entire or toothed leaves and white or yellow flowers.

A large genus, of nearly a hundred or more species, mostly inhabitants of cool climates, and many alpine or aretic. The limits of many of the species are with dificulty defined, and authorities differ much in their views respecting them.

\section{* Annual or biennial, with leafy stems: petals usually emarginate.}

1. D. cuneifolia, Nutt. Hirsute-pubescent throughout with branching hairs: stems usually branching at base, 3 to 6 inches high, leafy below or only at base: leaves obovate or spatulate with a narrow or cuneate base, $\frac{1}{2}$ to 1 inch long, sparingly toothed toward the apex: petals white, $1 \frac{1}{2}$ to 2 lines long, twice as long as the sepals: pod linear-oblong, 3 to 6 lines long, acutish, somewhat pubescent with short ascending hairs, on spreading pedicels 1 to 3 lines long: style none.-Torr. \& Gray, Fl. i. 108.

Frequent east of the Colorado to Texas and the Mississippi Valley. Reduced specimens were collected at Los Angeles by Gambel, and a more doubtful form by Brewer in the Temescal Mountains, near the tin mines. The latter specimens are scarcely an inch high, the leaves obovatespatulate, only two lines long and entire, the flowers smaller (a line long), and the young capsule broader in proportion and glabrous.

2. D. stenoloba, Ledeb. Somewhat villotis with spreading hairs, glabrous above: stems erect, slender, 4 to 12 inches high, with divergent or decumbent branches from near the base: leaves oblanceolate, $\frac{x}{2}$ to 1 inch long, rather thin, acute, rarely and sparingly toothed, ciliate and slightly villous-pubescent; the cauline few and sessile: petals bright or pale yellow, 1 to $1 \frac{1}{2}$ lines long, half longer than the calyx, obtuse: pod linear, 3 to 5 lines long, acute at each end, glabrous, in an elongated raceme, on spreading scattered pedicels 2 to 4 lines long: style none. - Fl. Ross. i. 154. D. nemorosa, var. lutea, Watson, Bot. King Exp. 22.

Dry soils in the Sierra Nevada, at 7,000 to 10,000 feet altitude, from Yosemite Valley and Mono Pass (Brever, Gray) to Donner Pass (Greene), and eastward in the Wahsatch and Yuintahs ( Watson) and Colorado. It appears to be identical with the original Unalaschkan form. It is readily distinguished from $D$. nemorosa, with which it has been confounded and which is frequent in the mountains from Washington Territory to Colorado, by its thiuner, narrower and more entire leaves and its shorter pedicels.

$$
\begin{gathered}
\text { * Biennial or perennial. } \\
+ \text { Stems leafy. }
\end{gathered}
$$

3. D. aurea, Vahl. Biennial, more or less canescently stellate-pubescent and usually somewhat villous with branching hairs: stems 3 to 18 inches high, solitary or several from the same root, simple or branched, leafy: leaves oblanceolate and petioled, $\frac{1}{2}$ to 2 inches long, the upper sessile and oblong to oblong-ovate, acute, entire or sometimes sparingly toothed: petals yellow turning to white, twice longer than the calyx, rounded at the apex or emarginate: pod linear-lanceolate, 4 to 6 lines long, attenuate upward into the short style, puberulent, often somewhat twisted. - Fl. Dan. t. 1460. Hook. Bot. Mag. t. 2934.

In the Rocky Mountains from Colorado to British America. Specimens collected by Brewer on Mt. Dana at 12,000 feet altitude, and by Lemmon farther north in the Sierra Nevada, must apparently be referred here though they have more of a perennial habit than is usual in the species. Their basal leaves are densely crowded, and the whole plant, including the pods, densely stellate-pubescent.

$$
++ \text { Stems naked and scape-like above the base, few-flowered. }
$$

4. D. crassifolia, Graham. Biennial or perennial (sometimes apparently annual), glabrous: stems slender, 1 to 5 inches high, solitary or few from a very short and nearly simple rootstock: leaves rosulate, thin, flat, narrowly oblanceolate or linear, $\frac{1}{4}$ to 1 inch long, rarely with 1 or 2 lateral teeth, more or less ciliate with long hairs: 
petals yellow, about a line long, a little exceeling the calyx : pouls lanceulate, acute

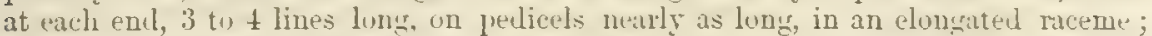
style none. - Torr. \& Gray, Fl. i. 106. D. Johannis, Gray, An. Jour. Sci. xxxiii. 242.

At Peregoy's, above Yosemite Valley, at 7,000 feet altitude, Gray. Rather frequent in the Rocky Mountains from Colorado to lat. $57^{\circ}$. Near $D$. lactea (referred to $D$. androsacea), but less cespitose and without the short style which is found in that species.

5. D. Douglasii, Gray. Gliucous: scantes numerous from a much-branched leafy caudex, [mbercent, to 1 in inches high, corrmbusely fhwered: leares below ovate, the uppermost oburate or spatulate, 1 to 2 lines lunis, entire, glabrous or somewhat pubeseent with simple hirirs, hispilly ciliate: petals white, 2 lines long, exceeding the rather fleshy nearly glabrous brual and cutuse sepals: poul ovite-oblong, acutish at each end, heaked with the slewder style. Imherulent, 2 lines lone; cells 2-ovuled. - Proc. Am. Acad. vii. 328; Watson, Bot. King Exp. 22.

South of Carson City, Nevada (Anderson); on Mount Daridson (W Watson); Sierra Valley (Lommon); and by Douglas, probably still farther to the north.

6. D. eurycarpa, (imy. Tomentuse with stellate hairs: scapes few-flowered, 1 to 2 inches high: leaves rosulate, spatulate, entire, 4 to 8 lines long: pod ovate, 5 to 10 lines long, acute and beaked with the long slender style; ovules rather numerous in each cell. - Proc. Am. Acad. vi. 520.

On a dry summit near Sonora Pass, at 11,500 feet altitude, Brewer. Known only from fruiting specimens that have shed their seeds.

i. D. alpina, Linn. Densely cespituse and much branched, more or less stellately pubencent and villous: seipes is to 6 inches high: leaves crowdinl at the base, spatulate or ollaneculate, 2 to 9 lines long, ciliate. mit carinate: Howers large, yellow;

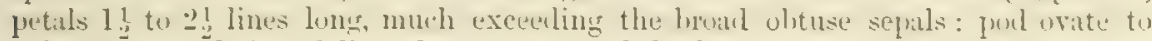
oblong-elliptical, 2 to 3 lines long, acute and beaked with the short thick style; cells 4-10-ovuled. - Regel, Fl. Ost-Sib. i. 181 ; Watson, 1. c. 20.

Var. algida, Regel. Pubescence villous, not stellate: leuves mostly small and splatulitte, strungly ciliate, nut carinate: style slightly louser. - Fl. (1-t-iib. i. $1 \& 3$. D. alyida, Adams; DC. Prodr. i. 167.

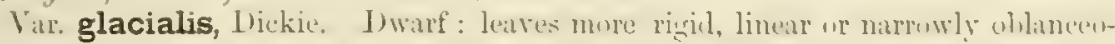

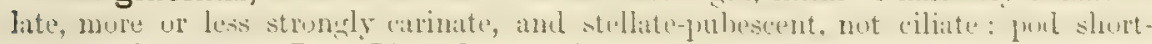
ovate, pubescent. - Jour. Linn. Soc. xi. 33. D. glacialis, Adams, l. c.

The typical Old World form, which occurs also in Greenland, has rather large and broad leares, not carinate, slightly stellate-pubescent, ciliate, the scrpe and pealicels someriant hairy; pod ovate, smooth, beaked with a short style. This has not been collected in California, though forms nearly approaching it are found in the nountains east and northward. Var. algida occurs on MIt. Dana and other peaks about the head of the South Fork of King's River, at 13,000 feet altitude (Brewer), and in the Yuintah Mountains (Wretson), as well as on the Aretic Coast. Var. glacialis is somewhat common on high peaks in the Sierm Fevala, and in the mountains eastward. A still more extreme form is found on the dry summit of Silver Hountain at 11,000 feet altitude (Brewer) and in the East Humbolit Mountains, Nevada (Wulson); very dwars and densely cespitose; the very short linear leaves appressed, strongly carinate and eiliate, but otherwise glabrous ; the short scajes and small orbicular pods hirsute.

\section{DENTARIA, Linn.}

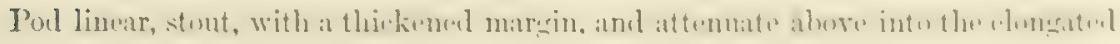
style; valves flat, nerveless. Seeds in one row, turrill, wingless; cotyledons peti-

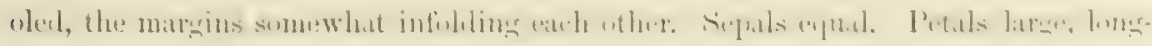
clawed, white or purplisb. - Low perennials, glabrous or nearly so; stems simple,

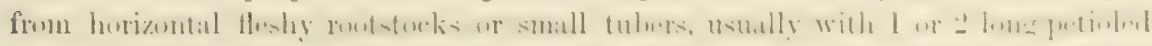

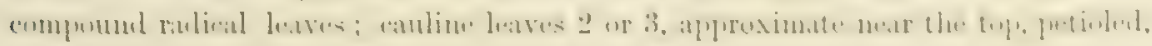
simple or compound; raceme short, few-llowered. 
A genus of about half a dozen North American species, and as many more of Europe and Northern Asia. Referred-to Cardamine by Bentham \& Hooker, but of peculiar habit and more conveniently kept distinct.

1. D. tenella, Pursh. Rootstock interrupted, of elongated and somewhat scaly joints : stem 6 to 10 inches high, with a pair of leaves (rarely 1 or 3) near the top, which are often puberulent, shortly petioled, palmately or pinnately 2-5-parted; the lobes narrowly oblong or linear, $\frac{1}{2}$ to 1 inch long, obtuse, often mucronate, entire or in the lower leaf rarely sinuate ; radical leaves said to be simple, roundish, about 5-lobed: flowers white or rose-colored, 3 to 6 lines long, on slender pedicels: fruit unknown. - Torr. \& Gray, Fl. i. 87. D. tenuifolia, Hook. Fl. i. 46, not Led.

Indian Valley, Plumas Co., Mrs. M. E. Pulsifer Ames. Northward to Vancouver Island and Lower Fraser River, Menzies, Nuttall, Lyall.

D. MachocaRPa, Nutt, of Oregon, is only known from Nuttall's description, drawn from a single specimen. It is described as having a tuberous root, the radical leaf with 3 reniform lobed leatlets ; canline leaf 3 -parted, the segments entire, obtuse; pod very long, with cuspidate style and capitate stigma.

\section{CARDAMINE, Linn.}

Pod linear, with somewhat thickened margins, merely pointed or beaked above; valves flat, nerveless. Seeds in one row, somewhat flattened, wingless; cotyledons flat, accumbent. Sepals equal. Petals white or purplish. - Mostly perennials, growing in moist or wet places, usually with running rootstocks or small tubers; stems leafy; leaves (in our species) all petioled, simple or pinnate; raceme elongated.

A rather large genus, inhabiting the temperate and cooler regions of all quarters of the globe.

\section{* Leaves pinnate with several pairs of small leaflets.}

1. C. Gambellii, Watson. Perennial, glabrons throughout, erect, about a foot and a half high: leaflets 4 to 6 pairs, ovate-oblong to linear, sessile, entire or sparingly toothed, acute, 3 to 12 lines long: flowers white, on slender pedicels: petals 4 lines long, twice longer than the sepals: pods narrowly linear, ascending, an inch long, equalling the strongly deflected pedicels: beak slender, a line long. - Proc. Am. Acad. xi. 147.

Collecterl near Santa Barbara by Gambell, and recently by Dr. J. T. Rothrock, of Lieut. G. M. Wheeler's Survey, in the same region. It much resembles C. pratensis, Linn., a species confined to colder northem latitudes, xanging from the northern border States to the Aretic Ocean, but differs especially in the sessile leaflets and in the divaricate pedicels, which are horizontal or even more reflexed. A very similar form, but somewhat pubescent, has been collected by Bourgeau near the city of Mexico.

2. C. oligosperma, Nutt. Annual, somewhat bairy or very nearly glabrous: steams weak and slender, 3 to 10 inches high: leaves all pinnate; leaflets small, 3 to 5 pairs, roundish, 1 to 6 lines in diameter, often obtusely $3-5$-lobed, petiolulate: petals white, 1 to $1 \frac{1}{2}$ lines long, twice longer than the calyx : pods few, somewhat approximate, 6 to 9 lines long by half a line broad, attenuate into the short style, erect; cells about 8-seeded. - Torr. \& Gray, Fl. i. 85.

In shaded places from the lower Sacramento to Fraser River ; perhaps also to Sitka.

C. HIRsuTA, Linn., which is common from Oregon northward to Alaska and eastward across the continent, may be found in Northern California, especially the more slender var. sYLYATICA, Gray. It may be known from the last by its rather stouter habit, leaflets sessile and larger and usually more or less oblong, flowers a little larger, and pods in a longer raceme, narrower, and with more numerous seeds.

$$
\text { * Leaflets 'few, larger: perennials, usually smooth. }
$$

3. C. paucisecta, Benth. Smooth or slightly pubescent: stems from small deep-seated tubers, rather stout, erect, 10 to 18 inches high, simple or branched 
above: lower leares often simple. subcordate-orhicular, 1 to 21 inches broad, $5-7$ nerved, repand; the upper deeply libed or pinnately 5-fuliolate, the leaflets urate tu oblong, mure or less irregularly touthed or entire : petals 6 to 9 lines long, white or pirkish: poils 1 to $1 \frac{1}{2}$ inches long, as many lines wide, pointed at each enul and tipuenl with a style 1 tu 1 lines long: pedicels spreading, to 11 inches lons. Pl. Hartw. 297. C. purpurea, Torr. \& Gray, Fl. i. 667. "Dentaria integrifolia \& Califarnica, Nutt. in Torr. \& Gray, Fl. i. 88. C. angulata, Torr. in Pacif. R. Rep. iv. $65, \& c$.

In the Coast Ranges from San Diego to Mendocino County. Specimens have also been received from the northern Sierra Nevada (Mrs. Ames, Lemmon, \&c.), which appear to belong to this species, though in the early state with all the babit of a Dentaria. The tubers, as usual, have a pungent taste, and the leaves are often marked with purple.

4. C. Breweri, Watson. (rlabrous or slightly pubescent at base: stems frum a running rootstuck, llexuous, dectmbent at base, 6 to 18 inches high, usually simple : leatlets 1 or 2 pairs, rounded or oblong, the terminal much the largest, is to an inch or more ling, entire or cuirsely simulte-tunthed or lubed, cobtuse, often cordatp at base; radical leaves mustly simple and cordate-reniform: petals 2 lines long, white: prods 8 to 15 lines long, obtuse or scarcely leaked with a short style, ascending on pedicels 3 to 4 lines long. - Proc. Am. Acad. ז. 339.

In the Sierra Nevada, from Sonora Pass northward (Brcuer, Anderson); Oregon (Hall), and in the mountains eastward to Wyoming.

C. AsGerata, Hook., and C. CondfFolis, Gray, both of this group, are found in Oregon and may reach the northern limits of the State. The first has tall slender simple stens : leaves all ternate, the leaflets cuneate-ovate or -oblong, with 3 or rarely 5 lobes or cosrse teeth ; flowers few; white, 3 to 4 lines long, on slender ascending pedicels; pods short. The latter is stouter, witl simple cordate-orbicular or -ovate leaves, the margin sinuate; flowers white, 4 to 6 lines long; porls an in hl long, attentitte abure, on rither short pedicels. This species ranges to Colurado and Now Mexico. Both have running rootstocks.

\section{ARABIS, Limn.}

Pull linear, flattened; valves 1-nervel, not strunely. Seeds in one or tro rotrs, flattened and usually winged; cotyledons accumbent. Sepals short or narrow, rarely colorel. Petals with a narrow claw amel Hat blate, white, ruse-culuret, or purple. Anthers short, wate or uhlunce scorecly emaryinate at hase. Stigmit entire or somewhat 2-lobed.- Erect, with perpendienlar routs, and unlivided leabes, the cauline sessile and usually clasping and auricled at base.

A large genus of perhaps 100 species, most abundant in Europe and Northern Asia. There are 20 or more species in North America.

\section{* Annual: pod reftexed, long-beaked : leaves narrowed at base.}

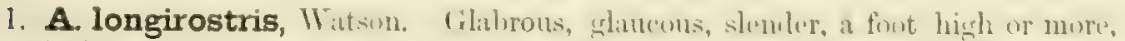

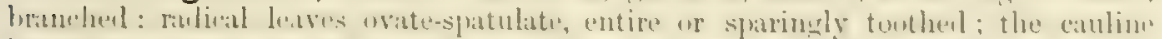

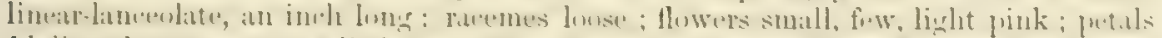

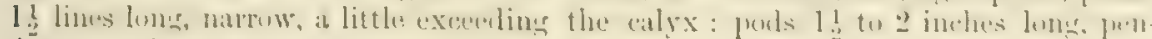

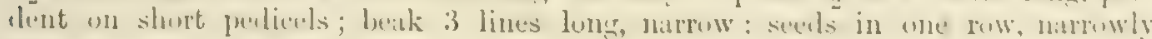
winged. - Bot. King Lxp. 17, t. 2.

In alkuline soil in the valleys of $\mathrm{N}$. W. Nevads, and on the islands in Salt Lake (Watson); S. Utuh, Parry: doubtless in Northenstern Californis.

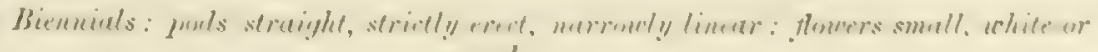
nearly so.

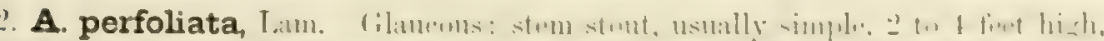

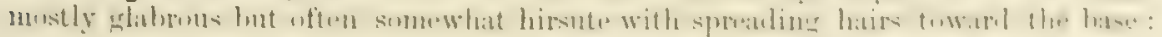

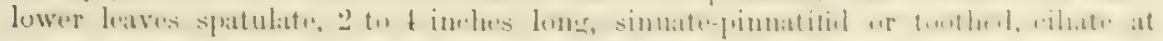


least on the petioles; the cauline entire, ovate or ovate-lanceolate, clasping by the sagittate base: petals 2 to 3 lines long, little exceeding the sepals: pods erect and usually appressed, 2 to 4 inches loug, less than a line wide, nearly straight, on pedicels 3 to 4 lines long; style short; stigma 2-lobed: seeds in two rows, narrowly winged or wingless. - Turritis glabra, Linn., and T. macrocarpa, Nutt. ; Torr. \& Gray, Fl. i. 78.

In the mountains from San Diego to the British Boundary and northward, and east across the continent; also in Europe and N. Asia.

A. HIRsuTA, Scop., has not been certainly found in California, but is frequent in the Columbia Valley and northward, and also east to Colorado and the Atlantic. It is usually more slender and hirsute than the last, 1 to 2 feet high, the stems often elustered and with slender strict branches above; leaves often rosulate at the base, 1 to 2 inches long, the carline ovate to oblong or lanceolate; pod shorter, 1 to 2 inches long, narrower, the wingless seeds strictly in one row.

A. spathulata, Nutt, is another nearly allied species, but little known, which may oceur in the State, having been found in Oregon and W. Nevada (if No. 67 Watson be correctly referred to it). It appears to be alow slender plant, much like small forms of $\boldsymbol{A}$. hirsuta, but with fewer leaves, those upon the stem scattered and entire; pedicels spreading; pods still narrower, less than an inch long, beaked with a narrow style.

* * Mostly perennials: pods erect or ascending: flowers mostly larger, deeper colored.

3. A. Lyallii, Watson. Bright green or glaucous and glabrous, or usually somewhat villous below with spreading hairs, especially on the margin of the petioles, rarely more or less canescent with stellate pubescence: stems slender from a branching pereunial base, 2 to 15 inches high : radical leaves oblanceolate, on slender petioles, acute, entire; cauline oblong-lanceolate, clasping and sagittate at base: petals light piuk, about 3 lines long, twice longer than the sepals : style none : pods straight, narrowly linear, 1 to 3 inches long: seeds in 2 rows, narrowly winged. Proc. Am. Acad. xi. 122. A. Drummondii, var. alpina, Watson, Bot. King Exp. 18.

In the high Sierra Nevada from Mono Pass to Washington Territory, and also enstward to Utah and W. Wyoming; often alpine and dwarf. A somewhat variable subalpine and alpine species, distinguished by its perennial root from $A$. Drummondit, which seems not to occur west of the Rocky Mountains.

A. CANESCENs, Nutt., of the mountains in E. Nevada and Wyoming, is like smaller forms of A. Lyallix, but is densely stellate-tomentose, the somewhat broader pods reflexed and often secund, and the seeds in one row and more broadly winged.

4. A. platysperma, Gray. Canescent with a short stellate pubescence : stems several from a perennial base, slender, 4 to 12 inches high : leaves entire, the lower

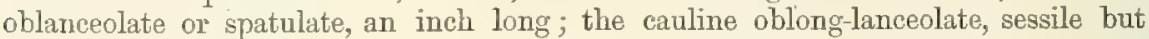
not auricled at base, 4 to 10 lines long: petals rose-colored, 2 to 3 lines long : pods straight, erect, 1 to 2 inches long and 2 lines wide, acuminate, without style, loosely reticulated: seeds in one row, with a broad thin wing.-Proc. Am. Acad. vi. 519 ; Watson, Bot. King Exp. 16.

Alpine or subalpine in the Sierra Nevada from the Yosemite to Mt. Shasta ; in the East Humboldt Mountains, Nevada, Watson.

5. A. blepharophylla, Hook. \& Arn. Smooth or slightly villous, the stems often tufted, 4 to 12 inches high : leaves strongly ciliate, entire or sparingly sinuatetoothed, the lower obovate or broadly spatulate, 1 to 2 inches long, the cauline oblong, sessile, obtuse or acutish : flowers large; sepals generally colored; petals bright purple, 6 to 9 lines long: pods 1 to $1 \frac{1}{2}$ inches long and as many lines broad, beaked with the short stout style, loosely spreading: seeds in one row, a line in diameter, wingless or narrowly margined. - Bot. Beechey, 321 ; Bot. Mag. t. 6087.

On low hills near the coast, from San Franciseo to Monterey. Blooming in early spring and "superb in cultivation."

6. A. repanda, Watson. Biennial, pubescent especially below with loose branched hairs: stem rather stout and coarse, 2 feet high, and with the spreading 
branches somewhat flexuous: leares ohlanceolate, 3 to 4 inches long, obtuse, coarsely sinuate-toothed, attenuate to a winged subclasping base, on the branches narrower and acutish: calyx pubescent, simewhat membruaceous, 1 to $1 \frac{1}{3}$ lines long, the pinkish petals a little longer: pods 3 inches lung, a line wile, ascending, falcate, somewhat jubescent, tipped with a very short style: seeds in one row, broadly winged. - Proc. Am. Acad. xi. 122.

Yosemite Valley, Bolander, n. 4881. A well-marked species.

* * * Mostly perennials : pods usually curved, more or less reflexed, or arcuate downoard: style none: seeds in 1 or 2 rows.

7. A. Holböllii, Hornem. Mure or less stellate-pulescent, rarely hirsute, or even glabrous: stem erect, to to 2 feet high, simple or branching: lower leaves spatulate, entire or denticulate; cauline ublong-lanceulate, sagittate aud clisping at base, $\frac{1}{2}$ to 1 inch long or mure: petals twice longer than the calyx, 3 to 4 lines lone, white or rose-color or rarely purple, becoming reflexed: pouls 1 to 4 inches ling, ? to 1 line wide, strondy retlexed : seerls wingless or narrowly margined. F1. Dan. xi, t. 1879. A. retrafracta, Grah.; Watson, Bot. King Exp. 18. Turritis patula, Grah. Sisymbrium reflexum, Kellogg, Proc. Calif. Acad. ii. 101, fig. 29.

Frequent in the Sierra Nevada from the Yosemite Valley northward, and east to New Mrexico and the Saskatchewan ; it ranges to the Aretic Circle and Greenland. Very variable, especially in its pubeseence, whirls is usually densely stellate, rarely tomentuse, sumetimes extending to the calyx and even to the pods.

8. A. arcuata, Gray. Canescently villous or tomentose with branching hairs, the pubescence of the inflorescence short, brancherl and entangled : stems ruther stout, erect from a branching peremnial hatse, 1 to 2 ficet ligh or more: lower leaves numerous, oblanceolate, on slenter petivles; the cauline whlener- or linear-lanceolate, 1 to 2 inche's long, auricled at base, acute; all sparingly sinuate-touther, sumetimes

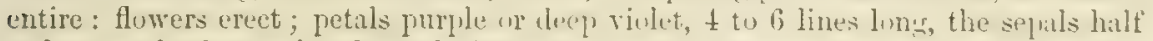

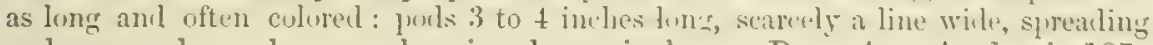
and recurved: seeds narrowly winged or wingless. - Proc. Am. Acad. vi. 187; Watson, 1. c. Sireptanthus arcuatus, Nutt.

From Santa Barbara (Niultall) and the mountains near Tejon (Wallace) northward in the Sierra Nevada to the North Fork of the American River. What is probably the same is also

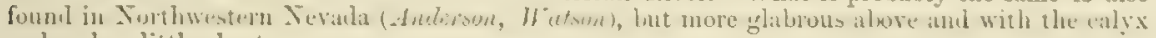
and pods a little shorter.

9. A. Breweri, Witson. Cospitnse, camesent with dhense stellate puhesecence,

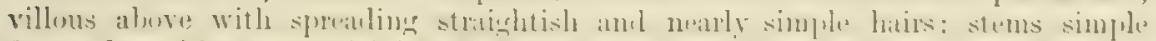

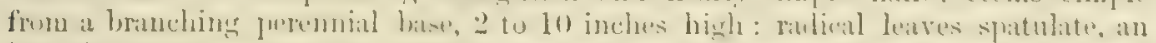

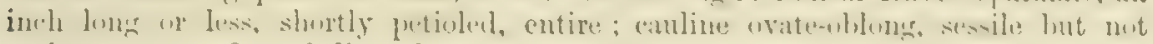
sagittate, acute, 6 to 9 lines long: petals deep rose-color, 1 to 4 lines long, twice

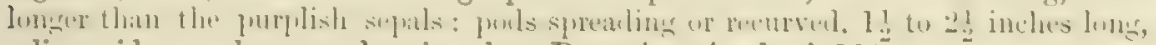
a line wide: seeds uarrowly winged. - Proc. Am. Acad. xi. 123.

From Mt. Diablo (Brewer, Bolauder) to Lake Co. (Grecnc) and Mfendocino Co., Bolander.

\section{STREPTANTHUS, Nutt.}

Pod linear, flat; valves 1-nerved. Seeds in one row, flattened, moro or less

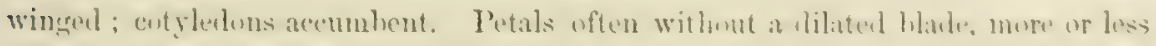

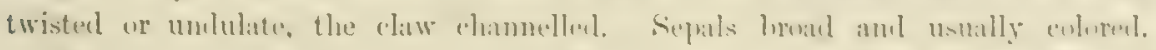

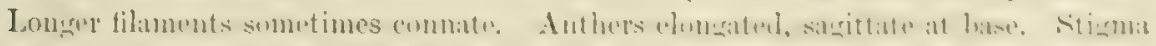

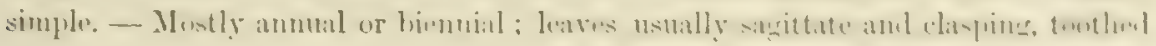
or entire or sarely pinnatifid.-Gray, Proc. Am. Acad. vi. 182. Watson, Bot. King Exp. $19 \& 429$.

A genus of a dozen or more species, confined to Western North Arwerica. 
* Glabrous or glaueous: stem-leaves broad and clasping by a cordate or sagittate base: a broad torus at the base of the ovary.

1. S. cordatus, Nutt. Perennial : stems simple, 1 to 2 feet high, rather stout: leaves thick, usually repandly toothed toward the apex, the teeth often setosely tipped; lower leaves spatulate-ovate or obovate, the petioles sparingly ciliate; cauline leaves cordate to oblong or ovate-lanceolate, obtuse or acute, with a broad roundauricled base: sepals broad, colored, 3 to 4 lines long, somewhat obtuse, the petals about half longer, greenish yellow to purple: pods broadly linear, 2 to 4 inches long, 2 lines broad or more, nearly straight, loosely spreading: seeds broadly winged. - Torr. \& Gray, Fl. i. 77 ; Watson, Bot. King Exp. 19.

Rare at high elevations in the Sierra Nevada, Ebbett's and Sonora Passes (Brewer) ; and eastward in the mountains of Nevada and Arizona to Colorado.

2. S. tortuosus, Kellogg. Annual, 1 to 3 feet high, with slender virgate branches: lower leaves oblong, narrowed to a winged base, 2 to 3 inches long, repandly toothed; the upper rounded, $\frac{1}{2}$ to $1 \frac{1}{2}$ inches in diameter, clasping by a deep closed sinus, entire: flowers subsecund; sepals broad, long-acuminate, yellowish or purplish, 3 to 6 lines long, the purplish petals a little longer: pods 2 to 6 inches long, a line wide, falcately recurved : seeds narrowly winged or often wingless. - Proc. Calif. Acad. ii. 152, fig. 46.

Common in the Sierra Nevada at 4,000 to 11,000 feet altitude, in dry sunny places, from the Yosemite to Yuba Co. and Mt. Shasta.

3. S. Breweri, Gray. Annual, branched from near the base, 1 to 2 feet high: lowest leaves broadly oval ox obovate, nearly sessile, dentate; cauline leaves ovate and clasping, the uppermost lanceolate and acuminate, entire or denticnlate : flowers purple; sepals acuminate, 2 to 3 lines long, somewhat pubescent or glabrous, the petals half longer: pods $1 \frac{1}{2}$ to $2 \frac{1}{2}$ inches long, less than a line wide, erect or ascending, straight or somewhat incurved: seeds not margined. - Proc. Calif. Acad. iii. 101, \& Proc. Am. Acad. vi. 184.

In the Mt. Diablo Range, on dry summits of San Carlos Mountain and near the head of Arroyo del Puerto, Brewer.

\section{* * Glabrous: stem-leaves very narrovly linear : sepals very unequal.}

4. S. polygaloides, Gray. Annual: stems 1 to 2 feet high, virgate, with simple branches: stem-leaves 1 to 2 inches long, folded or involute and apparently filiform: sepals yellow, the outer rounded and subcordate, 3 lines in diameter, somewhat scarious, the inner oblong-lanceolate, acuminate, about equalling the purple petals: pods 1 to $1 \frac{1}{2}$ inches long, half a line wide, reflexed and somewhat secund on very short pedicels, straight or nearly so, attenuate upward to the short style: seeds narrowly winged. - Proc. Am. Acad. vi. 519.

$A$ rare and remarkable species; lower leaves unknown. On dry barren magnesian soil near Jacksonville on the Tuolumne (Brewer), and on Mt. Bullion, Bolander.

* * More or less hispid with simple hairs: flowers purple or red.

5. S. glandulosus, Hook. Annual, more or less hispid with spreading hairs, $\frac{1}{2}$ to 2 feet high, branched: radical leaves spatulate, sinuately toothed; stem-leaves narrow to oblong-lanceolate, 1 to 6 inches long, auricled at base, sparingly repand or laciniately denticulate, the teeth with somewhat thickened tips: petals bright purplish-red, 6 to 8 lines long, half longer than the acutish sepals: pods 2 to 3 inches long, a line wide, ascending or spreading, straight or somewhat curved: stigma sessile, dilated : seeds narrowly winged. - Ic. Pl. t. 40 ; Bot. Beechey, 322.

On dry hillsides from Clear Lake to San Luis Obispo.

6. S. heterophyllus, Nutt. Glabrous above, branching, 3 to 5 feet high : leaves gash-pinnatifid, the stem-leaves sagittate: flowers pendulons; sepals deep purple; 
petals linear, purple or whitish : pods 3 to 5 inches long, very narruw, pendulous; pelicels 4 lines lung: seeds half a line lone, narrowly winged. - Turr. d Gray, Fl. i. $77 \& 666$.

Annual or biennial, known only from Nuttall's description and the specimen in herb. Hooker. Bushy hills near San Diego ; distinguished from other species of the genus by its pendent pods. A specimen collected by Bolander, probably in the same region, seems referable here, though simple and but $1 \frac{1}{3}$ feet high : sepals narrow, acute, deep purple, 3 lines long ; petals narrow, purple-veined, nearly twice as long; style short, with dilated stigma.

7. S. hispidus, Gray. Annual, lirsute thronghout, simple or branched, 2 to 5 inches high: leaves obovate-oblong or cuneate, coansely toothed or incised above, the teeth whtuse; stem-leares sessile, scircely at all chajpin's ritceme short, lunsely flowered, the flowers spreading or at length recurved; sepals somewhat membranacenus, purplish, acutish, 2 to 3 lines long. half as long as the bright purplish-red petals: pods hispid, $1 \frac{1}{2}$ to 2 inches long, a line wide, straight, erect: style none: seeds winged. - Proc. Calif. Acad. iii. 101 ; Proc. Am. Acad. vi. 186.

On the dry summit of Mt. Diablo, Brewer, Bolander.

* * * Pilose with simple hairs: leaves not sagittate nor clasping: flowers yellow.

8. S. flavescens, Iuvk. Anmul: stems simple, erect, a foot high: radical leaves linear-ubluns, nearly '2 inche's lone, sinuate-pinnatitil or -toothed, petioled, the cauline scarcely an inch long: Howers erect; petals rellowish, linear, nearly twice longer than the oblung acute sepals: punls crert, linsute, beaked with the slender style. - Ic. Pl. t. 44; Hook. \& Arn. Bot. Beechey, 322.

Near Monterey, Douglas. Mature fruit unknown.

S. REPANDUS, Nutt. Hirsute, especially below: stems simple, about 2 feet high: leaves oblong-lanceolate, elongated, clasping, angularly toothed or repand above : petals white, linear, about equalling the linear sepals : pedicels shorter than the calyx. Santa Barbara - Only known from Nuttall's inperfect deseription. It may be a species of Arabis.

\section{CHEIRANTHUS, Linn.}

Pod elongated, compressed; valves 1-nerved or somewhat carinate. Seeds in one row, lattened, nut wingel; entyledums atembent or rarely ublipue. Petals with

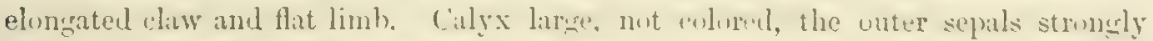

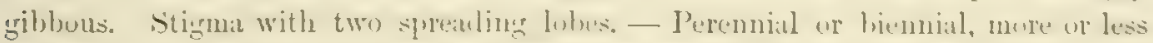

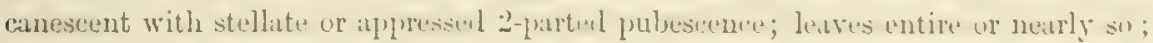
flowers large, purple or yellow.

A genus of perhaps a dozen species of the northern hemisphere, distinguished from Erysimum by the more flittened pods and aceumbent cotyledons. Besides the aretic C. pygmaus only the two following species aro found in America.

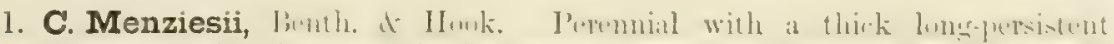

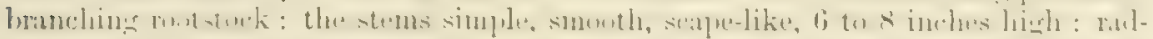

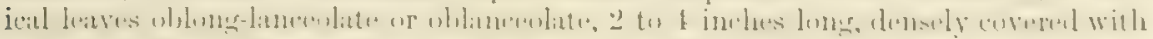

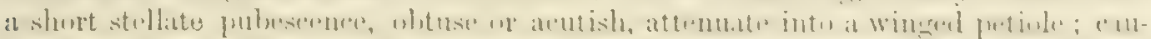

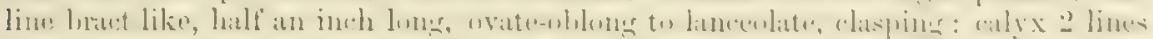

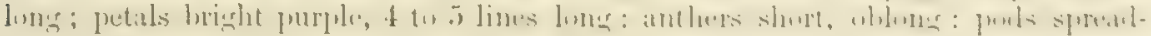
ing, broad, 1 to 2 inches long, not carimate, attemute to the slender stylo: stigma searcely lobed. - Gen. Pl. i. 68; Watson, Bot. King Exp. 1.t. Hesperis Menziesui, Hook.; Bot. Beechey, 322, t. 75. Phoenicuulis cheiranthoiles, Nutt. 1. c. i. 89.

In the mountains, from Ebbutt's Pass in the Sierra Nevala (Brevor), to the Columbia River (Douglas), and in Northwestern Nevada, Walson.

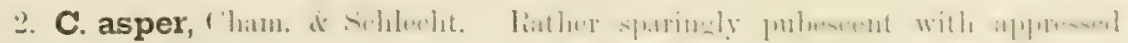
2-parted hairs: stem simple from an apparently biennial root, erect, leafy, 3 to 18

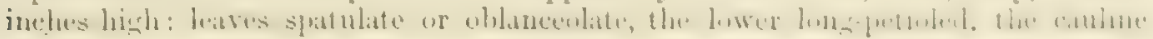


more or less attenuate to the base, 1 to 2 incles long, entire or usually sinuatetoothed: sepals broad, 4 to 6 lines long, half the length of the bright yellow or orange petals: anthers long, sagittate: pods $1_{2}^{\frac{1}{2}}$ to 2 inches long, $1 \frac{1}{4}$ lines wide, somewhat carinate, spreading on rather stout pedicels: stigma 2-lobed: cotyledons accumbent or slightly oblique. - Linnæa, i. 14 ; Torr. Bot. Mex. Bound. 32 . C. capitatus, Dongl. in Hook. Fl. i. 38. Erysimum grandiflorum, Nutt.

On the sea-shore from Monterey to Mendocino Co., usually stunted and the base of the stems crowded with the persistent petioles of old leaves. It seems also to extend to sandy hills a few miles from the coast, where it is taller and more slender, haviug much the habit of Erysimum asperum, with which immature specimens may be confounded.

\section{CAULANTHUS, Watson.}

Pod terete, elongated, sessile upon the receptacle; valves 1-nerved. Seeds in one row, oblong, somewhat flattened, scarcely or not at all margined; cotyledons more or less incumbent. Sepals large, nearly equally saccate at base. Petals but little longer, undulately crisped, the blade only a somewhat dilated rhomboidal extension of the broad claw. Anthers linear, sagittate at base, curved: filaments included. Stigma somewhat 2-lobed. - Stout biennials; with pinnatifid or toothed leaves, and purple or greenish-white flowers. - Bot. King Exp. 27.

A genus peculiar to California and the interior basin. A fifth species, C. hastatus, Watson, l. c., t. 23 , is found in the mountains of Utah.

1. C. procerus, Watson, l. c. Glabrous or glaucous throughout: stems 4 to 7 feet high, stout, branching: lower leaves petioled, coarsely laciniate-pinnatifid, 4 to 12 inches long; the upper lanceolate, sessile, acuminate: flowers greenish white, 4 to 5 lines long, on ascending pedicels half as long: pod terete, very slender, 3 to 5 inches long, less than a line broad, pointed, erect or somewhat spreading: stigma nearly entire. - Streptanthus flavescens, Gray, Proc. Am. Acad. vi. 186, in part. S. procerus, Brewer, in same, vi. 519.

Rich clay soils from Monte Diablo to Pacheco Pass; locally known as "Wild Cabbage" and sometimes used as a poor potherb.

2. C. Coulteri, Watson, 1. c. Mostly hispid: stems rather slender, 1 to 2 feet high, simple or branched: leaves mostly dentate, sessile, the radical broadly spatulate and sinuately toothed; cauline oblong-lanceolate, clasping with a cordate base; the uppermost entire: sepals 3 to 4 lines long, broad, acute, hispid: pod straight, terete, 3 to 4 inches long, nearly $1 \frac{1}{2}$ lines broad, pendent upon the hispid pedicel, beaked by the stout style: stigma 2-lobed. - Streptanthus heterophyllus, Gray, 1. c., in part, not of Nuttall.

Southern California (Coulter); Fort Tejon, Xantus.

3. C. pilosus, Watson, 1. c. Somewhat pilosely hispid, at least at base : stout, erect, branching, 3 to 4 feet high: leaves petioled, lyrate-pinnatifid; lobes sparingly angular-toothed: flowers spreading, in a loose raceme, greenish white, the oblong petals narrowed above, 4 lines long; calyx slightly hairy : pod slender, 3 to 5 inches long: stigma slightly 2-lobed, nearly sessile.

Truckee and Humboldt Valleys, W. Nevada (Watson), and probably oceurring in the low valleys of Northeastern California.

4. C. crassicaulis, Watson, 1. c. Glabrous, glaucous : stem hollow, inflated, erect, 2 to 3 feet high, rarely branched : leaves mostly radical, petioled, runcinate or runcinate-pinnatifid: flowers 6 lines long, dark purple; calyx very woolly: pod terete, 3 to 5 inches long, $1 \frac{1}{2}$ lines broad, ascending on very short pedicels : stigmaa 2-lobed, sessile. - Streptanthus crassicaulis, Torrey, Stansb. Rep. 384, t. 1.

From the eastern base of the Sierra Nevada to Utah, on dry foot-hills; also known as "Wild Cabbage" and at times used for food. 


\section{THELYPODIUM, Endl.}

Pod linear or elongated, terete or slightly compressed, sessile or short-stipitate; valves strongly 1-nerved. Seeds in one row, oblong; somewhat flattened, not winged; cutyledons more or less incumbent. Sepals narrow, equal at base. Petals with a narrow claw and flat linear to orbicular limb, exserted, white or rose-color. Anthers linear, sagittate at base, curved ; filaments often exserted. Stigma mostly entire. - Probably all biennials, mostly stout and coarse. - Watson, Hot. Fing Exp. 25. Pachypodium, Nutt. in Torx. \& Gray, Fl. i. 96 ; Benth. \& Hook. Gen. Pl. i. 81 .

A genus of ten recognized species, chiefly confined to the western coast and interior basin, a single species occurring in Texas and the Atlantic states. The Mexican flora probably includes some others.

* Leaves all entire: stipe obsolete or very shomt: filaments scarcely erserted: glabrous.

1. T. integrifolium, Endl. Stout, 3 to 6 feet high, branched at the summit, often corymbusty : riulical leaves large (often a foot lun: or more), chlong-elliptical, long-petiuled; canline leaves mostly narruwly lanceolate, 1 to 2 inches long, sessile, ascenling, the uppermust linear: Howers criwdent and almost corymbuse at the end of the branches; sepals $1 \frac{1}{2}$ to $2 \frac{1}{2}$ lines long; petals spatulate-obovate, pale rosecolor: fruiting racemes short and crowded; pod 6 to 15 lines long, somewhat torulose, acuminate with the slender style. - Watson, 1. c. Pachypadium integrifolium, Nutt. l. c.; Hook. \& Arn. Bot. Beechey, 321, t. 74.

Edge of the Mohave Desert (Hecrmann), and frequent on the eastern side of the Sierra Nevada from Oregon to the Upper Missouri and New Mexico.

2. T. sagittatum, Endl. Stems weak, mely erect, 12 to is inches high,

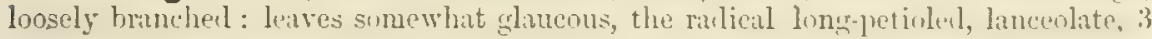
to 4 inches long; cauline leaves sagittate and clasping: potals pale pink, 3 to 5 lines long, twice longer than the purplish calyx : the loose raceme elongated in fruit: pod 1 to 2 inches long, somewhat torulose, acuminate with the rather long style, sprealing, on purlicels 3 to if lines ling : cotylerluns often nearly incumbent.

-Watson, 1. c. Pachypodium sagittatum, Nutt. l. c.

Under bushes in alkaline localities, from Carson and Truckee Valleys, Nevada, to Western Wyoming; doubtless in the nurthenstern portion of the State.

3. T. Nuttallii, Witson, l. e. Fiesembling the list, hut stmiter ambl mure ereet, 3 to 5 feet high: radical leaves ovate, long-petioled, often 6 to 8 inches long; the

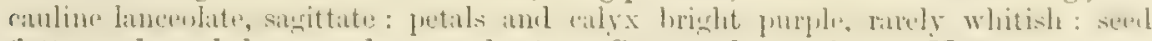
flatter and cotyledons nearly accumbent. - Streptanthus sagittatis, Xitt.

In similar localities, from tho Blue Mts., Oregon (Nevius), and Sonthern Idaho (Mivtealt) to Nevadr and Utah (Walson) and Arizonn, Ivcs.

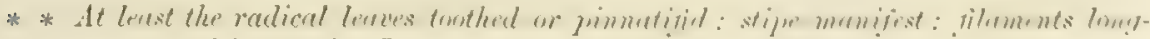
exserted (except in No.6 and 7): hirsute at base (glabrous in No. 5).

4. T. brachycarpum, Torr. Stem nsilally uret, virgate, rarely lomellime, 1 in

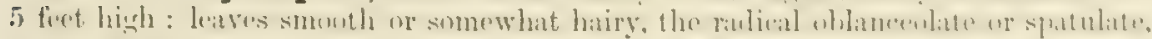

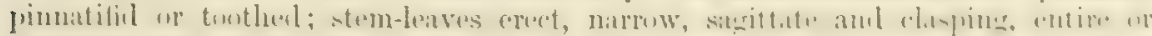

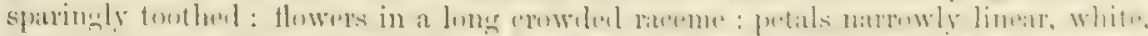

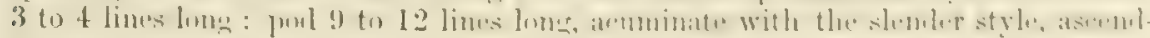
ing on short pedicels. - Bot. Wilkes Exp. 231, t. 1.

Mono Pass and near Mono Lake (Brelocr) and northwarl to the Trueke River (Torrey, Bailcy); first collected by Pickering, probably on the Upper Sncramento.

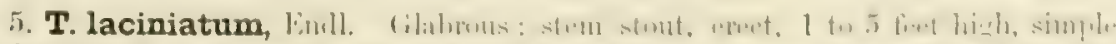

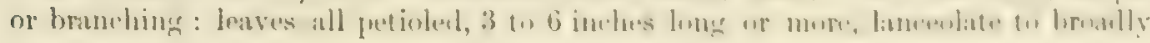


oblong, laciniately pinnatifid or coarsely and unequally sinuate-toothed: raceme long and crowded: petals linear, 3 to 5 lines long, nearly white: pod $1 \frac{1}{2}$ to $2 \frac{1}{2}$ inches long, pointed with the slender style, on short stout divaricately spreading pedicels. - Macropodium laciniatum, Hook. Bot. Misc. i. 341, t. 68. Pachypodium, Nutt. 1. c.

From Carson and Truckee Valleys to the Columbia River.

6. T. longifolium, Watson, 1. c. Erect, rather slender, 1 to 2 feet high : lower leaves oblanceolate, 2 to 3 inches long, petioled, sinuately toothed, the upper linear and entire: flowers scattered, on slender pedicels : sepals purplish, broad, obtuse, 2 lines long, a little shorter than the purple petals: filaments not exserted: anthers short : pod terete, 1 to $1 \frac{1}{2}$ inches long, very narrow, acute with the very short style, ascending. - Streptanthus longifolius, Benth. Pl. Hartw. 10. S. micranthus, Gray, Pl. Fendl. 7.

Huevis Valley, W. Arizona (Bigelow), to New Mexico and southward; probably in S. E. California.

7. T. flavescens, Watson, 1. c. Pilose: lower leaves sinuately toothed; the upper sessile and entire, not auricled at base: sepals and pedicels hairy: pod $1 \frac{1}{2}$ inches long, nearly terete, sparsely hirsute, beaked with the long slender style, strictly erect. - Streptanthus flavescens, Torrey in Pacif. R. Rep. iv. 65, not Hook.

A little known species, collected only by Bigetow near Benicia; said to have yellowish flowers.

An imperfect fruiting specimen, collected by Cooper at Fort Mohave, is probably to be referred to this genus rather than to Sisymbrium, - well marked but not according with any known species of either genus. It is glabrous above, with narrow entire leaves, sagittate at base and clasping; pods few and scattered, strongly reflexed on short pedicels, an inch long, terete and rather stout, beaked with a slender style; seed-coat gelatinous on boiling. The lower part of the stem is wanting.

\section{STANLEYA, Nutt.}

Pod linear, elongated, terete, long-stipitate; valves 1-nerved. Seeds in one row, oblong, not winged; cotyledons linear, incumbent. Sepals equal at base, narrow, spreading, yellow. Petals yellow, narrow, with long connivent claws. Anthers linear, not sagittate, at length closely coiled; filaments much elongated. Stigma sessile, entire. - Stout perennials with large flowers in elongated racemes.

A genus of but three species, confined to the interior of the continent, a single one reaching the southern portions of the State.

1. S. pinnatifida, Nutt. Glabrous: stems soveral from a perennial woody base, 1 to 8 feet high, simple': lower leaves coarsely lyrate-pinnatifid with few oblong segments; the upper entire, lanceolate, narrowed to a slender peticle : calyx 3 to 4 lines long: petals half longer, the claws and stipe of the ovary somewhat pubescent : pod 2 inches long, a line wide, curved, attenuate into a slender stipe 6 to 9 lines long, exceeding the spreading or horizontal pedicels. - Gray, Gen. Ill. i. 154, t.·65. S. integrifolia, James. S. heterophylla \& fruticosa, Nutt.

Pose Creek (Heermann); Santa Barbara Co. (Torrey) ; Fort Mohave (Cooper) ; and north and eastward through the interior to the Snake River, the Upper Missouri and New Mexico, Californian specimens have the leaves all narrow and entire, and the pods horizontally recurved, corresponding to the figure of the Arizona plant in Sitgreaves Rep. t. I.

S. viridiflora, Nutt, is known by its lanceolate sessile and clasping stem-leaves, the radical ones obovate or lanceolate, entire or with a few runcinate teeth toward the base; calyx and petals greenish yellow; pod torulose. It is found in the valleys of Northern Nevada and north and eastward, and may occur in Northeastern California.

\section{ERYSIMUM, Linn.}

Pod 4-angled by the prominent midnerve of the valves, not stipitate. . Seeds in one row, oblong, not margined; cotyledons incumbent or oblique. Sepals erect, 
the alternate ones strongly rribbous at base. Petals long-clawed, with a flat blurle. Anthers sarittate at base, not coiler. Stigma 2-lober, dilated. - Biennials or perennials; with narrow entire or repandly toothed leaves, not clasping; the Howers often large, yellow or orange, or occasionally purple.

A rather large genus of the northern henzisphere, most numerously represented in the Old World. But two or three species are found in America.

1. E. asperum, DC: Licmial, cimescent with short appressed hairs: stems solitary and simple, rarely branched above, 1 to 3 feet high, or less: leaves oblanceolate or dirrowly spatulate; the cauline linear to linear-lanceolate, entire or sparingly repand with short acute teeth, 1 to 3 inches long: sepals narrow, 4 to 6 lines long, strongly uilibous: petals 8 to 12 lines lom, light yellow to deep orange or purple: pods 1 to 4 inches long, a line wide, beaked with a stout style, ascending on stout spreading pedicels 3 lines long. - Hook. Fl. i. 64, t. 22.

Var. (?) pumilum, Watson. A low form, the stem branching from the base; blossoming in early spring. - Bot. King Exp. 24.

Var. (!) inconspicuum, Watson, 1. c. Tall and slender, the flowers smaller, light yellow, the petals narrow and claw scarcely exserted.

A variable species, widely diffused, ranging from Mexico to British America, and from the Pacific to Texas and Ohio, - and in elevation from the low hot valleys of the interior to above the forest line in the Sierra Nevada. Alpine specimens are much dwarfed. The flowers are very showy and usually fragrant. The low variety referred to, from saudy hillsides in the Washoe Mountains near Carson City, Nevada (Watson), much resembles the Colorado E. pumilum of Nuttall, which is, however, a decided peremuial, with simple stems from a branching rootstock, though in the original description it is said to be an annual. The var. inconspicurem ranges from Northern Nevada to the Saskatchewan and is likely to be found in N. California.

\section{BRASSICA, Linn. MUstard, \&e.}

Pod linear, narly terete or somewhat 4-sided, pointed with a long conical beak, not stipitate; valves 1 -3-nerved. Seeds in one row, globose, not marrined; cotyledons infolding the rudicle. Lateral sepals usually gibbous at base. Putals yellow. Anthers long, sagittate at base. - Coarse erect herlos; lower lenves mostly pinnate or lyrate with a large terminal lobe. - Sinapis, Linn.

A large genus of nearly 100 species or more, natives of the Eastern Continent, but many widely naturalized as weeds or extensively cultivated. Among the latter, $B$. oleracca in its several varieties gives the Cabbage, Broccoli, Cauliflower, Kale, Kohlrabi, \&c. ; $B$. campestris, the Turnip, Rutabaga, Rape, \&c.; while the White and Black Mustards and Churlock belong to distinct species.

1. B. nigra, Buiss. Chlahous or with some seatterel spreading hairs, ammal,

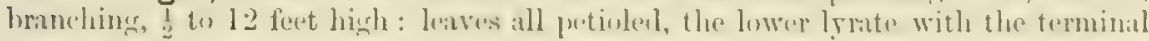

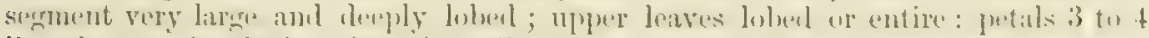

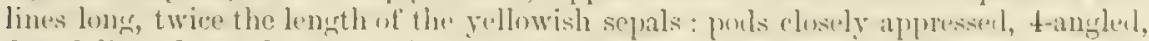
6 to 9 lines long, sharply beaked with the long style: seeds dark brown.

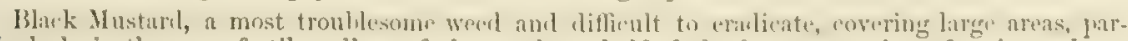
ticularly in the more fertile valleys of the southern half of the State, sometimes forming a dense

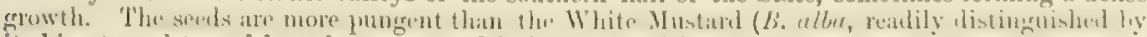
its hirsute pods), and have been exported in large quantities.

2. B. campestris, Iinn. Annual or sometimes hiamial, smoth, 2 to 3 fint

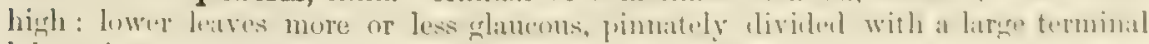

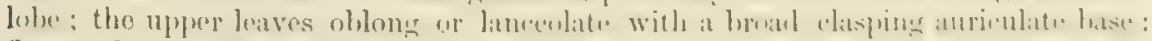
flowers 3 to 4 lines long: pods nearly terete, 2 iuches long or more, 2 lines wide, ascending on spreading pedicels; the stout beak 8 to 10 lines long.

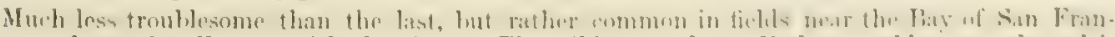
cisco and occasionally met with elsowhore. The wild state shows littlo rosemblauce to tho cultivated forms. 
3. B. Sinapistrum, Boiss. Annual, rough with spreading hairs, 2 to 5 feet high : lower leaves usually with a large coarsely toothed terminal lobe and a few smaller ones upon the rhachis; the upper leaves often undivided, oblong or lanceolate: pods somewhat torulose, 1 to $1 \frac{1}{2}$ inches long, more than a third occupied by the stout 2-edged beak; valves often rihbed by the prominent nerves. - Sinapis arvensis, Linn.

The Charlock of the Eastern States and Europe, where it is often a troublesome weed in grainfields. Sparingly naturalized in Southern California.

\section{BARBAREA, R. Brown. WiNTer CRESS.}

Pod linear, somewhat flattened, pointed; valves somewhat carinate. Seeds in one row, oblong, turgid, marginless; cotyledons slightly oblique. Petals yellow. Glabrous erect branching biennials or perennials, with angled stems and entire or pinnatifid leaves.

A small genus of temperate regions, some of the species widely distributed. The only one native to America is the following.

1. B. vulgaris, R. Br. Perennial, 1 to 3 feet high: lower leaves lyrate-pinnatifid (the radical pinnate), with a large rounded terminal lobe and 1 to 5 pairs of lateral ones, oblong in the cauline leaves; upper leaves obovate, more or less pinnatifid at base : flowers 2 to 3 lines long: anthers short, oblong: pods erect, often appressed, 1 to $1 \frac{1}{2}$ inches long, somewhat angled when mature, about 25-seeded, beaked with the rather slender style. - Gray, Gen. III. i. 148, t. 62.

Var. arcuata, Koch. Pods and pedicels spreading.

Inhabiting marshes and damp places. OnIy the variety seems to have been collected in California, near San Francisco and northward to Sitka, though the typical form is common in Oregon and eastward; the species ranges nearly round the world.

\section{SISYMBRIUM, Linn. Hedge Mustard.}

Pod linear, terete or nearly so, short-pointed or obtuse; valves somewhat $1-3$ nerved. Seeds usually in one row, small, oblong and teretish, not margined; cotyledons incumbent. Sepals scarcely gibbous at base. Petals yellow or yellowish. Anthers mostly linear-oblong, sagittate. - Erect herbs, with small flowers, the leaves (in our species) not clasping or auriculate at base, rarely entire, often finely dissected.

A large genus of rather diffeult definition. prineipally confined to the northern temperate zone. The American species, less than a dozen, belong to the region west of the Mississippi, S. canescens alone ranging farther eastward.

\section{* Seeds in two rows: leaves usually finely dissected.}

1. S. canescens, Nutt. Annual, canescent with short branching hairs : stems branched, $\frac{1}{2}$ to $2 \frac{1}{2}$ feet high: leaves $1-2$-pinnate, the segments more or less deeply pinnatifid or toothed: petals light yellow, equalling the sepals, usually a line long or less: pods oblong to linear, 3 to 6 lines long, a line broad or less, acute at each end and beaked with the very short style, shorter than the slender spreading pedicels: seeds ovate-oblong, a third of a line long. - Gray, Gen. Ill. i. 152, t. 64 ; Fournier, Sisymb. 65; Watson, Bot. King Exp. 23.

In dry soils from Monterey southward, and very abundant in the valleys on the eastern side of the Sierra Nevada, where its seeds are collected by the Indians. The species ranges in the interior from the Arctic Circle to Mexico, and as far eastward as New York and Pennsylvania. The $S$. brachycarpum cited by Fournier as from San Diego is probably but a form of this, as is certainly the northem plant so named by Richardson. The species is quite variable, especially in the section of the leaves and length of the pod. 
* * Seeds in one row.

\section{+ Leaves pinnate or bipinnate.}

2. S. incisum, Engelm. Anmual; pubescence short, more or less glandular: stems branched, 1 to 4 feet high: leaves pinnate, the serments linear to ovateoblong, mure or less deeply pinnatifid, sonetimes entire: petals yellow, about $1 \frac{1}{3}$ lines long: porls natrowly linear, usually pointed at both ends, half an inch longt and $8-12$-seeded, or sometimes much shorter and few-seeled, mostly exceerling the spreading pedicels. - Grizy, Pl. Fendl. 8. Smelowskin (!) C'alifornica, Gray, Proc. Am. Acad. vi. 520. Sisymbrium Californicum, Watson, But. King Exp. 23, tile Gray in Am. Jour. Sci. 3 ser. iii. 150.

Var. filipes, Gray. A form with divaricate pedicels, 6 to 8 lines long, exceeding the pods. - Pl. Fendl. 8. S. longepedicellatum, Fourn. Sisymb. 59, excl. syn.

Var. Hartwegianum, Watson, has the rather shurt pods on somewhat appressed or nearly erect pedicels about 2 lines long. - S. Hartwegianum, Fourn. 1. c. 66.

In dry soils in the Sierra Nevada at 6,000 to 10,000 feet elevation (Brever), and in the mountains northward and eastward to Washington Territory, Winnipeg Valley, and New Mexico. The var. flipcs occurs both from Oregon (Spaldiny), perfectly glabrous, and from Arizona (Palmer), canescent with a fine dense pubescence. Frequent intermediate forms connect var. Hartwegianum with the typical state.

A peculiar type, perhaps distinct, with short clavate almost pointless pods, 2 to 3 lines long, on still shorter pedicels, was collected by Tolmie in the "Snake Country" (S. brachycarpum of Bot. Beechey, not Richardson), and more recently by Dr. Gray in Humboldt Valley, Nevada. It will probably be found in Northeastern California.

\section{++ Leaves pinnatifid or sometimes entire.}

3. S. reflexum, Nutt. Annual, with scattered simple hairs: stems rather slender, often simple, to 2 feet high : leaves 2 to 4 inches loner, pinnatitid with divaricate trothed segments, the upper often only sinuate-tonthed: petals rose-color, white or yellowish, 1.: to $2 !$ lines long : pod slender, 1 to 2 inches lonis, half a line wide, terete, strongly deflexid, straight or snmewhat curved, on short peelicels. - Pl. Giambel. 183. Tarritis (?) lasiophylla, Hook. \& Arn. Bot. Beechey, 321. S. deflexum, Harv.; Torrey, Pacif. R. Rep. iv. 66; Fournier, l. c. 108.

From the Columbia River to S. California, mostly near the const; Guadalupe Island (Palmer); S. Utah, Parry. Characterized by its deflexed pouls.

4. S. junceum, Bieb. P'erenuial, fhahrous, glaucous: stems lorancherl, 1 to 1 ! feet high: leaves narrowly ohlinceolate or linear, 1 to 2 inches 1011 . attenuate tor it narrow base, entire or sometimes pinnatifid with a few narrow segments: petals light yellow, 3 limes long : pods ascendime on short spreating perliceds, 10 to 15

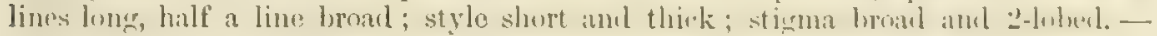
Torr. \& Gray, Fl. i. 91 ; Watson, l. c. S. pygmeum \& linifolium, Nutt. ; Torr. \& Gray, Fl. i. 91. Erysimum (?) glaberrimum, Hook. \& Arn. Bot. Beechey, 323.

Oregon to Montana ; Snake Country (Tolmie); kast Humboldt Mfountains, Nevada (Watson): will probably be found in Northeastern California. It is also native to Siberia.

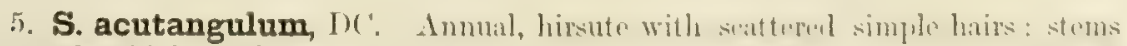

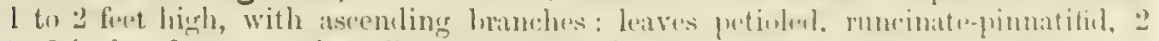
to 6 inches long: petals yellow or yellowish, 1 to 2 lines long: pods terete, 1 to

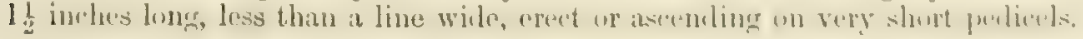

A native of S. Europe, naturalized near the older towns from San Frnneisco to Los Angeles.

6. S. officinale, scop. Anmul or hionnial, springly himute, disarimaty

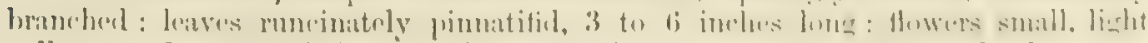
yellow: pods terete, half an inch long, a line wide, tapering from the baso to a sharp point, nearly sessile, closely appressed in a long slender mceme.

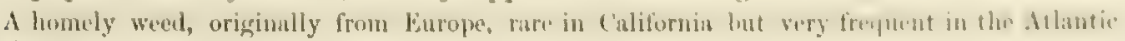
Stateg. 


\section{SMELOWSKIA, C. A. Meyer.}

Pod short, pointed at each end, 4-angled, few-seeded: valves strongly I-nerved and carinate. Seeds in one row, oblong, not margined; cotyledons incumbent. Petals white or pinkish : anthers oval to oblong. - Dwarf alpine perennials; leaves narrowly pinnatifid.

A genus of 4 or 5 species, all Siberian, and one of them also found in the mountains of Western America. A doubtful Californian species is added.

1. S. calycina, C. A. Meyer. Densely white-tomentose to nearly glabrous, cespitose, the much-branched rootstock thickly covered with the sheathing bases of dead leaves: stems erect, simple, 2 to 6 inches high: leaves mostly radical anid with long slender petioles, pinnate or pinnatifid; segments linear to oblong, entire or sparingly lobed: calyx villous: petals 2 lines long: pods 3 to 6 lines long, a line wide, attenuate to each end and beaked with the short style and broad stigma, ascending on spreading pedicels: seeds 2 to 8, a line long. - Hutchinsia calycina, Desv. ; Hook. Fl. i. 58, t. 17, fig. B ; Watson, Bot. King Exp. 24.

On Lassen's Peak and in the northern Sierra Nevada (Lemmon) : from Colorado to Oregon and northward to the Arctic Ocean.

2. S. (?) Fremontii, Watson. Pubescent with scattered short spreading hairs, the branching woody base with few remnants of old leaves: stems 2 to 4 inches high: leaves less than half an inch long, pinnate with 1 to 3 pairs of linear leaflets, which are strongly nerved and somewhat revolute: sepals smootb, ovate to broadly oblong, less than a line long, the white petals twice longer: pods (not mature) 2 to 3 lines long, somewhat obcompressed, obtuse at base and scarcely attenuate above, beaked with the short thick style; valves faintly nerved: seeds small, 10 or more in each cell; cotyledons obliquely incumbent. — Proc. Am. Acad. xi. 123.

Hills around Klamath Lake (Fremont); Sierra Co. (?), Lemmon. Much resembling the last species in habit, but referred to the genus with doubt as the fruit is apparently abnormal in being comparatively obtuse and terete, and in the obliquity of the cotyledons.

\section{NASTURTIUM, R. Bт̃wn.}

Pod oblong or short-linear, terete or nearly so: valves nerveless. Seeds in 2 rows, small, turgid : cotyledons accumbent. - Growing in water or in moist places, smooth or nearly so, with white or yellow flowers, and with the leaves (in our species) pinnatifid or lyrate.

A genus widely distributed, of scarcely 20 species according to Bentham and Hooker, but many more are recognized by most authors. There are about 10 native American species, chiefly confined to the Mississippi Valley and the region westward.

* Flowers small, pale yellow: stems not rooting: leaves pinnatifid or toothed.

1. N. palustre, DC. A stont biennial, glabrous, erect, 1 to 3 feet high, branching: leaves lanceolate, lyrately pinnatifid, petioled, 2 to 6 inches long: petals a line long: pods oblong, 3 to 4 lines long, equalling the spreading pedicels, acutish at each end or obtuse above, tipped by the prominent style.

Var. hispidum, Fischer \& Meyer. Somewhat hispid: pods shorter, globoseoblong, 2 lines long.

Near the eastern border of the State in Truckee Valley ( $W$ atson), and common north and eastward, from Arctic America to the Gulf of Mexico.

2. N. curvisiliqua, Nutt. Annual or biennial, smooth, usually erect, $\frac{1}{2}$ to 1 foot high: leaves narrowly oblong or oblanceolate, pinnatifid with oblong usually toothed lobes, rarely only sinuate-toothed: petals a little exceeding the sepals : pods rather slender, 4 to 6 lines long; style prominent or none; pedicels usually nearly 
as long, and both often strongly curved. - Torr. \& Gray, FL i. 73. N. cernuum \& polymorphum, Nutt. 1.c.

Var. lyratum, Watson. Often decumbent and diffusely branched from the hase: leaves with broader coarsely toothed lobes, frequently narrowed at the base: pod more turgid, sbortly pedicelled. - N. lyratum, Nutt. l. c. Watson, 1。 c. 15.

Frequent in Washington Territory and Oregon, ranging southward (especially the variety) to the Sacramento and N. Yevada.

3. N. sinuatum, Nutt. I. c. Stems diffuse, slender, decumbent, smooth or slightly ruughuncu, "from perennial creeping or subterranean shouts": leares lanceolate, usually narrow, $1 \frac{1}{2}$ to 3 inches long, regularly sinnate-pinuatifid with numerous linear-oblong nearly entire lubes: fluwers "2 lines lon: pouls linear, half an inch long or less, tipjerl with the lung style, becoming curved, as also the slencler pedicel. - Watson, 1. c. 15 .

W. Hunboldt Mountains, Nevada (Watson), S. Nevada (Whceler), and probably along the eastern base of the Sierra Nevada, ranging eastward to New Mexico and the Upper Mlississippi.

$$
\text { * Flowers rather large, white: introduced perennials. }
$$

4. N. officinale, $\mathrm{I}_{\text {. }}$. $\mathrm{r}$. Aquatic, smonth, procumbent, rooting at the joints : leaves pinnite witl rounded to oblong obtusely sinuate leatlets, often reduced to only the terminal one: petals $1 \frac{1}{2}$ to 2 lines long: pods half an inch long, acute at each ent, equalling the spreading pediculs; ralves slinhtly nerred; style short, thick.

The Water-Cress of Europe, often cultivated and midely naturalized.

N. Armoracts, Fries, the common Horseradish, will doubtless become naturalized in the State. A stout perennial with fusiform root, rarely fruiting; leaves large, oblong-lanceolate, crenately toothed; petals 3 lines long; pods 2 lines long, turgid.

\section{VESICARIA, Tourn. BLADDER-POD.}

Pod ovate to globose; valves rigid, strongly convex, nerveless. Seeds few, in 2 rows, flattened, rarely somewhat marginel : cotyledons aceumbent. Style long and slender. - Low densely stellate-canescent herbs; with largo yellow flowers, aml entire or sinuately toothed leaves.

A genus of about 20 American species, most abundant in Texns and northward, with $a$ ferr species in Southern Europe and Syria, which differ in habit and in their large broadly wixged seeds.

1. V. montana, Gray. Perennial: stems ascending or decumbent, 3 to 8

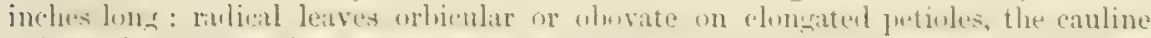

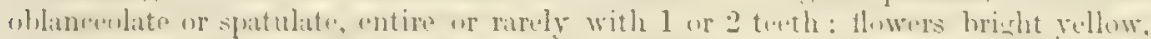

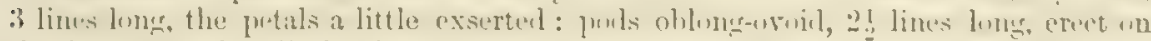

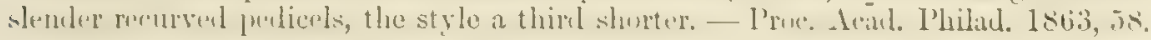

Lassen's Peak (Lemmon), and eastwand in the mountains to Colorado.

\section{SUBULARIA, Linn. Awwort.}

Porl small, obuil, slightly compressenl contrary to the putition : valves conrex, 1-nerved. Seeds several, not winged: cotyledons incumbent. Style none. - A dwarf stemless annatic, with tuted subulate leaves, and fir minute white flowers.

A single species, inhabiting the margins of lakes in Europo, Siberia, and N. America.

1. S. aquatica, Linn, Sipes slender, 1 th 3 inches high, from slemler rum-

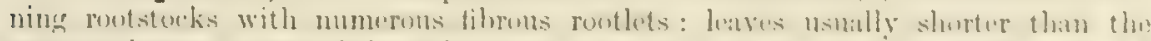

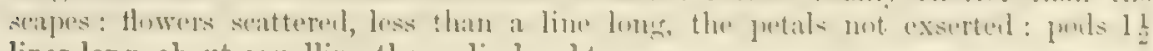
lines long, about equalling the pedicels, obtuse.

In pools in Mono Pass on the Upper Tuolumne River (Bolander), at 10,000 foct altitude. Yellowstone Lake, Wyoming (Parry); lakes of Jaine and New Hampshire. 


\section{TROPIDOCARPUM, Hook.}

Pod linear, flattened laterally, often 1-celled by the disappearance of the narrow partition: valves carinate, 1-nerved. Seeds in two rows, minute, flattened, not winged: cotyledons incumbent. Style short. - A low slender hirsute branching annual, with pinnately divided leaves, and yellow solitary axillary flowers.

1. T. gracile, Hook. Stems weak, 2 feet high or less: leaves pinnatifid or rarely 2-pinnatifid, with narrow or linear segments : flowers in the axils of the upper bract-like leaves; petals $1 \frac{1}{2}$ to 3 lines long, nearly twice longer than the obtuse sepals: pods 6 to 20 lines long, more than a line broad, pointed at both ends, ascending on slender spreading pedicels 10 to 20 lines long. - Ic. Pl. t. 43. T. scabriusculum, Hook. 1. c. t. 52.

Valleys and low hills in the Coast Ranges from Los Angeles to the Sacramento.

\section{CAPselila, Monch.}

Pod obcordate or oblong, much flattened laterally, many-seeded: valves carinate, 1-nerved. Seeds not winged : cotyledons incumbent. Style none or very short. Slender and mostly smooth annuals; with small white flowers, and simple or pinnate leaves.

Only half a dozen species are known, somewhat diverse in habit and characters, natives of the northern hemisphere, - two North American, of which one enters California.

1. C. divaricata, Walp. Glabrous, very slender and diffusely branched, 3 to 12 inches high : radical leaves an inch long or less, pinnate or pinnatifid with few lobes, the upper oblanceolate to linear, entire: pods elliptic-oblong, 2 lines long, on very slender spreading pedicels. - Watson, Bot. King Exp. 28. Hymenolobus divaricatus \& erectus, Nutt. in Torr. \& Gray, Fl. i. 117.

In saline or alkaline soils; Vallejo (Greene); S. California (Coulter); and eastward of the Sierra Nevada from the Columbia River to Colorado and S. Utab.

2. C. Bursa-pastoris, Moench. Usually somewhat hirsute at base, 12 to 18 inches high, branching : radical leaves mostly runcinate-pinnatifid, the cauline lanceolate auricled at base, toothed or entire: pods cuneate-triangular, truncate above, 1 to 2 lines long and broad: pedicels widely spreading : seeds numerous, minute.

Originally from Europe, now naturalized as a harmless weed over most of the civilized world ; known as Shepherd's Purse.

\section{IYROCARPA, Hook. \& Harv.}

Pod fiddle-shaped or reniform-obcordate, strongly flattened laterally, somewhat acutely carinate: cells 2-5-seeded. Seeds rounded, flattened, narrowly winged: cotyledons accumbent. Style very short: stigma 2-lobed. - Pubescent annuals; leaves lyrately pinnatifid, petioled; flowers purplish, with long narrow calyx.

1. L. Coulteri, Hook. \& Harv. Canescently pubescent throughout with branched hairs; stem about a foot high, loosely branched : leaves all petioled, oblong, lyrately pinnatifid, 1 to 2 inches long: flowers in a very open raceme, spreading or deflexed: petals linear, acuminate, 9 lines long: pods fiddle-shaped, 6 to 8 lines long, 4 to 5 wide, pubescent : stigma dilated, depressed. — Lond. Jour. Bot. iv. 76, t. 4.

Collected only by Coulter, the precise locality unknown; probably in S. California or W. Arizona. An immature specimen from Cape San Lueas (Xantus) is perhaps distinct, having shorter petals, with a dilated blade, and a less depressed conical stigma.

L. Palmeri, Watson, Proc. Am. Acad. xi. 123, from the Big Cañon of the Tantillas Mountains, below San Diego, differs from the original type of the genus in its reniform-obcordate pod, 4 to 5 lines wide, with 2-seeded cells; upper seed horizontal, the lower pendulous : petals linear. 
23. THLASPI, Linn.

Pod cuneate-oblong or obcordate, laterally compressed, usually emarginate at the apex, few-seeded; valves acutely carinate or winged. Seeds somewhat turgid, not winged; cotyledons accumbent. Style rather loug. - Low glabrous herbs with simple stems; lower leaves rosulate, entire or toothed ; the cauline oblong, auricled and clasping; flowers white or pinkish.

About 25 or 30 species, inhabiting the temperate and colder regions chiefly of the northern hemisphere. But a single species is indigenous to America, common also to the mountains of Lurope and Asia.

1. T. alpestre, Linu. Stems several from a branching perennial rootstock, 1 to 15 inches high: radical leaves obovate or elliptical, an inch long including the slender petiole, entire or sparingly torthed; cauline leaves orate to oblons, entire, obtuse or acutish: flowers white, 2 or 3 lines loug: pods obovate to cuneate-oblong, 3 or 4 lines long, emarginate or truncate or rounded at the summit, 4-8-seeded, tipped by a style a line long, horizontal on short pedicels. - Watson, Bot. King Exp. 31. T. cochleariforme, DC., and T. montanum, Hook. Fl. i. 58; Torr. \& Gray, Fl. i. 114. T. Fendleri, Gray, PI. Wright. ii. 14.

Alpine in the Rocky Mlountains from New Mexico to British America, in Oregon and in the mountains of Nevada and Arizona. Probably to be found in N. California and perhaps southward in the Sierra Nevada.

\section{LEPIDIUM, linn. Pepper-grass.}

Pod orbicular or obovate, strongly flattened laterally, emarginately 2-winged at the summit; valves acutely carinate; the cells 1 -seeded. Seeds not winged; cotyledons incumbent (very rarely accumbent). - Low herbs; with pimnatifid or toothed leaves, and small white (in one species fellow) flowers. The petals in many of our species are often wanting, and the stamens only 2 or 4.

A genus of nearly 100 species, of both temperate zones. Of the 16 North American species a single one is found on the Atlantic Coast, the rest being limited chiefly to the southwest and to the region west of the Rocky Mountains, and mostly low annuals of peculiar habit.

* Low annuals: pedicels flattened: petals white, often wanting: stamens 2 to 4: style none.

+ Pod reticulated.

1. L. latipes, IIook. Ilispid with short spreating hairs or the lenves glabrous :

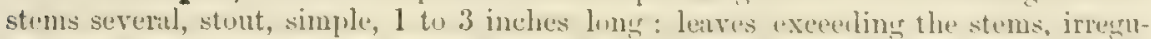

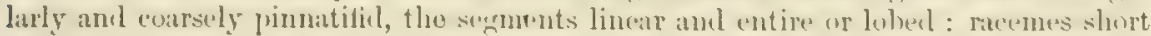
and capitate, in fruit an inch long or less; pedicels 1 or 2 lines long: sepals very

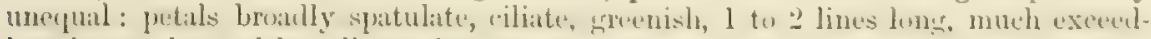

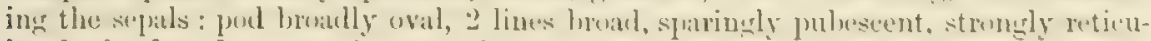
lated, the broad acute wings nearly as long as the pod. - Ic. Pl. t. 41 ; Torr. Gray, Fl. i. 116.

In saline soils near the coast, from Martinez to San Luis Rey.

2. L. dictyotum, firay. Puhesesnt thruelume with short sprealing hairs or

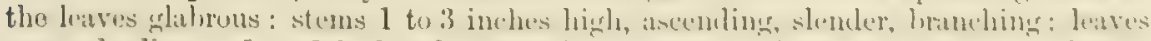
aarrowly linear, 1 or 2 inches long, entire or pinnatilid with a few linear lobes:

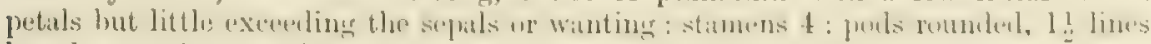

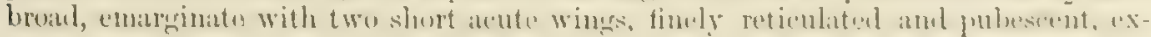
ceeding the thick erect perlicels. - Proc. Am. Acal, vii. 329; Watson, Bot. King Exp. 30, t. 4 .

Under sage-brush in early spring at Carson City and Steamboat Springs, Nevada, Andersom, Watson, Mann. 
3. L. oxycarpum, Torr. \& Gray. Nearly smooth : stems slender, ascending, simple or branched, 3 to 6 inches high: leaves linear, pinnatifid with a few narrowly linear or filiform segments or entire: raceme lax, elongated : sepals unequal; soon deciduous: petals none: stamens 2 : pods smooth, rounded, $1 \frac{1}{2}$ lines broad, nodding on slender pedicels as long as the pod, the broad and acute teeth short and divergent. - Fl. i, 116.

Var. (?) strictum, Watson. Sepals green, persistent: fruiting racemes crowded, the pedicels erect: wings less acute and spreading: lobes of the leaves less elongated.

Vallejo, Greene. Also by Douglas and Coulter, probably in the same region. The variety has been collected only by Ratian, near Placerville, and is hardly referable to this species.

\section{$\div+$ Pod not reticulated or scarcely so.}

4. I. nitidum, Nutt. Glabrous or somewhat pubescent: stems simple or branched, 3 to 16 inches high: leaves pinnately cut into narrow linear acuminate segments, the uppermost often entire : petals present, small : pods in a loose raceme, spreading, glabrous and shining, rounded, $1 \frac{1}{2}$ to 2 lines broad, acutely margined; the wings short, obtnse and slightly spreading: pedicels 1 or 2 lines long: seeds often ash-colored. - Torr. \& Gray, Fl. i. 116. L. leiocarpum, Hook. \& Arn. Bot. Beechey, 324.

In winter and early spring, from above San Francisco to Los Angeles.

5. I. Menziesii, DC. Hispid or pubescent: stems 3 to 6 inches high, branched: leaves oblong, all pinnatifid with short oblong or spatulate acutish segments, which are rarely sparingly toothed: petals none: pods glabrous, rounded, 1 to $1 \frac{1}{2}$ lines broad, not margined except by the short very obtuse teeth at the summit : pedicels spreading or recurved, 1 or 2 lines long, slender and often scarcely flattened. Syst. ii. 539 ; \& Prodr. i. 205.

Santa Barbara (Nuttall) to Los Angeles (Brewer); Guadalupe Island, Palmer. These speeimens accord with others raised from seeds cultivated under the name in the garden at Geneva prior to 1840 , and with De Candolle's description based upon the original specimens of Menzies from "California." The Oregon plant referred to this species has been for the most part L. intermedium, though the one so named by Torrey in Bot. Wilkes Exp. is apparently L. Virginicum with unusually deeply pinnatifid leaves.

6. L. lasiocarpum, Nutt. Roughly puberulent or pubescent with short spreading hairs: stems rather stont, branched, 3 to 10 inches high, decumbent: lower leaves 3 to 4 inches long, more or less ciliolate at least on the petioles, pinnate, with ovate to oblong sparingly toothed segments; upper leaves 1 to 2 inches long, incisely pinnatifid with narrow lobes, or the uppermost entire: petals none or very small: stamens 2 : pods rounded, $1 \frac{1}{2}$ to 2 lines broad, hispid on the margin, winged at the apex with short very obtuse teetl, crowded in a narrow raceme on short ascending or horizontal pedicels. - Torr. \& Gray, Fl. i. 115.

Santa Barbara (Nuttall); Guadalupe Island, Palmer. Closely allied to the last species.

L. WRIGHTII, Gray. A very similar species, hirsute with spreading hairs; leaves pinnatifid or toothed; pods hispid, rather broadly winged at the summit. Of the Rio Grande Valley, ranging westward nearly to the Colorado; appears to be in N. W. Nevada, Torrey, Lemmon.

* * Low annuals: pedicels terete: petals yellow: stamens 6 : style elongated - pods reticulated.

7. L. Alavum, Torrey. Glabrous, decumbent, diffusely branched: stems 3 to 6 inches long: radical leaves pinnatifid with short abtuse lobes; cauline leaves few, oblanceolate, acutely toothed or entire: racemes short, nearly sessile : pétals bright yellow: pods orbicular, a line broad or more, shortly winged with broad divergent acutish teeth, on spreading or deflexed pedicels 2 to 4 lines long: style nearly as long as the pod.-Pacif. R. Rep. iv. 67; Watson, Bot. King Exp. 30.

On the Mohave River (Fremont, Bigelowv); also about Humboldt Lake and in the upper valley of the Humboldt River, N. Nevada. 
* * Stouter and often tall, mosily biennial or perennial: pedicels terete.

+ Annual : petals small or usually none: stamens 2 : style none or very short.

8. I. intermedium, Gray. Erect and branching, with the habit of L. Tirginicum, 1 to 1 l. teet high, puberulent or glahrous: lower leaves 1 to 2 inches long, touthed or pinnatifid, the upper often entire or but sparingly touthed, oblanceolate or linear: petals witnting in the westera form : pods smouth or rarely puberulent, rounded, I to 1 l. lines broad, very shortly winged with sumewhat divergent obtuse teeth: pedicels spreading, 2 lines lung. $-\mathrm{Pl}$. Wright. ii. 15 .

The nore common species east of the Sierma Sevada, witely distributed through the interior, ranging from the Culumbia Valley to Hudson's Bay and southward to Texas, New Mexico, and s. Calitornia. The typical form of Texus and New Jexico has rather small petals.

++ Biemial or prerennial : petals conspicuous: stamens 6 : style exceeding the wings.

9. L. montanum, Jutt. Biennial, puberulent or pubescent or nearly glabrous, 1. feet high or less: Ieaves pinnatitil, the oblung to lanceulate semments usually nure or less lividenl, especially on the upper sille; uppermust leares with few segments or linear and entire: petals twice as long as the sepals : pods a line broad, orate, narrowly wingel above with shurt acutish teeth. - Turr. \& Gray, Fl. i. 116; Watson, Bot. King Exp. 29.

In dry vallevs and on hillsides from the "Snake Country" (Tolmic) through Nerada to Sonora, New Mexico, and Coloralo. Anderson's specimens from near Carson City are perennial and approach the next.

10. L. alyssoides, Grav. Puherulent or often glabrous and glauenus, from a perennial rut, cliffilsely brinched, is to 1 foot high: leaves linear, 2 to 3 inclies long, the lowest spangly lobed with linear sements: Howers large: pods from narrowly oblung or linear becuming avate, 1 to 1 ! lines broal, shortly winged above with acutish teeth. - PL. Fendl. 10.

In alkaline soils, from N. Nevada and Colorado to Northern Mexico.

11. L. Fremontii, Watson. Perennial with a somewhat wooly hase, diffusely brancherl, glabrons and glucous, 1 to 11 feet hish: leaves linear, 1 to 3 inches long, entire or sparingly lubed : racemes rather shurt and few-fluwered, terminal and lateral : pouls rounded, abruptly cuneate at hase, 2 to 4 lines hroal, slightly emarginate with short very obtuse teeth. - Bot. King Exp. 30, t. 4.

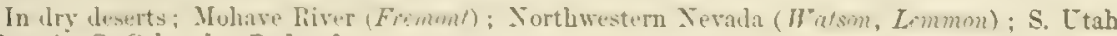
(Parry); S. Colorado, Rolkrock.

25. PHYSARIA, Nutt.

Pod dilymous, with a short narrow partition: cells inflateil. nearly globular,

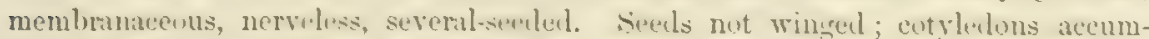
bent. - Low and stellately caneseent perenials; leaves mustly cntire ; the flowers yellow.

Three species are known, confined to the interior of the continent, with the habit of Fesicaria, to which they are reforred by Bentham and Hooker.

1. P. didymocarpa, tiray. Ihrembunt, difnsely hranchel: milieal leaws

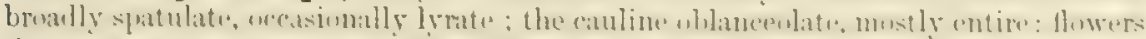

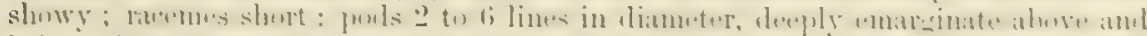

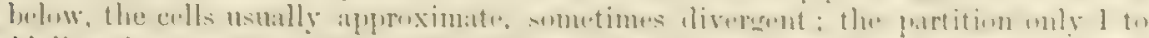

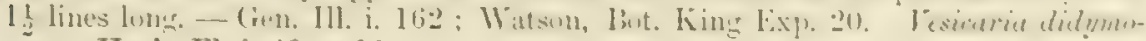
carpa, Hook. Fl. i. 49, t. 16.

On the eastern side of the Sierra Nevada in the mountains to Colomdo and northwanl to British Anerica. 
26. SENEBIERA, DC.

Pod didymous, 2-celled; cells indehiscent, subglobose, separating at maturity from the persistent linear axis, nerveless, strongly rugose or tubereulate, 1-seeded. Seed turgid, not winged; cotyledons incumbent. - Diffuse or prostrate annuals or biennials, with minute white flowers in racemes opposite to the pinnatifid leaves. Stamens often only two.

Half a dozen species, natives of the warmer and temperate regions of both hemispheres.

1. S. didyma, Pers. Somewhat hirsute : stems diffusely branched, $\frac{1}{2}$ to $1 \frac{1}{2}$ feet long: leaves petioled, with small narrow segments: pods small, emarginate above and below, strongly reticulated, a line broad or more. - S. pinnatifida, DC. ; Gray, Gen. Ill. i. 166, t. 72.

San Pablo Landing (Bolander) ; introduced and probably confined to sandy localities near the Bay of San Francisco. Widely distributed in warm regions around the globe.

\section{BISCUTELLA, Linn.}

Pod flattened laterally, 2-celled; cells nearly orbicular, indehiscent, with a thickened margin, separating at maturity from the persistent linear axis, 1-seeded. Seeds flat, horizontal, not winged; cotyledons accumbent. - Erect annual or biennial, hispid or tomentose branching herbs; with entire or pinnatifid leaves, and yellow or purplish flowers.

A genus of 3 or more species, belonging to the Mediterranean region, to which Bentham and Hooker have added the two following, previously kept distinct under the name Dithyrac. They form a section differing from the Old World species in the nearly sessile and conical or 2-lobed broad stigma, the simple racemes, whitish or purplish flowers, stellate tomentum, and more leafy stems.

1. B. Californica, Benth. \& Hook. Tomentose with stellate hairs, annual : stems 6 to 15 inches high, erect or ascending: radical leaves spatulate, sinuately toothed or pinnatifid ; the upper cuneate-oblong, sessile: sepals tornentose, linear, 2 to 3 lines long; petals (purple?) linear-spatulate, half an inch long: racemes loose and elongated in fruit: pods 4 or 5 lines wide and half as long, emarginate above and below, pubescent especially on the margin, with a small cavity adjoining the axis : style short : stigma dilated and depressed: pedicels horizontal, a line long.Gen. Plant. i. 91. Dithyroea Californica, Harv. in Lond. Jour. Bot. iv. 77, t. 5.

On sand-hills near the Colorado River; rare. B. WISLIZENI, Engelm., is found farther to the east, from Arizona to Texas. It is a foot or two high, more leafy; pods larger, broadly truncate abore, deeply cordate at base; stigma conical; pedicels 5 to 8 lines long.

\section{THYSANOCARPUS, Hook.}

Pod 1-celled, indehiscent, plano-convex and much compressed, orbicular, winged or margined, 1-seeded: seed pendulous, somewhat flattened, not winged. - Erect and slender sparingly branched spring annuals; with minute white or rose-colored flowers, the fruit mostly pendulous on slender pedicels in elongated racemes.

1. T. curvipes, Hook. Somewhat hirsute at base, glabrous above, $\frac{1}{2}$ to 2 feet high: radical leaves oblanceolate, 1 to 3 inches long, pinmatifid or sinuately toothed; the upper linear or narrowly lanceolate, acuminate, clasping by a broad auricled base, entire or sparingly toothed: pods round to obovate or ovate, densely tomentose or glabrous, 2 to 4 lines in diameter including the entire or crenate veined and often perforated wing, emarginate at the summit and tipped by the short purple style: pedicels 2 to 4 lines long. - Fl. i. 69, t. 18. T. pulchellus \& elegans, Fischer \& Meyer ; Hook. Ic. Pl. t. 39. 
Very common on dry hillsides from I The form with perforated wing is frequently known as Lace-pod.

2. T. laciniatus, Jutt. Smaller and more slenler: leaves narrowly linear or else pinnately or runcinately cut into nurowly linear segments; the cauline scarcely auricled at base : pods obovate, pubescent or glizbrous, 2 to 3 lines long, cuneate at base, surrounded by a narrow entire or somewhat crenate wing. - Torr. \& Gray, F1. i. 118 ; Watson, Bot. King Exp. 31.

Var. crenatus, Brewer. The broader wing more deeply crenate or fringed with rounded lobes. - T. crenatus, Nutt. 1. c.

Less common than the last, ranging from the Sacramento to $\mathrm{S}$. California and eastward in Arizona; the variety sometimes known as Fringe-pod.

3. T. radians, Benth. Glabrous, 1 to 11 feet hirh : radical leares runcinatepinnatitil, the cauline ovate-lanceolite aul auriculate-clisping : petals about equalling the sepals: ponls rouml, + to 5 lines in diameter, tomentuse or sworth, scarcely emarrinate, with a brual entire translucent wing conspicundsly markel by radiating nerves: style very short: pedicels 6 to 8 lines long, recurved. - Pl. Hartw. 297.

Valleys and low hills in Central Califormia, much less frequent than the preceding.

4. T. pusillus, Inok. Pinurhly pubescent throughout, 3 to $1:$ inches high: lower leaves broadly oblanceolate, entire or remotely dentate, $\frac{1}{4}$ to 1 inch long, shortly petioled; cauline leaves similar but smaller, usually entire, sessile but not clasping: flowers barely a line lones, sometines apetalous: purls obovate to orbiculiur, a line long or less, hirsute with hooked hairs, scarcely or not at all emarginate: style short: pedicels 1 to 2 lines long, at length reftexed. - Ic. Pl. t. 43 ; Hook. \& Arn. Bot. Beechey, 324. T. oblongifolius, Nutt. in Torr. \& Gray, F1. i. 118.

Common on low dry hills from Los Angeles to Vaneouver Island.

T. ERECTUs, Watson, is an additional species from Guadalupe Island, Palmer. Glabrous and

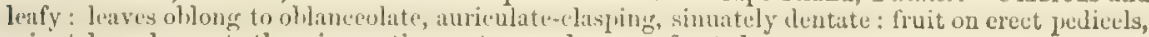
minutely pubescent, the wing entire, not nerved nor perforated.

\section{RAPHANUS, Linn. RADISY.}

Pol indehiscent, elongatel, terete, attenuated abore, 2-juinted ; lower joint often seredless, the upper inflated or constrieted betwern the several seeds. Style long and

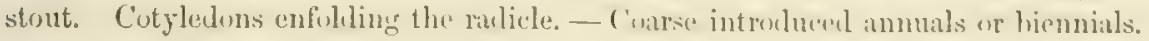

The speeics are now redueed to half a dozen or less, all natives of the Eastern Continent.

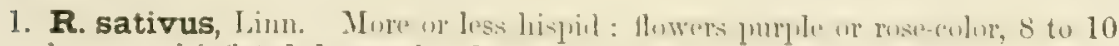
lines long: pod inflated, long-pointed, 1 to 21 inches long, usually 2 -seeded.

The ordinary Radish, common in fields in various parts of the Stnte; the root not fleshy but tough and stringy. There are numerous varieties in cultivation.

R. Raphanistrum, Linn. Petaly yellow, veined, becoming whitish or purplish : pods necklace-shapred, long-beaked, 1-9-seeded, breaking ensily between the seeds. Known as Wikl

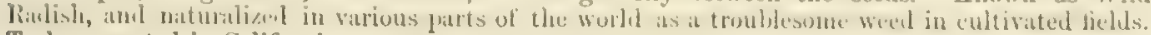
To be expected in Culifornio.

\section{Order VIII. CAPPARIDACE正.}

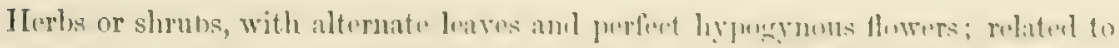

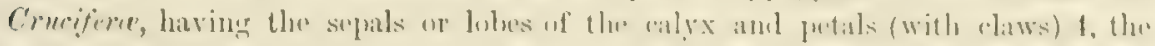

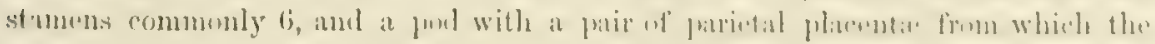

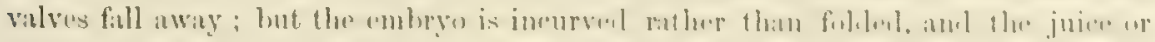

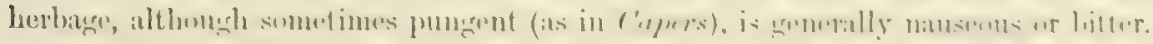

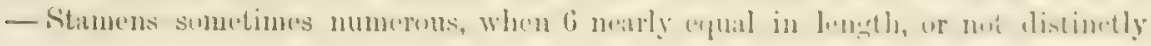


tetradynamous. Style and stigma one. Ovary and fruit commonly raised on a stipe, 1-celled, sometimes 2-celled, few-many-seeded. Seeds globose-reniform. Leaves either simple or palmately compound. Pedicels commonly bracteate.

An order of 24 genera and about 300 species, of warm-temperate and tropical regions, here characterized from that portion of it which has capsular fruit, only 2 placentæ, and few stamens, the tribe Cleomes. But the larger part of the order in warm regions, of the tribe CAPPAREA (of which the Caper-plant is the type), consists of shruls or trees, with fleshy fruit, sometimes with several placenta and numerous stamens. Of the six genera here admitted, one is peculiar to the coast-district of California ; the others belong to the dry interior region and barely reach the eastern borders of the State.

ATAMisquea EMARginata, Miers, a shrub, with a fleshy 1-2-seeded fruit, native of Chili or Buenos Ayres, is said to be in Coulter's Californian collection; but we find no trace of it in the State nor in Arizona.

* Shrubby, with racemose flowers and an inflated eapsular fruit.

1. Isomeris. Calyx 4-cleft, persistent. Corolla yellow. Stamens 6. Ovary long-stipitate.

* * Herbs, with racemose flowers.

+ Fruit pod-like, 1-celled, several-many-seeded.

2. Polanisia. Stamens 8 to 32 . Flowers whitish or purple. Pod elongated.

3. Cleome. Stamens 6. Flowers yellow or pink-purple. Pod oblong or linear.

4. Cleomella. Stamens 6. Flowers yellow. Pod rhomboidal, 2-horned, or globular, few-seeded. + * Fruit didymous, 2-celled; the cells separating as small 1-seeded nutlets!

5. Wislizenia. Stamens 6. Style filiform. Nutlets open at the scar.

6. Oxystylis. Style becoming subulate and spinescent. Nutlets closed.

\section{ISOMERIS, Nutt.}

Calyx persistent, 4-cleft, the lobes ovate, acuminate. Petals sessile, oblong, equal. Torus fleshy, dilated above, somewhat produced on the upper side. Stamens 6 , on the torus, at length long-exserted. Pod large, inflated, coriaceous, long-stipitate, 1-celled, many-seeded: style very short: stigma minute. Seeds large, smooth. - A low ill-scented shrub; with puberulent branches, trifoliolate petioled leaves, and large yellow flowers, axillary or in bracteate racemes.

1. I. arborea, Nutt. Stout, much branched, 3 to 5 feet high : leaves glandularpuberulent or nearly smooth, the uppermost and the floral bracts 1-foliolate; leafiets thickish, narrowly oblong or elliptical, $\frac{1}{2}$ to 1 inch long, entire, mucronate, nearly sessile : pedicels equalling the leaves : petals 5 to 8 lines long, twice longer than the calyx : pod 1 to $1 \frac{1}{2}$ inches long, abruptly acute above, attenuate at base into a stipe nearly as long. - Torr. \& Gray, Fl. i. 124 ; Hook. Bot. Mag. t. 3842 ; Torr. Bot. Mex. Bound. t. 4.

Common in dry soils from Santa Barbara to San Diego. The wood is hard, brittle, and yellow.

\section{POLANISIA, Raf.}

Sepals 4, deciduous, lanceolate, sometimes connate at base. Petals unguiculate or sessile, equal or unequal. Torus small, depressed. Stamens 8 or more, inserted below the torus. Pod membranaceons, very shortly stipitate, elongated, compressed or cylindrical, many-seeded. Seeds rounded-reniform, rugose or reticulated. Annual herbs, ill-scented and mostly glandular; with simple or 3-9-foliolate petioled leaves, and yellowish, rose-colored or white flowers in leafy-bracted racemes; pods erect on spreading pedicels.

A genus of about a dozen species of tropical and warm regions, of which the following reaches the eastern borders of the State. 
1. P. trachysperma, Torr. \& Gray. Glandular-pubescent, erect, $\frac{1}{2}$ to 2 feet high: leaves 3 -fuliolate; leaflets lanceolate, 1 to 2 inches long, acute, about equalling the petioles, nearly sessile; floral bracts mostly simple, ovate to lanceolate, shortly petioled: petals 3 to 5 lines long, with slender claws as long as the sepals, and an emarginate blade: stamens 12 to 16 ; tilaments exserted: style 2 to 3 lines long: pod 1 to $2 \frac{1}{2}$ inches lung, very rarely on a short slender stipe: seeds finely pitted and often warty.-Fl. i. 669; Gray, Gen. Ill. i. 182, t. 79. P. uniglandulosa, Tor. Pacif. R. Rep. iv. 67 ; Watson, Bot. King Exp. 34.

From the Columbia River to Kansas and southward to $N$. Nevada and Texas. The $P$, unigland. ulosa, Cav., of Mexico and New Mexico, to which it has been referred, differs in its much larger flowers, greatly elongated style, larger pods upon a stout terete stipe, and snooth seeds. The eastern $\mathcal{H}$. gruccolens may be distinguished by its smaller flowers, shorter style, lewer and shorter stamens, and smoother seeds; its leaves are also mostly obtuse or obtusish.

\section{CLEOME, Linn.}

Sepals 4, sometimes united at base. Petals with cliws or sessile. Stamens 6, upon the small torts. Pod (in our species) linear or oblong, stipitate, many-seeded: style short or none. Seeds globose-renifurm to orate. - Uur species are all erect branching annuals; with palmately $3-i$-fuliolate leaves (leatlets entire), and yellow or purple flowers, in bracteate racemes; pods pendent on sprealing pedicels.

About 70 species, inhabitants of hot and dry regions, chiefly of America and Africa. The following species approach the eastern or southern borders of the State.

1. C. Iutea, Hook. Smooth or slightly pubescent, 1 to 2 feet high: leaflets 5, linear- to obling-lanceolate, one or two inches lung, acute, short-petiolulate, equalling the petioles; stipules setaceous, caducous; bracts simple, bristle-tipned: flowers shuwy, bright yellow, corymbose, the raceme elongated in fruit : petals 3 to 4 lines long, much exceeling the ovate-lanceolate sepals : stamens much exserted : poid 6 to 15 lines long, abut 2 lines broarl, acute at each end: strle less than a line long: the stipe and pedicel each about half an inch long. - Fi. i. 70, t. 2.5; Lindl. Lot. Reg. xxvii. t. 67. C. aurea, Nutt. in Torr. \& Gray, Fl, i. 122; Watson, 1. c. 32.

Abundant in the valleys of Northwestern Nevada, thence northward to the Columbia and east to Colorado.

2. C. platycarpa, Torr. With the hal hit and characters of the list, but pules-

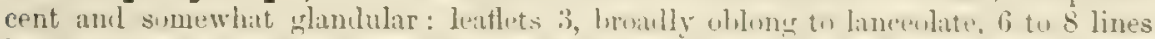
long, obtuse or antish: seprals linear-setikents: juml of lines lonir, about 4 lines broad, 10-12-seeded : style 2 lines long- - Bot. Wilkes Exp. 235, t. 2.

Klamath River, N. California (Pickering); Bluo MLountains, Oregon, Nevins.

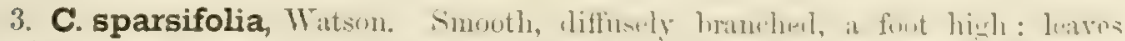

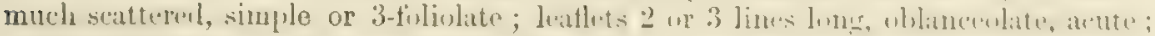

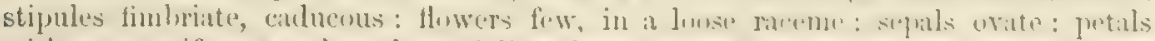

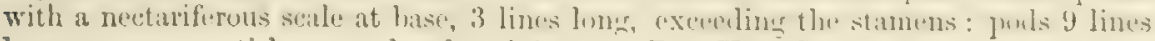
long, narrow, acutish, very shortly stipitate. - Bot. King Exp. 32, t. 5.

In dry sand, near Ragtown, Carson Desert, Nevada, Watson.

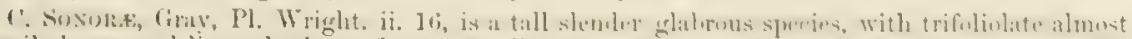

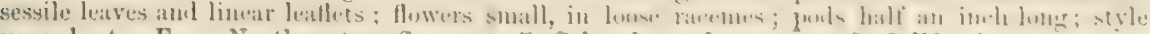
very short. From Northwestern Sonora to S. Colorado, and may enter S. California.

\section{CLEOMELLA, DC.}

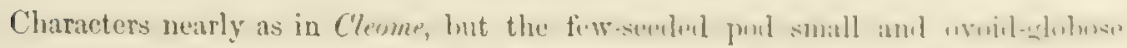

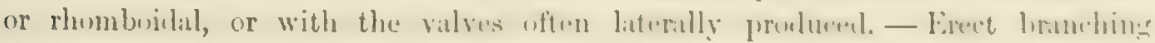
annuals; flowers yellow, racomose; leaves 3 -foliolate.

A geuus of half a dozen species, confined to the interior regiou of North America. 


\section{* Stipe longer than the pod.}

1. C. longipes, Torr. Rather stout, 1 or 2 feet high, glabrous : leaflets narrowly obovate to spatulate, obtuse or retuse, $\frac{1}{2}$ to 1 inch long: sepals ovate, acute: petals 2 or 3 lines long: stamens long-exserted: pods nearly triangular in outline, acute at base, 2 lines high, 3 to 5 in breadth, the valves being more or less strongly horned: style half a line long or less; stipe 4 to 7 lines long, about equalling the pedicel. - Gray, Pl. Wright. i. 11 ; Watson, Bot. King Exp. 33.

Var. (?) grandiflora, Watson, 1. c. Leaflets and bracts narrowly obovate to orbicular: sepals long-acuminate: style about a line long.

Valleys and foothills in N. W. Nevada (Anderson, Watson); New Mexico (Wright); stouter and larger leaved forms than the original Mexican specimens of Gregg and Berlandier.

2. C. obtusifolia, Torr. Somewhat pubescent, branching, a foot high or more: leaflets oval or oblong, 3 to 6 lines long, equalling the petioles, glabrous above; stipules long and fimbriate: flowers small, in leafy racemes: sepals ovate, lacerateciliate: petals 1 or 2 lines long: pods 2 to 5 lines broad, the valves acutely and often narrowly horned: style very slender, 2 lines long: stipe 3 lines long, reflexed upon the equal pedicel. - Frem. Fiep. 311.

Near Sacramento? (Fremont); Soda Lake on the Mohave River (Cooper); Arizona, Wheeter.

3. C. plocasperma, Watson. Low, glabrous, diffusely branching: leaflets linear-oblong, 3 to 6 lines long; bracts mostly small: petals $1 \frac{1}{2}$ lines long: stamens short or exserted: pods short-rhombic, the valves somewhat dilated: style short; stipe once or twice the length of the pod, usually equalling the pedicel: seeds minutely tessellated under the microscope. - Bot. King Exp. 33.

Valleys of Northern Nevada, Watson, Rev. $R$. Burgess.

4. C. oocarpa, Gray. Very similar: leaves and flowers slightly larger: pods ovate, the valves not dilated: seeds smooth. - Proc. Am. Acad. xi. 72.

Saline valleys of Humboldt Co., Nevada (Torrey, Gray); S. W. Colorado, Brandegee.

\section{* Stipe shorter than the pod.}

5. C. parviflora, Gray. Low and slender, decumbently branched, smooth: leaflets and bracts linear, half an inch long: flowers rather few: petals scarcely a line long, equalling the stamens: pods on long slender pedicels; valves slightly horned: style and stipe almost none. - Proc. Am. Acad. vi. 520; Watson, 1. c.

At Camp Cady on the Mohave (Cooper); Northem Nevada, Anderson, Watson.

\section{WISLIZENIA, Engelm.}

Characters nearly as in the preceding, but the pod didymous; valves contracted upon the solitary seeds and deciduous with them, nutlike, nerved or reticulated, open at the scar : style elongated._- Smooth erect branching annuals; with yellow racemose flowers and 1 -3-foliolate leaves. The following are the only species.

1. W. refracta, Engelm. One to two feet high, wilely branching: leaflets 3 , oblanceolate to obovate, 5 to 9 lines long, usually exceeding the petioles : flowers in dense racemes, at length elongated : petals a line long : stamens and ovary exserted: cells of the ovary 2-ovuled: fruit $1 \frac{1}{2}$ lines broad or more; the divergent obovate reticulated valves separated by a perforated partition: style filiform, 1 to 2 lines long: stipe 2 to 3 lines long, strongly refracted upon the rather longer pedicel. Wisliz. Rep. 14; Gray, PI. Wright. i. 11, t. 2.

Mohave Valley (Newberry); Colorado Desert (Blake); thence to Sonora and New Mexico.

2. W. Palmeri, Gray. With the habit of the last: leaves simple (lowest unknown), linear, $1 \frac{1}{2}$ inches long, very shortly petioled: racemes fewer-flowered: 
petals 2 lines long: fruit 3 to 4 lines broad; the oblong-obovate ralres nerved and surrounded at the truncate extremity by a row of stout blunt tubercles: style 3 lines long: stipe 3 to 4 lines long, refracted. - Proc. Am. Acad. viii. 628.

On the Lower Colorado River, Palmer.

\section{OXYSTYLIS, Torr.}

Distingrished (so fir as knomn) from Mislienia by the subulate persistent at length spinescent style, and by the oroid-globose 1 - 2-seeded valves completely clused at the scar. - I smouth annual, with 3 -foliolate leares. and small yellow flowers in capitate axillary racemes.

1. O. Iutea, Torr. Ratber stout, erect, 12 to 15 inches high: leaflets 1 to 1 ? inches lonic, ohtuse: hearts of flotrers half an inch in diameter, not elongrated in fruit: petals 2 lines long. - Frem. Rep. $264 \& 313$.

Known only from specimens collected by Fremont in April, 1844, in a single locality in the valley of the Armagosa River near its bend.

\section{ORDER IX. RESEDACEA.}

A small urder of herhs, or slightly shrubby plants, related only to the preceding; with alternate leaves, merely chlanis fur stipules, and terminal racemes or spikes of small and rither inconspicuuls flowers; these both irregular and unsymmetrical, the stamens not covered in the bul, the one-celled ovary am capsule 3-6-beaked and with as many parietal placente. - Flowers perfect, bracteate. Calyx 4 -7-parterl, herhaceous, hyporynous, persistent. Petals 2 to 7 , mostly with lroad and thickened nectariferous claws, and the hiale cleft. Stamens 3 to 40 , usually on a more or less one-silder hypogynous disk. Sitinmas 3 to 6 , terminating the divering heaks of the

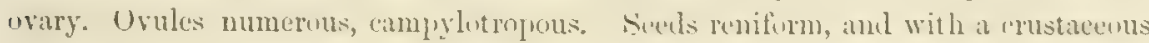
coat, filled by the incumbently incurved embryo.

The farmily helungs to the (H, Work, mainly to the Malitermean and aljacent warm regions; the watery juice is destitute of pungency and generally of active properties.

REsEDA Luteola, Linn., the Dyer's Weed or Weld, however, has been used for dyeing yellow.

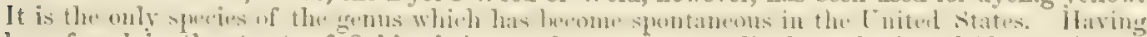
been found in the streets of Oakland, it may become a naturnlized weed of roadsides, as in tho Atlantic States. The genus may he known by the severnl-lobed or parted petals, and the 10 to 40 stamens borne on the inside of a fleshy disk, which projects on the upper side of the flower:

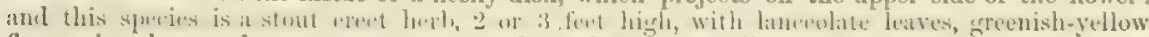
flowers in a long and narrow raceme, 4 petals, and a short small capsule.

li. cImnatr, Linn., the common sweet Mignonette, eultivated its an amnual for its fragrant flowers, may also escape from cultivation.

\section{OLIGOMERIS Cambess.}

Seprals t, lateral. Petals 2, next to the axis, free or united at base, entire or 2-3-lohnd, persistent. Disk none. Sitamens :3 to 8 : filaments unitol at bilse.

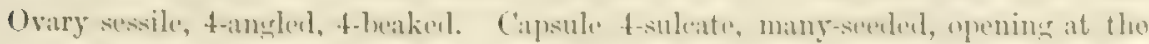
summit. - Iaw branching lurhs; with numerous linear entire leaves, and small whito flowers in terminal spikes.

A genus of only 5 species, four confined to $\mathrm{S}$. Afrita, the fifth minging from the Cannry Islunds to India, and also semingly iudigenous to $\mathbb{N}$. Amerien.

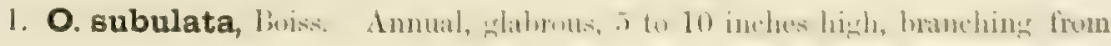


the root: leaves somewhat succulent, often fascicled, $\frac{1}{2}$ to 1 inch long: flowers minute, subtended by small bracts : capsules in long loose spikes, depressed-globose, about $1 \frac{1}{2}$ lines in diameter, angled and suleate, shortly 4-beaked. - Müll. in DC. Prodr. 162. 587. O. glaucescens, Cambess. in Jacquem. Voy. 4. 24, t. $25 . \quad$ Ellimia ruderalis, Nutt. in Torr. \& Gray, Fl. i. 125.

San Diego (Nuttall); Mohave Desert (Newberry); Colorado Desert (Blake, Coulter); Guadalupe Island (Palmer); and in the interior to New Mexico and Mexico.

\section{ORder X. CISTACE无.}

Distinguished from the other orders with free one-celled ovary, parietal placentx, and hypogynous petals and stamens, by the orthotropous ovules on slender stalks, and the slender more or less curved or convolute embryo in mealy albumen. Flowers perfect and regular. Sepals persistent, usually 5 ; and two of them smaller, wholly exterior, and bract-like. Petals usually ephemeral. Stamens indefinite or in some flowers few, with filiform filaments: anthers short. Style one. Ovules with 3 parietal placentæ. Capsule 3-valved; the seeds borne on the middle of the valve, few or numerous. - Herbs or low shrubs, with opposite or alternate simple and entire leaves; chiefly of the Mediterranean region, but several.in the Atlantic United States, none in the interior, only one on the Pacific coast.

\section{HELIANTHEMUM, Tourn.}

Petals 5, hroad. Stamens usually numerous. Style short, articulated with the ovary: stigma 3-lobed. Capsule ovoid, 1-celled, 3-valved, few-many-seeded. Embryo curved or hooked. - Low branching herbs, or somewhat woody; flowers yellow, often showy, opening only once, in sunshine.

A genus of from 30 to 150 species according to the views of authors, principally native to the Mediterranean region and Western Asia. Five species are found in the Atlantic States and the following in California.

1. F. scoparium, Nutt. Perennial (?), woody at base, much branched, pubescent with stellate hairs or glabrate, a foot high; the upper branches green and slender: leaves narrowly linear, 4 to 12 lines long, alternate: flowers on slender pedicels, solitary or subcorymbose at the ends of the branchlets : sepals 3 lines long, acuminate, the outer ones limear and shorter : petals 4 lines long: stamens about 20 : style short: capsule equalling the calyx, often, with the other parts of the flower, much reduced. - Torr. \& Gray, Fl. i. 152; Lindl, in Jour. Hort. Soc. v. 79. Linum trisepalum, Kellogg, Proc. Calif. Acad. iii. 42, fig. 10.

Rather common on dry hills from Lake Co. to San Diego.

\section{ORDER XI. VIOLACE正。}

Herbs (at least those of temperate climates and the northern hemisphere), distinguished by the somewhat irregular one-spurred corolla of 5 petals, 5 stamens, adnate introrse anthers conniving over the pistil, which has a single club-shaped style with a one-sided stigma, a one-celled ovary with 3 parietal several-ovuled placentæ; the ovules anatropous; the rather large seeds with a smooth hard coat, and a large and straight embryo in fleshy albumen; its cotyledons broad and 
flat. - Flowers perfect. Sepals (persistent) and petals imbricated in the bud, hypogynous. Capsule 3-ralred; the ralves bearing the seeds along their midille; each, after dehiscence, in drying firmly folds together lengthwise, and by its increasing pressure projects the oburate seeds. - Fepresented only by the familiar genus

\section{VIOLA, Linn. VIOLET.}

Sepals uneinul, more or less auricled at base. Petals unequal, the lower spurred at base. Anthers broal, nearly sessile, often cuherent, the connectives of the two lower bearing spurs which project into the sjur of the petal. - Mostly jerennial herbs; with alternate leaves, fuliacens persistent stipules, anil 1-fluwered axillary peduncles. Fluwers usually dimurphus: the earlier ones perfect and conspicuuus, but often sterile; the later (near the grrund in the stemless species) with small and rulimentary petals, fertilizel in the buil and producins numerous seeds.

A large genus of 100 speries or more, largely lelonging to the temprentw regions of the northern hemisphere, but 30 species are found in the mountains of $\mathrm{S}$. America, and a very fer occur in $\mathrm{S}$. Africa, Australia, and New Zealand. The North American species number about 30, half of which belong to the western side of the continent. Many of them are very variable and their limits not easily definet. Some of the fortign species are hrorites everywhere for their fragrance or beauty. The Californian are as a whole very shorry, but generally not sweet-scented. Some, however, have a peculiar and rather agreeable fragrance, very unlike the typical "odor of violets."

* Stemless, the lintes and scapes all firm a subtermanean rontstock: leares not lobed nor parted: flowers white or purple.

1. $\boldsymbol{\nabla}$. blanda, Willd. Fontstock creeping aml at lengtl prolucing runners: leaves rounded-ordate or reniform, $\stackrel{1}{2}$ to 2 inches in diameter, minutely and spar-

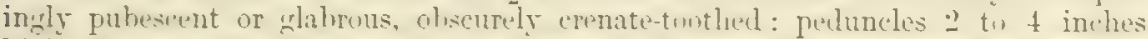
high: Hhers white, the liwer futals reined with purple, nearly bearlles, usually 3 or 4 lines long; spur short and blunt.

Wet places in the Sierra Nevada, at 6,000 to 9,000 feet altitude, rather rare : common eastward to the Atlantic.

V. PALUSTRIs, Linn., very similar, but with pale lilac flowers, does not certainly occur in Cali-

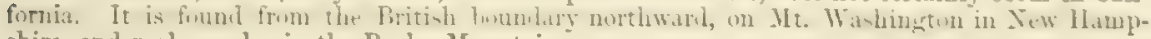
shire, and perhaps also in the Rocky Mountains.

2. V. cucullata, lit. Iirutstuck thick and branching, not prolueiner mumers:

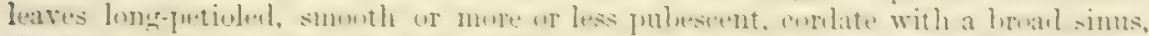

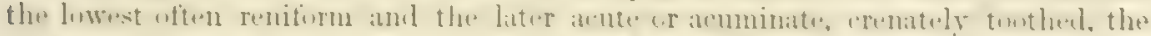

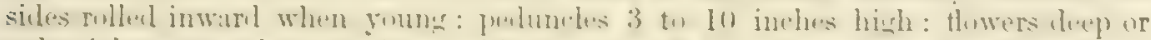

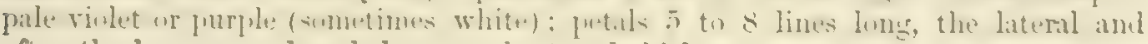
often the lower ones bearded; spur short and thick.

Cucamonga, San Bernardino Co. (Bigelow); above Carson City and in Sierra Co. (Andersom, Lemmon); and more common northward and eastward to the Atlantic States, where it is the most common of all the species, and very rariable.

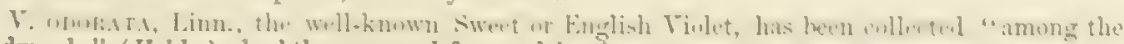
redwoods " (Holder), doubtless escaped from cultivation.

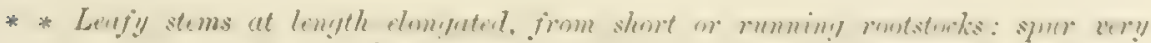
short, except in the first speries.

+ Stems leafy throughout, erect or ascending: leaves all undivided.

++ Flowers purple, or not bright yellow.

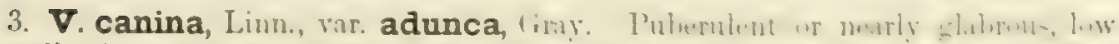
(usmally 3 (1) + inches high), at length semling out rummes: lestes wate often 
somewhat cordate at base, acute or obtuse, $\frac{1}{2}$ to $1 \frac{1}{2}$ inches long, obscurely crenate : stipules foliaceous, narrowly lanceolate, lacerately toothed : flowers violet or purple, rather large; lateral petals bearded; spur "as long as the sepals, rather sleader, obtuse, hooked or curved. - V. adunca, Smith, in Rees Cyc.

Var. longipes, Watson. Very similar, but the stout and obtuse spur is nearly straight. - V. longipes, Nutt. in Torr. \& Gray, Fl. i. 140. V. adunca, Hook. Fl. i. 79 , in part.

Var. oxyceras, Watson. Flowers rather smaller; spur slender, nearly equalling the petals, acute and curved.

The first two forms of this very variable species are common in the Coast Ranges, in meadows and moist places, from San Franciseo to Washington Territory, apparently extending into the Sierra Nevada. Nearly identical forms are found eastward in the Rocky Mountains and to Winnipeg Valley. The var. oxyceras has been collected only in the Sierra Nevada, in Yosemite Valley (Brewer, Gray), and near Donner Pass, Torrey. The species to which these are all referred is distributed throughout the northern zones around the world. The var. sylvestris of the Atlantic Coast, from the Northern States to Greenland, is glabrous, with more deeply cordate or reniform leaves, the spur straight and obtuse.

4. V. ocellata, Torr. \& Gray. More or less pubescent with spreading hairs, rarely glabrous : stems nearly erect, 6 to 12 inches high : leaves cordate to cordateovate, acutish, conspicuously crenate, 1 or 2 inches long; stipules small, scarious, entire or slightly lacerate: petals 5 to 7 lines long, the upper ones white within, deep purple-brawn without, the others pale-yellow veined with purple, the lateral ones with a purple spot near the base and slightly bearded on the claw. - Fl. i. 142 ; Hook. \& Arn. Bot. Beechey, 325.

From Monterey northward to Mendocino Co., in wooded districts.

V. TRICOLOR, Linn., the Pansy or Heart's-ease of the gardens, often escapes from cultivation and becomes wild. It is a native of Europe and Siberia, erect, with angled stems, large foliaceous divided stipules, rather small cordate or ovate or even lanceolate leaves, and flowers variously colored with puple, violet, yellow and white. Nature furnishes several varieties and art has produced many more.

$$
+4 \text { Flowers yellow, more or less veined or tinged with purple. }
$$

5. V. pedunculata, Torr. \& Gray. Nearly glabrous or somewhat puberulent, the ascending stems 2 to 6 inches high from a slender decumbent or procumbent base : leaves rhombic-cordate, with base usually truncate or abruptly cuneate, obtuse, $\frac{1}{2}$ to $1 \frac{1}{2}$ inches long, often small, coarsely crenate: stipules foliaceous, narrowly lanceolate, entire or gashed: peduncles much exeeeding the leaves: flowers showy, deep yellow, usually large: sepals oblong-lanceolate, obtuse or acute: petals 6 to 9 lines long, the upper more or less tinged with brown on the outside, the others veined with purple; lateral petals bearded: capsule oblong-ovate, 5 to 6 lines long, glabrous. - Fl. i. 141 ; Hook. \& Arn. Bot. Beechey, 325 ; Hook. Bot. Mag. t. 5004 .

In the Coast Ranges from Southern California to San Francisco, and probably northward.

6. V. aurea, Kellogg. More or less pubescent with short spreading hairs: the stems ascending from a straight rootstock, 2 to 6 inches high: leaves ovate to lanceolate, cuneate or sometimes truncate at base, obtuse, $\frac{1}{2}$ to $1 \frac{1}{2}$ inches long, coarsely crenate: stipules foliaceons, lanceolate, laciniate: peduncles a little longer than the leaves: sepals linear, acuminate: petals 4 to 6 lines long, as in the last but lighter yellow: capsule nearly globular, 3 lines long, pubescent.-Proc. Calif. Acad. ii. 185, fig. 54. T. Nuttallii \& pramorsa, Benth. Pl. Hartw. 298. V. pedunculata, Torr. in Pacif. R. Rep. iv. 68, in part. $V$. Nuttallï, var. promorsa, Watson, Bot. King Exp. 35.

Var. venosa, Watson. Alpine and more slender ; flowers rather smaller; leaves often purple-veined. - V. purpurea, Kellogg, Proe. Calif. Acad. i. 56. V. Nuttallii, var. (?) venosa, Watson, Bot. King Exp. 35. 
In the Coast Ranges from Santa Barbara and Fort Tejon to Mendocino Co. : also in the Sierm Nevada at an altituce of 5,000 to 6,000 feet; Yosemite Valley (Bolander); above Carson City, Anderson, Watson. The variety more alpine, at altitudes of 8,000 to 10,500 feet, from Mit. Brewer to Donner Pass, and in the high mountains eastward to the Wahsatch.

7. V. Nuttallii, Pursh. Frum densely puhescent with spreading hairs to nearly glabrous: stems ascending from a straight rootstock, usilally luw, often very short: leaves oblong-ovate to oblonir, atterutute into the long pretiole, obtuse, 1 to 3 inches long, entire or abscurely sinuate; stipules mostly narruw, entire: jecluncles usially shorter than the leaves: petals half an inch long, yellow, tinged more or less with brown or purple: capsule ovate, smooth. - Hook. Fl. i. 29, t. 76; Torr. \& Gray, Fl. i. 141. V. premorsa, Dougl. ; Lindl. Bot. Reg. xv, t. 1254.

From Washington Territory and Oregon to the Saskatchewan and Colorado; probably to be found in the northern or northeastern parts of the State.

\section{++ Stems leafy prostrate stolons: leaves undivided: flowers yellow.}

8. $\mathbf{\nabla}$. sarmentosa, Dund. Slightly pulsescent: leaves rounded-cordate, reniform, or sometimes ovate, ${ }_{2}^{\prime}$ to 1.3 inches broul, tiuely crenate, lark sreen above, often rusty beluw, usually junctite with numerous dark dots: peduncles mustly exceerling the leaves: flumers rather small, licht yellow. - Houk. Fl. i. \&o ; Turr. \& Gray, Fl. i. 143.

Near the sea, commonly in woods, from Monterey to British Columbia. At the north it ranges farther inland.

\section{+++ Stems erect, naked below, or nearly sa: flowers yellow.}

+ Leaves undivided.

9. V. glabella, Nutt. Minutely pubescent or glabrous: stems slenter fron a creeping rootstock, naked or sparingly leafy below, 5 to 12 inches high: radical leares on elongatenl petioles, the upper shortly petiolerl, reniform-cordite to corlate, acute, crenately toothed or crenulate, 1 to 4 inches broad; stipules usually small and membranaceous, entire or serrulate: flowers bright yellow, half an inch long: petals more or less veined with purple, the lateral ones bearded : capsule ovateoblong, 3 to 4 lines long, abruptly beaked.-Torr. \& Gray, Fl. i. 142. V. Cana-

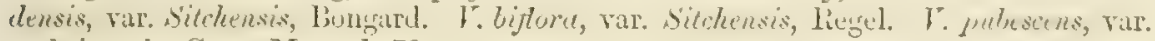
scabriuscula, Gray, Manual, 79.

In shady places, Mendocino Co. (Bolander) ; Mariposa Grove (Mrrs. S. P. MIonks) ; Sierra Co. (Lommon); northward to Alaskn and eastward across the contiment.

$$
++ \text { Leaves usually lobed or parted. }
$$

10. V. lobata, Bunth. Findy jubescent or neirly dianus: stems rather stout,

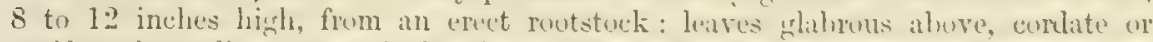
reniform in outline, 2 to 4 inches broal, the ciuline shintly petinled, more or less depply palmate inte 5 to 9 narrowly oblons lebes, the ecentral lobe usually mere elongated; some of the ralical leave's oceasionally less lubed, or entire and cuarsely

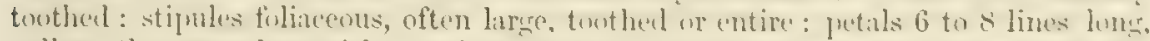

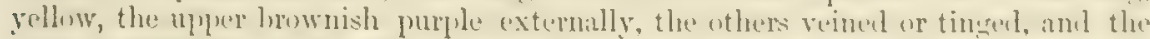

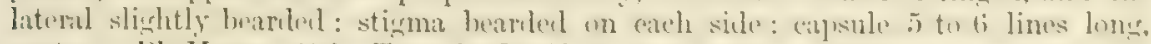

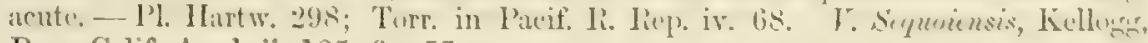
Proc. Calif. Acad. ii. 185, fig. 55.

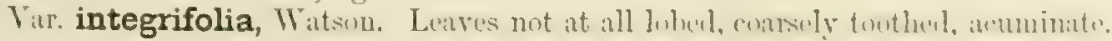

From San Diego to Mt. Shasta, most common in the central Sierra Nevadn at 3,000 to 5,000 feet altitude, but not abundant even there: the variety in Sierra Co., Lemmon. Very variable in its folinge and pubescence. As in the last species, the upper and later joints of the stem aro short and the leaves approximate.

V. HAth, Gray, Proe. Am. Acad. viii. 377 , from Oregon, is a similar hut more slender species; glabrous; leaves 3-parted, the narrow seginents 1 -3-lohed; lower potals yellow, tho upper deep violet; stigma surrounded by hairs. 
* * Stems very short, usually clustered, from a deep subterranean rootstock: leaves all divided: flowers yellow; spur very short.

11. V. chrysantha, Hook. More or less pubescent with short spreading hairs: leaves bipinnatifid with narrow oblong or linear segments; stipules lanceolate, entire or toothed: peduncles equalling or exceeding the leaves, 2 to 5 inches long: flowers usually large: petals 5 to 9 lines long, bright yellow, the upper brownpurple on the outside, the others veined, the lateral ones not bearded: stigma slightly hairy below the rounded summit : capsule 5 lines long, acute: seeds large. - Ic. Pl. t. 49 ; Hook. \& Arn. Bot. Beechey, 325 ; Kellogg, Proc. Calif. Acad. ii. 229 , fig. 72 .

In dry soil on low hills from Monterey (Donglas) and Knight's Ferry (Bigelow) to Mendocino Co. (Bolander) and northward; Snake Country, Tolmie.

12. V. Beckwithii, Torr. \& Gray. Glabrous or pubescent: leaves broadly cordate in outline, 3 -parted; the divisions lobed and cleft into linear or oblong segments : peduncles about equalling the leaves: petals 4 to 7 lines long, very broad, the upper purple, the others yellow with purple veins, the lateral ones bearded and the lower deeply emarginate: stigma lightly bearded at the sides : capsule obtuse. Pacif. R. Rep. ii. 119, t. 1. T. montana, Kellogg, Proc. Calif. Acad. i. 56.

In the central Sierra Nevada upon both sides of the range, from Alpine Co. (Anderson) to Sierra Co. (Lemmon): Diamond Mountains, N. Nevada, Beckwith.

13. V. Sheltonii, Torr. Glabrous or nearly so: leaves as in the last: petals rather smaller, narrower, all yellow, veined with purple, the lateral ones and the stigma glabrous; lower petal not emarginate-Pacif. R. Rep. iv. 67, t. 2.

In the northern Sierra Nevada, in Plumas, Sierra, and Nevada counties, Rev. Mr. Shelton, Bigelow, Lemmon, Mrs. Pulsifer Ames.

\section{ORDER XII. POLYGALACE无.}

Herbs or shrubs, with simple entire leaves and no stipules, remarkable for the papilionaceous-looking flowers (but of structure unlike the papilionaceous corolla), monadelphous or diadelphous stamens coherent with the petals, and one-celled anthers opening at the top;- an order not closely related to any other, to which is appended the very peculiar genus Krameria.

\section{POLYGALA, Tourn.}

Sepals 5, very unequal, the 2 lateral ones large and petal-like (called wings). Petals 3, united to each other and to the stamen-tube, the middle one (or keel) hooded above and often crested or beaked. Stamens 6 to 8 , the filaments united below into a split sheath, adnate at base to the petals: anthers 1-celled, often cupshaped, opening at the apex. Ovary 2-celled: ovules solitary, pendulous, anatropous: style long, curved, dilated above: stigma terminal or apparently lateral. Capsule membranaceous, flattened contrary to the narrow partition, rounded and often notched above, loculicidal at the margin. Seed carunculate at the hilum : embryo large, straight, with thin albumen. - Herbaceous or somewhat shrubby; with simple entire leaves, and racemose or spicate flowers. The Californian species are perennials with a woody base, alternate leaves, and few large flowers in terminal racemes.

A genus of some 200 species, of the temperate and warmer zones, represented by 30 or more species in the region east of the Rocky Mountains. A bitter principle is common to the genus, of medicinal value in some instances. 
1. P. cucullata, Benth. Stems slender from a woody base, 2 to 8 inches high, mostly simple, puberulent above : leaves glabrous or slightly pubescent, oblong-lanceolate or sometimes ovate-elliptical, $\frac{1}{2}$ to $l$ inch long, acute or obtuse, cuneate at base and very shortly petioled: flowers rose-culored, on pedicels 1 to 3 lines long, without bracts: sepals glabrous or nearly so; the outer 21 lines long, rutunded-saccate at base; the wings rather broadly spatulate, $t$ to 6 lines long: lateral petals linear-lanceolate, somewhat ciliate, equalling the broad obtuse more or less curred beak of the rounded hood: fruit mostly from apetalous flowers near the root; capsule glabrous, broadly ovate, $2 \frac{1}{2}$ to 3 lines long, retuse above, nearly sessile, narrowly margined: seed 2 lines long, somewhat pubescent ; the caruncle vesicular and wrinkled, calyptralike, half the length of the seed. - Pl. Hartw. 299. P. Nutkana, Torrey, Bot. Mex. Bound. 49, t. 12.

From Santa Barbara to Ukiah, on dry hillsides. This has usually been confounded with the next, and with it referred to $P$. Nutkana, Moçino, which however is doabtless a Mexican plant and the same as $P$. ovalifolia, DC.

2. P. Californica, Nutt. Much resembling the last; but stems more shrubhy, stouter and more branched, $\frac{1}{2}$ to 1 foot high or more: flowers greenish white, usually fruiting: sepals all densely tomentose; the wings oblong, scarcely narrowed at base: lateral petals only equalling the hood, which bears a straight narrow erect beak: capsule ovate, 4 lines long, emarginate or retusely 2-toothed at the apex, narrowly winged : seed 3 lines long, densely hairy; the caruncle firm and terete, with a thin lateral wing partially covering the body of the seed. - Torr. \& Gray, Fl. i. 6il. P. Nutkana, Torr. \& Gray, 1. c. P. cucullata, Newberry, Pacif. R. Rep. vi. 70. P. cornuta, Kellogg, Proc. Calif. Acad. i. 61.

In the Sierra Nevada, from El Dorado Co. to Oregon (Newbermy); in pine forests. Possibly Nuttall invluded both species under his description, but specimens ticketed by him helong to the present form. Dr. Torrey ticketed specimens of his own collection as from Santa Barbara, probably by mistake.

3. P. subspinosa, Watson. Glahrous or more or less pubescent: the stems numerous, 2 to 8 inches ligh, branchel ahove, the branches often spinose: leaves $\frac{1}{2}$ to an inch lons, oblong or ublanceolate, acute or ubtuse, attenuate to a narrow base: bracts narrow, scarious; peelicels 2 to $t$ lines long, at length usually dedlexed : sepals glabrous or ciliate; the outer uarrow, rounded-saceate at base : the bhlong rose-colered wings $t$ to 5 lines long: lateral petals linear, equalling the hroad rounded heak of the yellow keel: capsule ohovate, emaryinate, narruw at hate, 3 lines lons: seed hairy, 2 lines long; the short caruncle with membranous lateral wings more than half the length of the seed. - Am. Naturalist, vii. 299.

On dry hills near Silver City, Nevada, Kellogg: Southern Utah, from several collections, and Arizonn, Palmer. The only ather species of the inner basin is $P$. acanthoclada, Gray, collected by Brandegee in S. Colorado, similar to this but more woody and with much smaller scattered whitish flowers.

P. XAxtr, (inay, of Lower California, is also a low perennial, pulneseent throughout: leaves oval, shortly pettioled; flowers resurved, 3 lines long, white tinged with yellow and purple, the

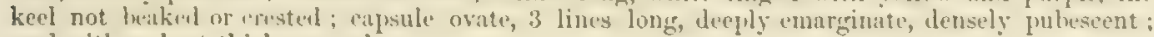
seed with a short thick caruncle.

\section{KRAMERIA, Linn.}

Sepals 5, somewhat unequal, more or leses petal-like. Potals 5 ; the 3 upper similar. lonerelitwel, approximate, the lower short, sessile and fleslay. Stamens t, mitul

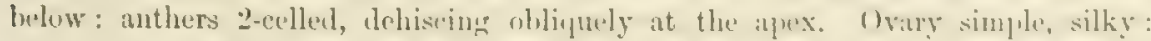
ovules 2, pendulous from towarl the atpex of the coll: style simple, straint,

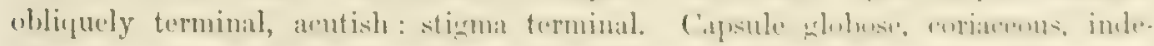

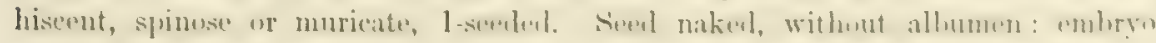
straight, the cotyledons aurieulate at base and ineluding the mulinle.- . Suall shruhs 
or somewhat woody perennial herbs, silky-tomentose and often prostrate; with alternate and entire narrow leaves; flowers solitary, on axillary bracted peduncles, purplish.

A genus of about a dozen species, confined to the warmer portions of America, three or four indigenous on the southern border of the United States.

1. I. parvifolia, Benth. A rigid diffusely branchel shrub, 1 or 2 feet high, with silky appressed pubescence, the slender divaricate branchlets often spinose: leaves linear, 4 to 8 lines long; the lower obtuse (often small and ovate to oblong), the upper aculeately tipped and, with the inflorescence, usually sprinkled with short rigid gland-bearing hairs: flowers 2 to 4 lines long; peduncles with 2 or 3 pairs of leaf-like bracts : the ovate silky sepals purple within: petals with claws united nearly to the top, the middle blade narrow : stamens nearly free : fruit with numerous very slender prickles retrorsely barbed their whole length, cordate-globose, 4 lines long, shortly acuminate, obscurely ridged on each side. - Bot. Sulph, 6, t. 2 ; Gray, Pl. Wright. 1. 41 ; Berg, Bot. Zeit. xiv. 766.

From San Diego (Cleveland) to Fort Mohave (Cooper) and Sonora (Thurber), and eastward to New Mexico ; southward on the coast to Magdalena Bay.

2. I. canescens, Gray. Very similar in habit and foliage: pubescence short and tomentose: leaves lanceolate to linear: peduncles shorter, 2-bracted: sepals lanceolate, the smaller one linear: capsule ovate-globose, tipped with the stout curved style, and armed with slender prickles barbed at the apex. - Pl. Wright. i. 42 ; Torr. Bot. Mex. Bound. 49, t. 13.

"Desert west of the Colorado" (Antisell), and New Mexico.

K. Lanceolata, Torr., is a more eastern species, from Tucson, Arizona (Palmer), to Florida. It is silky-villous, with 2-bracted peduncles, the fruit armed with stout and straight retrorsely scabrous spines.

\section{ORDER XIII. FRANKENIACE出.}

Low perennial herbs or undershrubs, with opposite entire leaves and no stipules; distinguished from the first tribe of the following order mainly by the parietal placentæ, and oval or oblong anatropous seeds with a straight embryo; - of a single genus.

\section{FRANKFNIA, Linn.}

Calyx tubular or prismatic, furrowed; the 4 or 5 lobes valvate and induplicate in the bud. Petals 4 or 5 , hypogynous; the blade tapering into a claw, which bears an appendage (crown) on its inner face. Stamens 4 to 7 or rarely more, hypogynous. Ovary 1-celled, with 2 to 4 few- to several-ovuled parietal placentæ: style 2-4-cleft into filiform divisions: stigmas unilateral. Capsule included in the persistent calyx, 2-4-valved; the few or several seeds attached by filiform stalks to the margin of the valves. - Leaves small, mostly crowded and also fascicled in the axils, sessile or nearly so, the pair often united by a membranous somewhat sheathing base: flowers small, perfect, solitary and sessile in the forks of the stem, or by . the reduction of the upper leaves to bracts becoming cymose-clustered on the branches: corolla pink or purplish.

A widely diffused genus, of 30 or more species, only three of them North American, and these all southwestern.

1. F. grandifolia, Cham. \& Schlecht. Smooth or somewhat pułeseent with short spreading hairs, rather woody at base, erect or prostrate, 6 inches high, leafy: 
leaves thickish, obovate to linear-oblanceolate, 3 to 6 lines long, the margin revolute: calyx 3 lines long, linear, very strongly furrowed, the lobes short and acute: petals exserted 1 to 1. lines, the blate oblong, erose at the summit, the appendage bificl: stamens 4 to $T$ : style 3-cleft : capsule linear, angled, shorter than the calyx: seeds numerous. - Linnæa, i. 35 ; Torrey, Bot. Mex. Bound. 36, t. 5.

Sea-shore from San Francisco to San Diego and southward, and eastward in the desert to Arizona and S. Nevada.

F. PAlurri, Watson, collected by Dr. E. Palmer on the eastern side of Lower California, is a rather slender shrub, a foot high, the numerous fascicled leaves only 1 or 2 lines long, thick and strongly revolute, canescent with a white encrustation : calyx $1 \frac{1}{2}$ lines long : petals linear, a little exserted : stamens 4: style bifil : capsule 2-seeded. - Proc. Am. Acad. xi. 124.

F. Jamesu, Torr. (Gray, Proc. Am. Acad. viii. 622), is a more eastern species, of Colorado and New Mexico, with the habit of $F$. grandifolia, but more pubescent, leaves narrower and with revolute margins, flowers larger, and ovary 3-ovuled.

\section{ORDER XIV. CARYOPHYLLACE开。}

Herbs, sometimes suffruteseent at base, bland and inert, with regular and mostly perfect flowers, persistent calyx, its parts and the petals 4 or 5 and inbricated or the latter sometimes convolute in the but, the distinct stamens commonly trice as many as the petals (when of the same number alternate with them, sometimes fewer), ovary 1 -celled with a free centril placenta, bearing many or several campylotropous ovules; the reniform seeds with a slender embryo coiled aruund the outsile of farinaceous albumen. - Stems usually swollen at the nodes. Leares often united at the base by a transverse line, in one group with interposed scarious stipules. Petals sometimes wanting. Stamens mostly hypogynous around an annular disk, sometimes perigynous by its cohesion with the base of the calyx. Strles 2 to 5, mostly distinct, and with stigma ruming down the inner face, in the last genera more or less united into one. Fruit a cinsule opening by ralves, or by tecth at the summit. Flowers terminal or in the forks, or in cymes.

A large moler, found in every part of the world, but alounling in temperate and fichil resions, of a thousand or more species, under about 35 genern, of no important properties or uses, except

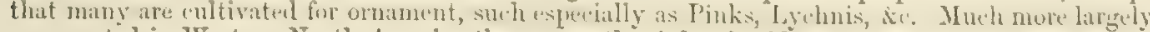
represented in Western North America than upon the Atlantic side.

Tribe I. SILENE.E. Sepals united into a 4-5-toothed or lobed calyx. Petals commonly

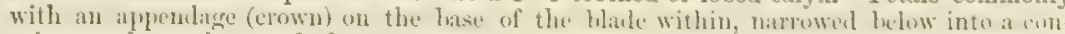
spicuous claw; these and the stamens borne on a stipe under the ovary. Styles distinet. Capsule dehiscent at the summit by as many or twice as many teeth as styles. Stipules none. Flowers comparatively large.

1. Silene. Styles 3. (Lycuxis, with 4 or 5 styles, not yet found in Californin.)

TRIBE II. ALSINEA. Sepals distinct to the base or nearly so. Petals without crown or distinct claw, inserted with the stamens on the margin of the hypogynous or sometimes perigynous disk under the sessile ovary, not rarely wanting or inconspicuous.

* Stipules none.

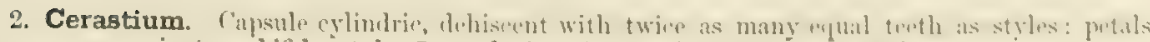
emarginate or bifid : styles 5 , raroly 3 or 4 , opposite to as mony sepals.

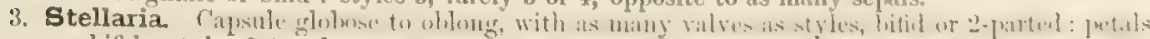
bifid: styles 3 (rirely 2,4 , or 5 ), opposite to ns mnny seprils.

4. Arenaria. Petals entire or wanting: styles 3 (rarely 2, 1 , or 5), opposite to as many sepals: capsule glohose to oblong, with as many valves as styles, these entire or bifid or i-partul.

6. Sagina, Petals entiro ol wrating: styles as many as tho sepals, alternnto with them and with the ontire valves of the exipsule. 
* * Stipules scarious or setiform.

+ Petals conspicuous : styles distinct.

6. Spergula. Styles 5, alternate with the sepals and with the entire valves of the capsule.

7. Lepigonum. Styles and valves of the capsule 3.

+ + Petals inconspicuous or minute: styles united below.

8. Polycarpon. Sepals and petals entire. Leaves ovate or oblong: stipules scarions.

9. Lœellingia. Sepals rigid and with a setiform tooth on each side. Leaves subulate or setaceous : the setiform rigid stipules adnate to each margin.

DRYMaria, Willd., is represented by one or two species in Lower California and by others in Arizona. They have the aspect of Chickweeds (Stellaria), small and searious stipules, and 2-6cleft petals.

\section{SilENe, Linn. Catchflt. Campion.}

Calyx tubular, cylindro-clavate to campanulate, 5-toothed, 10-nerved. Petals 5, with narrow claws; the blade mostly 2 -many-cleft, and usually crowned with 2 scales at the base. Stamens 10, borne with the petals upon the stipe of the ovary. Ovary 1-celled, many-ovuled: styles 3. Capsule dehiscent by 6, rarely 3, short teeth. Seed opaque, tuberculate or echinate, attached marginally: embryo peripherical. - Annual or mostly perennial herbs, of various habit.-Rohrbach, Monog. Silene, and in Limnea, xxxvi. 170; Watson, Bot. King Exp. 430, and Proc. Am. Acad. x. 340 .

A genus of 300 or more species, most abundant in the northern temperate regions of the old World. Of the 25 American species, the larger number is confined to the Rocky Mountains and the region westward.

* Annuals : flowers small.

Glabrous : flowers in an open naked dichotomous panicle.

Villous : flowers racemose or spicate : leaves spatulate.

4. S. ANTIRRHINA.

* * Perennials : calyx campanulate, inflated : flowers few.

Glandular-puberulent : flowers nodding: blade 4-parted; claws and filaments pubescent.

Mostly glabrous : flowers erect : blade bifid; claws narrow, naked.

Puberulent: calys somewhat inflated : flowers erect: blade bifid; elaws broader.

1. S. Campandlata.

2. S. LYALLII.

17. S. Douglasir.

* * * Perennials: calyz oblong-cylindric or clavate.

Usually low : inflorescence leafy.

Flowers white, small : blade bifid, without crown.

Flowers large, pale pink : blade 4-6-parted : tomentose above.

Flowers large, deep scarlet: blade 4-parted : glandular-pubescent or puberulent.

Taller : floral bracts small and narrow.

Blade of the petals 4-parted or 4-cleft.

Flowers large, bright scarlet: blade deeply 4-cleft : leaves narrowly lanceolate or linear.

Slender, subglabrous : calyx short : blade equally 4-parted : capsule nearly sessile.

Stout and tall, glandular: calyx long: blade deeply 4-cleft; claw narrow, villous: stipe long.

Slender, puberulent : calyx long : blade 4-cleft; claw naked ; anricles and crown lacerate: stipe long.

Slender, puberulent : calyx and petals short : blade narrowly 4-parted ; narrow claw and filaments villous: stipe short.

3. S. Galitica.

5. S. Menziesir.

6. S. HOOKERI.

7. S. Califorica.

\section{S. Laciniata.}

9. S. LeMmoNi.

10. S. OCCIDENTALIS.

11. S. MONTANA.

12. S. Palmerr.

Blade of the petals bifid, mostly light rose-color; lobes mostly oblong.

Stout, glandular : calyx-teeth long, lanceolate : petals purplish ; claw narrow, not auricled.

Tall, lax: leaves broadly lanceolate : elaw narrowly auricled : stipe short: seed not tubercled.

13. S. PECTINATA.

14. S. INCOMPTA. 
Low: leaves narrow: claw narrowly auricled: stipe short: seed strongly tuberculate on the back.

15. S. VERECUNDA.

Puberulent : leaves narrow : claw broadly auricled : stipe rather long: seed tubercled.

Petals white, very narrow; lobes linear: styles long-exserted. 16. S. BrIDGEsII.

\$1. Calyx cumpanulute, influted: flourers few in a loose panicle or paniculate raceme: perennials.

1. S. campanulata, Watson. Glanlular-puberulent: sterus erect, 6 to 10 inches high, simple or dichotumously branched at the summit: leaves lanceolate, 1 to $1 \frac{1}{2}$ inches long, acute or acuminite: flowers sulitary or few, on short nodding pedicels: calyx 5 to 6 lines loug, finely net-veined, the teeth broad and acute or acutish: petals pale flesh-culur, 9 lines long ; claws pubescent, narruwly auricled; blade t-parted, the lubes bitid or the lateral ones entire or notched ; appendages oblong, entire: filaments pubescent, exserted : ovary subglubuse, shortly stipitate. Proc. Am. Acad. x. 342.

Red Mountain, Mendocino County, Bolander, Kellogg.

2. S. Lyallii, Watson. Glabrous except the subglandular puberulent inflorescence: stems slender, ascending: leaves linear-oblunceolate, 1 to 2 inches long: flowers few in a dichotomnous cyme, erect on slender pealicels: calyx 4 lines long, net-reined above ; teeth broad, obtuse : petals brownish jurple, 7 lines long; blade oblong, shortly bitid; claw naked, scarcely auricled; appendages oblong, entire: anthers ineluded : ovary narrowly oblong. - Proc. Am. Acad. x. 342.

In Gold Lake and Sierra Valleys, Sierra Cuunty, Limmon. Caseade Mountains, Washington Territory, Lyall.

What ayprars to be another species of this group, with pendulous flowers, has heen collected in the Sierra Nevada above Cisco, but the material is too meagte for a specific description. The Howers are clustered, on short pedicels; calyx greenish, 4 to 5 lines long; blate shortly bifid, obscurely toothed at the side, and with short entire appendages; inflorescence puberulent.

S. Moxastiu, Watson, l. c., the one other western species with inflated calyx, has been found

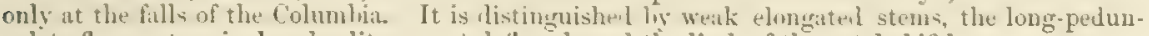
culate flowers terminal and solitary, not deflexed, and the limb of the petals bifid.

\section{\$2. Calyx oblong-cylindric or clavete, becoming expanded by the enlarying ourtry.}

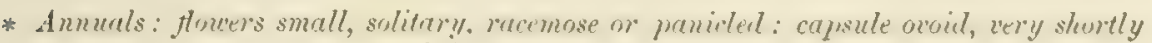
stipitate, 3 to 4 lines long.

3. S. Gallica, Linn. Villuts-puluecent: leaves spratulate, 1 to 1.1 inches long: flowers on very slort peilicels, racemesie, 4 to is lines lung, the rose-colored petals little exceeding the calyx.

A European species now widely distributed. Abundant in many localities menr the corst.

f. S. antirrhina, Linn. Cilahrnus, with a part of parh juint viscid, erect, slen-

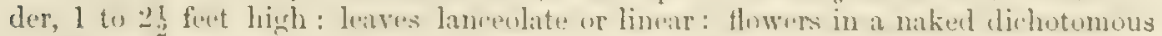

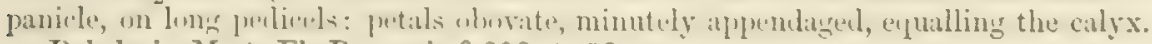
- Tobrb. in Mart. Fl. Bras. xiv. ${ }^{2} 292$, t. 66.

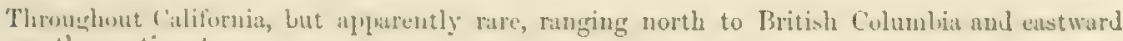
across the continent.

$$
\text { * Perennials, spreading or decumbent, usually low: inflorescence leafy. }
$$

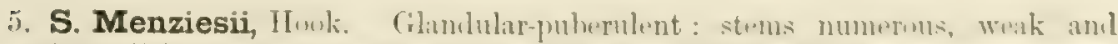

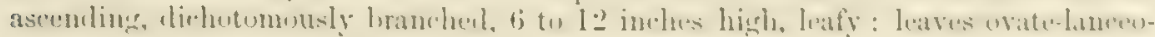
late or oblong, acute or acuminate at ench end, an inch or two long: peduncles

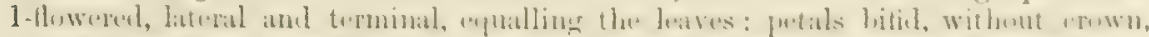

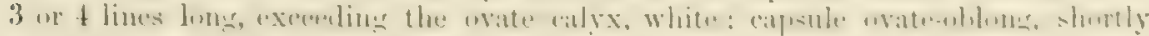

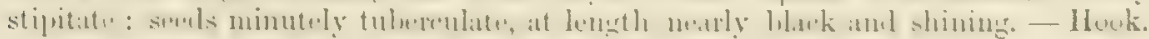
Fl. i. 99, t. 30. S. Dormi, Kellogg, Proc. Calif. Acad. iii. 44, fig. 12. 
From Mono Lake to the British boundary and frequent in the mountains eastward, from Slave Lake to New Mexico.

6. S. Hookeri, Nutt. Somewhat white-tomentose, especially above, the leafy stems 3 to 10 inches high from a deep perpendicular root: leaves spatulate, acute, an inch or two long: flowers 1 to 5, large, erect, on pedicels $1 \frac{1}{2}$ inches long: calyx oblong-clavate, 8 to 10 lines long: petals pale-pink, twice longer than the calyx, the broad claw ciliate below, the cuneate blade 4-6-parted with lanceolate or linear entire or bifid segments; appendages lanceolate, decurrent upon the claw : ovary nearly sessile. - Torr. \& Gray, Fl. i. 193 ; Hook. f. Bot. Mag. t. 6051. S. Bolanderi, Gray, Proc. Am. Acad. vii. 330. Melandryum Hookeri \& M. Bolanderi, Rohrb. in Linnæa, xxxvi. 254.

Wooded hillsides, from Plumas and Mendocino counties to the Columbia River.

7. S. Californica, Durand. Glandular-pubescent or puberulent: stems $\frac{1}{2}$ to 2 feet high, lax, leafy, somewhat branched above : leaves oblanceolate to ovate, $1 \frac{1}{2}$ to 4 inches long, acnte or acuminate: flowers large, deep scarlet, few at the ends of the branches: pedicels short, the lower deflected in fruit: calyx 7 to 10 lines long: petals deeply parted, with bitid segments, the lobes 2-3-toothed or entire, with often a linear lateral one ; appendages oblong-lanceolate : capsule ovate, $\frac{1}{2}$ inch long, rather shortly stipitate. - Pl. Pratten. 83. S. laciniata, var. Californica, Gray; Watson, Proc. Am. Acad. x. 341. Melandryum Californicum, Rohrb. 1. c. 252.

From Mendocino and Placer counties to Santa Cruz, Fort Tejon, and the Mariposa Grove. It probably extends southward in the Coast Ranges to San Diego. The flowers much resemble those of the next species, to which it has been referred.

* * Erect perennials, with the flowers in a panicle or racemose-paniculate, the floral bracts small and narrow.

+ Petals 4-parted or 4-cleft.

8. S. laciniata, Cav. Pubescent with more or less viscid hairs or puberulent: stems erect or ascending from a thick woody rootstock, 1 to $1 \frac{1}{2}$ feet high: leaves narrowly oblanceolate to linear, 2 to 3 inches long: flowers one or few on the elongated branches, large, hright scarlet, on pedicels $\frac{1}{2}$ to 3 inches long, not reflexed in fruit: petals deeply 4-cleft with linear acute lobes, the lateral ones spreading and shorter; appendages ovate: capsule oblong, shortly stipitate, not greatly distending the calyx: seed strongly tuberculate on the back. - Icon. vi. 44, t. 564 ; Lindl. Bot. Reg. xvii. t. 1444. Lychnis pulchra, Cham. \& Schlecht. Melandryum laciniatum, Rohrb. l. c.

From the Sacramento southward into Mexico, and eastward to New Mexico.

9. S. Lemmoni, Watson. Glabrous or puberulent, the inflorescence glandular: stems erect from a decumbent perennial branching base, slender, 8 to 12 inches high, branched: leaves mostly on the young shoots, an inch long, spatulate to oblong-lanceolate, acute: flowers in an open panicle, erect or at length deflexed, on slender pedicels 4 to 9 lines long: calyx ovate-cylindric, 4 lines long, the teeth acutely triangular : petals rose-colored, 6 to 8 lines long; the broad blade 4 -cleft nearly to the base, with linear entire or notched lobes; the lanceolate appendages entire and the villous claw narrowly auricled : ovary oblong, very shortly stipitate. - Proc. Am. Acad. x. 342.

Webber Lake Valley, Sierra Co., Lemmon.

10. S. occidentalis, Watson. Glandular-puberulent, or below somewhat tomentose : stems often stout, erect from a vertical rootstock, $1 \frac{1}{2}$ to 2 feet high, simple or branching: leaves oblanceolate, 2 to 4 inches long, acute, the lower ciliate at base : flowers in an open panicle, erect or sometimes nodding, on slender pedicels 6 to 15 lines long: calyx cylindrical, 6 to 8 lines long, the teeth ovate and obtuse: petals deep purple, one half longer, deeply 4-cleft into nearly equal lobes or the lateral 
ones shorter; appendages linear, entire, half the length of the limb; claw slightly villous, without auricles : filaments slightly exserted: stipe 3 lines long, as long as the oblong ovary. - Proc. Am. Acad. x. 343.

Big Meadows, Plumas Co., Lemmon.

11. S. montana, Watson. Puberulent: the stems slender, from a decumbent branching perennial base, mostly simple, a foot high: leares narrowly oblanceolate, 1. to 2 inches lous, acuminate: Howers in a narrow panicle, erect upon usually short pedicels: calyx cylindrical, $T$ to 9 lines long, the oblong teeth acutish : petals apparently rose-culored, scarcely longer; the broad blade deeply $t$-cleft into linear entire equal segments; claws naked, the auricles and broud orate appendines somewhat lacerate: capsule oblong, the stipe 2 lines long. - Proc. An. Acad. ז. 343.

Fear Carson City (Anderson), and in Sierra Valley, Sierra County, Lemmon. A perhaps distinct form from the Blue Mountains, Oregon, has the short quadrate limb barely notuhed, the coronal appendages and auricles entire or nearly so, and the stipe shorter.

12. S. Palmeri, Watsm. Puberulent with short sprealing hairs, the inflorescence olandular: stıms slemler, a fint high, from a branching rootsturek: leaves oblunerolate, an inch long: flowers purplish, on slender perlicels in an open panicle: calyx four lines long; teeth short: petals very narrow, half an inch long; blade 4-parted into linear entire or bifid lobes; appendages linear; claw not auricled, and with the filaments very villons: styles aml stamens much exserted : capsule oblong, exceeding the calyx; stipe about a line long : seeds tubereulate, not crested. - Proc. Am. Acad. xi. 124.

Cuiamaca Mountains, San Diego Co., Dr. Edward Palmer.

S. Oregaxa, Watson, also from the Blue MIts., Oregon, may extend into California. It has its petals 2-jarted, with filiform lifid segments, very narrow claws with the aurictes produced upward, and a long-stipitate capsule.

\section{++ Petals bifid.}

13. S. pectinata, Watson. Viscilly pubescent : stems erect, stout, simple or branched, 1 to $1 \frac{1}{2}$ fiect high, several from a stont perpendieular rout : leave's lancenlate,

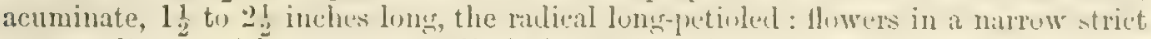

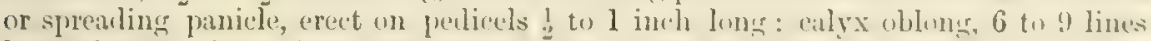

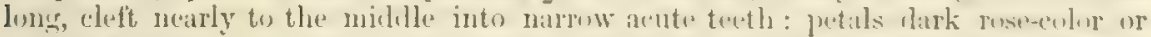

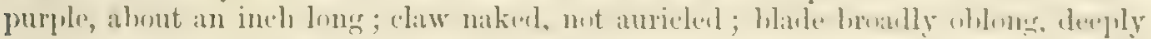

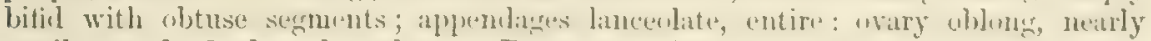
sessile: seeds finely tuberculate. - Proc. Am. Acad. x. 344.

Near Carson City (Anderson); Wulker's Jeadows (Brcucer); Plumas and Sierra counties, Mrrs. M. E. P. Ames and Lemmor.

14. S. incompta, Gray. Tiscilly pulurulent or puhesent : stems tall amd lax,

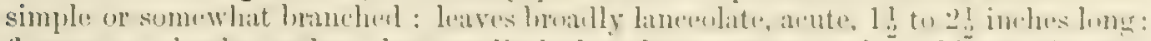

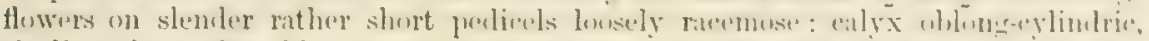

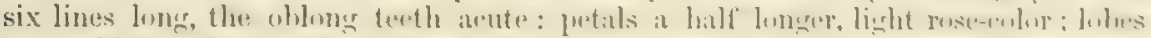

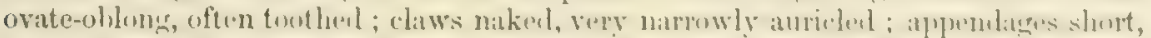

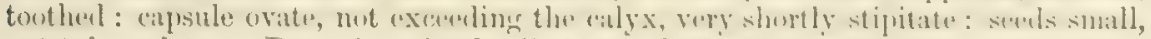
not tuberculate. - Proc. Am. Acad. vii. 330. S. Engelmani, Rohrb. 1. c. 264.

Sfount Bullion and Yosemite Valley, Bolander, Torrey.

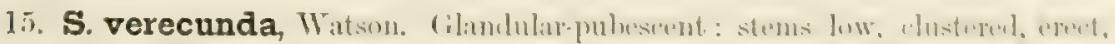

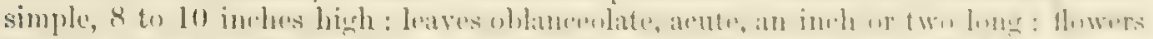

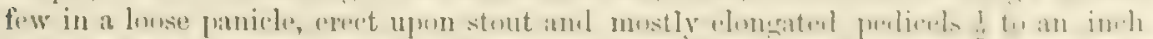

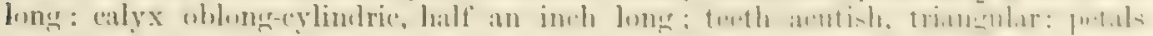

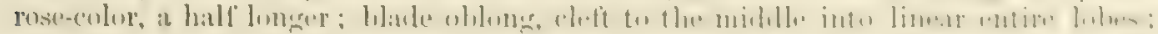

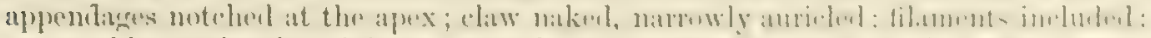

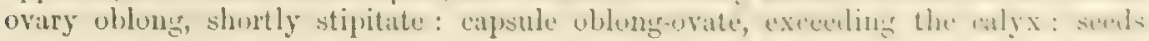


strongly tubercled on the back. - Proc. Am. Acad. x. 344. S. Engelmanni, var. Behrii, Rohrb. in Linnæa, xxxvi. 264.

Rocky hills near Mission Dolores, Bolander, Behr.

16. S. Bridgesii, Rohrbach. Finely pubescent below and viscid above : stems simple, slender, erect, a foot high or more: leaves rather narrowly oblanceolate, acute or acuminate, an inch or two long: flowers simply racemose, on slender spreading pedicels 3 to 6 lines long: calyx oblong-cylindric, 4 to 5 lines long, with rather narrow acute teeth: petals white, very narrow, 8 lines long, the claw scarcely auricled and lobes narrowly linear; appendages very small : styles greatly elongated: capsule equalling the calyx, ovate. - Ind. Sem. Berol. 1867, \& Monogr. Silene, 204.

In Yosemite Valley and at Clark's on the Merced, Bridges, Gray.

17. S. Douglasii, Hook. Finely puberulent throughout, and rarely somewhat glandular above : stems erect or ascending from a branching decumbent rootstock, slender, 6 to 15 inches high, simple, few-flowered: leaves narrowly oblanceolate to linear, an inch or two long : flowers erect, on slender pedicels : calyx oblong-cylindric, often somewhat inflated, 5 to 7 lines long, with broad acutish teeth: petals rosecolor or nearly white, 8 to 10 lines long, with broad obtuse lobes, a broadly auricled claw, and narrow appendages: capsule oblong-ovate, equalling the calyx, rather longstipitate : seeds strongly tubercled on the back.-Fl. i. 88 ; Torr. \& Gray, Fl. i. 190. S. multicaulis, Nutt.; Torr. \& Gray, Fl. i. 192.

From Washington Territory and Montana to the Sacramento River, Donner Pass in the Sierra Nevada, and the Wahsatch Mits.; the most frequent of all the species. Scanty specimens, doubtfully referred here, were collected by Palmer in the Cuyamaca Mts., San Diego Co.

S. Scouleri, Hook, and S. Spaldivgir, Watson, both from beyond the limits of the State northward, but perhaps to be found on its northern borders, belong to a group of stout perennials with the flowers shortly pedicelled and often fascicled in the axils of the rather leaf-like bracts. The first has conspicuous petals, the broad bifid limb with notched lobes and appendages; elaw auricled ; capsule ovate, long-stipitate; leaves narrow, distant. The latter is viscidly pubescent throughout, with numerous lanceolate leaves; petals with a very broad claw, but short and obtuse emarginate limb, and four short distinet appendages ; capsule oblong, short-stipitate.

One or two dwarf alpine species occur in the Sierra Nevada, apparently undescribed, but the material collected is too scanty for satisfactory description. Specimens from Mt. Dana (Brewer), near Ebbett's Pass (Brexter, n. 2081), and from some locality farther north (Lenmon), are alike in habit, having mostly 1 -flowered stems, linear leaves, a short subcampanulate calyx and short bifid petals, but differ in pubescence and in some of the characters of the flower. They are closely allied to that group of the genus Lychnis which includes $L$. affinis, triftora, apetala, \&ce., - alpine and arctic species of doubtful limitation, - none of which seem to have been found in California, though some occur farther north and in the Rocky Mountains.

\section{Cerastium, Linn. Mouse-ear Chickweed.}

Sepals 5, not carinate nor 3-nerved. Petals 5, emarginate or bifid. Stamens 10. Styles 5, rarely 4 or 3. Capsule cylindric or eylindric-conic, often incurved, 1-celled, many-seeded, dehiscent by twice as many equal teeth as there are styles. Seed subreniform-globose, ustally granulate.-Mostly pubescent or hirsute low herbs; leaves rarely subulate; flowers white, in terminal leafy or scariously bracted dichotomous cymes.

Distinguished from Arenaria and Stellaria by habit, as well as by the form and dehiscence of the capsule. A genus of perhaps 100 species, widely distributed, but sparingly represented in America.

1. C. nutans, Raf. Annual, viscid-pubescent, erect, usually branched at the base, about a span high : leaves narrowly oblong or linear-lanceolate, acute, clasping, $\frac{1}{2}$ to $1 \frac{1}{2}$ inches long, the lowest spatulate : cyme open, rather many-flowered; pedicels often nodding or reflexed in fruit: calyx $1 \frac{1}{2}$ to 2 lines long, the petals slightly longer : capsule 4 to 6 lines long, curved,-Gray, Gen. Ill. ii. 40, t. 114. 
From the Atlantic States to Washington Territory, Ttah, and Northern MLxico; collected by Anderson in the mountains above Carson City, Nevada.

2. C. arvense, Linn. Perennial, downy with reflexed hairs, cespitnse; stems erect, 3 to 12 inches high: leares linear to linear-lanceulate, $t$ to 12 lines lunes, acute, clasping: cyme few-Howered, usually narrow; pedicels mostly long, erect ur nodding: calyx $1 \frac{1}{2}$ to 3 lines lons, the petals nearly twice louger: capsule little exceeding the calyx, nearly straight.

Nortbern States and westward in the mountains to Coloralo anl Washington Tervitory : also European and Asiatic. Found but sparingly in California, at the Russian Colony, and by Bolander in Mendocino County at Noyo, in sandy fields among shrubs, and on the East Fork of

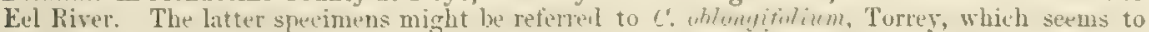
be but a form of $C$ artense with the capsule a half longer than the calyx.

3. C. pilosum, Ledeh. Perennial, erect, rather stout, zmore or less densely pilose, glandular-puhescent abore: leaves ohlong-lumerolate, ! to an inch long, 1 to 6 lines broal, acute, almost sheathing at hase: Howers larese, few : calyx 3 to 4 lines loner, the petals half longer: carsule 6 to 10 lines hong, the slemler teeth at length circinate.-Icon. Ross. t. 351. C. stellarioides, Moçino, Icon. Ined. t. 54.; Torr. \& Gray, FL. i. 187.

Alaska and Siberia ; Punta de los Reses (Eiyrlor), referred to C. dwangifulium in Pacif. R. Rep. iv. 70 .

\section{STELlaria, Linn. CHICKWEE.}

Sepals 5, rarely 4. Petals as many, 2-cleft, rarely none. Stamens 10, or ferrer by abortiou. Styles 3 , or rarely 2,4 , or 5 , opposite to as many sepals. Capsule glubose to oblong, many-seederl, llehiscent to below the millie intu twice as many valves as styles. Seeds reniform-globose or laterally compressed. - Low herbs, mostly diffuse; leaves rarely subulate; Howers white, solitary or cymose, terminal or becoming lateral; stems mostly 4-angled.

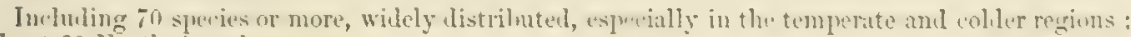
about 20 Nortle American.

* Leaves ovate, petioled: stems marked by a pubescent line: petals shorter than the calyx : annual or nearly so, introduced.

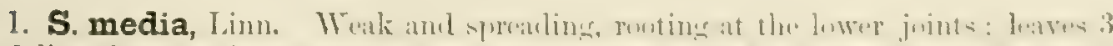

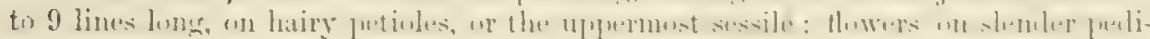
cels, deflexed in fruit, with foliaceous bracts: calyx pubescent: stamens 3 to 10 : capsule oblong-ovate, 2 to 3 lines long, equalling or exceeding the calyx.

A common introduced weed, in shady places, nativo of Europe.

* Leaves linear to lanceolate, sessile: perennials, excepting the first.

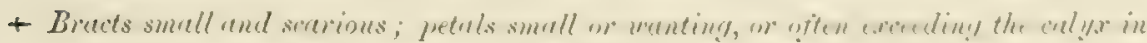
the last.

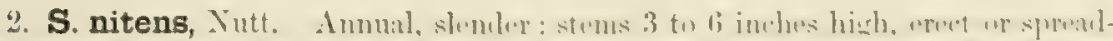

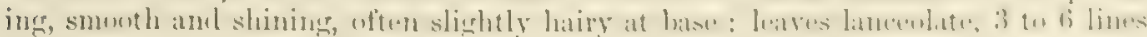
long, acute, the lower shortly petiolate: flowers erect, on short pedicels: sepals

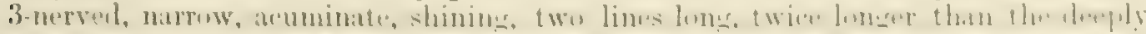

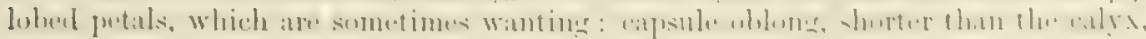
rather fow-seeded. - Torr. \& Grny, Fl. i. 185; Torr. in Pacif. R. Rep. iv, 69.

Valleys and foot-hills from Los Angeles northward to the British boundary ; Gualalupe Island, Fulluer.

3. S. umbellata, Turen Glabrons: stums very slender, nscending. frum slen-

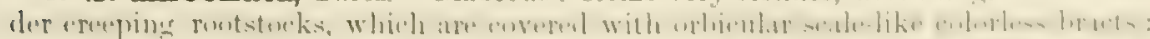

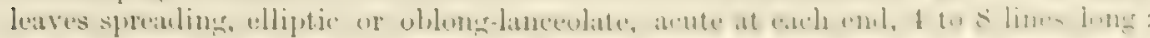


flowers in a simple or compound open umbel-like few-rayed cyme; pedicels elongated: sepals ovate-lanceolate, 1-nerved, 1 to $1 \frac{1}{2}$ lines long: petals none: capsule at first ovate, at length nearly twice longer than the calyx. - Ledeb. Fl. Ross. i. 394 ; Watson, Bot. King Exp. 38.

Rocky Mountains of Colorado ; in the Wahsatch (Watson); at Peregoy's above the Yosemite, Gray. Identical with the Asiatic form.

4. S. longipes, Goldie. Sinooth and shining or glaucous, erect or ascending, 2 to 18 inches high: leaves linear or linear-laneeolate, $\frac{1}{2}$ to $1 \frac{1}{2}$ inches long, 1 to $1 \frac{1}{2}$ lines wide, acute, rather rigid and usually ascending : Howers few, on long slender erect pedicels, the scarious bracts often wauting in the less developed specimens: sepals scarcely nerved, $1 \frac{1}{2}$ to $2 \frac{1}{2}$ lines long: petals about equalling or exceeding the calyx : capsule ovate-oblong, at length exserted, usually dark-colored at maturity : seed smooth. - Torrey, Bot. Wilkes Exp. 245.

In the Sierra Nevada from the Yosemite northward, ranging to the Arctic Sea and eastward to Maine and Labrador : also Asiatic.

S. KingII, Watson, Bot. King Exp. 39, t. 6, of the mountains of Nerada, may be found in California: stenas low, from a woody base, strict, glandular-pubescent; leaves linear, rigid, short; capsule half longer than the calyx.

++ Bracts foliaceous: petals exceeding the calyx, or wanting in the first.

5. S. borealis, Bigelow. Glabrous : stems usually weak, erect or spreading, branched, $\frac{1}{2}$ to $1 \frac{1}{2}$ feet high: leaves linear-lanceolate to ovate-oblong, $\frac{1}{2}$ to 2 inches long, 1 to 5 lines wide, acute, usually spreading: flowers in dichotomous cymes, on pedicels $\frac{1}{2}$ inch long, at length spreading or deflexed : sepals orate to lanceolate, a line or two long, usually short: petals 2-parted, included, 2 to 5 , or more usually wanting: capsule ovate, $1 \frac{1}{2}$ to 2 lines long: seeds smooth.

Wet places in Mendocino County, Bolander; the form with larger calyx. A common species northward, and in the mountains, across the continent; also in the Old World. The variety alpestris, Gray (var. corollina, Fenzl), with the bracts small and partly scarious, and with roughish seeds, occurs in Oregon and may be found in California.

6. S. Jamesii, Torrey. Somewhat viseidly pubescent, rather stout, ascending, branched, a foot or two high: leaves linear- to ovate-lanceolate, 1 to 3 inches long, 3 to 9 lines wide, acuminate, dark green : pedicels divaricate, rather short, at length deflexed: sepals oblong, acnte, 2 or 3 lines long, the bifid petals mostly twice longer : capsule ovate, shorter than the calyx: seed smooth. - Torr. \& Gray, Fl. i. 183; Watson, Bot. King Exp. 38.

In the Sierra Nevada (Bolander, Mrs. Ames), and in the mountains eastward to Colorado and New Mexico,

7. S. littoralis, Torrey. Pubescent throughout, ascending, a foot high, rather stout: leaves ovate, an inch long, acute, rounded at base, rather thick: flowers in a terminal compound eyme: sepals lanceolate, acnte, obscurely 3-nerved, 2 lines long, a little shorter than the 2-parted petals: styles sometimes 4: capsule shorter than the calyx. - Pacif. R. Rep. iv. 69.

Sea-shore, Punta de los Reyes, Bigelow.

\section{ARENARIA, Linn, SANDWoRT.}

Sepals 5, rarely 4. Petals as many, entire or rarely emarginate, or wanting. Stamens 10. Styles 3, rarely more or fewer, opposite to as many sepals. Capsule globose or short-oblong, dehiscent into as many entire, 2-cleft, or 2-parted valves as there are styles, few - many-seeded. Seed reniform-globose or laterally compressed. Mostly low annuals or perennials, usually tufted; with sessile leaves, often subulate and more or less rigid, without stipules ; flowers white, cymosely panicled or capitate.

A large genus of about 130 species, very widely dispersed, many of them aretic or alpine. 
\$1. The 3 valves of the capsule 2-cleft or parted: seeds not appendaged at the hitum: cespitose perennials, mostly scarious-bracted. - ARENARIA proper.

1. A. congesta, Nutt. Smooth, glaucous, 4 to 12 inches high: leaves very narrowly subulate, scabrous on the margin, often pungent, the lower 1 to 21, inches long, the cauline $\frac{1}{2}$ to 1 inch long: flowers in 1 to 3 dense subumbellate fascicles, with large dilated membranous bracts : sepals ovate-oblong, strongly concare, scuriously margined, obscurely 3-nerved, $1 \frac{1}{2}$ to $2 \frac{1}{2}$ lines long, acute: petals narrowly oblong, nearly twice as lung as the calyx: stigmas capitellate: capsule equalling the calyx. - Torr. \& Gray, Fl. i. 178; Watson, Bot. King Exp. 39. Brewerina suffrutescens, Gray, Proc. Am. Acad. viii. 620.

Var. subcongesta, Watson. Flowers less densely fascicled and somewhat cymose. - A. Fendleri, var. subcongesta, Watson in Bot. King Exp. 40.

In the mountains from Washington Territory to Colorado; at Summit in the Sierra Nevada (Bolander); above Carson City, Anderson. The variety in the northern Sierra Nevada (Lemmon), and eastward. The typical form has the flowers nearly sessile in close heads. Brewerina suffrutescens, Gray, is a form somewhat woody at base and with the flowers upon longer nearly equal pedicels. The remarkable character of capitellate or somewhat capitellate stigmas it has in common with $A$. Fendleri, and they are also found in A. capillaris and A. Franklinit.

2. A. capillaris, Poir. More or less glandular-pubescent above, erect, 3 to 12 inches high: leaves linear-subulate, 1 to 2 inches long, pungent; the cauline few, short and erect: flowers few, in an open cyme; bracts small, lanceolate: sepals ovate, acute, $1 \frac{1}{2}$ to 2 lines long, 3-nerved, membranously margined: petals half lunger : capsule somewhat exceeding the calyx. - Inchding A. nardifolia, Leuleb. (Hook. Fl. i. 98, t. 32), and some other Asiatic forms. A. formosa, Torr. Bot. Wilkes Exp. 243 ; Watson, Bot. King Exp. 39.

In the mountains from the British boundary southward; Donner Pass (Torrey); Silver Monntain, at 11,000 feet altitude, Brevocr. The more typical glabrous form seems not to occur here.

3. A. pungens, Nutt. Pubescent throughout, cespitose, 2 to 3 inches high: leaves linear-subulate, 3 to 5 lines long, pungent, crowded: flowers in an open cyme, leafy-hracted : sepals lanceolate, acuminate, pungent, 1 to to 3 lines long, rather obscurely 3-nerved: petals about equalliner the calyx: the capsule shorter: seeds very few, smooth. - Torr. \& Gray, Fl. i. 179; Watson, l. c.

In the Sierra Nevada, above the Big Tree Grove (Bolander); Silver Mountain, at 11,000 feet (Brewer) ; above Carson City (Auderson); and eastward to Colorado.

A. FrankLinir, Dougl., is of similar habit, but stouter and less pubescent; sterns leafy at base : flowers fascicled in a rather close cyme: sepals 3 to 5 lines long, smooth and shining, scariously margined, as also the large bracts : petals as long, and capsule shorter. - Oregon to Colorado, and perhaps to be expected in the mountains of California.

\$ 2. The 3 vrelnes of the capsule entire: septs not appendaged at the hilum: lown annuals with foliaceous bracts (the Californian species). - ALsixe.

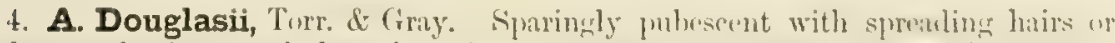

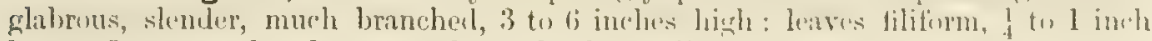
long: flowers rather large, on long slender pedicels: sepals oblong-ovate, acute,

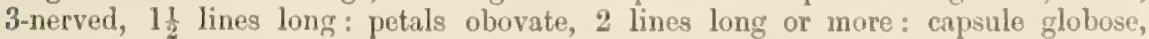
equalling the calyx: seeds large, flat, smooth, acutely margined. - Fl. i. $67 t$.

Dry hillsides, throughout Califomin The very similar A. TExwLLA, Nuth, of Oregon and Washington Territory, is distinguished by narrower and more strongly nerved sepals, oblong capsule, and small minutely roighened seeds.

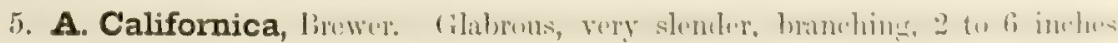
high: leaves lanceolate, 1 to 2 lines long, obtusish: flowers smill, on slender peilicels: sepals oblong-ovato, acuto, 3 -nerved, 1 to $1 \frac{1}{2}$ lines long; petals spatulate, about a half longer: capsule oblong: seeds small, sharply muriculate - Bolander, Cat. 6. A. brevifolia, var. (i) Californica, Griny, Proc. Calif. Acad. iii. 101.

Sonoma County to Santa Cruz and eastward; Auburn, Bolaraler. 
6. A. palustris, Watson. Apparently annual, smooth, the stems weak, simple, 4 to 8 inches high : leaves linear, flaccid, $\frac{1}{2}$ to 1 inch long, acute : flowers few, large, on long pedicels: sepals elliptic, obtuse, $1_{2}^{\frac{1}{2}}$ to 2 lines long, herbaceous, not nerved: petals oblong, twice longer: capsule oblong, shorter than the calyx: seeds numerous. - Alsine palustris, Kellogg, Proc. Calif. Acad. iii. 61.

Swamps near San Franciseo, Bolander, Kellogg.

\section{\$. Parts of the flowers sometimes in fours : valves of the capsule bifid; the young ovary 3-celled: seed appendaged at the hilum with a small caruncle. - MøHRINGIA.}

7. A. macrophylla, Hook. Perennial, with rumning rootstocks ; stems ascending, 3 to 8 inches high, mostly simple, leafy, puberulent above: leaves 3 to 4 pairs, narrowly lanceolate, acute at each end, 1 to 2 inches long, thin, bright green : Howers few, on slender pedicels: sepals ovate-oblong, acuminate, $1 \frac{1}{2}$ to $2 \frac{1}{2}$ lines long, 1-nerved, exceeding the obtuse petals: capsule ovoid, nearly equalling the calyx: seeds several, smooth, rather large. - Fl. i. 102, t. 37. Moehringia ambrosa, Gray, Pl. Fendl. 13, not Fenzl. M. macrophylla, Torr. Bot. Wilkes Exp. 246.

From Washington Territory to California (Bigelow); Sierra County, Lemmon. Also in New Mexico, Fendler. Another species of this section, A. LATERIF LORA, Linn, with broader obtuse leaves and exserted petals, occurs in Oregon and is of wide range northward and eastward.

\section{SAGINA, Linn. Pearlwort.}

Sepals 4 to 5. Petals as many, entire or slightly emarginate, often minute or wanting. Stamens as many as the petals, rarely twice as many or fewer. Ovary 1-celled, many-ovuled: the styles alternate with the sepals, and as many. Capsule dehiscent to the base by entire valves alternate with the sepals. - Low green herbs, with subulate or filiform leaves without stipules, and small terminal usually longpedicelled flowers.

A small genus, inhabiting moist places in temperate and frigid regions, chiefly of the northern hemisphere.

1. S. occidentalis, Watson. Annual, glabrous, very slender and delicate, 2 to 6 inches high, decumbent at base or ascending: leaves not fascicled, 3 to 6 lines long, pungent: flowers pentamerous, on elongated straight pedicels: sepals obtuse or acutish, a line long: petals nearly equalling the sepals: stamens 10 : capsule exceeding the calyx. - Proc. Am. Acad. x. 345. S. procumbens, Bolander, Cat. 6.

Valleys and borders of salt-marshes from San Francisco to Washington Territory.

2. S. Linnæi, Presl. Biennial or perennial, glabrous, densely matted and decumbent, 1 or 2 inches high : leaves somewhat fascicled, 3 to 6 lines long, pungent: flowers on long pedicels, at length nodding: sepals a line long, obtuse, exceeding the petals: stamens 10 : capsule at length nearly twice longer than the calyx, Spergula saginoides, Linn.

Webber Lake, Lemmon. Aretic America and southward in the Rocky Mountains to New Mexico; also in the Old World.

\section{SPERGULA, Limn. Corn-Spurrey.}

Sepals 5. Petals 5, entire. Stamens 10, rarely 5. Ovary 1-celled, many-ovuled : styles 5, alternate with the sepals. Capsule 5-valved, the entire valves opposite to the sepals. Seeds laterally compressed, acutely margined or winged : embryo spiral. - Annuals, dichotomously or fasciculately branched; with subulate fascicled or apparently whorled leaves, and small scarious stipules; flowers pedicelled, in dichotomous cymes.

A genus of 2 or 3 species, of Europe and Asia, widely naturalized as weeds in cultivated fields. 
1. S. arvensis, Linn. Smooth; stems several, a foot or two high : leaves filiform, numerous in apparent whorls, 1 or 2 inches long; stipules small : flowers white, the long pedicels at length reflexed: sepals oblong to ovate, 2 or 3 lines long, equalling the pretals, a little shorter than the broadly ovoid capsule: seteds rough, acutely margined.

Sparingly naturalized; near San Francisco (Torrey); Mark West Creek, Bolander.

\section{LEPIGONUM, Fries. SAND-SpURrey.}

Sepals 5. Petals 5, entire, rarely fewer or none. Stamens 10, or fewer by abortion. Ovary 1-celled, many-ovuled: styles 3, or rarely 5. Capsule 3-valved. Seeds winged ur naked: embryo annular. - Low herbs, usually ditfuse; with setaceous or linear fascicled leaves and scariuus stipules; flowers white or pink, pedicelled, in at length subracemose cymes. - Kindberg, Monog. Lepig.

A genus (known also as Spergularia) of 5 or 6 species, chiefly confined to the sea-coast or saline localities; widely distributed through the tempurate zones. Species of rather diffieult detinition.

1. L. macrothecum, Fischer it Meyer. Perennial, rather stout, often a foot high, decumbent at base, glabrous beluw, pubescent above, the calyx more or less tomentose: leaves fleshy, $\frac{1}{2}$ to 2 inches long, with large ovate stipules: flowers large, subracemose; pedicels \pm to 12 lines long, becoming reflexed: sepals 3 lines long or more, equalling or exceeting the petals : capsule orvid, a little exceetling the calyx: seeds smooth, narrowly winged. - Kindberg, I, c. 16, t. 1, fig. 1. Spergularia rubra, Torr. in Pacif. R. Rep. iv. 70.

In salt-marshes from Marin County to San Diego.

2. L. medium, Fries. More slemiler and diffusely branched than the last, annual or biennial (sometimes perennial ?), more or less pubeseent or often nearly glabrous: leaves fleshy, $\frac{1}{2}$ to 1 inch lonir or more; stipules shurt : pedicels $\frac{1}{2}$ to if lines long, often short, reflexed: flowers smaller; calyx 1 to 2 lines long: "seeds snaller, smooth, wingless or narrowly winged.

In saline localities from San Diego to Puget Sound and across the continent; also European and Asiatic. A very variable species as at present received.

\section{POLYCARPON, Linn.}

Sepals entire, searious upon the margin. Petals small, hyaline. Stamens 3 to i. Ovary 1-celled: style short, 3releft. Capsule 3-valved, several-seedent - Low diffuse dichotomously branched ammuls ; leaves flat; stipules small, scirions; fluwers small, cymose.

Half a dozen species, in the temperate and warmer regions of both hemispheres.

1. P. depressum, Nutt. Viry small and mull brumbl, searenly an ind

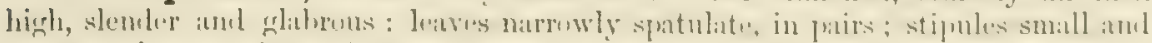

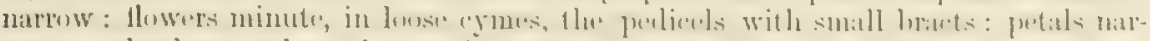

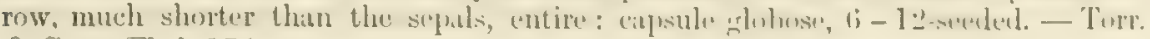
\& Gray, Fl. i. 174.

On bare sand-hills near Sin Dipgo (Nuttall); nenr San Bernardino, Lemmono

P. TETrApIYLLCM, Linn. $f_{0}$, is found around the world, but is not yet known from Californin.

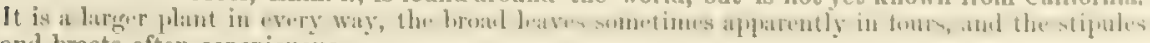
and bracts often conspicuous.

\section{LCEFLINGIA, Linn.}

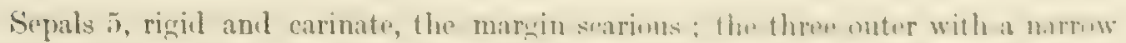
tooth upon each side. Petals very small or none. Stamens. 3 to 5 . () vary 1-4rellial: 
style very short or none. Capsule 3-valved, several-seeded. - Low rigid dichotomous annuals; leaves subulate, with adnate aud connate setaceous stipules; flowers small, sessile in the axils.

A genus of perhaps five species, of the Mediterranean region and Central Asia, with the following from North America.

1. I. squarrosa, Nutt. Glandular-pubescent, much branched, the stems 2 to 6 inches long: leaves and sepals subulate-setaceous, rigid and squarrose, the leaves 2 or 3 lines long, exceeding the flowers: capsule triangular, at length exserted, many-seeded. - Torr. \& Gray, Fl. i. 174; Gray, Gen. Ill. ii. 24, t. 106. L. Texana, Hook. Ic. Pl, t. 285.

San Diego (Nuttall), and eastward to Texas.

\section{ORDER XV. IULECEBRACE正。}

Distinguished from the scarious-stipulate Caryophyllacece only by the solitary or sometimes geminate ovules, undivided or 2-cleft style, and one-seeded utricular or akene-like fruit; the petals wholly wanting or reduced to mere filaments; these and the stamens usually more perigynous. Closely related on the other hand to Amarantacece and other apetalous orders. Here represented by only two plants, but several species of other genera are found in the Atlantic States.

1. Pentacæna. Calyx of 5 unequal awn-tipped sepals: stamens inserted on their base.

2. Achyronychia. Calyx 5-cleft, with a 10-nerved tube and blunt silvery-scarious lobes : stamens inserted on the throat.

\section{PENTACANA, Bartling.}

Sepals 5, nearly distinct, hooded, unequal, terminating in a short divergent spine, the inner more shortly awned. Petals minute, scale-like. Stamens 3 to 5 , inserted at the base of the sepals; staminodia none. Style very short, bifid. Utricle included in the rigid connivent calyx. - Low densely tufted perennials ; leaves subulate, densely crowded on the branches; stipules dry and silvery; flowers sessile, clustered in the axils.

A genus of 2 or 3 species, of S. America and Mexico, only one reaching our western coast.

1. P. ramosissima, Hook, \& Arn. Prostrate and matted, the stem 2 to 18 inches long, somewhat woolly: leaves 3 to 5 lines long, pungently awned, at length recurved; stipules lanceolate, acuminate, shorter than the leaves, 1-nerved: calyxtube nearly a line long, the divergent outer lobes twice longer: stamens usually $\mathbf{5}$ : stigmas subsessile: utricle apiculate. - Hook. Bot. Misc. iil. 338. Paronychia ramosissima, DC. Paronych. 12, t. 4; Torr. \& Gray, Fl. i. 172. Acanthonychia ramosissima, Rohrb. in Mart. Fl. Bras. xiv. ${ }^{2} 249$, t. 56.

On the sea-coast from Oregon to Southern California and Mexico, forming large patches on the drifting sands about San Francisco. Also on the South American coast from Chili to Patagonia, and in $\mathrm{S}$. Brazil.

\section{ACHYRONYCHIA, Torr. \& Gray.}

Calyx 5-cleft, persistent, the turbinate 10-nerved tube at length cylindrical and coriaceous; lobes oval, obtuse, thickened at base, silvery-scarious above and nerveless. Petals none. Filaments or staminodia 15, in one row at the summit of the tube, filiform, only 1 or 2 antheriferous. Style short, bifid. Ovules 2 , on very short funicles, one abortive. Utricle thin, included. Seed oblong-pyriform. - A 
depressed annual ; with opposite spatulate leaves, large hyaline stipules, and Howers in dense axillary cymose clusters.

1. A. Cooperi, Torr. \& Gray. Slender, glibrous, the stems 2 or 3 inches long: leaves rather thick, "veinless, 1 to 1 inch long, the alternate ones only half as long, attenuate to a slender base: stipules interpetiolar, ovate or rounded, entire or lacerate: calyx 1 to 1 lines long, the tube at length equalling the lobes, apparently 5-toothed by the herbaceous bases of the conspicuous white-scarious lobes : tilaments very slender, much shorter than the lobes: ovary Hattened at the top : utricle equalling the tube, bursting irregularly at the apex. - Proc. Am. Acad. vii. 331.

Southeastern California, in the Colorado Desert (Schot') and near Camp Cady (Cooper), growing in dry sand; also collected in Southern Arizona or Sonora.

\section{Order XVI. PORTULACACE画.}

More or less succulent herbs, with simple and entire leares (either opposite or alternate), and regular but unsymmetrical perfect flowers; the sepals (except in Lewisia) only 2, while the petals are from 2 to 5 or more; the stamens opposite the petals when of the same number or ferer; the orary 1-celled with few or many campylotropous or amphitropous ovules on a free central placenta, in fruit becoming capsular; the seels with a slender embryo curved or coiled on the outside of farinaceous albumen, as in C'aryophyllacece. - Ovary free and the parts of the Hower hypogynous, except in Portulace. Stamens sometimes indefinitely numerous, commonly alhering to the base of the petals; these sometimes united at base. Style $2-8$-cleft ; the stigmas accupying the inner face of the lobes. Stipules none, or scarious, or reduced to hairs. Flowers open only in sunshime or bright daylight, in many ephemeral, in some opening for two or three days.

Comprises 15 genera and over 100 species, the greater part American jand many more restern than eastern), some in frigid and others in torrid regions, a few widely dispersed over the world.

- Sejals 2, united below and adherent to the ovary, the free upper portion at length deciduous.

1. Portulaca Stamens 7 to 20. Flowers solitary, red or yellow. Capsule opening by a lid.

* * Sepals 2, distinct, persistent : ovary free.

+ Style 3-cleft : capsule 3-valved : sepals equal.

2. Calandrinia Stamens more than 5. Petals 5 or more. Seeds mostly snooth and shining.

3. Claytonia. Stamens 5. Petals 5, equal. Seeds smooth and shining.

4. Montia. Stamens usually 3. Petals unequal, Seeds dull, tuberculate.

++ Style 2-cleft : capsule 2-valved : sepals unerqual, hyaline.

5. Spraguea. Stamens 3. Petals 4. Stems simple, scapeliko,

6. Calyptridium. Strumen 1. Petals 2. Stems branching, leafy.

* Sepals 4 to 8 , distinct, much imbricated.

7. Lewisia. Stamens many. Style 3-8-cleft. Petals 8 to 16. Scapes 1-flowered.

1. PORTUlaca, Tourn. Pursuane.

Seprals 2, coherent at base into a tube and adnate to the (1vary, the fre limb

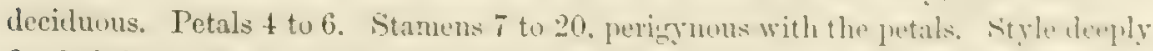
3 -8.heft. Capsule opening hy a lil. Seets numerous, small. - Fleshy diflise or ascemling ammals ; with entire leaves, am axillary or tominal phlumeral yellow or rose-colored flowers. 
Species about 16, belonging to warm and tropical regions, chiefly American, a few widely naturalized as weeds in temperate countries.

1. P. oleracea, Linn. Prostrate, glabrous, purplish : leaves flat, obovate to spatulate, rounded at the summit : sepals acute, cariuate : petals yellow, $1 \frac{1}{2}$ to 2 lines long: stigmas 5 : capsule 3 to 5 lines long: seeds black, dull, finely tuberculate.

The common Purslane, from Europe, naturalized as a weed in gardens and cultivated grounds.

2. P. retusa, Engelm. Like the last, but greener and the stems more ascending, sometimes covering a space several feet in diameter: leaves usually smaller : sepals obtuse, broadly carinate-winged : petals yellow : stigmas 3 or 4 : capsule $2 \frac{1}{2}$ or 3 lines long, broader in proportion: seeds more strongly tuberculate.-Pl. Lindh. 154 ; Schlecht. in Bot. Zeit. xi. 739.

Along the Colorado (Newberry) and eastward to Texas.

3. P. pilosa, Linn. Prostrate or ascending, with tufts of long hairs in the axils of the linear more or less terete leaves: sepals membranaceous, not keeled, acute: petals bright red, 2 or 3 lines long: stamens 15 to 25 : stigmas 5 or 6 : seeds black, tuberculate. - Engelm. 1. c. 155 ; Lindl. Bot. Reg. t. 792 ; Rohrb. in Mart. FI. Bras. xiv. ${ }^{2} 303$.

Dry sandy soil near Soda Springs on the Upper Sacramento (Brewer), which is the only reported Californian locality : New Mexico, Texas, and through Tropical America to Brazil.

P. GRANDIFLorA, Hook. Bot. Mag. t. 2885, from Brazil, is much cultivated for its large bright flowers of various colors, and sometimes escapes from gardens. Its leaves are terete, stamens numerous, and the seeds ash-colored and shining.

\section{CALANDRINIA, HBK.}

Sepals 2, green, persistent. Petals mostly 5 (3 to 10). Stamens 5 to 15 , indefinite. Ovary free, many-ovuled: style 3-cleft, short. Capsule globose or ovoid, membrauaceous, 3-valved. Seeds black, usually shining, smooth or minutely tuberculate.-Low succulent herbs ; with alternate or radical leaves, and purplish ephemeral flowers in bracteate racemes or panicles, or few upon short scape-like stems.

A genus of about 60 species, all South American and Australian, with the exception of the following. The closely allied genus Talinum, differing in its deciduous sepals and carunculate seeds, has half a dozen or more species chiefly eastward or south of the Rocky Mountains, a single one (T. spinescens, Torr.) occurring in Washington Territory. None are likely to be found in California.

* Caulescent annuals, of the plains and foot-hills : flowers in racemes: petals 3 to 5 : seeds minutely tuberculate.

1. C. Menziesii, Hook. Glabrous or slightly pubescent, branching from the base, the stems ascending: leaves linear to oblanceolate, the lower on slender petioles, 1 to 3 inches long: racenies simple; peduncles erect or ascending: sepals keeled, the calyx 4-angled in bud: petals broadly obovate, red to purple, 2 to 6 lines long: capsule ovate, acute or acuminate, 2 to 4 lines long, about equalling or a little exceeding the ovate acute or acuminate sepals: seeds shining, minutely tuberculate, $\frac{1}{2}$ to 1 line broad. - Torr. \& Gray, Fl. i. 197. Talinum Menziesii, Hook. Fl. i. 223 , t. $70 . \quad$ C. speciosa, Lindl. Bot. Reg. xix. t. 1598.

Abundant in winter and early spring, in the valleys and on sunny hillsides, from Vancouver Island to Lower California. Very variable in height, and in the size and color of the flowers. Cattle are fond of it.

2. C. Breweri, Watson. Much resembling the last: peduncles divaricately spreading or deflexed: sepals triangular-ovate: capsule 4 to 5 lines long, conical, blunt, exceeding the sepals: seeds half a line broad, not shining, more strongly tuberculate. - Proc. Am. Acad, xi. 124. C. Menziesii, var. macrocarpa, Gray in Proc. Calif. Acad, iii. 102. 
Santa Iñez Mountains, near Santa Barbara, Breucr. The specimens collected are a foot tall or more, the racemes elongated.

3. C. maritima, Tutt. Glaucous : stems spreading, 3 or 4 inches hirh, with small bract-like leaves above the base : lower leaves obovate or obuvate-spatulate, an inch long, fleshy, obtuse: flowers in a loose dichotomous terminal pawicle, on slender pedicels, "red, rather large and showy": sepals ovate, acute : capsule oblongrovate, 2 lines long, exceeding the sepals, acutish. - Torr. \& Gray, Fl. i. 197.

San Diego (Nutlall); Coronados Islands, Thurber. A little known species.

* * Alpine plants with thick fusiform roots, the scape-like mostly 1-Howered stems shorter than the leaves: petals 6 to 8 : seeds black and shining, not iuberculate.

4. C. pygmza, Gray. Smooth : leaves all radical, linear, 1 or 2 inches long, with broad scariuusly wingerl underground petioles: scapes mostly simple, 1 or 2 inches high, with a pair of small scarious bracts: sepals suborbicular, glandulardentate, 2 or 3 lines long: petals red: ovules 15 to 20 : capsule obtuse, nearly equalling the calyx. - Proc. Am. Acad. viii. 623. Talinum pygmaeum, Gray in Am. Jour. Sci. 2 ser. xxxiii. 407 ; Watson, Bot. King Exp. 42, in part.

In the Sierra Nevada on the Yosemite Trail, at 8,000 feet altitude (Bolander); Mt. Lyell (Mfuir); northward to Washington Territory, and in the mountains eastward to Colorado and Southera Utah.

5. C. Nevadensis, Gray, 1. c. Closely resembling the last, but somewhat larger: scapes 1 to 3 inches high, with a pair of larger leafy bracts, 1 -3-florered: sepals entire, 3 or 4 lines long: petals white: ovules 30 to 40 . - Tulinum pygmueum, Watson, 1. c., in part.

In the Sierra Nevada; Cisco (Kellogg); Summit (Bolander); Plumas Co. (Mrs. Pulsifer Ames); and eastward in the E. Humboldt and Wahsatch Mountains, Walson.

\section{CLAYTONIA, Linn.}

Sepals 2, persistent. Petals 5, equal. Stamens 5. Ovary free, few-ovuled: style 3-cleft. Capsule membranaceous, globose or ovoid, 3-valved. Seeds few, black and shining. - Low glabrous succulent herhs; with opposite or alternite leaves, and delicate white or rose-colored Howers in loose terminal or axillary, simple or compound naked racemes, or sumetimes umbellate, lasting more than one day.

A genus of ahout 20 speries, helonging principally to the cooler portions of Forth America and northeastern Asia. The species aro most numerous in western North America.

$$
\text { * Annuals, with fibrous roots. }
$$

+ Stems simple, bearing a single pair of leaves which are often connate.

1. C. perfoliata, I)onn. Stems 2 to 12 inches high: ralieal leaves long-

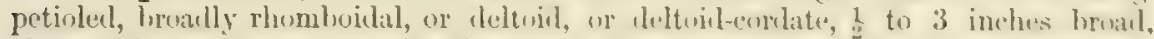
obtuse ; the cauline pair more or less unitml upun one we both sieles, usually forminer

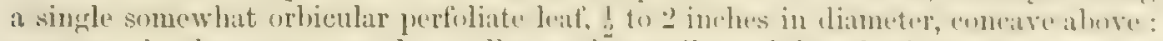
raternes simple or compound, usually nearly sescile and lensely thwered, the shert podicels often sucund: pretals a line or two lons: capsule ahout 3-seenled. - Lint. Mag. t. 1336. C. Cubensis, Bonpl. Pl. Equin. t. 26.

Var. parviflora, Torr. Lialiral leatres all lineare or linearespattulate: the canline perfoliate. - Pacif. R. Rep. iv. 71. C. parviftora, Dougl.; Hook. Fl. i. 225, t. 73.

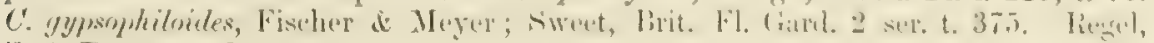
Sert. Petrop. t. 34.

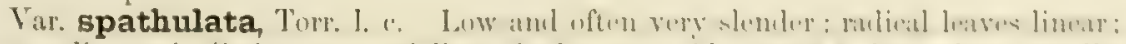

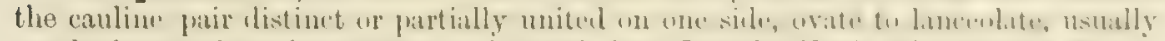

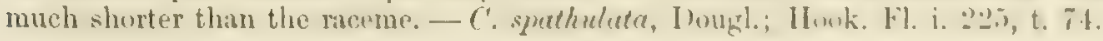


Var. exigua, Torr. 1. c. Low ; radical leaves narrowly linear or filiform ; the cauline distinct, linear, usually exceeding the short raceme.-C. exigua \& tenuifolia, Torr. \& Gray, Fl. i. 200.

Abundant on the western coast, ranging from Alaska to S. California, and in the interior through Nevada to the Wahsateh and Southern Utah. It is also found in Cuba and Mexico and is naturalized in Europe. The larger forms from shadier or damper localities have usually white or pale rose-colored flowers ; in drier and more exposed situations they are often deepercolored. The succulent leaves are in popular use as a potherb.

2. C. Sibirica, Linn. Stems 6 to 15 inches high: radical leaves lanceolate to rhombic-ovate or nearly orbienlar, an inch or two long, long-petioled; the cauline pair ovate (varying from lanceolate to spatulate-obovate), sessile, distinct, $\frac{1}{2}$ to 2 inches long: raceme very loose, the flowers on long pedicels : petals 2 to 4 lines long, white or rose-colored. - Sims, Bot. Mag. t. 2243. C. alsinoides, Sims, Bot. Mag. t. 1309. C. Unalaschkensis, Fischer. C. asarifolia, Bongard.

In cool woods and swamps, from Bolinas Bay and Sierra Co. to Alaska. The pedicels are often an inch long or more.

$$
++ \text { Stems usually branching, leafy. }
$$

$$
+ \text { Leaves opposite. }
$$

3. C. Chamissonis, Esch. Stems weak and slender, erect or decumbent, a foot high or often much less, stoloniferous and rooting at the joints: leaves oblanceolate or spatulate, $\frac{1}{2}$ to $1 \frac{1}{2}$ inches long: racemes few-flowered, the flowers very variable in size, on slender pedicels; petals 1 to 4 lines long, white. - Spreng. Syst. i. 790. C. stolonifera, C. A. Meyer, Mem. Soe. Mose. vii. 139, t. 3. C. aquatica, Nutt., \& C. flaellardis, Bongard, Torr. \& Gray, Fl. i. 201.

In wet places in the mountains, from Yosenite Valley to Alaska, and eastward to Colorado. The stolons are frequently bulbiferous.

$$
+++ \text { Leaves alternate. }
$$

4. C. parvifolia, Moçino. Stems filiform or slender, branching from the base, 4 to 10 inches high, erect or ascending: lower leaves clustered, broadly oblanceolate or spatulate, an inch long or less; cauline leaves usually much smaller: racemes loose, few-flowered: petals 2 to 4 lines long, rose-colored.-DC. Prodr. iii. 361 ; Torr. \& Gray, 1. c. C. filicaulis, Dougl.; Hook. Fl. i. 222, t. 72.

In shaded moist places among rocks, about Yosemite Valley (Bolander, Gray), Donner Lake (Greene), and northward to Vancouver Island. The most slender of all our species and sometimes exceedingly succulent.

5. C. linearis, Dougl. Stems usually 3 to 6 inches high, more branching: leaves narrowly linear, 1 to 2 inches long, clasping at base : racemes often secund: sepals very broad, firm and conspicuous, often colored, 1 to $2 \frac{1}{2}$ lines long : petals a little longer, white: seeds sharply margined. - Hook. Fl. i. 222, t. 71. C. dichotoma, Nutt. in Torr. \& Gray, Fl. i. 202, a reduced form.

In cool moist localities, from Napa (Biyelow) and Sierra counties (Lemmon) northward to the British boundary; Falls of the Yellowstone, Hayden.

6. C. diffusa, Nutt. 1. c. Stem diffusely and dichotomously branched, 6 inches high, leafy: leaves all ovate or deltoid, petioled, acute, $\frac{1}{2}$ to 1 inch long: racemes numerous, terminal and axillary: pedicels slender : petals 2 lines long or less, little exceeding the sepals, pale rose-color.

Pine woods, Oregon (Nuttall); also Kellogg \& Harford, but locality uncertain.

$$
\text { * Perennials, with deep-seated tubers. }
$$

7. C. Caroliniana, Michx., var. sessilifolia, Torr. Radical leaf narrow ; cauline 2, opposite, sessile, lanceolate to linear, 1 or 2 inches long: raceme nearly sessile, few-flowered and eymose, with a single scarious bract at base : sepals ovate, 
acutish : petals 2 to 4 lines long, pale rose-color. - Pacif. R. Rep. iv. 70. C. lanceolata, Pursh, Fl. 175, chiefly; Gray, in Am. Jour. Sei. xxxiii. 406. C. Caroliniana, var. lanceolata, Watson, Bot. King Exp. 42.

Subalpine and alpine in the Sierra Nevada (Cisco, Kellogg), northward to the British boundary, and east to Colorado. The typical form of the Atlantic States has leaves with slender petioles.

8. C. triphylla, Watson. A similar species, slender, the cauline leaves 3 in a whorl, or rarely 2, narrowly linear: raceme compound, pedunculate; the pedicels each with a small scarious bract: sepals rounded, obtuse : petals 2 lines long. Proc. Am. Acad. x. 345.

In the Sierra Nevada: Yosemite Valley (Gray); above Cisco (Watson, Lellogg); Sierra Co., Lemmon, and probably frequent.

9. C. umbellata, Watson. Very low and fleshy : cauline leaves two, opposite, orbicular or rhomboidal to oblong-ovate, 4 to 9 lines long, on slender petioles: flowers 3 to 5 in a sessile umbel shorter than the leaves : petals 3 to $t$ lines long, a little exceeding the rounded obtuse sepals. - Bot. King Exp. 43, t. 6.

On MIt. Davidson and in Truckee Pass, Nevada (Watson); near Steamboat Springs, W. Nevada, Mann. Probably in northeastern California.

$$
\text { * * * Perennial, with a thickened caudex. }
$$

10. C. Nevadensis, Watson. Apparently propagating by runners, the leaves and scapes clustered at the summit of a rather slender rootstock: leares orbicular or obovate, an inch or less in diameter, abruptly attenuate into a very slender petiole : scapes about equalling the leaves, with a pair of sessile oblong-ovate leaflets, 4 to 8 lines lons : Howers umbellately fascicled or in 2 or 3 very short racemes: sepals ovate-oblong, acute: petals broally spatulate, 4 lines long, with narrow claws.

Northern Sierra Nevada, Lemmon. Nearest C. sarmentosa, Meyer, of Alaska, a more slender species, with long racemes, rounded sepals, and petals broad at base. C. arctica, of Alaska, \&c., and C. megarrhize of the liocky Mountains have decidedly fusiform roots.

\section{MONTIA, Linn.}

Sepals 2, ovate, persistent, herbaceous. Petals 5, united at base, 3 somewhat smaller. Stamens 3, rarely more, on the tube of the corolla. Orary free, 3-oruled: style 3-cleft, very short. Capsule 3-valved, 3-seeded. Seels black, dull, tuberculate, rarely smoothish and shining. - A small branching glibrous succulent anmual ; with opposite leaves, and small axillary or mocmose flowers. A single speeites.

1. M. fontana, Linn. Stems procumbent or ascenling, 1 to 3 inches long: leaves spratulate to linear-oblanceolate, 3 to 9 lines long: fluwers a line long or less: capsule globose. - Torr. \& Giny, F1. i. 202. 1 . fontene is hemprosperme, Cham. in Linnæea, vi. $565, t .7$.

Wet places near san Francisco, and in the foot-lills of the Sierra Nevala, and northwarl to Behring straits ; fireenland. Common in Luroge, s. Anerica, de. Lsually readily distinguished from Claytonia by the opaque seed.

\section{SPRAGUEA, Torr.}

Sipgals 2, orbicular-cordate, scarions-hyoline, persistent. I'etals 4. Stamens 3. Ovary $8-10$-ovuled : style long, bifil at the apex. ('apsule 2-valves], membramaceous. Seeds black and shining. - I glabrous bennial herls; with mustly rulical fleshy leaves, and ephemeral fluwers in dense scorjivid spikes mubellate-elustered on a scape-like peduncle.

1. S. umbellata, Torr. Stems several from a thiekenell met, simple, erent or ascending, "2 to 12 inches high: rudical leaves spatulate or ublanceciatle, on thick 
petioles, $\frac{1}{2}$ to 4 inches long; the cauline similar but smaller, frequently scariously stipulate, often reduced to a few bracts; an involucre of broader scarious bracts subtending the dense capitate umbel of nearly sessile spikes: flowers light rosecolor; sepals very conspicuous, 2 to 4 lines in diameter, about equalling the oblongobovate petals: stamens and style somewhat exserted. - Pl. Frem. in Smith. Contrib. vi. 4, t. 1 ; Hook. Bot. Mag. t. 5143.

In the Sierra Nevada at 3,000 to 10,000 feet altitnde, from the Yosemite Valley northward to the British boundary; E. Humboldt Mountains, Nevada (Watson); N. W. Wyoming, Parry: usually in dry rocky or sandy localities.

S. Paniculata, Kellogg, Proc. Calif. Acad. ii. 187, t. 56. Stems paniculately branched : " growing in a dense ball or cluster prostrate upon the ground and seldom 3 inches in height; at length melting into an exeretory mucilaginous watery mass. Found in a ravine abont six miles west of Virginia City, Nevada, Dorr." "Known only from Dr. Kellogg's description and figure; probably an unusual form of the last.

\section{CALYPTRIDIUM, Nutt.}

Sepals 2, unequal, broadly ovate or orbicular, scarious, at least on the margins. Petals 2, somewhat coherent at the apex. Stamen 1, opposite the lower sepal, included. Style very short, bifid. Capsule 2-valved, 6-12-seeded, membranaceous. Seeds black, shining. — Smooth prostrate diffusely branched annuals; with alternate succulent leaves, and small ephemeral flowers in axillary or terminal, clustered or compound scorpioid spikes. Only the following species.

1. C. monandrum, Nutt. Stems 2 or 3 inches long: leaves spatulate to nearly linear, an inch long or more: sepals and petals a line long or less, the latter at length borne calyptra-like upon the summit of the elongated linear capsule. Torr. \& Gray, Fl. i. 198.

San Diego (Nuttall) ; Colorado Desert (Newberry) ; Fort Tejon (Horn); Santa Clara Valley, Peckham.

2. C. roseum, Watson. A similar but rather larger flowered species: the larger sepal $1 \frac{1}{2}$ to 3 lines broad; the petals much smaller, free or scarcely coherent: capsule oblong-ovate, shorter than the calyx. - Bot. King Exp. 44, t. 6 .

Lake Co. (Torrey) ; Sierra Valley (Lemmon); and eastward in the valleys of Nevada (Watson) to W. Wyoming on the Little Sandy River, Parry.

\section{LEWISIA, Pursh.}

Sepals 4 to 8 , broadly ovate, unequal, persistent, strongly imbricated. Petals 8 to 16 , large and showy. Stamens numerous. Style 3-8-parted nearly to the base. Capsule dehiscing transversely at the base, there somewhat 4-8-valved, manyseeded. Seeds black, shining. - Low acaulescent fleshy perennials, cespitose, with thick fusiform roots, and short 1-flowered scapes; flowers showy, opening for several days. The following are the only species.

1. I. rediviva, Pursh. Leaves densely clustered, linear-oblong and subterete, 1 or 2 inches long, smooth and glaucous: scapes but little exceeding the leaves, jointed at the middle, and with 5 to 7 subulate scarious bracts verticillate at the joint: sepals 6 to 8 , with broad scarious margins, 6 to 9 lines long : petals usually 12 to 15 , rose-colored or sometimes white, oblong, 8 to 16 lines long: stamens 40 or more: capsule broadly ovate, 3 lines long. - Torr. \& Gray, Fl. i. 677 ; Hook. \& Arn. Bot. Beechey, 344, t. 86; Hook. f. Bot. Mag. t. 5395. L. alba, Kellogg, Proc. Calif. Acad. ii. 115, fig. 36.

Summit of Mt. Diablo (Brewer), northward to British Columbia and east to Montana, Utah and Arizona. The thick farinaceous root is largely collected by the Indians for food. It is exceedingly tenacious of life, and several instances are on record of its restored vigor and growth 
after one and two years drying in the herbarium and even a preliminary immersion in boiling water. The specific name was given with reference to this fact.

2. L. brachycarpa, Engelm. Leaves spatulate or nearly linear: seapes not jointed, 2-bracted at the very base, shorter than the leaves: sepals 4 , mostly herbaceous, 3 lines long: petals 7 to 9 , oblong, 2 or 3 times longer than the calyx: stamens 10 to 15 : capsule shorter than the calyx. - Proc. Am. Acad. vii. 400.

In granite sand, eastern side of the Sierra Nevada, Fresno Co., at 8,000 feet altitude (Muir); Arizona (Nevberry, Palmur) ; S. Ltah, H. Engclmann, Purry. Much resembling the acaulestent Calandrinias in habit.

\section{ORDER XVII. TAMARISCINE五.}

A small Old World order of trees and shrubs, mainly represented by the Tamarisks (Tamarix), and distinguished from all related orders with free ovary and separate styles by its comose or long-hairy anatropons seeds. To it has lately been referred, by Bentham \& Hooker, Gen. Pl. i. 161, the following anomnlous (chiefly Mexican) genus.

\section{FOUQUIERA, HBK. CANDLEWOOD.}

Sepals 5, free. Petals united into a tube; the 5 lobes of the limb imbricated, spreading. Stamens 10 to 15 , hypogynous, exserted; filaments thickened at base. Ovary imperfectly 3-celled; placentre about 6-ovuled: styles 3, long, somewhat united. Seeds 3 to 6 , oblong, flattened, surrounderl by a dense fringe of long white hairs or by a membranous wing. - Shrubs or small trees, with soft frayile wood, smooth; the branches alternately spinose-tubercled, and with single or fascicled thick entire leaves in the axils; flowers brilliant crimson, in terminal spikes or panicles.

A Mexican genus of three species, only one of which passes northward into the United States. Its charucters are anomalous, and it has been placed by different authorities in the orders Polemoniacex, Frankeniacen, Portulacacen, and Crassulacex, and taken for a distinet order Fouquieracee.

1. F. splendens, Engelm. Tranching nent the base and senling up simple slender stems 10 to 20 (or more) feet hich, with ashen-gray bark and latre pith, leafy only near the summit, strongly grooved amd rideerl hy the derurrent hases of the spines: leaves spatulate to obovate, $\frac{1}{2}$ to an inch long, the primary attenuate into

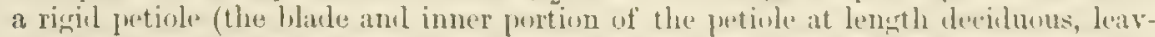
ing the clorsal part as a stout divaricate spine an inch loner or less, the spine often developing without the blate); axillary leaves seswile: Howers on short pedieds in

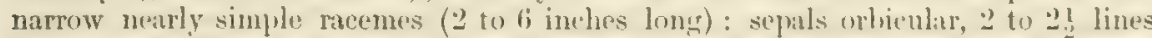

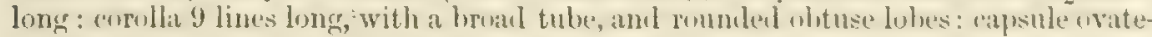
oblong, hatf an inch long: seeds white-tomentose, 3 lines long, surroumded by a dense white villuus fringe, - Wisliz. Rep. It; Gray, Pl. Wright, ii. 63. F' spmose, Torr. in Emory Rep. 147, t. 8.

In the desert region of S. E. California, along the Colorado River (Nerberm, Antiscll, Blake), and eastward to W. Texas and Northern Nexico: a very ornanental shrub when in flower.

F. sprxosa, HBK., of Lower Califomin and Northern Mexico, rises with a trunk 3 to 4 feet

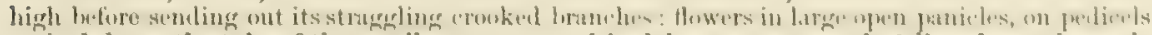
an inch long, the tube of the corolla narrower and its lobes acuto: capsule 9 lines long, tho seeds naked and surrounded by a broad membranous veined wing. The Idrin columnaris of Kellogg, Proc. Calif. Acad. ii. 34, also from Lower California, is a very similar species, but is deserihed as without spines, with a shorter corolla, and a short included style : fruit unknown.

F. Fonmoss, HBK, a Mexican species, and reported from Lower Cnliforniß, has the larger flowers (an inch long) sessile in very short spikes, and the spines very short. 


\section{ORder XVIII. ELATINACE画。}

Low annuals, with membranous stipules between the opposite dotless leaves, regular and completely symmetrical flowers, with free sepals, hypogynous petals and stamens, and distinct styles bearing capitate stigmas, all of the same number ( 2 to 5 ), or the stamens rarely twice as many; the ovary $2-5$-celled, axile placenta many-ovuled, capsular fruit mostly septicidal or septifragal, and anatropous seeds with a crustaceous coat, filled by the embryo. Seeds straight or somewhat curved, and the embryo taking the form of the seed. - Comprises only the two following genera. Flowers axillary.

1. Elatine. Small prostrate aquatics. Parts of the flower each 2 to 4 . Sepals obtuse.

2. Bergia Erect. Parts of the flower in fives. Sepals acute.

\section{ELATINE, Linn.}

Parts of the flower in twos, threes, or fours. Sepals membranaceous, obtuse, nerveless. Ovary globose. Capsule membranaceous, the partitions remaining attached to the axis or evanescent. - Small prostrate glabrous annuals, growing in water or wet places, with entire leaves and oblong usually solitary flowers.

A genus of half a dozen species, belonging to temperate or subtropical regions, all round the world.

1. E. Americana, Arnott. Stems an inch or two long, tufted : leaves obovate to linear, 1 to 4 lines long: flowers sessile, their parts in twos or rarely in threes: capsule half a line or more in diameter, with 5 or 6 oblong seeds in each cell, rising from the base. - Gray, Gen. Ill. i. 220, t. 95.

Near Washoe Lake (Torrey); Oregon (Hall); in the Rocky Mountains, and frequent in the Atlantic States. Also in Australia and the Fiji Islands.

\section{BERGIA, Linn.}

Parts of the flower in fives. Sepals with a strong midrib or herbaceous in the middle, acute. Ovary ovoid. Capsule somewhat crustaceous, more or less of the partitions in dehiscence remaining with the axis. - Branching and often pubescent, nearly erect, with entire or serrate leaves, and larger fascicled or solitary flowers.

About 14 species in warm or tropical regions, the following the only species found in the United States.

1. B. Texana, Seubert. Annual, glandular-pubescent, branching from the base, a span high, the lower branches somewhat decumbent: leaves oblanceolate, acute, serrulate, $\frac{1}{2}$ to $1 \frac{1}{2}$ inches long, attenuate to a short petiole: flowers fascicled, shortly pedicelled: sepals carinate, nearly $1_{2}^{1}$ lines long, exceeding the petals and stamens: capsule globose: seeds smooth and shining. - Watson, Bot. King Exp. 45. Merimea (?) Texana, Hook. Ic. Pl. t. 278. Elatine Texana, Torr. \& Gray, Fl. i. 678; Gray, Gen. Ill. i. 218, t. 96 . Bergella Texana, Schnitz. Icon. t. 219, fig. 1,2 , and 26 .

Sandy river-bank near Sacramento (Greene); Carson River bottom, Nevada (Watson) : identical with the plant common in Texas.

\section{ORDER XIX. HYPERICACEA.}

Herbs or shrubs, with opposite entire leaves punctate with translucent or darkcolored glandular dots (containing balsamic-resinous secretion), no stipules, and per- 
fect flowers with the 4 or 5 petals and numerous stamens hypogynous, the fruit in septicidal many-seeded capsule. - Calyx of $t$ or 5 persistent sepals, imbricated in the bud. Petals as many, almost always oblique and convolute in the bud, deciduous or withering, usually glandular-punctate. Filaments mostly in 3 sets or bundles. Styles 2 to 5, usually distinct or becoming so: stigmas terminal, generally capitate. Ovary and capsule with 2 to 5 parietal placentix, or 2-5-celled by their union in the axis. Seeds anatropous, with a somewhat crustaceous coat, filled by the straight cylindraceous embryo.

- A rather small but willely dispersed order, of which the following is the largest genus and the only one occurring in California.

\section{HY PERICUM, Linn. ST. JoHN'S-WORT.}

Sepals and petals 5. Stamens numerous, usually connate at base into 3 to 8 clusters. Ovary 1-celled, with 3 to 5 more or less prominent parietal placentre, rarely $3-5$-celled by the union of the placentre with the axis. Capsule septicidal (in our species tricarpellary), many-seeded. Seeds mostly straight and cylindrical. -Our species (like most of the genus) are smooth herbaceous perennials, with sessile entire punctate leaves, and yellow cymose flowers.

A genus of about 160 species, widely dispersed, but chiefly through the northern temperate zone. Of the 30 North American species all but the following are confined to the Atlantic and Gulf States.

1. H. Scouleri, Houk. Stems erect, from a running rootstock, $\frac{1}{2}$ to 2 feet hish, terete, simple ur sparingly branched : leaves ovate to ublong, clasping, usually obtuse, an inch long or less: Howers rather few, in an open erme, black-punctate : sepals ovato, olstuse or acute, 2 lines loner: petals 3 to 5 lines lones: stimens in 3 fitseicles, very numerous (60 or more) : styles elunsated : capsule 3-celled.-Fl. i. 111; Turr. \& Gray, Fl. i. 160.

By streams in the mountains, from S. California and eastward (San Diego, Cleveland; Sonora,

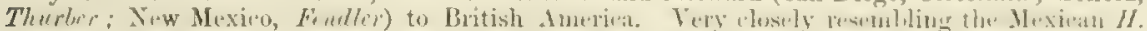
furmosim, HBK., Nov. Gen. ₹. 196, t. 460 , which is perhaps distinguished by its longer narrow acuminate sepals and fewer $(30$ to 40$)$ stamens.

2. H. concinnum, linth. Sitems ascending from a sumewht womly lifumhing

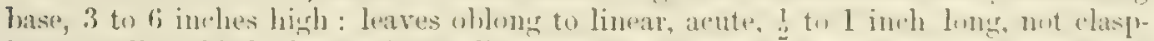

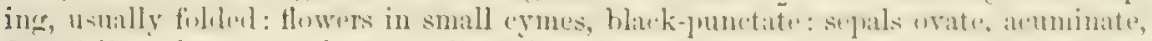

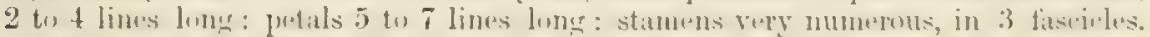

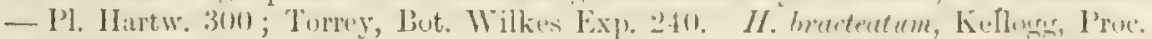
Calif. Acad. i. 65.

Central Californin, probably in dry places in the foot-hills of the Sierra Nevada; mather rarely collected: "Sacramento Valley" (Üartuceg); Marysville and Placer Co. (Pralten, Kéllogg) ; Mit. Plumas, Pickering; \&c.

3. H. anagalloides, cham. \& Sichleeht. Stems mumerous, weak anl slemiler,

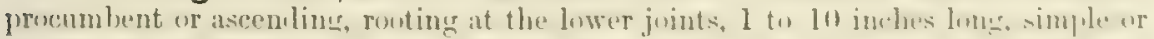

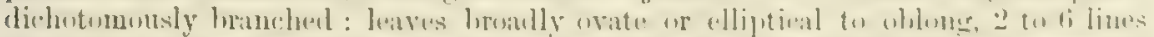

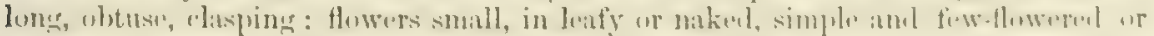

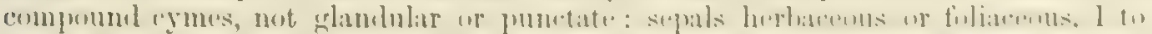

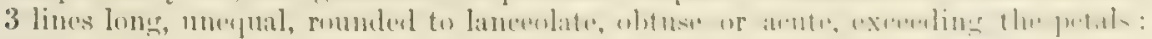
stamens 15 to 20 , distinct: styles short: capsule 1-celled. - Linnar, iii. 127; Torr. \& Gray, Fl, i. 167 and 674.

From San Francisco to the British boundnry; Lassen's Peak and Sicra Co., Lemmon. A small species in moist places, somotimes covering large tracts. 


\section{ORDER XX. MALVACE画。}

Herbs or shrubs, with mucilaginous juice, a tough fibrous inner bark, alternate leaves with stipules, and often a stellate pubescence; distinguished from all related orders by the valvate calyx, convolute petals, their bases or short claws united with each other and with the base of a column of numerous monadelphous stamens, these with reniform one-celled anthers. - Flowers almost always perfect, regular. Calyx 5-cleft or parted, persistent, in many genera augmented by an apparent accessory calyx, i. e. a whorl of bractlets, forming an involucel. Petals 5, hypogynous, nsually withering or deliquescent without falling off. Pistil usually either a ring of ovaries around a projection of the receptacle, from which they fall away singly at maturity, or a 3-10-celled ovary becoming a capsule in fruit: styles united at least at base into one. Ovules single, several, or numerous in the carpels or cells, amphitropous от nearly anatropous. Seeds commonly roundish or reniform, with little or no albumen, and a curved embryo; its cotyledons broad and foliaceous, variously crumpled or doubled up, mostly involving the radicle. Leaves most commonly palmately ribbed. Peduncles axillary. Flowers in many large and showy.

A rather large order, found in all parts of the world excepting the arctic regions, well represented in North America and in its western or central districts, but not conspicuous in Califormia. The demuleent properties are turned to account only in the mucilage of the root of Marsh Mallow (Althad officinalis); but many are cultivated for ornament, and one, the Cotton-plant, for the wool which invests its seeds.

TRIBE I. MALVE⿸广s. The column of stamens bearing anthers at the summit. Carpels closely united into a ring around the axis and separating from it more or less at maturity.

* Styles stigmatic on the inner side : carpels indehiscent: ovules solitary, ascending.

1. Lavatera. Bractlets 3 to 6 , united at base. Axis of the fruit dilated above and exceeding the few carpels.

2. Malva. Bractlets 3, distinct. Axis broad, shorter than the numerous carpels.

3. Sidalcea Bractlets none, Filaments in a double series, those of the outer series united in 5 clusters. Carpels fewer, covering the axis.

* * Stigmas capitate : carpels mostly dehiscent at least at the apez.

4. Malvastrum. Bractlets 1 to 3. Ovule solitary, ascending.

5. Spheralcea. Bractlets 1 to 3. Ovules 2, the lower ascending, the upper pendulous.

6. Sida. Bractlets 1 or 2 , or usually none. Ovules solitary, pendulous or horizontal.

7. Abutilon. Bractlets none. Ovules 3 or more in each cell.

TRIBE II. HIBISCE无. Column of stamens naked at the summit and 5-toothed. Carpels united into a few-celled capsule, dehiscing loculicidally.

8. Hibiscus. Involucel of several distinct bractlets. Capsule mostly 5-celled, many-seeded.

Gossyputm HERBACEUM, Linn., the cultivated Cotton-plant, also belongs to this tribe, - the genus characterized by its three ample cordate usually incised bracts, a truncate or shortly 5-cleft calyx, a 3-5-celled capsule, and long-woolly seeds. In Lower California and on Cerros Island there has been found a native species, G. DAvidsoniI, Kellogg (Proc. Calif. Acad. v. 82), shrubby, with small and usually entire cordate leaves, the flowers also comparatively small, an inch long, yellow with purple base.

\section{LAVATERA, Liñ. Tree Mallow.}

Involucel 3-6-cleft. Stamineal column divided above into numerous filaments. Styles filiform, stigmatic on the inner side. Fruit depressed; the several carpels separating from the prominent more or less dilated axis, indehiscent, 1-seeded; seed ascending. - Leaves angled or lobed; flowers axillary or in terminal racemes; our species stout and shrubby. 
An old World genus of about 20 species, sonte common in eultiration in gardens, and the following indigenous upon the coast of California.

1. I. assurgentiflora, Kellogg. Shrubhy, 6 to 15 fect hish, with slender

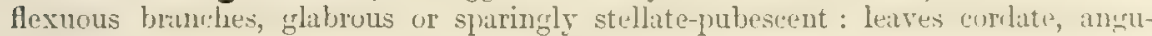
larly 5-7-lobed, 3 to 6 inches broad, on long petioles, the lobes acute, coarsely toothed or lobed: flowers 1 to 4 in the axils, on slender deflexed and eurved pedicels: involucel persistent, 3 lines long, ball the length of the campanulate densely

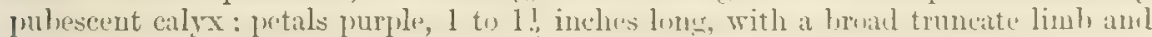
long narrow glabrous claws, having a pair of dense hairy tufts at base: stamineal column glabrous: styles exserted: fruit half an inch broad, the 6 to 8 carpels not beaked, somewhat appressed-hairy, 2 lines w more in dianeter, about exualling the low-conical sumnit of the axis. - Proc. Calif. Acad. i. 11 \& 14.

Said to be native of the island of Anacapa and now frequently cultivated in the soutlem counties of the State. It is nearly allied to $L$. acerifolice \& phonicea of the Canary Islands.

L. occiventalis, Watson, Proc. Am. Acad. xi. 12t, of Guadalupe Island, Palmer, is a similar species : flowers on short deflexed pedicels, with large and foliaceous bractlets and calyx-lobes, the calyx hecoming 1 f inches long : petals 2 inches long, spatulate, emarginate, purplish, with a dark spot in the centre, the claws glabrous at base: fruit half an inch broad or more, pubescent.

\section{MaLVA, Linn. Mazlow.}

Involucel 3-leaved. Petals obcordate. Axis of the fruit broad but not projecting. Otherwise as Lavatera. - Natives of the Old World, but several of the species now naturalized almost everywhere.

1. M. borealis, Wallman. Anunal, erect or somewhat lecumhent, hairy it nearly glabrous: leaves round-cordate, crenate, more or less strongly 5-7-lobed: peduncles axillary; solitary or clustered, 1 to 3 lines long: calyx-lobes acute, becoming very broad and enlarged in fruit: petals 2 or 3 lines long: carpels transversely reticulate-rugose.

From Europe, a common weed on the western corst from Puget Sound to Mexico; it has also been collected in New Mexico. It is readily distinguished form the biennial snecies $M$, rotundifolia, which takes its place in the Atlantic States and may appear in Califomia, by its short peduncles, smaller flowers, and rugose carpels.

\section{SIDALCEA, Gray.}

Involucel none. Stamineal column double; the filaments of the outer series

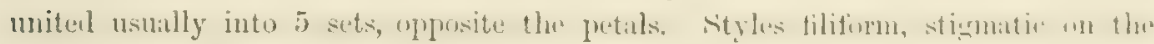

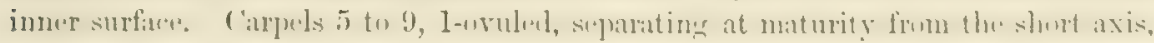

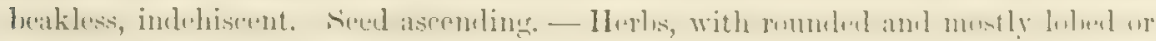
parted leaves; the usually purple flowers in a nartow terminal raceme or spike.

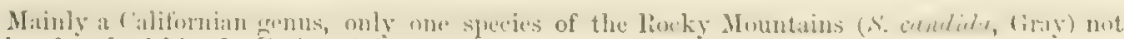
being found within the linuits of the Strte.

\section{* Perennial.}

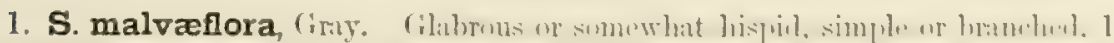

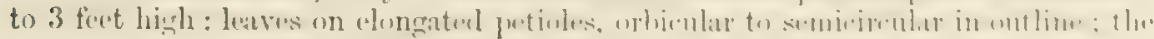
lower more or less deeply toothed or eleft, the upper more narrowly and deeply 5 -9-lobed or parted; the segments sparingly toothed or divided, often linear and entire: flowers in naked often elongated racemes; bractlets small, laneenlate; perticuls short, naked: calyx ofton tomentose, the lobes acute or acuminate: pretals emarginato: carpels 7 to 8 , smooth and glabrous, - Pl. Wright. i. 16 ; Watsou, Bot. King Exp. 46. Sida malvathora, DC.; Lindl. Bot. Reg. t. 1036. Callirrhe spicata, Reegel, Gart. Fl. 1872, 291, t. 737. 
In meadows, more widely diffused than any other species, ranging from Oregon to Northern Mexico, and eastward to Colorado. It varies much in the size of all its parts; calyx 1 to 3 lines long; the petals from half an inch to an inch long, or sometimes but little exceeding the calyx. $S$. Oregance is a stout and branching northern form.

2. S. humilis, Gray. Much resembling the last, but usually lower and often decumbent at base, with smaller leaves, and somewhat more hairy : Howers fewer and more generally scattered in the racemes: calyx larger, 3 to 6 lines long, with acuminate lobes: carpels reticulated and somewhat pubescent. - Pl. Fendl. 20. Sida delphinifolia \& Californica, Nutt. in Torr. \& Gray, Fl. i. 233 and 235.

Throughout California in meadows and on hillsides.

$$
\text { * * Annuals. }
$$

3. S. Hartwegi, Gray. Slender, 1 or 2 feet high, more or less hispidly pubescent, especially the pedicels and calyx: leaves orbicular, the lowest deeply cleft, the upper digitately 5-9-parted; segments linear, entire, acute, usually exceeding the petioles: bractlets linear, persistent: flowers nearly sessile, in a short terminal spike: calyx 3 to 6 lines long, the lobes acuminate: petals $\frac{1}{2}$ to 1 inch long, broad and emarginate: carpels strongly reticulated, shortly crested, hispid above on the inner side.-Pl. Fendl. 20 ; Benth. Pl. Hartw. 300. S. delphinifolia, Gray, 1. c. 19, \& Gen. Ill. ii. 58, t. 120, fig. 10-12. S. hirsuta, Gray, Pl. Wright. 1. 16 ; the larger and more hairy form.

In the valleys of the Sacramento basin. The species was founded on a reduced few-flowered sparingly hispid state.

4. S. diploscypha, Gray. Pubescent with long spreading hairs, 1 or 2 feet high: leaves deeply 5 -9-cleft with lobed segments, the uppermost often digitately parted; stipules parted: bractlets conspicnous, 5-7-parted, hispid: flowers nearly sessile in close $3-5$-flowered clusters : calyx-lobes acuminate : petals $\frac{1}{2}$ to 1 inch long, broad and emarginate: filaments of the outer stamens united into 5 broad membranaceous overlapping lobes, usually enclosing the inner anthers: carpels glabrous much depressed, transversely rugose, longitudinally sulcate above. - Pl. Fendl. 19.

Common in grass-fields and by roadsides through Central California.

5. S. malachroides, Gray. Stout, hirsute, 3 to 6 feet high, tufted: leaves cordate, 2 to 5 inches broad, $3-7$-angled with acutely toothed lobes: bractlets subulate, caducous: flowers small, white or purplish, nearly sessile in close terminal heads on the short leafy branches: calyx-lobes acute: petals narrowly obcordate-: sets of stamens indistinct: carpels smooth and glabrous, with a narrow more or less distinct ridge down the back. - Proc. Am. Acad. vii. 332. Malva malachroides, Hook. \&. Arn. Bot. Beechey, 326. S. vitifolia, Gray, 1. c., is a less hispid form.

From Mendocino County to Santa Cruz.

\section{MALVASTRUM, Gray.}

Bractlets 1 to 3 , or none. Stamineal tube simple, antheriferous at the summit. Styles filiform : stigmas capitate. Carpels 5 or more, 1-ovuled, separating from the axis, often dehiscent, sometimes 2-valved. Seed ascending. - Herbaceous tufted perennials, or shrubby; the flowers in narrow naked or leafy subpaniculate racemes. Distinguished from Sphoralcea only by the solitary ovules.

Species about 60, North and South American and S. African.

* Perennials.

1. M. Munroanum, Gray. Branching from the base, 1 or 2 feet high, grayish or hoary-pubescent: leaves broadly ovate, usually cordate at base, 3-5-lobed or deeply cleft, crenately or acutely toothed, 1 or 2 inches long, equalling or exceeding 
the slender petiole: raceme often dense: calyx-lubes acute or acuminate, 2 to 4 lines long: petals scarlet, 6 to 9 lines long: carpels oblong, 2 lines long, rounded or shortly beaked above, reticulated on the silles near the base, pubescent un the hack. - Pl. Fendl. 21 ; Watson, Bot. King Exp. 47. Malva Munroana, Dougl.; Lindl. Bot. Reg. xvi, t. 1306 ; Bot. Mag. t. 3537.

From Washington Tenitory to Nevada and Utah; found eastward of the Sierra Nevada.

2. M. Thurberi, Gray. Shrubhy at base, 3 to 5 fuet high, with wand-like branches, densely tomentose : leaves thick and subrugose, shortly petioled, the upper nearly sessile, rounded, cordate or truncate at base, sumewhat $3-5$-lobed, crenate, 1 to 1.1 inches long : flowers small, nearly sessile in an interrupted naked spike, or the inflorescence more expanded and racemose: calyx-lobes short, acute: fruit broarly oborate, the carpels 1.1 lines long, rounded or subtruncate abore, beconing glabrous, not reticulated. - PI. Thurb. 307. Malva fasciculata, Nutt. 1. c. 225.

In the Coast Ranges of Southern California; at Pacheco's Pass (Bolander), Santa Barbara (Nultall), San Diego (Parmy), and in Sonora (Thurber). No. 554 Brewer, from the Santa Lucia Mountains above the Nacimiento, is probably the same, but with the flowers fewer and less crowded, and the leaves rounded-rhomboidal and very tomentose; described as very fragrant.

3. M. splendidum, Kellogg. $\Lambda$ shruh 10 to 12 feet high or more, the hranches and leaves gray-tomentuse : leaves shortly jetioled, cordate-ovate, 5-lobed, the lobes acute and erenate: flowers nearly sessile in terminal branching panicled racemes, the spreading peduncles 1 to 2 inches lonic: calyx-lobes sbort, acute: carpels oblong, 1.1 lines long, rounled at each end, with a short mucronate beak abuve, becoming glabrous, reticulated on the sides below. - Proc. Calif. Acad. i. 65.

Imperfectly described by Dr. Kellogg fron a small specimen colleeted in the neighthorhood of Los Angeles and said to have been taken from a tree 15 to 20 feet high and a foot in circumference. The above deseription is based upon specimens found by Prof. Brewer in the Sierra, Santa Monica, which accord sufficiently well with the original account. Differing from the last mainly in the form of the leaves and in the open inflorescence.

4. M. marrubioides, Durand \& Hilgarl. Densely pubestent, two feet high leaves thick and shortly petioled, ovate, subcritate, ohscurely 3 -lohed, acutely serrate: flowers nearly sessile, in paniculate clusters of 3 to 5 in a somewhat naked raceme: caly x-lubes longacuminate, little shorter than the rose-colored pretals: earpels rounded or oblong, glabrous, not reticulated. - Pacif. R. Rep. v. 6, t. 2.

Collected only near Millerton on the San Joaquin, Hecrmann.

5. M. Coulteri, Wiatson. Branches slender, somewhat puhesent: leares an

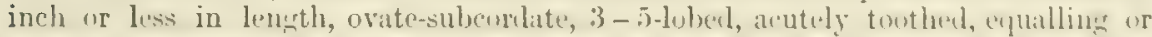
excecling the slemler petioles: Howers small, in a mother locise raeeme : ealyx-lubes acuminate: petals 4 or 5 lines long, rose-color' : carpels mumlenl, less than a line in diameter, with a thin horizontal uhner projection inwarel at hase, very strungly reticulated, pubescent on the under surface. - Proc. Am. Acad. xi. 125.

Collected by Coulter (n. 96) probably in Southenstern California, and by Scholl in the Giln botton on the Mexican Boundary Survey. Well distinguished by its peculiar carpels.

$$
\text { * * Annuals. }
$$

6. M. rotundifolium, (iray. lather stont and spars] le hispid with spreating

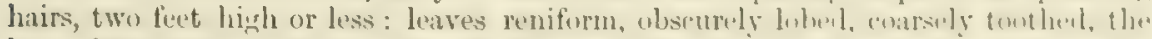

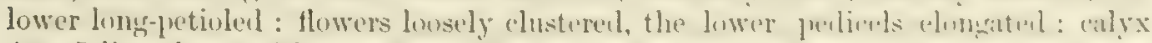

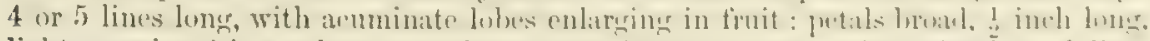

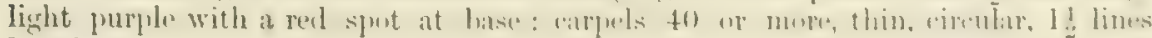
broad, glabrous, reticulated; the axis dilated. - Proc. Am. Acad. vii. 333.

On and-hills near Fort Mohave (Comer), and enstward in Arizona.

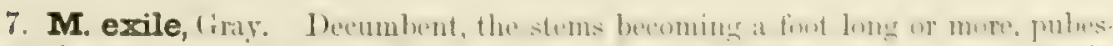

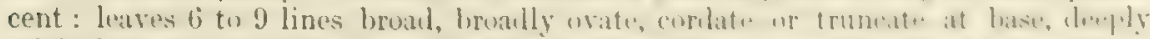
5-Inher, sparingly toothed, enualling the pet inles: How mo moty sulitary and axillary. 
on slender elongated pedicels: calyx-lobes lanceolate, acuminate, the linear bractlets persistent: petals obovate, purple, 2 to 5 lines long: fruit $2 \frac{1}{2}$ lines broad; carpels 12 to 15, orbicular, glabrous, indehiscent, transversely rugose-reticulated, the sides smooth and contiguous except near the margin. - Bot. Ives Colorado Exp. 8.

Dry plains, Merced County, and southward, ranging east to Utah; near Pyramid Lake, Nevada (Lemmon), and probably along the entire eastern base of the Sierra Nevada.

\section{SPH开RALCEA, St. Hilaire.}

Differing from Malvastrum only in the 2-ovuled cells of the ovary, the lower ovule ascending, the upper pendulous and often abortive in fruit. - Perennials.

About 20 species are referred to the genus, all American and S. African.

1. S. Emoryi, Torr. Resembling Malvastrum Munroanum. Stems 1 to 2 feet high: leaves ovate-cordate, usually obtusely $3-5$-lobed, crenate: inflorescence and fruit as in that species, excepting the 2-ovuled cells of the ovary. - S. Emoryi \& incana, Torrey in Gray, Pl. Fendl. 23. S. Wrightii, Gray, Pl. Wright. ii. 21.

Frequent on the eastern side of the Sierra Nevada from Northern Nevada to Utah and Mexico; San Felipe in S. California (Thurber) and San Diego, Cleveland.

S. sulphurea, Watson, Proc. Am. Acad. xi. 125, of Guadalupe Island, Palmer, is more tomentose and has the inflorescence usually much more paniculate and diffuse : petals sulphuryellow, tinged with pink, villous at the base of the claw, 5 to 6 lines long: fruit globose.

2. S. Lindheimeri, Gray. Stout, densely tomentose, 2 or 3 feet high, erect or decumbent at base: leaves broadly ovate, cordate at base, obscurely 5 -lobed with the lobes rounded and slightly crenate, 2 inches long, equalling or exceeding the petioles : flowers small, in a narrow raceme, often nearly sessile: calyx with acuminate lobes, usually very densely tomentose : fruit prominent; carpels $1 \frac{1}{2}$ lines long, rounded above, projecting nore over the axis than in the last, the sides transversely rugose below. - Pl. Lindh. 162. Malvastrum Fremontii, Torrey, 1. c. 21.

Central California (Fremont); Corral Hollow, Brewer: the specimens are apparently identical with the species of the Rio Grande Valley to which they are here referred.

3. S. angustifolia, Spach. Slender, erect, 2 to 4 feet high, hoary-pubescent : leaves oblong to narrowly lanceolate, 2 inches long, usually subcordate or rounded at base, often somewhat lobed below, crenate or rather coarsely toothed, on short petioles : flowers small, in a naked or often leafy narrow raceme: calyx 2 to 3 lines long, with acute or acuminate lobes: fruit subglobose with a central depression, pubescent; carpels $1 \frac{1}{2}$ to 2 lines long, oblong, blunt or sometimes sharply beaked at the apex, reticulate on the sides below. - Malva angustifolia, Cav. Diss. i. 64, t. 20; Bot. Mag. t. 2839.

At Fort Mohave (Cooper), and frequent eastward to the Rio Grande and in Mexico.

\section{SIDA, Linn.}

Calyx usually without bractlets. Stamineal tube simple, antheriferous at the summit. Petals oblique. Styles 5 or more, with capitate stigmas. Carpels as many, 1-ovuled, indehiscent or 2-valved, at length separating from the axis. Seed pendulous or horizontal. - Mostly softly tomentose ; flowers yellow or whitish.

About 80 species, of which 50 are American, most abundant in subtropical regions. A few species are very widely distributed, among which $S$. rhombifolia and $S$. carpinifolia approach the southern borders of the State, and other species are frequent in Northern Mexico and the adjacent texritory. The one Californian species, having a bracteolate calyx, would belong to Malvastrum but for the pendulous ovule.

1. S. hederacea, Torr. Stems decumbent, from a perennial root, leafy, a foot long or less: leaves reniform, about an inch broad, very oblique, serrate or crenate, shortly petioled: flowers in short axillary panicles or solitary, the pedicels at length 
deflexed: calyx with one or two setaceous bractlets at base, the lobes acuminate : petals yellowish, pubescent externitly, 1 to 6 lines long : fruit short-conical, smunth, glabrous; carpels 6 to 10, triangular, $1 \frac{1}{2}$ lines long, blunt above, attached by the straight ventral edge to the slender axis. - Gray, PI. Fendl. 23. Malva hederacea, Dougl. in Hook. Fl. i. 107. M. plicata, Nutt.; Torr. \& Gray, Fl. i. 227. Sida (?) obliqua, Nutt. 1. c. 233.

From Oregon to Arizona and Now Mexico; dry valleys and hillsides.

\section{ABUTILON, Tourn.}

Bractlets none. Sceds or ovules 3 to 9 in each cell. Otherwise as Sida.-Herbs or shrubs, usually soft-tomentose; flowers mostly axillary, often yellow.

Species about 70, in the warmer region of both hemispheres; a dozen or more on the southern borders of the United States, the following scarcely entering within the limits of California.

1. A. crispum, I)un. Very finely tomentuse: brinches very slentex, elongated: leaves cordate, acutish or acuminate, crenate, 1 to 3 inches long; the upper small and nearly sessile: Howers solitary, small, yellow, c,u slender axillary peedicels as long as the leaves and jointed near the top : carpels about 12, membranaceous, inHated, rounded above, 2-valved to the base, 4-5-seeded, at length half an inch long. - Gray, Gen. 1ll. ii. 67, t. 126. Sida crispa, Linn.; Torr. \& Gray, Fl. i. 235 .

Widely distributed through the tropies, and found from Florida westward aeross the continent; Cañon Tantillas, below San Diego, Palmer.

2. A. Newberryi, Watson. Sumewhat wooly at base, 4 to 5 feet high, densely tomentose: branches short and stout: leaves thick, oblong-lanceolate, cordate at base, acutish, 1 to 2 inches long, on short petioles: pedicels fascicled in the axils, much shorter than the leaves: flowers deep yellow, 3 lines long: carpels about 8 , nearly membranaceous, rounded hut narrower abuve, 2-valved to the hase, 3-seeded, three lines long.-Proc. Am. Acad. xi. 125. Splearalcea incana, Gray, Bot. Ives Colorado Exp. 8.

In the same locality (Palmer); also on the Lower Gila (Emory), and at Canebrake Cañon on the Lower Colorado, Ncwberry.

A. Palmeri, Gray, Proc. Am. Acnd. viii. 289, a taller larger-flowered and larger-lented species, of Arizona and Sonora, may reach California. The calyx is densely villous, nearly half an inch long; the deep-yellow corolla somewhat longer; carpels also hairy, acuminate above and equalling the calyx, 3 -4-seeded; leaves cordate with a deep closed sinus.

\section{HIBISCUS, Linn.}

Involucel of numerous hractlets. Stamineal culumn antheriferous much of its length, but nakerl at the summit aml truncate or 5-tentherl. Sityles uniterl: stigmas

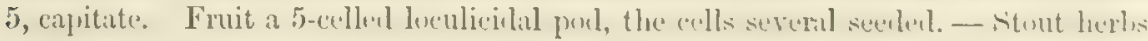
or often shrubby, with large and showy axillary and solitary flowers.

$\Lambda$ large genus of about $\mathbf{1 5 0}$ species, distributed around the morld, mainly in tropical or sub-

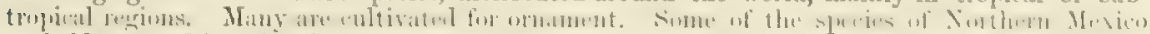
probably extend into Southenstern Californin, though only a singlo ono has yet been collected.

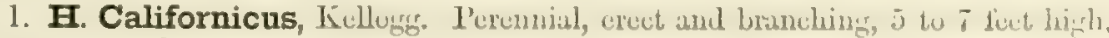
the younger leaves and branches velvety pubescent: leaves cordate, acuminate,

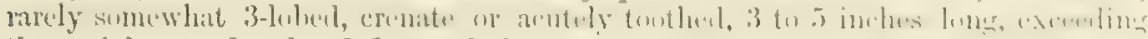
the petioles: peduncles 1 -flowered, 2 or 3 inches long, jointed above tho milllle, united with the petiole at base: calyx 9 to 12 lines long, cleft to the millle, the lobes acute; flowers whito, with a purple centre, 2 to 3 inches long: capsule equal. ling tho calyx, acute, velvety-pubescent: seeds nearly globose, over a line brout, striate and roughened with small scattered tubercles. - Proc. Calif. Acad. iv. 292. 
On an island in San Joaquin River at Webb's Landing. This is probably also the $H$. moscheutos, var. occidentalis, of Torrey in Bot. Wilkes Exp. 256.

2. H. denudatus, Benth. Erect, woody at base, very tomentose, two feet high, the stems slender and flexuous: leaves broadly ovate or nearly orbicular, an inch broad or less, rounded or obtuse and dentate above, on short petioles: peduncles $\frac{1}{4}$ to 1 inch long: bractlets narrowly linear, very short or sometimes nearly obsolete: calyx cleft nearly to the base, the lobes lanceolate: petals light purple, an inch long: capsule acute, dehiscent to the base, shorter than the calyx : seeds reniform, densely silky. - Bot. Sulph. 7, t. 3.

In the desert region of Southeastern California, thence to New Mexico and Northern Mexico. This species belongs to the section Bombicella, which is distingrished by the small involucre and silky seeds.

\section{ORDER XXI. STERCULIACE开.}

A polymorphous order chiefly of shrubs and trees, nearly all tropical or of the southern hemisphere, related to Malvacece and Tiliacece, distinguished from the former by the 2-celled anthers (the petals not rarely wanting), and in our solitary representative by the imbricated calyx.

\section{FREMONTIA, Torr.}

Bractlets 3 to 5, small. Calyx 5-cleft nearly to the base, the lobes imbricate in the bud, large and petaloid, bright yellow, pitted at the base, persistent. Petals none. Stamineal column 5-cleft to the middle, each of the divisions bearing above a linear adnate curved anther: staminodia none. Ovary 5-celled, many-ovuled: style elongated, the acute apex stigmatic. Capsule $4-5$-valved, loculicidally dehiscent; cells 2-3-seeded. Seeds ovate: embryo in thick fleshy albumen; cotyledons ovate, nearly flat, much longer than the radicle. - A stellately pubescent shrub; with alternate lobed leaves, and showy axillary solitary shortly pedicelled flowers.

1. F. Californica, Torr. Branching, 10 to 20 feet high, sometimes a foot through at base: wood hard: bark dark-colored: leaves thick, usually rusty beneath, broadly cordate or ovate, 3-lobed or rarely entire or 5-7-lobed, $\frac{1}{2}$ to $2 \frac{1}{2}$ inches long, the lobes obtuse, mucronulate; petioles shorter than the blade: flowers numerous, 1 to 3 inches in diameter: sepals obovate, often mucronate, pubescent externally and with a rounded hairy pit at base, the 3 inner a little larger: capsule ovate, an inch long, densely hairy, persistent; the cells villous within: seeds ovate, 2 lines long or more, pubescent. - Pl. Frem. in Smith. Contrib. vi. 6, t. 2 ; Hook. f. Bot. Mag. t. 5591. Cheiranthodendron Californicum, Baill. Hist. Pl. iv. 70.

On dry hills from Pit River to San Diego, most abundant in the foot-hills of the Sonthern Sierra Nevada. Very closely allied to Cheirostemon (or Cheiranthodendron) of Mexico and Guatamala, which differs in the more deeply pitted purple calyx, the oblique stamineal tube, and connective produced beyond the anthers. The stipules in Fremontia are small and caducous.

\section{Order XXII. LINACE无.}

A small family, recently enlarged by the incorporation of three wholly tropical tribes of shrubs and trees, all with simple and entire mostly alternate leaves; as to the proper Flax tribe well marked by the perfectly isomerous regular flowers; the sepals, petals, stamens and parts of the pistil being each 5, or in one instance 4, or sometimes the parts of the pistil fewer; the fugacious petals convolute and the 
persistent sepals imbricated in the bud, these and the stamens hypogynous; and only a pair of suspended anatropous ovules and seeds in each carpel. - Represented solely by the genus

\section{LINUM, Linn, FLAX.}

Parts of the flower 5, except sometimes in the pistil. Filaments monadelphous at the very base, and commonly with a little tooth in each sinus. Styles 5 , often united into one below, or in some of ours only 3 or eren 2, and distinct : stigmas capitate or oblong: ovary globose, of as many true cells or carpels as styles, but each cell more or less divided into two by a filse partition proceeding from the dorsal suture. Capsule splitting in dehiscence through these false partitions, and sometimes through the true ones also. Seeds solitary in each half-cell, flattened, ovate, the coat mucilaginous when wetted: embryo large and straicht, surrounded by a thin coating of albumen; the cotyledons flat and broad. - Herbs; with tough fibres in the bark (flax), sessile entire leaves, no stipules or mere glands in their place, and cymose or panicled flowers.

A genus of 80 or more species, mostly of temperate or warm climates, nearly 20 indigenous to the I'nited states, chiefly to the region west of the Mississippi. The Californian species (with two exceptions) are slender annuals, remarkable for having only two or three pistils, and forming a peculiar section.

L. Usitatissrmum, Linn., the common Flax of cultivation, may sometimes be found near fields. It is an annual, with linear-lanceolate very acute leaves, blue flowers, 1-nerved sepals, and a globose acuminate capsule.

$\$ 1$. Styles of the same number as the other parts of the flouter: perennials: leaves alternate.

1. I. perenne, Linn. Smooth and glancous, 1 to 21 fect high, branching above, leaty: leaves linear to linear-lanceolate, 3 to 18 lines lung, acute; stipular glands none: flowers large, blue, in few-flowered corymbs or seattered on the leaty branches, on slender peticels : sepals $3-5$-nerved, ovate, acute or obtuse, $1 \frac{1}{2}$ to 21 lines long: capsule glohose, acute, exceeding the sepals, at length lehiscent by ten valves, the prominent false partition long-ciliate: fruiting pedicels erect or deflexed. - L. decurrens, Kellogg, Proc. Calif. Acad. iii. 44, fig. 11.

Common on dry soils nearly throughout the state, the species ranging from the Aretie Circle, along the Rouky Mountains and westwarl, to Northern Mexico. It is also common in Europe and Northern Asia.

2. L. aristatum, Engrelm. Smooth, if to 3 foet high; branches numerous, slender, angular: leuves few, linear to subulate, awned, og to thes long: the uplyer and the brats, as well as the sepals, riliate-denticulate on the scatrins marius; stipular glands conspicuous: Howers mostly solitary on the branchlets, suluhuryellow, an inch broal: sepals linear-lincestite, acuninate, 3-nervenl, 4 lines long: capsule ovate, acute, half as long, 5-valverd and lo-celled, the false partitions membranaceous: seeds small. - Wisliz. Rep. 17.

Sandy hills along the Colorado (Newbermy); eastward to New Mexico and S. Utah. The only other Forth American yellow-llowered peremial is $L$. Kingii, Witsun, of the momitains of Utah.

\$2. Styles and curpels funer thun the other purts of the nonury, 2 nr 3: cupsutes 4-celled or 6-celled: sepals 1-nerved: annuals - Hesperousos, Giny.

* Leaves opposite, oblong: styles 2 : petals not appendaged at lase, yellow.

3. L. digynum, (ilay. (ilabrous, six inches high, simple, sulwy masty ham hed at the summit: leaves oblong, acutish, 3 to 6 lines long: stipular frlinds none: 
pedicels very short: sepals lanceolate, acuminate, ciliate-denticulate, a line long: petals twice longer: capsule globose, obtuse, shorter than the calyx. - Proc. Am. Acad. vii. 334.

Near Yosemite Valley on the Mariposa Trail, Bolander. A rare and very peculiar species.

* * Leaves alternate, narrowly linear (a half to an inch long): styles 3: petals appendaged at base with a tooth on each side and usually a third adnate to the inner face of the claw.

\section{+ Flowers yellow: pedicels short.}

4. I. Breweri, Gray. Smooth, glaucous, slender, 3 to 8 inches high or more, few-flowered at the summit: leaves linear-setaceous, 6 to 8 lines long; stipular glands conspicuous: sepals ovate, acute, somewhat glandular on the margin, $1 \frac{1}{2}$ lines long: petals more than twice as long, 3-appendaged at base: fruit unknown. Proc. Calif. Acad. i. 202, and Proc. Am. Acad. vi. 521.

Dry hillsides, Contra Costa Co., at Marsh's Ranch, east of Monte Diablo, Brewer. Flowering in May and June.

+ + Flowers white, rose-colored, or purple: pedicels short and mostly cymoseclustered.

5. I. congestum, Gray. Nearly smooth, excepting the calyx, a foot high, shortly branched above: stipular glands very small : flowers in close terminal clusters: sepals pubescent, lanceolate, acuminate, $1 \frac{1}{2}$ limes long, not glandular : petals twice as long, apparently rose or purple, 3-appendaged at base : capsule globose, shorter than the calyx. - Proc. Am. Acad. vi. 521.

Marin Co., Bolander. A well-marked species on account of its clustered flowers and pubescent calyx.

6. I. Californicum, Benth. Glabrous and glaucous, paniculately branched above, 6 to 18 inches high : stipular glands conspicuous: flowers in small eymes or the lower solitary: sepals ovate-lanceolate, $1 \frac{1}{2}$ lines long, acute, slightly glandulartoothed: petals 4 lines long, rose-colored becoming white, 3-appendaged at base: capsule acute, shorter than the calyx. - Pl. Hartw. 299 ; Gray, 1. c.

Dry soils in the valleys and on low foot-hills, in early spring, from about San Francisco Bay to Marysville (Bifelow) and southward to San Carlos; especially common on the eastern slope of the Monte Diablo Range.

+++ Flowers white, rose-colored, or purple: pedicels more elongated and mostly solitary: stems diffusely paniculate above.

7. I. spergulinum, Gray. Glabrous, 6 to 15 inches high: leaves without stipular glands: pedicels 3 to 6 lines long: sepals ovate-oblong, acute, slightly glandular, a line long: petals 2 to 3 lines long, rose-colored or white, 3-appendaged: capsule obtuse, rather exceeding the calyx. - Proc. Am. Acad. vii. 333.

Coast Ranges, \&c., Marin and Sonoma counties, Bolander, Kellogg, Miss Monks.

8. I. micranthum, Gray, 1. c. Somewhat puberulent, 6 to 15 inches high: stipular glands minute or none: pedicels 2 to 4 lines long: sepals lanceolate, acute, a line long, slightly slanlular : petals white, a little longer than the sepals, 2-toothed at base : capsule obtuse, exceeding the calyx.

In the Sierra Nevada, at 3,000 to 5,000 feet altitude: Mount Bullion (Botander) ; Sierra and Plumas counties, Lemmon, Mrs. Pulsifer Ames.

9. I. adenophyllum, Gray. Somewhat pubescent, a font high : leaves more broadly linear, margined with stipitate glands; stipular glands minute or none: pedicels 1 to 6 lines long: sepals lanceolate, acute, a line long or more, glandularserrulate, half as long as the white (yellowish ?) petals : capsule rather shorter than the calyx. - Proc. Am. Acad. viii. 624.

Near Clear Lake, Bolander, Kellogg \& Harford. 


\section{ORDER XXIII. ZYGOPHYLLACE无.}

Distinguished from the allied orlers by the opposite compound leaves, with interposed stipules and entire dutless leaflets. - Flurrers perfect, regular ur nearl 5 so, completely symmetrieal, the parts in fives or rarely in fuurs. Sepals distinet or nearly so. Petals hypogynous, in ours imbricated in the hud. Stamens as many or more commonly (in all ours) twice as many as the petals and inscrted with them, in two sets: filaments distinct, often appendaged with a scale on the inner side. Orary of 4 or 5 earpels (rarely 2 or 3), but sometimes twice as wany cells, and terminial style only one : stigrma 5 -10-lubed. Ovules anatropunts, peneluluns. Fruit alry. Seets with a large embryo, straight or nearly so, with llat or brond cotylekluns, with ur without some alhumen. - Herbs, shrubs, or (in Guaiecum) small trees, witl redy hard and acrid-bitter resinous wood; a few with simple leaves: stipules often spinescent: flowers solitary, on lateral or terminal naked peduncles.

An order of 17 genera and barely a hundred species, of tropical and warm-temperate countries, on this continent chiefly Mexiean and South American, four representatives, belonging to three genera, barely reaching California.

1. Tribulus. Leaves abruptly pinnate, 6-10-foliolate. Fruit tuberculate. Herbs.

2. Fagonia. Leaves 3-foliolate. Fruit nearly smooth. Herbaceous.

3. Larrea Leares 2-foliolate. Fruit densely hairy. A heavy-scented shrub.

\section{TRIBULNUS, Linn.}

Sepals 5, mostly persistent. Petals 5, fugacious. Disk annular, 10-lobed. Stamens 10 ; the alternate filaments a little shorter amd with a fland at bise on the outer side. Ovary 5-12-celled; cells $1=5$-ovuled. Fruit lobed, separating from the persistent axis into 5 to 12 indehiscent 1 -seeded tuberculate or winged or spinose earpels. Seeds without allumen. - Lonsely branched hairy frustrate herhs; with abruptly finnate (ppposite leaves (the alternate ones smaller or wanting), and solitary apparently axillary white or yellow flowers.

Species 15 or more, natives of the warmer regions of both hemispheres. Our species aro annuals, belonging to the section Kallstromia, having the outer stamens adnato at base to the petals, the ovary $10-12$-celled and 10 -12-oruled. A true Tribulus, with 5 carpels ( $T$. Califorzices, Watson, Proc. Am. Acad. xi. 125), from the western side of the Gulf of Culifornin, has very small flowers and deeply 5-lobed fruit, the carnels with 4 or 5 stout tubereles on the back,

1. T. maximus, Iinn. Nitems at length elengated: leaflets 3 ur 4 pairs, ovate-

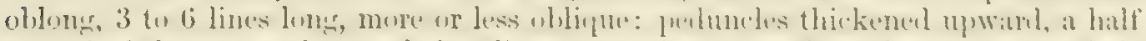
to an imolo long: sopals very hatry, linear, aneminate, two lines long : pudals a half

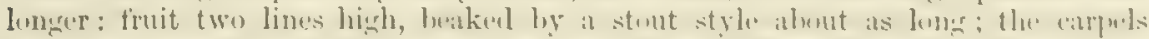

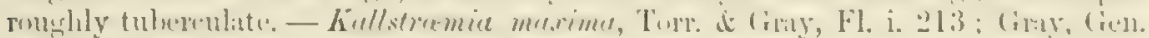
Ill. ii. 117, t. 146 .

"Southern Californin" Purm. Common in the dry region eastward to Texas, and through Mexico and the W. Indics. The specific name is in no respect nppropriato.

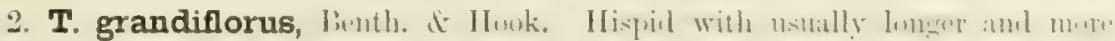
spreading hairs: leaflets 4 to 6 pairs: peduncles mono elongated: sepals 3 to 6

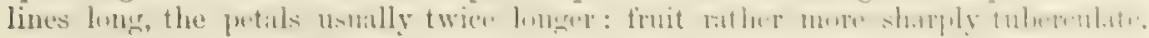
the beak 3 to 5 lines long, - Gen. P1. i. 26t. Lallstrumia grandiftora, Tort. in Gray, Pl. Wright. i. 28.

In the Gila Valley, Arizona, and probably in Southenstern Califurnia; ranging to Now Mexico, Sonore and Lower Califurnia. 


\section{FAGONIA, Linn.}

Sepals 5, deciduous. Petals 5, unguiculate. Stamens 10, on an obscure disk; the filaments naked. Ovary 5-celled; cells 2-ovuled near the base. Fruit deeply 5 -angled, 5-seeded; the smooth carpels at length separating from the axis and dehiscing on the inner edge. Seeds with a horny albumen. - Branching diffuse or prostrate herbs; with opposite 1-3-foliolate leaves, mucronate leaflets, spinescent stipules, and apparently axillary solitary rose-colored flowers.

A genus of hot and desert regions in both hemispheres, but chiefly of the Old World. The 26 published species are considered by Bentham and Hooker as reducible to perhaps 2 or 3 , in some respects very variable.

1. F. Californica, Benth. Perennial, herbaceous, glabrous: the stems a span long or more, diffusely branched, angled: leaflets lanceolate, 1 to 3 lines long; stipules linear, recurved-spreading, short: peduncles nearly equalling the leaves: petals 2 or 3 lines long, twice longer than the lanceolate sepals: fruit ovate in outline, attenuate above into the slender style, 2 lines long. - Bot. Sulph. 10 ; Torr. in Pacif. R. Rep. v. 359, t. 1; Watson, Bot. King Exp. 418.

Desert of S. E. California (Thomas, Schott, Newberry), to Arizona and Lower California. The species much resembles $\boldsymbol{F}$. Chilensis.

\section{LARREA, Cav. Creosote-bUsh.}

Sepals 5, deciduous. Petals 5, unguiculate. Stamens 10, on a small 10-lobed disk; the filaments winged below with a bifid scale on the inner side. Ovary 5celled; the cells about 6 -ovuled. Fruit globose, shortly stipitate, densely hairy, the 5 indehiscent 1-seeded carpels at length separating from the axis. Seeds with horny albumen. - Evergreen heavy-scented shrubs; with nodose branches, opposite 2-foliolate leaves, small stipules, and solitary yellow flowers.

A genus of 3 or 4 species, of Mexico and extra-tropical South America, the following species the only one in the United States.

1. I. Mexicana, Moricand. Diffusely branched, 4 to 10 feet high, densely leafy, of a yellowish hue: leaves nearly sessile; the thick resinous leaflets inequilateral, oblong, 3 to 6 lines long, with a broad attachment to the rhachis, somewhat curved, acute: sepals ovate, obtuse, silky: petals bright yellow, 3 to 4 lines long: scales a little shorter than the filaments, somewhat lacerate: fruit $2 \frac{1}{2}$ lines in diameter, beaked by the slender style; carpels obtuse. - Pl. Nouv. Am. 71, t. 48 ; Torrey in Emory Rep. 137, t. 3 ; Gray, Gen. Ill. 2. 120, t. 147.

Abundant in the dry valleys of Kern Co. and eastward, from Walker's Pass and Tahichipi to W. Texas, and southward into Mexico, blooming in early summer. It is called by the Mexicans Gobernadoro and Hideondo. The leaves are sticky with a strongly scented gum or resin, and burn with a black smoke and rank odor. No animal of the country will eat it. It has various reputed medicinal properties, and miners say that a strong decoction "will clean amalgam." It is reported that the Indians make a glue from it, with which they fasten the heads of arrows to the shaft.

\section{Order XXIV. GERANIACE正.}

An order difficult to define by any certain marks, becoming composed of several suborders or tribes, diverse in habit and details of structure, which have to be separately characterized. - Leaves often with stipnles, either toothed, lobed, or compound. Flowers perfect, on axillary peduncles, either regular or irregular, but commonly symmetrical, and the parts in fires, rarely in threes. Stamens mostly in two sets, those alternate with the petals sometimes sterile: filaments often 
either dilated or monadelphous at the base. Ovary 3-5-lobed and 3-5-celled, with a central axis. Ovules anatropous. Seeds wholly or nearly filled by the embryo.

A rather large order, owing to the size of a few leading genera, widely distributed over the world, mostly in warm-temperate and subtropical elirnates; many with handsome flowers and cultivated for ornament. The representation in North America is small, in California meagre. The following irregular-flowered genera may claim admission.

ImPATIENS, Linn., represented in gardens by the Balsam, I. Baisamisa, and in the Eastern United States by the Jewel-weeds, I. FULVA and I. PALLIDA, which range northwestward to Washington Territory. The only indication of them near California is the mention of an undetermined species in Dr. C. L. Anderson's list of Nevada plants (in the Nevada State Geologist's Report for 1870 ?), no station assigned. The genus is familiarly known by its extremely irregular handsome flowers, the larger piece of which is a spurred sac, and by the capsule bursting elastically, breaking up at the touch into five twisting valves and a central axis; the stems succulent and translucent.

Tropeotum, Linn., the familiar Nasturtium of the gardens, of South American origin; one sepal consticuously spurred, and the leartes peltite. T. Brosus, the common species, is likely to become spontaneons in the sonthern part of the State.

Pelargonius, L'Her, to which belong the so-called Geraniums of garden and house cultivation, natives of the Cape of Cood Hope. Here, again, one sepal has a spur; but it adheres to the pedicel so as to escape cursory notice. P. Graveoless, the Rose Geranium, P. INoeinass, Scarlet Geranium, and P. zONALE, Horse-shoe Geranium, with their mixtures, are the speeies most disposed to escape into waste grounds near dwellings, in the southern portion of the State.

Tribe I. GERANIEE. Sepals imbricated in the bud, and petals generally so. Carpels 5 , 2-ovuled but one-seeded, separating elastically at maturity from the long-beaked and indurated central axis from below upward; the styles forming long tails which become revolute upwards or spirally twisted. Cotyledons convolute-plaited and incumbent on the radicle. - Herbs or shrubs, mostly with aromatic or strong-seented leares, furnished with stipules.

1. Geranium. Fertile stamens 10. Tails of the carpels not bearded. Flower regular.

2. Erodium. Fertile stamens 5. Tails of the carpels bearded inside. Flower regular.

Pelarconium has stamens about 7 , some of these without anthers, and flower irregular.

TrIBE II. LIMNANTHEE. Sepals valvate and petals convolute in the bud. Fleshy and indehiscent carpels distinct (except their common style) or soon becoming so, one-ovuled. Embryo straight : cotyledons fleshy and hemispherical, filling the seed, cordate at base, covering the short radicle. - Tender annuals; with alternate dissected leaves and no stipules. Juice with more or less Cruciferous pungeney.

3. Limnanthes. Sepals, petals, anel carpels 5. Stamens 10. (In Ft,crket all am in threes.)

TRIBE III. OXALIDEE. Sepals imbricated and petals mostly convolute in the bud. Car-

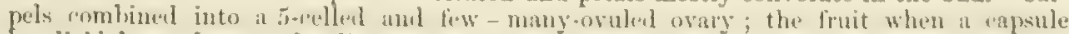
loculicidal : styles mostly distinct. Embryo straight in a thin albumen: cotyledons plane. - Flowers regular. Leaves mostly compound, with leaflets entire or notched at the end: stipules rare. Juice acid.

4. Oxalis. Sepals, petals, and styles 5. Stamens 10. Leaves in ours 3 -foliolate.

\section{GERANIUM, Linn. Cranesbils.}

Stamens 10 with anthers; a glimd hehind the base of each of the 5 shorter mes: filaments slender, in wur speries bearled at base. (Witry 5-luhed, 5-celled : style 5)-

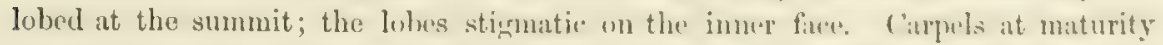

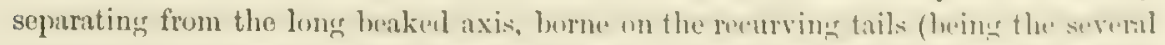
styles splitting away from the persistent heak), these heardless : the fruiting tarpels

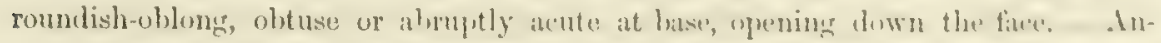

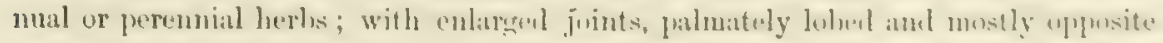
leaves, searious stipmles, and 1 -3-fluwered peduncles. Flowers violet or rusecolored or white. 
About 100 species are found distributed through the temperate regions of both hemispheres, of which only 7 or 8 are found in North America.

\section{* Annual or biennial: flowers small.}

1. G. Carolinianum, Linn. Decumbent or ascending, diffusely branched, pubescent: leaves 1 to $2 \frac{1}{2}$ inches in diameter, palmately 5-7-parted, the divisions cleft into oblong-linear lobes: pedicels short or frequently slender and more or less elongated : petals rose-colored, equalling the awned sepals, 2 or 3 lines long: carpels hairy, $1 \frac{1}{2}$ to $2 \frac{1}{2}$ lines long, the tails a half to an inch long.

From Los Angeles to British America and eastward across the continent; rather common in spring and early summer.

\section{* * Perenuial: flowers large: stems naked below, dichotomously branched above.}

2. G. Richardsonii, Fischer \& Meyer. Stems 1 or 2 feet high: pubeseence usually fine and apjressed, or somewhat glandular and spreading upon the pedicels: leaves 2 to 5 inches broad, 5-7-cleft nearly to the base; the rather broad lobes more or less incisely toothed: sepals 3 or 4 lines long, including the awn : petals purple or sometimes white : carpels and beak 12 to 15 lines long. $-G$. albiftorum, Hook. Fl. i. 116, t. 40, \& Bot. Mag. t. 3124 ; not of Ledebour.

Bloody Cañon by Mono Lake, Brewer. Abundant eastward in the watered cañons of Nevada and Utah, and in the Rocky Mountains from British America to New Mexico.

3. G. incisum, Nutt. Closely resembling the last, but more villous and glandular-pubescent; leaves rather more narrowly and laciniately eut: sepals 5 or 6 lines long: petals usually deep-purple: carpels with the beak $1 \frac{1}{2}$ inches long. $G$. albiflorum, var. (?) incisum, Torr. \& Gray, Fl. i. 206. G. erianthum, Lindl. Bot. Reg. xxviii, t. 52, excll. syn.

Yosemite Valley (Brewer) ; Sierra Co. (Lemmon); northward to the British boundary, Montana and the Saskatchewan. Intermediate forms between this species and the last appear to occur.

G. C. tral Arizona and may perhaps reach the borders of California. It is more slender and more diffusely branched, with smaller broadly lobed leaves, finely pubescent.

\section{ERODIUM, L'Her.}

Characters as in the last; but with the filaments dilated, the 5 opposite to the petals sterile and scale-like; carpels closed, obconical, attenuate to an acute horny bearded base; the tails long-bearded on the inner side and becoming spirally twisted. - Leaves commonly pinnate and bipinnately parted or lobed: peduncles terminal or lateral, umbellately 2 -several-flowered, with a 4 -bracted involucre at the base of the pedicels; petals small.

A genus of perhaps 50 species, mostly of the Old World, very widely dispersed. Ours are essentially annuals.

\section{* Leaves pinnate or pinnatifid, the divisions lobed or toothed. All introduced?}

1. E. cicutarium, L'Her. Hairy, much branched from the base: leaves pinnate, the leaflets laciniately pinnatifid with narrow acute lobes; stipules mostly small : peduncles exceeding the leaves, bearing a 4-8-flowered umbel : sepals 1 to 3 lines long, acute: petals bright rose-color, a little longer: tails of the carpels 1 or 2 inches long: pedicels slender, at length reflexed, the fruit still erect.

Very common throughout the State, extending to British Columbia, New Mexico, and Mexico; also widely distributed in South America and the Eastern Continent. It has been generally considered an introduced species, but it is more decidedly and widely at home throughout the interior than any other introduced plant, and according to much testimony it was as common throughout California early in the present century as now. It is popularly known as Alfifaria, 
or less commonly as Pin-cloner and Pin-grass, and is a valuable and nutritious forage-plant, reputed to impart an excellent flavor to milk and butter.

2. E. moschatum, L'Her. Leaves pinnate; the ohlong-orate leaflets unequally and doubly serrate; stipules couspicuous: pedicels mostly shorter and stouter: sepals larger, 3 or 4 lines long: odor musky.

Los Angeles (Antisell); Santa Iñez Valley (Brever), and northward, as well as southward in Mexico. Doubtless introduced from Europe.

3. E. Botrys, Bertuloui. Leaves oblong, pinmatifil; the lobes dentate, obtuse; stipules suall: sepals 4 lines long: beaks of the carpels 2 or 3 inches long.

Sacramento Valley, E. L. Greene. Introduced from Southern Europe.

* Leaves cordate and lobed. All native species.

4. E. macrophyllum, Hook. \& Arn. Pubescence with more or less of sprrailing oludula hitis especially above: leares renifom-ordate, 1 to 3 inches broat : stipules small: peduncles elongated: sepals broad, 5 to 6 lines long: carpels oblong, with the stout beak 1 i inches long. - But. Beecbey, 327; Torr. \& Limy, Fl. i. 679 .

Common in valleys and on the lower hills west of the Sierra Nevada, from San Diego northward to the Sacramento Valley. Next to $E$. cicutarium this is the most abundant species.

5. E. Texanum, firay. Puhescence appressed, not glawhlula : leaves ovatecoriate, smaller and nore deeply lobed, nsually ahout an inch long: peiluncles shorter: sepals narrower, 3 to 5 lines long: carpels narraw, with the slender beak $1 \frac{1}{2}$ to 3 inches long. - Pl. Lindh. 157 ; Gen. Ill. ii. 130, t. 151.

Colorado bottom (Newerry); sandy plains near Fort Mohave (Cuoper), and eastward to Texas.

\section{LIMNANTHES, R. Brom.}

Flowers recrular, the parts in fives: sepals valvate in the hud. Glands 5, alternating with the petals. Stumens 10. Style 5-cleft at the apex. Orary with sulitary aseending wrules. Carpels rlistinct, sulghlohose, at first fleshy, at length hawl and rugose, indehiscent, separating from the short axis. - Annual low dilfuse herhs, growing near watter ; leaves pinnate, without stipules; fluwers showy, white, yellowish, or rose-colored, solitary on axillary peeluneles. The following are the only species; possibly not distinct.

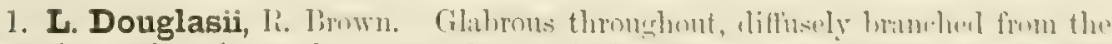

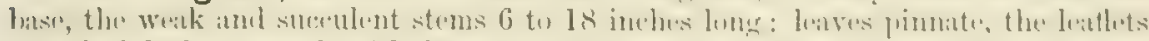

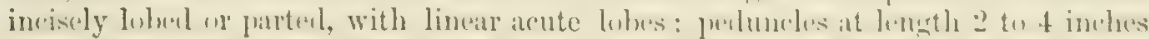

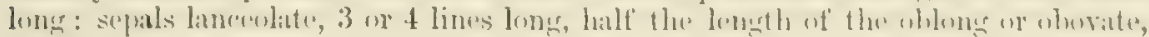
emarginate or truncate petals: style very slender, 3 or 4 lines long. - Lindl. Bot. Reg. xx, t. 1673 ; Hook. Bot. Mag. t. 3554. L. rosea, Hartw.; Benth. Pl. Hartw. 302. Floerkea Donglasii, Baill. Hist. Pl. v. 20, fig. 50-54.

Mendocino County to Los Angeles and the foot-hills of the Sierra Nerads. The stems anil

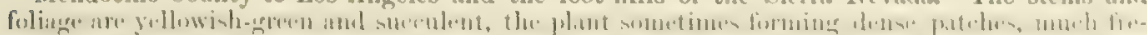
quented by bees. Flowers pale-yellow to nearly white, or tinged with rose-color. Carpels about 2 lines in diameter.

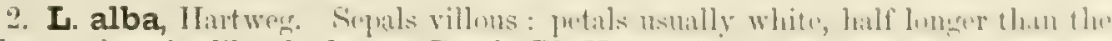
calyx: otherwiso like the last. - Benth. Pl. Hartw. 301.

Sacramento Valley and foot-hills of the Sierra Nevada; usually somewhat smaller than tho last, but porhaps only a form of it.

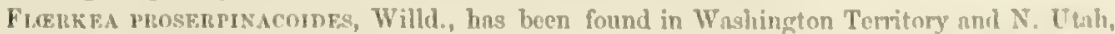
and may he looked for in Northern Californin. It is a slender nnumbl of moist lowlitios, with pinnate leaves and small flowers, tho genus distingnishet by having the parts of tho fluwer in threes. This is the only species, and is common in the Northern Atluntic states. 


\section{OXALIS, Linn. WOOD-SORREL.}

Flowers regular, the parts in fives: sepals imbricated. Stamens 10 ; the filaments somewhat dilated and united below. Glands none. Capsule columnar or ovoid, beaked with the short style, 5-celled, loculicidal; the valves remaining attached by the partitions to the axis. Seeds two to several in each cell, pendulous, the outer fleshy aril-like coat at length splitting and elastically recurved upon the rhaphe. Low, often acaulescent, with a sour watery juice; leaves alternate, mostly digitatetrifoliolate (leaflets obcordate), rarely stipulate; peduncles umbellately or cymosely few-many-flowered.

A genus of perhaps 200 species, chiefly natives of sub-tropical America and S. Africa, with a few in temperate regions. Of the 10 species of the United States only one is peculiar to the Pacific Coast.

1. O. Oregana, Nutt. Acaulescent, more or less rusty-villous ; rootstock creeping: leaflets broadly obcordate, 1 to $1 \frac{1}{2}$ inches broad; petioles 2 to 8 inches long: scapes equalling or exceeding the leaves, 2-bracted near the top, mostly 1-flowered: petals oblong-obovate, 9 to 12 lines long, white or rose-colored, often veined with purple: capsule linear, 9 lines long; cells about 6-seeded. - Torr. \& Gray, Fl. i. 211. O. Acetosella, Hook. Fl. i. 118, in part.

Shady woods near the coast, from Santa Cruz to Washington Territory. With the habit of O. Acetosella, of the Eastern States and the Old World, which however is a smaller plant, with smaller flowęrs, and an ovoid few-seeded capsule.

2. O. corniculata, Liun. Annual, or perennial by running rootstocks, usually more or less villous : stems slender, branching, erect or ascending, 3 inches to 3 feet high : leaflets usually deeply obcordate, very variable in size; petioles slender, with small villous stipules: peduncles with two or more flowers, elongated : petals yellow, 4 to 6 lines long: capsule erect in fruit, linear, half an inch to an inch long, manyseeded.

Dry places, Oregon to Mexico, most eommon south of Santa Barbara. The species is widely distributed round the world, everywhere very variable, and has received numerous names. The common species in the Atlantic States, without stipules (O. stricta, Linu.), is now generally considered a mere variety.

\section{ORdER XXV. RUTACE再。}

Pellucid or glandular-dotted aromatic leaves, along with definite hypogynous stamens and defiuite usually few seeds, distinguish this order; although some of the Orange-tribe have numerous stamens. - Flowers generally regular and symmetrical. Sepals and petals 4 or 5 , imbricated in the bud. Stamens as many or twice as many as the petals, distinct, inserted outside of a hypogynous disk. Seeds anatropous or amphitropous, with a little or no albumen. Leaves either simple or compound; stipules none.

A large order of trees, shrubs, or herbs; the latter not very numerous and mainly of the warmtemperate parts of the northern hemisphere and in the old World; the great bulk of the rest of the order South African and Australian, a moderate number American, the Orange tribe mainly Asiatic. The glands or dots in the foliage, \&c., contain aromatic volatile oil, which in Rue, Prickly Ash, and the like is very pungent or acrid. Oranges, lemons, citrons, limes, \&u., are the most important products. One of our genera, Cneoridium, peculiar to the State, is referred to the Simambacece, a related order not otherwise represented in California. But, baving dotted leaves, it may as well be kept here. The two other plants represent different tribes of the order.

1. Ptelea. Leaves 3-foliolate. Fruit orbicular, indehiscent, broadly winged. Stamens 4 or 5.

2. Thamnosma. Leaves simple, alternate. Fruit a 2-lobed coriaceous capsule. Stamens 8.

3. Cneoridium. Leaves simple, opposite. Fruit a fleshy globular drupe. Stamens 4 or 8. 


\section{PTELEA, Linn, Hop-TREE.}

Flowers polygamous. Sepals, petals, and stamens 4 or 5. Ovary with a short thick stipe, 2-celled; cells 2-oruled, the luwer ovule abortive: style short. Fruit a hroully widged orbicular samara, 2-celled and a-seeted ; the wing embraring is sh-nder stipe. Seeds oblong. Embryo straight, with ovate-oblong cotyledons. Shrubs or small trees; leaves mostly tritioliolate, with sessile leatlets; Howers small, greenish-white, in terminal cymes or compound corymbs.

A genus of half a dozen species, confined to the United States and Mexico.

1. P. angustifolia, Buth. A shruh 5) to 2.5 fivet hish, with chestnut-colored

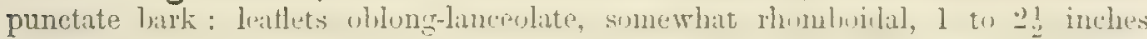

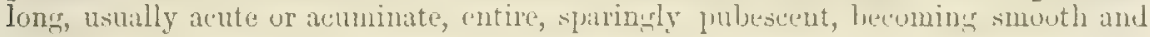
shining with age: flowers numerous, in compound corymbs, pubescent: sepals small: petals 2 or 3 lines long, spreading: fruit 6 to 8 lines broau, emarginate at base and often above; stipe narrow, 1 to 2 lines long. - Pl. Hartw. 9; Gray, Pl. Fendl. 28.

Frequent about Clear Lake and on Mt. Diablo, extending to Texas and Mexico. It differs from $P$. Irifoliata of the Atlantie States in its narrower and smaller leaves, larger flowers, more narrowly winged fruit emarginate at base, and shorter marrower stipe. Its odor is sometimes agreeable (like that of Lindera Benzoin), sometimes unpleasantly rank, most fragrant when the wood is broken or crushed.

\section{THAMNOSMA, TorT.}

Sepals 4. Petals 4, erect. Stamens 8, at the base of a cup-shaped crenate or lobed disk. Ovary stipitate, 2-lobed and 2-celled, with 5 or 6 orules in each cell: style clongater. Caysule dirlymous, corliceons, dehisent down the inner eists of each lobe. Seeds 4 to 6 in each cell, reniform. Embryo curved, terete. - Low

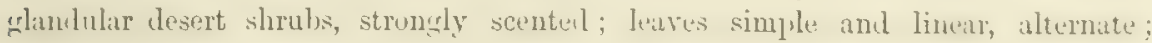
flowers purple or yellow, solitary. The following are the only species.

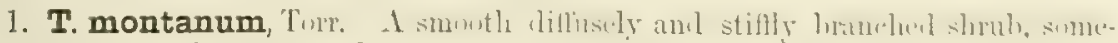
what spinose, a foot or two high, with yellowish-green bark: leaves scattered, 4 to 12 lines long, soon deciduous: peduncles axillary, I to 4 lines long, with several suall bracts: calyx short: petals 4 or 5 lines long, nearly closed, apparently purple: capsule yellow, of two subglobose nearly distinct cells, three lines long; stipe about a line long. - Frem. Rep. 313; Pacif. R. Rep. iv. 73, t. 3.

On the southern borlers of the State, from San Felipe to Fort Mohave, and eastward to S. Utah ; rather rare.

T. Texascis, Torr. (Rulosma Texanum, Gray, Gen. 11l. ii. 144, t. 155.) Woody only at base, the slender stems 3 to 15 inches high : flowers much smaller; on short naked pedicels, vellow tinged with purple: capsule very shortly stipitate, lobed nearly to the middle, rather sunuler. Frequent from Texas to Arizona and Sonora; perhaps reaching S. E. California.

\section{CNEORIDIUM, Hook. f.}

Seprals, petals, and stamens 4 , or stamens sometimes 8 , the alternate ones much shorter. Disk annular, obtusely 8-angled. Ovary globose, sessile, of a singlo carpol, 1-celled, 2-ovuled: style lateml, curved, short. Fruit "drupaccous," 1-2seeded. Seed globose, with fleshy albumen: enbryo curved. - A low smooth

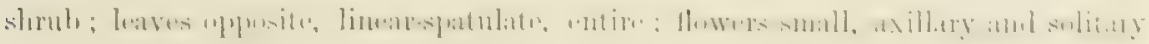
or somewhat corymbose, on short bracted peduncles. A single species.

1. C. dumosum, Honk, fo Heavy-scented, much-hmanched, 2 to 4 fect high, lenfy: leaves often fiscicled, $\frac{1}{2}$ to $1 \frac{1}{2}$ inches long, narrow: Howers white, 2 to 3 
lines in diameter, solitary or 2 to 4 together, exceeding the pedicels: petals twice longer than the ovate sepals: fruit 3 lines in diameter; the outer integument thin and crustaceous when dry : seed-coat dark brown, hard and thickened. - Benth. \& Hook. Gen. Pl, i. 312. Pitavia dumosa, Nutt. in Torr. \& Gray, Fl. i. 215; Torr. Bot. Mex. Bound. 43.

About San Diego and San Pascual ; flowering in February. Leaves pungent to the taste.

\section{ORDER XXVI. CELASTRACE出.}

Shrubs, with simple and undivided leaves, no stipules or hardly any, and small dull-colored or white chiefly perfect regular flowers, the stamens as many as the petals and inserted on the surface or margin of a broad perigynous disk, - distinguished from the following order (with which only comparison need be made) by the imbricated calyx and corolla, stamens alteruate with the petals, and the arillate seeds, these oftener two or more in each cell and sometimes pendulous.

A rather large order widely spread over the world, feebly represented in North America, especially on the western side of the continent.

1. Euonymus. Flowers rather conspicuous. Ovary 3-5-celled. Fruit colored, Seeds in a bright red aril. Deciduous shrubs.

2. Pachystima. Flowers very small. Ovary 2-celled. Fruit small, not colored. Evergreen undershrubs.

Celastrus obtusatus, Presl, Bot. Bemerk. 34, from Monterey, is doubtless Simmondsia Californica, Nutt.

\section{EUONYMUS, Tourn. SPINDLe-TREe. BURNing-BUSH.}

Sepals and petals 4 or 5, widely spreading. Stamens as many, very short, on a broad angled disk. Ovary immersed in the disk, 3-5-celled : style short or none. Capsule 3-5-lobed and 3-5-valved, loculicidal, coriaceous, colored, often warty. Seeds 1 to 4 in each cell, covered with a fleshy red aril. - Shrubs, with 4-angled branches, opposite petioled serrate glabrous leaves, and flowers in loose cymes ou axillary peduncles.

A genus of about 40 species, chiefly of Asia and Europe; two or three in the Atlantic States, and one in California.

1. E. occidentalis, Nutt. A shrub 7 to 15 feet high, with slender upright greenish branches: leaves ovate to oblong-lanceolate, acuminate, serrulate, 2 to 4 inches long, on short petioles: peduncles slender, 1-4-flowered: flowers dark brown, 4 to 6 lines in diameter, the parts in fives: fruit smooth, deeply lobed. Torr. Pacif. R. Rep. iv. 74. E. atropurpureus (?), Hook. Fl. i. 119.

From Tomales Bay (Bigelow) northward to the Columbia River, Resembling E. atropurpureus, Jacq., of the Atlantic States, which has more numerous and smaller 4-merous flowers.

\section{PACHYSTIMA, Raf.}

Calyx with a short obconical tube, and 4 rounded lobes. Petals 4. Stamens 4, short, inserted at the edge of the broad disk which lines the calyx-tube. Ovary free, 2-celled : style very short. Capsule small, oblong, coriaceous, 2-valved, 1-2seeded, at length loculicidally dehiscent. Seeds enclosed in a white many-cleft membranaceous aril. - Low evergreen shrubs; leaves smooth, opposite, very shortly petioled, serrulate; flowers small, green, in one - few-flowered axillary cymes.

A genus of two species, the second ( $P$. Canbyi, Gray) known from a single locality in the Alleghany Mountains, in Virginia. 
1. P. Myrsinites, Raf. Much branched, a foot or two high, leafy: leaves ovate to obluug or oblanceolate, 2 to 13 inches long, cuncate at base, serrite or serrulate, obtuse or acutish : flowers a line in diameter, on pedicels a line or two long: fruit 2 lines long, smooth. - Ilex (?) Myrsinites, Pursh. Myginda myrtifolia, Nutt. ; Hook. Fl. i. 120, t. 41. Oreoplila myrtifolia, Nutt.; Torr. \& Gray, Fl. i. 259.

Hillsides on the South Yuba (Biyclow); Mt. Shasta, at 4,000 to 5,000 feet (Brever); northward in the mountains to British Columbin, and in the liveky Heuntains rangiug south to New Mexico.

\section{ORder XXYiI. RHAMNACE正.}

Shrubs or small trees, with simple undiviled leaves, smill and often carlucons stipules, and small reegular flowers; well distinguished from the related orders by the valvate astivation of the calyx, and the periegnous stanens as many as its lobes and alternate with them; the ovules solitary (rarely in pairs) and erect in the 2 to 4 cells of the ovary. - Flowers sometimes polygamo-dicecious, often apetalous. A conspicuous disk arlnate to or lining the short tube of the calyx. Petals often unguiculate, mostly involute each around a stamen in the bud. Orary either free or adnate by the disk to the tube or base of the calyx: style or stigma 2-4lobed. Seeds solitary in the cells, anatropous, with a large straight embryo in sparing fleshy albumen: cotyledons flat or plano-convex : radicle short.

A widely distributed order, of between 30 and 40 genera and four or five hundred species, of which Ceanothus is the only extensive North American genus. The herbage has some bitterness and astringency, and the fruit when fleshy or juicy is commonly mawkish or nauseous, but edible in Zizyphus, one species of which furnishes the basis of Jujube paste.

- Fruit with a single 1-3-celled hard stone.

1. Zizyphus, Cells 1-ovuled. Leaves alternate, not punctate. Spiny shrubs.

2. Karwinksia. Cells 2-ovuled. Leaves opposite, pellucid-punctato. Unarmed.

* Fruit berry-like or dry, containing 2 to 4 soparating seed-like nutlets.

3. Rhamnus. Calyx and disk free from the ovary; calyx-lobes erect or spreading. Petals small, short-clawed, or none. Filaments very short. Fruit berry-like, with 2 to 4 mostly indehiseent nutlets. Loaves alternate.

4. Adolphia. Disk covering the calyx-tube, free from the ovary; calyx-lobes sprending. Petals short-spafulate, lrooled. Fruit dry, with 3 dehiseent nutlets. Spinose : leaves opposite and very small, or none.

5. Ceanothus. Calyx and disk adnate to the base of the ovary ; calyx-lobes connivent. Petals long-elawed, hooded. Filaments exserted. Fruit dry, with 3 deliscent nutlets.

\section{ZIZYPHUS, Juss.}

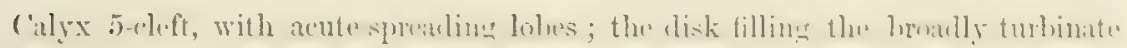
tube. Petals 5, hooded, deflexed. Ovary connate with the disk at base, 2-celled or rarely 3-4-celled; cells 1-ovuled: styles 2 to 4, free or united. Drupe fleshy, with a woody 2-3-celled nut. - Spiny shrubs or trees; with thick alternate leaves, mostly 3-5-nerved; stipules small and deciduous or spinulescent; flowers small, greenish, in axillary cymes; fruit often edible.

About 50 species, chiefly of Egynt and Southern Asin. Three species are found in the region between the Gulf of Mexico and the Pacilie, with the hahit rather of the Amerienn genus Conslalin, and with characters which tend to tho union of the two genera. Another seareely distinct genus is Microrhemnus, Gray (referred to Condulie by Baillon), of a siugle species, inhatiting Arizona and New Ilexico.

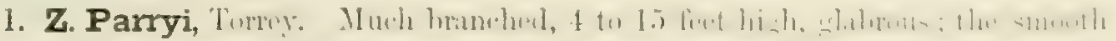

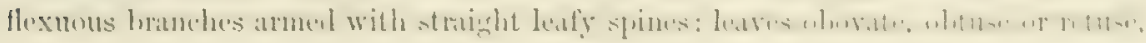


entire, 6 to 10 lines long, attenuate into a short slender petiole, coriaceous, peuninerved; stipules minute, deciduous: peduncles 1 -3-flowered, recurved in fruit : fruit nearly dry, ovate, apiculate, free from the disk, 6 to 8 lines long, lemon-yellow; peeluncle half an inch long: nut very thick and hard, 1-3-celled, 1 -3 seeded: seed narrowly oblong, without albumen : embryo green. - Bot. Mex. Bound. 46.

Frequent in gravelly ravines near San Felipe, San Diego Co. (Parry, Thurber); Rock House Summit, in same region (Dunn, Palmer); east of San Bernardino, Parry.

\section{KARWINSKIA, Zuccarini.}

Calyx 5-cleft; the acute lobes carinate or spurred within near the apex. Petals 5 , hooded, with short claws. Disk covering the calyx-tube. Ovary subglobase, not adnate to the disk, $2-3$-celled: ovules 2 in each cell, collateral : style $2-3$-lobed at the apex. Drupe surrounded at base by the calyx, apiculate : nut thin, 1-2celled; the cells 1-seeded. Seed obovate, with thin albumen. - Unarmed shrubs; with somewhat opposite entire petioled leares, penninerved and pellucid-punctate; stipules membranaceous, deciduous ; flowers small, in axillary cymes.

A genus of only 2 or 3 species, Mexican and in the adjacent region on the north.

1. I. Humboldtiana, Zuce. More or less pubescent, 2 to 6 feet high or more, with straight brownish glandular branches: leaves oblong to ovate, $\frac{1}{2}$ to 2 inches long, mostly rounded at base, obtuse or acute, shortly petioled, rather thick, more or less ferruginous: peduncles short, several-flowered, mostly 1-fruited: mature fruit ovoid, fleshy, 3 to 4 lines long, 1-3-seeded.

Throughout northern Mexico, in W. Texas and New Mexico, Lower California, and probably in the southeastern part of the State.

\section{RHAMNUS, Linn. BuckthorN.}

Flowers perfect or polygamo-diceious. Calyx 4-5-cleft, with erect or spreading lobes, the campanulate tube lined with the disk and persistent. Petals 4 or 5, or none, on the margin of the disk; claws short. Stamens 4 or 5 : filaments very short. Ovary ovoid, free, 2-4-celled: style short, 3-4-cleft. Drupe baccate, containing 2 to 4 bony or cartilaginous 1 -seeded nutlets, mostly indehiscent. Seed obovate. - Shrubs or small trees; with alternate petioled pinnately veined leaves, small deciduous stipules, and axillary cymose or racemose small greenish flowers.

About 60 species, most frequent in the temperate regions of Europe and Asia. The N. American species are six, divided equally between the eastern and western coasts.

1. Seeds and nutlets deeply sulcate or concave on the back, the rhaphe in the hollow: cotyledons foliaceous, with recurved margins: flowers mostly dioecious, solitary or fascicled in the axils. - RHamnus proper.

1. R. alnifolia, L'Her. A shrub, 2 to 4 feet high: leaves deciduous, ovateoblong, acute at each end or acuminate, 2 or 3 inches long, crenately serrate, the slender petioles slightly puberulent: lobes of the calyx and stamens 5: petals wanting: fruit black, obovate, 3-lobed, three lines long, equalling the pedicels. - Hook. Fl. i. 122, t. 42 .

Sierra Co., Lemmon. Washingtou Territory, and eastward to Canada and New England.

2. R. crocea, Nutt. Much branched, 3 to 15 feet high, the young branches pubescent: leaves evergreen, coriaceous, oblong or obovate to orbicular, obtuse or retuse or acute, equally variable at hase, 3 to 18 lines long, acutely and often glandularly denticulate, glabrous, usually more or less yellowish brown or copper-colored beneath; petioles a line long or less: flowers tetramerous, apetalous : fruit about 
three lines long, obovoid, 2-4-lobed and 2-4-seeded, bright red. - Torr. \& Gray, Fl. i. 261. R. ilicifalius, Kellogg, Proc. Calif. Acad. ii. 36.

Hillsides and mountains, from San Diego northward to Clear Lake, Yosemite Valley, and the Upper Sacramento and eastward into Arizona. Wood yellow or dark-colored, very fine-grained

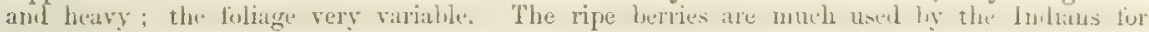
food, and their veins are said to become tinged by a deposition of the red coloring matter.

\$2. Seeds and nutlets conves on the back, the rhayhe lateral: cotylealoms Heshy. Hint: flowers mostly perfect, in pedunculate cymes. - Fravgula, (Frangula, Brongin.)

3. R. Californica, Eschscholtz. A sprealing shruh, $t$ to 18 teet high ; young branches somewhat tumentuse : leaves ovate-oblung to chliptical, I to $t$ im hes lonig, 1. ${ }_{2}$ to wide, acute or obtuse, mostly rounded at hise, denticulate wr nearly entire,

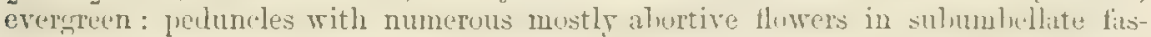

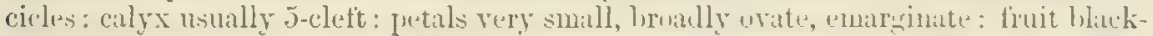
ish purple, with thin pulp, 3 or 4 lines in diameter, $2-3$-lobed and $2-3$-seeded. R. oleifolize, Hook. Fl. i. 123, t. 44. Frangula Californica, Gray, Gen. Ill. ii. 178.

Var. tomentella. Densely white-tomentuse, especially on the luwer sitle of the leaves. - $h$. tomentellus, Benth. P1. Hartw. 303. Frangula Californica, var. tomentella, Gray, Pl. Wright. ii. 28.

Throughout California from the Upper Sacramento and Klamath Lake to Santa Barbara and

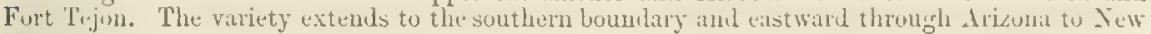
Mexivo.

4. R. Purshiana, DC. A shrub or small tree, sometines 20 feet ligh: renms branches tomentose: leaves elliptic, 2 to 7 inches long, 1 to 3 wide, mostly acute, obtuse at batse, denticulate, deciluous, somewlat jubescent benteath : fluwers rather

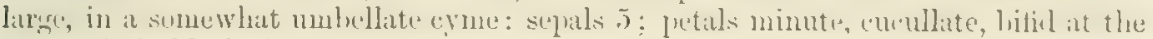
apex: fruit black, broadly obovoid, 4 lines long, 3-lobed and 3-seeded. - Hook. Fl. i. 123 , t. 43 ; Torr. \& Gray, Fl. i. 262.

Mendocino County, and northward to the British Boundary.

\section{ADOLPHIA, Meisner.}

Calyx hemisplerical, with sprealing lobes: the tulbe linet with the thin disk.

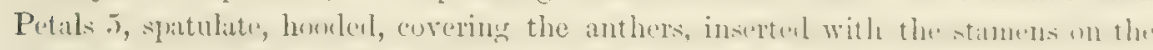

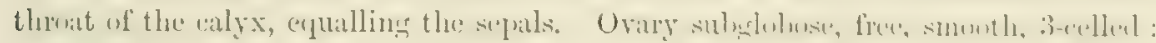

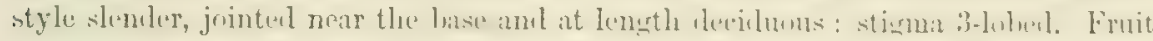

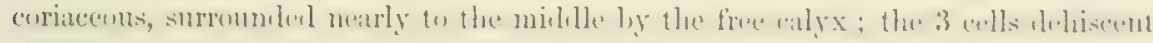
on the inner angle. Seed convex on the back: cotyledons rounded. - Slirubs with

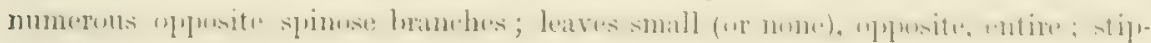
ules small, brown, rigid and subpersistent; flowers suall, in axillary fascicles. Only the following species are known.

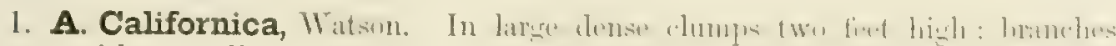
terete, with spreading spiny branchlets, puberulent: leaves orbicular to oblongovate, often retuse, a line or two long, abruptly attenuate to a slender potiolo:

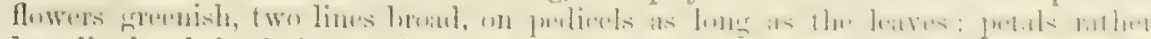
broadly hooded: fruit two lines in diameter; the short styles jointal at the very base.-Proc. Am. Acad. xi. 126. A. infeste, Torr. in Bot. Mex. Bound, 45, in part.

At Solednd and in Chollas Valley, near San Diego (P(arry, Clcwland, Pnalmer); also at Monteroy, Purry.

A. infersta, Meisner. Resembling the lnst : threo to four feet high : lenves linear to ohlonglanecolate, mucronate, attenuate to a short netiole, 2 to 6 lines long: pretals namowly hooler :

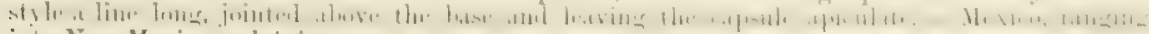
into Now Mexico and Arizona. 


\section{CEANOTHUS, Linn.}

Calyx 5-cleft; the lobes acute, connivent; disk thick, adnate to the turbinate or hemispherical tube and to the ovary. Petals on long claws, hooded. Stamens 5 ; filaments filiform, long-exserted. Ovary 3-lobed: style short, 3-cleft. Drupe subglobose, 3-lobed, surrounded at base by the adnate calyx-tube, soon dry; the 3 crustaceous nutlets at length separating and dehiscing on the inner edge. Seed obovate, convex on the back: cotyledons oval or obovate. - Shrubs or small trees, sometimes spinescent; with petioled leaves, and showy thyrsoid or cymose flowers. - Watson, Proc. An. Acad. x. 333.

Species 28, of which three are Mexican and four in the Atlantic States, the others belonging to the region between the Rocky Mountains and the Pacific.

\$1. Leaves all alternate, 3-nerved or pinnately veined, glandular-toothed or entire: fruit not crested. - Ceanothus proper.

* Leaves three-nerved from the base.

+ Erect, the branches not rigidly divaricate nor spiny: inflorescence thyrsoid: leaves usually large, glandular-servelate (except in No. 3).

1. C. thyrsiflorus, Eschscholtz. A tall shrub or small tree, 6 to 15 feet high, nearly glabrous; branches strongly angled: leaves rather thick, oblong to oblongovate, 1 to 1 inches long, usually smooth and shining above, canescent beneath: flowers bright blue, in dense coropound racemes, terminating the usually elongated and somewhat leafy peduncles. - LindI. Bot. Reg. xxx, t. 38 ; Nutt. Sylva, ii. 44 , t. 57 .

In the Coast Ranges from Monterey to Humboldt County. Known as "California Lilae" and often cultivated.

2. C. velutinus, Dougl. A stout diffusely branching shrub, 2 or 3 feet high, usually glabrous: leaves thick, broadly ovate or elliptical, $1 \frac{1}{2}$ to 3 inches long, resinous and shining above, sometimes velvety beneath; petioles stout, half an inch long: flowers white, in a loose thyrse: peduncles usually short.-Hook. Fl. i. 125, t. 45 , \& Bot. Mag. t. 5165 .

From Northern California to the Columbia, and very frequent eastward to Colorado.

3. C. integerrimus, Hook. \& Arn. A more slenderly branched shrub, 2 or 3 feet high, glabrous or soon becoming so, rarely pubescent; branches terete, usually warty: leaves thin, bright green, ovate to ovate-oblong, 1 to 3 inches long, entire or very rarely slightly glandular-serrulate, on slender petioles 2 to 6 lines long: thyrse often large and open, terminating the slender branches or axillary and rather shortly peduncled, mostly white-flowered. - Bot. Beechey, 329. C. Californicus, Kellogg, Proc. Calif. Acad. ii. 55. C. Nevadensis, Kellogg, l. c. ii. 152, fig. 45.

Var. (?) parvifolius, Watson. Of very slender habit, wholly glabrous : leaves much smaller, about half an inch long, shortly petioled: flowers light blue, in rather short simple racemes. - Proc. Am. Acad. x. 334.

Frequent in the mountains from Central California to the Columbia. The variety, seeming to $17 n$ into the typical form, is confined to the Sierra Nevada, from Yosemite Valley northward.

+ + Low, the branches not rigidly divaricate nor spiny: flowers blue, in short simple racemes or pedunculate clusters: leaves small, glandular-serrate.

4. C. dentatus, Torr. \& Gray. Erect, hirsntely pubescent or rarely nearly glabrous : leaves $\frac{1}{4}$ to 1 inch long, usually small and fascicled, obovate to oblong-elliptic or lanceolate, acute at both ends or obtuse at the apex, the margin becoming strongly undulate or revolute; the smaller leaves apparently pinnate-veined and often more or less resinous: flowers in small roundish clusters, on naked terminal peduncles 
about an inch long. - Fl. i. 268 ; Torr. Bot. Mex. Bound. 46, t. 10. C. Lobbianus, Hook. Bot. Mag. t. 4810. C. diversifolius, Kellogg, 1. c. i. 58 \& 65 ?

On dry hills in the Coast Ranges, from Santa Barbara (Mrs. S. A. Plummer) to Mendocino Co.

5. C. decumbens, Watson, 1. c. Slenler, trailing, hirsutely jubescent with sprealing hatis: leares rather thin, not unclulate, obloner, chbtuse or actutish, somewhat cumeate at lase, the greenish glands upun the

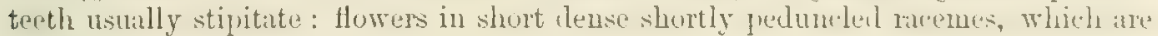
about half an iuch long or less. - $C$. smediatus, var., Torr. in Pacif. $R$. Rep. iv. 74.

Frequent in the Sierra Nevada, from the Mariposa Grove northward.

+++ Erect, with usually rigid divaricate or spinose branches: flowers in simple racemes or clusters: leaves rather small.

+ Rarely or never spinose: leaves glandular-serrate: flowers blue, racemose.

6. C. hirsutus, Nutt. silky-pubesent with soft snlapplressed or sprealing hairs, or sometimes hirsute; the branches rather rigid and said to be sometimes spinose: leaves ovate to oblongrovate, usually subcordate or rounded at base and acute at the apex, $\frac{1}{2}$ to $1 \frac{1}{2}$ incles long, nut smonth above: Howers in simple axillary and terminal ritem s, 1 to 3 inches lung, or rarely thyrsuid. - Turr. d (iray, Fl. i. 266. C. oliganthus, Nutt. in same.

About Santa Barbara, and in the Santa Susanna. Mountains, Nuttall, Wallace, Brever.

7. C. sorediatus, Hook. \& Arn. Branehes nearly glahroms, the intlurescence pubescent: leaves smooth above, more or less tomentuse heneatle or arely nearly

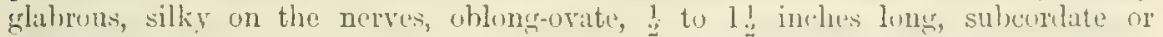
rounded or often acutish at base, acute or obtuse at the apex: flowers in shortly peduncled simplo racemes, $\frac{1}{2}$ to 2 inches long. - Bot. Beechey, 328. C. nitidus, Torr. in Pacif. R. Rep. iv. 75. C. azureus, Kellogg, 1. c. i. 55.

From Sun Diego to the Sacramento.

+++ Branches mostly spinose, grayish: leaves usually entire, someuthat coriaceons: flower's mostly white, racemose.

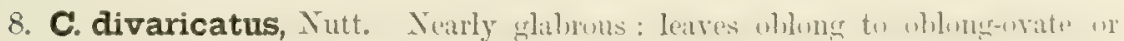
ovate, $\frac{1}{3}$ to $1 \frac{1}{4}$ inches long, rounded at base, actute or obtuso above, not tomentose beneath: flowers light blue or white, in nearly simple often elongated racemes, 1 to 4 inches long: fruit resinous, 3 lines in diameter. - Torr. \& Gray, Fl. i. 266.

From San Diego northward to Oregon. The spines often wholly wanting, and branehes green.

9. C. incanus, Torr. \& Gray. Leaves hoary beneath with a very minute

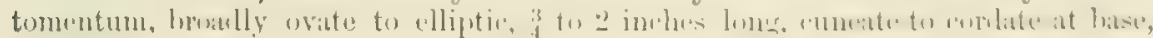
acutish or obtuse at apex: flowers in short racemes: fruit resinously warty, over two lines in diameter. - Fl. i. 265 ; Hook. \& Arn. Bot. Beechey, 328.

From Snnta Cruz to Lako County ; a largo stragrgling shrub on tho banks of creeks.

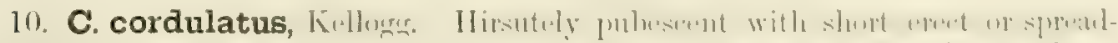

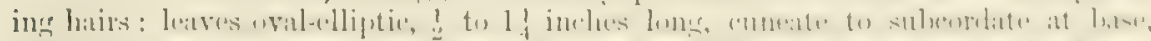

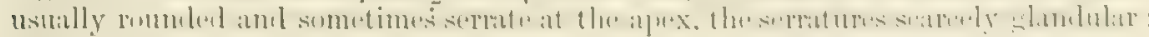
flowers white, in short simple racemes, an inch long or less: fruit smaller, not resinously dotted. - Proc. Calif. Acad. ii. 12t, tig. 39. C. divaricatus, var. eglandulosus, Watson, Bot. King Lxp. 51.

In the Sierra Nevada from the Yosemite northward. Low, flat-topned, and much sprealing; known as "Snowbusla."

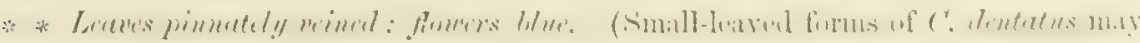
be referred here.)

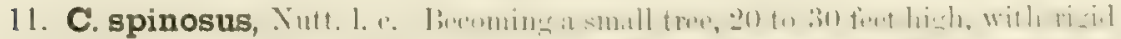

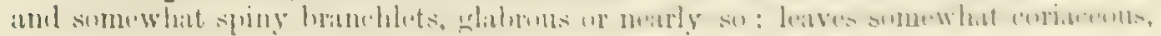


entire, oblong, 9 to 15 lines long, obtuse or retuse, somewhat cuneate at base, on slender petioles 2 to 4 lines long: flowers deep blue, in a thyrse or in simple racemes, very fragrant: fruit resinously coated, $2 \frac{1}{2}$ to 3 lines in diameter.

From Santa Barbara to Los Angeles, Nuttall, Purry, Brewer. Commonly known in that region as "Redwood," from the color of the timber, which is of sufficient size to be of value.

12. C. papillosus, Torr. \& Gray. More or less hispidly villous or tomentose, 4 to 6 feet high : leaves glandular-serrulate, and the upper surface glandnlar-papillose, narrowly oblong, 1 to 2 inches long, obtuse at each end, on slender petioles: flowers in close clusters or short racemes, terminating slender naked peduncles: fruit $1 \frac{1}{2}$ lines broad, not resinous. - Fl. i. 268 ; Hook. Ic. Pl. t. 272 ; Bot. Mag. t. 4815.

In the Coast Ranges from Monterey to San Francisco, Douglas, Bolander, Gray.

13. C. floribundus, Hook. Pilose-scabrous: leaves small, 3 to 4 lines long, oblong, acute, glandularly denticulate and undulate, shortly petioled: flowers in globose clusters sessile at the ends of the short branchlets. - Bot. Mag. t. 4806.

This species is as yet known only from the figure and original description drawn from cultivated specimens. But for the peculiar inflorescence it might be a form of $C$. dentatus.

14. C. Veitchianus, Hook. Glabrous nearly throughout: leaves thick, obovate-cuneate, rounded at the apex, glandular-serrate, smooth and shining above, minutely tomentose beneath between the veinlets, 6 to 9 lines long, on short stout petioles : flowers bright blue, in dense crowded clusters at the ends of the leafy branches. - Bot. Mag. t. 5127.

Also unknown from wild specimens. Raised from seeds sent by $T$. Bridges.

\$2. Leaves small, often opposite, very thick, with numerous straight lateral veins, spinosely toothed or entire: stipules mostly large and warty: flowers in sessile or shortly peduncled axillary clusters : fruit larger, with three horn-like or warty prominences below the summit: rigidly branched or rarely spiny shrubs. Cerastes, Watson.

15. C. crassifolius, Torr. Erect, 4 to 12 feet high, the young brauchlets white with a villous tomentum: leaves ovate-oblong, $\frac{1}{2}$ to 1 inch long, obtuse or retuse, more or less tomentose beneath, rarely entire and revolutely margined; petioles stont: flowers light blue or white, in dense very shortly peduncled clusters. Pacif. R. Rep. iv. 75 \& Mex. Bound. 46, t. 11.

In the Coast Ranges from Mendocino County to San Diego ; Guadalupe Island, Palmer.

16. C. cuneatus, Nutt. Erect, 3 to 12 feet high, less tomentose or nearly smooth: leaves cuneate-obovate or -oblong, rounded or retuse above, on rather slender petioles, entire or very rarely few-toothed: flowers white or occasionally light blue, in rather loose clusters. - Torr. \& Gray, Fl. i. 267. C. verrucosus, Nutt. 1. c. ; Hook. Bot. Mag. t. 4660. C. macrocarpus, Nutt. 1. c., and C. megacarpus, Nutt. Sylva, ii. 46.

From the Columbia River to Santa Barbara; Guadalupe Island, Palmer.

17. C. rigidus, Nutt. Erect, 5 feet high, the branchlets tomentose: leaves 2 to 5 lines long, cumeate-oblong or usually very broadly obovate, often emarginate, fewtoothed above, very shortly petioled: flowers bright blue, in sessile clusters. - Torr. \& Gray, Fl. i. 268; Hook. Bot. Mag. t. 4664; Torrey, Bot. Mex. Bound. 45, t. 9.

About Monterey, and reported also from Nakland.

18. C. prostratus, Benth. Prostrate, nearly glabrous: leaves 3 to 12 lines long, obovate or usually oblong-euneate, mostly spinose only near the apex, on short slender petioles: flowers bright blue, the clusters loose, on stout peduncles. - Pl. Hartw. 302. C. cuneatus, Kellogg, Proc. Calif. Acad. i. 55 ?

Frequent in the mountains, on shaded slopes, from Humboldt County and the Upper Sacramento to Mariposa County, and also on the eastern side of the Sierra Nevada. 


\section{Order XXVIII. VITACE正。}

Woody plants, mostly climbing by tendrils, with a watery more or less acid juice, branchlets articulated and often thickened at the nodes, usually palmately veined or lubed or compund alternate leaves, panicled cymose or thyrsoid influrescence, smail greenish or whitish fluwers, and a baccate fruit; distingrished from the related orders by a minute truncate or 4-5-toothed calyx, caducous or early deciduous petals valvate in the bud, and the stamens (as in likamnacee) of the same number as these ( 4 or 5$)$ and opposite them. - Flowers very commonly jolygamous or dicecious. Style short or conical : stigma depressed, harlly lobed. Orules in pairs or solitary in the cells of the ovary, erect, anatrojous. Steeds with a thick and bong coat. Embryo minute in cartilaginous albumen. stijules sometines manifest.

About 250 species, in 3 or 4 genera, the principal one being the typical genus.

\section{VITIS, Tourn. Grape.}

Calyx very short or small; the burler often wholete, and the tube filled with the fleshy disk, which hetrs the 4 or 5 thick callucous petals and the distimet stamens, and in which the base of the ovary is commonly immersed. Ovary - - -celled : ovules and usually the seeds a pair in each cell. - Tendrils and Hower-clusters opposite the leaves; the former almost always at least once forked.

In true Grapes the Eastern United States are richer in species than any other part of the world, having 7 or 8 species, four of which have given rise to valuable or promising cultivated varieties. The Californian species is unpromising.

V. vIXIFER, Linn., the Vine of the Old World, however, flourishes in Califormia much better than in any other of the United States, and some varieties have long been in cultivation.

1. V. Californica, lienth. Leaves tumentuste wanesent, esperially henerth, about 3 inches in diameter, round-cordate with a deep and narrow sinus, obtuse, rather coarsely serrate and often somewhat 3-lobed: fruit 4 lines in diameter, in rather large clusters, purple, covered with bloom: seed brond. - Bot. Sulph. 10; Engelm. in Am. Naturalist, i. 321 \& ix. 269.

Along streams, from San Diego northward to Russian River and the Sacramento Valley. The flavor of the fruit is rather pleasant; its value for cultivation has not been tested. The Indians of the Sacramento Valley call it Vaumec.

V. Artzonica, Engelm., Am. Naturalist, ix. 269, is an allied species of Arizona and S. Utah, and may be looked for in San Beruardino Co. The leaves are smaller, flocese-tomentose at first, at length glabrous and shining, the sinus broader, the lobes and teeth much more acute; fruit small, in small clusters, said to be quite luscious. It should be tested under cultivation.

\section{ORDER XXIX. SAPINDACE无.}

Truses shruls, or sometimes herles, mostly with enmpenul or lohed leaves, usually with nnsymmetrieal or irregular flowers aml asoles few but soldom solitary:

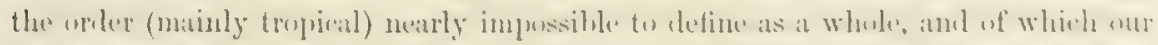

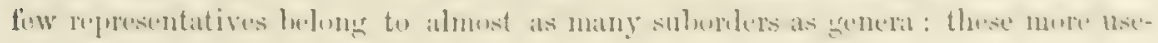
fully characterized under the suborders.

Suborder I. SAPINDACEE proper.

Flowers polygamous, irregular or unsymmotrical; the stamens more numerous than the petals, seldom twice as many. Seeds without albumen. Stipules nono. 
Cardiospermum is represented in Lower California by a single species (C. tortuosum, Benth. Bot. Sulph. 9, t. 6), and in cultivation by the Balloon Vine (C. Halicacabum, Linn.), which is native from Texas through Tropical America. The species are climbers, with biternate leaves, and bladdery inflated 3 -lobed and 3-celled capsules.

1. Asculus. Leaves opposite, palmately 5-9-foliolate. Calyx tubular. Petals 4 or 5, with claws. Ovules 6, a pair in each cell of the ovary, only one or two maturing into the large chestnut-like seed.

\section{SUBORdER II. ACERINEE.}

Flowers polygamous or diøecious, regular, often without petals. Ovary 2-lobed and 2-celled; the cells 2-ovuled but only 1 -seeded, each producing a wing and becoming a samara. Seed without albumen; the embryo coiled or folded. Leaves opposite, without stipules.

2. Acer. Leaves palmately lobed or rarely divided. Flowers polygamous.

3. Negundo. Leaves pinnate. Flowers diocious, apetalous,

\section{Suborder III. STAPHYLEACEA.}

Flowers perfect, regular, and symmetrical except the pistil. Fruit capsular, mostly several-seeded. Seeds with a bony coat, and a straight embryo with broad flat cotyledons, in fleshy albumen.

4. Staphylea. Erect and unguiculate petals and stamens 5. Styles and lobes of the bladdery several-seeded capsule 3. Leaves opposite and compound, stipulate and stipellate.

\section{Anomalous Genus.}

5. Glossopetalon. Lobes of the calyx and the slender spreading petals 5. Stamens 10. Pistil a single 2-ovuled carpel, in fruit a cartilaginous follicle : style hardly any. Leaves alternate, simple and entire, with small adnate stipules.

\section{AmSCULUS, Linn. Horse-chestnut. Bucheye.}

Flowers polygamous. Calyx tubular, unequally 5-toothed. Petals 4 or 5, unequal, with claws. Stamens 5 to 8 , exserted and often unequal. Ovary 3-celled : ovules 2 in each cell, one or both abortive: style elongated. Fruit a large leathery loculicidally 3-valved pod. Seed without albumen; its coat thick and shining, showing a large round scar. Cotyledons large and fleshy, somewhat coherent. Trees or shrubs; leaves opposite, digitate, without stipules; leaflets serrate, pinnately veined; flowers showy, on jointed pedicels, in a large terminal thyrse or panicle, mostly sterile.

A genus of abont 15 species, nearly half North American, two in the mountains of Central America, the rest in Asia. The Horse-chestnut, $E_{E}$. Hippocastanum, Linn., originally from Asia, is often seen in cultivation, and grows to be a large tree. The seeds are farinaceous but unpalatable and unwholesome; those of the Californian species are said to be eaten by the Indians.

1. 理. Californica, Nutt. Leaflets 4 to 7 , usually 5 , smooth, oblong-lanceolate, acute, obtuse at base, slenderly petiolulate, serrulate, 3 to 5 inches long: flowers in a close finely pubescent thyrse which is 6 to 12 inches long: calyx 2lobed, the lobes searcely toothed: petals slightly unequal, white or pale rose, half an inch long or more: stamens 5 to 7 ; anthers orange-colored: ovary densely pubescent : fruit unarmed, usually 1-seeded : seed an inch in diameter. - Torr. \& Gray, Fl. i. 251 ; Nutt. Sylva, î. 69, t. 64 ; Newberry, Pacif. R. Rep. vi. 20, fig. 1 ; Hook. Bot. Mag. t. 5077.

From San Luis Obispo to Mendocino Co. and Mt. Shasta, and in the foot-hills of the Sierra Nevada. It is ustally a shrub 10 to 15 feet high, but sometimes in the valleys, particularly 
between Monterey and Clear Lake, it is a widely branched tree, the base much expanded and occasionally 6 feet in diameter, the trunk half as large and branching low, the main branches 1 to 2 feet thr.k, the whole forming a dense head 25 to flo feet high and of still sreater brealth. In May, when in full flower, it is a beatiful tree, but the leaves often fall before midsummer, so that for much of the year it is bare. Usually only two or three flowers in each thyrse perlect their fruit, often but one. The wood is soft and brittle.

\section{ACER, Tourn. MAPLE.}

Flowers polygamo-divecious. Calyx colored, usually 5-lobel. Petals as many or none. Stamens 3 to 12 , usually 8 , inserted with the petals upon a lobed disk. Ovary 2-lobed, 2-celled : ovules a pair in each cell: styles 2, elongated. Fruit a double samara or kej, divaricately 2-winged abore, selmalle at waturity, each I-seeded. Alhunen nome. Cotyleduns large and thin, variously coiled or folderl. - Trees or shrubs; leaves oplusite, palmately luberl (in American species), withont stipules; Hower small, in terminal racewes, umbel-like curymbs, or fiscicles, the pedicels not jointed.

About 50 species, mostly of the northern hemisphere. Of the 9 species of the United States 5 are confined to the Atlantic States, some of them valuable forest trees and extensively planted for shade and ornament. The other species of the Rocky Mountains and westward are of far less importance. The wood in general is hard and close-grained, and sugar is made from the sap of several species.

\section{* Flowers in racemes: body of the fruit hispid.}

1. A. macrophyllum, Pursh. A tree, 50 to 90 tiet high, 2 or 3 feet in liameter: leaves 6 to 10 inches broad or more, pubeseent when young, becoming gla-

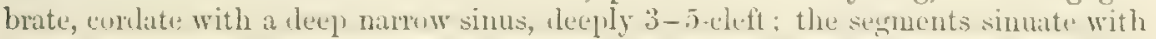

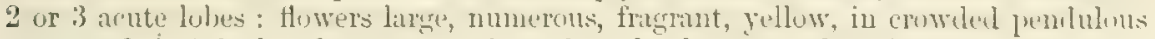
racemes 3 to 6 inches long, appearing after the leaves: calyx 2 or 3 lines long: petals oblong: stamens 9 or 10, with hairy filaments: fruit densely hairy, the glabrous wings 15 to 20 lines long and more or less divergent. - Hook. Fl. i. 112, t. 38 ; Nutt. Sylva, ii. 77, t. 67 ; Newberry, Pacif. R. Rep. vi. 21.

In mountain ravines from Santa Barbara to Fraser River ; in California mostly confined to the ranges along the const and not so large as in Oregon, where it is sometimes found five feet in diameter and valuable for its timber. The wood is white, hard, and takes a fine polish. The bark of the trunk is light gray, on the younger branches green with stripes of lighter color.

$$
\text { * Flowers in loose umbel-like corymbs: fruit smooth. }
$$

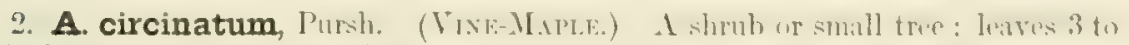

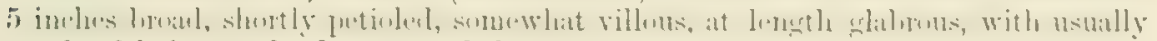
a tuft of hairs at the base, rounded-cordate with a broad and often shallow sinus, 7-9-lobed nearly to the midule; the lobes acuninate, sharply sermite: corymbs

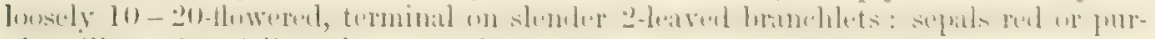

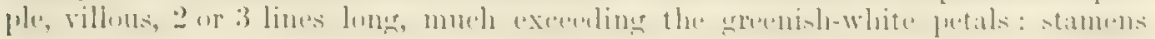
8; filaments villous at base : fruit 10 to 14 lines long, the wings sprealing at right angles to the peduncle. - Houk. Fl. i. 112, t. 39 ; "Xutt. Sylva, i. 80 , t. 68 ; Nowberry, Pacif. R. Rep. vi. 21.

Northern California, in pine forests, and northwnerl to British Columbin; in this Stato n mero slurub, in Oregon sometimes a tree 30 or 40 feet high. In moist places and on rich alluvial snils it often takes complete possession, the vine-liko stems growing in elusters from tho sune root, nnd thenselves striking root wherever they tonch the ground and sending out numerous offshonts. Thus interlaced and fastened together they forn dense dark thickets almost inupenetrable. The wood is heavier and closer-grained than in the last species.

3. A. glabrum, Torr. A shrub or small treo: lenves ghbrous, 2 to 4 inches broad, rounded-cordate in outline with a shallow sinus, laciniately 3 -5-lobet, more

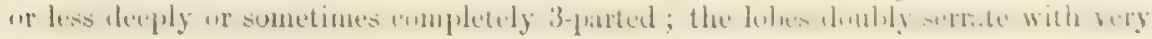


acute teeth: flowers corymbose on short 2-leaved branchlets: sepals and petals greenish-yellow, linear, 2 to 3 lines long: filaments naked: fruit with broad erect or spreading wings, an inch long or less. - Ann. Lyc. N. Y. ii. 172; Torr. \& Gray, Fl. i. 247 ; Watson, Bot. King Exp. 52. A. Douglasie, Hook. in Lond. Jour. Bot. vi. 77, t. 6. A. tripartitum, Nutt. in Torr. \& Gray, l. c., and Sylva, ii. 85, t. 71.

In the Sierra. Nevada from Yosemite Valley northward, ranging to Vancouver Island, and eastward to Colorado and New Mexico. Usually a shrub, but sometimes a small tree 30 or 40 feet high; not abundant nor large enough in this State to be of much importance. Oregon speeimens rarely show the leaves as deeply lobed or parted as is usual in California and the Rocky Mountains.

\section{NEGUNDO, Monch. Box-ELDER.}

Flowers diccious. Calyx minute, 4-5-cleft or parted. Petals and disk none. Stamens 4 or 5, hypogynous. Ovary and fruit as in Acer. - Trees; leaves pinnate; sterile flowers on clustered capillary pedicels, the fertile in drooping racemes.

A genus of only four species, of the Atlantic States, California, Mexico, and Japan, each region having its peculiar form.

1. N. Californicum, Torr. \& Gray. Usually a small tree, sometimes reaching a height of 70 feet: leaves pinnately 3-foliolate, more or less villous-pubescent, densely so when young; leaflets ovate, or the lateral ones oblong, acute, 3 or 4 inches long, the terminal largest and 3-5-lobed or very coarsely serrate; the lateral ones coarsely serrate or somewhat lobed on one side and much more shortly petiolulate: fertile racemes slender, at length 4 to 6 inches long: fruit pubescent, 15 to 18 lines long, including the slightly spreading wings. - Fl. i. 250 \& 684; Hook. \& Arn. Bot. Beechey, 327, t. 77 ; Nutt. Sylva, ii. 90, t. $72 . \quad$. aceroides, Torr. in Pacif. R. Rep. iv. 74 \& Bot. Wilkes Exp. 259.

Common along streams in the Coast Ranges, from San Luis Obispo northward. It closely resembles $N$. aceroides, Moench, which ranges from British America to the Gulf of Mexico and Utab, and is distinguished by its 3 to 5 smaller and narrower leaflets, which are coarsely toothed, but less distinctly lobed.

\section{STAPHYLEA, Linn. BLADDER-Nut.}

Flowers perfect, regtrlar. Sepals and petals 5, equal, erect, whitish. Stamens 5, alternate with the petals on the margin of a thick disk lining the base of the calyx. Ovary 2-3-parted to the base or to the axis; the lobes or carpels several-ovuled: styles elongated, lightly coherent. Fruit large and bladdery, dehiscent at the summit. Seeds 1 to 4 in each cell, globose, bony : albumen thin. Embryo straight, with broad thin cotyledons. - Erect shrubs; leaves opposite, stipulate, pinnately 3 -5-foliolate and the leaflets stipellate; flowers in drooping terminal racemose or cymose panicles.

The five species are natives of as many regions in the northern temperate zone, viz. Europe, the Himalayas, Japan, California, and the Atlantic States.

1. S. Bolanderi, Gray. Leaflets 3, glabrous, broadly oval or orbicular, 1 to 2 inches long, abruptly acute, serrulate: sepals 3 lines long: petals a little longer: style and stamens much exserted. - Proc. Am. Acad. x. 69.

On McClond's Fork, Shasta Co., Bolander. Fruit unknown, and size of the shrub not indicated.

\section{GLOSSOPETAION, Gray.}

Flowers perfect. Calyx deeply 4-5-cleft, persistent; the lobes ovate or triangular; its flat base within filled by an 8-10-lobed depressed perigynous disk. Petals 4 or 5, spatulate, becoming linear-ligulate, inserted on the margin or under 
the edge of the disk, somewhat withering-persistent. Stamens 8 or 10 , inserted at the sinuses of the lisk, shorter than the ealyx: filaments subulate, persistent: anthers dielymous. (Ovary one-celled, of a single ovoil carpel, with style extremely short or none, and a depressed entire or obscurely 2-lobed stigma. Ovules 2, collateral or nearly so, inserted on the ventral suture barely above the base of the cell, ascending, oborate, anatropous. Fruit a firm-coriaceus fullicle, ovoil, oblique, aeute, many-striate, opening down the ventral suture, 1-2-seeded. Seed obovate, compressed, with a smooth crustaceous testa, in which on both sides is a small bulging empty cavity; a suall arillus or caruncle at the hilum. Embryo or even well-filled nndeus not seen. - Low and rigid shrubs (of the interior arid region); with slender spinescent hranches, and small alteruate simple and entire leares, which separate in age by an indistinct articulation from a dilited scali-like minutely 2-stipulate lase; the stipules anlnate to the seale and setaceons-subulate; flowers small, solitary, terminatiugr sluert axillary branches or spur-Irke fascicles: petals white. - Pl. Wright. ii. 29, t. 12, \& Proc. An. Acad. xi. 73.

1. G. Nevadense, Gray, 1. c. Two or three fect high, much brunched, pale or slightly huary with almost impereeptible pulnescence: leaves oval, half an inch or less in length, witle short petinle abruptly terminating in the retuse broad stipuliferous scale: calyx-lobes and petals 4 : stamens 8 .

Dry hills, Washoe Co., Nevada, Lcmmon and Case, 1875. An interesting acquisition.

G. sprvescens, Gray, the only other species, of New Mexico and Southern Utah, is smooth, has smaller and narrower leaves and mostly 5 -merous flowers.

\section{ORDER XXX. ANACARDIACE两.}

Shrubs or trees (largely tropienl or subtropical), with a resinous and usually acrit juice, alternate leares (cither simple or compound) withont stipules and almost

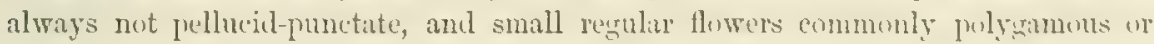
dicecious; the stamens as many or twice as many as the petals; the free ovary in the genuine representatives of the oriler 1 -eelled and I-ovukd, but the styles often 3 ; the fruit drupaceous; and the seed without albumen.

A large order of nearly 50 genera, and 450 species, represented in California, ns in the Atlantic United States, only by the large and polymorphous genus Rhus.

Pistacia Mexicasa, HBK., of Central Mexico, mnging to the valley of the Rio Grunde, is reported by Dr. Cooper as from San Diego. It is a small tree, with pinnate lenves; leaflets 5 to

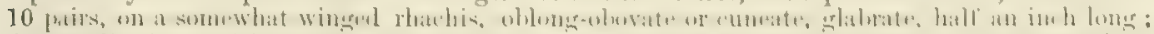

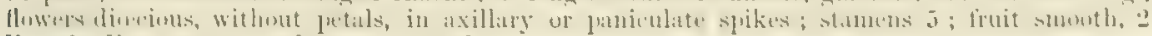
lines in dinneter, somewhat compressed.

Schusus Morde, Linn., a mative of Mexico and South Americs, is common as a cultivated ornamental shrub in the southern part of the State, under the name of Pepper-tree or Chili Peppor. It is an evergreen tree of moderate size, and very graceful habit; lestves with 20 or more

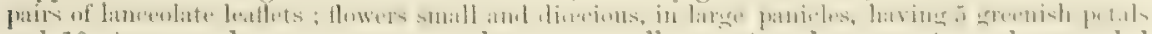
and 10 stamens; drupes numerous, as large as a small pen, strongly pungent; scel susperuleul above the middle of the cell, instend of from a basal stalk as in most genera. The apparently

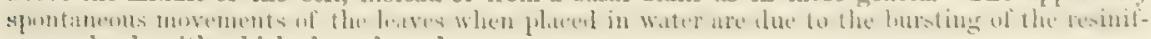
erous glands with which they abound.

\section{RHUS, Linn.}

Sepals and potals ( 4 to 9) usually 5. Stamens as many or twice ns many, with subulate filaments, inserted under the edgo of a disk lining the hase of the calyx. Fruit a small dry drunn. Seod nendulous upon a slenter sced-stalle arising from 
the base of the cell. - Shrubs or small trees; leaves simple or pinnate; flowers small, polygamous or polygamo-diœecious, in axillary and terminal bracteate panicles, or sometimes in racemes or spikes.

A widely distributed genus of at least 120 species, natives of the warmer extra-tropical regions of both hemispheres, most numerous in S. Africa. There are 14 species in tlre United States, differing considerahly in their characters and so distributed into five sections. The astringent leaves of some species of the section Sumac (not represented in California) are extensively used in tanning, and the resinous juice of others in Japan yields the peculiar well-known laequer of that country, and the fruit a useful regetable wax or tallow.

\$1. Flowers polygamous or dioecious, in loose axillary panicles: fruit glabrous and whitish; nut striate: leaves 3-foliolate: juice and effluvium poisonous.-ToxICODENDRON.

1. R. diversiloba, Torr. \& Gray. (Poison OAK. Yeara.) Usually somewhat puberulent, the slender shrubby stem erect, or stouter and climbing by rootlets, 3 to 8 feet high: leallets ovate, obovate, or elliptical, 1 to 3 inches long, obtuse or acutish, 3-lobed or coarsely-toothed or sometimes entire, the lobes and teeth obtuse: panicles peduncled : flowers whitish, $1 \frac{1}{2}$ lines long : fruit 2 to 3 lines in diameter, somewhat compressed. - Fl. i. 218; Lindl. Bot. Reg. xxxi, t. $38 . \quad R$. lobata, Hook. Fl. i. 127 , t. 46.

From Southern California to British Columbia, in this State most abundant in the Coast Ranges. It resembles $R$. Toxicodendron, Lina., of the Atlantic States, which differs, however, in its acuminate leaflets, sharply toothed or entire, and nearly sessile panicles, usually more dense in fruit. The species are alike very poisonous, causing a severe cutaneous eruption accompanied by intense smarting and itching. The reputed remedies are more numerous than efficacious; prominent among those in popular use is said to be the bruised leaves or a decoction of the leaves of Grindelia or "Gun-plant."

\$ 2. Flowers polygamo-diocious, in short sessile scaly-bracted spikes, preceding the leaves: fruit globose, villous, light red; nut smooth: leaves 3foliolate. Lobadium, Raf.

2. R. aromatica, Ait., var. trilobata, Gray. A shrub, 2 to 5 feet high, diffusely branched, strongly scented, more or less pubescent, at length nearly glabrous: leaflets sessile, cuneate-obovate or rhomboidal, 1 or 2 inches long, exceeding the petiole, coarsely toothed above and often 3-lobed, the segments obtuse: spikes half an inch long or less, approximate at the ends of the branches: flowers yellowish, a line long: fruit somewhat viscid, 2 or 3 lines in diameter. - Watson, Bot. King Exp. 53. R. trilobata, Nutt. in Torr. \& Gray, Fl. i. 219.

Throughout the State, ranging to Washington Territory and eastward to the Rocky Mountains and Texas. The typical form of the Atlantic States has the leaves ordinarily larger and less lobed, and the odor of the plant is perhaps more aromatic. The fruit is said to be pleasantly acid, and is eaten by the Indians : the slender twigs are used in their ehoicest basket-work.

\$ 3. Flowers polygamous, on bracted pedicels in numerous short dense racemes closely paniculate at the ends of the branches: sepals orbicular, concave, colored: fruit densely pubescent and very viscid, dark red: leaves simple, coriaceous. StrpHonia, Benth. \& Hook. (Styphonia, Nutt.)

3. R. integrifolia, Benth. \& Hook. A diffusely branched stont evergreen shrub, 5 to 10 feet high: leaves puberulent when young, soon glabrous, broadly ovate, acute or obtuse, usually entire but sometimes spinosely toothed, $1 \frac{1}{2}$ to 3 inches long, on short stout petioles: flowers rose-colored, in close panicles 1 to 3 inches long: petals rounded, ciliate, exceeding the sepals, $1 \frac{1}{2}$ lines long: fruit ovate, 3 lines long. - Gen. Pl. i. 419. Styphonia integrifolia, Nutt. in Torr. \& Gray, Fl. i. 220 \& Sylva, iii. 4, t. 82 ; Torrey, Pacif. R. Rep. vii. 9, t. 2. S. serratu, Nutt.; Torr. \& Gray, Fl. i. 220.

From Santa Barbara to San Diego, mostly on the coast; western Arizona, Palmer, Wheeler. Along the eliffs near the sea it forms close thickets, sometimes on the seaward side presenting a 
surface of dense foliage as smooth and uniform as that of the best trained hedge. According to Nuttall the smooth gray bark exudes in small quantities a very astringent gum-resin. The fresh red berries are described by Palmer as coated with an icy-looking white substance, which is pleasantly acid and used by the Indians to make a cooling drink.

\$. Flowers perfect or polygumous, in ample terminal or axillary compond prnicles: fruit small, glabrous: leaves simple, coriaceous. - Lithrsi, Benth. \& Hook. (Lithrcea, Miers. Rhus § Malosma, Nutt.)

4. R. laurina, Nutt. A large evergreen unch-branchel and very leafy slurub, exhaling an aromatic ollor, glabrous: leaves lanceolate, acute, mucronate, rounded at base, flaucous, entire, 2 ur 3 inches long, on slender petioles: panicles dense, 2 to 4 inches long: Howers yellowish, a line long, or less : fruit whitish (!), ovate, $1 !$ lines long, heakel by the stout styles. - Torr. it Giry, Fl. i. 219. Lithua laurina, Walp.; Torrey, Pacif. R. Rep. iv. 73, \& Bot. Mex. Bound. 44, t. 7.

From Santa Barbara to San Diego, in the valleys; Guadalupe Island, Palner. According to Dr. Torrey "the thin pulp of the dry fruit consists chiefly of a white waxy material, soluble in strong alcohol, whith secms to be almost entirely cerine." The seeds are said to yield a pungent oil.

\section{Order XXYI. LEGUMINOS开.}

The single and simple free pistil, becoming a legume in fruit, and the alternate leaves with stipules (to which in the proper Pulse family are added the papilionaceous corolla and 10 (liatelphous or monatelphous or rarely distinct stamens) mark this crllor, one of the largest and next to Gramince the most impurtant of the regetable kingdom. It comprises the following suborlers.

\section{SUBorder I. PAPILIONACEE.}

Fluwer irregular. Calyx mostly 5-cleft or 5-tuothed, the tube or cup extending beyond the perigynous disk which lines its bottum and bears the petals and stat mens. ('orulla of 5 petals (rarely fewer), indricited in the husl; one (the stambarl) surerior (next the axis of influrescence), linyer and always external, covering in the bud the two lateral ones (wings), and these covering the inferior pair, which togrether form the kinl, beiner commonly united or at least coherent by their lower

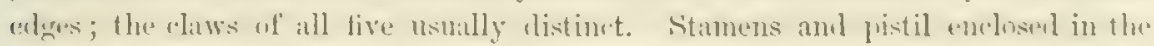

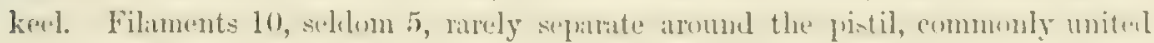
from the base upward into a sheath enclosing the ovary, which is either entire

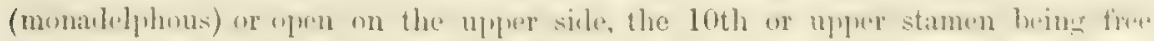

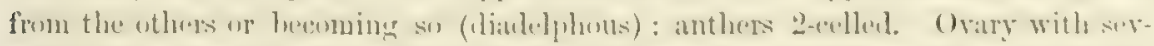

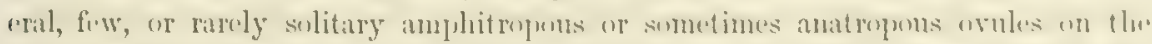

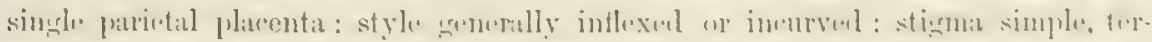
minal or nearly so. I.

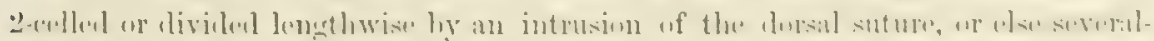

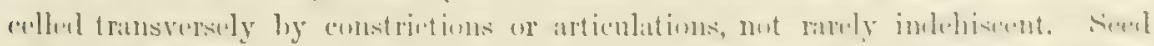

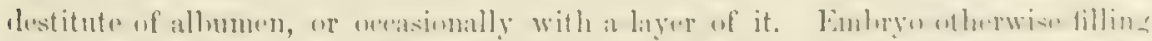

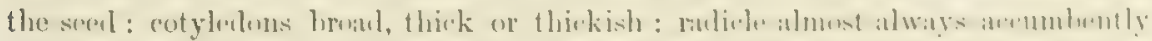

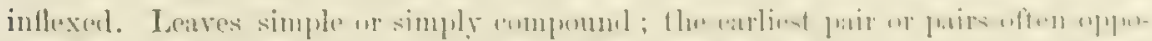

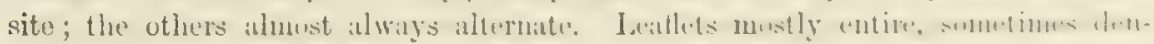


ticulate. Flowers perfect, solitary, or several in a raceme, spike, head, or sometimes panicle.

Our 16 genera represent almost half as many tribes, corresponding to the principal divisions of the following key.

I. Stamens distinct.

* Leaves digitately 3-foliolate.

1. Thermopsis. Herbs, with conspicuous stipules, and yellow flowers in racemes.

2. Pickeringia. Shrub, with minute stipules or none, and purple solitary flowers.

* * Leaves unequally pinnate : shrubby.

3. Sophora. Pod thick, large, several-seeded, often transversely constricted : leaves coriaceous,

10. Amorpha. Pod small, 1-2-seeded. Petal one! Stamens monadelphous at the very base.

II. Stamens monadelphous, or diadelphons (9 and 1).

* Anthers of two forms : filaments strictly monadelphous: leaves digitate, of more than 3 quite entire leaflets.

4. Lupinus. Calyx deeply bilabiate. Standard with recurved sides : keel falcate. Pod large, straight.

* * Anthers uniforma.

+ Leaflets 3 , or rarely digitately 5 to 7 , denticulate or serrulate : stamens diadelphous or nearly so : pods small and enclosed in the calyx, or curved or coiled.

5. Trifolium. Flowers capitate. Corolla persistent, wnited with the filaments. Pod small, mostly in the calyx,

6. Melilotus. Flowers in axillary racemes or spikes, small. Petals free, deciduous. Style filiform. Pod small, wrinkled, globular.

7. Medicago. Flowers mearly of Melilotus. Pod spirally coiled or curved. Style subulate.

+ + Leaves unequally pinnate (very rarely digitate or simple); leaflets entire : no tendril.

++ Flowers umbellate or solitary, on an axillary peduncle.

8. Hosackia. Herbaceons or shrubby. Corolla yellow or partly white, or turning reddish : claw of the standard usually remote from the others. Pod linear, several-seeded.

++ ++ Flowers in spikes, racemes, or heads, never umbellate.

$=$ Herbage glandular-dotted : stamens mostly monadelphous.

9. Psoralea. Herbs, with 3-foliolate leaves and axillary spikes. Stamens mostly monadelphous. Pod indehiscent, one-seeded. Ovule solitary.

10. Amorpha. Shrubs, with pinnate leaves and terminal or panicled racemes. Wings and keel of the corolla wanting. Stamens monadelphous only at base, otherwise distinct. Pod nearly indehiscent, 1 -2-ovuled, 1-2-seeded.

11. Dalea. Shrubby or herbaceous, with pinnate or simple leaves and terminal spikes or heads. Wings and keel inserted on and articulated with the monadelphous stamen-tube. Pod indehiscent, 2-6-ovuled, mostly one-seeded.

$==$ Herbage glandular or glutinous and more or less punctate : leaves unequally pinnate: stamens diadelphous; anthers confluently 1 -celled.

12. Glycyrrhiza. Flowers, \&c., of Astragalus. Pod prickly or muricate, short, 1-celled.

$===$ Herbage neither glandular nor dotted : stamens diadelphous; anthers 2-celled : leaves pinnate.

13. Astragalus. Herbs, unarmed. Pods mostly bladdery or turgid, or more or less 2-celled by intrusion of the dorsal suture.

14. Olneya. Tree, spinescent, nearly destitute of stipules. Pod 2-valved, several-ovuled, 1-2. seeded; valves very thick and firm.

+++ Leaves abruptly pinnate, terminated by a tendril or bristle (occasionally by an imperfect leaflet) : stamens diadelphous: peduncles axillary : pod 2-valved : seed-stalks broad or expanded at the hilum: herbs.

15. Vicia. Stamen-tube oblique at the summit. Style fliform, hairy around and below the apex.

16. Lathyrus. Stamen-tube nearly truncate. Style dorsally flattened toward the apex, hairy on the inner side, usually twisted half round. 


\section{Suborder II. C.ESALPINEE.}

Flower more or less irregular. Perigynous disk lining the tube or base of the calyx. Petals imbricated in the bud, the superior one (answering to the standurd) within the lateral ones. Stamens 10 or fewer, distinct. Seeds sometimes with albumen. Radicle not incurved.

* Corolla seemingly papilionaceous.

17. Cercis. Trees or shrubs, with simple rounded leaves, and lateral fascicles of rose-purple flowers. Calys barely 5-toothed.

* Corolla not at all papilionaceous, yellow. Calyx 5-parted, Seeds with albumen.

18. Cassia. Herbs or sometimes shrubs, with simply and abruptly pinnate leaves. Anthers fixed by the base, mostly opening by terminal pores, either 10 and unequal or some of the upper ones imperfect, abortive, or wanting. Calyx imbricated in the bud.

19. Parkinsonia. Somewhat spinescent shrubs or trees, with twice piunate (or apparently only pinnate) leaves: leaflets small. Anthers 10 , fixed by the middle, opening leugthwise. Calyx valvate.

\section{SUBorder III. MIIMOSE.F.}

Flowers regular, small, and numerons in spikes or heads. No perigynous disk. Calyx and corolla valvate in the bud, 4-5-merous. Stamens as many or twice as miny as the petals, or numerous, hyporgnus. Sceds mostly withunt albumen. hadicle not incurved. Leaves usually twice pinnate.

20. Prosopis. Stamens 10. Petals distinct or becoming so. More or less spiny shrubs or trees. Flowers greenish.

21. Acacia. Stamens indefinitely numerous. Petals united below. Flowers yellow.

\section{THERMOPSIS, R. Brown.}

Calyx campanulate, cleft to the millule; teeth erual or the two upper ones unitwil. Stamliarl roumlish, shorter than the oblemer wines, the siles retlexel : keed nearly straight, obtuse, its jutals sumewhat mitul, explalling the wings. Stamems distimet. Style slightly incurved: stigma minute. Pod linear to oblong-linear, much compressed, few - many-seeded, shortly stipitate or nearly sessile, straight or incurved. - Stout perennial herbs, with erect clustered sterns; leaves digitately 3 -foliolate,

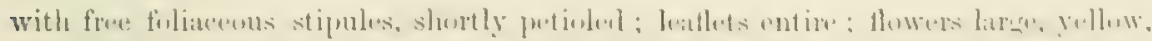

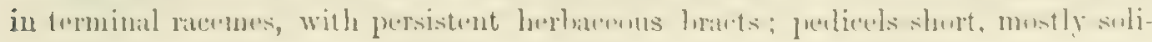
tary, naked.

About a dozen species, half belonging to Asin, and the rest to North America. Three of these are confined to the Atlantic States and ono to the Rocky Mountrins.

1. T. macrophylla, Ifwk. of Am. Villus with lume speraling hairs: stimles

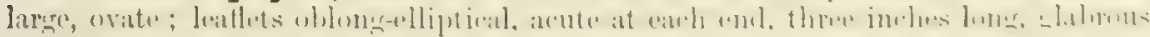
above, tomentose and villous beneath: calyx-teeth acuminate: stmens somewhat

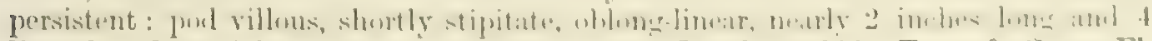
lines broad, straight, erect, 4-5-seeded. - Bot. Beechey, 329 ; Torr. \& Gray, Fl. i. 388 .

Collected by Dougles in Californin, but the locnlity unknown. All the specinens from other cullections that havo been refeired to the species, seeni to belong to tho next.

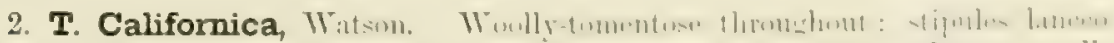
late; leaflets obovate to oblanceolate, an inch or two long, acute or nhtuse, eyually

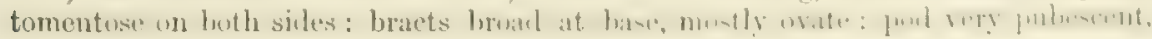


on a short glabrous stipe, 6-8-ovuled; mature fruit not known. - Proc. Am. Acad. xi. 126. T. macrophylla, Torr. in Pacif. R. Rep. iv. 81. T. fabacea, Torr. in Bot. Mex. Bound. 58.

From Marin and Napa counties southward.

3. T. montana, Nutt. More glabrous, somewhat silky-villous especially above: stipules ovate to lanceolate; leaflets oblong-obovate to oblong, 1 to 3 inches long, obtuse or acutish, sparingly villous beneath, smooth above: bracts mostly lanceolate: pod pubescent, on a rather slender stipe about equalling the calyx-tube, linear, 2 or 3 inches long, straight, erect, $10-12$-seeded. - Torr. \& Gray, Fl. i. 388. T. fabacea, Hook. Fl. i. 128 ; Bot. Mag. t. 3611 ; Lindl. Bot. Reg. xv. t. 1272 ; not DC. T. macrophylla, var. $\beta$., Torr. \& Gray, 1. c. T. fabacea, var. montana, Gray; Watson, Bot. King Exp. 53.

From Washington Territory and Oregon, in the mountains, through the interior to Colorado and Mew Mexico; probably in Northern California. The typical form, more common eastward, has narrowly oblong leaves. The $T$. fabacea of Eastern Asia, to which this species has been usually referred, has more spreading pods, with larger and broader more compressed seeds. The only other western species is T. RHOMBIFoliA, Richardson, confined to the Rocky Mountains, and distinguished by its recurved many-seeded pods.

\section{PICKERINGIA, Nutt.}

Calyx campanulate, turbinate at base, repandly 4-toothed. Petals equal: standard orbicular, the sides reflexed: wings oblong: keel-petals oblong, distinct, straight, obtuse. Stamens distinct. Style slightly incurved: stigma minute. Pod membranaceous, linear, compressed, stipitate, several-seeded, straight. - A low stout muchbranched spinose shrub; leaves evergreen, small, nearly sessile, digitately 1 -3-foliolate, without stipules; flowers large, purple, axillary, solitary, nearly sessile.

1. P. montana, Nutt. Widely spreading, densely branched, 4 to 7 feet high, roore or less silky-tomentose or glabrate, leafy, the branchlets becoming spinose: leaflets oblanceolate or cuneate-oblong, 3 to 9 lines long, acute or obtuse: flowers near the ends of the branchlets, "on very short minutely 2-bracteolate peduncles, from light cinnamon-red to purple, 7 to 9 lines long: stamens persistent: pod about two inches long, 6-10-seeded (or fewer by abortion), somewhat constricted between the seeds, pubescent; stipe exserted: seeds oblong, slightly compressed, dark-colored. - Torr. \& Gray, Fl. i. 389 ; Torr. Bot. Mex. Bound. 51, t. 14, \& Bot. Wilkes Exp. 282.

Frequent on dry hills from LakeiConnty to San Diego. The characters of the pod distinguish the genus clearly from Anagyris.

\section{SOPHORA, Linn.}

Calyx-tube campanulate; teeth short. Petals nearly equal: standard broad. Stamens distinct; anthers uniform, versatile. Style incurved : stigma minute. Pod stipitate, terete or somewhat compressed, thick or coriaceous, mostly indehiscent, several-seeded, constricted between the obovoid or subglobose seeds and usually necklace-like. - Trees, shrubs, or herbs; leaves unevenly pinnate, with few or many entire often coriaceous leaflets; stipules small or obsolete; racemes terminal.

A genus of about 25 species, of the warmer regions of the globe. 'Two low herbaceous species are found in Colorado and New Mexico, and 2 or 3 evergreen shrubs in Texas and Northeastern Mexico, besides a similar West Indian species in Florida. The following is the only species occurring near the limits of California.

1. S. Arizonica, Watson. An evergreen shrub, somewhat canescent with short appressed silky hairs: leaflets 2 or 3 pairs, narrowly oblong, acutish, an inch long; 
stipules small, subulate: racemes short (1, inch long) and few-flowered; bricts ihciluous ; pedicels 3 lines long, bracteolate : calyx narrowed at base: pods smooth, coriaceus, compressed, reticulated and with m.relike warkins, 3 or 4 in hes lons,

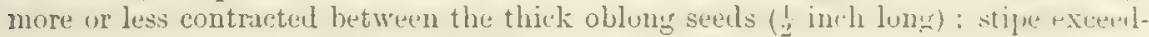
ing the calyx. - Proc. Am. Acad. xi. 135. S. speciosa, Torr. in Pacif. R. Rep. iv. 82 ; not Benth.

Collected by Dr. Bigelow at Cactus Pass and on White Cliff Creek, near Bill Williams River in Western Arizona; in fruit, January. The pod is thinner and more compressed than is usual in the genus, and the seed more oblong.

\section{LUPINUS, Linn. LOPINE.}

Calyx deeply bilabiate, bibracteulate. Standard broad, the sides reflexpl: wings united above, enclusing the incurved beaked keel. Stamineal tulne not cheft ; anthers alternately whlong and rounded. Stigma bearded. Ponl o-valverl, conuressed, coriaceous, 2-12-seeded. - Annuals or peremuials, herbaceous, or a few species somewhat wonly. Latves palmately 1 -16-teliolate; stipules alnate to the petioles; leaflets entire. Flowers in terminal racemes, verticillate or soutteres (s)litiry am axillary in a single species), bracteate. - Watson, Proc. Am. Acad. viii. 517.

Mnch the larger number of the species of this very difficult genus belong to Western America, only a few annuals occurring in the Meditertanean region, and less than half a clozen in the Atlantic States, two of which are peculiar in having unifoliolate leaves. Two species are found in Alaska and British Columbia, 60 or more are natives of our western coast and the interior region west of the Rocky MLuntains, a dozen are Mexican, and 15 or 20 belong to the Andes. Ours are of little value economically, but rather the contrary, some growing so abundantly in our grain-fields as to be injurious. Many species are showy, and several have long been cultivated for ornanent.

$$
\text { * Annuals }
$$

Flowers axillary, solitary : ovules 2 : dwarf.

44. L. UxCIALIS.

Flowers racemose : ovules 2 : bracts yersistent.

Rathor stout : flowers in whorls: peduncles elongateul,

Leaves approximate; petioles long. Long-villous: flowers mostly nurple.

Snoother: flowery yellow to white.

Leaves scatterel; petioles short: pubescence short, appressed.

Low or dwarf: flowers scattered.

Hinute: leaflets 5 : rucemes nearly sessile.

Villous or subglabrous : leaflets 7 : peduncles long.

Flowers racemose: ovules sevoral.

l'lowers in whorls: bracts deciduous.

Puberulent: leallets broad, smoother above : bracts short.

Villous: leaflets narrow, pubescent hoth sides.

Bracts olongated: lowers rather largo: banner broal.

Bracts short: flowers small, narrow.

Flowers seattored : bracts mostly somewhat persistent.

Rather tall, slender: leallets linear.

leaflets 8 to 10 , smooth above : bracts long, deciduons.

Villous : leaflets 5 to 9 , tho upjer much smaller: brocts short.

Puberulent: leaflets 5 to 7 , tmunente: bracts short.

39. L. Merocarpus.

40. L. DENSIFLon:

41. L. LUTEOLUS.

42. Lo PUSILTES

43. L. BHEVICAULIS.

29. L. AFFISIS.

30. L. Naxlis.

31. L. MIELA:THU:

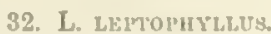

33. L. SLAIREIF, TIR:

34. L. THUNCATI:s.

Stouter, branched : leaflets bromler : flowers large: bracts short.

P’uberulent : standard yellow ; wimgs piuk : bracts deciduous : prod smooth.

Very hispid: llowers purple.

Low, villous: leatlots broaler: flowers small : bracts short, persistent.

Hairs long: potals 3 or 4 lines long: lower lip of tho calyx uarrow snd tritid.

Hairs short: flowers snaller, nnrow : ruenes sulsessile: lower lip broal, subentire.

35. L. STIVEIT.

36. L. HLELTTLSIMU'

37. Lo conesings,

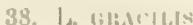


* * Perennials, dwarf and cespitose. - In the Sierra Nevada.

Stems completely herbaceous, with rather long internodes.

Loosely villous with long hairs.

Appressed-silky, the hairs shorter.

Stems leafy, from a spreading woody caudex : appressed-silky.

Leaflets 7 to 10, obtuse : peduncles short : standard orbicular.

Leaflets 5 to 6 , acutish : peduncles elongated : standard elliptical.

25. L, ARIDUS.

26. L. MINIMUS

27. L. BrEWERI.

28. L. Lyalis.

* * * Perenuials, more or less shrubby at base, tall and leafy, silky-pubescent: petioles mostly short: flowers large: ovules 6 to 12 .

Pubescence not dense: leaflets narrowly lanceolate: flowers yellow : ovules 10 to 12 .

1. L. ARBorEUS.

Pubescence dense : leaflets broader, obtuse : flowers blue to white : ovules 6 to 8 .

- Pubescence short, mostly tomentose : leaflets oblanceolate: bracts long: flowers blue : ovules 8 or 9

2. L. Chamissonis.

3. L. DouglasiI.

**** Perennials, herbaceous, mostly tall : flowers large : ovules 6 or more, excepting $L$. Sitgreavii and $L$. Grayi.

Leaflets smooth above, oblanceolate : flowers not yellow.

Petioles elongated : stem somewhat succulent : bracts short and deciduous. Sparingly villous: leaflets 10 to 16 , large : stipules broad: ovules 9.

Petioles scarcely exceeding the ( 5 to 10 ) leaflets: bracts mostly long.

Nearly glabrous, erect: stipules nariow: ovules 8 to 10 .

Calyx subvillous : stipules broader: bracts more hairy, subpersistent : lower petioles elongated : pedicels short

More pubescent or villous, subdecumbent, leafy : leaflets 5 to 8 , smaller : keel ciliate : ovules 10 to 12

Puberulent and subvillous : bracts short: ovules 5.

Leaflets pubescent both sides, as long as the petioles : ovules 6 to 8 .

Flowers yellow: keel ciliate: bracts long.

Flowers not yellow : bracts short : leaflets 5 to 9.

Erect, tall : pubescence often scanty : keel narrow, strongly falcate, naked; standard naked.

Subdecumbent, appressed-silky : standard silky ; keel ciliate.

Hoary-tomentose, a span high : standard naked; keel ciliate.

4. L. POLYPHYLLUS.

5. L. RIVULARIS.

6. L. BurkeI.

7. L. LITTORALIS.

10. L. Sitgreavesit.

8. L. SABINII.

9. L. ALBICAULIS

11. L. ORNATUS.

14. L, Grayi

***** Perennials, herbaceous, mostly rather low : flowers smaller : ovules 6 or less.

Leaflets glabrous above,

Mostly shorter than the petioles : standard naked.

Tall, scantily puberulent: keel usually naked: pod small, 24-seeded.

A span high or less, sparingly villous : keel strongly ciliate : pod broal, 6-ovuled.

Equalling the petioles : appressed-silky: petals naked or nearly so: pod shont, 3-5-ovuled.

Leaflets pubescent on both sides.

Leaves distant; lower petioles elongated.

Pubescence villous, spreading : bracts deciduous, often long: standard hairy : keel ciliate.

Densely silky-tomentose, stout: pedicels very short: bracts subpersistent: standard very hairy : keel subciliate.

Densely appressed silky-villous, often low: bracts deciduous : standard naked.

Silky-villous : raceme dense : bracts persistent: standard oblong, naked.

Stems leafy ; petioles short.

Standard and keel naked : calyx not spurred.

Puberulent, much branched, slender.

Densely silky-tomentose : flowers very small.

19. L. PARVIFLORUS.

17. L. oNustus

22. L. ARGENTEUS.

12. L. SERICEUS.

13. L. LEUCOPHYLLUS.

15. L. LEPIDUึS.

16. L. CONFERTUS.

18. L. ANDERSONII.

24. L. MEIONANTHUS.

Standard and keel more or less hairy : calyx spurred.

Finely appressed-silky: calyx strongly spurred : standard longest. 20. L. CALCAratus.

Appressed-puberulent : leatlets narrower : petals equal.

Close silvery-silky : calyx slightly spurred.

21. L. LAXIFLORUS.

23. L. HOLOSERICEUS. 
\$1. Flowers in terminal racemes: sides of the standrud rettecent: ountes sterul: cotyledons petioled in germination. - Lupixus proper.

* Perennials, not dwarf: stems somewhat woody in Nos. 1 to 3, the rest voholly herbaceous, and $\mathrm{T}$ os. 4 to $T$ mostly succulent and fistulons: prods oblong. Spec. 1 to 24.

+ Flowers large: ovules 6 to 12.

++ More or less uondy at base, tall, lenfil, with short petioles: pubescence silky, mostly appressed: bracts deciduous: founers on slender pedicels: calyx-lips nenrly equal: ovules mostly 8 to 12 .

1. L. arboreus, sims. Shrubly, often \pm to 10 feet high: pubescence not dense, short : leathets $i$ to 11 , musty 9 , clabrate ahove, narruwly lanceolate, 3 to $1 \frac{3}{4}$ inches lonis, acute: raceme luse; bracts linear, equalling the calyx: fluwers mostly rerticillate, sulphur-yellow, frarrant : calyx-lips brokd, entire or nearly so: keel slimhtly ciliate: peul pubescent, usually 10 - I-2-setele 1,11 to 3 inches long, 4 to 6 lines wile: seeds ohlonesoval, terete, three lines lons, dark-colured. - But. Ifag. t. 68.2; Liull. Bot. Iieg. xxiv, t. 32; Watson, 1. c. 523. L. riveluris, Agardh, Synopsis, 24. L. macrocarpus, Hook. \& Arn. Bot. Beechey, 138.

From Sacramento Valley to San Diego, common; from April to August. Specimens rarely

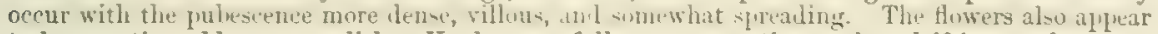
to be sometimes blue or purplish. Used successfully as a protection against drifting sands.

2. I. Chamissonis, Esch. Less shmbhy, 1 to $\&$ feet hirh : puhesence rense, appressed: Deatiets 7 to 9, cuneate-obovate, a half to an inch lim s. olituse and rut cronulate or acutish, very silky on both siles: bracts lancenlitte. shorter than the calyx: Howers sulwerticilate, blue, violet, pink, or white : upper calyx-lip deeply cleft; bractlets smill, setaceous: lieel msially slishtly eiliate: orules 6 to 8: mol

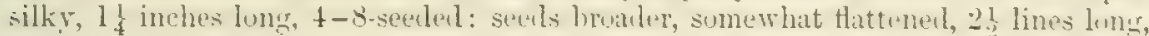
lisht-colored and mottled. - Mem. Acad. Petr. x. 288. L. albifrons, Benth. in Hort. Soc. Trans. n. ser. i. 410 ; Linill. Bot. Reg. t. 1642; Watson, 1. c. 523. L. sericeus, Hook. \& Arn. Bot. Beechey, 138.

Var. longifolius, 1 iatson. Sureely wouly at hase: stams less leaty and petioles more elongated: keel pubescent near the margin.

Var. (l) longebracteatus, Witson. Stem and hrampes more nr lose villnus : bracts much exceeding the calyz. - L. macrocarpus, Torro in Pacif. R. Rep. iv. 81.

From Oregon to Southern California, common. The variety longifolins from San Diego (CleveTencl) to Ojai (Pechham), San Pascual (Thurber) and San Antonio River, Breacer. The var. longcbradeches about San Francisco (Bigelow, Grcene), and Punta de los Reyes, Bigclore.

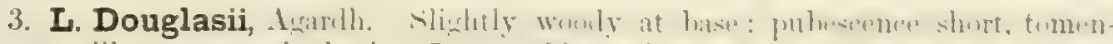

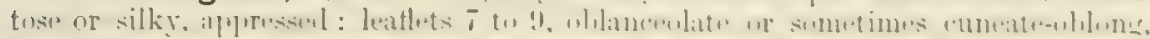

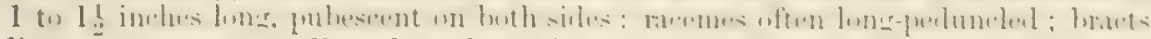
linear-setaceous, exceeding the calyx: flowers scattered or subverticillate, blue or

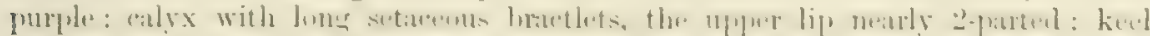
ciliate: ovules 8 to 9 : pod unknown. - Synopsis, 34 ; Watson, 1. c. 524.

From above San Francisca to Monterey and Los Angeles.

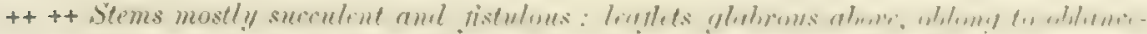

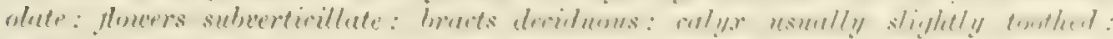
ovules 8 or more.

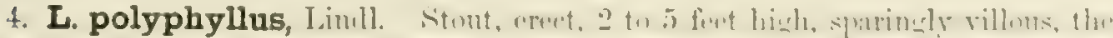

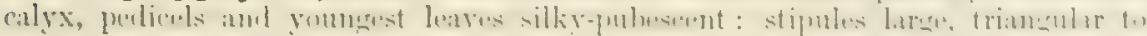
subulate: leaves distant, long-petioled; lenflets 10 to 16 , or often 8 to 10 in tho upper leaves, 2 to 6 inches long: racemes frequently a font or two lnng; bmets ob-

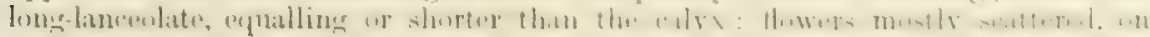

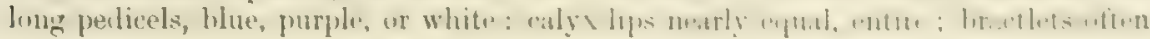


wanting: keel naked: pod 1 to $1 \frac{1}{2}$ inches long, 3 to 4 lines broad, 7 -9-seeded. Bot. Reg. t. 1096 \& t. 1377; Watson, 1. c. 524. L. macrophyllus, Benth.; Sweet, Brit. Fl. Gard. 2 ser. t. 356. L. grandiflorus, Lindl.

From Washington Territory to Klamath Valley and San Francisco.

5. I. rivularis, Dougl. Stout, erect, 2 to 6 feet high, nearly glabrous, the short and silky pubescence closely appressed, or very rarely spreading on the calyx and pedicels: stipules subulate or setaceous; leatlets 7 to 10 , about equalling the petioles, $\frac{1}{2}$ to 5 inches long, oblanceolate, acute or the lower ones obtuse : raceme long-peduncled, often 1 to 2 feet long; bracts setaceous, exceeding the ealyx: flowers seattered or subverticillate, purple or sometimes white: bractlets caducous ; upper calyx-lip sometimes entire: keel slightly ciliate: pod large, 8-10-seeded. - Lindl. Bot. Reg. t. 1595 ; Watson, 1. c. 525. L. cytisoides, Agardh, Synopsis, 18.

Var. latifolius, Watson. Leaflets 5 to 7 , spatulate or oblanceolate, obtuse and mucronulate or the upper acute: the pubescence upon the calyx more frequently spreading. - Proc. Am. Acad. viii. 525. L. latifolius, Agardh, Syn. 18; Lindi. Bot. Reg. t. 1891.

From the Columbia River to Southern California, common; the typical form frequent in the Sierra Nevada; the variety more common nearer the sea.

6. L. Burkei, Watson. Resembling L. rivularis, but distinguished by broader stipules, and the lower leaves long-petioled: raceme usually short and dense, the pedicels mostly only 1 or 2 lines long; bracts villous and often persistent: the pubescence of the calyx somewhat villous and more or less spreading: pod 8-seeded. - Proc. Am. Acad. viii. 525. L. polyphylles, Watson, Bot. King Exp. 55.

On the east side of the Sierra Nevada from Northern Nevada to Montana, and probably to be found in Northeastern California.

7. I. littoralis, Dougl. Stems slender, decumbent or ascending, 1 or 2 feet long, often not succulent, leafy : pubescence silky, rather thin, short and appressed, or villous and spreading especially about the axils: leaflets 5 to 8 , oblanceolate or cuneate-oblong, acute, a half to an inch long, at least half as long as the petioles: racemes short; bracts setaceous, exceeding the calyx : flowers blue or violet, with some yellow, verticillate or scattered, on rather short pedicels : calyx large, with small bractlets: keel ciliate: ovules and seeds 10 to 12. - Lindl. Bot. Reg. t. 1198; Hook. Bot. Mag. t. 2952 ; Watson, 1. c. 526. L. versicolor, Lindl. Bot. Reg. t. 1979. L. Nutkatensis, var. fiuticosus, Bot. Mag. t. 2136.

Near the coast, from Vancouver Island to San Francisco. The taper root is said to be known in Washington Territory as "Chinook Liquorice."

+++++ Leafy and branching; the petioles not longer than the leaflets: flowers sub-

verticillate, yellow in L. Sabinir: bracts deciduous, shorter than the calyx: ovules

6 or 7 , rarely 8, only 5 in L. Sitgreavii: mostly erect or ascending, 1 or 2 feet high.

8. L. Sabinii, Dougl. Stout, erect : pubescence short, appressed, silky : stipules long, setaceons; leaflets 8 to 11, oblanceolate, acuminate, 2 or 3 inches long, silky on both sides: raceme 6 to 10 inches long, rather dense and long-peduncled ; bracts exceeding the calyx, linear-setaceous : flowers bright yellow : upper calyx-lip short, nearly entire, the lower narrow: standard emarginate, naked; keel ciliate : pod unknown. - Hook. Fl. i. 166 ; Lindl. Bot. Reg. t. 1435 ; Watson, l. c. 527.

This has been collected only by Dorglas and Nevins, in the Blue Mountains of Oregon, but may occur in Northern California ; distinguished by its long racemes of yellow flowers.

9. L. albicaulis, Dougl. Pubescence short and appressed, or more or less villous and spreading, often scanty: leaflets 5 to 9 , oblanceolate, 1 to 3 inches long, acute, pubescent on both sides or glabrous above: raceme mostly short-peduncled; bracts subulate: calyx long, with nearly equal lips, the upper narrowed and shortly toothed: petals blue, verging to white; the standard naked, acute, with the margins 


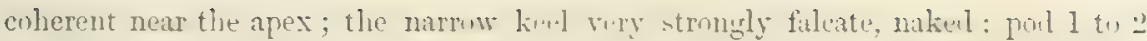
inches long. - Hook. Fl. i. 165 ; Watson, 1. c. 527.

Var. Bridgesii, Watson, 1. c. The more villous form, with very large flowers and dense racemes : seeds nearly 4 lines long.

Frequent, from the Columbia River to San Diego, throughout the State; variable but well marked by the characters of the flower. The mature fruit of the ordinary forms is mot kuown.

10. L. Sitgreavesii, Witsum, l. c. l'uherulent and sumerbat silky-rillus with spreading lairs: stipules setaceous; leaflets 7 to 9 , oblanceulate, acute, 1 to 3 inches long, usually glabrous above: raceme open, shortly peduncled; pedicels slender:

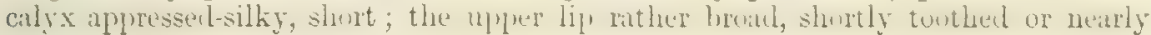
entire: standard rounded, naked; keel ciliate or naked : ovules 5.

Found on the San Francisco Mlountains in Arizona and eastward, and also what appears to be a. more glabrous form (2012 Brewer) at Ebbett's Pass in the Sierra Nevada.

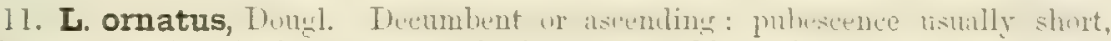

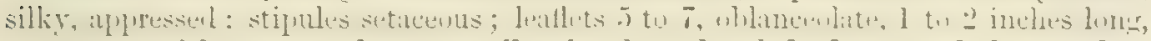
acute or acutish : raceme loose, usually shortly peduncled; bracts subulate: calyx-

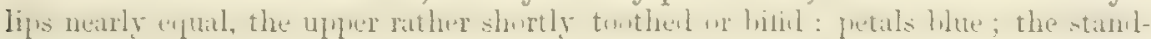
ard acutish, somewhat silky on the back, often paler especially in the centre; the keel ciliate: pod 11 inches long: seed white, nearly orbicular, compressed, 21 lines long. - Lindl. Bot. Reg. t. 1216; Sweet, Brit. Fl. Gard. 2 ser. t. 212; Watsun, 1. c. 528 .

From the Columbia River to Lassen's Peak and Mit. Shasta, at 8,000 to 10,000 feet altitudo (Brewer); Montana and W. Wyoming, Parry.

+ + Flowers smaller, except in L. Grayi, never yellow: ovules 3 to 6.

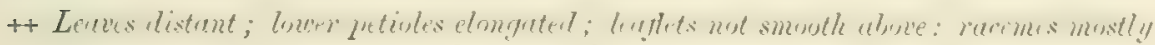
dense: ovules + to 6.

12. L. sericeus, Pursh. Rather stout, 1 to 2 feet high: pubescence of coarse or somewhat silky spreadiug hairs: leaftets 5 to 8 , rarely 10 , narrowly oblanceolate, 1 to $2 \frac{1}{2}$ inches long, acute: peduxules short: bracts deciduous, often much exceeding the calyx: pedicels slender, 2 or 3 lines long: calyx strongly gihbous, densely

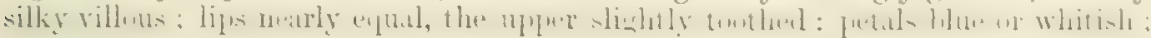
the standard hairy and keel ciliato: pod densely hairy, an inch long. - Flora, i. 468 ; Watson, 1. e. 529 .

From Oregon to Northern Nevada, Utah, and Montana, and doubtless to be fount in North. castern Calitornia.

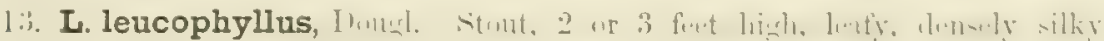
tomentose throughut and somewhat villous: leaflets 7 to 10 , oblanceolate or cune-

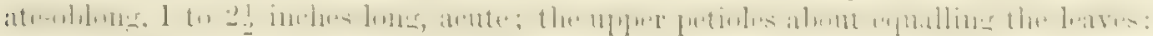

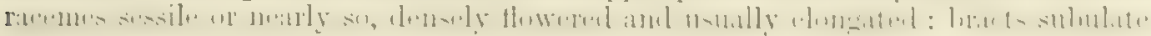
or linear, subpersistent or deciduous: pedicels stout, a line long or less: upper calyx-lip rather deeply cleft: petals blue or pink; the stanulard densely villous, the keel naked or ciliate. - Lindl. Bot. Ileg. t. 1124 ; Watson, 1. c. 529. L. plumosus, Dougl. ; Linill. Bot. Leg. t. 1217.

From the Caseade Mountains of Oregon to Utah und New MLxico ; abovo Carson City (Adudersone) and probubly morthward in the Sierra Nevalu

14. L. Grayi, Watson. A span high, rather stout, rensely hoary-tomentose, usually with some silky hairs: leaftets 5 to 9 , cuneate-oblung or oblanceolate, ubtuse or acutish, t to $1 \frac{1}{2}$ inches long, shorter than tho petioles: racerues perluucled, short and loosely flowered; bmets subulate, equalliner the calyx; pedicels more slenter, 1 or 2 lines leng: flowers subverticillate, light blue, 6 to 7 lines long, with hrual wings aul broul usked stantart: keel ciliate: pol an inch long or more, 5-6. seeted. - Proc. Am. Acad. xi. 126. 
In the Sierra Nevada from Mariposa Co., near Clark's (A. Gray), to Indian Valley, Plumas Co., Nrs. M. E. P. Ames.

L. Patmeri, Watson, 1. c. viii. 530, from the San Francisco Mts., Arizona, is densely pubescent with rather rigid straight more or less spreading hairs ; leaflets swall, acute ; flowers small, in a narrow peduncled raceme, with short deciduous bracts; corolla deep blue; standard somewhat hairy ; keel naked.

L. NIveus, Watson, 1. c. xi. 126, is another allied species, from Guadalupe Island (Polmer), densely white-tomentose, not villous; the deep blue rather small flowers on slender pedicels; petals all naked.

15. L. lepidus, Dougl. Slender, often low, a span to two feet high, leafy at base, densely appressed silky-villous : leaflets 7 to 9 , narrowly oblanceolate, $\frac{3}{4}$ to $1 \frac{1}{2}$ inches long, acute, on elongated petioles : bracts not exceeding the calyx, deciduous: flowers verticillate or scattered, on short pedicels, in an elongated long-peduncled raceme: upper calyx-lip toothed or deeply cleft : petals violet, the standard naked and keel ciliate: pod an inch long. — Lindl. Bot. Reg. t. 1149; Watson, l. c. viii. 530 .

From Puget Sound to Klamath Lakes, and collected by Bolander in Bear Valley in the Sierra Nevada ; near Carson City, Nevada, on foot-hills, Bloomer, Watson.

16. I. confertus, Kellogg. Erect or ascending, a foot high or more: pubescence silky-villous, appressed or spreading: leaflets 5 to 8 , cuneate-oblong to narrowly oblanceolate, $\frac{3}{4}$ to $1 \frac{3}{4}$ inches long, acute: raceme usually dense, rather longpeduncled; bracts persistent, setaceous, about equalling the calyx : flowers verticillate, nearly sessile, blue or rose-colored : upper calyx-lip 2-cleft : standard naked, rather narrow ; the keel ciliate: pod three fourths of an inch long, 2-4-seeded : seeds nearly round, white.-Proc. Calif. Acad. ii. 192, fig. 59 ; Watson, 1. c. L. Torreyi, Gray; Watson, Bot. King Exp. 58. L. sellulues, Kellogg, Proe. Calif. Acad. v. 36.

In the Sierra Nevada from Yosemite Valley to Washoe Lake and Donner Pass. Well marked by its conspicuous persistent bracts.

17. L. onustus, Watson. Low, a span high or less, with a decumbent somewhat woody base, rather sparingly silky-villous: leaflets 5 to 8 , oblanceolate, acute or acutish, glabrous above, about an inch long; the petioles two or three times longer: flowers deep blue, small, scattered in a loose short and shortly peduncled raceme: bracts short, deciduous: pedicels slender: standard naked ; keel strongly ciliate: pod an inch and a half long, half an inch broad, 6-ovuled : seeds large, over three lines broad. - Proe. Am. Acad. xi. 127.

Iadian Valley, Plumas Co. (Mrs. M. E. Pulsifer Ames); Sierra Co, Lemmon. Somewhat resembling $L$. parviftorus on a reduced scale, but the fruit very distinct.

+++ Stems leafy: petioles and peduncles mostly short: bracts deciduous, usually short: ovules 3 to 5 .

18. I. Andersoni, Watson. Slender, about a foot high, much branched and leafy, finely appressed pubescent: leaflets 7 to 9 , narrowly oblanceolate, acute or obtuse, pubescent both sides, about an inch long, equalling the petioles: racemes short and shortly peduncled; pedicels 1 or 2 lines long: calyx not saccate, the lips nearly equal : petals blue or pinkish; standard and keel naked: pod $1 \frac{1}{4}$ inches long: seed light-colored, 3 lines long. - Bot. King Exp. 58, and 1. c. viii. 531.

Var. (?) Grayi, Watson, 1. c. Leaflets cuneate-oblong, obtuse or emarginate, 6 to 9 lines long; the whole plant densely appressed-hairy.

In the Sierra Nevada, near Carson City (Anderson); the variety, a very doubtful form, near Clark's Ranch in Mariposa Co., A. Gray. Scanty specimens of another allied form, densely hairytomentose, with narrowly oblanceolate leaflets, have been collected by Rothrock on the North Fork of Kern River, at 8,500 feet altitude.

19. L. parviflorus, Nutt. Stems mostly solitary, strict, erect, slender, 2 or 3 feet high, at length somewhat branched: pubescence scanty, short, appressed, the ealyx and pedicels silky: leaves rather distant; leaflets 5 to 11 , oblanceolate to 
obovate, 1 or 2 inches long, acute or obtuse, glabrous ahove, the lower lenves shorter than the petioles: raceme $l$ to 1 foot long, slender; bracts linear-subulate, erqualling the calyx; pedicels slender, 1 to 2 lines long: calyx-lips nearly equal : petals lightitblue; the standard naked; the keel naked or ciliate: porl $\frac{3}{4}$ inch lung, $2-4$-seetert, pubescent : seeds light-colored, two lines in diameter. - Hook. \& Arn. But. Beechey, 336 ; Watson, 1. c. 531.

In the mountains from the Columbia River to Yosemite Talley, and eastward to the Walsatch.

20. I. calcaratus, Kellogr. Stems elustererl, as in most perennial species, rather stout, 1 to 2 feet high, finely appressed-silky: leaflets 6 to 12 , usually 9 , oblanceolate, 1 or 2 inches long, acute, more or less silky on both sides, at least half as long as the petioles: ricemes 3 to 6 inches long; brats subulate; pedicels slender, 1 to 3 lines long: calyx silky, conspiruously spurred, the lips unequal: petals white or lolue; the pubescent stamlarl six lines long, exceeling the wings and ciliate keel: poul an inch long : seeds licht-enlurecl, nearly three lines lung. - Proc. Calif. Acad. ii. 195, fig. 60 ; Watson, 1. c. 531.

On the eastern slope of the Sierra Nevada and eastward in Northern Nevada.

21. L. laxiflorus, Dougl. Wlender, 1 to 2 feet high: pubescence short, silky, appressed : leaflets 6 to 8 , narrowly ohlanceolite, acute, silky on both sides, at least hillf as long as the petioles: racenes loose and slender; pedicels 2 to 3 lines lomer : calyx narrowed and saccate at hase, the upper lip shortly toothed: petals blue, 3 to 5 lines long, equal; tho standard somewhat pubescent and keel ciliate: poul less than an inch long: seeds two lines in diameter. - Lindl. Bot. Reg. t. 1140 ; Watson, 1. c. 531. L. arbustus, Dougl.; Lindl. Bot. Reg. t. 1230. L. caudatus, Kellogg, Proe. Calif. Acad. ii. 198, fig. 61.

From Vancouver Island to Klamath Valley and Donner Pass, and eastward to the Walisatch Mountains; also Arizona, Palmcr.

22. L. argenteus, Pursh. Slender, 1 or 2 feet high, honry with short silky appressed pubescence: leaflets 5 to 8 , linear-lancelate, 3 to 1 inches long, acuti, smooth above or nearly so, about equalling the petioles : racemes nearly sessile. "- to 6 inches long; pedicels very slender, usually short: calyx campanulate, cribuus hut not spurrent at base, the upper lip broul and touthed : petals hlue or creamcolored, 3 or 4 lines long; standarl very broal, naked or slightly hairy; the keol naked or subciliate : pod short: ovules 3 to 5. - Florn, i. 468 ; W atson, 1. c. 532.

Plains of the Columbia and Snake Rivers, and eastward; probably in Northeastern California.

23. I. holosericeus, Nitt. Silemler, 1 to 11 fert high: puhesence silvery-

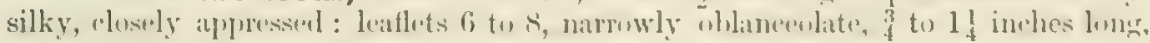
at least half ats long as the petiolos, acute, rery silky on both silles: ratermes nearly

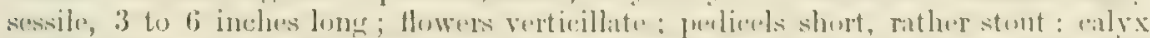

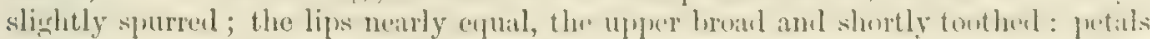

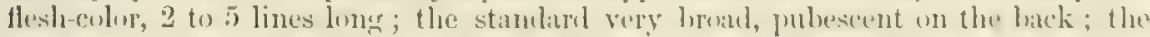
keel ciliate: pod an inch long: seeds mather large. - Torr. \& Gray, Flora i. 380 ; Watson, 1. c. 532.

Liast of the Sierra Nevada from the Columbin River to Sonthern Nevada.

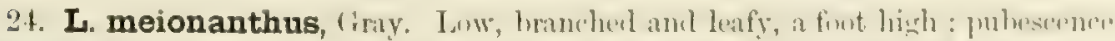

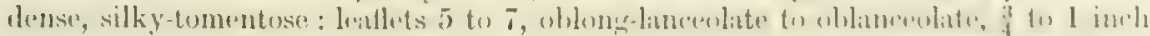

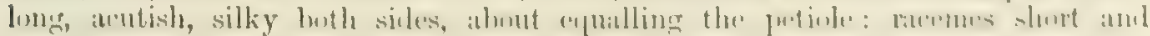
small, nearly sessile; bracts ovate; flowers subverticillate or senttered, blue, on pedicols $\frac{1}{2}$ to 1 line long: calyx campanulate, not spurred, densely tomentose:

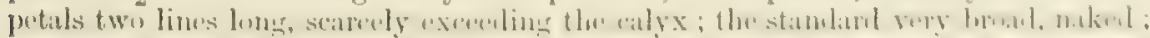

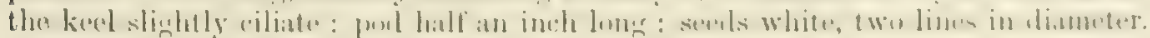
- Proc. Am. Acad. vi. 522 ; Watson, 1. c. 533.

Collected only by Dr. Anderson near Carson City, probably in the Sierm Neval... 
* * Dvarf perennials, mostly cespitose: racemes usually short and dense; bracts somewhat persistent; flowers subverticillate, on short pedicels: upper calyx-lip 2-cleft (2-toothed in L. aridus), the lower 3-toothed: keel ciliate: ovules 3 to 6: pod hairy, oblong, 3-4-seeded.

25. L. aridus, Dougl. Stems cespitose, 2 or 3 inches long : pubescence villous, both loose and appressed: leaflets 5 to 7 , oblanceolate, an inch long or less, acute, the petioles 3 or 4 times longer: raceme dense, 2 or 3 inches long; peduncle shorter than the leaves; bracts nearly equalling the calyx: petals purple, 5 lines long; the elliptical standard usually shorter: pod 5 lines long. - Lindl. Bot. Reg. t. 1242 ; Watson, 1. c. 533.

Var. Lobbii, Watson, l. c. Leaflets obovate or oblanceolate, half an inch long, the petioles 2 or 3 times longer: peduncles exceeding the leaves: calyx-lips more strongly toothed: standard broader.

Washington Territory and Oregon: the variety in the higher Sierra Nevada $(L \circ b \bar{b})$; above Ebbett and Sonora Passes, at 8,500 and 12,000 feet altitude, Brewer.

26. L. minimus, Dougl. Appressed silky-villous: stems 3 to 6 inches high: leaflets 5 to 7 , obovate or oblanceolate, 3 to 8 lines long, mostly acutish, the petioles 3 or 4 times longer: peduncles equalling or exceeding the leaves : bracts linear: upper calyx-lip deeply bifid: petals purple, 4 or 5 lines long; the standard orbicular. - Hook. Fl. i. 163; Watson, l. c. 534.

Oregon and Washington Temitory, to Northwestern Wyoming (Potry), and in the high Sicrra Nevada ; above Cisco (Kellogg); Summit Station, in shade, Greene.

27. L. Breweri, Gray. Stems 6 inches long or less, from a spreading branched woody caudex, very leafy: pubescence dense, silky, appressed: leaflets 7 to 10 , obovate, obtuse, 4 to 6 lines long, at least half as long as the petiole: racemes very short, the peduncle equalling the leaves; bracts short: calyx-lips nearly equal ; the upper deeply bifid, the lower shortly and equally toothed: petals blue, equal, 3 to 4 lines long; the standard orbicular. - Proc. Am. Acad. vi. 334; Watson, l. c.

In the Sierra Nevada from Mt. Pinos and the North Fork of the Kern River, from 8,000 to 12,000 feet altitude (Rothrock) and Yosemite Valley, at 6,000 to 8,000 feet altitude (Brewer, Groy), to Sierra Co., Lemmon. Stems sometimes very short and densely matted.

28. L. Lyallii, Gray. Stems leafy, from a spreading woody caudex: pubescence dense, villous, appressed : leaflets 5 or 6 , obovate, 3 or 4 lines long, acutish, the petioles much longer: racemes very short, the peduncles much exceeding the leaves; bracts short: calyx-lips nearly equal: petals purple, five lines long, nearly equal; the standard elliptical. — Proc. Am. Acad. vi. 334; Watson, 1. c.

Var. Danaus, Watson, l. c. Stems less leafy : pubescence less abundant : flowers nearly white; the keel tipped with dark-purple. - L. Danaus, Gray, 1. c.

Alpine; summits of the Caseade Mountains, Washington Territory (Lyall); the variety on Mt. Dana, at 12,500 feet altitude (Bolander), and on the North Fork of Kern River, at 8,000 feet, Rothrock.

$$
\begin{gathered}
\text { * * Annuals: leaflets mostly } 5 \text { to } 7 \text { (in L. leptophyllus, } 8 \text { to 10) : upper calyx-lip } \\
\text { 2-parted or bifid: pod linear, 4-8-seeded. } \\
\text { + Flowers verticillate: bracts deciduous. }
\end{gathered}
$$

29. I. affinis, Agrarth. Stem a foot high, rather stout : pubescence very short, more or less spreading: leaflets broadly wedge-obovate, an inch long or more, emarginate or obtuse, smoother above; the petioles twice longer: peduncles long; bracts short: petals 5 lines long; the keel usually naked: ovules 5 to 7 . - Synopsis, 20, in part; Watson, 1. c. 535. L. cervinus? Kellogg, Proc. Calif. Acad. ii. 229 , fig. 73 .

From San Francisco and Bear Valley (Kellogg) to San Diego; in early spring. Distinguished from the larger-flowered forms of the next species by its short pubescence, broader and obtuser 
leaflets, usually smooth above, and its short bracts. Dr. Kellogg's $L$. cervinus appears to be a stout form, with large leaves and short pedicels.

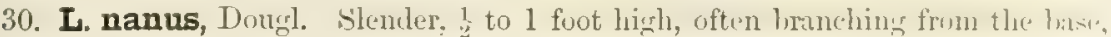
villous or finely pubescent: leaflets linear to oblanceolate, half to an inch long, usually acute, pubescent on both sides, the petioles 1 to 3 times longer: racemes loose; bracts exceeding the calyx; pedicels sleuder : upper calyx-lip 2-cleft: petals usually 5 or 6 lines long, very broad, bluish-purple or at first nearly white; the stamlard shorter and usually marked with dark-purple lines: uvules $6 \mathrm{j}$ to $\mathrm{s}$ : junl to $1 \frac{1}{4}$ inches long. - Benth. in Hort. Trans. n. ser. i. 409, t. 14; Watsou, l. c.

From Sacramento Valley to Southern California, frequent. Flowering in early spring and rather variable.

31. I. micranthus, Dougl. Slender, 3 to 12 inches high, villuus: leatlets linear, $\frac{1}{4}$ to 1 inch long: racemes short, often rather dense; bracts shorter than the calyx; pedicels a line long or less: calyx-lips broad, the upper with slort triangular lobes: petals 2 or 3 lines long; the wings and standard very narrow.-Lindl. Bot. Reg. t. 1251 ; Watson, l. c.

Var, microphyllus, Watson, l. c. The lower and more hirsute form, with the leaflets but 3 to 6 lines long.

Var. bicolor, Watson, l. c. Flowers a little larger, with the petals somewhat broader, and pedicels 1 or 2 lines long. — L. bicolor, Lindl. Bot. Reg. t. 1109.

Var. trifidus, Watson, L. c. Very hairy; lower lip of the calyx 3-parted.

From Puget Sound to Southern California, very frequent; the var. trifudus uear San Francisco, remarkable for the division of the calyx. The var. bicolor approaches forms of $L$. nunzes, and tends to unite the two species.

++ Flowers scattered: bracts more or less persistent, except in L. leptophyllus and L. Stiveri: ovules 4 to 6 , or 8 in $L$. truncatus.

32. I. leptophyllus, lientli. Slender, rumb brinchenl, 1 or 2 fiet high, ril. lous: stipules linenr-setaceous: leaflets 8 to 10 , narrowly linenr, 1 to $1 \frac{1}{2}$ inches long. glabrous above; the very slender petioles 2 or 3 times longer: racemes 3 to 10 inches long; bracts setaceous, much exceeding the calyx: upper calyx-lip narrow, deeply cleft: petals 5 or 6 lines long, bluish-lilac, with a deep-crimson spot upon the standard. - Hort. Trans. n. ser. i. 409 ; Watson, 1. c. 536.

Sacramento Valley and southward, on bills and in rocky places. A form occurs with rather bruader lenves.

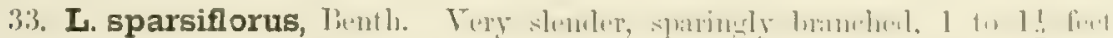
high, villous with spreading hairs: upper leaves much reduced: leaflets 5 to 9 , linear, $\frac{\pi}{4}$ to 1 inch long; the narrow petioles 2 to 4 times longer: bracts linearsetaceous, shorter than the calyx, subpersistent; pedicels short: upper calyx-lip 2-parted: petals violet, 5 lines long; the standard shorter: pod a half to an inch long. - Pl. Hartweg. 303 ; Watson, 1. c.

From the Sacramento Valley to Southern California.

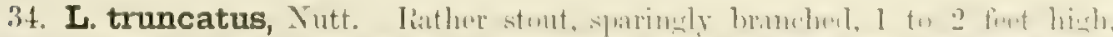

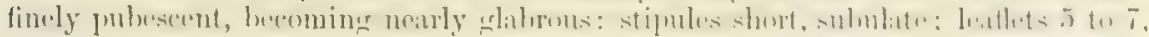
linear, narrowed from the truneate or somewhat 3-toothed apex to the base, smooth

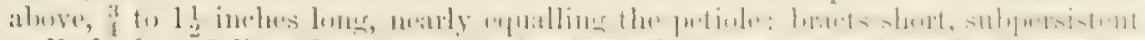
pealicels to to 2 lines long: upper calyx-lip 2-cleft: protals decp-purple, 4 or 5 lines long; the staudarl shorter: pod 1 t inches long. - Houk. of Arn. Bot. Becehey, 3:36; Watson, l. c.

From San Fruncisco to San Diego.

35. L. Stiveri, Kellngg. Diffusely branched, about a foot high, fincly amu rather sparingly pubescent: leaflets 5 to 7 , brually cunento-obovate, $\frac{1}{2}$ to $1 \frac{1}{2}$ inches

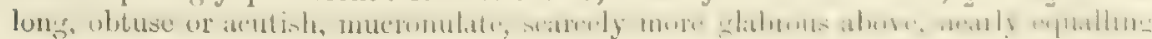


the petioles: racemes 2 or 3 inches long, 5 -10-flowered, rather long-peduncled; bracts short; pedicels 1 or 2 lines long: upper calyx-lip 2-parted with broad acute lobes: petals 6 or 7 lines long; the yellow standard shorter than the rose-colored wings: pod an inch long, nearly glabrous. - Proc. Calif. Acad. ii. 192, fig. 58 ; Watson, 1, c. 537 .

In the Sierra Nevada from Nevada Co. to Mariposa Co. A peculiarly handsome and well marked species.

36. I. hirsutissimus, Benth. Stout, a foot high or more, very hispid with spreading straight and viscid stinging hairs: leaflets 5 to 7 , broadly cuneate-obovate, obtuse or retuse or sometimes acute, mucronulate, $\frac{3}{4}$ to $1 \frac{1}{2}$ inches long, half as long as the petioles: racemes loose, 3 to 8 inches long; bracts short, subulate, usually deciduous; pedicels 1 or 2 lines long: calyx large, the broad upper lip deeply cleft : petals six lines long, nearly equal, reddish-purple : pod hirsute, an inch long. - Hort. Trans. n. ser. i. 409 ; Watson, 1. c.

In dry places, from the Sacramento to Southern California.

37. L. concinnus, Agardh. Low, 4 to 6 inches high, densely villous or hirsute: leaflets 5 to 8 , oblanceolate, 4 to 10 lines long, obtuse; the slender petioles 2 to 4 times longer : raceme short, often nearly sessile; bracts short, linear-setaceous, persistent; pedicels very short: upper calyx-lip 2-parted, the lower rather deeply trifid: petals 4 lines long; violet; the standard shorter, with a yellow spot in the centre: pod 4-seeded. - Synopsis, 6, t. 1; Watson, 1. e.

Var. Arizonicus, Watson, 1. c. Rather stout, a span high, more sparingly hirsute: leaflets oblanceolate to linear, obtuse or acute: raceme more elongated: petals 3 or 4 limes long, equal, ochroleucous or tipped with violet : pod half an inch long, $3-5$-seeded.

From Monterey to Sonora, rarely collected; the variety in Southeastern California and Arizona.

38. I. gracilis, Agardh. Slender, 3 to 6 inches high, very hairy : leaflets 5 to 7, cuneate-obovate, 3 to 6 lines long, the slender petioles 2 or 3 times longer: raceme short, loose, flexuous; bracts short; pedicels less than a line long: petals blue and white, 2 or 3 lines long, narrow; the standard slightly shorter; the flowers nearly as in $L$. micranthus: pod half an inch long: seeds a line in diameter. - Synopsis, 15, t. 1 ; Watson, 1. c.

From Monterey to Southern California; rarely collected.

\$ 2. Flowers as in $\$ 1$ : ovules 2 : cotyledons broad and clasping after germination, usually long-persistent. Erect annuals: leaflets cuneate-oblong or -obovate: bracts persistent: pod ovate. - Platycarpos, Watson.

* Flowers verticillate: stems tall, with elongated peduncles.

39. I. microcarpus, Sims. Villous with long hairs, $\frac{1}{2}$ to $1 \frac{1}{2}$ feet high : stipnles long, setaceous; leaves mostly approximate, on elongated petioles; leaflets usually 9 , cuneate-oblong, 1 to 2 inches long, obtuse or emarginate, sometimes acutish, smooth above: pedicels 1 or 2 lines long: bracts subulate-setaceous, equalling the calyx or shorter: calyx densely villous, large; lips toothed, the upper very short and subscarious ; bractlets often wanting : petals purple to white, 6 or 7 lines long, equal; the keel slightly ciliate: pods villous, 8 lines long. - Bot. Mag. t. 2413; Watson, 1. c. 538. L. palustris \& lacteus, Kellogg, in Proc. Calif. Acad. v. 16 $\& 37$.

Frequent from the Columbia River to Southem California ; also a native of Chili.

40. I. densiflorus, Benth. Mueh resembling the last: more sparingly villous with shorter hairs : bracts usually much shorter than the calyx, which is smooth or finely pubescent; the upper lip often entire : petals yellow or ochrolencous, rarely white or pink. - Hort. Trans. n. ser. i. 409 ; Lindl. Bot. Reg. t. 1689 ; Watson, 
1. c. - L. Menziesii, Agardh, Synopsis, 2; Hook. Bot. Mag. t. 5019. L. Menziesii, var. aurea, Kellogg, 1. c. v. 16.

From the Sacramento Valley southward; frequent.

41. I. Iuteolus, Kellogg. Rather slender, 1 or 2 feet high: pubescence short, appressed, rather silky, the bracts and poil villous: stipules short; leaves scattered, on short petioles; leaflets usually $\bar{\gamma}$, crneate-oblong, an inch lung, obtuse or acute, sumetimes smooth above : bracts linear-setaceous, exceeding the callyx: Howers as in the last; the petals pale-yellow, six lines long.-Proc. Calif. Acad. v. 38. L. Bridgesii, Gray; Watson, 1. c. 538 .

Sacramento Valley (Bridges); Napa Valley (Greene); Mendocino Co., Botcinder, Kellogg.

$$
\text { * Low: flowers scattered in the racemes: bracts shorter than the calyx. }
$$

42. L. pusillus, Pursh. Rather stout, 3 to 10 inches high, hirsute with long spreading hairs: leatlets mostly 5, cuneate-oblong or -oblanceolate, ${ }_{4}^{3}$ to $1_{4}^{1}$ inches long, acute or obtuse, nearly smooth above, about half as long as the petioles: raceme's 2 or 3 inches long, nearly sessile; pedicels 2 or 3 lines long : upper calyx-lip 2-cleft: petals purple or ruse-culor, four lines long: pod half an inch lung or more: seed nearly two lines broad. - Flora, i. 468 ; Watson, 1. c. 538.

From the Missouri to the Columbia and southrvard, east of the Sierra Nevada, to Arizona and New Mexico; doubtless occurring in Northeastern California

43. L. brevicaulis, Watson. Less hairy, or villous with soft spreading hairs, 1 to 6 inches high : stems often short or nearly wanting: leaflets usually 7 , cuneateobovate or oblanceolate, 5 to 8 lines long, obtuse: racemes dense, 1 or 2 inches long, the perluncles equalling or exceeding the leaves; pedicels a line or two long : upper calyx-lip scarious, very short or truncate: petals light or lark blue, 3 ti 5 lines long: poul 3 to 5 lines lung: seed about a line broad. - Bot. King Lxp. 53, t. 7, \& Proc. Am. Acad. viii. 539.

From Northwestern Nevada to Arizona; probably in California eastwand of the Sierra Nevada. The ovules and seeds are rarely three or four. Very variable in habit, amount of pubescence, size of the flowers, \&c. A slender and caulescent villous form much resembles $L$. Sileri, Watson, of $\mathrm{s}$. L'tah and $\mathrm{s}$. Colorado, which is distinguished by the nearly equal herbaceous lip's of the ealyx.

\section{\$3. Flowers acillary, solitrry: sides of the standurd scurcely rettexed: keel nearly straight: pod ovate: ovules 2.-Lupineluus, Watson.}

44. L. uncialis, Wation. Annual, less than an inch high, diflusely hronched,

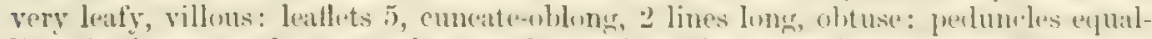
ling the leaves or sherter: calyx not batendite, the upper lip deeply cleft : petals

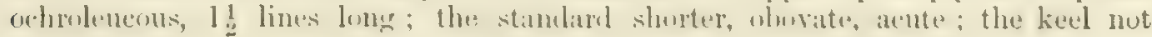
beaked, obtuse: pod two lines long. - Bot. King Exp. 54, t. 7, \& 1. c.

On rocky hillsides near tho Big Bend of the Truckee in Northwestem Nevala.

\section{TRIFOLIUM, Linn. Crover.}

Calyx 5-eleft, with nearly cyual tecth, pursistent. Cormllat withering aml persistent; claws all more or less adnate to the stamineal tube, or the oblong or ovate

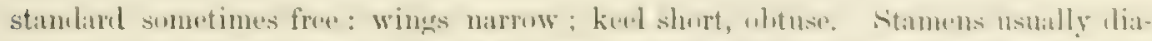
delphuss; anthers unifurm. Style filiform. Foul small and usually undesind in the

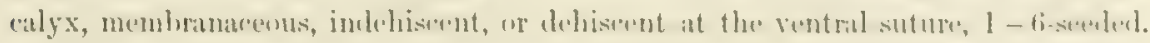
- Herbs; leaves palmately compound, with 3 or maly 5 to 7 usually toothel

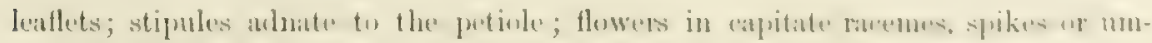

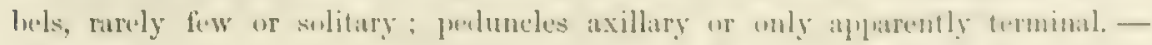
Watson, Proc. Am. Acad. xi. 127. 
A genus of perhaps 200 or more species, in temperate and subtropical regions, chiefly of the northern hemisphere. In North America it is most largely represented on the western side, only five species being native in the Atlantic States, while 40 or more are found in the region west of the Rocky Mountains, including a section with involucrate heads peculiar to the western parts of North and South America. Most of the species of the Coast Ranges and interior valleys are normally " winter annuals," the perennials belonging chiefly to the Sierra Nevada and cooler portions of the State. Few of then are sufficiently abundant to yield any important amount of forage, and none are equal in this respect to the commonly cultivated. European speeies.

* Heads not involucrate : leaflets 5 to 7 : flowers sessile : calyx-teeth filiform, plumose : perennial.

Stout, somewhat villous: flowers spicate, very large.

Dwarf, densely villous: flowers umbellate, half an inch long : leaflets nearly entire.

Dwarf, alpine, somewhat pubescent : flowers spicate, very small : leaflets coarsely toothed.

* * Heads not involucrate : leaves 3-foliolate.

Perennial or biennial : heads terminal : flowers sessile or nearly so.

More or less pubescent : calyx-teeth very narrow, much longer than the tube, plumose or hairy.

Teeth filiform, curved, very plumose : usually pubescent : heads ovate.

Teeth straight, plumose : pubescent: heads ovate to oblong : leaflets long and narrow.

Teeth straight, hairy : stem usually smooth : heads ovate.

Glabrous, stout : teeth subulate, twisted, twice longer than the tube : heads ovate to oblong.

Glabrous : teeth scarcely exceeding the tube.

Slender : heads rather small : leaflets usually narrow and acuminate, coarsely veined and toothed.

Stouter: heads large : leaftets usually broader and obtuse.

Low and cespitose : heads very small : leaflets small, broad and obtuse, finely reticulated and scarcely toothed.

Annual, pubeseent : heads mostly terminal : flowers sessile : calyx-teeth long-filiform, very plumose.

Annuals, mostly glabrous : heads axillary : flowers shortly pedicellate : calyx-teeth subulate, not plumose.

Glabrous : calyx-teeth lanceolate, rigid, the scarious margin rough. ciliate.

Glabrous or nearly so: calyx campanulate, the teeth equalling the petals : heads rather dense.

Leaflets not notched.

Leaflets deeply notched or 2-cleft.

Subpubescent throughout: calyx narrow; teeth shorter than the petals : heads very loose.

Glabrous : flowers sessile : calyx short : corolla inflated.

*** Heads subtended by an involucre : annual.

Corolla not becoming inflated : involucre not membranaceous, deeply lobed, the lobes laciniately toothed.

Glabrous : heads many-flowered: calyx-teeth thin, long and narrow, gradually attenuate, entire or setosely cleft : orules several.

Glabrous or glandular-puberulent: heads many-flowered : calyx-teeth rigid, rather abruptly narrowed from a broad base into the spinulose apex, entire or shortly toothed: ovules 2 .

Glabrous, very slendex: heads small : flowers little exceeding the calyx : teeth rigid, setosely acuminate, entire.

Often villous, small, very slender : flowers 1 to 4 , very much longer than the calyx : teeth thin, shortly acuminate.

Corolla not inflated : involucre membranaceous, at least at base, less deeply lobed ; lobes entire or serrate.

Villous: lobes of involucre entire: calyx-teeth subulate, with broad scarious margin.

Villous : lobes 3-toothed : calyx-teeth triangular, acute ; margin narrow, serrulate.

Smooth : involucre very broad; lobes serrate: calyx-teeth setosely many-branched.
1. T. MEGACEPHAIUM.

2. T. ANDERSONII.

3. T. LEMMONI.

4. T. ERIOCEPHALUM

5. T. PLITMOSUM.

6. T. LONGIPES.

7. T. Altissimdi.

9. T. KingII.

8. T. BECKWITHII.

10. T. BOLANDERI.

11. T. Macrei.

12. T. ciliatum.

13. T. GRACILENTUM.

14. T. BIFIDUM.

15. T. BREWERI.

25. T. DEPAUPERATUM.

16. T. INVOLUCRATUM.

17. T. TRIDENTATUM.

18. T. PAUCIFLORUM.

19. T. MONANTHUM.

20. T. MICROCEPHALUM.

21. T. MICRODON.

22. T. CYATHIFERUM. 
Corolla becoming conspicuously inflated.

More or less villous: involucre broad, setaceonsly many-toothed: calyx-teeth filiform, plumose.

Smooth, stout : flowers large : involucre broad, deeply lobed or parted ; lobes entire : teeth narrowly subulate.

Smooth, low and slender: Howers few, small : calyx-tecth narrowly subulate.

Involucre with oblong entire obtuse lobes, equalling the calyx. Involucre nearly wanting, merely a toothed or entire disk.

23. T. BARBIGEREM.

24. T. rucatuM.

26. T. ANILECTESS.

25. T. DEPAUPERATUS.

\$ 1. Heads not involucrate, dense: leaflets 5 to 7 , rarely 3, thick: flowers sessile: calyx-teeth nearly equal, filiform, plumose: perennial.

1. T. megacephalum, Nutt. Ntout, a span ligh or less, somewhat rillous: stipules large, ovate-oblong, serrate; leaflets cuneate-oblong to obovate, obtuse,

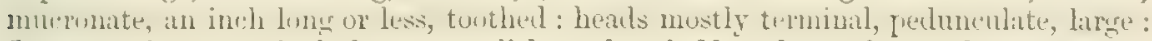
flowers spicate, an inch long, purplish: calyx half as long, the teeth very much longer than the tube: pod stipitate, 6-ovuled, smooth. - Gen. ii. 105; Torr. \& Gray, Fl. i. 315. Lupinaster macrocephalus, Pursh, Fl. ii. 479, t. 23.

Sierra Valley, Sieria ('o. (Lemmon); Diamond Mts., N. Nevada (Whecler); northward in the mountains to the British boundary (Lyall) : rather rare.

2. T. Andersonii, liray. Dwarf, cesplituse, densty silky-rillens, leafy: stipnles linceulate, acuminate, entire : leatfets cuneate-nhlong, half an inels lung, acute, nearly entire: peduncles mostly axillary, shorter than the leaves: flowers half an inch lons, purplish, umbellate; the outer bracts forming in rulimentiry involuche: callix-terth a little shorter thin the petals: pod tomentuse, about j-oruled, 1 - 22seeiled. - Prac. Am. Acad. vi. 522.

Sierra Valley (Lemmon); Carson Valley, Nevada, Anderson. Growing in dense tufts or mnts,

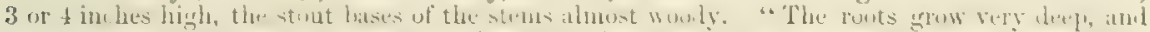

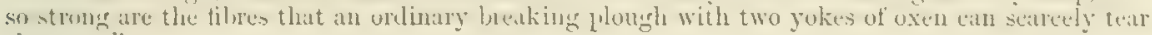
them up."

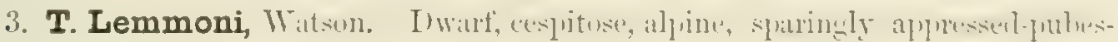
cent: stems rather slender, from a thick root: stipules ovate, acuminate, coarsely toothed; leaflets obovate, obtuse, consely toothed, half un inch long or less : pechucles mostly terminal, equalling the leaves: heads small, the rhachis only two lines

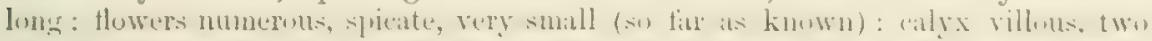

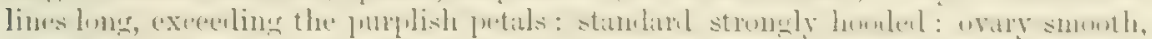
2-ovuled. - Proc. Am. Acal. xi. 127.

Lassen's Peak, Lemmon. The few specimens are imperfect, only a few perhaps undeveloped flowers remaining upon the receptacle.

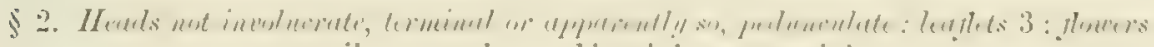
sessile or nearly so: biennial or perennial.

* More or less pubescent: calyx-teeth very narrov, longer than the tube, plumose or hairy: stipules lanceolate, acuminate.

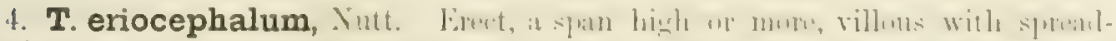

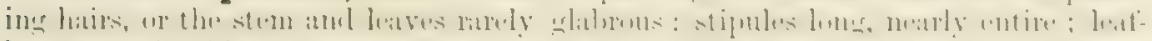

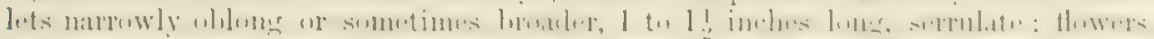

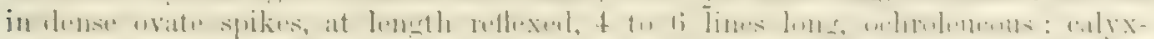

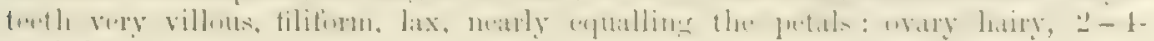
ovuled. - Torr. \& Gray, Fl. i. 313.

Mendocino Co. (Bolander), and freynent in Oregon and Idaho, on moist soils.

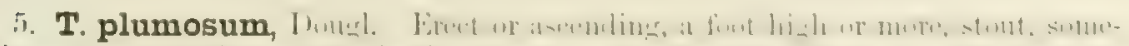

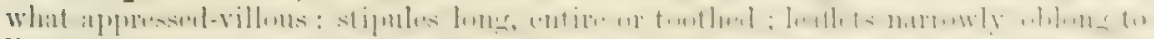
linear, 2 to 4 inches long, serrulate: fluwers in deaso oblong or ovato spities, not 
reflexed, half an inch long, "white" : calyx very villous; its teeth straight and equalling the corolla: ovary smooth, 4ovuled.-Hook. Fl. i. 130, t. 49.

In Oregon and Central Idaho (Douglas, Nuttall, Spalding), but not yet detected in California.

6. T. longipes, Nutt. Erect or ascending, slender, about a span high: stem usually glabrous, the leaflets and calyx sparingly villous: stipules mostly narrow, entire or toothed; leaflets narrowly oblong to linear, usually very acute, about an inch long, serrulate: flowers spicate or very shortly pedicellate in smaller and less dense ovate heads, at length usually reflexed, 5 or 6 lines long, ochroleucous or tinged with purple: calyx-teeth straight, more or less hairy, shorter than the corolla: ovules 2 to 4 . - Torr. \& Gray, Fl. i. 314.

Var. latifolium, Hook. Leaflets broader: flowers obvionsly pedicellate, in loose heads: stems often low. - Lond. Jour. Bot. vi. 209. Var. pygmaeum, Gray, Bot. Ives Colorado Exp. 9.

Moist meadows in the Sierra Nevada, from Yosemite Valley and above Mono Lake to the British boundary, and east to the Rocky Mountains. The variety sometimes takes on the aspect of $T$. repens, but the calyx is always hairy and the teeth slender.

T. PRatense, Linn. (Red Clover.) Stems ascending, somewhat hairy: stipules bristlepointed ; leaflets oval or obovate, obtuse or emarginate ; heads large, ovate, sessile : calyx-teeth lax, shorter than the corolla : ovules 2. - Native of the Old World, extensively cultivated, and perhaps the most valuable species of the genus. It belongs to a cooler and moister climate than ours, but is cultivated in some parts of the State. There are several varieties, differing chiefly in size and time of flowering.

* * Glabrous throughout: calyx-teeth subulate, rigid, contorted, twice longer than the tube: flowers sessile: stipules lanceolate, acuminate.

7. T. altissimum, Dougl. Erect, stout, a foot high or more: stipules very long, toothed; leaflets narrowly oblanceolate, very acute, two inches long, strongly veined, the veins excurrent: flowers in dense oblong or ovate spikes, at length somewhat reflexed, 6 to 8 lines long, red : lower calyx-tooth straight, the rest curved or twisted downward: ovary smooth, 2-ovuled. - Hook. Fl, i. 130, t. 48.

Mountains of Oregon and Central Idaho; to be looked for in Northern California.

* * * Glabrous throughout: calyx-teeth scarcely longer than the tube: stipules mostly ovate, acute, entire: flowers on very short pedicels, at length reflexed.

8. T. Beckwithii, Brewer. Stems stout, ascending, a foot high or more : stipules lanceolate to ovate; leaflets oblong to oblanceolate, obtuse or acute, serrate, 1 or 2 inches long: flowers on very short pedicels, 7 to 9 lines long, in large dense globose heads, red : calyx-teeth linear-subulate, straight, equalling the tube: ovary smooth, 2-6-ovuled. - Watson, Proc. Am. Acad. xi. 128. T. altissimum, Torr. \& Gray in Pacif. R. Rep. ii. 120.

In the northern Sierra Nevada (Beckwith); Sierra Co. (Lemmon); Humboldt Valley, Nevada (Groy) ; Snake Country, Burke. Perhaps a large and stout form of the next. .

9. T. Kingii, Watson. Resembling the last, but smaller and more slender, with smaller heads, and usually acuter leaflets: rhachis often produced above the head, with a few spinescent bracts : flowers 4 to 7 lines long, rose-colored or purplish : lower leaves (as in other species) often rounded or obovate. - Bot. King Exp. 59. T. Haydeni, Porter in Hayden Rep. 1871, 480.

In the Sierra Nevada, at Summit (Bolander) and Sierra Co. (Lemmon), and in the mountains eastward to Montana and Utah.

10. T. Bolanderi, Gray. Cespitose, small, the short stems decumbent : leaflets obcordate to cuneate-oblong, half an inch long or less, very finely reticulated, slightly serrulate: peduncles slender, elongated, occasionally axillary: heads small; the purplish flowers few, 3 or 4 lines long: calyx-teeth lanceolate, scarcely equalling the tube: ovary smooth, 2-ovuled. - Proc. Am. Acad. vii. 335. 
Moist or wet ground, ahore Yosemite Valley, at Westfall's Meadows, and Peregoy's, at 8,000 feet altitude, Bolander, Gray.

T. REPEXS, Linn. (WhITE or DUTCH Cluver.) May be mentioned here though separated from the group by its wholly axillary peduncles. Stem slender and creeping : leaflets rounded or obcordate : flowers small, white, in loose globose heads. - Native of Europe, probably not indigenous in America, though very widely naturalized and often cultivated as a valuable forago plant. Introduced into the cooler parts of the State; more common northward.

§ 3. Heads not involucrate, pedunculate: leaflets 3: ovules 2 : annuals.

* Heads mostly terminal: flowers sessile, not reflexed: calyx-teeth filiform, plumose.

11. T. Macræi, Hook. \& Arn. Somewhat villous with appressed or spreading hairs, erect, slender, a half to a foot high: stipules ovate to lanceolate; leaflets obovate to narrowly oblong, obtuse or retuse, serrulate, about half an inch long: flowers dark purple, 3 lines long, in dense ovate lung-peduncled beids: calyx very villous; the straight teeth as long as the petals, often tinged with purple: pod 1-seeded. - Bot. Misc. iii. 179 ; Bot. Beechey, 330. T. albopurpureum, Torr. \& Gray, Fl. i. 313.

Vir. dichotomum, Brewer. I taller and stouter form, with larers flowers in heads nearly an inch loug: corolla more conspicuous, tipped with white. $-T$. dichotomum, Hook. \& Arn. Bot. Beechey, 330 ; Torr. \& Gray, Fl. i. 690.

On dry hillsides in early spring, chiefly in the Coast Ranges, from Santa Barbara to the Columbia River; also in Chili. The Chilian form appears to have nearly sessile heads and stouter calyx-teeth.

* * Heads axillary, small: flowers on short pedicels, at length reflexed: calyx-teeth subulate: mostly glabrous.

12. T. ciliatum, Nutt. Gliahrous, erect, often 1 to 2 feet high : stipules ustuilly narrow, acuminate; leaflets cuneate-oblong to obovate, a half to an inch long, obtuse or retuse, serrulate: corolla white or purplish, little exserted, 3 lines long: calyx-tulse campanulate; teeth lanceolate, very acute, rigill, the scarious malyin rigidly ciliolate. - Pl. Gambel. 152. T. ciliolatum, Benth. Pl. Hartw. 304.

On dry lillsides from Los Angeles to the Columbia ; readily distinguished by the calyx.

13. T. gracilentum, Torr. \& (iray. Ereet, slenter, follumus (the peedunches

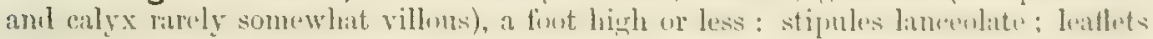
cuneate-oblong to obovate or obcordate, retuse, about half an inch long, serrulate:

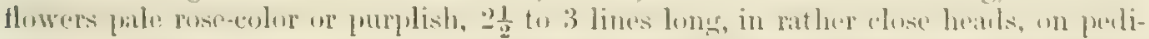

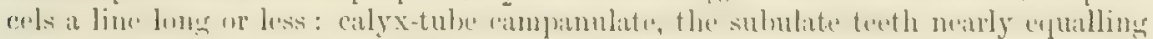
the corolla. - Fl. i. 316. T. denudetum, Nutt. Pl. Gambel, 152, t. 24.

On low hills and in the valleys from Los Angeles to the Columbia River.

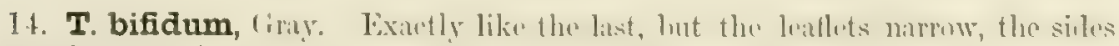

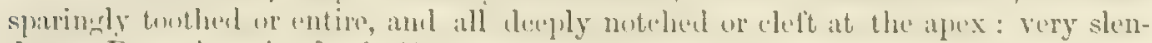
der. - Proc. Am. Acad. vi. 522.

Marsh's Ranch, near Mt. Diablo (Brevoer); New Almaden (Torroy); near Wkiah (Bolander); Oseron, Ifull.

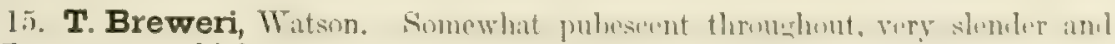
diffuse, a span high or more: stipules lanceolate; lesflets obcordate to oblong, mostly retuse, toothed or serrulate, 3 to 9 lines long: flowers few, in very loose

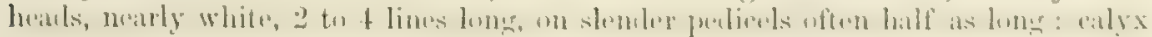
very narrow, the slender teeth much shorter than the corulla. - Proc. Am. Acal. xi. 131 .

In the Sierra Novada, from Mariposa Co. to Sierm Co.

T. PALMeri, Watson, of Guadnlupe Island (Pulmer), is a smonth difuso species, with laneenlate long-numinto stipules and narrowly oblong lenflets, acute at ench end, half an inch long: flowers purplish, 3 lines long, in rather close heals; teoth subulate, nearly equalling tho corolla. 
\$ 4. Heads short, subtended by an involucre, which is usually many-cleft: leaflets 3 : peduncles manifestly axillary: flowers mostly small, in whorls, sessile or nearly so, not reflexed: annuals.

* Involucre not membranaceous, deeply lobed, and the lobes laciniately and sharply toothed: corolla not becoming inflated.

16. T. involucratum, Willd. Glabrous: stems ascending, often a span high or more: stipules lanceolate to ovate, entire or usually lacerately toothed; leaflets mostly oblanceolate and acute at each end, a half to an inch long : involucre manycleft into narrow laciniate teeth: flowers half an inch long, in close heads, purple or rose-eolored : ealyx-teeth narrow, thin, gradually attenuate from the base, exceeding the tube, all entire: ovules mostly 5 or $6 .-T$. Wormskioldii, Lehm. Ind. Sem. Hort. Hamb. 1825, 17. T. fimbriatum, Lindl. Bot. Reg. t. 1090. T. spinulosum, Dougl. in Hook. Fl. i. 133.

Var. heterodon, Watson. Heads mostly somewhat larger and leaflets usually broader: some of the calyx-teeth setaceously eleft. - Proc. Am. Acad. xi. 130. T. heterodōn, Torr. \& Gray, Fl. i. 318.

Of wide range, from the British boundary to Mexico, and from the coast to Colorado and New Mexico; and quite variable. The variety, from Washington Territory to California. Though the original species of Willdenow is of uncertain habitat and has been known only from cultivated specimens, yet there appears to be no sufficient reason for distinguishing from it the better known $T$. fimbriatum of Lindley. The Californian form is not distinet from the Mexican and New Mexican plant ordinarily referred to $T$. involucratum, and Kunth's figure of Humboldt's Mexican specimen, which was compared by him with a garden specimen of Willdenow's species and believed to differ only in its smaller size, represents fairly a low decumbent form of the present species.

17. T. tridentatum, Lindl. Glabrous or sometimes glandular-puberulent, slender and usually erect, a half to two feet high: stipules ovate to lanceolateacuminate, laciniately toothed; leaflets linear to narrowly lanceolate, sharply serrate: heads rather large ; involncre many-cleft : flowers 6 to 8 lines long, in close heads, purple, often tipped with white: calyx strongly nerved; the rigid teeth usually shorter than the tube, broad at base and rather abruptly narrowed into the spinulose apex, often with a stont tooth on each side : ovules usually two. - Bot. Reg. xiii, under t. 1070. T. involucratum, Torr. \& Gray, Fl. i. 318, not Willd. T. aciculare \& polyphyllum, Nutt. in Torr. \& Gray, l. c.

Var. obtusiflorum, Watson, l. c. Stouter and often glandular-puberulent, with usually broader (oblong-oblanceolate) leaflets and large heads of flowers : calyx-teeth entire. - T. nbtusiftorum, Hook. Ic. Pl. t. 281.

Var. melananthum, Watson, l. c. Smooth, slender, often low : heads smaller; the dark purple flowers 4 or 5 lines long: calyx-teeth entire or toothed: leaflets narrowly oblanceolate or the lower obcordate. $-T$. melananthum, Hook. \& Arn. Bot. Beechey, 331. T. variegatum, var. $\beta$., Torr. \& Gray, Fl. i. 317 \& 691.

A common and very variable species, from the British boundary to Southern California, mostly confined to the Coast Ranges; the varieties from Middle California, the latter ranging southward and into Arizona, Palmer. Forms of this species and of the last sometimes approach each other so closely as not to be readily distinguished.

18. T. pauciflorum, Nutt. Glabrous, very slender: stems usually ascending or decumbent: stipules ovate to lanceolate, laciniate; leaflets obovate to oblanceolate or sometimes linear, usually obtuse or retuse, half an inch long or less, serrulate: heads rather few-flowered; involucre small : flowers 3 or 4 lines long, not greatly exceeding the calyx, deep purple or light rose-colored : calyx-teeth rigid, subulate and setosely acuminate, exceeding the tube, entire: pod 2-seeded. - Torr. \& Gray, F1. i. 319. T. variegatum, Nutt. 1. c. T. oliganthum, Steudel.

Common, usually in moist ground, from Washington Territory and Montana to Southern Califoruia and Utah, both in the valleys and mountains; Yosemite Valley (Bolander, Torrey, \&c.); Sonora Pass, Brewer. 
19. T. monanthum, Gray. Still more slender, one to four inches high, usually sparingly villous with long seattered hair, decumbent: stipules lanceolate, entire or nearly so; leaffets obcordate to oblanceulate, one to four lines long, mostly retuse, sparingly toothed: lieads $1-4$-flowered ; involucre very small, $2-3$-parted and usually unilatcral: flowers 4 to 6 lines long, white or purplish, much exceeding the short calyx: ealyx-teeth subulate, shortly acuminate, thin. - Proc. Am. Acad. vi. 523. T. panciflorum, var. (?) parvum, Kellogg, Proc. Calif. Acad. v. 54.

On moist sunny slopes in the Sierra Nevada; on the Upper Tuolumne, at 8,900 feet altitude, and at the head of the South Fork of King's River (Brewer); Yosemite Valley (Gray); at Cisco (Kellogg); Lassen"s Peak, Lemmon. Also in the mountains of Nevada, Whccler.

* * Invalucre membranaceous, at least at base, less deeply lobed; the lobes entire or toothed: corolla not becoming inflated.

20. T. microcephalum, Pursh. Villous with soft hairs, slender, erect or decumbent: stems often a foot or two long : stipule's ovate to lanceolate, acuminate, mostly entire; leaflets oblanceolate to ohorate, usually retuse, serrulate: heads small, dense; involucre about 9-lobed, the lobes acuminate, 3-nerved, entire: calyx hairy; its teeth subulate, with a broal scariously marginet sometimes toothed base, attrintate to a long spinulose apex, nearly equalling the whits or light ruse-culored corolla: ovules two: pod globose, 1-seeded. - Torr. \& Gray, Fl. i. 317.

Common on hillsides and the sandy beds of dry creeks, chjefly in the Coast Ranges, from Puget Sound to Southern Culifornia; Guadalupe Island (Palmer); Northern Nevada, Watson.

21. T. microdon, Hook. \& Arn. Resembling the last: involucre broader, nearly enclosing the head; its lobes about 3-toothed: calyx smooth, angled; the teeth rigil, broally triangular, aeute, with a narrow scarions serrulate margin. Bot. Beechey, 330, t. 79 ; Torr. \& Gray, Fl. i. 691.

From about San Francisco northward; Washington Territory, Lyall, Hall. Also Chilian.

22. T. cyathiferum, Lindl. Smooth : stems erect or ascending, a fout high or less: stipules ovate to lanceolate, laciniately toothed; leatlets oblanceolate to obovate, obtuse or acute, a half to an inch long: heads larger; involuere conspicuous, very broad and membranaceous, with short many-nerved and toothed lobes: calyx strongly 5-nerved, membranareous and somewhat intlatml: the merves exeur-

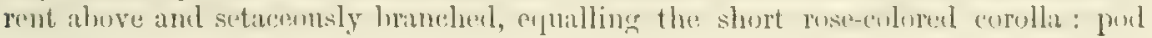
2-seeded. - Bot. Reg. xiii, umler t. 1070 ; Hook. Fl. i. 133, t. 50.

Sierra Valley, Sierra Co. (Lemmon); Northern Nevada (Auderson, Watson); and northwand to the Columbia River. A remarkable species.

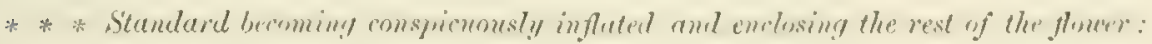
involucre nearly obsolete in $T$. depanperatum.

+ Heads mostly large: involucre conspicuous.

23. T. barbigerum, Torr. Simewhat puhsisent: stems rather stmut, 1herumbent or ascending, a span high or less: stipules searious, broadly ovate, laciniato; leaflets obovate or ovate-oblong, obtuse or retuse, half an inch long or less: invo-

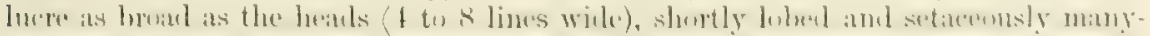

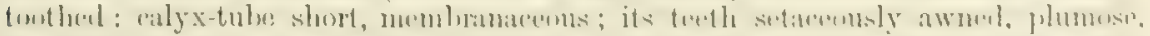

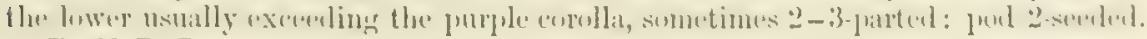
- Pacif. R. Rop. iv. 79.

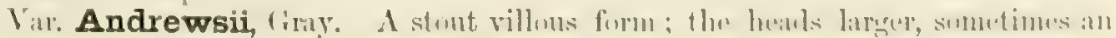
inch broad: calyx-teeth very long. - Proc. Am. Acarl, vii. 335.

Near the cosst from Monterey to Mendocino County; very variable.

24. T. fucatum, Lindl. Smooth : stems stout and suceulent, a foot or two high or more: stipules large and scarious, usually very brond and entiro; lealluts

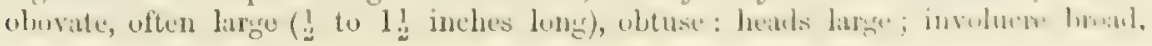


deeply cleft or parted into entire acuminate lobes: flowers often an inch long, pale rose-color or purplish : calyx-tube very short, membranaceous; the teeth thin, narrowly subulate, entire or occasionally 2-3-cleft: pod 2-6-seeded. - Bot. Reg. t. 1883. T. physopetalum, Fischer \& Meyer, Ind. Sem. Petrop. iii. 47. T. Gambellii, Nutt. Pl. Gambel. 151.

A common species in the Coast Ranges and in the foot-hills of the Sierra Nevada, through the length of the State; in some places very abundant and affording good pasturage.

\section{++ Heads small, few-flowered: involucre small or wanting.}

25. T. depauperatum, Desvaux. Smooth, low and slender, decumbent or ascending : stipules small, lanceolate, acuminate, entire; leaflets obcordate to linear and acute, half an inch long or usually less: heads 3-10-flowered; involucre reduced to a very small toothed or truncate often minute and scarious ring: flowers white or purple, 2 or 3 lines long: calyx short; the teeth narrowly subulate: ovules 2 to 6 : pod usually 1 -2-seeded. - Jour. Bot. iv. 69, t. 32 ; Gray, Proc. Am. Acad. vi. 523. T. stenophyllum, Nutt. Pl. Gambel. 151.

Hillsides and valleys from Southern California to Sonoma and Placer counties. It is also Chilian.

26. T. amplectens, Torr. \& Gray. Like the last: involucre shorter than the flowers, 4-5-parted or cleft; the segments oblong, usually obtrise, entire or obscurely toothed. - Fl. i. 319 ; Hook. \& Arn. Bot. Beechey, 330, t. 78 ; Gray, 1. c. T. diversifolium, Nutt. 1. c. 152.

In similar or the same localities; also Guadalupe Island, Primer. Probably only a variety of T. depauperatum.

\section{MELILOTUS, Tourn. Sweet Clover.}

Flowers as in Trifolium, except that the petals are free from the stamens and deciduous. Pod small but longer than the calyx, ovoid or subglobose, scarcely dehiscent, 1-2-seeded. - Annual or biennial herbs; leaves pinnately 3-foliolate, the leaflets usually serrulate, and stipules adnate to the petiole; flowers small, yellow or white, in slender axillary pedunculate racemes.

An old World genus of about 10 species, several of which are often cultivated for forage purposes, and readily rum wild in waste places. The herbage is fragrant in drying.

1. M. parviflora, Desf. Annual, smooth, erect, often 2 or 3 feet high, branching: leaflets mostly cuneate-oblong, obtuse, denticulate, an inch long or less: flowers yellow, a line long, nearly sessile. - M. occidentalis, Nutt. in Torr. \& Gray, Fl. i. 321 .

Native of the Mediterranean region, now widely naturalized in warm countries, and common in California. Cattle are fond of it.

M. officinairs, Willd, with yellow flowers twice as large and on slender pedicels, and

M. ALBA, Lam., with white flowers, the standard longer than the other petals, are the other species most likely to oceur in the State.

\section{MEDICAGO, Linn.}

Characters nearly as in the last: style subulate: pod compressed, falcate, incurved or spirally coiled: seeds one or several. - Mostly herbs, annual to perennial; stipules often laciniate; flowers yellow or violet.

Like the last wholly from the Old World, where there are about 40 species.

1. M. sativa, Linn. (Lucerne. Alfalfa.) Stems ereet, 2 to 4 feet high, from a deep perennial tap-root, glabrous: leaflets cuneate-oblong or oblanceolate, toothed above: flowers comparatively large, purple, racemed : pods numerous, spirally twisted, finely veined, not armed. 
Sparingly naturalized. In cultivation it is probably the most valuable of forage plants for

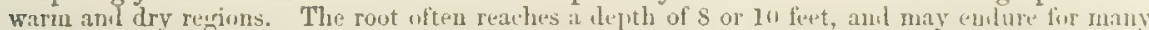
years. The herbage is very nutritious, and on deep soils with proper moisture it yields several crops, in some parts of the state growing and blooming nearly through the year. There is no

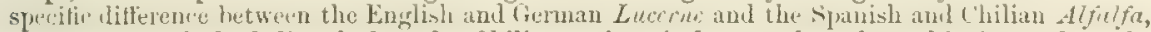
but it is popularly believed that the Chilian variety is better adapted to this State than the

\section{European}

2. M. denticulata, Willd. (Bcr-Clover.) Annual, nearly glabruns, prostrate or ascending: leaflets cunente-oborate or obcordate, tootled abure: flowers small, yellow, usually 3 to 8 in a swall cluster: puls spiral, strumbly reticulated; the marerin thin, keeled, armed with a double row of curved or houked prickles.

Native of the Mediterranean region, and naturalized in most warm countries. It is valuable as a forage plant, but the burs are a source of great damage to wool. It fruits abundantly and the pods are eaten with great avidity by cattle and sheep, remaining good until the winter-rains.

3. M. lupulina, Linn. Innual, pubescent, jorucumbent : leaflets cuneate-obovate, touthed abuve: Howers very small, yellow, in short spikes: pods small, reniform, 1-seeded, not armed, black when ripe.

Sparingly introduced.

\section{HOSACKIA, Douglas.}

Cilyx-tecth nearly equal, usually shorter than the tube. Petals free from the stamens, nearly eyuil : staudard ovate or roundish, the claw often remote from the others; wings obuvate or oblong; keel sonewhat incurvel, olstuse or sumewhat acutcly beaked. Stamens dialelphous; anthers uniform. Style incurvel. Pol linur, compressed or somewhat terete, sessile, several-seeled, partitioned betwe'n the sueds. - Herbacous or rarely suflutesent; leares pinnate, 2-many-foliolate; stipules minute and gland-like, rarely scarious or foliaceous; flomers Jellow or redilish, in axillary sessile or pedunculate umbels. - Cray, Proc. Acad. Philad. 1863, 346; Watson, Bot. King Exp. 432.

A North American genus of about 30 species, almost wholly confined to the western side of the continent and ranging from Mexico to British Columbio. It is very closely related to Lotus of the Old World, to which genus the section Microlotus is referred by Bentham \& Hooker, Gen. PI. i. 490 , with apparently good reason. The yellow or orange color of the fresh flowers in most of the species tums to reddish or reddish-brown in drying. The section Syrmatium is the most strongly characterized and might well be considered generically distinct.

* Pod shortly acute, linear and many-seeded, straight, glabrous (except in $\Pi$. rigida) : seeds suborbicular : flowers and fruit not rellexed : peduncles long : keel broad above, mostly obtuse.

Stipules largo and foliaceous : perennials.

Densely villous : leaflets 9 to 15 : bract lenf-like, near the umbol.

Less villous, viscid : leaflets 15 to 21 : bract leaf-like, distant.

Stipules scarious, mostly small : perennials.

Stout, nearly glabrous : lenflets 9 to 15 , thickish : brnet below the umbol : calyx-tecth short: pod thick.

Glabrous: leaflets 5 to 9 : bract usually none or small : tecth half as long as the tube: pod slender : wings usually white.

Glabrous, low: bract 1 -3-foliolnto, at the umbel : teeth longer : pou shorter: keel and wings purplish.

Appressed-puberulent : bract at the umbel, usually 1-foliolate : flowers yellow and purplish.

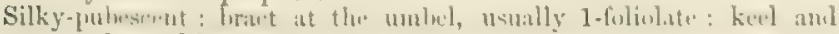
wings white.

Stipules reduced to blackish glands.

Perennials, appressed-pubescent : flowers 1 to 8 , rather large.

Mostly tall and stout: leaflets 5 to 7 ; rhachis elongated: poul long, glabrous.

Moro slenter: leaftets 3 to 5 ; rhachis short or none: pod shorter, pubescent.

1. H. INCANA.

2. H. STIPULARIS.

3. H. crassifolia.

4. H. BICOLOR.

5. H. GRACILIS

B. H. OBLONGIFOLM.

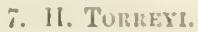

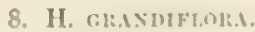

9. H. I:1เiD, 
Annuals, low : flowers smaller.

Umbels 2-5-flowered : standard remote from the wings : leaflets 5. 10. H. Maritima.

Flowers mostly solitary : petals approximate; keel obtuse; standard attenuate below : leaflets 5 to 9 .

Flowers very small, solitary : keel acute : blade of the standard eordate: leaflets 3 to 5 : pod 5-7-seeded : nearly glabrous.

11. H. STRigosA.

12. H. PARVIFLORA.

* Pod shortly acute, 3-7-seeded, straight: flowers small, mostly solitary : keel narrowed into an acute beak : stipules gland-like : annuals, more or less villous.

Flowers peduncled : corolla scarcely exceeding the calyx : leaves nearly sessile, 1 - 3-foliolate.

Flowers nearly sessile, not bracteate: corolla longer : leaves petioled, 3-5-foliolate : low.

Calyx-teeth about equalling the tube : pod 6 to 9 lines long, 5-seeded. 14. H. sumpivnata.

Teeth much longer than the tube: pod 3 to 4 lines long, 2-4-seeded, 15. H. Brachycarpa,

* * Pod long-attenuate upward, subterete, incurved, pubescent : stipules gland-like : leaflets 3 to 7 : seeds 1 or 2 , terete : peduncles short or none : flowers and fruit reflexed.

Glabrous or sparingly pubescent : pod slightly pubescent, elongated and much exserted beyond the calyx: calyx-teeth much shorter than the tube.

Somewhat woody : nearly glabrous : stems angled : leaflets mostly 3.

Leaflets oblong to linear: umbels sessile : teeth narrow, erect.

Leaflets oblong to linear: peduncles short or nearly wanting : teeth attenuate, usually recurved.

Leaflets obovate to oblong: peduncles very short: teeth short and blunt.

Herbaceous, sparingly pubescent: stems very slender, terete : leaflets usually 5 to 7 : calyx-teeth sliort.

Peduncles slender : flowers 2 or 3 lines long : style glabrous.

Peduncles very short : flowers very small : style pubescent.

Very silky-pubescent or tomentose : stems herbaceous, terete : pod pubescent, shorter.

Pubescence appressed.

Densely white-silky : leaflets mostly 3, narrow : umbels loosely fewflowered, often sessile: flowers 3 lines long : calyx-teeth short. 21. H. SERICEA.

Leaflets 5 to 7 : umbels peduncled : flowers usually larger : calyxteeth nearly equalling the tube.

More or less silky : umbels close, capitate : calyx very silky.

Villous and subtomentose : umbels less dense: calyx less hairy.

Pubescence more or less spreading: pod very short: umbels mostly on short peduncles : leaflets 5 to 7 : calyx-teeth filiform, equalling the tube.

Very pubescent throughout: flowers 3 or 4 lines long.

Less pubescent; stem glabrous : flowers smaller.

16. H. GLABRA

17. H. CYTISOIDES.

18. H. JUNCEA.

19. H. PRostrata.

20. H. MICRANTHA.

22. H. ATGOPHYLLA.

23. H. DECUMBENS.

24. H. TOMENTOSA.

25. H. HeErmannt.

\$1. Pod acute above, linear, straight or nearly so, terete or somewhat compressed, many- (5 - 20-)seeded, glabrous except in H. rigida: seeds mostly compressed, suborbicular: keel broad above, mostly very obtuse: flowers and fruit ascending or erect. - EuHosackia, Benth.

* Stipules scarious or foliaceous: leaflets 5 to 21, upon a more or less elongated rhachis : umbels pedunculate, few-many-flowered: flowers rather large : perennials.

- Stipules broad and foliaceous: bract of several leaflets, below the top of the peduncle.

1. H. incana, Torr. Low, stout, erect, densely silky-villous throughout : leaflets 9-15, obovate-oblong, acute, nearly half an inch long; stipules ovate: peduncles shorter than the leaf (half an inch long), 6 -9-flowered: bract near the top, 5 -foliolate: calyx 3 lines long; the subulate teeth half the length of the tube. - Pacif. $\mathrm{R}$. Rep. iv. $79, \mathrm{t} .4$.

On dry hills near South Yuba, Bigelow.

2. H. stipularis, Benth. Rather tall, stout, two feet high or more, less densely villous with spreading hairs, glandular, the leaves smoother: leaflets usually 15 to 21 , 
obovate-oblong, acute and mucronate, a half to an inch long; stipules large, ovate: peduncles an inch or two long, 4-8-flowered: bract near the middle, leaf-like, 3-9-foliolate: calyx two lines long; teeth subulate, short: pod straight, 1 to 11 inches long. - Trans. Linn. Soc. xvii. 365. H. macrophylla, Kellogg, Proc. Calif. Acad. ii. 123. H. balsamifera, Kellogg, 1. c. 125 , fig. 40.

From the Contra Costa Hills to Monterey. Plant often more or less viscid with a fragrant glandular secretion.

$$
\begin{aligned}
& ++ \text { Stipules scarious, mostly small. } \\
& + \text { Glabrous throughout or becoming nearly so: bract petioled or wanting. }
\end{aligned}
$$

3. H. crassifolia, Benth. 1. c. Stont, erect, often 2 or 3 feet high: leaflets 9 to 15 , ninutely jubescent or somewhat villous hut soon glabrate, thickish, ubuvite or ollome, usually olstuse and mucronulate, a lablf to an inch long: pedumcles wearly equalling the leaves, usually many-flowered : bract below the unlacl, 1 - 3-fuliolate: fluwers on slemler perlicels, greenish yellow or purplish: calyx-teeth short, triangular: pods thick, about 2 inches long. $-H$. stolonifera, Lindl. Bot. Reg. t. 1977. H. platycarpa, Nutt. in Torr. \& Gray, Fl. i. 323.

From the Columbia River to the Sacramento and common in the foot-hills of the Sierra Nevada as far south as the Merced River.

4. H. bicolor, Dougl. Glabrous throughout, erect, rather tall and usually stout: leaflets 5 to 9 , obovate or oblong, obtuse or acutish, a half to an inch long; stipules rather large: peduncles mostly longer than the leaves, $3-7$-flowered, naked or sometimes with a small scarious or 1-3-foliolate bruct at the summit: flowers nearly sessile, yellow, the wings often white: calyx-tecth triangular, ouly half as long as the tuhe: pod slender, nearly 2 inches long. - Benth. in Lindl. But. Iix. t. 1257. Lotus pinnatus, Hook. Bot. Mag. t. 2913.

A showy species, in low grounds, from Washington Territory to San Francisco Bay.

5. H. gracilis, Benth. Much like the last: usually low and slender, the weak stems a span high or more: umbel with a petioled 1-3-foliolate bret: flowers yelluw, the keel and wings purplish: ealyx-teeth nearly eyulling the tuhe: punt shorter. - Trans. Limn. Soc. xvii. 365 ; Torrey, Bot. Mex. Bound. 54, t. 15.

From the Columbia River to Monterey.

$$
++ \text { Pubescent or puberulent: bract nearly sessile at the top of the peduncle. }
$$

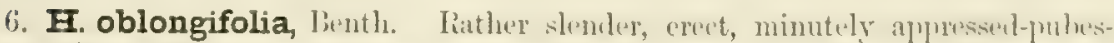

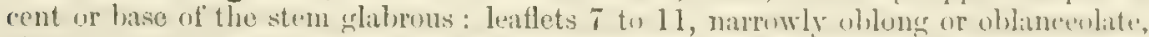

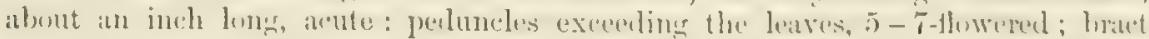

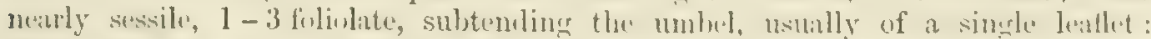

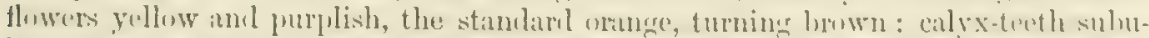

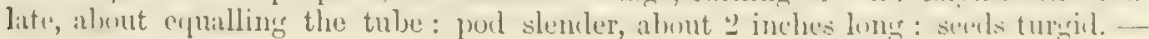
P1. ILurtw, 305.

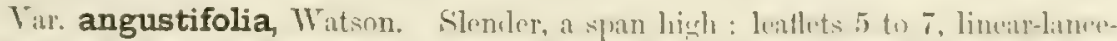

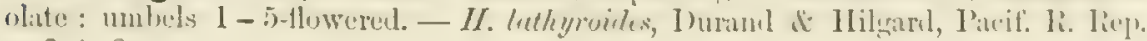
v. 6, t. 3 .

Mainly in Southern California : Monterey (Coulecr); Fort Tejon ( $I \mathrm{~mm})$; mountains enst of San Diego (Parry, Palmer); the variety at Fort Miller on the San Jonquin (Hecrmann) and Los Angeles, Wallace, Coulter's locality is very uncertain.

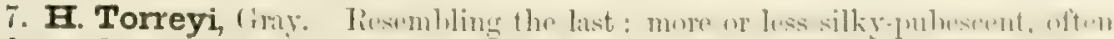
glabrous bolow, slender, orect, a foot or two high: leaflets obovinto to narrowly

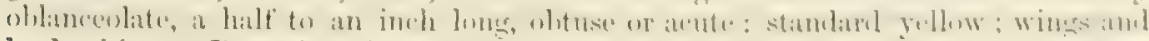
keel white. - Proc. Am. Aciel. viii. 625.

In tho Sierm Novaln, nlong shaded strenm-busks, from the heal of Kern River to Donner Iake ; near Fort Tejon, Rolkrock. 
* * Stipules gland-like, dari-colored: leaflets 3 to 9 ; rhachis mostly elongated: peduncles 1-several-flowered, bracteate at the summit or sometimes naked: claws of the petals not exserted from the calyx.

+ Perennials: flowers rather large: umbels 3-8-flowered.

8. H. grandiflora, Benth. Mostly tall and stout, 1 to 5 feet high, more or less appressed silky-pubescent: leaflets 5 to 7 , on an elongated rhachis, obovate to oblanceolate, 6 to 9 lines long, acutish : peduncles elongated : umbel 3-8-flowered, usually subtended by a single leaflet: flowers nearly sessile, 6 to 11 lines long, yellowish or greenish white, often tinged with purple: calyx half as long, the subulate teeth nearly equalling the tube: pod slender, elongated, glabrous. - Trans. Linn. Soc. xvii. 366. H. ochroleuca, Nutt. in Torr. \& Gray, Fl. i. 323.

From Mendocino Co, and the mouth of the Yuba to Santa Barbara; Guadalupe Island, Palmer.

9. H. rigida, Benth. A span to a foot high or more, more or less appressed silky-pubescent: leaflets 3 to 5 on a very short petiole, or palmately crowded and sessile, obovate to oblancenlate, acutish, 3 to 8 lines long: peduncles usually exceeding the leaves, 1-5-flowered, with a sessile 1-3-foliolate bract or naked: flowers half an ixch long, yellow turning to brown: calyx-teeth half as long as the tube or nearly equalling it: pod an inch long, rather broad, pubescent: seeds subglobose. - Pl. Hartw. 305.

Arizona, Sonora, and eastward, and probably to be found within the southeastern limits of the State; Tantillas Mits., below San Diego, Palmer. Coulter's original specimens were referred to Monterey, doubtless through mistake. H. puberula, Benth., with linear or oblanceolate leaflets upon a more developed rhachis, and $H$. Wrightii, Gray, with flowers on shorter peduncles or sessile, are apparently but forms of $H$. rigida, and may likewise occur in California.

Dr. Palmer collected at the Big Cañon of the Tantillas Mts. a very similar plant, but with the pod broader and quite glabrous. The same was found by Newberry at Sitgreaves Pass in Arizona, and perhaps also by Bigelow on Bill Williams River. It may be distinct.

++ Annuals: rhachis of the leaf somewhat dilated: flowers smaller. $\rightarrow$ Peduncles mostly 2-5-flowered: standard remote from the wings.

10. H. maritima, Nutt. A span high, minutely strigose-puberulent or nearly glabrous: leaflets mostly 5 , succulent, obovate to oblanceolate, 4 to 6 lines long: peduncles abont equalling the leaves: umbel usually subtended by a 1 -3-foliolate bract: flowers yellow, 4 lines long: calyx-teeth linear-subulate, abont equalling the tube: pod an inch long, narrow, $10-12$-seeded. - Torr. \& Gray, Fl. i. 326.

Near the sea, from Santa Barbara to Los Angeles.

+++ Peduncles 1 -2-flowered, about equalling the leaves: petals all approximate.

11. H. strigosa, Nutt. Strigosely pubescent, small, diffusely spreading, prostrate or ascending: leaflets 5 to 9 , obovate or usually linear-oblong, 1 to 5 lines long: bract $1-5$-foliolate or wanting: flowers light yellow, 3 to 5 lines long or less : keel very obtuse, shorter than the wings; standard attenuate into the claw : calyx-teeth subulate, shorter than the tube: pod narrow, an inch long, 10-12-seeded. - Torr. \& Gray, Fl. 326. H. microphylla, nudiflora \& rubella, Nutt. 1. c.

Frequent through the lower part of the State, from Monterey and Calaveras Co. to the Colorado River. Very variable.

12. H. parviflora, Benth. Glabrous or nearly so : stems very slender, ascending, a span high or less: leaflets 3 to 5 , obovate and very small to narrowly oblong and 6 to 8 lines in length : bract $1-3$-foliolate: flowers very small (about two lines long), yellow : keel with a sharp incurved apex, nearly equalling the wings; blade of the standard cordate: pod 6 to 12 lines long, 5-7-seeded, compressed and often contracted between the seeds. - Bot. Reg. xv, under t. 1257. Lotus micranthus, Benth. in Trans. Linn. Soc. xvii. 367 .

From Monterey and Sacramento northward to the British boundary. Very variable. 
\$2. Pod as in EuHosıckis, usually somewhat compressed, 3-7-seeded, gluhrous: seeds broadly oblong to orbicular: keel narrowed above into a rather short mostly acute incurved beak, equalling or exceeding the wings: claws equally approximate to each other, inchuded in the calyx: flowers small, mostly solitary, ascending: leaflets 1 to 5, on a more or less dilated rhachis; slipules gland-like: annuals.-Microlorus, Beath.

* Flowers solitary, peduncled, usually bructente with a single lentlet: corolla scarcely exceeding the calyx: leaves nearly sessile, 1 -3-foliolate.

13. H. Purshiana, Benth. MLre or less silky-villous or sometimes glabrous, erect or ascenting, often a fuot high or more: leaftets rarying frum orate to linceolate, 3 to 9 lines lung : pecluncles usually exceeding the leaves : Howers 2 or 3 lines lung: calyx-teeth linear, much longer than the tube, abont equalliug the corolla: pod narrow, linear, glabrous, about an inch long, 5-7-seeded: seeds oblong. Bot. Reg. xv, under t. 1257. H. elata, fluribunda, pilosa, \& mollis, Nutt. in Torr. \& Gray, Fl. i. 327.

A very variable species and of wide range, extending from. Washington Territory to Northern Mexico, and eastward to the Upper Missouri, Arkansas, and even North Carolina

* Flowers nearly sessile and mostly solitary in the axils, not bracteate: conolla exceeding the calyx: leaflets 3 to 5 , obovate to oblanceolate, scattered on a somewhat dilated rhachis: low and much branched.

14. H. subpinnata, Torr. \& Gray. Villous or glabrite, deeumbent or ascem iner, a span high or less: leaflets half an inch long or less: Howers 3 or 4 lines loner; calyx searcely half its long, the subulate teeth about equalling the tube : port linealloblong, compressed, 6 to 9 lines long, about 5-seeded. - Fl. i. 326. Lotus subpinnatus, Lag.; Hook. \& Arn. Bot. Beechey, 17, t. 8.

Frerquent near the coast from Washington Territory to Santa Barbara, and more rare eastward in the interior to S. Utah, Parry. Also in Chili.

15. H. brachycarpa, [enth. Resembling the last : softly villous : calyx lonerer, the teeth linear and very much lonser than the tube: joul 3 ur $t$ lines loner ublong or linear-oblong, villous, 2-4-seeded. - Pl. Hartw. 306.

From the upper Sacramento River in the foot-bills of the Sierra Nevadn, and also near tho coast, to Southern California.

§ 3. Pod long-attenuate upward, incurved, somewohat terete, 1-2-seeded: seeds terete, linear or oblong: keel broad above and mostly obtuse; claw of the stundard renote from the rest: stigma minute, glabrous: umbels few-flowered, sessile or pedunculate; flowers and fruit reflexed: stipules minute dark-colored glands : leaflets 3 to 7 : mostly perennial. - SYRMatidM, Gray. (Symatium, Vogel.)

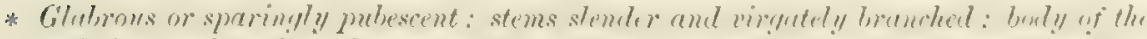

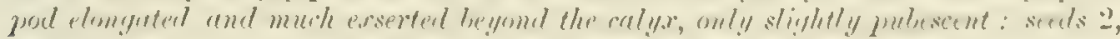
straight, $1 \frac{1}{2}$ lines long: calyx-teeth much shorter than the tube.

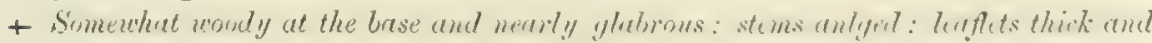
approximate, usually 3.

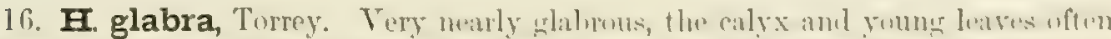

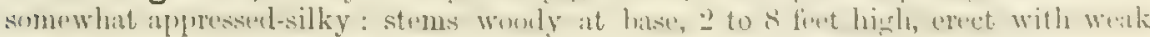

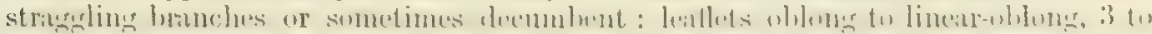
6 lines long, obtuso or acute: umbels numerous, sessile: flowers 3 or 4 lines long:

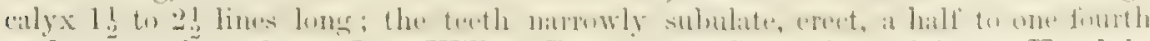
as long as the tube. - Bot. Wilkes Exp. 2⿰t. Symatium glabrum, Vogel in Linnea, x. 591. H. scoparia, Nutt. in Torr. \& Gray, F1. 1. 325 ; Gray, 1. c. 346. II. crassifolia, Nutt. 1. c.

Common in the Coast Runges from Lake Co. (Torrey) to Sun Diego. 
17. H. cytisoides, Benth. Resembling the last: calyx-teeth attenuate, mostly recurved: peduncles equalling or exceeding the leaves, or sometimes very short, usually with a $1-3$-foliolate bract at the top. - Trans. Linn. Soc. xvii. 366.

From near San Francisco to Monterey and southward; Salinas Valley, Antisell.

18. H. juncea, Benth. 1. c. Very nearly glabrous, somewhat shrubby, erect: leaflets obovate to oblong, 2 to 4 lines long: umbels on very short peduncles or sessile : flowers about 3 lines long: calyx 2 lines long or less; teeth short and blunt.

Monterey to San Diego (Douglas, Nuttall, Erever, Goodale); Colorado Desert (Schott); and reported also from near San Francisco.

++ Herbaceous and sparingly pubescent: stems terete: leaflets usually 5 to 7 , and less approximate.

19. H. prostrata, Nutt. Slightly appressed-silky : stems very slender, diffuse, 2 or 3 feet long: leaflets cuneate-oblong to obovate, 2 or 3 lines long, acutish : umbels on slender peduneles, often a half to an inch long, naked or with a $\mathbf{1 - 3 - f o l i o l a t e}$ bract: flowers two or three lines long: style glabrous: ealyx a line long; its teeth short, triangular, acute.-Torr. \& Gray, Fl. i. 325. H. decumbens, var. glabriuscula, Hook. \& Arn. Bot. Beechey, 137.

Santa Barbara and San Diego, near the sea, Nuttall, Palmer, \&c.

20. H. micrantha, Nutt. "Diffusely procumbent from an apparently annual root," very slender: leaflets obovate-oblong, $1 \frac{1}{2}$ to 3 lines long: umbels on very short naked peduncles: flowers very small (not two lines long): style covered with short straight ascending hairs : calyx-teeth short, acute. - Torr. \& Gray, Fl. i. 324.

Monterey (Nuttall) ; Catalina Island, Gambel probably. No good specimens of this apparently good species have been collested.

* * Very silky-pubescent or tomentose, herbaceous: stems terete: body of the pod less elongated, often scarcely longer than the calyx, pubescent, usually much curved: seed often solitary, somewhat curved: leaflets 3 to 7 , not approximate.

\section{+ Pubescence appressed.}

21. H. sericea, Benth. 1. c. Densely white-silky, much branched, ascending, a foot or two high: leaflets usually 3 , cuneate-oblong to linear, 3 to 6 lines long: umbels loosely few-flowered, sessile or often on short peduncles: flowers three lines long: calyx half as long, with short slender teeth.

Rare : collected by Douglas, probably at Monterey, and in Salinas Valley by Brewer.

22. H. argophylla, Gray. More or less densely silky, often silvery : stems decumbent or ascending: leaflets usually 5 or 7 , from obovate and rounded to oblong and acute at both ends, 2 to 7 lines long : umbels mostly dense and capitate, on short simply bracted peduncles, sometimes nearly equalling the leaves: flowers 4 or 5 lines long: calyx balf as long; its teeth conspicuous, filiform and silky, usually nearly equalling the tube. - Pl. Thurb. 316. H. argentea, Kellogg, Proc. Calif. Acad. iii. 38, fig. 8 .

In the foot-hills of the Sierra Nevada from the Merced River (Gray) southward, and through the southern part of the State; Guadalupe Island, Palmer. Variable in pubescence, length of calyx-teeth, \&c.

23. H. decumbens, Benth. 1. c. Villous-pubescent and somewhat tomentose, perennial : stems ascending or diffusely procumbent, a foot long or more: leaflets 5 to 7 , cuneate-obovate to -oblong, mostly acute, 3 to 6 lines long : umbels less dense, on short peduncles, with a 1-3-foliolate bract: flowers 4 or 5 lines long: calyx less silky ; its teeth slender, often as long as the campanulate tube.

Var. (?) Nevadensis, Watson. Low and apparently anuual : flowers somewhat smaller : calyx-teeth half as long as the tube.-H. Heermanni, Anderson, Cat. Pl. Nevada, 119 ; Watson, Bot. King Exp. 63, in part. 
The typical form is frequent in Washington Territory, Oregon, and Idaho, but seems not to have been found in California. The variety is common in the Sierra Nevada from the Yosenite to Sierra Co., Lemmon.

\section{++ Pubescence somewhat tomentose and more or less spreading: pod very short, the body scarcely exceeding the calyx.}

24. H. tomentosa, Hook. \& Arn. Very pubescent: the stem covered with spreading hairs, weak and flexuous, prostrate or asceneling, a fout lung or more : leatlets 5 to 7 , cuneate-oblong to obovate, acute, 3 to 6 lines long: umbels on short bracteolate peduncles, or the uppermust sessile: Howers 3 or $t$ lines long: calyx half as long or more, very villous; the teeth lax, tiliform, as long as the tube. Bot. Beechey, 137 ; Torr. \& Gray, Fl. i. 324. Syrmatium tomentosum, Vogel in Linnæea, x. 591.

In dry places near the coast, from San Francisco to Monterey.

25. H. Heermanni, Durand \& Hilgard. Less densely pubescent: the stem nearly glabrous, utch branched and sprealing: leatlets smaller, 2 to $t$ lines lons: umbels on short peeluncles or often sessile : fluwers smaller, 2 or 3 lines loug : calyx less villous, half as long; the filiform teeth about equalling the tube. - I'acif. $I$. Rep. v. 6, t. 4.

Sand-hills near San Francisco (Filch) and southward to San Diego.

\section{PSORALEA, Linn.}

Calyx-lobes nearly equal, or the lower one larger; the two upper often connate. Keel broal and ohtuse above, united with the wings. Stamens dialelphons or sometimes monalulphus: anthers uniform. Pol ovate, indehiscent, 1-seeded, thick and often wrinkled, sessile. - Perennial herbs (our species), punctate with dark grlandular duts; leaves diritate or pinnate, mustly 3 - J-fuliolate, the leaflets entire; stipules nut alnate to the petiole; Howers white or puplish, in axillary pedunculate spikes or racemes, with mostly memhranaceous and deciluous bracts.

A genus of about 100 sqrecies, foumd in all tempurate and tropical regions, lut most numeromsly in North Ameriar and sunthern Africa. of the 30 North American species, most are confined to the eastern and southern portions of the United States.

$$
\text { * Leaves pinnately 3-foliolate. }
$$

\section{+ Stems prostrate, creeping: leaves large, orbicular.}

1. P. orbicularis, Limll. Fimely puleesent, the influresene villuts: latirs un

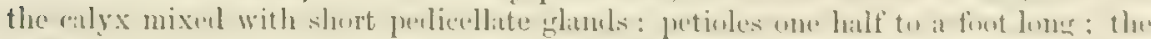

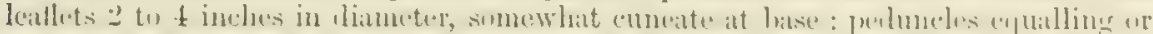

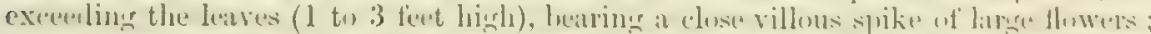

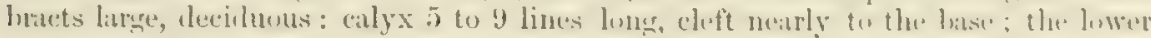

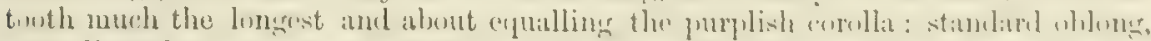

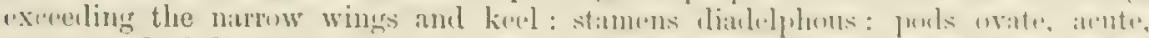
compressed, 3 lines long. - Bot. Reg. t. 1971; Torr. in Bot. Wilkes Exp. 269.

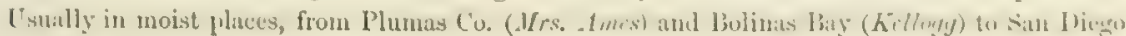
Co., Paliner.

\section{++ Stems erect.}

2. P. strobilina, IIonk. \& Arn. Two or three fert high, mote ut less villums

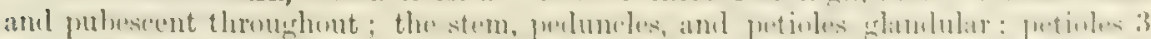

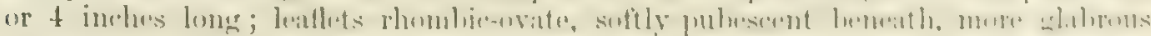

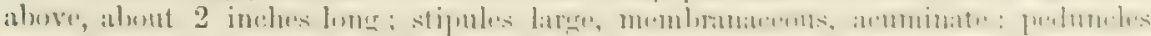
shorter than the lestves: flowers in short oblong spikes; bratets vory large, deciduous: calyx half an inch long or more; lower tooth much the longest and at least 
equalling the purple corolla: stamens monadelphous: ovary pubescent. - Bot. Beechey, 332, t. 80 ; Torr. \& Gray, Fl. i. 689, excl. var.

In the hills from Contra Costa County to Santa Cruz. Differing from the next in its greater pubescence, rather larger leaves, larger stipules, short peduncles, aud larger bracts and flowers.

3. P. macrostachya, DC. Three to six (or sometimes 10 or 12) feet high, puberulent or nearly glabrous, rarely somewhat tomentose : petioles shorter ; stipules small, lanceolate ; leafiets ovate-lanceolate, often acutish at base, an inch or two long or more : peduncles much exceeding the leaves: spikes cylindrical, silky-villous, the hairs often blackish; bracts broad, acuminate, as long as the flowers: calyx 3 or 5 lines long; the lower tooth a little longest, scarcely equalling the purple petals: tenth stamen nearly free: pod villous, ovate-oblong, acute, compressed, 3 or 4 lines long. - Prodr. ii. 220 ; Lindl. Bot. Reg. t. 1769 ; Torr. \& Gray, Fl. i. $689 . \quad$ P. strabilina, $\beta$., Torr. \& Gray, l. e.

Through nearly the length of the State : Rag Cañon, near Shasta (Brewer $)$, and frequent in the foot-hills of the Sierra Nevada; Arroyo Seco, Santa Lucia Mts. (Brewer); San Felipe Cañon, San Diego Co., Palmer.

4. P. physodes, Dougl. A foot or two high, nearly glabrous, slender : petioles short and slender; stipules small, lanceolate; leaflets ovate, mostly acute, about an inch long: peduncles about equalling or sometimes exceeding the leaves: flowers in short close racemes; bracts small : calyx somewhat villous with usually dark hairs, half as long as the corolla, at length much enlarged and inflated, becoming 4 or 5 lines long; its teeth short, nearly equal: petals half an inch long or less, white or purplish : stamens monadelphous: pod rounded, compressed, 3 lines long. - Hook. Fl. i. 136 ; Torr. \& Gray, Fl. i. 304.

In the Coast Ranges from Monterey northward, extending to Puget Sound.

$$
\text { * * Leaves digitately } 3 \text {-foliolate. }
$$

5. P. lanceolata, Pursh. Erect, a span or two high, glabrous or with a few scattered hairs: petioles short; stipules linear-lanceolate; leaflets linear to oblongobovate, acute, about an inch long: peduncles about equalling the leaves: flowers small (2 or 3 lines long), bluish-white, in short spikes; bracts small: calyx very small ; its teeth short, obtuse, nearly equal : stamens diadelphous : ovary very silky : pod compressed, very glandular, 2 lines in diameter. - Hook. Fl. i. 135, t. 51.

Frequent in the interior from Washington Territory to Northern Arizona and eastward to the Saskatchewan and Nebraska. Probably to be found in the northeastern part of the State.

P. FLoRibunda, Nutt., a similar species, ranges from Texas to Western Arizona and may enter S. E. California. It is more or less caneseent with short white hairs, the peduncles exceeding the leaves, and the flowers on short slender pedicels ; petioles mostly very short.

\section{AMORPHA, Linn.}

Calyx obconical, nearly equally 5-toothed. Wings and keel wanting: standard erect, folded together. Stamens slightly united at base, exserted : anthers uniform. Pod oblong, exceeding the calyx, indehiscent, sessile, 1-2-seeded. - Shrubs, glandular-punctate; leaves unequally pinnate, the leaflets usually stipellate; stipules small ; flowers purple or violet, small, in dense clustered terminal spikes.

Half a dozen species, peculiar to the United States, chiefly southern.

1. A. Californica, Nutt. Three to eight feet high, puberulent, the young leaves silky-pubescent: branches often beset with stout projecting glands: leaflets 5 to 7 pairs, oblong-elliptical, obtnse, mucronulate, shortly petiolulate, an inch long: stipules and bracts snall, lanceolate, deciduous: spikes 1 to 3 , and 2 to 6 inches long: flowers purple, $2 \frac{1}{2}$ lines long: calyx balf as long; the teeth silky, triangular, acnte: pod pubescent, half-obcordate, 3 lines long. - Torr. \& Gray, Fl. i. 306. A. fruticosa, Torr. Bot. Mex. Bound. 53. 
In the Coast Ranges, near the sea, from Marin Co. (Bolander) to San Diego Co. It closely resembles $A$. frulicosa of the Atlantic States, but differs in the shape and pubescence of the pod, the more acute calyx-teeth, and the almost spinescent glands. These last, however, are sometimes entirely wanting. Some of the specimens from Marin Co. are remarkable for conspicuous stipules and larger bracts.

\section{DALEA, Linn.}

Calyx nearly equally 5-cleft or toothed. Standard corlate, its claw free: wings and keel usually longer; their claws adnate to and jointed upon the cleft stamineal tube. Stamens 10 (sometimes 9), monadelphous; anthers uniform. Ovary 2(rarely $4-6$-) oruled. Pul ovate, compressed, usually indehiscent, included in the calyx, 1 - 2-seeted. - Herbs or shrubs, crlandular-puntate; leaves unequally pinnate, very rarely dicitately 3 -fuliulate or simple; leaflets small, entire, sometimes stipellate; stipules small, subulate; flowers nearly sessile in terminil peduneulate spikes or rarely solitary.

An American genus of nearly 100 species, a dozen natives of South America, 50 Mexican, and the rest belonging to the warmer portions of the United States. The Californian species are confined to the southeastern desert region.

Petalostemos, Michx, is a similar genus, differing in having only five stamens, the flowers always in dense bracteate cylindrical spikes. There are over 20 species, contined to the United States, several as far westward as Central Arizona, Utah, and the basins of the Snake River and Columbia, but none have been found near the borders of California.

\$ 1. Clawes of the wings and keel adnate to the stamen-tube nearly to their midulle: ovules a single pair. - DaLEA proper.

* IIerbaceous: flouers erect or ascending, in dense spities, with conspiruous bracts: calyx very villous, with long slender teeth: leaflets several or many.

No species of this group of the genus hare heen collected in california, hut the following approach it and some of them may yet be found.

D. BRAchystachys, Gray. A low glabrous annual : flowers yellow, in globose or oblong spikes: bracts villous-ciliate, somewhat persistent : leaflets about 5 pairs, $-S$. Arizona to New Mexico.

D. Alopecuroloes, Willd. A rather tall glabrous annual : flowers light rose-color, in cylindrical spikes : bracts pubescent, scariously margined, deciduous : leaflets 10 to 20 pairs. - From Southern Arizona eastwarl to the Mississippi.

D. LevicatA, Gray. A tall glabrous perennial : flowers yellow or white, in cylindrical spikes: bmets very silky, somewhat persistent : leaflets many pairs, very small. - From Southeru and Central Arizona to New Mexico.

D. ALBIFLoRA, Gray. A tall pubescent perennial : flowers white, in cylindrical spikes ; bracts narrow, very silky, deciduous : leallets 8 to 16 pairs, smull. - From Central and Southern Arizona to New Mexico.

D. NANA, Torr. A low silky biennial or perennial : flowers yellow, in short thick spikes: bracts very silky, decidıous : lenflets 2 or 3 pairs, oblong, obtuse. - From Central and Southeru Arizona to Texas and Mexico.

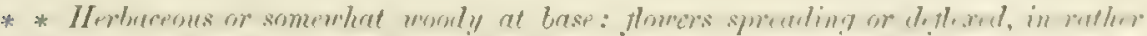

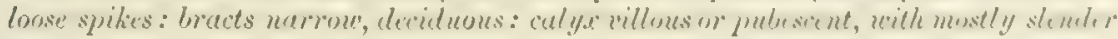
teeth.

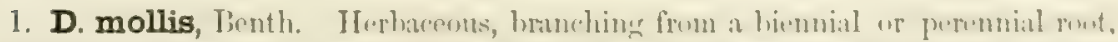

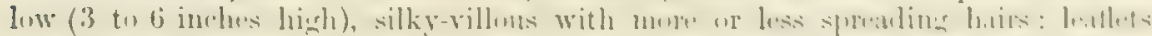

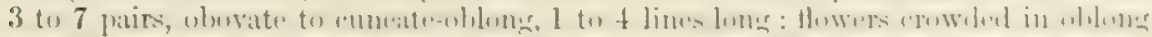

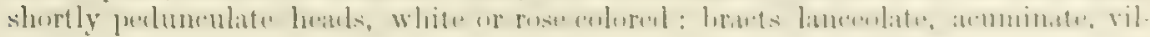
lous: calyx very villous, 2 or 3 lines long; the filiform plumose tecth much longer

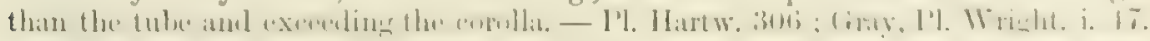

At Fort Mohnve (Cooper) ; on the Colondo (Nevebcry); and eastward to New Mexico. First colloctel by Couller, probubly in S. Arizona. 
2. D. calycosa, Gray. Herbaceous from a biennial or perhaps sometimes perennial root, canescent with a silky puberulence, diffuse and decumbent, slender, about 6 inches high: leaflets 5 to 13 pairs, oblong-obovate, a line or two long, obtuse, glabrous above: flowers 3 lines long, in short loose spikes: peduncles slender: bracts linear : calyx silky ; its teeth narrowly lanceolate, longer than the tube, a little shorter than the purple and white petals. - Pl. Wright. i. 40.

On the San Pedro, S. Arizona (Thurber); ; entrance of the Great Cañon of the Tantillas Mts., below San Diego, Palmer.

3. D. Parryi, Torr. \& Gray. Herbaceous, very slender, puberulent or glabrate : leaflets 6 to 10 pairs, obovate to oblong, a line or two long, obtuse : flowers 4 lines long, bright purple, in loose elongated long-peduncled spikes: calyx not half the length of the corolla, canescent with short silky hairs; its teeth broadly ovate, acute, about equalling the tube : pod smooth. - Gray, Proc. Am. Acad. vii. 397. D. divaricata, var. cinerea, Gray, 1. c. 335.

Gravelly hills near Fort Mohave (Cooper) ; also on the Colorado in W. Arizona, near the mouth of Bill Williams River.

D. Wrsuizeni, Gray. Somewhat woody at base, erect, slender, a foot high, silky-villous : leaflets 7 to 9 pairs, oblong, obtusish, 2 or 3 lines long: spikes short, rather dense : flowers rosecolored, 4 lines long, showy, twice longer than the slender very villous calyx-teeth. - Santa Cruz, S. Arizona (Thurber); Chihuahua (Wistizenus); New Mexico, Wright.

\section{\$2. More or less woody and shrubby: claws of the petals adnate to the stamen-tube only at the very base: ovules 2, rarely 4 or 6 : flowers spreading or reflexed, mostly in loose spikes or racemes. - XYLODALEA, Watson.}

* Calyx very pubescent; its teeth slender.

4. D. Emoryi, Gray. Shrubby, much branched, 2 to 5 feet high, hoary-tomentose throughout with a very fine pubescence: leaflets 1 to 3 pairs, narrowly oblong to obovate, 2 to 4 lines long, the terminal leaflet much longer: spikes very short, pedunculate: flowers 2 or 3 lines long, purple: calyx-teeth as long as the tube, a little shorter than the corolla: ovary pubescent. - Pl. Thurb. 315 ; Torr. Pacif. R. Rep. v. 360 , t. 11.

In sandy soils on the Colorado and Gila ; desert east of Sau Bernardino, Parry.

5. D. arborescens, Torr. "A small tree," much branched, somewhat spinose, the jounger branches, leaves, and calyx densely hoary-tomentose: leaflets 1 to 3 pairs, obovate, approximate, 2 or 3 lines long: flowers in short nearly sessile rather close spikes, purple, 4 or 5 lines long: calyx large, but shorter than the corolla, the broader oblong or narrowly lanceolate teeth nearly equalling the tube. - Gray, Pl. Thurb. 316.

Collected only by Fremont at the eastern base of the San Fernando Mountains.

6. D. polyadenia, Torr. A stout divaricately branched shrub, 2 to 5 feet high, somewhat spinose, canescent with a fine retrorse pubescence, and sprinkled with numerous reddish glands; the leaflets more hairy and the calyx densely villous: leaflets 3 to 6 pairs, obovate, a line or two long: flowers in short nearly sessile spikes, violet, 3 lines long: calyx-teeth narrow, about equalling the tube, shorter than the corolla: pod scarcely exceeding the calyx, pubescent. - Watson, Bot. King Exp. 64, t. 9 .

In Truckee and Carson Deserts, Northwestern Nevada.

$$
\begin{gathered}
\text { * Calyx slightly pubescent; its teeth broad. } \\
\text { + Leaves pinnate: flowers in loose spikes. }
\end{gathered}
$$

7. D. Californica, Watson. Shrubby, canescent with a fine appressed pubescence, sparingly glandular; the glands upon the peduncles sometimes prominent and prickle-like: leaflets 1 or 2 pairs, decurrent upon the rhachis, 1 to $1 \frac{1}{2}$ lines 
long, linear-oblong: flowers purple, 4 lines long, on short pedicels: calyx half as long, the ovate acute teeth shorter than the tube. - Proc. Am. Acad. xi. 132.

Known only from a scanty specimen collected by Parry in dry washes in the San Bernardino Mountains, near Cajon Pass.

8. D. Fremontii, Torr. Shrubby, much branched, silky-puberulent or puhescent: leaflets 1 to 3 pairs, oblong-oborate, abtuse, 2 or 3 lines long : Howers purple, 4 lines long, rery nearly sessile : calyx bilf as long, somerlat pubescent; the teeth triangular, acute, nearls equalling the tube: pod 4 to 6 lines long. - Gray, Il. Thurb. 316; Watson, Bot. King Exp. 65.

On rocks near Muddy River, S. Nevada (Fremont); also by Licut. Whecter in the same region.

9. D. Kingii, Tatson. Low, somewhat shrubbr, diffusely branched, sparingly appressed silky, the lax spinulose branches and fuliage yellurrish-green : leatlets 1 to 4 pairs, oblong, chetnse, 2 or 3 lines long; the terminal longer, linear-oblung: thwers seattered upon the branchlets, nearly sessile, purple, 3 or 4 lines long: calcr fincty pubescent; the shortly acuminate teeth equalling the tube, shorter than the corolla : pod small, pubescent. - Bot. King Exp. 64, t. 10.

On drifting sand in the Hot Spring Mountains, Northwestern Nevada, Watson.

\section{++ Leaves simple.}

10. D. Schottii, Torr. Shrubby, slender, nearly glabrons, somewhat spinose, the branches nearly glandless: leaves scattered, narrowly linear, an inch lung: fluwers few, on short slender pedicels in an open racene, sometimes solitary, purple, 4 lines long: calyx half as long, obseurely glanelular; the teeth rery short, atutish: ovary pubescent, 2-ovuled: pod 4 lines long, with a single large seed. - Bot. Mex. Bound. 53.

Banks of the Colorado, near Fort Yuma (Schott); Colorado Desert, Palmer.

11. D. spinosa, Gray. A shrub, nuch branched and rery spinose, 4 to 1.5 fert high, hrary with a minute appresserl puhescence: leaves scattered, cuneate-ohling or nearly linear, obtuse, nearly sessile, 4 to 8 lines long, very deciduous: flowers noarly sesile, in a lonse spitite purple, 5 lines long : calrx half as lone, markerl hy

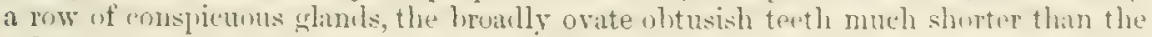
tube: ovules 6 : pod twice longer than the calyx, 1-seeded. - Pl. Thurb. 315; Torrey, Pacif. R. Rep. vii. 9, t. 3. Asagrae spinosa, Baillon, Adansonia, ix. 232.

On Carico Creek (Antiscll), in the Colorado Desert (Thurber), and eastward on the Gilth Made a distinct genus by Baillon, mainly on the larger number of ovules and tho simplo leaves.

\section{GLYCYRRHIZA, Linn. Liqunice.}

Flowers nearly as in Astregalus. Stamens momblelphous or dialdphons : anthercells cunfletent at the trip, the alternate anthers smaller. Orary susile, 2-many-

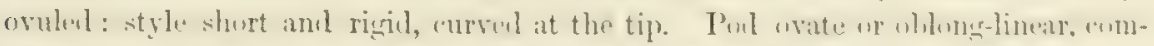

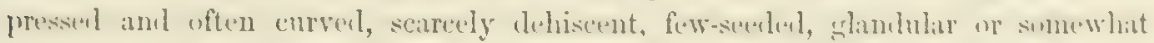

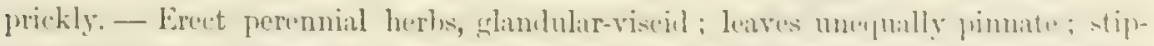

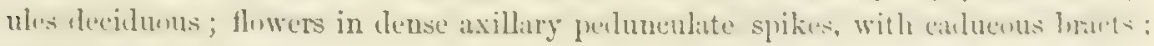
ront large and sweet.

About a dozen species, found in all quarters of the globo but Africa; only ono Nortl American.

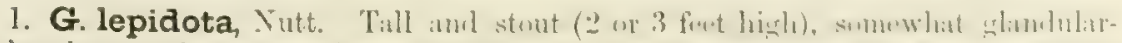

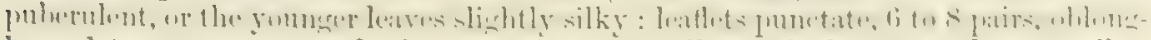
lanceolate, mucronate and often acuminate, usully an inch or two long: spikes short: flowers ochrolencous, nearly 6 lines long: calyx half as long; the slender

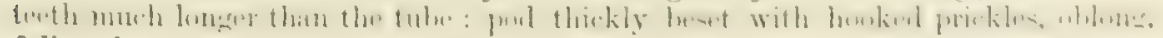
6 lines long, 2 -6-semled. - Hook. Bot. Mag. t. 2150; Torr. \& Gmy, Fl. i. 298 
Var. glutinosa, Watson. More or less covered with stout spreading glandular hairs, especially the peduncles, which are shorter than the spikes: calyx very glandular. - G. glutinosa, Nutt. in Torr. \& Gray, Fl. i. 298.

The typical form of the species ranges from Washington Territory to Hudson's Bay and southward to Arkansas, New Mexico, and Nevada, and may be found on stream-banks in Northeastern California. The rarer variety has been collected in Washington Territory (Nuttall, Lyall), and in Corral Hollow, Alameda Co., Brever. It is described as having the wings and keel tinged with purple ; the fruit is not known. The leaves in both forms are often sprinkled beneath with minute resinous globules.

\section{ASTRAGALUS, Tourn. Rattle-Weed. (By A. Gray.)}

Calyx 5-toothed. Corolla and its slender-clawed petals usually narrow : keel not pointed. Stamens diadelphous. Stigma terminal and minute. Legume (pod) very various, commonly turgid or inflated, one or both sutures usually projecting inward more or less, the dorsal one frequently so much as to divide the cell into two. Seeds few or many, on slender stalks, generally small for the size of the pod. - Herbs, or a few woody at base; with unequally pinnate leaves, and rather small flowers, chiefly in simple spikes or racemes from the axils; the peduncle commonly elongated. - Gray, Rev. in Proc. Am. Acad. vi. 188 ; Watson, Bot. King Exp. 435.

A vast genus, of five or six hundred species, mainly of the northern hemisphere and the ternperate or frigid zones, most numerous in Asia, and next in North America between the Mississippi and the Pacific. In California they have the reputation of being poisonous to sheep, which would be most unexpected were it not that several Papitionacea of Australia are known to be so. The fruit is needed for the determination of the species, To aid in this rather difficult matter an artificial key is here given. Besides the following, several other of the almost 150 North American species now known may reach California or its borders; but it is impossible to indicate them beforehand.

OxYTRopIs, DC., a genus which is distinguished from Astragalus by a subulate beak at the tip of the keel, might be expected at alpine elevations in the Sierra Nevada, at least in the northern portion. But no representative has been met with within or near the State.

* Leaflets not prickly-pointed.

+ Root annual.

Pod wrinkled, didymous, 2-seeded.

Pod not wrinkled, several-many-seeded,

Narrowly oblong, 5-10-seeded: flowers 5 to 9 in a head.

Ovate-oblong, 4-6-seeded : flowers as the last.

Linear, falcate : flowers few and crowded, very small.

Ovate, inflated, acute or pointed,

Thin-bladdery, incurved, 1-celled.

Chartaceous and bladdery, 2-celled.

Firm-chartaceous, canescent, 1-celled.

1. A. DIDYMOCARPUS.

2. A. TENER.

3. A. BREWERI.

4. A. Nuttalliarts.

5. A. GEYERI.

6. A. Coulteri.

7. A. ARIDUS.

+ Root perennial.

++ Pod bladdery-inflated, thin-membranaceous, ample.

Pod 2-celled, ovate, often purplish-mottled.

Plant slightly or very pubescent : stems 6 to 18 inches long. 8. A. LENTIGINosus.

Plant silvery-silky, nearly stemless.

9. A. PLATYTRopis.

Pod 1-celled, the dorsal suture not intruded,

Stipitate in or raised out of the calyx.

Stems a span high : pod very obtuse,

Obovate, 1 or 2 inches long.

Oval, an inch or less long.

10. A. Hookeriants,

Stems a foot or more high.

Stipe little if at all exceeding the calyx.

Pod ovate, acute, not oblique.

11. A. WHITNEXI.

Pod semi-ovate, acntish, on a recurved rigid stipe. 14. A. curTIPES.

Stipe filiform, an inch long, almost equalling the oval pod. 15. A. LevcophyLLUs. 
Stipe half shorter : poul acute at base,

Stipe a quarter of an inch long, half the length of the pod.

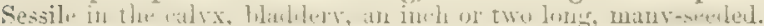

Corolla pale yellow, short and broad : stipules herbaceous.

Corolla white or whitish, narrow, an inch long: stipules scarious.

Stipules distinct : pod rather firm-walled.

Sripules united opposite the petiole : pod thin-bladdery.

Corolla yellowish-white or cream-color, 4 lines long, bardly twice the length of the calyx.

Herbage villous when young : calyx-teeth as long as the tube.

Herbage puberulent when young : calyx-teeth shorter than tube.

Sessile in the calyx, half an inch long : flower a quarter-inch long.

Nearly glabrous : pods capitate, ovate, acuminate, 10-15-seeded.

Villous : pods few, ovate-incurved, 3-8-seeled.
16. A. TETCOPSIS.

17. A: TRICHOPHYLLES.

18. A. OOCALPUS

19. A. Crotalaris.

20. A. Mexziesit.

21. A. Macrodox.

22. A. Dotghasil.

23. A. HoRNII.

24. A. Pulsiferf

+++ Pod coriaceous or cartilaginous, or chartaceous, not bladdery-inflated,

$=$ Long-woolly or long-hairy, sessile in the calyx, many-seeded.

Plant white with soft wool, very low : pod densely woolly.

Plant and pods long-hairy, taller.

Plant and pods downy with short hairs, slender.

25. A. Purshit.

26. A. Ma Laclis.

27. A. AxDELSONu.

$==$ Pod glabrous or pubescent with short hairs.

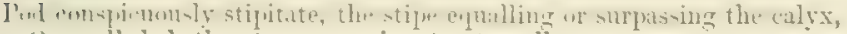
Une-velled, both sutures prominent externaliy.

C'alyx very obliquely attached to the pedicel and recurved on it: pod curved or coiled, rigid.

Herbage soft-downy : pod pubescent.

Herbage minutely pubescent : pod glabrous,

Calyx not oblique : pod struight, thinner-walled, linear-oblong.

Almost glabrous: pod obtuse at base; stipe half an inch long.

Iloary-pubescent : pod tapering into a stipe a quarter-inch long.

Glabrous: stipe 2 lines long.

Two-celled by intrusion of the dorsal suture, turgid,

Narrowly oblong, straight, erect.

Ovate, incurved, reflexed on the stipe.

28. A. CTRTOINES.

29. A. SPEIIOCARPUS.

30. A. FILIPES.

31. A. ANTISElti.

32. A. YORRECTUS.

33. A. ARRECTIS.

34. A. BOLANDERI.

Pod very short-stipitate in the calyx, peadulous, oblong-linear, straight. 40. A. ATRATUs.

Poil sessile in the ealy $x$ or nearly so, and exceeding it.

Stems a span to a fnot or more high.

Flowers an inch long, few : pod oval, 1-celled.

Flowers one third to two thirds of an inch loug,

Fesw or seattered in the spike.

Pod llattened fore and aft, ming-margined.

Pod more or less flattened or narrower fore and aft, marginless, curved nt maturity.

Ienflets 5 to 15, linear, scattered, honry-pubescent.

leaflets 11 to 21 , crowiled,

Obovate or roundish, lonsely pubeseent or glabrous : flowers purple.

35. A xtDes.

Oblong or obovate, minutely silvery-silky : flowers white.

Poil terete with a groove on the back, narrow, straight,

Short-stipitate in the calyx, not erect.

Not at all stipitate, erect.

Many flowers and pouls croweled in a dense snike.

l'ouls oblong, obtuse, 2-cellerl, many-seeried.

l'orls ovate, acute, lenticular, I-cellei, $2-5$-seceded.

Flowers and few-seeded 2 -celled porls only 2 or 3 lines long.

Herbago and turgiil pods minutely pubescent; the latter gronvel. on the lonek.

Iferhngo and laternlly flattish pods very puheseent.

Stems or rootstorks not rising from tho ground: leutlets few : scape few-flnwerel : por? small.

l'oul sessile in and shorter than tho ealyx, few-sected.

36. A. PTERocarpts.

37. A. CASEI.

38. A. IODANTHTS.

39. A. WEBBERT.

40. A. Atrates.

41. A. obsccres.

42. A. Mกвтолi.

43. A. PYCNUSTAinYs.

44. A. TEMmoxi.

45. A. LENTIFuR.

46. A. cintronits.

47. A. Atsrisis.

- Leufets priıkly pointed and rigil, persistent.

Peiluncles vory short, 1-3-flowened : poul vory small, 1-4-seched.

48. A. ReistiupHYT. 
I. Species with an annual root, all low, mostly small.

\$ 1. Pod strongly transversely wrinkled, didymous, 2-seeded.

1. A. didymocarpus, Hook. \& Arn. Slender, from 3 inches to a foot high, pubescent with some fine and rather scattered hairs, those of the peduncle and calyx blackish: leaflets 9 to 15 , narrowly. oblong to linear and more or less cuneate, deeply notched at the apex: spike an inch or much less in length, close: flowers $1 \frac{1}{2}$ to $2 \frac{1}{2}$ lines long: corolla white and violet, its keel inflexed at tip : pod not over two lines long, short-oval and deeply 2-lobed lengthwise so as to be divided into two cells, each nearly filled by the single proportionally large seed. Bot. Beechey, 334, t. 81. A. Catalinensis \& A. nigrescens, Nutt. Pl. Gamb. 152.

Low groumds and slopes, common through the western part of the State from Marin Co. southward, flowering in spring. Like most annuals varying greatly in size and robustuess.

\section{\$2. Pod not wrinkled, few-many-seeded.}

* Calyx blackish-hairy, much shorter than the violet or white and violet-tipped corolla: pod not inflated, between oblong and linear: flowers few and nearly sessile, crowded in a small head which does not lengthen in fruit.

2. A. tener, Gray. Slender, a span or so in height, sparsely and minutely pubescent: leatlets 9 to 15, linear or cuneate-linear, with or without a retuse or notched apex: head 5-9-flowered: pod between coriaceous and cartilaginous, about half an inch long, 2-celled, 5-10-seeded. - Proc. Am. Acad. vi. 206. Phaca astragalina, var., Hook. \& Arn. Bot. Beechey, 334. Astragalus Hypoglottis, var. strigosa, Kellogg, Proc. Calif. Acad. ii. 115, fig. 37.

Moist grounds, common around San Francisco Bay, \&c. Corolla 4 or 5 lines long, often bright violet, sometimes pale and violet-tipped.

3. A. Breweri, Gray, 1. c. Much like the preceding: leaflets broader, oblongobcordate : forming pod more ovate, 6-ovuled, and 1-celled or nearly so.

Sonoma Valley, common in fields, Brevicr. Not since met with; the fruit unknown. Perhaps not distinct from the preceding.

** Calyx whitish-haired or neanly so: pod linear: flowers few and crowded at the apex of the peduncle.

4. A. Nuttallianus, DC. More or less pubescent or hoary with white appressed hairs, soon diffusely branched from the base: leaflets 11 or 13, oblong or broadly linear and mostly notched at the end: calyx-teeth slender and as $1 . \mathrm{ng}$ as the tube: corolla whitish and purple, about 3 lines long; the keel with the inflexed tip narrowed: pod over half an inch long, laterally flattish, slightly scythe-shaped, the incurvation mostly near the base, deeply grooved on the back, acutish on the other edge, 2-celled, several-seeded; the surface minutely reticulated, either glabrous or with minute appressed hairs.

Southeastern borders of the State (on the Rio Colorado, Newberry), and east to Texas and Arkansas.

* * * Calyx white-pubescent or canescent: pod ovate and inflated: flowers racemose.

5. A. Geyeri, Gray. Strigosely somewhat hoary, branching from the base, a span high: leaflets 7 to 11 , linear, less than half an inch long: raceme $3-7$-flowered: corolla yellowish-white, 3 lines long: pod thin-bladidery, half an inch long, very oblique and the acute tip incurved, minutely hoary-pubescent, 1-celled, many-seeded. - Phaca annea, Geyer.

W. Nevada, not far from the boundary (Watson); thence east to Wyoming, Geyer, Parry.

6. A. Coulteri, Benth. A span to a foot high, stouter, tornentose-canescent or the leaves silvery-silky : leaflets 9 to 19 , obovate or oblong, sometimes emarginate, 3 to 5 lines lonir : raceme or spike locsely 10-20-flowered : calyx-teeth shorter 
than the tube: corolla purple, about half an inch long : pod ovate and pointish, inflated, of somewhat chartaceous texture, nearly three fourths of an inch long, hoary with appressed hairs, nearly or quite 2-celled. - Pl. Hartw. 307. A. Arthu-S'chottie, Gray, 1. c. 209.

Near Monterey, Couller, according to his herbarium; but probably collected in the arid region of the southeastern borders of the State, where it was found by Fremont, Schoth, Cooper, \&.c.

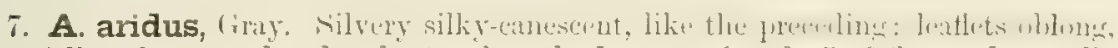
3 or 4 lines long: peduncles shorter than the leaves, spicately 5-8-fowered: corolla barely twice the length of the calyx, hardly over 2 lines long, yellowish-white: pod obliquely ovate, acute, inflated, of firm chartaceous texture, half an inch long, cauescent, one-celled. - Proc. Am. Acad. vi. 223.

Southern borders of the State, between Colorado and San Diego, Thurber.

II. Species with perennial roots: leaflets and stipules not spinescent.

\$1. Pnd bladdery-inflated (the walls thin and membranous), several-many-seeded,

* Troo-celled by the turning in of both sutures till they meet or nearly so, more or less didymous, being grooved externally down both sides, sessile in the calyx.

A. Drpirsus, Gray, Pl. Fendl. 34, which extends from New Mexico to the centre of Nevada, comes near $A$. lentiginosus, but is glabrous throughout, excent sometimes a little pubesence ou the calyx, and has rather large pods.

8. A. lentiginosus, Dongl. A span to a foot or so high, the tufted stems soon diffusely spreading, from slightly to hoary-pubescent: leaflets 11 to 19 , from obovate or obcordate to oblong, a quarter to half an inch long: peduncle short: flowers and fruits mostly crowded in the oblong spike or raceme: corolla either white or purple, nearly half an inch long: pod turgid-ovate and pointed, more or less incurved, usually pubernlent, occasionally purplish-mottled, seldom an inch and sometimes only half an inch long. - A. ineptus, Gray, Proc. Am. Acad. vi. 525, appears to be only a narrow-leaved and pubescent form. A. diaphames, Dougl. in Hook. Fl. i. 151.

Var. Fremontii, Watson. More hoary-pubescent, with looser-flowered spikes, usually on a longer perluncle: stem flexuous. - A. Fiemontii, Torr. \& Griy.

Common through the atial interior region, from Washington Territory and the enstern part of the Sierm Nevalla to the southom borlers of the State; the rarity mostly southward. Var. foribundus, Gray, is the ordinary form well developet. This species is one of the poisonous "Rattle-weeds" of the southern and eastern parts of the State.

9. A. platytropis, Gray. Dwarf and tufted on long anel stout horizontal motstocks, densely silvery-silky; the stems very short, harlly rising above the ground: leatlets 7 to 13, obovate or oblong, 3 lines or less in length: slender scape-like poluncles about the leagth of the tufted leaves, bearing a litule heal of 5 or 6 fluwers: corolla yellowish-white, except the broad and round-tipped keel, which is purplish and as long as tho other petals: pod turgid-ovate, very short-pointed, puberulent, sometimes purplisl-wottled, an inch or less in lengtl. - Pruc. Am. Acad. vi. 526.

Sierm Nevada abovo Sonom Pass, at 10,000 feet, Brewer. Enst Ilumboldt Mfountains, Nevada. at 11,000 feet, $W$ itsons.

* * One-celled pod, with no turning in of the dorsal suture,

+ Stipitate, $i$. e. the pod ratsed more or less on a stalk of its uxm abme the caly.r.

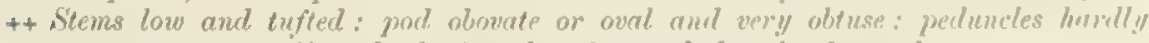
exceding the lenf, rather fow and dewsely flowerd.

10. A. Hookerianus, Gray. Silky-villons or puheseent, diffusely tufted, $\pi$ span high : leathets 13 to 19 , ohlong or linear, 2 or 3 lines long : Howers very shurtpedicelled: corrlla whito or whitish: pod obovate and not in the least pointed, 
thin-bladdery, one or two inches long, glabrous; its stipe slightly exceeding the short-campanulate calyx. - Phaca Hookeriana, Torr. \& Gray.

Mountains in the interior of Oregon (Douglas), and W. Nevada (Anderson, Watson), extending into Nevada and Sierra counties, Bolander, Lemmon.

11. A. Whitneyi, Gray. Minutely appressed-pubescent: stems erect: leaflets 11 to 19 , linear-oblong, 3 lines long : flowers short-pedicelled : corolla "red-violet," in the specimen seemingly only purplish : immature pods smaller than in the foregoing, oval, and narrowed at base into a more slender stipe which becomes nearly twice the length of the oblong-campanulate calyx. - Proc. Am. Acad. vi. 526.

In the Sierra Nevada at Sonora Pass, at 10,000 feet, Brewer.

+++ Stems very short and tufted on the rootstocks: pod ovate and acute, longer than the few-flowered common peduncle, short-stipitate within the calyx.

A. megacarpus, Gray in Proc. Am. Acad. vi. 215 (Phaca, Nutt.), is here mentioned to complete the series, and because its var. PARry , Gray, with narrower pods and leaflets, found in Southwestern Utah, may approach the eastern border's of California.

$$
4+\div+\div \text { Stems a foot or more high and mostly erect. }
$$

= Stipe of the nore or less acute pod equalling or little exceeding the calyx.

12. A. oophorus, Watson. Glabrous throughout: stems lax or decumbent, a foot or two long: leaflets 9 to 13 , oblong, obtuse, half to three quarters of an inch long: peduncles equalling the leaf, racemosely several-flowered: calyx-teeth setaceous from a dilated base, as long as the broadly campanulate tube: corolla yellowish-white, sometimes violet-tipped, half an inch long: bladdery pod ovate, not oblique, acute, an inch and a half long, pendulous on a stipe which barely exceeds the calyx-tube. - Bot. King Exp. 73.

Shoshone Mountains at Reese River Pass, Nevada, Watson. The only station yet known.

13. A. oxyphysus, Gray. Canescent with very soft silky pubescence: stem ereet, 2 or 3 feet high: leaflets 9 to 21, oblong, an inch or less in length: peduncles much exceeding the leaves: raceme elongated, rather densely flowered: calyx-teeth subulate, barely half the length of the oblong tube: corolla greenish-white, two thirds of an inch long: bladdery pod clavate-obovate, oblique, acuminate at both ends, and especially tapering into the recurved stipe (which exceeds the calyx), almost glabrous, about an inch and a half long. - Proc. Am. Acad. vi. 218.

Dry hills in the Monte Diablo range, Arroyo del Puerto, Erewcr. A striking species.

14. A. curtipes, Gray, 1. c. Cinereous with a minute appressed pubescence, or green with age : stem a foot or two high: stipules mostly united opposite the petiole: leaflets 13 to 33 , oblong or almost linear, retuse, half to three fourths of an inch long: peduncles in fruit longer than the leaf: raceme short and rather dense: calyx-teeth setaceons-subulate, little shorter than the broadly campanulate tube: corolla not seen : bladdery pod semi-ovate or oval, acutish, an inch and a half long, glabrous, pendulous on a recurved rigid stipe which hardly exceeds the calyx-tube.

Dry hills at San Luis Obispo, Brewer. Near Ojai, Prof. G. L. Goodale. In fruit only.

$=$ Stipe of the slightly pointed or obtuse glabrous pod filiform, much exceeding the calyx: stem erect: raceme or spike densely flowered and long peduncled.

15. A. leucophyllus, Torr. \& Grry. Canescent with fine and soft silky pubescence when young, when older rather greenish: stem rather stout, 2 or 3 feet high: leaflets in many pairs, broadly linear, often an inch long: flowers fully half an inch long: calyx-teeth subulate, about half the length of the oblong tnbe: corolla yellowish-white: thin-bladdery pod oval, unequal-sided, an inch and a half long, on a filiform pubescent stipe of almost equal length! - Phaca leucophylla, Hook. \& Arn.

Iower part of the Sacramento to Monterey? Not well named; when full-grown hardly hoary. 


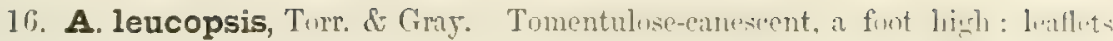
in muny pairs, from broadly oblong to almost linear, half an inch or more in length: spike-like raceme mostly short (an inch or two long, rarely longer): ealyx-teeth more than half the length of the campanulate tube: flower otherwise nearly as in the foregoing: the pod similar, but somewhat tapering at base into a nearly glabrous stipe of half an inch or less in length and only twice or thrice the length of the calyx-tube. - But. Mex. Bound. 56, t. 16. Phaca canescens, Nutt. P. leucopsis, Torr. \& Gray, Fl. i. 694.

Dry hills, Sinta Barbara to San Diego Co.

17. A. trichopodus, Gray. Strigulose-puberulent or at first hoary, in age almost glabrous : stem slender, a foot to a yard high: leaflets in many pairs, from narrowly oblong to nearly linear, about half an inch long: raceme short : flowers 4 or 5 lines long: calyx-teeth very much shorter than the campanulate tube: corolla yellowish white: pod oval, obtuse at both ends, over half an inch in length, but very much smaller and less blatdery than any other of this subdivision; its stipe only a quarter of an inch long. - Placa trichopada, Nutt.

Dry lills, common in and near Santa Barbara Co.

A. ampollarius, Watson, the only remaining known species of this subdivision, is dwarf, short-peduncled, with rather few leaflets, violet-purple flowers, extremely short calyx-teeth, and pod ovate with a truncate or abrupt base, on a stipe of its own length. It inhabits S. Utah, but may approach the borders of Calilornia.

\section{++ Pod sessile in the calyx (not at all stipitate),}

+ Large and very bladdery, over an inch and sometimes two inches long, manyseeded: leaflets mostly in many pairs: spike or raceme many-flowered.

= Stipules (at least the upper ones) herbaceous and rigidly deflexed: corolla apparently pale yellow or cream-color, short and broad, incurved: stems 3 to 6 feet long, straggling or decumbent and branching.

18. A. oocarpus, Gray. Glabrous, or young parts minutely pubescent: stems flexuous and with spreading branches: leaflets from oblong to broadly linear, obtuse (from half to an inch long), bright green and of thickish firm texture : peduncles sonetimes exceeding tho leaves: Howers loose in the raceme, 4 or 5 lines long: calyx campanulate and with very short triangular-subulate teeth: corolla comparatively short, with keel much incurved and staudart turned back: pod ovate or oval and short-pointed, an inch to an inch aud at half long, of parclinent-like texture; the seed-bearing suture somewhat projecting into the cell. - Proc. Am. Acad. vi. 213. A. Crotalaria, Torr. Bot. Mex. Bound. 56, t. 17, excl. syn.

Common through the mountains enst of San Diego, Parry, Clcrclanel, Pulmer. A strongly marked species, varying however in tho size and shape of the pod, which in the smaller form is ovate, but in the larger is elongated-oval and the walls more membranaceous.

$==$ Stipules scarions or nearly 80 : leaflets usually crovoded in very many pairs: peduncles elonyated and bearing numerous som deflexed flowers, which are usually cronded in the raceme: corolla straightish and narrow, fully half an inch long, yellowish-white or white, or sometimes the tips dusky-purplish.

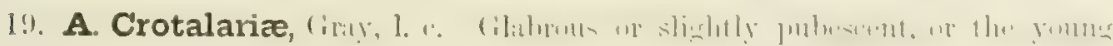
parts sometimes villous: stems erect or nearly so, 2 or 3 feet high, usually stunt: leattets from oblong-linear to obovate-nval or slightly obcorlate, thickish (from a quarter to a full inch long): stipules triangular and distinct: callyx-teeth suluulate, about half the length of the short-canpanulate tube: corulla white: pud of rather parchment-like texture, but much inflatesl, oroid, an inch to an inclu and a half in

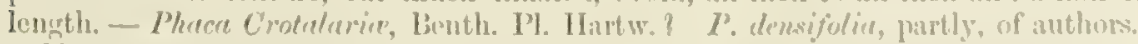

Var. virgatus, fray. Stipules ruore subulate: racemes virgato anil loose, t to 10 inches long: ralyx-torth subulate-setaceons anil longer. 
Hills and plains, from around San Francisco Bay to Santa Barbarn Co.; the variety about San Francisco Bay, Bridges, Kellogg or Holder. If Phaca Crotalarice, i. e. the specimen of Coulter, was really collected "near Nonterey," it is most probably a pubescent and fewer-flowered form. of this, with broad and less numerous leaflets. But several of Coulter's plants said to come from Monterey must have been gathered on the way thither in the southeastern part of the State, or in Arizona.

20. A. Menziesii, Gray, 1. c. Villous with whitish hairs, or soon green and almost glabrous: stems erect or decumbent, 1 to 4 feet high: stipules broader and less pointed, all but the uppermost united on the side of the stem away from the leaf: leaflets and dense spicate raceme as well as flowers nearly as in the preceding: pod similar, but larger (an inch and a half or more long) and more bladdery, the walls thin-membranaceous. - Plhaca densifolia, Smith; Hook. Ic. Pl. t. 283, excl. syn. Nutt. P. Nuttallii, Torr. \& Gray, Fl.

Meadows and sandy fields, San Francisco Bay to Santa Barbara near the coast.

$==$ Stipules scarious or thin-membranaceous, mostly subulate: peduncles shorter than the leaves and rather few-flovered: corolla hardly twice the length of the calyx. (about 4 lines long), yellowish-white or cream-color.

21. A. macrodon, Gray, 1. c. Villous-canescent, at least when young: stems a foot or two high: leaflets in numerons pairs and mostly crowded, oblong-linear (from a third to an inch long): flowers crowded, soon reflexed: calyx-teeth slendersubulate, as long as the campanulate tube, little shorter than the corolla: mature pod not seen. - Phaca macrodon, Hook. \& Arn.

Near San Franscisco or more probably Monterey, Douglas. More specimens are needed.

22. A. Douglasii, Gray, 1. c. Cinereous-puberulent, alnost glabrous in age: stems ascending, a foot or so in height: leaflets in rather numerous pairs, linear or linear-oblong (a third to three quarters of an inch long) : spike (half an inch to an inch long) 10-20-flowered: calyz-teeth subulate, from half to three fourths the length of the campanulate tube : pod thin-bladdery, gibbous-ovoid, $1 \frac{1}{2}$ to 2 inches long. - Phaca Douglasii, Torr. \& Gray, Fl. 346.

Gravelly beds of streams near the coast, San Francisco to San Luis Obispo.

+++ Smaller pods (about half an inch long), few-several-seeded: stems low or spreading: flower only a quarter of an inch long.

23. A. Hornii, Gray. Glabrous or minutely pubescent: stems slender, ascending: leaflets about 21, narrowly oblong ( 4 to 7 lines long): peduncle surpassing the leaves: flowers numerous in a dense head or short spike, which is equally dense in fruit: calyx-teeth subulate, about the length of the campanulate tube: corolla yellowish-white, straightish: pods ovate from a broad base and gradually acnminate, straight, villous-pubescent, 10 - 15-seeded. - Proc. Am. Acad. vii. 398,

Eastern side of the Sierra Nevada, in Owen's Valley (Dr. Horn), and at Bakersfield, to S. Utah. Said to be one of the sheep-poisons.

24. A. Pulsifera, Gray. Whitish-villous: stems numerous in a tuft and procumbent, slender, branching: stipules slender-subulate: leaflets 5 to 11, obovatecuneate, mostly retuse, 3 or 4 lines long: peduncles not louger than the leaf, rather loosely 3-5-flowered: flowers pedicelled: calyz-teeth linear-filiform, twice the length of the campanulate tube, about the length of the keel of the incurred white and purple-tinged corolla: the narrow wings and especially the standard (notched at the apex) much longer: pod ovate-inflated and incurved, villous-pubescent, 3-8seeded. - Proc. Am. Acal. x. 69.

Gravelly hills and banks, Sierra and Plumas counties, Mrs. Pulsifer Ames, Lemmon. The pods, although small (barely half an inch long), as in the inflated-fruited section; but otherwise, in aspect, mode of growth and size, wholly different.

A. Pebentissimus, Gray, Proc. Am. Acad. vi. 209, is nearly related to the preceding, and is probably perennial; but it has short stems, much broader stipules, leaflets hardly narrowed 
downwards, more numerous and rather larger flowers, slender calyx-lobes not so long in proportion to the tube, and the more hairy pod strongly inflexed.

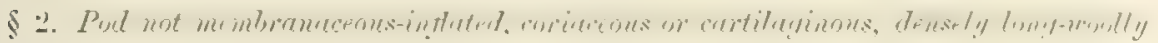
or long hairy, commonly turgid, incurved, many-seeded, sessile in the calyx.

* Cespitose and depressed, the stems very short or spreading on the ground: foliage. canescently woolly or silky-villous: flowers long and narrow, often an inch in length: tube of the calyx cylindrical: filiform claws of the petals much longer than the blades: pods very densely woolly, ovate-incurved.

25. A. Purshii, Dougl. Barely a span high, in matted tufts, canescently silkyvillous rather than tomentose: leaflets 9 to 19 , oblong ( 3 to 5 lines long): peduncles shorter than the leaves, beiring 5 or 6 crowiled flowers: calyx-teeth slendersubulate : corolla dull white with purple tip to the keel and sometimes to the other petals: pod an inch or less in length, very densely clothed with long white or yellowish hairs, so as to appear like pellets of wool, at length much incurved, of rather cartilaginous texture, one-celled, but at maturity the dorsal suture sometimes inward so as nearly to meet the ventral, but not strictly forming a partition. - Hook. Fl. i. 152; Gray, 1. c. Phaca mollissima, Nutt.

Eastern ranges of the Sierra Nevada (Anderson, Brcwer, \&ce.), and through the dry interior to the Rocky Mountains and the borders of British Columbia. Also on MIt. San Carlos, at 3,500 to 4,000 feet, on a very dry slope, Brevocr. The Californian forms are comparatively small-flowered, and have the corolla purple at tip. - Of the annexed nearly related species none have yet been collected in the State, hut most of them may probably be found.

A. Utahexisis, Torr. \& Gray. (Phaca mollissima, var. Ulahensis, Torr. in Stansbury Rep. 385, t. 2.) This belongs to the Salt Lake district, but appears to have been found by Watson even in the western part of Nevada It is distinguished from A. Pursliti only or mainly by rounder leaflets, clothed with truly tomentose white wool, and longer peduncles.

A. Thompsose, Watson, Proc. Am. Acad. x. 345, found in S. Utah by Mrs. Thompison and C'pltain Bishop, is between the two preceding in the shape of the leallets and the woolliness, but las flowers little over half an inch long, shorter calyx-teeth, and a poil (about the same length) with shorter wool, so that its shape is visible, with a conspicuous groore on both sides, the dorsal one forning a partition which divides the cell, exeept near the aente apex.

A. eriocarpus, Watson, Bot. King Exp. 71 (not of Parry's S. Utah collection, No. 44, which is A. Purshit), of the foot-hills in W. Nevala 'This is apparently more steniless than the preceding, has oval or obovate leallets over half an inch in length, \& thinner and longer silky pubescence, which is sparse and rather hirsute on the elongnted naked seape, a dark-haired calyx with filiform teeth more than half the length of the tube, deep-purple corolla over an inch lone and nearly twice the length of the calyx, and an oblong inflexed eurved pot, clothed with shorter and conrser hirsute wool, the sutures intruding helow, but not dividing the cell. This in some respeets approaches the more northern and still imperfectly known A. infterus, Dougl., which is

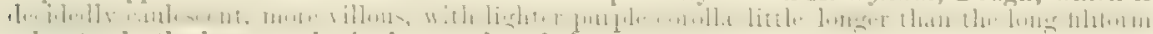
caly-x-teeth, the brats and stipules mostly subulate-sctaceous.

* Stems ascending or erect, a foot or so high: pods falcate, laterally compressed, 2-celled: stipules adnate to the brase of the petiole.

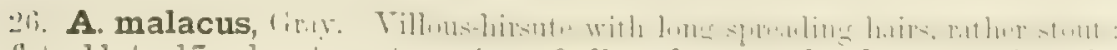
lenflets 11 to 17 , obovate, retuse, 4 to 8 lines long: peduncles surinssing the leaves, bearing a rathor close spike of several or many flowers; these two thirls of an inch long: calyx cylinilrical, dark-hairy; the slender teeth much shorter than the tube, not very much shorter than the usually deep purple corolla; tho claws of the lutter long and slender: pouls pemilulous or sprealing, lunatelanceolate, an inch long, 3 or 4 lines widlo, densely long-hairy, turyid and grooved on the back, sharp-edged ventmlly, many-seeled. - Proc. Am. Acad. vii. 336.

Fistern muges of the Sierra Nevada, from the Virginia Mountains, \&e. (Andersm, WFnlsom), to Owen's Vallev, Dr. Murn.

27. A. Andersonii, (Mny. Cnnescent with denso somewlint silly pulpesenter,

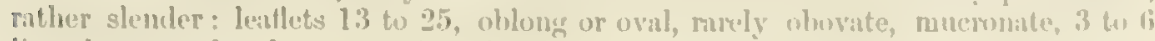
lines longr: peduncles surpassing tho leaves: flowers numerous and crowded in an 
oblong or cylindrical spike: calyx-teeth subulate-setaceous, nearly the length of the campanulate whitish-villous tube, much shorter than the curved yellowish-white corolla; this half an inch long, and the broad claws shorter than the blades: pods pendulous, linear-oblong, falcate or sickle-shaped, half to three fourths of an inch long, 2 lines wide, abruptly pointed, soft-downy, 10 - 20-seeded. - Proc. Am. Acad. vi. 524 .

Eastern ranges of the Sierra Nevada, Sierra Co. to Washoe Co., Nevada, Anderson, Torrey, Lemmon, \&c.

\section{\$3. Pod neither membranaceous and bladdery-inflated, nor long-hairy or woolly,}

* Conspicuously stipitate in the calyx (stipe equalling or much exceeding the latter).

+ One-celled pod with both sutures prominent externally and not within, narrow.

+ Calyx very obliquely attached to the pedicel and soon recurved on it: corolla yellowish-white: pod curved, cartilaginous or rigid, not compressed, the cross section obovate: stems a foot or two long, mostly spreading or decumbent: stipules small, distinct.

28. A. cyrtoides, Gray. Soft-pubescent throughout and mostly hoary, rather stout: leaflets 11 to 21, from obovate-oblong and retuse to obcordate, becoming smoother above: peduncles exceeding the leaves: flowers numerous in a dense spike-like raceme : calyx downy; the teeth not half the length of the oblong-campanulate tube: pod oblong-linear, pubescent, an inch or more in length, on an ascending slender stipe of balf an inch or more, either falcate or at length curved into a ring; the thick cartilaginous valves very turgid at maturity, obscurely reticulated. - Proc. Am. Acad. vi. 201 \& 525 ; Watson, Bot. King Exp. 75.

Eastern side of the Sierra Nevada, Placer to Sierra Co. and eastward (Anderson, Lcmmon), and W. Idaho, Spatding. Corolla half an inch long.

29. A. speirocarpus, Gray. Minutely cinereous-pubescent: stems rather slender: leatlets 9 to 17 , obovate and oblong, emarginate: flowers less numerous and crowded than in the preceding: calyx barely puberulent; the teeth not a quarter of the length of the cylindraceous tube: pod glabrous, tapering at base into a stipe only twice the length of the calyx, coiled nearly into one turn or at length into a flat spiral; the valves thinner and less indurated than in the preceding, more veiny, and less turgid. - Proc. Ama. Acad. vi. 225 ; Watson, 1. c.

Var. falciformis, Gray. Stipe filiform, half to three fourths of an inch long, nearly the length of the thinner-walled and less turgid falcate or merely hooked pod.

Sierra Co. (Lemmon) and adjacent mountains of Nevada (Watson); the original collected by Lyall on the Upper Columbia, in fruit only. Flowers narrower and rather longer than in the foregoing, which some forms approach.

++++ Calyx equal-sided and centrally attached to the pedicel: pod straight, linearoblong, compressed; the valves thin and parchment-like: stems ereit or somewhat spreading.

30. A. filipes, Torr. Minutely puberulent or glabrous : stems slender, branching, 2 feet high: stipules small and subulate: leaflets 9 to 17 , rather scattered, linear (one third to two thirds of an inch long) : racemes virgate, long-peduncled, loosely-flowered: pedicels soon spreading or pendulous: calyx-teeth not half the length of the campanulate tube: corolla yellowish-white (half an inch long): pod an inch or less in length and 2 or 3 lines broad, abruptly contracted at base into a filiform stipe of about half an inch in length. - Gray, Proc. Am. Acad. vi. 226.

N. W. Nevada (Watson, Lemmon ), extending towards and probably within the State, and in the dry interior country to Washington Territory.

31. A. Antiselli, Gray. Cinereous-pubescent, a foot or so in height: leaflets 21 to 29 , linear-oblong, crowded, 2 to 4 lines long, hoary beneath but glabrous 
above: raceme lonsely few-flowered : calyx-teeth about half the lenenth of the cimpanulate tube (corolla small and white?): pod two thirds of an inch long, 2 lines wide above the middle, thence tapering gradually into the stipe, which is at quarter of an inch long and thrice the length of the calyx. - Homalobus multiflorus, Turr. in Pacif. R. Rep. vii. 10, not of Torr. \& Gray, Fl.

Hillsides, Santa Barbara Co.; Santa Iñez (Dr. Antisell), Ojai, Dr. G. L. Goodalc.

A. MULTIFlonUs, Gray (the Homalobus dispar \& nigrcsens, Nutt., \& H. multiflorus, Torr. \& Gray, Fl.), is not known west of the E. Humboldt Mountains, Nevada, nor soutl of Oregon. It has white flowers not over 2 lines long, and pods half an inch long, on a stipe not exceeding the calyx.

32. A. porrectus, Watson. Almost glabrous, a foot or two high: stipules rather large, nearly scarious, the lower united: leaflets 7 to 11 , thickish, broadly obovate, about half an inch long: racemes virgate, long-peduncled, loosely manyflowered: pedicels very short, spreading: calyx-teeth slender-subulate, a little shorter than the campanulate tube : corolla "yellow" (apparently crean-color), narrow, half an inch long: pod half an inch or so in length, 2 lines wicle, dorsally conver and ventrally almost straight, nearly erect upon an ascending pedicel; the stipe 2 lines long and barely exceeding the calyx-teeth. - Bot. King Exp. 75.

Trinity Mountains, N. W. Nevada, at 5,000 feet, Watson. Probably to be found within tho borders of the State.

++ Pod two-celled (by strong intrusion of the dorsal suture), turgid; the cross section broadly obcordately 2-lobed, coriaceous, glubrous: leaflets 7 to 12 pairs.

33. A. arrectus, Gray. A foot or more high, minutely pubescent or glabrate: stipules distinct: leaflets from linear to oblong, retuse (a third to two thirds of an inch long): peduncles usually elongated, racemosely 9-20-fowered: calyx-teeth much shorter than the tube: corolla jellowish-whits: pod narrowly oblom, straight, mather acute at both ends, upright on the ascenting stipe which is fully twice the length of the calyx. - Proc. Am. Acad. viii. 289; Watson, Bot. King Exp. 69.

Foot-hills of Nevada (Battle Mountain, Walson), and from S. Utah to Idaho. Not yet found very near the horders of California, but to be expected. Flowers two thirds of an inch long. Pod from that to an inch in length.

34. A. Bolanderi, Gray. A span or two high: stipules scarious and united on the side of the stem opposite the petiole: leaflets ublong-linear or narrowly oblong, grayish with soft pubescence (a third to half an inch long): petuncles not exceeling the leaf, almost capitately $6-12$-Howered : calyx-teeth slender-subulate, a little shorter than the tube: corolla white with a tinge of purple: poul ovate, incurved, transversely veiny, less than an inch long, abruptly recurved or retlexed on the conspicuous ascending stipe. - Proe. Im. Acul, vii. 337.

Gravelly soil, in the sierm Nevada at 6,000 feet and upwards, Mariposn Co. (Bolander, Brilges, \&c.), to Sierrm Co., Lemmon. Flowers half an inch long.

* Pod sessile in the calyx (or sometimes on a short included stipe) and in size much exceeding it, except in the last species.

+ Stens elongated, at least a span or two in length.

++ Flowers about an inch long, ferv and loose.

35. A. nudus, Watson. A foot or two high, cinereous with minute appresenl pubescence or glabrato: stems beanching and flexuous, slenter : petioles and anglent or flattish rhachis rigil, elongated, bearing a few scattered linear leatlets (virying

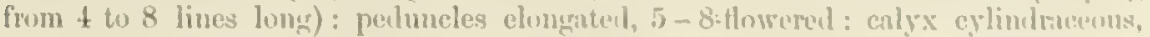
dark-pubescent; the lanceolate teeth not hatf the length of the tulbe : com lla viuletpurple, narrow: poul turgit-oval, glibruus, ascending, rather flrshy. when miture 
cartilaginous and thick-walled, obtuse at both ends, abruptly pointed with the persistent base of the style, one-celled, both sutures strong and prominent externally: seeds numerous. - Bot. King Exp. 74 .

West Humboldt Mountains, Nevada, Watson. Allied to A. pectinatus but very distinct. Leaflets not rigid and persistent as in that species and the next. Pods three fourths of an inch long and three eighths in diameter, the cross section oblate-oval.

$\div+$ Flowers smaller, from one third to half or rarely two thirds of an inch long,

$=$ Few or not very numerous in the spike: pods not densely spiked.

a. Flattened more or less fore and aft, i. e. contrary to the sutures, and with no proper partition.

36. A. pterocarpus, Watson. A foot or two high, but soon declined or decunibent, cinereous-puberulent or glabrate, loosely branched: leaflets linear-acerose, 3 to 9 on the rigid tiliform rhachis, persistent and equally rigid, of about the same breadth (an inch or so in length) : peduncles 7 -9-flowered : flowers (hardly known) about half an inch long : pod pendulous, glabrous, ovate or oval (an inch long) coriaceous, except the acute tip strongly flattened contrary to the sutures and margined with a narrow rigid wing, one-celled, the sutures narrow and not intruded: seeds numerous. - Bot. King Exp. 71, t. 12.

N. W. Nevada, in alkaline soil at the junction of the Reese River with the Humboldt. Probably not Californian : most remarkable for the winged margins of the strongly obcompressed legumes.

37. A. Casei, Gray. A span or more high, cinereous with minute appressed pubescence : stems and branches effuse, nearly filiform, rigid: leaflets 5 to 15 , scattered, linear, very obtuse, small (2 to 4 lines long, half a line or less wide), deciduous; the rhachis and petiole elongated and filiform: peduncles loosely few-flowered: Howers half an inch long, narrow: teeth of the calyx subulate, hardly one third the length of the cylindraceous or oblong tube: corolla apparently pale purple; pod oblong or lanceulate, acuminate at both ends, about an inch long and 4 lines wide, puberulent, sometimes browaish-mottled, cartilaginous, arcuate-ineurved, strongly flattened contrary to the sutures, both of which are narrow and externally prominent, one-celled, the cross section transversely narrow-oblong: seeds rather numerous.

High plateau near Pyramid Lake, N. W. Nerada, Lemmon and E. L. Case.

38. A. iodanthus, Watson. A span or two long, soon procumbent, either pubescent or almost glabrous, leafy; leaflets 11 to 21, rather crowded, obovate or roundish: peduncles equalling the leaves: flowers rather numerous and close in the oblong spike: teeth of the calyx setaceons-subulate, loose or spreading, more than half the length of the oblong-campanulate tube: corolla bright violet-purple, or rarely pale, half to two thirds of an inch long: pod oblong-linear, an inch or more in length, glabrous, coriaceous, pointed, curved at length into a semicircle, compressed contrary to the sutures, both of which are tumed inwards with a broad groove, so that the cross section is nearly that of a figure 8: seeds numerous. Bot. King Exp. 70.

Eastern ranges of the Sierra Nevada, from Sierra Valley to the W. Humboldt Mountains. Flowers in spring. Pods sometimes brownish-mottled.

39. A. Webberi, Gray. A span to a foot high, leafy : leaflet 11 to 21 , crowded, both sides silvery-canescent with a fine appressed silky pubescene, oblong or obovate, 4 to 7 lines long: peduncles surpassing the leaves: spike rather densely $9-20$ flowered : teeth of the calyx subulate, about half the length of the oblong-campanulate tube: corolla white or yellowish-white, half an inch long; pod oblong; an inch and more in length, glabrous, thick and fleshy when young, cartilaginous at maturity. blunt or nearly so, straightish or arenate, turgid, somewhat flattened cou- 
trary to the narmw and extemally prominent sutures; the cruss section transvirse] oblong ( 4 or 5 lines by 2 or 3 ) : seels numerous.

Indian and Sierra Valley, in the northeastern part of the Sierra Nevada, Lcmmon, Mrs. Put-

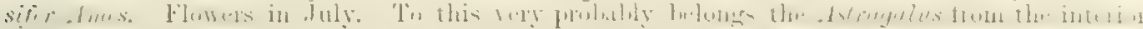

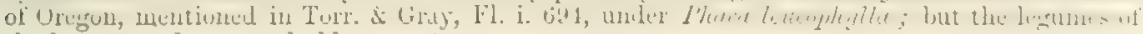
the latter are shorter and oblong-ovate.

b. Pods terete, straight, narrow, thin-coriaceous, grooved on the back and that suture intruded so as to divide the cell or nearly so, and render the cross section cordately 2-lobed.

40. A. atratus, Watson. A span to a foot high, loosely branching, slender, cinereous-puberulent or glabute: leaflets 7 to 15 , linear or oblong, 2 to 5 lines long: peduncles elongated, 5-10-flowered; the flowers usually sparse (half an

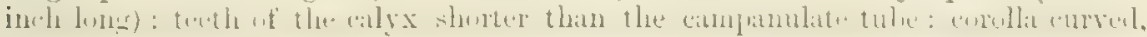
whitish or the keel violet-tipped: pod pendulous, short-stipitate in the calyx, slender (about 9 lines long and barely 2 in diameter), puberulent: seeds 10 to 20 . Bot. Kingr Exp. 69, t. 11.

N. W. Nevada, Watson. Not found so near Califormia as the next, which is very nearly relatel to it. Well marked among these species by the short stipe of the pod, wholly within the tube of the calyx.

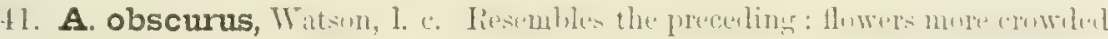
in the short spike: keel-petals longer and natrower, equalling the wings: pod sessile in the calyx, only half an inch long, fewer-seeded, erect or nenly so, terete, straight.

Near the eastern borders of the State : rocky foot-hills near Truckec Pass, $W$ atson. Eagle Valley, Nevada, Stretch.

$==$ Numerous flowers crowded in a dense cylindrical or wblong spike: pods ulso densely spicate: stem erect: leaftets numerous, 21 or more.

42. A. Mortoni, Nutt. Two feet high or less, minutely appressed-pubescent, greenish: leaflets oblong (half to an inch long): flowers nearly sessile, reflexech as they open, but the fruit erect: corolla dull greenish-white or crean-color, lnalf an

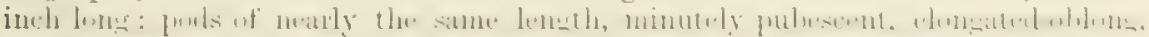

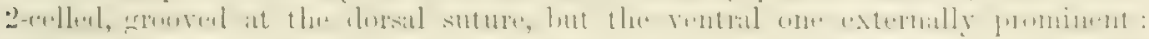

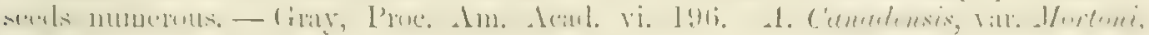
W atson, 1. c.

Moist grounds, along the eastern ranges of the Sierm Newadn, from Mono Lake (Brencer) northward to the interior of Oregon and Utah. Noted hy Mr. Lemmon as "adendly sheep lroison."

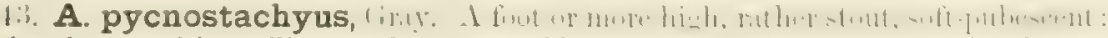
leatlets hoary with a villuus pubescence, oblong (abunt half an inch long): flowers closely sessile in a very denso oblong or cylindraceous spike : pols retrursely imbricated, ovate, acute, slichtity flattened laterally and margined by the slemer proninent sutures, one-cellel, the walls thin-coriaceous, conrsely reticnlated, glabrous: seeds fow ; the ovules only 5. - Proc. An. Acad. vi. 527.

Salt marshes, Bulinns Bay, Bolander, 1863. Not elsewhere or since collected. Flowers apparently whitish and ouly 5 lines long.

++++++ Flourers and ferv-sected 2 -celled pods both small, 2 or 3 lines Inng: stiqmu

capitale: stems difinse or decumbent, flnwering abundantly almost jom the buse

upuerards: stipules ovate or the upper triengulur: pretioles short.

44. A. Lemmoni, Gray. Minutely appresserl-puhescent, green: stems slemler, a foot or two long, soon prosumbent: leatlets 9 to 11 , linear-oblong, mucronate ( 4 or 5 lines longs): peiluncles filiform, mether shorter thatn the lenves (an inch or two

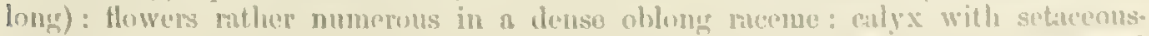
subulate tecth fully equalling the short-campanulate tubo: corolla whitish tinged 
with purple: pod canescent-puberulent, chartaceous, hardly over 2 lines long, ovateoblong, obtuse, turgid, broadly and deeply sulcate down the back, the eross section obcordate : ovules and seeds not exceeding 8. - Pros. An. Acad. viii. 626.

Sierra Valley, Lemmon and Bolander, June, 1872 : received only from the latter, and apparently not since met with.

45. A. lentiformis, Gray. Villous-pubescent, and more or less hoary: stems ascending, soon diffuse, a span to a foot long: leaflets 11 to 15, from obovate to oblong-spatulate, retuse or emarginate (3 to 5 lines long): peduncles short, a quarter to half an inch long, seldom equalling the rather dense several-manyflowered raceme: ealyx-teeth rather shorter and the (apparently yellowish-white) corolla larger than in the preceding: pods broadly oblong, canescently pubescent (3 lines long, almost 2 lines broad), lenticular, not at all sulcate on the back, both sutures marginal, but a partition from the dorsal one completely dividing the $6-8$ seeded cell into two.

Sierra Nevada, in Clover Vailey, \&c., on the borders of California and N. W. Nevada, Lemmon.

$$
++ \text { Acaulescent-depressed, on cespitose rootstocks: leaflets few. }
$$

46. A. calycosus, Torr. Silvery-canescent with close-pressed silky pubescence, barely 2 or 3 inches bigh in matted tufts: leaflets 5 to 11, or in some leaves only 3 and seemingly digitate, from oblong to ovate or obovate ( 1 to 4 lines long), thickish: scape-like peduncles somewhat exceeding the leaves, 2-6-flowered: calyxteeth lanceolate or subulate, shorter than the oblong-campanulate tube : corolla half an inch long, yellowish-white, with purple tip to the rounded keel: pod oval-oblong, very obtuse, puberulent, 3 or 4 lines long, turgid, chartaceons, slightly sulcate dorsally, 2-celled, abont 10-seeded, barely twice the length of the calyx. - Watson, Bot. King Exp. 66.

Eastern ranges of the Sierra Nevada, at 8,000 to 11,000 feet, near the borders of California (Torrey), and in the Clover and Humboldt Mountains, Nevada, Watson.

\section{* * Pod sessile in and shorter than the calyx, turgid: flowers capitate.}

47. A. Austinze, Gray. A span high, in dense tufts, silvery silky-pubescent: stipules scarious and mostly united into one ovate body opposite the leaf: leaflets 9 to 17 , oblong or oval-lanceolate, acute or mucronate, 4 or 5 lines long: peduncle (an inch or two long) mostly longer than the leaf, bearing 10 or 12 sessile flowers in a close head: bracts nearly filiform, persistent, nearly equalling the calyx, both white-villous; the filiform teeth of the latter rather longer than the campanulate tube, and nearly equalling the (pale or whitish) corolla, of which the standard and wings are externally villous-pubescent: pod turgid-oval, chartaceous, hoary-pubescent, imperfectly 2-celled, few-seeded, only 2 lines long, not equalling the calyxteeth and the marcescent corolla, the transverse section almost circular.

Summit of Mount Stanford (Castle Peak), Nevada Co., at 9,000 feet, Lemmon. In foliage somewhat resembling $A$. Andersonit, but more dwarf and condensed, and with capitate flowers (only 3 or 4 lines long); most of all related to $A$. Spaldingii of Idaho and Oregon: dedicated to Mrs. R. M. Austin of Butterfly Valley, who has much helped on our knowledge of the botany of this portion of the Sierra Nevada, and made interesting observations upon the Pitcher-Plant of the region.

\section{Perennial : persistent leaflets and stipules spiny-tipped. (Kentrophyta, Nutt.)}

48. A. Kentrophyta, Cray. Hoary with very minute silky pubescence, cespitose, rigid : stems much branched, mostly prostrate, somewhat woody at base: lower stipules membranaceous or scarious, the upper rigid and pungent: leaves crowded on the branchlets: leaflets 5 to 7 , acerose-subulate, divaricate: peduncles very short, 1-3-flowered : calyx-teeth subulate-setaceous: corolla whitish or tinged with violet, 2 lines long: pod ovate, acuminate, turgid-lenticular, 1-celled, 3-4-ovuled, 1-2-seeded, about 3 lines long. 
Tar, elatus, Tatson (Bot. King Lxp. T7); a form with ereet and less-lormeleel stems, 6 to 18 inches high.

Mount Dana, near the sumamit, at 13,000 feet, Brevoer. Also in W. Nevada, with the taller variety (Walsum), S. Utah (Parry), and through the dry interior to Idaho, Wyoming, and New Mexico.

14. OLNEYA, Gray.

Calyx camplanulate; the teeth nearly equal, the trro upper ones united. Petals free, enual : stamlarl orbicular, deeply ewarerinate, reflexel; wings oblong; keel brum, uhtuse, incurvel. Stamens 10, dimlelphus : anthers miform. Ovary severalovuled: style incurved, bearled above. Pod thick, with coriaceous valves, 1-2seeded, broally linear. Seeds ovate. - A small tree, often armed with spines below the leares; leares equally or unequally pinnate; leaflets thick, entire; stipules none; flowers white or purplish in short axillary racemes.

1. O. Tesota, Gray. Fifteen to twenty feet high or more, canescent with minute hairs: spines short and stout, in pairs near the base of the petivles: leaflets 5 to 7 pairs, cuneate-oblong, 2 to 8 lines long, obtuse: flowers 3 or 4 in a loose racemose cluster, 4 lines long: calyx half as long: pod linear-oblong, an inch or two long, 4 or 5 lines broad, rough with short glandular hairs. - Pl. Thurb. 313 \& 328 ; Torrey, Pacif. R. Rep. vii. 10, t. 5.

In dry valleys near the Colorado River and eastward in Arizona. The Arbol de hierro or Ironwood of that region.

\section{Vicia, Tourn. Vetch. Tare.}

Calyx J-cleft or troutherl, usually unexual. Things alherent to the midllle of the slunt ketel. Stamens diallelphous ar nearly so; the mouth of the sluath oliliogne; anthers uniform. Ovary 2-many-ovuled: style filiform, inflexed, the apex sur-

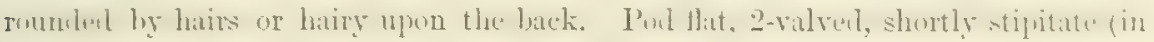

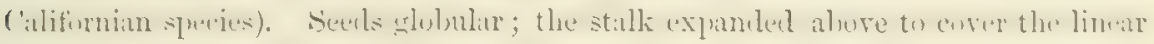

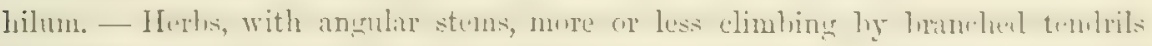

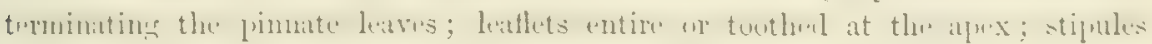
semisagittate; flowers solitary or in loose peluncled axillary racemes.

A genus of 100 species or more, in the temperate regions of the northern hemisphere and in South Ameriea There are ten species indigenous in the United States and a few others Mexican.

$$
\text { * Peremials: flowers in pedunculate racemes. }
$$

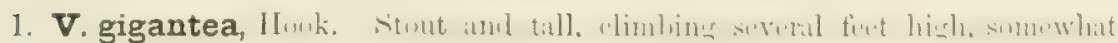
pubescent : leatlets 10 to 15 pairs, oblong, obtuse, mucronate, an inch or two long; stipules largo: peluncles 5-18-flowered: calyx short, somewhat villous; lower teeth about equalling the tube: corolla 6 or 7 lines long, pale purple: pod broally oblung, 11 inches long or more, glabrous, 3-4-seedeul. - Fl. i. 157 ; Torr. \& Grny, Fl. i. 270. V. Sitchensis, Bongard, Veg. Sitcha, 129. V. ILookeriena, Walpers, liep. i. 715 .

In woods and moist places from ahout San Francisco Bay northwarl to Oregon and Sitka The seeds are as large as peus and eatable when young: the plant turns blackish on drying.

2. V. Americana, Muhl. Usually rather stout, 1 to 4 feet ligh, glabrous: leaflets 4 to 8 pairs, very variable, linear to ovate-oblong, truncate to ncute (moru usually oblong and obtuse, mucronulate), 支 to 2 inches long: pecluncles $4-8$ flowered: flowers purplish, 6 to 9 lines long : calyx slightly pulnescent; teeth broadly subulate, the lower narrower and not half as long as the petals: style very villous at the top: pods uhlong, glabruns, an inch long or more, 3 - 6 -seeded: seeds 
dark purple, $1 \frac{1}{2}$ lines in diameter. - Torr. \& Gray, Fl. i. 269. V. Oregana \& V. sparsifolia, Nutt. in Torr. \& Gray, 1. c. 270.

Var. truncata, Brewer. Usually somewhat pubescent: leaflets truncate and often 3-5-toothed at the apex. - V. truncata, Nutt. l. c.

Var. linearis, Watson. Leaves all linear. - Proc. Am. Acad. xi. 134. Lathyrus linearis \& $L$. dissitifolius, Nutt. 1. c.

The typical form, which ranges from Washington Territory and Oregon to New Mexico and across the continent, is rarely found in California. The variety truncato is frequent from San Benito Comty northward to Washington Territory, and in the Sierra Nevada. The variety linea$r$ is is also common throughout California and eastward through the interior to the Rocky Mountains. It is seareely more than a western form of the species, as both broad and linear leaves are often found upon the same plent. The species is popularly known as Peavinc.

V. PULChelid, HBK. Slender, 2 or 3 feet high, somewhat villous-pubescent : leaflets about 6 pairs, linear, obtuse or acute, mucronate, 6 to 9 lines long: flowers small, 3 lines long, in a narrow raceme, reflexed, white or purplish: calyx membranaceous, short; teeth very short, the lower narrower and twice longer : pod linear-oblong, an inch long, 6-8-seeded. - Bill Williams Mountain, W. Arizona (Anderson), to Texas and Mexico; may be found in S. E. California.

$$
\text { * Slender annuals: flowers mostly solitary. }
$$

3. V. exigua, Nutt. A span to two feet high, more or less pubescent: leaflets about 4 pairs, linear, acute, a half to in inch long: peduncles usually short, rarely 2-flowered: flowers 3 lines long, purplish: calyx-teeth lanceolate, nearly equalling the tube: pod smooth, linear-oblong, about 6-seeded. - Torr. \& Gray, Fl. i. 272.

From the Lower Sacramento to San Diego; Catalina Island (Nuttall); Guadalupe Island (Pulmer) ; and eastward to Southern Colorado and New Mexico. The similar $V$. micrantha, Nutt., of Texas and eastward, has usually two pairs of leaflets, and the pod is sessile.

4. V. sativa, Linn. Rather stout, somewhat pubescent: leaflets 5 or 6 pairs, obovate-oblong to linear, retuse, long-mncronate : flowers nearly sessile, an inch long, violet-purple: pod linear, several-seeded.

The Common Vetch or Tare, in cultivated fields and waste places (Coulter, Wallace) ; originally from Europe.

\section{LATHYRUS, Linn,}

Style dorsally flattened toward the top, and usually twisted, hairy along the inner side: sheath of filaments scarcely oblique at the mouth: otherwise nearly as in Vicia. Peduncles in our species usually equalling or exceeding the leaves and several-flowered, in a single species short and 1-flowered. - Watson, Proc. Am. Acad. xi. 133.

A hundred species or more, ranging as in the last genus. The 12 or 15 North American species are perennials, with a single eastern exception.

* Rhachis of the leaves tendril-bearing: pod sessile: racemes several-flowered.

+ Stipules large and broad, ovate or somewhat semi-hastate with broad lobes: glabrous.

1. I. maritimus, Bigelow. Stout, a foot high or more: stipules broadly ovate and halbert-shaped, acute (not acuminate), the lower lobe larger and usually coarsely toothed, nearly or quite an inch long; leaflets 3 to 5 pairs, thick, ovateoblong, 1 or 2 inches long, obtuse or acutish, rearly sessile: peduncles a little shorter than the leaves, $6-10$-flowered: flowers purple, 9 lines long: calyx-teeth sparingly ciliate, subulate, the upper tooth half as long as the lower: pod about 10ovuled, 3-6-seeded, $1 \frac{1}{2}$ inches long or more. $-L$. Californicus, Dougl.; Lindl. Bot. Reg. t. 1144.

A frequent form near the sea in Washington Territory, referred to this eastern and European species, may extend down the coast into Northern California.

2. L. polyphyllus, Nutt. Less stout, 2 feet high or more: stipules smaller, scarcely longer than broad, triangular, acute or somewhat acuminate ; leaflets 6 to 
10 pairs, thin, ohlons, olbtuse or acutish, listinctly petilulate : otherwise very simi lar to the last. - Torr. \& Gray, Fl. i. 27 .

In open woods near the coast, Humboldt Co. (Bolander), and northward to the Columbia; rarely collected.

3. L. sulphureus, Brewer. Rather stout, a foot or two high or more: stipules semisagittate, acmminate, 6 to 12 lines long, the lower lobe obtuse or acute, sometimes toothed; leaflets 3 to 5 pairs, oblong-ovate to linear-lanceolate, acute, 9 to 18 lines long: peduncles nearly equalling the leaves, few - many-flowered : flowers smaller, about 6 lines long, sulphur-yellow : calyx-teeth glabrous, the upper much shorter than the lower. - Gray, Proc. Am. Acad. vii. 399. L. oclerolencus (?), 'Torr. in Pacif. R. Rep. iv. 77.

In the Sierra Nevada to an altitude of 7,000 feet, from the Yosemite to Plumas Co. ++ Stipules narrower and semisagittate; the lobes most frequently lanceolate,

+ Leaflets 4 to 6 pairs: peduncles rather many-finwered.

4. L. venosus, Mulh. Stout, 2 or 3 feet bigh or more, climbing, usually somewhat finely julsescent: stems not wingerl: stipules mostly uarrow and short, 4 to 9 lines long; leatlets oblong-ovate, mostly obtuse, often pubescent beneath, $1 \frac{1}{2}$ to 2 ? inches long: flowers purple, 6 to 8 lines long: calyx densely pubescent or nearly glabrous, the rather short teeth at least ciliate: pod glahrous, about 2 inches long. - L. decaphyllus, Hook. Bot. Mag. t. 3123.

Var. Californicus, Watson, 1. c. Very stout; stems often strongly winged : stipnles broader; leaflets acute and nartower: flowers larger. $-L$. vennsus, Benth. Pl. Ilartw. 307 .

The L. venosus of the Eastern States ranges northwestward to the Saskatchawan and thence across the continent to Washington Territory, perhaps extending down the const into Northern California, varying considerally in tho amount of pubseence, but not greatly otherwise. The variety is found from Sonoma County to Monterey, in valleys and on stream-banks, and in the foot-hills of the Sierra Nevada. It may prove to be distinct, but specinens collected by Bolander near Oakland appear intormediate. The mature fruit has not been compared.

5. I. vestitus, Nutt. Slender, a foot hirg or more, often tall (6 to 10 feet high), more or less soft-pubescent, rarely nearly chlabrous : stems not winged : stipules narrow, often small; leaflets ovate-oblong to linear, a half to an inch long, acute: flowers pale rose-color or violot, usually large ( 7 to 10 lines long): lower enlyxteeth about equalling the tube: ovary appressed-pubescent. - Torr. \& Frry, Fl. i. 276. L. strichus, Nutt. 1. c. L. venosus, var. grandiflorus, Torrey, Pacif. R. Rep. iv. 77. L. nuritimus, Torrey, Bot. Mex. Bound. 49.

The common species of the southern part of the State, from Sonoma County to Snn Diego, on dry lills in the Const Runges: very variable.

$$
++++ \text { Lenflets } 2 \text { to } 4 \text { pairs: peduncles 2-6-1lowered. }
$$

6. I. paluster, Linn. Slenter, a foot or two high or more, glabrous or somewhat pubescent: stern often winged: stipules mostly narrow, often small; leaflets narrowly oblong to linear, acute, an inch or two long: flowers purplish, half an inch long: lower calyx-tecth about equalling the tube: pod smooth, 2 inches long or less. - L. Latszavertii, Kelloger, Proc. Calif. $\Lambda$ cul. ii. 150 , fig. $4 t$.

Var. myrtifolius, Gray. Stipules usually hrouler and lurer ; leaflets ovate to oblong, an inch long or less. - L. myrrifolins, Muhl. L. pubescens, Nutt. L. decarphllllus, var. minor, Hook. \& Arn. Bot. Beechey, 138. L. venosus, var. S., 'Turr. \& Gray, Fl. i. 274.

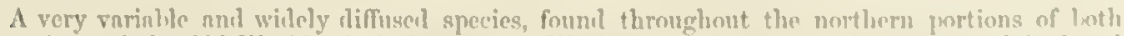
Amerien and the Old World: it is frequent in Washington Territory nut tregon, now is foumd more rarely southward on hillsides and in the monntains neurly the whele length of the stathe. A low form oceurs with the tendrils often undeveloped. 
* Rhachis of the leaves not tendril-bearing or rarely so: pod shortly stipitate.

$$
\text { + Peduncles long, } 2 \text {-6-flowered. }
$$

7. I. littoralis, Endlicher. Densely silky-villous throughout: sterns numerous from ereeping rootstocks, stout, decumbent or ascending, $\frac{1}{2}$ to 2 feet long: stipules ovate-oblong, acute, entire, half an inch long; leaflets 1 to 3 pairs, with a small linear or oblong terminal one, cuneate-oblong, 4 to 6 lines long: calyx-teeth nearly equal, as long as the tube: standard bright purple, 6 to 8 lines long, exceeding the paler wings and keel: style flattened most of its length: pod oblong, villous, an inch long, 3-5-seeded: seed nearly 3 lines broad. - Gen. Pl. 1279. Astrophia littoralis, Nutt. in Torr. \& Gray, Fl. i. 278. Orobus littoralis, Gray, Pacif. R. Rep. xii. 58, t. 6 ; Torrey, Bot. Wilkes Exp. 268.

On the coast near San Francisco (Andrews) : more frequent from the month of the Columbia River northward. This and the following species are the American representatives of the Linnean genus Orobus, chiefly of the Old World, now generally made a section of Lathyrus.

8. L. Nevadensis, Watson, l. e. Slender and usually low, finely pubescent or nearly glabrous: stipules narrowly acuminate; leaflets 2 to 4 pairs, thin, ovate to ovate-oblong, an inch or two long, obtuse or acute: flowers large, 7 to 12 lines long, ochroleucous (?): calyx-teeth shorter than the tube: fruit unknown, perhaps sessile. - L. venosus, var. obovatus, Torrey, Pacif. R. Rep. iv. 77.

In the Sierra Nevada; Duffield's Ranch and Big Trees, Calaveras County, Bigelon, Brewer, GoodaTe, Mann. Apparently the same plant, though with rather narrower and acuter leaflets, has been found by Nevius in the Blue Mountains of Oregon and by Geyer in Northern Idaho.

L. polymorpHes, Nutt. Rather stout, usually low, somewhat finely pubescent or glabrous, glaucous : stipules narrowly acuminate ; leaflets 3 to 6 pairs, narrowly oblong, acute, thick and strongly nerved, an inch or two long : flowers very large, purple : pod two inches long, 3 or 4 lines wide : seeds with a remarkably narrow stalk and short hilum. - This species ranges from New Mexico and Colorado to Central Arizona, and perhaps to the borders of California, L. ornatus, Nutt., of Colorado and Utah, has narrower and shorter leaves, broader pods, and broader seed-stalk.

$$
++ \text { Peduncles very short, 1-flowered. }
$$

9. L. Torreyi, Gray. Sparingly villous throughout, erect, very slender, a foot or two high: stipules narrow, acuminate, the lower lobe short; leaflets thin, 4 to 6 pairs, with or usually without a similar one terminating the slender rhachis, ovate to oblong, acute, about half an inch long: flowers purplish, 4 to 6 lines long: calyxteeth narrowly subulate, nearly equal and exceeding the tube, or the upper somewhat shorter and broader: pod linear-oblong, pubescent, an inch long, 3 -5-seeded. - Proc. An. Acad. vii. 337 ; Torrey, Bot. Wilkes Exp. 267. L. (?) villosus, Torr. in Pacif. R. Rep. xii. 58.

In thickets near the coast, Shelter Cove, Humboldt Co. (Bolander); Washington Territory, Pickering, Cooper, Hall.

\section{CERCIS, Linn. RED-BUD. JUDAS-TREE.}

Calyx campanulate, very broadly and shortly 5-toothed. Petals 5 ; the standard smaller and enclosed by the wings. Stamens 10, free; anthers versatile, longitudinally dehiscent. Pod shortly stipitate, oblong, flat, and thin, many-seeded, 2-valved; the ventral suture narrowly winged. Seeds compressed, obovate, transverse, albuminous. - Small trees; leaves simple, cordate to reniform, entire, palmately-veined; stipules caducous ; flowers on slender pedicels in axillary fascicles, appearing before the leaves, red or purplish.

A genus of 4 species, one belonging to Europe, one to temperate Asia, one in the Atlantic States, and a fourth in Califormia and eastward.

1. C. occidentalis, Torr. A small tree or shrub, glabrous: leaves round-cordate, very obtuse and not at all produced above, occasionally emarginate, about 2 
inches in diameter: petals 4 lines long, ruse-culored: pod about 2 inches long, \& lines broad, acute at each end, on pedicels about half an ineh long. - Gray, Pl. Lindh. 177; Torrey, But. Wilkes Exp. 283, t. 3. C. Siliquastrum, var., Benth. Pl. Hartw. 307. C. Californica, Torro in Benth. 1. c. 361.

From Mt. Shasta and Mendoeino Co. southward to San Diego Co.; Cuiamaca Mountains, Palmer. Also in Northern Mlexico (Grcgg) and Texas. The common species of the Atluntic States, $C$ occidentalis, differs in its larger pointed leares and narrower and longer pods. The Texan form of the present species ( $C$. renifornis, Engelm. MSS.) differs in having its leaves some-

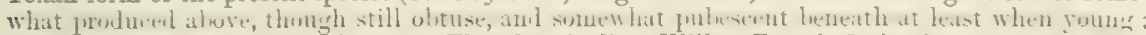
the pedicels also are often shorter. The plate in Bot. Wilkes Exp. is faulty in representing the western form as with shortly acute leaves.

\section{CASSIA, Linn. SENMa.}

Calyx-tulue very short; the divisions 5, imbriated. Petals 5, sprealins, nearly equal or the lower one larger; the upper one within. Stamens 5 to 10 (in ours 7); anthers erect, attached by the base, opening by two pores or chinks at the apex.

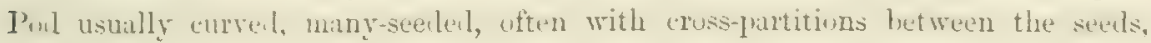
indehiscent or 2-valved, terete or flattened, thick-coriaceous to membranaceous.

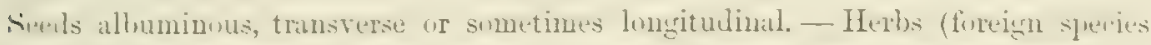
uften shrubs or trees); leares abruptly pindate; llowers mostly yellow, nsually in terminal or axillary racemes or clusters.

A genus of over 300 species, abounding in the tropical and warmer regions of America, and frequent in Afriea and tropical Asia. The 18 or 20 species found in the United States belong mostly to the Southern States and especially near the borders of Mexico.

1. C. armata, Witson. Herbaceous, 3 feet high, minutely puberulent, light

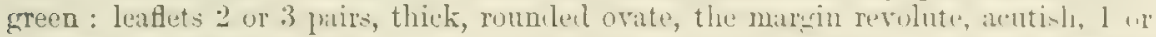

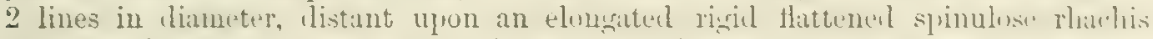
(2 inches lon: ; stipules and glands wanting: flowers in a short terminal ratwine.

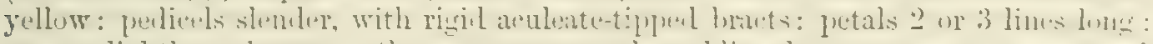

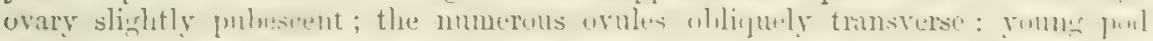

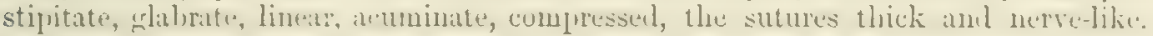
- Proc. Am. Acad. xi. 136.

Mountains between Fort Mohave and Cajon Pass (Cooper); also in Western Arizona, Licul. Whecler. A remarkable species.

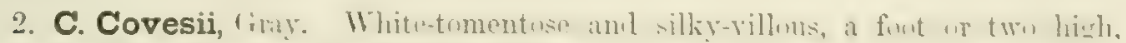

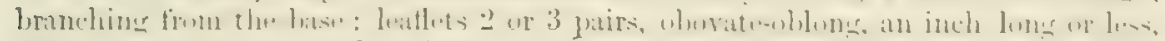
obtuse, mucronate; stipules filiform, lax, caducous, 1 to 3 lines long; a glaml to

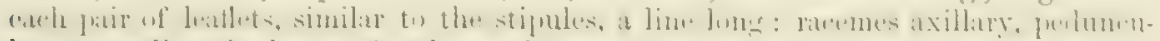

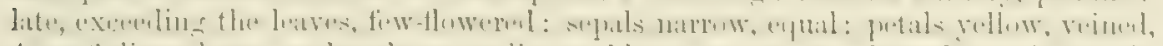

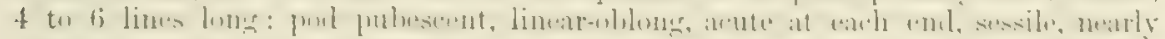

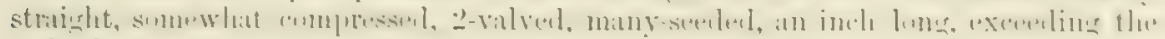
pedicel: seeds transverse. - Proc. Am. Acad. vii. 399; Watson in Wheeler's Cat. 8.

Big Cañon of the Tantillas Jits., below San Diego (Palmer); W. Arizona, Palmer, Whecler.

19. PARKINSONIA, Lim.

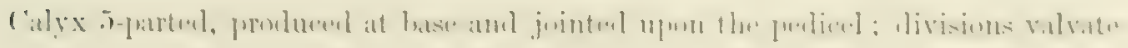
or narrowly imbricate. Petals 5, with claws; the upper one within and brouler than the rest, somewhat cordute, the claw pubescent and nectariforums on the inner side. Stamens 10, free; filaments pilose at base, the upper one gribhous on the

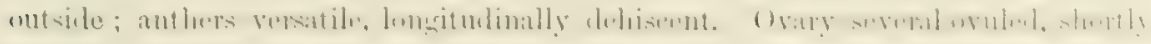
stipitate: style filiform, acute. Pod compressed, 2.rolved, lincar to linurr-nblong, 
obliquely or longitudinally veined, thin-coriaceous, usually more or less torulose and compressed between the seeds. Seeds compressed, broadly oblong, longitudinal, albuminous; hilum minute. - Trees or shrubs, often armed with short spines: leaves bipinnate with 1 or 2 pairs of pinnæ; the common petiole short, ofteu obsolete or spinescent; stipules minute or none; flowers yellow or whitish, on slender pedicels in short loose axillary or terminal racemes. - Cercidium, Tulasne.

A genus of 8 species, one of S. Africa, three of S. America (including $P$. aculeata which is widely distributed through tropical America), the remainder belonging to the region between Texas and S. California.

* Leaflets usually very numerous, upon a much-elongated flattened rhachis: divisions of the calyx narrowly imbricate in the bud.

1. P. aculeata, Linn. A small tree, glabrous throughout, the slender branches often pendulous: spiny petioles a half to an inch loug or less, bearing 1 or 2 pairs of pinna? near the base, or wanting; leaflets very small, oblong, scattered upon a broad rhachis $1 \frac{1}{3}$ to $1 \frac{1}{2}$ feet long; stipules small, spinescent : racemes axillary 3 to 6 inches long: pedicels joiuted a little beluw the Hower: stamens shorter than the jellow petals: pod 2 to 10 inches long, $1-5$-seecled, attenuate at each end and cuntracted between the distant seeds. - Benth. in Mart. Fl. Bras. $\mathrm{xt}^{2} .78, \mathrm{t} .26$.

Hills of the Colorado near Fort Yuma, and through Mexico to Texas. Probably of American origin, but now naturalized or cultivated in most of the tropical and warmer regions of the globe.

\section{$\therefore$ Pinnce short and leaflets jew; rhachis terete: calyx valvate in the bud.}

2. P. microphylla, Torr. A much-branched shrub, 5 to 10 feet high, with smooth light-green bark, the straight rigid branchlets spinose at the ends; younger branches and inflorescence somewhat puberulent: common petioles very short or none, not spinescent or rarely so ; leaflets 4 to 6 pairs in each pinna, broadly oblong or nearly orbieular, obtuse or acutish, not narrower at the oblique base, two lines long or les;, glaucous: racemes short (an inch long or less), axillary and sessile; pedicels evidently jointed a little below the flower: petals deep straw-color, the upper one white, 3 or 4 lines long: anthers orange, exserted: ovary appressedsilky : pod attenuate at each end, 1-3-seeded, contracted between the seeds, 2 ог 3 inches long. — Bot. Mex. Bound. 59 ; Benth. 1. c.

On the Colorado near Fort Yuma, on Bill Williams River, and eastward through S. Arizona; flowering in May.

3. P. Torreyana, Watson. A small tree, 20 or 30 feet high, with light green and smooth bark; younger branches and leaves sparingly pubescent : leaflets 2 or 3 pairs, oblong, obtuse, narrower toward the scarcely oblique base, 2 or 3 lines long, glaucous: flowers on longer pedicels in racemes terminating the branches: pedicels jointed near the middle, the joint not evident until in fruit: petals 4 lines long, apparently bright yellow; gland upon the upper petal very prominent: ovary glabrous: pod 2 or 3 inches long, with a double groove along the broad ventral suture, acute, $2-8$-seeded, scarcely or decidedly contracted between the very thick seeds. - Proc. Am. Acad. xi. 135. Cercidium floridum, Torrey, Pacif. R. Rep. v. 360, t. 3 ; not of Benth.

A frequent tree in the Valley of the Colorado and eastward ; the Palo Verde of the Mexicans, - usually bare of folinge, the leares being soon deciduous. The species has been mistaken for the $P$. floridu (Crecidium floridum, Benth.) of the Rio Grande Valley, which has axillary racemes, pols with a narrow acute nargin on the ventral side, thinner seeds, and somewhat larger leaflets.

\section{PROSOPIS, Linn. MESQUTT. SCREW-BEAN.}

Flowers regular. Calyx campanulate; the teeth very short, valvate. Petals 5, valvate, united below the middle or at length free, woolly on the inner side (in our 
species). Stanens 10, free, exserted; anthers tipned with a decilunns gland. Ovary villous (in American species): style filiform. Pod linear, compressed or

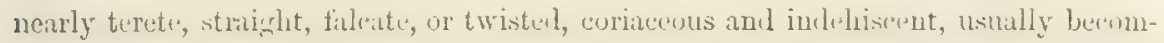

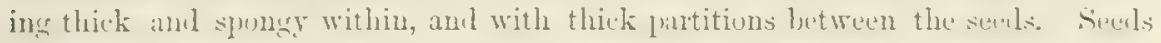
numerous, ovate, compressed. - Trees or shrubs, often armed with axillary spines or spinescent stipules; leaves bipinnate, with 1 or 2 pairs of pinnæ, and usually mumerums small entire leaflets; Howers small, gresuish, in cylimlrical or glubuse axillary pedunculate spikes.

- Species about 18, of which 5 belong to Africa and tropical Asia, the remainder to Mfexico and South America, the following extending into the United States.

* Pod elongated, straight or falcate, compressed or at length thichened and fleshy: seeds each in a distinct cartilaginens envelope: spines axillary: spikes cylindrical. - Algirobia, Benth.

1. P.juliflora, IM: A shrub ur tree (sometimes 30 to to feet high), whatoms or puberulent, with stout axillary spines or often unarmed: leaflets 6 to 30 pairs, short-oblong to linear, 3 to 18 lines long, obtuse or acute: spilies shortly peduncled, 2 to 4 inches long, usually dense, 1 - 3 -fruited : flowers nearly sessile, a line long: pod 4 to 6 inches long or more, straight or eurved, at first flat and constricted between the seeds, 3 to 6 lines broad, at length sweet and pulpy within, acuminate, longitudinally veined; stije 3 to 6 lines long. - Procl. i. 447; Benth. in Trans. Linn. Soc. xxx. 377. P. glandulnsa, Torrey, Amn. N. Y. Lyc. ii. 192, t. 2. Algarobia glandulose, Torr. \& Gray, F1. i. 399; Gray, Pl. Wright, i. 60. Prosopis adorata, Torr. in Frem. Rep. 313 , t. 1, excl. fruit.

This is the Algaroba of the Mexicans, or Honey Mesquit, found as a small shrub in Sontheastem C'alifornia from San Felipe Cañon to Fort Mohave, and eastward to Texas. The species in various forms extends sonthward through Mexico, and along the Andes to Chili, and to Buenos Ayres. The abundant fruit is eaten by the Indians and often by whites, and is a valuable food for horses. The shrub also furnishes a valuable gum, resembling Gum Arabic, which in Texas and Mexico is collected in considerable quantity for export.

* * Pod thick, spirally twisted in numerous turns: stipules spinescent: spikes globose to cylindrical. - Strombocarps, Benth.

2. P. pubescens, Benth. A shrub or small tree 15 to 30 feet high, resembling the last, eanescontly puberulent or glabrato: leaflets 5 to 8 pairs, oblong, 3 to 4 lines long, acutish : spikes lax, $1 \frac{1}{2}$ to 2 inches long, on pecluncles about equalling the leaves, several-fruited : flowers sessile, 1 t lines long: ovary very villous: poil twisted into a narrow straight eylinder 1 or 2 inches long, pulpy within, nearly sessile. - Lond. Jour. Bot. v. 82, \& 1. c. 380 . Serombncurpus pubescens, Grity; Torrey, Pucif. R. Rep. v. 360, t. 4. Prosopis Emnryi, Torrey, Emory liep. 139.

The Tornille of the Mexicans, and Serew-bean or Serew-pod Mesuzuit of the Americuns. In San Diugo Co. at Valleeito (Thurber), Mountain Springs (Pulmer), Fort Mohave (Coojwr), and east to Now Mexico. The pools are ground into meal and used for food lyy the Indians, $P$. cincrasicns, (inuy, a speries of the lio (imade Valley with similar fruit, has nuth smaller leaves amb leathets, the eommon petiole nestrly obsolete, the sleuder spines usually exceding the leaves, and the flowers in long-peduncled globoso heads.

\section{ACACIA.}

Flowers perfect or polygamons. Calyx 4-5-tonthel. Petals more or less united below. Stamens numerous, exserted, free or united at baso; anthers suall. Stylo filiform. Pot 2-valved or imbliscent, many-scoded, compressed and membrinaceous or more or less thickened and rounded. Sreets compressed : allumen none. - Shrubs or trees, often spinose or prickly; leaves bipinnate, with small leallets; 
stipules spinescent or inconspictons ; flowers small, in globose heads or cylindrical spikes, on axillary peduncles, yellowish.

A genus of over 400 species, belonging to the warmer regions of the globe, especially abundant in Australia and Africa. About a dozen are native on the southern borders of the United States, and numerous Australian species are frequent in cultivation.

1. A. Greggii, Gray. A small tree 10 to 20 feet bigh, pubescent with spreading hairs or glabrous, unarmed or with scattered short stout hooked prickles: leaves short, of 2 ог 3 pairs of pinnæ an inch long : leaflets 4 or 5 pairs, oblong or oblongobovate, inequilateral, rounded or truncate at the summit, narrower below, 2 or 3 lines long, rather thick and with $\mathbf{2}$ or $\mathbf{3}$ straight nerves: flowers in eylindrical spikes an inch or two long, the peduncles equalling or exceeding the leaves: pods compressed, curved, 3 or 4 inches long, 5 to 7 lines broad, attenuate at base to a short stipe and acute above, more or less constricted between the seeds; the thin-coriaceous valves reticulated: seeds $\frac{1}{2}$ inch long, elliptical. - Pl. Wright. i. 65 .

San Diego (Cleveland) ; San Felipe Cañon (Palmer) ; Fort Mohave (Cooper) ; and eastward to Texas. The species closely resembles $A$. Wrightii, Benth., of the Rio Grande region, which has a broader and obtuser pod, and usually rather larger leaflets.

A. Farnestana, Willd. A small spreading tree, with straight slender stipular spines, pubescent or glabrous : pinnæ 4 or 5 pairs; leaflets 10 to 25 pairs, linear, a line or two long, crowded : heads globose : pod oblong, cylindrical, at length turgid and pulpy, 2 or 3 inches long and 6 to 9 lines thick, longitudinally veined. - Widely spread over the subtropical and tropical regions of the New and Old World, and often cultivated for the perfume of its flowers; native land unknown. About the Missions in the southern part of the State.

\section{ORder XXXII. ROSACE再.}

Herbs, shrubs, or trees, with alternate leaves, usually evident stipules, perigynous mostly numerous stamens, distinct free pistils from one to many, or in one suborder few and coherent with each other and with the calyx-tube into a 2-several-celled inferior ovary, and anatropous few or solitary seeds destitute of albumen or nearly so: these are the characters of this great order. But the stipules are sometimes evident only upon vigorous shoots, and rarely fail altogether, the stamens are sometimes even fewer than the petals or lobes of the calyx, and in a few cases the albumen of the seed is somewhat copious. - The Californian representatives belong to three great groups, best exhibited as suborders.

\section{SubordER I. AMYGDALEA.}

Carpels solitary, or rarely 5, becoming drupes, entirely free from the caly $x$, this or its lobes deciduous. Ovules 2, pendulous, but seed almost always solitary. Style terminal. - Trees or shrubs, with bark exuding gum, and mostly as well as the seeds yielding the flavor of prussic acid. Stipules free, deciduous.

1. Prunus. Flowers perfect. Carpel solitary.

2. Nuttallia. Flowers polygamo-dioecious. Carpels and thin-fleshed drupes 5.

\section{SUBORDER II. ROSACE E PROPER.}

Carpels free from the persistent calyx (the limb of the latter rarely deciduous), becoming akenes, or in the first tribe follicles, or ouly in Rubus (where they are very numerous) drupe-like in fruit. Stipules commonly adnate to the petiole. Calyx dry and open, or sometimes strictly enclosing the fruit (one or two akenes), or in Rosa fleshy and pome-like enclosing numerous akenes. 
TRIBE I. SPIREACEA. Carpels few, rarely solitary, becoming 2-several-seeded follicles (dchiscent prods). Calyx open.

3. Spiræa. Follicles 2 to 8 . Seeds pendulous, linear; the coat membranaceous : albumen none. Shrubs or herbs, witl simple or compound leaves, and compound inflorescence.

4. Neillia. Follicles 1 to 5 . Seeds erect and pendulous; the coat crustaceous, shining: albumen present. Slirubs, with simple leaves : corymbs sinple.

TRRBE II. RUBEÆ. Carpels several or numerous on a spongy receptacle, becoming drupelets in fruit. Calyx open, without bractlets. Stamens numerous. Orules 2 and peudulous, but seed solitary.

5. Rubus. Carpels indefinitely numerous, berry-like in fruit. Perennial herbs, or soft-woody shrubs with bienuial stems.

Tirrbe III. DRYADE.E. Carpels numerous, several, or solitary, I-ovuled, becoming dry akenes. Calyx not enclosing or at least not constricted over the fruit. Seed erect or ascending.

- Shrubs : carpels mostly solitary : style not elongated in fruit : stigma decurrent : calyx imbricated, without bractlets : radicle inferior (except in Coleogyne).

6. Chamæbatia. Flowers corymbose. Petals 5. Leaves thrice pinnate, with minute leaflets.

7. Purshia Flowers solitary. Petals 5. Leaves 3-cleft.

8. Coleogyne. Flowers solitary. Calyx 4-parted, colored. Petals none. Leaves opposite, small, narrow, entire.

* * Trees or shrubs : carpels solitary or numerons: styles elongated and plunose in fruit : calyx imbricated, without bractlets (except in Fallugia) : seed erect.

9. Cercocarpus. Flowers solitary, axillary, small. Petals none. Carpels solitary, rarely 2. Calyx-tube long-cylindrieal ; the limb deciduous. Leaves simple, entire or toothed.

10. Cowania. Flowers solitary, short-peduncled, terminal, showy. Petals 5. Carpels 5 to 12. Calyx short and turbinate. Leaves cuncate, lobed.

11. Fallugia. Flowers somewhat panicled, on long peduncles, showy. Petals 5. Carpels numerous. Calyx turbinate. Leaves with linear lobes.

* * * Herbs : carpels few to many: calyx concave or campanulate, valvate in the bud, bracteolate.

+ Seed erect from the base of the cell : radicle inferior: style strictly terminal, persistent.

12. Geum. Carpels very numerous on a dry recentacle: the elongated style in fruit mostly geniculate or plumose.

+ + Seed suspended or ascending : radicle superior: style small, naked, not geniculate.

13. Fragaria. Carpels very uumerous, in fruit on a large fleshy scarlet receptacle. Styles luteml. Leaves 3-foliolite.

14. Potentilla. Petals yellow, rarely white, sessile. Stamens usually 20 or more; filaments nartow or filiform. Carvels mostly numerous, on a dry receptacle. Leaves pimate or digitate; leaflets toothed or eleft, not contluent.

15. Sibbaldia. Petals yellow, sessile, minute and narrow. Stamens 5 ; filaments yery short, filiform. Carpels 5 to 10 , on a dry receptacle. Leaves 3-foliolate; leaflets 3-toothed.

16. Horkelia. Petals white or pink, with claw's, ol spatulate. Stamens 10, rurely 20; filaments usually dilated or subulate. Carpels usually many, on a dry nearly maked receptacle. Laves pinnate; leallets many, toothed, cleft, or parted, the upper confluent.

17. Ivesia. Petals white or yellow, with claws, or spatulate. Stamens 5 to 20 ; filaments filiform. Carpels 1 to 15 , on a dry villous receptacle. Leaves pinnate; leaflets cleft or parted, often small and very numerous and closely imbricated.

Trume IV. POTERIEA. Carpels 1 to 3 , in fruit akenes, conpletely enclosed in the dry and firm calyx-tube, the throat of which is constricted or sometimes nearly closed. Seed suspended.

- Henth-like shrubs, with simple entire fascicled lenves : ovules 1 or 2. (Anomalous genus.)

18. Adenostoma. Calyx 10-norved, st length cylindraccous. Petals 5. Stumens 8 to 15.

- Herbs (as to ours), with compound or lohed lenves: ovule solitary.

19. Alchemilla Calyx naked, urceolate, minutely bracteolate. Petals nono. Stamens 1 to 4. linwers minute, chustered.

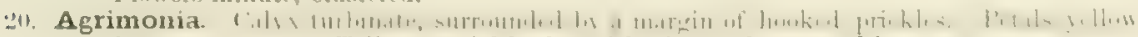
Stameus 5 to 12. Tall perenniul herbs, with pinnate leaves and long racemes. 
21. Acæna. Calyx-lobes valvate, deciduous; the tube oblong, becoming armed with barbed prickles. Petals none. Perennial herbs, with pinnate leaves, and densely spicate-clustered flowers.

22. Poterium. Calyx-lobes imbricate, deciduous, petaloid; the tube 4 -angled, naked. Petals none. Herbs with pinnate leaves, and densely capitate or spicate flowers.

Tribe V. ROSEE. Carpels many, in fruit bony akenes, enclosed and concealed in the globose or urn-shaped fleshy calyx-tube, which resembles a pome. Petals conspicuous. Stamens numerous.

23. Rosa. The only genus. Erect shrubs, with pinnate leaves.

\section{SUBorder III. POMEA.}

Carpels 2 to 5, enclosed in and mostly adnate to the fleshy calyx-tube, in fruit becoming a 2 -several-celled pome. Ovules erect or ascending, a pair in each carpel (more numerous in cultivated apples), ascending. Styles often united below. Trees or shrubs, with stipules free from the petiole or nearly so.

\section{* Evergreen : carpels partly free and separating.}

24. Heteromeles. Carpels only 2 , tomentose above, lightly united and in flower nearly superior, becoming thin and papery, and closely included in the berry-like calyx.

* * Deciduous-leaved : carpels 2 to 5, united and coalescent with the fleshy or berry-like calyx.

25. Cratægus. Ovary 2-5-celled; the fruit drupaceous, of 2 to 5 bony 1 -seeded stones, either separable or united into one. Branches usually thorny.

26. Pyrus. Ovary 2-5-celled; the fruit a proper pome, with papery or cartilaginous and undirided 2-seeded cells or carpels.

27. Amelanchier. Ovary 5-celled; the cells 2-ovuled and 2-seeded, but in fruit each divided into two by a partition from the back. Otherwise like Pyrus.

\section{Anomalous Genus.}

28. Canotia. Calyx free from the septicidally 5-valved exserted capsule. Cells 1-seeded. Stamens 5, lyypogynous. A leafless shrub, with solitary flowers.

\section{PRUNUS, Toura. Plum, Cherrix, \&e.}

Calyx campanulate or turbinate, 5-cleft, deciduous. Petals 5, spreading. Stamens 15 to 25 , inserted with the petals. Ovary solitary, free, with 2 pendulous ovules: style terminal. Fruit a more or less fleshy drupe, with nsually a bony stone containing one or rarely two seeds. - Trees or shrubs; leaves alternate, simple, usually serrulate; flowers white or rose-colored, solitary or fascicled in the axils, or in terminal racemes.

Species about 80 , widely dispersed through the northern hemisphere, but mostly confined to temperate regions. Of the 20 North American species, 14 are found only in the Atlantic States, from Canada to Mexico. This comprehensive genus now includes several of our most delicious and useful fruits, formerly referred to several genera, such as the Almond, with a somewhat fibrous pitted stone, $P$. (Amygdalus) communis, - the Peach and Nectarime, with wrinkled stone, $P$. (Amagdalus) Persica, - the Apricot, $P$. Armeniaca (Armeniaca vulgaris), - the Garden Plum, $P$. domestica, - the Sloe, P. spinosa, — the Garden Cherries, $P$. Cerasus (Cerasus vulgaris), - also the Cherry-Laurel, $P$. Lauro-Cerasus (Laurocerasus officinelis), \&c. Many of the species have medicinal virtues, and the principle or elements of prussic (cyanohydric) acid so abound in sone species, especially in their kernels and bark, as to make them actually poisonous when eaten freely. The foliage and young branches of some of the Cherries become poisonous to cattle when wilted. The six Californian species represent nearly as many sections, which have been more or less recently regarded as genera, but the limiting characters prove to be too indefinite. The American species of Plum (belonging to the first section) differ from those of the Old World in having the leaves folded (conduplicate) instead of convolute in the bud, the fruit with little or no bloom, and some of them have very turgid instead of flattened stones, thus connecting this section with the following one. 
\$1. Fruit oldong, fleshy, glatrous: the stone Alattinh, smooth, usurnlly acutely murgined, or grooved on one edge: flowers white, few to several in umbel-like chusters from lateral scaly buds in early syring. - PRUNos.

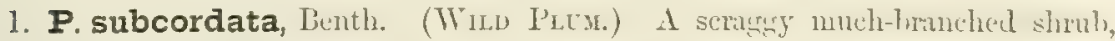

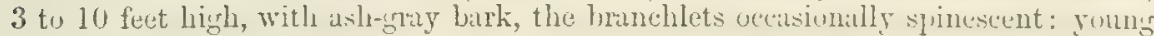
branches and leares finely pubescent, becoming glabrous: leaves ovate, cordate to cuneate at base, obtuse or acute, sharply and finely serrulate, about an inch long, shortly petioled; glands at the base of the blade 1 to 4 , or wanting: umbels 2-4flowered; pedicels 3 to 6 lines long: calyx puberulent: corolla half an inch broad: fruit red, large and edible, about 3 inch long: stone acutely edged on one side, grooved upon the other. - Pl. Hartw. 308.

On dry rocky hills and in open woods, mostly eastward of the central valley from San Felipe to Oregon ; most abundant in the northern part of the State, where also the fruit is larger and more pulpy. It is pleasantly acid and is gathered in considerable quantities by both lndians and whites. Flowering in April or MIay, the fruit is ripe in August and September.

\$2. Simaller fruit and stome awhid or sultuglabose, the latter margindess: flower's corymbose or umbellate: otherwise as \$ 1. - CERAsus.

2. P. emarginata, Walpers. A shrub $t$ to 8 feet high, with bark like that of the ordinary Cherry-tree, and chestnut-brown very slencler branches, glaurous or nearly so): leaves oblong-ohovate to ohlancenlate, mostly olstuse, erenately serrulate, 1 to 3 inches long, narrowed to a short petiole, with usually one or more glands near the base of the blade: corymb 6-12-flowered, shorter than the leaves: flowers 4 to 6 lines broad : fruit globose, black, about 4 lines long, bitter and astringent: stone with a thick grooved ridge upon one side. - Cerasus emarginata, Dougl.; Houk. Fl. i. 169. C. glandulosus, Kellogg, Proc. Calif. Acad. i. 59.

Var. mollis, Brewer. Taller, becoming a small tree 25 feet high: more or less woolly-jubescent, especially on the under sicle of the leaves. - Cerasus mollis, Dougl. 1. c. ; Nutt. Sylva, ii. 14, t. 46. P. mollis, Walpers.

Mostly in open forests, in the Sierra Nevada, from Yosemito Valley northwarl to Puget Sound: also nore rarely near the coast; Oakland Hills und Tamalpais, Bolander. The variety is tho more common Oregou form.

\section{\$3. Fruit small, globose, Aleshy, glabrous: stone broaully ovoid, marginless: Alowers white in terminal racemes, appearing after the leaves. - PiDus.}

3. P. demissa, Walpers. (WiLd Cherry.) An erect slender shmb 2 to 12 fuet high: leaves ovate or oblungr-ubuvate, usually broalest above the millile, abruptly acuminate, mostly rounded or somewhat cordato at base, sharply sermate with straight slender tecth, usually moro or less pubescent beneath, 2 to 4 inches long, with 1 or 2 glinds at baso: racemes 3 or 4 inches long, many-flowered: fruit globose, purplish-black, or red, sweet and ecliblo but somewhat astringent: stone glubose. - Cerasus demissa, Nutt.; Torr. \& Gray, F1. i. 411 ; Watson, Bot. King Exp. 80. P. Virginiana, var. demissa, Torrey, Bot. Willes, 28t; Gray, Proc. Am. Acad. viii. 381.

In the mountains thronghout the Stato from San Diego County (Parry, Palmer) to the Columbia liver, except near the coast, and enstwand to the lineky Mountains It fruits abundantly, often when only 2 or 3 feet high. It resembles the following species very closely.

P. Vinsisiasi, Linn. Leaves ruely at all pubescent, more frequently somewhat cunente at lase : fruit dark red, very astringent and searecly edible; the stone more ovoid and acutish: otherwise like the lust, but moro diffuse in lnbit, and preferring stream banks and moist locnlities. - It is doubtful if this species, the enstern Choke ('herry, is found west of the liorky Mountains. A sonewhat similar form, distinct from the lnst, with eonspicuous linear stipules mul bracts in the enrly stage, is found in the West Ilumboldt Mts.. Nevada (II rasm), and is to be looked for in the northenstern part of the State.

P. slisotssa, Fithrart, the Wild Back ('herry of the Athantic States, has been introlucerl alwout san Fronciseo. It heromes a tree, and may be distiaguished by its more genuminate leaves and short incurved callens-pointed teeth, only the nidveis of the beaf sometimes pulnessent. 


\section{\$ 4. Fruit less pulpy: stone thin: leafless racemes from the axits of evergreen leaves. - Laurocerasus.}

4. P. ilicifolia, Walp. (Islay.) A much-branched evergreen shrub, 8 to 12 feet high, with grayish-brown bark, glabrous: leaves thick and rigid, shining above, broadly ovate to ovate-lanceolate, obtuse or acute, truncate or somewhat cordate at base, spinosely toothed, an inch or two long, very shortly petioled: flowers small, in racemes $\frac{1}{2}$ to 2 inches long: fruit large (half an inch thick or more), somewhat obcompressed, apiculate, usually red, sometimes dark purple or black; the thin pulp somewhat acid and astringent but of pleasant flavor.-Cercsus ilicifolius, Nutt.; Sylva, ii. 16, t. 47 ; Hook. \& Arn. Bot. Beechey, 340, t. 83.

- On dry hills of the Coast Ranges from Sam Franeisco to San Diego, and in Western Arizona, Bigelow. A very onamental species, with shining dark green foliage, somewhat like the Holly. It flowers from March to May, maturing its fruit in November and December.

\$ 5. Fruit velvety-pubescent, subglobose: stone smooth or nearly so: flowers solitary or in pairs, from lateral scaly buds, appearing with the leaves: calyx somewhat persistent. - EMPLectocladds, Gray. (Emplectocladus, Torrey.)

5. P. Andersonii, Gray. A low diffuse glabrous shrub, 1 to 3 feet high, with grayish-brown bark and spinescent branchlets: leaves mostly fascicled, oblanceolate, acute, attenuate to a short petiole, a half to an inch long, sparingly serrulate: peduncles shorter than the leaves: Hlowers rose-colored, half an inch broad; the petals orbicular : fruit with thin flesh, flattened globose, acute, 6 lines long; stone compressed, acutely margined upon one side and furrowed upon the other, acute at both ends, somewhat ridged. - Proc. Am. Acad. vii. 337 \& x. $70 . \quad$ Watson, Bot. King Exp. 79.

Sierra Co. (Lemmon), and frequent on the foot-hills of Northwestem Nevada. The fruit more nearly resembles the peach than does that of any other of our species. This whole section, indeed, of five species confined to the interior of the continent and to Mexico, shows the nearest approach in the American flora to the old genus Amygdalus of the Old World.

6. P. fasciculata, Gray. A divaricately branched shrub, 2 or 3 feet high, with gray bark, glabrous: leaves fascicled, narrowly spatulate, obtuse or acutish, nearly sessile, half an inch long, obsoletely 3-nerved, entire: flowers sessile or nearly so, very small: petals linear, white, recurved: stamens 10 to 15 : style very short: fruit subglobose, 5 or 6 lines long, hirsute-tomentose, the flesh thin: stone acute at both ends, smooth, subglobose, obtusely and scarcely at all margined. Proc. Am. Acad. x. 70. Emplectocladus fasciculatus, Torrey, PI. Frem. 10, t. 5.

In the Southern Sierra Nevada (Fremont); summit of Providence Mountains (Cooper); Arizona (Newberry) and S. Utah, Patmer, Parry.

\section{NUTTALLIA, Torr. \& Gray.}

Flowers polygarno-diocious. Calyx turbinate-campanulate, 5-lobed, deciduous. Petals 5, broadly spatulate, erect. Stamens 15, in two rows, 10 inserted with the petals, and 5 lower down upon the disk lining the tube; filaments very short, the lower declined. Carpels 5, inserted upon the persistent base of the calyx-tube, free, glabrous: styles short, lateral, jointed at base: ovules 2 in each carpel, pendulous. Fruit 1 to 4 oblong-ovoid 1 -seeded drupes, with thin pulp and smooth bony stone. Cotyledons convolute. - A shrub, with alternate simple entire deciduous leaves; stipules none; flowers white, in loose nodding racemes, which appear with the branchlets from the same buds. A single species.

1. N. cerasiformis, Torr. \& Gray. (Oso BerRY.) A shrub or small tree 2 to 15 feet high, with dark brown bark and rather slender branches, glabrous: leaves rather broadly oblanceolate, acute, attenuate to a short slender petiole, 2 to 4 inches 
long: racemes shorter than the leaves, shortly pedunderl; hracts conspicunus, lleciduous: flowers greenish white, 3 or 4 lines broad: drupes blue-black, with a slight furrow on the inner side, 6 to 8 lines long; flesh bitter; stone somewhat compressed.-Hook. \& Arn. Bot. Beechey, 337, t. 82; Torr. \& Gray, FI. i. 413; Lindl. in Trans. Hort. Soc. iv. 222, \& fig.

In moist places and on the north slopes of hills from San Luis Obispo to Fraser River, ehiefly in the Coast Ranges. Flowering in March and April ; fruit ripe from June to July.

\section{SPIR无A, Linn。 MEADOW-SWEET.}

Calyx persistent, 5-lobed; the tube campanulate or concave. Petals 5, rounded, nearly sessile. Stamens numerous (20 or more), inserted with the petals. Carpels usually 5 or more (2 to 12 ), distinct and sessile or nearly so, becoming membranaceous or corinceous several- $(2-15-)$ seeded follicles, not inflated. Seeds small, penlulous, linear, with a thin membranaceous testa, withont albumen. - Perennial herbs or mostly shrubs; leaves alternate, mostly withuat stipules (in our sluecies); flowers white or rose-colored, in compound corymbs or panicles, or rarely spicate.

A genus of about 50 species, belonging chiefly to the temperate and cooler regions of the northern hemisphere. Muny exotic ornamental species are commou in cultivation. Of the 13 found in North America 4 are confined to the Atlantic States.

Vauquelinia Tonmexr, Watson, Proc. Am. Acad. xi. 147, the Spirce Californica of Torrey in Emory Rep. 140, has not been detected within the State, but oceurs in Southern Arizona. It is a small tree, with narrowly lanceolate serrate leaves, white-tomentose beneath; flowers white, in small terminal panicles; stamens 25 ; the silky carpels united into a 5 -celled capsule ; seeds 2 in each cell, erect, and winged at the summit.

\$1. Erect shrubs, with simple and usually lobed or toothed leaves: stipules none: flowers perfect. - SpIREA proper.

* Petals rose-colored or purplish, orbicular, exceeding the calyx : filaments much exserted: carpels smooth: ovules several.

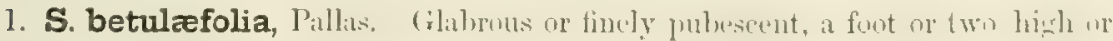
more, with reddish bark: leaves broadly ovate to ovate-oblong, rounded at base, usually obtuse, acutely and unequally serrate or incised, an inch or two long, on short petioles or nearly sessile: flowers pale purple, in fastigiate compound often lenfybracted corymbs: calyx-lobes as long as the tube, reflexed: carpels 5 , a line long: ovules 5 to 8. - Fl. Ross. t. 16. S. chamcedrifolia, Pursh, not Linn. S. corymbosa, Raf.

Among rocks in the Siern Nerada, at 5,000 to 9,000 fect altitude, from Mono Pass (Breurer) northward: muging to Alaska and the hend-waters of the Missouri; also eastward in the Alleghany Mountuins, and in Northern Asia and Japan.

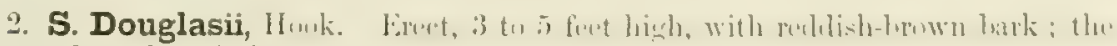
young branches, inllorescence, and lower side of tho leaves more or less densely white-tomentose: leaves oblong, 1 to 3 inches long, unequally serate towarls the rounded or acutish apex, often somewhat cunente at base, very shortly petioled, the upper surfue bright green or sometimes pubescent: flowers rose-colored, crowded in a narrow usually elongated sessile panicle: calyx-lobes mostly reflexed : carpels 5 , glabrous: ovnlos 9 to 11. - F1. i. 172; Bot. Mag. t. 5151.

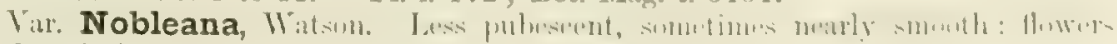
in brond thyrsuid panicles: leaves often 3 or 4 inches long. - S. Nobleana, Ilook. loot. Marg. t. 5169.

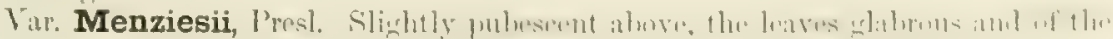
same color on buth sicles or paler beneath: panicle narTow. E Epinelia Bot. 195. S. Menziesii, Hook. Fl. i. 173.

In wot places from the Upper Sacramento to the British boundary and Idaho. 
* Petals white, broadly oblong, about equalling the 5-parted calyx: filaments scarcely exserted: carpels densely hairy: ovules 2 : flowers in loose spreading panicles.

3. S. discolor, Pursh. A diffuse shrub, 4 feet high or more, with grayish brown bark, pubescent: leaves broadly ovate, obtuse or acutish, truncate at base or cuneate into a slender petiole, more or less silky-tomentose beneath, nearly smooth above, pinnatifidly toothed or lobed, the lobes often dentate: panicle much branched, tomentose : calyx pubescent, the lobes oblong, obtuse, spreading. - Flora, i. 342.

Var. ariæfolia, Watson. Often tall ( 5 to 15 feet high): leaves 2 or 3 inches long, somewhat canescent beneath or scarcely so: panicle large and open. - S. aricefolia, Smith in Rees Cyc.; Lindl. Bot. Reg. t. 1365.

Var. dumosa, Watson. Only 1 to 3 feet high; leaves usually small, an inch long or less, cuneate into a short margined petiole, often white-tomentose beneath: panicle mostly smaller and less diffuse. $-S$. dumosa, Nutt.; Torrey, Stansbury Rep. 387, t. 4; Watson, Bot. King Exp. 80. S. ariofolia, var. discolor, Torr. \& Gray, Fl. i. 416 .

On low hills and in the valleys, mostly in the Coast Ranges, from Monterey County northward to Fraser River., The var. dumosa is found in the Sierra Nevada, in dry rocky places, at 5,000 to 11,000 feet altitude, and thence to Oregon, Colorado, and New Mexico; more rarely in the Coast Ranges also. Fragrant, with the odor of Sweet Birch.

\$2. Erect shrubs, with twice pinnate leaves and numerous minute leaflets: stipules present: flowers perfect, large, in a leafy terminal racemose panicle.-СНамbatiaria, Porter.

4. S. Millefolium, 'Torr. Stout, diffusely branched, 2 to 5 feet high, glandular-pubescent and more or less tomentose: leaves narrowly lanceolate in outline, seattered or fascicled at the ends of the branclies, 1 to 3 inches long, with very numerous (about 20) pinnæe and minute oblong obtuse leaflets (about 6 pairs) ; stipules linear, entire: flowers white, half an inch broad : calyx-tube turbinate; the erect acute lobes longer than the tube and nearly equalling the orbicular petals: stamens included: carpels 5, pubescent: styles elongated: ovules 6 to 8 , suspended: seeds over a line long. - Pacif. R. Rep. iv. 83, t. 5.

Rare in the Sierra Nevada and the mountains eastward: above Owen's Lake at 10,000 feet altitnde (Muir); at Noble's Pass, Shasta 'Co. (Nevberry), referred by oversight to Chamabatia; W. Arizona and S. Nevada (Bigclow, IVheeler); S. Utah (Mrs. Thompson, Parry); Wyoming Territory, Coulter.

\$3. Tall herbaceous perennial, with thrice pinnate leaves and no stipules: flowers diocions, small, white, in, numerous filiform panicled spikes : pedicels in fruit reflexed. - ARUNCUS.

5. S. Aruncus, Linn. (Goat's-Beard.) Smooth, branching, 3 to 5 feet high: leaves large; leaflets thin, sparingly villous beneath, ovate to lanceolate, acuminate, 2 to 5 inches long, sharply and laciniately doubly toothed, the terminal ones broadest: panicle large and compound, pubescent: flowers a line broad, nearly sessile: petals spatulate: filaments long-exserted: carpels 3 to 5 , smooth, several-seeded.

In ravines and along streams, Trinity and Shasta counties (Brewer), and northward to Alaska. Also in the Alleghanies, and in N. Asia and Europe.

\$ 4. Low herbaceous perennial, woody at base, with simple entire leaves and no stipules: flowers perfect, white, in dense cylindrical spikes on scape-like stems. - Petrophytum, Nutt.

6. S. caspitosa, Nutt. Cespitose, on rocks, with simple or branching scapelike stems: leaves rosulate on the short tufted branches of the woody spreading rootstock, oblanceolate or linear-spatulate, acute, silky on both sides, 2 to 12 lines long; those of the scape scattered and narrower: scape 2 to 6 inches high: flowers 


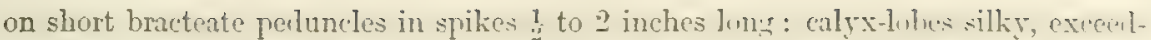

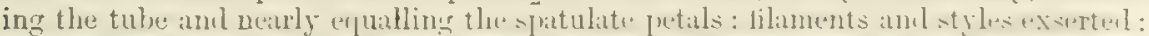

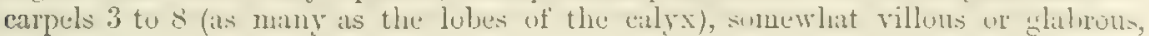
2-seeded. - Torr. \& Gray, Fl. i. 412 ; Watson, Bot. Kiug Exp. 81.

In the mountains from New Mexico and Utah to Northern Nevada (Walson) and the Cascade Mountains, Oregon (Nercberry); probably in Northern California A singular subalpine species.

S. PECTINATA, Tort. \& Gray. A low herbaceous cespitose nearly glabrous perennial, with ereep-

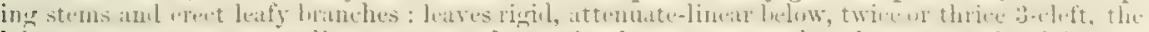

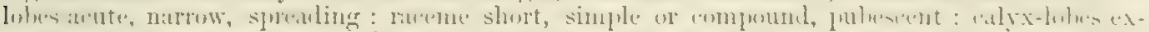

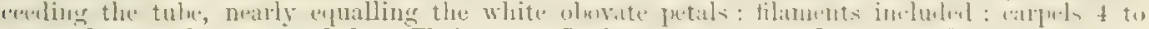
6, nearly smooth, 4-6-seeded. - Fl. i. 417. Luekeu sibbuldivides, Bongard, Veg. Sitcha, 130, t. 2. Erionymia pectinala, Hook. Fl. i. 255, t. 88. From Behring Straits to the Cascade Mountains (Newberry), and perhaps on the higher mountains of Northern California.

\section{NEILLIA, Don. NINE-BARE.}

Carpels 1 to 5 , in our species inflated and divergent: ovules two to several, some

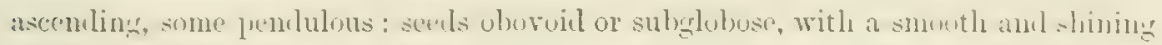
crustaceous testa, evident rhaphe, and copious albumen: otherwise as Spiraca. Dilluse shrubs; leaves simple, touthed or loled; stipules rather large, leciluous; llowers large, white, in simple corymbs or panicled racemes.

Only 4 or 5 species, confined to the mountains of $A$ sia, with the following exceptions.

1. N. opulifolia, Benth. if Hook. A shrub 3 to 10 fiet high, with slender

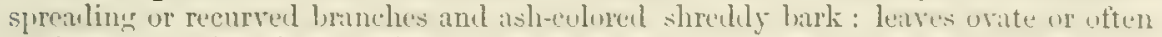
cordate, 3-lobed and toothed, 1 to 3 inches long, on slender petioles, nearly gla-

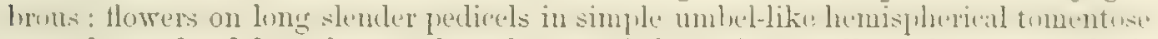
corymbs: calyx-lobes shorter than the rounded petals, usually pubescent on both sides: carpels 2 to 5 , at length 2 to 4 lines long and membranaceous, glabrous, 2 - 4-seeded: seeds oblong-ovate, a line long. - Spircea opulifulia, Linn.

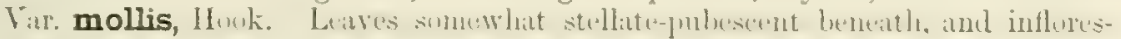
cence more densely tomentose. - Fi. i. 171. Spiraca capitata, Pursh.

On the rocky banks of streams from the Bay of San Francisco northward to British American and eastward across the continent. Another species, N. Torreyi, Watson, with smaller leaves and flowers, and tomentose ovaries, is found from the East Humboldt Mts., Nevada, to Colorado.

\section{RUBUS, Linn, Raspberre. Blackberir.}

Calyx persistent, 5-lobed, without bractlets; tubo short and open. Petals 5, conspicuous. Stamens numerous. Carpels usually mumerous upon a convex receptacle, becoming small globose 1-seeded drupes: styles nearly terminal: ovules 2, pen-

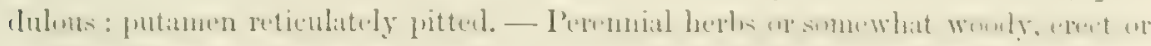

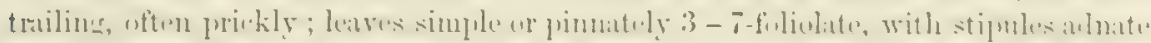

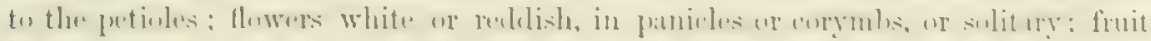
usually edible, black, red, or yellowish.

A large genus of nearly 500 deseribed species, relucible to half ns many, widdy distributegl

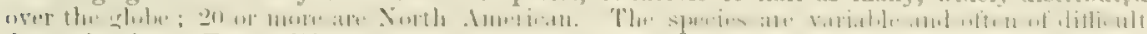
determination. Two ('alifornian species are cultivated abroad for ormunent, but none for fruit.

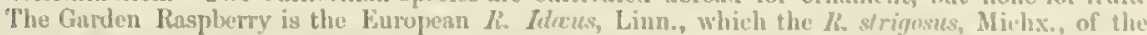

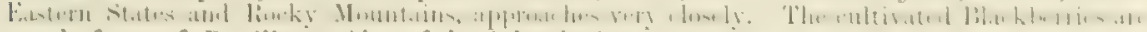
mostly forms of $\mathbb{R}$. rillosics, Ait., of the Atlantic States.

\$1. Fruit with a bloom, separating from the receptacle achen ripe. - R.ispuEntrY.

* Leaves simple, palmately lobed: stem snft-woody, without prickles: Aloners livge.

1. R. Nutkanus, Moçino. (A.suon-RErRY.) Stoms erect or almoping, 3 to 8

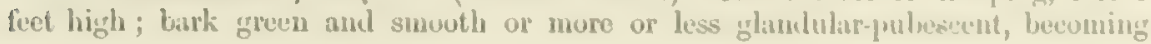


brown and shreddy: leaves palmately and nearly equally 5-lobed, cordate at base, unequally serrate, 4 to 12 inches broad, the lobes acute or acuminate, glabrous or somewhat tomentose, the veins beneath as well as the petioles and peduncles usually more or less hispid with gland-tipped hairs ;- stipules lanceolate, acuminate : flowers rather few, white, an inch or two broad: calyx densely tomentose: carpels very numerous, tomentose : fruit red, large, hemispherical, sweet and pleasantly flavored. — Lindl. Bot. Reg. t. 1368 ; Hook. Bot. Mag. t. 3453.

Var. velutinus, Brewer. Densely tomentose, especially on the under side of the leaves. - $R$. velutinus, Hook. \& Aru. Bot. Beechey, 140.

In shaded places from Monterey to Alaska, and eastward to New Mexico and Lake Superior. The variety is confined ehiefly to California. The species differs little from the $R$. odoratus of the Atlantic States, which has purplish rose-colored petals, more abundant glandular hairs, the lobes of the leaves usually more acuminate, and the fruit smaller. The flowers in $R$. Nutkunns are occasionally pale rose-color.

* * Leaves 3-foliolate, sometimes simple on the flowering branches, rarely 5-foliolate: stems soft-woody, more or less prickly.

2. R. spectabilis, Pursh. Stems rather robust, 5 to 10 feet high, sparingly armed with straight stout prickles: leaves 3 -foliolate, or occasionally some simple; leaflets ovate, acute or acuminate, doubly incised-serrate and often 2 - 3-lobed, acute or acuminate, the veins beneath, as well as the petioles and peduncles, sparingly villous-pubescent; stipules linear: flowers mostly solitary, red, large and showy: calyx-lobes pubescent, broadly ovate, acuminate: fruit large, ovoid, red or yellow, smooth: styles long, persistent. - Fl. i. 348, t. 16; Lindl. Bot. Reg. t. 1424.

Var. Menziesii, Watson. More or less densely tomentose and silky. - R. Menzicsii, Hook. Fl. i. 141.

Shady woods, near streams, from Mendocino County (Botcnder) to Alaska. The variety near San Francisco and northward; Punta de los Reyes (Bigelow) ; Saucelito Hills (Kellogg \& Harford); Crater Pass, Oregon, Andrews, \&c.

3. R. leucodermis, Dougl. Erect, 3 to 5 feet high, glaucous, armed with stout straight or recurved prickles: leaves 3 -foliolate, or sometimes pedately 5 -foliolate, never simple; leaflets ovate to lanceolate, acuminate, doubly serrate, whitetomentose beneath, the veins, petioles, and peduncles prickly; stipules setaceous: flowers few, corymbose, white, half an inch broad: sepals lanceolate, long-acuminate, exceeding the petals: ovaries tomentose: fruit yellowish-red, rather large, with a white bloom and agreeable flavor. - Torr. \& Gray, Fl. i. 454; Regel, Gartenfl. xix. 353, t. 670. R. glaucifolize, Kellogg, Proc. Calif. Acad. i. 67.

In the Redwoods between Santa Clara and Santa Cruz (Bolander); Upper Yosemite Valley (Gray); more frequent in Oregon and Washington Territory. Also in N. Utah (Watson), and in the San Francisco Mountains, Arizona, Bigelow. Very near the Black Raspberry or Thimbleberry ( $R$. occidentalis, Linn.) of the Eastern States, from which it is hardly distinguished by rather more coarsely toothed leallets, stouter and more hooked prickles, and the color of the fruit.

* * Stems herbaceous, trailing, unarmed: leaves 3-foliolate: the carpels few.

4. R. pedatus, Smith. Stems slender, pubescent: leaves smooth or sparingly villous; leaflets cuneate-obovate, an inch long or less, incisely toothed, the lateral ones often parted to the base; stipules ovate-oblong: flowers often solitary, on long slender peduncles, white, 6 to 9 lines broad : sepals ovate-lanceolate, nearly glabrous, entire or incised, exceeding the petals, at length reflexed: fruit of 3 to 6 large red pulpy drupelets. - Icon. Pl. t. 63 ; Hook. Fl. i. 181, t. 62.

In woods, near the coast above San Franciseo (Newberry), and northward to Alaska.

\section{\$2. Fruit persistent upon the somewhat juicy receptacle, black and shining: stems prickly: flowers white, - BLACKBERLY.}

5. R. ursinus, Cham. \& Schlecht. Stems becoming woody, weak or trailing, 5 to 20 feet long, sending out numerous lateral fruiting branches, armed with straight 
rather slender prirkles, somewhat cliucous: leares 3-fuliolate, rarely 5-filinlate. often simple and 3 -lobed on the flowering branchlets; leaflets ovate to oblons, coarsely toothed, smooth or more or less pubescent or tomentose; veins, petioles,

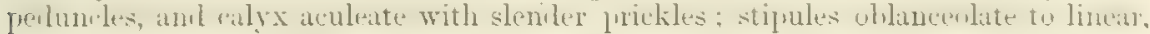

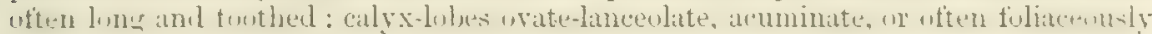
tipped and exceeding the petals: fruit oblong, sweet. - Linnae, ii. $11 . R$. macropetalus, Dougl.; Hook. Fl. i. 178, t. 59. R. vitifolius, Cham. \& Schlecht. 1. c, the simple-leaved form.

Frequent in the Coast Ranges from Santa Barbara and Ventura counties (Ojai, Goodalc) to Fraser River ; also in Idaho. A very variable species.

\section{CHAM ÆBATIA, Benth.}

Calyx persistent, turbinate-campanulate, 5-lobeul. Petals 5, sprealing. Stamens very numerous, in several rows on the throat of the calyx, short. Carpel solitary,

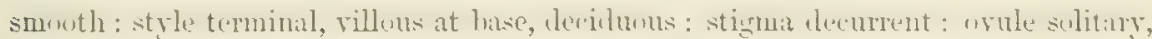
erect. Fruit a coriaceous obovoid akene, included. Seed with a spougy testa ancl small albumen: radicle inferior. $-\mathbf{A}$ glandular-pubescent fragrant shrub; leaves thrice pinnate with numerous minute leaflets; flowers white, in a loose cyme.

1. C. foliolosa, Benth. An erect shrub, a foot or two high; branches numer-

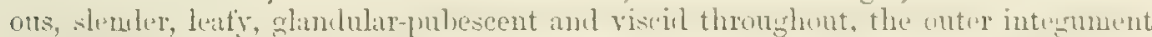
soon deciduous, leaving a smooth dark-brown bark: leaves ovate or oblong in out

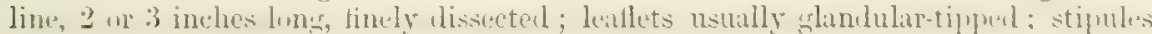
small, linear: cymes few-flowered, terminating the young branches; bracts leafy, toothed or pinnatifid: calyx densely glandular-hairy, villous within, the ovate acuminate lobes as long as the tube or at length longer: petals white, obovate, 3 or 4 lines long: akene nearly filling the calyx, abruptly acute. - Pl. Hartw. 108; Torrey, Pl. Fremont. 11, t. 6 ; Hook. Bot. Mang. t. 5171 .

On the western slope of the Sierra Nevula, at 3,000 to 7,000 feet altitude, from Mariposa Co. to Nevala Co., flowering from May to July. 'It is very abuudant in some places, filling the air with its strong resinous rather disagreeable odor.

\section{PURSHIA, DC.}

Calyx persistent, funnel-shaped, 5-lobed. Petals 5, exceeding the calyx-lobes, yellow. Stamens about 25, in one row. Campols solitary, sometimes 2, narrowly oblung, attenuate into the persistent style: stigma rlecurrent: avule solitiry, erect. Fruit a coriaceous akene, pubescent, attenuate at each end, exsertel. Seed oblongobovate, without allumen, the thin seed-coats separated hy a layer of dark-purple intensely bitter resinous matter: radicle inferior. - A diflusely branehed shruh; leaves mostly fascicled, cuneate, 3-lobed: flowers solitary, terminal on the short brunchlets.

1. P. tridentata, DC. Usually 2 to 5 (rurely 8 or 10 ) feet high, with brown or gruyish bark; the young branches and numerous short branchlets pubescent: leaves cuneate-obovate, 3 to 12 lines long, 3-lubed at the apex, petiolect, whitetomentose beneath, greener above; stipules short: Howers nealy sessile: calyx 2 to 4 lines long, tomentose with some glandular hairs, the ololong ohtuse lohes shorter than the tube: petals spatulateabovate, 3 to) 5 lines long: fruit half an inch long. - Hook. F. i. 170, t. 58 ; Linll. Bot. lieg. t. 1446; Torr. \& Gar, 1Fl. i. $42 \times$; Watson, Bot. King Exp.82.

Frenuent throumhout the interior from the enstern slopu of the Sicrn Nevadu to the Rorky Mountains, and from the British boundury to Arizona and New Mexico. 


\section{COLEOGYNE, Torr.}

Calyx persistent, 4-parted; lobes large, ovate, imbricated, with a membranaceous margin, colored within. Petals none. Stamens numerous, inserted upon the base of a tubular torus which includes the ovary. Carpels solitary (rarely 2), glabrous, oblong: style lateral, very villous at base, twisted, exserted, persistent: stigma decurrent: ovule solitary, ventrally attached opposite the base of the style. Fruit a coriaceous akene, glabrous, included. Seed with a rather spongy testa, without albumen: radicle superior. - A diffusely branched somewhat spinescent shrub; leaves opposite, small, entire, coriaceous ; stipules minute; flowers solitary, terminal on the short branchlets, subtended by 1 or 2 pairs of 3 -lobed bracts, yellow, showy. A remarkable genus, of a single species.

1. S. ramosissima, Tогr. Much branched, 3 to 6 feet high, the short rigid branches opposite and spinescent; bark gray: leaves approximate upon the branchlets, linear-oblanceolate, 2 to 4 lines long, thick, usually 2-4-sulcate on the lower side, puberulent with appressed hairs attached by the middle; stipules short, triangular: flowers half an inch broad: calyx-lobes often ciliate-toothed: tube of the torus membranaceous, dilated below and narrowed to the shortly 5-toothed apex, as long as the calyx and very slender filaments, densely white-villous within: akene somewhat compressed, oblong-ovate, the obtuse apex incurved: seed suspended from near the summit and filling the akene. - Pl. Frem. 8, t. 4; Parry, Am. Naturalist, ix. 270.

About the head-waters of the Mohave (Fremont) and eastward in Sonthern Nevada and Arizona to Southern Colorado.

\section{CERCocarpus, hBK. Mountain Mahogany.}

Calyx narrowly tubular, the campanulate 5-lobed limb deciduous; lobes slightly imbricated. Petals none. Stamens 15 to 25 , in 2 or 3 rows on the limb of the calyx. Carpels solitary (rarely 2), narrow, terete: style terminal : stigma terminal : ovule solitary, ascending. Fruit a coriaceous linear terete villous akene, included in the enlarged calyx-tube, caudate with the elongated exserted plumose twisted style. Seed linear, with membranous testa: radicle inferior. - Shrubs or trees; leaves alternate, simple, evergreen; stipules very small ; flowers small, axillary or terminal, solitary or somewhat fascicled.

A genus of 4 or 5 species, chiefly of the interior of the continent, one being Mexican.

1. C. ledifolius, Nutt. A shrub or small tree, usually 6 to 15 feet high : leaves narrowly lanceolate with the margins more or less revolute, thick-coriaceous and somewhat resinous, entire, more or less tomentose, but usually glabrous above, $\frac{1}{2}$ to $1 \frac{1}{2}$ inches long, acute, narrowed at base to a short petiole; midnerve prominent: flowers sessile, tomentose: limb of the calyx 2 lines long, deeply toothed; tube becoming 3 to 5 lines long: tail of the akene at length 2 or 3 inches long. - Torr. \& Gray, Fl. i. 427 ; Hook. Ie. Pl. t. 324 ; Nutt. Sylva, ii. 28, t. 51 ; Watson, Bot. King Exp. 83.

Olanche Mts. (Rothrock) at 9,400 feet altitude, and on the eastern slope of the Sierra Nevada from Mono Pass at 9,000 feet altitude (Botander) to Oregon, and eastward in the mountains to the Wahsatch. It is popularly known as Mountain Mahogany, having a hard and heary darkcolored wood, susceptible of a fine polish. It sometimes becomes a handsome tree, 40 or 50 feet high, but is usually low, with a compact head.

2. C. parvifolius, Nutt. A shrub, usually 2 to 10 feet high, branching from a thick base, sometimes 15 to 20 feet high: leaves cuneate-obovate, less coriaceous, 
serrate toward the obtuse or rounded summit, more or less silky above, densely hoary-tomentose beneath, $\frac{1}{2}$ to $1 \frac{1}{2}$ inches long, shortly petioled; veins prominent beneath: flowers tomentose, on short slender pedicels: calyx-limb nearly 2 lines long, with short teeth; tube becoming 4 to 6 lines long, exceeding the pedicel : tail often 4 inches long. - Hook. Ic. Pl. t. 323; Hook. \& Arn. But. Beechey, 337.

Var. glaber, Watson. Glabrous throughout, or the calyx somewhat appressed pubescent: leaves dark green. - C. betulaefolius, Nutt.; Hook. Ic. Pl. t. 322. C. betuloides, Tort. \& Gray, Fl. i. 427.

In the Coast Ranges from Lake Co. (Torrey) to S. California, and in the Rocky Mountains from Wyoming Territory to New Mexico and Utah. The variety occurs in the mountains nenr Santa Barbara (Nutkell) and San Diego, Clcveland, Palmer.

\section{COWANIA, Don. CLIFF-Rose.}

Calyx persistent; tube narrowly turbinate; limb 5-parted, imbricated. Petals 5 , obovate, spreading. Stamens numerous, in 2 rows, inserted with the petals at the throat of the caiyx-tube. Carpels 4 to 12 , free and distinct, sessile, deusely villous: style terminal, included: stigma terninal: ovule solitary, erect. Fruit a coriacenus narrowly oblong striate akene, nearly, included in the dilated calyx-tube, candate with the elongated plumose style. Seed linear, somewhat triangular: radicle inferior. - Shrubs or small trees; leaves small, toothed or pinnatifid, coriaceous, glandular-dotted; flowers showy, solitary, terminal.

A genus of 3 species, confined to Mexico and the adjacent interior region northward.

1. C. Mexicana, I wn. I much-hmanchel shrul, I to 6 feet hich; the trunk with abundant shreddy light-colored bark: leaves approximate upon the short brunchlets, cuncate-obovato in outline, 4 to 7 lines long, pinnately $3-7$-lobed, dirk green above, tomentose beneath, and the margin somewhat revolute: flowers yellow, an inch or less in diameter, the calyx-tube attenuate into a short glanclular-hairy pedicel ; calyx-lobes obtuse, tomentose, 2 lines long, equalling the tube: tril of the akene at lengtl 2 inches long or more. - Trans. Limn. Soc. xiv. 57t, t. 22; Watson, Bot. King Exp. 83. C. Stansburiana, Torrey, Stansbury Rep. 386, t. 3.

"Mountains of Califoruia along the Virgen River" (Fromont, probably in Southern Neralis), and frequent eastward in the mountains to $\mathrm{N}$. Utah and Now Mexico, and sonthwarl to Centmin Mexico. The wool is light coloren? and very fine grained. The other species are $C$. pricutu, Don, of Nurthern Mexico, with toothed leaves and purplish flowers, and C. ericefolin, Tort., with smaller white thowers and linear entire leaves, found only by Parry on the Rio Grande.

\section{FALLUGIA, Endlicher.}

Calyx persistent; tubo short-hemispherical, villons within; lina 5-parterl, the ovate lobes imbricated in the bud, with alternate linear buetlets. Petals 5, lawge and romnled, sprealing. Stamens numerous, inserted in a triple row upon the margin of the calyx-tube. Carpels mumerous, deusely villous, inserted upon a small conical receptaclo: stylo terminal: stigma minute: ovules solitary, erect. Fruit a coriacenus narrowly oblong akene, exserted, caudate with the elongated. plumose style. Seel linear: malicle inferior. $-\mathrm{A}$ low undershrub; leaves pinnately loheri, maryin revoluto; stipules small; flowers white, showy, solitary or panicled, teruinating slender elonerated naked peduncles.

1. F. paradoxa, Endlicher. Much branched with somewhat virgate slomeler branches, 2 or 3 feut high; opielernis white, persistent: leaves scattered or fits. ciclect, somowhat villous, rather thick, 3 to 10 lines longr, sessile, cumpate and alfernunto into a linear buse, pinnatrly 3-7-cleft above, the segments linear, ohtuse: 
flowers few, an inch or more in diameter: calyx-lobes ovate, 3 or 4 lines long, the apex linear or trifid; bractlets linear, entire or bifid or 2-parted: akenes very numerous, $1 \frac{1}{2}$ lines long, the slender plumose tail an inch or two long. - Torrey in Emory Rep. 140, t. 2. Sieversia paradoxa, Don, 1. c. 575, t. 22.

Providence Mountains (Cooper) and eastward to S. Utah and the Rio Grande; also Mexican.

\section{GEUM, Linn.}

Calyx persistent, concave; limb 5-lobed, usually with 5 alternate bractlets, valvate. Petals 5. - Stamens many. Carpels numerous, upon a conical or clavate receptacle: style terminal, straight or geniculate: stigma small: ovules solitary, ascending. Akenes small, compressed, caudate with the elongated naked or plumose styles. Seed erect: radicle inferior. - Perenuial herbs; leaves mostly radical, lyrate or pinnate; stipules adnate to the sheathing petioles; flowers rather large, solitary or corymbose.

About 30 species, distributed through the temperate and frigid zones. A dozen species occur in the United States, several of them found also in N. Asia and Europe or closely allied to Old World species.

$\S 1$. Styles jointed and bent near the middle, the upper part deciduous, the lower naked and hooked, becoming elongated: calyx-lobes reflexed. - GEuM proper.

1. G. macrophyllum, Willd. A coarse herb: stems mostly solitary, 1 to 3 feet high, bristly-hairy, leafy: radical leaves lyrate and interruptedly pinnate, six inches to a foot long or more, the terminal leaflet very large and round-cordate, lobed and toothed, the lateral very unequal and often very small; cauline leaves similar but with a short rhachis, or reduced to the terminal leaflet; stipules large, toothed: flowers yellow, half an inch broad, in an open panicle : bractlets of the calyx small and often wanting: fruit hispid, upon a nearly naked oblong receptacle: styles 3 lines long, at length reflexed.

In the Sierra Nevada, on the eastern side; Mono Pass (Bolander), Sierra Co. (Lemmon), north of Lassen's Peak (Newberry), and northward to Sitka, ranging east to the Atlantic.

\section{§ 2. Style straight, not jointed, and wholly persistent, naked or plumose, elongated: calyx-lobes not reflexed. - SiEverisi.}

2. G. triflorum, Pursh. Low, villous; stems clustered, from stout branching rootstocks, 6 to 15 inches high, simple, nearly naked: radical leaves pinnate somewhat interruptedly with numerous cuneate-oblong incised segments; the cauline reduced to a few small linear-lobed leaves or bracts: flowers large, few, on long peduncles: calyx often purplish, as well as the upper part of the stem, the linear bractlets 4 to 9 lines long, usually exceeding the lobes and equalling the oblong purplish erect petals : tails of the small akenes plumose, at length 2 or 3 inches long: receptacle small, hemispherical. — Sieversia triflora, R. Br.; Hook. Bot. Magr. t. 2858.

In the Sierra Nevada at 4,000 to 9,000 feet altitude (Brewer, Bolander ), and in the mountains north and eastward, to Arctic America and Labrador.

\section{FRAGARIA, Tourn. STrawberry.}

Calyx persistent, concave; limb 5-lobed, with 5 alternate bractlets, valvate. Petals 5, white, spreading. Stamens many, in one row. Carpels numerous, smooth: styles lateral, very short: orule solitary, ascending. Receptacle much enlarged and fleshy in fruit, conical, scarlet, bearing the small turgid crustaceous akenes upon the surface. Radicle superior. - Acaulescent stoloniferous perennials; leaves palmately 
trifuliolate, the leaflets obovate-cuneate, coarsely toothed; flowers fer, cymose upon short erect scapes.

A snall genus widely distributed through the temperate and alpine regions of the northern hemisphere, and also in the Andes. Many species have been proposed, but scarcely half a dozen are now recognized by botanists. Their unstable character and " the great facility with which fertile cross-breeds are produced, give reason to suspect that the whole genus may prove to consist of but one species" (Bentham). Many varieties are in cultivation, some of which flourish with special luxuriance in this State. The three first following are the generally acknowledged North American species : but it is difficult to make a satisfactory reference of all the Californian forms as found in collections.

1. F. Virginiana, Ehrhart. "Akenes imbedded in the deeply pitted fruiting receptacle, which usually has a narrow neck: calyx becoming erect attur flowering and connivent over the hairy receptacle when sterile or unfructified: leaflets of a firm or coriatcens texture: the bairs of the scapes, and especially of the pualicels, silky and appressed." - Gray, Manual, 155.

Var. Illinoensis, Gray, 1. c. "A coarser or larger plant, perhaps a distinct species, the flowers more inclized to be polygamo-diocious, the villous hairs of the scape and podicels widely sprending." - F. Grayana, Vilmorin.

The typical form of this species seems to be confined to the Atlantic States. The variety extends westward to the Rocky Mlountains and it is said even to Washington Territory and Oregon. If found in the northem part of the State it should be distinguished trom the following species by the characters of the fruit. The leaflets are cuneate-obovate, rounded at the summit.

2. F. vesca, Limu. "Akenes superficial on the glabrous conical or hemispherical fruiting receptacle (not sunk in pits): calyx remaining spreading or reflexed: hairs on the scape mostly widely spreading, on the pedicels appressed: leatlets thin, even the upper face strongly marked by the veins." - Gray, l. c.

This European species is also widely indigenous through North America, and specinens from the Sietra Nevada have been referred to it. It is doubtful, however, whether it is really found within the State. The leaflets are usually less obtuse than in the last.

3. F. Chilensis, Ehrhart. ['sually low, densely villous with silky hairs, spreitling upon the petioles, scapes and pedicels, appressed upon the under side of the leaves and the calyx: scapes and petioles rather stout: leaflets thick, perfectly smooth above, cuneate-obovate, rounded at the summit: flowers large (often an inch broad) : calyx lobes and bractlets elongated, entire : fruit not described. - Torr. \& Gray, Fl. i. 448.

Near the sen, from San Francisco to Alaska; identical with the Chilian form.

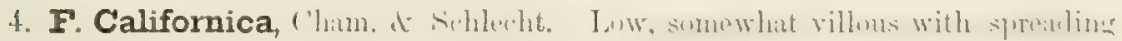
hairs, which are less closely approssed on the uncler side of the leaves and calyx: scapes and petioles usually slender: leaves thinner, cuneate-obovate and rounleu, sparingly villous on the upper side: flowers half an inch broad: calyx-lobes shorter, often toothed or cleft: fruit small; akenes superficial. - Linnsea, ii. 20. F. lucide, Vilmorin; Gay, Aun. Sci. Nat. 4 ser. viii. 201. F. vesca, Benth. Pl. Hartw. 309 ; Seem. Bot. Herald, 282.

From San Diego to Mt. Diablo (Brencer) and tho Oaklaml Hills (Holder); also in Northwestern Mexico, Secmann. This appears to be distinct from the ordinary $F$. wesca, and from other Californian forms.

14. POTENTILLA, Linn. FIVE-FINoER.

Calyx persistent, concave or flattish; limb 5-lobed, with 5 alternato bractlets, valvate. Petals 5, obcordato or brondly obovate, sessile, yellow (rarely white or red). Stamens 20 to 50 or more (rarely fewer), marginal in 2 or 3 rows upon the hairy sometimes thickened base of the calyx; filaments filiform. Carpels 10 to 40 or more, usually numerous: styles lateml or nearly terminal, short, decicluutus: 
ovule solitary, ascending or suspended. Akenes small, turgid, crustaceous, usually sessile, upon a dry more or less elevated receptacle. Radicle superior. - Herbaceous or rarely woody; leaves pinnate or digitate with distinct leaflets; stipules adnate to the petioles; flowers cymose, or axillary and solitary. - Lehmann, Revis. Potent.; Watson, Proc. Am. Acad. viii. 549.

A genus of about 120 species, aceording to Bentham \& Hooker (who include in it also the next three genera), confined almost exclusively to the temperate and cold regions of the northern hemisphere. The species are very variable, and many more than this number have been published. Of the 30 or more native to North America, a dozen are also indigenous in Europe or Northern Asia.

* Styles fusiform, thickened and glandular at base: carpels very numerons, glabrous: flowers cymose.

1. P. glandulosa, Lindl. Perennial, erect, a foot or two high, somewhat glandular-villuus, branched above: leaves pinnate; leaflets 5 to 9 , rounded, ovate, or somewhat rhomboidal, coarsely serrate, an inch or two long: cymes at length open and pedicels slender, the upper leaves and floral bracts conspicuous: calyx 4 to 6 lines long, somewhat tomentose and usually villous with coarse hairs; bractlets linear to oblong, shorter than the lobes: petals yellow or sometimes white, usually shorter than the calyx: stamens 25, in one row on the maryin of the thickened disk: style attached below the middle of the ovary. - But. Reg. t. 1583. P. Wrangeliana, Fischer \& Meyer; Lehm. Revis. 49, t. 19.

Var. Nevadensis, Watson. A sleuder form with small leaflets: inflorescence more naked, the upper leaves and floral bracts being much smaller: calyx 2 to 4 lines long: flowers white or yellow: stamens occasionally only 20.

From Monterey northward to Washington Territory; the variety in the Sierra Nevada from the South Fork of Kern River (Rothrock) to Oregon. P. fissa, Nutt, is a usually low and slender form of this species with occasionally 5 pairs of leaflets, common in the Rocky Mountains; it does not appear to have been collected in California.

2. P. rivalis, Nutt. Annual or biennial, erect or ascending, often diffusely branched, softly villous with spreading hairs or nearly glabrous: leaves pimnate, with 2 pairs of closely approximate leaflets, or a single pair and the terminal leaflet 3-parted; upper leaves ternate; leaflets cuneate-ovate to-lanceolate, coarsely serrate, 1 to $1 \frac{1}{2}$ inches long: cymes loose, with slender pedicels: bractlets and calyx-lobes equal, $1 \frac{1}{2}$ to 3 lines long: petals minute, yellow: disk not thickened: stamens 10 to 20 : style terminal. - Torr. \& Gray, Fl. i. 437.

Var. millegrana, Watson, 1. c. Leaves all ternate: akenes usually small and light-colored. $-P$. millegrana, Engelm.; Lehm. Revis. 202 ; Watson, Bot. King Exp. 85.

The variety ranges from the eastern slope of the Sierra Nevada, and from Fort Mohave (Cooper), eastward to New Mexico and the Missouri. The typical form is not found west of the Rocky Mountains.

* Style filiform, terminal: carpels glabrous: stamens 20: herbaceous perennials, with cymose yellow flowers.

- Leaves pinnate or digitate, with 5 or more (rarely 3) leaflets: bractlets sharter. than the sepals.

3. P. Breweri, Watson. Alpine, densely white-tomentose throughout, the calyx and upper leaves silky-villous with appressed hairs: stems decumbent at base, rather stout, 3 to 10 inches high: stipules broad, mostly incised; leaflets 7 to 13 , nearly uniform in size, 3 to 6 lines long, cuneate-obovate, deeply incised : cymes mostly crowded : petals emarginate, 3 to 4 lines long, much exceeding the calyx: carpels 20 to 25 , on villous pedicels; the receptacle and disk hairy. - Proc. Am. Acad. viii. 555 . 
Var. expansa, Thatson. Less densely tomentose above : çrmes loosely expanded, the flowers on long pedicels.

In the Sierta Nevada; Mono Pass (Brevoer); Sunmit, above Cisco, Bolander. The variety in Sierra County, J. G. Lemmon.

4. P. Plattensis, Nutt. Luw, decumbent, sparingly appressed silky-rillous or nearly glabrous: stems slender, 3 to 12 inches long: stipules linear-lanceolate to oblong, mostly entire; leaflets 7 to 15 or more, approximate and nearly uniform in size, 3 to 6 lines long, ovate to oblong, pinnatifid or parted into 3 to 7 or more linear entire or cleft segments : flowers on slender pedicels in an open cyme: petals 2 or 3 lines lnag, usually a little exceediner the lanceolate calyx-lobes: earpels 25 to 40. - Torr. \& Gray, Fl. i. 439 ; Lehm. Revis. 28, t. 6.

Sierra Valley, abundant in meadows (Lemmon); frequent in the Rocky Mountains and Uintas, and northward to British America.

5. P. gracilis, Dougl. Ascending, 1 to 3 feet high, villous and more or less tomintese, sparingly leafy : leaves cligitite or rarely pinnate; leatlets usually $\bar{T}$, soluetimes 5 , cuneate-ullung, 1 to 2 ? inches long, deeply serrate or pinnatitid with linear luhes, white-tomentuse beneath, sTeen and somewhat villuus above: "yme loose, somewhat fastigiate: petals 3 w 4 lines long, a little exceeling the ealyx : carpels 40 or more. - Hook. Lot. Mag. t. 2984. P. Jiluschlecene, Turez; Lehw. Revis. $107, t, 64$.

Var. flabelliformis, Torr. \& Gmr. Leaflets vers deenly piunatifil. - Fl. i. 440. P. flabelliformis, Lehm.; Hook. Fl, i. 192, t. 66.

Var. fastigiata, Watsun, l. e. Cyme shorter and more compact, more densely pubescent: often low. - P. fastigiata, Nutt.; Torr. \& Gmy, Fl. i. 440.

Var. rigida, Watson, l. c. Villous, but without tomentun; nsually tall and stout. - P. rigida, Nutt.; Torr. \& Gray, Fl. i. 440. P. Nuttallii, Lehm. Revis. 89, t. 33; Watson, Bot. King Exp. 88.

Chicfly eastward of the Sierra Yerada, from Oregon and Nevala to the Rocky Mountains.

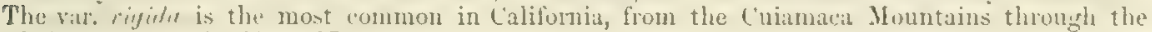
whole length of the Sierra Nevada.

6. P. dissecta, Pursh. Low and alpine, silky-villuns withut tomentum or nearly glabrous: leaves elosely pinnate or as often digitate; leaflets 5 to 7 , or rarely 3 , cuneate-oblong, an inch long or less, pinnatifid with narrow segments or coarsely serrate, the segments tufted with white hairs: flowers few in an open slender cymo: calyx more or less villous with sprearling hairs: petals 2 to 4 lines long, exceeding

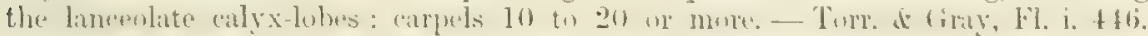
P. diversifolia, Lehm. Revis. 72, t. 31 ; Watson, Bot. King Exp. 86.

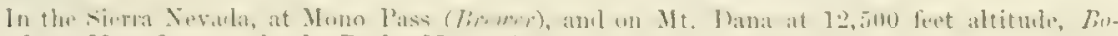
lander. More frequent in the Rocky Mountuins; a very varinble species.

7. P. Wheeleri, Watsm. Small aml subalpine, denmbent, silky-rillous : stems 2 or 3 inclies long, branched and flowering from near the base, leafy: lenves digi-

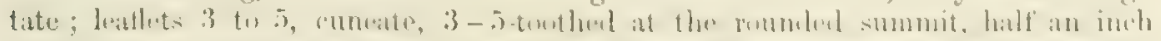

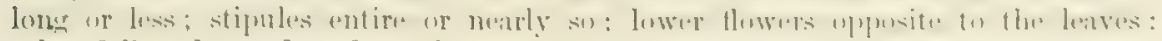
calyx 3 lines long; bractlets a little smaller than the lobes, obtusish: petals obcordate, slightly exceeling the calyx: carpels 20. - P'roc. Am. Acad. xi. 1+7.

In the Sierra Nevada, about tho head-waters of Kern River, at 8,200 feet altitude, Rolhrock.

$$
++ \text { Leaves ternate. }
$$

8. P. Grayi, Watson. Stems slender, low, 3-6-flowered: pubesconce scanty, villous: lealfets obovate or nenrly orbicular, half an inch long, the truncate or rounded apex 5-7-tonthed; terminal leaflet long-petiolulate: bractlets obtusish, only half as long as the calyx-lutes: petals 2 or 3 lines long, exceeding the calyx: carpels 15 to 20 . - Proc. Am. Acul. viii. 560.

Yosemite Valley (Bolander, Gray); Lake Tennyn (Brever); peaks above Owen's Lake, Kollogg. 
9. P. gelida, C. A. Meyer. Nearly glabrous, the pubescence minute or villous : stems low, slender, 1 -3-flowered : leaflets very broadly cuneiform, 6 to 9 lines long, rounded at the apex and coarsely 7 -9-toothed; terminal leaflet shortly petiolulate: bractlets and calyx-lobes nearly equal, obtuse or acute: petals 2 or 3 lines long, a little exceeding the calyx : carpels numerous, - Watson, 1. c. 559. P. flabellifolia, Hook.; Torr. \& Gray, Fl. i. 442 ; Lehm. Revis. 153, t. 51.

In the Sierra Nevada at Summit (Bolander) and on Lassen's Peak (J. G. Lemmon), and northward to Washington Territory; also in Northern Asia.

* * * Style filiform, attached at or below the middle of the ovary: leaves pinnate: flowers yellow : receptacle small, villous.

+ Herbaceous, stoloniferous and creeping: akenes glabrous: flowers axillary, solitary.

10. P. Anserina, Linn. White-tomentose and silky-villous: leaves all radical, often a foot long or more; leaflets 3 to 10 pairs, with smaller ones interposed, oblong, sharply serrate, tomentose at least beneath; stipules many-cleft: bractlets often incised, about equalling the calyx-lobes: petals 3 to 6 lines long, exceeding the calyx: stamens 20 , rarely 25 : carpels 20 to 40 ; the style attached to the middle : receptacle very villous.

On stream banks; frequent throughout North America, as also in South America and the Old World. Very variable in size and amount of pubescence.

++ Shrubby: akenes villous: flowers terminal, cymose or solitary.

11. P. fruticosa, Linn. Much branched, 1 to 4 feet high, silky-villous: stipules scarious; leaflets 5 to 7 , oblong-lanceolate, entire, approximate, 2 to 12 lines long, lighter colored beneath and the margin revolute: petals 2 to 6 lines long, exceeding the calyx: stamens 30 : carpels 20 , very villous, the style attached below the middle.

In the Sierra Nevada from Ebbett's Pass northward, and throughout the northern portion of North America. Also frequent in the Old World.

**** Styles filiform, attached to the middle of the numerous glabrous carpels, which are sessile upon a large spongy receptacle; herbaceous perennal, with large purple flowers and pinnate leaves.

12. P. palustris, Scop. Stems stout, ascending from a decumbent rooting perennial base: nearly glabrous: leaflets 5 to 7 , oblong, an inch or two long, serrate: flowers few, in an open cyme: calyx purplish, 6 to 10 lines long in fruit; bractlets linear, much shorter: petals spatulate, acute, 2 or 3 lines long: stamens 20, upon the margin of the thickened disk. - Comarum palustre, Linn.

Collected only in Sierra County, by $J$. G. Lemmon. More frequent northward from Puget Sound to Alaska, and eastward across the continent.

\section{SIBBALDIA, Linn.}

Petals linear-oblong, minute. Stamens 5, alternate with the petals; filaments very short. Carpels 5 to 10 : styles lateral: ovule ascending. Otherwise as Potentilla. - Dwarf and cespitose aretic от alpine perennials; leaves thick, trifoliolate, the leaflets few-toothed at the truncate summit; flowers cymose, yellow.

Of the 4 or 5 Asiatic species the following is also European and American.

1. S. procumbens, Linn. Somewhat villous: stems creeping, leafy at the extremities: leaflets cuneate, 3-5-toothed, 3 to 12 lines long: peduncles usually shorter than the leaves: calyx-lobes 1 to $1 \frac{1}{2}$ lines long; bractlets linear and shorter: petals much shorter, acute: akenes on very short hairy stipes.

In the Sierra Nevada from Mt. Dana, at 12,500 feet altitude (Bolander), to Lassen's Peak (Lemmon) and Mt. Shasta, at 8,400 feet, Brewer. Also in the Rocky Mountains of Colorado, and the White Mountains, and northward to Alaska and Greenland. 
16. HORKELIA, Cham. \& Schlecht.

Calyx campanulate. Petals oborate to linens, often unguiculate, white or pink. Stamens 10 (20 in $H$. purpurascens), in two rows; filaments more or less dilated and deltuil or subulate (witen scarcely at all so in $I I$. tridentate), those opgosite to the sepals bruaclest. (arpels few to many : styles nearly terninal, tilifurm ur thickenel at base: ovules suspended. Akenes tixed hy the milhle to the nearly naked receptacle. Otherwise as Potentilla. - Herlateous Califinnim perennials; leaves pinnate with several pairs of tenthed or cleft leaflets, the uprer ones contiluent; flowers cymose, mostly crowded. - Gray, Proc. Am. Acad. vi. 528 ; Watson, But. King Exp. 447.

$$
\text { * Styles very short, thickened at base: bractlets narrono. }
$$

1. H. fusca, Lincll. Cilanclular-pulescent: stems to 11 feet high: leaflets 6 to 8 pairs, cuncate-oblong to -ovate, incisely toothed or lobed, a half-inch to an inch long: cymes usually dense; bracts short: calyx about 21 lines long: petals cuneate-oblong, 2 lines long. - Bot. Reg. t. 1997. H. parviflora, Nutt.; Torr. \& Gray,

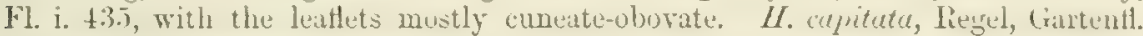
1872, t. 711 .

Var. tenella, Wilson. Low and slender: leaflets small, deeply lobed: fluwers small, scarcely $1 \frac{1}{2}$ lines long.

Freqnent in the Sierra Nevada, from Yosemite Valley northward to Oregon; the variety in Sierra County, Lemmon.

2. H. capitata, Linll. Tery similar: leaflets often lirre: bracts hroid and as long as the flowers, which are somewhat larger; petals 3 lines long: styles with the thick base less cellular and firmer. - Bot. Reg. under t. 1997.

Collected in Oregon by Douglcs, and in Klamath Valley by Cronkfite. It is perhaps but a form of the last.

$$
\begin{aligned}
& \text { * * Styles long and filiform, about equalling the stamens. } \\
& + \text { +Bractlets nearly as broad as the calyx-lobes. }
\end{aligned}
$$

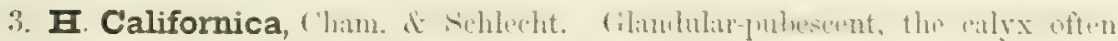
somewhat villons with coarse hairs: stems a foot high or more: leaflets usually 5 to 10 pairs, cuneate-obovato to -oblong, toothed above, 3 to 8 lines long: flowers usually crowded in the cymes, those in the forks on long pedicels; bracts short:

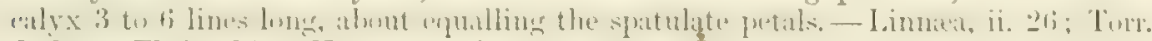
\& Gray, Fl. i. 434. H. cuneata, lindl. Bot. Reg. under t. 1997, a form with cune-

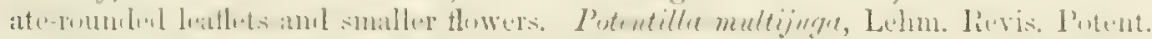
29, t. 7 , is probably the sume.

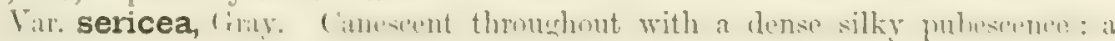
stout form, with leatlets sometimes $1 \frac{1}{2}$ inches long. - Proc. Am. Acad. vi. 529.

Very frequent in the Coast Ranges from Los Angeles to San Francisco; the variety in Alameda County, Holder, Kellogg \& Harjord.

$$
\begin{gathered}
++ \text { Bractets much narrower than the calyx-lobes. } \\
++ \text { Leaflets deeply incised or lobed. }
\end{gathered}
$$

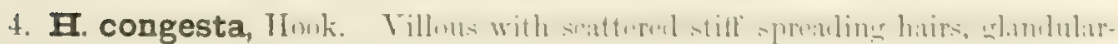
puberulent above: stems slender, a span or two high: leaflets 5 to 8 pairs, linenroblong, incised towards the apex, 6 to 9 lines long; stipules many-parted: flowers in a ruther loose cymo; bructs very short: calyx about 2 lines long, shorter than the roumlerl limb of the petals. - Bot. Mag. t. 2880 ; Torr. \& Gray, Fl. i. 434.

Orgon (Douglas, Hall); perhaps in Northera California. 
5. H. tenuiloba, Gray. Canescently villous, a foot high : leaflets 8 to 12 pairs, small ( 2 or 3 lines long), cuneate-obovate, deeply 4-8-cleft with linear lobes, or in the upper leaves narrow and few-lobed or linear and entire: flowers in close cymes; bracts short: calyx 2 lines long; lobes linear, a little shorter than the oblong-spatulate petals. - Proc. Am. Acad. vi. 529 ; Watson, Bot. King Exp. 448. H. congesta, var. tenuiloba, Torrey, Pac. R. Rep. iv. 84. H. congesta, Newberry, Pacif. R. Rep. vi. 73 .

On Santa Rosa Creek (Bigelow) ; on Hat Creek, near Lassen's Peak, Newberry.

6. H. Bolanderi, Gray. Densely hoary-pubescent, cespitose, the stems 3 or 4 inches high: leaflets numerous, abont 2 lines long, cuneate-obovate, with 3 to 5 oblong or rounded lobes: flowers in a rather open cyme: calyx 2 lines long, about equalling the oblong-spatulate petals. - Proc. Am. Acad. vii. 338; Watson, 1. c.

Var. Parryi, Watson. Less densely pubescent : leaflets often broadly and abruptly cuneate: flowers larger, 3 or 4 lines long.

Dry alkaline soil, near Clear Lake, Bolander. The variety in the mountains above San Bernardino, Parry, 1875.

7. H. purpurascens, Watson. Pubescent and somewhat villous, 6 inches high: leaflets uumerons, approximate, 2-4-parted; segments oblong to obovate, 2 or 3 lines long or less: flowers few, in an open cyme: calyx purplish, about 4 lines long; bractlets small and narrow: petals rose-colored, broadly cuneate-oblong, nearly equalling the calyx: stamens 20 ; the filaments opposite to the calyx-lobes and bractlets subulate, the alternate ones filiform: carpels 20 to 25. - Proc. Am. Acad. xi. 148.

In the Sierra Nevada, about the head-waters of Kern River, at 9,000 feet altitude, Dr. J. T. Rothrock. Peculiar in the number of the stamens.

\section{$+\div+t$ Leaflets few-toothed at the truncate apex.}

8. H. tridentata, Torr. Pubescence silky-villous, mostly appressed, often dense: stems usually a span high or more: leaflets 2 to 5 pairs, cuneate-obovate to narrowly oblong, usually 3 -toothed at the apex, a half-inch to an inch long: flowers on slender pedicels in a contracted much-branched cyme: calyx 2 or 3 lines long, a little shorter than the linear to broadly spatulate petals : filaments often filiform or the longer ones only slightly broader below, sometimes dilated: receptacle often villous : akenes occasionally rough-tuberculate. - Pacif. R. Rep. iv. 84, t. 6. Ivesia tridentata, Gray, Proc. Am. Acad. vii. 338. H. Tilingi, Regel, Trudi Peterb. i. 151, \& Gartenfl. 1872, t. 711.

In the Sierra Nevada, from Yosemite Valley to Plumas Co., Mrs. M. E. P. Ames. A species which goes far in its variations to unite this genus with the next.

\section{IVESIA, Torr. \& Gray.}

Stamens 20, in one to three rows; filaments slender, filiform. Carpels few, upon a villous receptacle: styles filiform. - Herbaceous perennials of the Sierra Nevada and eastward; leaflets usually numerous and parted or very deeply cleft, often closely imbricated; flowers white, yellow, or purple, in cymes or open panicles. Characters otherwise as in Horkelia. - Gray, Proc. Am. Acad. vi. 530; Watson, Bot. King Exp. 448.

* Flowers in rather close panicled cymes: stems slender, mostly leafy: not alpine.

1. I. Pickeringii, Torr. Densely white silky-villous, about a span high : leaflets very numerous, at first closely imbricated, 2-5-parted or lobed or often entire, the segments oblong, 1 to 4 lines long: stems panicled above, the cymes densely many-flowered: calyx 2 lines long or less; bractlets linear: petals yellow- 
ish, spatulate, equalling the calyx: stamens 20: carpels 4 to 6. - Dot. Wilkes Exp. 288 , t. 4 ; Gray, 1. c. 531.

On the Klamath River (Pickering); Sierra Valley, Lemmon.

2. I. unguiculata, (xray. Closely resembling the last, sometime's less densely villous: cymes less crowded: calyx 2 or 3 lines long, with narrow acuminate lobes ind bractlets: petals white, unguiculate, the blule orbicular, smuewhat excereling the calyx: stamens usually 15 : carpels 5 to 8.-Proc. Am. Acad. vii. 339; Watson, 1. c. 448 .

Yosemite valley (Bolander, Gray); Sierra Co., Lemmon.

3. I. Webberi, Cruy. Low, loosely villous with spreading hatirs: leaflets 4 to 6 pairs, approximate, 2 -5-parted, with linear segments, 3 to 5 lines long: stems neirly makeil, smooth above: Howers mostly un long redicels in rather loose cymes: calyx 2 or 3 lines long; lobes lanceulate; iractlets small : petals yellow, narowly oblong, about equalling the calyx: stamens 5 to 10 : carpels 3 or 4 : akenes large, ovate, a line long or more - Proc. Am. Acad. x. 71.

Sierra and Indian valleys, in ravines, $W$ cbbcr, Lemmon.

\section{* Flowers yellow, in a rather compact cyme upon a nearly naked stem: low or dwarf, alpine.}

4. I. Gordoni, Torr. \& Gray. Viscid-pubesent and often somewhat hirsute, or glabrate: stems 3 to 10 inches high from a thick resinous caudex: leaflets numerous, approximate, 1 to 6 lines long, obovate, 3-5-cleft or parted, witl oblong or spratulite segments; canline leaves one or two, pimnatifid: Howers in a close cyme, at lenoth somewhat open: calyx 2 or 3 lines long: petals yellow, narrowly olinng to broadly spatulate, usually not exceeding the calyx: stamens 5 : carpels' 2 or 3 , or more. - Pacif. R. Rep. vi. 72 ; Gray, Proc. Am. Acad. vi. 530 ; Watson, Bot. King Exp. 90. Horkelia Gordoni, Hook. in Kew Jour. Bot. v. 341, t. 12. H. (?) mullifoliolata, Torr. in Sitgreaves Rep: 159.

Var. pygmae, Watson. Much reduced, an inch or two high or even less, glandular and hirsute: leaflets very small and crowded: stamens sometimes 10 . I. pygmaca, Gray, 1. c. 531.

Vir. lycopodioides, 11 atsun. Vearly glithrous: leatlets still more cruweded and imbricated, thick and rounded. - I. lycopodioides, Gray, 1. c. 530.

In the Sierra Nevada from MIono Pass (Brewer) to Sierra Co. (Lemmon), and in the mountains of $W$ voming, Utah, and Arizona. The varieties in the higher Sierm Nevada, at 11,000 to 12,000 feet altitude.

5. I. Muirii, firty. I warf, densely silky-rillous: stens an inch hith, from a thick canlex: leaves terete with the very numerous small crowded and imbricated silky leaftets : flowers snall, in a close cyme: calyx a line long, purplish, exceeding

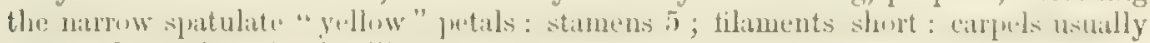
two. - Proc. An. Acad, viii. 627.

On Mt. Hoffmann, at 9,000 feot altitude, John Mruir. Except for the reduced number of stamens and shorter filiments it would be referred to $I$. santolinoides.

\section{* * *lowers in a diffuse panicle: stems leafy.}

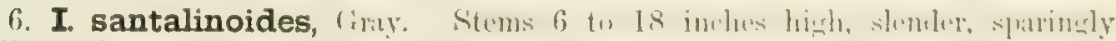
villous: leaves densely silky-villous with whito hairs, 2 to 4 inches long, tereto with the very numerous small crowded and imbricated leatlets: panicle very diffusely branched; bracts very small, villous: flowers on slemler at length elongated pedicels: calyx a line long, villous or nearly glabrous, often purplish; bractlets short: petals whito, spatulato to obovato, exceeding the calyx: stanoens 15 ; filitments long and slender; authers purple: carpels solitary. - Proc. Am. Acad. vi. 531 \& vii. 339 . 
In the Sierra Nevada, from Mt. Brewer (Brewer) and Mt. Pinos (Rothrock) to Lake Tahoe, Lemmon.

7. I. gracilis, Torr. \& Gray. Canescently villous with spreading hairs: stems slender, a span high, from an apparently annual or biennial root: leaflets 5 to 10 pairs, scattered on the slender rhachis, $3-5$-parted with oblong segments, 2 to 4 lines long: flowers on elongated pedicels in a very diffuse panicle: calyx nearly 2 lines long, broadly campanulate; bractlets nearly equalling the lobes: petals white, obovate, as long as the calyx: stamens 15 or 20 : carpels nunerous : akenes rugose. - Pacif. R. Rep. vi. 72, t. 11. Potentilla Newberryi, Gray, 1. c. 532.

On the banks of Rhett Lake, Newberry. A species peculiar in its annual or biennial root and in the large number of its carpels.

8. I. Baileyi, Watson. Viscidly pubescent : stems slender, 6 inches high : leaflets 3 to 10 pairs, cuneate-obovate, 3 -7-toothed or parted: flowers on slender pedicels in a diffuse panicle: calyx $1 \frac{1}{2}$ lines long, exceeding the yellow spatulate petals: stamens 5 : carpels 1 to 5. - Bot. King Exp. 90.

Var. setosa, Watson, l. c. Leaflets all parted, the lobes setosely tipped: more glandular-hairy.

West Humboldt Mountains, Nevada (Baitey); the variety in the East Humboldt Mountains, Watson. The remaining species also belong to this group.

I. KingII, Watson, 1. e. 91. Glabrous throughout : stems a-span long or more : leaflets numerous, entire or 2-3-parted, the lobes rounded, a line long : flowers on slender pedicels in an open panicle: calyx 2 lines long, shorter than the white orbicular petals : stamens 15 or 20 : carpels 5 to 8. - Valleys of Northeasteru Nevada, in alkaline soil, Watson.

I. Depauperata, Gray in herb. Sparingly pubescent : stems erect, a foot high or more : leaflets numerous, cuneate-obovate or oblong, deeply 2 -3-cleft : flowers pedicelled, in a rather open panicle: calyx 2 or 3 lines long, purple within, exceeding the linear dark-purple petals: stamens 5, purple: carpels 2. - Potentilla depauperata, Engelm.; Gray, Proc. Am. Acad. vii. 399. San Francisco Mts., Arizona, Anderson, Palmer, Loew. The only purple-flowered species.

\section{ADENOSTOMA, Hook. \& Arn, Chamiso.}

Calyx persistent, 5-lobed, calyculate; tube obconical, 10-ribbed; lobes membranaceous, broad. Petals 5, orbicular, spreading. Stamens 10 to 15, usually 2 or 3 together between the petals. Ovary simple, obliquely obovoid, the oblique or truncate summit pubescent: style lateral, curved, with an obliquely dilated stigma: ovules 1 or 2, suspended. Fruit a membranaceous akene, coriaceous at the summit, included in the indurated calyx-tube. Seeds unknown. - Evergreen shrubs, somewhat resinous; leaves thick and coriaceous, small and numerous, entire, solitary and rarely opposite, or fascicled; stipules small ; flowers small, white, shortly pedunculate in terminal racemose panicles.

1. A. fasciculatum, Hook. \& Arn. A diffusely branched shrub, 2 to 20 feet high, with reddish virgate branches, and grayish bark becoming shreddy: leaves fascicled, linear-subulate, 2 to 4 lines long, acute, usually channelled on one side, smooth and often resinous, rarely lobed above; stipules small, acute: flowers nearly sessile, rather crowded : calyx green, nearly a line long, much exceeding the calycu-

late bracts, strongly nerved, the lobes much shorter than the small petals: ovary obliquely truncate, often 1-ovuled: stigma small. - Bot. Beechey, 139, t. 30 ; Torr. \& Gray, Fl. i. 430.

Var. obtusifolium, Watson. Leaves short, obtuse: branchlets usually puberulent. - A. brevifolia, Nutt.

Abundant on dry soils in the Coast Ranges and more rarely in the foot-hills of the Sierra Nevada, from S. California to Lake Co. (Torrey) and Sierra Co., Lemmon. The variety near San Diego. It is nsually 6 or 8 feet high, often covering extensive areas with a dense and almost impenetrable chapparal or "chamisal," producing an effect upon the landscape similar to that of the heaths of the Old World. 
2. A. sparsifolium, Torr. A shrub or small tree, 6 to 12 or snmetimes 30 fiet

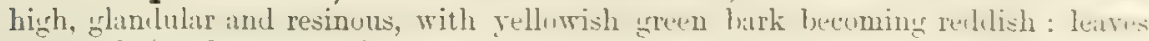
seattered (rarely opposite), narrowly linear, obtuse, 3 to 5 lines long; stipules wanting: flowers larger (nearly 2 lines broad), distinctly peduncled, in open pan-

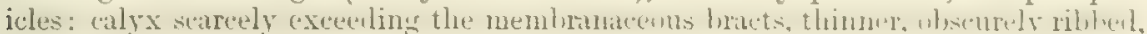
the broad white lobes half as long as the petals: ovary trumcate, 2-ovuled: style thickened upward to the broad stigma. - Emory Rep. 140, \& Bot. Mex. Bound. 63, t. 20.

Mountains east of San Diego, sometimes very abundant; flowers very fragrant.

\section{ALCHEMILLA, 'Tourn. Lady's Maitle.}

Calyx-tube pitcher-shaped, persistent; limb 4-5-parted, with as many minute bractlets. Petals none. Stamens 1 to 4 , very small. Carpels 1 to 4 , free from the calyx, distinct: style basal or ventral : ovule solitary, ascending. Akenes enclosed in the calyx-tube, crustaceous. Seed nearly orthotropous. - Low leafy herbs; leaves litluately lohed, with sheathing stipules; Howers minute, usually in swall curymbose clusters.

A bout 30 species, chiefly in the mountains from Mexico to Chili, a few being scattered through Europe, Asia, and S. Africa. The only species knows within the limits of the United States is the following.

1. A. arvensis, sicopuli. Amntal, leafr, hrunched at the base, 3 tn 8 inclues high, somewhat villous: leaves rounded, cuneate at base and shortly petioled, 2 to

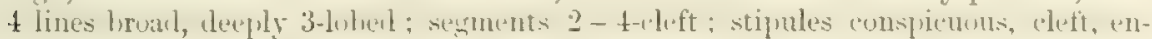
clesine the freenish flowers, which are fitsichel in the axis, halt a line lous, on slender pedicels or nearly sessile : bractlets very small : stamens 1 or 2 : akenes solitary, ovate, compressed. - A. occidentalis \& A. cuneifolia, Nutt. in Torr. \& Gray, Fil. i. 432 .

On sandy soils nenr the sea from S. California to the Columbia; Guadalupe Island (Palmer); in central Luaho, Spalding. Apparently indigenous, but not differing essentially from the European form, which is not elsewhere found on this continent except as introduced in some of the Atluntic States.

\section{AGRIMONIA, Tourn. Agrmosy.}

Calyx-tube turbinate, persistent, somewhat contracted at the throat and sur-

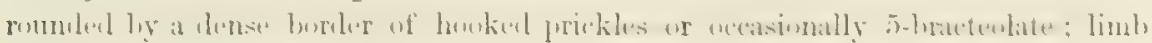
5-lobed, at length connivent. Petals 5, yellow. Stamens 5 to 15 , in one row. Carpels 2, free and distinct: styles terminal : stigma dilated, 2-lobed: orule pendulous. Akenes 1 or 2, enclosed in the indurated calyx-tube, membranaceous. Tall perennial herbs; leaves interruptedly pinnate; flowers in slender spicato racemes, with 3 -cleft bracts; fruit pendulous.

A genus of perhaps a dozen or more speries, of the northern hemisphere and the Andes. Three species are found in the Atlantic States, of which the following renclues Californin.

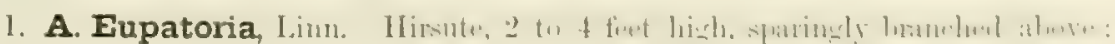
leaflets 5 to 7 , usually 2 to 4 inches long, with small ones intermixed, oblongubovate, coarsely toothed, acute at each end; stipules larye, semicorlate, incised: ealyx 2 lines (becoming 3 or 4 lines) long, the tube at longth 10-suleato above: petals exceeding the calyx lohes: akenes solitary, subglobnse, a line in diameter.

Cuiamaca Mountrins (Polmer); Sierm Co. (J. O. Lemmon); and also by Kirllogy \& Harford probably in Northern Califoruia, but loenlity not given. It oceurs rarely in Washington Terri. tory and in Now Mexico, but is common in the Atlantic States, in tho bonlers of wouls, as woll is in Europo and Northem Asia. 


\section{ACAPNA, Linn.}

Calyx-tube oblong, persistent, contracted at the throat, at length armed with retrorsely barbed prickles; limb 3-7-parted, valvate, deciduous. Petals none. Stamens 1 to 10, usually 3 to 5. Carpels 1 or 2, free from the calyx: style terminal: stigma capitate and multifid: ovule solitary, suspended. Akene enclosed in the indurated calyx, membranaceous. - Perennial herbs, often woody at the decumbent or creeping base; leaves unequally pinnate, and leaflets incised or pinnatifid; flowers in crowded spikes or heads.

Species about 30 , belonging largely to Chili and Peru, and almost exclusirely to the temperate and warmer regions of the southern hemisphere. There is a single Mexican species, besides the following Chilian species in California.

1. A. trifida, Ruiz \& Pavon. Silky-villous: stems erect from a woody caudex, 3 to 15 inches high: leaves mostly crowded at the base; leaflets about 6 pairs, nearly uniform, oblong-ovate, 3 to 5 lines long, pinnately cleft into 3 to 7 segments: flowers green, in a cylindrical crowded spike, the lower often remote: calyx-lobes $1 \frac{1}{2}$ lines long, exceeding the tube: spreading stamens purple; filaments exserted: fruit ovate, 2 limes long, 3-4-angled; angles armed with 2 to 4 stout prickles, and shorter ones in the intervals: akene round-oblong. - FI. Peruv. i. 67, t. 104. $A$. pinnatifida, Hook. \& Arn. Bot. Beechey, 339, not Ruiz \& Pavon; Torr. \& Gray, Fl. i. 430 ; Torrey, Bot. Mex. Bound. t. 19.

Dry hills in the Coast Ranges, from Monterey to Marin Co.

\section{POTERIUM, Linn. BURNE.}

Calyx-tube turbinate, contracted at the throat, persistent, becoming 3-4-angled or winged and thickish; limb 4-parted, imbricate in the bud, petal-like, deciduous. Petals none. Stamens 4 to 12 or more; tilaments often elongated. Carpels 1 to 3 , free from the calyx: style terminal, filiform: stigma tufted: ovule solitary, suspended. Akene enclosed, membranaceous. - Herbs, mostly perennial; leaves pinnate, with coarsely toothed petiolulate leaflets and foliaceous adnate stipules; flowers small, often polygamous or diœcious, bracteate and 2-bracteolate in a dense spike upon a long naked peduncle.

Species 15 or 20 , of the temperate regions of the northern hemisphere. Besides the following there is a single species in the Atlantic States, and a second in Alaska.

1. P. officinale, Benth. \& Hook. Perennial, usually glabrous, often 2 to 4 feet high: leaflets about 4 pairs, ovate to oblong, cordate at base, $\frac{1}{2}$ to 2 inches long: flowers deep purple or red, polygamous, in oblong spikes, a half to an inch long: bracts often pubescent: stamens scarcely exserted : fruit a line long, equalling the calyx-lobes. - Sanguisorba officinalis, Linn. S. microcephala, Presl in Epimeliæe Bot. 202.

Mendocino plains (Bolander); Oregon (Halt); Alaska, Kinnicut. Frequent in Europe and Northern Asia.

2. P. annuum, Nutt. Annual, glabrous, slender, 6 to 15 inches high : leaflets 4 to 6 pairs, ovate to oblong, half an inch long or less, deeply pinnatifid; segments linear : flowers perfect, greenish, in ovoid to oblong heads, $\frac{1}{4}$ to 1 inch long : bracts scarious, ovate, persistent, a line long: stamens 2 or 4 , short : fruit shorter than the bracts. - Hook. Fl. i. 198. Sanguisorba aninua, Tort. \& Gray, Fl. i. 429 ; Torrey, Marcy Rep. 285, t. 5. S. myriophylla, Braun \& Bouche, Ind. Sem. Berl. 1867, 10. Poteridium annum, Spach, Ann. Sci. Nat. 3 ser, v. 43.

In the Sacramento Valley, Hartweg, Bolander. Also in the valley of the Columbia, on the Upper Missouri, and in the Indian Territory. 


\section{ROSA, Tourn. Rose.}

Calyx-tube pitcher-shaped or globuse, contracted at the throat: limb 5-parted, without bractlets. Petals 5, spreading. Stamens many, on the thickened margin of the silky disk, which nearly closes the mouth of the calyx. Ovaries several, hairy, free and distinct: styles ventral, exserted: stigmas thickened: ovules sulitary, pendulous. Akenes bony, included in the enlarged fleshy red calyx-tube. Radicle superior. - Shrubs, usually prickly; leaves pimate, with alnate stipules and mostly serrate leaflets; flowers corymbose or solitary, showy.

A strongly marked genus, diffused through the temperate and subalpine regions of the whole northern hemisphere, but the species most abundant in the Old World. "It comprises a considerable number of true species; but several of them are of very ancient and universal cultivation, and having been multiplied and bybridized with all the skill of modern horticulture, their more or less marked varieties and races are now reckoned by thousands. Even in the wild state endeavors have been niade to characterize so large a number of proposed species that the confusion amongst them " is very great. Upwards of 250 species have been exumerated, reduced by modern authors to about 30 , and even when thus limited "specimens will occasionally be found that the most experienced botanist will be at a loss to determine" (Benthum). The North American species number about 10, of which perhaps but two are found in California. Some cultivated varieties are occasionally found near the oller settlements, uscaped from gardens, and often inicapable of determination.

1. R. Californica, Cham. \& Silhlecht. Erect, diffusely bruched, 2 to 8 feet high, sparingly armet with rather strut usually recurved prickles: fuliage anch influrescence more or less tomentose: leaflets 2 or 3 pairs, ovate to oblong, acute or obtuse, a half to an inch long: corymbs 1 -6-Howered; pedicels often pubescent, oceasionally glandular: calyx-tube globose or ovoid, mostly glabrous; the lobes tomentose, often glandular, foliaceously tipped: petals 6 to 9 lines long, rarely larger: fruit globuse, 4 or 5 lines in diameter, abruptly and narrowly constricted below the calyx-lobes, which are spreading or erect. - Linnea, ii. 35.

Var. ultramontana, Watson. Tomentuse, but not glimdulir : callyx-tube aml

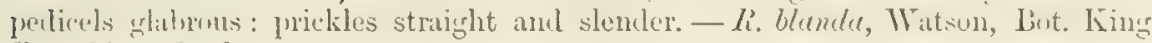
Exp. 91, and others.

Common on stream-banks, from San Diego northward to Oregon; the variety on the eastern side of the Sierra Nevada, ranging to the Rocky Mountains.

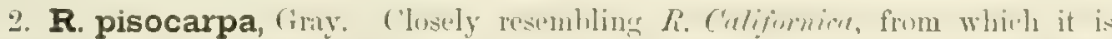

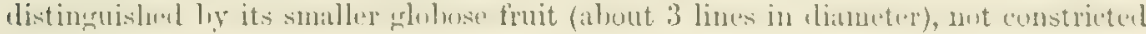
below the closely reflexed calyx-lobes. - Proc. Am. Acrd. viii. 382.

Collected by Hall in Oregon, and probably extendiug into Californin. The characters by which flowering specimens of the two species can bo distinguished are not yet apparent.

3. R. gymnocarpa, Nutt. Slenker. I tu + fent high, armoel with wites numerous straight very slender prickles, or sometimes unarmed, glabrous: leaflets 2 to 4

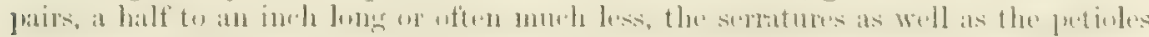
and stipules moro or less glandular: flowers solitary, rarely 2 or 3, small, rarely an

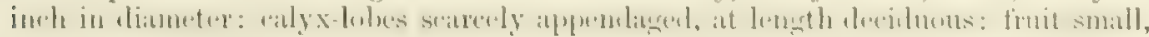
ovate or pear-shaped, 3 to 5 lines long, very narrowly constricted at the summit: seeds fow, smooth. - Torr. \& Gray, Fl. i. 461; Torrey, Bot. Mex. Bound. t. 21.

Var. pubescens, Watson. Lenves finely pubescent.

On dry hills in the Const Ranges from San Diego northward, and to the British houndary ; the variety in the Sierra. Nevada, at Clark's (A. Gray), and on Silver Mlountnin, at 9,000 feot alti. tude, Breacer.

R. BLANDA, Ait. (?) Another species is common in Oregon extending enstwart to the Rocky Mountains, resembling tho eastern $R$. brunde, but probably not identical with it. It may bo fouzd in Northern California, and can he distinguished from the preceling species by its lnrger flowers and fruit, the latter half an inch or more in diameter and not at all constricted at tho summit. It is moro glabrous than $h$. Culifornica, and tho prickles aro stout, either straight or recurved. 


\section{HETEROMELES, J. Romer.}

Calyx turbinate; limb 5-parted, persistent. Petals 5, spreading. Stamens 10, in pairs opposite to the calyx-teeth ; filaments thickened, dilated at base and somewhat connate. Carpels 2 , lightly united, very tomentose, adnate to the calyx-tube at first only dorsally to the middle: styles terminal, distinct: ovules 2 in each cell, ascending. Fruit red, berry-like, ovoid, the fleshy calyx-tube connate with the membranaceous carpels to the middle, and the thickened teeth closed over them above. Seeds 1 or 2 in each cell. - A shrub or small tree; leaves simple, coriaceous and evergreen, sharply serrate; stipules minute; flowers white, in terminal corymbose panicles. A single species.

1. H. arbutifolia, Rømer. (Toyon or Tollon.) Usually a shrub, 4 to 20 feet high: young branches, petioles and inflorescence somewhat tomentose-pubescent: leaves dark green, lighter beneath, narrowly to oblong-lanceolate, acute at each end, 2 to 4 inches long, on short petioles, slightly revolute on the margin: flowers numerous, 3 or 4 lines broad, on short pedicels in diffuse panicles: calyx 2 lines long or less: fruit 3 or 4 lines in diameter: seeds half as long. - Syn. Monog. iii. 105 ; Decaisne, Mem. Pom. in Arch. Mus. x. 144, t. 9. Cratogus arbutifolia, Ait. f. Hort. Kew, iii. 202. Photinia arbutifolia, Lindl. Bot. Reg. t. 491 ; Torr. \& Gray, Fl. i. 473. P. Fremontiana, Decaisne, 1. c.

In the Coast Ranges, from Mendocino Co. to San Diego; frequent on stream-banks, flowering in June and July and maturing its fruit in December, when it is very ornamental from the contrast between the abundant bright red fruit and the dark shining foliage. The fruit tastes like that of some species of Cratcogus.

\section{PIRUS, Linn. PEAR, ApPLE, \&e.}

Calyx pitcher-shaped or turbinate; limb 5-cleft, persistent or deciduous. Petals 5 , spreading, sessile or unguiculate. Stamens 20 ; filaments filiform. Carpels 2 to 5 , inferior (wholly covered by the adnate tube and disk of the calyx), becoming papery. or cartilaginous in fruit: styles woolly at base and distinct or more or less united: ovules 2, ascending. Fruit fleshy or berry-like, pear-shaped or subglobose. - Trees or shrubs; leaves deciduous, simple or pinnate, mostly serrate; stipules deciduous ; flowers corymbose, white or pink.

A genus of about 40 species, inhabiting the temperate regions of the northern hemisphere. As generally received it includes the Pear, Apple, Crab-apple, Quince, Choke-berry, Service Tree, \&c., most of which have been at times recognized as distinct genera, and are so ranked by Decaisne in his recent revision of the Pomacee. $P$. communis, Linn, the common Pear, indigenous to Europe and Asia, is considered by him as including all the thousands of varieties of that fruit. It is occasionally found escaped from cultivation in neglected places, but rarely fruiting. The Apple, P. Malus, Linn. (Malus communis, Lam.), also a native of Europe and Asia, is likewise sometimes found growing without eultivation and bearing a small sour fruit.

\section{\$ 1. Leaves simple: styles more or less united: fruit fleshy, mostly sunken at each end: cymes simple. - MaLus.}

1. P. rivularis, Dougl. (Oregon Crab-Apples) A shrub or small tree, 15 to 25 feet high: leaves ovate-lanceolate, acute or acuminate, 1 to 3 inches long, sharply serrulate, occasionally 3-lobed, more or less woolly-pubescent, as well as the young branches, pedicels, and calyx: cyme shortly racemose, leafy at base; pedicels slender, an inch long: limb of calyx, with the stamens, at length deciduous: petals white, orbicular, 3 or 4 lines broad: styles 2 to 4, glabrous: fruit red or yellow, obovateoblong, not sunken at base, half an inch long or more.-Hook. Fl. i. 203, t. 68 ; Nutt. Sylva, ii. 22, t. 49. P. diversifolia, Bongard, Veg. Sitch. 133. Malus rivularis \& diversifolia, Decaisne, Mem. Pom. 155. 
On banks of streams, from Sonoma Co. (Bigelono) and northwand (Bolander, Kellogy) to Alaska. In Oregon it sometimes becomes a foot in diameter, but nore usually is low, forming dense and almost impenetrable thickets. The wood is very hard, and the fruit is used as food by the Indians. There are some discrepancies in the deseriptions of the color and size of the fruit. Nuttall speaks of it as small and purple.

\section{\$2. Leaves pinnate: styles distinct, villous at base: fruit berry-like, small, globose on turbinate: cymes componnd.-SORBUS.}

2. P. sambucifolia, Cham. \& Schlecht. (Western Mocstain AsH.) A shrub, 4 to 8 feet high, nearly glabrous; the leaf-buds and inflorescence usually sparingly villous: leafiets 4 to 6 pairs, oblong, acute, sharply serrate with somewhat spreading tecth, an inch or two long: cymes rather flat: flowers white, 4 or 5 lines broad: fruit red, globose, about 4 lines in diameter. - Linnæa, ii. 36; Gray, Manual, 161. Sorbus sambucifolia \& Sitchensis, Romer, Syn. Monog. ii. 139.

In the Sierra Nevada at 6,000 to 10,000 feet altitude, on the Big Tree road and Ebbett's Pass (Brever), and northward to Sitka; in the higher mountains eastward to Colorado, and through British America to the Atlantic: also in Kimtschatka. The eastern $P$. Amoricana, DC., has more acuminate leaflets with less spreading serratures, smaller fruit in more roun 'ed cymes, and

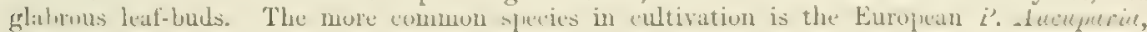
(iturtuer.

\section{CRAT无GUS, Linn. THORN.}

Calyx-tube pitcher-shaped; the limb 5-parted. Petals 5, spreading. Stamens 5 to 20. Carpels 2 to 5 , inferior, becoming bony 1-seeded nutlets, contignous or united : styles slender, distinct: ovules 2, ascending. Fruit drupe-like, globose or ovoid. - Shrubs or small trees, mostly thorny; leaves simple, toothed or lobed; flowers corymbose, mostly white.

A genus of 30 or more species, about half of which are North American and Mexican, the rest (excepting one in New Grenada) belonging to Europe and N. Asia. Many of the species are of very diffieult limitation, and the characters of the Califormian species are still in some doubt.

1. C. rivularis, Nutt. A shrub or small tree, 10 to 15 feet high, glabrous throughout or nearly so: spines short and stout: leaves ovate to oblong-ovate, obtuse or acute, cuneate at base into a short slendor petiole, serrate more or less irregularly, but rarely at all lobed, 1 or 2 inches long: flowers 4 or 5 lines broad, in small corymbs: calyx-lobes short and obtuse, often purplish and slightly pubescent on the margin: fruit nearly black, probably rather smaller than in the next. - Torr. \& Gray, Fl. i. 464 ; Nutt. Sylva, ii. 9.

Sierra and Plumas counties (IIrs. Ames, Lcmmon), and northwarl to the Columbia.

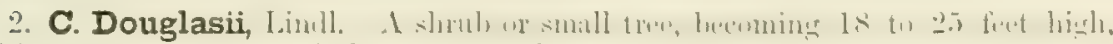
with stout spines an inch long or less: leaves broally ovate, cuneate or sometimes rounded at base, acute, usually somewhat lobed or incised above, rather finely serrate, somewhat villous-pubescent on both sides, $1 \frac{1}{2}$ to 3 inches long, shortly petioled: flowers often numerous, 5 to 8 lines broad: calyx-lobes lanceolate, nearly as long as the tube, more or less pubescent: fruit dark purple, nearly half an inch in dinmeter, sweet and edible. - Bot. Reg. t. 1810. C. senquined, var. Douglasii, Torr. \& Gray, Fl. i. 46t; Nutt. Sylva, ii. 6, t. 44. Anthomeles Douglasii, Rwmer, Syn. Monog. iii. 140 .

On Pit River (Brewer), and northward to the British boundury. Both theso species are apparently common through Oregon and Washington Territory, on strean-hanks, muging eastward to Montana. The specios of Colorado and Whah, which has becu referned to $C$. rivuluris, is probably distinct.

\section{AMELANCHIER, Medicus, JUNE-BEmY. SEIRYCE-nERRY.}

Calyx-tubo campanulate; the limb 5-parted, persistent. Petals 5, oblong, ascending. Stamens 20, short. Carpels 3 to 5 , inforior, becoming membrannceous and 
partially 2-celled: styles united below or distinct. Fruit berry-like, globose; the cells 1-seeded. — Shrubs or small trees ; leaves simple, serrate ; flowers white, racemose; fruit purplish, edible.

A genus of perhaps half a dozen species in Europe, Western Asia, and Japan, besides the North American forms which have received a dozen or more speeific names but are usually referred to a single polymorphous species. The prevalent form on the western coast is sufficiently well marked to be considered distinct from $A$. Canadensis of the Atlantic States.

1. A. alnifolia, Nutt. A shrub, 3 to 8 feet high, glabrous throughout or often more or less woolly-pubescent: leaves broadly ovate or rounded, occasionally oblongovate, obtuse at both ends or rarely acute, often somewhat cordate at base, serrate usually ouly toward the summit, $\frac{1}{2}$ to $1 \frac{1}{2}$ inches long: racemes short: calyx usually tomentose within: petals 3 to 12 lines long, narrowly oblong: fruit mostly 3 or 4 lines in diameter. - Aronia alnifolia, Nutt. Genera, i. 306. Amelanchier florida, Lindl. Bot. Reg. t. 1589. A. Canadensis, var. alnifolia, Torr. \& Gray, Fl. i. 473.

On mountain-sides throughout the State, from near the level of the sea to an altitude of 10,000 feet in the Sierra Nevada. It ranges northward to British Columbia and eastward to the Rocky Mountains, varying much with the character of the locality in which it is found.

\section{CANOTIA, Torrey.}

Calyx small, campanulate, deeply 5-cleft, persistent, imbricate in the bud. Petals 5, oblong. Stamens 5, hypogynous ; filaments attenuate-subulate, persistent. Ovary superior, 5-celled : styles united, stout, persistent: stigma terminal : ovules several, amphitropous, attached to the central angle. Capsule woody, oblong, attenuate into the persistent style, septicidally 5-valved, the valves 2-cleft. Seed solitary, attached by the middle, oblong, compressed, produced below into a membranaceous wing. Embryo surrounded by fleshy albumen; cotyledons broad; radicle inferior. - A leafless shrub or small tree, with straight spinose branches, and smooth green bark; flowers white, in small lateral cymes.

A genus of a single species, very anomalous in its characters, and here appended to the Rosacece (with which it has little in common) only because it is so referred by Bentham \& Hooker.

1. C. holacantha, Torr. Often 10 to 20 feet high, much branched; the light green striate surface of the branchlets marked by scattered small dark scars from which small scale-like leaves appear to have fallen: cymes few-flowered, bracteate with small thick triangular bracts : calyx very small : petals 2 lines long, equalling the stamens and pistil: capsule 9 to 12 lines long, dehiscent to the middle: seeds half as long, including the wing, which is as long as the dark finely tubereulate body. - Pacif. R. Rep. iv. 68.

On the Providence Mountains (Cooper), and in the desert region of W. Arizona, Emory, Bigelow, Newberry, Parry, and Palmer.

\section{ORdER XXXIII. CALYCANTHACE正.}

Aromatic shrubs, with opposite entire leaves (not punctate), no stipules, sepals, petals and stamens indefinite, as it were passing into each other, and all coalescent below into a closed cup which is lined by a hollow receptacle or disk, bearing numerous simple pistils (becoming akenes) in the manner of the Rose: the anthers achnate and extrorse : cotyledons foliaceous and convolute.

Consists of the United States genus Calycanthus, and the Japanese genus of a single species, Chimonanthus; probably most allied to the apetalous order Monimiacea, of the southeru hemisphere, but generally ranked next to Rosaceo; by Bentham and Hooker placed next to Magnoliaceo, and the cup taken to be wholly receptacle or torus. But the same interpretation is now commonly 
given to the rose-hip, penr, \&ce. Our genus will naturally be looked for among the perigynous, not among the hypogynous orders.

\section{CALYCANTHUS, Linn. SweEt-scented Shrub.}

Sepals numerous, imbricated; their bases united in many ranks into a persistent

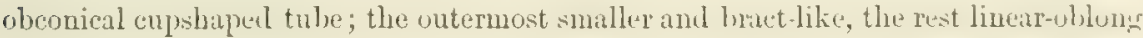
and colored like the petals, deciduous. Petals in several rows on the mouth of the tube, the inner ones shorter. Stamens numerous, inserted at and toward the top of the tube, with very short persistent filaments, the outer (ahout 12) perfect, the inder ones without anthers; anthers apjeulate, extrorse. Carpels usually numerums, elistinet, inserted upon the base and sides of the calyx-tube: styles terminal: ovules 1 or 2 , ascending. Akenes enclosed in the enlarged and at length dry ovoid or oblong calyx-tube. Seed erect, without albumen : cotyledons foliaceous, convolute: radicle inferior. - Shruls ; leaves oppusite, entire, without stipules; flowers teminal, sulitary, purple or livid, wore or less fragrant.

A North American genus, of three species confimed to the Atlantic States, and the following in California.

1. C. occidentalis, Hook. \& Arn. In erect shruh, 6 to 12 feet high: lenves dark-green, ovate to oblong-lanceolate, acute, rounded or somewhat cordate at base, scabrous, 3 to 6 inches long, on very short petioles: peduncles 1 to 3 inches long: the larger sepals and petals an inch long or more, linear-spatulate, purplish red becoming tawny at the tips; inner petals incurved: anthers 2 lines long; sterile filat ments linear-subulate, densely villous : fruiting calyx ovate, scitrcely contriuctul at the summit, $1 \frac{1}{4}$ inches long:- akenes numerous, villous, oblong, 4 lines long, Bot. Beechey, 340, t. 84; Hook. Bot. Mag. t. 4808; Baillon, Hist. Pl. i. 292, fig. 312,313 .

Rather common near streams, from the Lower Sacmmento northward; Plumas Co., Mrs. Ames. The flowers and bruised leaves and wood have a fruity frngrance, but less pleasant than that of the Atlantic species. It is said to sometimes have white flowers : blooming from April to November.

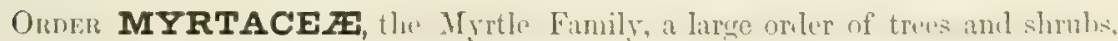
chiefly tropical and subtropical, with entire and punetate aromatic leaves, calyxtube adnate to the ovary, numerous stamens, and undivided style, has no American representatives except near and below the tropic. But Eucalyptcs, L'Her., a vast

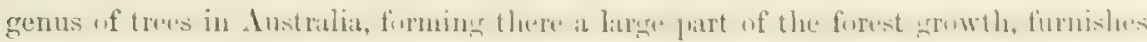

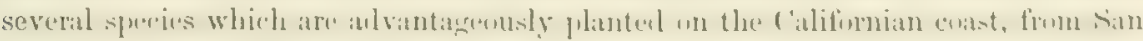

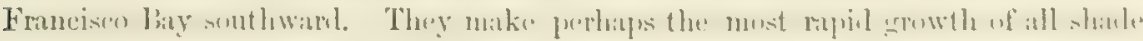
trees, and yet furnish excellent timber. In Australia some trees rival our Redwoods

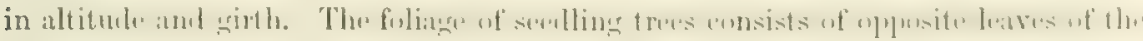
ordinary kind, generally brond; but when older they produce alternate lenves of another shape, usually narrower, longer, falcate, and hanging in a vertical position, which is assumed through a twist of the petiole. The calyx never opens; but the upper part, shaped like a candle-extinguisher or an inverted cup, separates transversely and fills away as a lid, under this is commonly another lid, thin and deciduous, which answers to the conereted petals, and then the very numerons inflexer stamens rise up and expand, producing a tassel-like blosson. The fruit is a $3-5$ -

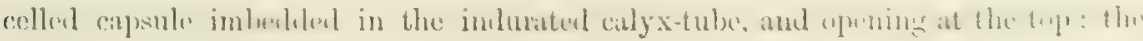
seeds numerous aud small. 


\section{Order XXXIV. SAXIFRAGACE画. (By A. Gray.)}

Herbs, shrubs, or sometimes small trees, distinguished from Rosacece by albuminous seeds and small embryo; usually by definite stamens, not more than twice the number of the calyx-lobes; commonly by the want of stipules; sometimes by the leaves being opposite; and in most by the partial or complete union of the 2 to 5 carpels (even when free from the calyx) into a compound ovary, with either axile or parietal placentæ. Seeds usually indefinitely numerous. Petals and stamens perigynous. Styles inclined to be distinct. Only the Hydrangiece have numerous stamens.

A large and polymorphous order, of about 75 genera and five or six hundred species, mainly of the cooler parts of the world, especially in the northern hemisphere. The Pacific and the Atlantic States have about the same number of genera, of which four or five are peculiar to each.

Tribe I. SAXIFRAGEE. Herbs. Leaves mostly alternate and without distinct stipules. Styles or tips of the carpels distinct and soon divergent. Fruit eapsular.

* Ovary with 2 or rarely more cells and placentæ in the axis, or of as many distinct carpels: fruit capsular or follicular.

1. Saxifraga. Stamens 10 (rarely more). Petals 5, dilated.

2. Boykinia, Stamens 5. Petals 5, dilated, deciduous. Calyx-tube adnate to the ovary.

3. Bolandra. Stamens 5. Petals 5, filiform-subulate, persistent. Calyx free.

* * Ovary 1-celled, with 2 or 3 parietal (or sometimes nearly basal) placentee alternate with the styles or stigmas : no sterile filaments.

4. Tolmiea. Stamens only 3. Calyx long and narrow, gibbous at base. Petals filiform, entire. Capsule tapering into a stalk-like base.

5. Tellima. Stamens 10, included. Petals cleft or lobed, rarely entire, conspicuous. Styles 2 or 3 , very short.

6. Tiarella. Stamens 10 and styles 2 ; both long, filiform and exserted. Petals small, entire, in ours inconspicuous and almost filiform. Capsule early and very unequally 2 -valved to the base.

7. Mitella. Stamens 10 or in ours 5, very short. Petals pinnatifid or 3-cleft into capillary divisions. Styles very short. Capsule depressed.

8. Heuchera. Stamens 5, and styles 2, both commonly slender. Petals entire, small, sometimes minute or none. Capsule ovate, 2-beaked, fully half inferior.

Chrysosplennum, if found in California, may be known by the prostrate habit, want of petals, and obcordate compressed capsule.

* ** Ovary 1-celled with 3 or 4 parietal placentæ directly under as many obtuse sessile stigmas : a cluster of united sterile filaments alternate with the stamens.

9. Parnassia. Calyx 5-parted. Petáls 5, large. Stamens 5. Flower solitary.

Tribe II. HYDRANGIEE. Shrubs. Leaves opposite, simple: no stipules. Fruit capsular.

* Stamens 20 or more : seeds numerons.

10. Philadelphus. Calyx-tube adnate to the 4-5-celled ovary. Petals convolute in the bud.

11. Carpenteria. Calyx nearly free from the 5-7-celled ovary and capsule.

$$
\text { * * Stamens fewer : seeds and ovules solitary in the cells. }
$$

12. Whipplea. Calyx nearly free from the $3-5$-celled ovary : styles distinct.

Tribe III. GROSSULARIEE. Shrubs. Leaves alternate, simple: stipules adnate to the petiole or wanting. Fruit a berry.

13. Ribes. Calyx-tube adnate to the 1-celled ovary : placentæ 2, parietal, many-seeded.

1. SAXIFRAGA, Linn. SAXIFrage.

Calyx 5-lobed or parted, free, or its tube more or less coherent with the lower part of the ovary. Petals 5, entire, imbricated in the bud, either withering-persistent or deciduous. Stamens 10 (rarely more), inserted with or below the petals on 
the base or tube of the calyx: anthers 2-celled. Carpels 2 (rarely 3 or more) nearly or quite distinct, or more or less united into a 2-celled ovary : styles distinct, persistent and at length diverging : stigmas thickish, mostly depressed-capitate or reniforn. Fruit of 2 follicles or a 2-lobed or 2-beaked capsule, opening down the beaks or by the ventral suture. Seeds numerous; the coat not wing-margined or appendaged, mostly thin. - Herbs, either stemless or short-stemmed; with alternate simple leaves, their petioles commonly sheathing at base, and small flowers in cymes, cymose panicles, or elusters, or sometimes solitary.

A large genus, mainly of the northern hemisphere, and of cool or frigid regions : nearly 50 are North American, fully half of them being common to the New and the Old World and chiefly of high northem range. There are few in California; but two of thera (forming the first two sections) are peculiar.

\$ 1. Stemless and large-leaved from a very thick and fleshy creeping rontstock: calyx 5-parted, spreading in fruit, nearly free from the two quite separate ovate diverging follicles: seeds pretty large, angled.

1. S. peltata, Torr. Tootstock large and long ( 1 to 3 inches in diameter), the younger part scaly; the apex sending up a stout scape (from a foot to at length sometimes a yard high) and later one or more large centrally peltate and orbicular 9 -14-lobed leaves on long and stout petioles: flowers pink-purple, numerous in a corymbose cyme: petals roundish-oval, without claws: mature follicles turgid-ovate. - Benth. Pl. Hartw. 311, \& Bot. Wilkes Exp. Atl. t. 5 (1862), \& 309 (1874); Hook. f. Bot. Mag. t. 6074. Leptarrhena inundata, Behr. in Proc. Calif. Acad. i. $45 \& 57$.

Along and in the beds of quick-flowing streamlets, through the Sierra Nevada from Mariposa Co. northward to the head-waters of the Sacramento (Pickering \& Brackenridge, Fremont, Hart$w \mathrm{cg}$, \&c.); also in Mendocino Co. (Bolander), \&c. The rather fleshy stout scapes and petioles (greedily eaten by the Indians, according to Dr. Kellogg) hirsute with rough tawny bristles; the former earliest appearing in spring, and bearing the ample at length loose cyme of flowers: the leaves, beginning to appear a little later, are at first from 3 to 5 inches in diameter, but at length a foot or more wide, of membranaceous toxture, cupped or umbilicate at the centre, and the short lobes or incisions irregularly toothed; the 5 to 9 ribs rather strong at base, branching above the middle. Calyx-lobes very obtuse. Petals 2 or 3 lines long and round-oval, becoming longer and narrower with age. Filaments subulate. Carpels dehiseent down to the base. Seeds rather few and large for the genus, oval or oblong, obtuse or truncate at both ends ; the coat thin, rather soft and lax. Embryo proportionally large, more than half the length of the nueleus. - Engler,

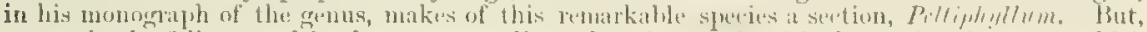
except in the folinge, and in the soon spreading calys, it accords with the section Bergenia, which Lingler even excludes from the Saxifrugo genus.

\$2. Stemless; the naked scape and later a shart leaf or two from a bulb-like corm: calyx slightly 5-lobed, campanulate, free from and nearly enclosing the twolobed capsule.

2. S. Parryi, 'lorr. Somewliat puhescent: scape filiform and naked, 2 to 4 inches high, bearing 3 to 7 short-pedicelled flowers, followed by one or moro shortpetioled rounded-subcordate slightly several-lobed and crenate-tnothed leaves (an inch or less in diameter): petals white, marked with brown-purplo veins, ovato and at length spatulate-oblong, inserted by short claws nenrly in the sinuses of the campanulate brown-nerved calyx : filaments slender-subulate, borne lower lown: styles slender, in fruit exserted out of the calyx : seeds minute, somewhat angled; the coat rather loose. - Bot. Mex. Bound. 69, t. 25.

Dry hills, in and around San Diego and San Luis Rey, Parmy, Newobrm, Clevelond, \&c. Flower. ing in November and Decomber after the nuus begin; then sending up its leaves; after fruiting all abovo the surface soon disappears until tho noxt miny season. Calyx harely 3 lines long, with a broadly truncate base, and with triangular-ovate short orect lohes. Petals 2 lines long. Tho habit and the high insertion of the petals in the orifice of the campanulate calyx aro poculin. 
§3. Stemless, or sometimes a leaf or two on the lower part of the scape, no permanent caudex rising above the ground: calyx 5-parted or 5-cleft: petals almost always white.

* Leaves not cordate, contracted at base into a margined petiole or nearly sessile: filaments not enlarged upward or rarely slightly so: herbage or at least the inflorescence more or less glandular or viscid-pubescent.

+ Naked simple scape and cluster of rather large thickish leaves rising from a short and thickish root or caudex: base of calyx caherent with the base of the 2-parted ovary: petals roundish, obovate or oblong-spatulate, very obtuse; the claw very short or none.

3. S. Virginiensis, Michx. Leaves from roundish- to oblong-ovate or spatulateobovate, conrsely toothed or almost entire, an inch or two long, and the margined petiole often as long: scape a span to a foot high, at length loosely many-flowered in a paniculate cyme: some of the pedicels slencler : petals obovate, twice the length of the merely spreading calyx.

Shaded rocky places in the Coast Ranges and Sierra Nevada: also in Oregon, the Rocky Mountains, and common in the Atlantic States. The Californian specimens resemble slender forms of the common vernal eastern species.

4. S. nivalis, Linn. Like the preceding, but mostly smaller and condensed: scape 2 to 5 inches high : flowers fewer, sessile or very short-pedicelled, and crowded in a capitate simple or compound cluster: petals oblong or spatulate, little exceeding the erect calyx-lobes: styles very short or hardly any: ovary and fruit usually dark purple.

High Sierra Nevada, above the Yosemite (Brewer) and above Cisco (Botander); thence to the arctic regions, \&c., and round the fiigid zone. The var. tenuis, Wichl. (E. Humboldt Mountains, Watson, thence northward and eastward), may oceur in the State. It has more open inflorescence, rather larger petals, and probably passes into $S$. Virginicnsis. Its filaments are not rarely distinctly broadened above the middle.

5. S. integrifolia, Hook. Leaves from ovate or obovate to lanceolate-spatulate, 1 to 5 inches long, denticulate or entire, narrowed at base into a very short and margined (or rarely longer and more distinct) petiole : scape 1 to 3 feet ligh, viscid: flowers in small clusters usually in a narrow thyrsiform panicle: petals obovate or broadly spatulate, somewhat longer than the reflexel calyx-lobes: seels much larger and with a looser coat than in the foregoing. - Fl. i. 249, t. 86 ; Watson, Bot. King Exp. 93. S. hierctifolia, var. (?), Gray in Am. Jour. Sci. xxxiii. 409. S. nivalis, var., Gray in Proc. Acad. Philad. 1863, 62.

Swamps, through the foot-hills of the Sierra Nevada, thence northward to Washington Territory, and east to the Colorado Rocky Mountains.

++ Slender scapes often paniculately branching and bracteate, and, with the tuft of thinner leaves, from a small annual or biennial root or offset: calyx free from the two almost distinct ovaries and reftexed: petals acute, on distinct claws, 2-spotted towards the base: filaments fliform: inflorescence not rarely bearing leaf-buds or bulblets in place of blossoms.

6. S. bryophora, Gray. Slender root or offshoots annual: leaves linear-oblong or spatulate, entire, thickish and nearly veinless, barely half an inch long, almost sessile, sparsely ciliate : scape glabrous, loosely paniculate and with filiform branches and pedicels, flowering only at the apex; the lateral branches or pedicels bearing a green globose leaf-bud or bulblet, soon deflexed: flower 3 or 4 lines in diameter: petals oblong-ovate, slightly unequal, and with a pair of yellowish spots at the abrupt base, twice the length of the broadly ovate and reflexed sepals: styles hardly any. - Proc. Am. Acad. vi. 533. S. leucanthemifolia, var. integrifolia, Engler, Saxifr. 135. 
In the high Sierra Nevada, at 8,000 to 10,000 feet, from Mt. Dana to Sicrra Co., Brever, Bo. lander, Torrey, Leminon.

S. LEUCANTHEstFoli, Michx, or an ambiguous form between it and S. slellaris, Jinn. (a gem. miparous state of which occurs in the Rocky Mountains and northward), is found from Washington Territory to Alaska. It has larger and toothed or incised leaves, narrow and dissimilar petals, evident styles, and is generally a nuch larger plant.

* Lectves rounded and cordate on long naked petioles: filaments broadened upward, spatulate, sometimes almost petaloid: calyx free from the 2-cleft ovary and capsule, soon reflexed: petals obovate or at length oblong, obtuse, on a shart claw: scape paniculately and loosely many-flowered: pedicels filiform.

7. S. Mertensiana, Bongard. Scaper and leares froru a scaly graulate hulb, more or less glandular-pubescent: base of petioles dilated into thin scarious budscales: leaves crenately or incisely many-lobed; the lobes often 3 -toothed at the end: panicle effuse; the branches mostly flowering only at the apex and bearing granulate bulblets down the sides: filaments sometimes 12 or more, oceasionally sterile and petaloid: capsule inflated-ovate. - Veg. Sitcha, 141. S. heterantha, Hook. Fl. i. 252, t. 78. S. ostivalis, var. (heterantha), Torr. \& Gray, Fl. i. 568.

Wooded banks in the Coast Ranges, from Sonoma Co. northward, extending to Alaska. Well marked by the stout and bulb-like caudex, producing bulblets, and usually by the clusters of little granulate bulblets on the slender branches of the panicle. Leaves 2 to 4 inches in diameter. Petals about 2 lines loug.

8. S. punctata, Linn. Scape and leaves from a short creeping rootstock, glabrous or somewhat pubescent: lenves reniform to round-cordate, of rather firm texture, coarsely and almost equally many-toothed or somewhat incised: petioles hardly dilated except at the insertion : panicle usually narrow, not bulblet-bearing: capsule oblong. - S'. cestivalis, Fischer, \&c.

Sierta Nevada at 8,000 feet and over (Torrey, Lemmm), and on the mountains enstwarl to Colorado; northward to Behring Straits, and in N. Asin. Leaves 1 to 3 inches in diameter. Seape a spau to 2 feet high. Petals about 2 lines long.

\$ 4. Leafy stems short, cespitose, and thickly beset with the small evergreen sessile leaves: scape-like peduncle few-flowered: calyx 5-parted, nearly free.

9. S. Tolmiei, Tour. \& Gray. Forming depressed tufts, glabrous or nearly so: leaves much crowded, spatulate, coriaceons, nerveless, or with obscure midrib, with revolute ontire margins ( 3 to 5 lines long) : peduncles 2 inches long, cymosely 1-6Howered: petals lanceolate, white, about twice the length of the ovate abtuse sprealing calyx-lobes: filaments dilated at the summit: carpels (often 3 or 4 ) in fruit very obtuse and large, united only at the base.

High Sierra Nevada, at 9,000 feet and upward (Brexter, Muir, Lemmon); also northwarl in the Cascade Mountains to Washington Territory. Flowers only 2 lines long: fruit 3 or 4 lines long.

\section{BOYKINIA, Nutt.}

Calyx 5-lobed; the lobes valvate but early open in the bud; the tnbo at length glohular or avate, adherent to the ovary. "Petals 5, entire (varying from imbricato to convolute in the bull), the base contracted into a short claw, deciduous. Stamens 5, short, alternate with the petals: anthers 2-celled. Ovary and capsulo 2-celled, dehiscent down the styliforous heaks. Seerls small and very numerous, ovoid, with a cluse somewhat crustaceous coat, very minutely and erenly papillose. - Perennial herbs (N. American); with creeping rontstacks, leafy simple stems, and panienlate or corymbose cymes of white flowers; the lenves all alternate, round-reniform, palmately lobed and incised or toothed, tho teeth with callons-gramlular tips, ami the petiole mustly with stipule-like dilations or appenduges at base. 
1. B. occidentalis, Torr. \& Gray. Smoothish, or with some rusty hairs, above somewhat glandular: stem slender, a foot or two high: leaves thin-membranaceous, 3-7-lobed: petioles with slightly dilated base fringed with some ramentaceons bristles: calyx-lobes lanceolate-triangular, very acute.-Fl. i. 577. Saxifraga ranunculifolia, Hook. Fl. i. 246 , t. 83 , probably, but surely no bulblets in the axils of the radical petioles. S. elata, Nutt. in Torr. \& Gray, Fl. i. 575, in part or wholly.

Woods of the Coast Ranges, from Santa Barbara to Mendocino counties and north to Washington Territory. Leaves 1 to 3 inches in diameter. Petals 2 or 3 lines long.

2. B. major, Gray. Stouter and larger, 2 or 3 feet high: leaves 4 to 8 inches in diameter, 5-9-cleft : petioles abruptly appendaged at base, the lower with scarious, the upper with foliaceous and rounded naked stipules: calyx-lobes triangular. - B. occidentalis, var. elata, Gray, Proc. Am. Acad. viii. 383.

Wooded region of the Sierra Nevada from Mariposa Co. northward (Bridges, Brewer, Bolander), and Oregon $(\boldsymbol{E} . \mathrm{Hall})$. As this extends to Oregon it may possibly be Nuttall's Saxifraga elata or have been confounded with it ; but the "tufts of long chaffy hairs" at the base of the petiole must rather refer to the preceding. The stipules in this are conspicnous, not bristly-appendaged, the upper foliaceous, partly elasping or appressed to the stem, 4 or 5 lines long.

B. Aconitifolia, Nutt., of the Alleghany Mountains, with more laciniate leaves, has some ramentaceous bristles either in the axils or fringing the slightly dilated base of the petiole.

B. RICHARDSONII, Gray, the Arctic species, has contracted thyrsoid infloreseence and no ramentaceous bristles on the dilated base or in the axil of the leaf-stalk.

\section{BOLANDRA, Gray.}

Calyx broadly campanulate, 5-lobed; the lobes triangular-lanceolate and acuminate, valvate in the bud, recurved; the tube free from the ovary. Petals 5, inserted on the throat of the calyx, small, very slender-subulate, recurved, persistent. Stamens 5 , alternate with the petals, short: anthers 2-celled, cordate-2-lobed. Ovary included in but wholly free from the dilated calyx, ovate with a broad 2-celled base, deeply 2-cleft above, into two tapering horns, each tipped by a truncate nearly sessile stigma. Capsule membranaceous, included in the calyx, early opening down the inside of the horns or beaks. Seeds very numerous and minute, with a thin rather loose coat. - $\mathbf{A}$ single species, with the foliage and habit of Boykinia or some Saxifrages, the calyx of Tellima, petals rather of Tolmiea, and perhaps the early dehiscent fruit of Tiarella, but the beaks equal. - Proc. Am. Acad. vii. 341.

1. B. Californica, Gray, 1. c. A span or two high, weak and ascending apparently from a filiform rootstock, granulate-bulblet-bearing at the base of the stem, glabrous or nearly so: leaves alternate, membranaceous; the lower round-reniform, about 5-lobed, on long and filiform petioles (the base of which is sometimes dilated and stipule-like); the upper sessile or clasping, merely incised or few-toothed, gradually reduced upward to small ovate or lanceolate bracts, borne on or subtending the slender one-flowered somewhat paniculate peduncles: petals dull purplish.

On wet rocks in and near the Yosemite; Mariposa trail (Bolander); Tenaya Falls, A. Gray. Larger leaves an inch or more in diameter, and the ultimate bracts only a line or two in length. Calyx 3 lines high. Attenuated petals 2 lines long. A humble plant, but a very distinct genus, which commemorates the signal services rendered by the diseoverer, Dr. H. N. Bolander, to Californian botany. Thus far it seems to have been collected only by Dr. Bolander and by the founder of the genus.

\section{TOLMIEA, Toir. \& Gray.}

Calyx funnelform, free from the ovary, thin and membranaceous, gibbous at "base; the 5 short lobes somewhat unequal and imbricated in the bud; the tube in age 
longitudinally splitting down one side. Petals 5, filiform or capillary, inserted in the sinuses of the callyx, recurved, persistent. Stanens 3, inserted in the thruat of the calyx opposite the uppermost and lateral lobes: filaments shurt: cells of the anther confluent into one. Ovary elongated-oblong or clavate, much attenuate at hase, above 2-cleft, l-celled with 2 parietal placentie: styles slender: stigmas capitellate. Capsule obversely sagittate (the base tapering into a stipe partly invested by the withering cleft calyx, \&e.), membranaceous, strongly few-reined lengthwise, dehiseent between the diverging equal beaks. Seeds numerous, globose; the elose firm coat minutely muricate. - A single species.

1. T. Menziesii, Torr. \& Gray. A hispilly pubescent perennial; a foot or two high, with slender creeping rootstocks and some summer runners, and the foliage and inflorescence of a Tiarella or Henchera: leaves round-cordate, more or less lolerl and erenately tonthed, stender-petioler, all alternate, those of the stern 2 to $t$ : scarious stipules more or less manifest: loose raceme a span or two long: flowers and capsule nearly half an inch lone, greenish or somewhat tinged with purple. Fl. i. 582. Tiarella Menziesii, Pursh, Fl. i. 313. Henchera Menziesii, Hook. Fl. i. 237 , t. 80 .

Forests of Mendocino Co. (Bolander), and north to Puget Sound. Propagating freely by adventitious buds, produced at the apex of the petioles of the radical leaves, and rooting when these fall to the ground.

\section{TELLIMA, R. Brown.}

Calyx campanulate or turbinate, 5-lubed; the base of the tube coherent with the base or lower half of the ovary, the short triangular lobes valvate in the bud. Petals 5, inserted in the throat or sinuses of the calyx, laciniate-pinnatificl, $3-i$ lobed, or entire, distant and sometimes involute in the bud. Stamens 10, short, included: anthers 2-celled. Ovary short, 1-celled, with 2 or 3 parietal placentr: styles 2 or 3, very short. stigmats capitate. Capsule conical, either all but the hase or wnly the upper half free, slightly $2-3$-heakenl, opening between the lutaks. Sweds very numerous, and with a close coat. - Perennials (all W. North American); with rumblecurlate and turthed or palmately divided chiefly alternate haves, few on the simple stems, their petioles with stipule-like lilatations at hase, ame the fluwers in a simple terminal raceme; petals white, whitish, or pink. - Benth. \& Hook. Gen. Pl. i. 637. Tellima \& Lithophragma (Nutt.), Torr. \& Gray, Fl. i. 583.

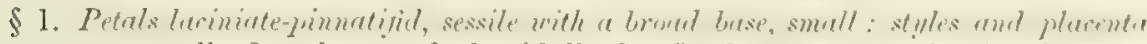
generally 2 : plant and the (dull-colored) flowers proportionally large. Eutellima. (Tellima, R. Brown.)

1. T. grandiflora, Douml. I fout or two high, from short amd rither stont infted rootstocks, hirsute or pubescent: leaves rounded-cordate and more or less lobed, 2 to 4 inches in diameter: calyx inflated-campanulate, from a quarter to

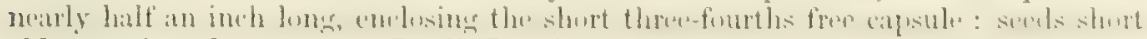
oblong, mimutely rugose. - Lindl. Bot. Reg. t. 1178. Mitella grandiylora, Push.

Woods, from Santa Cruz Co. northwand, extending to Alaskn.

\$2. Petals palmately 3-7-cleft or sometimes entire, on a slender claw, large for the size of the flower, bright white or rose-color: styles and placenta commonly 3: stem and rootstock slender. - Lituophragia, Nutt.

* Petals (white or nearly so) with the limb merely 3-lobed or entire, dilated: radical leceves undivided and round-reniform: no grain-like bulblets on the rontstocks. 
+ Ovary fully half free: petals entire: seeds minutely roughened.

2. T. Cymbalaria, Gray. Stem or scape filiform, a span to a foot high, bearing mostly only a pair of opposite 3-lobed or parted leaves: radical leaves roundreniform, somewhat 3-5-lobed (about half an inch in diameter): flowers few and slender-pedicelled: calyx short and dilated-campanulate, with an acute adnate base; its lobes very short and broad: petals spatulate-obovate, entire - Lithophragma Cymbalaria, Torr. \& Gray, Fl. i. 585 ; Gray, Proc. An. Acad. vi. 535.

Moist shady woods, Santa Barbara to San Diego, Nuttall, Brewer, Clcveland. Calyx 2 lines and petals 3 or 4 lines long.

++ Ovary and capsule almost wholly free from the broadly campanulate truncateor round-based calyx: seeds minutely roughened: styles smooth.

3. T. Bolanderi, Gray. Stems a foot or two high, not rarely branching, 1-4 leaved: radical and lower leaves round-reniform and more or less lobed ( $1 \frac{1}{2}$ to $2 \frac{1}{2}$ inches in diameter), the upper 3-5-parted: flowers very short-pedicelled: petals obovate or oval, entire, rarely with a small lateral tooth on each side, white. Lithophragma Bolanderi, Gray, 1. c.

Contra Costa to Mendocino counties, Brewer, Bolander, \&c. Calyx $2 \frac{2}{2}$ and petals 3 or 4 lines long.

4. T. heterophylla, Hook. \& Arn. Stems slender, a foot or less in height, 1 -3-leaved : leaves nearly as in the preceding, but smaller and usually more hirsute: flowers fewer and smaller: petals obtusely 3-lobed, sometimes flesh-colored. - Bot. Beechey, 346. Lithophragma heterophylla, Torr. \& Gray, 1. c.; Gray, l. c.

Shady grounds, in the western part of the State, especially near San Francisco and on the Sacramento. Calyx 2 and petals 3 or 4 lines long.

+++ Lower half or more of the ovary and capsule coherent with the turbinate calyx-tube: seeds smooth: styles granulose.

5. T. affinis, Gray. Rougher-pubescent or scabrous-puberulent: stem a span to a foot or more high, slender: leaves nearly as in the preceding or smaller (rarely an inch in diameter): flowers 5 to 12 in the lax raceme: pedicels inostly longer than the densely rough glandular-puberulent calyx: petals somewhat cuneate and with 3 short acute lobes or teeth. - Lithophragma affinis, Gray, 1. c.

Rocky and shady places, common through the western part of the State, and northeast to Plumas County in the Sierra Nevada. Petals 4 or 5 lines long, white or flesh-color, large in proportion to the calyx.

* * Petals (pink or sometimes white) with limb palmately 3-7-parted into narrow divisions: even the radical leaves mostly 3-5-parted or divided: slender or filiform rootstock and sometimes even the few-flowered raceme bearing clusters of small grain-like bulblets.

6. T. parviflora, Hook. Roughish-hirsute or scabrous-pubescent, a span to a foot high: divisions of the leaves narrowly cuneate and once or twice 3-cleft into narrow lobes: pedicels erect, about the length of the obconical or at length almost clavate calyx: petals deeply 3-cleft into linear or oblong divisions: ovary and capsule fully half inferior. - Fl. i. 239, t. 78. T. parvifolia, Hook. \& Arn. Lithophragma parviflora, Nutt.; Gray, 1. c.

Shady and rocky places, British Columbia to the mountains of Utah and Colorado, and probably in the northern part of California. "N. California, Menzios," according to Hooker : but the plant may more probably be $L$. affinis.

7. T. tenella, Watson. Small and slender, 2 to 9 inches high, roughish with a minute glandular pubescence: leaves smaller than in the preceding (about half an inch in diameter): pedicels ascending or spreading: calyx campanulate, the base either roundish or acutish: petals 3-5-parted or even irregularly 7-parted into mostly linear divisions: ovary and capsule free except the base. - Bot. King. 
Exp. 95. Lithophragma tenella \& L. glabra (a smoother form), Nutt. in Torr. \& Gray, Fl. i. 584 ; Gray, 1. c.

Rocky moist ground, through the northern portion of the Sierna Nevada; thence to the Rocky Mountains. Calyx 1 or 2 lines loug. Petals 2 or 3 lines long, generally pink or rose-color. Granulate bulblets copious at the root, and sometines in the place of Howers in the raceme.

\section{TIARELLA, Linn.}

Calyx 5-parted; the base almost free from the ovary, the lobes more or less colored. Petals 5, undivided, small, with short claws. Stamens 10 : filaments long and slender: anthers with 2 parallel cells. Ovary 1-celled, compressed, 2-horned (the horns or loles tapering into lung filiform styles), soon une gual and thehiscent, one valve or carpel in fruit lanceolate-elongated, the other remaining very much shorter. Seeds rather few and only at the base of each parietal placenta, globular, with a smooth and shining crustaceous coat. - Perennial low or slender herbs, often multiplying by summer runners; with palmately lobed or divided alternate leaves, and sometimes scaly stipules at the base of the petiole, and a terminal raceme or panicle of small white flowers.

A North American and North Asiatic genus of five species, one inhabiting the Atlantic States and two the Pacific coast.

1. T. unifoliata, Honk. Somewhat pubescent or hairy: flurering stmus a span to a foot or mure long: leaves thin, cordate, either rounded or somewhat triangular, 3-5-lobed and the lobes crenate-toothed; the radical ones slender-petioled; the cauline mostly one, smaller, and short-petioled, or sometimes (mainly on decumbent and later flowering shoots) 2 or 3 similar to the radical: panicle raceme-like and loose: petals small and inconspicuous, almost filiform.-Fl. i. 238, t. 81. II euchera longipetala, Moçino, Ic. Ined. t. 423.

Shaded mvines and woods, San Mateo Co. (Kellogg), Mendocino Co. (Bol(under), and north through British Columbia. The Californian and some of the more northern specimens incline to have elongated and 2-3-leaved flowering stems, and whole plant move hairy, the var. mocirn. but this is merely a luxuriant state. The lobing of the lenves varies, so that it may pass into

T. Tutfordats, Linn. (T. stenopelala, Presl), which extends from the mountains of Oregon to Mlaska and N. W. Asia, has most of its leaves divided into three distinct leallets.

\section{MitelLA, Toum. Mrtre-wort.}

Calyx short; the broad tube colerent with the base of the ovary and dilated beyond it, 5-loberl; the lobes valvate in the bud, spreading. Petals 5, inserted on the throat of the calyx, very slender, pinnately parted or 3-cleft; the divisions almost capillary. Stamens 10 or 5, very short: anthers cordate or reniform, 2celled. Ovary short and broad, 1-celled, with 2 parietal or almost basal placenta, mainly or partly superior: styles 2 , very short: stigmas capitellate. Capsule globular or depressed, hardly at all lobed, opening across the broad summit. Seels several to each placenta, obovate, with a firm and snooth black and shining close crustaceous coat. - Small perennials (N. American and N. E. Asian); with more or less creoping slender rootstocks and summer muners, small and greenish or sometimes white flowers in a simple raceme, and cordnte or round-reniform simple lenves, which are all radical and long-petioled, or two or more on flowering sterus, these in one species (of E. North America) opposite. Petioles, ifre, mostly loosely hirsute.

1. M. Breweri, Ciray. Leaves all in a cluster on the routstouk, mund-ronifurm, crenate and erenately incised, of comparatively firm texture, soon weatly glabous, 
2 or 3 inches in diameter: scape leafless, a span high, 10-20-flowered: flowers greenish : petals pectinately once or even twice pinnately parted: stamens 5, opposite the calyx-Iobes. - Proc. Am. Acad. vi. 533.

Woods of the Sierra Nevada at 6,000 to 11,000 feet, Marjposa Co. (Brever, \&ce.) to Sierra Co., Torrey, Lemmon. Capillary multifid petals 2 lines long, much exceeding the calyx.

2. M. trifida, Graham. Leaves all from the rootstock, round-reniform or cordate, crenately toothed and sometimes incised or lobed, thimnish, sparsely hairy, I to 3 inches in dianeter: scape filiform, a span to a foot high: flowers whitish, numerous and rather scattered in the commonly one-sided slender spike or spikelike raceme; the pedicels mostly very short : petals $3-5$-parted, small : stamens 5 , opposite the calyx-lobes. - Hook. Fl. i. 241, t. 82 .

Mountain woods of Mendocino Co. (Bolander), thence north to British Columbia and in the Rocky Mountains.

M. Pentandra, Hook. l. c. \& Bot. Mag. t. 2933, of the Rocky Mountains, is another species with naked scape and 5 stamens, but the latter opposite the petals.

M. CAULescens Nutt, has one or more alternate petioled leaves on the flowering stem or scape, similar to those of the rootstock and runners, a loose raceme, and the 5 stamens alternate with the pinnatifid petals. It extends from British Columbia to Oregon, and may probably occur on the northern borders of the State.

M. NUDA and M. DIPHYLLA are the two Linnæan and 10-androus species. The former extends westward to British Columbia, and recurs in N. Siberia : the latter is only an Atlantic species.

\section{HEUCHERA, Lina. ALUM-Rоoт.}

Calyx campanulate, 5-lobed; the lobes imbricated in the bud, obtuse, sometimes rather unequal; the tube coherent with the lower half of the ovary. Petals 5, unguiculate, small and entire, sometimes minute or wanting or early deciduous, inserted on the throat of the calyx. Stamens 5 : filaments either slender and long, or sometimes rather shorter than the calyx: anthers 2-celled. Ovary and capsule 1-celled, with 2 parietal placentæ, more or less 2-beaked; the beaks tapering into either filiform and elongated or subulate and shorter styles; dehiscent between the beaks. Seeds numerous, oval or globular, with a close crustaceous black coat, minutely muricate-roughened. - Herbs (all N. American); with stout rootstocks, sending up slender-petioled rounded and mostly cordate many-toothed and somewhat lobed leaves, and scapes or alternately 1-3-leaved flowering stems, bearing numerous small and mostly dull-colored flowers; the cymose clusters either open in a loose ample panicle, or sometimes condènsed into a spike-like thyrsus. Scarious stipules adnate or partly distinct.

There are about five species in the Atlantic States, as many more peculiar to the Rocky Mountain region, and the following in California, Oregon, \&c. A sterile plant collected on Guadalupe Island by Dr. Palmer may belong to a peculiar Lower Californian species.

\$1. Flowers in an open or sometimes more condensed and thyrsoid panicle: filaments more or less filiform, mostly exserted.

* Calyx oblong-campanulate, commonly tinged with purple or rose-color.

1. H. rubescens, Torr. Scape a span to a foot high, from stont creeping rootstocks, nearly glabrous: leaves thickish, rounded, crenately lobed and toothed, an inch or less in diameter: flowers loosely panicled: calyx 2 lines long, more or less acute at base: filiform filaments and styles and very slender white or flesh-colored petals conspicuously exserted. - Stansb. Rep. 388, t. 5 ; Gray, Pl. Wright, ii. 63 ; Watson, Bot. King Exp. 96.

Common in the Sierra Nevada, on rocks, at 5,000 to 11,000 feet, extending to Utah and New Mexico. 


\section{* Calyx short-campanulate and greenish.}

H. GuABrA, Willd, is a slender speries, a foot or two high, nearly glabrous except the calyx; leaves acutely lobed and incised ; panicle loose: from Oregon near the coast to Alaska.

2. H. micrantha, Ihingl. scape or ferw-leaved flowering stenus a fint or two high: leaves round-cordate or ovate-cordate, 2 to 4 inches in diameter, obtusely lobed, crenate-toothed: jetioles and at leatst the reins or ribs bencath hisute, often with rusty hairs: Howers in an ample levse pamicle: calyx a line or in fruit sometimes 2 lines long, mostly acute at base, shorter than the slenter frelliels, merely puberulent or glandular; the lobes erect : filaments, styles, and pretals slender and exserted. - Lindl. Bot. Reg. t. 1302. H. Barbarossa, Presl, Rel. Hrenk. ii. 56.

Woods in the Coast Ranges and the Sierra Nevada, fron Monterey and Mariposa counties

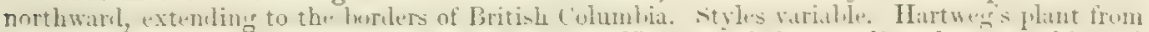
Monterey, named $H$. pilusissina in Pl. Hartw. 311, No. 1142, is intermediate between this and the most open and least hairy forms of the next, but seems to belong here.

3. H. pilosissima, Fischer of Merer. Tery villous-pulfesent or hirsute with sprealing viseid hairs: srapes or few-leaved flowering stems a fout or two high. rather stout: leaves round-cordate, obtusely lobed and crenate, 1 to 3 inches in diameter: Howers in a clese and clustered or sometimes lonse paniche, usully as long as their pedicels: calyx somewhat globular, heing roundel or whtuse at hase

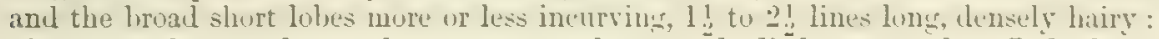
filaments, short styles, and narrow spatulate petals little exserted. - Ind. Sem. Hort. Petrup. v. 56. H. hisprila, Hook. d . Arn. But. Leechey, 3ti, nut of Pursh. H. lirciflora, Tort. \& Gray, Fl. i. 582.

From near II muterey or San Francisco to Humboldt ( $\mathrm{C}$., in the Coast Ranges. Aprarently raries into smoother forms, with calyx much less hairy.

\section{\$2. Flowers spicate or nearly so: subulate fildments mwh shorter than the climgatut- oblong and erert lobes of the calyx.}

4. H. cylindrica, Ihoul. Commonly hirsute and thowe glanilulit. muthesent: lenves ruund-reniform or corlate-ovate. crenately donhly touthed and commonly

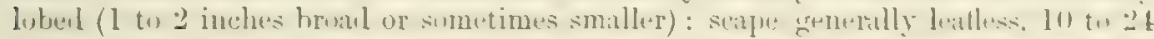

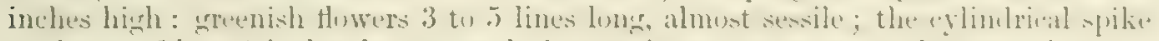

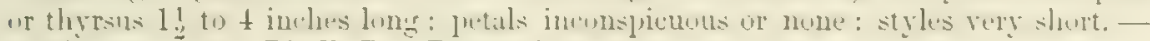
Hook. Fl. i. 237 ; Lindl. Bot. Reg. t. 1924.

Common in Oregon, Nevada, \&ce, chiefly in the interior; probably in Northern Californin.

\section{9. parnassia, Tourn. Grass-of-Parsassus}

Calyx 5-parted; the base free from or alnate to the hase of the orary ; the livisions usal or whleng, herbacens, somewhat imlericated in the bul. l'etals aral or oblome, imbricated in the loul, comsplenously reincol, wilely spmanling, tarlily deciluuns. Stauens 5 , alternate with the petals: filaments sululate, pursistent anthers 2-cellew. Appendages or sterile stamens a cluster of more or less mated

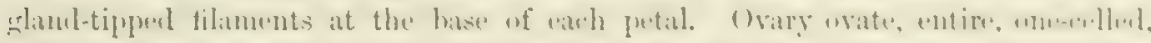

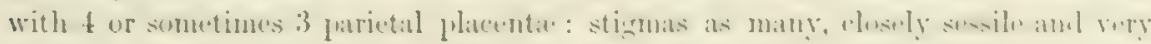

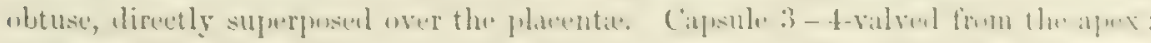

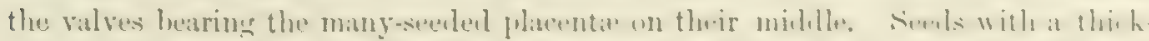

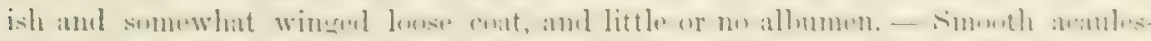

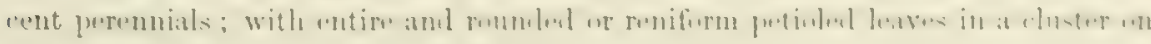
the short rootstock, slender simple scapes, not rarely hearing a small aud sessilo leaf or two, and a handsome white terminal flower. Petioles with somewhat scarious-dilated base, but no stipules. 
A geaus of about a dozen species, of the northern temperate and frigid regions, one species extending round the world, and two peculiar to the Atlantic United States.

1. P. palustris, Linn. Leaves from ovate to slightly cordate, an inch or less in length: scape a span to a foot high: petals oval or obovate, naked and without a claw, half an inch or less in length, the veins sparingly branching: bristle-like filaments of the appendages 8 to 20 in each set.

Var. Californica, Gray. Larger: leaves one or two jnches long and scape a foot or two high, often leafless : petals very broad, full half an inch long, more veiny, and the veins more numerous and freely branching: bristles of each appendage about 24 and almost capillary.

Wet places in the Sierra Nevada, \&c., from Mariposa Co. northward, and on Red Mountain, Mendocino Co. (Kellogg, Bolander), chiefly the var. Californica. The species extends far northward and round the world along the northern border of the temperate zone.

2. P. fimbriata, Banks. Leaves from reniform to cordate-ovate, an inch or more in diameter: scape slender, about a foot high : petals obovate or oblong ( 4 or 5 lines long), with a narrowed base or short claw, the margins fringed below the middle or towarls the base: filanents of the appendages 5 to 9 in each cluster and united below into a fleshy carinate scale, or sometimes a dilated scale destitute of bristle-like filaments. - Hook. Bot. Misc. i. 43, t. 23.

Near Shasta Mountain, with Darlingtonia, Brewer. Also mountains of Nevada and Colorado, and northward to British Columbia. Varies in the form of the leaves, form and size of the petals, in the amount of fringe, and greatly in the stamen-appendages.

\section{PhiladelfhUS, Linn. Syringa. Mock Orange.}

Calyx with turbinate tube adnate to the ovary nearly or quite to its summit; the limb 4-5-parted, valvate in the bud, persistent. Petals 4 or 5, large, obovate or roundish, convolute in the bud. Stamens 20 to 40 : filaments subulate or filiform. Styles 3 to 5, united at base or sometimes almost to the top: stigmas oblong or thickish, introrse, sometimes connate. Capsule inferior, 3-5-celled, loculicidally 3 -5-valved from the apex, and the valves in age commonly 2-parted. Seeds very numerous on placentre projecting from the axis, mostly pendulous, oblong, with a thin and loose reticulated coat, nsually prolonged at both ends or fimbriate at the hilum. - Shrubs; with opposite and entire or toothed ovate or oblong leaves, more or less petioled, deciduous, and without stipules; the flowers large and showy, sometimes odorous, thyrsoid- or paniculate-cymose, or occasionally solitary in the axils, white or rarely cream-color.

A genus of a dozen or more ill-defined species, probably reducible to five or six, natives of both sides of temperate North America, Japan, and the Himalayas, two or three of them much planted for ornament.

1. P. Lewisii, Pursh. Shrub 3 to 5 feet high, spreading, glabrous or almost so : leaves all entire or nearly so, from ovate to ovate-lanceolate, an inch or two long: flowers in a narrow thyrsus, short-pedicelled: calyx-lobes rarely twice the length of the tube: petals obovate or oblong, half an inch or ratber more in length : styles distinct at the apex: stigmas narrow. - Torr. \& Gray, Fl. i. 595.

Var. Californicus, Gray: a form with the flowers more numerous in a mainly leafless and perlunculate terminal cluster. $-P$. Californicus, Benth. Pl. Hartw. 309. P. Lewisii, var. parvifolius, Torr. in Pacif. R. Rep. iv. 90.

Foot-hills of the Sierra Nevada, along streams, from Mariposa Co. to the Upper Sacramento; chiefly the naked-flowered variety. The species extends through Oregon and Idaho to British Columbia.

2. P. Gordonianus, Lindl. Shrub 6 to 12 feet high, with spreading or recurved branches, sparsely pubescent or hairy, or almost giabrous: leaves ovate or 
oblong-ovate, 2 to 4 inches long, mostly serrate with some coarse acute teeth: flowers in loose clusters which are leafy at base: petals from three fonths to an inch long: styles mostly distinct to the midclle: stigmas more or less dilated: calyxlobes twice the length of the tube. - Bot. Reg. xxv. t. 32.

Shaded banks of streams in the Coast Ranges, Mendocino and Humboldt counties (Kellogy, Bolander), north to Washington Territory.

\section{CARPENTERIA, Torr.}

Characters of Philadelphus, except that the calyx is 5-parted, its very short tube adnate only to the base of the ovary and the ovate-conical capsule, which is pointed with the undivided persistent style: a thin loculicidally 5-valved epicarp separates from the body of the capsule, which splits septicidally into 5 broal valves, each pointed with its portion of the style, and tardily if at all dividing down the dorsal suture. - A single insuficiently known species, named in memory of the late Prof. Carpenter of Louisiana.

1. C. Californica, Torr. Shrub, apparently tall, with lighti-colured and laminated loose bark, mainly glabrous: leaves broadly lanceolate, entire, thickish, perhaps persistent, 2 or 3 inches long, pinnately veined, whitened beneath with a minute ant close pubescence, tapering into a petiole: peduncles long and naked, terminal and from the upper axils: seeds oblong, with a short aud obtuse appendare at both ends. - Pl. Fremont. in Smiths. Contrib. vi. 12, t. 7.

Sierra Nevala, probably on the head-waters of the San Joaquin, Fremont: As yet known in fruit only; with some vestiges of flowers, from which Dr. Torrey ascertained that there were orbieular petals, and numerous stamens with filiform filaments: also that the parts of the calyx and capsule are sometimes 6 or 7 .

\section{WHIPPLEA, Torr.}

Calyx 5-cleft; the tube arluate to the lower part of the ovary; the lobes thin and petaloid (white or whitish). Petals 5, ovate or oblong with contracted base. Stamens 10 (rarely 8 or 12): flaments subulate or linceolate: anthers short, 2-cellerl. Ovary 3-5-celled, with a single suspemled ovule in each cell. Styles distinet, subulate: stigmas introrse. Capsule septicidally dehiscent into 3 to 5 cartikginous 1-seeded portions, which open down the ventral suture only. Seed oblong, with a close coat. - Small and low liffuse shrubs, pubescent with simple hairs; with opposite slightly petioled and somewhat 3-ribbed leaves, no stipules, ami small whito cymose-clustered flowers: peduncle terminal, naked. Parts of the blossom occasionally 4 or 6.

This interesting genus commemomates the lato Lieut. (afterwards Goneral) Whipple, the lealer of the survey in which tho Californim speeses was cliscovered.

W. Uranrssis, Watson, the seenul speeies, is an upright and much-branched liftle shrub: leaves thickish, from a ruarter to half an inch long, elliptical or linear-olldong, very obtuse, entire : eyme rather short-peduncled, 3-7-flowered: calyx-tube elongated-turhinate, adunte to the lower hulf of the cylindracenus 3.celled eapsule: styles 3, persistent : seed eylindrical : lud.

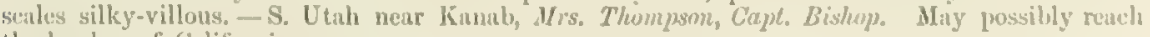
the boraless of California.

1. W. modesta, Torr. Stems slender, spreading or trailing: leaves memhmnaceous, ovato or oval, obtuscly fow toothed or sometimes entire, an inch or less long: pedunclo slomter, learing a sinall and close fow-flowered cluster: flowers harilly 2 lines long: calyx-tube almost hemispherical, adnate to the base of tho 4-collurl (sometimes 3-5-celled) ovary and glubular capsulo: styles at longhto decielnous: seed oblong. - I'acil. R. Iien. iv. 90, t. 7. 
In the Coast Ranges, from Monterey to Mendocino counties, mostly under Redwoods. Flowers fragrant. Divisions of the capsule only a line lung.

\section{RIBES, Linn. Currant. Gooseberry.}

Calyx with tube adnate to the globose ovary and more or less extended beyond it; the limb 5-cleft or rarely 4-cleft, and commonly colored or petaloid. Petals erect, mostly smaller than the calyx-lobes, inserted in the sinuses. Stamens as many as the petals and alternate with them: anthers commonly very short. Ovary 1-celled, with 2 parietal placentæ: styles 2, or more or less united into one: stigmas terminal. Berry erowned more or less by the withered remains of the flower, manyseeded, rarely rather few-seeded. Seeds with a gelatinous outer and a crustaceous inner coat. Embryo minute in firm albumen. - Shrubs, often resinous-glandular or viseid ; with alternate (often fascicled) palmately veined and lobed leaves ; stipules wanting or adnate to the petiole, and peduncles one-flowered or racemosely 2 - many-flowered, mostly terminating short and 1-2-leaved axillary shoots; pedicels subtended by a bract, and usually bearing a pair of bractlets. Placentæe and styles occasionally 3 or 4 .

A rather large genus of the northern temperate zone, with a few species extending down the Andes. North America is rich in species, and only in California are all the sections of the genus represented. The thorns under the fascicles in the first two sections answer to leaves, as in the Barberry.

\$ 1. Thorny: parts of the flower more commonly 4: calyx turgid at base; the narrow lobes erect: stamens long-exserted: ovules and seeds rather few: othervise as in the following section. - RoBsovia, Berlandier.

1. R. speciosum, Pursh. Tall, the trunk sometimes as thick as a man's arm, and attaining 6 to 10 feet in height: branches bristly-prickly and armed with large triple thorns under the fascicles: leaves small, coriaceous, nearly evergreen, glabrous or almost so, roundish or cuneiform and slightly $3-5$-lobed: flowers 2 to 5 on the bristly glandular peduncle, drooping, cylindraceous, bright red, almost an inch long and the stamens as much longer: anthers very short: berry dry, densely glandularbristly. - Bot. Reg. t. 1557 ; Bot. Mag. t. 3530. R. stamineum, Smith.

Woods and ravines, Bay of Monterey to San Diego. Remarkable and prized in cultivation for its showy Fuchsia-like blossoms. Calyx-lobes erect.

\$2. Mostly thorny under the fascicles, and sometimes (but variably) scattered-prickly or bristly along the branches: leaves plaited in the bud: peduncle (except in the last) only 1-4-flowered: calyx mostly recurved or reflexed at floweringtime, afterwards erect: berry many-seeded. - Grossularia, A. Richard. (Grossularia, Dill. Gooseberry.)

* Calyx-tube campanulate to cylindraceons: peduncle 1-4-flowered.

+ Anthers sagittate, mucronate-tipped: berry prickly, large and rather dry.

2. R. Menziesii, Pursh. Shrub 2 to 6 feet high, with naked, glandular-bristly or more prickly branches and stout usually triple thorns under the fascicles: leaves pubescent or sometimes glabrous (from a half to one and a half inches in diameter), roundish or round-cordate, 3-5-lobed; the lobes crenately toothed and incised: peduncles 1-2-flowered: calyx about half an inch long, purplish-red; its oblong lobes spreading or recurved in anthesis, elongated-oblons, more or less longer than the somewhat funnelform tube, hardly longer than the stamens, which surpass the whitish petals: berry 4 to 6 lines in diameter, besides the prickles, which generally thickly cover it, and are either short or long, usually straw-colored, sometimes 
pubescent and sometimes rather few and sparse. - Hook. FI. i. 229 ; 'Torr. Bot. Mex. Bound. t. 23, cusp of anther omitted. $R$. ferox, Smith. $R$. Californicum \&

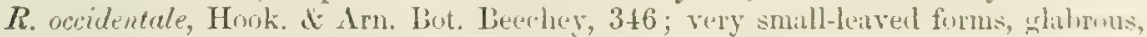
but sometimes pubescent. $R$. subvestitum, Hook. \& Arn. I. c. (not of Bot. Mag.); a form with densely glandular ovary, the glands in fruit developing mostly into very numerous and gland-tipred short prickles. $R$. C'alifomicum, Grily in I'ateif. IR. Iiep. iv. 88, combining the three last named.

Hillsides, from San Diego to Humboldt counties, and also along the Sierra Nevada to Plumas Co. Also Oregon, coll. E. Hall. A variable species, but well marked by its sagittate (ovateoblong or oblong-lanceolate) and mucronate-pointed anthers; these about a line and a quarter in length.

$$
\begin{aligned}
& + \text { + Anthers oval or didymous, very obtuse and pointless. } \\
& ++ \text { Flowers comparatively large, dark purple-red. }
\end{aligned}
$$

3. R. Lobbii, (iray. Minutely puhesent or glimiular : stems with stout triple thorns, but apjarently destitute of scattemel prickles or bristles: leaves small (less than an inch), round-cordate, 3-5-cleft, and the roundish lobes obtursly toothed: peeluncles ruostly l-llowered: Hower pendulons, three fourths of an inch long, similar to those of $R$. Menziesii, but the anthers oval and very obtuse, the back beset with scattered warty grinuls: ovary densely cluthed with sessile glands. - Ih. suluestitum, Hook. Bot. Mas. t. 4931, but not Hook. \& Arn.

The living plant figured was "sent by $\mathbf{M} r$. Lobb to Messrs. Veitch and Son," from California, probably from the nortlrern part near the coast. It exactly accords with an indigenous specimen, named at Kew, " $R$. subrestitum, Hook. \& Arn., Vancouver Island, Wood." It is not the plant of Douglas on which $R$. subrestitum was founded.

+ Flaners yellow or yellowish, small: leaves very small, seldom half an inch in diameter: anthers oval-oblony.

4. R. leptanthum, Gruy. Much hramber and rigil, 1 to 4 feet high, lestitute of scattered prickles, but with compramively larese simble ar triple thorns: leaves roundish (often only a quarter of an inch wide and shorter than the thorns), 3-5cleft, and the lobes crenately incised or toothed: peduncles very short, 1-2.

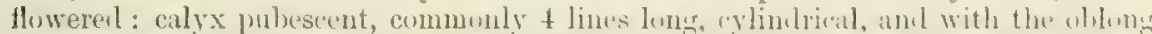

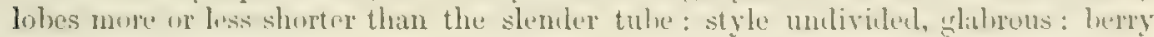
glabrous. - PI. Fendl. 53.

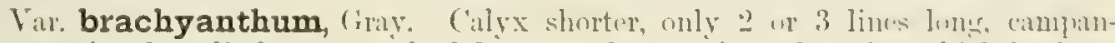
ulate or barely cylindmceous; the lobes even longer than the tube, which is about as broad as long: ovary densely glandular. $-R$. leptanthum, Watson, Bot. King Exp. 98, as to Calif. plant.

Rocky Mountains of Colorado (where it wns first collected by Dr. James in Long's Expedition) to New Mexico, Sierra Nevada on Mount Raymond at 8,000 to 9,000 feet, and above Summit (Bolander) to near Fort Tejon (Davidson); between the original form and the varicty which comes from foot-hills near Carson City, Anderson, $W$ atson. This short-flowered variety is rewarkable; rnature fruit of it unkwown.

+ + Flowers greenish, white or dull purplish: leaves mostly an inch or two in diameter: anthers shorter, mostly didymous: ovary and berry unarmed and ghabrous.

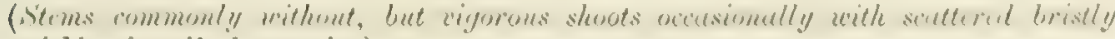
prickles in all the species.)

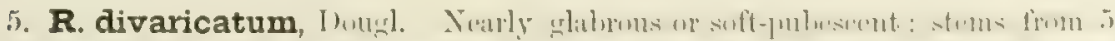

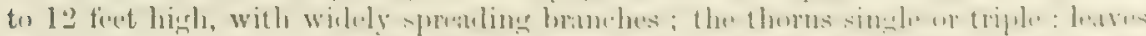
roundish, 3-5-lobed; the lobes incisely toithed: 2-4-flowered pelluncle and pedicols slender, drooping: flower one third of an inch long : calyx livid-purplish or

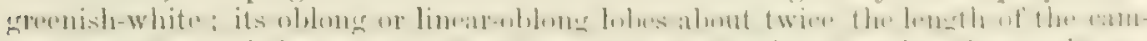

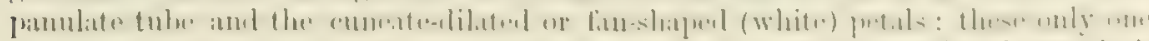

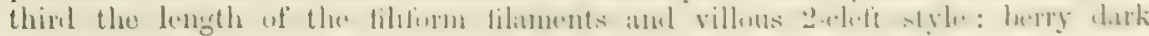


purple, pleasant.-Hort. Trans. vii. 515; Lindl. Bot. Reg. t. 1359. R. villosum, Nutt. in Torr. \& Gray, Fl. i. 547, a soft downy form.

Var. irriguum, Gray. Leaves more nervose-veiny at base: flowers narrower and whiter, half an inch long. - R. irriguum, Dougl. 1. c. (?) ; Watson, Bot. King Exp. 98, chiefly.

Shady banks and flats, from Santa Barbara northward to British Columbia. The variety N. W. Nevada to Idaho, \&c. Peduncles a half-inch to an inch long : pedicels 2 to 4 lines long.

6. R. oxyacanthoides, Linn. Mostly glabrous, 2 to 4 feet high; the thorns single or triple, small: leaves roundish, usually deeply-5-lobed; the lobes incised and coarsely toothed: 2-3-Howerd peduncles lengtly shorter than the pedicels, and these seldom longer than the (3 or 4 lines long) flower: calyx greenish-white or flesh-colored; its short-oblong lobes at first not longer than the campanulate tube, a little longer than the cuneate-obovate petals, about equalling the stamens: style 2-cleft, villous below, rather longer: berry small, purple, pleasant. $-R$. hirtellum, Michx. R. saxosum, Hook. Fl. i. 231.

In the Sierra Nerada at 6,000 to 9,000 feet, from Mariposa Co. (Brewer) to Sierra Co. (Lemmon); thence eastward and northward to the Rocky Mountains, the Northern Atlantic States, and British Anerica to Hudson Bay. This wide-spread species, or a northern form of it, is most probably the original $R$. oxyacanthoides of Linneus (Dillenirus); that of Michaux is $R$. lacustre; that of Hooker mainly $R$. setosum of Lindley.

* Calyx-tube saucer-shaped, expanding immediately above the ovary: peduncle racemosely 5-15-flowered: anthers very short, pointless: berry small and currantlike, beset with some scattered gland-tipped bristles.

7. R. lacustre, Poiret, var. molle, Gray. A foot or two high, much branched: branches bristly-prickly or naked, armed with short triple or multiple thorns under the fascicles: leaves small (usually about an inch in diameter), downy-pubescent, roundish in outline, 5-parted, and the lobes incisely toothed and cleft: racemes 5 -9-flowered, short-pedtncled: flowers greenish-white; the open calyx 3 lines in diameter, its short lobes rounded: small petals and stamens very short : berry light red, not larger than peas, acid (intermediate between a gooseberry and a currant), sometimes nearly or quite naked.

In the Sierra Nevada at 6,000 to 10,000 feet, from Mariposa Co. northward. Extends mainly in the form of the var. parvulum (mistaken for $R$. sctosum), which is nearly glabrous, east to the Rocky Mountains and north to British Columbia, and in the ordinary and larger form of the species to the Northern Atlantic States, Labrador, \&c.

§ 3. Thornless and prickless: leaves plaited in the bud: racemes few-many-flowered: stamens short: berry unarmed (rarely glandular-bristly), many-seeded. Ribesia, Berlandier. (Currant.)

* Calyx dilated immediately above the ovary, rotate or saucer-shaped, 5-parted.

R. Prostratum, L'Her., and R. LAxiflorum, Pursh, have their small red berries beset with scattered gland-tipped bristles, in the manner of $R$. lacustre. The first is unknown west of the mountains of Utah, the second south of Washington Territory.

R. HudsoniandM, Richardson, is between the above and the following, has numerous white flowers erowded in an erect raceme, minute deciduous bracts, and a smooth dark berry. It has not been found nearer California than the E. Humboldt Mountains, N. E. Nevada ( $R$. bracteosum, Watson in Bot. King Exp., not of Douglas).

8. R. bracteosum, Dongl. Almost glabrons, at least with age, sprinkled with some resinous dots, 4 to 10 feet high: leaves large ( 3 to 9 inches in diameter), 5-7-cleft; the lobes ovate or narrower, acute or acuminate, coarsely and doubly serrate: petioles long: racemes erect or ascending, many-flowered, 3 or 4 inches long, or in fruit sometimes almost a foot long and loose: bracts persistent, from filiform to spatulate, or the lower foliaceous and petioled, sometimes passing into leaves: flowers greenish-white : calyx-lobes roundish : berry black, resinons-dotted, a third of an inch in diameter, and with the flavor of black currants (?). - Hook. Fl. i. 233. 
Shady woods, Cottonaby Creek, Mendocino Co., Bolander. Through the western part of Oregon to Sitka.

9. R. cereum, Dougl. A foot to a yard high, much branched, minutely pubescent, usually resinous-dotted and more or less glutinous, sometimes glabrous: leaves rounded or reniform, obscurely or more decidedly 3-lobed, crenately toothed or incised, half an inch to an inch in diameter, of rather firm texture: racemes drooping, compactly 3-5-flowered: pedicels hardly any or shorter than the bract: alyx waxy-white, sometimes greenish or pinkish; the tube eylindrical, 4 or 5 liues long, very much longer than the ovate recurved lobes: petals orbicular : berry reddish, sweetish. - Bot. Reg. t. 1263 ; Hook. Bot. Mag. t. 3008.

Not rare through the drier parts of the Sierra Nevada, from Mit. Pinos (Rothrock) northwarl, and through the interior to Washington Territory, New Slexico, and Dakotah. A var, pediccllare, from Montau, has slender pedicels longer than the bract.

* * Calyx prolonged above the ovary into a campanulate or cylindrical tube: fruit and foliage more or less glandular: leaves rounded or with roundish lobes: bracts conspicuous.

+ Flowers dull white or greenish, or somelimes purplish-tinged: raceme somewhat corymb-like and few-flowered.

10. R. viscosissimum, Pursh, A funt to a yard high, juluscent and visinlghandulix: leaves cordiate-rounded and moderately lobed, thinuish, veiny, 1 to 4 inches in diameter : racemes ascending: flowers slender-pedicelled, about half an inch long and comparatively broad: calyx-tube at tirst campanulate; its lobes oblong and at least half the length of the tube: berry black. - Hook. F1. i. 23t, t. 76.

Woods in the Sierra Nevada at 6,000 to 8,000 feet, from Mariposa Co. northward to tho British houndary and also in the Rocky Mountains. A form with smooth ovary, Siera Co., Lenmon.

++ Flowers rose-red, or varying to white: racemes drooping, mostly many-flowered.

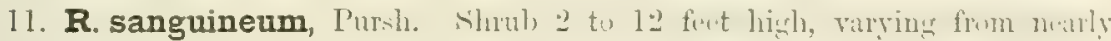
glabrous to tumentose-eanescent, either almost glandless or glandular: leaves rounder-cordate and obtusely $3-5$-lobed: racemes dense: calyx-tube above the ovary from campanulate to short-cylindraceous, 2 or 3 lines long, equalling or exceeding the oblong lobes: berry mostly somewhat hispid-rilandular, tough aud not juicy, blackish, rather bitter. - Dougl. in Hort. Trans. vii. t. 13; Lindl. Bot. Reg. t. 1349 ; Hook. Bot. Mag. t. 3335. - Runs into indefinite varieties, such as

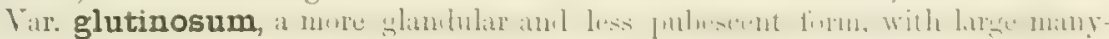
flowered rucerues. $-k$. glutinosum, Benth. in Hort. Trans. 11. ser. i. \pm 76.

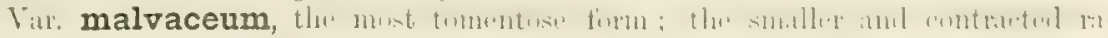

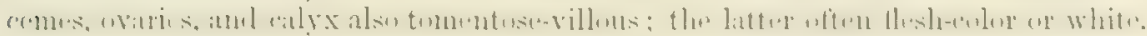
- R. maluncenm, Smith; Dou in Brit. Fl. Gard. ser. 2, t. 3t0.

Var. variegatum, IVatson. Low, nearly glabrous: racemes short and ilense, ascending, barely glandular: calyx-tube broadly campanulate, not longer than the lobes, rose-color with the petals white (as they often are in the typical form), the whole flower only 3 lines long. - Bot. King Exp. 100. K. Wolfii, Rothruck in Am. Natumlist, viii. 358, \& in TTheeler, Cat. 38.

Common through the Coast Ranges, on rocks nul hills; the var. gintiusmm and var. malva. renm commoner southward; the onlinary form extendiug northwarl to Britisli Columbin. Var. verieguen in the Sierra Nevuda, from Plumas to Placer counties; also in the mountsins of Colorado, huthruck:

\$ 4. Thomless and prickless: leaves convalute in the bud: racemes severnl-fonmered: calyx-lube elongated: berry naked and glabrous, many-seded. - SirHucalix, lindl. (Chrysobotrya, sipach.)

12. R. aureum, Push. Slirub 5 to 12 fect hicrh, glibrous or almost so, crlamlless: leaves 3-5-lubul, rarely at all cordato; the lohos usually fur-toutherl or 
incised : racemes short, 5 -10-flowered, with mostly foliaceous bracts: flowers golden-yellow, spicy-fragrant; tube of the salverform calyx (half an inch or less in length) three or four times longer than the oval lobes: stamens short: berry small, yellowish turning blackish, mawkish. - Lindl. Bot. Reg. t. 125. R. tenuiflorum, Lindl. Bot. Reg. t. 1274. R. fragrans, Lodd. Bot. Cab. t. 1533.

Banks of streams, in the Coast Ranges and in the Sierra Nevada: extending to the eastern side of the Rocky Mountains. Common in cultivation in the Atlantic States and Europe.

\section{Order XXXV. CRASSULACE开.}

Succulent or fleshy plants, mostly herbaceous, and not stipulate, with completely symmetrical as well as regular flowers, the sepals, petals, stamens, and pistils all of the same number (3 to 12) and distinet, or the stamens twice as many, and the petals sometimes united into a tube, always free from the pistils, generally slightly perigynous, and instead of a disk a series of hypogynous scales, one behind each carpel; these become follicles in fruit. Otherwise as in Saxifragacea. The one or two exceptions are not Californian.

An orter of about 400 species in little over a dozen genera, of temperate and subtropical regions, most abundant in Europe and $\mathrm{S}$. Africa, more fully represented in Calitornia than in the Atlantic States. All are inert, with watery juice; many are cultivated for ornament, mostly for the foliage rather than the flowers.

Semplavivum tectorum, Linn, the Houseleek or Live-for-ever, of Europe, is often found half wild about old houses: parts of the flowers mostly in twelves: leaves oval or obovate, mucronate, on the flowering stems oblong and clammy-pubescent, as well as the clustered purple or greenish flowers.

1. Tillaea. Parts of the flower each 3 to 5 ; the stamens only as many. Small annuals, with opposite leaves and minute axillary flowers.

2. Sedum. Parts of the flower each 4 to 7 ; stamens twice as many. Petals distinct. Low annual or perenuial herbs, with cymose conspicuous flowers.

3. Cotyledon. Parts of the flower in fives; stamens 10. Petals somewhat united. Stout perenuial herbs, or fleshy-woody at base, with showy spicate or racemose flowers.

\section{TILL尔A, Linn.}

Sepals and petals 3 to 5, distinct or united at base. Stamens as many. Carpels distinct: styles short-subulate: ovules one to many. Seeds longitudinally striate. — Small and slender somewhat succulent glabrous annuals; leaves opposite, entire; flowers minute, axillary, mostly white.

A cosmopolitan genus of about 20 species. In addition to the following, there is a single species on the Atlantic coast and another in Texas.

* Flowers clustered: petals acuminate: hypogynous scales minute or none: carpels 1 - 2-seeded. - TiLL $x$ A proper.

1. T. minima, Miers. Diffusely brancher, 1 to 3 inches high, erect or ascending: leaves ovate to oblong, connate at base, acute, about a line long: flowers in short leafy axillary panicles, nearly sessile or on pedicels a line or two long : sepals 4, scarcely half a line long, oblong-ovate, acute, a little exceeding the linear-lanceolate acuminate petals: carpels not longer, acute: seeds usually solitary. - Torr. \& Gray, Fl. i. 557.

Var. subsimplez, Watson. Branchlets more elongated, mostly from the base: pedicels usually shorter. - T. leptopetala, Benth. Pl. Hartw. 310.

On sandy soils, in the rainy season, often abundant, from Sonoma Co. to San Diego ; Guada. lupe Island, Palmer. Also in Chili, and very similar to the older T. verticillaris, DC., of New Holland, Tasmania, and New Zealand. Often reddish. 
* Flowers solitary: petals oval or oblong: hypogynous scales linear: carpels several-seeded. - BulliarDA.

2. T. angustifolia, Nutt. Sitems derumbent, ruting at hase, diffusely hrancherl, an inch long: leaves linear, acute, connate, a line or two long: flowers sessile or on very short pedicels: sepals 4 , ovate, obtuse, a half shorter than the oblong petals and broad obtuse 8-12-seeded carpels. - Torr. \& Gray, Fl. i. 558.

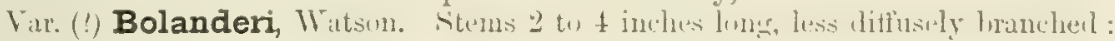
flowers nearly sessile, the parts in threes or fours: seeds nearly a half larger.

From Oreaon to Colorado; the variety on the muddy banks of streams near San Francisco, Bolander. The typical form may be expected in Narthern California It is very near the T. Drummondii, Tors. \& Grisy, of Texas, being distinguished apparently only by the shorter pedicols. The var. Bolanderi has been collected only in fruit, and may prove distinct.

\section{SEDUM, Linn. STOXE-Crop.}

Sepals 4 or 5, united at base. Petals as many, distinct. Stamens twice as many. Carpels distinct or rarely connate at base, few-many-seeded, I-seeded in a single species. - Herbs, mostly perennial and glabrous; leaves fleshy; flowers rarely diceious, in cymes, often secund.

Alout 120 species, inhabiting with fow exceptions the cooler and temperate remions of the northem bemisphere, chiefly of the Old World. Fifteen species or more are found within the limits of the United States.

* Stout, perennial: flowers mostly diocious, in a regular compact compound cyme, deep purple or becoming so: leaves serrate, flat.

I. S. Rhodiola, I) : Stems simple, nearly erect, fron a thick fratrant mot, 1 to 10 inches high, leafy: leaves alternate, oblong-oblanceolate, acute, mely entire, $\frac{1}{2}$ to $1 \frac{1}{2}$ inches long: cyme sessile, often an inch or two broad: flowers on short maked pedicels, usually 4-merous: sepals short, oblong: petals $1 \frac{1}{2}$ lines long, linearoblong: carpels becoming 3 liues long, shortly beaked.

In the Sierra Nevada, at 9,000 to 12,000 feet altitude (Breveer, Bnlander, Lemmon), nortliward to the Arctic Coast, and eastward across the continent. Also in the mountains of Europe.

* * Flowers perfect, decandrous, secund upon the branches of a forked cyme, mostly yellow or yellowish: styles filiform: leaves entire, very fleshy: low and comparatively slender.

+ Leaves narrowed toward the base, obtuse: perennials.

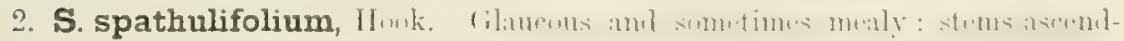
ing from a branched rooting caudex, 4 to 6 inches high, simple: lenves obovato or spatulato, flat, 6 to 10 lines long: branches of the cyme rpproximate: flowers on short pedicels or sessile, 3 lines long: petals yellow, lanceolate, acute, twice louger than the ovate acute sepals and scarcely exceeling the stamens and styles. - Fl. i. 227 ; Torr. \& Gryy, Fl. i. 559.

In dry rocky places from Monte Diablo to Vancouver Island.

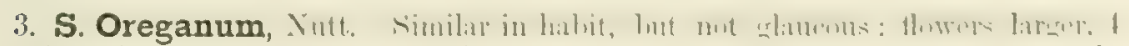
or 5 lines long: petals pale rose-color, narrowly lancenlate and acuminate, nearly twice longer than the stamens: sepals acute or acuminate. - Torr. \& Gray, Fl. i. 559 .

Mentocino Co. (Bolander), and northward to Wushington Territory. Ravely collected.

4. S. obtusatum, Gray. Of similar habit, but the branches of the eyme usurlly more numerous and scattered: flowers distinetly pediecllewl, 3 or 4 lines long: petals oblong-linceolate or ovate, neute, pale yellow, twica longer than the brond obtusish sepals aud littlo oxceding tho stamens mol styles. - I'roc. Am. $\Lambda$ cald. vii. 342. 
On granite rocks in the Sierra Nevada: Yosemite Valley (Bolander, Torrey, Gray, \&c.); Mt. Hoffmann, at 10,000 feet altitude, and Sonora Pass, Brewer. These closely allied species need to be defined from living specimens.

S. Debile, Watson, Bot. King Exp. 102. Stems weak, 2 to 4 inches high, from very slender running rootstocks: leaves rounded or obovate, 1 to 3 lines long : flowers on rather long pedicels, in small cymes, 3 lines long, yellow : petals lanceolate, acuminate, twice longer than the acute sepals and little exceeding the stamens and styles. - In the monntains of Northern Nevada and Utah (Watson, Hayden), and probably of Northeastern Califorria ; first collected by Tolmie.

++ Leaves broadest at base, acute.

5. S. stenopetalum, Pursh. Stems erect or ascending from a branched perennial rootstock, 3 to 6 inches high, simple or sometimes branched : leaves narrowly lauceolate, sessile, 2 to 4 lines long or more: flowers bright yellow, nearly sessile, 3 to 5 lines long: petals lanceolate, acuminate, twice longer than the acuminate sepals, and equalling or exceeding the stamens and elongated styles. - Torr. \& Gray, Fl. 1. 560 ; Watson, Bot. King Exp. 101.

Frequent from Oregon and Nevada to the Rocky Mountains, and doubtless to be found in North. eastern California.

6. S. variegatum, Watson. Probably perennial with a sulterranean rootstock, dwarf, the slender simple stems only 2 inches high: leaves purplish, ovate-oblong, 2 lines long or less: flowers 3 to 6 , in a contracted cyme, nearly sessile: petals broadly lanceolate, acute, 2 lines long, yellow veined with purple, twice longer than the purple ovate acute sepals and a little exceeding the stamens and styles. - Proc. Am. Acad. xi. 137.

Near San Diego, D. Cleveland, 1875.

7. S. Douglasii, Hook. Branching at base, from a stout proliferous rootstock, the rather stout stems 3 or 4 inches high: leaves lanceolate or the lowermost linearsubulate, acute, membranaceous when dry, 3 to 6 lines long: flowers sometimes polygamous, yellow, sessile, in an open cyme: petals 2 or 3 lines long, lanceolate, acuminate, twice longer than the acuminate sepals and exceeding the stamens: follicles at length divaricately spreading from their united bases. - Fl. i. 228; Torr. \& Gray, Fl. i. 559.

Mendocino Co. (Bolrender); among limestone rocks on Gavilan Peak (Brever); and northward to Oregon. Remarkable for its divergent follicles. It is described as an annual, but may perhaps be more persistent.

8. S. pumilum, Benth. Annual, slender, branching or simple, 1 to 3 inches high: leaves ovate-oblong, a line or two long: flowers sessile in sparingly branched cymes, yellow : calyx-lobes very small, triangular, acute : petals linear, acute, $1 \frac{1}{2}$ lines long, exceeding the stamens and styles: follicles short, 1-seeded; the seed erect, filling the cavity, - Pl. Hartw. 310.

On gravelly soil in the Sacramento Valley (Hartweg); at Placerville (Rattan); Table Mountain (Mrs. Ames) ; Oregon, Nuttall. It was also collected by Fremont. Peculiar in its minute calyx and solitary seeds.

\section{COTYLEDON, Linn.}

Calyx 5-parted. Petals united into a 5-lobed pitcher-shaped or cylindrical corolla. Stamens 10, inserted on the corolla-tube. Carpels distinct, or rarely united at base, many-seeded, beaked by the subulate styles.-Herbs, or soft-woody at base, ours stout perennials; leaves very thick and fleshy, entire, the lower rosulate; flowers often large and showy, mostly scarlet and yellow, in our species scorpioid-cymose or in long racemes. - Benth. \& Hook. Gen. Pl. i. 659 ; Baker, Refug. Bot. i. (February, 1869). Echeveria, DC. Prodr. iii. 401.

About 60 species, belonging to the dry or hot regions of the Old World and North America. The Mexican species number 25 or 30 , and there is also another in New Mexico near the boundary, 
hesiles those of California, which are still imperfectly known. These American forms frelong to the genus Eiluziesice, DC. (now merged in Cotyludun), distinguished by the larger ulten fuliacteus caly $x$, and the terete or sulcate pitcher-shaped corolla more deeply parted.

* Leaves terete: petuls yellowish, spreading: carpels divergent abme the unitud betse.

1. C. edulis, Brewer. Glaucous, nearly acaulescent, the stem very short, thick, and covered with the bases of dead leaves: rosulate leaves numerous, terete or somewhat triangular, acute, dilated at base, the outer ones 3 to 5 inches long: 1lowering stems a foot high or more, with similar scattered leaves an inch or two long, the uper and thorl unus rery smill: infloresence paniculate, the suttereml

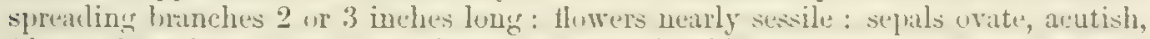

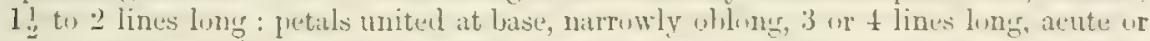

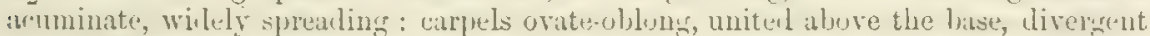
almov, 3 lines long: seuls rather fer, linear-sblunes, very acute at buth ends, half a line long. - Sedum edule, Nutt. in Torr. \& Gray, F1. i. 560.

On dry banks near the sea at San Diego, Nullall, Parry, Cooper, \&c. The young leaves are eaten by the Indians. A very peculiar species.

$$
\text { * Leaves flattened: carpels nearly distinct, erect. }
$$

- Petals united to the middle, red: carpels linear": pedicels mostly horizontal.

2. C. pulverulenta, lenth. \& Howk. More or less white-pulverulent thrumbout: stem shont and very stout: leaves rather thin and flaccid, in a fiatened rosette often a foot or more in diameter, broadly spatulate and very abruptly acute, becom-

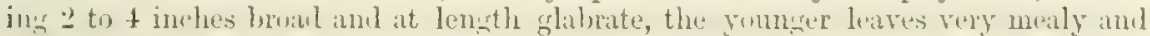
more gradually acuminate: flowering stems $1 \frac{1}{2}$ feet high or more, stout, with very broadly cordate often approximate acute leaves, or the lower ovate and acuminate;

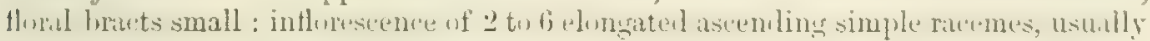
6 to 12 inches long; pedicels mostly horizontal, slender, 3 to 8 lines long: flowers erect or ascending: calyx-lobes orate, acute, 2 or 3 lines long: corolla narrow, sulcate, red ("pale-scarlet or coral-color"); lobes oblong, acute: carpels 6 lines long: suels very numerous, smaller than in the last. - Echeveria pulverulenta, Nutt. in Iore. \& Gray, Fl. i. 560.

Frequent in rocky mavines from tho Sierm Santa Monica (Brexer) southward to San Diego, Nulfull, Clevcland, Palmer. Eaten by the Indians. The figure of C. pulverulenla, Baker, l. c., t. 66 , cannot be cited as a representation of the typical form of the species. It is uncertain to what it should be reforred. The Echeveria pulverulente and E. lanceslate of Bot. Mex. Bound., fron the Corinados Islands near San Diego (Thurber), are not satisfnctorily determinable.

++ Petals united only near the base, yellow more or less tinged with red: carpels ovate- to linear-oblong: pedicels ascending.

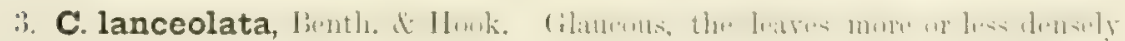
white-puberulent: stem very short, moro slender than in the list: rosulate leaves less spreading, lanceolite to ovate-lanceolate, acuminate, tho outer ones 2 to 4 inches long: flowering branches 15 inches high or more, slenler, the lower leaves lanceolate, becoming above broadly triangular-ovate, clasping, actite; the floml bracts wuch shorter than the pedicels: inflorescence in a compound cyme or often of 2 or 3 short simplo racemes; pelicels 2 to 4 lines long: sepals triangular-ovate, acute, 2 lines long: petals oblung, acute, 4 to 6 lines long, erect, recldish-yellow: carpets linear-oblong, 5 lines long including the style: seeds oblong, acutish at ench end, a third of a line lung. - Echeveria lanceoluta, Nutt. in Torr. \& Gray, lil. i. 561; Torrey, But. Mex. Bumnd. t. 24.

Southern California, near the sea; San Dingo, Nielall, Parm, Cleceland, Pulner.

4. C. farinosa, Benth. \& Hook. Acaulescent, more or less mealy-pulverulent: rosulate leaves rather flaccid, ascending, lnnceolate, acuminate, the lirger ones a to 
4 inches long, very acute : flowering branches a span high or often less, with scat tered broadly ovate to lanceolate clasping leaves: inflorescence a rather close and short compound cyme; bracts ovate-lanceolate, rather large; pedicels stout, 1 to 3 lines long: sepals broadly lanceolate, about 3 lines long: petals yellow, oblonglanceolate, mostly acuminate, 4 to 6 lines long: carpels ovate-oblong, about 3 lines long. - Baker, 1. c., t. 71. Echeveria farinosa, Lindl. in Jour. Hort. Soc. iv. 292.

Mt. Carmel (Hartweg); Pacheco's Peak (Brewer) ; Knight's Ferry, Bigelow. It probably also includes a more northern form with longer pecticels, collected on the upper tributaries of the Sacramento (Fremont), at Sonoma (Bigelow), and also by Bridges. It seems to be a variable species, distinguished from the last by its more lanceolate and narrowly acute less farinose leaves, shorter flowering branches, longer sepals, and shorter carpels. A cultivated specineen at Cambridge has very large bracts, much exceeding the pedicels.

5. C. crespitosa, Haworth. Acaulescent or nearly so, glabrous : rosulate leaves "glaucous-green," ovate-oblong to oblong-lanceolate, acute, the larger $1 \frac{1}{2}$ to 3 inches long; flowering branches 6 to 12 inches high, with broadly triangular-ovate clasping leaves : inflorescence a short and rather close compound cyme; bracts broad and rather large; pedicels short and stout: sepals ovate, 2 lines long or less: petals yellow, broadly lanceolate, acute, 4 or 5 lines long: carpels ovate-oblong, nearly 3 lines long. - Misc. Nat. 180 ; DC. Rar. Pl. Genev. 50, t. 14; Baker, 1. c., t. 69. Sedum Cotyledon, Jaeq. Eclog, i. t. 17 ; Reichenb. Hort. Bot. ii. 10, t. 125.

Near San Fraucisco and northward, first collected by Menzies and enltivated at the Kew Gardens in 1796 ; near Clear Lake (Torrcy); also from Gibbons and Pickering.

6. C. laxa, Benth. \& Hook. Nearly acaulescent, very glaucous : rosulate leaves lanceolate, sharply acuminate, the larger 3 or 4 inches long or more: flowering branches a foot or two high, slender, with seattered leaves, the lower usually narrowly lanceolate, the upper shorter and broader: inflorescence of 2 to 4 simple secund racemes 3 to 5 inches long; floral bracts small; pedicels 2 or 3 lines long: sepals ovate, acute, 2 lines long or more: petals yellow, oblong-lanceolate, acute or acuminate, 5 to 7 lines long: carpels ovate-oblong, 4 lines long. - Echeveria laxa, Lindl. in Jour. Hort. Soc. iv. 292. Cotyledon Californica, Baker, 1. c., t. 70.

Near Monterey (Hartweg); Cajon Pass (Bigclow); on dry rocks in the Gavilan Range (Brewer); Ft. Tejon (Xantus); rocky hills back of Santa Barbara, Rothrock. Some of the latter specimens have reddish flowers, and the mature carpels are linear-oblong.

7. C. Nevadensis, Watson. Acaulescent, glaucous : rosulate leaves obovate to oblanceolate, somewhat rhomboidal, acute or acuminate, the larger 2 to 4 inches long: flowering branches 6 to 10 inches high, with scattered lanceolate to broadly triangular acute leaves: inflorescence a rather close spreading compound cyme; bracts small; pedicels 3 to 9 lines long: sepals ovate, acute, 2 lines long or less.: petals lanceolate, acute, 5 lines long, yellow tinged with red: carpels very short, ovate-oblong, 3 lines long in fruit.

Hillsides and rocky places, Sonora (Bigelow); Yosemite Valley, Torrey, Gray.

\section{Order XXXVI. DROSERACE丑.}

Herbs, growing in bogs, or rarely aquatic, most resembling Saxifragece in habit and structure, and seemingly somewhat connected with that tribe through Parnassia, but with petals and stamens hypogynous or nearly so, anthers commonly extrorse, and the leaves provided with secreting glands of some kind, which appear to be in some way subservient to the capture of insects.

A small order of five very small and local genera and one rather large and widely diffused one : represented in N. America only by the wonderful Dionce, or Vemus's Fly-trap, of North Carolina, and by a few species of the principal genus, Drosere. 


\section{DROSERA, Linn. SUNDEW.}

Calyx 5-parted, imbricater in the burl, persistent. Petals 5, mostly convolute in the bud, withering-persistent. Stamens 5. Styles mostly 3, and each 2-parted, so as to appear as 6 filiform or somewhat clavate ones, stigmatose down the inner side. Cipusule oblons, 1-celled with 3 parietal plicentie, 3-valvexl fron the topl, a plicentir on the middle of each valve. Seeds very numerous and small, anatropous, with a small embryo at the base or in the axis of the fleshy albumen. - Low perennials or biennials, of brownish or reddish rather than green hue; the herbage beset with bristle-stalked glands which secrete a drop of clear and glairy linuir ; stipules is villous fringe at the base of the petiole; leaves inrolled from the apex or the blade inflexed in the bud, in ours all crowded in a rosulate tuft at the base of a naked scape, which betrs a unilateral scoryinid (apparent) racene or spike; but the lluwers are not in the axils of the bracts. Flowers generally (in ours) white, each one opening in the morning for a single day.

Of the $\mathbf{1 0 0}$ species, or thereabout, only six or seven are North American, and half of these are also European, two of them occurring rarely in Califormia. Tho grenter number are $\mathrm{S}$. Australian. All at leist of the common species are insectivorons. For an account of their remarkable habits and structure see Durwin, Insectivorous Plants, 1875.

1. D. rotundifolia, Linn. Leaves sprealing; the hlate rounlet, 2 to 6 lines in diameter, abruptly narrowed into the slender hairy or naked petiole: scape 3 to 6 inches high, few-flowered: petals oblong, 2 lines long, a little exceeding the oblong sepals: styles very short : capsule included in the calyx: seeds liuear, with a loose coat.

In cold swamps in the Sierta Nevada (Brever, Bolander, Lemmont); Mendocino Co. (Bolander); and northward to the Arctic circle. On the Atlantic side of the contiment it ranges southward to Florida; it is also found in Europe and Asia.

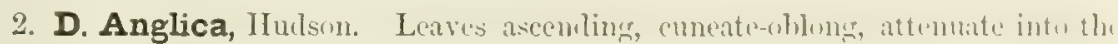
slender naked petiole: scape 3 to 6 inches high, sometimes forked at the top, fewflowered: petals lincar-oblanceolate, 3 or 4 lines long, nearly twice longer than the oblong sepals: capsule exceeding the calyx: seeds linear, with a loose coat.

Sierra County, Lemmon. Common in Europe and Siberia, but rarely collected in North America, beingr reported only from tho Northwest Coast (Menzics), British America (Richardsom), and Newfoumdland. The more frequent D. intcrmedia, Hayne (tho D. longifolia of authors and at least in part of Linnoeus), is distinguished by the close rough seed-coat, rather smaller llowers, sc.

\section{Order XXXVII. LYTHRACE正.}

Herbs (or in warm countries sometimes shrubs or trees), with simple and entire leaves, calyx tubular or campanulate and free from the orary and capsule but enclosing it, the petals (often wanting) and definite stumens borno in its throat, a single style, numerous suall anatropous seeds on a central placenta, and no albumen. Capsule generally becoming one-celled by the vanishing of thin partitions. No stipules, and no translucent dots in the leaves. Distinguished from the two following orders by the free ovary, from the first of them also by the numerous sects.

An order of littlo consequence and fueble representation in temperate regions, especially in $X$.

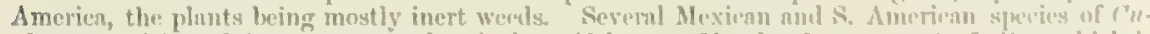

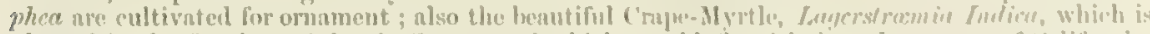
planted in the Sonthern Atlantie: States, and which would flusish in a large part of califin'min.

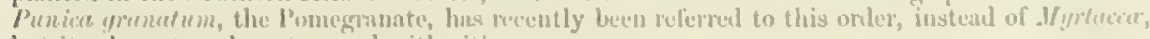
lout its clantelers do not aceord with aither. 
1. Ammannia Calyx barely 4-angled, short. Stamens 4 or 8 . Capsule globular. Leaves opposite.

2. Lythrum. Calyz striate, cylindrical. Petals commonly 6 (4 to 7 ), and stamens as many or sometimes twice as many. Consule oblong or cylindraceous.

\section{AMMANNIA, Houston.}

Calyx campanulate or short-tubular, usually 4-angled, 4-toothed, and with as many intermediate small tooth-like processes. Petals as many, small and fugacious, or none. Stamens usually 4. Capsule enclosed in the calyx, nearly globular, mostly 4-celled. - Low and smooth annuals; stems 4-angled; leaves opposite, sessile; flowers small, axillary.

A genus of about 30 species, inhabiting swamps and wet places. Only 4 species are found in the United States, of which the following is of wide range.

1. A. latifolia, Linn. Stems erect, a foot or two high, with a few spreading branches: leaves linear-lanceolate, 1 to 3 inches long, with a broad auricled base, acute: flowers 1 to 5 in each axil, mostly closely sessile: calyx oblong, $1 \frac{1}{2}$ lines long, becoming 2 lines in diameter in fruit : stamens sometimes 8 : style variable in length, as well as the filaments.

Banks of Cache Creek (Bolander); Carson Valley, Nevada (Watson); on the Lower Colorado (Blake); on Milk River, N. Montana (Succleley); also in the Southern Atlantie States, the West Indies and Brazil.

\section{LYTHRUM, Linn. LOOSESTRIFE.}

Calyx cylindrical, striate, $4-7$-toothed, with as many intermediate tooth-like processes. Petals 4 to 7 , oblong-obovate, often conspicuous and sometimes unequal. Stamens as many or twice as many. Capsule oblong, 2-celled. - Erect slender herbs (rarely woody at base); stems angled; leaves linear-oblong or lanceolate, alternate, opposite, or rarely whorled; flowers axillary, mostly solitary.

A small genus, widely distributed over the world. Four or five species are found in the United States, one of which is polymorphous and extends across the continent.

1. I. alatum, Pursh. Biennial от perennial, herbaceous, with straight virgate branches, a foot or two high, glabrous; the stems angled and narrowly margined: leaves oblong-ovate to narrowly lanceolate, sessile, acute, an inch long or less, the upper scarcely exceeding the flowers; the lowest opposite, the rest usually scattered: flowers solitary, sessile or shortly pedicelled: calyx about 3 lines long, deeply furrower, the teeth usually little exceeding the intermediate processes : petals 6 , deep purple, 2 lines long : stamens 6 : capsule narrow, nearly as long as the calyx.

Var. linearifolium, Gray. Leaves linear, the lower cauline ones only sometimes lanceolate. - P1. Lindh. ii. 188. L. Californicum, Torr. \& Gray, Fl. i. 482. L. lineare, Hook. \& Arn. Bot. Beechey, 343, not Linn.

The variety only has been found in California, from Napa Valley to San Diego, and ranging eastward to New Mexico. The species is very variable, aud extends from the northern Atlantic States to Mexico.

\section{ORDER XXXVIII. HALORAGE正.}

Aquatic herbs (as to the N. American representatives), with inconspicuous and often apetalous flowers sessile in the axil of leaves or bracts, calyx adnate to the ovary in the fertile ones, and its limb then short and almost entire or obsolete; the fruit indehiscent and nut-like, 1-4-celled, with a single anatropous seed suspended from the summit of each cell; embryo in the axis of copious albumen, its cotyledons 
small and short; styles or sessile stirmas 2 to $t$ and distinct, or in Hippuris only one and simple.

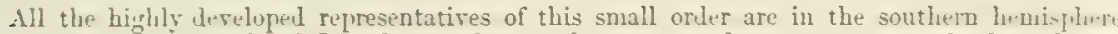
(except one in the Sandwich Islands): such as we have are much more numerous in the Atlantic than in the Pacific States.

Cachitriche as well as Ceratophyllos is referred to the Apctala.

1. Hippuris. Leaves linear, in whorls of 8 or 12. Flowers perfect. Calyx entire. Petals none. Stamen and cell of the ovary one.

2. Myriophyllum. Inmersed leares pinnately dissected. Flowers mon eciuus or prolygamous, Parts of the flower in fours.

\section{HIPPURIS, Linn. MLARE'S TAIL.}

Flowers perfect or sometimes polrgamous. Callyx-tube globular ; the limb entire. Putals none. Stamen 1 ; tilament subulite; anther lirre. Ovary l-cellenl: style becoming tiliform and elungated, stignatic the whole length. Fruit ublung-uroid, nut-like. - Smooth aquatic perennial herbs, with ereet simple leafy stems; leare's linear or oblong, entire, in whorls of 1 to 12; Howers minute, solitary and sessile in the axils of the leaves.

Only two sinwies are known, or perhaps only one, distributed through the temperate and colder regions of the northern hemisphere and also in the southern.

1. H. vulgaris, Linn. Stems a foot or two high, rather stout: leaves acute, nsually a half to an inch lung but often much longer, esjerelally the sulumerued ones: calyx harlly half a line lons: style and stamen comparatively conspicunts, persistent : fruit nearly a line long.

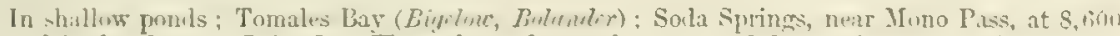
feet altitude, Brever, Bolander. Throughout the northern part of the continent (as well as of the old World), and southward in the Rocky Mountains as far as New Mexico.

\section{MYRIOPHYLLUM, Linn. WATER-MILFOIL.}

Flowers monocious or polygamous. Limb of the calyx 4-lobed in the sterile Howers, wanting or minutely toothed in others. Petals 2 to 4 , minute or wantine

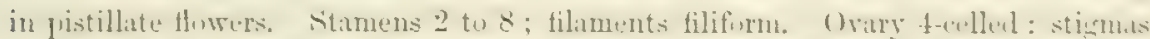

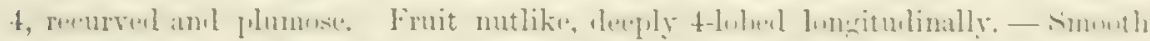

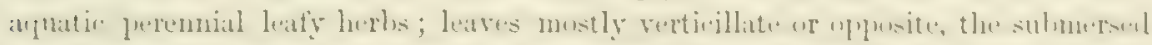

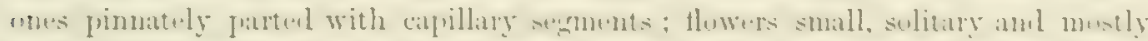

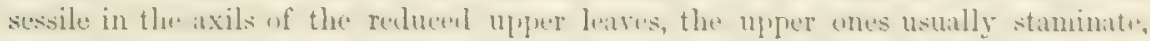
the lower pistillate, and the intermediate ones perfect.

A genus of about 15 species, distributed over nently the whole globe, ono half of the number being found within the United States.

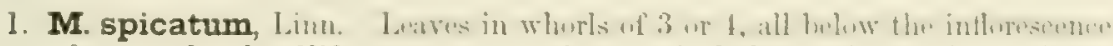
pinnately parted; tho filiform segments often an inch long: flowers in an interrupted spike: bracts ovate, entire or toothed, usually shorter than the flowers: petals ovate, greenish white, nenrly a line long, deciluous: stamens 8: fruit subglobose, deeply lobed ; the rounded carpels smooth, a line long.

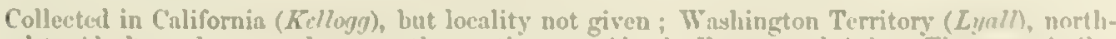
ward to Alaska and eastwarl neross the continent. Also in Europe and Asin. The very similar I/. verlicillatum, Linn, is distinguished by the larger and pectinutely pinnatifid flomi bracts.

2. M. hippurioides, Nutt. Leaves in whorls of 4 , the lower pinnate and iapillary; upper leaves linear, acute, acutely and rather remotely tontherl, 3 to 5 lines long, the uppermost nearly entire: petals white, obuvate, somewhat prorsistent: 
stamens 4 : carpels nearly smooth, less rounded. - Torr. \& Gray, Fl. i. 530. M. scabratum, Cham. \& Schlecht, in Linnæa, iv. 506, not of Michx.

Collected in Oregon (Nuttall, Hall), and reported as from near San Francisco, without fruit, Chamisso.

\section{ORDER XXXIX. ONAGRACE无.}

Herbs (or in warmer regions one or two genera of shrubs), with perfect symmetrical flowers, the parts of which are most commonly in fours, the calyx-tube adnate to the ovary and its (often colored) lobes valvate in the bud, the petals bome on its throat or at the sinuses and convolute in the bud, the cells of the ovary usually of the same number, and the stamens as many or twice as many. Style always single: stigma of as many lobes as cells to the ovary, or capitate. Seeds anatropous, filled by the embryo: no albumen. Leaves simple, but sometimes lobed or divided, either alternate or opposite: no stipules. Flowers often showy.

An order of over 300 species, widely distributed over the world, but for the larger part American, especially $\mathrm{N}$. American and Mexican, inert, and of no economical importance except in ornamental cultivation, and that the large fleshy seeds of Trapa or Water Caltrops in the Old World are eaten as nuts.

Fuchsia, Linn., the principal shrubby or arborescent genus, of the Mexican and S. American Andes, well marked by the brightly colored calyx, long and straight stamens and style, opposite leaves, and a berry for fruit, is too familiar in ornamental cultivation to be overlooked.

TRIBE I. JUSSIEE. Limb of the calyx divided quite down to the ovary, and persistent on the many-seeded capsule. Seeds naked.

1. Jussiza. Petals 4 to 6. Stamens twice as many. Capsule elongated.

2. Ludwigia. Petals 4 or none. Stamens 4. Capsule short.

TRIBE II. ONAGRE\&. Limb, with the free tube of the calyx when there is any, deciduous from the ovary or cansule; the latter loculicidal, many-seeded, or the cells varely only several-seeded. Parts of the flower in fours.

* Seeds comose at the apex: stamens 8 : lower leaves often opposite.

3. Zauschneria. Calyz-tube continued much beyond the ovary, funnelform.

4. Epilobium. Calyx 4-parted nearly down to the ovary, or with a short and campanulate tube beyond it.

* * Seeds naked (not comose) : leaves all alternate.

* Anthers attached near the middle and versatile : petals generally yellow or white or sometimes changing to rose-color.

5. Gayophytum. Calyx-tube not produced beyond the ovary; this and the membranaceous capsule only 2-celled. The stamens opposite the petals usually sterile. Slender and very small-flowered annuals.

6. Eulobus. Calyx-tube hardly at all produced beyond the ovary. Stamens opposite the petals shorter and with rounded anthers. Capsule long-linear, straight, refracted. Annual.

7. Enothera. Calyx produced beyond the ovary into a linear or obconical tube. Anthers all uniform. Petals without claws.

* + Anthers attached at or near the base, remaining erect; those opposite the petals much shorter, or sterile, or rarely wanting: petals never yellow : annuals.

8. Godetia Calyx-tube above the ovary obconical ; its lobes reflexed. Petals sessile, entire, rarely 2-lobed. Capsule coriaceous. Seeds numerous, angled or margined.

9. Clarkia. Calyx-tube above the ovary obconical; its lobes reflexed. Petals with claws, either lobed or entire: the stamens opposite them often steríle. Capsule coriaceous.

10. Eucharidium. Calyx-tube above the ovary filiform; the lobes reflexed. Petals with claws, loberl; the stamiens opposite them wanting. Capsule coriaceous.

11. Boisduvalia. Calyx-tube above the ovary obconical; its lobes erect. Petals sessile, 2-lobed. Capsule membranaceous; the cells few-seeded. Seeds smooth. 
Tribe III. GAURINEE. Limb or produced tube of the calyx deciduous from the ary aul iadehiscent 1 - 4-seeded fruit. Parts of the llower in fours or rarely threes. Leaves altemate.

12. Gaura Stamens 8 , all perfect : anthers attached by the middle, versatile.

13. Heterogaura. Fertile stamens 4 , with anthers attached at the base: sterile stamens before the petals 4.

TRIBE IV. CIRCEE E. Limb of the calyx deciduous from the indehiscent bur-like 1-2. seeled fruit. Parts of the flowers in twos throughout. Leaves opposite.

14. Circaea. The only genus.

\section{JUSSI Æ̇A, Linn.}

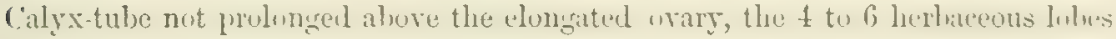
persistent. Petals as many, obovate, spreading, yellow. Stamens 8 to 12.0 ovary 4-6-celled: style simple: stigma capitate, 4-6-grooved. Capsule clavate, 4-6valved, dehiscing septicidally, or sornewhat irregularly between the ribs, manyseeded. Seeds in several rows in each cell (or in one row in the following species, and surrounded by a thick epicarp), naked. - Aquatic or marsh herbs; leaves entire, alternate, with very small stipules; Howers sulitary, axillary, usually un "z-bratetevlate pedicels.

Species about 40, belonging mostly to Tropical America.

1. J. repens, Linn. Perennial, glabrous or puberulent: stems creeping and rooting at base, 1 or 2 feet long, the branches ascending: leaves oblanceolate or

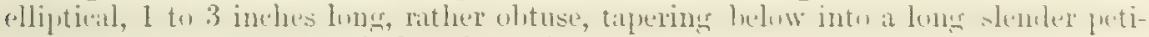
ole : flowers nearly an inch broad: style stout, hairy: capsule 1 to $1 \frac{1}{2}$ inches long, nearly terete, 1 lines broal: pedicels 1 to 2 inches long, bracted: sceds in une

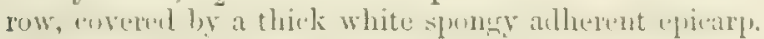

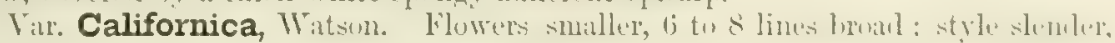
slabrous: capsule smaller, 8 to 10 lines long, 2 lines broad: pedicels shorter, \& to 6 lines long: seeds slightly larger.

Cedar Lake, Cache Creek (Bolander) ; Northem Sonora (Coulter, Thurber) ; the variety only;

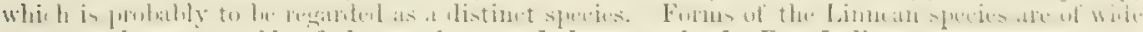
range on the eastern side of the continent and also occur in the Eust Indies.

\section{LUDWIGIA, Linn.}

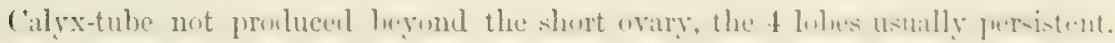
Petals 4, often small or wanting. Stamens 4 ; filaments short. Capsule short or

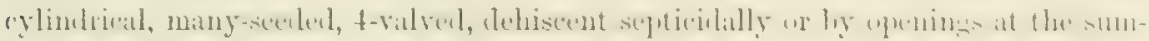
mit. Soeds minute. - Aquatic or marsh perennials; leaves entire (opposite in our species); flowers axillary, mostly solitary and sessile.

About 20 species, mostly North Ameican, a fen belonging to the Old World. A single species is native to the Westeru Const, of rare occurrence.

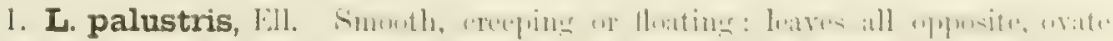
or oval, f to 1 inch loug, tapering to a short petiole, acute: flowers solitury, sessile: petals none or short and rechlish: capsule short-oblong, 2 lines loug or less, somewhat 4-angled.

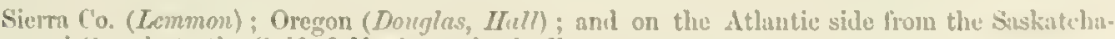
wan and Cinada to the Ciulf of Mexico: also in Europe.

\section{ZAUSCHNERIA, Presl.}

Tubo of the calyx funnelfurm and deeply colored above the ovary, with a small

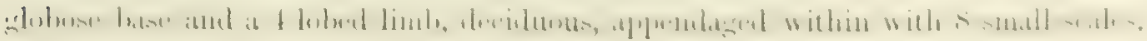


4 erect and 4 deflexed. Petals 4 , inserted on the throat of the calyx and rather shorter than its lobes, obcordate or 2-cleft, scarlet. Stamens 8, exserted; the filaments opposite to the petals shorter; anthers linear-oblong, attached by the middle. Ovary 4-celled: style long and exserted: stigma capitate or peltate, 4-lobed. Capsule linear, obtusely 4-angled, 4-valved and imperfectly 4-celled, many-seeded. Seeds oblong, with a tuft of hairs at the apex. - Low decumbent pereanial, somewhat woody at base; leaves sessile (the lower opposite); the large scarlet Fuchsialike flowers in a loose spike. A single variable species.

1. Z. Californica, Presl. More or less villous and often tomentose, much branched, the ascending or decumbent stems a foot or two long: leaves narrowly lanceolate to ovate, $\frac{1}{2}$ to $1 \frac{1}{2}$ inches long, acute, entire or denticulate: flowers 10 to 16 lines long above the ovary; the calyx-lobes 4 lines long: capsule attenuate to the slender base, $\frac{1}{2}$ to 1 inch long, sometimes shortly pedicellate. - Rel. Haenk, ii. 28, t. 52 ; Bot. Mag. t. 4493. Z. Mexicana, Presl, 1. c., ii. 29.

Var. microphylla, Gray in herb. Pubescence tomentose, scarcely or not at all villous: leaves linear, often very small ( 3 to 4 lines long), fascicled in the axils.

In dry localities from Napa and Plumas counties to S. California and Northern Mexico, and eastward of the Great Basin from N. W. Wyoming (Parry) to the Wahsatch (Watson) and New Mexico (Wright) ; the variety in $\mathrm{S}$. California. Very variable in its foliage and pubescence, and in its flowers, which are broadly or narrowly funnelform, more or less deeply colored, and with the style and stamens more or less exserted.

\section{EPILOBIUM, Linn. Wiliow-Herb。 (By W. Barber.)}

Tube of the calyx not conspicuonsly prolonged bejond the ovary; the limb deeply 4-cleft, campanulate or funnelform, or 4-parted to the base with the lobes spreading, deciduous. Petals 4, spreading or somewhat erect. Stamens 8, the 4 altermate ones shorter; anthers elliptical or roundish, fixed near the middle. Stigma oblong, clavate, or with 4 spreading or revolute lobes. Capsule linear, 4-sided, 4-celled, 4-valved. Seeds numerous, ascending; the summit furnished with a coma or tuft of long hairs. - Perennial or annual herbs; leaves alternate or opposite, nearly sessile, denticulate or entire, often fascicled; flowers rose-colored, purple or white, very rarely yellow.

A genus of about 100 species, inhabiting the temperate and colder regions of the globe, many of them very variable, and the number greatly multiplied by authors.

* Flowers large: stamens and style declined: stigma-lobes spreading: perennial.

1. E. spicatum, Lam. Stem erect, simple, often 4 to 7 feet high, mostly glabrous: leaves scattered, lanceolate, sessile, nearly entire, the veins anastomosed near the edge: flowers in a long spicate raceme, bracteate, purplish lilac: $\operatorname{limb}$ of the ealyx nearly 4-parted, often colored, spreading: petals obovate, unguiculate, spreading: stamens purple : style jellow, hairy at the base, at first deflexed; stigmalobes linear: capsule canescent. $-E$. angustifolium, Linn.

In the Sierra Nevada (Bridges) ; northward to Behring Straits and eastward across the continent. Also in Europe and Asia.

2. E. obcordatum, Gray. Roots diffuse: stems branching from the base, decumbent, 3 to 5 inches long, 1 - 5 -flowered, glabrous throughout: leaves opposite, ovate, sessile, numerous, mostly longer than the internodes (4 to 8 lines long), glaucous, opaque: flower-buds of somewhat irregular shape: calyx-limb 4-cleft, the lobes of irregular width : petals obcordately 2-lobed, spreading, of a bright rose-color, half an inch long: stamens yellow, shorter than the purple declinate style : stigma 
shortly 4-lobed: capsule shurt, thick, pedicellate, with comparatirely few secels. Proc. Am. Acad. vi. 532 ; Barbey, Mon. Epil. ined. t. 3.

In the sierra Nevalil, from Tulare county northwarl, at an altitule of 8.1100 to 11 , (mii [...t

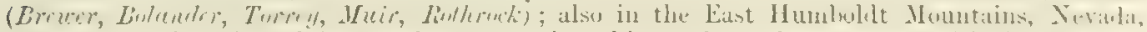

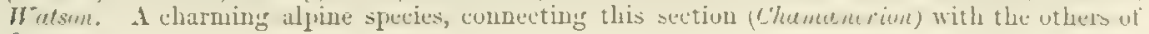
the genus.

E. LAtifolius, Linn., of Europe and Asia, differing from $E$. spicatum in its short ascending

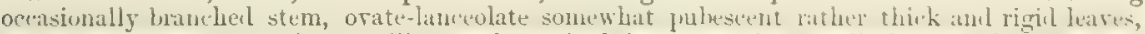
veins nut aprarent, very litge axillary and teminal flowers on shont pelicels, aml the sonewhit erect glabrous style shorter than the stamens, is found from Arctic America to the bigher mountains in Colorado and perbaps reaches California. The E. opacum, Lehro. in Hook. Fl. i. 205, from the banks of the Columbia (Douglas, Scouler), with erect pubescent stem, narrowly lauceolate leaves, and the thowers of $E$. latifolium, may be a hybrid between it and $E$. spicalum.

E. Luteva, Pursh, may be mentioned as our only other allied species, and remarkable in the genus for its large yellow flowers. It ranges from Alaska to Oregon.

* * Flowers small. petals, stamens, and style erect: stigma clavate or cylindrical: limb of the calyx 4-cleft.

+ Herbaceous perennials.

+ Leaves not strictly sessile: more or less pubescent.

3. E. Watsoni, Barhey. Hoary-pubescent thruurhout: ruots sprealing in mud, with stolons (?): stems terete, branching, about 18 inches high: leaves oblonglanceolate (the length thrice the width), denticulate-serrulate shorty retionlen: petals elongated obcordate, comparatively narrow: stigma cylindrical and not expanded: seeds granulately furrowed. - Mon. Epilob. ined. t. 6.

Near the Russian settlement, Sonoma Co.; only from Russian collectors. The flowers are of medium size. Much resembling E. hirsutum, Linn., differing in its smaller petals, cylindrical not expanded stigma, furrowred seeds, and leaves not clasping.

4. E. coloratum, Muhl. Iinots sprealing in rich wet suil: stem nurly terete, erect, 1 to 3 feet high, much branched, puberulent: leuves mostly opposite, lanceolate, acute, on very short petioles, denticulate-serrulate, the veins often reddish:

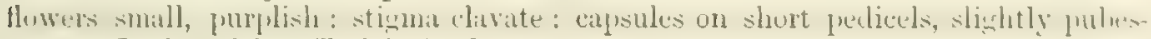
cent. - Barbey, Mon. Epilob. ined. t. 9.

Throughout the Sierra Nevada, and to the Cuiamaca Mountains (Palmer); also northward and eastward through the Northern Uniter States. With better material it is probable that the Pacific form will have to be distinguished from the enstern by the form of the sceuls, the glabrous tecth of the leares, sec.

5. E. alpinum, Lim. Alpine: ronts capillary, with neratinnal filifum stulus: stems creeping at the base, 2 to 6 inches high, usually with two pubescent lines:

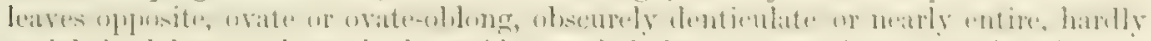

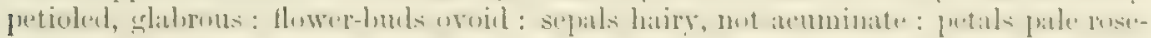
color, with a few hairs on the outer surface, little longer than the calyx : anthers

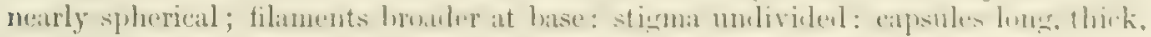

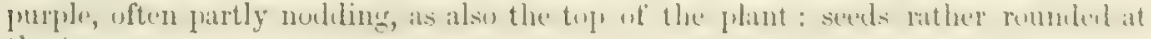
the top.

In the Sierra Nevada; Westfall's Meadows (Bolander); nenr Soda Springs, at 9,000 feet alti-

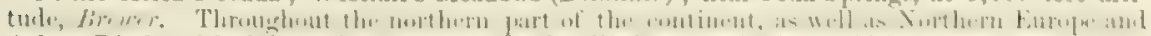
Asia. Distingnished from the following closely allied species by its ovoid buds.

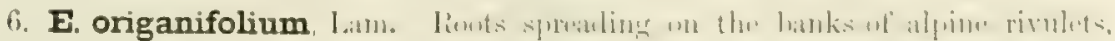
with occasional stulons: stem generally simple, terete, with two pubescent lines, 6

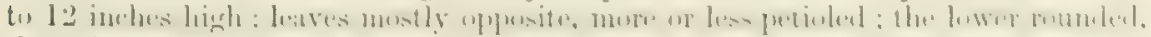
the middle ones oval and equally pointed at each end, the upper acuminato: buds somewhat angular at the base: flowers lawge, varying from clark purplo to puro white: sepals half the length of the obeordate pretals: anpsules sometimes noulding: seeds rather long-acuminate at hoth ends, somewhat light colored. 
In the Sierra Nevada, from the head of Kern River (Rothrock) northward ; at Ebbett's Pass and Mt. Shasta (Brewer); at Crater Pass in the Cascade Mountains (Newberry); through all the colder portion of North America, and also in the European Alps and the Himalayas.

\section{$\div+$ Leaves strictly sessile: not alpine.}

7. E. Franciscanum, Barbey. Somewhat hoary, roots spreading in the mud: stem straight, branching above, with 2 to 4 elevated longitudinal lines, 12 to 20 inches high: leaves mostly opposite, connected at base, nearly glabrous, oblonglanceolate, rounded at base, serrulate: bud ovoid: top of the ovary much contracted at the insertion of the calyx: sepals slightly hoary: petals purple, emarginate: stamens shorter than the style: stigma cylindrical: capsule hoary: seeds with striate testa and broad sides to the furrows. - Mon. Epil. ined.

Near San Francisco (Bigelow, Torrey); Lobos Creek (Kellogg); also at the Shumagin Islands, Alaska, Harrington.

8. E. brevistylum, Barbey. Somewhat hoary: stem terete, erect, 10 to 18 inches high, slightly branched at top, marked with 2 or 4 decurrent glabrous lines, tinted with purple: leaves mostly opposite, sessile, broadly lanceolate, slightly denticulate with rigid teeth: flowers small: calyx cleft nearly to the middle, almost glabrous: petals slightly cleft, obcordate, pinkish : inmer row of stamens short; the onter ones longer than the style: capsule nearly sessile: seeds acuminate at the top, tufted with silvery hairs. - Mon. Epilob. ined.

Sierra County, Lemmon. Corresponding somewhat to the European E. roseum, Schreber.

9. E. glaberrimum, Barbey. Whole plant glaucous and perfectly glabrous, stoloniferous: stem terete, straight, simple or somewhat curved and branching, 6 to 15 inches high: leaves mostly opposite and connected at the base, broadest below, bluntly lanceolate, slightly serrulate: sepals somewhat shorter than the petals, which are deeply notched: filaments rather short and thick: stigma clubshaped, with a slight depression at top: capsule very slightly hoary : seeds with furrows terminating below the apex, tufted with very fine hairs. - Mon. Epilob. ined. t. 5 .

Var. latifolium, Barbey, 1. c. Leaves broader : stem more branching, curved.

In the Sierra Nevada: Yosemite Valley (Botander); Sierra Valley (Lemmon); and collected also by Bridges. The variety in Sierra Co. (Lemmon), and above Carson City, Anderson. Rather variable and perhaps embracing several species.

\section{++ Annuals.}

10. E. paniculatum, Nutt. Glabrous or pubescent above (rarely throughout): roots spreading: stem erect, slender, 10 inches to 10 feet high, terete, dichotomous above: leaves narrowly linear, obscurely serrulate, acute, attenuate at the base, mostly alternate and fascicled; the uppermost subulate: flowers few, terminating the spreading filiform and almost leafless branches: pedicels pubescent : calyx-tube funnelform: petals obcordate, nearly twice the length of the calyx-lobes: capsule short, acute at each end, straight or a little curved, erect or speading. - Torr. \& Gray, Fl. i. 490; Barbey, Mon. Epil. ined. t. 8.

From the Cuiamaca Mountains and the Southern Sierra Nevada to Washington Territory, and eastward to the Rocky Mountains; frequent.

11. E. minutum, Lindl. Roots bright and shining: stem terete, erect, puberulent, occasionally branching, 3 to 10 inches high : leaves mostly alternate, ellipticlanceolate, rather obtuse, nearly entire, slightly pubescent: flowers minute, contracted at the base of the calyx: petals pale rose-color, obcordate: the four longer stamens equalling the style: stigna clavate, the lobes at length expanded and fimbriate: capsule short, somewhat pedicelled, slightly arcuate, at length erect: seeds large and not very numerous. - Hook. Fl. 1. 207 ; Barbey, Mon. Epil. ined. t. 7. Crossostigma Lindleyi, Spach, Mon. Onag. 84. 
Tar, foliosum, Torr. \& Frar. Leares line:r-spatulate, nearly slat runs, with smaller ones fascicled in the axils: petals nearly white. - Fl. i. 490.

Napa Valley and Knight's Ferry (Bigclone); Geysers (Grecne); dry woods near Ukiah (Bolan- der); and northward to Oregon. Guadilupe Island, Palmer.

\section{GAYOPHYTUM, A. Juss.}

Calyx-tube not produced above the ovary; the 4-parted deciduous limb reflexed. Petals 4 , white or rose-colored, very small, obovate or oval with a very short claw.

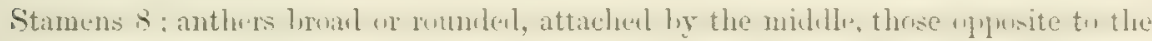

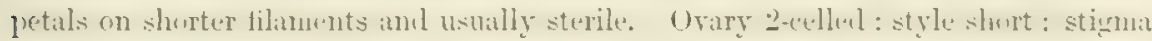
capitate or clavate. Capsule membranaceous, clavate, 2-celled, 4-valved. Seeds few to many, in one row in each cell, small, smooth, oblong, naked, ascending. Very slender branching annuals, of westeru North America and Chili, with alternate linear entire leaves and axillary flowers. The following are the only North American species.

1. G. ramosissimum, Turr. of (riny. Glabrous or the influpesene sometimes puberulent, diffusely much branched, 6 to 18 inches high: leaves an inch long or less: flowers half a line long, mostly near the ends of the branches: capsule oblong, 2 or 3 lines long, on pedicels of about the same length or shorter, often deflcxed, 3-5-seeded. - Fl. i. 513 ; Watson, Bot. King Rep. 105.

From Oregon to Mariposa, Co. and eastwarl to Colorado, in the mountains on dry slopes.

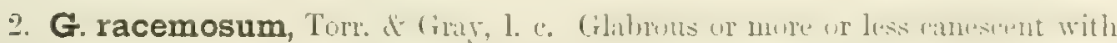
short appressed pubescence, 6 to 18 inches high, the elongated branches mostly

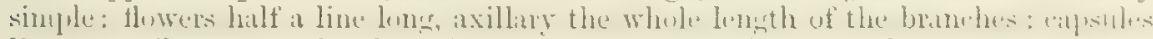
linear, sessile or very shortly pedicelled, 8 to 10 lines long, usually many-seeled. Watson, 1. c. G. Nuttallii and G. casium, Torr. \& Gray, 1. c.

From the Columbia River to Central California and eastward to Colorado.

3. G. diffusum, Torr. \& Gray, 1. c. Nearly glabrous, 6 to 18 inches high:

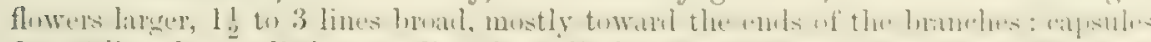

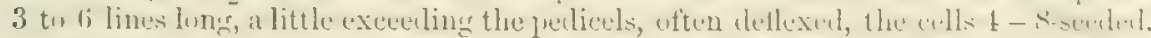
- Watson, l. c.

Less frequent ; from Oregon to Southern Californis and eastward to Idaho and N. Utah.

\section{EULOBUS, Nutt.}

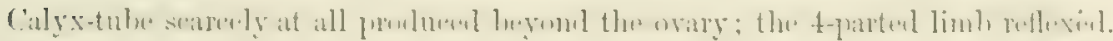
Petals 4, rhombic-ovate, sessile, light yellow turning to red. Stamens 8 ; anthers

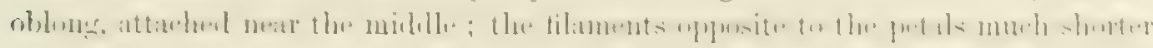
and with smaller globose anthers. Ovary 4-celled: stigma capitate. Capsule

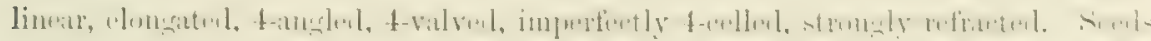
very many, obovate-oblong, naked, erect. - A smooth erect annual, with somewhat

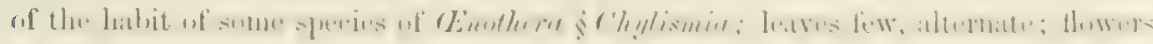
sessile along the virgate branches. A singlo species.

1. E. Californicus, Nutt. Stem 1 to 3 feet high, rather stont, with $n$ fow sprealing virgate branches: leaves linear, 1 to 2 inches long, sinuitely pinnatifil with numerous short unequal divaricate acute teeth : calyx-tube prolonged less than half a line ahove the ovary: petals 4 or 5 lines long, the flowers mither showy: capsules 3 or 4 inches long: seeds swooth, 3-nugled, two thirds of a lino long Toiт. \& Gray, Fl. i. 515.

Dry places, from Snntn Barbaru to San Diego; Comp Gmut, Arizonn, Potmer. 


\section{ENOTHERA, Linn.}

Calyx-tube more or less prolonged above the ovary (obconic to linear), deciduous (except in \$ 2 ); segments reflexed. Petals 4, obcordate to obovate, sessile, yellow to white, often tinged with red or turning red in fading. Stamens 8 , equal or those opposite to the petals shorter; anthers perfect, versatile. Ovary 4-celled, manyovuled: style filiform: stigma 4-lobed or capitate. Capsule coriaceous or somewhat woody to membranaceous, dehiscing loculicidally and more or less perfectly 4-valved; the partitions more or less coherent to the valves. Seeds in 1 ог 2 rows in each cell, horizontal or ascending, often somewhat margined. - Herbs, or sometimes woody at. base; leaves alternate; flowers axillary, spicate, or racemose. - Watson, Proc. Am. Acad. viii. 573.

A genus of perhaps 100 species, almost exclusively American, there being over 50 in the United States and most of the remainder Mexican or South American. Many of them are ornamental and several have long been in cultivation. Our species are usually found frequenting dry valleys and hillsides.

* Calyz-tube linear above the ovary : anthers and stigma-lobes linear : capsule rigid-coriaceous.

Tall : flowers yellow, erect in the bud; calyx-tips free: seeds in two rows in each cell.

Low : flowers large, whitish, nodding in the bud : capsule narrow : seeds in 1 row.

Peremnial : calyx-tips free : capsule linear : seeds not compressed.

Smooth or puberulent : calyx not villous: seed terete, narrowly oblong.

Villous and pubescent: seeds oblong, turgid, somewhat angled.

Annual, villous and pubescent: calyx-tips not free: capsule thicker toward the base : seeds ovate-oblong, compressed.

Acaulescent or nearly so : flowers large, erect in bud : capsule ovateoblong, winged or crested : seeds in 2 rows.

Capsule strongly ribbed or tuberculately crested: more or less pubescent.

Capsule winged at the angles : nearly glabrous.

1. E. BIENNIS.

2. E. ALBICAULIS.

3. CE. Californica.

4. CE. TRICHOCALYX.

5. CE. CESPITOSA.

6. E. TRILOBA.

* * Calyx-tube filiform : anthers oblong : stigma capitate : capsule ovoid-oblong, membranaceous, sessile : seeds in 2 rows. Acaulescent, mostly perennial : flowers yellow, ereet in bud, tips of calyx not free.

Densely pubescent : leaves deeply pinnatifid.

Glabrous: leaves oblauceolate, nearly entire.

Somewhat pubescent: leaves ovate- to oblong-lanceolate, entire, ciliate: seeds punctate.

Annual, dwarf, hirsuite: Ieaves linear : capsules winged above.

7. E. Nuttalli.

8. E. Heterantha.

9. E. OVATA.

10. E. GRACILIFLORA.

* * Calyz-tube obconic : anthers oblong : stigma capitate : capsule narrow, membranaceous, sessile: seeds in 1 row : caulescent, mostly annual.

Flowers axillary, yellow, mostly showy, often turning green : capsule usually contorted, sharply 4-angled.

Canescently prbescent: leaves thick, mostly entire : maritime, often woody at base.

More or less hirsute : leaves thimner, denticulate.

Petals 4 to 7 lines long, usually with a brown spot at base.

Petals a line or two long, not spotted.

Flowers axillary, yellow, mostly very small and usually turning red.

Capsule elongated, very narrowly linear, obtusely angled : slender, with narrow leaves.

More or less hirsute : petals rarely reddening : capsules shortly beaked.

Somewhat appressed-puberulent or hirsute : petals usually reddening : capsules obtuse, often pedicellate.

Capsule short, attenuated upward from the base : dwarf.

11. E. CHEIPANTHIFOLIA.

12. E. BISTORTA.

13. E. MiCRANTHA.

lowers in a nodding spike, white or rose-colored : capsule narrowly linear, terete, much contorted.

\section{E. DENTATA.}

15. E. STRIGULOSA.

16. E. ANDINA. 
Canescently puberulent, slender: leaves nearly entire: capsitule very slender, not attenuate upward.

Viscidly pubescent: leaves denticulate: capsule attenuate from the base.

Glabrous : stem white and shining: spike nearly erect: capsule attenuate from the base.

17. QE. ALTSSOIDES.

18. E. Bоотніr.

19. E. GATREFLORA.

* * *apsule pedicellate, linear or somewhat clavate, obtuse, not contorted: otherwise as in the preceding.

Flowers in a nearly naked raceme : calyx-tube funnelform.

Leaves all near the base, usually lyrate.

Puberulent or nearly glabrous : calyx-tips not free: capsule an inch long or less.

20. E. SCAPOIDEA.

Villous: calyx-tips free, stout : capsule 1 to 3 inches long.

21. C. BRETIPES.

Leaves scattered, cordate or ovate: calyx-tube long-funnelform ; tips not free.

Flowers with leafy bracts, very small : calyx-tube obconic: seeds with involute margins : dwarf, slender.

22. E. CAIDIOPHYLLA.

23. E. TTLROSPELMA.

\$1. Calyx much prolonged beyond the nvary: stamens neavly equal; anthers linear or linear-oblong: stigma-lobes linear: capsule coriaceous. - EvenotHERA.

* Tall, erect: flowers yellow, in a leafy spike, erect in the bud, opening at evening: tips of the calyx-lobes free: capsule narrowly oblong, sessile, straight: seeds in 2 roros in each cell. - Evening Primrose.

1. $\boldsymbol{E}$. biennis, Linn. Biennial, stont and usually simple, 1 to 5 feet high, canescently puberuleut and more or less hirsute: leaves lanceolate to oblong- or rarely ovite-lanceolate, acute or acuminate, 2 to 6 inches long, reprandly ilentieulate, mostly sessile : calyx-tube 1 to 212 inches long: putals 6 to 9 lines long: calysule about an inch long or less: seets oluloner, with sonuewhat mawined angles.

Var. grandiflora, Lindl. Petals as long as the calyx-tule: capsule more or

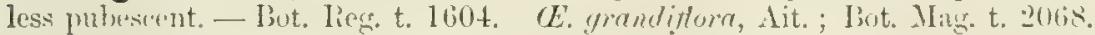

Var. hirsutissima, Gray. Flowers is in the last, but the orary celnecially more hirsute. - Pl. Fendl, 43. OE. Hooker, Torr. \& Gray, Fl. i. 493.

From Oregon to the Atlantic and from British America to Mexico; forms of it are also widely naturalized in Europe (where it has long been cultivated), as well as in S. Africa, India, and Australia. The var. hirsulissima is the more common form in California, ranging to New Mexico, the others being more prevalent east of the Sierra Nevada.

* Usually low: stems white: flowers large, white becoming pinkish, axillary, nodding in bud, opening by day: capsules long and narrow, sessile, often curved: seeds in a single row in each cell, ascending.

2. $\boldsymbol{\Phi}$. albicaulis, Nutt. Glabrous or pubemlent: stems herbaceous, from a

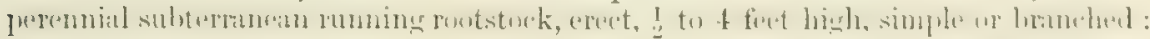

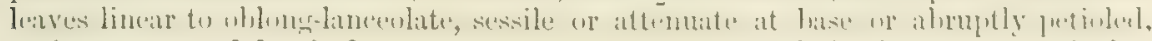
entire or repand-denticulate or sinuate-pinnatifid toward the base, 1 to 3 inches long: tips of the calyx-lobes free in the bud; the tube an inch long or less: petals about as long as the tube, entire or emarginate: capsulo an inch or two long, not

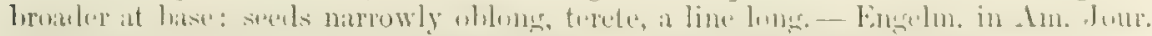

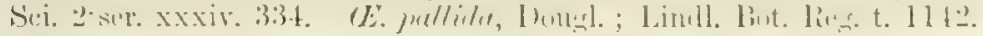

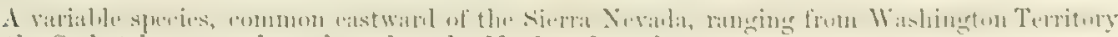
to the Saskatchewan and southward to the Mexicas boundary.

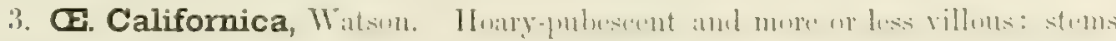
herbaceous from a running rootstock, decumbent, about a span long: leaves narrowly

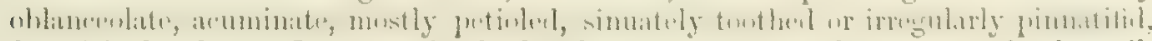
2 to 4 inches long: flowers as in the last but often larger; the ovary and calyx villous, and tho petals lobed with a rounded sinus: capsule 2 inches long, not thick-

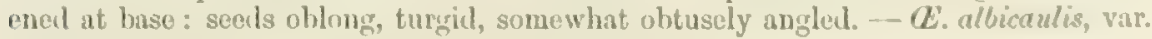
Californice, Watson, Proc. Am. Acad. viii. 58:. 
Central and Southern California : at Larken's station, east of San Diego (Palmer) ; Fort Mohave (Cooper); also by Wallace, and others. Flowers fragrant.

4. $\boldsymbol{E}$. trichocalyz, Nutt. A very similar species in appearance, glabrous or canescently puberulent or somewhat villous: root annual : stem mostly erect, often stout, a span high: calyx very villous, the tips of the lobes not free in the bud: petals large, usually with a deep sinus: capsule thickened toward the base: seeds ovate-oblong, somewhat compressed. - Torr. \& Gray, Fl. i. 494. EE. deltoidea, Torr. in Fremont Rep. 315; Watson, Bot. King Rep. 107.

Chiefly eastward of the Sierra Nevada from Northern California to Arizona and New Mexico; Fort Mohave (Cooper) ; also in Corrul Hollow and Tulare Plain, Brewer.

* * Acaulescent or nearly so: flowers large, axillary, erect in bud, opening by day: capsule ovate or ovate-oblong, mostly sessile: seeds large, in 2 rows in each cell.

5. ‥ caspitosa, Nutt. Glabrous or usually more or less villous with spreading hairs: root apparently biennial: leaves oblong to narrowly oblanceolate, on long petioles, usually irregularly sinuate-toothed or repand-denticulate, often somewhat pinnatifid: calyx-tube 2 to 7 inches long, the tips of the lobes not free in the bud: petals white or rose-color, broadly obcordate, $\frac{3}{4}$ to $1 \frac{3}{4}$ inches long: capsules ovate-oblong, attenuate above, usually sessile, 1 to $1 \frac{1}{2}$ inches long, strongly ribbed on the sides and with a thick more or less tuberculate crest on each side of the sutures: seeds $1 \frac{1}{2}$ lines long, oval-oblong, with a narrow groove along the ventral side, minutely tuberculate on the back. - Sims, Bot. Mag. t. 1593. EE. montana \& E. marginata, Nutt. in Torr. \& Gray, Fl. i. 500; Hook. f. Bot. Mag. t. 5828.

Near Carson City (Anderson, Stretch); Oregon (Nevius); and frequent eastward to the Upper Missouri, Nebraska and New Mexico.

6. ๔. triloba, Nutt. Nearly glabrots: root annual or biennial: leaves narrowly oblanceolate, often large, usually irregularly pinnatifid with narrow lobes: calyx-tube 2 to 4 inches long, the tips of the lobes free in the bud: petals yellow, broadly obovate, $\frac{1}{2}$ to $1 \frac{1}{2}$ inches long, somewhat $3-5$-nerved: capsule sessile, oblong to obovate with more or less broadly winged angles, 9 to 15 lines long, usually somewhat beaked above, the sides ribbed and at length net-veined: seeds a line long, angled and minutely tuberculate. - Hook. Bot. Mag. t. 2566.

Sierra Valley (Mrs. Ames, Lemmon); Truckee Valley (Watson); Oregon (Nevius); and eastward to the Saskatchawan, Colorado and Texas.

\$ 2. Calyx-tube filiform above the ovary, somewhat persistent: stamens opposite to the petals shorter; anthers oval or oblong: stigma capitate: capsule sessile, ovateoblong to linear, somewhat membranaceous: seeds ascending, in 2 rows in each cell: flowers yellow, erect in bud and the tips of the lobes not free: acaulescent. - TARAXIA.

7. ש. Nuttallii, Torr. \& Gray. Canescently pubescent: root biennial or perennial : leaves narrowly oblanceolate, 2 to 6 inches long, petioled, deeply sinuate-pinnatifid; the numerous very unequal segments usually rounded or obtuse: calyxtube 1 to 21 inches long: petals about half an inch ( 5 to 9 lines) long: capsules rarely developed, narrow, attenuate upward, 6 to 10 lines long, obtusely 4-sided: seeds oblong, terete, a line long, obscurely lined.-FI. i. 506. QE. tanacetifolia, Torr. \& Gray, Pacif. R. Rep. ii. 121, t. 4; Watson, Bot. King Exp. 110.

At the eastern base of the Sierra Nevada, from Carson City (Anderson, Stretch, \&c.) to the Columbia River.

E. BREvifloRA, Torr. \& Gray. A similar species, but nearly glabrous, flowers smaller and shorter, and segments of the leaves acute or acutish : seeds more numerous, half a line long. Oregon (Nevirs) to W. Wyoming and Colorado; may be found in the northern part of the State.

8. $\boldsymbol{\omega}$. heterantha, Nutt. Nearly glabrous: root biennial or perennial : leaves oblong-lanceolate, acute or acuminate, entire or slightly repand-denticulate, 6 inches 
long: calyx-tube 1 to 3 inches long: petals 3 to 6 lines long: capsules oroidoblong, narrowed at each ent, nearly an inch long, rather acutely anderl, sumetimes shortly pedicellate: seeds miuutely pitted. - Torr. \& Gray, Fl. i 507.

Tar, taraxacifolia, Watson. Leaves larger, mure or less lyrately pinuatifid. Proc. Am. Acad. viii. 589.

East of the Sierra Nevada in moist meadows, from N. Nevada to Idaho and Utah; the variety in Plumas and Sierra counties (Mrss. Ames, Lcmmon), and mear Austin, Nevada, Watson.

9. E. ovata, Nutt. Iirsembling the last: leaves ovate- to chlong-lanceolite, entire or denticulate, ciliate with short hairs: calyx-tube 1 to 4 inches long: petals 3 to 10 lines loner: rapsules oldusely amsletl, strongly torulese, short : seeds ovuidoblong, few, smooth, a line long. - Torr. \& Gray, Fl. i. 507.

Near the coast, from about San Francisco to Monterey.

10. G. graciliflora, Houk. \& Am. ('anescently villous: ront annual : leaves linear, short, entire or olsentrely denticulate: ealyx-tube mearly ergualling the leares, I. to 1! inclies long: petals wherdate, 3 to 5 lines long, turning greenish : eapsule somewhat coriaceous, half an inch long or less, angled at base and 4 -winged above the nilille; the wings oblinuely truncate and hairy: seeds smowth. - bot. beechey, 341 ; Hook. Ic. Pl. t. 338.

Dry hillsides and valleys near the coast, from the Sacramento River to Monterey.

\$ 3. Culyr-tube obromic or shortly funnelform: stamens somearhut uneunal; anthers oblong: stigna capitate: capsules narrow, sessile, terele or angled, membranaceous, often contorted: seeds ascending in 1 row in each cell. Caulescent annuals or biennials: flowers usually spicate: the tips of the calyx-tobes not free in the bud. - SpHerostigaA.

* Flowers arillury, yellow, often turuing greenish, mostly shrumy: crelyr-tube olyomic: capsules linear-oblong to linear, sharply 1-angled, often much contorled: seeds ovateoblong: stem leafy throughout or early specimens acaulescent.

11. CE. cheiranthifolia, Hornemann. Canesecntly puhescent: stems lecumhent. or ascending, often 2 feet long or more: leaves thick, oblong or narrowly oblanceo-

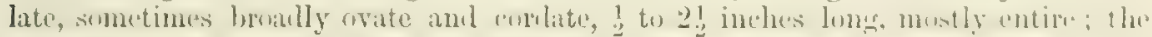

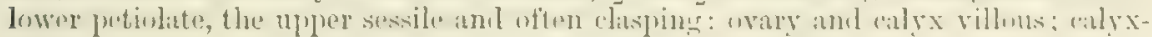
tube a line or two long, about half the length of the petals: capsules stont, linearoblong, 4 to 8 lines long: seeds oblong-ovate, compressed, smooth, nearly half a line long. - Lindl. Bot. Reg. t. 1040. E. spiralis, Hook. Fl. i. 214.

Va1. suffuticosa, Wiltsin. Winuly at hiso amd very leaty, densily lomary-

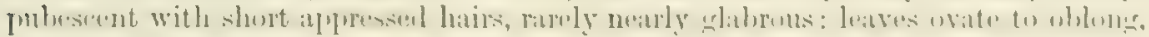
mostly small and sessile: flowers larger, the petals 4 to 9 lines long. - Proc. Am. Acad. viii. 592. E. viridescens, Hook. F1. i. 21 t.

Near the sea on dry drifting sands, often ahundant, from San Francisco southward ; the variety from Monterey to San Diego. The typienl form is said also to bo Chilian.

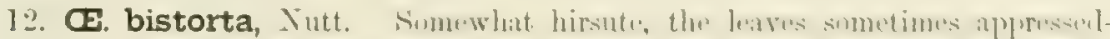
pubescent : stems rather stout, decumbent or ascending, a font or two high : leaves thimner, narrowly lanceolate to ovate, the upper mostly sessilo and rounded or cordate at base, all denticulate or dentate: petals 4 to 7 lines long, usually with a dark brown spot at base: capsule 4 to 9 lines long, a line or more wide, attenuate upward : seerls nearly black. - TorT. \& Gray, Fl. i. 508.

Var. (l) Veitchiana, Hook. More slender: capsule moro elongateel and merrowed ( 1 to $1 \frac{1}{2}$ inches long and less than a line broad), attenuato into a narrow beak. - Mot. Miag. t. 5078 .

On sand-lills nerr the sen, San Dingo; the variety from Los Angoles southwarl. Farly fower. ing speeimens are often very smull and nearly or quito acaulescent, much resembling UE., agracilio fora, from which they are readily distinguished by the linear ovary. 
13. C. micrantha, Hornemann. A very variable species closely resembling the last: flowers very small : the petals a line or two long, not spotted at the base, entire or emarginate or sometimes 3-lobed at the summit: capsules 8 to 18 lines long, about a line wide, usually much contorted. - Torr. \& Gray, Fl. i. 509.

From the Lower Sacramento to San Diego. Probably a mere variety of $E_{0}$. bistorta.

* * Flowers axillary, yellow, often reddish or tuming red, mostly very small : calyxtube obconic, very short.

+ Capsule elongated, very narrowly linear, obtusely angled, slightly curved: slender leafy annuals.

14. ․․ dentata, Cavanilles. Usually diffusely branched, a span high or less, more or less hirsute with short spreading hairs especially below, the pubescence above often shorter and somewhat glandular or wanting: leaves linear, sessile, usually narrowed at base, denticulate, $\frac{1}{2}$ to $1 \frac{1}{2}$ inches long : petals rounded, entire, 2 to 4 lines long, rarely reddening: capsules an inch long or more, less than half a line broad, somewhat attenuate at the summit. - Icon. iv. 67, t. 398; Torr. \& Gray, Fl. i. 511.

Var. cruciata, Watson. Petals narrowly obovate to oblong, often emarginate, 2 lines long. - Proc. Am. Acad. viii. 594.

From San Francisco southward; also in the foot-hills of the Sierra Nevada : less frequent than the following. A Chilian species; perhaps also Australian.

15. G. strigulosa, Torr. \& Gray. Like the last: nearly glabrous, the ovary and calyx usually somewhat appressed-puberulent: leaves entire or sparingly denticnlate: petals a line or two long, usually reddening : capsules sessile or upon a very short pedicel adnate to the base of the leaf, abruptly obtuse or scarcely attennate at the summit. - Fl. i. 512. E. contorta, Hook. Fl. i. 214. E. parvula, Nutt. in Torr. \& Gray, 1. c.

Var. pubens, Watson, I. c. Pubescence hirsute and spreading as in $\mathbb{E}$. dentata, especially below, often somewhat glandular above and shorter.

From the Columbia River to San Diego, frequent; the variety also ranging eastward throngh Northern Nevada to the Wahsatch Mountains.

$$
++ \text { Capsule shorter, attenuated upward from the base: dwarf annuals. }
$$

16. $\boldsymbol{E}$. andina, Nutt. Canescently puberulent, only 1 to 3 inches high, branched: leaves linear-spatulate, entire, attenuate into slender petioles, a half to an inch long: spikes leafy, many-flowered: petals a line long or less: capsules 3 to 6 lines long, obtusely angled, somewhat curved. - Torr. \& Gray, FI. i. 512.

From Oregon and N. W. Nevada to Colorado ; probably in Northeastern Califormia.

CE. Guadautpensis, Watson, Proc. Am. Acad. xi. 137, collected by Palmer on Guadalupe Island, is stouter, with larger oblanceolate leaves, few flowers, and the capsule oblong-pyramidal, half an inch lung, rather acutely angled.

* * * Flowers white or rose-colored, in a nodding spilie: calyx-tube short-funnelform: capsule narrowly linear, terete or obtusely angled, much contorted: seeds linearoblong: annuals.

17. F. alyssoides, Hook. \& Arn. Slender, canescently puberulent: stems simple or branching from the base, erect or ascending, 3 to 12 inches high: leaves oblanceolate or oblong-lanceolate, narrowed into a slender petiole, entire or repanddenticulate, 1 to $2 \frac{1}{2}$ inches long; the floral leaves much smaller but similar: spike often many-flowered, becoming elongated: calyx-tube 2 or 3 lines long, equalling the rounded petals: capsules an inch long or less, very slender, not attentate upward from the base, puberulent: seeds ash-colored, very minutely pitted. - Bot. Beechey, 340 ; Hook. Ic. Pl. t. 339. 
Var. villosa, Watson, 1. c. More or less villous throughout.

Var. minutiflora, Watsun. Fluwers mush reluced, scarcely more than a line long. - Bot. King Exp. 111.

Through the interior from the base of the Sierra Nevada eastward to Utah.

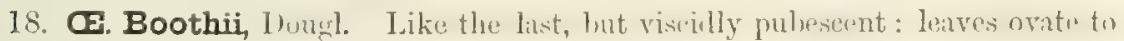
lanceolate: capsules somewhat bronder: seeds brownish, angled, very minutely tuberculate. - Hook. Fl. i. 213. E. pygmaca, Dougl. l. c.

Eastward of the Sierra Nevada from S. Oregon to N. W. Nevada.

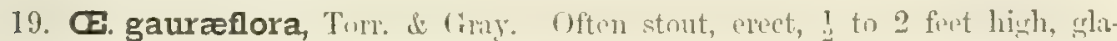
brous or the inflorescence and younger leaves sparingly puberulent; the bark loose, white, and shining: leaves lanceolate to narrowly oblanceolate, attenuate into the petiole, usually denticulate: spike often many-flowered, nearly erect: calyx-tubo and the obovate petals $1 \frac{1}{2}$ to 3 lines long: capsules attenuate from the base to a narrow beak, 8 to 15 lines long: seeds dark, a line long, angled. - Fl. i. 510.

From the Lower Sacranento to the Colondo Desert and eastward to S. Utah.

\$ 4. Capsule pedicellate, linear or somewhat clavate, obtuse, not contorted: otherwise as in $\$ 1$. Caulescent annuals: tips of the calyx-lobes sometimes free in the bud. - Cir lisMia.

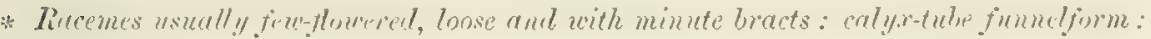
seeds narrowly oblong, smooth: leaves mostly lyrate or pinnatifid.

20. CE. scapoidea, Nutt. Erect, usinily hranching from near the lase, y to 1 ? feet high, puberulent or nearly glabrous: leaves mostly near the base, with long petioles, lymately pinnate; the terminal leaflet nuch the largest, ovate to oblonglanceolate, cuneate or cordate at base, sinuate-toothed, the prominent veins often darker colored; lateral leaflets few or many, sometimes wanting, very irregular: raceme at first nodding; bracts very small or none: calyx-tube a line or two long ; tips not free: petals yellow, 1 or 2 lines long: capsules glabrous, clavate, 4 to 12 lines long: pedicels spreading, 2 to 8 lines long. - Torr. \& Gry, Fl. i. 506.

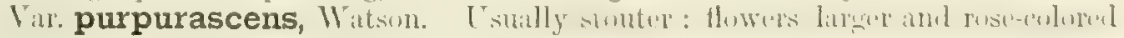
or purplish, rarely yellow: calyx-tube 2 or 3 lines long : petals 3 or 4 lines long. Proc. Am. Acad. viii. 595. EE. clavnformis, Torr. \& Gmy, Pacif. R. Rep. ii. 121. Q. cruciformis, Kellogg, Proc. Calif. Acad. ii. 227, fig. 71. QE. scapoidea, var. clavreformis, Watson, Bot. King Exp. 109.

Var. aurantiaca, Watson, 1. c. Low : inflorescence puberulent: flowers of the size of the last, but the calyx-tube tinged more or less deeply with orange: petals light rose-color or orange: capsule usually puberulent. - $Q$. claveformis, Torrey in liremont liep. 314.

On the castem side of the Siern Nevala from Oregon to Nono Lake, W. Wyoming and Utals; the var, aurantiece from Southeastern Califoruis to Sonthern Utah.

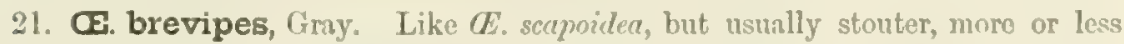
villous with stiff hairs, not puberulent: calyx-tubo obconic to fumelform, 1 to 3 lines long; the lobes strongly nerved and their stout tips freo: petals apparenlly pale yellow or whitish, 3 to 6 lines long: capsules 1 to 3 inches long, 1 f lines broad: pedicels 2 to 12 lines long. - Pacif. R. liep. iv. 87.

Near the Coloralo River and enstward to Southem Ltah.

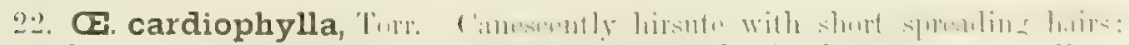
stems lenfy, often rather slender, 3 to 10 inches high, simple, erect or nsemeling: leaves simple, corlato or ovato, repanilly serrate, lone-potioled, an inch long or less: calyx-tube rather narrowly funnelform, 3 to 8 lines long, usually tingenl with red; tips of tho lobes not free : petals yellow becoming redlish, 3 or 4 lines long : eapsule 3 to 1 inch long: peiticel only 1 to 3 lines long. - Pacif. R. Linp. v. 360 .

Near the Colomilo River, and enstward in Arizona. 
* Flowers fero, with leafy bracts: calyx-tube short, obconic: leaves simple: tips of the calyx not free in the bud.

23. ‥ pterosperma, Watson. Slender, erect, 2 or 3 inches high, simple or branched, more or less hispid or glabrous: leaves oblong-lanceolate, obtuse, entire, 6 to 9 lines long: flowers very small: petals obcordate, rose-colored, a line long or less: capsule linear-clavate, 6 to 9 lines long, on a spreading pedicel half as long: seeds nearly a line long, with thin incurved margins, minutely cellularly papillose. - Bot. King Exp. 112, t. 14.

Foot-hills of the Trinity Mountains, N. W. Nerada (Watson); S. Utah, Parry. Very pecnliar in the character of its seeds.

\section{GODETIA, Spach.}

Calyx-tube above the ovary obconic or shortly funnelform, deciduous; lobes reflexed. Petals 4, broad and sessile, entire or emarginate or very rarely 2-lobed, lilac-purple or rose-colored. Stamens 8, unequal, the filaments opposite to the petals shortest; anthers perfect, oblong, attached at the base and erect or arcuate. Ovary 4-celled, many-ovuled: style filiform: stigma-lobes short, linear or roundish. Capsule ovate to linear, 4-sided, somewhat coriaceous, loculicidally dehiscent. Seeds ascending or horizontal, in 1 or 2 rows, obliquely angled, the upper surface with a thin tuberculate margin. - Annuals, simple or branched, erect; leaves alternate, denticulate or entire; flowers mostly showy, in usually leafy racemes or spikes. Enothera § Godetia, Torr. \& Gray, Fl. i. 502 ; Watson, Proc. Am. Acad. viii. 596.

A genus confined to the western coast of North and South America, chiefly Californian. Several of the species are ornamental and have been introduced into cultivation.

* Flowers in a strict mostly compact spike : capsule ovate to oblong : stems leafy.

Calyx-tips not free in the bud: sides of the eapsule not 2-costate: seeds in 2 rows.

Flowers very large : stigma-lobes 3 lines long : capsule puberulent.

Petals $\frac{1}{2}$ inch long or less : stigma-lobes very short : capsule villous.

Calyx-tips slightly free: capsule somewhat 2-costate on alternate sides: seeds in 1 row.

Flowers in a short simple spike : petals 1 inch long or less.

Flowers in lateral mostly crowded spikelets : petals half an inch long or less.

1. G. GRANDIFLORA.

2. G. PURPUREA.

3. G. LEPIDA.

4. G. ALBESCENS.

* * Flowers in a simple usually loose spike or raceme, mostly nodding in bud : capsule linear : seeds in 1 row: leaves distant.

Capsule sessile : calyx-tips slightly free.

Calyx-tube funnelform and villous; lobes villous : capsule short, puberulent, attenuate from the base.

Ovary and short eapsule villous: flowers small.

Capsule puberulent, 8 to 14 lines long, not costate: flowers small.

Capsule smoother, 8 to 18 lines long; sides 2-costate: flowers large.

Capsule pedicellate, not costate : calyx-tips not free.

Capsule attenuate at each end.

Anthers purple: stigna-lobes linear : petals 8 to 15 lines long: capsule 1 to $1 \frac{1}{2}$ inches long: leaves mostly entire. Central and Northern California.

Stigma-lobes mostly short : petals 6 to 12 lines long : capsule 10 to 15 lines long, long-pedicellate: leaves often dentate : nearly glabrous. Southern California.

Tomentose-puberulent: stigma-lobes short: petals 3 to 6 lines long : capsule 6 to 14 lines long: pedicels short.

5. G. WILLIAMSONI.

6. G. QUADRIVULNERA.

7. G. TENELLA.

8. G. VIMINEA.

Capsule abruptly narrowed at base.
Calyx and ovary with short spreading pubescence : stigma-Iobes linear : capsule 4 to 9 lines long.

Puberulent : pedicels short : petals 2-lobed.

9. G. AMGNA.

10. G. BотT止.

11. G. EPILOBIOIDES.

12. G. HISPIDULA.

13. G. BILOBA. 
* Flowers in a strict mostly compact spike: stems leafy: capsule ovate to olitung.

+ Tips of the crely.x-lobes not at all free in the bul: sides of the capsule not :-trstute: seeds in 2 rous in each cell.

1. G. grandiflora, Lindl. Puberulent: stem a fuot or two high, stunt, simple or with a few short hranches near the top : leares lanceulite", 2 or 3 inches limer acute at each ent, shortly petioled, uhseurely repand-denticulate or entire: spike dense, leafy: calyx-tube broadly obconical, 4 to 6 lines long: petals an inch or two long, emarginate, light purple with often a linge: crimson spot in the centre: stinnit-lubes linear, 3 lines long: capsule puberulent, ublong to linear, 8 to 15 lines long, a line or two broad or more, 4-toothed at the apex: seeds in 2 rows in each cell. - Bot. Reg. xxvi, t. 61. Enothera Whitneyi, Gray, Proc. Am. Acad. vii. 340 \& 400; Hook. f. But. Mag. t. 5867. E. grandiflora, Watson, 1. c. 596.

On hillsides, Humboldt and Mendocino counties, Bolander, Kellogg \& Harford. With larger flowers than any other species; in cultivation.

2. G. purpurea Watson. Mostly very leafy, a fixut or two bigh, puherulent, the orary lensely villous: leaves oblong to oblunin-oblancenlate, usually an inch or two long, entire, sessile with an obtuse or narruwed hase: Howers mustly in a leafy terminal cluster: calyx-tulye 2 or 3 lines long, half the length of the cleep' purple petals: style shorter than the stamens ; stigma-lobes very short, purple: catrisules ovate to linear-oblong, 6 to 9 lines long, 2 to 21 lines broad, acute, obtuse at base, hairy; the silles nearly flat, with a strong milvein. - Enothere purpureu, C'urtis, Bot. Mag. t. 352 ; Watson, 1. c. Godetia Willdenoroiana, Spach.

From the valley of the Columbia to Monterey.

++ Tips of the caly.x-lobes slightly fiee in the bud: copsule 2-costate on at least the alternate sides: seeds in one row in each cell.

3. G. lepida, Lindl. Cancsently puherulent, the stem usually white aml

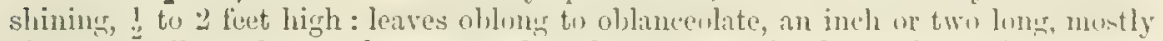
obtuse, sessile and scarcely narrowed at base, sparingly denticulate: flowers in a short simple spike: calyx-tube 2 or 3 lines long: petals rose-colored with a dark spot near the summit, 9 to 12 lines long: stigmas very short, purple: capsule short hairy, 5 to 8 lines long, 2 lines broad near the base and attenuate to the apex. Lot. Reg. t. 1849. Enothera lepich, Hook. \& Arn. Bot. Beechey, 342.

Vir. parviflora, Witson, l. e. Fluwers and ealjsules somewhat smaller; the?

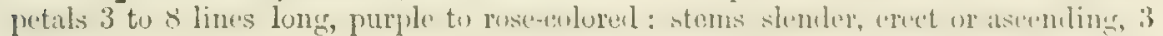
inches to 3 feet high : leaves linear to obloug, a half to an inch long. $-E$. decum-

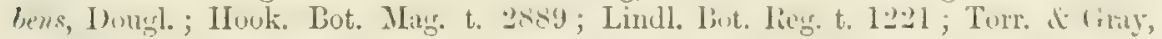
Fl. i. 504 .

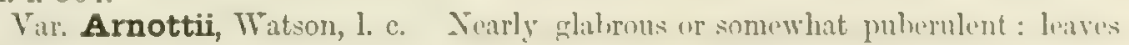
linear to lanceolate, acute, entire or sparingly denticulate, 1 to $1 \frac{1}{2}$ inches long:

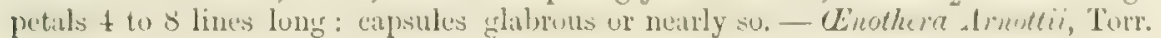
\& Gray, 1. c.

From the Columbia River to Monterey and San Simeon.

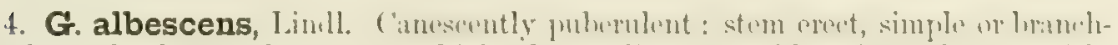
ing from the base, a foot or two high: leaves linear to oblong-lancoolate, acutish,

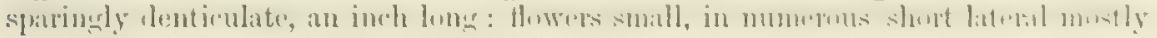

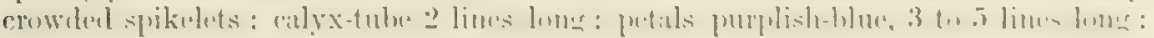
stigmas greenish to purple: capsules oblong, 3 to 6 lines long, 1 l lines broal, shortly hirsute or puhescent. - Bot. Reg. xxviii, t. 9. Enothera albescens, Watson, I'roc. $\Lambda$ m. Acul. viii. 597.

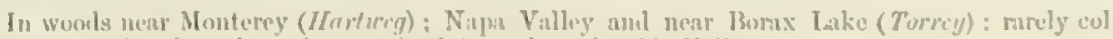
lected. Said to lave been tirst received from tho Colambia Valley. 
* Flowers in a simple spike or raceme, usually scattered and mostly nodding in bud: capsules linear: seeds in one row: stems slender, with leaves rather distant.

+ Capsules sessile: calyx-tips slightly free. Exceptions in No. 8.

5. G. Williamsoni, Watson. Canescently puberulent, the calyx-tube and lobes villous: stem erect, a foot high: leaves linear, sessile, entire, 1 to 1 inches long: calyx-tube funnelform, 3 to 5 lines long; tips of the lobes free: petals yellow at base and with a deep purple spot in the centre, 6 to 12 lines long: stioma-lobes short, oblong, yellow: capsules attenuate upward from the base, 6 to 8 lines long, puberulent, 2-costate on the sides. - Enothera Williamsoni, Durand \& Hilgard, Pacif. R. Rep. v. 7, t. 5 ; Watson, 1. c. 597.

In the foot-hills of the Sierra Nevada from Millerton (Hcermann) to Placer Co, Rattan.

6. G. quadrivulnera, Spach. Puberulent, ovary and capsule more or less villous: stem usually very slender, a foot or two high : leaves linear to linear-lanceolate, sessile or attenuate to a short petiole, entire or slightly denticulate, an inch or two long: calyx-tube obconic, 2 (rarely 3) lines long: petals deep purple or purplish, 3 to 6 lines long: stigma-lobes short, purple: eapsules 5 to 10 lines long, usually short, attenuate at the apex, 2-costate at the alternate angles. - Enothera quadrivulnera, Dougl. ; Lindl. Bot. Reg. t. 1119 ; Watson, l. c. 598.

Near the coast from Puget Sound to San Diego.

7. G. tenella, Watson. Puberulent, erect and slender, 6 to 18 inches high, very rarely decumbent: leaves linear, acute or obtuse, mostly entire, more or less attenuate at base, $\frac{1}{2}$ to 2 inches long: calyx-tube shortly obconic, 1 to 3 lines long; tips of the lobes rarely not free: petals deep purple, 3 to 5 lines long: style shorter than the stamens; stigma-lobes purplish : capsules puberulent, attenuate at the apex, 8 to 14 lines long, nearly flat upon the sides. - Enothera tenella, Cav. Icon. iv. t. 396, fig. 2; Ruiz \& Pavon, Fl. Peruv. iii. t. 316 ; Sweet, Brit. Fl. Gard. t. 167. Godetia Cavanillesii, Spach, Monog. Onagr. 71.

Near the coast from Oregon to San Diego; also in Chili and Peru.

8. G. viminea, Spach. Like the last: sometimes stout, 1 to 3 feet high: leaves linear to linear-lanceolate, entire, narrowed at base, an inch or two long: ealyx-tube 2 to 4 lines long: petals deep purple or purplish, sometimes yellowish at base with a dark spot in the centre, 9 to 15 lines long: capsules smoothish, 8 or 18 lines long, 2-costate on the sides, occasionally shortly pedicellate. - Monog. Onagr. 69. Enothera viminea, Dougl. ; Hook. Bot. Mag. t. 2873 ; Lindl. Bot. Reg. t. 1220.

From the Columbia southward to the Sacramento, and in the Sierra Nevada to the Yosemite Valley.

G. Romanzovir, Spach (Enothera, Ledebour), is known only from cultivated specimens, originally from seeds collected by Chamisso on the "Northwest Coast." It is rather stout, puberulent, the ovary white with a silky pubescence : leaves oblanceolate, petioled : calyx-tube very short, and tips not free : filaments stout, the alternate anthers nearly sessile; stigmas included within the calyx-tube: capsule attenuate at each end, sometimes shortly pedicellate, the sides 2-eostate.

++ Capsules pedicellate, not costate: stigma-lobes mostly yellow: calyx-tips not free in the bud, or rarely so in the first species.

9. G. amcena, Lilja. Minutely puberulent, usually slender, a foot or two high: leaves linear to narrowly oblanceolate or sometimes lanceolate, entire or nearly so, petiolate, 1 to 3 inches long: calyx-tube obeonic, 2 to 4 lines long: petals frequently rather villous (as also the purple anthers), varying from nearly white to rose-color, with more or less of purple, 8 to 15 lines long: filaments rather stout: stigma-lobes linear, $1 \frac{1}{2}$ lines long: capsules 1 to $1 \frac{1}{2}$ inches long, attemate to ench end: pedicel 2 to 6 lines long. - Linnæa, xv. 265. Enothera amoena, Lehm. Nov. Act. Leop. xiv. 811, t. 45; Regel, Gartenfl. xiii. t. 443. W. roseo-clba, Horuem. W. Linalleyi, 
Dontrl.; Hook. Bot. Mass. t. 2832 ; Linıl. Bot. Reg. t. 1405. Godetia rubicunde \& G. vinosa, Lindl. Bot. Reg. t. 1856 \& t. 1880.

From Vancouvel Island and Fraser River to Santa Cruz; Plumas Co., Mrs. Ames.

10. G. Bottæe, Spach. Canescently puberulent or nearly glabrous, ereet or somewhat decumbent, 1 to $1 \frac{1}{2}$ feet high: leaves narrowly linear to lanceolate, entire or sparingly toother, an inch or two long, on slender petioles: calyx-tubo short:

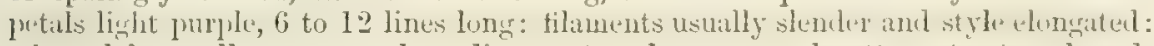
stigna-lobes yellow or purple, a line or two long: capsule attenuate at each end, 10 to 15 lines long: pedicel 3 to 9 lines long. - Enothera Botta, Turr. \& Gray, FL. i. 505 .

In the Coast Ranges, from Monterey to San Diego.

11. G. epilobioides, Watson. Tomentnsely puberulent, erect, 1 to 3 fert hierh: leaves linear to linear-lanceolate, entire or sparingly denticulate, an inch or two long, petioled: calyx-tube a line or two long: petals light purple or rose-color, 3 to 6 lines long: stigma-lobes short: capsules acuminate, attenuate to a short pedicel or rarely nearly sessile, 6 to 14 lines long. - Enothera epilobioides, Nutt.; Torт. \& Gray, Fl. i. 511 ; Watson, Proc. Am. Acad. viii. 599.

Frequent in the foot-hills of the Sierra Nevada upon both sides, and ranging from Oregon to Mariposa County and southward; San Diego, Nuttall, Thurber, Cloveland.

12. G. hispidula, Watson. Iispinl with short sprealing pulusener, esperially above, erect, mostly simple and often 1 -flowered, about a span high: leaves very narrowly limear, an inch or two long: calyx-tube 2 or 3 lines long: petals purple, 6 to 12 lines long: filaments rather slender: style elongated and stinua-lubes lineit: capsules attenuate at top, abruptly contracted at base, 4 to 9 lines long, perhaps costate: pedicels 2 to 4 lines long. - Enothera hispidula, Watson, 1. c. 599.

Sacramento and Tulare Valleys, Fromonl, Prallen, Rallan.

13. G. biloba, Watson. Minntely pulserulent, erect, a span or two hing : leaves nearly glabrous, linear or narrowly linceolate, an inch or two long, obscurely denticulate, the luwer on long slender petioles: ealyx-tube a line or two long: petals light purple, cuneate-obovate, more or less deeply 2-lubed, 4 to 9 lines long: eapsules puberulent, 6 to 9 lines long, attenuate at the apex, abruptly contructer at base into a perlicel about a line in length. - Enothera biloba, Durand, Pl. Pratten. 87; Watson, 1. c.

In tho foot-hills of tho Sierra Nevada from Tuolumne to Nevada counties.

\section{CLARKIA, Pursh.}

Calyx-tube obconical above the ovary, deciduous; the 4-cleft limb reflexerl.

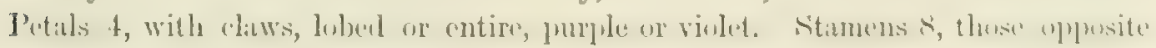

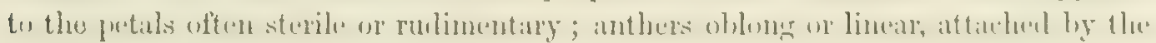
buse. Ovary 4-celled: stylo clongated: stigma with 4 broad lobes, sometimes unequal, at length spreading. Capsule linear, attenuate above, coriaceous, erect, somewhat 4-angled, 4-celled, and 4-valved to tho michlo. Secls numerous, angloul or margined. - Anmuals, with erect brittle stems and alteruate lonves on short slender petiules, the uppermost sessilo; flowers showy, nodding in tho bud, in terminal ritcemes.

A genus confined to our Pacific const, some of the species well known in cultivntion.

1. C. pulchella, Pursh. Stom ( $\frac{1}{2}$ to 2 feet high) and inflorescence puberulent:

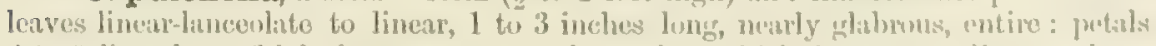
6 to 9 limes long, 3-lober, athunate to a long chaw which has a spremeling tonth on 
each side: perfect stamens with a linear scale on each side at base, the alternate stamens rudimentary and filiform: stigma-lobes equal, dilated: capsule 8 to 12 lines long, 8-angled, on a spreading pedicel 2 to 3 lines long: seed obliquely cubical, minutely tuberculate, two thirds of a line long. $-\mathrm{Fl} .260, t .11$.

Washington Territory, Oregon and Idaho; not yet collected in Califormia. Frequent in cultivation, in several varieties, and often figured.

2. C. Xantiana, Gray. Stem glabrous, about a foot high : leaves linear or narrowly lanceolate, entire, ashy-puberulent, as also the inflorescence: petals 2-lobed with a subulate tooth in the sinus; the claw short and broad, not hairy nor appendaged at base: stamens 8, all perfect, withont scales at the base: stigma-lobes broadly oval, short: capsule nearly sessile, 9 lines long. - Proc. Bost. Soc. Nat. Hist. vii. 145.

Near Fort Tejon, Xantus.

3. C. elegans, Dougl. Glabrous or puberulent, $\frac{1}{2}$ to 6 feet high, simple or branched: leaves broadly ovate to linear, repandly toothed: petals entire, rhomboidal; the long slender elaw without teeth: anthers all perfect; filaments with a densely hairy scale at each side of the broader base: stigma-lobes equal: capsule nearly sessile, 6 to 9 lines long, obtusely 4-angled, rather stont and often curved, somewhat villous. - Lindl. Bot. Reg. t. 1575. C. unguiculata, Lindl. Bot. Reg. under t. 1981. Phoeostoma Douglasii, Spach, Monog. Onagr. 74.

Valleys and hillsides, from Mendocino Co. to Los Angeles and the foot-hills of the Sierra Nevada. Common in cultivation.

4. C. rhomboidea, Dougl. Puberulent or nearly glabrous, 1 or 2 feet high: leaves oblong-lanceolate to -ovate, 2 inches long, the upjer narrower, all on slender petioles, entire: petals entire, rhomboidal, with a short broad claw which is often broadly toothed: anthers all perfect; filaments with hairy seales at the base: stigmalobes short: capsules 8 to 12 lines long, 4 -angled, nearly glabrous, on pedicels about a line long, - Hook. Fl. i. 214 ; Lindl. Bot. Reg. t. 1981. C. gauroides, Don in Sweet, Brit. Fl. Gard. 2 ser. t. 379. Opsianthes gauroides, Lilja, Linnaa, xv, 261.

Of wider range than the preceding, but not frequent. San Diego (Cleveland); in the Sierra Nevada northward to Washington Territory, and in the mountains eastward through Nevala to the Wahsatch.

\section{FUCHARIDIUM, Fischer \& Meyer.}

Calyx-tube linear-elongated above the orary. Stamens 4, opposite to the sepals, not appendaged at base. Otherwise as Clarkia, to which it should probably be referred. - Only the following species.

1. E. concinnum, Fisch. \& Mey. Glabrous or puberulent, closely resembling Clarkia rhomboidea in habit and foliage: calyx-tube nearly filiform, an inch long: petals 3-lobed, without teeth upon the claw, 6 to 9 lines long: filaments filiform: stigma-lobes unequal: capsules 8 to 12 lines long, sessile : seeds imbricated, papillose, concave and margined on the upper side. - Ind. Sem. Petr. ii. 11 ; Lindl. Bot. Reg. t. 1962 ; Hook. Bot. Mag. t. 3589. E. grandiflorum, Fisch. \& Mey. 1. c. vii. 40 ; C. A. Meyer, Sert. Petr. t. 13.

In the Coast Ranges from Santa Barbara to Mendocino County, and especially about the Bay of San Francisco.

2. E. Breweri, Gray. A foot high: leaves narrowly lanceolate, an inch long or moore, attenuate to a short petiole: calyx-tube 12 to 18 lines long: petals large, cuneate-obcordate, with a narrow subulate lobe in the deep sinus: filaments clavate: stigma-lobes linear: capsule stout, sessile, 15 to 18 lines long. - Proc. Am. Acad. vi. 532 .

On the dry summit of Mount Oso, Stanislaus Co., Brewer. 


\section{BOISDUVALIA, Spach.}

Calyx-tube funnelform above the ovary, deciduous; the lobes erect. Petals 4, obovate-cuneiform, sessile, 2-lubel, purple to white. Stamens $\&$, thuse olprosite to the petals shorter; filaments very slencler, nakel at base; anthers all juetiect, ul, long, attached near their base. Ovary 4-celled, several-ovuled: style filiform: stigna-lubes short, somewhat cuneate. Capsule membranaceuns, ovate-ublung to linear, nearly terete, acute, sessile, dehiscent to the base. Seeds ascencling, few (3 to 8 ) in one row in each cell, ovate-oblong, somewhat angled, smooth. - Frect leafy annuals; leaves alternate, sessile, simple; flowers small, in leaty simple on compound spikes. - Enothere \$ Boischevalie, Torr. \& Gray, Fl. i. 505; Witsun, Proc. Am. Acad. viii. 600.

A smill grenus confined to Western America, there being two Chilian species in adlition to the following.

1. B. densiflora, Watson. Canescently pubescent anil more or less villuns, often stout, $\frac{1}{2}$ to 2 feet high: leaves lanceolate to linear-lanceolate, acuminate, mostly denticulate, 1 to 3 inches long; the floral leaves usually much shorter and broader: flowers in a usually close terminal spike or numerous short lateral spikelets: calyx 1.t to 3 lines long, abont lailf the length of the petals: calpsules ovateoblong, smooth or slightly villous, 2 to 4 lines long; cells $3-6$-seeded, the partitions wholly seprarating from the vitves and ailherent to the placenta : seeds nearly or quite a line long. - Enothera densiflora, Lindl. Bot. Reg. t. 1593. Boisduvalia Douglasii, Spach, Monog. Onagr. 80, t. 31, fig. 2.

From Washington Territory to Monterey (Nuttalt), near Fort Tejon (Rolkrock), and in the foot-hills of the Sierra Nevada to Tuolumne County : near Carson City, Anderson. Very variable.

2. B. Torregi, Watson. Tillous throughout with short stiffish sprealing hairs, rather slender, a span or two high: leaves linear to lanceolate, usually narrow at base, entire or somewhat denticulate, 4 to 9 lines long; the floral leaves similar and searcely smaller: flowers in a loose simplo spike, very small (a line or two long), purplish: crpsules linear, acuminate, 4 to 6 lines long; cells 6 -8-sceded, the partitions adherent to the valves: seeds more ovate and smaller, half a line long or less. - Gayophytum strictum, Gray, Proc. Am. Acad. vii. 340. Enothera Turreyi, Watson, l. c.

Oregon (Hall) and southward in the Coast Ranges; New Almaden, Torrey.

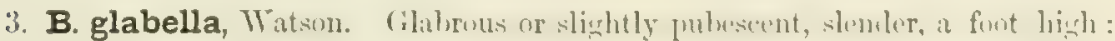
lenves ovate to oblong-lanceolate, acute, serrate, a half to an inch long; the flural bracts scarcely smaller: flowers in a simple spike, shorter than the leaves: petals deep purple, less than a liue long: capsules ovate-oblong, 2 to 4 lines long; partitions adherent to the valves: seeds 4 to 6 in ench cell, linear-lanceolate, a line long. - Enothera glebelle, Nutt.; Torr. \& Gray, F1. i. 505.

Vulley of the Columbia (Nuttall, Hall); Truekeo and Carson River valleys, Nevada, Bailey, Wutson.

\section{GAURA, Iinn.}

Calyx-tube prolonged beyond the obconic or clavate ovary; the 4-parted limb deciduous. Petals 4, with claws. Stamens 8 , nearly erjual; filaments furnishur with a scalc-like appendago on the inside next the base; anthers oval, versatile. Ovary 4-celled: ovules 1 to 2 in ench cell, pendulous: style filiform, hairy below: stigma 4-lobel, surrounted by an obseure ring or indusium. liruit nut-like, indehiseent or splitting at the spex, oblusely 1 -angled and ridged upon the sides. 
Herbs, with mostly sessile alternate leaves; flowers in spikes or racemes, white or rose-colored, turning to red.

A genus of about 20 species, belonging chiefly to the warmer portions of $\mathrm{N}$. America east of the Rocky Mountains, extending into Mexico.

1. G. parviflora, Dougl. Annual, usually with a dense soft spreading pubescence, ereet, 1 to 5 feet high: leaves ovate to lanceolate, repand-denticulate : flowers very small, in rather dense strict spikes: petals spatulate-oblong, scarcely unguiculate, shorter than the calyx-lobes : fruit 3 to 4 lines long, obscurely 4 -angled at the summit, 4-nerved, about 2-seeded, indehiscent. - Torr. \& Gray, Fl. i. 519; Bot. Mag. t. 3506 ; Watson, Bot. King Exp. 113. Schizocarya micrantha, Spach, Monog. Onagr. 62.

Fort Mohave (Cooper); Oregon (Douglas, Hall); Salt Lake (Watson) ; more common eastward from Colorado to New Mexico and Texas.

\section{HETEROGAURA, Rothrock.}

Calyx-tube with a short obconic prolongation above the small ovary ; limb 4-cleft, spreading, deciduous. Petals 4, entire, with claws. Stamens 8; filaments naked; anthers ovate-cordate, attached by the base and not versatile; those opposite to the petals on shorter filaments, lanceolate, acute, sterile. Ovary 4-celled, with a solitary pendulous ovule in each cell: style long: stigma discoid, entire. Fruit nut-like, indehiscent, obovoid, 2-4-celled, 1-2-seeded.-Rothrock, Proc. Am. Acad. vi. 354.

A single species : a Clarkia in every respect but the fruit and stigma.

1. F. Californica, Rothr. 1. c. Smooth or sparingly puberulent, 1 to $1 \frac{1}{2}$ feet high: leaves lanceolate, entire, 1 or 2 inches long, tapering to a slender petiole: petals purple, narrowly spatulate, 2 lines long : anthers very small : fruit 2 lines long, obovate, 4-angled, $1 \frac{1}{2}$ lines long, smooth, on a short spreading pedicel. Gaura heterantha, Torrey, Pacif. R. Rep. iv. 87.

In the mountains from Fort Tejon to Placer Co.

\section{CiRC开A, Linn. Enchanter's Nightshade.}

Calyx-tube slightly prolonged above the ovoid ovary, the base nearly filled by a cup-shaped disk; the limb 2-parted, deciduous. Petals 2, obcordate. Stareens 2, alternate with the petals; anthers small, nearly round. Ovary 1 -2-celled: ovule solitary in each cell, ascending. Fruit indehiscent, pear-shaped, covered with hooked bristles. - Low slender erect perennial herbs; leaves thin, opposite, petiolate; flowers small, white, in terminal and lateral racemes; fruit on slender spreading or deflexed pedicels.

A genus of 3 or 4 species, inhabiting cool damp woods throughout the northern portion of the hemisphere.

1. C. Pacifica, Ascherson \& Magnus. Mostly glabrous: stem usually simple, 1 to 1 foot high, from a perennial slender running rootstock: leaves ovate, rounded or cordate at base, somewhat acuminate, repandly denticulate, 1 to $2 \frac{1}{2}$ inches long; the slender petioles about as long: racemes without bracts: flowers half a line long: calyx white, with a very short tube: fruit a line long, rather loosely covered with soft hairs curved above, 1-celled, 1-seeded. - Bot. Zeit. xxix. 392. C. alpina, var. intermedia, Watson, Bot. King Exp. 113.

In the mountains from Washington Territory to the Yosemite Valley, and eastward to Colorado and the Saskatchewan. Distinguisher from $C$. celpine by its less toothal leaves, and more clearly from.C. Lutctiana by its snaller less actuminate leaves, smaller fowers, and smaller less bristly 1-celled fruit. 


\section{ORDER XL。 LOASACE旡。}

Herbaceous plants with either stinging or jointed and rough-barbed hairs, no stipules, calyx-tube adnate to a 1-celled ovary, parietal placenta, or sometimes : solitary suspended ovule, a single style, and anatropous seeds with a strainht embryo, mostly with little or no albumen. Stamens usually very numerous, rarely few and definite, some of the outer occasionally petaloid or intermediate between stamens and petals. Flowers perfect, often showy.

An American order (with one African exception), of about 100 species, many in ornannental cultivation, especially species of Loasa and Bluncrbachu of S. America (which twine and sting), and of our first two genera of no other economical importanee.

1. Mentzelia. Stamens many, inserted below the petals. Style 3-eleft at the aprex. Seeds few to many, on 3 parietal placentre.

2. Eucnide. Stamens many, adnate to the united hases of the petals and deciduous with then in a ring. Style 5-cleft. Seeds minute, very numerous, covering 5 expanded placentie.

3. Petalonyz Stamens 5. Stylo entire. Seed solitary.

\section{MENTZELIA, Linn.}

Calyx-tube cylindrical to ovoid or turbinate; the limb 5-lobed, persistent. Petals 5 or 10. Stamens numerous, inserted below the petals on the throat of the calyx and not adnate to them: filaments free or in clusters opposite the petals, filiform, or the outer more or less dilated or sometimes petaloid and barren. Ovary truncate at the summit, 1-celled: style 3-cleft, the lobes often twisted: ovules pendulous or horizontal, few to many in one or two rows on the three linear parietal placentie. Capsule short-oblong to cylindrieal, few-many-seceled, opening hy valves or usully irregularly at the truncate apex. Seeds flat or angled. - Annual or bieminil herls. erect, more or less rough with rigid tenacious barbed hairs, the stems becoming white and shining; leaves alternate, mestly cuarsely tuothed ur pinnitifid; fluwer: cymose or solitary, sessile or nearly so, orange, golden yellow, yellowish, or white.

About 30 species, nearly all confined to western North and South America; forming several wellmarked subgenera. Confined, like the other genera, to dry hillsides and valleys.

\$1. Seeds few, pendulous, ablong (1 to 2 lines long), somewhat flattened, not winged, minutely flexuous-striate longitudinally: petals 5, not large: filuments all filiform: leaves petioled, serrately toothed. - EuMExtzelia.

M. Aspera, Linn. Annual, slender : lenves hastately 3-lohed, on slender petioles : flowers axillary, sessile : potals about 3 lines long, but little exceeding the calyx-lobes: eapsule marrowly linear-clavate, an inch long. - A tropical species reaching to Lower California (Xientus), Sonom (Thurber), and Arizona (Kothrock), and to bo looket for in Southerstern California. This is the only species of true Menzelice that approatehes the borlers of the State.

\$2. Seeds pendulons, few to vather many, small, in I to 3 rows, irregnelurly angled or somevohat cubical, not winged, opreque, minutely tuberculate: jouters in terminal cymes, mostly small: calyx.limb 5-parted: petels 5 : filiements all viliform or the 5 outer more or less diluted: capsule lincur: leaness sessile, flut, sinuately loothed or pinnatifid: annuals. - Tracurpurtum, Torr. \& Cimy. (Trachyphylum, Nutt.)

1. M. albicaulis, Dougl. Slender, $\frac{1}{4}$ to 1 foot high or more: lenves linenr. lanceolate, pinnatifid with numerons narrow lohes, the upper leaves bromler and often lobel or toothed at base only : flowers mostly approximate near the ends of the brunches: calyx-lobes 11 to 2 lines loug, a little shorter than the spatulates on obovate petals: filaments not clilated: capsule linear-clavate, 6 to 9 lines long: seods numerous, rathor strongly tuborculate, irrgularly angled with obtuse marzilns, 
less than half a line long. - Torr. \& Gray, Fl. i. 534 ; Watson, Bot. King Exp. 113, excl. vars. M. Veatchiana, Kellogg, Proc. Calif. Acad. ii. 99, fig. 28.

Dry valleys and foot-hills in early spring. Southeastern California (Fort Tejon, Xantus; Mohave Creok, Bigelow, Cooper), and on the eastern side of the Sierra Nevada to Oregon; also eastward to Colorado and New Mexico. The tubereulate seeds distinguish it from the next two.

2. M. dispersa, Watson. Very similar to the last, but the leaves sinuatetoothed, sometimes entire, rarely pinnatifid, the uppermost often ovate: calyx-lobes a line long: capsule narrowly linear-clavate: seeds very often in a single row, somewhat cubical, more or less grooved upon the angles, very mearly smooth. - Proc. Am. Acad. xi. 137. M. albicaulis, var. integrifolia, Watson, Bot. King Exp. 114.

Washington Territory and Oregon to Colorado; Yosemite Valley (Bolander); Guadalupe Island, Palmer. Apparently confined to rather higher altitudes than the last.

3. M. micrantha, Torr. \& Gray. Leafy, branched, 1 to $2 \frac{1}{2}$ feet high : leaves ovate, an inch long or less, somewhat sinuately toothed: flowers clustered, shorter than the broad floral leaves: calyx-lobes a line long; the ovate petals a half longer: onter filaments more or less dilated: capsule broadly linear, 3 to 5 lines long: seeds few, irregularly angled, a line long, very mearly smooth. - Fl. i. 535. Bartonia micrantha, Hook. \& Arn. Bot. Beechey, 343, t. 85.

Rarely collected. California (Douglas, Wallace); Clear Lake (Torrey); Ojai, Peckham. Distinguished from the last by its foliage and habit, and especially by its shorter broader and fewseeded capsules and larger seeds.

4. M. congesta, Torr. \& Gray. Habit and foliage of $M$. albicaulis; a foot high: flowers clustered at the ends of the branches, conspicuously bracted with broad toothed bracts, which are membranaceous at base: calyx-lobes $1 \frac{1}{2}$ to 2 lines long: petals bright orange, 3 to 6 lines long : filaments all filiform : capsule clavate, half an inch long: seeds irregularly angled, minutely tuberculate, nearly a line long, - Fl. i. 534 ; Watson, Bot. King Exp. 114.

A rare species, on dry hillsides. Interior of Oregon (Nuttall); Sierra County (Lemmon); near Austin, Nevada, Watson.

5. M. gracilenta, Torr. \& Gray. Stems often simple, 1 to $1 \frac{1}{2}$ feet high : leaves narrowly lanceolate, pimnatifid with many narrow lobes or sometimes only coarsely sinuate-toothed: flowers usually clustered at the summit: calyx-lobes 2 to 5 lines long: petals obovate to oblanceolate, rounded or acutish at the apex, 4 to 8 lines long : capsule linear-clavate, $\frac{1}{2}$ to 1 inch long: seeds in 3 rows, irregularly angled, very minutely tuberculate, two thirds of a line long. - Fl. i. 534. M. albicaulis, var. gracilenta, Watson, Bot. King Exp. 114.

From Los Angeles northward to the Sacramento ; also in Northwestern Nevada, Watson. Possibly a small form of the next species.

6. M. Lindleyi, Torr. \& Gray. Slender, 1 to 3 feet high, branched: leaves ovate to narrowly lanceolate, 2 or 3 inches long, pectinately pinnatifid or only coarsely sinuate-toothed: flowers axillary and terminal: calyx-lobes 5 to 9 lines long, lanceolate: petals obovate, abruptly acurninate, an inch long: filaments all very slender: capsule linear-clavate, 12 to 15 lines long: seeds as in the last. Fl. i. 533. Bartonia aurea, Lindl. Bot. Reg. t. 3649 ; etc.

Rarely collected ; first found by Douglas, probably in Central California, and introduced into British gardens, and afterward by Bridges; Corral Hollow, Brewer: It is also reported as found by Bigelow on gravelly hills near the Colorado River, but this locality is somewhat uncertain.

\$3. Seeds numerous in double rows upon the 3 broad placenta, horizontal, flattened, suborbicular-winged, minutely tuberculate or nearly smooth: flowers often large and showy: calyx-limb 5-cleft nearly to the base: petals 5 or 10 : filaments numerous, the outer often more or less dilated or petaloid: capsule broad, oblong: leaves sessile (or petioled in No. 8), simuately toothed or pinnatifid: biennials. - Bartunia, Torr. \& Gray. (Bartonia, Nutt.) 
7. M. Levicaulis, Torr. \& Gray. Stout, 2 or 3 feet high, branching : leaves lanceolate, 2 to 8 inches long: flowers sessile on short branches, very large, light yellow, opening in sunshine: calyx-tube naked, the lobes 1 to $1 \frac{1}{4}$ inches long: petals atcute at each end, 2 to 21 inches long, the filiments and slender style a little shorter: capsule $1 \frac{1}{4}$ inches long, 3 to 4 lines in diameter: seeds very minutely tuberculate, $1 \frac{1}{2}$ lines in diameter. - Fl. i. 535; Watson, Bot. King Exp. 114. Bartonia lavicaulis, Dougl.; Hook. Fl. i. 221, t. 69.

From Santa Barbara (Torrey) to the Columbia River, and more frequent east of the Sierra Nevada, in the valleys and on dry foot-hills, to Salt Lake and Western Wyoming. Other species of this section are common in Colorado and New Mexico.

8. M. tricuspis, Gray. Apparently annuil, 6 inches high or more, rather stout: leaves oblong-lanceolate, 2 or 3 inches long, acute or acuminate, cuarsely sinuatetoothed, attenuate at base to a petiole, the upper ovate and sessile: flowers sessile on the short branches: calyx-limb half an inch long: petals broadly spatulate, light yellow, 12 to 15 lines long: filaments very numerous, shorter than the calyx, linear, somewhat dilated above and marked by a transverse orange band, and prolonged into two lateral linear cusps nearly equalling the oblong-linear inther: style stout and rigid, 3-cleft, equalling the stamens: capsule half an inch loug. - Arn. Naturalist, ix. 271.

Only two specimens have been collected, one at Fort Mohave (Cooper), the other in S. Utah, Purry. The mature fruit and seed are unknown, and the slecies is probably to lee excluded from this section.

\section{\$ 4. Seeds few, oblong, pointed at base, olscurely angled, smooth and shining, some- what rugose: calyx-limb 5-cleft to below the middle: pelals 5: filaments all filiform: capsule urcenlate: leaves sessile, coarsely pinnatifid, with revolute margins: a cespitose perennial, very densely and tenaciously hispid.}

9. M. Torreyi, Gray. Stems several from a perennial root, much brunched and densely tufted, 3 to 6 inches high: leaves oblong, an inch long, acuminate, attrnuate at lase, deeply pinnatifid with about 2 ( 1 to 3 ) lukes on catch side, which are acuminate by the strong revolution of the margin: flowers solitary, axillary, shorter than the leaves: calyx-limb 3 lines long: petals oblanceolate, 5 lines long, pubescent on the outside: style cleft to the middle, not twisted : capsule ovate, contracted below the broad summit, 21 lines long: seeds a line long. - Proc. Am. Acad. x. 72 .

A very peculiar species, collected hy Dr. Torrey in the dry valleys of Humboldt County, Nevada, and also by Lemmon in similar localities in Washoe County.

\section{EUCNIDE, Zuccarini.}

Calyx-tube oblung; the limb 5-holud, presistent. Petals 5, uniterl at lase and inserted on the throat of the ealyx. Stamens numerues ; filaments all filiform, adnate to the base of the petals and ileciluons with them in a rime. Oyary slurtconical at the summit, 1-celled: style 5-angled, 5-cleft, the lobes often twisted: ovules very numerous, covering the 5 prominent expanded placentae. Capsulo

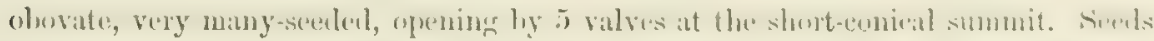

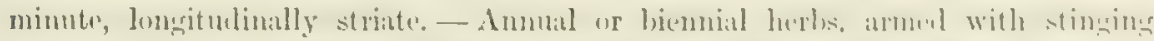

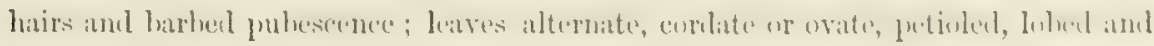
serrately toothed ; flowers yellow, pedicelled, in terminal cymes.

A genus of three species (or more), confined to Northern Mexico aud the adjacent region; male a section of Mcruzclia by Benthnm \& Hooker.

1. E. urens, Parry. Stout, low, very hairy and pubescent: leaves broally ovate, 1 or 2 inches long, cordate or rounded at base, obscurcly lobed, conrsely 
toothed, the upper sessile, the lower on rather short petioles: flowers large, on pedicels 3 to 6 limes long, in terminal bracteate cymes: calyx-lobes lanceolate, 6 to 10 lines long; petals twice longer, broadly spatulate, abruptly acuminate, hairy at the apex, united at base into a tube 3 lines long: filaments equalling the calyxlobes: style stout, cleft to the middle: capsule broadly obovoid, half an inch loug, opening by 5 erect valves as in the other species; the seeds also exceedingly numerous, linear-oblong, about a fifth of a line long, marked by a few longitudinal strix. - Am. Naturalist, ix. 144. Mentzelia urens, Gray, Proc. Am. Acad. x. 71, Am. Naturalist, ix. 271.

Collected by Bigelow in rocky arroyos near the confluence of the Williams River with the Colorado, and eastward to Southern Utah, Parry.

\section{PETALONYX, Gray.}

Calyx-tube very small, cylindrical, with 5 linear deciduous lobes as long as the ovary. Petals 5, with long connivent claws and ovate-spatulate blade. Stamens 5, with free filiform filaments, inserted with the petals on the outer edge of an epigynous disk; anthers small, didymous. Ovary l-celled: style simple, elongated: stigma entire: ovule solitary, pendulous from the summit of the cell. Capsule very small, oblong; bursting irregularly. Seed oblong, smooth. - Erect perennial herbs, or shrubby at base, pubescent or rough with short barbed hairs; leaves alternate, entire or toothed; flowers small, yellowish, in terminal heads or short leafy spikes. Three species, of Arizona and the adjacent region.

1. P. Thurberi, Gray. Stems 1 to 2 feet high from a somewhat woody base, branching: leaves ovate to oblong, an inch long or less, smaller and becoming bractlike ( 2 to 3 lines long) on the branches, sessile, acute, entire or rarely few-toothed; the floral bracts ovate, acminate, toothed at hase: flowers in short and dense spikes, sessile: calyx 2 lines long: petals light yellow, 2 lines long or more, slightly lispid : filaments and style half an inch long: capsule a line long, not angled or winged. - PI. Thurb. 319; Torrey, Bot. Mex. Bound. t. 22.

San Diego and San Bernardino counties, and adjacent parts of Arizona to S. Nevada, Thurber, Cooper, Schott, Palmer, \&c.

P. NITIDUS, Watson, is found in S. Nevada and probably extends into S. E. California; distinguished by its ovate petioled coarsely toothed leaves, rounded at base, not greatly reduced on the branches, and with a somewhat vitreous and shining surface.

P. PArliti, Gray, is a more eastern species, of S. Utah, decidedly shrubby, the leaves rhomboidal-ovate, cuneate into a short petiole, scarcely smaller above.

\section{Order XLI. CUCURBITACE两.}

Herbs, mostly tendril-bearing and climbing, rather succulent, with alternate and palmately reined or lobed leaves, no proper stipules; the flowers monocious or dioecious, with petals more connmonly united into a cup or tube and also blended with the calyx. Sterile flowers with $2 \frac{1}{3}$ stamens, that is, two complete, with 2-celled anthers, and one with a 1-celled anther; the cells usually long and contorted. Fertile flowers with calyx-tube adnate to a 1-celled or 2-3-celled ovary; the placentre either parietal, or confluent in or projecting from the axis. Seeds anatropous, without albumen.

A peculiar but familiar family, of great diversity as to the fruit, \&c., yet easy to recognize, widely distributer over the world, but mainly indigenous to warm regions. (hiefly important for the esculent fruits it produces (Nelon, Watermelon, Cneumber, Pumpkin, Squnsi, \&ce), and 
for the hard-rinded Gourd, used for vessels. Bnt the fleshy fruits of several are acid and progative (as in Llaterum and Colocynth, valuable in medicine), and so are the roots of all the perennial species. The Megarthiza-roots of California in this respeet, as in size, are like those of Bryony in Europe.

* Seeds dattened : cotyledons thin, rising out of the ground and foliaceous in germination : fruit fleshy : united calyx and corolla tubular-eampanulate.

1. Cucurbita. Flowers all solitary, large, yellow. Filaments distinct, but the flexuous anthers confluent.

2. Melothria. Sterile flowers racemose, small, yellowish. Filaments and anthers distinct; the cells of the latter straight. Berry small and juicy.

* * Seeds large, turgid : cotyledons thick and fleshy, remaining under ground in germination.

3. Megarrbiza. Flowers small, white; the sterile meemose. Corolla rotate. Fruit becoming dry and fibrous, few-seeded.

\section{CUCURBITA, Linn.}

Flowers monocious, solitary. Calyx-tube campanulato; lobes 5. Corolla campanulate, 5-cleft to the middle or lower; lobes recurved. Sterile flowers with the stamens at the base: filaments free; anthers linear, confluent, flexuous. Fertile flowers with 3 rudimentary stamens: ovary oblong, with 3 placentas and numerous horizontal ovules: style short: stigmas 3, 2-lobed. Fruit fleshy, indehiscent, often with a bard rind. Seed ovate or oblong, fiattened. - Annual or perennial, mostly prostrate and rooting at the joints; leaves cordate, lobed; tendrils compound; fluwers large, yellow; fruit often large.

A genus of half a dozen or more species, from some of which have come by cultivation all the many diflerent varicties of Pumpkin and Squash.

1. C. perennis, Gray. Root perennial, very large and fusiform: stems long, trailing: leaves thick and scabrous, slightly tomentose beneath, triangular-cortate, 6 to 12 inches long, 4 to 8 wide, acute, the basal lohes rounded or anglect, usuilly mucronately denticulate, rarely sinuato; petioles shorter than the leaves: tendrils 3-5-cleft: flowers violet-scented, 3 or 4 inches long, with obtuse mueronate luhes: calyx-tube half an inch long, equalling the linear lobes: ovary pubescent: fruit globose or obovoid, 2 or 3 inches in diameter, smooth, yellow, on a slender pedicel an inch or two long; shell filled with bitter fibrous pulp: seed thin, obovate, 4 or 5 lines long, obtusely margined. - Pl. Lindh. 193. Cucumis (3) perennis, James; Torr. \& Gray, Fl. i. 543.

Temeseal (Brexer), San Diego (Clevelund, Palmer), and through Arizona and Northem MEexico to Texas. The root sometimes descends 4 to 6 feet in the ground, with a circumference nearly as grent. In Southern Califormia the plant is known as Chili. Comote and Calabrzilln, and the pulp of the green fruit is used with sonp in wasling and to remove stuins from clothing. The macerated root is also used as a remedy for piles, and the seeds are eaten hy the Indians.

2. C. digitata, Gray. Root perennial, fleshy: stems slencler, elongated, usually prostrate and rooting: tendrils short and delicate, $3-5$-cleft: leaves seabrons, palmately 3-5-parted; the lobes narrowly lanceolate, 2 to 4 inches long, entire or - somewhat sinnate-toothed, or the lower lobed at base, abont equalling the petioles: flowers 2 or 3 inches long, acutely lobed, on slender pedicels 1 to 4 inches long: calyx-tube $\frac{1}{2}$ to 1 inch long, the marrow teeth only a line or two long: fruit subglobose, 2 or 3 inches in diameter, yellow, long-pedicelled: seeds thin, oval. - I'l. Wright. ii. 60 .

Lower Colomlo Valley to Now Mexico; autheutic specimens havo not been collected within the limits of the Stiste.

3. C. palmata, Watson. Canescent with short rongh pubesecnce, appressed on tho leaves: stems leafy: leaves thick, cordato in outliue, 2 or 3 inehes broul, pal- 
mnately 5-cleft to the middle with lanceolate acuminate lobes, which are often obtusely toothed near the base, usually exceeding the petioles: flowers 3 inches long, on stout pedicels, lobes acutish: calyx-tube an inch long, the teeth broader and three lines long or more: fruit globose: seeds 5 lines long. - Proc. Am. Acad. xi. 137.

San Diego County; Cajon Valley (Cleveland) ; Larken's Station, near the Jacumba Mountains, Pulmer.

4. C. Californica, Torrey in herb. Canescent with a short white rigid pubescence: leaves thick, 5-lobed, two inches broad, the triangular lobes acute or acuminate, mucronate : tendrils slender, parted to the base: flowers an inch long or more, on pedicels $\frac{1}{2}$ to 1 inch long; calyx 4 or 5 lines long, the linear teeth 2 lines long. - Watson, 1. c. 138.

Imperfect specimens of this evidently distinct species were collected by Dr. Pickering on the Wilkes Exploring Expedition, in Sacramento Valley, and what is apparently the same was also found by Emory on Cariso Creek in the southern part of the State.

\section{MELOTHRIA, Linn.}

Flowers monocious; the sterile in axillary racemes; the fertile solitary. Calyx campanulate, shortly 5-toothed. Corolla 5-parted into oblong or linear-oblong segments. Sterile flowers with the stamens on the calyx-tube: filaments short, free; anthers free, short and ovoid, rarely all 2-celled; the cells straight and connective usually produced. Pistillate flower on a long and slenider pedicel, with 3 abortive or rarely perfect stamens : ovary ovoid, constricted below the flower, with 3 placentas and numerous horizontal ovules: style short, on an annular disk: stigmas 2-lobed. Fruit small, baccate, juicy. Seed ovate, flattened. - Slender herbs, with simple tendrils, and small yellow or white flowers.

About 30 species, in the warmer regions of the world.

1. M. pendula, Linn. Stems very slender, climbing: leaves rather thin, cordate, an inch or two broad, repand-toothed, or acutely 5-angled or lobed, scabrous or nearly smooth: sterile flowers few, in small racemes, 2 lines long, yellowish; calyx-teeth minute: fertile flowers on filiform pedicels at length as long as the leaves: ovary oblong: fruit subglobose, half an inch long, blackish when ripe: seed numerous, $1 \frac{1}{2}$ lines long. - Torr. \& Gray, Fl. i. 541.

From the sonthern Atlantic States westward across the continent. In Southeastern California, on the Colorado River, Bigelow.

\section{MEGARRHIZA, Torrey. Big-RooT.}

Flowers monocious; the sterile racemose or panicled; the fertile solitary, from the same axils. Calyx-tube broadly campanulate: teeth obsolete or very small. Corolla rotate, deeply 5-7-lobed, with oblong papillose segments. Sterile flowers with the stamens at the base: filaments short and connate: anthers free or somewhat adherent; the cells somewhat horizontal, flexuous. Pistillate flowers pedicelled: abortive stamens present or none: ovary oblong to globose, usually more or less echinate, 2-celled or more : cells 1 - several-ovuled: ovules ascending, horizontal, or pendulous, the attachment mostly parietal : style short: stigma 2-3-lobed or parted. Fruit mostly echinate, more or less fibrous within, becoming dry, at length bursting irregularly? Seed large, turgid, ovoid or subglobose, smooth, not margined; hilum linear, acute: cotyledons thick, remaining under ground in germination. - Stems 
elongated and climıing, from large fusiform perennial roots; leaves cordate, palmately 5-7-lobed or angled; tendrils 2-5-cleft; flowers small, white. Flowering in early spring. - Watson, Proc. Am. Acad. xi. 138.

A genus confined to the Pacific Coast, the species not well known, nearly allied to the Echinocyslis of the Atlantic States, to which it has been referred, but from which it is separated by its thick perennial roots, its large turgid immarginate seeds, and its thick fleshy cotyledons, which remain under ground in germination. The fruit in some species appears to be wholly indehiscent.

1. M. Californica, Torr. Nearly glabrous, with short scattered curved hairs: stem 20 to 30 feet long: leaves 2 to 6 inches broad, with a deep closed sinus, more or less deeply 5 -7-lobed, but rarely to the middle; lobes broad-triangular, abruptly acute, mucronate, the sinuses obtuse: sterile flowers $(5$ to 20$)$ in slender racemes 3 to 5 inches long, somewhat pubescent, on slender pedicels a line or two long; corolla 3 or 4 lines broad: fertile flowers 5 or 6 lines broad, without abortive stamens: ovary globose, densely echinate, 2 - (rarely $3-4$ )-celled, the cells 1 -2-ovuled; lower ovule ascending, the upper horizontal, attached to the outer side of the cell: fruit globose or ovoid, 2 inches long, densely covered with stout almost pungent spines ( $\frac{1}{2}$ to 1 inch long), $1-4$-seeded : seed obovoid, 10 lines long, 6 in diameter, surjounded by a shallow groove or darker line, the hilum at the narrow base. - Pacif. 1. Rep. vi. 74. Echinocystis fabacea, Naudin, Ann. Sci. Nat. 4 ser. xii. 154, t. 9, and xvi. 188.

Near the const from San Diego to Punta de los Reyes. A specimen from Knight's Ferry on the Stanislaus (Biycluw) has the ripe fruit much less strongly armed. Specimens from Cocomungo (Bigelow) may also belong here, though having the leaves more deeply divided with narrower lobes, and the 4-celled fruit with 4 or $\mathbf{5}$ seeds in each cell.

2. M. Marah, Watson, I. c. Scabrous or nearly smooth : stems 10 to 30 feet long: leaves cordate or reniform, 3 to 6 inches broad, lobed nearly as in the last: sterile flowers a half to an inch broad, in simple or panicled loosely flowered rncemes, 4 to 12 inches long; pedicels slender, 2 to 6 lines long: fertile flowers with abortive stamens : ovary oblong-ovate, more or less covered with soft spines, $2-3$-celled; ovules 1 to 4 or more in each cell, ascending or horizontal, attached to the onter side of the cell : fruit ovate-oblong, 4 inches long, somewhat attenuate at each end, more or less muricate all over with weak spines: seerls horizontally imposed, flattish, suborbicular or irregularly elliptical, an inch in diameter, about Jalf as thick, with an obsenre marginal furrow and prominent lateral hilum. Marah muricatus, Kellogg, Proc. Calif. Acad. i. 38.

Common around and near San Francisco Bay. Catalina Island (Balicr), but sterile flowers only.

3. M. Oregona, Torr. Much resembling the list: fertile flowers without ahortive stamens: young fruit similar in shape, sparingly muricate with soft spines, 3-4-celled, the cells imbricated above ench other, 1-seeded: mature fruit (so far as known) an inch or two long, unarmed, with very thin walls: seeds as in the last, or somewhat smaller ( 8 to 11 lines broad), attached to the outer side of the cell. Pacif. R. Rep. vi. 74 .

Common in Washington Territory and said to range from Puget Sound to Kilamath Take.

4. M. muricata, Watson, l. e. Nearly glabrous or somewhat senbrons, often more or less glaucous: stems 6 to 8 feet long: leaves 2 to 4 inches broad, orbicularcordate with a nerrly closed sinus or broally reniform, deeply 5 -lobed, the divisions all broader above and sharyly sinuate-toothed or -lobed : sterile racemes slender, often very few-flowered: fertile flowers 3 to 4 lines broul, withont abortive stamens, on slender pedicels an inch or two long: ovary smooth or sparingly muricate, ohlong, acute at each end : fruit nearly glohose, an inch in diameter, nakerl or with a fow short weak spines near the base, 2-eelled, 2-seeded : seed nearly glohose, half an inch in diameter, ascending, attached to the onter side of the enll near the base, the margin smooth. - Echinocystis muricata, Kellogg, Proc. Calif. Acad. i. 57. 
Angels Camp, Calaveras County (Kich, Bigelow) ; near Placerville, Kellogg, Bolander. Specimens collected by Fremont, Hulse, and others, in the same region (from the Mokelumne River to the Upper Sacramento), may belong here though with the ovary 3-or 4-celled, and in some other minor respects different.

5. M. Guadalupensis, Watson, 1. c. Nearly glabrous, the inflorescence somewhat pubescent: leaves thin, 3 to 8 inches broad, 3-5-lobed to the middle, the lower lobes quadrangular, the npper acuminate, with few short teeth: racemes nearly simple, 4 to 6 inches long : calyx-teeth filiform: corolla 6 to 8 lines broad: fertile flowers without abortive stamens : ovary on a slender pedicel an inch long, ovoid, densely covered with short soft spines, 2-celled; ovules 1 or 2 in each cell, ascending: fruit ovoid, $1 \frac{1}{2}$ to 2 inches long, acute above, somewhat pubescent and with short scattered stiff spines, usually 2 -seeded: seeds subglobose, an inch in diameter, attached to the inner side of the cell, the margin smooth.

Guadalupe Island, on high rocks near the centre of the island, Palmer, 1875.

\section{ORder XLII. DATISCACE正.}

A very small and peculiar order, chiefly represented by the following genus of only two species.

\section{DATISCA, Linn.}

Flowers dioecious, sometimes perfect. Calyx of sterile flowers very short, with 4 to 9 unequal lobes: stamens 10 to 25 ; filaments short: rudimentary ovary none. Pistillate flowers with calyx-tube ovoid, somewhat 3-angled, 3-toothed: stamens three, when present, alternate with the teeth: styles 3, bifid, opposite the teeth, the linear lobes stigmatic on the inner side. Capsule oblong, coriaceous, 1-celled, opening at the apex between the styles. Seeds very numerous and small, in two to several rows upon the 3 parietal placente: embryo cylindrical, in the axis of small albumen. - Smooth stout perennial herbs; leaves unequally pinnatifid, with coarsely toothed lanceolate segments, the upper scarcely lobed; flowers axillary, fascicled, nearly sessile.

Only two species known, one native of W. Asia, the other of California.

1. D. glomerata, Benth. \& Hook. Erect, 2 or 3 feet high or more, branching: leaves ovate to lanceolate in outline, acuminate, 6 inches long, the numerous floral ones shorter and more narrowly lanceolate: flowers 4 to 7 in each axil of the elongated leafy raceme, the fertile mostly perfect: anthers nearly sessile, 2 lines long: styles longer than the ovary: capsule oblong-ovate, 3 or 4 lines long, slightly narrowed toward the truncate triangular 3-toothed summit. - Gen. Pl. i. 845. Tricerastes glomerata, Presl, Rel. Hænk. ii. 88, t. 64; Lindl. Veg. Kingd. 316, fig.

On stream-banks from Napa County to San Bernardino, and in the foot-hills of the Sierra Nevada from Amador to Tuolumne County.

\section{Order Xliti. CACTACe开. By Dr. George Exgelmann.}

Green fleshy and thickened persistent mostly leafless plants, of peculiar aspect: globular or columnar, tuberculated or ribbed, or jointed and often flattened, usually armed with bundles of spines from the "areolae," which constitute the axils of the (mostly absent) leaves. Flowers with numerous sepals, petals, and stamens, usually 
in many series, the cohering bases of all of which coat the inferior 1-celled manyovuled ovary, and above it form a tube or cup, nectariferous at base. Style 1, with several or numerous stigmas. Fruit a pulpy or rarely dry l-celled berry, with numerous campylutropous seets (without or with some albumen) (n sereral parietal placentæ.

An order of fer genera, comprising a large number of species, peculiar to the warmer parts of America, and confined in California to the southern and southeasteru districts.

\section{SEBorder I. CACTEE.}

To leaves proper: spines never barbed. Flower-bearing and spine-bearing areolie listinct. Tube of the sessile solitary flowers well developed, often long. Seeds brown or black, mostly small. - The limits between the genera are arbitrary.

1. Mamillaria Globose or oval plants, covered with spine-bearing tubercles. Flowers (usually small) from between the tubercles. Orary naked. Sceds without albumen.

2. Echinocactus. Globose or oval plants, stonter than the last, usually ribhed; bundles of spines on the ribs. Flowers mostly larger, from the youngest part of the ribs close above the nascent bunches of spines. Ovary covered with sepals. Seeds albuminous.

3. Cereus. Oval or columnar plants, sometimes tall, ribbed or angled; bundles of spines on the ribs. Flower's usually larger, close above bundles of full grown (older) spines. Ovary covered with sepals. Seeds without albumen.

\section{Suborder II. OPUNTIEA.}

Leaves small, subulate, early deciduous. Sessile and solitary flowers from the same areolie as the always barbed spines: tube of the flowers short, cup-shaped. Seeds larger, whitish, covered with a bony arillus.

4. Opuntia. Branching or jointed plants: joints flattened or cylindrical.

Stmornel: III. PEIRESCIEI, with flat persistent leares, spines never barbed, flowers usullly pelumcled and often paniculate, with a very short tube, and large black albuminous seck, inclules the genus Peirescia of the tropies, in aspect very unlike the rest of the order. No species lave been found in California, but they may be expected in the Peninsula.

\section{MAMILLARIA, Haworth.}

Flowers about as long as wide; the tube campanulate or funnel-shaped. Orary, often hidden between the bases of the tubercles, as well as the exsert succulent herry, naked. Sceds yellowish-brown to black, exalbuminons or nearly so. Embryo mostly short and straight, with extremely short cotyledons parallel to the siles of the seed. - Small more or less globose or oval simple or cespitose plants, the spinebearing areolie borne on cylindric, oval, conic, or angular tubercles, which cover the body of the plant. Flowers from a distinct woolly or bristly areola at the base of these tubercles, fully open in sunlight, mostly only for a few hours.

$\$ 1$. Flowers usually small, lateral from the axils of older or full-gronon tubercles. Our species have limpid juice and exsent ovaries. - Ecmamllama.

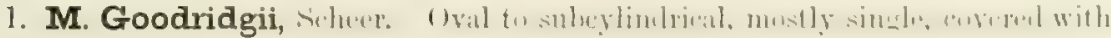
crowiled ovate tubercles and a dense mass of gray and dusky thin spines; axils of the younger tubercles woolly and bristly: the 10 to 15 outer spines malinting and whitish; the 1 to 3 inner ones longer, stenter anl dark brown, of which the stoutest is strongly hooked: lower sepals fringed: petals about 8, ovate, awned: stigmis 5 to 6 : club-shaped berry scarlet: seuls ohovate, mimute, black, delicately pittul. Silm. Cact. 1849, 91 ; Lingelm. Cact. Mex. Buund. 8, t. 8, fig. 9-11. 
Common on sandy or gravelly soil or among rocks about San Diego (Parry, Agassiz, Hitchcock), and on the neighboring islands, and southward through the Peninsula, $W$. Gabb. From 2 or 3 to 6 or 7 inches high, 1 to $1 \frac{1}{2}$ thick; tubercles $2 \frac{1}{2}$ to 3 lines long; radial spines $2 \frac{1}{2}$ to 5 , and central ones 5 to 7 lines long; flowers 9 to 12 lines in diameter, dirty yellowish tinged with red.

2. M. Grahami, Engelm. Similar to the last: smaller, with smaller less closely pitted seeds, but longer and more numerous ( 15 to 30 ) spines, and without axillary bristles. - Cact. Mex. Bound. 7, t. 6, fig. 1-8.

Common on the most rugged rocks on both sides of the Colorado (Schott, Nevberry), and eastward into New Mexico. Heads 1 to 3 inches high, 1 to $1 \frac{1}{2}$ thick.

3. M. phellosperma, Engelm. Ovate to cylindrical, usually simple : tubercles long-oval, with wool and bristles in their axils, and 30 to 60 spines at the apex, in 2 or 3 series; the outer thinner and paler; the inner stonter and often darker; the 3 or 4 central spines stouter, dark brown, and one or several hooked: flowers with ciliate sepals and 12 to 13 acuminate petals: stigmas 5: berry obovate or clavate, crimson, containing rather few large globose reticulated and warty brown seeds, with a large spongy appendage. - Cact. Mex. Bound. 6, t. 7 .

From the eastern slope of the mountains near San Felipe to the Mohave country, and through out Western Arizona. Heads 2 to 5 inches high, 13 to 2 inches thick; tuhercles 4 to 7 lines long, not as much erowded as in the last two speeies, but with a much larger number of spines, 4 to 9 lines in length ; flower dirty yellowish red, about an inch wide. The seed is partially imbedded in a curious spongy mass, an aril-like enlargement of the funiculus.

\section{\$2. Flowers larger, vertical, from the base of a groove on the young or nascent tubercles. - CoRYPHANTHA.}

4. M. Arizonica, Engelm. n. sp. Globose or ovate ; tubercles long-cylindrical, ascending, deeply grooved, bearing numerous straight rigid spines: the 15 to 20 exterior spines whitish; the 3 to 6 interior ones stouter, deep brown above : flowers large, rose-colored: sepals 30 to 40 , linear-subulate, fimbriate: petals 40 to 50 , lance-linear, awned: stigmas 8 to 10 , white: berry oval, green, with obovate compressed pitted light brown seeds.

On sandy and rocky soil in Northem Arizona, from the Colorado eastward (Concs, Palner, F. Bischoff $)$, and into Southern Utah (J.E. Johnson) ; probably in Southeastern California. Larger in all its parts than the foregoing species; 3 or 4 inches thick; tubercles an inch long; spines 5 to 15 lines long; flowers 2 to $2 \frac{1}{2}$ inches wide, very showy.

\section{ECHINOCACTUS, Link \& Otto。}

Flowers about as long as wide. Ovary covered with sepaloid scales, naked or woolly in their axils. Fruit succulent or sometimes dry, covered with the persistent calyx-scales, sometimes enveloped in copious wool, and usually crowned with the persistent remnants of the flower. Seed obliquely obovate, black. Embryo curved оver the small albumen; cotyledons parallel to the sides of the seed. - Mostly larger, sometimes gigantic, globose or depressed, or ovate, or rarely subcylindric, simple or very rarely cespitose; bunches of spines on the more or less vertical ribs. Flowers contiguous to and above the spines, on the latest growth of the plant, often from the nascent woolly areolæ and therefore more or less vertical, open only in sunlight.

* Scales of the ovary ovate, orbicular, or cordate, and mostly fringed, their axils almost naked: fruit scaly, never woolly. - Leiocarpi.

\section{+ Spines smooth.}

1. E. Whipplei, Engelm. \& Big. Heads solitary, slobose or ovate, middle-sized, with 13 (to 15 ) compressed and interrupted ribs: of the 7 to 11 outer and 4 inner spines, the ivory-white upper ones are the longest and broadest and recurved or 
twisted; the lower are shorter, darker, and terete, and the lowest middle one hooked: flowers 1 to 1 inches long, yellow: few (2 to 5) rounded fringed sepals on the ovary, 10 to 15 oblong ones on the tube: petals ahout 8 : stigmas 5 to 7 , short: seeds large, minutely tuberculated. - Cact. of Pacif. R. Rep. iv. 28, t. 1 ; Bot. Ives Colorado Exp. 12.

On the lower Colorado, on the confines of California, Arizona, and Utah (Bigelozo, Neroberry, H. Engelmann), and to Southern Colorado, Brandegee. Heads 3 to 5 inches high; spines 3 to 20 or 24 lines long, on prominent tubercles, which give the ribs a wary or intertupted appearance : seeds 1 t to 1 lines long.

2. E. polyancistrus, Engelm. \& Rig. Heads solitary, millile-sized, orate to cylindrical, with 13 (to 17 ) interrupted ribs: outer spines 20 or more, white, the uppermust bruader and longer; central spines 5 to 10 , the upper one bruadest, longest, recurvel, white, the others brown, terete, and mostly houket : flowers yellow, 2 to 21 inches long, with about 8 rounded fringen sepals on the ovary : seeds as in the last. - Cact. of Pacif. R. Rep. iv. 29, t. 2, fig. 1, 2.

From the head-waters of the Mohave River (Bigclow) to the sage plains of Southwestern Nevada, $G a b b$. Perhaps too near the last, from which it is distinguished by the more numerous spines, many of the inner ones being hooked, the larger flowers, and more numerous sepals and petals. Heads 3 to 10 inches high, 2 to 4 thick; larger spines of the Mohave form 3 to 5 , of the Nevada plant only 1 or 2 inches long.

\section{++ Spines, at least the lurger ones, transwersely ribbed or annulated.}

3. E. viridescens, Nutt. Heads solitary, middle-sized, globose or depressed, with about 13 obtuse tuberculated ribs and a woolly depressed summit: spines stunt, reddish, straight or recurved, all annulated, about 12 radiatiner and 4 (to 6) stonter central ones : Howers greenish (1.1 inches long), with numerous ( 25 or more) roumlish denticulate imbricated sepals on the ovary, as many on the tuhe, ind about the sane number of ublong ohtuse lenticulate petals : stigmas 12 to 15 , linear : herry pulpy, green, scaly, with numerous small pitted seeds. - Torr. \& Gray, Fl. i. 554; Engelm. Cact. Mex. Bound. 24, t. 29.

Abont San Diego, from the sea-beach to the arid hills and ridges inland; cultivated in Europo under the name of $E$. Californicus. Heads 4 to 7 inches in diameter, 3 to 5 inches high, more rarely globose; woolly vertical area (the youngest growth, where the spines are nut yet developed) an inch wide, surrounded by the numerous flowers.

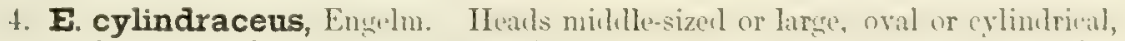
often proliferous at base, with 21 (to 27) obtuse somewhat tuberculate ribs, and a woully spineless hepresised top: rechlish spines all stout am annulated, recurven or flexious, 12 to 18 exterior, the lowest usually hooked, and 4 very stont central ones:

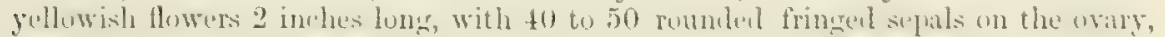
and about 25 fringed petals : stigmas and fruit as in the last. - Cact. Mex. Bound. 25, t. 30. E. viridescens, var. (?) B. cylindraceus, Engelm. in Am. Jour. Sci. 2 ser. xiv. 338 .

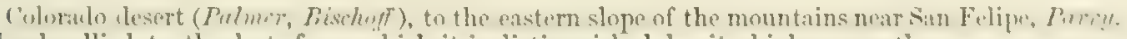
Closely allied to the last, from which it is distinguished by its higher growth, more numerous

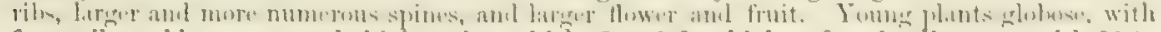
fewer ribs; older ones much higher than thick, 2 or 3 feet high, a foot in dinmeter, with 20 to nenrly 30 ribs; rudial spines 1 or 2 , the central 2 inches or over in length ; green berry about an inch thick.

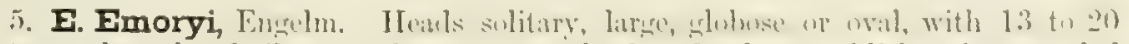
obtuse tuberculated ribs: on the ovate areolic 8 or 9 robust redlish spines, angled and annulated and slightly recurved, a stouter and longer one in the centre, turned downwarl or more or less hooked: flowers large, purple, with numerons (25) reniform ciliate sepals on the ovary and as many spatulate ones on the tubo: petals ahout the same number, lanceolate, heiniate-tuothed towanls the acuninate tip: stigmas 18 to 20, erect, almust as long as the very robust stylo - Limory Rep. 156; Cact. Mex. Bouml. 23, t. 28. 
Arizona and Sonora to the Mohave region (Emory, Bigelow, Schott), and into Lower California, Gabb. Plants 1 or 2 and even 3 feet high, 1 or 2 feet thick; all the spines very stout and strongly cross ribbed, $1 \frac{1}{2}$ to 3 inches long; flowers 3 inches long, purplish brown outside ; petals red, with yellow margix; seeds much like those of the next species.

6. E. Wislizeni, Engelm. Very large, oval, at last cylindrical or often elubshaped, with 21 to 30 compressed crenate ribs: oblong areolæe bearing various spines; in the centre 4 stout cross-ribbed ones, the lower one flattened and curved or hooked; above and below 6 to 10 slightly ribbed, and laterally 10 to 20 long slender often flexuous ones: flowers greenish yellow, 2 to $2 \frac{1}{2}$ inches long: ovary and fruit imbricately covered with 30 or 40 to 60 or 100 roundish cordate sepals; inner sepals spatulate, 20 to 30 : petals as many, lanceolate, crenulate: style divided to the middle into 12 to 20 stigmas : yellowish berry at last hard and dry; seeds over a line long, reticulated. - Wislizemus Rep. 1848, note 14; Cact. Mex. Bound. 23, t. 25, 26.

From the Rio Grande to the Colorado, northward into Utah and west into California ; flowering throughout the summer and autumn. Often 3 and even 4 feet high and 1 or 2 in diameter, with a woolly spineless top; spines $1 \frac{1}{2}$ to $2 \frac{1}{2}$ inches long, grayish red, the thinmer ones whitish. E. Lecontei, Engelm., seems to have been founded on weaker plants of this, with the seeds of perhaps No. 4.

\section{* * Scales of the ovary subulate, often spinescent, copiously woolly in their axils; fruit enveloped in wool. - Eriocarpi.}

7. E. polycephalus, Engelm. \& Big. Middle-sized or large, glohose, at last cylindric, sprouting from the base; ribs 13 to 21 , acnte : circular areolæ bearing 8 to 12 stout compressed annulated curved reddish gray spines: flowers enveloped in a mass of dense white wool: petals about 30, lance-linear, yellow : stigmas 8 to 11 , linear: dry berry full of large angular seeds.- Cact. of Pacif. R. Rep. iv. 31, t. 3, fig. $4-6$.

Gravelly or stony soil on the Colorado and Mohave rivers, and in the Californian desert (Bigelow) ; flowering in February, fruiting in March. Heads sometimes 20 or 30 from a single base, $\frac{1}{2}$ to $1 \frac{1}{2}$ feet high, the larger eylindrie ones 2 to $2 \frac{1}{2}$ feet high; spines either all radial, or 6 to 8 outer ones surrounding 4 stouter central ones ; flowers $1 \frac{1}{4}$ inches long; about 100 rigid dark pointed sepals upon the ovary are hidden in the wool, those of the tube similar and abont as many ; petals about 30 , narrow, yellow, just emerging from the wool ; seeds 2 lines long, wrinkled and minutely tuberculate.

\section{CEREUS, Haworth.}

Flowers about as long as wide or elongated. Scales of the ovary distinct, with naked or woolly axils, or almost obsolete and the axils spiny. Berry succulent, covered with spines or scales or almost naked. Seeds black, without albumen. Embryo short and straight or curved or hooked; cotyledons usually contrary to the sides of the seed. - Plants of all sizes, low or climbing or erect, sometimes enormous; spine-bearing areolæ on vertical ribs. Flowers from the older or, at least, fully formed parts of the plant, not from any preformed areola, but bursting through the epidermis just above the bunches of spines; some open only in sunlight, others only at night, others again are not thus influenced. Fruit often edible, sometimes of very large size.

\$1. Low and usually cespitose plants, mostly with numerous oval or cylindric heads, short flowers, green stigmas, and spiny fruit: seeds subglobose, covered with conAluent tubercles: embryo straight, with very short cotyledons. - ECHINOCEREUS.

1. C. Engelmanni, Parry. Heads several from a single base, oval or cylindrical, with 11 to 13 interrupted ribs: radial spines about 13, whitish, often somewhat angled, straight or curved, the lateral ones the longest; central ones 4 , longer, 
angular, variously colored: large purple flowers open only in sumlight: ovary and fruit with 25 to 30 spiny areolæ, 15 to 20 upper sepals, and as many lance-oblong petals: stigmas about 12, ereet. - Am. Jour. Sci. 2 ser. xiv. 338 ; Cact. of Pacif. R. Rep. iv. 35, t. 5, fig. $4-10$.

From the eastern slopes of the Southem Sierra Nevada, at San Felipe, into Arizona and Utah, apparently abundant, Purmy, Newbcrry, Palmer, and others. Heads usually 4 to 6 together, 5 to 10 inches high, 2 or 3 thick; outer spines $\frac{1}{4}$ to $\frac{3}{4}$, inner 1 or 2 inches long; Howers $2 \frac{1}{2}$ to 3 inches long and wide, appearing in June.

\$2. Prismatic or cylindric, mostly branching: flowers usnally longer than wide: stigmas whitish: seeds obovate, usually smooth or pitted: embryo with foliaceous carved cotyledons. - EucEREus.

\section{* Ovary and fruit spiny.}

2. C. Emoryi, Engeln. Stems erect, branching from the base, cylintrie, with 16 to 20 ribs, closely set with prominent hemispherical areola bearing numerous ( 30 to 50 ) thin straight yellow spines $\frac{1}{4}$ to 1 or $1 \frac{3}{4}$ inches long; the 3 to 6 inner ones louger and deflexed: Howers short, greenish yellow, cruwled on one sile of the top of the stems: ovary with few short spines, which become formidable upon the subglobose fruit. - Ars. Jour. Sci. l. c.; Cact. Mex. Bound. 40, t. 60, fig. 1-4.

On the gravelly mesas near the sea-shore at San Diego (Parry, Agassiz, Hilchcock), and quite abundant on rocky hills from Los Angeles to the Salinas Valley (Brewer), and into the Peninsula, to Rosario, Gabb. Stems 2 to 4 feet high, $1 \frac{1}{2}$ to 2 inches thick, often from a prostrate rooting base, and forming dense thickets; areolie 2 lines wille and 3 or 4 lines apart, densely covered with the thin sharp and very brittle spines; flowers usually on one side only, like those of § Piloccreus, 1 to to $1 \frac{1}{2}$ inches long and a little less wide; fruit about an inch long; seeds over a liue long, shining, minutely tuberculate.

$$
\text { * Ovary and fruit scaly. }
$$

C. Giganteus, Engelm., 15 to 30 or even 40 feet high, very stout, with few erect branches towards the upper part, eream-white short-tubed flowers, and large oval edible fruit, which at maturity bursts irregularly, and

C. THUлBвrr, Engelm., 10 to 15 feet high, more slender, with many equally high nscending hranches from the base, similar flowers, and larger globose delicious fruits, are found in the adjoining territories of Arizona aud Lower California, and may be looked for in this State.

\$3. Tall, cylindric, mostly unbranched; upper flower-bearing portion with more crowded areole and longer denser thinner bristly or hairy spines: flowers short: seeds as in the last. - Pilocereus.

C. Scrotrir, Engelm., 4 to 10 feet high, the lower part 5-angled, with distant areolis and few very short and stont spines; the upper flowering portion denply 5 -ribbed, with close-set arpole bearing munnerous setacrous spines, almost hiding the small flowers and small berries, - from the same localities as the last two species, - may also be found in Southern Californin.

\section{OPUNTIA, Tourn., Miller.}

Tube of tho flower very short, cup-shaped. Petals spreading or ravely erect. Ovary with bristle-bearing areoli in the axils of small terete deciluous sepals. Berry succulent or sometimes dry, marked with bristly or spiny areole, truncato with a wide umbilicus. Seeds large, white, compressed, with tho embryo coiled around the albumen: cotyledons large, foliaceous. - Articulated much-branched

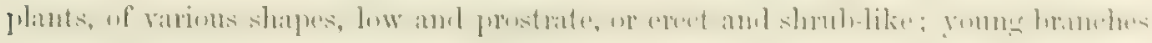
with small terete subulato early deciluous leaves, and in their axils an areola with numerous short easily detached bristles and, usually, stutter spines, all burludl. Flowers on the joints of the previous year, on the sume arolat with tho spines, mostly lurge, open only in sunlight. Fruit often edible, often lurge. 
\$1. Joints compressed: rhaphe forming a prominent bony margin around the seed: embryo completing a little more than one circle around the scanty albumen; cotyledons contrary to the sides of the seed. - Platopuntia.

* Fruit pulpy.

1. O. Engelmanni, Salm. Bushy, erect-spreading, much branched : obovate joints $\frac{1}{2}$ to 1 foot long, sparsely armed with bundles of 1 to 3 or sometimes even 5 spines, the stonter ones angled, yellow, sometimes with a red-brown base; old trunks losing their spines: flowers yellow, about 3 inches wide: petals broadly obovate, truncate: the purple oval juicy berry about 2 inches long, with a large flat umbilicus, and with 20 to 25 brown-woolly and slightly bristly areolæ. - Salm. Cact. cult. 1849, 235 ; Engelm. Cact. Mex. Bound. 47, t. 75, fig. $1-4$.

Var. $\beta$. occidentalis, Engelm. Spines fewer, stouter, farther apart: seeds larger. - O. occidentalis, Engelm. \& Big. in Cact. of Pacif. R. Rep. iv. 38, t. 7.

Var. (?) $\gamma$. littoralis, Engelm. Joints often larger, 1 to $1 \frac{1}{2}$ feet long: bunches of longer and more slender spines closer together : fruit similar, but with 40 to 50 areolæ: seeds smaller.

Apparently a polymorphous species, extending from Southern Texas to the Pacific, which will probably be identified with some older Mexican species when these plants come to be better understood. The two forms of California are easily distinguished by the characters given above. The var. occidentalis has been found on the western slope of the mountains east of Los Angeles and southward to San Isabel, etc., at an elevation of 1,000 to 2,000 feet, Parry, Schott. The areolæe of the joints are $1 \frac{1}{2}$ to 2 inches apart; spines $\frac{1}{3}$ to $1 \frac{1}{4}$ inches long; flowers 3 to $3 \frac{1}{2}$ inches wide, yellow with orange centre; fruit often 11 inches thick; seeds $2 \frac{1}{3}$ to 23 lines wide. The second form, var. littoralis, extends on the coast from Santit Barbara and the islands in its gulf (O. Tittmann) to San Diego, and sonthward, G. $N$. Hitchcock. Seeds 2 to $2 \frac{1}{2}$ lines in diameter. - The limits of these species are difficult to circumscribe, especially because complete specimens are so hard to preserve and extensive observations in the field have not yet been made. Of the three following no more is known now than there was twenty years ago.

2. O. chlorotica, Engelm. \& Big. Erect, bushy; old trunks covered with large areolæ which, retaining their vitality, constantly produce new spines; joints large, pale green, orbicular-obovate, with close-set areolæ, each bearing 1 to 5 slender deflexed yellow spines: flowers yellow, $2 \frac{1}{2}$ to 3 inches wide, with spatulate petals. - Cact. of Paeif. R. Rep. iv. 38, t. 6, tig. $1-3$.

From Mohave Creek eastward to Bill Williams Mountain in Arizona (Bigelow) ; 4, 5, or even 7 feet high, readily recognized by the very spiny trunk and very pale broad joints 8 to 1 foot long.

3. O. angustata, Engelm. \& Big. Prostrate or ascending, with obovate elongated joints: large oblong areolæ sprarse, bearing brown bristles and few ( 1 to 3 ) deflexed spines : fruit rather small, deeply umbilicate, with few large seeds. - Cact. 1. c. 39 , t. 7 , fig. 3,4 .

From Cajon Pass eastward into Arizona, Bigelow. Joints 10 inches long or more, not half as wide above, narrowed downward ; berry $1 \frac{1}{2}$ inches long, narrow; seeds 3 lines wide.

4. O. Mohavensis, Engelm. \& Big. Prostrate, with large nearly orbicular joints, and more numerous ( 2 to 6 ) stout and long often curved brown spines. Cact. 1. c. 40 , t. 9 , fig. $6-8$.

On Mohave Creek, Bigclow. A doubtful form, of which flowers and fruit are unknown. It seems to approach 0 . phedeantha of New Mexico, and perhaps even the stouter western forms of $O$. Rafinesquiz. It is indicated here merely for the attention of future explorers.

O. Tuna and O. Ficus-InDica, Mill., are probably both naturalized about the old missions; one with stout yellow spines and insipid fruit, the last with weaker whitish spines, fruit delicious.

$$
\begin{aligned}
& + \text { Fruit dry. } \\
& + \text { Joints and fruit spiny. }
\end{aligned}
$$

5. O. rutila, Nutt. Prostrate, with thick obovate or elongated joints: areole close, armed with numerous slender reddish or gray flexible spines: large flowers purple: stigmas green: berry deeply umbilicate, with large flat broadly margined 
ivory-white seeds. - Nutt. in Torr. \& Gray, Fl. i. 155. O. erinacea, Engelm. \& Big. Cact. 1. c. 47 , t. 13, fig. $8-11$.

From the Mohave region (Bigelow) to Southern Utah (Palmer), and up the Colorado Valley, Nuttall. This plant seems to bo Nuttall's long-lost O. ruila, and also O. erinacea of the Mohave, the flower of which is unknown. Joints 2 to 4 inches long, $1 \frac{1}{2}$ to 3 wide, and often, especially in young plants, thick and almost terete, thus approaching to 0 . fragitis: seeds 3 lines wide.

\section{$\div+$ Joints and fruit pubescent, without spines.}

6. O. basilaris, Engelm. \& Big. Low, with obovate often retuse or fan-shaped joints, branching only from the base: areola very close, clensely covered with short brown bristles: flowers large, rose-purple: fruit sulgrlobose, with leep nubilicus, and rather few large and thick seeds. - Cact. 1. c. 43, t. 13, fig. $1-5$.

From the eastern base of the mountains near San Felipe through the desert and into Arizona, Biyclow, Nevobrry, Palmer, \&e. Joints 5 to 8 inches long, and often as wide near the top; distinct from all other species of this region in its mode of growth, its pubescence, absence of spines proper, and its very large seeds ( $3 \frac{1}{2}$ to 5 lines wide), which have a thicker but less prominent rim than any other of this section.

\$2. Joints cylindrical, more or less tuberculated: rhaphe usually not prominent, therefore seed not margined: embryo forming less than one circle around the more copious albumen; cotyledons inconstant, contrary, oblique, or parallel to the sides of the seed. - CYLindropuntis.

* Low plants with clavate joints, without a firm ligneous skeleton: larger spines angular-compressed, without sheaths: berries dry and very bristly.

7. O. Emoryi, Engrelm. Joints long, clavate-cylindrical, with linear-ohlong anıl very prominent tubercles: spines numerous (15 to 30$)$ in the upper bundles, tho 5 tw 9 inner ones stunter, angular-compressed : seeds large, irregular, the rhiphe indistinct. - Cact. Mex. Bound. 53, t. 70, 71.

Colorado desert from San Folipe (Parmy, Bigclow) enstward, and into Arizona (Schot, Palmer) and the Peninsula, Gabb. Joints 5 to 9 inches long, 1 to $1 \frac{1}{2}$ thick; tubercles 1 to $1 \frac{1}{2}$ inches long; fruit 2 to $2 \frac{1}{2}$ inches long; seeds $2 \frac{1}{2}$ to 3 lines wide.

8. O. Parryi, Engelnu. Jeints short, ovate-clavate with oblong tuhereles: spines 12 to 20 , reddish gray, the 3 or 4 inner ones stouter, triangular-compressed: seeds smaller, regularly circular, with a broad and distinct rhaphe. - Am. Jour. Sci. 2 ser. xiv. 339 ; Cact. of Pacif. R. Rep. iv. 48, t. 22 , fig. $4-7$.

Gravelly plains near the Mohave River (Bigcluwe), and through the desert to the base of the mountains, Parry. Joints 3 or 4 inches long, If thick; tubereles about 8 ineh long.

- 9. O. pulchella, Fingelm. Joints smaller, slender: tulereles small : spines 1.) to 25, of which usually one only is stouter, flattened, deflexed: flowers purple: ovary and fruit with long flexuous bristles: seeds small, with a broad rhaphe. Trans. Acad. St. Louis, ii. 201 ; Bot. King Exp. 119 ; fig. in Simpson Rep. ined.

Sandy deserts of Southenstern California and Nevadn, and among the sage-bushes of the mountains, H. Eugchman, W. Gabb, Widson. The prettiest and smallest of the clavate Opuntice, the only one with purple flowers; joints rarely longer than 1 or 2 inches; flowers $1+$ to $1 \frac{1}{2}$ iuches wile; seeds 2 lines in diametor.

* * More or less erect, much branched: joints cylindric: ligneons skeleton solid or tubular and reticulated: larger spines terete, coated with a loose sheath.

$$
\text { + Fruit dry and spiny: flowers yellow. }
$$

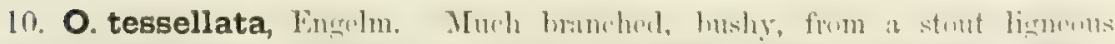

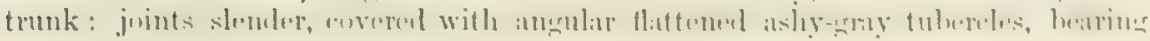
above long single lonsely sheathed spines: fluwers small, yollow: small oval fruit covered with long hrown bristles: seeds with a very broad that rhaphe. - Cact. of Pacif. R. Rep. iv. 52, t. 21. 
Throughout the Californian desert from the mountains to the Colorado, and into Arizona. Bushes 4 to 6 feet high; trunk solid, sometimes 2 inches in diameter; joints only $\frac{1}{4}$ or $\frac{1}{3}$ inch thick; spines an inch or two long; flowers 6 to 9 lines wide; fruit 9 lines long; seeds 2 lines wide.

11. O. echinocarpa, Engelm. \& Big. A low much-branched and spreading shrub: joints ovate-clavate, densely covered with numerous spines (3 or 4 stouter, 8 to 16 weaker ones in a bunch), which are loosely coated with a whitish glistening sheath: flowers pale greenish yellow, about $1 \frac{1}{2}$ inches wide: fruit depressed, deeply umbilicate, very spiny : seeds few (2 lines wide), with a broad flat rhaphe. — Cact. l. c. 51 , t. 18, tig. 5-10 ; Bot. Ives Colorado Exp. 14.

Common in the desert from the mountains to the Colorado River, and into Arizona. Usually only 1 to $1 \frac{1}{2}$ feet high, very showy from its conspicuous shining spines, an inch or two long.

12. O. serpentina, Engelm. A large straggling densely branched shrub: joints elongated, covered with oblong prominent tubercles, which bear bunches of numerous short spines, very soon losing their inconspicuous sheaths: flowers clustered, greenish yellow, reddish externally: petals spatulate, obtuse: stigmas 8 , whitish: fruit broadly oval, deeply umbilicate: seeds thick, irregular, with a narrow rhaphe. - Am. Jour. Sci. 2 ser. xiv. 338.

Common near the coast, at San Diego, Parry, Hitchcock. Bushes 3 to 5 feet high; spines 8 to 15 in a bunch, 3 to 6 lines long; flowers $1 \frac{1}{1}$ inches wide ; fruit about 9 lines long.

$$
+ \text { Fruit green, fleshy, and without spines: flowers red. }
$$

13. O. prolifera, Engelm. An arborescent shrub with elongated joints, covered with oblong obtuse tubercles, which bear 3 to 6 or 8 spines, obscurely sheathed: flowers densely clustered at the ends of the branches, small, brick-red : fruit clavate, obovate, or subglobose, strongly tubercled, clepply umbilicate, almost always sterilo and often proliferous: seeds large, regular, with a broad prominent rhaphe. - Am. Jour. Sci. I. c.

San Diego (Parry, Schott, Agassiz), up the coast to San Buenaventura, and southward into the P'eninsula, Gabb: Larger than the last, with stonter more strongly tubercled joints, and fewer and shorter spines, and easily distingrished from it in flower and truit : longest spines 1 to $1 \frac{1}{2}$ inches long; flowers $1 \frac{1}{2}$ inches wide; seeds 3 lines in diameter, with a more prominent and broader rhaphe than its allies.

Several other Opruntioe, belonging to this last section, all with red flowers and fleshy fruit, are found in Western Arizona and may also be expected on the western side of the Colorado. They are all erect much-branched bushes, covered with shining sheathed spines. The more northern

O. Bigflovit, Engelm, has short tribercles.

O. FULGENs, Engelm. \& Big., and O. Mamillata, Schott, both south of the Gila (perhaps forms of a single species), have very prominent tubercles, and small curiously irregular seeds $1 \frac{1}{2}$ to 2 lines loug, with a linear rhaphe.

O. LEPTOCAULIS, DC., including O. frutescens, Engelm., O. vaginata, Engelm., and several other synonyms, is the slenderest of all Opuntice, with long branches searcely thicker than a goose-quill, small yellow flowers, and a small pulpy scarlet fruit; common throughout all Northern Mexico, ranging into Texas, New Mexico, and Western Arizona, and may also be found west of the Colorado River.

\section{ORDER XLIV. FICOIDEF.}

A niscellaneous group, chiefly of fleshy or succulent plants, with mostly opposite leaves and no stipules; differing from Caryophyllacece and Portulacacece by having distinct partitions to the ovary and capsule (which are therefore 2-many-celled); the petals and stamens sometimes numerous in the manner of Cactacea (but the former wanting in most of the genera); agreeing with all these orders in the campylotropons or amphitropous seeds; the slender embryo curved partly or completely round a mealy albumen. 
It is mainly a tropical and subtropical family, of the old World. Our Pacific Coast has only two indigenous representatives, both insignificant, and as many naturalized ones, which appear as if wild on the sea-shore.

* Calyx-tube adnate to the ovary : petals and stamens very numerous.

1. Mesembryanthemum. Capsule 5-valved or more, Very fleshy.

* Ovary free: petals none: stamens few or many.

2. Sesuvium. Calyx-lobes 5, petaloid. Stamens 5 to 60 . Capsule circumscissile. Succulent. 3. Mollugo. Sepals 5. Stamens 3 or 5 . Capsule 3-valved. Not succulent.

\section{MESEMBRYANTHEMUM, Linn. ICe-Plant。 Fig-Marygold.}

Calyx-tube adnate to the ovary; the lobes usually 5, unequal, foliaceous. Petals very numerus, linear. stamens inmuneral,le, with slenler filaments, inscterl witls the petals on the tube of the calyx. Styles 4 to 20, ustally 5. Capsule 4-20celled, dehiscing in a star-like manner at the depressed summit. Seeds minute, very numerous. - Fleshy herbs or shrubs, rarely annual; leaves mostly opposite, without stipules; flowers mostly showy, terminal and in the forks of the branclies.

A genus of about 300 species, principally S. African, but a few found in the Merlitermnean region, Western S. America, and Australia. The Calilomian species are probably introduced.

1. M. æquilaterale, Haworth. Porennial, with stunt pustrate ur asceuling sterns and short ascending flowering branches: leaves very fleshy, opposite and clasping, linear, acutely triangular, 1 to 3 inches long, smooth: Howers solitary, red, pedicellate or nearly sessile, about $1 \%$ inches in diameter: calyx-tube turbinate, half an inch long or more, angled or ter te; the larger lobes often as long: stigmas 6 to 10 . - DC. Prod. iii. 429.

On the sea-shore and in saline soils from San Diego to Punta de los Reyes, Also in Chili and abundant in dustralia and Tasmania, and very similar to $\mathbf{M}$. acinaciforme of S. Africa. Fruit edible and pleasant, and the flowers very fragrant.

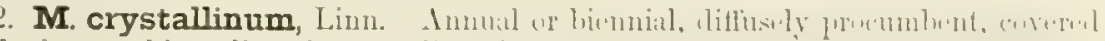
with large white glistening papillze: leaves Hat, fleshy, often altermate on the branches, clasping, ovate or spatulate, undulate: flowers axillary, nearly sessile, white or rose-colored: calyx-tube campanulate, terete, 4 or 5 lines long; lobes ovate, retuse or acute: st rmas 5.-DC. Prodr. iii. 448.

San Diego (Clevelanel); Santa Cruz Islund (Rothrock); collected also by Fromonto Appareutly idertical with S. African specimens.

\section{SESUVIUM, Linn. SeA Pershave}

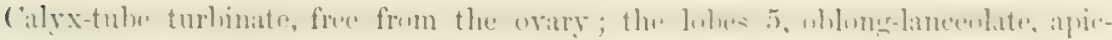
ulate on the back near the top, membranously margined, often colored within. l'etals none. Stamens 5, alternate with the lobes, or many, inserted at the top of the calyx-tube. Styles 3 to 5. Capsulo ovate-oblong, membranaceous, 3 -5-celled,

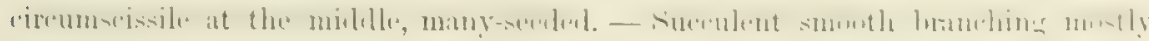
prostrate herbs, sometimes wooly at baso; leaves opposito, linear to spatulate, entire, without stipules or united by a stipule-like membrane; flowers axillary and terminal, solitary or clustered.

About $\mathbf{4}$ species are known, freqnenting the sea-const and saline localities through the tropies and warmer regions of the glotice.

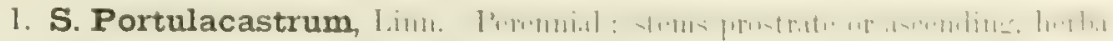
ceons, often a foot long or more: leaves linear- to ciblong-oblincenlate, at to $1 \frac{1}{2}$ inches long, acute or wbtuse: fluwers sessile or peelicellito: calyx 3 to 5 lines lung ; 
the lobes more or less purple: stamens many. - Rohrbach in Mart. FI. Bras. xiv². 310 , t. 70 .

A very variable species, widely distributed around the globe. It has been collected near Fort Mohave (Cooper), and is frequent in saline or alkaline valleys through the interior from N. Nevada to Colorado and New Mexico, often with much broader leaves than is usual in the sea-coast forms.

\section{MOLLUGO, Linn. CARPET-WEED.}

Calyx 5-cleft nearly to the base; the lobes herbaceous, membranously margined. Petals none. Stamens 3 or 5, rarely twice as many, hypogynous. Styles 3. Capsule free, thin-membranaceous, 3-5-celled, loculicidally 3-5-valved, the partitions breaking away from the persistent central placenta. Seeds several in each cell, longitudinally sulcate on the back. - Annuals, low and much branched, glabrous, not succulent; leaves linear to obovate-spatulate, entire, opposite and apparently verticillate; stipules obsolete; flowers mostly on long pedicels and axillary.

About a dozen species in the warmer regions of the globe. The following is the only one indigenous to N. America.

1. M. verticillata, Linn. Prostrate, covering the ground, slender : leaves spatulate to linear-oblanceolate, an inch long or less: pedicels umbellately fascicled at the nodes, slender, 2 or 3 lines long: sepals and oblong-ovoid capsule about $1 \frac{1}{2}$ lines long: seeds reniform, shining. - Kohrbach, 1. c. 240, t. 55 .

On light sandy soils from the Columbia River southward; at Fagle Creek, near Shasta, and at MeCumber's Flat (Brewer, Newberry); from Arizona to Colorado and New Mexico, and frequent in the Atlantic States as a weed in cultivated gromnds : thence southward to the W. Indies aud Brazil.

\section{Order XLV. UMBELLIFER Æ⿸尸}

Herbs with small flowers in umbels (sometimes contracted into heals), five epigynous stamens and petals, and two styles; the calyx adnate to the 2-celled ovary, which contains a solitary ovule suspended from the summit of each cell; and the fruit splitting into a pair of dry seed-like indehiscent carpels. Seed with a minute embryo in hard albumen. Petals mostly valvate in the bud." Stem commonly hollow. Leaves mainly alternate, mostly compound, often decompound : the petiole expanded or sheathing at base. Umbels usually themselves umbellate, forming a compound umbel : this is then usually called the umbel, and the partial umbels are called umbellets. The bracts under the general umbel, when present, form an involucre; those under the umbellets, an involucel. The enlarged base of the styles, or the common base of the two, takes the name of stylopodium : it is often surrounded by or confluent with an epigynous disk. Each of the two carpels is commonly traversed by 5 longitudinal ribs: in the intervals between them are usually lodged one or more longitudinal canals containing aromatic oil, the vitta or oil-tubes. The face by which the two carpels cohere is the commissure: a slender prolongation of the axis between them is the carpophore: it is apt to split into two branches, a carpel suspended for some time from the tip of each.

A family of almost 200 genera and wuch above a thousand species, dispersed over all parts of the world, but abundant only in warm, temperate, or cooler regions. Many are poisonous (Hemlock, Water-Hemlock, \&c.) : others afford esculent roots (Parsnip, Carrot), or their herbage may be eaten after blanching (Celery); several are inmocent and aromatic (Dill, Fennel), at least the fruits (Caraway, Anise, \&c.). 
The genera are difficult, as they have to rest mainly on the fruit and seed : these are best exanined in transerse slines. The whole onler is divided into numerous tribes. These, lueing somewhat recondite, are here dispensed with.

I. Umbels simple, or irregularly or imperfectly compound, the flowers sessile or slightly pelicellate. Oil-tubes none or obscure.

* Ieaves simple, not strongly lobed nor toothed : umbels simple or proliferous : flowers white, without bracts : oil-tubes none.

1. Hydrocotyle. Leaves peltate or orbicular. Fruit rounded, laterally compressed, smooth : ribs filiform. Creeping, aquatic or subaquatic.

2. Bowlesia. Leaves reniform, opposite! Fruit ovate, turgid and ribless, pubescent. * Leaves spinosely toothed, or palmately lobed or pinnatifid : oil-tubes obscure.

3. Eryngium. Leaves rigid, spinosely toothed. Flowers perfect, bracteate, sessile in dense heads, bluish. Fruit covered with hyaline scales.

4. Sanicula. Leaves lobed and incised. Flowers polyganous, in imegrlarly compound umbels, mostly yellow. Fruit covered with hooked priekles or tubercles.

II. Umbels regularly compround. Fruit without prominent secondary ribs and not furnished with hooked or barbed prickles. Oil-tubes rarely wanting.

* Fruit more or less compressed laterally, broadly ovate or subglobose to elliptic-oblong, not broadly winged.

+ Seed terete, with involute margins : oil-tubes conspicuous : carpophore entire : flowers yellow.

.5. Deweya. Fruit oblong or nearly orbicular; ribs filiform or prominent : oil-tubes 2 or 3 in the intervals.

* + Seed deeply sulcate on the face : oil-tubes wanting : carpophore 2-parted : flowers white.

6. Conium. Fruit broadly ovate, with prominent equal obtuse ribs.

+++ Seed nearly terete or but slightly concave on the face: flowers white.

+t Fruit small, not prominently ribbed: oil-tubes solitary: stylopodium depressed: umbels naked, sessile or nearly so.

7. Apium. Fruit broadly ovate : seed not concave : carpophore entire. Biennial.

8. Apiastrum. Fruit cordate : seed concave und longitudinally incurved : carpulhore 2- parted. Anumal.

+++ Fruit not prominently ribbed : stylopolium more or less prominent : arpophore bifid or 2-parted.

9. Carum. Fruit ovate or oblong: ribs filiform: ofl-tubes solitary. Involucre and involucels nsually present. Leallets linear, entire.

10. Pimpinella. Fruit ovate, with a broad commissure: ribs shightly prominent: oil-tubes numerous. Umbels nerrly naked. Leaflets cuneate-ovate, pinnatifid.

11. Berula. Fruit nearly globose, emarginato at base, with thickenel epicarp): oil-tubes numerous and contiguous. Involucre and involucels present. Leaflets ovate-oblong to linear, laciniately toothed.

t+ +t+t+Fruit with prominent corky wings, didymous: stylopodium depressed : carpophore 2-parted. Stout peremnials, with involucels and often involucres also.

12. Cicuta. Fruit brondly ovate, with thick obtuse wings : oil-tubes solitary.

13. Sium. Fruit oblong or ovate: ribs wing-like: oil-tubes 2 or 3 in the intervals.

* Fruit somewhat compressed laterally, linear-oblong, with broad commissure, not winged; seed sulcate or reniform in section: carpophore 2-parted, persistent : flowers white.

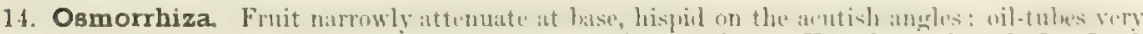
obscure: seed sulcate on the face or somewhat involuto. Umbels nearly naked. Leaflots ovate, cleft and toothed.

15. Glycosma. Similar; fruit not attenuate at base, very rarely hispid: seed brondly sulente.

16. Podosciadium. Fruit not atteruate at baso, glabrous: ribs tiliforma : oil-tules solitary or in prirs: seed reniform in section and longitudinally ridged on the face. luvoluere and involuecls present. Leaflets linear.

- Fruit not compressed, or more or less compressed dorsally, oblong to orbicular.

+ Fruit not compressed : flowers white.

17. Enanthe. Fruit oblong to globose : ribs corky and rounded, with very narrow iutervals and solitury oil-tubes. 
+ + Fruit somewhat compressed dorsally ; the dorsal ribs rather narrowly winged; the lateral wings broader, distinct : stylopodium sonewhat prominent: seed sulcate or concave : tall herbs, with white flowers.

18. Iigusticum. Dorsal ribs narrowly winged: oil-tubes several in the intervals, obscure: seed reniform in section.

19. Selinum. Dorsal wings broader : oil-tubes solitary: seed nearly flat on the face.

$$
+++ \text { Fruit much flattened dorsally. }
$$

++ Laternl wings broad, distinct, the dorsal more or less prominent : seed concave on the face or nearly tlat.

20. Angelica. Dorsal wings narrower than the lateral : oil-tubes solitary. Stout herbs, with white flowers and naked or nearly naked umbels.

21. Cymopterus. Dorsal wings as broad as the lateral ones: oil-tubes one to several in the intervals. Low perennial herbs; flowers yellow or white; involucres present.

+++ Lateral wings coherent till maturity; dorsal ribs filiform : seed nearly flat on the face.

22. Peucedanum. Lateral wings thin : oil-tubes as long as the fruit. Involucre none. Low perennials; flowers yellow or white, not radiate.

23. Heracleum. Lateral wings thin: oil-tubes solitary, clavate, not reaching the base of the fruit. Stout pubescent perennials, with white, often radiate flowers.

24. Ferula. Lateral wings corky, as thick as the fruit: oil-tubes numerous, mostly obscure.

III. Umbels regularly compound. Secondary ribs most prominent, armed with barbed or hooked prickles: oil-tubes solitary under the wings or ribs, conspicuous. Hispid herbs, with white flowers.

25. Daucus. Seed flat on the face. Biennial or annual.

26. Caucalis. Seed furrowed on the face or involute. Annuals.

\section{HYDROCOTYLE, Toum. Marsh Pexnywort.}

Calyx-teeth obsolete. Petals slightly concave, valvate. Fruit flattened laterally, suborbicular, acutely margined, and with 2 or 3 more or less prominent nerve-like ribs on each side; oil-tubes none; carpels not separating. - Smooth herbaceous perennials, growing in or near water, with slender creeping stems; leaves orbicularpeltate or reniform, with scale-like stipules; flowers inconspicuous, appearing through the summer, the umbels simple or proliferous one above the other, on slender peduncles.

A genus widely dispersed over the globe, of about 70 species, the larger number belonging to the southern hemisphere; sparingly represented in the Uuited States.

1. H. prolifera, Kellogg. Leaves peltate, emarginate at base, simply crenate, on petioles 1 to 3 inches long: peduncles about equalling or exceeding the leaves: whorls 1 to 4 , about 8 -flowered (12-20-flowered, Kellogg), with numerous bractlets, the pedicels a line or two long ( 3 to 6 lines, Kellogg): fruit a line broad, slightly emarginate at base; ribs two on each side, prominent; commissure narrow. Proc. Calif. Acad. i. 15.

A slender species, growing about San Francisco and elsewhere, first collected by Chamisso; collected also by Coulter in "Sonora Alta," and by others in Mexico. It has been referred to $H$. vrulgaris of the Old World, from which it is distinguished by its much longer peduncles and pellicels, the fruit in $H$. vulgaris being nearly sessile.

2. H. ranunculoides, Linn. fil. Stouter, usually floating: leaves not peltate, orbicular, with 3 to 7 crenate lobes, on petioles 2 to 9 inches long: peduncles much shorter than the petioles, $\frac{1}{2}$ to 3 inches long, reflexed in fruit: flowers 5 to 10 in a capitate umbel : fruit 1 to $1 \frac{1}{2}$ lines broad, with thickened scarcely angled margins, rather obscurely 3-nerved on each side, longer than the pedicels.

About San Francisco; San Diego Co. (Palmer); and probably elsewhere. Common also in the Atlantic States, and from Florida westward through Mexico. 


\section{BOWLESIA, Ruiz \& Pavon.}

Calyz-teeth rather prominent. Petals elliptical, obtusish. Fruit broadly ovate in outline, with a narrow commissure, turgid, becoming depressed on the back, without ribs or oil-tubes. Seed flat on the face, slightly hollowed on the back, not filling the calyx. - Slender herbs, with scattered stellate pubescence; leaves opposite, simple, with scarious and lacerate stipules; flowers white, minute, in simple few-flowered umbels on axillary peduncles.

A dozen species, chiefly South American, one ranging northward to Mexico, Arizona, and California.

1. B. lobata, liuiz \& Piron. Annual, weak and sinter, thinly pulweent, the stems dichotomously branched, a foot or two long: leaves thin, reniform to cordate, $\frac{1}{2}$ to $1 \frac{1}{2}$ inches broad, shorter than the slender petioles, deeply 5 -lobed, the acutish lobes entire or 1-2-toothed: peluncles much shorter than the petioles; the umbels 1-4-flowered: fruit a line long, sessile or nearly so, pubescent, the inflated calyx not adherent to the carpels, which are at first but partially occupied by the seed. 11. Peruv. iii. 28, t. 251; Torr. \& Gray, Fl. i. 601.

In damp shady places, from the Sacramento Valley southward, rather rare. The species doubtless includes $B$. tencra, sprengel.

\section{ERYNGIUM, Tourn. Button Sxakeroot.}

Calyx-teeth manifest, rigicl aml persistent. Fruit oroid or ohovoil, smatedy compressed, covered with hyaline scales or vesicles; the ribs obsolete, and oil-tubes (in our species) wanting; carpels and seeds semi-terete. - Herbs, chiefly perenninl; leaves rigid, coriaceous, spinosely toothed or divided; flowers white or blue, sessile in dense heads, bracteate, the outer bracts forming an involucre.

A genus of 100 or more species, of the warm and temperate regions of the globe. The 15 to 18 American species are mostly confined to the Southern Atlantic and Gulf States.

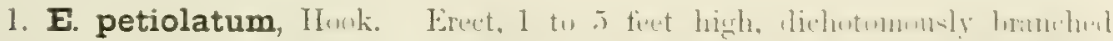
alove, gluncous: rudical leaves oblanceolate, spinosely and unequally serrate, attenunte into an elongated fistulous petiole, the cauline mostly sessile: henls globose, half an inch in diameter, peduncled; bracts linear-lanceolate, spinosely tippred, at least the outer ones much exceeding the bluish flowers: calyx-teeth a line long, exceeding the fmit, which is covered with subulate at length rigicl seales. - Fl. i. 250 ; Torrey, Bot. Wilkes Exp. 315. E. articulatum, Hook. in Lond. Jour. Bot. vi. 232 .

Var. armatum, Watson. Bracts broader, entire, all similar and much exceeding the flowers, scarcely dilated at base, rigid and with a thickened margin: style shorter than the calyx: usually less glamcous.

In marshes from San Diego to the Columbia; or in driel places, a dwarf state but 2 or 3 inches high. The submerged leaves consist unly of the terete jointed pretiole without lamina.

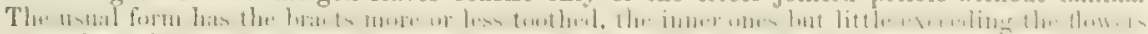
or rarely as long as the outer ones, the styles exceeling the calyx-tecth. The variety is mentioned by Dr. Torrey, in Bot. Wilkes Exp. 315, ns jerhngs distinct. It has been collected from Monterey to Humboldt County, Brewer, Samucls, Kicllogg, dic.

\section{SANICULA, Toura. SANICLE.}

Calyx-tecth somewhat folinceous, persistent. Fruit suhgloboso or obovoil, densely covered with hooked prickles or tuberculato; ribs obsolete; oil-tulies numerous. Seenl hemispherical. - Smooth perennials, with nearly naked stems; leaves palmately divided, the lobes more or less pimmatifid or incised; flowers unisexual, 
in irregularly compound few-rayed umbels, involucrate with sessile leafy usually toothed bracts, the bracts of the involucels small and entire.

A genus of a few scattered species, more than half of them native of North America, and of these only two are confined to the region east of the Rocky Mountains. The Californian species are chiefly limited to the Coast Ranges and are peculiar in their habit, small fruit, \&c.

* Leaves palmately divided, the lobes toothed, or lacerate, or pinnatifid with decurrent segments: rootstocks thickened.

- Mature fruit shortly pedicellate: flowers yellow.

1. S. arctopoides, Hook. \& Arn. Stems very short, with several divergent scape-like branches, often much exceeding the leaves ( 3 to 6 inches long), each bearing an umbel of 1 to 3 elongated rays: leaves deeply 3 -lobed, the cuneate divisions once or twice laciniately cleft, with lanceolate acute spreading segments : involucre of 1 or 2 similar leatlets: heads large, 3 to 6 lines in diameter, with conspicuous involucels of 8 to 10 narrowly oblanceolate mostly entire bracts : fruit shortly pedicellate, $1 \frac{1}{2}$ lines long, naked at base, strongly armed above. - Bot. Beechey, 141 ; Hook. Fl. i. 258, t. 91.

About San Francisco and eastward in the Sacramento Valley, in the plains and on dry hillsides. Strougly marked by its low scape-like branches, large involucels, and laciniately lobed leaves; plant yellowish green. The figure in Hook. Fl. represents the species poorly, and but for the large solitary head might be supposed to be from a low form of S. Zaciniata.

2. S. Menziesii, Hook. \& Arn. Stem solitary, erect, 1 to $2 \frac{1}{2}$ feet high, branching: leaves rounded-cordate, 2 or 3 inches broad, very deeply $3-5$-lobed; the broad lobes sharply toothed or somewhat cleft and the teeth tipped with slender bristles; upper leaves more narrowly lohed and laciniately toothed: umbel of 3 or 4 slender rays; involucre often small, of 2 or 3 narrow leaflets, the involucels of 6 to 8 lanceolate entire bracts a line or two long: sterile flowers nearly sessile: fruit 4 to 8 in each head, becoming distinctly pedicellate and divergent, obovate, a line long or more, covered with hooked prickles. - Bot. Beechey, 142 ; Hook. Fl. i. 258, t. 90.

In shaded woods from Santa Clara County to the British boundary.

$$
++ \text { Fruit sessite. }
$$

3. S. Nevadensis, Watson. Stem very short, the peduncles mostly from the base, 1 to 6 inches long: leaves ternate, the divisions oblong-ovate, 3-5-lobed; the segments lobed or toothed: involucre pinnatifid and toothed, a half to an inch long: rays about 5, sometimes branched, 2 to 5 lines long in flower, becoming $\frac{1}{2}$ to $1 \frac{1}{2}$ inches long; involucels somewhat one-sided, of several oblong acute bracts more or less united at base: flowers yellow, the sterile equalling the pedicels : fruit covered with stout hooked prickles. - Proc. Am. Acad. xi. 139.

Indian Valley, Plumas County, Mrs. M. E. P. Ames, 1874 ; Lemmon.

4. S. laciniata, Hook. \& Arn. With the habit of S. Menziesii: leaves cordate or triangular, 3-parted, the divisions laciniately $1-2$-pinnatifid and the segments laciniately toothed; the teeth spinosely pointed: flowers yellow: mature heads small, globose; the numerous fruit naked at base, hooked-bristly above. - Bot. Beechey, 347. S. nudicaulis, Hook. \& Arn. 1. c.

From San Diego to Humboldt County. A form is collected at San Diego and on the Buenaventura with larger heads of flowers and the divisions of the leaves more oblong; perhaps distinct, but the fruit is unknown.

5. S. bipinnatifida, Dougl. Erect, a foot high or less, with usually a pair of opposite leaves at base and 1 to 3 leaves above: leaves long-petioled, triangular to oblong in outline, 2 or 3 inches long, pinnately 3 -5-lobed; the segments distant, incisely toothed or lobed, decurrent on the toothed rachis; teeth spinose-pointed or only acute: nmbel with usually 3 or 4 elongated rays, the cleft involucre lateral : 
hends dense, 3 lines in diameter: flowers purple or snmetimes yellowish; involucels very short : fruit covered with hooked bristles - Hook. Fl. i. 258, t. 92 ; Torrey, Bot. Wilkes Exp. 31t.

From the Sacramento Valley to the Columbia; Sierra Co., Lemmor.

* * Leaves twice or thrice pinnate, the segments small and not decurrent: flowers yellow: fruit sessile: erect, very slender, branching.

6. S. bipinnata, Iouk. \& Arn. Tiut fusiform, slender: stems a font high tre more: ultimate segments of the leaves 3 or 4 lines long, acutely toothed: umbels about 3-rayed, with a leafy involucre; heads small, two lines in diameter, with a small menlmanaceous 6 - 8 -jarted involucel : fruit tuberculate at base, armed abover, $1 \frac{1}{2}$ lines long. - Bot. Beechey, 347 .

From Mronterey to the Upper Sacramento Valley.

7. S. tuberosa, Torrey. Stem 3 inches to a font hich, from a small tuherous root: leaves usually very finely divided, the segments less than a line in length: rays 1 to 4 ; involucres leafy ; involucels small, of unequal lobed segments: heads sinall, the sterile flowers on hing pedicels: fruit few, lepersed, strundy tuberculate, unarmed. - Pacif. R. Tep. iv. 91.

Dry hills, Mendocino County, to the Sacramento Valley. In the Sierra Nevada (Duftield's Ranch, Biyclow, and Plumas County, Mrs. Ames) there is found a low form with less finely divided leaves.

\section{DEWEYA, Torr. \& Gray.}

Calyx-tecth small or obsolete. Disk and stylopodium depressed or wanting. Fruit oblongrelliptieal or orhicular, compressed laterally ; rilss somewhat prominent, and with 2 or 3 obscure secondary lines between each pair; oil-tubes 2 to 3 in the intervals, conspicuous. Seed terete, involute, often enclosing a central cavity. Carpophore entire. - Smooth erect perennial herbs, 1 or 2 feet high; lenres pinnate or hipinnate, mostly rulical ; flowers yellow, in larese umleds; involuere nome or partial, the involucels 1 -sided.

An exclusively Californian genus, distinguished from Conium by the conspicnous oil-tulues, from Arracucia (to which it is referred by Benth. \& Hook. in Gen. Pl. i. 885) by the depressed stylopodium and terete seed, and from both by the undivided carpophore and more involute seed.

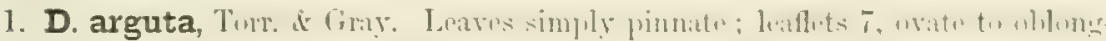
ovate, the lowest shortly petiolulate and often subcordate, 1 to $1 \frac{1}{2}$ inches long, finely and sharply sermte with mucronate tecth, the terminal one often 3-lobed: perluncle elongated : rays albout 12, without involuere, 2 or 3 inches long: involncels of 2 or 3 linear acuminate entire or toothed bmets: perlicels two lines long: fruit oblung, three lines long, acutely ribbed, with rather hroad commissure amd somewhat prominent erect calyx-teeth. - Fl. i. 6t1; Torr. But. Mex. Bnund. t. 26.

Southern ('nlifornin, near the const, from Sunta Barbum to San Diego. In wools aud on dry hillsilles, mrely collected: root large and fisiform.

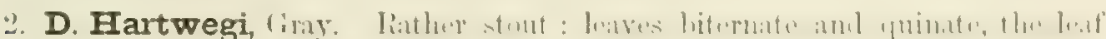
lets mure decply lobed and less sharply tonthed than in tho last: umbels similar; involucre none or of 1 or 2 leaflets: fruit brouler, 3 lines long; calyx-tecth obsolete; rilss prominent, and oil-tubes marked by intervening ridges: sved involute, enclosing a central carity. - P'roc. Am. Acal. vii. 342.

Itills bordering the lower Sacmento (Harlurry); near San Francisco, Kellogg.

3. D. Kelloggii, Grny. M Ioro slender, leafy at hase: lenves 3-ternate, the leaflets a half to an inch long, mostly 3-Inherl, nuneronately toothed: involueto none: rays 10 to 12, an inch long or moro; involucols of vory small subulato bracts: 
fruit two lines long and broad, with narrow commissure and no calyx-teeth, the ribs filiform: seed involute, enclosing a central cavity. - Proc. Am. Acad. vii. 343.

About San Francisco and Bolinas Bay, Kellogg, Bolander.

\section{CONIUM, Limn. PoIson HeMlock.}

Calyx-teeth obsolete. Fruit broadly ovate, laterally compressed, the carpels with 5 prominent obtuse equal ribs; oil-tubes none. Seed terete, with a deep narrow groove on the inner face. Carpophore 2-parted. - Tall smooth biennials; leaves large, decompound; involucres and involucels small, 3-5-bracted; flowers white.

A genus of only 2 ог 3 species, natives of the Old World, with virulently poisonous but valuable medicinal properties.

1. C. maculatum, Linn. Stem 2 to 5 feet high, from a white fusiform root, branching, often spotted with purple: leaves bright green, the segments half an inch long, pinnatifid, with acute lobes: umbels 12 -20-rayed, the rays 1 to $1 \frac{1}{2}$ inches long: petals obtuse or with a very short inflexed point : fruit $1 \frac{1}{2}$ lines long, shorter than the pedicels.

Sparingly introduced in waste places in the neighborhood of the older towns. The bruised leaves exhale a sickly disagreeable odor. The extract of the plant has powerful narcotic and alterative properties, and is a valuable remedial agent in the hands of competent physicians. The root ignorantly eaten by children and others has not rarely proved fatal in its effects.

\section{APIUM, Linn. Celery.}

Calyx-teeth obsolete. Stylopodium depressed. Fruit broadly ovate, laterally compressed, the carpels nearly straight, somewhat ribbed obtusely; oil-tubes solitary in the intervals. Seed nearly terete, not channelled nor concave on the face. Carpophore entire. - Smooth; leaves decompound; umbels terminal, often nearly sessile opposite the leaves; flowers white; involucre and involucels small or none.

Including about a dozen species, as limited by Bentham \& Hooker, some widely distributed, but half of them confined to the Southern United States east of the Rocky Mountains. The only species found in California is a native of the coasts of Europe, widely naturalized, under cultivation much changed and improved, becoming the garden Celery. The cultivated Parsley is another member of the genus (A. Petroselinum).

1. A. graveolens, Linn. Biennial, with a fibrous root, erect, branching and rather leafy, a foot or two high: leaves pinnate with 1 or 2 pairs of broadly cuneateobovate or rhomboidal leaflets, 3 -5-lobed and sparingly toothed, an inch or two long, the upper ternate with nearly entire oblanceolate leaflets: umbels sessile or very shortly pedunculate, naked; rays 6 to 12 or fewer, slender, an inch long or less: fruit two thirds of a line long.

Rare in California, but has been collected in salt marshes from Santa Barbara to San Diego, and also at Fort Tejon.

\section{APIASTRUM, Nutt.}

Calyx-teeth obsolete. Petals ovate, concave, obtuse. Stylopodium depressed; styles short. Fruit cordate in outline, laterally compressed with a narrow commissure; carpels incurved when mature, with 5 often obscure rugulose ribs; oil-tubes broad and solitary in the intervals, and a narrow one under each rib. Seed concave and somewhat incurved longitudinally. Carpophore 2-parted, rigid.-A smooth slender branching Californian annual; leaves dissected, with linear segments; umbels sessile, naked, few-rayed, in the forks or opposite to the leaves; flowers small, white. 
1. A. angustifolium, Nutt. A span or two bigh; branches somewhat dichotomous: leaves 1 or 2 inches long, biternately or triternately divided, with linear or nearly filiform segments: umbels and umbellets very unequally 3 -4-rayed, the slemler pedicels at lenth spinusely pointed with the persistent caryophore: fruit half a line long, somewhat broider, variable in the curvature of the carpels and in the prominence of the ribs, which are sometimes nine, the primary and intermediate ones being nearly equally developed. - Torr. \& Gray, Fl. i. 644; Torrey, Bot. Mex. Bound. t. 28. A. latifolizm, Nutt. 1. c., the more coarsely dissected form. Helosciadium leptophyllum, var. (?) latifolium, Hook. \& Arn. Bot. Beechey, 347.

Frequent in spring in the western portion of the State, from San Diego to Mendocino County, on hillsides. In the figure cited, some of the characters of the fruit are incorrectly shown.

\section{CARUM, Linn.}

Calyx-teeth small. Stylopodium conical. Fruit ovate or oblong, laterally compressed; ribs obtuse, scarcely prominent or nerve-like; vil-tubes solitary in the intervals. Seed subterete or somewhat dorsally compressed, convex, flat, or slightly concave on the face. Carpophore 2-parted. - The American species form the section Edosmia, - smooth erect slender biennial herbs, with tuberous or fusiform fascicled roots; leaves mostly simply pimate with few linear leaflets; involucre and involucels of few to many entire leaflets; flowers white; calyx-teeth rather prominent; section of the seed very variable in outline.

The genus as limited by Bentham \& Hooker includes about 50 species in temperate and subtropienl regions, chiefly of the Old World, one species (C. Carvi, the garden Carroway) being often cultivated and extensively maturalized. The roots of both the Californian species are a prominent article of food among the Indians.

1. C. Gairdneri, lienth. \& Hook. Stem 1 to 4 feet high, from a tuherous root: leaves few, usually simply pinnate, with 3 to 7 linear leatlets 2 to 6 inches long, the lower leatlets rarily pinnate with entire or tonthed divisions; upper leaves usually simple: umbels on long pectuncles, 6 to 12 rajed ; the involucre of a single linear leatlet, or often wanting; ratys an inch or two long ; involucels of several linear acuminate bracts equalling the flowers: fruit 1 to $1 \frac{1}{2}$ lines long, ovate to oblong, the styles usually halt as long as the fruit. - Atenia Gairdneri, Hook. \& Arn. Bot. Beechey, 349. Edosmia Gairdneri, Nutt. in Torr. \& Gray, Fl. i. 612.

Frequent from Washington Territory and Idaho to Southern Californin (eliefly in the Sierra

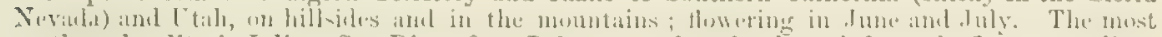
sonthern locality is Julian, Sun Dicgo Co., Palmer. A broaler leaved form (lenflets 2 to 8 lines wide) is the var, latifoliem of Gray, Proc. Am. Acad. vii. 344.

2. C. Kelloggii, Gray. Root tuberous and fascicled: stem 2 to 5 feet high: lower leaves ternate or biternate with pinuate divisions and linear segments; upper leaves becoming linear: involucre and involucels of 1 to 9 linear-subulate leaflets: fruit usate to ublung, 1! to 21 lines long, with prominent stylopertim and very short styles, the ribs filiform. - Proc. Am. Acad. vii. $34 t$.

Central California, near the coast. A rather stouter plant with larger flowers and fruit.

\section{PIMPINELLA, Linn.}

Calyx-tceth minute or obsolete. Stylopodiun cushion-like or conical. Fruit ovate or broader than long, laterally compressed, with a broad commissuro; carpels 5-angled, with distant usually slender ribs and several oil-tubes in the intervalls. Seed subterete or clorsally compressed, nearly flat on the face, often free from tho loose epicarp. Carpophore divided. - MLstly smonth perennials; leaves decom. pound; umbels nearly naked; flowers white or yellow. 
A large genus in the Old World of 60 to 70 species, the following almost its only representative in America.

1. P. apiodora, Gray. Smooth, erect, 2 or 3 feet high, rather stout: leaves mostly radical, 2 - 3-ternate, the cuneate-ovate leaflets laciniately pinnatifid and toothed, an inch long: umbels long-peduncled; rays 6 to 15, hispidly puberulent, an inch or two long; involucre and involucels of 1 or 2 bracts, or wanting: flowers white or pinkish : fruit broadly ovate, $1 \frac{1}{2}$ lines long, the carpels 5 -angled with slightly prominent ribs: oil-tubes numerous ( 4 to 5 in the dorsal intervals, 6 in the lateral, and 8 or more in the commissure): styles short: carpophore 2-parted. Proc. Am. Acad. vii. 345, \& viii. 385; Watson, Bot. King Exp. 121.

San Francisco and northward; Mendocino County (Bolander); Oregon (Hall); Eastern Nevada, Watson. Perfectly mature fruit has not yet been collected. The plant has a strong pleasant odor, like that of Celery.

\section{BERULA, Koch.}

Calyx-teeth minute. Stylopodium conical and styles short. Fruit nearly globose, with a broad commissure, emarginate at base, the ribs nerve-like, not raised above the thick epicarp; oil-tubes numerous and contiguous, surrounding the terete seed. Carpophore 2-parted, very slender. - A smooth perennial aquatic; leaves pinnate and serrate; involucres and involucels of several leaflets; flowers white.

A single species (often referred to the genus Sium) common in Europe, and widely though sparingly distributed through the United States and Mexico.

1. B. angustifolia, Koch. Erect but usually low, $\frac{1}{2}$ to 3 feet high, the stem stout and angled: leaflets about 6 pairs, ovate-oblong to linear, $\frac{1}{2}$ to 2 inches long, often laciniately lobed at base, and the upper ones especially more or less deeply cut-toothed: peduncles 1 or 2 inches long: rays an inch long or less; involucre and involucels of 6 to 8 entire linear-lanceolate leatlets : fruit two thirds of a line long. - Sizm angustifolium, Linn.

Collected at Fort Tejon (Xantus, Rothrock) though without fruit, and reported from San Francisco ; Sierra Co., Lemmon. The Heloseialium (?) Califormicum of Hook. \& A Am. Bot. Beechey, 142 , has been doubtfully referred to this species, but is deseribed as procumbent, the lower leaflets fimnatifid or pinnate, and the styles long. Benth. \& Hook. (Gen. Pl. i. 893) speak of the fruit of the specimen in herb. Kew as having the epicarp thin over the intervals as in species of Sium. The reference is therefore probably incorrect and the species remains uncertain.

\section{Cicuta, Linn. Water Hemlock.}

Calyx-teeth small, acute. Stylopodium depressed. Fruit broadly ovate or suborbicular, slightly compressed laterally but the commissure narrow ; ribs broad and obtuse, corky; the oil-tubes solitary in the intervals. Seed subterete, flat or rounded on the face. Carpophore 2-parted. - Smooth tall branching marsh perennials, with stout hollow stems; leaves pinnate or pinnately decompound; umbels of white flowers many-rayed, the involucre small or none, and involucels of several small bracts : roots thick and fascicled, very poisonous : flowering in summer.

A small genus of about half a dozen species, growing in damp or wet places, two of them very witlely distributed round the world in the northern hemisphere. The aromatic roots of the first species have often proved fatal to those eating them, and the others are probably as dangerous.

1. C. maculata, Linn. Stout, 3 to 6 feet high: lower leaves on petioles 1 or 2 feet long, bipinnate; the leaflets ( 1 or 2 inches, sometimes 4 inches, long) oblonglanceolate, acuminate, coarsely serrate with the veinlets running to the sinuses, occasionally lobed, the lower petiolulate: rays an inch or two long, rather slender; involucre usually wanting; involucels of 6 to 8 narrow lanceolate leaflets: fruit 
nearly $1 \frac{1}{2}$ lines long, broadly ovate; ribs and broad oil-tubes conspicuous: seed nearly terete or somewhat hollowed on the face.

Across the continent from New England and Florida to Washington Territory and the Sierta Nevada; Mono Pass (Bolander), and reported from Fort Tejon, Xantus. It is doubtful whether it extends to the coast, most of the specimens reported from that region belonging apparently to C. Californica. The species is also native of Europe and Asia.

2. C. Bolanderi, Watson. Leares hipinnate, the leatlets narrowly linceulate, sharply long-acuminate, two inches in length, very acutely serrate, the veinlets passing to the sinuses; the lower leaflets petiolulate and often deeply lobed: involucre of several linear leaflets: fruit two lines long, nearly orbicular, strongly ribbed and with broad oil-tubes, which are sunk in the channelled seed. - Proc. Am. Acad. xi. 139.

\section{At Suisun, in salt marshes, Bolander.}

3. C. Californica, Gray. Very stout, 3 to 5 feet high: leaves pinnate, or the lower bipinnate at base; the leaflets 2 to 4 inches long, lanceolate, shortly acuminate, rounded at base, serrate with the veinlets running to the teeth, often dceply lobed on the lower side: involucre none, or a narrow leaflet; involucels of several lanceolate bracts: fruit broadly ovate, $1 \frac{1}{4}$ lines long, strongly ribbed: seed not channelled under the oil-tubes, rhomboidal or ovate in section, thinnest at the commissure. - Proc. Am. Acad. vii. 344.

In the neighborhood of San Francisco and southward to Santa Cruz (Hartweg) and Monterey, Brewer.

\section{SiUM, Linn. Water Parswir.}

Calyx-teeth minute. Stylopodium depressed and styles short. Fruit oblong or ovate, laterally compressed with a narrow commissure, the ribs prominent and winglike, corky; oil-tubes 2 or 3 in the intervals. Carpophore 2-parted, slencler and usually decidnous with the fruit. - Smooth perennial aquatics, with angled stems; leaves pinnate and leaflets serrate or pinnatifid; involucre and involucels of several bracts; flowers white.

Half a dozen species are found in the northern tempernte zone and a single ono in South Africa. The following species, also Asiatic, is the only one indigenous in California.

1. S. cicutzolium, fimelin. Sitont, 3 to 6 feet hidh, hrunehing: luwe haves long-netioled, the cauline with a short dilated base; leallets 6 to 8 pairs, oblonglanceolate to linear, 2 to 4 inches long, acuminate, sharply serrate or rarely pinnatifil, the upper ones shorter and narrower: rays 1 to $1 \frac{1}{2}$ inches long; involucre and involucels of 6 to 8 linear bracts: fruit oblong, $1 \frac{1}{2}$ lines long, very strongly ribbed. - S. lineare, Nichx.

Reported from Posé Creck, and mentioned by Torrey in Bot. Wilkes Exped. and by Bolandor as growing nent San Francisco. It is certainly found on the ensterne slope of the Sierna Nevadia in Sierra and Truckee Valleys, and thence muges to $W^{z}$ ashington Territory, Colorado, the Saskatchewan, and the Atlantic. It is also identical with the plant of Siberia, the older name of which is here adopted. Bentham \& Honker refer hoth this speeies and the enstern S. Carsuni to the genus Apium, but they are certainly not to be separated from the typical species S. Inlifolium and lencifolium of the Old World. In all, the earpophore though dulieate is always 2-parted, and the oil-tubes are 2 or 3 (perhaps rarely solitary) in the intervals.

\section{OSMORRHIZA, Rafinesquo. SweEt Cicelr.}

Calyx-teeth obsolete. Fruit linenr-oblong, narrowly attenuato at baso, acuto above and tipped by the erect stylo, compressed laterally and narrowed at the commissure; carpels 5-angled, with somewhat prominent slightly corky wings, hispicl with short ascencling bristles; oil-tubes numerous and very obseure. Shed hereh, 
sulcate on the face or with margins contiguous and enclosing a central cavity. Carpophore 2-cleft. - Perennials, with thick aromatic roots, more or less hirsute; leaves large, 2-3-ternately compound; involucre small or noue; umbels few, fewrayed and few-fruited; flowers white.

A genus of half a dozen species. The two species of Eastern America extend to Asia, while the two of California are confined to the western coast.

1. O. nuda, Torrey. Rather slender, 2 or 3 feet high, more or less pubescent with spreading hairs: leaves twice ternate; leaflets ovate, an inch or two long, acute or obtusish, rather deeply cleft and toothed: umbel long-peduncled, 3-5rayed, naked or with small caducous involucre and involucels; rays 2 or 3 inches long: pedicels 3 to 9 lines long: fruit slender, 6 or 7 lines long and a line broad or less, acutely ribbed; the style and stylopodium very short; the attenuated base 2 lines long: seed terete, sulcate on the inner face. - Pacif. R. Rep. iv. 93. O. brevistylis, Hook. Fl. i. 272 in part, t. 97.

In the mountains from San Diego Co. to Alaska and eastward to Colorado. It is doubtful if the allied 0 . brevistylis extends so far west as the Rocky Mountains. That species is distinguished by its larger and more acuminate leaffets, involucrate umbels, and larger fruit, and the seed more angular and involute.

2. O. brachypoda, Torrey. About a foot high: leaves 2-3-ternate; leaflets ovate, an inch long or less, acute, laciniately lobed and toothed: rays rather shorter; involucre of one or few and involucels of 4 to 6 linear-acuminate bracts, the latter equalling the flowers; pedicels very short: fruit strongly and acutely ribbed, 6 lines long by $1 \frac{1}{2}$ broad, the stout base but a line long; stylopodium depressed and styles very short: seed strongly 5-angled, the margins contiguous and closing the deep central sulcus. - Pacif. R. Rep. iv. 93.

A strongly marked species, seemingly confined to Central California; Nevada Co. (Bigelow, Pratten), Santa Clara Valley (Goodale), and Monterey, Parry.

\section{GLYCOSMA, Nitt.}

Characters as in Osmorrhiza except as regards the fruit, which is linear but not attenuate to a narrow base, and usually glabrous; stylopodium depressed and styles very short: seed semiterete or angled, with a rather broad sulcus on the face. Involucre and involucels wanting.

A group of plants of Western America, more nearly allied to Osmorrhiza than to Myrrhis of the Old World, to which it is referred, by Bentham \& Hooker. The species are very much alike.

1. G. occidentale, Nutt. Rather stout, 2 feet high or more, finely puberulent thronghout, excepting the inflorescence: leaves 2-ternate, the leaflets oblong-lanceolate, $1 \frac{1}{2}$ to $2 \frac{1}{2}$ inches long, serrate : rays somewhat erect; pedicels 2 to 4 lines long, exceeding the sterile flowers: fruit 7 or 8 lines long, rather acutely angled. - Torr. \& Gray, Fl. i. 639; Gray, Proc. Am. Acad. viii. 386. Myrrhis occidentalis, Benth. \& Hook. Gen. Pl. i. 897 ; Gray, Proc. Am. Acad. vii. 346.

In the mountains from Oregon to Mono Pass, and eastward to the Wahsatch; S. Utah, Parry.

2. G. ambiguum, Gray. Glabrous, or somewhat hairy near the nodes: leaflets rather smaller and more deeply gash-toothed, an inch or two long, ovate-oblong, acute : rays more spreading; pedicels a line or two long, not exceeding the barren flowers: fruit 6 or 7 lines long, rarely bristly on the ribs at base. - Proc. Am. Acad. viii. 386.

Collected by Kellogg \& Harford in shady woods at Cahto, California, and by Hall at the foot of the Cascade Mountains, Oregon.

3. G. Bolanderi, Gray. Stout, somewhat puberulent: leaflets ovate, acute, rather deeply gash-toothed and lobed: rays spreading; pedicels 1 or 2 lines long; 
shorter than the sterile flowers: fruit 9 or 10 lines long, $12_{2}^{1}$ lines broad. - Proc. Am. Acad. vii. 346 \& viii. 386 .

Shady woods of Humboldt and Mendocino counties, Bolander, Kellogg.

\section{PODOSCIADIUM, Gray.}

Calyx-teeth small, scarious, subulate. Stylopodium sbort, conical. Fruit linearoblong, laterally compressed, with a rather broad commissure, somewhat contracted at the apex; ribs uarrow and filiform; oil-tubes 1 or 2 in the intervals; 4 on the conmissure. Seed reniform in section, slightly channelled on the back under the oil-tubes, broadly furrowed on the face, with a central longitudinal ridge. Carpophore 2-parted. - Sinooth branching Californian perennials; leares pinnately or somewhat ternately decompound, with linear leaflets; umbels long-peduncled, with involucres and involucels of several lanceolite acuminate subscarious bracts; flowers white, polygamous.

1. P. Californicum, Gray. Stem 3 or 4 feet high: segments of the leaves linear, entire or toothed, the terminal one elongated, an inch or two long; uppermost leaves simple: unbels 9-12-rayed, the primary umbel fertile, with rays two inches long; the others sterile, with rays an inch long and very slender pedicels exceeling the bracts: petals shortly acuminate: fruit 4 lines long, shorter than the pedicels, $1 \frac{1}{2}$ lines broad, with obtuse ribs: oil-tubes and seeds as described in the generic character. - Proc. Am. Acad. vii. 346. Charoplyyllum (?) Californicum, Torrey, Pacif. R. Rep. iv. 93.

Collected only by Bigelow at Knight's Ferry; May.

2. P. Bolanderi, Gray. Tro feet high: leaflets pinnate, the segments more narrowly linear: unbels many-rayed; rays 5 to 9 lines long; the conspicuous scarious involucels exceeding the pedicels: petals very long-acuminate, with the mirlvein strongly impressed: fruit 1.1 lines long, oblong, the narrow ribs becoming elevated and undulate; oil-tubes more numerous and obscure, 2 or 3 in the intervals: seed more compressed dorsally, and broader in proportion, not grooved on the back, the facial sulcus broad and shallow and but slightly raised in the centre. Proc. Am. Acad. vii. 346.

Mariposa Trail, among rocks, Bolander.

A closely allied plant, lut differing from any of the preceding genera, has been collected in the Yosenite Valley by both Dr. Torrey and Dr. Gray, with the fruit lowever too immature for its satisfactory determination. The fruit as found is narrowly oblong, 4 lines long, laterally com-

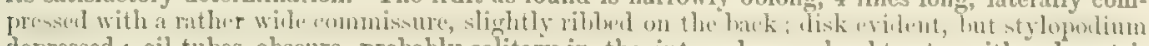
depressed; oil-tubes obscure, probably solitary in the intervals; seed subterete, with a deep triangular facial sulcus; carpophore 2-parted. The plant is a foot high or less, glabrous, slender, shortiy caulescent; leaves ternate or bipinnate, with linear acute segments, 1 to 3 lines long; umbels few-rayed, the rays very unequal, an inch long or less; involucre none; involucels of 1 or 2 small bractlets; flowers yellow, the calyx-teeth obsolete.

\section{CENANTHE, Linn.}

Calyx-teeth rather prominent, acute. Styloporlium short-eonical, the styles at

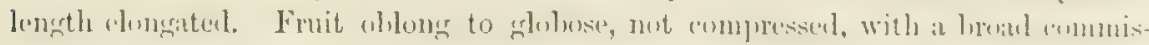
sure, the ribs roundod and corky, with very narrow intervals; oil-tubes solitary. Seed somewhat compressed dorsally, flat on tho face. Carpophore none. - Glabrous herbs, mostly aquatic; leaves pinnate or decompound; umbuls usually in. volucrite; flowers white.

The following are our only representatives of this genus, of which there are 20 or moro sprecieg in the temperate regions of the Old World. 
1. Ф. Californica, Watson. Biennial or perennial ; stems sucenlent, usually weak, 2 to 5 feet high: leaves ternate and bipinnate, the pinnæ nearly sessile; leaflets approximate, ovate, acute or acutish, toothed, often lobed at base, a half to an inch long: umbels many-rayed, with one or two linear involucral bracts or naked; rays an inch long or less; pedicels numerous, short: fruit crowded, nearly $1 \frac{1}{2}$ lines long, oblong, obtuse at each end, tipped with the long spreading styles; ribs and commissure very corky: seed somewhat dorsally compressed, usually angled; oil-tubes at the angles.-Proc. Am. Acad. xi. 139.

In marshes at Point Lobos, and southward to San Diego County.

2. ๔. sarmentosa, Nutt. Very similar: leaves usually broader and more open; leaftets acuminate, mostly smaller. - Torr. \& Gray, Fl. i. 617. Phellandrium aquaticum, Pursh.

Washington Territory and Oregon; Plumas Co., Lenmon. The succulent stems have the taste of Celery and are eaten by the Indians.

\section{LIGUSTICUM, Linn.}

Calyx-teeth obsolete. Stylopodium usually conical; margin of the disk undulate. Fruit ovate or oblong, with a broad commissure, somewhat dorsally compressed; ribs somewhat prominent and acute or narrowly winged, the lateral ones usually broadest; oil-tubes obscure. Seed dorsally flattened, somewhat concave on the face. Carpophore 2-parted. - Smooth perennials, usually tall; leaves pinnately or ternate and pinnately decompound; umbels many-rayed, naked or involucrate; flowers white.

A genus of about 20 or 25 species, of the northern hemisphere, chiefly of the Old World and most of them rather obscurely characterized.

1. I. apiifolium, Benth. \& Hook. Rather stout, 2 to 4 feet high, hranching above: leaves ternate or biternate, the divisions pinnate or bipinnate; segments ovate, $\frac{3}{4}$ to $1 \frac{1}{2}$ inches long, laciniately pinnatifid, the lobes acute or acuminate: umbels long-peduncled, without involucre or rarely with 1 or 2 slender bracts, the rays 1 or 2 inches long, scabrous-puberulent above; involucels of several narrowly linear entire bractlets; pedicels slender, 2 or 3 lines long: fruit oval, 2 lines long, with a conical stylophore; carpels somewhat quadrangular; ribs narrow, acute; oil-tubes 3 to 5 in the intervals, 4 to 8 on the commissure: seed reniform in section, with a medial longitudinal ridge. - Gen. i. 912. Cynapium apiifolium, Nutt. in Torr. \& Gray, Fl. i. 641.

In the mountains from the Columbia River southward; Yosemite Valley (Bolander); Big Tree road and Ebbett's Pass (Brewer); Donner Lake, Torrey. The Californian plant agrees with that of Oregon in all its characters, Specimens collected at Tamalpais by Bigelow were referred here by Dr. Torrey, probably correctly, but they were only in flower. What appears to be the same is also found in Colorado, but the segments of the leaves are smaller, the involucels wanting, and the fruit (immature) somewhat larger.

A doubtful form, var. MINor, Gray in herb., is found at Ostrander's Meadows (Bolander), and Ebbett's Pass(Brever); stem 9 to 15 inches high, with 1 or 2 umbels; leaves all nearly radical, ternate-pinnate; the still immature fruit $2 \frac{1}{2}$ lines long, rather strongly ribbed, the seed more depressed and without the central ridge.

L. scopulorvm, Gray, the more prevalent species in the Rocky Mountains, may perhaps be found in the northern Sierra Nevada, distinguished by the more depressed-reniform seed and by the oval more broadly winged fruit.

\section{SELINUM, Linn.}

Characters of Ligusticum, but the fruit rather more prominently winged, the oiltubes solitary and conspicuous in the intervals, and the seed nearly flat on the face. - Tall stout branching perennials, with pinnately decompound leaves. 
A genus of about 25 species (according to Benth. \& Hook.), almost exelusively of the northeru hemisphere; perhaps half a dozen in North America.

* Involucels conspicuous: pedicels slender: fruit smooth, with thin wings.

1. S. Pacificum, Watson. Leaves ternate-bipinnate, the ovate acutish segments an inch long, laciniately toothed and lobed: umbels on stout peduncles, about 15-rayed, with an involucre of 2 or 3 lobed and toothed leaflets, an inch long, equalling the rays; involucels of several narrowly linear entire or 3-toothed bracts equalling the flowers; pedicels 2 or 4 lines long: fruit oblong, 3 or 4 lines long, $1 \frac{1}{2}$ lines broad; stylopodium slightly prominent above the disk; the wings rather narrow; oil-tubes conspicuous, very rarely in pairs: seed channelled under the dorsal oil-tubes.-Proe. Am. Acad. xi. 140.

Saucelito Hills, near San Francisco, Kellogg \& Harford.

* * Umbels naked; pedicels very short or none, the flowers and hirsute fruit crowded or in globose heads: wings corky.

2. S. capitellatum, Benth. \& Hook. Tery stont, 2 to 5 feet high, smonth: leaves latre, with much dilatenl petioles, bipinmate, the fuw leaflets ublume- to linearlanceolate, an inch or two long, coarsely laciniately toothed or lobed: umbels 2 or 3 , tomentose, 6-8-rayed; umbellets globose, 3 to 6 lines in diameter, the pubescent flowers sessile on a dilated receptacle : disk prominent, the stylopodium depressed: fruit cuneate-obovate, 3 lines long, strongly ribbed, the lateral wings broader than the 3 upright dorsal ones: seed reniform, with shallow grooves for the dorsal oiltubes.-Gen. 1.915; Watson, Bot. King Exp. 126. Spluenoscialium capitellatum, Gray, Proc. Am. Acad. vi. 536.

Stream-banks in the Sienra Nevada, from Mono to Donner Pass, especially on the castern slope. Another closely allied species is found in the mountains of Northern Nevada, S. Kivgri, Watson, 1. c., with less tomentose inflorescence, the fruit oblong-oval, on pedicels a line or two long.

\section{ANGELICA, Linn.}

Calyx-teeth obsolete or minute. Stylopodium depressed. Fruit ovate, strongly fattened dorsally with a very broad commissure, margined by the broad membranous distinct lateral wing; dorsal ribs prominent but narrower; oil-tubes solitary in the intervals, or the lateral in pairs. Seed flattened, the face flat or slightly concave. Carpophore 2-parted. - Usually tall and stout perennials; leaves pinuate or compound, the toothed segments usually broad and the petioles much dilated; umbels many-rayed, naked or nearly so ; flowers white or purple.

About 30 species in the north temperate and Aretic zones; ten or moro North American.

1. A. Breweri, Gray. Glabrous or somewhat puberulent, 3 or 4 feet high: leaves ternate or quinate and pinnate; leaflets lanceolate or oblong-lauceolate, acuminate, 2 or 3 inches long, sharply serrate with cuspilate teeth, the lower sometimes lobed at baso: peduncles long, often with 1 or 2 entire dilated somewhat membranous bracts: umbels naked; rays 2 inches loug: fruit puhescent, oblong, 4 lines long and 2 broad, the lateral wings narrow and corky, as thick as the seed, the dorsal obtuse and little prominent; oil-tubes usually 6, besiles 2 to 4 on the commissure, the lateral or dorsal in pairs: seed more or less concave on the face, with sometimes a longitudinal medial ridgo, the oil-tuhes sunk in deep depressions on the back. - Proe. An. Acad. vii. 348; Watson, Bot. King Exp. 126.

In the Sierra Nevmln from Plumas Co. (A/rs. Ames) to Ebbett's Pass and the Big Treo roal

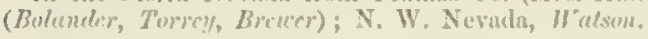

2. A. tomentosa, Witton. Very stont, houry-tomentuse throughunt or thes stem glabrous: leaves yuinately bipinate, tho leaflets thick, wrate, acute, very 
oblique at base, 2 to 4 inches long, the lower sometimes lobed, unequally serrate with acutish teeth: umbels naked, often dense, the rays 1 to 3 inches long: fruit broad-elliptical, 3 lines long by 2 to $2 \frac{1}{2}$ broad, the lateral wings thin and the dorsal acutish : seed thin, flat on the face, the solitary oil-tubes in channels on the back. - Proc. Am. Acad. xi. 141.

In the Coast Ranges, from San Francisco to Mendocino County.

3. A. lineariloba, Gray. Glabrous, stout, 2 or 3 feet high: leaves twice to thrice quinate, the leaflets linear, 1 or 2 inches loug, cuspidately acuminate, entire or the lower ones 3-parted with the decurrent sometimes coarsely toothed lobes divaricate: umbels naked, the rays an inch or two long: fruit smooth, 4 lines long by two wide; lateral wings a little narrower than the seed, rather corky: oil-tubes solitary, the lateral in pairs: seed nearly flat on the face, channelled under the dorsal oil-tubes.-Proc. Am. Acad. vii. 347.

Mono Pass (Botander) ; in the Southern Sierra Nevada, Rothrock. The thick root is said not to be sweet-scented.

\section{CYMOPTERUS, Raf.}

Calyx-teeth prominent or often small or obsolete. Stylopodium depressed. Fruit ovate or elliptical, obtuse or retuse, dorsally flattened, the lateral ribs and some or all of the dorsal ones expanded into more or less thickened and corky wings; oiltubes narrow, one to several in the intervals. Seed dorsally flattened, and more or less concave on the face. Carpophore 2-parted. - Perennials, mostly low and often cespitose, with a thickened root; leaves pinnately and finely decompound, with small narrow segments; umbels usually both involucrate and involucellate, fewrayed; flowers white or yellow.

Natives of Western North America, about 15 species, most of them confined to the region between the Rocky Mountains and the Sierra Nevada The roots are extensively used by the Indians for food.

$$
\text { * Shortly caulescent: flowers yellow. }
$$

1. C. terebinthinus, Torr. \& Gray. Erect, 6 to 18 inches high, smooth, leafy at base : leaves rather rigid, thrice pinnate; leaflets a line long or less, linear-oblong, acute, entire or $1-2$-toothed : fertile rays 4 to 6 , unequal, $\frac{1}{2}$ to 2 inches long; involncre a single linear leaflet or wanting, the involucels of several short linear bracts; pedicels 1 to 2 lines long: fruit 3 or 4 lines long, 2 or 3 broad, the rather thin corky ribs a line broad; calyx-teeth evident: oil-tubes 2 to 4 in the intervals, 4 to 10 on the commissure: carpophore persistent. - Fl. i. 624. Selinum terebintlinum, Hook. Fl. i. 266, t. 95. C. foniculaceus, C. albiflorus, \& C. thapsoides, Nutt. in Torr. \& Gray, Fl. i. 624.

One of the most widely distributed of the species, ranging from the Cascade Mountains in Washington Territory to Ebbett's Pass (Brewor, at 9,000 feet alt.), and the Yosemite Valley (Gray), and in the mountains eastward to Colorado.' As in other species the number of developed dorsal wings is variable.

$$
\begin{aligned}
& \text { * Acaulescent or nearly so: flowers white. } \\
& + \text { Not alpine. }
\end{aligned}
$$

2. C. montanus, Nutt. Nearly acaulescent: leaves clustered at the summit of the very short stem, smooth and glaucous, pinnate or bipinnate, the oblong segments pinnatifid with oblong obtuse entire or toothed lobes: peduncles 1 to 4 inches high, rather stout: involucre and involucels of broad and membranaceous bracts, united at base, the involucre often short and cup-like: rays about half an inch long or less; pedicels a line or two long: fruit 3 to 6 lines long, with thin flat wings 1 or 2 lines broad; calyx-teeth small; oil-tubes 3 in the intervals, 6 to 8 on 
the commissure: seed concave. - Torr. \& Gray, Fl. i. 624; Watson, Bot. King Exp. 123, exel. var.

$\checkmark$ ar. purpurascens, Gray. Involueres and involucels rery broml amel conspicicuous, nearly enclosing the flowers, obtuse, tinged or veined with purple and green: fruit nearly sessile, large and very broadly winged. - Ives Colorado Rep. 15.

One of the earliest spring flowers in the Great Basin, from Westem Nevada and Northern Arizona to Utah ; doubtless in Eastern California. The typical form seems to be mostly confined to the vieinity of the Rocky Mountains.

3. C. globosus, Watson. With the haloit of the last, the segnents of the leaves somewhat broaler in outline: involucre and involucels apparently none, and the rays and pedicels obsolete, the flowers and fruit being in dense globose heads, $\frac{1}{2}$ to 1 inch in diameter; fruit 3 or 4 lines long, the thin flat wings a line broad, narrower at base: oil-tubes solitary in the intervals, 2 on the conmissure: seed slightly concave on the face. - Proc. Am. Acad. xi. 141.

Northern Nevada ; near Carson City (Strelch, Watson); Goshont Mountains, Bcckwilh. Referred to by Dr. Torrey, in Pacif. R. Rep. ii. 120, under C. montanus as an abnormal form, and made a variety of the same species in Bot. King Exp. 124, the true fruil not having been examined.

\section{+ + Dwarf and alpine.}

4. C. cinerarius, Gray. Acaulescent, with a subterranean creeping rhizoma: scape ( 2 or 3 inches high) and petioles glabrous: leaves somewhat cordate in outlime, bipinnate with toothed segments, glaucous-cinereous with a fine rongh puberulence: rays few, short or almost none; involucre of numerous united somewhat membranous long-acuminate seaments: flowers purplish; calyx-teeth small : fruit 3 lines long, the nudulate wings less than a line broad; oil-tubes 3 in the intervals, several on the commissure: seed narrow, strongly curved with a deep central channel. - Proc. Am. Acad. vi. 535.

At Sonora Pass and above Mono Lako in the Sierra Nevada (Brcwor), at 9,000 to 10,000 feet altitude.

5. C. Nevadensis, Griy. Cespitose, leafy, roughish puberulent : leitres mether rigil, half an inch long, on short petioles, 3-lobed, the lobes 3-5-parted with lanceolate-subulate serments : scape less than an inch high, terminated by an umbel ot 3 to 5 nearly sessile umbellets, involucrate by several broad 3 -5-cleft herbaceous acute bracts: calyx-teeth lance-subulate; styles long; ovary obseurely winged.Proc. Am. Acad. vi. 536.

On the summit of Mt. Dana, at over 13,000 feet altitude, Brecer. Ripe fruit is wanting, and the determination of the plant is therefore in some measure uncertain.

\section{PEUCEDANUM, Linn.}

(allyx-tueth olsulete ur slightly prominent. Thisk and stylopolium small and

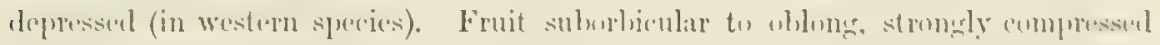

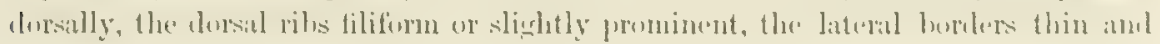
coherent till maturity; oil-tubes solitary in the intervals, or in pairs, or in a few species still more numerous. Seed Hattened, scarcely concave on the face, not chan-

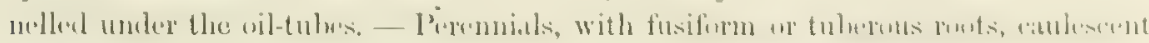
(usually shortly so) or aculescent; umbels without involuces (in western species),

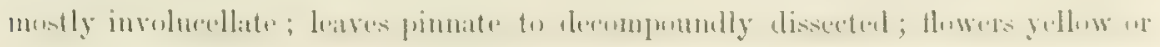
white. - Watson, Proc. Am. Acal. xi. 121.

A comprehensive genus of 100 or more sprecies, restricter? in America to the region west of the Mississippi, whero 20 species are found. They differ in general habit from most of those of the Ohd Workl, but there seems no gooul ground for a sepantion. The roots of nearly ull, as in the last gonus, are an importint article of food among the ludiuns. 
* Leaves not decompound, the segments large or broad or elongated : flowers yellow : fruit glabrous ; oil-tubes solitary.

Acaulescent, glabrous : leaflets ovate to narrowly lanceolate, entire or toothed at the apex : involucels none : fruit oblong.

Mostly caulescent, puberulent : leaflets linear, entire : involucels small : fruit oblong.

Shortly caulescent, glabrous : leaflets ovate, toothed : involucels pres= ent : fruit orbicular.

Leaves ternate : leaflets cordate : fruit large, emarginate at each end.

Leaves biternate : leaflets oval, laciniate or pinnatifid : fruit smaller, scarcely emarginate : calyx-teeth prominent.

1. P. Leiocarpum.

2. P. Thiternatum.

3. P. Euryptera.

4. P. PARTifolium.

* * Leaves decompound; segments narrowly linear; petioles broadly dilated: involucels conspicuous : flowers yellow : fruit glabrous, elliptical : caulescent, puberulent.

Segments $\frac{1}{2}$ to 2 inches long : bractlets often lanceolate : ribs obsolete: oil-tubes indistinet.

Segments rarely $\frac{1}{2}$ inch long : bractlets usually much dilated : ribs distinct : oil-tubes broad.

5. P. CARUIFOLIUM.

6. P. utriculatim.

* * * Leaves much dissected : low, pubescent.

Segments narrow : flowers yellow : fruit pubescent, oval : acaulescent.

Segments small : flowers white : somewhat caulescent.

Pubescent: fruit glabrous, oblong or broadly elliptical : involucels conspicuous.

Villous-tomentose : fruit tomentose, orbicular or ovate.

7. P. VILlOSUM.

Glaucous, puberulent : fruit somewhat pubescent, roundish to orate.

8. P. MACFOCATEPUM.

9. P. DASYCARYUM.

10. P. NEVADENSE.

§ 1. Leaves not finely dissected, ternate or biternate, sometimes quinate or with pinnate divisions, the segments large, broad, or elongated: involucels small or none: flowers yellow; calyx-teeth obsolete, except in No. 4 : fruit glabrous; oil-tubes solitary in the intervals.

* Acaulescent, glabrous: fruit oblong: involucels none.

1. P. leiocarpum, Nutt. Scape often very stout, $\frac{1}{2}$ to $1 \frac{1}{2}$ feet high, from a thick elongated root: leaves biternate or ternate-quinate; leaflets usually thick, ovate to narrowly lanceolate, an inch or two long, acute, sharply few-toothed near the apex or the narrower form entire: base of the umbel and umbellets often dilated; rays usually few, unequal, 2 to 8 inches long; pedicels 1 to 5 lines long, usually short: fruit 4 or 5 lines long, 2 lines broad, narrowed below, the ribs rather prominent, and the wing half as wide as the seed; oil-tubes distinct, the lateral sometimes in pairs, 4 on the commissure - Torr. \& Gray, Fl. i. 626 ; Seseli leincarpum, Hook. Fl. i. 262, t. 93.

From Puget Sound to the Sacramento River, and in the mountains eastward from Idaho to Sierra County, Lemmon. The Californian specimens are the broader-leaved form, approaching P. Nrttaldi1, Watson ( $P$. lutifolium, Nutt.), which appears not to have heen collected within the State. It is distinguished by its more ovate, very narrowly winged and more obseurely ribbed fruit ( 3 to 4 lines long and 2 wide), with 3 or 4 obscure oil-tubes in the intervals and 4 to 6 on the commissure; leaves biternate and leaflets ovate to orbicular.

\section{* * Caulescent, except sometimes in No. 2: involucellate. \\ + Fruit oblong: leaflets linear, entire : puberulent.}

2. P. triternatum, Nutt. Finely puberulent: stems 1 to $2 \frac{\pi}{2}$ feet high, with rarely more than a single cauline leaf, often acaulescent: leaves biternate or teruatequinate, the divisions rarely pinnate; the segments linear, or rarely oblong, acute, 1 to 4 inches long: rays few, unequal, 1 to 4 inches long; involucels of a few narrow bractlets, usually small; perlicels very short: fruit rarely pubeseent, 3 or 4 lines long. 1 to 1. lines wide, narrowest below, very narrowly winged, distinetly ribbed; oil-tnbes distinet, 2 broad ones on the comnissure. - Torr. \& Gray, Fl. i. 626. Seseli tritematum, Pursh; Hook. Fl. i. 204, t. 94. 
From Puget Sound and Idaho to Mendocino and Placer counties. The acaulescent form

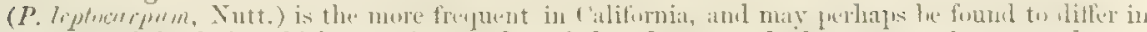
the form of the fruit, which sometimes at least is broadest near the base, narruwing upward.

P. sisplex, Nutt., of Utah, is very similar, but with leaves only ternate or biternate, fruit orbicular, 5 or 6 lines long, emarginate at each end, the wings broader than the bouly, and the ribs prominent.

P. AMBrGÜ, Nutt., which includes $P$. levigalum, Nutt., extends from Oregon and Washing-

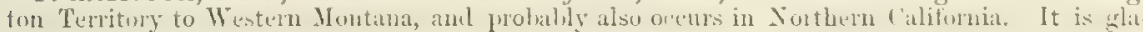
brous, a foot high or often much less : leaves with much dilated petioles, at least the lower ones

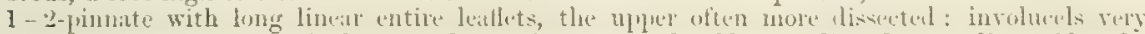
small or none; rays an inch of two long: fruit narrowly oblong, 4 lines long, a line wide, the wing half the wilth of the seerl; oil-tulus solitary in the intervals, 2 broad and thin ones on the commissure.

P. Famixosum, Geyer, Hook. Jour. Bot. vi. 235, is a dwarf species of Oregon and Idaho, which has not yet been collected in mature fruit. The short stems are slender, from a small round tuber; leaves twice or thrice pinnate, with linear entire leaflets; flowers white, in small open few-rayed umbels; involucels of one or few small linear bracts.

There is apparently at least another allied species among those used extensively by the Oregon Indians, and which may extend into Northern Californis, but of which the fruit has not been collected. It is low and acaulescent, with a very thick root, glabrous, the leaflets linear; flowers white (?), nearly sessile in the umbellets, with often a quite conspicuons involucel.

++ Fruit orbicular: leaflets ovate, toothed: glabrous.

3. P. Euryptera, ciray. Shortly cunlescent, 6 to 10 inches high, rather stont: laves ternate; leallets hroully cordate, somewhat lobet, coarsely amb uncronately tustherl, 1 to 1 inch long: rays 10 to 15 , a half to an incle long, the perdiceds short: involucels unilaterul, of several lanceolate bractlets: fruit 5 lines in diameter, emarginate at each end, the wings broader than the body; oil-tubes solitary in the intervals and on each side of the commissure. - Proc. Am. Acad. vii. 348. Euryptera lucila, Nutt. in Torr. \& Gray, Fl. i. 629 ; Torrey, Bot. Mex. Bound. 70, t. 27.

Gravelly hills near San Diego, Nuttall, Parmy.

4. P. parvifolium, Torr. \& Gray. Very shortly caulescent, slender, 6 to 10 inches high: leaves biternate, deltoid in outline, 2 inches long, the divisions ovate, laciniately lobed and acutely toothed or pinnatificl: rays about ten, a half to an inch long; pedicels 3 or 4 lines long; involucels of a few linear bractlets: calyxtecth acute, one or two usually prominent: fruit orbicular to broally elliptical, 3 to

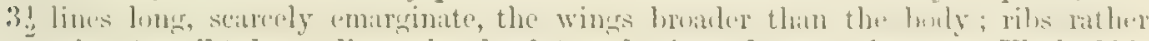
prominent; oil-tubes solitary in the intervals, 4 on the commissure. - Fl. i. 628. Ferula parvifolia, Hook. \& Am. Bot. Beechey, 348.

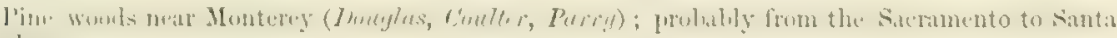
liarliti:ı.

A somewhat similar species, P. Hatru, Watson, occurs in Oregon, but with leaves more ohlong

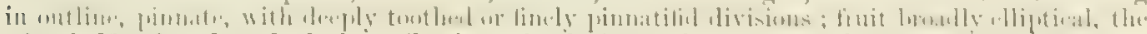
wing half as broad as the body; oil-tubes 3 in the intervals, 4 or 6 on the commissure.

\section{\$2. Leaves decomponnd with narrowly linear segments and very broadly dilated peli- oles: invohuels conspicuous, of usually dilated scarinusly margined spatulate or lanceolate bracts: flowers yellow; calyx-teeth obsolete: fruit broadly ellip- tical, glabrous: caulescent, finely puberulent.}

5. P. caruifolium, Torr. \& Gray. Stems short, with elongated perluncles,

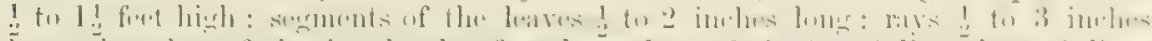

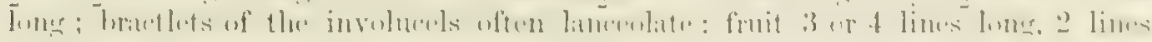
broal, the ribs obsolete; wings half as wido as the bolly: oil-tubes inlistinet, 2 or 3 in the intervals, none on the commissure. - Fl. i. 628. P. marginatum, Benth. P'I. Hartw. 312.

Central Californin, valleys and hillsiles; from Sucmmento Valley to Santa Barkan, frequent.

6. P. utriculatum, Nutt. More canlescent: leaves more finely dividen, the segments 1 to 6 lines long: bractlets mely lanceolate, usually much dilated: fruit 
similar but distinctly ribbed; the broad oil-tubes solitary in the intervals, 4 to 6 on the commissure. — Torr. \& Gray, Fl. i. 628.

From Washington Territory and Idaho to Southern California, frequent; Los Angeles (Rich); Ojai, Goodale.

\$ 3. Leaves very finely dissected with narrow segments: flowers yellow: acaulescent, pubescent.

7. P. villosum, Nutt. More or less densely pubescent, 3 to 6 inches high: leaves with very numerous somewhat crowded small narrow segments: flowering umbels dense; involucels of several small linear bractlets: fruit oval, pubescent; oil-tubes probably several in the intervals. - Watson, Bot. King Exp. 131.

The mature fruit is not known. The range appears to be from the base of the Sierra Nevada in Western Nevada to Northern Arizona and eastward to Nebraska and S. Utah. The speeies nearly resembles $P$. foniculaceum, Nutt, of the eastern plains, which is taller, with ample leaves and nearly filiform segments, the fruit smooth, with prominent ribs and 1 to 3 oil-tubes in the intervals.

Another species, allied to $P$. fouciculaceum, ranging from N. Utah to Idaho and possibly to N. E. California, is P. MuLefouIdM, Watson. This is glabrous throughout, with ample finely dissected leaves, large broadly winged glabrous fruit, and solitary oil-tubes.

\$ 4. Leaves much dissected with small segments: flowers white; calyx-teeth present: somewhat caulescent or nearly acaulescent, pubescent.

* Fruit glabrous, oblong or broadly elliptical.

8. P. macrocarpum, Nutt. More or less pubescent: stems usually tufted, $\frac{1}{2}$ to 1 foot high: fertile rays nearly equal, an inch or two long; involucels conspicuous, of several somewhat foliaceous lanceolate or linear bracts, often united and unilateral: fruit oblong, 4 to 10 lines long, 2 or 3 lines wide, exceeding the pedicels; ribs filiform; wings half as wide as the seed; oil-tubes solitary or rarely 2 or 3 in the intervals, 2 to 4 on the commissure. - Torr. \& Gray, Fl. i. 627 ; Watson, Bot. King Exp. 130.

Var. eurycarpum, Gray. Fxuit 4 or 5 lines wide, but slightly narrower at the ends, the wings broader than the seed : leaves usually rather more coarsely divided. - Proc. Am. Acad. viii. 385. P. nudicaule, var. (?) ellipticum, Torr. \& Gray, Pacif. R. Rep. ii. 121.

Frequent from Washington Territory to the Saskatehewan, southward to N. California and N. Nevada. The variety is apparently the more prevalent form in California, ranging from Oregon to the Sacramento, and scarcely occurring east of the Sierra Nevada.

$$
\text { * Fruit tomentose or puberulent, oval-orbicular. }
$$

9. P. dasycarpum, Torr. \& Gray. More or less densely villous-tomentose, $\frac{1}{4}$ to 1 foot high: leaves finely dissected with narrow or filiform segments: fertile rays nearly equal, an inch or two long; involucels of several linear to lanceolate or oval bractlets, free or united at base: fruit orbicular or ovate, often acutish above, tomentose, 4 to 7 lines long, 3 to 5 broad; ribs prominent; oil-tubes usually 3 (rarely solitary) in the intervals, 4 on the commissure.--Fl. i. 628. P. tomentosum, Benth. Pl. Hartw. 312.

Central California, from Mendocino and Placer counties to San Luis Obispo, on dry hillsides.

10. P. Nevadense, Watson. Glaucous, puberulent: leaves less compoundly dissected, the segments coarser: rays often unequal, 1, or 2 inches long; involucels smaller, of several linear-lancenlate bractlets, usually distinet : fruit somewhat pubescent,. nearly orbicular to ovate, 3 to 5 lines long, 2 to 4 wide; ribs prominent; calyx-teeth obsolete; oil-tubes 2 or 3 in the intervals, or 4 in the lateral ones (perhaps very rarely solitary), 4 to 6 on the commissure. - Proc. Am. Acad. xi. 143. P. mudicaule, Watson, Bot. King Exp. 130, and others, not Nuttall.

On the eastern side of the Sierra Nevada from Northeastern California to Sonora and New Mexico. This much resembles $P$. NUdicadLE, Nutt, to which it has been ordinarily referred, a more northern and eastern species, ranging from Nebraska and Northern Colorado to Idaho. 


\section{HERACLEUM, Linn. Cow PARsNip.}

Calyx-teeth small or obsolete. Disk undulate; stylopodium conieal. Fruit stronsly flattencel, orbicular or elliptical, the brual wings cuherent till waturity;

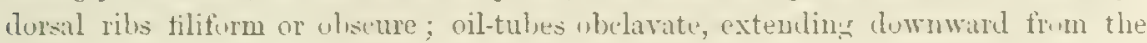
apex rarely to the base, solitary in the intervals, 2 on the commissure. Seed flat and thin.-Perennials or biennials, mostly stout and pubescent; leaves ample, lubet or conpound; mubels many-1ayed ; involucre usually few-leaved, cuducuts ; involucels many-leaved; flowers white.

About 50 species are found in the north temperate zone of the Old World, a single one extending to America and ranging throngh much of British America and the United States

1. H. lanatum, Michx. Very stout, 4 to 8 feet high, pubescent: petioles

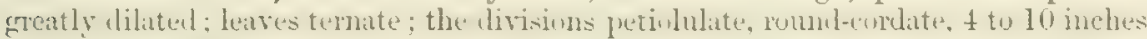
broad, unequally lobed; lobes acuminate, toothed: rays 3 to 6 inches long: flowers

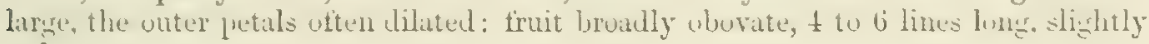
pubescent.

Wet soils in the mountains, from MLonterey northward, and in the Sierra Nevada at a height of 6,000 to 8,000 fret.

\section{FERULA, Linn.}

Calyx-teeth obsolete. Disk small and stylopodium depressed. Fruit oblongelliptical or neary urbicular, strongly compressed clorsally, the corky marginal wims (in Ameriran species) as thick as the seed, coherent till maturity; the lursal ribs filiform; oil-tubes very numerous, obscure, or sometimes wanting. Seed flattened. Carpulhore liticl. - smooth, nearly acaulesent perennials, with thick fusiform roots; leaves pinnately decompound; flowere yellow, in many-rayed umbels.

Nuttall's genus Leplotenia, of the western const, kept distinct by Bentham \& Hooker, is referted by Dr. Gmy to this large Old World gents. Polytania, of the Eastern States, is separated only by its manifest calyx-teeth and more acuminate and inpressed petals. In acldition to the following westenu species a fourth is found in S. Utah and New Mexico, F. NewiBerry (Pincedanum Nerberny, Watson, in Am. Naturalist, vii. 301), of dwarfer habit, strictly acaulesceut, and with less divided leaves.

\section{* Leaves finely divided.}

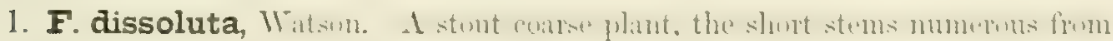
a very thick root, leafy at base: leaves broad, temate and thrice pinnate, the ovate

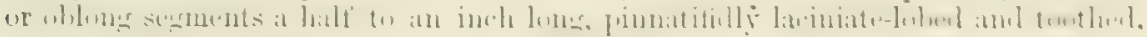
puberulent on the veins beneath: peduneles stont, 1 or 2 feet long; rays 2 to 5 inches long, involucrate with a few linear entire or lohed bracts; involucels of several linear bmatlets: flowers yellow or purplish, numerous: fruit 8 or 9 lines long, $3 \frac{1}{2}$ broad, almost sessile, the thickened margin $\frac{2}{3}$ of a line broad; dorsal ribs filiform; oil-tubes very obscure and much intermpted, wanting on the commissure. - Leptotenia dissecte, Nutt. in Torr. \& Gray, Fl. i. 630. Cymapium (?) Binelovii, Torrey, Pacif. R. Rep. iv. 94. Ferula dissecta, Gray, Proc. Am. Acul. vii. 348, not Lelebour.

Valleys and hillsicles, flowering in early spring, from Meudlocino County north to Puget Sound: Kilunath Lake (Fremone); Murphy's Camp, Bigelme. A specimen from Borax Lake (Torrey), having brond regularly elliptical fruit only 5 lines long, is no otherwiso different.

2. F. multifida, Gray, 1. c. Like the last, but with moro finely divided leaves, tho umbels without involucre, flowers less densely croweded, and the pedicels of the fruit 2 to 12 lines long.-Watson, Bot. Kiug Exp. 127. Leptotenia mullifich, Nutt. 1. c.

On the enstern side of the Sierm Nevada from Carson City northward to Orugon, and east to Utah. The root is often very largo. 


\section{* * Leaves more coarsely divided.}

3. F. Californica, Gray. Habit of the preceding: leaves ternate and pimnate, or twice ternate, the leaflets cuneate-obovate or oblong, an inch or two long, usually 3-lobed, coarsely toothed above, smooth : rays 2 to 4 inches long; involucre of 1 or 2 narrow elongated bracts; involucels wanting: fruit 5 to 7 lines long, 3 or 4 wide, a little narrower below, on pedicels 2 to 4 lines long; dorsal ribs indistinct except at the ends; oil-tubes distinct, somewhat anastomosing; wing thinner than in the preceding. - Proc. Am. Acad. vii. 348. Leptotonia Califomica, Nutt. 1. c.; Tomey, Pacif. R. Rep. iv. 92.

Napa Valley to Mendocino County.

\section{DAUCUS, Tourn. CARROT.}

Calyx 5-toothed. Disk and stylopodium mostly small and depressed. Friuit ovate or oblong, the carpels semiterete or somewhat dorsally flattened; primary ribs filiform and bristly, the intermediate more prominent and winged with a row of more or less united barbed prickles; oil-tubes solitary under the wings. Seed flat on the face or nearly so. - Annual or biennial, setosely hispid; leaves pinnately decompound with very small segments; involucral bracts foliaceous and divided, those of the involucels entire or 3-lobed; outer rays of the umbels often longest and connivent over the inner ones in fruit; flowers mostly white.

Some 30 or more species inhabit the northern temperate regions of the Old World, of which the eultivated Carrot, D. Carota, is in many places naturalized, becoming a noxious weed. The only recognized native species of the United States is the following.

1. D. pusillus, Michx. Annual or biennial, erect, a foot or two high, retrorsely hispid: leaves bipinnate, the segments pinnatifid, with short narrowly linear lobes: rays 2 to 6 lines long, nearly equal; involucre bipinnatifid, as long as the small umbel ; involucels equalling the yellowish flowers: fruit $1 \frac{1}{2}$ to 2 lines long, shortly pedicellate, the prickles usually equalling or exceeding the width of the body : seed somewhat concave on the face.

Widely distributed, ranging from the S. Atlantic States to the Pacific, and on the western coast from Nootka Sound to Mexico. It has also been found in N. Patagonia and the Sandwielk Islands. A peculiar form was collected by Dr. Torrey near San Francisco, very low and scarcely caulescent, the stout peduncles 2 or 3 inches long; fruit 1 to $1 \frac{1}{4}$ lines long, in dense subglobose heads, the rays being obsolete.

\section{CAUCALIS, Linn.}

Calyx-teeth prominent. Stylopodium thick and conical. Fruit as in Daucus, but somewhat more laterally compressed, and the seed involute or deeply channelled. Annuals, mostly hispid; leaves dissected; umbels few-rayed, often opposite the leaves or sessile; flowers white or purplish.

About 20 species, chiefly of the Mediterranean region, one or two widely naturalized.

1. C. nodosa. Hudson. Decumbent, branching only at base, the stems 1 or 2 feet long, retrorsely hispid: leaves pinnate with pinnatifid divisions: umbels naked, opposite to the leaves, nearly sessile, of 2 or 3 very short rays: fruit ovate-oblong, a line long, entirely covered with rough tubercles or usually with stout prickles barbecl or bent at the point: seed involute.

Native of Europe and N. Africa, introduced into Chili and Pern, and thence into California: seen only from around San Francisco, Holder, Kellogg.

2. C. microcarpa, Hook \& Arn. Erect, slender, 6 to 15 inches high, nearly glabrous: leaves much dissected, slightly hispid: umbels apparently sessile at the 
ends if the stem and brunches, subtended by 2 or more foliaceous dissected bracts, $3-6$-rayed; rays slender, 1 to 3 inches long; umbellets few-flowered, with unequal pedicels ; involucels of short entire bracts, rarely more foliaceous and divided : fruit oblong-oval, 2 lines long, armed with rows of hooked prickles: seed deeply channelled. - Bot. Beechey, 348 .

Dry hillsides, Sacramento Valley. Of reputed efficacy, applied in poultice, as a remedy for the bite of rattlesnakes. This plant is peculiar in habit, but has a seed similar to that of several of the species of Caucclis. It has been referred to Daucus brachiculus of Australia, which however has the prickles always barbed and is a true Daucus.

\section{Order XLVI. ARALIACE出。}

Like Cmbelliferce, but the umbels not recularly compound, stens apt to be roouly, petals imbricated in the bud, styles and carpels mure than two, and the fruit fleshy (berry-like or drupaceous).

A rather large order in the warm parts of the world, represented in Europe and in cultivation by the Ivy, and in North America and Northern Asia mainly by the following genus.

\section{ARALIA, Linn. SpikeNard.}

Calyx 5-toothed or entire. Petals 5, ovate, slightly imbricate. Stamens 5. Disk depressed or rarely conical. Ovary 2-5-celled: styles free or connate at base, at length divaricate : sticrmas terminal. Fruit laterally compressed, becoming 3-5-angleul, Heshy externally; endocary chartaceous. - Perennial herbs or shrubs; leaves alternate, divitate or compound, with serrate leaflets: umbels mostly simple, solitary, racemed, or panicled; pedicels jointed; bracts small.

About 30 species, of which 8 belong to North America, chiefly east of the Rocky Mountains, the remainder to Eastern Asia. Probably the only Californian representative of the order is the following species.

1. A. Californica, Watson. Herlaceons, unarmed and nearly tabrous, s to 10 feet high, from a larese thick root: leaves hipinnate, or the mpun jimmate with 1 or 2 pairs of leaflets, which are cordate-ovate, 4 to 8 inches long or more, shortly acmuinate, simply or lunhly serrate with short acute terth: uprernust leaves aratelanceolate: umbels in loose terminal and axillary compound or simple racemose panicles, which are a foot or two long and more or less glandular-tomentose; rays numerous, 4 to 6 lines long; involucres of several linear bractlets: flowers $1 \frac{1}{2}$ to 2

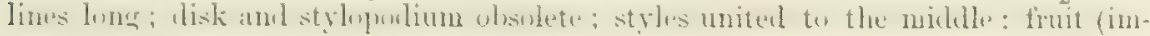
mature) $1 \frac{1}{2}$ lines long. - Proc. Am. Acad. xi. 144.

In shaded mountain ravines and moist places; Gavilan Mountains (Brever); Bolinas Bay (Biyelow); Sierra County, Lemmon. Much resembling the eastern A. racemosa, but differing in its much grenter size, fewer unbels, larger and with more numerous ravs, and larger flowers and involneres. It has not been collected in mature fruit. A. humilis, of Mexico and New Mexico, is distinguished especially by its large pulvinate stylopodium.

A. sprxosa, another enstern species, known as Hercules' Club, has become somewhat common in cultivation.

Fatsia hormina, Benth. \& Hook. (Échinopanax, Decaisne \& Planch.), is reported in Hook. Fl. as having been collected in California by Douglas. It is frequent in shady fir woods in the Cascade and Coast Ranges, from the Columbia northward to Sitka, and also extends southwarl in the Const Range, but it is doubtful as belonging to this State. It has a stout woody stem 6 to 12 feet long, creeping at base, leafy at the summit, and very prickly throughout, making the forests in places almost impassable; the very large leaves palmately lobed, anil the capitate umbels in a long raceme. The genus is diatinguished by valvate petals, 2-3-celled fruit, pedicels not jointed, and palmatifid leaves.

Hedert Helix, the European Ivy, is very frequently cultivated, and near the const is alrearly half wild. 


\section{ORDER XLVII. CORNACE\#.}

Trees or shrubs, rarely herbs, with simple and entire mainly opposite leaves, no stipules, and flowers in cymes (or capitate clusters) or spikes; the valvate petals and stamens 4 and epigynous in fertile flowers (the former sometimes wanting); calyx adnate to the 1-2-celled ovary, which becomes a 1-2-seeded drupe or berry in fruit. Seed suspended, anatropous, with a minute embryo in hard albumen.

An order of a dozen genera and less than a bundred species, widely distributed, but mainly in the tenperate regions of the northern hemisphere; most related to the first tribe of Cajrifoliacca, but with distinct petals valvate in the bud. Many are cultivated for ornament. The bark of Cornus is bitter, and has been used as a substitute for Cinchona.

1. Cornus. Flowers perfect, in cymes or a head-like cluster. Petals 4. Style 1: stigma terminal. Ovary 2-celled.

2. Garrya. Flowers dicecions, in catkin-like spikes. Petals none. Styles 2, stigmatic down the inner side. Ovary 1-celled, 2-ovuled.

\section{CORNUS, Linn, Dogwood, Cornel.}

Flowers perfect. Calyx minutely 4-toothed. Petals 4, oblong or ovate, valvate in the bud. Stamens 4, with slender filaments. Style slender: stigma capitate or truncate. Drupe ovoid or oblong, with a 2-celled 2-seeded stone. Cotyledons foliaceous. - Shrubs or perennial herbs, rarely arborescent; leaves opposite, entire; flowers small, in dichotomous cymes or involucrate heads, white, yellowish or greenish.

Mostly of the northern hemisphere, a sirngle species growing in Peru; about 25 species, of which 15 are found in the United States.

* Flowers greenish, in a close cyme or head, surrounded by a conspicuous involucre of 4 to 6 white petal-like bracts: fruit red.

1. C. Canadensis, Linn. Stem simple, herbaceous, 3 to 8 inches high, from a slender creeping subterranean rootstock : leaves inostly in an apparent whorl of 6 at the summit, slightly pubescent with appressed hairs, nearly sessile, ovate to oblong, acute at each end, 1 to $2 \frac{1}{2}$ inches long; in the middle of the stem a pair of smaller leaves, and scale-like bracts below: peduncle abcut an inch long: involucral bracts 4, ovate, 4 to 8 lines long: ovary silky : fruit globular, 2 lines in diameter.

Mendocino County (Bolender), in swamps; north to Sitka and across the continent.

2. C. Nuttallii, Audubon. Usually a small tree, sometimes becoming 50 to 70 feet high: bark smooth: leaves more or less pubescent, obovate, 3 to 5 inches long, acute at each end: involucre of 4 to 6 obovate to oblong bracts, $1 \frac{1}{2}$ to 3 inches loug, abruptly acute to acuminate, yellowish or white, often tinged with red: flowers numerous, in dense heads 6 to 9 lines broad: fruit crowded among the large abortive ovaries, 5 to 6 lines long, crowned by the broad limb of the calyx. - Nuttall, Sylva, iii. 51, t. 97 ; Newberry, Pacif. R. Rep. vi. 24.

From Monterey and Mendocino to Plumas counties, and northwarl to Fraser Piver. A showy tree, or large shrub, flowering in May, the flowers followed by large clusters of crimson berries. Much resembling the eastern $C$. florida, and apparently even more worthy of cultivation. Wood close-grained and very hard.

* * Flowers yellowish, in sessile umbels, appearing before the leaves, involucrate with 4 small caducous bracts.

3. C. sessilis, Torr. A shrub, 10 to 15 feet high, with green bark : leaves approximate, ovate, shortly acuminate, pale beneath and appressed silky-pubescent : unbel terminal, becoming lateral by the development of the shoot; pedicels numer- 
ous, slender, silky, 3 to 4 lines long: involucte nearly as long, membranaceous, snon decilunus: petals narrow; acuminate: fruit oblunig, 3 lines long. - bot. Mex. Bound. 94, t. 7 .

Moist ravines and foot-liills, Placer County. Mature fruit has not been collected. The American representative of an Old World group of two species, $C^{\prime}$. mas and $C$. officinalis.

* * Flowers white or cream-colored, cymose, not involucrate: fruit white, leadcolored, or blue.

4. C. Californica, C. A. Heyer. A shrub, 6 to 15 fert hicgh, with smooth purplish branches: leaves ovate, acute, mostly rounded or obtuse at base, 2 to 4 inches long, lighter colured and more or less jubescent beneath with luose silky hairs (not straight and appressed): flowers in small dense round-topped cymes: fruit snall, 2 lines broad, sulurlubrse, but little tleshy, slishtly jubescent, blute (!): stone broader than high, somewhat compressed, furrowed on the edges. - Mem. Acad. Petr. v. 30, and Ann. Sci. Nat. 3 ser. iv. $72 . C$. circinatus (?), Cham. in Linnea, iii. 139. C. alba, Hook. \& Arn. Bot. Beeclıey, 142.

From San Francisco southward to San Diego County ; on stream-banks.

5. C. pubescens, Nutt. Lesembling the last and with a similar pulhescence: leaves oblong-elliptical or rarely ovate, acute or somewhat acuminate, shortly cuneate at base: flowers in a somewhat larger and more spreading round-topped cyme:

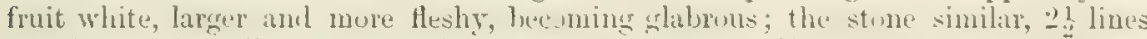

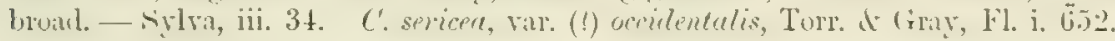

Oregon and Washington Territory, and in the Sierra Nevada to the Yosemite Valley; also in the Cuinmaca Mts., San Diego Co., Pulner. These two species have always been confounded, but seem to be separated by gond characters. The Cornel of the Rocky Mountains and Utah, which has been referred to this species, is the eastem $C$. slolonifern, which also extends westward to the Columbia. It is at once distinguished by the straight appressed hairs, attached by the middle, and has not been found in California.

6. C. glabrata, Iienth. I shrub, 5 to 12 feet high, glabrous or very nearly so : bark gray : lenves oblong to narrowly ovate, acute at each end or somewhat acumi-

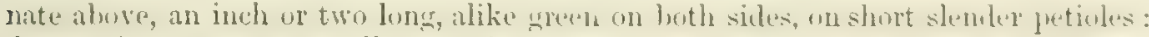

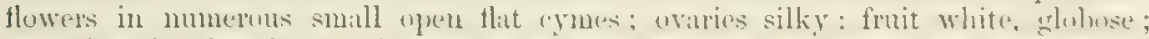
stone hroaler thim high, 22 lines wide or mure, starcely conpressed, nut furrowed. Bot. Sulph. 18.

In the Coast Ranges from Lake County to the southern part of Monterey; also on the Cosumnes River, licuttan.

7. C. Torreyi, Watson. Shrubloy: leaves obovate or oblanceolate, abruptly

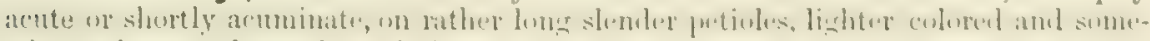

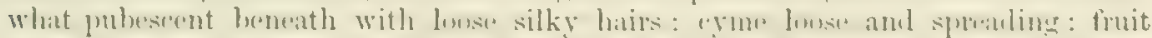

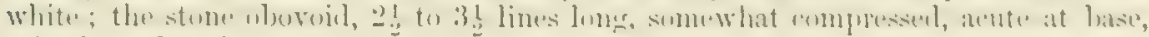
rilged on the elges, tubercled at the summit. - Proc. Am. Acad. xi. 145.

Collected by Dr. Torrey in Central Californin, but the locality not noted. The charncters of the fruit are very peculiar.

\section{GARRYA, Dongl.}

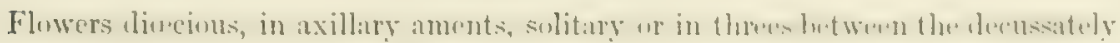
connate bracts, without petals. Calyx of sterile flowers 4-parted, with linear valvate segments: stamens 4, with distinct filaments: disk and ovary none. Fertile flowers with the calyx-limb shortly 2-lobed or obsolete: disk and stamens none: ovary 1-celled, with 2 pendent ovules: styles 2, stigmatic on the inner side, persistent. Berry ovoid, 1-2-seeded. Seed oblong, compressed: embryo minute, with oblong cotyledons. - Evergreen shrubs, with 4 -angled brunchlets; lenves opposite, entire, coriaceous, the short petioles comnate at base; fruit blue or purple. 
A genus of about a dozen species, peculiar to the region from California to Texas and southward, with a single one in the West Indies.

1. G. elliptica, Dougl. A stout shrub or small tree, usually only 5 to 8 feet high: leaves elliptical, $1 \frac{1}{2}$ to 3 inches long, rounded or acute and mucronate at the apex, mostly truncate or rounded at base, undulate on the margin, densely tomentose beneath, smooth above: aments solitary or clustered; the sterile 2 to 5 inches long, with bracts truncate or acute, silky, as also the calyx-lobes; fertile aments stouter, 1 to 3 inches long, with acuminate or acute bracts: ovary densely silkytomentose, sessile: fruit globose, 4 lines in diameter. - Lindl. Bot. Reg. t. 1686; Maout \& Decne, Traité Bot. 256, figs.

From Monterey northward to the Columbia near the coast; dry soil and hillsides, flowering in winter and early spring; the staminate plant then very ornamental.

2. G. Fremontii, Torr. Shrub, 5 to 10 feet high, becoming glabrous : leaves ovate to oblong, not undulate, $1 \frac{1}{2}$ to $2 \frac{1}{2}$ inches long, acute at each end, on petioles 4

in to 6 lines long: aments solitary, 2 or 3 inches long, with acute somewhat silky bracts; the fertile aments rather slender: ovaries nearly glabrous: fruit globose, 2 to $2 \frac{1}{2}$ lines in diameter, shortly pedicellate.-Pacif. R. Rep. iv. 136.

From the Upper Sacramento to the Yosemite Valley and in the Coast Ranges to Mount Hamilton, Brewer. Leaves lighter green and less pubescent than in the last.

3. G. buxifolia, Gray. A small shrub, 2 to 5 feet high : leaves oblong-elliptical, 1 to $1 \frac{1}{2}$ inches long, 4 to 8 lines broad, acute at each end, smooth above, densely white appressed-silky beneath; petioles 1 to 3 lines long: fertile aments an inch long, the short bracts acute, more or less silky: fruit globose. glabrous, nearly sessile, $2 \frac{1}{2}$ to 3 lines in diameter. - Proc. Am. Acad. vii. 349.

Red Mountains, Mendocino Co., Bolander, Kellogg.

4. G. flavescens, Watson. A rather spreading shrub, 6 to 8 feet high, pubescent with closely appressed silky hairs: leaves coriaceous, elliptic-ovate to -oblong, acute at each end, scarcely mucronate, an inch or two long, flat, entire, at length nearly glabrous above, on petioles 3 to 6 lines long: aments pendulous; bracts 6 to 10 pairs, broad, connate, acute or the lower acuminate, silky; sterile aments 1 or 2 inches long, loose, the pedicels ( 1 to 3 together) equalling or exceeding the bracts; fertile aments an inch long, dense, with solitary sessile flowers: fruit densely silky, ovate, 3 lines long. — Am. Naturalist, vii. 301. G._—?, Watson, Bot. King Exp. 421.

Var. Palmeri, Watson. Pubescence densely tomentose: leaves smooth above, mucronate, on shorter petioles: fruit globose, 3 or 4 lines in diameter.

Frequent from Southern Nevada and Utah into Arizona and New Mexico. The variety at Milquatay, 60 miles from San Diego, on the Fort Yuma road, Palmer. Branches and leaves yellowish; the pulp upon the seed stains a bright violet color. 


\section{Division II. GAMOPETALA. (By A. Grat.)}

Floral envelopes both present; the petals more or less united into a gamopetalous (otherwise called monopetalous) corolla.

\section{Order XLVIII. CAPRIFOLIACE无。}

Distinguished generally by having opposite leaves without stipules, an inferior $2-5$-celled orary, and 4 or 5 equal stamens borne on the tube of the corolla, as many as the lobes of the latter (in a single instance one fewer) and alternate with them. - Flowers perfect. Corolla $t$-5-cleft, sometimes irregular; the lobes inbricated in the bud. Stamens distinct. Ovary 2-5-celled, or not rarely by abortion becoming one-celled: ovules either solitary and suspended or more numerous, anatropous. Fruit a berry, drupe, or capsule. Embryo small, commonly minute, in fleshy albumen. - Shrubs, or rarely herbs, with a colorless juice and no very active sensible properties, normally destitute of stipules, but in several species these, or appendages resembling them, appear : the influrescence generally cymose.

A family of about a dozen genera and 200 species, of staall economical importance (except as afforling Honeysuckles and some other plants for ornamental cultivation), nainly indigenous to the northern temperate zone, rather feebly represented in California

Tribe I. SAMBDCEE. Corolla wheel-shaped or open bell-shaped, regular. Style short and 2-5-parted, or as many sessile stigmas. Orules solitary in the cells, suspended. Fruit a berry-like drupe.

1. Sambucus. Leaves pinnate. Seed-like nutlets of the berry-like fruit 3 to 5 .

2. Viburnum. Leaves simple. Nutlet of berry-like drupe only one, flattened.

Tribe II. LONICERE E. Corolla from bell-shaped to tubular, often irregular. Style elongated, entiro : stigma capitate. Leaves simple, mostly entíre, but occasionally sinuatetoothed or pinnatifid on some vigorous shoots.

3. Linnæa. Corolla obscurely irregular, 5-lobed. Stamens 4, unequal. Orary 3-celled, two of the cells containing several imperfect ovules, the third a solitary fertile orule. Fruit dry, 1-seeded.

4. Symphoricarpus. Cornlla regular or nearly so, $4-5$-loherl. Stamens as many as the botees. Ovary 4-celled; but the terry-like fruit only 2 -seeded.

5. Lonicera. Corolla more or less irregular, commonly 2-lipped (4). Stamens 5. Ovary and berry 2 -3-celled, several-seeded.

\section{SAMBUCUS, Tourn. ElDER.}

Calyx with 5 minute teeth. Corolla wheel-shaped or npen urn-shaped, rezularly 5-lobed. Stamens 5. Stirmats and cells of the ovary 3 to 5. "lineries," really"

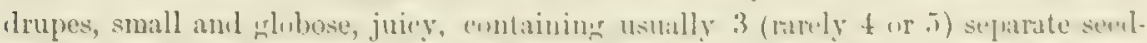

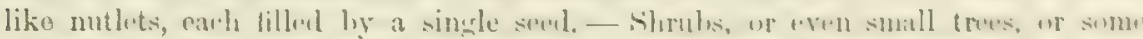

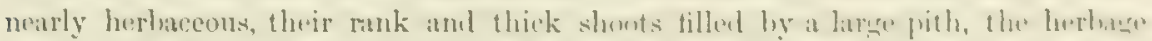

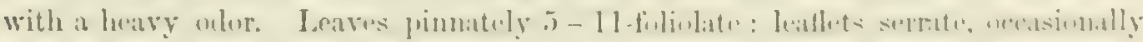
incised or even divibul, anduinte, sumetimes stipellate. Fluwers small and rery numerous, in compound cyraes, in ours white. 
1. S. glauca, Nutt. Arborescent, glabrous, or often somewhat pubescent with short and stiff spreading hairs: leaflets 3 to 9 , of firm texture, ovate or lanceolate, sharply serrate with rigid spreading teeth : cyme flat, 5-parted : fruit black, but very glaucous, so appearing to be white: nutlets obscurely rugose: pith of shoots white. - Nutt. in Torr. \& Gray, Fl. ii. 13.

Common throughout the State, and north and east of it ; 6 to 18 feet high, sometimes with trunk 6 to 12 inches in diameter. Not easy to distinguish from S. nigra of Europe except by the whitened fruit. It well may be S. Mexicana, Presl, to which it was referred by Torrey in Pacif. R. Rep. iv. 95, Bot. Mex. Bound. 71, and in Bot. Wilkes Exp. 330, but with doubt.

2. S. racemosa, Linn. Shrubby, mostly glabrous : leaflets 5 to 7 , thin, oblonglanceolate, much acuminate, very sharply serrate: cyme ovate or pyriform : fruit bright red; its nutlets obscurely rugose : pith of shoots brown. - Hook. Fl. i. 279.

Along the mountain ranges, in woods, extending far north. The Californian and Rocky Mountain specimens are as glabrous as the European plant ; in British America and Alaska it is commonly pubescent, as in the Atlantic States variety pubens, S. pubens, Michx.

\section{VIBURNUM, Linn. ARROW-WOOD, \&c.}

Calyx 5-toothed. Corolla wheel-shaped or open campanulate, deeply and regularly 5-lobed. Stamens 5, exserted. Stigmas 1 to 3. "Berries," really drupes, containing a single flat or flattish hard seed-like stone. - Shrubs or small trees, with simple, but commonly toothed, and sometimes deeply lobed leaves, and white flowers in a compound terminal cyme.

A genus represented by a dozen species in the Eastern United States, only two of which extend, well northward, to the Pacific. One of these is the Cranberry-tree, as well as the Snowballtree or Guelder Rose of ornamental cultivation: in this the cyme is radiate in the manner of Hydrangex, the marginal flowers being neutral and greatly enlarged. There is one peculiar species ou the coast of Oregon, which extends into California, viz. :-

1. V. ellipticum, Hook. Shrub 2 to 5 feet high, with scaly buds: leaves broadly oval or elliptical, roundish or very obtuse at both ends, 3-5-ribbed from the base, coarsely dentate above the middle, the lower surface and petioles with the young shoots hairy : cyme dense, peduncled : flowers all perfect : fruits oval, bluishblack (half an inch long); the stone grooved on both sides. - Hook. Fl. i. 280.

In woods, Mendocino Co. (Kellogg) ; extending to the Columbia River. Related to V.pubescens and $V$. dentatum of the Atlantic side.

\section{LINN正A, Gronov. TwiN-FLower.}

Calyx 5-lobed; the lobes subulate, deciduous. Corolla obscurely irregular, funnelform, 5-lobed. Stamens one fewer than the lobes of the corolla, i. e. 4, inserted low down on the corolla, included, two of them shorter. Ovary and the small dry fruit 3-celled, one cell with a suspended fertile ovule and seed, the two others with several abortive ovules. Style slender: stigma somewhat capitate. - Contains a single species.

1. L. borealis, Gronov. A low and almost herbaceous little evergreen, with slender and creeping or trailing stems: leaves round-oval, sparingly crenate, narrowed at base into short petioles: peduncles erect, slender, forking into two pedicels at the top, each bearing a single delicate and fragrant nodding flower : corolla tinged with purple or rose-color, hairy inside.

Moist mossy woods, Mendocino Co. ; common in Oregon and eastward, extending all round the northern cool-temperate zone. The California locality rests on Dr. Bolander's authority. It would be interesting to know if the specimens are of the ordinary type, or of the variety longiflora, Torr. in Bot. Wilkes Exped., which is the usual form in Oregon, and is remarkable for its larger flowers, the tube of the corolla with a long tapering base, and the slender calyx-lobes three times longer than the ovary. In Colorado the ordinary form only is found. 
4. SYMPHORICARPUS, Dill, JusG, SNOWBERRY.

Calyx 5-toothed, occasionally 4-toothed, persistent. Corolla nearly or wholly regular, from open campanulate to salverform, 5-4-lobed. Stumens as many as the lobes of the corolla, inserted on its throat. Ovary 4 -celled; two of the cells few-ovuled but sterile; the two alternatr eells each with a solitary suspended orule, which ripens into a seed: style slender: stigma capitate, entire or 2-4-lobed. Fruit globular and berry-like, ripening two little bony seed-like nutlets, each filled with a seel. - Low and branching shrubs, with scaly buds, oval or oblong leaves (entire, or occasionally some of them sinuate-pinnatifil), and 2-bracteolate flowers in axillary and terminal spikes or clusters, rarely solitary; the corulla white or fink. - Gray in Jour. Linn. Soc. xiv. 9.

A North American genus, of several species, at least one of them in the mountains of Mexico. S. racemoszes, the common Snowberry of eultivation, and all the California species have snowwhite fruit.

\section{§1. Corolla short-campanulate.}

1. S. racemosus, Michx. Shrub erect, $2-t$ feet high, smooth, or the lower face of the oblong or ovate-oval leaves pubescent: flowers in conmonly terminal short and loose interrupted spike-like racemes, which are often leafy at base, or sone solitary in upper axils : corolla very villous within at base of the lobes, which are rather shorter than the tube: style and mostly stamens included.

Hillsides, from San Diego Co. to Oregon, thence eastward to the Northera Atlantic States. - The marked variety parciflores, Robbins in Gray Man., is not known from California : it approaches the following species. S. occidentalis, $\mathrm{K}$. Br., if on the Pacific side of the contiment, is ouly at the north : it may be known by the deeper-cleft corolla with stronger beard, exserted stamens and style, and greater robustuess.

2. S. mollis, Nutt. Low, diffuse or decumbent, softly and usually densely pubesent: leaves oval, small (half an inch or less than an inch lomg): flowers few. in terminal clusters or in upper axils: corolla short and broad, inconspicuously bearlerl or pubescent insile: stameus equalliner the corolla : style shorter. - Turr. \& Gray, Fl. ii. 4. A less downy form is $S$. ciliatus, Nutt. 1. c.

Woods, scco, common on the Coast Range, and not rare in the Sierra Nevada up to 5,000 feet.

\$ 2. Comlla from campanulate-glong to tubular: stumens inchulul: style glalmous.

3. S. rotundifolius, Gray. Luw, suft-pubseent, sometimes minutely so: leaves orhicular or oblong, thickish: corollit between ohlong-campanulite and funnelform, its tube only twice or thriee the length of the lobes ant at little lomere than

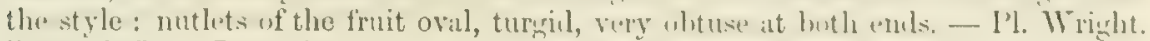
ii. $66, \&$ Jour. Linn. Soc. 1. c.

Near Carson City, Nevada (Anderson), and in Oregon (Kellogg \& IIarford); therefore, doubtless, within the enstern boundary of the State; theneo to Utah and New Mexico. - Leaves 6 to 10 lines long. Corolla not over 4 lines long, broad from tho base.

4. S. oreophilus, ciray, l. \&. L.w, glabroms, or in westrern forms commonly

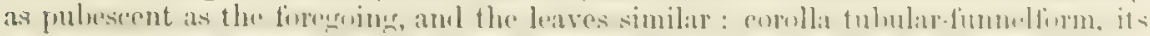
tube 4 or 5 times longer than the lobes and twice the length of the style: nutlets of the fruit oblong, tapering to a point at base. $-S$. montanus, Gray, in An. Jour. Sci. xxxiv. 249, not of IIBK.

Eastern part of the Sierra Nevada, from Mono Pass (Bolander) to Sierm Valley (Lemmon); thenco east to the Rocky Mountains in Coloralo. Corolla 5 or oven 6 lines long, and nurrow;

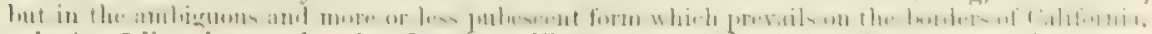
only 4 or 5 lines long and rather brouler. The nutlets of the fruit, when secn, mark n stronge dillerence.

S. Loxcifloros, Grry, 1. c., from S. E. Nevada and Utah, has a still longor corolla, with oblong lobes and a beardod stylo, which woll distinguish it. 


\section{LONICERA, Linn. HoNEYSUCELE. WOODBINE.}

Calyx minutely 5-toothed. Corolla tubular, funnelform, or oblong-campanulate; the tube commonly gibbous at base; the limb irregularly or sometimes almost regularly 5-lobed, often bilabiate ( $\frac{4}{1}$, i. e. 4 lobes in the upper, 1 in the lower lip). Stamens 5, inserted on the tube of the corolla. Ovary 2-3-celled, with numerous ovules in each cell : style filiform: stigma capitate. Berry several-seeded. Twining or erect shrubs, with sealy buds, and spicate or geminate flowers. Leaves entire, or occasionally sinuate-pinnatifid on vigorous young shoots.

Genus widely dispersed over the northern hemisphere, several cultivated for ornament and fragrance, especially the European Honeysuckles, L. Caprifolium and L. Etrusca; the American Trumpet H., L. sempervirens, which has an almost regular corolla ; Chinese or Japan H., L. Japonica, ete. ; and, among the upright species, L. Tartarica, the Tartarean Honeysuckle.

L. Ciliosa, Poir., a common Oregon species with corolla slightly bilabiate, may occur in California. Apparently a form of it, with rather smaller leaves and flowers, was collected on San Francisco Mountain, in Arizona, by Dr. Palmer.

§ 1. Stems or branches more or less twining or disposed to twine: flowers sessile in a terminal interrupted spike or head, or some in the axils of the upper (and commonly connate) leaves, usually rather large and showy: calyx-teeth persistent on the (red or orange) berry: corolla in all the Californian species decidedly bilabiate, the upper lip 4-lobed, the lower narrow and entire. (Sometimes there are foliaceous stipules or what seem to be such between the leaves.) CAPRIFOLIUM, DC.

1. I. hispidula, Dougl. in Bot. Reg. Foliaceous stipular appendages between the leaves often present: leaves mostly oval, the lower short-petioled; uppermost pairs commonly connate: spikes naked, slender : corolla pink or yellowish; its tube hairy inside, not longer than the limb: stamens and especially the long style exserted, more or less hairy at base:- All the Californian specimens seem to belong to one species, of which this is the oldest name. - Gray, Proe. Am. Acad. viii. 627. The leading forms are :-

Var. Douglasii, the first described form, from Oregon : leaves ( $\frac{1}{2}-1 \frac{1}{2}$ inches long) at least beneath and their margins and slender branches hirsute or pubescent with spreading hairs: inflorescence and pink flowers glabrous. - L. microphylla, Hook. Fl. i. 283. Caprifolium hispidulum, Lindl. Bot. Reg. t. 1761.

Var. subspicata: a bushy form, along the coast from Monterey Bay to San Diego, seldom climbing, with small leaves more or less pubescent, the uppermost often distinct; the branchlets, inflorescence, and flowers glandular-pubescent. $-L$. subspicata, Hook. \& Arn. Bot. Beech. 349 ; Torr. Bot. Mex. Bound. 71, t. 29.

Var. interrupta: resembling the preceding, but glabrous throughout, often glaucous : filaments slightly hairy at base. - L. interrupte, Benth. Pl. Hartw. 313.

Var. vacillans: mostly climbing, larger, either glabrous or pubescent, with or without hirsute hairs: inflorescence and flowers glandular-hirsute or pubescent, varying to glabrous. - L. Californica, Torr. \& Gray, Fl. ii. 7. L. ciliosa, Hook. \& Arn., not of Poir. L. pilosa, Kellogg, Proc. Calif. Acad. i. 62.

Common throughout the State, on hillsides, \&c. Corolla about half an ineh long.

\$2. Stems in the American species erect, never twining: all the leaves distinct: flowers a pair (sessile or their bases united) at the summit of an axillary peduricle. XxLosteum, DC.

2. I. involucrata, Banks. Pubescent, leafy: leaves varying from ovateoblong to broadly lanceolate, mostly acuminate, thin, petioled: peduncles shorter than the leaf: bracts 4 to 6 , forming a conspicuous foliaceous involucre: corolla tubular, with short lobes, viscid-pubescent, yellowish: ovaries and black-purple 
berries distinct. - L. Ledlelouri, Esch., published a year later than Banks's name by Sprengel. L. intermedia, Kellogg, Proc. Calif. Acad. ii. 154, fig. 47.

Common in shady places, reaching to the Rocky Mountains, British Columbia, and Lake Superior. Shrub 2 to 10 feet high : leaves 3 to 6 inches long. Involucre a pair of foliaceous outer ovate bracts, which become half an inch long, and 4 interior and thinner rounded bracts which are commonly united in pairs, all becoming yellowish or purplish in age. Corolla from half to two thirds of an inch long, obscurely bilabiate.

3. L. conjugialis, Kelloges. Shrub slenter, strageling, soft-pubescent, or smoother when old: leaves ovate or oval, thin, short-petioled; the lower obtuse; the npper acute or acuminate : peduncles long and slemler: bracts nearly wanting or minnte at hase of the partly or wholly minterl ovaries: corolla broadly gilubuns at base, nearly or cuite glahrous ontsile, dark and clull purple. bilabiate to betow the

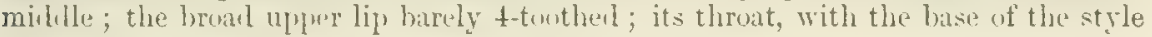
and filaments, hairy: berry red. - Kellogg, 1. c. 67, fig. 15. L. Breweri, Gray, Proc. Am. Acad. vi. 537, \& vii. 349.

Woods of the Sierra Nevada, from Mariposa Co. northward, and in adjacent parts of $\mathrm{Ne}$ vadia. Peduncle an inch or less in length, and shorter than well-developed leaves, or rarely longer and exceeding the leaf, as described by Dr. Kellogg. Corolla hardly half an inch long.

4. L. cærulea, Linn. Low, pubescent: leaves oval or oblong, obtuse at both encls, aluost sessile : peduncles very short : bracts a single pair, linear-subulate, loner than the united ovaries, which furm a single grohular blue herry : corulla yellowishwhite, funnelform, little gilbbous and bilalivate; the lubes shorter than the tube.

Sierra Nevada, at 7,000 feet, Mariposa Co. (Bolander); thence northward, into Asia, \&c. : the form with villous-pubescent leaves and corolla : the Atlantic form has a glabrous corolla

\section{Order Xlix. RUbiace㕕.}

Knnwn by having opposite entire leaves with intervening stipules (ur one trihe with whorled leaves without stipules), along with an inferior orary and regular 4-5-androus flowers. Flowers generally perfect. Calyx and corolla 4-5-lobed or toothed; the limb of the former above the union with the ovary sometimes obsolete. Stamens alternate with the lobes of the corolla and borne on its tube or throat, distinct. Ovary 2-5-celled. Ovules amphitropous or anatropous. Embryo in fleshy or horny albumen. - Herbs, shrubs, or in the tropics trees,

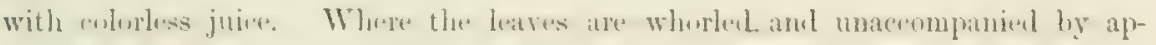
parent stipules, the supernumerary leaves are supposed to answer to stipules.

A vast onder, of over 4,000 species and 310 genera, mainly tropical and subtropical, although the tribe or division Slelluta (with whorled leaves) is prevailingly of the northern temperate zone, in no part of which is the whole family more feebly represented than in California.

The order yields important products; but Rubia tincloria, the Madder plant, is the only one cultivated for economical use out of the tropics. The Coffee-plant and species of Cinchona (yiolding Peruvian Bark) are the most important representatives of the family. - The three following are all the Califormian or even Pacific North American genera; but one of them is peculiar.

1. Cephadanthus. Shruh, with opjosite or whorlul leaves and stipules within the petinles: flowers in a dense head.

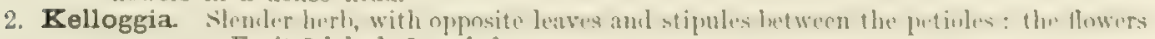
cymose. Fruit 2-lobed, 2-seeded.

3. Galium. Herbs with whorled leaves and no apparent stipules. Fruit 2-lobed, 2-seeded.

\section{CEPHALANTHUS, Linn. BrtTon-Bush.}

Flowers in a dense spherical head. Calyx inversely pyramidal, 4-toothed. Corolla with a long and slender tube and a small 4-cleft limb. Stamens 4, short, borne on the throat of the corolla. Style very long and slender, much exserted; 
stigma capitate. Ovary 2-4-celled, with a solitary ovule suspended from the summit of each cell, ripening into a dry inversely pyramidal fruit, which splits from the base upwards into 2 to 4 closed one-seeded portions. - Leaves ample, shortpetioled, opposite or in whorls of three or four: a short scale-like stipule between and within the petioles. Peduncles axillary and terminal, bearing single heads.

1. C. occidentalis, Linn. Shrub or small tree, with ovate or lanceolate leaves 3 to 5 inches long, smooth or pubescent: heads an inch in diameter, terminating slender peduncles: flowers white.

Along streams, common in California as in the Atlantic States, and extending into Mexico. The Californian shrub (var. Californicus, Benth. Pl. Hartweg), like other southern forms, is commonly short-petioled. All the forms vary from smooth to soft-pubescent. Ovary 2-celled.

\section{KELLOGGIA, Torr.}

Calyx-tube obovoid, somewhat flattened laterally, thickly clothed with stiff short bristles; the 4 teeth very small, subulate, persistent. Corolla funnelform, with 4 narrow oblong lobes, valvate in the bud. Stamens 4 , in the throat of the corolla: filaments flattish, short: anthers linear. Style very slender: stigmas 2, filiform, papillose. Ovary 2-celled, with a single anatropous ovule rising from the base of each cell. Fruit small, oblong, coriaceous, 2-coccous, hispid with hooked bristles, splitting at maturity into 2 closed carpels, to the walls of which the seed adheres. Embryo large in the fleshy albumen, straight. - Torr. Bot. Wilkes Exp. t. 6 (1862); Gray, Proc. Am. Acad. vi. 539 ; Benth. \& Hook. Gen. ii. 137 ; Torr. 1. c. 332 (1874).

1. K. galioides, Torr. 1. c. Slender perennial-rooted herb, about a foot high, rather diffuse, glabrous or minutely pubescent: leaves opposite, lanceolate, sessile: interposed stipules small and scarious: flowers small, in a loose forking cyme terminating the stem or few branches; the long pedicels thickened at the apex and articulated with the flower: corolla dull greenish-yellow, 3 lines long, pubescent outside.

Damp places, commonly under the shade of trees or shrubs, along the foot-hills and in the Sierra from Mariposa Co. northward, extending to Oregon, and eastward to Arizona (Palmer) and Wyoming (Parry); first discovered on the Walla-Walla River, by Dr. Pickering and $M r$. Brackenridge, in Wilkes' Expedition, when crossing from Oregon to California. The genus was dedicated to Dr. Albert Kellogg of San Francisco, in fitting reeognition of the arduous endeavors of the earliest botanist resident in the State of California, whose botanical labors, prosecuted for many years under abounding difficulties, entitle him to the gratitude of those who are engaged in the preparation of this work, and of those who will use it. The plant is modest and unpretending, but peculiar. In the foliage and stipules it recalls Houstonia, in the flower an Asperula, and the fruit is like that of Asperula and Galium, except that the embryo was found by Dr. Torrey to be nearly straight.

\section{Galium, Linn, Bedstraw, Cleavers.}

Limb of the calyx obsolete. Corolla wheel-shaped, 4-parted, rarely 3-parted. Stamens as many as the corolla-lobes, short. Styles 2, short: stigmas capitate. Ovary 2-lobed, 2-celled: ovnles solitary. Fruit twin, biglobular, dry, or sometimes fleshy when ripe, separating into two closed one-seeded carpels. - Herbs or sometimes woody at base, with slender square stems, whorled leaves, destitute of any apparent stipules (the stipules being supposed to be developed into leaves or blades), and small flowers usually cymose. Roots of many species red, containing a coloring-matter like madder, which is from a nearly related genus. 
A large genus, dispersed throurh all temperate regions. When the uppermost leares are reduced to a single pair, they occasionally show some rudiments of the proper stipules of the order. In several Californian species the flowers are dicecious. - The species, being rather numerous, may be more readily determined by the aid of the following artificial key.

Leaves mostly in whorls of eight,

Leaves all in sixes: fruit not hairy,

Leaves in fives and sixes: fruit hairy,

Leaves mostly in fives or sixes on the stem, in fours on the branches,

Leaves in fours, or some only in pairs.

Fruit berry-like, not hairy.

Low, hispid: leaves ovate : root fibrous,

Taller, with thick or woody root: leaves small, narrow,

Perennial-tufted, dwarf : flowers perfect, white: leaves crowded, awl-

Fruit dry. shaped,

Low annual: leaves lanceolate: flowers perfect, white,

Perennials, with dull purple flowers.

Leaves oblong-linear, minutely hirsute or nearly glabrous,

Leaves ovate or oblong, cinereous-pubescent,

Perennial herb, erect, white-flowered: leaves 3-nerved, lanceolate,

Perennial, or woody at base : flowers dull yellowiso or whitish, dicecious : fruit long-hairy.

Tall: leaves linear,

Low: leaves ovate or broadly lanceolate : fiuit very long-haired. Glabrous and smooth, Cinereous-puberulent,
4. G. Aparine.

5. G. Aspenimem.

6. G. TRIFLULUM.

7. G. TRIFIDUM.

1. G. Californicom

2. G. Nuttalli.

14. G. ANDREWSII.

3. G. BIFOLIUM.

8. G. Bolanderi.

9. G. PUBENS.

10. G. BOREALE.

11. G. Axgustifolium.

12. G. Bloomeri.

13. G. MULTIFLORUM.

\$ 1. Frut berry-like at maturity, as in Mfudder. - Telbuxium, Endl., Benth. \& Hook.

1. G. Californicum, Hook. \& Arn. Low, nuch branched from an annual (1) rerklish fibrous rout, hispid with widely spreading stiff hairs: leaves in fours, thinnisl, ovate and ovate-lanceolate, cuspidately acute or mucronite: flowers diweciously polynamous; the fertile ones sulitary on short naked peduncles at the end of the branches or on upper forks, recurved in fruit; the sterile ones terminal in threes: corolla yellowish ; its lohes ovate-lancenlate, acuminate, glabrous : fruit purple, glabrous or nearly so. - Bot. Beech. p. 349 ; Torr. \& Gray, Fl. ii. 20, ex̃cl. var.

Common from San Francisco southward towards the coast. The larger forma with less rigid hairiness resemble the S. American $G$. Relbun (and like it are apt to have a minutely hirsute or pubescent ovary); but that is well distinguished by a small 4-leaved involucel at the apex of the peduncle, within which the flower is sessile.

2. G. Nuttallii, Gray. Stem rising from a thick and firm or wooly rout or rootstock, 1 to 3 feet high, or climbing higher on bushes, and much branching:

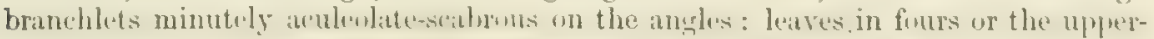
most often only in prirs (3 to 5 ar un hranchlets unly 2 or 3 lines long), thickish, varying from ovate-uhloner to linear-lincenlate, mostly smoth exeept the spinuluse-

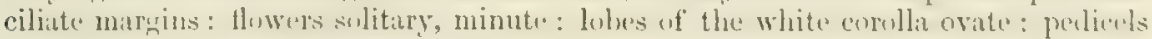
naked, reflexed in fruit: ovary glabrous: fruit small, decidedly baccate. - Pl. Wright. i. 80, in note. G. suffruticosum, Nutt. in Torr. \& Gray, l. c.

Hills and low grounds, Marin Co. to San Diego. Apparently varies greatly. Often "forms thickets," or is supported on shrubs, in the manner of the eastern G. asprellum.

\section{§2. Fruit dry at maturity.}

* Annuals: fruit minutely hispid with hooked. bristles: flowers perfect.

3. G. bifolium, Watson. Simoth and glahrous, small (3 to fo imehes high), int length branched: leaves in depauperate specimens only a single pair, with bases connected by a scarious stipular line; in vigorons sperimens 4 in the whorls, lanceolate, the alternate pair (answering to stipules) from latf to three quarters smaller: peduncles solitary, lateral and terminal, naked, l-flowered, about equalling the leaves whan in fruit, spreading: corolla minute, white: fruit recurved on the apex of the peduncle. - Bot. King. 134, t. 14, fig. 8 . 
Marshes near.Peregoy's, Mariposa Co., at 7,000 feet (A. Gray) ; Sierra Valley (Lcnmon) ; discovered by $M r$. Watson in the mountains of Nevada. Fruit proportionally large, a line or a line and a half in diameter.

4. G. Aparine, Linn. Stem weak and spreading: leaves mostly in eights, linear-oblanceolate; the margins, midrib, and angles of the branches armed with spreading or retrorse spinulose bristles : peduncles elongated, 1-2-flowered : corolli greenish-white : fruit rather large.

Moist grounds, apparently throughont the State, and without doubt a native plant; but only in the smaller form (var. minor, Hook.): the leaves barely an inch or thereabouts in length, whereas in the ordinary eastern and European plants they are of twice that length, and the frait larger.

$$
\text { * Annual (?) with perfect flowers : fruit granulate-scabrous. }
$$

5. G. asperrimum, Gray. Diffusely much branched, weak: the branches slender, minutely and retrorsely spinulose: leaves in sixes, lanceolate or the lower oblanceolate verging to oblong, tipped with a slender cuspidate point, smooth and shining both sides, the margins and midrib beneath thickly and retrorsely spinulose-ciliate: flowers numerous, in naked cymes terminating the branchlets : peduncles and pedicels filiform: lobes of the apparently greenish-white corolla ovate and acute: immature fruit muricate granulate. - Pl. Fendl. 60, \& Pl. Wright. ii. 67. (New Mexico and Arizona.)

Var. asperulum: leaves thinner, duller, all more lanceolate, their margins and midrib much less strongly ciliate, the bristles sometimes obscure and not retrorse: peduncles and pedicels fewer and not divaricate : corolla apparently purplish : fruit not seen. - G. asperrimum, Watson, Bot. King. 134.

In Mariposa Sequoia Grove (Bolander), Sierra Valley (Lenmon), and Ruby Valley, Nevada (Watson). If a variety of G. asperrimum, it must be a form growing in more shady places. Leaves $\frac{1}{2}$ to $\frac{3}{4}$ of an inch long, those near the flowers smaller, almost awn-pointed. Corolla a line and a half in diameter. Perhaps the root is perennial.

$$
\text { * * Perennials. }
$$

\section{+ With diffuse or decumbent wholly herbaceous stems: fruit not long-villous: leaves with more or less prominent midrib, but no lateral nerves.}

6. G. triflorum, Michx. Slightly and sparsely hairy or nearly glabrous, bright green: stems procumbent or reclining, minutely spinulose backwards on the angles (or rarely smooth): leaves in sixes or sometimes in fives, thin, oblong-lanceolate, acute at both ends, or cuspidate-acuminate, the margins and often the midrib beneath beset with very short commonly retrorse and hooked bristles : peduncles once or twice 3-forked; the pedicels divergent: corolla greenish : fruit hirsute with slender hooked bristles, or when mature merely roughened.

Rather common in woods and thickets, from San Francisco northward and to the Sierra, extending through the northern parts of the continent. The foliage when drying exhales the sweet scent of the European Asperula odorata. Leaves one or two inches or less in length, 3 or 4 lines wide.

7. G. trifidum, Linn. Glabrous or nearly so : stems slender, ascending or erect, diffusely branched, mostly roughened on the angles: leaves $4-6$ in the whorl, commonly 5 or 6 on the stem and 4 on the branches, varying from linear to oblanceolate, obtuse, the midrib and margins more or less scabrous : peduncles solitary or in threes, not longer than the leaves: flowers very small : lobes of the white corolla and the stamens often only 3 : fruit smooth and naked.

Wet and shady places, same range as the preceding. Stems 5 to 15 inches high. Leares 3 to 9 lines long. Corolla barely a line broad.

8. G. Bolanderi, Gray. Apparently erect, diffusely and paniculately branched, minutely hirsute or nearly glabrous: leaves all in fours, thickish, oblong-linear, short, the margins and midrib beneath minutely hispid-ciliate: cymes several-flowered, paniculate: pedicels about the length of the flowers: corolla dull 
purple, its lobes ovate and acute: ovary glabrous but granulate. - Proc. Am. Acad. vii. 350 .

Sierra Nevada (on the Mono trail, Bolander; Sierra Valley, Lemmon). Apparently of the same species is a plant in Rattan's collection, with similar (sterile?) flowers, but branches and foliage minutely hirsute. Plants apparently one or two feet high : base of stem not seen. Leaves 3 to 6 lines long. Corolla a line and a half broad.

9. G. pubens, Gray, 1. c. Cinereous-pubescent throughout with short and rather soft spreading hairs, diffusely much branched: leaves in fours, thickish, ovate, or on the brauchlets oblong or even oblong-linear, acute or mucronatepointed: flowers polygamo-dioecious, the sterile in several-flowered close cymes, the fertile ferrer: pellumeles and pedicels short: corolla dull purple, its lobes ovate and acute : fruit minutely pubescent, becoming glabrous and smooth.

Var. scabridum, with shorter, less copious, and rather scabrous pubescence: ovary glabrous.

Yosemite Valley (Bolander, Torrey, Gray). Stems about 2 feet long. Leaves 4 lines long. Corolla 2 lines broad, sometimes 3 -5-cleft. Fruiting pedicels little over a line in length.

++ With erect and wholly herbaceous smooth stems: fruit smooth or merely pubescent: leaves 3-5-nerved.

10. G. boreale, Linn. Glabrous and smooth, or nearly so, strictly erect, leafy: leaves in fours, lanceolate or almost linear, bluntish: cymes many-flowered, in a thyrsiform pauicle: corolla white: fruit very minutely hairy or smonth.

Shaded or open banks of streams, towards Oregon; thence northward and eastward to the Atlantic. (The plant of Xantus from Fort Tejon, No. 40, belongs to the mext speeies.)

+++ With erect or ascending stems more or less woody, and polygamo-dioecious (yellowish-white) flowers: sterile ovaries glabrous or naked: the fruit clothed with long white hairs, which are not hooked at the tip.

11. G. angustifolium, Nutt. Shrubly at base, 1 to $t$ feet hich, glabrous: the branches rigid or strict, smooth on the angles: leaves in fours, linear, mucronateacute, rigid, l-nerved, veinless, with barely scabrous nargins: cymes small and numerous in a narrow panicle: flowers very small, greenish-white: fruit hispid or hirsute, with straight bristles not longer than itself. - G. trichocarpum \& angustifolium (under trichocarpum), Nutt. in Torr. \& Gray, Fl. ii. 22.

Near the coast, Santa Barbara to San Diego, and east to Fort Tejon. Rising to 3 or 4 feet high when supported on bushes. Leaves from 3 to 8 lines long. The male plant, which has smooth and glabrous abortive oparies, was taken for G. suffruticosum in the Botany of the Mexican Boundary, and for G. boreale in the Tejon collection by Xantus. The female plant does not aceord with any Chilian species, neither with the G. eriocarmum of Bartling (whether that be Hooker and Arnott's species of that name, or G. Gillicsii), nor with G. trichocarpasm, DC., which by the ebaracter answers to G. Chamissonis, Hook. \& Am. Wherefore Nuttall's name for one of the forms may be adopted for this species.

12. G. Bloomeri, Gray. Lenr, 3 to 12 inches high, wholly smoth and gritbrous, much branched from the suffrutescent base: leaves in fours, and some of the uppermost only in pairs, ovate, cuspidate-acuminate, rigid, $1-3$-nerved: flowers yelluwish-white, somewhat panicled ; the sterile ones very short-podicelled: the fertile mostly longer than the long villous hairs of the fruit, and erect.-Proc. $A m$. Acad. vi. 538 ; Watson, Bot. King. 135.

Vite. hirsutum, (ivay. Stems and leares hirsute with spreading hatrs: leaves thinner: otherwise like a small form of $G$. Bloomeri.

Sierra Nevada, on the dry eastern slopes, towards Virginia City and to Lassen Peak, se. Hairs of the fruit a line or rather more in length. In this and the next the substerile or imperfectly fertilo ovary is apt to develop a fow long hairs; but the truly fertile fruit is mostly covered with long hairs. - The variety, from Sierta Valley, Lemmon.

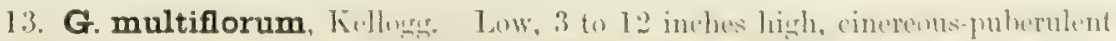
or minutely scalmons, hamehed from the suffrutesent base: leaves in fours, or some 
of the floral ones in pairs (or even alternate), varying from roundish-ovate to oblong-lanceolate, apiculate, rigid, mostly 3-nerved: flowers yellowish-white, solitary or in threes at the end of short branches: fruit-bearing pedicels mostly longer than the long villous hairs of the fruit, at length recurved. - Proc. Calif. Acad. ii. 97 (1861); Watson, 1. c. G. hypotrichium, Gray, 1. c. (1865).

Dry eastern portion of the Sierra Nevada; near Donner Pass (Torrey); Sonora Pass (Brewer); Sierra Valley, \&ce; and in Nevada.

G. stelitatum, Kellogg, 1. e. (to which is evidently to be referred $G$. acutissimum, Gray, Proc. Am. Acad. vii. 350), extends from New Mexico through Arizona (Palmer) to Cerros Island, off the coast of Lower California, and may be found within the State. It is remarkable for its ovate-lanceolate rigid leaves, tapering to a pungent point.

++++ With low and depressed stems thickly set with persistent leaves, forming cushion-like tufts on the ground: flowers perfect.

14. G. Andrewsii, Gray. Cæspitose on slender creeping rootstocks, glabrons: leaves crowded in fours and in axillary fascicles, subulate or acerose, rigid, shining, pungent, 1-nerved, or rather with a stout midrib, either naked or spinulose-ciliate on the margins: flowers solitary or in threes, terminating the branchlets, very small, on short or slender pedicels: corolla white.-Proc. Am. Acad. vi. 538.

Dry hills near the coast, from the Bay of Monterey south to Fort Tejon, \&c. Plant forming tufts from 2 inches to a span in height; leaves 2 to 5 lines long, half a line or less in width. [The fruit, recently collected by Palmer, proves to be baccate and glabrous, showing that the species is most nearly allied to $G$. Nuttallii of the RELBUnium section.]

\section{ORDER L. VALERIANACE正.}

These are herbs, with opposite leaves and no stipules; the distinct stamens ( 1 to 4) almost always fewer than the lobes of the corolla, and borne on its tube; the inferior ovary with two abortive or empty cells, and a single fertile one containing a solitary pendulous ovule, ripening into a kind of akene. - Flowers perfect or by abortion dicecious. Calyx sometimes obsolete, except its tube consolidated with the ovary, sometimes with a limb composed of teeth, chaff, or bristles. Corolla tubular or funnelform, often irregular; its limb 3-5-eleft; the lobes imbricated in the bud. Style filiform: stigmas 1 to 3 : ovule anatropous. Fruit dry and indehiscent, either one-celled, the two other cells having disappeared, or more or less 3-celled, two of the cells empty or mere vestiges. Seed destitute of albumen, filled by the large and straight embryo : radicle superior. - Inflorescence cymose.

A family of nine genera and about 300 species, of small economical importance, except as yielding the officinal Valerian (the peculiar odor and properties of which prevail in the roots of most of the perennial species), mainly belonging to the temperate and frigid parts of the world, sparingly represented in North America. Only one Valerian has thus far been detected in California, but there is a peculiar genus.

Corn Salads (Fedic or Valerianella) are likely to occur in grain-fields, introduced from Europe, but are not yet met with.

1. Valeriana Limb of the calyx inrolled and concealed in flower, evolute and pappus-like in fruit, of plumose bristles. Corolla spurless. Stamens 3. Perennials.

2. Plectritis. Limb of the calyx obsolete. Tube of the corolla bearing a spur. Stamens 3. Annuals.

1. VALERIANA, Tourn. Valerian.

Limb of the calyx involute and concealed in the flowering state, evolute in fruit, formed of numerous plumose bristles, resembling a pappus, deciduous. Corolla with more or less cylindrical or obconical tube, which is often gibbous but not spurred at 
the base: the limb about equally 5-lobed. Stamens 3. Abortive cells of the ovary small or obscure, obliterated in the alene-like fruit. - Perennial herbs, with strongscented mostly thickened rootstocks or roots, simple or pinnate leaves, and white or flesh-colored fluwers in a terminal often panicled cyme. The flowers in some species are either dimorphous or polygamo-dicecious. - The roots of several are used in medicine. The only species yet detected in this State is,

1. V. sylvatica, Richarlson. Minutely pubescent or nearly glabrous : rootstock creeping: root-leaves entire and spatulate or oval, or sometimes 3-parted: stem-leaves mustly pinnately divided into 3 to 11 bruadly lanceolate or ubluns-ovate unequal entire or toothed leaflets: flowers all perfect: corolla short and broad: stigma almost entire.

Wet places in the Sierra Nevada, \&ce., from the Yosemite to Donner Lake, thence eastward and northward through the Continent. This has been thought to be the European $\boldsymbol{V}$. dioica, or too near it; but the stigma is not 3-cleft, and no form is known with included stamens and long style. At the north it sometimes has smaller flowers with less protruded stamens; but then the style also is short.

V. EDCLIS, Nutt., is common in the Rocky Mountains and enstward; and it may be found in the northeastern part of California. It is well marked by the long lanceolate or linear leaves or lobes of the leaves, with minutely downy margins; and the flowers are dicecious.

\section{PLECTRITIS, (Lindl.,) DC.}

Limb of the calyx obsolete or none. Tube of the corolla very gibbous, spurred at the base; the short limb more or less bilabiate; upper lip 2-cleft, lower 3-cleft. stamens 3. Ovary triangular, with empty cells at two of the angles : style slender: stigma somewhat capitate. Fruit winged on each side of the fertile cell by the remains of the open and enlarged sterile cells, the wings incurved, making the fruit saucer-shapel. - Amuals, nearly glabrous (except that the fruit is often puberulent), with slender erect stems, ublong or spatulate entire or barely sinuate-toothed leares, the cauline ones sessile ; the dense contracted cymes in the axils of the upper small leaves and terminal, forming an interrupted spike or heal. Fluwers small, ruse-color, sultended by pairs of subulate bracts, perfect. Stamens and style sumetimes exserted, sometimes more or less included in the same species.

There is a Chilian species referred to this genus by Bentham and Hooker, which has wingless fruit. The two genuine species, confined to the western side of North America, are just alike in herbage, and to be distinguished only by the flowers.

1. P. congesta, IC: Corulla about a quarter of an inch long; its spur much shorter and smaller than the tube; the limb distinetly bilabiate.

Moist soil, less abundant than the next; common in Oregon and extending into Utah. Varying from a span to a foot or two in height.

2. P. macrocera, Turr. \& liray. Corolla mnsilmpluly smallep: its thick spur about the length of the body, so that it appears as if attached at the middle; the limb smaller and less evidently bilabiate. - Torr. \& Gray, Fl. ii. 50. P. brachystemon, Fisch. \& Meyer, Ind. Sem. Petersb. 1835.

Common in low grounds, towards the coast and in the valleys. - Fischer \& Meyer's name is the older, but is misleading, as the length of the stamens is not a specific character, and they omitted all mention of the real distinctions of the species.

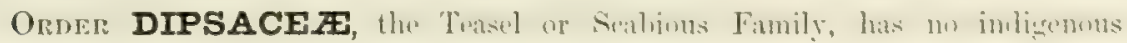
representatives in America, and no truly naturalized splecies in Califirnia, liut Dipsacug FLloxur, the Fuller's Teasel, has been met with in waste grounds

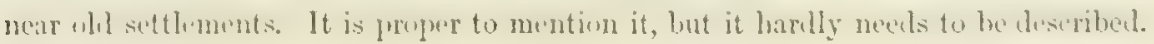




\section{ORDER LI. COMPOSIT 开.}

Known by having the flowers in a head, surrounded by an involucre (forming the compound flower of the older botanists), and syngenesious anthers. - Flowers either perfect, polygamous, or monøecious, or rarely diøcious, or some neutral. Corolla gamopetalous (monopetalous). Stamens 5, or sometimes 4, inserted on the tube of the corolla alternate with its lobes: filaments generally distinct: anthers syngenesious, i. e. united into a tube. Ovary 1-celled, with a solitary erect anatropous ovule: style one, 2-cleft or 2-lobed at the apex; the lobes or branches of the style bearing stigmas in the form of marginal lines on their inner face. Fruit an akene. Seed destitute of albumen, filled by the straight embryo. - Calyx with tube investing and incorporated with the ovary; its limb either wanting, or in the form of a border or crown, or of teeth, scales, awns, bristles, \&c., surmounting the ovary: it is called a pappus, whatever be its form or texture. Corolla epigynous, either strap-shaped (ligulate) or tubular; in the former case the 5 or 4 petals of which it is composed are sometimes indicated by the teeth or notches at the apex of the ligule or expanded portion: in the latter case 5-lobed or occasionally 4-lobed, the lobes valvate in the bud, the veins of the tube forking at the sinuses and bordering the lobes. Anthers 2-celled, introrse, opening on the inner face; the pollen brushed out of the tube by the lengthening of the style, some portion of which, or of its branches, in staminiferous flowers usually is beset externally or tipped with a rough-bristly or papillose surface. Heads homogamous, i. e. with all their flowers alike, or heterogamous, i. e. of more than one sort of flowers. Homogamous heads are sometimes completely liguliflorous, i. e. all the flowers with strapshaped or ligulate corolla, and in this case all hermaphrodite; sometimes discoid, i. e. with no ligulate flowers. Heterogamous heads are commonly radiate, $i$. e. the outermost or marginal flowers have enlarged and mostly strap-shaped corollas, and are always female or else neutral: these are called flowers of the ray, or rayflowers, or shortly rays: those within are termed flowers of the disk or diskflowers. Some heterogamous heads are discoid, i. e. the marginal flowers although unlike the central ones are all tubular, or at least not developed into rays. The bracts or leaves of the involucre which surround the head are commonly termed scales, whatever their texture. The commonly dilated extremity of the peduncle on which the flowers are inserted is the receptacle. When the receptacle bears only flowers within the involucre, it is said to be naked: when there are bracts, usually in the form of chaffy scales (therefore termed palea, palets, or chaff) borne on the receptacle, mostly one outside of each flower, the receptacle is said to be paleaceous or chaffy. - Herbs, shrubs, or sometimes trees, various in foliage, with determinate inflorescence as to the order of the heads, $i$. e. the terminal or central one first developed; but the evolution of the blossoms in each head centripetal, i. e. the marginal ones earliest. - DC. Prodr. v., vi., \& vii., part 1 ; Torr. \& Gray, Fl. ii. 54 504 ; Benth. \& Hook. Gen. P1. ii. $163-533$.

An immense order, found in all parts of the world, comprising about one tenth of all Phænogamous plants, in North America and especially in California a still larger proportion. Very few are important for any active properties or useful products; but many are cultivated for ornament. 


\section{Key to the Tribes in California.}

I. TUBULIFLORE; the corollas tubular and 5- (rarely 4-) toothed or cleft in the perfect flowers; those with ligulate corollas (rays) at the margin either pistillate or neutral.

Style-branches club-shaped, obtuse, neither hairy nor appendaged : flowers all perfect, never yellow.

Style-branches of perfect flowers flat and tipped with a distinct flat appendage : anthers without tails : leaves all alternate.

Style-branches of the perfect flowers neither truneate nor tipped with any appendage: anthers with tails: heads heterogamous: receptacle not long-bristly : corollas not deeply eleft.

Style-branches of perfect Howers truncate-capitate or tipped with an appendage : anthers without tails : leaves or some of them often opposite.

Receptacle chaffy, at least next the margin : involucre not scarious: pappus not capillary.

Receptucle not chaffy: involuere not of imbricated scarious scales: pappus not capillary.

Receptacle not chatfy or rarely so : involucre of imbricated partly scarious scales : pappus a short crowu or none.

Receptrcle not chaffy: pappus capillary and copious.

Stylc-branches without tips or appeudage, more or less concreted to or near the apex : corollas all tubular and very deeply (sometimes irregularly) 5-cleft into long linear lobes : receptacle densely bristly : anthers sagittate or with tails.

2. Eutatoriace.

3. AsteroLnes.

1. InvLoides.

5. Heliaxthorde.e.

6. Helentorde.s.

7. ANThemides.

8. SENECIUNIDE.E.

9. Cyxarolde.e.

II. LABIATIFLOR E; the corollas bilabiate and the flowers perfect. 10. Mutrisicex.

III. LIGULIFLORE; the corollas all ligulate (and 5-toothed at the apex), and the flowers perfect. Juice milky.

11. Cichorlacee.

\section{Key to the Genera.}

TRIBE I. VERNONIACEE. Heads homogamous and the flowers all perfect, with tubular corolla, never yellow. Anthers sagittate at base. Branches of the style slender-subulate, minutely hispid.

No plant of this tribe, as thus defined, is known in California or in the regions north of it. The only genus to be expected is Elepllantopus, of which one ar two species are widely spread over the warmer parts of the world, and these may come in at the soutl.

Tribe II. EUPATORIACE E. Heads homogamous and the flowers all perfect, with regular tubular corolla, never yellow, or more than eream-color. Anthers nearly entire at hase. Branches of the style obtuse, oftener thickened upwards or club-shaped, minutely papillosegrauular or smoothish, the stigmatic lines inconspicuous.

* Pappus of 2 to 12 stout bristles or awns, alternating with as many scales.

1. Hofmeisteria. Involucre and flowers as in Brickellia. Akenes 4-5-angled or ribbed.

* Pappus of numerous capillary bristles.

$$
\text { + Receptacle naked. }
$$

2. Eupatorium. Akenes 5-angled. Bristles of the pappus scabrous, mother rigid.

3. Brickellia. Akenes 10-ribbed or striate. Bristles of the pappus about in one series, scabrous or almost plumose, rather rigid. Involuere imbricatel.

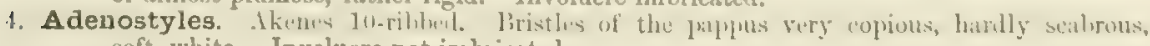
soft, white. Involuere not imbricated,

++ Receptacle chaffy, at least among the outer flowers.

5. Carphephorus $\$$ Kँ

TUBB III. ASTFROIDE E. Hends either heterngmous or homommons, the disk-fowers with regular tubular corolla, the ray-flowers when present ligulate and pistillate only, raruly neutral. Receptaclo naked (not chaffy) except sometimes in No. 20. Anthery nearly entire at base (without tails). Branches of the style in perfect flowers flattened, tipped with an appendage. Lenves mostly alternate.

Subtrihe I. ASTERINF.E. Heads homognmons and the flowers perfect or heterngamous and mostly muliate, yet several are discoid, or with merely filiform corollas to the pistil. late flowers, but none diceions. 
* Pappus paleaceous or aristiform or coroniform, i. e. of chaffy scales or awns of of few stont awn-like bristles, or of very short bristles or scales sometimes united in a crown, raxely obsolete or wanting, never of indefinitely numerous capillary bristles.

+ Flowers all yellow.

++ Involucre of coriaceous or firm-chartaceous scales mostly with herbaceous or greenish tips, commonly (No, 9 excepted) coated with a resinous or balsamic exudation.

6. Gutierrezia. Heads small and corymbose or clustered, with rays; the flowers all fertile. Pappus of several short chaffy scales.

7. Amphiachyris. Heads small, clustered, with fertile rays; the disk-flowers not fertile. Pappus in the disk-flowers of long flattish and soft bristles rather thau seales; in the few ray-flowers of chaffy scales concreted at base into a cup.

8. Grindelia. Heads larger, solitary, terminating simple branches, many-flowered, mostly with rays and all the flowers fertile. Akenes glabrous. Pappus of 2 to 8 rigid and stout caducous awns.

9. Acamptopappus. Heads without rays. Scales of the involucre ehartaceous, with scarious and lacerate-fimbriate margins. Akenes turgid, very densely white-woolly. Pappus persistent, of numerous rigid chaffy awns, the longer ones equalling the corolla.

++ + Involucre of thin more or less imbricated scales, destitute of herbaceous tips.

10. Pentachæta. Akenes compressed. Pappus of 5 (rarely 2 to 8 ) persistent slender rigid bristles, sometimes unequal or all very short, sometimes obsolete or wanting.

+ + Rays white, blue, or purple (never yellow) : disk-flowers yellow : akenes compressed.

10. Pentachata sometimes has white rays in one species.

11. Monoptilon. Pappus a small crown and a single decidnous bristle which is plumose at top.

12. Eremiastrum. Pappus of 8 to 10 thin scales cut almost into bristles, and within these some stout bristles. Akenes with merely nerved margins.

* Pappus of copious slender or capillary bristles.

+ Flowers all with the limb of the corolla 5-parted into linear or elongated-oblong lobes, either regular or the marginal ones palmate : no ligulate rays.

13. Lessingia. Heals 5-25-flowered. Flowers yellow, purple, or white.

+ + Disk-fiowers with the tubular corolla merely 5 -toothed or with 5 short lobes, perfect : rayflowers when present ligulate (pistillate, or in a fow cases neutral).

+ Rays yellow, their akenes destitute of pappus.

14. Heterotheca. Nearly the same as Chrysopsis (No. 15), except that their larger and thicker ray-akenes have no pappus.

+++ Rays yellow or sometimes none : disk-flowers yellow : all the akenes with pappus.

a. Pappus double.

15. Chrysopsis. Heads radiate or in one section rayless. Pappus of two sorts ; the interior of long capillary bristles, the exterior a set of short bristles or chaffy scales. Akenes compressed.

b. Pappus simple : involucre imbricated.

16. Aplopappus. Heads radiate, excepting one or two species which have more or less foliaceous or green-tipped scales to the involucre, commonly broad and solitary, or somewhat clustered, usually large or middle-sized. Bristles of the pappus copious and unequal, somewhat rigid.

17. Bigelovia. Heads rayless (rarely an imperfect ray or two), homogamous, mostly cymosely or corymbosely clustered, and narrow. Scales of the involucre dry, coriaceous or commonly chartaceous, appressed, rarely with green tips. Bristles of the pappus copious and unequal.

18. Solidago. Heads radiate, narrow, numerous and mostly small, racemed or panicled, or sometimes cymose. Seales of the narrow involucre appressed, destitute of herbaceous tips. Bristles of the pappus equal and nearly in a single series, slender. Style-appendages lanceolate or broader, never filiform.

++++++ Rays white, purple, or blue, never yellow : disk-flowers yellow, rarely turning purplish.

19. Sericocarpus. Rays few (about 5, white) : disk-flowers rather few. Involucre narrow, imbicated, of appressed firm-coriaceous white scales with abrupt green tips. Akenes silky, not flattened. Pappus copious, simple.

20. Corethrogyne. Rays mostly sterile! (the style wanting and the ovary abortive), numerous in a single series. Involucre imbricated. Style-appendages of the disk-flowers thickly beset with long bristles, forming a brush-like tuft. Akenes flattened. Pappus sinple, of pretty rigid unequal bristles. 
21. Aster. Rays numerous, almost always in a single series, Involuere imbricated. Styleappendages subulate or lanceolate, not long-bearded. Akenes mostly llattened. Pappus simple, copious.

22. Brachyactis. Rays very numerous and in more than one series, short. Involuere herbaceous. Style-appendages lanceolate, naked. Akenes flattish Pappus simple, copious, longer than the corollas.

23. Erigeron. Rays numerous, long and slender, or sometimes short, in one or more series. Involucre of numerous narrow and mostly equal seales, little imbricated, not herbaceous. Style-appendages short and broad, mostly obtuse. Akenes small, flattened, commonly with a nerve or rib at each margin, rarely with one or more on the faces. Pappus sinple or double; the outer when present of short bristles or chaffy scales; the other of capillary scabrous bristles as in Aster, but commonly scantier, in a single series, and more fragile or deciduous.

Subtribe II. CONYZE死. Heads heterogamous but never radiate; the pistillate flowers in more than one series; their corollas a mere filiform tabe, much shorter than the style the perfect flowers with tubular 4-5-toothed corollas, much fewer in the centre of the disk.

24. Conyza. Involucre campanulate, of many narrow scales. Akenes and pappus as Erigeron. Heads small : flowers yellowish or whitish.

Snbtribe III. BACCHARIDEL. Heads discoid and homogamous, unisexual, dicecious ; the pistillate and staminate flowers on different plants, the former with filiform corollas shorter than the style.

25. Baccharis. Involucre imbricated; the scales dry, not herbaceous. Pappus of very copious and soft capillary bristles, less copious in the staminate flowers.

Tribe IV. INULOIDEæ. Heads.discoid in all Californian genera, and heterogamons, or only when diocious homogamous, with the ordinary tubular regularly $4-5$-toothed corol. las, or commonly the pistillate flowers (which are exterior) with slender or filiform corollas. Anthers sagittate at base, their auricles pointed or tailed, rarely only acute. Branches of the style never tipped with appendages: sterile (hermaphrodite-sterile) flowers with style commonly undivided. Leaves almost always alternate, but opposite in No. 30.

Subtribe I. PLUCHEINEE. Scales of the imbricated involucre (at least the outer ones) not scarious. Receptacle not chalfy. Head many-flowered; the pistillate flowers with very slender or filiform truncate or minutely 2 -3-toothed corollas, the hermaphrodite but often sterile flowers few on the centre of the flat recoptacle. Akenes not exserted.

26. Pluchea. Involucre not white-woolly, its scales dry and thin. Pappus of fine capillary bristles; their tips not enlarged.

27. Tessaria. Involucre whito-woolly, of coriaceous rather rigid scales. Pappus of the central. flowers with thickened tips to the bristles.

Subtribe II. ADENOCAULONE质. Scales of the involucre herbaceous, few in a single series. Receptacle not chaffy. Head few-flowered; both pistillate and hormajuroditesterile flowers with similar dilated tubular corollas; the former mather fewer, and with enlarged exserted akenes.

23. Adenocaulon. Akenes club-shapel and several times longer than the imvoluce, luest with some stipitsto glands : pappus none.

Subtribe III. FILAGINEE. Senles of the involucre mostly thin and scarious. Receptaele with chaff (scales of various texture) subtending or enclosing the fertile flowers or akenes. Pistillate flowers with filiform truncate or 2-3-toothed corollas. Low floccose-woolly herbs with sessile and commonly glomerate small heads.

* Akenos gibbous and compressed : corolla and style Jateml : pappus nono.

29. Micropus. Fortilo flowers fow and in a single series on the slort receptacle, included in the laterally compressed. very gibbous scales of the receptacle, which aro tirm-corinceous or eartilnginous in fruit, strictly enveloping the akene.

* Akenes straight or slightly oblique : corolla and style terninal.

+ Chaff loosely enclosing at least the akenes : central flowers sterile.

30. Psilocarphus. Fertilo flowers numereus in several series on a globular receptalls, cnch in an ohovite hooded-snecate turgil membranacous and reticulated cluatr. l'apuns none. Lenves mostly opposito. 
31. Stylocline. Fertile flowers 5 to 10 or numerous, in two or more series on a cylindrical or columnar receptacle; their chaff thin, saccate or boat-shaped. Pappus of a few caducous bristles to the sterile flower's, or none.

+ + Chaff more open, subtending or hardly enclosing the fertile flowers or their akenes, these in more than one series: central flowers sometimes fertile.

32. Evax § Hesperevax. Receptacle villous, its centre elongated into a narrow column. Akenes pear-shaped, flattish parallel to the subtending scale : pappus none.

33. Filago. Receptacle obconical or cylindraceous with a flat summit. Alkenes oblong, nearly terete: pappus of numerous bristles to the perfect or sterile flowers, fewer or none to the outer fertile flowers.

Subtribe III. GNAPHALIEE. Scales of the involucre all thin and scarious, often pearly, persistent. Receptacle naked. Floceose-woolly herbs. Flowers in all the American genera with capillary pappus, nearly in a single series; the pistillate ones with filiform or very slender corollas.

34. Antennaria. Heads completely dicecious; the stanoinate with undivided style and bristles of the pappus thickened or barbellate at the apex; pistillate with slender bristles of the pappus united at base into a ring. Low cæspitose herbs.

35. Anaphalis, Heads incompletely dicecious; i. e. the staminate ones with a few hermaphrodite but sterile flowers in the centre. Style commonly 2-cleft at the apex. Bristles of the pappus all separate, those of the sterile flowers little thickened upward. Taller herbs.

36. Gnaphalium. Heads all heterogamous, with pistillate flowers very numerous in more than one series, and bermaphrodite fertile ones fewer in the centre. Bristles of pappus slender, not thickened upward.

TrIBE V. HELIANTHOIDE正, Heads heterogamous with ligulate ray-corollas, or discoid and homogamous (or rarely heterogamons) ; the perfect or staminate flowers with tubular regularly 4-5-lobed corollas. Receptacle chaffy (except sometimes among the disk-flowers especially when sterile). Anthers often sagittate at base, but without tails. Branches of the style in perfect flowers either truneate or tipped with an appendage. Pappus of 2 to 4 chaffy scales, awns, teeth, \&c., or a cup or crown, never of capillary bristles. Leaves mostly opposite, at least the lower ones. Corollas most commonly yellow.

Subtribe I. AMIBROSIEA. Heads small and discoid : only the pistillate flowers fertile ; these few and with no corolla, or a rudimentary one in the form of a short tube surrounding the base of the style. Hermaphrodite-sterile or staminate flowers with campanulate limb to the corolla; anthers slightly cobering or nearly distinct, their inflexed tips often mucronate or cuspidate; the abortive style entire, with truncate apex tipped with a minute radiate tuft or brush. Pappus none. Akenes in our genera obovate and thick.

* Heads heterogamous, a few fertile flowers at the margin.

37. Oxytenia. Fertile flowers apetalous: akenes long-villous, crowned with a protuberant epigynous disk. Leaves pinnately divided, or the upper entire.

38. Iva. Fertile flowers with short tubular corolla: akenes naked. Leaves simple.

* * Heads homogamous, unisexual, monocious ; the fertile with 1 to 4 pistillate apetalous flowers in a closed and bur-like or akene-like pointed involucre; sterile with rather numerous flowers in an open

+ 5-12-lobed or almost truncate involucre.

39. Hymenoclea. Fertile involucre one-flowered, appendaged with 9 to 12 scarious spreading scales. Stem shrubby.

40. Ambrosia. Fertile involucre one-flowered, akene-like, bearing no more than a single row of tubercles or short spines. Herbs.

41. Franseria. Fertile involucre 1-4-flowered, 1-4-celled, armed with more than one row of tubercles or prickles.

+ + Involucre to sterile heads of a few distinct scales.

42. Xanthium. Fertile involucre oblong, bur-like, 2-flowered, 2-celled, beset with numerous hooked prickles.

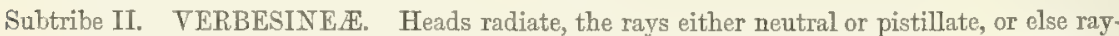
less; the disk-flowers perfect and fertile, each subtended by a chaff of the receptacle. Akenes thick and 3-4-angular; or those of the disk laterally compressed (i. e. contrary to the subtending chaff), never obcompressed (i. e. flattened parallel with the chaff). Pappris none, or a cup or crown, or of 2 to 4 rigid awns or chaffy scales from the angles, with or without some intermediate small scales. 
* Receptacle clongated, becoming columnar.

43. Rudbeckia Rays neutral, or very rarely none. Akenes quadrangular and compressed.

* * Receptacle flat, convex, or rarely conical.

+ Rays pistillate and fertile.

44. Balsamorhiza Pappus none. Akenes of the ray obcompressed, of the disk prismaticquadrangular or somewhat compressed.

45. Wyethia. Pappus a chalfy-coriaceous crown or cup, continuous with the broad summit of the prismatic-quadrangular or compressed akene, persistent, irregularly uleft into 5 or more lobes or teeth, those on the angles sometimes elongated into rigid chaffy awns.

46. Verbesina. Pappus 2 slender or small awns; the flat akene margined by a broad wing, at least in the disk-flowers.

$$
++ \text { Rays neutral, or rarely none. }
$$

47. Encelia. Akenes flat and thin-edged but marginless, strongly villous-ciliate : pappus none or a pair of awns, but no intermediate little scales.

48. Helianthella. Akenes flat and the thin edges more or less margined : pappus a pair of persistent allns or chaffy teeth, and a crown of intermediate (sometimes very minute) thin chaffy scales.

49. Helianthus. Akenes thick, quadrangular-compressed or with the sides convex, the edges obtuse: pappus a pair of caducous chaffy seales or amras. Receptacle flat or merely ronvex.

50. Viguiera. Akenes of Helianthus: pappus with chaffy scales between the awns. Receptacle convex or conical.

Subtribe III. COREOPSIDEE. Heads, as in the preceding subtribe, except that the chaff of the receptaclo is flat or barely conoave, and mostly deciduous with the fruit. Akenes all obcompressed, $i$. e. flattened parallel with the subtending scales of the involucre and chatf of the receptacle: pappus of 2 to 4 awns or teeth from the angles, or none. Involucre in our genera double, tho outer loose and more or less foliaceous.

51. Pugiopappus. Rays pistillate, perhaps sometines neutral. Akenes long-villous or ciliate: pappus of 2 large and bayonet-shaped naked chafiy awns.

52. Leptosyne. Rays pistillate. Akenes gaked, winged or margined : pappus none or a minute cup.

53. Bidens. Rays neutral or none. Pappus of 2 to 4 rigid retrorscly barbed awns.

Subtribe IV. GALINSOGEde. Heads, \&c, ns in subtribes II. and V. Akenes neither comyressed nor obeompressed. Pappus in both ray-and disk-flowers of numerous chulfy scales or awns (rarely nenrly none). See one exceptional Homizonia, No. 57.

54. Blepharipappus. Head rather few-flowered; the rays pistillato. Akenes turbinate: papjus of 12 to 20 narrow and thin cut-fringed scales having a strong midrib, occasionally nearly or wholly wanting.

Subtribe V. MLIDIEL. Heads heterogamous, with rny-flowers fertilo; those of the disk either perfect and fertile or sterile; rurely the ray-flowers wanting. Involuere a series of seales, each enclosing more or less a ray-akene, sometimes a few outer and empty or bractenl seales. Receptacle.chaffy only at tho marcin, tho chaff forming a sort of interior involuere, or else subtending either some or all of the disk-flowers. Style-branches of the latter terminated by a subulate hispid tip. Pappus nono for the my-akenes (or abnormally some rudiments in a few cases), composed of several awns or chaffy senles or else none in the lisk-flowers. Herbs mostly glandular and viscid, and heavy-scented: upper leaves alternate, the lower or lowest opposite.

- Akenes all lntemlly compressed, those of tho ray wholly enelosed in the carinato strongly in. folled scales of the involnere, which thereforo beeones deeply sulente.

55. Madia. Pappus none, or of some small seales in the sterile flowers of one sectiun.

- * Ray-skenes turgid, moro or less ohlique or incurved, never latenully compressed, but mostly" rather obeompressed; the investing scales of the involuere rounded on the lawe.

50. Hemizonella. Involuero strongly $4-5$-sulento (in the muner of Mradin) liy the complete chnmppring of tho 4 or 5 akenes. Ijisk-flower one, fertile, in a sort of intrior involu-

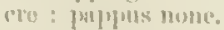

57. Hemizonia Involuero many-few-flowered, less if at nll sulente or lolual : its senales nt,

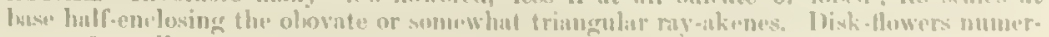
ous or few, whl or some of them intertile : papplus of chatfy scales or none. 
* * * Ray-akenes obcompressed or elavate, completely enclosed in the involucral seales, which are at base flattish on the back with their thin margins abruptly infolded.

58. Lagophylla. Head few-flowered: ray-akenes about 5, obovate, much obcompressed, smooth. Disk-flowers infertile: pappus none.

59. Layia. Head many-flowered: rays 8 to 20, with obovate or somewhat clavate smooth akenes, Disk-flowers or most of them fertile, their similar or narrower akenes often pubescent : pappus composed of bristles (either plumose below or naked) or of subulate-pointed scales, or sometimes none.

60. Achyrachæna. Head many-flowered; the flowers all fertile. Akenes limear-cuneate or clavate, 10-ribbed, some or all the ribs tuberculate-scabrous; those of the disk with a pappus of blunt silvery-scarious. chaffy scales in two series, the inner as long as the corolla.

TRIBE VI. HELENIOIDE无. Heads heterogramous with ligulate ray-corollas, or discoid and homogamous by the absence of rays : the tubular disk-flowers perfect and fertile or rarely sterile. Receptacle never chaffy (in one or two cases with awn-like bodies resembling chatf). Anthers without tails. Branches of the style in perfect flowers either truncate or tipped with an appendage. Pappus of several chaffy scales or sometimes of awns or rigid bristles, not rarely wanting. Leaves opposite, or all but the lowest alternate. Involucre of herbaceous or membranaceous scales, in one or two or rarely 3 or 4 series. Corollas most commonly yellow, both in disk and ray.

Subtribe I. JAUMIEA. Involucre of broad seales regularly imbricated, the outer successively shorter, destitute (as also the herbage) of oil-glands. Akenes narrow, angled, in ours destitute of pappus. Rays deciduous from the akenes.

61. Jaumea. Involuere campanulate. Leaves opposite, connate at base, narrow, fleshy.

62. Venegasia Involucre very broad. Leaves alternate, ovate or cordate, membranaceous, long-petioled.

Subtribe II. RIDDELLIE $\mathbb{E}$. Involucre of narrow equal seales. Rays persistent on the akenes, becoming papery. No oil-glands. Plants more or less white-woolly.

* Pappus of chaffy scales : rays very broad and few.

63. Riddellia. Head several-flowered; the 3 or 4 rays broader than long, few-nerved, raised on a short slender tube, 3-lobed. Leaves alternate.

* Pappus none: rays 5 to 50 .

64. Baileya. Rays destitute of a tube, 7-nerved. Akenes many-striate, all fertile. Receptacle nearly flat, Leaves opposite.

65. Whitneya. Rays with a short tube, 10-16-nerved. Akenes few-nerved, those of the disk sterile. Receptacle conical. Leaves opposite.

Subtribe III. HELENIEA. (Boriece \& Euhelenicce, Benth.) Involucre of nearly equal or narrow scales in one or few series. Rays if any deciduous. No oil-glands.

* Akenes linear or linear-cuneate, 4-angled or compressed, but not with cartilaginous margins.

+ Receptacle conical, convex, or in part of No. 67 \& 68 flattish or flat : involucre of few or several erect appressed or united herbaceous scales.

++ Rays few, very short and included : receptacle high-conical : leaves all opposite, entire.

71. Lasthenia in part. Involucre a many-toothed cup.

66. Burrielia. Involucre of 3 to 5 separate flat scales. Receptacle subulate or almost filiform. Akenes slender : pappus of 1 to 4 rigid awn-shaped scales.

$$
\text { ++ + Rays exserted and spreading. }
$$

67. Bæria. Receptacle high-conical and mostly acute, minutely muricate. Scales of the involucre separate, flat, in a single series. Akenes linear or linear-cuneate. Leaves all opposite, entire or laciniate-pinnatifid.

68. Actinolepis. Receptacle convex or conical, or rarely almost flat. Scales of the involucre wholly separate, becoming concave and involute around the ray-akenes. Anthers tipped with a narrowish or very slender appendage. Akenes slender. Leaves opposite or alternate.

69. Bahia. Receptacle flat, convex, or obtusely conical. Scales of the involuere separate or partly united into a cup, not embracing any of the akenes. Rays entire or barely toothed at apex. Akenes linear or oblong-linear, with large terminal areola: pappus of blunt nerveless scales, rarely wanting. Leaves opposite or mostly alternate, commonly lobed or divided. Ours all woolly plants. 


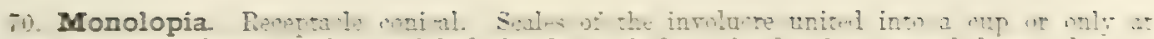
base. Rars broad, $2-4$-lobed, in the typical species bearing a rounded appendage on the opposite side of the throat. Akenes oborate or oblong, the outer ones obcumpresised; the terminal areola small : pappos none. Leares alternate or rarely opposite, entire or pinnately parted. Woolly plavats.

71. Lasthenia Howorins Receptade conical. Scales of the involucre naited almost to their tips into a 10 - 15-toothed cup. Akenes linear-oblong : pappus none. Leaves all opposite, entire, sessile and connate at base Glabrous plaut.

$\$+4 \div$ Rays none, the marginal pistillate flowers having short tabalar corollas.

72. Amblyopappas. Head several-flowered. Involuere of \pm to 6 seales Corollas all very short, those of pistillate flowers 2 -4-toothed, of the perfect flowers 5 -toother. Alkenes oblong-euneate, 1 -angled: pappus of blunt scales

$$
++ \text { Receptacle flat: scales of the involucre narrow, chiefly linear. }
$$

+ Heads with regular ligulate and pistillate rays.

73. Amauria. Irolucre hemispherical, many-flowered, of numerous stales Pappus none. Leaves rond-cordate, petioled, palmately lobed or toothed, all the lower ones opposite.

it. Hulsea Involucre heraispherical, very man-flowereu, of very mumerous suales. Pappus of 4 short thin-hyaline blunt and nerreless scales. Leaves alternate, pinnately lobed or toothed.

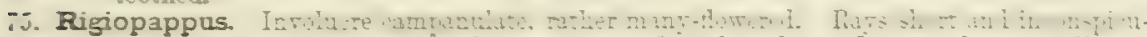
ous. Pappus of 4 or 5 rigid opaque amn-shaped seales Leaves alternate, linear, entire.

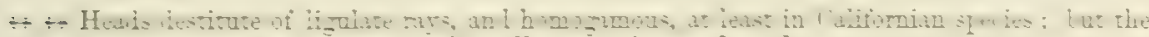
marginal corollas sometimes enlarged.

76. Palafozia Inrolucre narrow, sereral-flowered. Lobes or teeth of the conolla narrow. Pappas of hyaline suales traversed by a stout midrib. Roughish herbs or shrubs, with altemate entire narrow leaves, and rose or purple flowers.

77. Chaenactis. Involucre campanulate or hemispherical. Lobes or teeth of the corolla short and broad. Pappus of blunt hyaline nerreless or mearly nerveless seales, rarely wanting. Woolly, viseid-glandular, or nearly smooth herbs, with alteraate 1-3-pinnately

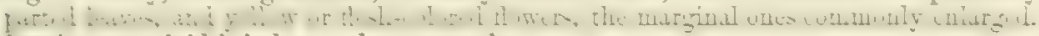
liss iy some rigid bristles on the receptacle.

a Akenes turbinate or obpyramilal : leares all or all bat the lower alternate.

+ Srales of the involucre or their tips spreading or reflexed: rays cuneate, 3-5-lubed: pappus of hyaline commonly awn-pointed sciles.

78. Gaillardia Rays peutral. Reveptacle with some rigid awns among the fowers. Akenes involucellate with rillous haiss.

79. Heleniam Rins commonly fertile. Receptacle wholly anked.

$\div+$ Scales of the involucre erect or appressed: disk-tlowers fertile, their style 2-cleft: akenes irsute or villous.

S0. Actinella Rays $S$ to 12, pistillate. Involucre of numerous seales Receptacle conical or conrex. Pappus of 5 to 12 hyaline entire scales.

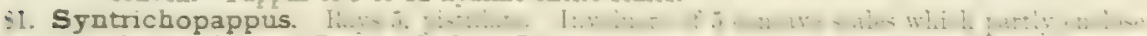
the ra-akenes. Receptacle tlat. Pappus of numerons rongh bristles, all united at baso into s ring.

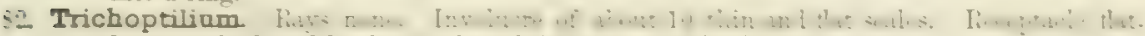
Pappos of 5 broail hyaline scales, cleft into many slender bristles.

+++ Scales of the involucre not reflexed, united at the base, in a single series : disk-flowers sterile, their style entire : akeaes powdery-papillose.

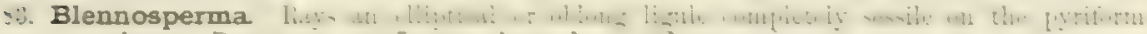
akene. Pappus none. Leares pinnately partecl.

$$
\text { - - dkenes oblong, tlat, surrounded by a cartilaginous margin. }
$$

S4. Perityle Involucre campanulate, of narrow scales Disk-corollas 4 -tootherl. Pappus a

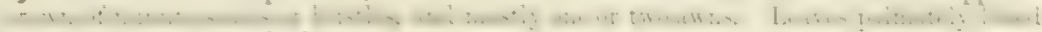
or inciseyl, petiolend ; the lower opposite.

Subtribe IV. TACRTIXE.E. Involuere of fer or sereral equal senles in a single series with or without some brantlets at hase, spotterl, as also the (glabous) foliage, with large

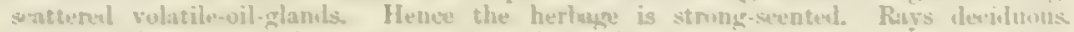
it Terytes, the type of the group common in gardens, probably oecurs in waste plices near uselliug .) 
* Styles with long and slender branches.

85. Dysodia. Head mostly with rays. Pappus single, of rigid chaffy seales dissected into many bristles.

86. Nicolletia. Head with rays. Pappus double; the outer of capillary bristles, the inner of 5 chaffy awn-pointed scales.

87. Porophyllum. Head rayless. Pappus single, of copious rough capillary bristles.

* * Styles long, thickish upward, and with very short blunt branches.

88. Pectis. Head with rays. Pappus of awns or bristles. Leaves opposite, undivided, mostly fringed near the base with slender bristles.

TrIBE VII. ANTHEMIDEÆ. Heads heterogamous either with ligulate ray-corollas or rayless, the pistillate flowers being small and tubular or none, or homogamous, all the flowers perfect with regular tubular corollas. Receptacle naked, or in some with narrow chaff subtending the flowers. Anthers without tails. Branches of the style in the perfect flowers with truncate or truncate-capitate tips, or in hermaphrodite-sterile flowers undivided. Akenes small, destitute of pappus or with a short scarious crown or ring. Jeaves alternate, commonly dissected. Involucre of dry or partly scarious scales, appressed and imbricated in two or more (rarely almost in a single) series. Herbage mostly strong-scented.

* Receptacle chaffy, at least among the central flowers : heads in our species with rays.

89. Achillea. Involucre narrow : rays short. Akenes obcompressed, margined.

90. Anthemis. Involucre broad : rays conspicuous. Akenes 4 -5-angled or 8 -10-ribbed.

* Receptacle not chaffy.

+ All the flowers furnished with corolla.

91. Chrysanthemum. Rays numerous and conspicuous. Receptacle flat or convex. Akenes several-ribbed or angled.

92. Matricaria. Rays in our species wanting; the flowers all alike and perfect. Receptacle high-conical. Akenes angled, truncate at top.

93. Tanacetum. Rays none, but sometimes the marginal pistillate with enlarged and oblique corollas. Heads corymbose. Akenes broad at the top, more commonly with a coroniform pappus.

94. Artemisia Rays none. Corollas in the marginal pistillate flowers (when there are any) slender and 2-3-toothed. Heads panicled or xacemose, small, often nodding. Akenes mostly obovoid and rounded at the top, with a small terminal areola and no pappus.

+ + Pistillate flowers apetalous, merely naked pistils : akenes obcompressed.

95. Cotula. Heads peduncled. Akenes not pointed with persistent style, those of pistillate flowers stalked.

96. Soliva. Heads sessile. Akenes pointed with a long and indurated style, sessile.

TrIBE VIII, SENECIONIDEE. Heads heterogamous with ligulate (rarely filiform) raycorollas, or sometimes homogamous and discoid; the flowers perfect, or rarely staminate, and with regular tubular corollas. Receptacle not ehaffy. Anthers often sagittate at base, but without tails. Branches of the style in perfect flowers mostly with truncate, or somewhat capitate, or obtuse tips, rarely with any distinct appendage. Pappus of numerous usually very fine and soft capillary bristles. Leaves mostly alternate. Involucre almost always of equal herbaceous scales, in one or two series, or with some short ones or bracts added. Flowers usually yellow.

Subtribe I. TUSSILAGINE出. Heads monceious, the tubular disk-flowers staminate (in Tussilago), or diocious: style in the tubular sterile flowers undivided or nearly so.

97. Petasites. Heads diocious and heterogamous : flowers white or purplish; the fertile ones pistillate and more or less conspicuously radiate.

Subtribe II. EUSENECIONEA. Heads heterogamous or homogamous : the tubular diskflowers perfect and fertile, with 2-cleft style.

* Leaves all alternate : bristles of the pappus barely scabrous or denticulate.

98. Tetradymia. Heads homogamous, 4-18-flowered. Limb of the corolla 5-parted into long linear or linear-lanceolate recurved lobes. Scales of the involucre dry, rather rigid.

99. Luina. Heads homogamous, about 10-flowered. Corollas with slender tube, long and inarrow limb, and 5 short ovate-Ianceolate lobes. Style-branches obtuse. Pappus soft and white.

100. Psathyrotes. Feads homogamous, rather many-flowered. Corollas with very short proper tube, long and narrow limb, and 5 short and obtuse glandular or villous teeth, Pappus brownish and rather rigid, very unequal. 
101. Senecio. Heads heterogamous and radiate, or homogamous. Disk-corollas 5-toothed or 5-lobed, mostly with slender tube. Pappus copious, fune and soft, white,

* Leaves mostly opposite or all radical : bristles of the pappus in a single series, rigiil, strongly scabrous, barbellate, or plumose.

102. Arnica Heads heterogamous or occasionally homogamous. Pappus scabrous or barbellate. Leaves all or some of them opposite.

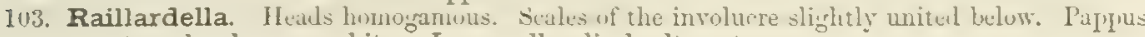
strongly plumose, white. Leaves all radical, alternate.

TribE IX. CYNAROIDEE. Heads homogamous and the flowers all perfect, with corollas all tubular and deeply 5-cleft, often bilabiately so $\left(\frac{7}{7}\right.$ or 3$)$, or rarely incompletely dioecious, sometimes (in introduced representatives) with a row of neutral flowers at the margin, the corollas of which may be enlarged, forming a kind of false ray. Lobes of the corollan not revolute. Receptacle generally densely bristly. Anthers sagittate, with their auricles often prolonged into tails. Style destitute of all terminal appendages or tips ; the stigmatic branches either short or slender, but mostly united to the apex or near it, minutely puberulent or granulate: at the origin the style is more commonly thickened into a kind

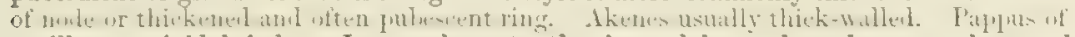
capillary or rigid bristles. Leaves alternate, the tips or lobes and teeth commonly amed with prickles. Involucre often of spiny-tipped scales, imbricatecl in many series. - Only Thistles are indigenous to the country, but one or two other genera have been introduced from the Old World.

* Flowers of the head all alike: bristles of the pappus cohering at base in a ring.

104. Cnicus. Pappus plumose : filaments separate, papillose-pubescent.

105. Silybum. Pappus naked: filaments monadelphous, glabrous, Leaves blotched.

* Flowers at the margin of the head mostly sterile : bristles of the pappus separate, not plumose.

106. Centaurea. Akenes attached to the receptacle obliquely or by one side of the base.

TRIBE X. MUTISIACE.E. Heads homogamous or sometimes heterogamous, with the limb of the corollas bilabiate $\left(\begin{array}{l}2 \\ )\end{array}\right)$, one lip $3-$, the other 2 -toothed or eleft. Receptacle not clothed with bristles. Anthers with long tails. Style-branches obtuse or trumcate and destitute of any tip or appendage. Leaves altemate. - Only one scanty Californian genus.

107. Perezia. Head few-many-flowered : the flowers all perfect and similar, with distinctly

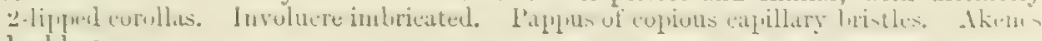
beakless.

TribF. XI. CICHORIACEA. Heads homogamous, the flowers all perfect and with ligulate corollas, the ligule 5 -toothed at the apex. Style-branches filiform, papillose. Herhs (except a few insular species) with milky bitter juice. - The subtribes, not being well-marked by obvious characters, here give place to artificial sections.

- Pappas none All but No. 108 are genera which ordinarily have a pappus.

108. Phalacroseris. Seape simple: head erect before flowering. Akenes obscurely 4-5angled.

109. Microseris, partly. Scape simple: hend nodding before flowering. Akenes 10.ribbed.

116. Malacothrix \$AxATHBIx. Suape corymbose-panicled: heads rather numerous.

* Pappus either chaffy or plumose, i. e. of awn-tipped chaffy scales, or of awns or bristles more or less dilated into a seale at base, or of plumose bristles.

+ Receptacle destitute of chaff or bristles : akenes more or less hollowed out at the insertion.

109. Microseris. Flowers yellow. Akenes 8-12-ribhed: pappus more or less chaffy. Stemless or short-stemmed and long-peduneled, with head comnonly nodeling before flowering.

110. Stephanomeria. Flowers pink or white. Akenes short, truncate at both ends, ahout 5-ribted or angled: [mippus of plumose or partiy plumose bristles, or iarely elually awris, or narrow senles. Lenfy-stemmed and hranching, with small hearts.

111. Rafixesquia. Flowers white or pink. Akenes truering upwarils into a narrow heak, ohsidurely ribhed: pappus of cobwebhy-plumose slender bristles. Leafy-stemuned and branching, with metuer large heads.

+ + Receptacle with slender chaff between the flowers: akenes inserted by a pointed buse: pap. pus of plumoso bristles: flowers yellow.

112. Hypochaeris. Akenes glubmus, the inner ones at least tapering upwarls into a beak : pitpus sordiul or lirty white.

113. Anisocoma. Akenes silky-pubesent, truncate aud with a little crown at the summit patpus bright white. 
* * Pappus of copious capillary and merely scabrous or at most minutely barbellate bristles. Receptacle naked, or in No. 115 and 116 with some delicate bristles between the flowers.

* Akenes not flattened : pappus white, mostly bright white,

* All or most of it early deciduous or caducous more or less in a ring.

114. Glyptopleura. Akenes 4-5-angled and with a sculptured surface, abruptly short-beaked trom a cup-shaped shoulder, and the beak cup-shaped at apex or hollow. Receptacle naked.

115. Calycoseris. Akenes tapering into a slender beak, the apex of which is dilated into a scarious crown or shallow cup. Receptacle with delicate bristles between the flowers.

116. Malacothrix. Akenes columnar, truncate at both ends, 10-15-ribbed; the broad apex with a prominent crown-like margin or sharp edge, either entire or denticulate, sometimes bearing a more persistent outer pappus of 1 to 8 stronger bristles.

++ Pappus more persistent, simple, the bristles separately if at all deciduous from the akene: flowers mostly yellow.

117. Crepis. Scales of the involucre commonly carinate-thickened at base or with firmer midrib when old. Akenes 10-20-ribbed, smooth, more or less tapering at the apex, not long-beaked.

118. Troximon. Scales of the involucre unaltered in age. Akenes 10-ribbed, not muricateroughened, above contracted into a neck or beak.

119. Taraxacum. Scales of the involucre unaltered in age. Akenes 4-10-ribbed or angled, the ribs becoming muricate, the apex developed into a long filiform beak.

* * Akenes not flattened nor beaked : pappus tawny or dirty white, mostly fragile.

120. Apargidium. Head many-flowered on a simple scape. Flowers yellow. Akenes short, not ribbed: bristles of the pappus barbellate-denticulate.

121. Hieracium. Heads many-flowered. Flowers yellow. Akenes short, 5-10-ribbed : bristles of the pappus scabrous.

122. Lygodesmia. Heads 5-10-flowered. Flowers rose-color or pink. Akenes narrow or slender : bristles of the pappus copious, scabrous.

* + * Akenes flat: pappus almost always bright white, fine and soft.

123. Lactuca. Involucre not tumid at base. Akenes with a beak or neck under the dilated disk that bears the pappus, the bristles of which fall separately.

124. Sonchus. Involucre becoming tumid or fleshy-enlarged at base. Akenes destitute of beak or neck, and having no dilated pappus-bearing disk : bristles of the pappus deciduous more or less in connection.

Criptostemma calendolacea, R. Br., of the tribe Aretotideo, a native of S. Africa, but naturalized in Australia, has been gathered by Mr. E. L. Greene near the landing at South Vallejo ; probably a ballast weed, and we may hope transient. It is a stemless plant, with leaves resembling those of Dandelion, but white-tomentose, at least beneath, the solitary heads on slender seapes, and the ray-akenes enveloped in very long wool. It is not worth while to introduce another tribe into the series for this waif.

\section{(TRIBE I. VERNONIACEE, wanting.)}

\section{TRIBE II. EUPATORIACEE.}

Heads all homogamous and discoid; the flowers perfect, with regular tubular corollas, never truly yellow. Anthers obtuse at base. Branches of the style obtuse, inclined to club-shaped, minutely papillose-roughened or almost smooth, destitute of any appendage; the stigmatic lines indistinct.

\section{HOFMEISTERIA, Walpers.}

Head many-flowered. Involucre of imbricated narrow acuminate scales, the exterior successively shorter. Receptacle flat, naked. Corollas slender, 5-toothed. Branches of the style club-shaped. Akenes 4-5-angled. Pappus of 2 to 12 slender bristles alternating with as many chaffy scales. - Low plants, suffruticose at base and branching, nearly glabrous, with long-petioled incised or lobed leaves, the 
lower opposite, the upper alternate, and long naked peduncles bearing sulitary heads. - Walp. Repert. vi. 106 ; Benth. \& Hook. Gen. ii. 243. Helogyne, Benth. Bot. Sulph. 20, t. 14, not of Nutt.

Neither of the two known species have yet been found within the actual limits of the State, oue being farther south, the other southeast.

1. H. fasciculata, Walp. Scales of the involuce very numerous and clusely ilppressed, scarecly striate: akenes slender, Hattish, hispid un the lateral andes: pallyns of 2 or 3 almost barbellate awns and as many lrvad chatfy scalles which arm truncate and lacerate at the summit: leaves palmately 3-5-parted or cleft, and with the divisions sinuate-lobed. - Helogyne fasciculata, Benth. Bot. Sulph. 1. c.

Var. Xanti, Giny, with the leares round-reniform and mustly ouly ubscurely lobed. - Proc. Am. Acad. v. 158.

Lower California, Magdalena Bay, Hinds. Cape San Lucas, Xuntus, the variety.

2. H. pluriseta, Griy. Scales of the involucre striate, louser and fewer (20 tw In 25): akenes shorter, terete-5-angular, pubescent: pappus of 10 to 12 slenter barcly scabrous awns or bristles and as many narrow acute or pointed chafly seales: leaves small, acutely and irregularly cleft or incised. - Pacif. R. Rep. iv. 96, t. 9.

sin Bernardino Desert to Willians' liver and cañons of the Coloradu, Ligclow', Nexcbrry, Permy.

\section{EUPATORIUM, Tourn.}

Head 3-many-flowered. Involucre various. Receptacle naked. Corollas 5lobed or 5-toothed. Akenes 5-angled, with no intermediate ribs. Pappus of numernus rather ricril capillary scahrous bristles, forming about a singhe series. Perennials, mostly with opposite leaves.

A lugge and widely dispersed genus, copious in the Atlintie States, extremely seanty in those of the Pacific, two species barely reaching Califormia.

1. E. occidentale, Houk. Almust glahrous, slightly glamlular, a fimt ur two high from a suffrutescent base: leaves commonly more or less alternate, on very short petioles, ovate, triple-ribbed near the base, somewhat serrate: corymbs smail in a crowled panicle: heads $15-25$-flowered: seales of the involucre in mearly a single series, shorter than the pink or pinkish flowers.

From eastern slopes of the Sierra. Nevada south to Ebbett's Pass and the Yosenite Valley; not rare in Nevada and the interior of Oregon, in cañons, \&ce.

2. E. sagittatum, (imy. Mimutely puherulent: leares all "Imusite, futirlenl, hastately sagittate, entire: heads single or in threes at the ends of the diverging

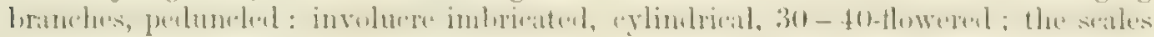

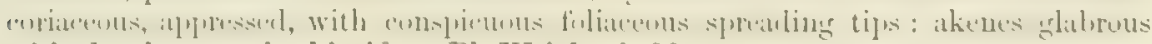
with the sharp angles hispid. - Pl. Wright. i. 88, note.

Southeastern part of California probably ( 294 , coll. Coulter), and adjacent parts of Mexico.

\section{BRICKELLIA, Ell.}

Heal several-many-flowered. Involucre of imbricated striate-nerved scales, the outer shorter. Receptaclo naked. Corollas slender, 5-toothed or with 5 short lobes. Style bulbous at base, the branches commonly thickened upward. Ikenes 10-striate or ribbed. Pappus of numerous scabrous or barbellate cenpillary bristles, about in a single series. - Herbaceous perenuial or partly shrubhy plants, commonly mother glandular or viscid or ilatted, most resembling Eupatorinm, except in the many-ribled or striato akenes; the flowers white, whitish, or flesh-color. Giray, Pl. Wright. i. 84. Brickellia, in part, Bulbostylis, \& Clevigere, DC.

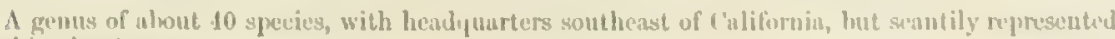
within the sitate. 
B. oBdongrfouta, Nutt, an herb, with lanceolate-oblong entire and sessile leaves, a few terminal rather large and many-flowered heads, and minutely glandular akenes, occurs along rivers in Oregon, and may be expected in the northern part of the State.

B. LINIFOLIA, Eaton, like the preceding but with rather narrower leaves, fewer heads, and minutely hinjid akenes, growing in Arizona and Nevada, may reach California, but is less likely.

B. HAsTAT, Benth., a cimescent tonentose slecies, with oplosite hastately 3-lobed leaves, and corymbose 12-flowered heads, has been found only far down in Lower California.

B. Coulteri, Gray, with barely pubescent opposite hastate-triangular and sparsely toothed lraves, and long-peduncled about 12 -flowered heads, is known only by a speeinen in Coulter's collection, which may not have been collected within the State. Several plants of his "California " collection were gathered only in Arizona, or east of the Rio Colorado.

* Heads about an inch long: scales of the involucre obtuse: plant woolly.

1. B. incana, Gray. Plant probably woody at base, white at least when young with a close soft wool: leaves of the branches ovate or cordate, nearly entire, sessile, alternate (small), becoming naked and green with age: heads solitary terminating the loose branches, peduncled, very many-flowered: scales of the involucre in 3 or 4 ranks, the outermost roundish, the inner linear-oblong: akenes silky. - Proc. Am. Acad. vii. 350.

Providence Mountains, San Bernadino Co., Dr. Cooper.

* * Heads half to three quarters of an inch long: plants minutely puberulent or pubescent, and more or less glandular or viscid.

2. B. grandiflora, Nutt. Herbaceous, 2 or 3 feet high, simple or corymbosely branching, not viscid: leaves cordate-triangular, acute or acuminate, thinnish, coarsely serrate, 2 or 3 inches long, on slender petioles; the lower opposite, uppermost alternate: heads numerous in a naked corymbose cyme: scales of the involucre thin, mostly acute : akenes nearly glabrous.

Rocky banks of streams in the Sierra Nevada (Yosemite Valley, \&c.); and eastward through the Rocky Howntains. Notwithstanding the name of this species, the heads are only three fourths of an inch long, or often shorter, cylindraceous, and less than half an inch broad.

3. B. Californica, Gray. Shrubby at base, 2 to 3 feet high, paniculately branched: leaves alternate, ovate, somewhat triangular, or sometimes slightly cordate, mostly obtuse, irregularly erenate-toothed, 3-ribbed from the base, reiny, roughish (an inch or so in length), on short petioles: heads spicate or racemose along the leafy branches, half an inch long, 10-15-flowered: scales of the involucre with thinnish mostly obtuse straight tips. - Pl. Fendl. 64. (Bulbostylis, Torr. \& Gray, Fl. ii. 79.) B. Wrightii, Durand \& Hilgard, Pacif. R. Rep. v. 8.

Dry hillsides, from Mendocino Co. nearly through the State, and eastward at least to Utal.

4. B. microphylla, Gray, 1. c. More branched than the last, viscid and glandular: leaves smaller and with acute teeth; those of the branches almost sessile, half an inch long or less: heads elustered at the ends of diverging branchlets, smaller: scales of the involucre rigid, all but the innermost with squarrose-spreading herbaceous tips. - Bulbostylis microphylla, Nutt.

Tellac Peak, near Lake Tahoe (Lemmon) ; adjacent parts of Westeru Nevada (Torrey); thence north and east to Oregon and Utah.

\section{ADENOSTYLES, Cass.}

Head few-many-flowered. Involucre of a single series of erect scales, or sometimes with one or two smaller and Iax exterior ones additional. Receptacle naked, flat. Corollas dilated above the slender tube, the 5 lobes spreading. Branches of the style somewhat thickened upward. Akenes terete, 10-striate, glabrous. Pappus of very copious soft and white capillary bristles. - Perennial herbs, with simple stems, alternate cordate or reniform leaves, mostly on long petioles, and corymbose heads of flesh-colored, white, or cream-colored flowers. - Benth. \& Hook. Gen. ii. 247. 
1. A. Nardosmia, Gray. Floccose-woolly: stem rather stout, 1 to 2 feet high, $2-3$-leaver, and bearing 4 to 7 large lousely corymbose heads: leaves round-reniform, 5-9-cleft, white-woolly beneath, becoming naked above, the lobes coarsely toothed or cleft: heads an inch long, peduncled, about 50-flowered: scales of the campanulate involucre 12 to 30 , lanceolate-linear, acuminate, a little shorter than the disk : corollas yellowish, with elongated eylindraceous throat: anthers exserted: akenes distinctly striate. - Proc. Am. Acad. viii. 631. Cacalia Nardosmia, Gray, Proc. Am. Acad. vii. 361.

Open woods of Spruce and Pine, Sonoma to Humboldt Co., April, May, Bolander, Kellogg. "Flowers of the color of yellow beeswax, and exhaling the odor of honey or beeswax." This striking and peculiar plant indeed appears to belong (notwithstanding the yellowish flowers and their far greater number in the head) to a small genus otherwise restricted to the mountains of Middle and Southern Europe. The leaves much resemble those of Petasites palmata.

\section{CARPHEPHORUS, Cass. Sect. KUHNIOIDES, Gray.}

Head many-flowered. Involucre campanulate or hemispherical; its scales imbricated as in Brickellia, but less striate. Receptacle flat, furnished wit.' some chafl * (resembling the innermost involucral scales) among the flowers, at least the outer ones, and deciduous with the fruit. Corollas narrow, rather deeply 5-toothed, the teeth open or spreading. Akenes 10-ribbed, five alternate ribs mostly stronger, often 5-angular. Pappus a single series of equal plumose bristles. - Gray, Proc. Am. Acad. viii. 632.

This genus is founded on four species of the Southern Atlantic States, with herbaceous mostly simple stems, alternate leaves, and middle-sized heads of rose-purple flowers, most resembling those of Liatris, the pappus of rather copious and unequal bristles, which occupy more than one series, and are at most short-barbellate. The Californian species have loosely branching stems, suffrutescent at base, the lower leaves are opposite, the corollas pale and probably yellowish-white, and the pappus, as above deseribed, almost as plumose as that of Kuhnia.

C. Atriplicifolius, Gray, was collected only in Lower California, near Cape San Luers, by Xmutus. It may le known liy its liteiniate-lober? leaves and the striate glabrous seales of the involuere.

1. C. junceus, Benth. Minutely hispid or nenly smonth, much hrnmehel: branches long and slender, rush-like, terminated by sulitary or lonely corrmiluse

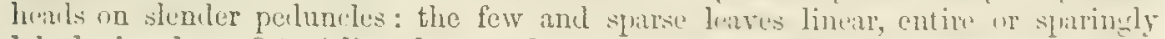
lobed: involucre 3 to 4 lines long, rather shorter than the flowers, the onter scales

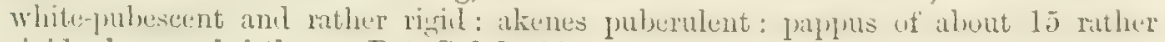
rigid plumose bristles. - Bot. Sulph. 21.

S. E. borders of California, on or near the Colomdo, Coulter, Nexbermy, Coopcr, \&c. : apprarently common in the adjacent parts of Arizona, and first made known from Hind's collection in Lower California. The flowers were noted by Dr. Cooper as "yellow," which is not likely. They may be cream-color.

\section{TRIBE III. ASTEROIDEE.}

IIeals hetermamous with some marrinal flowers pistillate (mamly nontral) and rommonly ruliato (lignlato). or else homogamme, the comblas all tulmiar, or in

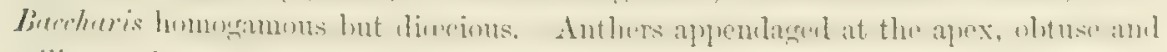

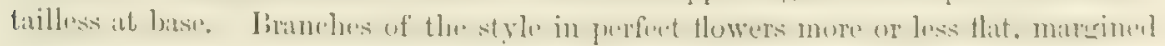

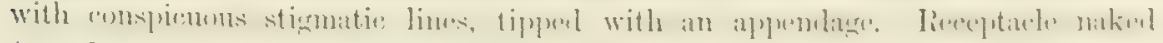
(not chaffy), except in one Corethrogyne. In Baccharis only the flowers are dine-

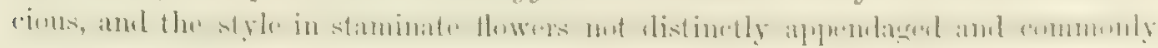

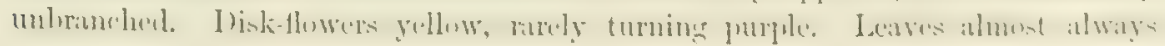
alternate. 


\section{GUTIERREZIA, Lagasca.}

Heads corymbose, small or rather small, heterogamous; the rays few and fertile; disk-flowers perfect (in one species apparently infertile). Involucre obovate or cylindraceous, its scales coriaceous, with greenish tips, closely imbricated, the outer ones shorter. Receptacle convex or conical. Rays short. Appendages of the style lanceolate or linear, hispid. Akenes terete, often somewhat turbinate. Pappus paleaceous, viz. of 7 to 9 or more chaffy scales, commonly distinet, and those of the ray-flowers shorter than those of the disk (in some Eastern species short and more or less united in a ring or crown). - Herbaceous or suffrutescent, glabrous, often resinous, much branched from the base, with narrow entire leaves, and corymbose or fasciculate-crowded mostly small heads of bright yellow flowers. - Torr. \& Gray, Fl. ii. 193; Benth. \& Hook. Gen. ii. 250, excl. sp. Brachyris, Nutt.

Two or three other species occur in Arizona, \&c., but have not yet been found near the Californian borders.

1. G. Euthamix, Torr. \& Gray, 1. c. More or less woody at base, seldom over a foot high : leaves narrowly linear, crowded: heads fastigiately corymbose and crowded, or sometimes rather open-panicled: involuere turbinate, 2 lines long: flowers of the ray and disk each 3 to 9 : akenes silky-pubescent: pappus of about 9 chaffy scales; those of the disk-flowers linear or oblong-linear and obtuse, fully half the length of the corolla, at least as long as the akene; those of the ray shorter and broader. - G. Euthamice, divaricata, \& Californica, Torr. \& Gray, Fl. ii. 193. Brachyris, Nutt.

Dry hills along the coast and the Contra Costa Mountains : the var. CAlifornica (G. Californica, Torr. \& Gray, l, c.) ; taller than the eastern form, and usually with thicker heads, containing more numerous flowers, and the pappus rather longer. Tejon Valley, Dr. Hcermanz: a low form with the fewest-flowered heads (G. microphyllo, Durand \& Hilgard, Pl. Heerm. 40, - 2 lapsus for $G$. microcephala), which extends from W. Nevada (Watson, \&ce.) to the east of the Rocky Mountains. These are two extremes of apparently one variable and wide-spread species. $-G$. microcepluala, Gray, with which the Tejon plant was confounded, has still narrower, more cylindrical, and smaller heads, with mostly a single disk-flower, and that infertile.

2. G. linearifolia, Lagasca (?). Suffruticose or herbaceous, 1 to 2 feet high: leaves narrowly linear: heads loosely corymbose: involucre obovate, 3 lines long: akenes minutely appressed-pubescent: pappus of about 12 oblong and obtuse or spatulate chaffy scales hardly longer than the proper tube of the corolla.

Near Los Angeles, Dr. Gambel. - In the size of the heads and in the pappus this accords tolerably well with a specimen in Berlandier's collection, No. 1360, from San Luis Potosi, Mexico, - which may be the obserure original of the genus, $G$. linearifolia. Yet the flowers are as many as 5 to 8 in both ray and disk. It resembles the Chilian $G$. panicublata; but in that the scales of the pappus are narrowly lanceolate and nearly equal to the disk-corolla.

\section{AMPHIACHYRIS, Torr. \& Gray. (Sect. of BRACHYRIs, DC.)}

Heads corymbose or fascicled, small, heterogamous; the rays fertile; disk-flowers hermaphrodite but wholly or mostly sterile. Involucre obovate or cylindraceous; its scales rather few, coriaceous, closely imbricated, the outer successively shorter. Receptacle convex. Rays 1 to 10 : disk-flowers from 5 to 20 : appendages of the style in the latter oblong, obtuse. Akenes terete, pubescent. Pappus of the rayflowers chaffy and coroniform-concreted; of the disk-flowers setiform rather than paleaceous, the very narrow scales or flattish bristles about the length of the corolla and commonly more or less united at the base. - Low and bushy-branched glabrous plants, with entire subsessile leaves and yellow flowers. - Gray, Proe. Am. Acad. viii. 633 . 
1. A. Fremontii, Gray, 1. c. Shrubhy, 1 to 2 foet high: leares obovate-spatulate, acuminate, short: heads sessile in compound corymbose clusters: involucre (barely a quarter of an inch long) of 7 to 9 oval and obtuse thinnish scales, the tips of which are obscurely greenish: ray-flower only one, with a short obovate ligule and a parpus nearly als longr as its tube, composed of numerous narrow ehaffy scales united below into an irregularly cleft cup or crown: disk-flowers about 5, with aplarently well-formed but sterile ovary, and a pappus of about 20 flattish more or less tortuous denticulate-hispid bristles, some of them occasionally united or sparingly branched. - Amphiprippus Fremontie, Torr. \& Gray, in Juur. Lust. Nat. Hist. Soc. v. 4, \& Pl. Fremont. 17, t. 9.

On the Mohave River and in the vicinity of the Colorado, April : found only by Fremont. Bentham and Hooker (Gen. Pl. ii. 250), recognizing the affinity of this with Amphiachyris dracunculoides, refer them both to Greticrrezia; but it seems preferable to keep up the genus Amphiachymis and refer this peculiar and rare species to it.

\section{GRINDELIA, Willd. GuMr-PLANT.}

Ifeads solitary, terminating leafy hranches, or vecusionally more or lesis corrmbose, heturuamuls with the rays fertile, or in one species homonamous (myless), manyflowered. Involucre hemispherical or globular, commonly coated with resin or balsam; its scales very numerous, imbricated, narrow, with coriaceous appressed halse and slenter more or less spreating or squarruse green tips. Recepticle flat or convex, foveolate. Rays numerous, narrow. Brunches of the style tipped with a lanceolate or linear appendage. Akenes compressed or turgid, or the outermost somewhat triangular, glabrous, truncate. Parpus of 2 to 8 calucous awns or stunt corneous bristles. - Biennial or perennial and mostly coarse herbs, with sessile or partly clasping leaves, often viscid or resinous, and middle-sized or rather large heals of yellow flowers; flowering in summer. - Torr. \& Gray, Fl. ii. 246.

A characteristic genus of the plains west of the Mississippi, extending to the Pacific const and to Mexico, with two or three species in similar regions of Sonth America, not over a dozen or so in all. But they are difficult of discrimination, especially the western species, which are all different from the enstern. Somo good characters may be furnished by the ripe akenes, which are known in few species.

The balsamic resin which exules from the herbage, most largrely from the forming heads, is nsed medicinally, especially is a remedy for the effects of Prison Oak (Rhus lobaka). Either the bruised plant is applied directly, or a decoction or alcoholic infusion.

* Stems a foot to a yard high, leafy: leaves from obovate to lanceolate.

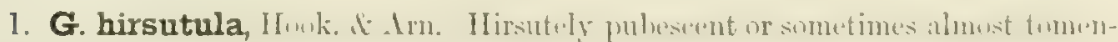
tose with suft sprealing hairs, or lower part of the stem glabrous, one to three feet high: leaves sharply and irregularly serrate, from lanceolate to oblong, the lower spatulate, uppernost usually with broad clasping haso: awns of the pappus 2 or 3 , flattish, nearly smooth. - Bot. Beech. 147. G. mibricaulis, DC. Prodr. v. 316.

Under redwoods, \&c., from Monterey northwarl, extending along the const to Puget Sound. Known by the pubescence, and usually by the red or purplish stem: the involucre sometimes tomentose, sometimes almost naked ; the tips of the scales, as in other species, either straight ot sųuartose.

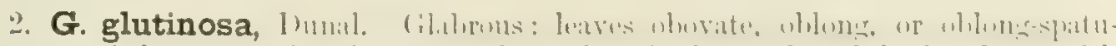
late, roundel at apex, sharply sermte above tho middln: seales of tho involuero with short tips: pappus of 5 to 8 rigid Hattened chatf-liko awns, their thin ellges sparsely servulate-ciliolato, - Aster glutinosns, Cav. Ic. ii. t. 16s.

Saudy moist grounds, on the const, Fort Point and Iohos Creek, near San Fruncisen : intmduwerl (:). The original of this species is still to have come from Southern Peru (not Mlexico), a disiriet which has given not a few plants to tho const of Califorma. 
3. G. robusta, Nutt. Very glabrous, pale, usually stout: Ieaves from broadly spatulate or oblong to lanceolate, or the upper cordate-clasping, commonly obtuse, sharply more or less serrate: involucre with at length squarrose tips: pappus of 2 to 3 or rarely 5 rigid and flattish nearly smooth awns: akenes mostly 1 - 3 -toothed at the apex. - Trans. Am. Phil. Soc. n. ser. vii. 314.

Var. latifolia (G. latifolia, Kellogg in Proc. Calif. Acad. v. 36) is a robust and broad-leaved form, with leaves 3 or 4 inches long, and the cordate-clasping oval upper ones almost as broad: heads proportionally large.

Var. angustifolia ( $G$. cuneifolia, Nutt. 1. c.) is a coast form, with rather fleshy leaves varying from cuneate-spatulate to lanceolate, the upper nearly entire, all narrowed at base.

Var. (?) rigida. A more glutinous and rigid form, with naked corymbose or paniculate heads, and rigid coriaceous leaves, some of them very sharply serrate: growing in dry or arid exposures, away from the sea.

Common along the coast; the last variety more inland, on the coast-range, the Contra Costa Mountains, \&c. A polymorphous species.

G. INTEGRIFOLIA, DC., of Oregon (which includes $G$. stricta, DC.) may occur in the northern part of the State. The larger forms of it and the more eutire-leaved forms of the preceding are not clearly distinguished.

W G. DISCOIDEA, Nutt., of Oregon is a small-headed species wholly destitute of rays.

a G. NANA, Nutt., from the same region, is a somewhat similar species, but dwarf, and with rays.

* A span or so in height: leaves narrowly and spatulate-linear, mainly radical.

4. G. humilis, Hook. \& Arn. "Glabrous: stem herbaceous, simple, with a single head: radical leaves linear, obtuse, tapering to the base; the cauline ones sessile, the lower narrowly linear and the upper reduced to subulate bracts: scales of the involucre linear-lanceolate, with squarrose tips." - Bot. Beech. 147.

Althongh Lay and Collie must have collected the specimen in the vicinity either of Monterey or of San Francisco Bay, it has not since been identified. From a description and sketch of the specimen in the Hookerian herbarium, it is ascertained that it is unlike any other known species: the narrow radical leaves 2 inches long: involucre about half an inch high, its seales acute, only the ontermost loosely recurved or spreading, the others appressed. Rays rather numerous and elongated. The pappus is not deseribed.

\section{ACAMPTOPAPPUS, Gray.}

Heads many- (12-30-) flowered, homogamous, the flowers all perfect and with tubular corollas. Involucre hemispherical; the scales imbricated in about three ranks and closely appressed, oval or oblong, very obtuse, concave, coriaceo-charta.ceous and whitish, with a greenish spot next the summit, margined with a scarious and lacerately ciliate or fringed border; the outer successively shorter. Receptacle convex, alveolate, fimbrillate. Corolla funnelform, 5-lobed. Branches of the style tipped with a thickish subulate appendage. Akenes short and thick, turbinate, densely silky-villous with very long white wool, 5-nerved under the wool. Pappus between chaffy and bristly, rigid, of 12 to 18 paleæ or flattened chaffy bristles, equalling the akene and the corolla in length and mostly somewhat dilated at tip, and of about as many more slender and unequal shorter bristles. - Proc. Am. Acad. viii. 634. - A single species:-

1. A. spharocephalus, Gray, 1. c. Glabrous low shrub (1 to 3 feet high), not at all glandular nor resiniferous, with rigid and angular straggling branches: leaves narrow, entire: flowers light yellow. - Aplopappus (Acamptopappus) spharocephalus, Gray, PI. Fendl. 76 ; Torr. in Pacif. R. Rep. vii. 12, t. 6.

Desert region bordering Arizona, first deseribed from Coulter's Californian collection (No. 281), 
who very probably found it only in Arizona, where it has since been collected by $D r$. Antiscll and Dr. Palmer, and in S. Utah by Porry. - Heads less than half an inch in diameter. Leaves liuear-lanceolate and somewhat spatulate, half an inch or less in leugth, about a line wide. Akenes 2 lines long, when mature resembling pellets of wool.

\section{PENTACH正TA, Nutt.}

Ireds sulitary, terminating slemler branches, heterogamous with the rays fertile, or sometimes rayless, several - mauy-flowered. Involucre of numerous or rather few thin amb smouth more or less scarinisly margined ublong or linceulate scales, louscly imbricater in two or more series, destitute of green tips. lieceptacle conrex, somewhat foveolate. Rays few or numerous, with oblong ligule on a slender tube, or sometimes the lirule and sometimes the whole pistillate ray-flowers wanting- Insk-

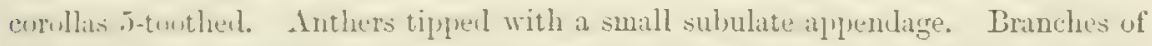
the style in the disk-llowers hearing a long tilitorm-subulate but flattish appentage, much lonstre than the stipmatic purtion. Akenes ohlong, compressed, hisute. Pappun of 5 (rarely somewhat fewer or more numerous) slenter and rigid persistent serrulate-scabrous bristles, which are shorter than the disk-corollas, abruptly en-

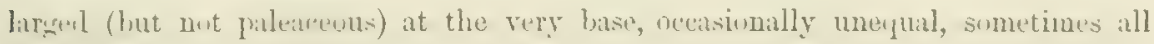

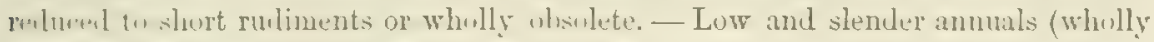

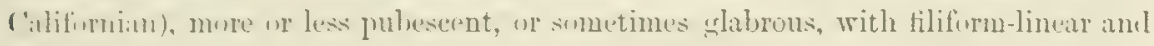
entire alternate leaves, and small or midlle-sized heads. Corollas either all yellow, or these of the disk snmetimes turning purple, the rays when present usually yellow, sonetimes white! - Torr. \& Gray, Fl. ii. 249 ; Gray, Proc. Am. Acad. viii. 633. Aphantochceta, Gray in Pacif. R. Rep. iv. 43, t. 11.

A peculiarly Californian genus of two species ( $P$. gracilis, Benth., of Mexico, being an Oxyporpuns), remarkable for having, like Lessingin, either yellow or white rays.

1. P. aurea, Nutt. At length difusely branched, 3 to 12 inches high: heads many-flowered: scales of the involucre lanceolate, mostly acuminate or acute, and with broal and thin scarious margins, the outer successively shorter: rays 7 to 40 , deep golden yellow : pappus of 5 (or sometimes 6 to 8) bristles.

Dry plains, southem part of the State, chiefly known from San Dingo Co., Nutlall, Parry, dec. Leaves an inch or less in length, the upper reduced to small sulualate bracts on the terminal

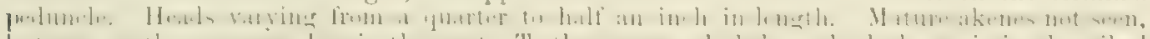

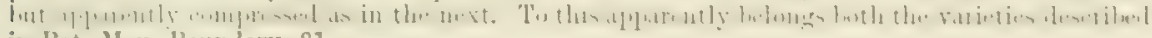
in Bot. Slex. Boundary, 81.

2. P. exilis, Gray, 1. c. Erect or with ascending branches, 3 to 8 inches high: scales of the involucre oblong, obtuse, but commonly mueronate, all of nearly equal length and with narrow searious maryins: heads in tho larger forms many-flowered and with 10 to 14.sulphur-colored or sometimes white rays: pappus of 5 equal or somewhat unequal bristles, or occasionally with some or all the bristles obsolete.

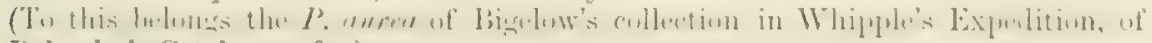
Bolander's Catalogue, \&c.)

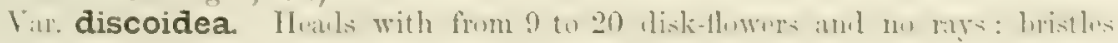
of the p:tppus present.

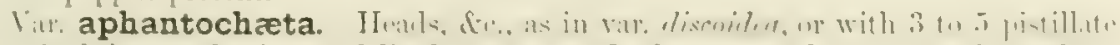
marginal Howers destitute of lignlo: pappus obsoleto or mearly so. - Aphonechedu exilis, Gray, 1. c. 99, t. 11.

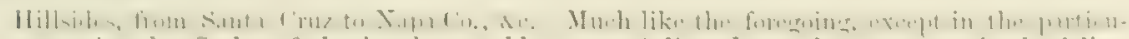
las mentioued. Seales of the involueve schlom over 2 lines long, nbout 16 or 18 in the fullerflowered heads, neeupying two muks of salout equal length, redned to 7 or 10 sud sommetines almost to a singlo raik in the fower-flowered aud depauperate states. Mature akenes that amd 
obovate, or some of them perhaps rather triangular, obscurely few-nerved, hairy. Forms without pappus, or with more or less reduced bristles, grow mingled with the normal state. 'The rayless variety has been collected at Auburn, Russian River, San Lorenzo Valley, \&c., and a very depauperate state about San Francisco. But the state with ray-corollas reduced to a tube, on which Aphantochata was founded, has as yet been detected only in $7 r$. J. M. Bigclow's specimens, from Napa Valley. Near Vallejo a form was collected by Rcv. E. L. Greene with well-developed rays pure white, except a pale yellow base.

\section{MONOPTILON, Torr. \& Gray.}

Head many-flowered, heterogamous; the rays numerous in a single series, fertile. Involucre of numerous narrow equal thin scales, almost in a single rank. Receptacle barely convex, naked. Corollas with rather hairy tube; the white or purple ligules oblong-obovate. Branches of the style tipped with a short obtuse appendage. Akenes oblong-obovate, compressed, one-nerved on each margin, or in the ray with a lateral nerve also. Pappus double; the onter a minute almost entire crown; the inner a deciduous bristle which nearly equals the disk-corolla, scabrous below and plumose for some distance from the summit downward. - Jour. Bost. Nat. Hist. Soc. v. 106, t. 13. Only one species:-

1. M. bellidiforme, Torr. \& Gray, 1. c. A delicate Daisy-like little annual, spreading on the ground, an inch or two high, villous-pubescent: leaves alternate, narrowly spatulate, entire : heads scattered, hardly peduncled, barely half an inch in diameter, including the white and purplish-tipped or pink-purple rays: diskflowers yellow.

On the Mohave desert or between California and the southwestern part of Utah, where a single specinen was collected by Fremont. Recently rediscovered in the latter region by Parry.

\section{EREMIASTRUM, Gray.}

Head many-flowered, heterogamons; the white rays numerous in a single series, fertile. Involucre campanulate, of nearly equal narrow scales, the outermost nearly foliaceous. Receptacle flattish, naked. Ligules oblong, entire. Branches of the style tipped with a lanceolate appendage. Akenes obovate-oblong, flat, one-nerved on each margin. Pappus of two sorts, i. e. the outer of 8 or 10 thin laciniately dissected seales, each apparently composed of several united bristles; the inner af about as many stout bristles or awns, and some smaller ones intervening. - Gray, Pl. Thurb. (Mem. Am. Acad. v.) 320. — A single species :- -

1. E. bellioides, Gray, 1. c, - A low, Daisy-like, hirsute or hispid annual, 1 to 4 inches high, and sending off procumbent branches; resembling Monoptilon but larger: leaves alternate, narrowly spatulate, entire, disposed to be crowded under the terminal solitary heads, and passing into scales of the involucre : head (including the expanded white rays) about two thirds of an inch in diameter, handsome; the disk yellow.

Dry plains on the Colorado and Mohave Rivers, Thurber, Schott, Newberry, Cooper, \&c. Also Southern Utah, Parry.

\section{LESSINGIA, Cham.}

Head 5-25-flowered; the flowers all perfect, with limb of the corolla regularly or sometimes obliquely parted down to the slender tube into 5 linear lobes, or the marginal ones with the enlarged limb palmately parted into a kind of ray, in these the stamens often abortive. Involnere campanulate or turbinate; its scales imbricated, appressed, and mostly with herbaceous often spreading tips. Receptacle flat, 
alveolate. Anthers included, tipped with a setaceous-subulate appendage. Branches of the style tipped with a very short and obtuse or truncate appendage which is thickly covered with hispid bristles in a tuft, and often with a central cusp, or else with a longer subulate and less strongly hispid appendage. Akenes all fertile, silky-villous, turbinate or cuneiform, more or less compressed. Pappus simple, mostly shorter than the corolla (especially in the marginal flowers), of numerous unequal rigid scabrous bristles, usually turning reddish-brown. - Annual or biennial (probably never truly perennial) herbs, all Cilifornian, with slender branches. clothed (at least when young) with theculent more or less deciduous wool. Leaves alternate, thickish, thuse of the lranches sessile. Heals rather small. Flowers in the original species yellow (sometimes turning purple in age), in most if not all the others blue-purple or white. (Nerves of the corulla-luhes deeply intrunarginal, the astivation induplicate up to the nerve.) - Cham. in Linnæa, iv. 203; Gray in Benth. Pl. Hartw. 315, in Proc. Am. Acad. vii. 351, \& viii. 634.

\section{\$1. Limb of the corolla more or less obliguely or palmately 5-parted, at least in the marginal flowers: branches of the style very obtuse and with a brush-like tuft of bristles, in which the minute setiform appendage (when there is any) is nererly hidden.}

1. L. Germanorum, Cham. Low, much branched, spreading on the grouml, at first whitish-tomentose, soon greener : lower leaves spatulate and pinnatifid; the upper oblong or limear and sparingly incised or toothed, or on the branchlets small and hract-like, and occisionally granulose-glamlular, as are the spreading sreen tips of the involucre: heads terminating slender divergent branchlets, 15-25-flowered: corollas yellow, the warginal ones conspicuously enlarged, palnate and forming a kind of ray, their stamens sometimes abortive. - Torr. But. Wilkes Exp. 336, t. 7 , (style wrongly delineated.)

Hillsides and open grounds, rather abundant from San Diego Co. to San Francisco. Head with flowers expanded about half an inch in diameter, the larger and palmate marginal corollas forming a Centaurea-like ray.

2. L. ramulosa, Gray. Frect and diffisely paniculate-linucherl, a span to a foot or two in height, white-woolly, becoming naked and usually glandular with age: cauline leaves oblong or lanceolate, thickish, entire or serrulate; those of the branches small, ovate or oblong, closely sessile by a cordate partly clasping base,

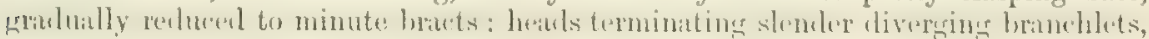
10-20-flowered: scales of the involucre acute and the greenish tips appressed:

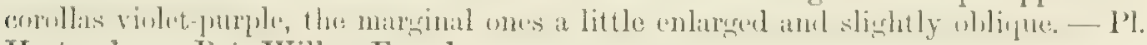
Hartw. 1. c. ; Bot. Wilkes Exp. 1. c.

Plnins, \&ce, from near San Francisco to Mendocino Co. Heads rather smaller than of the preceling. A slenthr und diffuse form, with smaller heads (var. tonuis), occurs from Montercy? (Douglis) to Peru Creek, at 5, 100 feet, Rothrock.

3. L. nana, Cring, 1. c. J)warf and dipresserl, I to 3 inches high, wery woully :

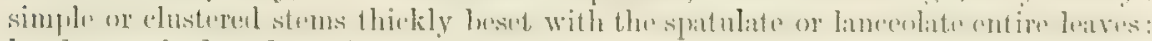
heads terminal and axillary, closely sessile, 10-12-flowered: scales of tho involucre linear-lanceolate, chartnceous and with scarious margins; the innermost conspienonsly acuminate, almost cartilaginons when dry, equalling the clisk: corollas

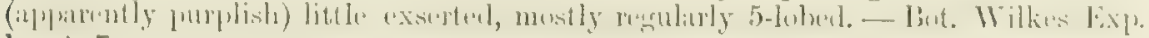
1. c. t. 7 .

On the Sacramento, Dr. Pickering, Rev, Mr. Filch. Fnot-hills of the sonthern Sierra Nevaln,

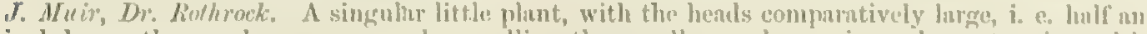
inch long; the puple pappus nealy epualling the coullas, and conspicuously contrasting with the white wook. It is poorly figured in the work reforved to. 


\section{\$2. Limb of the corolla regularly 5-parted: branches of the style tipped with a conspicuous slender subulate and less hispid appendage.}

4. I. virgata, Gray, 1. c. Erect, 1 or 2 feet high, with virgate branches, densely floccose-woolly, becoming naked with age, but not glandular : cauline leaves partly clasping, entire, oblong, or the lowest spatulate; those of the branches very short, appressed, concave, carinately one-nerved, somewhat sagittate, about the length of the $5-7$-flowered heads, which are solitary and sessile in their axils, so as to form a narrow interrupted bracteate spike: involucre cylindraceous, of rather few and blunt appressed scales: pappus much shorter than the tube of the (probably - pale purple) corolla.

Northern part of California, Dr. Pickering, Prof. Newberry. Heads about 4 lines long.

5. L. leptoclada, Gray. Finely white-woolly: the erect slender stem and filiform branches soon glabrous: lower cauline leaves spatulate and sparingly toothed; the upper lanceolate or linear and entire, closely sessile by a sagittate adnate base; the uppermost diminished into remote subulate bracts: heads terminating the very slender and mostly naked paniculate branches, 5 - 20-flowered : involucre turbinate, especially when many-flowered; its scales many-ranked and the outer successively shorter, all appressed and with acute greenish tips: corollas purple or sometimes white, the pappus equalling their tube. - Proc. Am. Acad. vii. 351.

Gravelly or sandy soil, near San Francisco (Crystal Springs, \&c.), and throughout the foot-hills and mountains in Mariposa Co., flowering July and Angust. Varies from 3 or 4 inches to a foot or two in height, and exceedingly in the number of flowers in the head, from 18 or 20 in the var. TYPICA, Gray, 1. e., to only five in the var. MrCRocephaLA, in which the inflorescence is most depauperate, while the var. TENUIS is a reduced forma, ouly 3 to 8 inches high. All are evidently states of one species, — to which seemingly belongs a very branched small form collected by Dr. Horn in Owens Valley.

\section{HETEROTHECA, Cass.}

Head many-flowered, heterogamous; the rays numerous and fertile. Involucre hemispherical, of numerous narrow imbricated scales. Receptacle nearly flat, alveolate. Ligules narrow. Branches of the style tipped with a hispid appendage. Akenes compressed; those of the ray triangular, very obtuse at summit, thickened and destitute of pappus; those of the disk thinner and flatter, silky-pubescent, with a copious pappus of rusty or reddish capillary bristles nearly equalling the diskcorollas, and an outer set of very short chaffy bristles. - Perennial or biennial hirsute or scabrous herbs, with alternate and mostly dentate leaves, and middle-sized heads of yellow flowers terminating the branches.

1. H. grandiflora, Nutt. A span to a foot high: the leaves as well as the stem hirsute with long and rather soft spreading hairs; lower ones oval, sparingly toothed, contracted into a slender petiole; upper ones small and narrow: heads mostly solitary: involucre glandular but not hairy : appendages of the style short and obtuse: short outer pappus copious.

Near the coast, on sandy plains, from Monterey to San Diego. Heads not so large as those of the Mexican $H$. inuloides. Akenes of the ray when young minutely pubescent, but becoming glabrous.

2. H. floribunda, Benth. Stem 2 feet or more in height, very leafy to the top, hispid, also minutely glandular: leaves mostly with a fine and appressed pubescence; the lower ones ovate and with petiole auricled at base; upper oblong and closely sessile: heads numerous, corymbed or panicled, small : involucre glandular: appendages of the style acute: short outer pappus copious. - Bot. Voy. Sulph. 24.

Near the coast, from San Pedro sonthward, Einds, Coutter, Parry. Heads less than half an inch long: rays small. 


\section{CHRYSOPSIS, Nutt.}

Tleal many-flowerel, heterentmous, with numerous fertile rays, or in two species

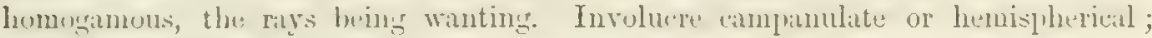
the sules imbricuterl, narmw, acute, mostly with somewhat scarious mar ins, destitute of herbaccous tips. Receptacle flat, foveolate, or alveolate-toothed. Appenlinges of the style-branches linear or subulate and hisjid. Akenes oblenc-linear or

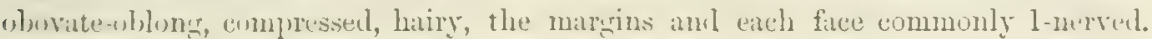
Pappus alike in disk and ray, double; the interior of copious rather rusty scabrous

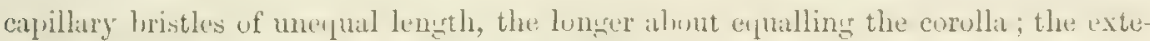
rior a set of very short chaffy bristles or narrow little seales (slender and inconspicuens in \$2). - Low herls (the Califurnim species perennial), with stems lat her thickly leset with alternate sessile leaves, and terminated by solitary or corymbuse (middle-sized) heads of yellow flowers. - Torr. \& Gray, Fl. ii. 252.

\section{\$1. Heals with rays: erterinr mimus frident and more or less chafjy: herbaye hir- sute or villous. - CHRTSOPSIS proper.}

1. C. sessiliflora, Nutt. Hirsute, varring from hispiul to soft-villous : stems in

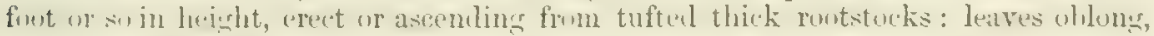
or the lower siatulate, mostly entire: clisk-corollats luset externally near the summit with some seattered very slender hairs: outer pappus squamellate. - The following apparently all of one variable species. Nuttall's original, from Santa Barbara, \&c. : not canescent, somewhat hispid and glandular: stem and branches leafy up to the head, which is as it were involucrate by some leafy bracts: scales of the involucre

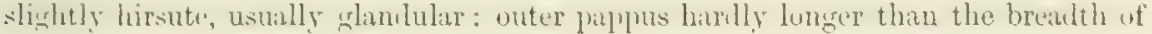
the ovary. (Involuere half an inch long.) - Nutt. in Trans. Am. Phil, Soc. vii. 317.

Var. Bolanderi, Gray. Less glandular and more villous; the obtuser leaves densely so, sometimes canescently silky: involucre mostly leafy-bracted and wore pubescent : the conspicuous squamellate outer pappus longer. - C. Bolanderi, Gray, Proc. Am. Acat. vi. 543. - Both this and the first pass into

Var. echioides, Gray. Stem and branches more slender and less leafy, the heads only half as large and not leafy-bracted: outer pappus as in the last or less conspicuous. - C. echinides, Benth. Bot. Sulph. 25, \& Pl. Hartw. 316.

Sunta Barbura and vicinity, Nullall, Conper; only their scanty specimens of the original form yet seen. The var. Bolanderi, San Francisco to Noyo on the coast, Bolender, Kellong. Var. rchinides, Santa Cruz to San Diego, Hinds, Couller, Nexberry, Harturcy, Bolander, \&c. - C. Bolauderi does not belong to the Achyrace section, which is well marked by its scunty inner and truly chalfy onter pappus. The present species is in some forms hard to distinguish from

C. vituosa, Nutt., an equally polymorphous species, extending from the eastern side of the

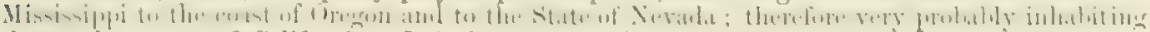
the northern part of Culifornia. It is destitute of the seattered long hairs near the tip of the disk-corolla, and tho involucro is not glandular, hut commonly minutely canescent.

\section{\$2. Heads rayless: exterior pappus setulose, inconspicuous or obscure. - Awsodis,} Gray. (Ammodia, Nutt.)

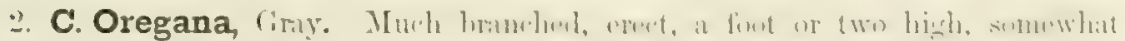
hirsutely pubescent and rather viscid: leaveg oblong or lanceolate, entire, with at prominent midrib: heads paniculate: involnere almost glabrous, composed of 3 or 4 ranks of successively longer thin and acuminate scales, only their midrib green, the innermost equalling the pappus: corollas slemler: akemes narrow: exterior pappus indistinct. - Gray, Proc. Am. Acaed. vi. 543. Ammorlia Oregena, Nutt. 1. c.; Torr. Thot. Wilkes Exp. t. 9.

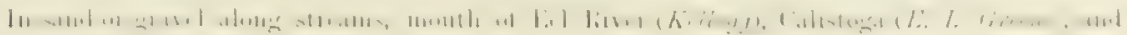

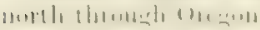


3. C. Breweri, Gray, 1. c. More minutely and sparingly pubescent and also viscid glandular, a foot or two high, with scattered and slender branches, which are mostly terminated by single pedunculate heads : leaves oblong-lanceolate, thin, entire, 3 -ribbed from the closely sessile broad base: scales of the involucre of firmer texture, lanceolate, rather few and in only about two ranks, the longer little exceeding the obovate and that akenes: corollas funnelform : exterior pappus of numerous very fine and short bristles.

Sierra Nevada, in or near forests, from Mariposa Co. to Sierra Co. at the altitude of from 4,000 to 11,000 feet, Brewer, Torrey, Greene, \&c. Heads half an inch long, fewer than in the preceding : pappus soft, merely tawny.

\section{APLOPAPPUS, Cass.}

Heads solitary, terminating the branches, or sometimes corymbosely or spicately clustered, many-flowered, rarely several-flowered, heterogamous and with fertile rays, or very rarely homogamous, the rays being wanting. Involucre imbricated, the scales with or sometimes without herbaceous or foliaceous tips. Receptacle flat or flattish, foveolate or alveolate-dentate. Appendages of the style-branches triangular-lanceolate, or in the N. American species more commonly elongated-subulate. Akenes varying from turbinate to linear, terete, angled, or more or less compressed. Pappus simple, of copious and unequal rigid capillary (scabrous or almost barbellate) bristles. - Herbs or low under-shrubby plants, of various aspect and foliage; with yellow flowers, and pappus varying from tawny to reddish, very rarely bright white. Leaves alternate, rigid. - Gray, Proc. Am. Acad. viii. 634. Aplopappus, Pyrrocoma (Hook.), Stenotus (Nutt.), Macronema (Nutt.), Prionopsis (Nutt.), Isopappre, (Torr. \& Gray), \& Ericameria (Nutt.), Torr. \& Gray, Fl. Haplopappas, Ericameria (and Macronema under Chrysopsis), Benth. \& Hook. Gen. ii. 253.

A pretty large American genus, which, like its analogue, Aster, has to take in a great diversity of forras, mainly andine and of the Rocky-Mountain region and adjacent dry plains, but so scantily represented in California that the species are more conveniently exhibited under an artificial key than in their natural subgenera or sections :-

Rays none : involucre elongated obconical, its coriaceous scales manyranked, all with short and abrupt squarrose herbaceous tips,

Rays none : involucre of a few thin and loose and 3 or 4 outer nearly foliaceous scales : style appendages long and exserted,

1. A. SQUARROSUS.

Rays 10 to 20 or more.

Akenes silky-villous : pappus white : head solitary, peduncled.

Shrub 2 to 4 feet high : leaves narrow linear,

Tufted plant 3 or 4 inches high : leaves spatulate,

Akenes silky-pubescent : pappus whitish : heads several,

Akenes glabrous or nearly so at maturity.

Herbs : paprus tawny or reddish.

Leaves laciniate: heads 1 to 3 , peduncled,

Leaves serrate or entire: heads spicate or clustered,

Shrub : pappus white: leaves filiform,

Rinys 1 to 9 .

Herbaceous, with leaves serrate and oblong,

Shrubby or suffruticose, with leaves entire, and

Cuneiform-dilated,

Filiform or shorter and very crowded: akenes glabrous,

Filiform-linear with tapering base: involucral scales naked: akenes pubescent,

Narrowly or spatulate-linear : involucre narrow, with outer scales leafy-tipped, and the inner ones ciliate,

Spatulate-lanceolate or linear : involucre broad, with outer scales loose and leafy, and the inner ones naked,

13. A. Macronema.

2. A. LINEARIFOLIUS.

3. A. ACAULIS.

5. A. paniculatus, var.

4. A. APARGIOIDES.

5. A. PANICULATUS.

8. A. PINIFOLIUS.

6. A. WhitNey.

7. A. cuneatus.

9. A. ERTCOIDES

10. A. RESTNOSUS.

11. A. BLOOMERI.

12. A. suffruticosus. 
1. A. squarrosus, Hork. \& Arn. Sihruhlyr, minutely puhescent and smmewhat glutinous: branches very leafy: leaves rigid, oblong-obovate, obtuse, thickly serrate with rigid pointed teeth, closely sessile or partly clasping, the midrib prouninent and the reins indistinct: heads several, spicate or racemose-clustered, elonsated-obconical : the linear coriaceous scales of the involucre regularly imbricated in many series, all with short and obtuse flimdular herbacteus tipe, which are usually squarrose-spreading: rays none: disk-flowers numerous: appendages of the style ovati-lanceulate: akenes glabrous: pappus mather scanty, ripricl. - Pyriocume yoin. delioides, DC.

Probably near Mnnterey; collected only by Douglas. Leaves an inch long. Heads three quarters of an inch : outer scales of the involucre very short; inner successively longer; inuermost equalling the disk.

2. A. linearifolius, I)C. Shruh one to four fuet high, much hrunchen, nearly glabrous, glutinous from a resinous exudation; the branches slender, teminated by a solitary pedunculate large and showy head: leaves much crowded, uarrowly linear, mostly tapering to each end, fully an inch long, entire, more or less punctate: scales of the hemispherical involucre about in two series, all nearly equalling the lisk, whlong-lanceulate, acute or acuminate, thin, with scariuns natrins and no herbaceous tip : rays 12 to 14 , oblong-lanceolate: disk-flowers numerous: akenes white silky-villous; pappus bright white, rather soft and deciduous. - Stenotus linearifolius, Torr. \& Gray, Fl. ii. 238.

Rocks and dry ridges, Monte Diablo and the Contra Costa range, and in the Sierra Nevada (Mono Pass, \&c.), extending to S. Utah. - Head almost an inch in diumeter; the bright yellow rays nearly an inch long. Appendages of the style rather broad.

3. A. acaulis, Gray. Depressed : suffruticose caudex cespitose, bearing rosuic late tufts of leaves: the flowering shoots simple and scape-like, or leafy only below, terminated by a solitary head: leaves oblanceolate or narrowly spatulate, entire, mucronate-acute, rigid, about 3-nerved, veiny, pale, scabrous with a very minute harsh pubescence: scales of the hemispherical involucre rather few in 2 or 3 series, ovate, acute, chartaceous with more or less scarious edges and a carinate midrib: mys 9 to 12 : disk-flowers rather numerous : akenes silky-pubescent: pappus white, rigid and rather scanty. - Proc. Am. Acad. vii. 353. Stenotus acaulis, Nutt. 1. c. Aplopappus Nevadensis, Kellogg, Proc. Calif. Acad. iii. 9, a large form.

High Sierra Nevaula, at Summit (Bolcunder, Kellogg, \&ce), and in similar stations enst to the Rocky Mountuins. Flowering stems or scapes 2 to $t$ inches high. Heads a third of an inch long : rays half an inch. Lassen's P'eak, Lommon.

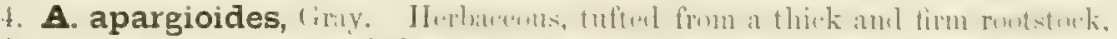

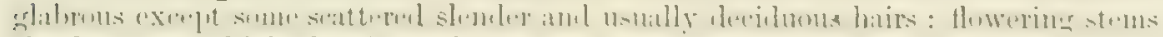
slender, a span high, bearing solitary or 2 to 3 peduncled heads: leaves lanceolate or linear in outliue, laciniately pinnatifid or spinulosely toothed, one-nerved and

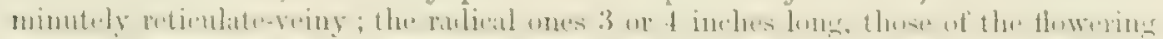
stems few and smaller: scales of the somewhat hemispherical involucre closely

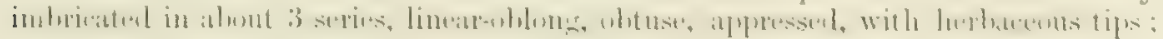
the outer successively shorter: rays 20 to 24, oblong: disk-flowers numerons:

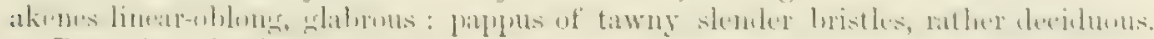
- Proc. Am. Acad. vii. 354.

Siorna Nevada, at Soda Surings, Tuolumno River, at 7,000 to 9,000 feet, Bolander. Heads half an inch long, exchusive of the ray.

5. A. paniculatus, Gray, 1. c. Iterbaceous, glabrons: stems norly simplo from a thickish rootstuck, rigid and mostly virgate, a span to a foot or more in height: leaves thick and coriacents, lanceulate, acute; the rulical ones elongated, sometimes spinulose-serrato ; the caulino snall, clusely sessile, entire, ciliolato: heads ratlere numeruns, single or 2 or 3 tugether in the axils of brat-like leares, forming a lense virgate spike or raceme, or sometimes perlunculate and panicled: scales of the 
hemispherical involucre rigid, linear-spatulate or oblong-lanceolate, with mostly obtuse but mucronate herbaceous tips, appressed, in 3 or 4 series, the outermost commonly short: rays 8 to 16 , narrow: disk-flowers numerous: ovaries more or less pubescent: akenes rarely pubescent: pappus tawny or reddish, rather rigid. Homopappres paniculatus, Nutt. 1. c. Pyrrocoma paniculata, Torr. \& Gray, 1. c.

Var. virgatus, Gray, l. c. Slender: heads much smaller but broadish, racemose or spicate.

Var. stenocephalus, Gray. Slender: larger stems branching and bearing paniculate heads: involucre narrow-oblong or cylindraceous, 4 or 5 lines in leugth, rather few-flowered: rays 7 to 10 : immature akenes silky-pubescent: pappus whitish.

Eastern slopes of the Sierra Nevada; Carson, Anderson; a virgate form, to which also belongs Hall's No. 256 of Oregon coll. (referred to $A$. Znnceolatrus), only that lias very silky-pubescent akenes. Bridgeport, Mono Co., Bolander; the var. virgahus. Sierra Co., Lommon; the var. stenocephalus. - A. tenuicaulis, Eaton, Bot. King., is another form, similar to the last variety, but soft-hairy when young, with broader involucre of less rigid scales: it has the same silkypubescent ovaries.

6. A. Whitneyi, Gray, 1. c. Herbaceous, slightly ronghish-pubescent and glutinous: stems numerous and one or two feet high from a thickish rootstock, equably leafy to the summit: cauline leaves oblong (an inch long), thin-coriaceous, sharply dentate with rigid teeth, partly clasping, minutely reticulate-veiny : heads paniculate-clustered and mostly leafy-bracteate : involucre oblong-campanulate 20-25flowered; its scales narrowly linear-lanceolate, acute, almost glabrous, between chartaceons and coriaceous, mostly destitute of herbaceons tips, imbrieated in 3 or 4 series, appressed, the outer successively shorter : rays 6 to 8 , small, little surpassing the disk: akenes glabrous, oblong-linear, striate : pappus copious, tawny or reddish, fine but rigid.

Open woods of the Sierra Nevada, Mono trail and Sonora Pass, alt. 9,000 feet, Bolander. Heads half an inch long. Disk-corollas narrow and merely 5 -toothed as in Pyrroenma; but involucral scales narrow and thin. Style-appendages subulate-filiform. A good link between the sections Pyrrocoma and Ericameria.

7. A. cuneatus, Gray. Shrub low and intricately branched, glabrous, at length glutinous with resinous exudation: branchlets very leafy: leaves small (merely half an inch long), thick, cuneate or obovate-spatulate with a narrowed base, and a broad truncate retuse or emarginate apex, conspicuously resinous-punctate, onenerved, veinless, entire : heads corymbose at the summit of the branches, about 24-flowered: involucre turbinate, shorter than the disk; its scales regularly imbricated in several series, lanceolate, coriaceo-chartaceous, with somewhat scarious margins and tip, carinate one-nerved ; the outer successively shorter: rays about 3 , not exceeding the disk: style-appendages lanceolate-subulate, about the length of the stigmatic portion: akenes linear-oblong, compressed, sparsely hirsute : pappus rather soft, scarcely tawny. - Proc. Am. Acad. viii. 635.

Bear Valley, Placer Co. in the Sierra Nevada, alt. 4,500 feet, Sept., Kellogg and Botander. Plant exhaling a creasotic balsamic odor, apparently a low and matted bush or undershrub. Head of the Ericameria section, somewhat larger and thicker than those of A. ericoides, the involucral scales more numerous and not ciliate; the outer ones decreasing into very short and loose squarrose bracts on the peduncle, none of them with foliaceous tips. In one (abnormal) head all the flowers were furnished with five or fewer linear or spatulate external accessory divisions, borne on the middle of the tube.

8. A. pinifolius, Gray. Shrub 2 to 4 feet high, erect, with fastigiate branches excessively leafy, slightly pubescent when young, glabrate, hardly glutinous: leaves crowded, filiform-linear or acerose, cuspidate-acute, an inch long, somewhat punctate, the fascicled ones when present very much shorter: heads solitary and sessile at the summit of the branchlets, mostly exceeded by the closely involucrate uppermost leaves, 25 -3C-flowered : involucre campanulate; its scales appressed, oblong or broadly lanceolate, acuminate, coriaceous, with somewhat scarious minutely villous-ciliate 
margins: rays 20 or more, short anil narrow: style-appendages sululiate-filifurm : akenes linear, nearly glabrous: pappus white.-Proc. An. Acad. viii. 636.

Near Los Angeles, in a dry river-bed, Bolander, 1873. Head 4 lines high. Rays 2 or 3 lines long. In some of the few specimens seen there are chaffy scales among the flowers and a transformation of some of the disk-corollas to rays, which is doubtless abnormal. The species is peculias and anomalous, but belongs to the same group as the next.

9. A. ericoides, Hook. \& Arn. Shrub a foot or two high, much branched, erect or clecumbent, glabrous or cinereous-pubescent, more or less glutinous, excessively leafy: leaves crowded and fascicled, nearly terete, the cauline filiform and half an inch or less in length, the fascicled ones only half as long and blunt: heads corymbose and panicled, 7-10-flowered: involucre turbinate, shorter than the lisk; its scales chartaceous, irabricated in few series, linear-oblong, obtuse, with linely ciliate margias, the outermost passing into short and loose subulate bracts: rays 3 or 4, short: style-appendages filiform-subulate: akenes glabrous: pappus soft, tawny. - Ericameria microphylla, Nutt., \&c.

Dry hills, Santa Barbara to San Francisco near the coast : common. A remarkable Heath-like shrub. Heads narrow, hardly half an inch long.

10. A. resinosus, Gray. Shrubby, a span or so in height, very much branched, glabrous, becoming very glutinous, leafy : leaves filiform-linear, about an inch long, acute, tapering to the base, mostly with some very short ones,fascicled in their axils: heads loosely corymbose, smaller than those of the preceding species, but with rather more numerous flowers both of ray and disk, and the scales of the involucre not ciliate: akenes pubescent. - Ericameria resinosa, Nutt. I. c.

Not yet found in California, but may be expected on the frontiers of Oregon. Apparently colloeted as yet only by Nuttall, in the Blue Mountains of Oregon, along with $A$. narus.

11. A. Bloomeri, Gray. Shrub a foot or two high, with numerous slender virgate branches, glabrous, little if at all glutinous, leafy to the top : leaves narrowly linear with tapering base, or spatulate-linear, mucronate, scarcely punctate, an inch or two long: heads narrowly panicled or corymbed, leafy-bracted, 10-25-Alowered: scales of the oblong cylindraceous involucre imbricated in 3 or 4 series, chartaceocorikceous with a greenish midrib and scarious margins; the inner linear-oblong, thinner, and villose-ciliate, obtuse, a little shorter than the disk; the outer shorter anil abruptly tipped with a subulate foliaceous appendage: ratys 2 to 4 or solitiry, oblong, conspicuously exserted: style-appenulages subulate-filiform and much exserted: akenes linear, finely pubescent, glabrate: pappus whitish or ferruginous, Proc. Am. Acad. vi. 511, vii. 35t (var. angustatus), viii. 636. A. resinosus, Gray in liot. Wilkes Exp. t. 10, not of Nutt.

Dry rillges and sterile plaius; head wuters of the Sacramento (Dr. Pickering); Mount Shastn at 6,000 feet (Brezocr) ; Sierra Nevalda enst of the Yosemite, at 2,700 feet ; Siena Yalley (Lemmon); to Kern Co. (Rothrock); and in W. Nevada, Bloomer, Anderson, Bolander. Heads from two thirds to three quarters of an inch in length, with bright yellow ligule conspicuous (half an inch long), and at least some of the outer involucral seales leafy-tipped in the manner of Bigelovia Parryi and Hoveardiz. The figuro in the Botany of the Wilkes Expedition does not represent these, although elearly made from a slender specimen of this species. Tho leaves vary from ihmost filiform to a line and a half in width.

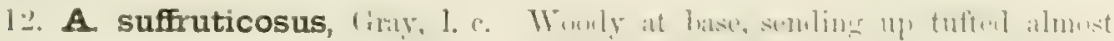
herbaceous branches a span or more in height, minutely glandular-pubescent and somewhat viscid throughout, leafy to the top, the corymbose or fastigiate branches mustly terminated with single heals: leaves linear with narrowed base, or spatulate, mucronate-acuminate, not rigid : involucre hemispherical or campanulate; its scales in fow series and almost equal in length, lanceolate, acute, thin, slightly glandular, some of the ontermost foliaceous-tipped or passing into foliaceous hracts: mys 3 to 9 , exserthel (or rarely none): disk-flowers 20 to 30 : style-appendages filiform: akenes ohlong-linear, compressed, pubescent: pappus rather soft, whitish, at length fermurinous. - Mecroneme sufireticosa, Nutt. l. c. 
High Sierra Nevada, at Mono Pass, Pyramid Peak, Summit, \&c., and throngh Nevada. Head nearly two thirds of an inch long.

13. A. Macronema, Gray, 1. c. Woody at base, sending up somewhat simple white-woolly branches, a span high: leaves oblong-linear or oblanceolate, viscidly glandular-puberulent, not rigid: heads terminal and solitary or somewhat clustered, about 25-flowered: involucre broadly campanulate, shorter than the disk; its inner scales thin, lanceolate or linear; the outer of equal length, more or less foliaceous or passing into leaves: rays none: style-appendages filiform and much exserted: akenes linear, 5-nerved, somewhat pubescent: pappus, \&c., as in the preceding. Macronema discoidea, Nutt. 1. c.

On rocks in the. Sierra Nevada; Mono Pass, at 10,000 feet (Botander); Mount Stanford, at 8,000 feet (Lennmon); thence east to Colorado or Wyoming.

A. ARENarius, Benth., known only from Cape San Lucas, at the southern end of Lower California, is quite out of our district.

A. Spinvlosus, DC., with pimnately cleft leaves, the commonest species east of the Rocky Mountains, occurs in Coulter's Californian collection ; but a part of it was made between California and Mexico, and this species was in all probability picked up in Arizona.

A. NANUS, Eaton, from Nevada, a broader-lcavel form of Ericameria nana, Nutt. (which, as

$\because \quad$ the latter states, is near his E. resinosa), in its broader forms approaches $A$. suffruticosus, and may occur in the northeastern part of the State.

\section{BIGELOVIA, DC.}

Heads corymbose or cymose-clustered, rarely paniculate, 5-30-flowered, homogamous, the flowers being all perfect and with tubular corollas. Involucre imbricated; the scales dry, charticeous or coriaceous, chiefly destitute of foliaceous or herbaceous tips. Receptacle flat, foveolate or alveolate-dentate, rarely with a chafflike projection in the centre. Appendages of the style-branches varying from ovatelanceolate to subulate or filiform. Akenes narrow, terete or angular, slightly if at all compressed. Pappus simple, of copious unequal capillary bristles as in Aplopappus, or softer and more equal, tawny at maturity. - Herbs or undershrubs, with narrow alternate leaves, and mostly small heads of yellow flowers (usually autumnal); all American and chiefly of the United States. - Gray, Proc. Am. Acad. viii. 638. Linosyris, Torr. \& Gray, \&c. Chrysothamnus, (Nutt.) Benth. \& Hook. Gen. ii. 255, changed in appendix to Bigelovia.

It appears that the genuine species of Linosyris, of the Old World, occasionally develop white or purple rays, thereby showing that they belong to Galatella, a subgenus of Aster. These American plants are, on the other hand, closely related to Aplopapprus, from which some of thent (even of the Chrysothammus section, which is on the whole so well-marked) are only arbitrarily separated. Bigelovia and Chrysothamnus are strictly of the same genus, so that the former name must be adopted. The species are more numerous in the interior region than in California. Ours may be most readily made out by means of the following analytical key, which is mainly founded, however, upon the proper characters of the natural sections here represented.

Scales of the involucre not in conspicuous vertical ranks.

Style-appendages ovate or triangular-subulate, shorter than the stigmabearing portion.

Leaves spatulate or oblanceolate, toothed or lobed: heads half an inch long, 12-20-flowered,

Leaves filiform or nearly so, entire.*

Heads a quarter of an inch long, densely corymbed, 20 - 25-flowered : scales of involucre lanceolate, acute,

Heads fewer: seales of involucre oblong,

Style-appendages very long and slender: branches mostly white-woolly.

1. B. Menziesir.

Heads 20-30-flowered, broad, leafy-bracted (see above),

2. B. ARBORESCENS.

3. B. COOPERI.

* B. DIFFusa, Gray (Enicaneria diffusa, Benth. Bot. Sulph., and Solidago diffusn, Gray, also Linosyris Sonoriensis, Gray) belongs here. As it has been found only at the southern extremity of Lower Califorma and on the opposite side of the Gulf, it is not likely to come within our limits. 
Heads 7-11-flowered, narrow: scales all thin, gradually acuminate, Heads 5-flowered, narrow : scales abruptly slender-atcuminate,

Scales of the involuere carinate and obviously imbrieated in 5 or sometimes 4 vertical maks : style-appendages slender-subulate or filiform (less so in No. 10) : heads small, 5-flowered.

Involucre with abruptly much-acuminate seales,

Involucre with obtuse or hardly acute scales,

Having distinct abrupt green tips,

Destitute of green tips.

Leaves punctate, very narrow,

Leaves not punctate.

Branchlets and leaves more or less white-woolly, at least when young : heads $\frac{1}{2}$ inch long,

Branchlets and leaves glabrous or roughish-puberulent : heads less than $\frac{1}{2}$ inch long: style-appendages shorter,
4. B. Botaxorei.

5. B. HOWARDIL.

6. B. CERUMisosa.

7. B. TERETIFOLIA.

8. B. PANicULATA.

9. B. GRAVEOLENS.

10. B. Douglasit.

1. B. Menziesii, Gray, 1. c. Shrubby at base, a foot or two high, nearly glabrous, often a little glutinous : leaves spatulate or lanceolate, rigid, spimulose-serrate or pinatifid-toothed: heads in small clusters terminating leafy branches, nearly half an inch long, 12-20-flowered: scales of the campanulate involucre numerous and regularly imbricated, coriaceous, with obtuse or rounded abrupt green tips: style-appendages short and broad: akenes short-linear, silky-hirsute: pappus rather rigicl. - Pyrrocoma Menziesii, Hook. \& Arn. Aplopappus (Aplodiscus) Menziesii, Torr. \& Gray, Fl. ii. 242.

Southern part of the State, extending into Arizona and Utah, and along the coast from Sun Diego to Santa Barbara, and perhaps farther north. Variable in folinge, \&c. To this may possibly belong Linosyris denlatıs, Kellogg, Proc. Calif. Acad. ii. 16, from Cerros Island, Lower Califuruia.

2. B. arborescens, Gray, 1. c. Shrulby, with mumerous tuftel erect branches on a short tree-like stem, 3 to 9 feet high: leaves very numerous, 2 to 4 inehes long, very narrowly linear or soon by revolution of the margins becoming filiform, resinous-punctate, glutinous: heads numerous in crowded corymbs terminating paniculate branchlets, 20 - 25-flowered, barely 3 lines long: scales of the turbinate involucre numerous and regularly imbricated, lanceulate, acute, destitute of green tips: style-appendages lanceolate-subulate, littlo shorter than the stigma-bearing portion : akenes turbinate, minutely silky-pubescent. - Linosynis arborescens, Gray, in Bot. Mex. Butund.

Dry hills through the Const Range, Santr Cruz to Tamalpais. Except in the woorly trunk, this resembles a Solidngo of the Eiuthamia section; and, indeed, a specimen collected by Prof. Brever shows a decided tendency to form rays; so that it rany have to be transferted to that grenus. But the shrubby character and the unequal bristles of the pappus are more congruous with the present genus.

3. B. Cooperi, Gray, l. c. Shrully, apparently low : leaves (unly these of the

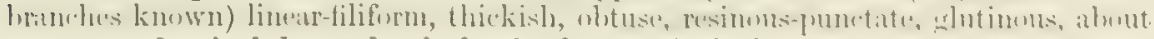
a quarter of an inch long: heads few in the terminal clusters, $6-7$-flowered, 3 lines

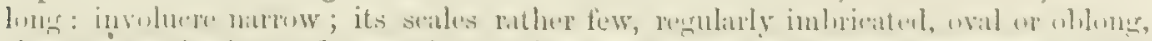

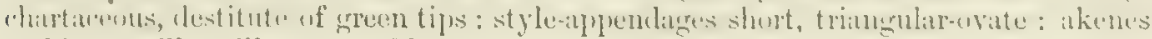
turbinate, silky-villous, 10-ribbed.

Eastern slope of Providenco Mountain, in the southenstern horlers of the State, Dr. J. G. Comper. Resombles $B$. ericoidss, which hns the 4-ranked involuero and filiform style-appendages of another section : also resembles $B$. diffisusa, fray, of $\mathrm{N}$. W. Mexico (mentioned in fnot-note on tho preceding pagu), which las moro slemer leaves with acute and recurved tip, blunter and greenish tips to the involucre, and deeply-cleft corolla.

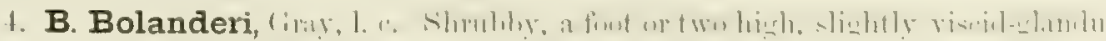
lar, except the bmenches, which aro conterl with a close matted whito wool: lenves spatulate-linear or oblancedate, about an inch long, not rigid, rather inclistinctly

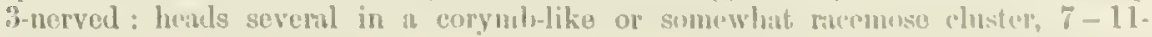
Huwered, nearly three fourths of an inch long: involuere narmo ; its stakles about 
10, all thin, lanceolate, gradually acuminate, and wholly destitute of green tips, except perhaps an outermost one passing into a bract: style-appendages much exserted, long and subulate-filiform: akenes linear, slender, silky-villous.

Sierra Nevada at Mono Pass, at 9 to 10,000 feet, Bolander. Much like Aplopappus Macronema (which was found near by, and might almost as well be of this genus); but the heads narrow'er, few-flowered, the outer scales of the involucre successively shorter and not foliaceous.

5. B. Howardii, Gray, l. c. Low, more or less shrubby, coated with some close white wool when young, almost naked when old : leaves rigid, 1-nerved, linear, 1 or 2 inches long, the upper forming bracts to the somewhat spicate heads or clusters: involucre narrow, only 5 -flowered; its scales 12 to 15 , regularly imbricated, broadly lanceolate, more or less cobwebby-woolly, particularly at the margins, abruptly and conspicuously acuminate, the outermost with a more or less foliaceous appendage, the inner with a slender cusp: style-appendages much exserted, long and subulate-filiform : akenes linear, silky-villous. —Linosyris Howardiz, Parry.

Var. Nevadensis, Gray, 1. c. More rigid, especially the leaves, which incline to be oblanceolate and indistinctly 3-nerved: involucre more cobwebby and sometimes glutinous, as well as more coriaceous, and with longer-tapering somewhat recurving tips.

Sierra Nevada, at Mono Pass, alt. 10,000 feet : a stunted form, Bolander. The var. Nevadensis at Ebbett's Pass, alt. 9,000 feet (Brever), and in N. W. Nevada, Bloomor, Anderson, Watson, \&c. The typical form chiefly in Colorado and N. E. New Mexico. Heads 8 or 9 lines long. This var. Nevcedensis, which is at least a very marked variety, inclines to have its involucral seales in 5 rather obvious vertical ranks, and so connects the preceding with the succeeding species.

6. B. ceruminosa, Gray, 1. c. Shrubby, fastigiately much branched, 2 or 3 feet high, minutely woolly-pubescent when young, becoming glabrate and usually balsamic-resinous with age : leaves filiform or narrowly linear with involute margins (an inch or less long); those of the flowering branches scattered, their tips often recurved or uncinate: heads in small and naked terminal clusters, barely 3 lines long, 5-flowered: involucre very narrow, resinous; the lanceolate carinate scales imbricated in 5 strict vertical ranks, yellowish, the keel extended into a long anit slender recurved tail-like acumination: limb of the corolla rather deeply 5-lobed, its lobes linear-lanceolate: ovary silky-pubescent : pappus rather scanty : style-appendages very slender. - Linosyris ceruminosa, Durand \& Hilgard, Pl. Heerm. and in Pacif. R. Rep. v. 9, t. 6.

Tejon Pass, Dr. Hcermann; who only las as yet collected it.

B. DEPREssa, Gray, 1. c., Nuttall's Chrysothamnus depressus, one of the three species with glabrous akenes as well as with involucral scales 5-ranked and taper-pointed, is said by Nuttall in Pl. Gambel. to have been collected "in the Sierna of Upper California." This must be wrong; for Dr. Gambel's own specimens are ticketed "Rocky Mountains," and were in all probability collected in the mountains of New Mexico, where alone others have met with this species.

7. B. teretifolia, Gray, 1. c. Shrubby, corymbosely very much branched, a foot or less in height, copiously balsamic-resinous, glabrous: leaves filiform; obtuse or somewhat thickened upwards, half an inch to an inch long, thickly resinouspunctate, minutely pruinose-hoary, but soon coated with transparent resinous exudation: heads almost half an inch long, numerous in somewhat spicate or racemose clusters, 5-flowered: involucre very narrow; its scales imbricated in 4 or 5 vertical ranks, carinate, all with small and abrupt thickish obtuse green tips, the inner linear-oblong, the outer successively shorter and passing into very short scale-like bracts : lobes of the corolla very short : akenes linear, silky-pubescent: style appendages long and filiform. - Linosyris teretifolia, Durand \& Hilgard, l. c. t. 7.

Common on the bare mountains around Tejon Valley, Dr. Hecrmann. "A small shrub, strongly varnished and smelling of fir-balsam, covering extensive tracts of land." Also collected, but past flowering, at Union Pass, Arizona, by Dr. E. Palmer. The small green tip of the involucral scales commonly bears a gland. 
8. B. paniculata, (amy, l. c. Shrublyy (l), ninutely pruinnse cinerents or flabrous: leaves (of the branches) linear-filiform, 3 to 5 lines long, and the uppermost very short and subulate, resinous-punctate, as also the slender brauchlets: heads barely half an inch long at maturity, loosely panicled, 5-flowered: scales of the short involucre only 10 to 12 , oblong, obtuse, thin-chartaceous and pale throughout, little carinate, the innermost hardly exceeding the full grown linear villous akenes: limb of the corolla rather deeply 5-lobed: style-appendages long and filiform. - Linosyris viscidiflora, var. paniculata, Gray in Bot. Hex. Bound. 80 .

California, Schott: the station unknown, but doubtless in the southern part, and probably in the interior. Imperfectly known, but seemingly a quite distinct species.

9. B. graveolens, (iray, l. c. Shruhly, 1 to 4 feet high, when young whitened more or less with a close white wool, at least on the branches, sometimes becoming green and glabrous with age: flowering branches virgate, leafy : leaves linear (one or two inches long, one or two lines wide), the broader ones 3-nerved, the narrower 1-nerved and at length often involute : heads half an inch long, mostly very numerous, in corymbose clusters, 5-flowered: involucre narrow; its scales imbricated in 5 vertical ranks, narrow-oblong or lanceolate, obtuse or hardly acute, moderately carinate, thinnish, destitute of greenish tips, imbricated in 5 vertical ranks : lobes of the corolla short: akenes linear, silky-pubescent: style-appendages subulatefiliform, considerably longrer than the stigmatic portion. - B. dracunculoides \& Missouriensis, DC. Prodr. v. 329. Chrysocoma graveolens \& nauseosa, Nutt. Gen. Chrysothamnus dracunculoides \& C. specioszes, Nutt. in Trans. Am. Phil. Soc. 13. ser. vii. 324. Linosyris graveolens \& L. albicaulis, Torr. \& Gray, Fl. ii. 234. - Has a wide range, and runs into several varieties, of which the following occur in California :-

Var. glabrata, Gray, 1. c., with little woolliness, and that deciduous, at least from the leaves and involucre, or the latter glabrous from the first.

Var. hololeuca, Gray, 1. c. Clothed with a dense close coat of white wool: scales of the involucre oblong-linear and very obtuse, only the innermost glabrous : corolla with very short lobes, its tube beset with a few long and delicate cobweblike hairs.

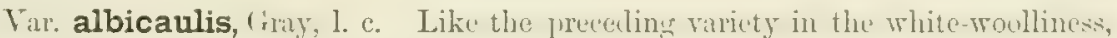
or the leaves (becoming naked in age) and the narrower and less obtuse scales of the involucre slightly or not at all woolly: corolla with rather long lobes (the length double the wilth), its tube beset with abundant long and cobwebby hairs. -Chrysothamnus speciosus, var. albicaulis, Nutt. 1. c. Linosyris albicculis, Torr. \& Gray, Fl. 1. c.

In alkuline soil, on the eastern slope of the Sierra Nevada, from Mono Lake to Sierra Valley; thence abundant through the interior to the borders of British Columbin and the plains east of the Roeky Mountains. The var. hololezca, Owens Valley, Dr. Horn. Var. albicullis, alove Donner Lake, at 10,000 feet, $E$. $L$. Greone, a rare form, apuarently confined to a narrow district in the interior, extending to the eastern part of Oregon and adjacent parts of Iclaho.

10. B. Douglasii, Gray, 1. c. Shrubby, from 6 inches to 6 feet high, never

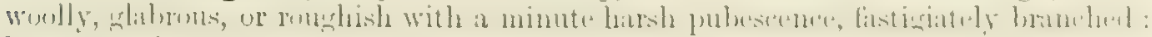
leaves varying from very narrowly to broally linear or lanceolate, rather rigid (an inch or two long), the broader ones 3-nerved: heads a quarter to a thind of an inch long, mostly numerous in a close corymb or cyme, 5-flowered: scales of the involucre oblong or oblong-linear, obtuse, rather firm, destitute of greenish tips, mather few in 4 or 5 vertical ruks: lobes of the corolla rather long, sprealing: akenes rather short, silky-villous: style-appendages narrowly subulate, usually only half the length of the stigmatic portion. - Linosyris viscidiflera, Torr. \& Gray, with the syn. Crinitaria viscidiflora, Hook. Fl. ii. 24, but the flowers not viscid, even the invo-

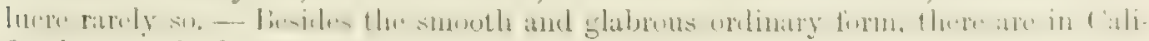
fornia or on its borders, - 
Var. serrulata, Gray, I, c. : the leaves minutely ciliate or as if serrulate with short and sharp rigid bristles. - $L$. serrulata, Torr.

Var. tortifolia, Gray, l. c. : nearly the same, but with the rather broad leaves remarkably twisted.

Var. puberula, Gray, 1. c. : chiefly a dwarf form, either minutely or more conspicuously and roughly puberulent.

Eastern part of the Sierra Nevada ; thence eastward to the Rocky Mountains, and northward to Washington Territory; abundant through the dry interior districts. Var. tortifolia, near Aurora (Brewer), on Mount Davidson, Nevada (Bloomer), and Sierra Valley (Lemmon).

\section{SOLIDAGO, Linn. GoLdenrod.}

Heads small, mostly in panicles or panicled racemose elusters, rarely in corymbs, heterogamous; the rays fertile. Involucre narrow, imbricated and the outer scales successively shorter, appressed, usually destitute of herbaceous tips. Receptacle small, alveolate or fimbrillate. Style-appendages lanceolate or triangular subulate. Akenes terete or angular, 5 - 12-ribbed. Pappus simple, of a single series of mostly equal and slender scabrous capillary bristles. - Perennial herbs, with virgate stems, alternate leaves, and yellow flowers, the pappus mostly dull white.

A large genus with headquarters in the Atlantic United States, only a few on the Pacifie side of the continent ; flowering in autumn.

\$1. Stem branching freely; the branches erect, leafy, and terminated by dense sometimes paniculate corymbs of clustered small heads: leaves linear: scales of the involucre narrow: rays inconspicuous. but numerous: akenes pubescent. Euthamia, Nutt.

1. S. occidentalis, Nutt. Glabrous throughout, 3 or 4 feet high, paniculately branched, slender: leaves linear, entire, obscurely 3 -nerved, 2 to 4 inches long, 1 to 3 lines wide: heads in numerous small clusters ( 1 inch long): scales of the involucre rather acute: rays 16 to 20 , not exceeding the 8 to 14 disk-flowers.

Common in wet places, especially near the coast, extending to British America.

\$ 2. Stem mostly simple: heads not in corymbs: rays usually more conspicuous and fewer than the disk-flowers: akenes glabrous or nearly so. - VirganREA, DC.

* Heads rather few and large (a third of an inch long), in a narrow or raceme-like panicle, or in simple clusters: disk-flowers 20 to 30.

2. S. spiciformis, Torr. \& Gray. Glabrous or nearly so, glutinous: stem rather stout, a foot or two high : leaves thickish, spatulate, serrate, tapering (especially the lowest ones) into a long and narrow entire base or winged petiole; the upper ones small and gradually passing into bracts of the narrow and spike-like panicle, becoming shorter than the heads and entire: involucre campanulate; its scales oblong and obtuse, the outer with somewhat greenish tips: rays about 7, very small and inconspicuous: akenes silky-pubescent. - Fl. ii. 202. S. petiolaris, Less. (?), Hook. \& Arn. in part.

About Monterey. Leaves so glutinous that they adhere firmly to the paper in drying. Spikelike interrupted panicle strictly erect, 5 to 9 inches long.

3. S. Virga-aurea, Linn., var. multiradiata, Torr. \& Gray. Glabrous or somewhat pubescent, a span to a foot high: leaves few, lanceolate, acute, slightly serrate or entire, the lower with long narrowed base: heads few in a rather loose cluster or panicle: scales of the involucre rather loose, lanceolate, acute, thin : rays about 12, narrow, conspicuous: akenes minutely pubescent. $-S$. corymbosa, Nutt.

Higher parts of the Sierra Nevada; apparently rare in California, more common in the Rocky Mountains, as are some other forms of this polymorphous or perhaps compound species. 
* Heads smaller and numerous, crowded in a pyramidal or elongated panicle.

4. S. Californica, Nutt. Inary or grayish with a fine and cluse pubescence: w stem strict, 1 to 3 feet high: leaves oblong, lanceolate-oblong and entire, or the lower spatulate or obovate and with a few scattered sharp teeth: heads in short erect or barely spreading racemes, which are collected in a narrow cluse virgate or pyramidal panicle: scales of the involucre lanceolate-oblong, acutish or obtuse, at least the outer ones puberulent : rays 7 to 12 and about as many as the disk-flowers, small : akenes minutely pubescent. - Varies with longer, mоге spreading, and then commonly one-sided racemes. - S. petiolaris, Hook. \& Arn. in part. S. puberula, Cham. \& Schlecht.

Vir. Nevadensis. Hoary with minuter pubseence, smaller, with lowser and fewer decirledly one-sided racemes, the involucre mostly glabrous: approaching S. nemoralis, but wants the canescent-silky akenes, \&c.

Dry ground, Santa Barbara to Sonoma Co. A Californian representative of S. nemoralis; but

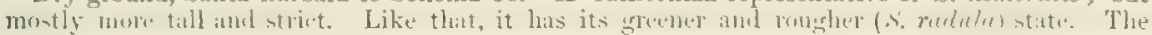
heads of the latter sometimes 4 lines long and full; ordinarily 3 lines long. Rinys occasionally abortive. Receptacle sometimes with alreoli extended into one or two amn-shapel scales, or else bearing chaff resembling the inner seales of the involncre. Leaves one, two, or the lowest three

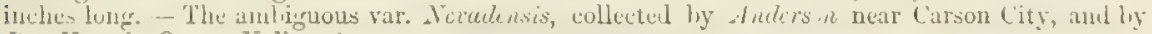
Dr. Horn in Owens Valley, \&c.

5. S. elongata, Nutt. Slightly and ninutely pubescent, or nearly shibruns: stem strict, very leafy to the top, 2 to 4 feet high: leaves green, rather thin, lanceolate or sometimes oblong, acute or acuminate, mostly serrate with some narrow and sharp teeth (occasionally all the upper ones entire), triple-ribbed from below the mikllle, veiny : heads very many, in compact erect or at length recurving racemes, which are crowded in a narrow or pyramidal panicle: scales of the involucre linear, small: rays 12 to 20 , slender, usually more numerous than the disk-flowers: akenes slightly pubescent. - S. stricta, Less. (?)

Moist or shady ground, from above Monterey, and along the Sierra Nevada, to Oregon and

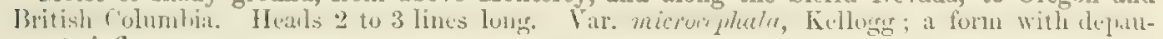
perate inflorescence.

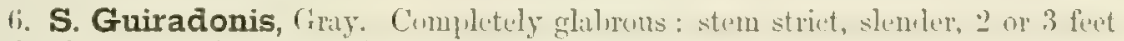
high: leaves bright green, thickish, entire; the upper linear and one-ribbed; the lower lanceolate or oblanceolate and tapering gradually into the long narrow base or margined petiole, somewhat triple-ribbed: hearls in a virgate panicle: scales of the involucre lanceolate-subulate: rays 8 or 9 , small : disk-llowers 10 or 12 : akenes almost glabrous. - Proc. Am. Acad. vi. 543.

Base of San Carlos, Fresno Co. (Guirado); Tejon, dc., Rollirock. The var. spectabilis, Eaton, in Bot. King., if of this species, ns is likely, has broader and obtuser scales to the involucre, broader lower leaves, de., and answers to narrow-leaved forms of $S$. speciosa. It inhabits Nevada, and probably occurs within the limits of California.

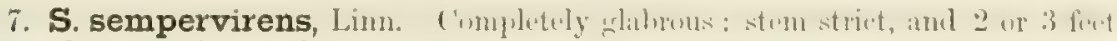
high: leaves rather fleshy, lanceolate, entire, the lower tapering into a long narrow

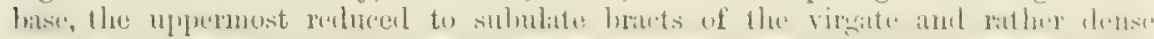

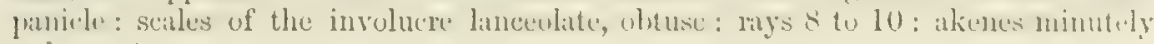
pubescent.

Salt marshes near San Francisco, Bolender. Near the sonthern boundary, 60 miles east of San Diego, Palmer. Appears to be the same as the Salt-Alursh foldenrod of the whole Atluntic shore down to Mexico. It is a form with small heads (3 lines long), appronching $S$. angustifulice of Elliutt.

\section{SERICOCARPUS, Nees.}

Head 12-15-flowered, hetorogmons; the rays abont 5, distant, fertile, white, sometimes inconspicuous. Involucre oblong or narrowly campanulate; its salues appressed, linear-obloug, firm-coriaceous or cartilagmous and white, with ahrunt 
short and more or less spreading green tips, imbricated; the outer successively shorter. Receptacle small, alveolate-toothed. Style-appendages lanceolate-subulate. Akenes narrow, little if at all compressed, silky-pubescent or villous (whence the generic name). Pappus simple, of copious capillary bristles. - Perennial Aster-like herbs, with corymbed and rather small heads; the disk-flowers pale yellow, and the rather small rays white.

A genus of three species of the Atlantic United States, and of the following on the Pacific side of the continent.

1. S. rigidus, Lindl, A foot or two high, scabrous with some very short and rigid pubescence, or almost glabrous, leafy to the top: leaves oblong-lanceolate, acute or obtuse, entire, an inch or two in length: heads half an inch or less in length: rays narrowly oblong, sometimes not exceeding the white pappus: akenes slender, clothed with fine short pubescence. $-S$. Oregonensis, Nutt., the state with rays conspicuous.

In woods, base of Mt. Shasta (Brever), Yosemite Valley (Bolander), and near Donner Lake (Torrey) ; extending to Washington Territory.

\section{CORETHROGYNE, DC.}

Head many-flowered, heterogamous; the rays numerous in a single series, neutral! Involucre hemispherical or turbinate; the scales narrow, mostly with green or greenish and more or less spreading tips, imbricated in several series, the exterior mostly shorter. Receptacle flat, naked or somewhat alveolate, rarely with some chaff similar to the innermost involucral scales interposed among the outer flowers. Anthers tipped with a slender cuspidate appendage, as in Lessingia. Style-appendages short, triangular-lanceolate or subulate, densely beset with long hispid bristles, forming a brush-like tuft (whence the generic name). Akenes and pappus of the ray abortive or rudimentary, of the disk compressed like those of Aster, silky-villous or pubescent: the pappus simple, of rather copious but rigid and unequal capillary bristles. - Rather low Aster-like herbs, apparently always perennial, branched from a somewhat woody base or rontstock, more or less white-woolly at least when young; the alternate leaves serrate with some sharp or coarse teeth towards the apex, or entire; heads middle-sized, solitary terminating the branches or somewhat corymbose-panicled: rays violet, purple or blue: disk yellow, sometimes changing to purple: pappus becoming tawny or reddish. - Torr. \& Gray, Fl. ii. 97 ; Gray in Bot. Mex. Bound. 76, \& Proc. Am. Acad. vii. 251.

De Candolle's character of chaff on the receptacle applies only to Douglas's specimens of the original $C$. Californicu; and in those it is not constant; so that the species must include $C$. incand, Tutt. Then all those with smaller and (when well developed) corymbose-panicled heads appear to belong to one species which blossoms through the season and under different exposures: some of the forms gathered and described were winter states. The genus is a particularly well-marked one, most related on the one hand to Lessingia, on the other to Aster.

* Bristles on the style-tips forming a rather scanty and small tuft: involucre campanulate or turbinate.

1. C. filaginifolia, Nutt. Stems erect or ascending, about a foot high, commonly branching corymbosely or paniculately at the summit and bearing several or numerous rather small heads: leaves oblanceolate or narrowly spatulate, the upper gradually reduced to subulate braets: involucre (4 lines long) between turbinate and campanulate; the numerous scales appressed, or with only the short greenish tips squarrose-spreading, the onter regularly shorter, all glabrous or at first more or 
less flocense-wolly, or minutely granulose-flandular but not pubesent. - Aser (?) filaginifolizs, Hook. \& Arn. Bot. Beech. 146. - Runs into various forms, of which a common one with the floccose wool considerably persistent on the stems and narrow leaves, and the involucre slightly if at all either glandular or squarrose, is the original type of the species; the more marked variant forms may be arranged under the following varieties.

Var. virgata, Gray. Becoming glabrate and the involucre more rigid and flandular: heads usually numerons and corymbed or panicled. - $C$. virgata, Benth. Bot. Sulph. 23. Aplopuppus (?) (Pyrocheta) Horkei, DC. Prodr. v. 349. (Hruke's plant is from Monterey, California, not Mexico.)

Var. tomentella, Gray. Very white-woolly, at least when young, and the leaves mostly shorter and broader. - C. tomentella, Torr. \& Gray. Aster (?) tomentellus, Hook. \& Arn. 1. c. Diplopappus leacophyllus, Lindl. in DC. Corethrogyne obovita, Benth. 1. c. C. incana (?) var., Benth. Pl. Hartw., is between the two varieties, and unusually glandular.

Open places, San Diego to Santa Cruz, and in the interior to Tejon and the Yosemite. Rays violet, a quarter of an inch long.

\section{* Bristles on the slylt-tips a dense and strong tuft: involucre hemispherical.}

2. C. Californica, DC, Stems erect or ascending, a foot or more high; the branches mother equably leafy throughout and terminated by single protty large heads: leaves linear-lanceolate or linear, chiefly entire: involucre broadly hemispherical (nearly half an inch longr); its seales mostly narrow and acute, in fewer ranks, and the onter only moderately shorter, rather loose, all glindular-pubescent: rurely some chaff on the receptacle among the outer flowers, - $C$. incana, Nutt. in Trans. Am. Phil. Soc. n. ser. vii. 290 (excl. syn. Lindl.); Torr. \& Gray, Fl. ii. 98, the form with no chaff on the receptacle.

Sandy soil, Monterey to San Diego : seldom collected. Rays light purple.

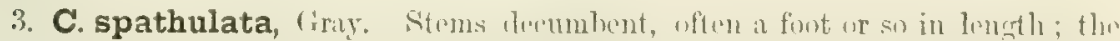
simple flowering branches 3 to 10 inches high, bearing single largo heals: leaves spatulate or obovate, obtuse, the larger half an inch to an inch wide, sermte at apex, those of the flowering branches gradually reduced to subulate or linear: the hemispherical involuere glamilular; its scales moderately unequal, and with loose herbaceous tips: no chaff on the receptacle. - Gray, Proc. Am. Acarl. vii. 317.

Mendocino and Humboldt Counties, near the eonst, at Shelter Cove and Fort Brigg, Bolinder, Kellogg. Heals as large as in the last: rays violet-blue, half an inch long. The dense white wool sometines decidnous from the leaves, which then become glandular-scabrous.

\section{ASTER, Linn, Benth. \& Hook.}

Head many-flowered, hotorogamons; the rays sevoral or numerous in a single series, fertile, very rarely neutral. "Involuere imbricated; the scales commonly with herbaceous or folinceous tips. Receptacle flat or convex, naked. Anthers tipued with the usual lanceolate ovate appendage. Styleappendages varying from triangular-lanceolate to subulate. Akenes moro or less compressed, rarely sleniler, 4-5nerved. Pappus simple, of copions slonder scalbrous capillary bristles. - Mostly perennial herbs, with varions alternate leaves, and solitary, corymber, or pmicleul heads; flowering late. Rays white, purple, or blue: disk-flowers yellow, often turning purple: pappus dull white or tawny.

An immenso genus, especinlly in North Amerien, its hendlquarters, but remarkably inconspicu. ous in Californin. For this flum at lenst it is lest to recelve it in the extenderl form which it reassumes in Prontham and llooker's fonem Pluntarum. There are no spueves west of the Rocky Mountains with cordato petioled leaves. 
§ 1. Biennials, rarely annuals or peremials, with leaves disposed to be incised or pinnatifid: scales of the involucre with green tips : rays sometimes sterile: akenes with strong marginal ribs and some slender nerves on 'both faces. (Involucre commonly resembling that of Corethrogyne.) - Machar.NTHERA. (Macharanthera, Nees. Dieteria, Nutt.)

$$
\text { * Rays styliferous, but sometimes infertile. }
$$

1. A. tanacetifolius, HBK. Biennial or annual, pubescent and somewhat viscid, a foot or less high: leaves once to thrice pinnatifid, the lobes small and narrow : heads large, loosely corymbose: scales of the hemispherical involucre linear and with spreading herbaceous tips: rays 20 or more, violet: akenes villous. Macharanthera tanacetifolia, Nees; Hook. Bot. Mag. t. 4624. Dieteria coronopifolia, Nutt. in Trans. Am. Phil. Soc. n. ser. vii. 301.

S. E. California, on the east side of Providence Mountains, Dr. Cooper; thence through Arizona to Colorado, east of the Rocky Mountains, and into Mexico.

A. (Macheranthrea) Parififlora, Gray, which oceurs on the Gila in Arizona, and may be found within the State, is smoother and much smaller.

2. A. incanus, Gray. Hoary with a fine and close soft pubescence, slightly if at all viscid, a foot or two high, loosely branched: leaves linear or narrowly lanceolate, entire, or some with a few lateral teeth, acute (an inch or so in length, about 2 lines wide): heads solitary terminating the branches, large: scales of the hemispherical involucre linear-lanceolate, with long and squarrose-spreading or reflexed foliaceous tips: rays 30 or more, violet: akenes canescent. - Diplopappus incanus, Lindl. Bot. Reg. t. 1693 ; Hook. Bot. Mag. t. 3382. Dieteria incana, Torr. \& Gray, Fl. ii. 100.

California, raised in England from seed collected by Douglas; the station unknown. Specimens which aceord with it were gathered in Guadalupe Cañon, Sonora, by Capt. E. K. Smith. Head over half an inch in diameter across the disk: rays two thirds of an inch long.

3. A. canescens, Pursh. Biennial, minutely puberulent-hoary or often green, a foot or so in height: stems rigid, corymbosely or paniculately branched above: leaves varying from oblong-lanceolate or the lowest spatulate to linear, incisely or almost spinulosely toothed, or sometimes entire, those of the flowering branches reduced to subulate bracts: heads few or numerous, solitary, or mostly corymbose or panicled: scales of the campanulate or obconical involucre rigid, appressed, with short more or less squarrose-spreading green tips, the outer successively shorter: rays 20 to 30 , violet or bluish-purple: akenes canescently-pubescent. A. biennis, Nutt. Gen. ii. 155. Dieteria canescens, pulverulenta, divaricata, viscosa, \& sessiliflora, Nutt. in Trans. Am. Phil. Soc. 1. c. Macharanthera canescens, Gray, l. c. ; Eaton in Bot. King.

Dry regions, in the mountains behind San Diego and on the eastern slope of the Sierra Nevada (Mono and Tahoe Lakes, \&c.), extending north to the British boundary, and east to the eastern base of the Rocky Mountains: a characteristic and most variable species of the region. Heads in the larger forms half an inch in diameter, and the rays half an inch long; in others barely half that size, and the flowers much fewer. It is useless to distinguish particular varieties. Only low and small-headed forms have as yet been found in California.

$$
\text { * Rays completely neutral. - Hesperastrum, Gray. }
$$

4. A. Shastensis, Gray. Dwarf from a perennial rootstock, branched and tufted from the base, a span high, puberulent-hoary: leaves small, spatulate or oblong, entire: heads solitary terminating the branches, small : scales of the campanulate involucre lanceolate, somewhat hoary and viscid, the outer with loose green tips, the inner nearly destitute of herbaceous tips: rays 15 to 20 , rose-violet. Macharanthera (Hesperastrum) Shastensis, Gray, Proc. Am. Acad. vi. 539.

On Mount Shasta, at about 9,000 feet, Brewer. Resembles a dwarf state of the last. Involuere 4 lines long : rays 3 lines. 
\$2. Perenninls (!) with traves spinulwsely pimnatifid-tonthed or incised (or sometimes entire): scales of the involucre with long-acuminate but not green tips: pappus of comparatively fero (20 to 35) and very rigid bristles. (Transition to Townsendia.) - Megalastrew, Gray.

5. A. tortifolius, (rray (nut Mirlax). At first lonsely white-wonlly, when oiri somewhat roughish-hirsute or glabrate, a foot or so high: branches naked and peduncle-like at summit, bearing a solitary very large head : leaves coriaceous, rigill, wfen twisted, whlong or lancenlate, veiny, struns ly dentate or incisuly finnatifid with divaricate spinulose teeth: involucre hemispherical; its very numerous scales lanceolate-subulate and setaceous-acuminate, the outer a little shorter: rays violet-purple, very numerous, an inch long: pappus becoming reddish. - Proc. Am. Acad. vii. 353. Aplopappus tortifolines, Torr. \& Gray, in Bost. Jour. Nat. Hist.

ILountains near the southeastern borders of California ( $D r$. Cooper); thence to S. Utah, Fremont, Nevberry, Mfrs. Thompson. This and A. (Heyalostrum) Wrigflii, Gray, form a remarkable section of the genus, which might almost as well be referred to Townsendir. Style-appendages short, obtuse. Akenes (young) linear-oblong, silky-villous. Bristles of the papjus about 20 in a single series, strong, flattish, serrulate-scabrous, nearly equalling the disk-corolla, and a few slender and shorter ones intermixed.

\section{\$ 3. Perennials, with leaves merely serrate or entire. - AsTER proper.}

* Pappus rather rigid, some of the longer bristles thickened towards the summit: involucre campanulate or turbinate; its scales very regnularly imbricated in many ranks, rigid, with short green or greenish tips, the outer successively shorter.

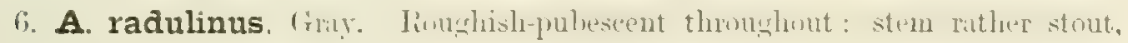
one or two feet high, branching above and bearing an open corymb of middle-sized heals: leaves rigid and coriaceous, oblong, or the lower obovate-spatulate, sharply serrate above, tapering below into a narrowed entire base, prominently reticulateveiny, scabrous both sides, the midrib very prominent beneath: peduncles short: involuere obconical, 4 or 5 lines long; its scales rigid, appressed, lanceolate or obInng, obtuse or abruptly pointed or mucronate, more or less glandular-pubescent, the tips mostly green: rays 15 to 18 , white (perhaps not always so): akenes minutely pubescent. - Proc. Arn. Acad. viii. 388. A. Radula, Less. in Linnsa, vi. 125 ; Durand \& Hilgard Pl. Pratten., not of Ait.

Dry open ground, Monterey to Mendocino Co. (thence to Oregon, E. Hall) : also in the Sierr from Nevada Co. northward, Torrey, Lemmon. This is nearly related to $A$. conspricutus, Lindl., of the region much farther north, - a plant with larger heads and leaves, - while the smaller forms are more like $A$. nontenus, equally a northern species.

* Pappus sofiter and equable.

+ Low and difuse: branches leafy to the top and bearing small mostly single heads.

7. A. Bloomeri, Cray, 1. c. Cospitose, a span or less in height, minutely cinereous-hirsute, and near the heads somewhat glandular : branehes aseendiug : leaves oblong-linear or the lower spatulate, 3 to 10 lines long, obtuse, entire, very rourh both sules with the short minutely hispid pubescence, the uppermost passing into scales of the involucre; these 25 to 30 , linear, acute, glandular and greenish : rays 12 to 15 , apparently purple, about $\$$ lines long : akenes minutely pubeseent.

Moist flats near Mfount Davidson, Nevala (probably also within the State boundary), Bloomer. Lcmmon. Heads 4 lines long.

++ Stems erect and branching, leafy, bearing several or numerons commonly paninlate or racemave heads: involucre imbricated,

++ Its scales many-renked, close, and with short green fips.

8. A. Menziesii, Limll. Minutely honry with a fine (nither snft or sculumus) pubescence, or glabrate below, a foot or two lish : stem and branche's virgate, rigiel: 
leaves lanceolate or linear, acute, entire, or the lower obtusely serrate, rather rigid (an inch or two long, 2 to 4 lines wide): heads racemose or panicled, 4 or 5 lines long: involucre campanulate; its scales numerous and imbricated in several ranks, thickish, linear, with short usually somewhat dilated and obtuse green tips, appressed, the outer successively shorter: rays about 20, purple or violet: akenes compressed, minutely pubescent. - Torr. Bot. Wilkes Exped. t. 8.

"California, Menzies," accorling to Herb. Banks : but in Herb. Hook, said to be from "N. W. coast." Upper Sacramento, Dr. Pickering. Fort Tejon, Dr. Horn, Dr. Hecrmanzn (A. Durandii, Nutt,, ex Durand, in Pacif. R. Rep. v. 8), and common in W. Nevada, mostly in a glabrate form, the pubescence only on the ultimate branches. The species has been mistaken for $A$. falcatus, Lindl, which may indeed belong to it, and likewise with the next. It is not at all related to $A$. concolor, as lindley supposed.

9. A. Chamissonis, Gray. Glabrous, or above somewhat hirsute : stems 2 to 5 feet high, paniculately branched: leaves lanceolate, acute, entire, or the larger

14 obscurely serrate, 2 to 5 inches long, scabrons with sparse appressed pubescence, or glabrous; those of the flowering branchlets becoming small or minute and squarrose-spreading: heads loosely panicled, 5 or 6 lines long: involuere broadly campanulate or somewhat obconical; its scales numerous and imbricated in several ranks, thickish, linear or linear-spatulate, with short and rounded green tips, the outer successively shorter: rays 20 to 25 , purple or violet, nearly half an inch long: akenes sparsely and minutely pubescent. - Gray, in Torr. Bot. Wilkes Exp. 341. A. Radula, Less. ex Nees. A. Chilensis, Nees Ast. 112 ; Torr. \& Gray, 1. c. A. spectabilis (?) Hook. \& Arn. Bot. Beechey.

Moist thickets, \&e., common from San Francisco to San Luis Obispo, and probably elsewhere. As this is not a Chilian species, and as Hrenke's no less than Chamisso's plant (if the former be of this species) must have been gathered in California, we ought not to continue the false name. Probably this as well as the preceding was included by Nuttall under the species (still unpublished) which he proposed to call $A$. Durandii. That name it was formerly thought might be adopted for the present species, but it appears strictly to belong to the foregoing. And so the present may be named after the first, or next to the first, discoverer.

$$
\div+ \text { Involucral scales looser and more foliaceous. }
$$

10. A. Douglasii, Lindl. Smooth and glabrous or nearly so: stem slender, 2 to 4 feet high, paniculately branched: leaves lanceolate, acute, entire or rarely serrate, mostly tapering at base, $2 \frac{1}{2}$ to 5 inches long: heads in a loose and leafy panicle, 5 or 6 lines long: involucre hemispherical; its scales glabrous, linear or spatulate-linear, mostly green except the base, loosely imbricated, the outer little shorter : rays 25 or more, purple, half an inch or more in length.

Moist soil, northern part of the State and in the Sierra Nevada; common northward.

11. A. adscendens, Lindl. (?) Smooth and glabrous or nearly so: stems rather simple, a span to two feet high: leaves lanceolate or the lower oblong-spatulate, entire: heads few, panicled or corymbose, peduncled, half an inch long : involucre hemispherical; its scales glabrous, linear or oblong, obtuse, chiefly green, fewranked, and of nearly equal length : rays, \&c., as in the preceding.

In the High Sierra Nevada, Yosemite Valley to foot of Mount Dana (Bolander), near Donner Lake (Torrey, Greene), and eastward in the Humboldt and Rocky Mountains. Whether this belong to the original $A$. adscendens or no, it is the var. Parryi, Eaton in Bot. King's Exploration, and apparently the same as the plant of the Colorado Rocky Mountains.

12. A. integrifolius, Nutt. Tillons-pubeseent when joung, becoming glandnlar and viscid toward the summit: stem rather stout, simple, a span to a foot or more high: leaves oblong-lanceolate and the lower spatulate, entire, thickish, 2 to 4 inches long, with strong midrib and inconspicuous veins; the upper clasping : heads few or several, somewhat racemose or corymbose, half an inch long: involucre campanulate; the loosely imbricated scales nearly equal in length, lanceolate, the inner ones thin and without green tips, the outermost partly foliaceous, all glandularpubescent: rays 15 to 25 , bluish-purple : akenes pubescent : pappus rather rigid. 
Sierra Nevada, between Clark's and the Yosemite, at about 8,000 feet, Bolender. Near Donner Lake (Torrey, Greene), and Sierra Valley, Lemmon. Found near Carson by Dr. Anderson; thence east to the Rocky Munitiains.

+++ Stems simple, naked at the summit, and bearing a single head, or rarely two or three: scales of the hemispherical involucre very little imbricuted, narrow, nearly equal, and destitute of foliaceous or green tips. (4 transition from Aster to Erigeron.)

\section{+ Leaves broad or narrowish: style-appendages short and broad.}

13. A. salsuginosus, Richardson. Minutuly puluscent or shbrate : stem is to 18 inches high, leafy to near the summit: leaves entire; the lowest spatulate, obovate, or oblanceolate, tapering into a margined petiole; the upper becoming lanceolate and ovate-lanceolate, acute, with broad base usually half-clasping; uppermost reduced to one or two subulate bracts: head solitary or two or three on naked peduncles: scales of the involucre slender, glandular, nearly equal, 4 liwes long, loose : rays 30 to 40 , violet or purple: akenes of the ray 5-6-nerved, of the disk 3-4-nerved. - Hook. Bot. Mag. t. 2942.

Var. angustifolius, (riay. Liulical and lowest canline leares linear-spatulate, ') to 5 lines wide; the upper linear: stems a foot high, naked above, bearing two or three slender-peduncled heads.

Subalpine and alpine meadows, in the Sierra Nevada, at 6,000 to 10,000 feet; thence to alpine regions of the Colorado Rocky Mountains, and north to Alaska and the subaretic regions. A handsome species; the heads an inch and a half in diazueter, including the expanded rays. The variety, Sienza County, Lemonon.

\section{++ + Leaves nery narrow: style-appendages long and slender-subulate.}

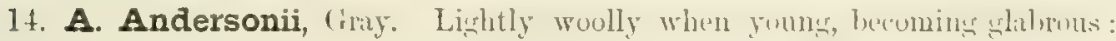
stem simple and scapu-like, a span to a foot high, terminated by a single rather large head : radical leaves tufted, linear, almost grassy ( 2 to 8 inches long, from a line to 4 lines wide), coriaceous, 3-7-nerved; the cauline smaller, the uppermost subulate: scales of the involuere lanceulate or linear, loose, more or less tomentose, almost equal in length ( 4 or 5 lines long), the outer ones greenish: rays 16 to 20 , purple : akenes oblong, 4-6-nerved : bristles of the pappus barbellitte-sermate.-Proc. Am. Acal. vii. 352. Erigeron Anlersonii, Grity, 1. c. vi. 540.

Wet alpine meadows, \&ce, Sierna Nevada, from Mariposa to Sicrm Co., at 7,500 to 10,000 feet. Diseovered by Dr. Anderson, near Carson, Nevada. Expanded head with the mys an inch or more in dianneter.

A. pulcueluus, Eaton in Bot. King Exp, is perhaps too nent this, and A. Alpierexus, Gay, 1. c. viii. 389 , is also closely related; they form a peculiar group in the Xylorkiza section of Drihomeris.

\section{\$ 4. Annuals or biennials, with chiefly entire narrow leaves: scales of the involucre imbricuted, narrow, destitute of distinct green tips: akenes narrov and 3-5- nerved: pappus fine and snft. - Oxxтnipolus, Torr. \& Groy.}

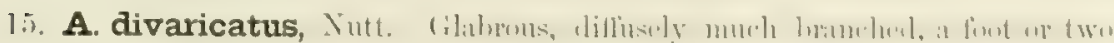
high: the branches slender: lower cauline leaves Innceolate; the upper linear and at length subulate, very acute: heads small ( 3 or 4 lines long), lousely panicled: scales of the involuere 25 to 30 , lanceolate-subulate, with greenish back and sctrious marcins : rays linear, exserted, numerous in a single row : akenes very minutely pubescont, 5-6-nerved. - Torr. \& Gray, Fl. ii. 163.

Sult marshes, San Franciseo, dec, Bolander. This is the Pacific furm, viz., Trimlium con-

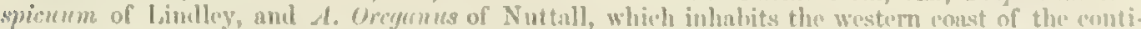

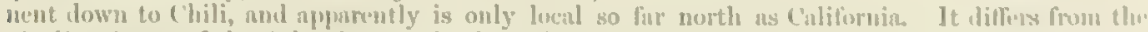

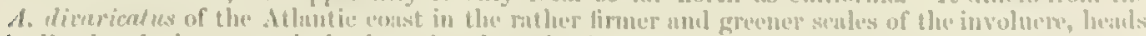

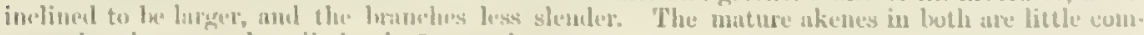
pressed and nore or less distinetly 5-nerved. 


\section{BRACHYACTIS, Ledeb.}

Head many-flowered, heterogamous; the rays very numerous and occupying more than one series, fertile: ligules small and very slender or almost wanting. Involucre loosely imbricated in few series of herbaceous scales, or the innermost somewhat searious. Receptacle flat, naked. Style-appendages lanceolate. Akenes more or less compressed. Pappus simple, of copious fine and soft capillary bristles. - Ours are annual and nearly glabrous herbs, with narrow and entire somewhat succulent alternate leaves, minutely ciliate towards their base, and paniculate or racemose heads; the rays when developed purple or rose-color. - Benth. in Hook. Ic. Pl. t. 1106, \& Gen. Pl. ii. 279 ; Gray, Proc. Am. Acad. viii. 647.

1. B. frondosa, Gray, 1. c. A span to a foot or so high, sometimes spreading on the ground, sometimes upright: leaves spatulate-linear, about an inch long, the uppermost passing into the rather broad and obtuse herbaceous scales of the involucre: heads hemispherical, 4 lines long: rays with exserted ligule when well developed a line long, linear, much longer than its style : akenes narrow, appressedpubescent. - B. ciliata, var. carnosula, Benth. 1. c. Tripolium frondosum, Nntt. Aster frondosus, Torr. \& Gray. A. angustus, Gray, Pl. Wright., \&c. ; Eaton, Bot. King Exp. 144.

Borders of boiling spring, Sonora Pass, in the Sierra Nevada, Bolender; thence to N. Nevada, S. Idaho, and New Mexico.

B. ciliata, Ledeb., found east of the Rocky Mountains and far north, also in Siberia, has narrow linear leaves, linear and acute scales of the involucre, and ligule a mere rudinent, nuch shorter than the pappus and the style. It is Tripolium angustum, Lindl, and Aster angustus, Torr. \& Gray, \&c.

\section{ERIGeron, Linn. Fleabane.}

Heads many-flowered, heterogamous; the rays fertile, very numerous and commonly occupying more than one series (in one or two species occasionally wanting); the ligules narrow, commonly elongated, in the last section very short and inconspicuous. Involucre hemispherical or sometimes campanulate, of numerous and narrow rather firm and not foliaceous nor gxeen-tipped scales, which are little imbricated and hardly unequal. Receptacle flat, rarely convex, nakecl. Corolla of the disk-flowers narrow, 5-toothed, sometimes 4 toothed. Style-appendages mostly short and broad, obtuse. Akenes small, flat, and with only marginal ribs, rarely 1-2nerved on the face (especially in the ray-flowers). Pappus rather scanty, i. e. of a single series of capillary rather fragile bristles, with or most commonly without an external series of short bristles, these occasionally united into a crown or ring. Herbs, with alternate leaves, and heads terminating the stem or branches; the rays violet-purple or white; the disk yellow, often changing to purplish.

A large genus, widely dispersed over the world, especially the northern hemisphere, passing on the one hand into Aster, from which it is chiefly distinguished by a simpler involucre and more seanty and fragile pappus, and by more numerons and narrower rays; while on the other hand a peculiar section, with short and often minute rays, passes into Conyza.

§ 1. Perennial (or No, 12 perhaps biennial).

* Rays inconspicuous, but exserted, short, filiform, extremely numerous : heads somewhat racemed, small: pappus simple.

1. E. armerizefolium, Turcz. Sparsely more or less hirsute with spreading bristly hairs: stems elustered on the small rootstock, a span to a foot high, leafy: 
leaves hirsut ly ciliate helow the midlle, otherwise crlabrous or slabmen, entire; the cauline linear or liuear-lancenlate ( $1 \frac{1}{2}$ to 4 inches long, 1 to 3 lines wide), the lowest linear-spatulate or oblanceolate and usually tapering into slender petioles: heads peduncled and simply racemose, or rarely pauicled: involucre 3 or 4 lines long: rays more numerous than the disk-flowers, the purplish or whitish nearly filiform ligules when fully developed projecting only one line beyond the pappus; disk-flowers uniform. - Gray in Proc. An. Acad. viii. 648. E. lonchophyllum, Hook., apparently a large form. E. glabratum, var. minor, Hook. E. racemosum, or at least the var. angustifolium, Nutt.

Saline gravel and moist meallows in the Sierra Nevada, at 6,500 to 9,700 feet, Breucer, Bolander. Also on mountains east to Colorarlo, and thence northward. Rare in Siberia.

E. ACrE, Linn., especially in smoother forms (E. Drobachcrsis, Mill, E. clongatus, Ledeb. \&c.), occurring in the Rocky Mountains from Colorado north, may be expected in the Sierra Nevada. It may be known by its broader leaves, and an inner set of pistillate flowers with tubular-filiform corolla. There are none of these in E. armeriafolium.

\section{* Rays elongated and conspicuous, or wanting in some specimens.}

+ Leaves once to thrice ternately compound: pappus simple.

2. E. compositum, Pursh. Dwarf: leaves all or mustly crowded on the cespitose rotstocks, slender-petioled, hirsute; their divisions linear, obtuse, spreading; the cauline (if any) simpler, or the uppermost mere linear bracts : scape an inch to a span high, bearing a solitary proportionally large head (involucre 3 or 4 lines high): rays 30 to 50 , violet, purple, or white, 2 or 3 lines long, oceasionally none.

High peaks of the Sierra Nevada, at 10,000 to 12,000 feet, on Mount Dana and Wood's Poak, Brever: Thence through the Rocky Mountains to Aretic America and Greenland.

++ Leaves entire and narrow, chustered on the rontstocks, fewer and scattered or somelimes hardly any m the mostly simple stems, which are terminated by solitary heads. (Wo. 5o and No. 8 have stems more leafy and disposed to branch.)

3. E. ursinum, Eaton. Sparsely more or less hirsute, green, a span or less high: leaves on the rootstock spatulate or linear-spatulate, tapering into a slender petiole; those of the simple scape-like floweriag stems linear-lanceolate (6 to is lines long), glabrate, the uppermost remote from the solitury head: scales of the involucre loose, glandular and sparsely hirsute: rays about 50, broadish, purple, fully 3 lines long: pappus with a fuw distinct short bristles of an outer series. Eaton in Bot. King Exp. 148.

On Mount Dana, at 12,800 feet, Bolender. More dwarf than the plant collected by Watson in the Ynintah Mountains, Utah; the scape less than 3 inches high. Perhaps this is E. radicalum, Hook.

4. E. uniflorum, Linn. Green and slightly hirsute, or almost glabrous below, a span or less in height: leaves of the rootstock tufted, spatulate, tapering into in petiole; those of the simple and sometimes scape-like stem becoming lanceolate: scales of the involucre loose, equal, very hirsute-woolly : rays 100 or more, blue or purple, about 4 lines long. - Tori. \& Gray, Fl. ii. 168.

High Sicrma Nevada, in Sierra ('o., at 10,000 feet (Kellogg), thenee northward along the high mountains and through the Rocky IIountains to the Aretie regions, and in N. Asin and Europe. A dwarl state, but otherwise like that of the ('oloraclo mountains, with the copions and character. istic long hairs of the involuere gray or whitish, not dark as in the more northern specimens.

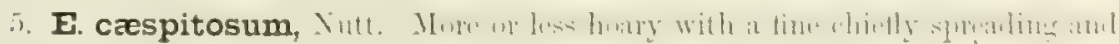
roughish pubescence: stems decumbent or ascending from the somewhat woorly rootstock, about a span high, mostly leafy: leaves from the rnotstock oblanceolate, tapering into a petisle, an inch or two long; the canline linear or somewhat lanconlate aml sessile, obtuse: heals sulitary (or sometimes two or three and rather small), short-peduncled : involuere hirsute with short hairs: rays 30 to 50 , whito 
or purplish (about. 3 lines long): appendages of the style extremely short and obtuse: akenes 2-3-nerved, minutely hairy: the short squamellate outer pappus conspicuous.

Var. tenerum, Gray. Slender and small, with weaker stems and small heads; involucre only 2 lines high, less hirsute.

Eastern side of the Sierra Nevada : thence to the Rocky Mountains and New Mexico. The only genuine form collected on the borders of the State is from Carson City, $D r$. Anderson. Var. tencrum, summit of Silver Mountain near Ebbett's Pass, alt. 11,000 feet, Brewer. Also collected by Watson on Star Peak, N. W. Nevada, at 9,000 feet.

At Mono Pass, around rocks, Dr. Bolander collected a plant which would appear to belong to E. coespitosum, althongh with rather longer and narrower leaves : but the pappus appears to be simple.

6. E. Nevadense, Gray. Slightly hoary with fine mostly appressed roughish pubescence: stems erect or ascending from long and slender subterranean rootstocks, a span to a foot high, simple, leafy below, mostly naked above or scape-like, bearing a solitary large head: leaves linear-lanceolate or spatulate-linear, narrowed below, the lowest into a petiole (the whole 2 to 6 inches long), the cauline acnte, the uppermost reluced to subulate bracts: involucre hirsute, also minutely glandular; the scales mostly equal (4 lines long): rays 25 to 30 in a single series, rather broadly linear, white, 3 or 4 lines long: style-appendages ovate and acute: akenes minutely pubescent, flat, oblong, 2-nerved, or some of the outer 3-nerved (2 lines long): the short setiform outer pappus scanty and inconspicuous. - Proc. Am. Acad. viii. 649. E. caespitosum, var. grandiflorum, Eaton in Bot. King Exp. 153, in part (viz. No. 548), not of Torr. \& Gray.

Var. (?) pygmaum, Gray, 1. c. Dwarf and densely cespitose : leaves spatulatelinear (half an inch or less than an inch long, barely a line wide at the summit), crowded on the rootstocks: flowering stems nearly naked and scape-like, an inch or two high : heads much smaller : rays narrower, barely 3 lines long, purple.

Sierra Nevada: Mount Stanford and Sierra Valley (Botander, Kellogg, Lemmon); and in Nevada, Cedar Hill and on Mount Davidson (Bloomer), and West Humboldt Mountains, Watson. Var. pygmceum, Ebbett's and Mono Pass, alt. 9,500 to 10,750 feet, Brewer.

E. Argentatum, Gray, I. c., which S. Watson collected on the foot-hills of the Pah-Ute Mourtains in Nevada, may be known by the fine silvery-silky foliage, soft-pubescent severalnerved akenes, and conspicuous outer pappus. E. CANux, Gray, has glabrous, narrow, severalribbed akenes.

7. F. Bloomeri, Gray. Somewhat hoary with minute appressed pubescence: leafy stems short and tufted on the thickish rootstock: leaves crowded, filiformlinear, or the broadest spatulate-linear tapering into a filiform petiole, 1 or 2 inches long: flowering stems erect, naked and scape-like at least above the middle, a span high, bearing a solitary head: involucre somewhat campanulate ( 4 or 5 lines high), villous; the seales equal : rays none: style-appendages acute : akenes minutely pubescent, flat, oblong-linear, and with only marginal nerves (2 lines long): pappus simple. - Proc. Am. Acad. vi. 540 ; Eaton in Bot. King Exp. 148.

Sierra Valley (?) Bolcander. Virginia and Carson City (Bloomer, Anderson), and W. Nevada, Watson. Allied to the foregoing; with foliage nearly of the following.

8. E. ochroleucum, Nutt. Minutely somewhat hoary with a fine appressed hirsute pubescence, or glabrate: leaves very narrowly linear and tapering to the base or nearly filiform, mostly crowded on the rootstocks, one or two inches long, the cauline rather few and scattered: flowering stems slender, about a span high, naked at summit, bearing solitary or rarely 2 or 3 heads: involucre more or less hirsute (barely 3 lines high); the scales rather rigid: rays 30 or 40 , cream-color or white ( 2 or 3 lines long) : akenes minutely pubescent, $2-3$-nerved: pappus plainly double, the outer of very short subulate squamellæ.

Sierra Nevada near Summit ; thence eastward and northward nearly to British Columbia. The forms with leafy stems approach the next. 
+++ Leaves tutire and narrone, mumernus all alung the branching flomering stems: akenes in all 2-nerved or only some of the outermost 3-nierved.

+ Leaves all filiform, canescent.

9. E. filifolium, Nutt. Huary with minute aypreset puluscence: stems a

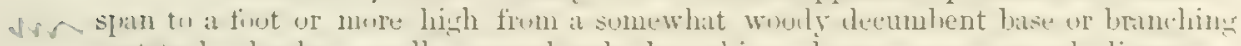

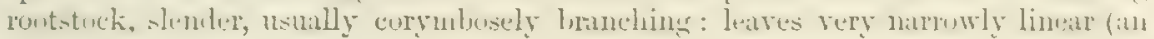
inch or two long, a line or much less in width), and becoming filiform, the uppermust rmluent to minute subulate bracts: involuere canescent and sonewhat hirsute, 2 or 3 lines high, the outer scales shorter: rays 50 to 80 , white or pink (3 or 4 lines long): akenes sparsely and minutely hairy, becoming glabrous: pappus

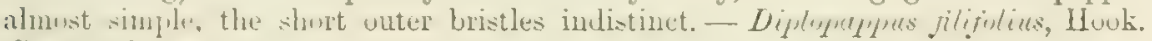
Chrysopsis canescens, DC.

Plumas Co. (Lemmon); near Carson City (Anderson), thence northrard, rather common in the interior districts to Oregron and Idaho.

++ Leaves flat, from narrowly linear to lanceolate.

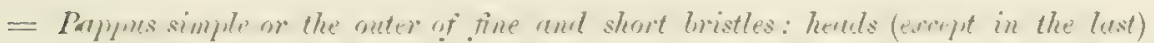
corymbose at the summit of the very leafy stem: rays in a single series.

10. E. Breweri, limy. Somewhat houry with fine am slurt scallums-hirsute pubescence: stems ascending or erect from a slender creeping rootstuck, a span to a foot high, slender, leafy to the summit, bearing solitary or few corymbose heads: leaves short (half an inch to an inch long), linear-spatulate or narrowly oblauceolate: involucre glabrous ( 2 or 3 lines high); its scales glabrous, unequal, the outer successively shorter: rays only about 15 (remarkably few for an Erigeron), violet, narrow: pappus nearly simple, the outer set of bristles if present very short and inconspicuous. - Proc. Am. Acad, vi. 541.

Woods of the Sierta Nevada, Mariposa Co., at 4,000 to 6,000 feet, Brower, Torrey, Gray. Above Carson City, Nevada, Anderson. This might as well be ranked as an Aster, of the urthomeris section, except for the style-appendages and an obrious relatiouship to some of the following species.

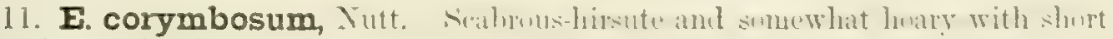
spreading pubescence: stems clustered, erect, a span to a foot or more high, corymbose at tho summit, bearing several pedunculate heads: leaves linear or linearlanceulate, acute, tapering to the base, about 2 inches long: involucre canescently hirsute ( 2 or 3 lines high), formed of nearly equal scales: rays 30 or 40 , violet or purple, slender: the short bristles of the outer pappus rather manifest. - Torr. \& Gray, Fl. ii. 178.

Eastern slope of Providenco Mountains, Dr. Conper. Inconzplete specimens, perlaps not of this species, which belongs mueh further north, in the interior of Oregon, \&ce, but may ho expected along the northeastem borders of the State. The hoary pubescence principally, and probably insulficiently, distingraishes this from E. decumbcrs, Nutt., of Oregon, which, in turu, weasly approaches tho next.

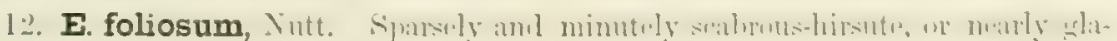
brous: stems orect from a creeping rootstack, one or two feet high, corymbosely hruched above, bearing several short-peduncled heals: leaves numerous to the summit, either broally or narrowly linear, obtuse (from an inch to at most 2 inches long, and from 2 lines to half a line wide), the lowest sometimes spatulate: involucre varying from minutely hirsute to glabrous ( 3 lines high), the narrow scales unequal: rays 30 or 40, nartow, purple-blue or white (sometimes none) : short bristles of tho outer pappus present, but inconspicuous. - Nutt. in Trans. Am. Phil. Soc. n. ser. vii. 309, \& Pl. Camb. 177. E. Dourflusie, Tour. \& (iray, Fl. ii. $17 \%$.

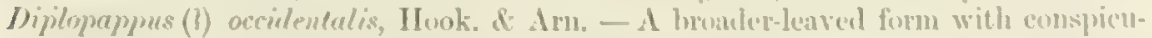
ous purple rays is the type of this polymorphous species. The extmene forms to be noted as varieties are 
Var. stenophyllum, Gray. Leaves a line or less in width, sometimes becoming almost filiform. - L. stenophyllum, Nutt. Pl. Gamb. 176, not of Gray in Pacif. R. Rep. iv. 98.

Var. inornatum, Gray. Leaves varying from spatulate-linear and 2 or 3 lines wide to very narrowly linear: involucre glabrous: rays none.

Open woods, \&c., from Humboldt and Nevada to San Diego Counties, both the broader and the narrow-leaved forms. Var. inomatum, which may prove distinet, Mendocino Co., Kellogg and Hurford, in several forms ; Upper Sacramento (Newberry, " $E$. Douglasii, var."); near Donner Lake (Torrey), and Sierra Valley, Lemmon, \&c. If this species, through its longerleaved forms, should be found to pass into $E$. decumbens, Nutt., of Oregon, it will still be most proper to preserve the name of $E$. foliosum, of the same age as the other, although Nuttall first described it from an imperfect specimen, and not very correctly as to the akene; but he re-identified it in his paper on Dr. Gambel's collection.

Kellogg and Harford's No. 398 is a remarkable dwarf form, apparently of the var. inornatum, approaching $E$, supplex: the involucre is minutely glandular, as also is the minute roughish pubescence on the branches and leaves.

13. E. supplez, Gray. Villous-hirsute; stems a span or two long from slender rootstocks, decumbent, mostly simple, terminated by a solitary and peduncled head: leaves spatulate-lanceolate, mostly acute (about an inch long and 2 lines wide), the uppermost becoming linear: involucre villous (about 4 lines high), the scales nearly equal and loose: rays wholly wanting: pappus nearly simple. - Proc. Am. Acad. vii. 353.

Humboldt and Mendocino Counties, Bolander, Kellogg. Colleeted by Mr. Andrews several years ago, station unknown.

\section{$==$ Pappus conspicuously double, the outer manifestly chaffy: rays very numerous or none. (Root perhaps not perennial.)}

14. E. concinnum, Torr. \& Gray. Very hirsute or hispid with long spreading hairs: stems tufted, a span or more high, commonly branching, more or less leafy: leaves spatulate-linear or the radical ones spatulate: involucre hirsute (about 2 lines high), its scales nearly equal: rays narrow, purple or white, 4 or 5 lines long, or in the

Var. aphanactis, Gray; the rays wanting or reduced to an abortive ligule shorter than its style. - Proc. Am. Acad. vi. 540.

Sierra Nevada on the eastern slope in Nevada (Anderson, Torrey), near to and doubtless within the State line; only the rayless form : thence eastward throughout the interior region. In both forms the outer pappus is sometimes of narrow and acute, sometimes of decidedly broad and erose or truncate chaffy scales. If not perennial-rooted the species should be placed next to E. divergens.

++ Leaves broader (from lanceolate to obovate), in one species serrate: rays extremely numerous: outer pappus indistinet if any.

15. E. speciosum, DC. Sparsely hirsute or almost glabrous: stem stout, erect, 1 to $2 \frac{1}{2}$ feet high, furrowed, branching above, very leafy to the top, bearing several or numerous corymbose heads: cauline leaves lanceolate, acute or acuminate, entire, bright green, hirsutely ciliate ( $1 \frac{1}{2}$ to 4 inches long), closely sessile or partly clasping; the radical ones spatulate and tapering into a petiole: heads rather large: scales of the involucre sparsely hirsute, very narrowly subulate: rays very narrow and numerous, violet-purple. - Stenactis speciosa, Lindl. Bot. Reg. t. 1577; Hook. Bot. Mag. t. 3607.

"California, Douglas"; but it has not since been collected in the State; yet probably it occurs in the northern districts, as it is common thronghout the moister parts of Oregon and Washington Territory, whence it was long ago introduced into gardens. Heads showy, fully an inch and a half in diameter, including the rays, which are half an inch long.

16. E. glaucum, Ker. Hirsute or villous with spreading hairs : stems ascending, a span to a foot high, leafy below, bearing solitary or few very large heads: 
leaves somewhat succulent, glabrate with age, 1 to 4 inches long, all broad and obtuse, obovate or spatulate-oblong, entire; the lowest and radical ones narrowed below into a margined petiole, and mrely with a few teeth : involucre villous and somewhat viscid : rays not very uarrow, violet. - Aster Californicus, Less. Stenactis glanca, Nees. Woodvillea calendulacea, DC. Erigeron maritimum, and probably E. hispidum, Nutt. 1. c.

Sea-shore, from Monterey to Oregon ; flowering at almost all seasons. Head 2 inches in diam: eter, including the rays. The name inappropriate, as the herbage is seldom at all glaucous.

17. E. Philadelphicum, Linn. Pulperent or rather hirsute: stems erent frem a perhaps biemnial root, 1 to 3 feet high, leafy to the summit, bearing several or numerous corymbose rather small heads: leaves oblong, or the upper oblong-lanceolate and partly clasping at base; the lowest obovate or spatulate; all more or less irregularly toothed, occasionally nearly entire: involucre minutely appressedhirsute: rays very narrow and numerous, flesh-colored or reuldish-purple: pappus simple. - E. purpureum, Ait.

Moist open grounds, apparently not rare through the length of California and in Oregon; common in the Atlantic States. Heads less than an inch in diameter, including the slender ray's.

\$2. Annuals or sometimes biennials, with small or rather small heads and conspicuous rays: pappus plainly double; the outer a crown or circle of chaffy squamella rather than bristles, hardly longer than the breadth of the akene and persistent; the inner of the ordinary slender bristles, but scanty, and deciluous or caducons. - Phalacrozoma, Torr. \& Gray.

* Branched from the base and spreading: pappus alike in ray and disk flowers.

18. E. divergens, Torr. \& Gray. Hoary-pubescent, diffuse, a span to a foot or so high, corymbosely branching; the branches terminated by solitary peduncled heads: leaves linear, the lowest spatulate and sometimes sparingly toothed or incised: involucre hirsute (about two lines high) : rays very numerous and slender, pale purple and white, or sometimes bright blue-purple, 3 lines long: receptacle commonly very convex. - E. Bellidiastrum, Gray in Hall, Oregon Coll.; Eaton in Bot. King Exp. 150, not of Nutt. (which has simple very deciduous pappus, broad white top to the akene, very flat receptacle, and is unknown west of the Rocky Mountains).

Sierra Valley (Lemmon, with bright-colorerl rays) : common in Oregon and Nevada, probably in all udjacent parts of Californis; extending to Nebraska and New Mexico. Near Fort MIolave, Dr. Cooper; a form like E. cincreum, Gray, which is apparently a low variety, witl less convex receptacle.

* * Stem erect, 2 to 5 feet high, branching only above : heads numerous, loosely corymbose, comparatively small: ray-fonvers having only the short outer pappus, the slender brislles wanting, and in the disk-flowers very deciduous: rays while.

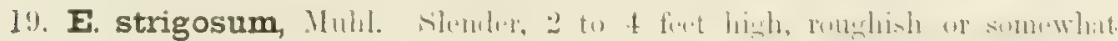
grayish with a very short appressed pubescence: leaves lanceolate, entire, or the lower spatulate and sometimes toothed: heads loosely corymbed: mys 2 or 3 lines long.

Plumas Co. (Lemmme) to Oregon; a form with coarser and looser hairiness than the eastern plant, approaching E. annuилn.

E. ANvuUs, Pers, diflers from this in being larger ( 3 to 5 feet high), hirsute with spreating lairs, and the ovate or ovate-lancenlate lower leaves coarsely tonthed or cut. It is a weed of eul. tivated grounds, originally from the Atlantic States, now dispersed over the northern temperate regions, and probabily has reached or will reach Californin.

\$3. Anmuals, with very numerous small (not over 2 liwes long) and narrove heals in a penicle: rays inconspicuous or minute (uhitish), havelly exceeding the pale yellow or whilish dish-flowers: preppus simple. C C.ENotus.

20. E. Canadense, Linn. (IILAsweEn.) A homely weet, with slender strictly erect stem, from a few inches to 4 or 5 feet high, maty glabrous or sparsely 
hirsute, thickly beset with linear entire leaves, or those at the base broader and cutlobed : leafy panicle generally long and narrow : pappus simple.

Waste and cultivated grounds, everywhere having the aspect of an introduced weed, comnon almost all over the world.

\section{CONYZA, Linn.}

Heads many-flowered, heterogamous, but not radiate; the pistillate flowers in many series and more numerous than the fertile ones, with only a filiform truncate corolla shorter than the style; the few central flowers tubular and perfect, or some of them infertile. Involucre of narrow numerous scales. Receptacle flat or convex, naked. Style-appendages short. Akenes small, flattened, usually nerved only on the margins. Pappus as in Erigeron, in ours of simple scanty capillary bristles. Mostly tropical or subtropical weeds, with alternate toothed or lobed leaves, and small corymbose or panicled heads of whitish or yellowish flowers.

1. C. Coulteri, Gray. Annual (?), somewhat viscidly pubescent, one or two feet high, very leafy to the top: leaves closely sessile, linear-oblong or the lower spatulate, coarsely toothed or incisely pinnatifid, about an inch long: panicle narrow, virgate: heads very numerous, small, barely 2 lines long: involucre hairy : central perfect flowers 5 to 7. - Proc. Am. Acad. vii. 355. C. subdecu'rens, Gray, PI. Fendl. \&c., not of DC. Erigeron discoidea, Kellogg in Proc. Calif. Acad. v. 55.

S. E. borders of the State (Coulter, Cooper); on the San Joaquin (Kellogg); and through Arizona to Colorado and Texas. A homely weed.

\section{BACCHARIS, Linn.}

Heads many-flowered, homogamous, diceious; in the sterile plant the flowers seemingly perfect as to style \&c, but with abortive ovary; in the fertile pistillate only. Involucre of dry imhricated scales, destitute of herbaceous tips, the exterior successively shorter. Receptacle commonly flat and naked. Corolla of the fertile flowers small and filiform, truncate, wholly destitute of lignle, shorter than the style: in the sterile flowers tubular with a somewhat expanded 5-cleft limb: the style usually 2-cleft at summit, sometimes undivided. Akenes small, several-ribbed. Pappus in the fertile flowers of copious mostly soft and fine capillary bristles; in the sterile commonly less copious or less elongated, often tortuous and more denticulate. - Shrubby or sometimes 'herbaceous plants, ours all glabrous, often glutinous, with alternate leaves and small mostly clustered heads of white or yellowish inconspicuous flowers.

A very large genus in South America, a few reaching the United States throughout its southern borders, and extending northward along either coast.

* Leaves broad, short and obtuse, commonly few-toothed: heads paniculate-glomerate on the very numerous branches: pappus in the fertile flowers at length much exceeding the involucre.

1. B. pilularis, DC. Shrub 2 to 4 feet high, glutinous: leaves sessile, obovate or cuneiform, about an inch long, coarsely or sinuately few-toothed, or occasionally entire: heads 2 or 3 or more in a cluster from the axils of the upper leaves, globular, 2 or 3 lines long, the fertile pappus becoming 4 or 5 lines long. - B. pitularis \& $B$. consanguinea, DC.

Common in sandy soil along the whole length of the coast, and reaching Oregon; flowering in autumn. De Candolle's specific name may relate to the size and form of the flowering heads, or to small globular excrescences, probably galls, which often occur on some branchlets. 
* Leaves long and narrow, acute, sharply sermulate or entire: heads in a naked compound corymb or cyme terminating the herbaceons striate flowering branches: bristles of the pappus in fertile flowers less copious (20 to 30) and little elongating.

2. B. Douglasii, DC. Shmulyy at likse, ghutinous: leares lancenlite and rery acute, or the lower ovate-lanceolate ( 3 or 4 inches long) and sharply more or less serrulate, triple-ribbed, the uppermost smaller and narrow: heals numerous in a terminal compound corymb: scales of the involucre in the sterile heads broadly, in

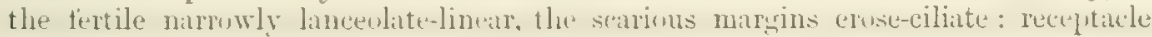
conical! - Torr. \& Gray, Fl. ii. 259, excl. syn. Nutt. \&e.

Sandy soil and borders of swamps, San Francisco to Los Angeles. The flowering branches are herbaceous. Bristles of the pappus in the fertile flowers denticulate-seabrous.

3. B. viminea, DC. More shrulhy, harlly glutinots, paniculately brauched: leares lanceolate, acute at both ends, entire or sparingly denticulate (one to barely three inches lones), indistinctly 3-nerved: hearls (3) lines high) rather numerous in trininal corvuls and somewhat ratemose elusters on short lateral branches: sales of the involucre very thin, broadly lanceolate or the outer ones triangular-ovate,

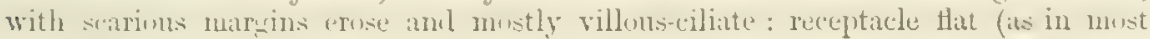
species): pappus of the fertile flowers of smooth bristles.

Border of streams, Napa Co. to Los Angeles. A willow-like shrub : foliage enten readily by horses and mules. This has been confounded sometimes with $B$. Dorglusii in collections.

4. B. glutinosa, Pers. Suffutiense, less hrancher than the latit : leatres lanemlate or linear-lanceolate, 2 to 4 inches long,"3-nerved from near the base: heads numerous in a terminal compound corymb, rather smaller than in the last: the scales of the involucre similar but of firmer and more chartaceous texture: bristles of the pappus scabrous-denticulate. - B. Pingrea, Nutt. in Trans. Amer. Phil. Soc., not of Molina, B. corulescens, var., Gray in Bot. Mex. Bound. 83.

San Diego, Nutlall. Los Angeles, Wallace. We cannot now aseertain whether this is

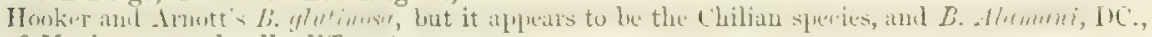
of Mexico, seems harlly different.

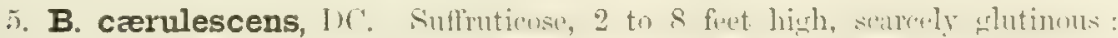
leaves lanceolate, 3 or $t$ inches long, acute or acuminate at both ends, sharply and rather remotely serrate or serrulate, 3 -nerved from near the base: heals very numerous in a compound terminal corymb, small: involucre only 2 lines high; the scales chartaceous, lanceolate or the outermost ovate-lanceolate, with very narrow and nearly naked scarious margins: pappus of the fertile flowers of seabrous bristles.

San Dirgo and San Luis Rey (Parry), Fort Mohave (Cooper, Scholl), and through Arizona to Texas and Mlexico.

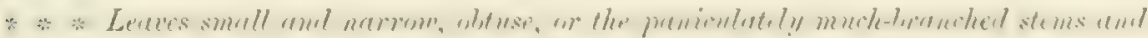 slender rush-like striate-angled branchlets nearly naked.}

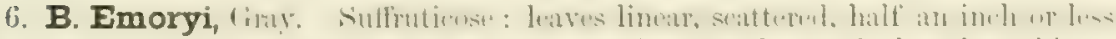

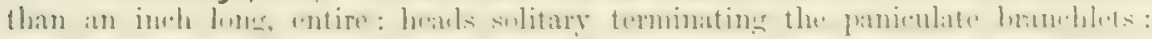
involucre of the sterile hends 2 , of the fertile 3 lines high; the seales subcoriaceons, obtuse, the outer ovate, inuermost linear: pappus of the fertile flowers fine and colitous, attaining half an inch in length: akenes 10-striate. - Bot. Mex. Bound. 83.

San Diego and San Bernardino countics, and in Arizona

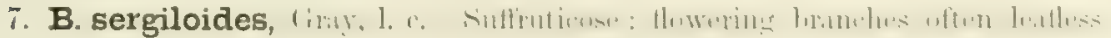
leaves spatulate or almost linear, a thirl or a quarter of an inch in lensth, or reducel to mere scales, mucromate, entire: heads numerous and panicled, the sterilo ones mostly clustered : involuere of the sterilo heads $1 \frac{1}{2}$, of the fertile 2 lines high; the scales ovate-laneenlate, or the innermost linear, rather acute: pappus of the fertile flowers less copious and little exceuling the involucre: akenes few-nerverl.

Sonthenstern borders of ('ulifornia, Ligelovo, Dr. Le Cunte, Pulmer. Also in Arizonah 


\section{Tribe IV. INULOIDEA.}

Heads heterogamous with the marginal or outer flowers pistillate (in the true Inulece radiate in the manner of Asteroidece, but there are none of these in California), or in our genera discoid, with wholly tubular corollas, but those of pistillate flowers mostly filiform or very slender, rarely homogamous and more or less diocious. Anthers appendaged at the apex, sagittate and the auricles acuminate or tailed (rarely only acute) at base. Branches of the style in perfect flowers margined with stigmatic lines up to the very apex, not tipped with an appendage: sterile flowers conmonly with undivided style. Akenes small, except in Adenocaulon. Leaves alternate, except in Psilocarphus. Flowers in the head all of one color.

\section{PLUCHEA, Cass.}

Head discoid, many-flowered, most of the flowers pistillate and with minutely 2-4-toothed corolla, a few hermaphrodite but sterile flowers in the centre with a tubular 5-lobed corolla. Scales of the involucre regularly imbricated, thin and dry (purplish), appressed, ovate or lanceolate. Receptacle flat, naked. Style of the hermaphrodite flowers minutely 2-toothed or undivided. Akenes small, 4-5-angled. Pappus uniform, a single series of fine capillary bristles. — Mostly glandularpubescent, with aromatic or heavy odor; the small heads in corymbose cymes, the flowers whitish or purple.

1. P. camphorata, DC. Annual herb, a foot or two high, with minute somewhat viscid pubescence: leaves oblong-ovate varying to broadly lanceolate, irregularly more or less toothed, nearly sessile, somewhat succulent: cyme corymbose, dense: involucre tinged with purple, minutely viscid-pubescent. - Torr. \& Gray, Fl. ii. 261.

Salt marshes, Bay of San Francisco (Pickering and Brackenridge, Bolander); San Diego, Palmer. Nevada and Arizona; also eastward along the whole Atlantic coast of the United States.

\section{TESSARIA, Ruiz \& Pavon.}

Head and flowers like those of Pluchea; but scales of the involucre of firm texture; the outer even coriaceous, broad and short, the innermost narrow and somewhat scarious. Pappus of the central flowers (in our species) of firmer bristles with abruptly dilated tips. - Silky canescent shrubby plants, with cymose or corymbose rather small heads of purplish flowers: all Western South American, except the following.

1. T. borealis, Torr. \& Gray. Shrub, with virgate branches, very leafy to the top: leaves lanceolate, very acute, entire, sessile, silvery-canescent : heads in a small sessile cluster terminating the branches: involucre broadly campanulate; its outer scales tomentose and ovate, the inner linear and scarious-fimbriate at the tip : receptacle not hairy: hermaphrodite flowers 6 to 8: the bxistles of their pappus more rigid and with conspicuously enlarged tips. - Emory, Rep. 143; Pl. Fendl. \& Pl. Wright.; Sitgreaves, Rep. t. 5. Polypappus sericeus, Nutt. Pl. Gamb.

Sandy borders of streams, from Ventura Co. (Fothrock) and southeastward (Coulter, Palmer) through Arizona and New Mexico. Called Cachimilla by the Mexicans, Arrowwood by travellers. 


\section{ADENOCAULON, T:0ok.}

Head discoid; the 4 to 7 marginal flowers pistillate; the 5 or 8 central ones sterile by the abortion of the ovary and stigma; both kinuls with nearly similar openfunnelform 4-5-lobed corolla. Involucre of 5 ovate herbaceous scales in a single series, reflexed in fruit. Receptacle flat, naked. Anthers sagittate at base, not tailed. Akenes oblong-club shaped, large, several times longer than the small involucre, obscurely few-ribbed, toward the summit beset with stipitate glands. Pappus none. - Herbs with slender paniculately branching stems, alternate and cordate or reniform thin leaves, which beneath are clothed with floccose white wool (as well as the stem), at least when young, long margined or winged petioles, and very small paniculate heads of whitish flowers; the peduncles beset with viscid glands. Hook. Bot. Misc. i. 119, t. 15, \& Fl. i. 308; Torr. \& Gray, Fl. ii. 94; Gray, Proc. Am. Acad. viii. 653 .

1. A. bicolor, Hook. Perennial, one to three feet high : leaves mostly deltoidcordate and more or less angulate-lobed, very white-woolly beneath, green and early glalurous above, 2 to 4 inches wide: upper part of the stem and especially the long and slender peduncles beset with stalked glands: akenes a third of an inch long or even more.

Redwoods, from Santa Cruz Co., also in the high Sierra Nevada, north to British Columbia, thence east to Lake Superior. Leaves rarely somewhat lyrate by a pair of small basal lobes. There are one or perhaps two nearly related species in Japan, Mandchuria, and tae Himalayas, and two in Chili.

\section{MICROPUS, Linn.}

Ifear iliscoil, several-flowered ; the pistillate flowers with filiform cornllit formins a singlo series, each wholly enclosed (except the branches of the style) in a con-

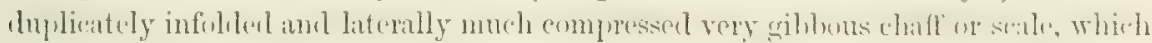
becomes firm-coriaceous or cartilaginous in fruit, and falls at maturity with the completely enclosed akene, inclined at length to dehisce into two valves: the hermaphrodite but sterile flowers, with 4-5-toothed tubular corolla, few and naked in the centre. Involucre of few scarious scales. Receptacle small and short. Akeno obovate and gibbous, laterally compressed, smooth, its apex (bearing the corolla and style) lateral. Pappus none - Low floceose-woolly annuals; with entire leaves, and the small heads in sessile elusters. - Benth. \& Hook. Gen. ii. 297 (excl. $\$ 3$ \& \$ 4); Gray, Proc. Am. Acad. viii. 651.

The genus belongs to the warm-temperate region of the Old World, excepting the following outlying but evidently indigenous species.

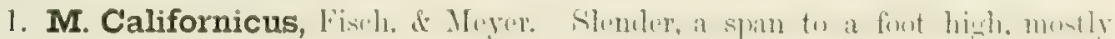
erect, simple or brunched, with rather close-presserl white wool: leaves linear: henils in lateral and terminal clusters which are inclined to be spicate: fructifernus scales very woolly, under the wool smooth and even, half-obeordate, and with a sululate beak terminating in a somewhat dilated scarions apex: embryo nealy straight. - M. (Rhynelonlepis) anqustiolius, Nutt.

Var. subvestitus, Gray: a form with smaller fructiferons senles, elothed with much less wool and that more appressed, so that the shape is distinctly seen: but it seoms to pass into the orlinary conlition.

Open groumis, common nesily throughout the length of the State, extending to the islumls off Lowel Califoruin; also in Oregon. Tho variety from Arroyo Grande, tho Cuntra Costa Inngere, \&e. 


\section{PSILOCARPHUS, Nutt.}

Head discoid, many flowered; the pistillate flowers with filiform corolla, numerous ( 20 to 40 , rarely 10 to 12 ), in several series on the depressed-globular-receptacle, each lonsely enclosed in an obovate or semi-obcordate hooded-saccate vesicular or inflated chaff or scale, clothed with soft wool, of membranaceous texture, its apex introrse and more or less beaked with a hyaline scale; the hermaphrodite but sterile flowers few and naked in the centre, with tubular 4-5-toothed corolla. Scales of the involucre few and small, scarious. Akene oblong or cylindraceous and moderately compressed, straight (its small areola terminal), small and loose in the sac of the scale, which is more or less open down the imner face. Pappus none. - Low and mostly depressed floccose-woolly annuals, with entire leaves, which are mainly opposite! Heads small, in terminal capitate clusters and in the forks of the branching stems, involucrate by the upper leaves. - Gray, Proc. Am. Acad. viii. 652.

Peculiar to Oregon and California, and one or two species in Chili. Ours appear to be reducible to two, from the first of which the Chilian $P$. globiferus differs, perhaps too stightly, in its broader leaves and proportionally wider as well as smaller akenes.

1. P. Oreganus, Nutt. Beset with loose white wool, especially the heads, becoming diffusely branched, mostly forming spreading tufts: leaves linear or the uppermost narrowly oblong: akenes cylindraceous and slightly compressed, about three fourths of a line long. $-P$. globiferus, Nutt. excl. syn.; a loose woolly form. $P$.brevissimus, Nutt.; dwarf-depauperate state of the same. $P$. Oreganus, Nutt.; a state with the white woolliness somewhat appressed.

Var. elatior, Gray, 1. c.: the most remarkable form, probably an unusually luxuriant condition, a span high, almost erect, with leaves nearly an inch long, and the cluster of heads large in proportion; as yet found only at Portland, Oregon.

Santa Barbara to Oregon near the coast, in low grounds along streams.

2. P. tenellus, Nutt. Canescently tomentose with finer and more appressed wool, which soon detaches from the slender or filiform diffusely very much branched stems, forming prostrate tufts a span or two in diameter: lower leaves spatulatelinear and the upper spatulate: heads smaller, in fruit 2 or 3 lines in diameter, but the fertile flowers quite as numerous : akenes fusiform-oblong, half a line long.

Low grounds, common from San Francisco, \&cc., southward.

\section{STYLOCLINE, Nutt, char. extended.}

Head discoid, many-flowered; the pistillate flowers with filiform corolla, several or many in 2 or many series on the columnar receptacle, each with the ovary and akene loosely enclosed in the base or body of an ovate broadly boat-shaped chaff or scale of the receptacle, of scarious or firmer membranaceous texture; the hermaphrodite but sterile flowers few in the centre, on the narrow summit of the receptacle, involucrate but not enclosed by 4 or 5 merely concave scales of the receptacle; their tubular corollas 4-5-toothed. Scales of the involucre hyaline and inconspicuous, or hardly any. Akenes obovate or oblong with a narrow base, slightly oblique or straight; the areola terminal. Pappus none to the akenes, commonly a few caducous scabrous bristles around the sterile flowers. - Low floccose-woolly anmuals, with entire and alternate leaves (in the manner of the tribe), and small heads in glomerate clusters. In affinity intermediate between the preceding genera and the next: Western North American, with one species in Affghanistan. Gray, 1. e. Micropus $\S 3 \& \S 4$, Benth. \& Hook. 1. c. 


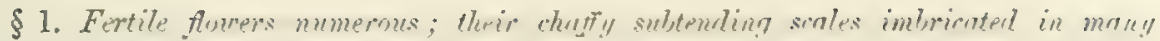
series in an ovoid head, thin, wholly or partly hyaline, those next the sterile flowers narrover but similar: pappus commonly present to the sterile flowers. - Eustyloclise, Gray. (Sitylodine, Nutt.)

1. S. gnaphalioides, X゙utt. I span or less in height. lowsily white-woilly, diffusely branched: leaves broadly linear or the upper oblong, obtuse (barely at quarter of an inch long): fructiferous scales lightly woolly on the back, broadly ovate, a firmer central portion at the base saccate and enclosing the akene; the remainder barely concave and hyaline. - Pacif. R. Rep. iv. 101, t. 13.

Open grounds, from the Stanislaus to Honterey, Nullall, Andreus, Bigclovo. Seldom collected ; appareatly not common.

2. S. micropoides, (iray: Lowrer : leaves linear and somenhat lancendate, acute: fructiferous scales ovate, with the whole lower portion boat-shaped and involving the akime, very wenlly on the back, except the upper expramed hyaline portion. - Pl. Wright. ii. 84.

Southenstern borders of California on the Colorado River (Acwberry), and through Arizona and New Mexico.

\$ 2. Fertile flowers 5 to 10 ; their chaffy scales in not more than two series, boatshaped and involving the akene, of firm membranaceous texture and with a small hyaline tip, as in Psilocarphus; the 5 uppermast scales sterile and larger, forming an involucre round the sterile flowers, herbaceo-coriaceous, oopen, tapering into a rigid incurved hooked cusp, persistent and at length stellately spreading. - Avcistrocarphus, Gray.

3. S. filaginea, tray, I. c. I span or less high, slemiler, erect, camesernt with

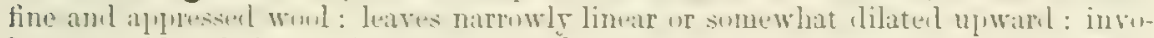
Incre outside of the woolly fructiferous scales obscure or none: pappus to sterile flowers none. - Ancistrocarphus filagineus, Gray, Proc. An. Acad. vii. 356.

Mendocino Co., at Round Valley, Eel River, Bolander. This curious little plant has the aspeet of Filago Gallica: the heads are inconspienous : the most prominent parts when developerl are the rigid sterile scales (about 2 lines long) with their hooked tips, adlapted to attuch the small plants, at maturity, to the fleece of sheep or the coat of eattle.

32. EVAX, Gsertn., subgenus HESPEREVAX, Gmy.

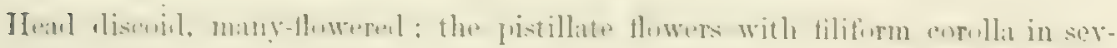
etal scries on a convex villous and centrally elevated columnar receptacle, each

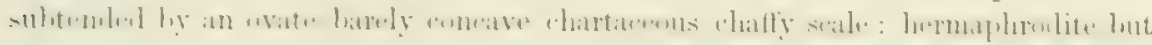
sterile flowers several $(6$ to 10 ) on the apex of the column of the receptacle, involucrate by a whorl of 3 to 5 thicker chaffy seales. Scales of the involucre few and resembling the chaff of the receptacle. Akenes obovate-oblong with a

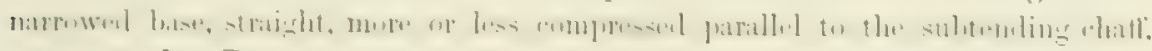
very smooth. Pappus none. - Gruy, in Pacif. R. Rep. iv. 101, t. 11; Proc. Am. Acal. vii. 356 , \& viii. 651 .

Erax is an Old-World genus, to which is apponded this peculine Californin type, apparentiy of $a$ single species.

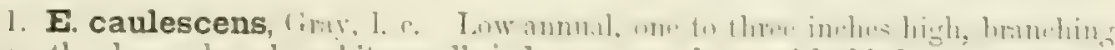
from the base, densely white-woolly: leaves spatulate, with blaclo a quarter to

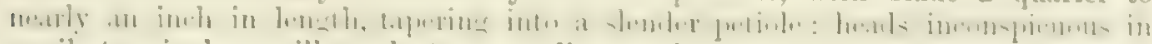
sessile teminal or axillary clusters, or solitary, n line or two in length : chatfy scales of the receptacle hecoming rigid, those surrounding the sterile flowers thicker aud woully insile. - Psilocarphens caulescens, Beuth. P1. Hartw. 319. 
Valleys in alluvial or gravelly soil, from Humboldt Co. and the Sacramento to San Luis Obispo. The specimens distributed under No. 415 of Kellogg and Harford's collection, with shorter and smaller leaves, have a very slender column to the receptacle, and less villosity. Bolander's from Mendocino Co., otherwise similar, have a shorter and thicker column, and much villosity-to the receptacle. In none is the column so thick as represented on the plate above cited.

\section{FILAGO, Linn.}

Head discoid, the pistillate flowers with filiform corolla few or many in more than one series on the obconical or short-columnar but flat-topped receptacle, each in the axil of a concave or boat-shaped hyaline chaff or scale, or nearly enclosed in it; the perfect and fertile or rarely infertile flowers several in the centre, with tubular $4-5$ toothed corollas. Akenes oblong, almost terete, commonly glandular or roughishpapillose. Pappus a series of rather copious capillary scabrous bristles, or commonly none to the outer pistillate flowers. - Mostly erect and low or slender floccosewoolly annuals, with alternate entire leaves, and small heads in capitate lateral and terminal clusters: natives of the old World, one or two sparingly naturalized and two indigenous in the New.

1. F. Californica, Nutt. Erect, a span or two high, slender, often paniculately branched: leaves linear or somewhat spatulate, about half an inch long: clusters of ovoid and sonewhat angled heads axillary and terminal: pistillate flowers 8 to 10 : their scales broadly ovate and deeply boat-shaped, very woolly outside, almost enclosing the akene, the hyaline tip broad and very obtuse: inner scales narrowly oblong, nearly glabrous, very obtuse: akenes glandular-roughish: pappus none to the exterior flowers. - F. Californica \& $F$. parvula, Torr. \& Gray. Gnaphalium (?) filaginoides, Hook. \& Arn. Bot. Beech. 359.

Open ground, common through the western part of the State, and evidently indigenous. Most like the European $F$. arvensis.

F. Arizonica, Gray, in Proc. Am. Acad. viii. 652, the second native species, collected in Arizona and Guadalupe Island, off Lower California, is a peculiar small species, with proliferous filiform naked branches, somewhat resembling $F$. spathulata, and is not unlikely to oceur in the southern part of the State.

\section{ANTENNARIA, Gærn.}

Head discoid, diœcious, many-flowered; the pistillate with filiform truncate corollas shorter than the 2-cleft style; staminate with tubular 5-lobed corollas and style with undivided truncate apex. Involucre of imbricated scarious persistent scales, at least their tips white or colored. Receptacle flat or convex, naked. Akenes small, nearly terete or flattish, mostly glabrous. Pappus a single series of capillary bristles; those of the fertile flowers very slender, connate at base and so falling from the akene in a body ; those of the sterile often crisped, mostly thickened at the apex, like the antennæe of some insects (whence the generic name). Low white-woolly cespitose perennials, with alternate entire leaves, and usually corymbose, sometimes solitary small heads; belonging to mountains or cold regions, excepting the common A. plantaginifolia, of the Atlantic States, which also extends westward and northward to Oregon. (The common Everlasting, A. margaritacea, is now included in the next genus.)

A. RACEMosA, Hook., of Oregon, \&e., is remarkable for little wool, loosely racemose or paniculate heads, bristles of the pappus rather less united at base, and style of sterile flowers slightly 2-lobed at the apex. 
\$ 1. Bristles of the papmus of the sterile fonwers hardly at all thiskened but sparsty barbellate at the summit; of the fertile flowers smouth: akene oblong-linear, cinereous with a minute pubescence, consisting of short bi-uncinate hairs!

1. A. cimorpha, Torr. \& Gray. Lejuressed, forming close matted tufts only an inch or two high: the thickish rootstocks creeping: leaves spatulate, silky-woolly both sides, crowded on the branches of the rootstock: heads solitary and sessile, proportionally laree, terminating extremely short or occisionally more developer (one or two inches long) leafy stems: scales of the turbinate involucre mostly glabrous, brownish; those of the sterile head ovate-lanceolate, of the fertile more narrowly lanceolate and acuminate.

On the Sierra Nevada, along the eastern border of the State; thence northward and eastward to and rather beyond the Rocky Mountains. There are two forms, one (var. Nultalli, Eaton, in Bot. King Exp.) with head only 3 or 4 lines long; the other (var. macrocephala, Eaton) with large head, the fertile when in fruit sometimes as much as 9 lines in length. On the Spipen River, Washington Terr, a var. (flagellaris) was gathered in the Wilkes Expedition, with filiform proliferous shoots or stolons.

\$ 2. Bristles of the pappus of the sterile flowers clavate or thickened at the apex: akene shorter, glabrous or minutely papillose: heads in a cluster (or occasionally solitary) terminating a leafy or rarely scupiform flowering stem.

* Cespitose by means of surculose or stolon-like leafy sterile shoots from the base: upright flowering stem simple.

2. A. dioica, Giertn. Thulical shonts forming broid matted tufts on the eroumel, bearing rosettes of spatulate or oblanceolate white silvery-tomentose leaves: Howering stems 2 to 10 inches high, bearing mostly linear leaves and several or numerous heads in a close corymb: scales of the involucre with obtuse or roundish mostly pearly-white but often rose-colored tips, of rather papery texture: bristles of the pappus of the sterile flowers abruptly clilated into a broad and flat tip.

Sierra Nevada above Yosemite Valley, and northward. Throughout the Rocky Mountains ani those of Nevada, Oregon, \&ce., usually at higher elevations than in the Old World : collected in the Klamath country by Dr. Cronkhile, and Sierra Valley by Lemmon, with bright rase-colored

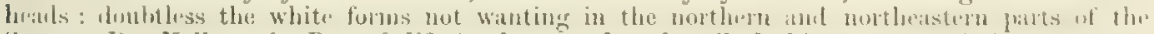
State. Dr, Kellogg, in Proc. Calif. Acad. v. 45, has described this as a Graphalium near $G$. purpurcum, viz. G. Nevaulcuse, Kiellogg.

3. A. alpina, Gertn. Radical shoots less tufted: leaves nearly as in the precerling, but less silvery: flowering stems an inch to 4 inches high, bearing a close cluster of fow heads, or sometimes a single head: scales of the involucte livil-brown and thin-searious (occasionally the innermost with white or whitish tips), acute or acutish in the fertile, more obtuse in the sterile heals: bristles of the pappus in the latter with less abrupt and broad tips.

Along the Sierra Nevada at 10,000 feet or more, and in the nlpine portion of the Rocky Mountains, extending to the aretic regions, also in the old World.

* * Destitute of stolons or prostrate sterile shoots, or with few very short ascending ones.

+ Stems simple and virgate from a rather stout rootstock, the naked summit bearing a corymb of broad heads: bristles of sterile pappus with conspicuously dituted tips.

4. A. Carpathica, R. Brown. Silvery white-woolly: stems a span to a font or more high: malical and lower leaves lancenlate and oblancelate, conspicuoushy 3-nerved; the upper becoming linear: heads large (at least the fertile ones 4 or 5

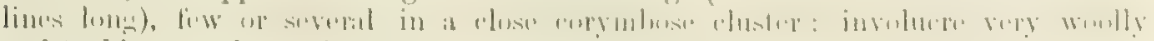
and turbinate at baso; its senles livid or brownish and in the sterile hends with oftuse white tips, those of the fertile heads more scarious and neutish or acute: akenes smooth and glabrous. - The form corresponding will tho Luropean plant abut a span high. 
Var. pulcherrima, Hook., is often a foot and a half high, with lowest leaves 3 to 5 inches long, and 3 to 12 lines wide; the uppermost reduced to linear or subulate bracts.

Not yet detected within the limits of Califoraia, the nearest stations being in the Havallah and East Humboldt Mountains, Nevada, Watson. The next much resembles it.

5. A. Iuzuloides, Torr. \& Gray. Silvery-silky : stems slender, 8 to 20 inches high: radical and lower leaves from linear-lanceolate to spatulate, obscurely 3-nerved, the others linear: heads small ( 2 or 3 lines long), numerous in a corymbose cluster: involucre nearly glabrous; its scales barely brownish at base, all with white (or rarely rose-colored) and rather papery tips, those of the sterile heads very obtuse, of the fertile less so: akenes glandular. - The typical form, with all the leaves very narrow, is known only in Oregon and Washington Territory.

Var. argentea, Gray, has all the lower leaves wider, oblanceolate or even spatulate, an inch or so long, 3 or 4 lines broad. - Pacif. R. Rep. iv. 54. A. argentea, Benth. Pl. Hartw. 319.

Mountains, Upper Sacramento to Mariposa Co., above the Yosemite Valley, \&c. Bristles of the pappus in the fertile plant very slightly united at base, much less so than in the American forms of $A$. Carpathica.

++ Stems simple or branched from a cespitose base, leafy: the heads panicled or racemose and narrow.

6. A. microcephala, Gray. Silvery-silky: stems slender, erect, a span high, leafy nearly to the summit: leaves narrowly oblanceolate, or the lower spatulate and the upper linear, above gradually reduced to small subulate bracts : heads small (about 2 lines long) and rather few-flowered, numerous in a loose naked panicle: involucre glabrate, of wholly scarious and thin obtuse scales, destitute of papery tips : akenes very glandular: pappus of fertile flowers not longer than the corolla, of the sterile with much dilated tips. - Proc. Am. Acad. x. 74.

Sierra Co. Lemmon: first detected in Washoe Valley, Nevada, by Mr. Slretch. Involucre light brownish, the tips of the inner scales sometimes rose-colored.

7. A. Geyeri, Gray. Densely white-woolly: branches barely a span high from a prostrate tufted base, very leafy to the top: leaves narrowly oblanceolate or spatulate, short: heads ( 3 or 4 lines long) thickish, cylindraceous, the fertile usually few and somewhat spicate, the sterile hardly more numerous and rather corymbose: involucre woolly below; the inver scales with glabrous obtuse papery tips, which are either ivory-white or deep rose-colored: bristles of the sterile pappus gradually and moderately thickened upwards. - Pl. Fendl. 107, \& Pacif. R. Rep. l. c.

Northeastern borders of California, Newberry. Sierra Co., Lemmon. Discovered by Geyer in the interior of Oregon.

\section{ANAPHALIS, DC. EverLasting.}

Heads discoid, incompletely diceious; viz. the pistillate with filiform 2-4toothed corollas very numerous, and a few (or occasionally no) hermaphrodite but sterile flowers, with tubular 5-lobed corollas, in the centre; the staminate nearly as in Antennaria. Involucre campanulate, of many ranks of mostly snow-white scarious scales. Receptacle flat, naked. Style in the staminate flowers usually 2-cleft merely at the apex. Pappus a single series of capillary bristles, unconnected at base, in the sterile flowers (at least in our species) slightly thickened upwards. - Perennials, all Asiatic (Himalayan, \&c.), except one species, with wholly the aspect of Gnaphalium, which is dispersed all round the northern hemisphere, especially through North America, viz. 
VW 1. A. margaritacea, Trnth. Thitewully, one to three feet hish, leafy up to the broad compound corymb: leaves lanceolate or linear-lanceolate, 2 to 4 inches long, mainly l-nerved, the upper face early becoming glabrous and green : scales of the involucre very numerous and pearly white, obtuse, not longer than the flowers. - Gnaphalium margaritaceum, Linn. Antennaria margaritacea, R. Brown, dc.

Thickets and open grounds, from near San Francisco northward, mostly in cool districts: apparently not abundant in California, but common in Oregon, as it also is in the Northern Atlantic States and in Northeastern Asia.

\section{GNAPHALIUM, Linn. Cudweed, Everlasting.}

Heals all alike, discuil, heterugamous; the pistillate flower's numerous in several series, with filifurm corollas; the perfect and lertile flowers fewer in the centre, with tubular 4-5-lobed corollas. Involucre campanulate or ovoid, of several or many ranks of scariuns or scarious-tipped scales. Recepticle Hat or comvex, naked. Sityle in perfect lluwers 2-cleft. Akenes oblung ur whrate. Paprus a single serips of carillary bristles, which are barely scabrous and uot thickened upwark. - Fluccust-wolly herbs, with alternate entire leares, and yelluwish or whitish fluwers.

A large genus, widely dispersed over the world, only a few of them North American.

\section{\$ 1. Bristles of the pappus unconnected, falling separately. - True GrapHaLIUM.}

* Heads or clusters terminating the erect stem or its branches: scales of the involucre very numerous and more or less bright-colored, white or whitish, rarely tinged rosecolor or yellowish, and glabrous except the base. (Hostly biennials?)

\section{+ Corymbose or sometimes densely glomerate heads broad.}

1. G. decurrens, Ives. Tiather stout, from one to nearly three feet high, viscid-glandular under the more or less decidnous or looso wool: leaves conspictiously decurrent, lanceolate or linear-lanceolate ( $1 \frac{1}{2}$ to 3 inches long, 2 to 4 liues broal), acute: heads very numerous in dense corymbose clusters : involucre brondly campanulate, white (sometimes becoming sordid); the scales oval or ovate. - The var. Californicum ( $G$. Californicum, DC.) has mostly a bright whito involucre, rarely tinged with rose-color; the scales obtuse.

Common on hillsides, from San Diego through Oregon, where it occurs with duller-white involucre, as in the G. decurrens of the Northern Atlantic States. Akenes smooth except under a strong lens, which shows minute scabrous points.

2. G. Sprengelii, IIwk. \& Irn. Commonly mether stout and striet, a span to

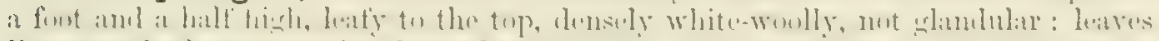

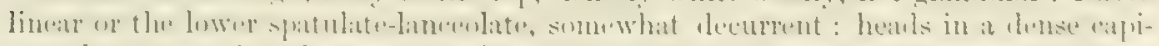

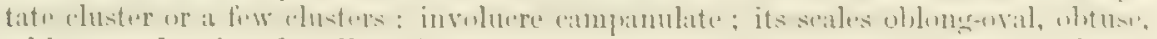
white, rarely tingal yellowish, often becoming rather sordid or tawny: akenes almost smooth. - Bot. Beechey, 150; Torr. \& Gray, Fl. ii. 427. G. luteo-album, mainly or wholly, of American authors.

Hillsides, \&e., apparently throughout the State, thenco northward to Oregon and eastward to New Mexico. G. huea-album, Linn. (which the more slender forms of this approash, and to which $G$. Vira-vira of Chili seems to belongs) is a weaker plant, with fewer elusters of lieads, morv tawny involuere, and akenes stuhled with glandular elevations. Very probably G. Sandwicensiun, Gitudichand, is an older uame of this species.

++ Paniculate malher than corymbose heads numons: stems at length loosely much branched.

3. G. microcephalum, Nutt. White-woolly, not glandular: stems a foot or Lwo high, stenter: leaves linear or the lower ublanceolate (an inch or so in length), 
slightly decurrent: heads in numerous small clusters terminating the paniculate branches: involucre cylindraceous becoming narrowly campanulate; the seales dull white, obtuse or acutish. - Nutt. in Trans. Am. Phil. Soc. n. ser. vii. 404; Gray, Pl. Wright., \&e.

Above the Yosemite Valley (Bolander), and Sierra Valley (Lemmon); perhaps also near Bay of San Francisco. Also in Oregon, Nevada, and east to New Mexico. Heads 2 or 3 lines long.

4. G. ramosissimum, Nutt. Visciu-glandular, green, lightly woolly : stems 3 to 6 feet high: leaves linear-lanceolate, acute, conspictously decurrent : heads very numerous and either separate or clustered on the loosely paniculate branches : involucre somewhat turbinate; the scales dull white and often tinged with rose-color, acutish. - Pl. Gamb. 173; Gray in Bot. Wilkes Exp. 363.

Bay of San Francisco to Monterey. Heads not larger than those of the foregoing species. The odor and the glandular herbage as in $G$. decurrens.

* Heads small, inconspicuous, in sessile lateral and terminal capitate woolly clusters, subtended by leaves: involucre of rather few and sordid or brownish scales: stems low and weak or diffuse, from an annual root.

5. G. palustre, Nutt. Loosely very woolly, an inch to a span high, mostly erect and branching mainly from thebase : leaves spatulate verging to lanceolate or linear: heads 2 lines long: scales of the involucre linear, obtuse, pale brown with whitish tips. - G. palustre \& G. gossypinum, Nutt. in Trans. Am. Phil. Soc. 1. c.

Common in moist grounds through the Pacific States, and eastward to and beyond the Rocky Mountains.

G. oLignosum, Linn., the common little Cudheed of the Eastern States and the Old World, has been credited to California, but probably by mistaking small forms of the foregoing, from which it may be distinguished by its juore diffuse growth, heads only a line long, and proportionally broader scales of the involucre, of a chestmut-brown color.

§2. Bristles of the pappus united at base into a ring: heads in axillary sessile clusters or spicate-glomerate: involucre as in the preceding subdivision (of brownish and not very numerous scales). - GAMOCHETA. (Gamochata, Weddell.)

6. G. purpureum, Linn. A span to a foot or more high, ascending from an annual or more enduring root, coated with appressed white wool: lower leaves spatulate, their upper surface often becoming naked and green; upper leaves mostly spatulatelinear, gradually diminished to bracts of the glomerate-spicate inflorescence, the lower small clusters of which are commonly rather distant: involucre tawny or brownish tinged with purplish.

Pacifie shore, from Columbia River to Santa Barbara (and again in Chili, \&c.), agreeing with the plant of the Atlantic coast. G. ustulatum, Nutt. l. c., from Santa Barbara, is probably the same, perhaps of the more southern G. spicatum form.

\section{Tribe V. HELIANTHOIDEE.}

Distinguished from Asteroidece chiefly by the chaff on the receptacle, at least next the margin, and subtending fertile flowers, pappus never capillary or of numerous bristles, and the leaves all or most of them opposite; the corollas commonly yellow; the branches of the style often truncate or tipped with a cone or cusp : from Helenioidea known by the chaff of the receptacle, \&c.

The first subtribe (Ambrosica, which might as well be regarded as a tribe) is most peculiar in the Artemisia-like hahit, and the few or solitary furtile flowers, with corolla wanting or reduced to a short tube, and leaves not rarely alternate.

The whole tribe is much more copiously represented in the Atlantic States than in California. 


\section{OXYTENIA, Nutt.}

Head heterogamous, discuid, about 5 marginal flowers pistillate and apetalons, consisting merely of ovary and 2-cleft style; the other flowers 10 to 20, staminate (their ovary and stigma abortive), with funnelfurm 5-lubed corolla and undiviled style, and nearly distinct anthers, these with blunt tips. Involucre of about 5 thin and broad scales. Receptacle chaffy, a spatulate villous scale subtending each or most of the sterile flowers and falling with them. Akenes obovate, turgid, beset with long villous hairs, crowned (at least when young) with a large and protuberant annular disk. Pappus hone. - Genus nearly related to the- next, of one species, viz.

1. O. acerosa, Nutt. Shrubhy, 3 or 5 feet high, whitened with a fine pulvescence: branches rigid, rush-like, mostly naked, terminated by the racemuse or paniculate-clustered inflorescence of small woolly heads: leaves as far as known alternate, either pinnately 3-5-foliolate or the uppermost simple and like the leaflets, i. e. very narrowly linear and revolute so as to appear filiform or acerose, 2 to 4 inches long, rigid. - Pl. Gamb. 172.

Southeastern borders of California and adjacent parts of Arizona, in a desert region, Gannbel, Licut. Whecler.

\section{IVA, Linn.}

Head heterogamous, discoid; a few marginal flowers pistillate and with a short tubular corollat the other and more numerous flowers staminate (their ovary am stigma alortive), with funnelform 5-lobed corollia and undivided style: anther's neirly distinct. Scales of the involucre few and mustly in a single series, commonly united into a cup. Reerptacle chatfy with linear or spatulate scales subtendinis sterile Howers. Lkenes obovate, thick, naked, often granulate; no disk at the aprex. - Leaves simple, at least some of the lower opposite. Heads small, nodding on short pedicels, either in the axils of the leaves, or in terminal spikes or panicles.

A genus of several species on the eastern side of the continent, one of which extends from the Missouri River to the Pacilic, viz.

1. I. axillaris, I'ursh. Peremial, hranching, a spon to a font and a half hish, varying from minutely hirsute to glabrous, and the sessile entire leaves from

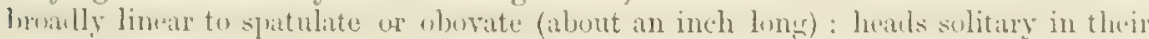
axils, hemispherical : scales of involucre about 5 , broad, united at base or beyond the micklle.

Vit. pubescens. Villous with lax sprealing hairs; the involucre turbinate am almost entire. - Gray in Bot. Wilkes Exp. 350.

Sandy and usually saline soil, near the coast, also along the western borders of the State, and north to British Columbia. The variety from Bay of Sin Francisco.

\section{HYMENOCLEA, Torr. \& Gray.}

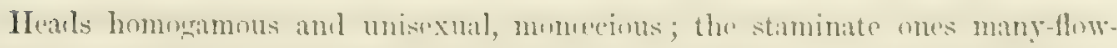

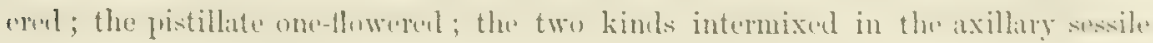
clusters, or the staminate in upper axils. Staminate flowers in a hemispherical head, with an open 5-6-lobed involucre, similar to those of Ambrosia (only the chalf of the receptacle is much dilated, and the inflexed tip of the anthers is blunt): pistillate flower solitary in a closed and akene.like involnere, which is pointed with a slember besk from the tip of which the style protrutes, its mildle ahormed 
with 9 to 12 broad and silvery-scarious persistent wings: corolla none. Akene as in Ambrosia, \&c. - Low and much branched shrubby plants, of arid deserts, Artemisia-like in habit; with alternate linear-filiform leaves, minutely canescent beneath, the lower sparingly pinnately parted, and small heads sessile in profuse panicled clusters. - PI. Fendl. 79 ; Torr. Pl. Fremont. t. 8.

1. H. Salsola, Torr. \& Gray. Fruiting involucre spindle-shaped and strobilelike, being covered with the spirally disposed orbicular scales (each a quarter of an inch long), which are imbricated when moist, but spreading when mature and dry.

Sandy saline uplands near the Mohave River (Fremont, Cooper), and through the desert interior to $\mathrm{N}$. W. Nevada, on the borders of California, Watson, Lemmon.

2. H. monogyra, Torr. \& Gray. Fruiting involucre smaller (2 lines long), bearing at the nuddle a single whorl of obovate or rhombic-reniform radiating scales.

River bottoms, San Diego (Cleveland), thence to the Gila : not rare in Arizona, \&c. Plant 3 to 5 feet high. The young plant so named in the Botany of King's Expedition belongs to the preceding species.

\section{AMBROSIA, Tourn. RAGWEED.}

Heads homogamous and unisexual, monюcious (sometimes nearly diœcious); the pistillate one-flowered, mostly in the axils of upper leaves; the staminate severalflowered in panicled or single terminal racemes or spikes, without bracts. Staminate flowers in an open several-lobed or almost entire truncate herbaceous involuere, subtended by slender or filiform chaff; their corollas broad and 5-toothed; their anthers almost distinct, tipped with a slender-acuminate inflexed appendage; ovary and stigma none or rudimentary; style with truncate tip radiately fimbriate. Pistillate flower in a closed akene-like one-celled involncre, which at maturity is armed below the short rigid beak with a single row of 4 to 8 tubercles or short spines, or sometimes naked: corolla none. Akene ovoid or obovate, thick: pappus none. Weedy coarse annuals, or perennials, with mostly lobed, pinnatifid, or pinnately divided and cleft leaves, the lower at least opposite; the small heads greenish, or the sterile flowers barely yellowish. Chiefly American and widely diffused, but apparently very scanty in California.

1. A. artemisizfolia, Linn. Annual, 1 to 3 feet high, roughish-hirsute: leaves thinnish, twice pinnatifid: fruit (i. e. fruiting involucre) smooth below, not reticulated, armed with about 6 very acute horns or spines.

This, the common Roman Wormwood or Bitterweed of the East, can hardly be absent from California S. Watson collected it in Nevada, and others in Oregon.

2. A. psilostachya, DC. Peremnial, more strigosely hirsute than the foregoing, with thicker and less divided leaves, the upper only once pinnatifid: fruit puberulent, rugose-reticulated, without horns or spines, or with short and rather blunt ones. - A. coronopifolia, Torr. \& Gray, Fl. ii. 291.

San Luis Rey (Coutter, Parry); Bay of San Francisco (Pickering and Brackenridge); San Diego Co., Palmer. Also in Nevada, and thence eastward to Texas and Illinois.

\section{FRANSERIA, Cav.}

Heads, flowers, \&c., as in Ambrosia, except that the fertile involucre is armed with more than one rank of prickles or spines, and is 1-4-celled and 1-4-flowered. - All American herbs or suffrutescent plants; the greater part North American west of the Mississippi. 
\$ 1. Fertile intolucre 1-2-celled, armed with sermel stout or futtenat und straight or merely curved spines.

* Annual: spines on the fruit very flat and broad.

1. F. Hookeriana, Nutt. A foot or so bigh, rough-hirsute: leaves twice pimnatitid, either green or strigosely hoary beneath: racemes panicled: fruiting involucre smooth or sometimes sparingly hirsute, about 3 lines long; its widely spreading spines lanceolate-subulate and thin. - Ambrosia acanthicarpa, Hook.

Los Angeles, Brever. Eastern borders of the State, Mlono Lake, Bolander. Thence common to Uregon, T'xas, Netraska, se. Involucte apparently always one-Howered and one-celled.

$$
\text { * * Perennial, sometimes woody at base. }
$$

+ Leaves twice or thrice pinnately parted, their ultimate divisions small.

2. F. dumosa, Gray. Shrubby and divergently much branched, a font or so high, canescent with tine and close white pubescence : leaves with rather few obtuse

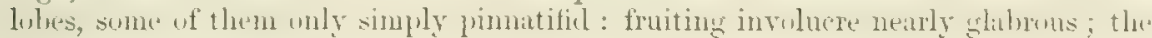
spines flat and subulate. - Rep. Frem. 2nd Exp. 316. F. albicaulis, Torr. Pl. Fremont. 16.

Gravelly plains, southeastern borders of the State, Coulter, Schoolt, Cooper, \&c. Also in Arizona.

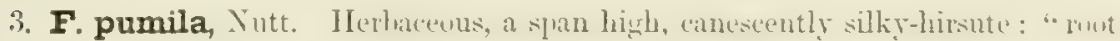
creeping": leaves thrice pinnatifid, the lobes crowded: spike dense: "spines of the fruit not exserted." - Nutt. in Trans. Am. Phil. Soc. n. ser. vii. 344.

Near San Diego, Nuthll, Parry. All the specinens seen are young, and the fruit unformed.

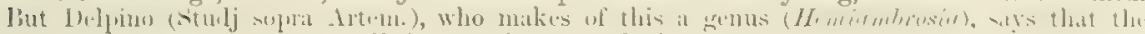
uprer fertile involueres are 2-celled and 2-flowered, the lower one-celled and one-flowered. Nut-

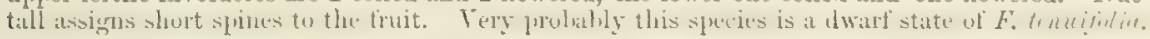

4. F. bipinnatifida, Nutt. Terbaceots: stems decumbent or trailing, 2 (n) 3 feet long, somewhat hirsute: leaves twice or thrice pinnatifid, canescently hirsute or

In almost silky: spike dense: fruiting involucre nearly glabrous; its spines rather short, stout, conical-subulate, flattened.

Along the ser-shore from San Diego to British Columbia. Fruiting involucre 4 or 5 lines long, rather narrow. Perhaps, as Lessing supposed, a form of the next.

$$
++ \text { Leaves undivided or merely incised. }
$$

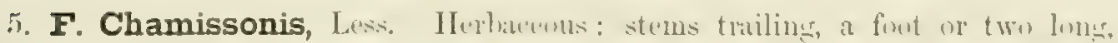
stout, appressed-hirsute: leaves silky-canescent or silvery, varying from oval to

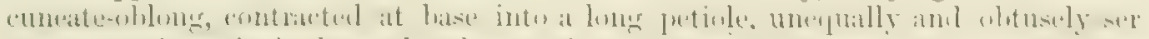

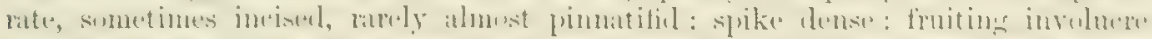

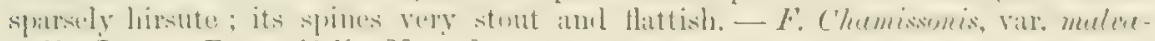
folia, Less. F. cuneifolia, Nutt. 1. c.

Sea-shore, in saml, from San Francisco north to British Columbia.

6. F. deltoidea, Tort. Herbaceous with more or less woody base, low, canescent with a tine and close woolliness, which is partly deciduous with age: bmuches slencler: leaves varying from eleltoid-ovate or almost hastato to rhombic-lanceolate, obtusely and finely serrate, sometimes sparingly incised, on slender petioles : sterile heads rather loosely racemed: spines of the ovoid 2-flowered involucre flat and thin, broally lanceolate subulate, pubescent or almost glabrous - Pl. Frenont. 15, \& But. Mex. Buunel. 86.

Southerstern frontiers of the State: eommon on the Giln: also in Lower California if, ns is

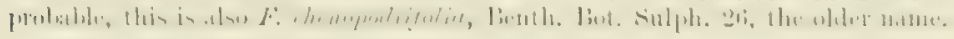

7. F. eriocentra, Gray. Shrubby, low, houry-pubescent: branches slenter:

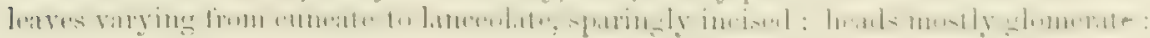
finiting involucre and its rigid nearly tercte subulate spines clothed with long villous wool. - Proce. Ant. Acal, vii. 3is. 
Southeastem borders of the State : eastern slope of Providence Mountains, Cooper. On the Colorado, Newberry. Fruiting involucre in the specimens examined one-celled and one-seeded.

\section{\$2. Fertile involucre mostly 2-celled and 2-flowered, small, armed with short and stout incurved hook-tipped spines: leaves dissected.}

8. F. tenuifolia, Gray. Herbaceous, apparently perennial : stem erect, 1 to 3 feet high, hirsute : leaves twice or thrice pinnatifid or dissected, strigosely pubescent or hirsute, or sometimes even canescent beneath; the ultimate divisions linear; small lobes often interposed on the rhachis: sterile spikes simple and elongated or paniculate: fertile involucres glomerate, at maturity only one or two lines long, ovoid or globular, minutely pubescent: its short and stont subulate spines more or less incurved and with unciuate tips. - Pl. FendI. 80 ; Pl. Wright., de.

Southeastern borders of the State, thence eastward to the Gulf of Mexico : also in the Sandwich Islands, and in Lower California, Cape San Lucas, Xrentres. Doubtless it is also F. hispida, Benth. Bot. Sulph. (although that is said to have sometimes four flowers in the involuere) : but the present name will still hold, as Ambrosia tenuifolia, Spreng., is, it appears, the very same species.

\section{§ 3. Fertile involucre 2-4-celled, 2-4-flowered, thickly beset (like Xanthium) with slender and rather soft hook-tipped prickles.}

9. F. ambrosioides, Cav. Tall, 4 to 6 feet high, with a woody base, hirsutepubescent: leaves oblong-lanceolate with mostly truncate or cordate base, acuminate, unequally toothed, 3 to 5 inches long, the petiole sometimes wing-appendaged at base: sterile raceme rather loose: fruiting involucre balf an inch long, minutely hispid.

Occurs near the southeastern and the southern frontiers of the State, and probably within its linits. Not rare in Mexico.

\section{XANTHIUM, Toum, COCKLEBdR, ClOTBUR。}

Heads homogamous and unisexual, monocious, in axillary or terminal clusters or short interrupted spikes; the pistillate 2-flowered and underneath the severalflowered staminate. Staminate flowers as in Ambrosic, except that the involucre is of several distinct and narrow scales, and the receptacle more or less elevated, its chaff broader. Pistillate flowers enclosed in a bur-like ovoid or oblong closed indurated involucre, which is 2-celled, 2-flowered, and armed all over with strongly hook-tipped prickles: corolla none. Akenes obovoid, thick: pappus none. Coarse and vile annual weeds, with alternate petioled leaves; the three or four species perhaps all natives of America, but now widely dispersed over the world; probably none indigenous to California.

1. X. strumarium, Linn. Stems a foot or two high, not prickly : leaves deltoid-ovate or somewhat cordate, irregularly serrate, often slightly incised, rough and green both sides, on long petioles : fruiting involucre over half an inch long, thick, tipped with a pair of strong beaks, pubescent or sometimes hispid between and on the lower part of the crowded prickles.

Waste ground near dwellings, \&c.; also on the sea-coast. The common Cocklebur, apparently less common than at the east; but both the ordinary form occurs and var. echinatum, Torr. \& Gray, with thicker and glandular-hispid involucre.

2. X. spinosum, Linn. Hoary-pubescent: sterns much branched, bearing long and yellowish triple spines by the side of the leaves: these lanceolate or ovatelanceolate, canescent beneath, often $2-3$-lobed or cut, tapering into a short petiole: fruiting involucre narrow, half an inch or less long, more sparsely prickly, the beak inconspicuous.

Sea-coast, San Juan, \&c. ; also in the foot-hills, Calaveras Co. : introduced from Chili. 


\section{RUDBECKIA, Linn. CONE-FLOWER.}

Head many-flowered, heterogamous, with neutral ray-flowers, rarely homogamous by the absence of these; disk-flowers perfect. Involucre of foliaceous commonly unequal scales in one or two series, mostly spreading. Receptacle remarkably elevated, in ours columnir, at least at waturity, su that the [rerfect flowers are spicate; each flower subtended or partly embraced by a chaff. Rays long and nearly entire. Disk-corollas cylindraceous, 5-toothed. Akenes quadrangular and mostly laterally compressed, smooth, crowned (in our species) with a persistent chaff-like cup or 4 chaffy teeth wore or less united into a cup. - Chiefly perennial herbs, with alternate leaves, disk-flowers from dark brown to greenishyellow, and mostly yellow rays; all North American, but only two west of the Rocky Mountains.

1. R. Californica, cimy. Sitem simple, abunt 3 feet high, $3-5$-lenvel, the: long and naked peduncle-like summit bearing a single large head: leaves finely soft-pubescent, 3 to 5 inches long, varying from ovate to oblong-lanceolate, acuminate, pinnately veined, sonewhat toothed; the middle ones sometimes with a pail

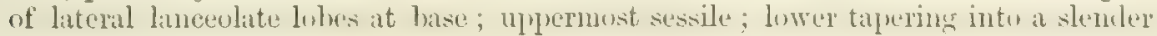
petiole: scales of the involucre linear: rays 2 or 3 inches long, narrowly oblong, yellow: disk columnar, one or two inches long, dusky brownish: akenes com-

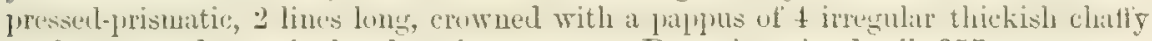
teeth more or less unital at base into a cup.-Proc. Am. Acad. vii. 357.

Wet grassy places in the Sierra Nevada: at the Mariposa grove, Bolander. Previously collected by Bridgcs, perhaps in the same district.

: $\quad$ R. occideNTAuIs, Nutt., of Oregon and Utah, differs in its smooth and more numerous as well as broader leaves, and has no rays at all.

\section{BALSAMORHIZA, Hook., Nutt. BALSAM-Root.}

Head many-flowered, heterogamous, with fertile ray-flowers, and perfect diskflowers. Involucre hemispherical or broader, of more or less imbricated scales, the outer loose and herbaceous or often foliaceous. Receptacle flat or barely convex,

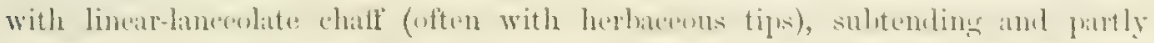

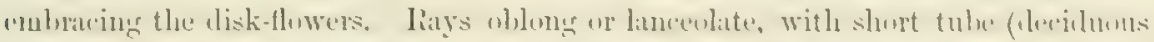

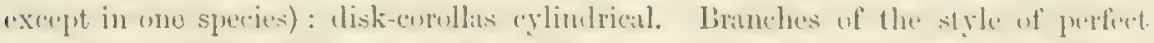

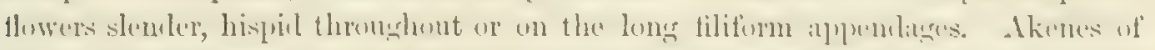

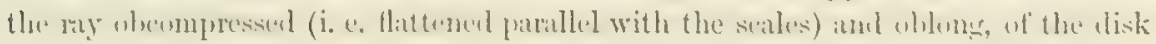
prismatic-quadrangular or moro or less compressed. Pappus none. - Low perennials of Wistern Korth Aneriea, mestly of the arit flitins; with thick terebinthime

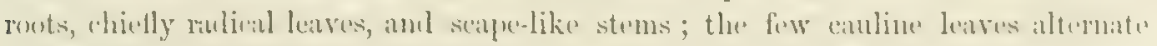

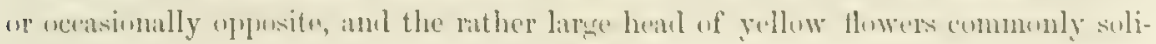
tary. (Named from the resin or balsam of the root.)

The thick roots, or tubers, from which sometimes the turpentine-tasted resinnus bark is peelel, aro cookerl for fool by the Indians, especially in Oregon, under the nanes of Pash, Kuyoum, \&e. The seets are also enten. - Besides the species here duscribed,

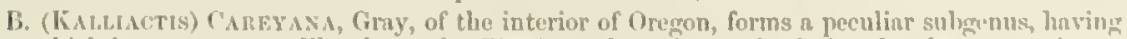
rays which become papery, like those of a Zinnice, and prersist on the fruit ; the akenes are cinerwous-pulyescent and all fundrungulis, those of the my less flattened (olvompressed) than is conmon in the genus. The stem, moreover, bears severul hesuls.

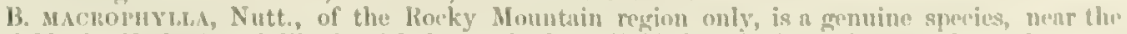
variable B. Howkeri, and like it with leaves both undiviled and pinnately parted on the sane?

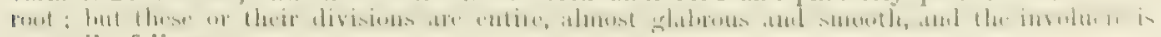
generally foliaceous. 
1. B. Hookeri, Nutt. Canescent with fine mostly soft and close pubescence: leaves usually once or twice pinnately parted or divided, lanceolate in outline, a span to a foot long, spreading; the divisions crowded, commonly incised: scapes naked or 2-leared near the base, equalling or surpassing the leaves in length, bearing a single head: scales of the involucre linear or lanceolate, acuminate, rarely some of the outermost broader and foliaceous. - Heliopsis (?) balsamorhiza \& terebinthacea, Hook. Balsamorhiza Hookeri, terebinthacea, hirsuta, \& incana, Nutt. in Trans. Am. Plill. Soc. n. ser. vii. 349.

Hills near Oakland, Kellogg. Near Sonoma, Bigetons (wrongly named B. macrophylla). On the eastern side of the Sierra Nevada, Bloomer, Anderson, Lemmon. Common on the plains of Nevada, Oregon, \&c. B. hirsuta is a form with more hirsute pubeseence: $B$. incana, a variety remarkable for its soft and white wool : $B$. terebinthacea, with roughish pubescence, has some of the leaves merely incised or sharply toothed, others piunately-parted or pinnatifid.

2. B. sagittata, Nutt. Silvery-canescent with dense mostly appressed soft wool : leaves entire, cordate-sagittate or sometimes deltoid-hastate, 4 to 9 inches long, on still longer petioles, all radical, or one or two small lanceolate petiolate bracts on the scape, which bears a single or sometimes 2 or 3 heads: involucre mostly very woolly. - Buphthalmum sagittatum, Pursh. Espeletia sagittata \& helianthoides, Nutt. in Jour. Acad. Philad. vii. 38. Balsamorhiza (Artorhiza) sagittata \& helianthoides, Nutt. in Trans. Am. Phil. Soc. l. c.

Eastern side of the Sierra Nevada, on the borders of the State, \&c. (Anderson, Bloomer, Watson); thence to and beyond the Rocky Mountains from Colorado to Idaho and Dakotah.

3. B. deltoidea, Nutt. Green and more or less pubescent, or almost glabrous: leaves deltoid-cordate or more broadly and deeply cordate, more or less serrate, occasionally entire, 3 to 9 inches long and on longer petioles, all radical, or 2 or 3 small ones or bracts on the scape: heads solitary or rarely a pair: scales of the involucre lanceolate or linear, obtuse. - B. glabrescens, Benth. Pl. Hartw., is only a smoothish form, with leaves entire.

Moist ground, from Tejon and Ojai to Humboldt Co. and Oregon. Akenes flat, those of the disk compressed; of the ray obcompressed; as they are in all these species.

4. B. Bolanderi, Gray. Glabrous or glabrate, somewhat glutinous; a span to a foot high, with mostly scales instead of leaves from the rootstock: leaves about 3 , alternate along the stout stem, cordate or ovate, entire, 3 or 4 inches long, on moderately long petioles: head solitary, short-peduncled; outer scales of the involucre oval or ovate-lanceolate, actuminate or acute, foliaceous; the inner ones narrow and very villous, resembling the chaff of the receptacle. - Proc. Am. Acad. vii. 356.

Auburn (Bolander), and on the Upper'Sacramento, Fremont, Rich. Head large. Akenes flat, of the disk compressed, of the ray obeompressed.

\section{WYETHIA, Nutt.}

Head many-flowered, heterogamous, with fertile ray-flowers and perfect diskflowers. Involucre hemispherical or campanulate, of 2 or 3 series of scales; the outermost foliaceous and often enlarged, the innermost mostly smaller and chaffy. Receptacle flat or nearly so ; the rigid linear or lanceolate chaff subtending the diskflowers flattish or partially folded around the akenes. Rays elongated : disk-corollas cylindrical, 5-toothed, glabrous or nearly so. Branches of the style in perfect flowers produced into subulate-filiform hispid appendages. Akenes prismatic-quadrangular, or those of the disk laterally compressed, and with obtuse or acutish angles, nervose, their broad summit continued into a persistent and firm chaffy-coriaceous crown or cup, which is unequally cleft into 5 or more lobes or teeth, or is 


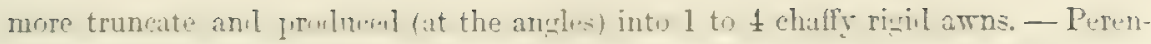

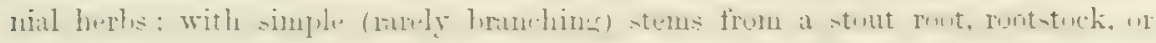

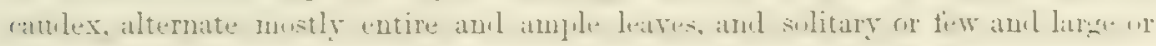
middle-sized heads of yellow flowers. - Nutt. Jour. Acad. Philad. vii. 38, \& Trans. Am. Phil. Soc. 1. c. 351 ; Gray, Proc. Am. Acad. viii. 65t. Alarçania, DC. Prodr.

A genus of several species, all natives of the region betreen the Rocky Mountains and the Pacific; - dedicated hy Nuttall to Captain W yeth, with whom he afterwards crossed the continent, and by De Candolle, two years later, to Hernando de Alarcon, a noble Spanish navigator who first (in 1540) risited and survered the coast of California. It is to be regretted that the genus cannot commemorate one of the earliest explorers of the country : but the name may designate a section.

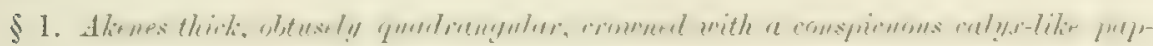
pus of ovate or lanceolate coriaceous teeth more or less united at base into a cup: heads very large and broad (the disk $1 \frac{1}{2}$ to 2 inches in diameter); involucre open and leafy. - ALARçosis, Gray.

1. W. helenioides, Nutt. Suft-tumentusw, ur with agr beconin! almust glitbrous, a foot or two high: leaves oblong or oval; radical ones a foot or more long, 4 to 6 inches wide; cauline about half the size, all contrasted at base into a short

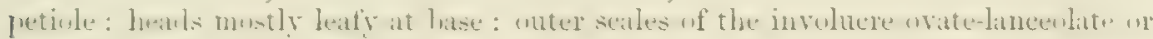
ovate, sometimes toothed: akenes more or less pubescent at top when young. Gray, Pl. Fendl. 82. Alargonia helenioules, DC. Melarhiza inuloides, Kellogg.

Hillsides; common near San Francisco and through the valley of the Sacramento. Akenes half an inch and the pappus 2 or 3 lines long. Teeth of the corolla ovate-lanceolate, somewhat hairy outside.

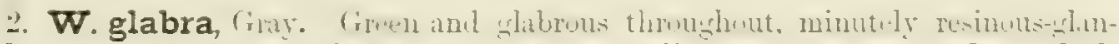
dular or viscill: leaves otherwise as in the preceding, or more commonly toothed,

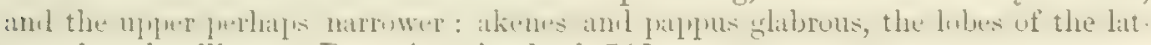
ter minutely ciliate. - Proc. Am. Acal. vi. 543.

Hillsides, San Luis Obispo to Marin Co. (A specimen from Bolander's collection is said to come fiom Mlount Dana, at 12,000 feet; but some error is to be suspecteil.) Heads nearly ats large and leafy as in $W$. helenioides, the bracts or leafy involueral seales often surpassing the rays. Disk-corolla with ovate wholly glabrous teeth. Foliage said to have a viseid exudation of agreeable odor.

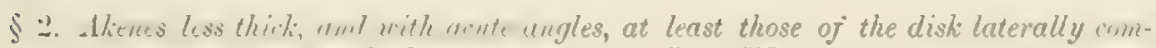
pressed: heads less large. - True WretmL.

* Involucre hemispherical or broader: pappus short and aumless.

3. W. ovata, Gray. Tomentose with soft pubescence: stem 2 feet or more

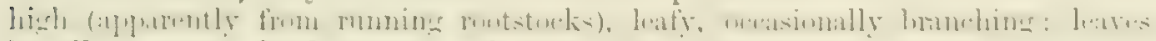
broadly ovate or the larger somewhat corkate, acute or acuminate, 3 to 6 inches long, all petioled: involucro an incli in diameter; its scales broally lanceulate, seldom equalling the disk-flowers, mostly with a coriaceous erect base and more

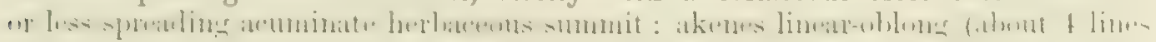
long), minutely pubescent, crowned with a pappus of 6 or 8 short and hroul nnequal chatly teeth, all of them somewhat united at the base. - Proc. Am. Acal. vii. 357.

Dry hillsiles, Mariposa Co., from the font-hills to above the Yosemite, Bridges, Bolander, de. Rays 10 to 24, about an inch long.

* Invaluere narmo, of rather few erect scales: pappus 1-4-anned.

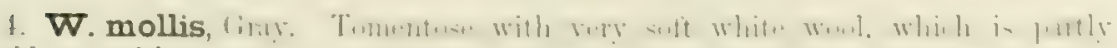
dechluous with ago: strms 2 or 3 feet high, often branching abovo and hearing 2 to I racemose naked heads, mather leafy: leaves ohlong or sumetimes ovate, 3 to 9

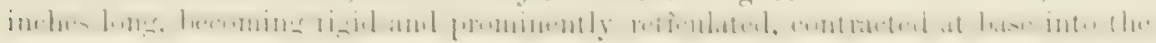


petiole, or the uppermost with rounded or almost cordate base : involucre campanulate; its scales 10 to 12 , ovate-lanceolate or oblong-lanceolate, mostly herbaceous, and longer than the disk-flowers: rays 10 to 15 : akenes linear-prismatic (5 lines long), minutely pubescent at summit, crowned with a very short truncate chaffy cup and 2 or in the ray 3 to 5 subulate awns. - Proc. Am. Acad. vi. 544.

Sierra Nevada, from above the Yosemite to Mono Lake, Mount Dana, Sonora Pass, \&e., and adjacent parts of Nevada. Involucre about an inch long, commonly very white-woolly, sometimes, like the whole plant, glabrate. Said to grow in large patches.

* * Involucre broadly campanulate, of numerous loose scales : pappus 1-4-awned.

5. W. angustifolia, Nutt. Green and hirsute, at least the simple stems, a span to 2 feet high: leaves elongated-lanceolate, acuminate at both ends, occasionally serrulate; the radical and lower ones a span to a foot long; the upper sessile, shorter and often broader: head naked: scales of the involucre numerous, broadly linear or lanceulate; most of them herbaceous or foliaceous, loose, eiliate with villous or hirsute hairs: akenes ( 3 lines long) minutely pubescent at summit, bearing one or two (or those of the ray 3 or 4 ) stout minutely hirsute awns, with some very short intervening chaffy scales, more or less united at base (rarely awnless). - Alarconia angustifolia, DC. Wyethia angustifolia \& W. robusta, Nutt. in Trans. Am. Phil. Soc. vii. 352. Helianthus longifolius, Hook. H. Hookerianus, DC.

Plains and hillsides, from Monterey east to the foot-hills and north to Oregon. A rather common and variable species. There are indications of an allied species in the foot-lills of Mariposa and Tuolumane Counties.

W. HeLIANThordes, Nutt, his original species, which is imperfectly known, but resembles $W$. angustifolia, with a more leafy stem, and

W. AMplexicaulrs, Nutt, which is very smooth and glabrous, with upper leaves closely sessile (both with commonly awnless pappus), inbabit a region northeast of California, but have not been found very near the borders of the State. Their thick roots or rootstocks are used for food by the Indians, along with those of Balsamorhizo.

\section{VERBESINA, Linn.}

Head many-flowered, heterogamous with fertile rays, or rarely by their abortion homogamous; the disk-flowers perfect. Involucre of numerous or rather few scales. Receptacle convex or conical; the chaff embracing the akenes. Akenes flat (laterally much compressed) and winged on the margins, or those of the ray wingless. Pappus of 2 awns, either free from or united with the wings. - Chiefly herbs; with opposite or alternate leaves, and mostly yellow flowers; natives of the warmer parts of America : only the following reaches the borders of California - Benth. \& Hook. Gen. ii. 379 .

1. V. encelioides, Benth. \& Hook. Anpual, more or less hoary-pubescent, or sometimes smoothish and green: stem loosely branching, a foot or two high: leaves triangular-ovate or somewhat cordate, or the upper nearly lanceolate, coarsely and incisely serrate, and with interrupted margined or winged petiole dilated at base into a toothed or laciniate foliaceons clasping auricle: heads large, corymbose: scales of the hemispherical involucre loose ; the outer set linear-lanceolate and acuminate, foliaceous, fully equalling the flattish disk: rays numerous, cuneate-oblong, bright golden yellow, 3-lobed at summit: disk akenes surrounded by a broad whitish and thickish wing, which at the summit is little if at all exceeded by the short and very slender awns of the pappus. - Ximenesia encelioides, Cav. Ic. ii. 60, t. 178 ; Torr. \& Gray, Fl. ii. 359.

On the Rio Colorado, or at least through that region all the way to Texas, and the northern provinces of Mexico, now widely diffused over the warmer parts of the world, and not rare in gardens. The wild plant along our borders is mostly a low and caneseent form (var. cana), but it becomes luxuriant and greener in moist and richer soil. 


\section{ENCELIA, Adanson.}

Heal many-flumerl, heterumuns, with several or numernus nentral rays, or rarely homucramons, the rays wanting; disk-Howers perfect. Involuere hemispherical or campanulate, of more or less imbricated and herbaceous scales. Receptacle flat-

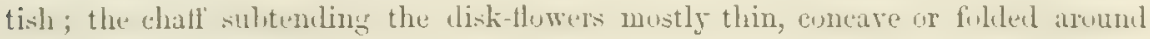
the akenes. Disk-corollas cylindraceous or somewhat funnelform, 5-toothed.

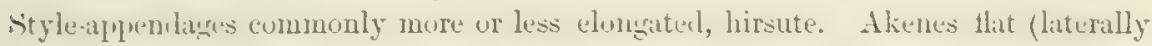
much compressed) and thin-enged, but wingless, whovate or oblongroval with more or less emarginate or bilentate summit, long-ciliate or maked. Pappus nume or a pair of awns; no intermediate stales. - I'erenuial herbs, or with shrubhy lase fall American and chietly Thestern); with "pposite or alternate aml simple but sometimes lobed leaves, and midelle-sized or pretty large slenter-peluncled hems of ehiethy yellow Huwers, those of the disk occasionally brownish or purple. - Benth. \& Houk. Gen. ii. 378 (incl. Geraea, Barattia, \& Simsia); Gray, Proc. Am. Acarl. viii. 656.

\section{\$1. Akenes villous-ciliate: pappus none, or mere mudimentary auns to the abortive ray-akenes: leaves all or all but the very lowest allernate. - True ExcEuld.}

1. E. Californica, Nutt. Wouly at hatse, 2 to 4 feet high, strong-seenterl;

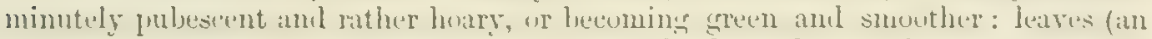
inch or two long) varying from ovate to broadly lanceolate, entire or occasionally repani-toutherl, rather indistinetly 3.ribined from the base, abruptly petioled, the broader ones rounded at base: involnere white-villous: rays numerous, an inch long, 2-4 toothed at the end: akenes obovate, very long-villous on the callous margins, the notch at summit very shallow.

Dry hills near the coast, Santa Barbara to San Diego, and thence to the Gila, where it is variable, often smaller, depauperate, apparently including all that has been referred to $E$. conspersa, Benth., of Lower California. Akenes less emarginate and leaves less narrowed at base than in the Chilian E. oblongifolia.

2. E. farinosa, (iray. Shruhby at the lase, silvery-enuesent with a dense and furfuraceous white tomentum, wholly glabrons where this is deciluous: leaves ovate or ovate-lanceolate with mostly cuneate base, entire, obtuse, 3-ribbed at base:

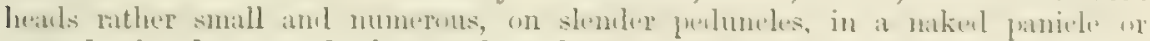
corymb: involucre much shorter than the disk: rays 6 to 10 , barely half an inch

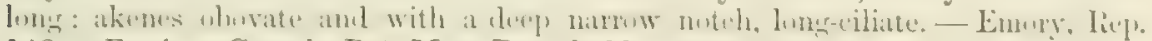
143. E. nivea, Gray in Bot. Mcx. Bound. 88, not of Benth.

Southeastern Californin, and adjacent parts of Arizona, Couller, Parry, Newberry, Cooper.

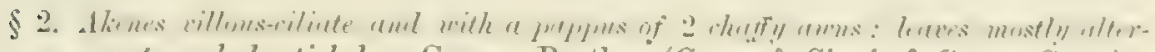
nate, naked-petioled. - Gerea, Benth. "(Gerca \& Simsia \$ Gerax, Gmy.)

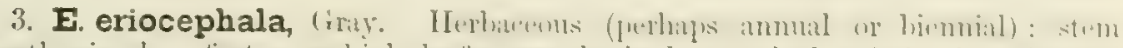

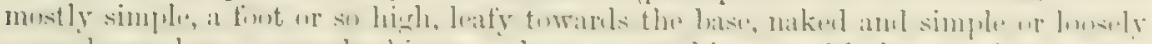

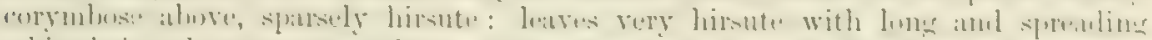

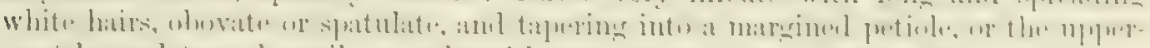

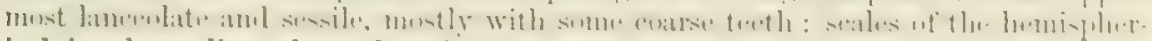
ical involucre linenr-lancenlate, loose, green and somewhat villous (as well as glanlular) on the back, densely villous-ciliate with very long white hairs: rays 12 or more, oblong-obovate, nearly entire: akenes cuneate-obovate, very villous on the

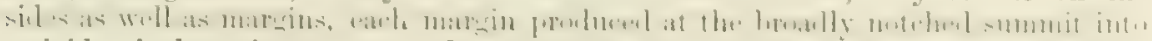
a riginl naked persistent awn. - Proe. Am. Acal, viii. 657. Gercen crnescens, Torr. \& Gray in Proc. An. Acad. v. 48. Simsin (Gevene) canescens, Gray, Pl. Fenell. 85.

Fort Mohave, Fort Yuna, and elsewhere along the Colomilo and vicinity, Cutler, Frement, 
Newberry, Schott, Cooper, \&c. This must be a showy plant, with its (mostly corymbose) heads adorned with broad golden yellow rays (less than an inch long), and underneath the green scales of the involucre fringed with long white hairs. The original specific name is changed on account of the old Encelia canescens.

4. E. frutescens, Gray. Shrubby below, hispid-scabrous, loosely much branched, . 2 or 3 feet high: branches terminating in single long-peduncled heads: leaves small (rarely an inch in length), oblong or ovate, sometimes slightly cordate, entire or obscurely toothed, short-petioled: heads small: involucre scabrous-hispid or canescent: rays 6 to 12 , cuneate-oblong and 3-4-lobed, sometimes wanting: akenes obovate and with a shallow notch, glabrous on the sides, very villous on the margins and the rather short or unequal (occasionally obsolete) persistent awns. Proe. Am. Acad. viii. 657. Simsia (Gercea) frutescens, Gray, Bot. Mex. Bound. 89.

Gravelly ravines, \&c., southeastem borders of California and adjacent parts of Arizona, Nevada, and Utah, Fremont, Emory, Newberry, \&ce. Cordilleras near San Felipe, Sutton Hayes.

\section{HELIANTHELLA, Torr. \& Gray.}

Head many-flowered, heterogamous, with rather numerous neutral rays and perfect disk-flowers. Involucre hemispherical, of Ioosely imbricated linear-lanceolate scales; the outer mostly foliaceous and attenuate-acuminate; innermost shorter and somewhat chaffy. Receptacle flat or convex : chaff embracing the akenes. Diskcorollas cylindraceous, 5-toothed; the teeth puberulent-bearded. Style-appendages hirsute, mostly short and obtuse. Akenes flat (laterally much compressed), obovate or oblong, with thin and acute or narrowly wing-margined edges, and commonly emarginate summit. Pappus an awn or chaffy tooth from each margin, and with intermediate (often very small) thin chaffy or almost setiform scales, both occasionally almost obsolete. - Perennial (North American) herbs; with both opposite and alternate entire leaves, large and chiefly solitary and long-peduncled terminal heads of yellow flowers, and the general habit of Helianthus or Wyethia. - Torr. \& Gray, Fl. ii. 333 ; the second section including the typical species; with leaves lanceolate or broader, and commonly triple-ribbed near the middle.

1. F. Californica, Gray. Minutely hirsute-pubescent: stems slender, one to three feet high, occasionally branched : leaves spatulate-lanceolate, mostly opposite, all tapering into petioles: head often foliaceous-bracted: rays seldom much if at all longer than the involucre: chaff obtuse: akenes obovate, smooth and glabrous throughout, narrowly margined, minutely ciliate when young only near the summit: pappus of two short triangular or subulate chaffy teeth and a crown of minute squarnellæ, nearly obsolete at maturity. - Pacif. R. Rep. iv. 103.

Napa Valley, Bigelow. Near Clark's, Mariposa County, A. Gray. Sierra Valley, Lemmon.

H. LAvceolata, Torr. \& Gray, which has akenes naked and with a pair of slender awns but hardly any crown; H. UNIFLORA, Torl. \& Gray, with large head, akenes silky-villous on the face as well as margins, a pair of stout awns, and a conspieuous crown of long and narrow squanella between them; and possibly H. PARRYr, Gray, with much smaller heads, nartower leaves, but similar akenes, yet shorter or obsolete awns (at least its variety multicaulis, $H$. multticaulis, Eaton in Bot. King Exp.), occurring north and east of California, may be found near its borders.

\section{HELIANTHUS, Linn. SUNFLOWER.}

Head many-flowered, heterogamous, with neutral ray-and perfect disk-flowers. Involucre hemispherical or broader, of imbricated scales, more commonly with narrow herbaceous or foliaceous tips. Receptacle flat or convex, with chaff embracing the akenes of the disk-flowers. Rays mostly entire: disk-corollas cylindrical, 5-toothed. 
Branches of the style tipped with a subulate hispid appendage. Akenes thick, commonly obovate-oblong, either 4 -angled or somewhat lenticular, laterally more or less compressed, the edges obtuse as well as marginless. Pappus caducous, of 2 chaffy awns or pointed scales, one from each principal angle of the akene, sometimes with two or more very small and thin intermediate scales, which are equally caducous. - Coarse annuals or perennials, with entire or merely toothed leaves, at least the lower ones mostly opposite, and solitary or somewhat corymbose heads, of large or midule size. Rays yellow : disk yellow, brownish, or sometimes dark purple.

A genus of nearly threescore species, all American and chiefly temperate North American, most of them in the Atlantic United States, very fow in California

* Annuals, with leaves 3-ribbed at base, all but the lowest usually alternate: receptacle flat : disk brownish or dark purplish.

1. H. annuus, Liun. Large, hispid and rough : leaves deltoid-ovate and the lower more or less cordate, acuminate, 3 to 7 inches long, all petioled: scales of the involucre ovate or ovate-lanceolate, abruptly slender-acuminate: chaff of the receptacle shorter than the flowers: akenes in the wild plants appressed silky-pubescent, 2.1 to 4 lines long: pappus of 2 chaffy scales. - The wild plant, with peduncles

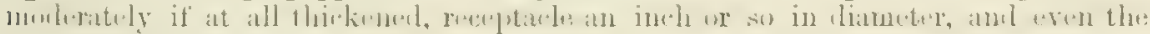
lower leaves not much corlate, is $H$. lenticularis, Dougl. in Bot. Reg. t. 1265.

Banks of streams, and open places, in the eastern and southeru part of the State, more common

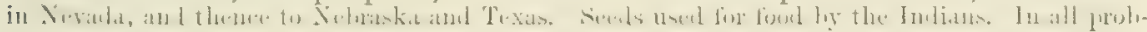
ability this wild sunflower of the plains is the origimal of the long-cultivated $H$. annurs. A specimen from Fort Tejon, by Xantus, would be referred to that species.

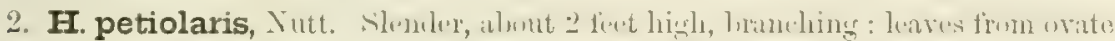

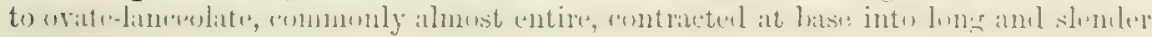
petioles : head rather small : acuminate tip of the chaff of the receptacle not longer than the flowers: akenes more or less appressed-pubescent.

Occurs sparingly in the eastern and southern parts of the State and Nerada : common in Utah nnd eastwarl almost to the Mississippi. Seemingly passes into depaupcrate forms of tho prececling.

3. H. Bolanderi, Gray. Stem hirsute, branching, 2 feet or moro high: leaves ovate-lanceolate or the lower rhomboid-ovale, acute or acuminate, very sharply and coarsely serrate, on slender petioles: heads somewhat panicled, short-peduncled: involucre loosely hirsute; its seales linenr-lanceolate, attenuate-acuminate, loose, foliaceous, longer than the disk, mostly ergualling the 10 or 12 mys : chaft" of the receptaclo entire or nearly so, tipped with an awn exceeding the dark-purple corollas: akenes silky-pubescent : pappus of 2 subulate chafly awns. - Proc. Am. Acad. vi. 544.

Lake County, at the Geysers, Bolander. Also collected by Bridges, but habitat unknown. Heads small. Leaves 3 to 5 inclues long, on petioles of about hall their length.

4. H. exilis, (irny, l. c. More or less hirsute: stems slender, branching, a font high: leaves linear-oblong or lanceolate, nearly entire, obscurely 3-nerved at base, tapering into a sliort petiole: heals very small, on slender sometimes leafy-bracted peduncles: scales of the involucro nearly as in the preceling : mys 5 to 8 : chaff of the receptacle produced into an awn-like cusp which equals the dark-purple corollats: akenes nearly glabrous: pappus of 2 ovate-lancedate chafty scales.

Wet plsees around Clear Lake, Bolander. Long Vnlley, Mendocino Co., a lnrger form, one or two feet high, Fellogg. Heuds 4 to 6 lines ligh. $A$ form, prohally of this species, with event

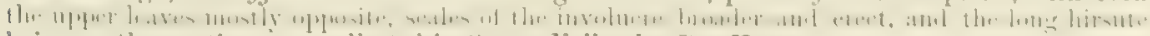
hairs mostly wanting, was collected in Owens Valley by Dr. Hurn.

$$
\text { * Peremials: recepucule convex: disk dull yelloro. }
$$

D. H. Californicus, DC. Stem glabrons, mither slender, 2 to 5 feet high,

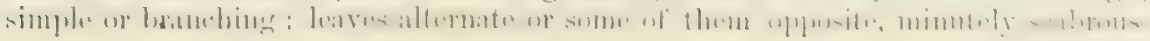


pubescent, short-petioled or nearly sessile; the lower lanceolate or sometimes ovatelanceolate and acuminate, either entire or obtusely serrate, 4 to 8 inches long; the upper usually smaller and more narrowly lanceolate, entire : heads mostly on slender rather short peduncles: scales of the involncre slender, linear-lanceolate, tapering into long and spreading acuminate tips: rays 15 to 20 , an inch or more long: chaff of the receptacle blunt: akenes very flat, glabrous: pappus of 2 or 3 lanceolate chaffy scales. - H. giganteus, var. insulus, Kellogg in Proc. Calif. Acad. v. 17.

Along streams, common near San Francisco, \&c.; extending into the foot-hills of the Sierra Nevada up to 4,000 feet. Rootstock thick and tuberous, with a terebinthine juice or exudation. Sides of the akene flat and entirely destitute of angles. Larger leaves triple-ribbed.

H. NutTaLlix, Torx. \& Gray, which grows in N. W. Nevada, has more slender stems, more linear leaves, scales of the involucre hirsute-ciliate towards the base, chaff of the receptacle acute, pappus more slender, and akene (when young) with evident lateral angles.

\section{VIGUIERA, HBK.}

Head, flowers, \&e. as in Helianthus, but usually of smaller size; imbricated invoIucre less herbaceous; receptacle inclined to be conical ; and, especially, the pappus less deciduous or even persistent, consisting of 2 or more scarious chaffy scales on each side between the awns. - Chiefly tropical or subtropical American : only one species has actually been observed within the limits of the State.

In Lower Califormia (Cape San Lucas) there are a few species, such as $V$. deltoidea and $V$. tomentosa, Gray in Proc. Am. Acad. v. 161, and $V$. subincisa, Benth., which may be related to the following.

1. V. laciniata, Gray. Shrubby (?), minutely scabrous-hispid, branching : leaves on the branches alternate, ovate-lanceolate or obscurely hastate in general outline, incisely lobed or pinnatifid, tapering at base into a short petiole, coarsely reticulateveined, sparsely papillose-hispid: heads corymbose, less than half an inch long: involuere short; its scales oblong-ovate and coriaceous: flowers yellow: rays 8 to 10 : receptacle convex: pappus apparently deciduons; its chaffy awns about the length of the sparingly ciliate akene; the truncate intervening scales conspicuous, more or less confluent into one on each side, and erosely fimbriate at summit. - Bot. Mex. Bound. 89.

East of San Diego, Schott, Newberry. Cleveland. Apparently a low bushy plant, shrubby at base, and with slender herbaceous branches.

2. V. nivea, Benth. (?) Silvery-white with appressed and dense silky puhescence (hairiness rather than tomentum), low or procumbent: leaves ovate, entire or nearly so, 3-ribbed at base, the lower ones opposite: peduncle slender, mostly bearing a single head: scales of the involucre ovate-lanceolate, silky-tomentose, in about 2 series, rather loose : chaff of the involucre rather shorter than the flowers: rays 10 or 12, yellow: akenes (ovaries) oblong, somewhat villous: pappus of a few thin and small chaffy scales and a pair of chaffy awns, or sometimes the awns reduced to scales and not longer than the hairs of the ovary, deciduous. - Encelia nivea, Benth. Bot. Sulph. p. 27 (?). Helianthus (Harpalium) tephrodes, Gray in Bot. Mex. Bound. 90. Bahiopsis lanata, Kellogg in Proc. Calif. Acad. ii. 35 (?).

S. E. California, at Mirasol del Monte, in the desert, Sehott. An incomplete specimen, probably identical (although the leaves are mostly alternate) with Bentham's Encelia nivea of Lower California, which he supposes may be Kellogg's Batiopsis lanata, of the same region, and would now (in Gen. Pl. ii. 376, 378) refer to Viguicra.

\section{PUGIOPAPPUS, Gray.}

Head many-flowered, heterogamous ; the rays 7 to 10 , more or less pistillate and fertile; disk-flowers perfect. Involucre broadly campanulate, double; the outer of 4 or 5 loose and somewhat folinceous, the inner of mostly 10 thinner, and rather 
longer erect scales. Receptiule flat; its chaft thin and scirrious, linear ur lance late, deciduous with the fruit. Rays mostly broad and truncate, obscurely 3 -4-lobed or crenate, many-nerved. Disk-corollas with a short-bearded or beardless ring at the summit of the slender tube; the dilated limb 5-lobed. Style-branches of the ray-flowers often short and included; of the disk-flowers tipped with a very short cone or nearly truncate." Akenes obcompressed, flat, oval or oblong; those of the ray broader, glabrous or nearly so, more or less wing-margined; those of the disk wingless, villous or ciliate, coherent at base with the subtending appressed chaff.

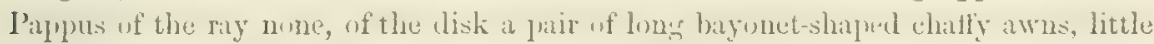
shorter than the corolla. - Glabrous annuals, all Califormian; with alternate leaves once or twice pinmately parted into linear löbes, and showy heads of golden-yellow flowers, terminating long naked peduncles. - Gray, Proc. Am. Acad. viii. 659. Agarista, DC. ; Torr. \& Gray, Fl. ii. 337, not of Don. Pugiopappus, Gray in Pacif. R. Rep. iv. 48, \& Proc. Am. Acad. vi. 545.

This genus and the next take the place of Corcopsis in California.

Coreorsis AtKinsonian, Dougl, the only species known to oecur west of the Roeky Mountrins, - a species which resembles the well-known $C$. tinctoria of the Arkansas region, common in all gardens, - belongs to Oregon, and may be expected in the bordering part of Calitornit.

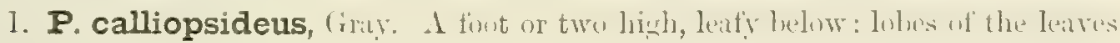
linear: heid large: scales of the outer involucre ovate, united at base: rays obovatecuneiform: ray-akenes with a thin winged margin; those of the disk clothed with very lung villous hairs on the margins and inner face. --Agarista calliopsidea, DC. Prodr. v. 569. Coreopsis calliopsidea, Bolander, Cat. Pl. San Fraucisco.

Moist hillsides and plains, from the Bay of San Francisco southward. Variable in size : mys from half an inch to an inch long, and from 4 to 10 lines wide. Disk-carollas with a shortbearded ring on the tube.

2. P. Breweri, firay, 1. c. Munch smaller than the preenline, with finer divisions to the leaves: scales of the uuter involucre linear: rays rather narrow: akenes of the disk long-villous on the margins and the midule of the inner face, otherwise glabrous : chalfy awns of the pappus stouter, only half the length of the akene.

Dry hills near San Buennventura, March (Brenocr) ; San Bernnrino desert, Parry. Rays half or two thiris of an inch long, 2 to 4 lines wide : disk-corollas with a beardless ring. Ray akenes nearly as in the next; those of the disk more like those of the preceding, except in their smaller size.

3. P. Bigelovii, Gray, 1. c. A span high, leafy only at the base: the small head on a nearly naked seape: leaves almost simply pinnately parted iuto a few narrowly liuear rather fleshy divisions: scales of the outer involuere broally linear: mys broad: ray-akenes narrowly ablong, roughish, and with thickish wing-like margins; those of the disk slightly ciliate.

Dry plains, on Mohave Creek (Bigelore) and Fort Tejon, Dr. Horve. The plant from Sum Bunenn. ventiva, inadvertently referred to this species in Proc. $\Delta \mathrm{m}$. Arad. $\mathrm{v} .645$, is the preceding. The head of this only half as large. Rays quadrate-oblong, 4 or 5 lines in length. Ring on tho tube of disk-corollas distinct but beardless. Akenes of the disk inclined to be sterile; but this is also tho case in the first species.

\section{LEPTOSYNE, DC.}

IIead many-flowererl, heterogamons; the rays several or numerous, pistillate: lisk-fluwers perfect. Involuere double; the outer of 5 to 8 narrow and lonso foliaceous scales; the inner of 8 to 12 erect more membranareous scales. Receptacle nearly flat; its chaff thin and sarious, linenr or lanceolate, decidwons with tho fruit. Rays oblong or obovate, 3-toothed or lohed at the end, 10-nervel. Disk- 
corollas with slender tube girt by a ring at the summit, and a fumelform or more dilated 5-lobed limb. Style-branches of the disk-flowers truacate-capitate or tipped with a very short cone; those of the rays little exserted. Akenes obcompressed, flat, more or less wing-margined, similax in disk and ray. Pappus none, or a minute callous cup. - Low glabrous annuals, or larger and more enduring plants. with thickened succulent stems, all Californian; leaves chiefly alternate, once to thrice pinnately parted into narrow linear or filiform lobes; the showy heads of yellow flowers terminating long naked peduncles. - Gray, Proc. Am. Acad. viii. 657. Tuckermannia, Nutt.

Coreocarpus (with ACoMA), Benth. Bot. Sulph., contains two or three still obscure species of Lower California, allied to this and the preceding genus, but not very likely to occur within the limits of the State.

\$. Annuals, a span or more high, with long naked peduncles: heads an inch or an inch and a half in diameter, including the oblong or cuneate-obovate more or less 3-lobed rays: scales of the outer involucre linear. - True Leptosyne.

1. I. Douglasii, DC. Leafy only at the base: the peduncles all scape-like: disk-corollas with a conspicuously bearded ring: akenes sparsely beset with capitate rigid bristles, the winged border at length very thick and corky, the summit with an entire cup-like ring in place of pappus.

Dry or sandy soil, from near San Francisco (?) to San Diego. Except in the southern part of the State apparently less common than the next.

2. I. Stillmani, Gray. Stems more leafy below: involucre commonly somewhat hairy at base: disk-corollas beardless: akenes surrounded by a thick and corky rugose wing, smooth and glabrous except the inner face, which mostly becomes sparsely papillose, and often bears a row of tubercles on the midnerve: the cup in place of pappus either entire or 2-lobed. - Bot. Mex. Bound. 92.

Hillsides and plains, Valley of the Sacramento to the Bay, \&c. : the common species in the central part of the State. Rays somewhat cuneate-obovate.

3. I. Newberyi, Gray. Leafy only at base: the peduncles scape-like: diskcorollas with a shorter tube bearing an inconspicuously bearded ring: akenes (young) with a very thin wing, both faces minutely glandular-bristly, the cup at the summit obscure. - Proc. Am. Acad. vii. 358.

Sitgreaves Pass, on the Colorado, Newberry. Camp Grant, Arizona, Palmer. Perhaps not within the State.

\section{\$2. Succulent thickened stems or rootstocks perennial, leafy, often branched: leaves rather fleshy: heads large. - Tuckermannia, Gray.}

4. I. maritima, Gray. Stems rather low, herbaceous, from a fleshy tuberous base or caudex: peduncles a span to a foot or more long: heads (including the narrowly oblong slightly 3 -toothed rays) 3 or 4 inches in diameter : ring of tube of the corolla naked: akenes smooth and glabrous, bordered by a narrow thinnish wing or margin, wholly destitute of pappus. - Proc. Am. Acad. vii. 538; Regel, Rev. Hort. 1872, with plate. Tuckermannia maritima, Nutt.; Torr. \& Gray, Fl. ii. 355 ; Torr. Bot. Mex. Bound. 92, t. 31.

Sea beach at San Diego, and on the islands. A striking and showy plant. In cultivation a short naked awn is rarely produced from each margin of the akene!

5. I. gigantea, Kellogg. Stems shrubby or fleshy-woody, 2 to 8 feet high and 1 to 5 inches in diameter, leafy at the top: heads numerous and corymbose, rather short-peduncled: inner scales of involucre with a prominent midrib: divisions of the leaves more filiform.

San Miguel and Santa Barbara Islands, Harford, Capt. Forncy. Guadalupe Island, Palnuer. 


\section{BIDENS, Linn. BUR-MLARIGOLD.}

Hent many-fluwered, heterogamms and the 3 to 10 ralys neutral, or homoramons and the flowers all perfect and tubular. Involnere double; the outer of a few mostly foliaceous loose or spreading scales; the inner of several erect and more membranaceous scales. Receptacle flat or convex; the thin narrow chaff deciluous with the

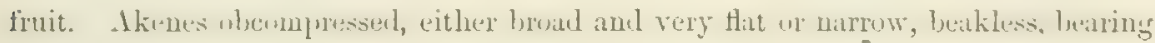
a pappus of 2 to 4 rigid and retrorsely barbed awns. - Anuual or peremnial herbs;

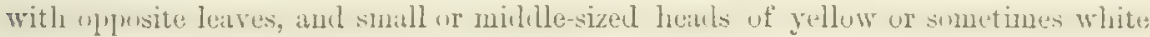
flowers; some of them vile weeds. The species are numerous, and very widely distributed over the world, but thore are remarkably few in California or in the Pacific region.

$$
\text { * Akenes broad: leaves merely serrate. }
$$

1. B. chrysanthemoides, Michx. Inmul, ulalurous, leafy to the top, a fuit or two high: leaves broadly lanceolate, tapering to both ends, closely sessile, serrate, 3 to 5 inches long: heads rather large and showy: scales of inner involucre broad: rays 8 to 10 , golden yellow, oblong or oval, an inch long: akenes wedge-shaped; their margins and the 2 to 4 rather long awns barbed with rigid or almost prickly reflexed bristles.

Wet places, apparently not rare through the western part of the State. Extends to Mexico, and is common in all the Atlantic States.

13. CERvoA, Linn., a tall variety of which gTows in Oregon, has smaller leaves, heads without rays, or with short ones of lighter yellow, and smaller barbs to the akene and awns. The two perhays run together. The plant named $B$. cermua by Hooker and Arnott, in the Botany of Beechey's Voyage, is probably the preceding.

\section{* Akenes long and narrow (Spanish Needles): leaves divided or componnd.}

2. B. pilosa, Linn. Annual, more or less hairy, or merely the leaves sparsely pubescent: these 3-parted or the lower 5-parted into ovate incisely cleft or sharply serrate thin leaflets: heads small, without rays or with 2 or 3 small and whitish ones: akenes linear, smooth, or the onter ones upwardly hispir-scabrous, at least towards the summit, 2-4-awned. - B. Californica, DC. Proulr. v. 599. Torr. di Gray, Fl. ii. 35 t.

Sinta Barbara to Los Angeles, near water-courses, \&c. A weed, widely diffused over tho warmer consts, especially of the Pacific : if correctly indentified with $B$. pilosia, doubtless introduced with cattlo into California.

Heternspersug Xastr, Gray, of Lower Californin, resembles a Bidens with finely divided leaves, and is intermediate between the two genera.

\section{BLEPHARIPAPPUS, Hook., Torr. \& Gray.}

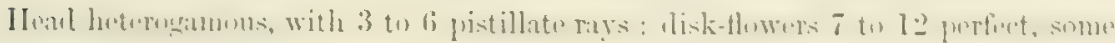
of the central infertile. Scales of the involucre 6 to 10 , nearly in a single series, lanceolate, crect, almost equal. Receptacle convex, chaffy; the chaff thin and membranaceous, deciduous with the fruit. Rays short and broad, cuneiform, 3-

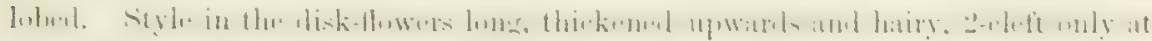
the apex (the branches olutuse ani not appendaged), or in the central and sterile? flowers nearly entire. Akenes turbinate, silky-villons. Pappus of 10 or 12 linear liyalino scales, traversed by a stout awn-like millrib, the margins lacerately fringed so as to appenr plumose, rarely wanting. - Anumal, corymbosely or puiculately branchen; both ruys and disk-corollas white; tho anthers brown-purple. Only one variable species. 
1. B. scaber, Hook. A span to a foot high, rough-pubertilent and somewhat hispid, above more or less glandular: leaves alternate, narrowly linear and with margins revolute (or small ones on the brunchlets involute) : heads a quarter or less than half an inch long, terminating slender branches.

Var. lavis, Gray: a form with the leaves, at least those of the branches, almost smooth and much appressed.

Var. subcalvus, Gray : a state with the pappus both of ray and disk reduced to minute hyaline vestiges, hardly exceeding the hairs of the akene.

Sierra Valley, and along the eastern ranges of the Sierra Nevada: common through the interior in Oregon and Nevada. Var. lovvis is No. 118 of Bridges coll. in herb. Kew, referred to under Hemizonia in Gen. Pl.; the locality not recorded. Var. subcalvus, Sierra Valley, Bolander, Lemmon: apparently mixed with the common state.

\section{MADIA, Molina. TARWeEd.}

Head few-many-flowered, heterogamous, with 1 to 20 pistillate rays, or rarely the rays entirely wanting; the disk-flowers hermaphrodite, either fertile or sterile. Involucre a'single series of herbaceous scales, which are carinate and conduplicate, enclosing as many akenes, their free tips erect or involute. Receptacle flat or convex, with somewhat herbaceous chaff between the ray- and disk-flowers, usually more or less united into a cup, otherwise naked or fimbrillate-hirsute. Rays more or less cuneiform, 3-lobed at summit. Akenes linear-oblong or clavate-oblong, incurved or nearly straight, laterally compressed, minutely many-striate, glabrous (those of the ray with flat sides), wholly destitute of pappus, or in one section a chaffy-plumose pappus to mostly stexile disk-flowers. - Glandular and more or less viscid heavy-scented annuals; with linear or lanceolate entire or slightly toothed leaves, at least the upper alternate; and either peduncled corymbose, or panicled, or clustered heads of yellow flowers, opening at evening, early morning, or in cloudy weather. All natives of the Pacific States, one species also in Chili. - Benth. \& Hook. Gen. Pl. ii. 293; Gray, Proe. Am. Acad. ix. 187. Madia, with Madaria (DC.), Anisocarpus (Nutt.), Amida (Nutt.), \& Harpacarpus (Nutt.), Torr. \& Gray, Fl.

§ 1. Rays conspicuous and mostly numerous (9 to 20): disk-flowers also numerous but sterile, or the exterior ones fertile, with pubescent corollas. - MADARIA.

* Disk-flowers with a pappus composed of fimbriate or plumose-lacerate and slender
chaffy scales. (Anisocarpus, Nutt.)

1. M. Nuttallii, Gray. Hirsute : stem slender, a foot or two high: all the lower leaves opposite, denticulate or occasionally beset with slender salient teeth: heads rather small and paniculate, terminating slender glandular peduncles: scales of the involucre with short inconspicuous tips, rather large for the size of the head: fertile akenes obovate-falcate, the many-striate sides nerveless; those of the disk all abortive : pappus very much shorter than the corolla. - Gray, Proc. Am. Acad. viii. 391, \& ix. 188. Anisocarpus madioides, Nutt.

In woods, not rare from Monterey to Oregon. Leaves 2 to 5 inches long, 2 to 6 lines wide, thin. Rays half an inch or less in length, cuneiform, strongly three-lobed, twice the length of the involucre.

2. M. Bolanderi, Gray. Villous-hirsute: stem 2 to 4 feet high: leaves all but the lower alternate, chiefly entire (the lower 3 to 10 inches long): heads middle-sized, racemose (on short or long peduncles): scales of the involucre with rather slender tips: rays short but exserted: chaff of the receptacle linear, uncon- 
nected : akenes narrow and elongated, minutely and all sparsely hairy, even those of the ray, the latter saliently 1-2-nerved on each face; outer ones of the disk apparently fertile: pappus of almost setiform plumose unequal chaffy scales, the longer ones little shorter than the corolla. - Anisocarpus Bolanderi, Gray, Proc. Am. Acad. vii. 360.

Woods of the Sierra Nevada : in the Mariposa Sequoia grove, and at Domner Lake, Bolander.

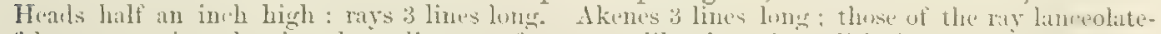

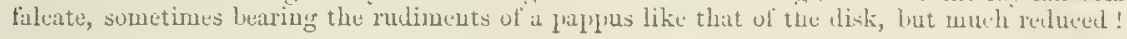

\section{* * Dish-flowers wholly destitute of pappus, either all or only the central ones sterile: leaves almost all alternate. (Madaria, DC.)}

3. M. elegans, Don. Pubescent, and more or less hirsute or even hispid, as well as glandular, one or two feet high, or in depauperate slender forms only a span or so in height: heals louscly corymbuse or paniculate: scales of the involuere with slender linear tips : rays (10 to 15 in the larger, 5 to 9 in depauperate forms) elon-

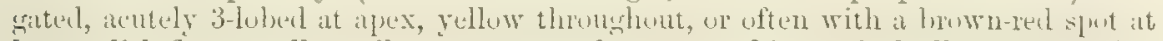
base: clisk-flowers all sterile, on a strongly convex hirsute-fimbrillate receptacle: fertile akenes obliquely obovate, the areola at the thick truncate summit depressed. - Madaria elegans \& M. corymbosa, DC., \&c. M. racemosa, Nutt., one of the slender forms.

Hills and plains, thronghout California and in Oregon and Nevada. Very variable in size, pubescence, glandulosity, and number of flowers in the head; but all apparently of one species. The larger forms are handsome in cultivation.

4. M. radiata, Kellogg. Viscid-pubescent and glandular, 2 or 3 feet high : heads pretty large: seales of the involucre with short tips: rays 9 to 20, goldenyellow, broadly oblong or somewhat cuneiform, obtusely 3-toothed: disk-flowers also fertile except the central ones, on a nearly flat and glabrous receptacle; their akenes somewhat clavate and 4-angular, straightish, with depressed areola at summit; raty-akenes narrowly obovate-falcate, that, tipped with a very short beak which is reflexerl upon the summit of the akene. - Proc. Calif. Acad. iv. 190.

Near the mouth of the San Joaquin River, Bolander. Head broad: ligules half an inch long, abrupt at base.

\section{\$2. Rays short and more or less inconspicuous, 12 to 1, or rarely wanting altogether; disk-flowers numerous or few, all fertile, destitute of pappus, and with corolla- tube pubescent: receptacle flat and smooth. - Ecasda.}

5. M. sativa, Molina. Viscid-hirsute and glandular, heavy-scented, one to

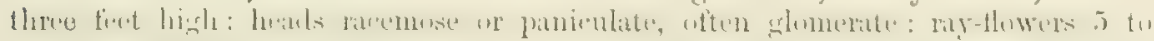

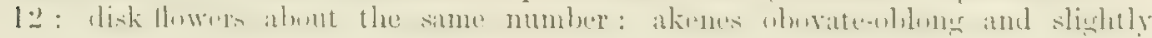
eurved, or those of the ray obovate-lunate, those of the disk commonly (and of the ray sometimes) 1-nerved down the siles. - The following forms pass freely into cach other.

Var. congesta, Torr. \& Gray : a large and very glandular, common form: the many-flowored heads sessile in crowded clusters: akenes (as in the Chiliun plant) rather narrow and mostly angled by the prominent nerve on the two sides. $-\boldsymbol{H}$. capitata, Nutt., not "conyesta" as printed in Torr. \& Gray, Fl. ii. 404.

Var. racemosa, Gray : a smaller and more slender form: commonly fewer-flowered heuls rather loosely racemose or punicled: akenes usual with less prominent or

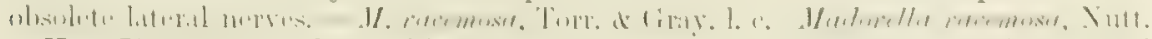

Var. dissitiflora, Gray : liko tho preceling or moro depanperate, with scattered

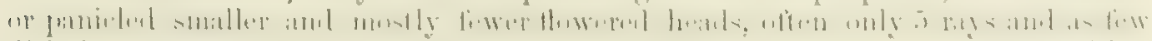
lisk-flowers: akenes inclined to short-obovate ( 1 t to 2 lines long), and with either that and nerveless or olse l-nerved sicles. - M. dissilffore, Torr. E Gray. Meclovelle dissitiflorer, Nutt. 
Plains and hilts, throughout California, Oregon, and the interior region; the Tarweed of the eastern part of the State. An exceedingly variable species.

6. M. glomerata, Hook. Ronghish-hirsute and glandular, slender, very leafy, about a foot high: leaves narrowly linear, entire ( 1 to 3 inches long): heads small and narrow, in close clusters terminating the stem or paniculate branches, or in the upper axils: ray-flowers 2 to 4, or sumetimes sulitary or wanting altonether : diskflowers 2 to 4 : akenes slender and straightish, at least those of the disk, which are either compressed or prismatic-fusiform and rather acutely 4-5-angled (2 to nearly 3 lines long). - Amida gracilis \& A. hirsuta, Nutt. ; Torr. \& Gray, 1. c.

Sierra Valley, and all the adjacent eastern portion of the Sierra Nevada; thence through the interior even to the Saskatchewan. A true Ifulia with flowers reduced, sometimes to a minimum.

\$ 3. Rays 4 to 8, very short, not exceeding the solitary disk-flower, which is fertile, and enclosed in a 3-5-toothed herbaceous cup: corolla glabrous: akenes of the ray obovate-lunate and more or less pointed: those of the disk straight and obliquely obovate. - HaRPeCARPUs. (Harpcecarpus, Nutt.)

7. IM. filipes, Gray. Hirsute and glandular, a span to a foot high, slender: leaves narrowly linear: heads small (hardly 2 lines in diameter), globular, on long filiform peduncles, loosely paniculate. - Proc. Am. Acad. viii. 391. Sclerocarpus exigurs, Smith (?). Harpacarpus madarioides, Nutt. $H$. exigurs, Gray in Bot. Mex. Bound. ]01.

Common in open grounds, at least from Monterey northwards, extending near the coast to Puget Sound.

\section{HEMIZONELLA, Gray.}

Head few-flowered, heterogamous; the rays 4 to 5 , pistillate; the disk-flowers solitary or rarely a pair, perfect and fertile. Involucre torosely lobed in the manner of Madia, i. e. of as many herbaceous scales as there are ray-flowers, each infolded and completely enclosing its akene, but rounded on the back and generally flattish on the inner face. Chaff of the receptacle an herbaceous 3-5-toothed cup or internal involucre enclosing the disk-flower. Corollas glabrous or merely glandular : rays extremely short. Akenes obovate or fusiform and more or less obcompressed, and those of the ray incurved, glabrous or sparsely hairy; the small terminal areola oblique, either sessile or raised on an apiculation or short beak. Pappus none. Low and diffusely branched or diminutive annuals, all Californian, hirsute and glandular; with linear entire and mostly opposite leaves, and small heads of yellow flowers, at least the lateral ones leafy-bracted. - Gray, Proc. Am. Acad. ix. 189.

In their heads, and somewhat in their general aspect, these little plants resemble the Harpcecorpus section of Madia; their akenes are as completely enclosed, although from the form of the akene the involucral scales are not conduplicate or carinate. It is better to separate them from Hemizonia, as a genus intermediate between that, or Lagophylla, and Modico.

1. H. parvula, Gray, 1. c. Diffusely branched, 2 or 3 inches high, hispid with white hairs: leaves narrowly linear, an inch or less long, the uppermost elustered around the short-peduncled or almost sessile heads : akenes narrow, falcate, between triangular-obcompressed and fusiform, tipped with a very short incurved beak. Hemizonia (Hemizonella) parvula, Gray, Proc. Am. Acad. vi. 549.

Klamath Valley, within the borders of Oregon, Cronkhite. Also in the collection of Kellogg and Harford, the station not recorded, and the specimens too young.

2. H. Durandi, Gray, l. c. Diffusely much branched, a span or so high, hirsute or somewhat hispid: leaves linear, about half an inch long: central heads naked on slender peduncles, the lateral ones 2-bracteate at base or short-peduncled: akenes 
slightly hairy; those of the ray obovate-oblong and obcompressed, tipped with a short inflexed beak. - Hemizonia (Hemizonella) Durandi, Giay, l. c. Harpacarpus madarioides, Durand, not of Nutt.

Dry hillis, common through the foot-hills and the Sierra Nevada from Mariposa County northward, and in Nevada.

3. H. minima, Gray, 1. c. An inch or two high: leaves half an inch or less in length; the uppermost equalling or barely surpassing the short-peduncled or almost sessile heads : akenes obovate, decidedly obcompressed, glabrous or nearly so, tipped with an inflexed apiculation, but not beakel. - Hemizonia (Hemizonella) minima, Giray, l. e.

Dry sterile soil in the Sierra Nevada: Soda Springs, Brewer. Between Nevada, Fall and Cloud's Rest, Gray.

\section{HEMIZONIA, DC, Torr. \& Gray. TARwEED.}

Head many-few-flowered, heterogamous, with 1 to 20 pistillate rays; the diskflowers several or numerous, hermaphrodite but usually all and always the central ones infertile. Involucre of as many scales as ray-flowers, which are concave and half enclosing their turgid akenes, or sometimes a few loose and empty outer ones. Receptacle flat or conical, chaffy only between the ray-and disk-flowers, or throughout. Rays 2-3-toothed, cleft, or parted: disk-corollas funnclform, 5-lobed. Akenes of the ray turgid, more or less gibbous, obovoid and often triangular, commonly minutely stipitate; those of the disk, when formed, narrower and seldom truly fertile. Pappus none in the ray, or in one species rudimentary; either none or of several chaffy scales or awns in the disk. - Annuals or biennials, some with indurated stems, and one frutescent, all Californian, mostly glandular and viscid, beavyscented: some of them are Tarweeds or Rosin-weeds of the Califomians. Leaves narrow, all but the lowest alternate: heads middle-sized or small; the flowers yellow or white, with brownish anthers. - Bentl. \& Hook. Gen. Pl. ii. 394; Graly, Proc. An. Ac. ix. 190. Hemizonia, Hartmannia, \& Calycadenia, DC. Osmadenin, Nutt. Hemizonia \& Calycadenia, Torr. \& Gray.

\$1. Fertile akenes very oblique, the small terminal areola from the summit of the inner angle or face on a narrow beak or apiculation; the surface dull, often rugose or tuberculate: flowers yellow. - Hartmannia, Gray.

* Receptacle flat or nearly so, chaffy only between the ray-and disk-flowers ; the chaff mostly united into a cup or internal involucre: heads small or middle-sized: akenes of the ray rugose or somewhat tuberculate when mature, inserted by a short and thichish incurved stipe: disk-akenes all sterile and mostly abortive, usually bearing a pappus of small scales. (Hortmannia, DC.)

+. Rays and disk-flowers few or several; the former with tube thickish at base; the latter with conspicuous pappus of chaffy lacerate-tonthed scales: heads comparatively small, bracteate, mostly sessile or fascicled: scales of the involucre lanceolate, more or less carinate toward the base.

$$
\text { ++ Perennial and woody, exceedingly leaiy: rays abont } 8 .
$$

1. H. frutescens, Gray. Erect, 2 feet or more high, decideily shrubby, with numerous fastiginto flowering branches very leafy to the top, hirsute, aromatic and viseid : leaves filifurm, and with tufts of shorter ones in the axils, entire, or rirely with one or two short lateral lobes: heads thyrsoid-racemose: involucre nearly inlibrous: rays 8 or 9 ; the ligules obovate-oblong, $2-3$-toothed, ahout the length of 
the involucre: chaff of the receptacle of as many narrow linear scales which are mostly distinct: receptacle convex: disk-flowers 10 to 12 , with well-formed but empty ovary: pappus of 5 linear deuticulate scales, about half the length of the ovary, - Proc. Am. Acad. xi. 79.

Rocky precipice in the interior of Guadalupe Island, off Lower California, Dr. Palmer, 1875. The only known species which does not inhabit the State, here given to complete the account of the genus. Leaves an inch or so long. Involucre little over 2 lines high. Ray-akcnes as in the section; the stipe at base and the curved beak at the apex pretty long: sterile disk-akenes containing an abortive ovule.

$++\div$ Annuals or biennials (as are all the following species of the genus), the stems, however, sometimes indurated in age: rays only 5, broad and short: disk-flowers 5 or 6.

2. H. ramosissima, Benth. Diffusely and paniculately much branched, slender, a foot or so in height, almost glabrous, above viscid-glandular: cauline leaves chiefly entire, linear, small, sessile with broadish base, oceasionally and sparsely beset, especially on the margins (as also are the branchlets), with some hispid or hirsute hairs: heads scattered or somewhat fascicled on the leafy branchlets : pappus of sterile akenes of 8 or 10 broad and thickish chaffy scales. - Benth. Bot. Sulph. 30 ; Bot. Mex. Bound. 100.

Common from Santa Barbara southward. Heads 2 or 3 lines long.

3. H. fasciculata, Torr. \& Gray. Paniculately branched above the base, a span to a foot or two high, sparsely hirsute or hispid: radical leaves once or twice pinnately parted; cauline leaves linear, either laciniate-pinnatifid, few-tonthed, or entire, an inch or two long, those of the branchlets shorter and mostly entire: heads fascicled in corymbose clusters: pappus of the sterile akenes of narrower chaffy scales. - Hartmannia fasciculata, DC. H. glomerata, Nutt.

Common from Monterey to San Diego. Exhales a strong balsam which is injurious to wool.

++ Rays 12 to 20, oblong-cuneiform, with slender glandular tube; their akenes generally occupying two series: disk-flowers more numerous: heads larger and mostly loose, terminating corymbosely paniculate branches.

4. H. angustifolia, DC. Diffusely branched from an at length indurater base, a span to a foot high, hirsute and viscid-glandular throughout: cauline leaves all entire, linear (chiefly less than an inch lung) : rays 12 to 15 : pappus of the sterile disk-ovaries none, or a row of minute short bristles rather than scales. $-H$. multicaulis, Hook. \& Arn., ex Gray in Bot. Mex. Bound. 100. H. decumbens, Nutt. Pl. Gamb. 175.

Var. Barclayi differs in having the ovaries of the disk-flowers enlarging into sterile akenes bearing a conspicuous chaffy laciniate pappus: mature fertile akenes more incurved and with an unusually conspicuous terminal beak.

Open grounds, from San Francisco and Monterey southward. Var. Burclayi, Monterey (Burclay, with laciniate pappus), San Luis Obispo (Brewer, with broader seales to the pappus, much as in $H$. ramosissima). Akenes rather obscurely rugose, tipped with the more or less prominent narrow beak, the little stipe at the base usually incurved and dilated at the insertion.

5. H. corymbosa, Torr. \& Gray. Corymbosely branched, a foot or so high, hirsute, more or less viscid and glandular: radical and most of the cauline leaves pinnatifid with linear lobes; uppermost and those of the branches linear and entire: rays 15 to 25 : pappus of the sterile disk-ovaries of minute scales, mostly cut into chaffy bristles, or sometimes almost none. - H. angustifolia, Benth. Pl. Hartw., not of DC. Hartmannia corymbosa, DC. Hemizmia macrocephala, Nutt. Pl. Gamb. 174. H. balsamifera, Kellogg, Proc. Calif. Acad. ii. 64, fig. 13.

Low grounds, common through the central and western portions of the State. Heads, including the expanded golden yellow rays, an inch or more in diameter, many-flowered. Ray-akenes with the short upturned beak somewhat dilated at the tip. 
* * Receptucle flat, with a distinct chaff for each of the 8 or 10 disk-flowers, half enclosing its sterite akene: heuds small: rays 5: akenes smooth and even, but dull.

6. H. virgata, Gray. More or less glandular, but glabrous or slightly hirsute: stem slender, a foot or two high, simple or virgately branched: cauline leaves linear; the lower laciniate or almost pinnatifid; upper entire; those of the branches and of axillary fascicles very small ( 2 or 3 lines loug), crowded, each tipped with a truncate* gland: heads numerous, virgately racemose: corollas glandular, the 5 ligules short and broad: scales of the involucre and the similar chatf of the receptacle rather chartaceous, obovate or oblong, conspicuously beset over the back with

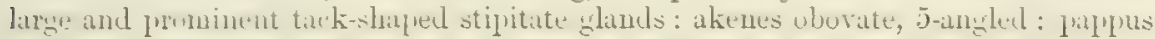
none. - Bot. Mex. Bunnd. 100.

Foot-hills, \&c., from Napa to Los Angeles. Heads narrow, 3 or 4 lines long; the glands often

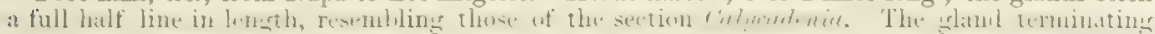
the smaller leaves is more or less cup-shaped in the dried specimens. Disk-akenes almost fertile. The plant exhales a balsamic odor.

* * * Receptacle convex or conical, many-flowered, chaffy throughout; the chaff distinct: heads middle-sized: rays rather numerous, and usually in more than one series, short, apparently pale yellow: akenes hardly if at all vugose, those of the dish some of them more or less fertile (these with a dejressed central terminal areola). - (\$Olocarpha, DC., excl. sp.)

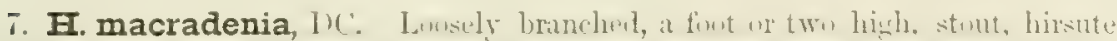

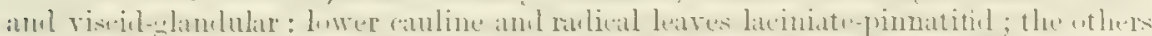

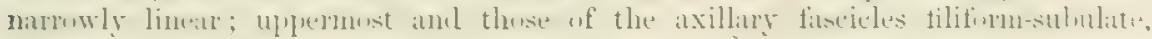
tipped with a truncate gland: heads mostly glomerate at the end of the branches: scales of the involucre and some of the chatf beset on the back with large longstipitate glimds : rays roundisl-cuneiform, 3-lobed : fertile akenes obovate, 5-augled, short-beaked from the inner angle: receptacle strongly conical: pappus none.

Dry open ground, from the Bay of Sin Francisso sonthward. One of the commoner "Tar-

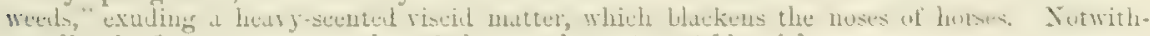
standing its frutescent aspect, the roo is annual, or at most biennial.

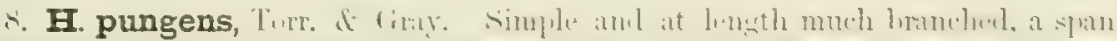

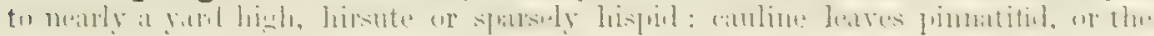
lower bipinnatifid with short spinulose-acuminate lobes; those of the branchlets and fascicles cntire, small and crowded, lanceolate or linear-subulate, rigid, spinulose-tipped, as are the seales of the leafy-bracted involucre and the narrow chati of the receptacle: rays scarcely exceeling the disk, narrow, 2-3-torthed: pappus none: receptacle strongly convex. - Hurtmannia pungens, Hook. \& Arm.; Hook. Ic. Pl. t. 334 .

Dry hillsides, from San Francisco sonthwarl to San Diego, where a very sparingly hirsute form occurs. The root of this species also is anmual. Akenes as in the preceling, but smaller.

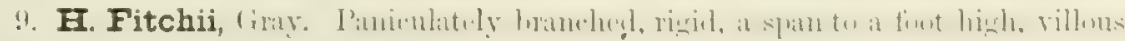
or somewhat hisute: raclical leaves 1-2-pimntely parted into fow linear or subulate divisions; cauline leaves (or the upper ones) like those of the brunches, subulate-linear (about an inch long), rigill and spinulosi-tipped, very pungent, the villons pubescence generally aecompunied with small very long-stalked glands: heals foliose-bracteate: scales of the involucre suhulate: rays oblung, 2-tontherl, little exceeling the disk: chaff of the convex and hairy receptaclo pointless, bearlent with long villous hairs: fertile akenes obovate, 3-angled, smouth, very gihbous; sterile disk-akenes with a pappus menty equalling their corollas, compused of $\&$ to I2 narrowly linear and rigid chatty scalles, which aro more or less united at bases and frimged or bearded at tip. - l'acif. R. Rep. iv. 108.

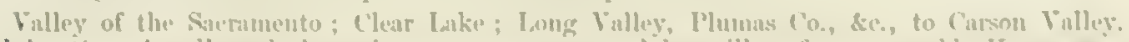

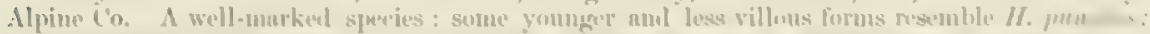

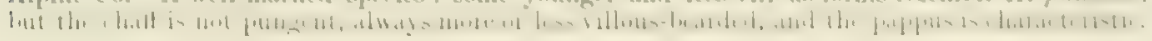


\$2. Fertile akenes slightly oblique and with depressed terminal areola hardly eccentric, glabrous, smooth and even, obovate and obscurely triangular, inserted by a minute inflexed stipe, mostly in two series : heads (corymbose) many-flowered, and with conspicuous strongly 3-lobed rays (expanding in sunshine): receptacle convex, chaffy throughout, the inner chaff very thin: disk-akenes abortive, destitute of pappus. - Eunemzonia, Gray. (Hemizonia, DC., as to the typical species of both sections.)

10. H. congesta, DC. Somewhat corymbosely or paniculately branched above, a foot high, rather villous than hirsute with long mostly soft hairs, slightly glandular towards the summit: leaves linear or linear-lanceolate, entire, or the lower (commonly opposite) oblanceolate and sparsely serrulate: heads rather few : scales of the involucre with lanceolate foliaceous tips: outer series of chaff of the receptacle somewhat similar to the scales and distinct or partly united: rays light yellow.

Low ground, in the western part of the State, Douglas, \&c. Hear, including the expanded broad rays, about an inch in diameter. This species is insufficiently known. Some specimens which have been referred to it prove to have white rays, and to be a less giandular and more villous form of the next; from which, however, the yellow flowers ought to distinguish the present species.

11. H. luzulzefolia, DC. Corymbosely or paniculately much branched, a span to 2 feet high, villous, or below floccose-woolly when young, above becoming very glandular and viscid: leaves linear, entire or merely denticulate, the lower elongated and 3-5-nerved: heads numerous, middle-sized or small, mostly on short naked - peduncles: scales of the iuvolncre with short herbaceous tips : outer series of chaff united into a cup: rays (6 to 10) and disk-flowers white, sometimes tinged with pink. - H. sericea, Hook. \& Am. H. mudis, Benth. Bot. Sulph.; a much-branched summer state, with small heads and small very glandular upper leaves; the long and silky-woolly Luzula-like lower leaves gone.

Dry open grounds, common throughout all the western part of the State, and very variable, especially in the size and number of flowers in the head; blooming continuously from. April or even March till November. Involucre from 5 or 6 to 2 lines high : ravs from 5 to 2 lines long, broadly cuneiform. The var. fragariondes, Kellogg, Proc. Calif. Acad. ii. 70, fig. 14, appears not different from the ordinary form of the species, but is said to have "the refreshing odor of strawberries."

\$3. Akenes of disk mostly well-formed and sometimes the outermost truly fertile (then hairy), turbinate-quadrangular or slightly obcompressed, straight, furnished with a conspicuous chaffy pappus; of the ray obovoid-triangular, slightly oblique, and the terminal areala little if at all eccentric: rays I to 7, very broad, palmately 3-lobed or parted: heads narrow, small: receptacle small and flat, the herbaceous chaff only between the ray-and disk-flowers: leaves entire and narrowly linear with revolute margins, or filiform, or those in axillary fascicles and clusters about the heads subulate, but obtuse, commonly tipped, and sometimes beset on the back, with disk-like or when dry saucershaped and either sessile or short-stipitate glands (whence the name). - CALYCADENIA, Gray. (Calycadenia, DC.)

* Diffusely paniculate-branched: branches filiform: chaff of the receptacle united.

+ Disk-shaped glands none: ray-akenes apiculate at both ends, rugose.

12. H. tenella, Gray. A span to a foot high, minutely glandular, also sparsely hispid when young: leaves linear-filiform, the lower an inch or two long, uppermost reduced to filiform bracts: heads terminating the very numerous and widely spreading filiform branchlets, cylinclraceous : rays 3 to 5, white, 3-parted down to the long and slender tube; disk-flowers 5, white marked with purple: ray-akenes glabrous, rugose, raised on a short stipe and tipped with a short and thick truncate 
heak; disk-akenes obsenrely hairy, their jappus of $t$ or 5 lancenlate firm-rhaffy scales tapering into stout rough awns, and of as many intermediate short truncate and lacerate scales. - Proc. Aro. Acad. ix. 191. Osmadenia tenella, Nutt. Calycadenia tenella, Tor. \& Gray.

Southern part of the State, especially around San Diego. Heads 3 or 4 lines long. Some of the disk-akenes are perfectly fertile.

++ Disk-shaped or saucer-shaped short-stalked gland terminating the fascicled leaves and bracts: ray-akenes not apiculate at either end, the terminal areola depressed, the surface smooth and even: flowers apparently white.

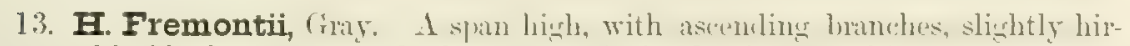
sute or hispid: leaves narrowly linear, roughish: heads several-bracted, terminal and axillary, short-peduncled or nearly sessile, campanulate: rays 5 to 7 , 3-parted, their tube very short; disk-flowers about 20 : chaff of the receptacle forming a 12 - 14-toothed cup: pappus of disk-akenes 10 chaffy scales, at least the alternate

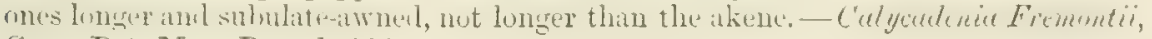
Gray, Bot. Mex. Bound. 100.

California, Fremont. The particular station unknown.

14. H. pauciflora, Gray. Shout it fint high, with filiform diverering often

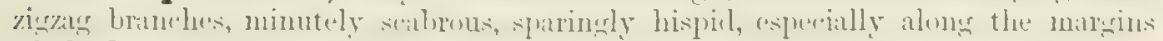
of the lower portion of the linear-filiform leaves: heads distant and sessile in the axils along the branches as well as terminal, cylindrical: ray solitary, 3-parted down to its short tube; disk-flowers 3 combined into a 3 -toothed tubular cup, their pappus

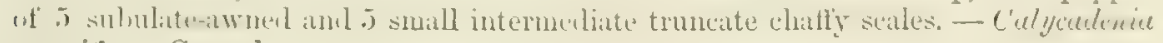
pauciflora, Gray, 1. c.

California, Fremont: the station unknown. Both species were collected in $18 \pm 6$, and have not since been met wíth.

* * Virgate; the stem or branches strict: heads mostly in the axils, either solitary or clustered: rays deeply 3-lobed or sometimes 3-parted; their akenes with iruncate summit sliyhtly if at all apiculate: disk-corollas narrow and long, 5-toothed: flovers in some and perhaps all the species open only through evening and morning.

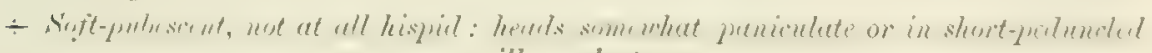
axillary clusters.

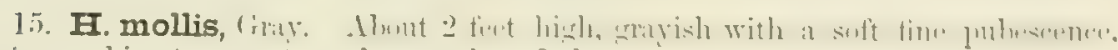
not even hirsuto except on the margins of the uppermost leares and bracts : theso tipped with a tack-shaped or saucer-shaped and short-stalked gland, or sparsely beset with similar glands: flowers white; rays 3 to 5 , almost equally 3 -parted anil with short but slender tube; disk-flowers 5 to 10 : chaff of the receptacle united into a 6-8-toothed cup: ray-akenes somewhat rugose, and the broal terminal

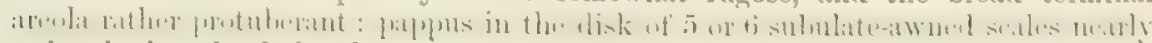
twice the length of the akenes, and of one or two additional short and blunt scales. - H. angustifolia, Duxand, PI. Herm., Pacif. R. Rep. iii. 10, not of DC. Calycrdenire mallis, Gmy, Proc. Am. Acarl. vii. 360.

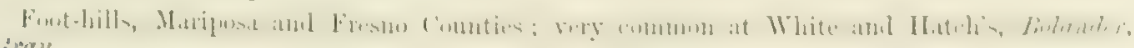
limuly.

++ Glabrous and smonth, or some of the lower leaves slightly and sparsely hispid: heads scuttered, solitary in the axils and terminal.

16. H. truncata, Gray. Slencler, a foot or two high; the vingate stom sometines panienhately brunched ahove: leaves very aarrowly linear, the short uppermost and the bracts tipped with a very larro and almost sessile saurer-shaped sfland: flowers yellow; mys 5 to 8 , 3-cleft, with very short tube; disk-lluwers 10 
to 20 : chaff of receptacle more or less distinct, truncate : ray-akenes as in the preceding: pappus of those of the disk short and awnless; the scales 7 to 10 , oblong, incisely or fimbriately toothed, very much shorter than the akene, rarely wanting. - Calycadenia truncata, DC.

Dry ground, Valley of the Sacramento to Mendocino Co., \&c.

+++ Setose-hirsute or hispid, at least on the margin of the leaves or bracts: heads sessile or nearly so, and often clustered in the axils and at the summit of the stem: short-stipitate or almost sessile saucer-shaped glands at the tips of the upper and fascicled leaves, bracts, \&c., and often on their sides.

17. H. Douglasii, Gray. Slender, a span to a foot or so high, more or less hirsute or hispid with white bristly hairs, especially on the margins towards the base of the almost filiform leaves: heads solitary in the axils: "flowers yellow": pappus of 10 subulate awn-pointed chaffy scales, or some of them shorter and truncate or obtuse. - Calycadenia villosa, DC.

Open grounds, in the western part of the State, Valley of the Sacramento, \&c. Collected in "Long Valley" by Dr. Kellogg, who notes that the "flowers are yellow," probably pale. Glands few or sometimes none except the terminal ones. Rays 3 or 4 ; disk-flowers 5 to 10 . Except in the slenderness, the scattered solitary heads, and, if constant, the "yellow" flowers, it is difficult to distinguish this from forms of the next. The specific name, villos $\alpha$, which is hardly ever appropriate even in Calycadcnia, may give way in the transferrence to Hemizonia.

18. F. multiglandulosa, Gray. A span to 2 feet high, more or less hirsute and hispid, especially towards the base of the almost filiform leaves: stipitate glands mostly present and often copious on the upper leaves, bracts, involucral scales and united chaff: heads solitary or clustered in the axils, and commonly capitately or spicately crowded at the summit of the stem : flowers white, sometimes tinged with rosecolor: pappus of 10 or 12 chaffy scales, either all or about half of them subulateacumimate or awn-pointed, the others short and pointless. - Calycadenia multiglandulosa \& C. cephalotes, DC.; Torr. \& Gray : the former a state with scattered heads and very copious tack-shaped glands; the latter with heads all or most of them capitate-crowded at the summit.

Open dry grounds; common through the western part of the State. No reliance can be placed upon the abundance or rarity of the glands, the crowded or more scattered heads, nor the pubeseence of the akenes, in this and the preceding species. The ray-ovaries are rarely quite glabrous, commonly a little hairy at top, or sparsely so thronghout. The scales of the pappus are sometimes all alike and subulate or awn-pointed, or some of them so ; but usually the alternate ones are short and blunt. These characters are so mingled that varieties cannot well be defined, at least with the present materials.

\$ 4. Akenes nearly as in $\$ 3$, but more nearly equal-sided, acutely 10-nerved or ribbed, all more or less hirsute and with depressed terminal arenla, this bearing a coroniform pappus in the ray, and a pappus of about 20 equal plumose awns in the disk-akenes, only the central ones of the latter sterile. - BLEPHARIZONIA, Gray.

19. I. plumosa, Gray. Two or three feet high, with the heads racemosepaniculate along the virgate branches, somewhat setose-hispid and with fine rather viscid pubescence: cauline leaves unknown; those of the flowering branches all short and bract-like, oblong, tipped and often sparsely beset (as are the similar scales of the involucre and the outer chaff of the receptacle) with short-stipitate and pale saucer-shaped glands: corollas "yellow" or more probably white; those of the ray 7 to 10, deeply and irregularly 3-lobed, of the disk 10 to 12. - Proc. Am. Acad. ix. 192. Calycadenia plumosa, Kellogg in Proc. Calif. Acad. v. 49.

Valley of the Sacramento. Sent from Stockton to Dr. Kellogg by an unknown collector. Heads rather broad, 3 lines high, exclusive of the rays; these with their short tube about 4 limes long. Receptacle flat or nearly so, pubescent; its chaff of distinct scales in about two series, the inner smaller. Ray-akenes fully a line and a half long, turbinate, with a more contracted base, and a rounded summit having a rather small and not protuberant areula, bearing a 
rather firm scarious cup-like small pappus, its margin ciliate and obscurely fimbriate. Diskakenes nearly 2 lines long, oblong-turbinate, and with a broad terminal depressed areola, bordered. with the pappus of about 20 equal and rather stout barbate-plumose awns, of fully a line in length. All the outer, and sometimes all but one or two of the inmost disk-akenes are seedbearing. On account of the anomalous jappus to the disk-flowers this syecies might be sought for in the group to which Blcphoripappus belongs, and which it much resembles in the diskpappus. It really forms a new section in the present genus.

\section{LAGOPHYLLA, Nutt.}

II anl screral-fowered, heteroganusu, with abunt 5 gistillate fertile rays, and as many hermaphrodite but sterile disk-flowers. Involuere of as many herbaceous scales as ray-flowers, which are flat on the back, with margins at base infolded, so as to completely enclose their obcompressed akenes, and commonly 2 or 3 looser and more foliaceous empty exterior ones or bracts. Receptacle swall and flat, bearing a series of 5 or 6 distinct chaffy scales, subtending disk-flowers. Rays cuneiform, palmately 3-cleft or parted : disk-corollas 5-lobed. Akenes of the ray more or less obcompressed, oborate-oblong, smooth, nearly straight, pointless; those of the disk slender and abortive, all destitute of pappus. - Soft-villous or hirsute annuals, of California and Oregon; with repeatedly branching slender stems, alter-

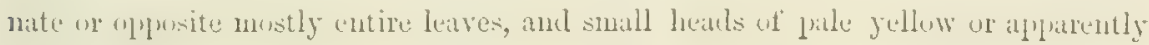
white flowers.

\section{* Leaves chiefly alternate: heads leafy-bracteate.}

1. I. ramosissima, Nutt. A foot or two high, at length paniculately very much branched: lower leaves oblanceolate or linear-lanceolate and somewhat silkyhirsute (an inch or two long); the upper and those of the branchlets successively smaller and copionsly villous with long and soft hairs, especially along their margins, often becoming concave or involute when dry: heads almust sessile, chintered on the leafy branchlets : rays harlly exserted, yellow : fertile akenes carinately onenerved down the inner face. - Torr. \& Gray, Fl, ii. 402. L. minima, Kellogg in Proc. Calif. Acad. v. 53.

Dry litlsides, common through the middle and northern part of the State, and in adjacent parts of Oregon and Nevads. Stems brittle : leaves early deciduous from the stems and the at length smooth filiform branches.

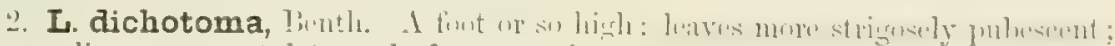
the cauline ones spatulate and often coarsely crenate, those of the branchlets and bracts hisutely ciliate: heads sessile in the forks of the repeatelly dichotomons almost naked branches, and terminating their filiform peduncle-like extremities: rays much exserted, apparently white: fertile akenes concave and nerveless (but minutely striate) on the inner face. - Pl. Hartw. 317.

Plains of tho Sacmmento and Feather Rivers, Hartwrg, Filch, Bigclow. Heads larger than in the precelling; the ligules conspicuous, about 3 lines long.

* Leaves commonly or mostly opposite: herds nated, terminal, slender-peduncled.

3. L. filipes, Grny. A span to a font high, maniculately hmoherl, soft-villous, and with some small stipitate glands: leaves linear; some of the lower enuline sparsely laciniate-denticulate ( 2 or 3 inches long); those of the branchlots short ( 4 to 2 lines long), not ciliate: head small, bractless, on a filiform peluncle: rays exserted, apparently white. - Pateif. R. Rep. iv. 109, \& Mox. Bouml. 101. Iemizonic filipes, Hook. \& Arn., apparently, but the specimens of Douglis not sien.

Californin, Douglas. On the Sacramento, Fitck, Necherry, de. Secuingly a ruro species. Akenes not yet known. 
59. LAYIA, Hook. \& Arn.

Head many-flowered, heterogamous, with 8 to 20 pistillate rays and numerous perfect disk-flowers, all fertile, except occasionally some of the central. Involucre hemispherical or very broadly campanulate, of as many scales as ray-flowers (and sometimes a few exterual empty ones), flat or nearly so on the back, their abruptly dilated thin or scarious margins or auricles below infolded on either side so as to meet and enclose the ray-akene. Receptacle broad and flat, or rarely convex (pubescent where not chaffy), a series of chaff like an inner involucre subtending: the outermost disk-flowers, or in some species with thinner chaff subtending all or most of them. Rays cuneiform or oblong, 2-3-lobed or toothed at the apex : diskcorollas cylindraceous-funnelform, 5-lobed at summit. Akenes of the ray obovateoblong or narrower, obcompressed, glabrous (with one exception) and smooth, destitute of pappus, but crowned with a protuberant disciform areola ; of the disk nearly similar or linear-cuneate, mostly hairy, and with a various pappus of 5 to 20 bristles, awns, or chaffy scales, either naked or plumose, or occasionally none. Annuals, all of the Californian region; with leaves nearly all alternate and often incised or pimatifid, and showy heads of yellow or yellow and white flowers (mostly with brown or purple anthers), terminating the somewhat paniculate or corymbose branches. - Gray, Pl. Fendl. 103; Benth. \& Hook. Gen. Pl. 2. 395, where the synonymy is given.

Rudiments of pappus occasionally occur on the ray-akenes, as a small seale, or a bristle or two, but they are evidently abnormal. The species are arxanged under three sections, mainly by the pappus : otherwise several of them are almost exactly alike.

\$1. Pappus of 10 to 20 (or rarely fewer) awns or stout bristles which are longplumose or villose below the middle: receptacle chaffy only at the margin, rarely among some of the outer disk-flowers: akenes all narrow and somewhat clavate, crowned with a protuberant annular or rarely almost cupulate disk, especially in the ray. Plants all hispid or hirsute and sprinkled above with dark-colored stipitate glands. - Madaroglossa, Gray. (Madaroglossa, DC.)

* Rays vohite (or rarely purple), cuneiform and 3-lobed; the disk yellow.

1. I. glandulosa, Hook. \& Arn. A span to a foot high, loosely branching, roughish with short hispid hairs: leaves linear, the upper ones all'small and entire, the lower often lanceolate and sparingly incisely pinnatifid: heads middle-sized or smaller: rays 8 to 13 , conspicuously exserted: disk-akenes appressed silky-villous: pappus mostly bright white, the very copious villous wool much shorter than the stout bristles, the inner portion at length crisped and interlaced. - Blepharipappus glandulosus, Hook. Firiopappus glandulosus, Arn. Madaroglossa angustifolia, DC.

Var. rosea, Gray. Rays rose-purple; otherwise apparently identical with the ordinary form.

Dry and open grounds and bare plains, from the Dalles of Oregon through the eastern portions of the Sierra Nevada to Los Angeles Co., and eastward to New Mexico and Utah. The Tar. rosea, at Ojai, Ventura Co., S. F. Peckham: apparently differing only in the color of the rays, which in the species are white. Heads variahle in size : rays from a third to half an inch in length. L. Neo-Mexicana, Gray, Pl. Wright., is the same, with the occasional development of a crown of chaffy pappus on the ray-akenes.

2. I. heterotricha, Hook. \& Arn. A foot or two high, erect, rough-hispid and somewhat viscid: leaves linear or lanceolate, from entire to laciniate-pinnatifid: heads pretty large: rays 10 to 18 , fnlly twice the length of the disk, oblong-cuneiform, bright white: disk-akenes villous-pubescent: pappus white or whitish; the 
villous wool all.straicht aur ereet, a little sr sometimes much shorter than the rather slender bristles. - Hook. Ic. Pl. t. 326. Madaroglossa heterotricha, DC.

Open grounds, through the western part of the State, especially in the San Joaquin Valley. Heads with disk half an inch high ; the large and showy elongated rays three quarters of an inch long. The eopious stipitate black glands, intermixed with the short hispid and above apparently somewhat viscid bristles, suggrested the specific name.

3. L. carnosa. 'Turr. \& Gray. Dwarf and depressed, rising only 3 to 5 inches high, more or less hirsute-pubescent : leaves succulent, spatulate or the upper linearoblong, the lower often sinuate-pinnatitid: heads small: rays 8 to 10 , very short (slightly surpussing the involuere), apprarently white : akenes both of ray and disk pubescent: pappus dull whitish, its slender bristles very sparsely plumuse with straight villous hairs to much above the middle. -Madaroglossa carnosa, Nutt.

Sands of the sea bench, San Diego (Nuttall), Monterey (Parry), Punta de los Reyes, Bigelowo. The rays (nowhere stated to be yellow) appear to be white, and they are very inconspicuous.

$$
\text { * Rays as well as disk-flowers yellow. }
$$

4. L. hieracioides, Hook. \& Arn. A foot or so high, very hispid with, long and spreading rigid bristles, which above are somewhat viscid: leaves varying from linear to oblong, laciniate-toothed or almost pinnatifid : heads small : rays 10 to 15 , small, a little exceeding the disk: disk-akenes minutely pubescent : pappus rustybrownish; the straight and erect villous hairs rather seanty and little shorter than the bristles. - Madaraglossa hieracioides, DC.

Open grounds, San Francisco to Monterey, \&c. Stem not rarely spotted by the dark-eolored bases of the bristles. Leaves mostly only an inch or so in length. Heads only 3 or 4 lines high: mys seldom 2 lines long; their akenes sometimes showing rudiments of pappus.

5. L. gaillardioides, Hook. \& Arn. A foot or two high, loosely branched, hispid and glandular like the preceding : leaves lanceolate or linear, the lower commonly pimatifid : heads pretty large: rays 12 to 20, orange-yellow, cuneate-oblongr, twice or thrice the length of the disk: disk-akenes silky-pubescent: pappus dull white or rather rusty ; the erect and not abundant villous hairs all straight and considerably shorter than the bristles.

Open grounds, common through the western part of the State, especinlly near San Frnncisco Bay. Rays in well-developed plants two thirds to three fourths of an incli loug. Chalf of the receptaclo sometimes (ns originally described) among the outer disk-flowers, but commonly only between the disk and my. In Bolander's collection from Forest Hill, Placer Co., are specinens undistinguishable from La pentenchata of that locality, and apparently growing with it, but with the pappus of the present species.

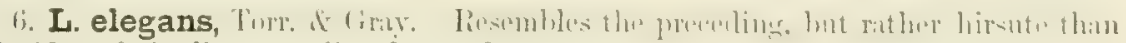
hispid, and the linear caulino leares less pinuatilit: rays 10 to 12 , lightor yellow, obovate-cuneiform, about twice the leugth of the lisk: pappus mostly white; its copions villous hairs much shorter than the awn-like bristles, the inner crisped and interlacod. - Muiduroglossa elegans, Nutt.

Open grounds, Ukiah to Santa Barbarn and Los Angeles. In the pappus this resembles L. glandulosa; and the rays are similar, except in their color and mather larger size.

\$2. Puppus, receptacle, glundular herbage, and nhole aspect of the preceling section, but the (5 to 25) awos or bristles of the papyns naked, or rarely wanting. Caldichon, Gray. (Callichroa, Fischer \& Meyer.)

7. I. pentachaeta, Gray. Sparsely hirsute or hispid as well as glanilular, loosely branched: lenves mostly pinntifid and the lower even bipinnatilid, with long linear lobes: rays large, goliten yellow, oblung-cuneiform : disk-akenes minutely pubeseent, sometimes almost glabrous: pmppus of 5 or rarely fower rigid smooth bristles, or sometimes wanting. - Pacif. R. Rep. iv. 108, t. 16.

Font-hills of the Sierra Nevada; on the Stanislius (Biuglore) and near Forest Hill, Plneer Co., Rimhuder. Heads showy: the numerous apparently deep yellow mys lublf an inch or so in length. 
8. L. platyglossa, Gray. More or less hirsute as well as glandular, loosely branching: lower leaves commonly pinnatifid: rays large, cuneate-obovate, bright light yellow, and commonly with whitish tips to the lobes: disk-akenes silky-hirsute: pappus of 15 to 25 upwardly scabrous stout and rigid awn-like bristles, which are usually only a little shorter than the corolla. - Pl. Fendl. 103. Callichroa platyglossa, Fischer \& Meyer, Ind. Sem., \& Hort. Petrop. t. 5 ; Brit. Fl. Gard. ser. 2, t. 373 ; Bot. Mag. t. 3719. Madaroglossa hirsuta \& M. angustifolia, Nutt.

Var. breviseta, Gray. Pappus barely one half the length of the corolla or of the akene: leaves mostly pinnatifid.

Common throughout the whole western portion of the State: the variety, Los Angeles, Bige7ow. The ordinary formo is familiar in cultivation. About San Francisco it is popularly named Tidy-tips.

\$3. Pappus of subulate awns or of chaffy scales, either naked or margined with scanty long villous hairs at base, or none: receptacle chaffy throughout : akenes oblong-obovate: herbage less hispid or hirsute than in the foregoing, and wholly destitute of glands. - Caldiglossa, Gray. (Calliglossa, Hook. \& Arn. Oxyura, DC. Calliachyris, Torr. \& Gray.)

These plants all look very much alike, and (excepting $L$. Fremontii) are hardly distinguishable in aspect; yet they differ in such particulars that they cannot be reduced to one or even two polymorphous species. The scales of the involucre are woolly inside at the summit and margins of the infolded portion, most so in $L$. Fremontii. The rays in all are ample, euneiform, and 3 -lobed at the end, yellow, or sometimes with nearly white tips.

L. Dougrasin, Hook. \& Arn., which is known only by a specimen collected "between the Narrows and the Great Falls of the Columbia" by Douglas, and preserved in the Hookerian herbarium, appears to be a species intermediate between the present section and Madaroglossa. See Proc. Am. Acad, ix. 104.

\section{* Receptacle flat: pappus present: disk-akenes more or less villous.}

9. I. Fremontii, Gray. Diffusely branching, slender, a span or two high, puberulent and somewhat hirsute: leaves mostly pinnately parted and with short linear-oblong divisions: scales of the involucre very woolly iaside at the infolded portion: rays deeply 3-lobed: pappus of about 12 ovate-lanceolate and subulatepointed chaffy scales, about the length of the akene, with some interposed attenuated villous hairs resembling those of the akene but longer. - Pl. Fendl. 103. Calliachyris Fremontii, Torr. \& Gray, in Bost. Jour. Nat. Hist. v. 140.

Valley of the Sacramento, Fremont, Stillman, Hartweg. Also near Auburn, Placer Co., Bolander.

10. L. calliglossa, Gray. Loosely branching, a foot or so high, rather glabrons, but the leaves (pinnately parted, or on the branches entire and small) thickly ciliate with short hispid bristles: rays commonly paler or whitish at the tips : pappus of 10 to 18 very unequal scabrous or near the base occasionally somewhat barbellateciliate awns. - Pl. Fendl. 103. Calliglossa Douglasii, Hook. \& Arn. Oxyura chrysanthemoides, Lindl. Bot. Reg. t. 1850; Fischer \& Meyer, Hort. Petrop. t. 6.

Var. oligochæta, Gray. Pappus of only two awns in many or most of the flowers, the others reduced to little scales.

Not rare through the western part of the State; the variety at Petaluma, and Santa Rosa Valley, Newberry, Bolander.

* Receptacle strongly convex: pappus none: disk-akenes glabrous. (Oxyura, DC.)

11. L. chrysanthemoides, Gray. Like the preceding in aspect, or leaves sometimes more scabrous-pubescent and less ciliate: akenes broader and glabrous, and with no epigynous disk, the dilated base of the corolla covering their apex. Oxyura chrysanthemoides \& Hartmannia ciliata, DC.

Hillsides and low grounds, near San Francisco, \&c. Rays, as in the foregoing, about half an inch long, deep yellow, the tips inclined to be whitish. 
60. ACHYRACH 列NA, Schauer.

Hear many-fluwered, heturinamen, with of to 10 very shert pistillate and fertile inconspicuous rays; the disk-flowers also fertile. Involuere oblong-campanulate; its seales lancenlate, as many as ray-Howers, Hattish on the back buluw and each ly its infolded thin margins enclosing an akene, or one or two empty ones besides. Receptacle nearly flat, chaffy at the margin and among some of the outer diskfluwers; the outernost chaff resembling the siale's of the involucre, the rest more membranaceous or scarious. Rays very small, hardly exceeding the disk, the palmately 3-cheft coneare ligule barely exceeting its style and much shorter than its slemler tuher : disk-corollas slender, 5-tunthed. Akenes linear-cuneate or clavate, sonewhiat whomprested, or in the lisk nearly terete, 10-ribleet, and with the alter-

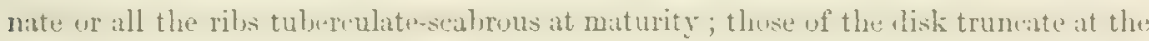
apex; those of the ray rounded and with an epigynous protuberant areula; the

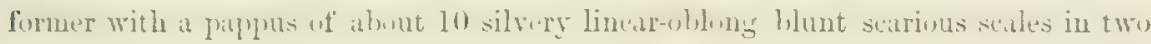
series, the 5 outer considerably shorter than the alternate inner ones, which are as long as the comlla. - I single (Californian) aumual species, with narrow leaves, only the lower opposite.

1. A mollis, Schauer. A span to a foot or so high, erect and mostly slender, villous-pubescent and somewhat glandular or viscid: leaves long-linear, entire, or the Inwer sparingly laciniate: leeals sulitary and peduncled, terminatine the stem or fastigiate branches, at most an inch long: flowers whitish or yellowish, the rays turning brownish. - Lepidostephanus madioides, Bartling.

Common in fields and open low grounds through the western and central portions of the State. Becoming conspicuous by the expansion of the mpipus when dry and divergence of the akenes, forming a globular silvery-chafly head, somewhat resembling that of Thrift (Arneria vulgaris): the longer pappus a quarter of an inch long; the akene about the same length.

\section{Tribe VI. HELENIOIDEE.}

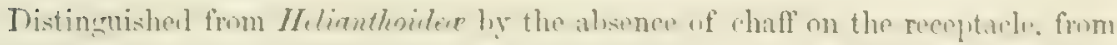

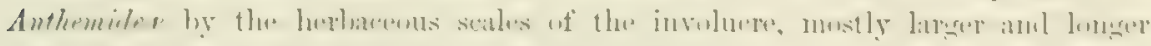

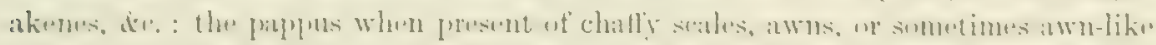

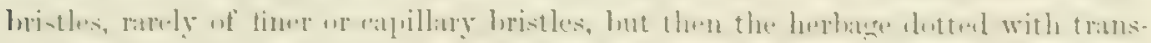

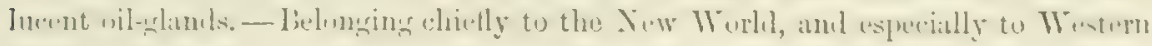
North America.

\section{JAUMEA, Pers,}

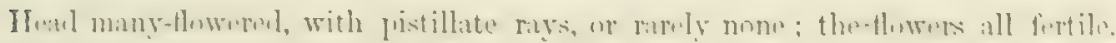

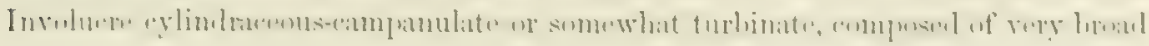
and imbricated scales, the outer shorter and feshy. Receptacle naked, in tho Cali-

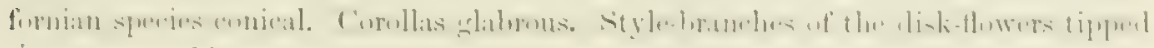
with a very blunt short cone. Akenes all alike, linear, 10-nervel, more or less angled. Pappus in S. Americun species chaffy, in ours none. - Herbs or slightly woody plants, glabrous, with opposite and entire linear fleshy lenves, connate at base, and solitary midille-sized heads of yellow flowers, on peduncles somewhat thickenel at the apex and terminating the brancheso - Benth. \& Hook. Gren. Pl. ii. 397 ; Gray, Proc. Am. Acad. ix. 194. Cruingyme, Less, DC. 
1. J. carnosa, Gray. Stems procumbent or ascending, herbaceous: leaves linear or spatulate-linear, very fleshy, somewhat terete when fresh: head erect on a short peduncle: rays 6 to 10, linear, small : receptacle highly conical, smooth and fleshy: akenes wholly glabrous, destitute of pappus. - Bot. Wilkes Exp. 360. Coinogyne camosa, Less.; Torr. \& Gray, Fl. ii. 410.

Salt marshes along the coast, from San Diego to San Francisco, and to Puget Sound. Its near relative inhabits the eastern shore of extra-tropical South Ameriea, and has a pappus, but no rays.

\section{VENEGASIA, DC.}

Head many-flowered, with numerous pistillate rays; the flowers all fertile. Involucre very broad, imbricated in several ranks; scales round-ovate; the outermost somewhat foliaceous, the inner successively more membranaceous and a little colored, a few of the innermost smaller, narrow and scarious. Receptacle flat, naked. Tube of the corollas glandular-bearded, especially at base : rays elongated, entire or 2-3toothed at the narrow apex: disk-corollas elongated-cylindrical. Style-branches of the disk-flowers very obtuse. Akenes oblong-linear, many-nerved, somewhat 5-angled, destitute of pappus. - A stout herb, with alternate cordate petioled leaves, and rather large heads of yellow flowers.

1. V. carpesioides, DC. Several feet high, with pithy and nearly glabrous branches, leafy to the top: leaves membranaceous, cordate or some of them ovatedeltoid, crenate, 2 to 4 inches long, sprinkled beneath with some minute resinous atoms, slender-petioled: heads terminal and from the upper axils, on short slender peduncles. - Parthenopsis maritimus, Kellogg in Proc. Calif. Acad. v. 100.

Rocky banks of streams, \&c. Santa. Barbara and southward. Heads handsome, fully two inches broad, including the (about 15) long rays. It would be well worthy of cultivation. The genus commemorates an early writer upon California, the Jesuit missionary, Michael Venegas.

\section{RIDDELLIA, Nutt.}

Heads several-flowered, with 3 or 4 pistillate rays and 5 to 12 disk-flowers, all fertile. Involucre narrow, cylindraceous, of 4 to 10 linear-oblong and coriaceous equal woolly scales, which are connivent but distinct, except at the very base, and a few thinner or scarious ones within, sometimes a narrow external bract or two. Receptacle flat, naked and smooth. Rays large for the size of the head, very broad, abruptly contracted at base into a short tube, truncate and 3-lobed at the end, $5-7$ nerved (the nerves converging and uniting in pairs within the lobes), becoming papery, persistent on the akene. Disk-corollas elongated-cylindraceons, with a very short proper tube, 5-toothed at summit; the teeth glandular. Anthers linear, minutely sagittate or emarginate at base. Style-branches of the disk-flowers short, truncate-capitate at the apex. Akenes narrow, terete or nearly so, obscurely striate or angled, glabrous, or in one species cobwebby-villous. Pappus of 4 to 6 hyaline nerveless and pointless chaffy scales. - Low and branching woolly herbs, probably all perennial; with alternate spatulate or linear leaves, either entire or the radioal ones pinnately incised, and corymbose small heads of golden yellow flowers, much resembling those of a section of Zimia which belongs to the same region. - Gray, Pl. Fendl. 94, \& Proc. Am. Acad. vii. 358.

There are three species, all of the Texano-Arizonian region; namely, $R$. arachnoidea, of Texas and Northern Mexico, which is remarkable for the long cobwebby hairs on the akene, and the pappus-scales as it were dissolved at the apex into similar hairs ; $R$. tagetina of Nuttall, with 
entire pappus-scales, which extends from W. Arkansas thrcugh S. Utah to S. Arizona, where a form with solitary slender peduncled heads was mistaken for the third or following species.

1. R. Cooperi, Gray. A foot or two high, tomentose-canescent; somewhat naked with age: leaves narrowly linear, entire, minutely punctate: heads solitary on filiform peduncles terminating the branches: akenes glabrous: pappus of oblong erose-laciniate chaffy scales, about a quarter of the length of the glandular disk-corolla. - Proc. Am. Acad. vii. 358.

Fort Mohave, on gravelly banks, Cooper. Also on or near the higher Rio Colorado, Nevberry. Leaves an inch or less in length. Involucre about 3 lines long. Hays nearly hall an inch long,

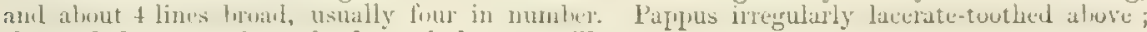
the teeth few, sometimes slender and almost capillary.

\section{BAILEYA, Gray.}

Head many-flowered, with 5 to 50 pistillate rays in one or more series; all the flowers fertile. Involucre hemispherical, of numerous and nearly equal thin-herba-

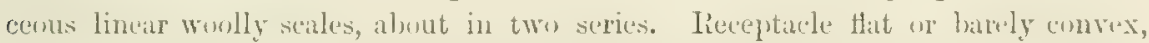

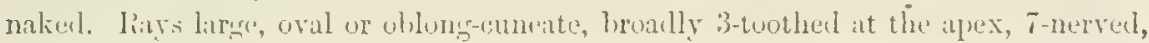
tapering into a narrow but not tubular base, becoming scarious-papery (but very thin), persistent on the truncate apex of the akene. Disk-corollas tubular-funnelform above the short proper tube, 5-toothed; the teeth glandular-bearded. Anthers linear, minutely sagittate at base. Style-branches short, with truncate-capitate apex. Akenes oblong-linear or slightly club shaped, somewhat angled, manyribbed or striate; the apex truncate, sometimes obscurely toothed by the extension of the ribs, or in the ray callous-thickened. Pappus none. - Floccosely whitewoolly herbs (of the Arizona-desert region), apparently all annuals, a foot or so in height; leaves alternate, soft, the upper lanceolate or linear, the lower once or twice pinnatificl; heads of yellow flowers terminating slender peduncles, mostly shuwy from the ahunlince of the gersistent, at length heflexid, thin and sulphurcolored rays. - Gray, Pl. Fendl. 105, \& Proc. Am. Acad. ix. 195.

This genus, which commemorates one of our worthiest natumlists, the late Professor Briley,

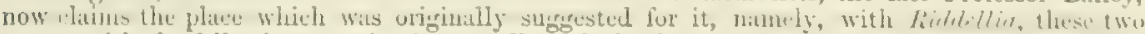
genera with the following constituting a well-marked subtribe.

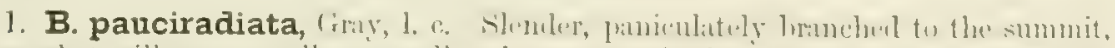

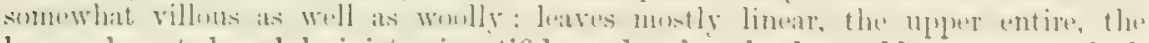
lower elongated and laciniate-pinnatifid: peduncles slender, seldom over an inch

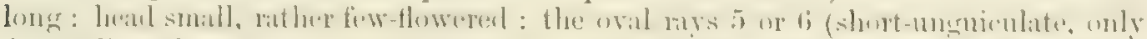

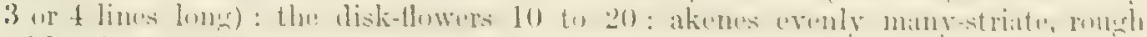
with minute points.

Southenstem border of the State, on the Rio Colomdo, in sand, Contler, Scholl, Conper.

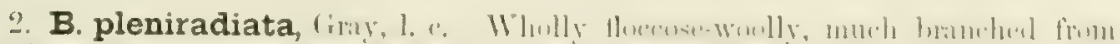

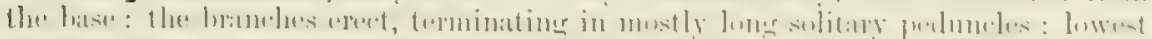

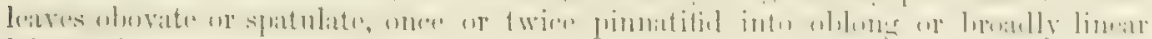
lobes; the upper linear, 3-cleft or entire: head middle-sized and many-flowerod: the rays 25 to 40 in 2 or 3 ranks, dilated-obovate and broally 3-toothed $(4$ or 5 lines long): akenes angled with strong and striat9 with intermediate more slender ribs, minutely scahrons or vearly smooth.

Culifornia, Coneller. Not uncommon in Arizone, and through Sonom and Southern Utuh to the borlers of Texas: perhaps not collected within the sitate.

3. B. multiradiata, Griy, 1. c. Densely flocense-woolly: stem simple nr

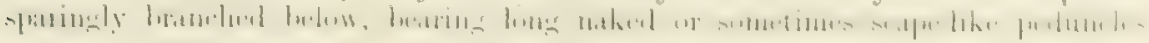


(from 4 inches to a foot in length) : leaves nearly all once or twice piunatifid: head large: rays 40 or 50 in about 2 rauks, cuneate-oblanceolate (fully half an inch long): akenes as in the preceding, smooth and glabrous or with some resinous globules. - Torr. in Emory Rep. 144, t. 6.

In the Californian collection of Coulter. Very probably collected in Arizona or Sonora, where this species occurs, as also farther eastward.

\section{WHITNEYA, Gray.}

Head many-flowered, with 7 to 9 pistillate fertile rays: the disk-flowers apparently perfect, but infertile. Involucre campanulate, of 9 to 12 thin-herbaceous lanceolate-oblong or ovate-lanceolate and equal scales, in a single or somewhat double series, more or less concave at base. Receptacle conical, somewhat foveolate, villous. Rays large, elongated, minutely 3-toothed at the apex, many- (10-16-) nerved, the nerves also prominent on the short tube, becoming thin-papery, and persistent on the mature akene. Disk-corollas tubular-funnelform, with a very short proper tube, persistent on the infertile ovary, obtusely 5-toothed. Anthers linear. Style-branches of the disk-flowers linear, hirsute-puberulent externally, extended a little beyond the stigmatic lines into an obtusish tip. Akenes of the ray oblong somewhat obcompressed, obtuse at both ends, lightly several-nerved, wholly destitute of pappus: those of the disk similar, but sterile. - A low perennial herb of the Sierra Nevada, canescent; the mostly simple stems bearing 2 or 3 pairs of opposite entire or obscurely denticulate leaves, and solitary or few sleuderpeduncled showy heads of golden yellow flowers. - Gray, in Proc. Am. Acad. vi. $549, \&$ ix. 195.

1. W. dealbata, Gray, 1. c. About a foot high, from slender and naked creeping rootstocks: leaves obovate or spatulate and tapering into petioles, or the upper small and lanceolate, hoary with a very fine and close woolliness : rays oblong-lanceolate, about an inch in length.

In open woods, Bcc., at an elevation of 5,000 to 7,000 feet, from above the Mariposa Sequoia grove northward along the Sierra Nevada, Brewer, Bolander, Groy, \&ce. A handsome plant, of a very distinct genus, which was dedicated to the accomplished Director of the Californian State Geological Survey, in the prosecution of which it was discovered. It seems to occur through a considerable range in the Sierra; and it is likely to be prized in cultivation. The original character of the genus is here materially corrected. The rays commonly bear rudiments of stamens in the form of sterile filaments : their lower surface is puberulent, as also the akenes and nearly the whole surface of the disk-corollas.

\section{BURRIELIA, DC, Benth.}

Head several-flowered, with one to five very short rays which hardly equal the more numerous disk-flowers, all fertile. Involucre cylindraceous, of 4 or 5 (rarely 3) oblong thin-herbaceous scales. Receptacle subulate or almost filiform, rough with projecting points on which the akenes are inserted. Tube of the corollas slender, as long as the campanulate 4-5-lobed limb and as the barely spreading oval or oblong ligule. Anthers oblong, more or less auricled or sagittate at base, tipped with a slender lanceolate or linear-filiform appendage. Style-branches tipped with subulate-acute minutely hirsute appendages. Akenes long-linear or somewhat fusiform, flattish, with indistinct marginal or other nerves. Pappus of flattened subulate awns or awn-like rigid scales, fully as long as the corolla, of the disk-flowers 2 to 4 , of the ray one or two or rarely none. - Small and slender annuals (all 
Californian), barely hairy ; with opposite entire linear leaves, anil slemler-perluneled heads of yellow flowers terminating the branches. - DC. Prodr. v. 663, in part; Benth. \& Hook. Gen. Pl. ii. 398.

1. B. microglossa, DC: Sparsely hairy, a span high, branching: rays 1 to 3 , inconspicuous, shorter than their style: appendages to the anthers lanceolate: style-appendages broadly subulate: ahenes minutely and sparsely hispid.

Low ground, in the neighborhood of San Francisco. Heads a quarter to a third of an inch in lengtl.

2. B. leptalea, Gray. Nearly glalurous: stems filiform, mostly simple: leaves very small and narrow: rays 4 or 5 , longer than their style but shorter than the disk: appendagres to the anthers almost filiform: style-appendages narrowly and abruptly subulate from a broad base: akenes minutely scabrous-hispid. - Proc. Am. Acad. vi. $5 \pm 6$.

Santa Lucia Mountains, on the Nacimiento River, Brewer. Receptacle subulate, gradually tapering from a broadish base, little shorter than the involucre.

67. B无RIA, Fischer \& Meyer, Benth.

Head many-flowered, with 5 to 12 or 14 exserted pistillate mys; all the flowers usually fertile. Involucre campanulate or hemispherical, formed of a single series of leerbacens oval or oblong-linceulate flat scales. Receptacte strongly and ustally acutely conical, rough or muricate with projecting points which bear the akenes. Rays oval or oblong, entire or 2-3-toothed: disk-corollas with a very slender or filiform tube equalling or louger than the campaudate or cyathiform 5-lubed limb. Anthers ullong, himurnulate or somewhat sagittate at base, tipered with a deltoilovate or oblong obtuse appendage. Style-branches tipped with a very short capitatetruncate or flattened and very obtuse appendage, but its centre sometimes pointed with a short bristle or rarely a more substantial cusp. Akenes linear, subelavate, or linear-cuneate, more or less compressed and 4-5-angled or nerved; those of the ray not at all embraced by the involueral scales. Pappus of a few awns with chaffy-

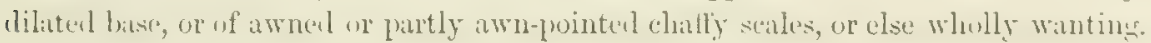
- Annuals (all Californian), mostly low or small, pubescent or almost glabrous; with opposite linear and entire leaves, or else laciniate-pinnatifid into linear lobes,

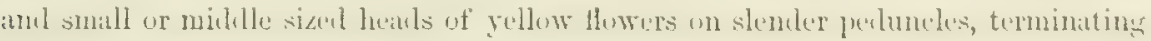
the stem and branches. - Benth. \& Hook. Gen. Pl. 1. c.; Gray, Proc. Am. Acad. ix. 196. Burrielia, DC. 1. c., excl. sp.; Torr. \& Gray, 1. c., excl. sp. Dichata, Nutt. ; Torr. \& Gray, 1. c.

§1. Puppus uniformly none: akenes somerohat rounded at the apex, the areola ralleer small: leaves all entire. (Baria, Fischer \& Meyer.)

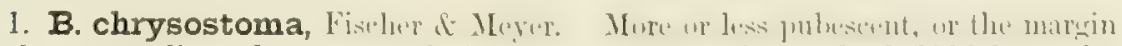
of the narrow linear leaves sparsoly hirsite, a span to a foot and a half high: scales of the involucre 5 to 12 , oblong-ovate or oval-oblong, acute: mys as many, oval or oblong: receptacle rather broadly conical but acute: akenes subclavate-linear, glilurous but most commonly glandular. - Fischer \& Meyer, Incl. Sem. Dec. 1835, \& Sert. Petrop. t. 7 ; Don., Brit. Fl. Gard. ser, 2, t. 395. Burrielia hirsulu, Nutt. B. chrysostoma, Tnrr. \& Gray, Fl. ii. 106, 379.

Var. macrantha (Burrelice chrysostome, var, mecranthe, Griy, Pacif. R. Rep. iv. 106) is a form strikingly large in all its parts, a foot or more high; the heart broal and ample; the oblong mas from half to three quarters of an inch long. 
Hills and moist ground, throughout the western part of the State; the large variety in wet meadows on the coast, from Marin Co. (Bigelow) to Humboldt Co. (Bolander, Kellogg, \&c.), passing into the ordinary form. The opposite depanperate extreme is common farther south and in the interior, probably in sterile soil, with filiform stems only 3 or 4 inches high, and the scales of the involucre and rays reduced to 5 or 6 , the latter only 2 lines long. Akenes narrow, sometimes sparsely dotted, sometimes thickly beset with minute glands or glandular points. Styleappendages truncate-capitate.

\$2. Pappus present and of 2 to 5 (rarely 8) uniform awns or awned chaffy scales (or rarely wanting): akenes trincate at the apex; minutely cinereous-puberulent: leaves except in B. platycarpha entire. (Burrielia, DC., mainly.)

* Chaffy scales of the pappus entire.

2. B. gracilis, Gray, 1. c. Closely resembles the preceding, but smaller than its larger forms, a span or more high, branching freely: scales of the involucre 10 to 14 , oblong-lanceolate: rays as many, oval or oblong: receptacle very narrowly conical, acute : akenes slender : pappus in the ray of 2 or 3 , in the disk of 4 or 5 awıs, with a subulate or lanceolate chaffy-dilated base. - Burrielia gracilis, DC. 1. e.; Hook. Bot. Mag. t. 3758 .

Open ground, apparently common from San Francisco Bay southward. Rays 3 or 4 lines long. Awns of the pappus sometimes very little dilated at base.

3. B. tenerrima, Gray, 1. c. Like the preceding or usually smaller and more slender: scales of the involucre and rays 5 to 9 or 10 : receptacle rather broadly conical and hardly acute: slender awns of the pappus 2 or more from a broad and ovate chaffy base. - Burrielia tenerrima, DC., probably. B. parviflora, Nutt. I. c. B. longifolia, Nutt. 1. c.?

From the Sacramento southward through the State, and in Arizona. Distingnished from the preceding chiefly by the broad and short scales of the pappus; probably passing into it.

4. B. platycarpha, Gray, 1. e. A span high, slender, loosely branehing, slightly pubescent: leaves narrowly linear and entire, or some of them 3-cleft: pednncle mostly thickened next the head: scales of the involucre 6 or 7 , ovate, distinctly 3-nerved: rays as many, oblong: receptacle acutely conical : akenes cuneate-linear: pappus both in ray and disk of 7 or 8 firm oblong-ovate chaffy scales, tipped with a slender awn of about the same length. - Burrielia platycarpha, Gray in Bot. Mex. Bound. 97.

Valley of the Sacramento, Stitlman. A slender form also collected by Rattan. Scales of the involuere 4 lines long in the principal specimens. Style-appendages truncate or very obtuse, but surmonuted by a short abrupt cusp.

$$
\text { * Chaffy scales of the pappus laciniate. }
$$

5. B. Palmeri, Gray. Dwarf, less than a span high, rather stout, diffusely branched from the base, hirsute-pubescent: leaves linear, thickish, all entire: peduncle thickened under the head: scales of the involucre 9 or 10 , ovate, thickishherbaceous, with midrib carinate-thickened and salient at base, and lateral nerves indistinct: rays as many, oval, rather short: receptacle obtusely conical : akenes linear and slightly narrowed below : pappus of 5 (or sometimes more) broadly ovate fimbriate-laciniate scales, those of the disk with a stout awn, of the ray mostly blunt and awnless. - Proc. Am. Acad. ined.

Guadalupe Island, off Lower California, Dr. E. Palmer. Introduced to complete the account of the genus. Head 3 lines high and broad: rays 2 lines long.

\section{\$3. Pappus of truncate or pointless short chaffy scales between 2 or 3 awned ones or naked awns, or sometimes wanting: akenes truncate at the apex: receptacle obtusely conical: leaves or some of the lowermost laciniately cleft or pinnati- fid.-Dicheta, Gray. '(Dichoeto, Nutt. 1. c.)}

6. B. maritima, Gray. Low and diffuse, pnbescent when young with loose cobwebby hairs, becoming nearly glabrous: leaves oblong-linear or lanceolate, entire, 


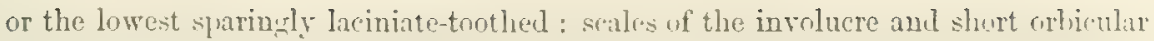
rays 6 to 8 : akenes minutely hairy: paypus of 3 to 5 stout awns and at least twice as many suall and narrow laciniate chaffy scales. - Burrielia maritima, Gray, Pruc. Am. Acad. vii. 358.

On the Farallones, rocky islets off San Francisco, Mr. Gmuber. The rays in the specimen do not exceed the disk, but, being broad and fat, probably they may become more conspicuous.

7. B. Fremontii, Gray, 1. c. Slender, a span high, somewhat hirsute-pubescent: leaves narrowly linear and entire, or with 2 to 5 very narrowly linear lobes: scales of the involucre and rather short oval rays 10 to 12 : disk-corollas slender and with a long narrow tube: pappus of mostly 4 slender awns, and as many or twice as many short linear or oblong and entire or 2-cleft blunt scales, or sometimes wanting. - Dicheta Fremontii, Torr, in Pl. Fendl. 102. Burrielia (Dicheta) Fremontii, Benth. Pl. Hartw. 317, a state (always?) without pappus.

Valley of the Sacramento (Frcmont, Harhwog) and near Vallejo, Greene. Ovaries minutely

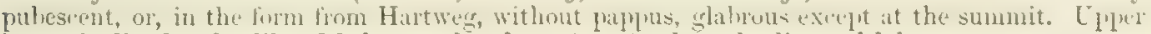
leaves inclined to be dilated below, and to lave 3 to 5 paimately-disposed lobes.

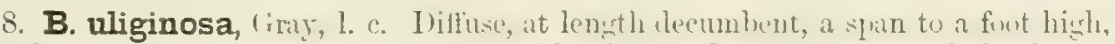
loosely puhescent with somewhat cobwebby hairs: lower or most of the leaves copiously pinnatifid from a broad or broadish rhachis; the lobes narrowly linear: scales of the involucre and oblong exserted rays usually 10 to 13 : throat of diskcorollas very broad, and narrow tube rather short: pappus of 2 or 3 stout chatfysubulate awns, and as many or twice as many intervening conspicuous and broad truncate and laciniate-fimbriate scales. - Dichata uliginosa, Nutt. 1. c.

Var. tenella, Gray, 1. c. (Dichata tenella, Nutt. 1. c.), is only a depauperate state, on drier soil, with narrow linear leaves, and more of them entire; the rays and involucral scales reduced to 8 or 9 , or rarely to 5 or 6 .

Low grounds, common through the western part of the State. Very variable. Lenves in the larger plants a span long, and the stems luxumant in proportion. Akenes a line long, oblonglinear and a littlo narrowed downward, sometimes pubescent, sometimes glabrous, apnarently in plants growing together.

\section{ACTINOLEPIS, DC., Benth.}

Head many-flowerel, with fex ur numerons pistillate mys; all the flowers fortile.

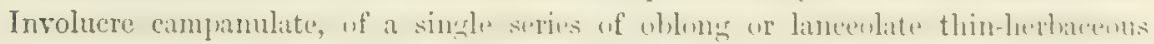
scales, which become concave or involute and embrice more or less the ray-akenes. Receptacle naked, convex or conical, or in an ambiguous species flat. Rays oval or oblong, 2-3-toothed: disk-corollas with narrow tube and campanulate 5-lobed limb. Anthers tipped with an abrupt narrowish or very slender appendage. Style-

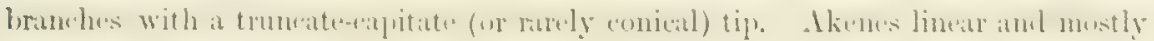
tapering to the base, or linenr-cuneate; those of the ray commouly somewhat incurved. Pappus a series of chaffy scales or squamella (either few or numerons), which are either pointless or extended into an awn, or sometimes none. - Low and diffuse or depressed annuals, all of the Californian region, mostly woolly, in one

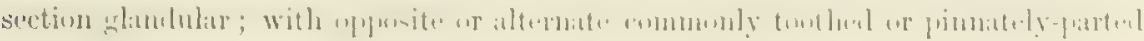
leaves, and small or proportionally rather large heals terminating the branches. Flowers all yellow, or the rays oceasionally white or rose-color. Gray in Proc. Aro. Acal. ix. 197.

A rather well-marked genus, as rightly clanraterized on the oriminal speries by Torrey and

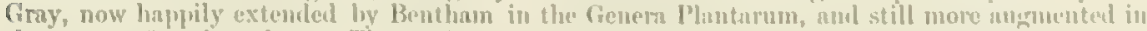

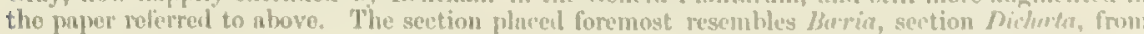
which it is distinguished by the partial enclosure of the ray-akenes in the seales of the involucre. 
§1. Not woolly, but mostly glandular, diffuse, with opposite pinnately parted or the radical twice pinnately dissected leaves, their segments linear and attenuate: heads on slender peduncles, and with rather large and numerous (yellow) rays: involucre rather broad: receptacle acutely conical: anther-appendages oblong. - Ptilomeris. (Ptilomeris, Nutt. Hymenoxys, Oxypappus, Torr. \& Gray.)

As yet, it is uncertain whether the following are mere varieties of one, or whether they retain their small distinctions uniformly. If at length reduced to one the name $A$. coronaria should be preferred, Nuttall's name (probably suggested by a likeness to Chryscnthemum coronariwm) being a year or so earlier than Hymenoxys Californica of Hooker.

* Minutely glandular-pubescent: rays 10 to 15, elongated-oblong: involucral scales oblong-lanceolate: receptacle pubescent.

1. A. coronaria, Gray, l. c. Diffusely branching slender stems a foot long: pappus of 10 (or 8 to 12) lanceolate or oblong denticulate scales, all tapering into awns a little shorter than the disk-corollas, or in the ray fewer and some of them awnless. - Ptilomeris coronaria \& P. aristata, Nutt. in Trans. Amer. Phil. Soc. vii. 382. Shortia Californica, Nutt. in garden catalogues. Hymenoxys Californica, Hook. Bot. Mag. t. 3828 ; Torr. \& Gray, Fl. ii. 280, with var. coronaria.

Near San Diego, Nuttall. So far as we know collected only by him, and in cultivation from his seeds. Described as "very glabrous" in the Botanical Magazine, doubtless incorrectly. Rays nearly half an inch long, usually 12.

2. A. anthemoides, Gray. Leaves perhaps more copiously divided and glandular, and heads rather smaller : pappus none - Ptilomeris (Ptilopsis) anthemoides, Nutt. l. c. Hymenoxys calva, Torr. \& Gray, l. c.

With the preceding, Nuttall. Also towards Julian City, Bolander.

3. A. mutica, Gray, 1. c. Like the foregoing : pappus of 6 to 8 quadrate-oblong scales, erose-laciniate at the truncate or very obtuse summit, shorter than the proper tube of the corolla, occasionally one or two of them slightly awned. - Ptilomeris mutica, Nutt. 1. c. Hymenoxys mutica, Torr. \& Gray, 1. c.

Near San Diego, Nuttall; by whom only it has yet been collected.

* * More or less pubescent, but hardly if at all glandular: rays 6 to 8, shorter, oval: involucral scales ovate: receptacle glabrous.

4. A. tenella, Gray, 1. c. Smaller than the foregoing: the heads and leaves about half the size of those of A. coronaria: lobes of the latter shorter and blunter as well as fewer: pappus of 5 to 8 short quadrate scales, which are fimbriate at the broad summit, or some of them occasionally bearing a delicate short awn. - Ptilomeris tenella, \& P. affnis, Nutt. Pl. Gamb. 173 ; the latter a form with some of the pappus awned.

Near Los Angeles, Gambel. Rays 2 lines long.

\$ 2. Floccose-woolly: most of the leaves alternate: involucre narrow: rays rather few, obovate: receptacle convex or obtusely conical: akenes minutely hairy or sometimes glabrous: pappus of 8 to 10 or more scales or squamelloe. - True ACTINOLEPIS.

* Heads small and sessile or leafy-bracted, with only 5 (or " 3 to 5") yellow rays : receptacle merely convex: anther-appendages ovate-lanceolute: pappus of subulate or almost setiform scales, commonly wanting in the disk-flowers. (Actinolepis, DC.)

5. A. multicaulis, DC. Seldon a span high, diffusely branched from the base, the white wool below somewhat deciduous with age: leaves cuneate or spatuIate with a long tapering base, the summit obtusely 3-toothed or 3-lobed: scales of the pappus 10 to 15 , unequal, very slender, usually (but not always) wanting in all the disk-flowers. - Hook. Ic. t. 325 ; Bot. Mex. Bound. t. 33. 
Dry plains, common from Santa Barbara southward. Heads somewhat clustered; the involacte only 2 lines long. Rays generally 5. The state with pappus in the disk as well as ray was collected by Prof. Brever in the Santa Maria Valley, Santa Iñez Mountains, \&e.

* Heads more or less peduncled terminating the branches, with 6 to 8 rays: receptacle obtusely conical: anther-appenduges abruptly tipped with a very slender

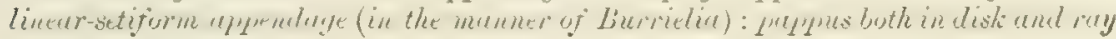
of 8 or 10 chatjy scules.

6. A. Wallacei, Gray, 1. c. Densely clothed with long and very floccose white wool, at length diffusely much branched, an inch to a span high: leaves ubovate or spatulate, entire or somewhat 3-lobed at the auex: scales of the involucre obtuse: pappus of 8 or 10 short and firm oval or oblong obtuse and pointless nerveless scales. - Bahia Wallacei, Gray in Pacif. R. Rep. iv. 105 ; the form with golden yellnw my as well as disk.

Var. rubella, Gray: a form with pale purple and white rays. — Bahia rubella, Gray in Bot. Mex. Bound. 95.

Dry plains, from near Los Angeles and San Felipe, IV allace, Parm (the variety). Also on the

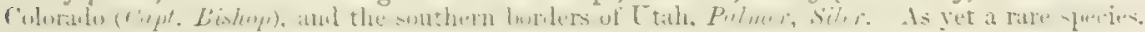
Style-loranches tipped with a short subulate cone! Scales of the involucre involute with age in the manner of the genus.

7. A. lanosa, Gray, 1. c. Loosely floccose-woolly, an inch to a span high, at length diffusely branched: leaves linear, mostly entire: scales of the involucre linear-oblong, rather acute: rays white or rose-color: akenes slender: pappus of 4 or 5 subulate scales tapering into a slender scabrous awn, and as many alteruating oblong and awnless or pointless scales. - Burrielia (Dichata) lanosa, Gray in Pacif. R. Rep. 1. c.

Gravelly hills and plains, on the Colorado, near the Mohave, \&c., Bigclow, Cooper. Also in

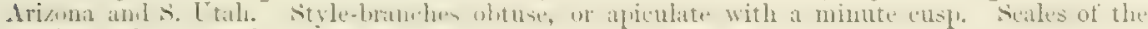
involucre almost conduplicately infolded at maturity, enclosing the akene.

\$ 3. Floccose-zooolly, depressed, with mostly alternate leaves: involucre narrovo: rays 8 or 9, small: receptacle flat: akenes linear, compressed, with callous margins exceedingly villous: pappus of 2 chaffy scales: anther-appenduges oblongovale. - Eatrosella, Gray.

8. A. nivea, Gray, 1. c. An inch or so high, in a small tuft from a slenuler root, white with soft wool: leaves much crowded, obovate-spatulate, cntire: heal barely exserted on a short naked peduncle: scales of the involucre linear-ablon: acute, partly exubracing the comparatively large akenes of the ray: pappus of a pair of broadly ovate conspicuous scales tapering into a slender short awn which

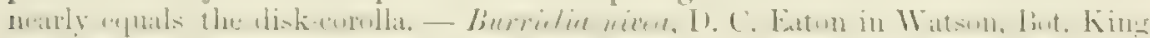
Exp. 174, t. 18.

Foot-hills on the eastem sicle of the Sierm Nerada, Walson. Very likely to occur within the State. A remarkable plant, evidently related to the foregoing, but it might he regarled as the type

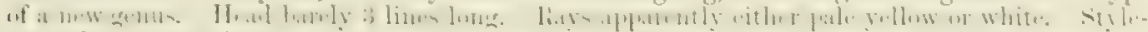

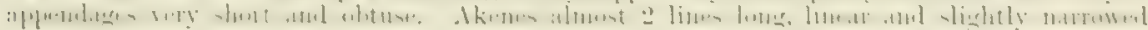
lowward; the faces flat, smooth and shining, blnckish; a callous strong rib to each nurgin,

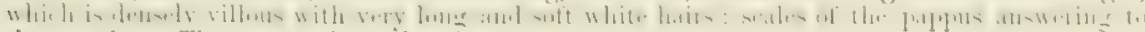
the margins. The receptacle is described as convex: but it is flat in the speeimen examined, naked and scrobiculate.

69. BAHIA, Lagasca.

IIead many-flowered, with 4 to 15 pistillate rays; all the flowers fertilo. Involucre a single or more or less doublo series of thin-herbaceous oval or lancenlate appressed equal scales, either plano or barely concave, unt embraning alienes, distinct, or united at bise, or marely for a crmater leneth. liereptaclo Hat, convex, or conical. Rays oval, obovate or ublung, entire, or barely touthed at the apex: disk- 
corollas with a narrow but commonly rather short and glandular or hirsute proper tube. Anthers tipped with an ovate appendage. Style-branches with truncatecapitate or obtuse tip, sometimes with a short subulate-conical appendage. Akenes narrow, linear or oblong-linear and tapering to the base, 4-angled, the pubescence minute or none; the terminal areola large. Pappus of several (4 to 12) blunt and nerveless scarious scales (in true Bahia often callous-thickened next the base), rarely obsolete or wanting. - W. North American with a few Mexican and extratropical S. American plants, perennials, with perhaps a single exception; with opposite or all but the lower alternate entire or divided leaves, and mostly peduncled heads of yellow flowers. - Benth. \& Hook. Gen. Pl. ii. 402.

Although the typical section is represented eastward of Californin, all our species are of the two following sections; the tirst species, however, approaches Balia proper ; the last section connects with Monolopia.

\$ 1. Perennial, sometimes shrubby at base, floccose-woolly or cottony: leaves mainly alternate and mostly either pinnately or ternately parted or lobed: scales of the campanulate or obovoid involucre erect, commonly a little united at base, oval or oblong, more or less carinately one-nerved: throat or limb of diskcorolla rather narrow: style-branches truncate, or rarely minutely tipped: scales of the pappus wholly nerveless. - ERiopHyludu, Gray. (Eriophyllum, Lagasca. Trichophyllum, Nutt.)

* Heads corymbose or cymose, small, short-pedicelled, with only 4 to 8 short rays : the wool close and cottony: stems woody at base, leafy to the top: leaves altemate.

1. B. artemisizefolia, Less. Two to four feet high, loosely branching, whitened when young with a coat of close cottony wool, which is mostly nearly deciduous with age, except from the lower surface of the once or twice pinnatifid leaves; their lobes few, linear, obtuse, with revolute margins: heads numerous in irregular paniculate cymes: involucre cylindraceous-camipanulate, slightly if at all woolly; its scales 8 to 10 , oblanceolate or narrowly oblong: receptacle convex, strongly alveolate and toothed: scales of the pappus 8 to 12 , oblong-linear, the four answering to

- the principal angles or nerves of the akene rather longer. - B. stochadifolia \& var. Californica, DC., a stunted form, with leaves less lobed, or the uppermost, as often happens, entire.

Rocks and bluffs, common from the Bay of San Francisco to Santa Barbara. Decidedly shrubby. Leaves somewhat like those of Artemisia vulgaris. Heads 3 or 4 lines long: scales of the involucre distinet to the base or nearly so, becoming concave at maturity. Rays 6 to 8 . If this is the Eriophyllum stachcclifolium of Lagasca, that specific name has priority; but the leaves of that are (by implication) entire, and it may be an unrecognized species from Mexico, as stated.

2. B. confertiflora, DC. A foot or two high, white with a coat of close wool, which is somewhat deciduous with age: branches erect and commonly fastigiate, slender, naked at summit and terminated by a small and dense few- to manyflowered corymbose cyme: leaves small, of cuneate outline, pinnately 5-7-parted (rarely 3-parted) into narrow linear lobes: involncre obovoid or narrow campanulate; its scales about 5, broadly oval : receptacle convex or low conical in the centre, not alveolate: scales of the pappus 8 to 14 , oblong-linear, somewhat unequal.

Var. trifida, Gray ( $B$. trifida, Nutt.), seems to be merely a form growing in more exposed stations; with the leaves mostly sessile or tapering into a broadly margined petiole, and 3-5-cleft at the apex into shorter lobes.

Hillsides, \&e., from the Bay of San Francisco to the Sierra Nevada and south to San Diego. Shrubby at base, the flowering shoots mainly herbaceous. Involucre 2 limes long. Flower's deep golden yellow : rays 4 or 5 , broadly oval or orbieular. 
* Heads larger, solitary, terminating naked peduncles: scales of the invalucre oval or oblong: stems herbuceous or nearly so, mostly unmeraus from the root, erect or ascending from a decumbent buse; the white wool usually floccose and copious: lower leaves often opposite, the others alternate.

+ Leaves narrow or cut into narrono lobes: akenes mostly slender: pappus conspicuous, of 8 or 10 oblong or oval scales, the alternate ones commonly shorter or smaller.

3. B. lanata, DC. A foot or two high, slender: leaves pinnately cleft or parted into 3 to 7 lanceolate or linear lobes, which are entire or sometimes again few-lobed or incisely toothed; uppermost and lowest leaves often undivided: peduncles slender: rays mostly 8 or 9 , oblong, conspicuous : akenes glabrous or minutely hirsutepuberulent. - B. lanata, temuifolia, lewcophylla, \& achillaoides, DC. Achillea lanata, Pursh. Trichophyllum lanatum, Nutt. Helenium lanatum, Spreng. Eriophyllum caspitosum, Dougl. in Bot. Reg. t. 1167, one of the broader leaved forms. The following are some of the varieties or forme of this polymorphous species: first taking for the type Pursh's and Nuttall's original, from the interior of Oregon, \&c. ; with middle-sized heads, glabrous and shortish akenes, and narrowly or ligulatelinear lobes to the leaves. $B$. leucophylla, DC., is founded on a form of this, with leaves rather laciniate-toothed or cleft than pinnatilid, and the wool more persistent on the upper surface.

Var. tenuifolia, Torr. \& Gray ( $B$. tenuifolia, DC.), is merely the most slender form, simple-stemmed, with very narrow lobes to the leaves, and small heads.

Var. grandiflora: has larger heads, the involucre (at most half an inch high) densely clothed with persistent wool: akenes sparsely hirsute-puberulent: leaves usually retaining the wool on both sides, and few-lobed or laciniate, or the upper linear and entire. - B. leucophylle, Tors. \& Gray, in part. B. lanata, Benth. Pl. Hartw. 317.

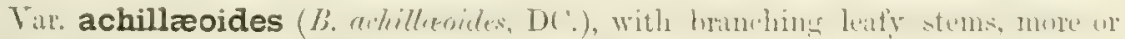

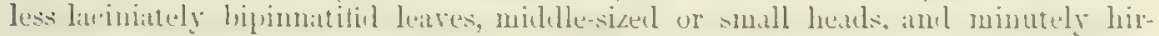
sute-puberulent (sometimes glabrate) akenes.

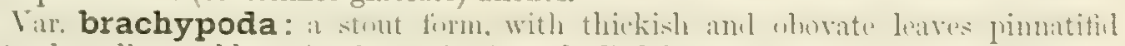
into short linear-oblong (entire or 1-2-toothed) lobes, some of the upper opposite:

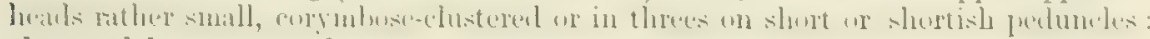
akenes gylabrous or nearly so.

Common in California, especially northward near the const, extending to Puget Sound and the interior of Oregon; the typucal form not seen south of Ukiah. Var. grandiftora, on hillsides, along the Sacrimento and its tributaries. ( $A$ form hetween this and the next variety, Gundalupe Island off Lower (alifornia, Dr. Pulmer.) Var. achilleoides, near San Francisco and northwarl. Var. brichypothe, on the sen-const at Shelter Cove, Mendocino $\mathrm{Co}_{2}$; a sen-side and seeningly mather abnormal form, perhaps of De Candolle's B. levcopplyella. Receptacle varying from eonvex to deciledly conical; but the differenees in this respect not correlated with the other very varions differences in folinge, size of the hend, smoothness or otherwise of the akenes, \&c. Tulne of the corolla mostly glandular-hirsute, sometimes heset with almost sessile glands. Scales of the pappus varying from oval to broally linear, sometimes of two lengths and forms, sometimes all nearly alike. It seens impossible to distinguish the forms here indieated into sprecies.

4. B. integrifolia, DC. Abont a span high, in tufts: leaves varying from linear to spatulate, entire, incisely few-toothed, or the lower and more dilated ones $3-5$-lobed : heads mther small or mildlle-sized: rnys 6 to 8 : disk-corollas minutely glandular, especially the tube: akenes ghabous, or somotimes obscurely crlandular wwards tho summit. - Trichophyllum muleiflorum, Nutt. in Jour. Acad. Philad. vii. 37. T. integrifulium, Hook. Fl. i. 316. Bahia lencopleylla, Torr. \& Gruy, in part. B. cuneata, Kelleggeg in Proc. Calif. Acad. v. 49, a form with more toothed or Jibed leaves.

Iligh Sierra Nevaln, at or ahove 8,000 feet, from Mfono Pass northwarl, through Nevmln and the interior of Oregon, to the Rocky Mountains. Involuere 3 or 4 lines high. Reteptate vary- 
ing from convex to low conical. B. integrifolia is the older specific name under this genus, and the better one, although Trichophyllum multiflorum was earlier published.

5. B. gracilis, Hook. \& Arn. A span or so in height, branched from the base, slender: leaves narrowly linear and entire, or dilated above and 3-parted or 3-lobed: heads slender-peduncled, rather small : rays 5 to 7 : disk-corollas and akenes conspicuously glandular. - B. leucophylla, in part, Eaton in Watson, Bot. King Exp. 173.

Known thus far only from Snake Fort, interior of Oregon (Tolmie), and the not remote Robert's Station, Nevada, Watson. Tolmie's plant has simple entire leaves, as far as known, head rather large in proportion, the involucre 4 lines high, and the receptacle low convex. The variety collected by Watson is canescent with fine appressed wool, leaves mainly 3-parted, naxrower and rather smaller heads, and a narrower conical receptacle. It is likely to occur, in one oi both forms, in the northeastern part of the State.

++ Leaves mostly broader and with short and broader lobes: pappus very short, sometimes obsolete or wanting!

6. B. arachnoidea, Fischer \& Meyer. A foot or two high, loosely branched, disposed to become rather woody at base, clothed with loose floccose wool: leaves dilated, varying from rhombic or cuneate in outline to oblong-lanceolate, mostly thin, 3-5-lobed or incised; the lobes or coarse teeth mostly oblong: involucre broadly campanulate or hemispherical ( 3 or 4 lines high) : rays 10 to 13 , large: disk-corollas with very glandular-hirsute tube : receptacle low convex or sometimes more elevated: akenes comparatively short and thickish, hardly longer than the disk-corolla: pappus of few or several very short scales, sometimes however longer than the breadth of the akene, sometimes almost or quite obsolete. - Gray, Pl. Fendl. 100. B. latifolia, Benth. Bot. Sulph. 30.

Open and shady places, especially among Redwoods, common near the coast from Santa Cruz to Mendocino Co. Leaves more frequently opposite on the lower part of the stem and on sterile shoots than in the other species. Pappus sometimes reduced to a mere border, or even wanting altogether. In a specimen of this sort, collected by Polander in the Mariposa Sequoia grove, quite beyond the ordinary range of this species, the leaves on the low flowering sterns are unusually narrow, so that the plant might almost be taken for an epaplose state of $B$. integrifolia. But the proper tube of the disk-corolla, as usual in the present species, is densely very hirsute with many-jointed and seemingly glandular hairs.

7. B. parviflora, Gray. A span or less high, diffusely branching, floccosewoolly, slender: leaves linear-oblong or spatulate, 3-5-lobed, от the upper entire, from half to a quarter of an inch or less in length: involucre narrow, only 2 lines long: rays 5 or 6 , hardly longer than the disk: disk-corollas nearly glabrous: receptacle conical: akenes somewhat fusiform, the outermost minutely hirsute, the inner glabrous: pappus of short nearly equal scales. - B. Wallacei, Gray in Proc. Bost. Soc. Nat. Hist. vii. 145, not' of Pacif. R. Rep.

Near Fort Tejon, Xantus. The smallest of the genus.

§2. Annual, flocculose-woolly: leaves alternate, entire: scales of the involucre united by their margins into a campanulate 8-9-lobed cup: style-branches truncate: scales of the pappus wholly nerveless. - Pseudo-Monolopia, Gray.

8. B. ambigua, Gray. More than a span high, slender, loosely branched; the branches terminated by slender-peduncled small heads: leaves spatulate-linear or oblanceolate, entire, tapering to the base, sessile : receptacle conical, narrow: rays 8 or 9 , oval, hardly exceeding the ovate-lanceolate lobes of the involucre: tube of disk-corollas hirsute: akenes linear or the outermost oblong-linear, prismatic, glabrous, or the outer ones slightly hairy: pappus a crown of 6 to 9 very short and obtuse hyaline scales, or sometimes none.-Lasthenia (Monolopia) ambigua, Gray, Proc. Am. Acad. vi. 547.

Near Fort Tejon, Dr. Horn, 1864. Not since met with. Leaves less than an inch long, 2 lines or less wide. Involucre about 3 lines long; the scales strictly in a single series and united for two thirds of their length into a rather nariow campnnulate cup. Receptacle minutely scro- 
biculate, barely smooth. Ravs barely two lines in length, oval, slightly 3 -crenate at the end. 1)isk-corollas with almost camipanulate limb; the ovate tecth or short lobes nearly beardless. As this has not only the pappus but the namow prismatic akenes of Bahiu, it is referred to this genus, as Bentham suggested, notwithstauling the gamophyllous involnere.

\section{MONOLOPIA, DC:}

IIead many-flowered, with 8 to 10 pistillate rays; some of the disk-flowers often sterile. Involucre a single (or in $\boldsymbol{M}$. minor somewhat double) series of thin-herbaceous flat equal seales, united at base or into a hemispherical cup. Receptacle more or less conical, naked. Rays broad, 2-4-toothed or lobed at the summit, sometimes with an opposite small lobe or appendage at the base of the ligule: diskcorollas with a rather slender tube and a dilated-funnelform or campanulate throat or limb, the ovate lobes more or less bearded. Anthers tipped with ovate appendages. Style-branches truncate-obtuse. Akenes obovate or oblong, quadrangularcompressed or flatter, the outer ones obcompressed or triangular, with terminal areola small, wholly destitute of pappus. - Californian floccose-woolly or cottony anuuals: with mostly alternate or sometimes mainly opposite entire or pinnately parted leaves, and terminal slender-peduncled heads of yellow flowers.

The type of the gemus, our second section, is $\boldsymbol{M}$. mujor. Except for this species it were better to include the first section in Buhic. The best character of the genus is furuished by the froaler and flattened akenes, supplemented by the constant absence of pappus, - not in the gamophyllous involucre, which varies in the original speres, and nearly fails in one form of it.

\$1. Low, a span high: leaves (alternate) not clasping, sometimes petioled and pinnatifid: rays destitute of the little appendage, barely $2-3$ toothed at the apex. - Pseudo-Buma, Griy.

1. M. bahizfolia, Benth. Slender, whitish with close cottony wonl: leaves linear-oblanceolate or spatulate and entire, or some of them obtusely 3-lobed (about half an inch long): scales of the involucre united about to the midlle: akenes hairy, especially towards the rounded summit. - Pl. Hartw. 317.

Var. pinnatifida, Gray. Leaves (sometimes an inch long) nenty all onco or even twice pinnately parted into oblong or linear lobes. - Monolopia Heermanni, Durand.

Hillsides, \&ce, Valley of the Sacramento, Hurlucg. The variety, Calaveras Co., Dr. Irermann. Also near Auburn, Placer Co., Bulcuder. Involuere broally campanulate or hemispluerical, 25 lines high. layss nbout 8 , oval or oblong, 2 or 3 lines long. Receptnele, at lenst in the variety, marrowly conical. Akenes a line long, nither broad and llattish, with smanl areoln.

2. M. minor, DC. Loosely very woolly, mostly pinnately 3 -5-parted into linear divisions: scales of the involucre united only below tho middle, rather obviously in two series: ovary glabrous. - Hook. Ic. Pl. t. 343.

Californin, the locality unknown, collected only by Dougless. Hend hemispherical : receptacle aprarently little elevated. Ovaries obovate-oblong. Lobes of the corolla bearded.

\section{\$ 2. Larger: leaves entire or somewhat toothed, sessile and parlly clasping: rays dilated, coarsely 3-4-toothed or lobed at the summit, the base on the opposite side of the style uppenduged with a small and rounded denticulate lobe. - True Mosolopia.}

3. M. major, DC. White or whitish with floceose wool, sometimes becoming shabrate and yreen, a span to 2 feet high: lenves varying from linear to brually: lanceulate or the upper lanceolate-oblong, entiro or coarsoly and uneyually repandserrate: seales of tho broally campanulate or hemispluerical involuere united to on above the michlle: akenes glabrous or very minutely hirsute-puberulent. - Hook. Ic. P1. t. 34t, \& bot. Mitg. t. 3839 . 
Var. lanceolata, Gray, is merely a state with the scales of the involucre separate down almost to the base, and the akenes perhaps uniformly puberulent. M. lanceolata, Nutt. Pl. Gamb. 175.

Common through the central part of the State, and from San Francisco Bay to San Diego. The variety about Los Angeles, \&c., Nuttall, Parry, Brewer. Also on the San Joaquin, Fremont. Leaves 1 to 4 inches long; the lower ones not rarely opposite. Heads pretty large. Rays about 10, from a third to a full inch long, proportionally broad, with base abruptly contracted into a short and slender tube. Akenes a line to a line and a half long. It is through some mistake, as the specimens and original description show, that Bentham refers Nuttall's $M$. lanceolate to Buchia arachnoidea. It is really a state rather than a variety of $M$. major.

\section{LASTHENIA, Cass.}

Head many-flowered, with 5 to 15 pistillate rays; all the flowers fertile. Involucre a single series of herbaceous scales, united by their edges almost to their tips into a 5-15-toothed campanulate or hemispherical cup. Receptacle conical, naked, muricate or papillose with projecting points which bear the akenes. Rays very short and included, obliquely truncate, or in one species large and exserted: diskcorollas with narrow tube and eampanulate or cyathiform 4-5-lobed limb. Anthers tipped with small ovate or oblong appendages. Style-branches capitate-truncate or obtuse. Akenes linear or linear-oblong, compressed (the faces hardly if at all angled or obviously costate), their terminal areola large, bearing a pappus of 5 to 10 firm and thickish mostly subulate-pointed scales nearly as long as the disk-corolla, or in one species none. - Slender (Western American) annuals, green and glabrous or nearly so, somewhat succulent; with the linear and mostly entire leaves opposite (even to the uppermost), sessile and more or less connate at the base; the heads of yellow flowers on terminal peduncles, which are more or less thickened at the summit, sometimes nodding. - The first section is intermediate between the genuine Lasthenia and Monolopia.

\section{\$1. Rays ample and conspicuous, numerous: akenes linear-oblong, wholly destitute} of pappus. - HoLOGYMNE.

1. I. glabrata, Lindl. A span to 2 feet high, simple or branched from the base and diffuse, glabrous or slightly pubescent: leaves sometimes one-toothed or lobed on each side ( 1 to 3 inches long, 1 to 3 lines wide) : involncre $10-15$ toothed : rays oval, 2 - 3-toothed at the end: disk-corollas as long as the glabrous akene, their lobes sparsely papillose-barbellate outside (as in Monolopia). - L. Culifornica \& glabrata, Lindl. Bot. Reg. t. 1780, \& t. 1823. Hologymne glabrata, Bartling.; Hook. Bot. Mas. t.. 3730. Monolopia glabrata, Fischer \& Meyer.

Low grounds, common from Mendocino Co. and San Francisco Bay to Santa Barbara. In the larger forms showy; the expanded ray becoming an inch or more in diameter.

\section{\$2. Corollas short; the fere and very short rays wholly inconspicuous, not exceeding the disk-flowers, little surpassing the pappus. - True Lasthenia.}

2. L. glaberrima, DC. Low, with stems weak or decumbent, a span or two long: leaves rather succulent, entire (an inch or two long, a line or two broal): involucre broad, about 15-toothed: corollas shorter than the rather broadly linear and minutely pubescent akenes, their lobes naked: pappus of 5 to 10 firm chaffy scales, 2 or 3 of them subulate-pointed or short-awned, the others mostly laciniately cleft or erose.

Wet meadows, along or near the coast, from Monterey? to Mendocino Co., and Oregon. Involucre about 3 lines high. Receptacle broadly conical. Ours is not very different from the Clilian species, the only remaining one of the genus. 


\section{AMBLYOPAPPUS, Hook \& ARn.}

Fearl several-florerenl, latetrugumous but disenil, 4 or 5 marginal flowers pistillate; the 10 or 12 others perfect; all fertile. Involucre of 4 to 6 oval or obovate thin-herbaceous equal scales, as long as the disk, their concave-carinate centre partly embracing ray-akenes. Receptacle small, conical. Corollas all very short, tubular, and with short and obtuse at length connivent teeth; those of the pistillate Howers unequally 2-4-toothed and shorter than their style; those of the perfect flowers 5-toothed. Anthers short. Style-branches short, in the perfect flowers truncate and minutely tufted at the summit. Akenes oblong-turbinate, 4-angled. Pappus of 8 to 12 equal oblong blunt and nerveless chaffy scales, which are opaque and thickened at bise, much shorter than the akene, about equalling the corolla. - Only one species.

1. A. pusillus, $\Pi(n)$ k. \& $A$ In. I low glabrous but somewhat glutinous aromatic annual, a span or so high, corymbosely branched above, and with small heads of yellowish flowers terminating the numerous branchlets: leaves alternate or the lower opposite, narrowly linear, mostly simple and entire, some pinnately $3-5$-parted. - Hook. \& Arn. in Hook. Jour. Bot. iii. 321. Aromia tenuifolia, Nutt. Infantea Chilensis, C. Gay, Fl. Chil. iv. 257, t. 48.

Around San Diego : probably introduced from Chili, where it is common along the coast. It also inhabits Guadalupe Island, off Lower California.

\section{AMAURIA, Benth.}

Ileal many-fluwerel, with numeruus pistillate rays; all the flowers fertile. Involucre hemispherical ; its scales linear, aluost equal, in 2 or 3 series, the outer nearly herbaceous, the inner somewhat scarious. Receptacle flat, naked. Rays almost entire: disk-corollas narrow, 5-toothed. Style-branches filiform, tipped with a short-subulate acute appendage. Akenes linear, 4-angled, destitute of pappus. Only the following species.

1. A. rotundifolia, Thenth. I smmewhat shrubhy (!) viscil-pubesent and luw plant; with the leaves opposite or the upper alternate, petioled, orbicular-cordate, incisely toothed or lobed: heads (about half an inch in diameter) loosely corymbose : corollas yellow, those of the disk and the tube of the (about 20) rays glantular-hispid: akenes nearly glabrous. - Benth. Bot. Sulph. 32, \& Gen. Pl. ii. 404.

San Quentin, Lower California, lat. $30^{\circ} 21^{\prime}$, Hinds Known only by the specimen deserihed

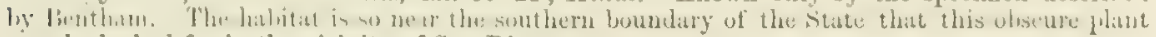
niay be looked for in tho vicinity of San Diego.

\section{HULSEA, Torr. \& Gray.}

Ilad many-floweres, with numerous narrow pistillato riys anul bory many ulisknowers; all fertile. Involucre hemispherical or broader, of narrow and lax somewhat equal scales in 2 or 3 series, the outermost herbnceous, the innermost moro searious. Receptaclo flat, naked, somewhat foveolate. Rays linear, entire or minutely 2-3-toothed at the tip : disk-corollas narrow and elongated, and with a slender proper tube, 5-toothed. Anthers tipped with an ovato appendage. Stylebranches with somewhat dilated rounded tips. Akenes clavate-linear, compressedqualrangular, black at maturity, villous. Pappus of 4 short and very thin hyalino

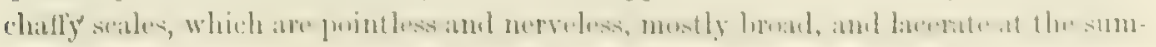


mit. - Perenuial and some of them apparently biennial or annual herbs, all of the Californian Sierra Nevada, glandular-pubescent, and some also woolly; with alternate pinnately lobed or toothed leaves, and large heads of yellow flowers, or the rays in one species purple.

An interesting genus, dedicated to the discoverer of the first species, the late Dr. G. W. Hulse, formerly of Louisiana, who made some collections in California.

* Stems elongated and bearing several racemose or corymbose heads: scales of the involucre linear and acuminate.

1. H. Californica, Torr. \& Gray. Tall, viscid-pubescent: heads 3 to 7 on an apparently naked stem or peduncle, subtended by ovate-lanceolate bracts (half an inch long): rays yellow: scales of the pappus rounded-cuneate, the truncate apex denticulate. - Bot. Mex. Bonnd. 98.

Mountains east of San Diego, in bushy places, Perry. Base of stem and leaves still unknown. Rays half an inch long, furnished with sterile filaments. Akenes a quarter of an inch long.

2. H. heterochroma, Gray. Two feet high or more, viscid-pubescent, leafy to the top: leaves oblong, thin, coarsely and sharply toothed; the uppermost subtending the 4 or 5 racemose heads ovate and partly clasping; lowest narrowed to the sessile base: corollas hirsute: rays very numerous, purple: scales of the pappus erose-denticulate, two of them oblong, the alternate two much shorter. - Proc. Am. Acad. vii. 369 .

Yosemite Valley, on granite debris, Botander. Involucre fully half an inch high. Rays 40 or 50 ; the small ligule only 2 or 3 lines long, sparsely hirsute : tubes of all the corollas very hirsute ; those of the disk apparently tipped with purple when old. Akenes $3 \frac{x}{2}$ lines long.

$$
\text { * Stems or branches leafy and terminated by a solitary head. }
$$

3. F. brevifolia, Gray, 1. c. A foot high, glandular-pubescent: stem simple or with slender simple branches: leaves narrowly oblong or the lower spatulate, repand-toothed, obtuse, sessile: head rather small and narrow: scales of the involucre linear, barely in two series: rays only 10 or 12 , light yellow: scales of the pappus nearly entire, oblong, the alternate ones rather shorter.

In the Mariposa Sequoia grove, Bolander. Leaves an inch and a half or less in length. Involnere half an inch high. Rays 3 or 4 lines long. Akenes 3 or 4 lines long. The habit of the plant is more like that of the foregoing species; but the stem or branches with only terminal heads.

4. H. algida, Gray. A span to a foot high, glandular-pubescent, and when young more or less villous or woolly: stem stout and simple (or several from a thickish rootstock or root), very leafy below: leaves ligulate or linear-spatulate, coarsely toothed or incisely almost pinnatifid, sessile; the lower crowded and with entire scarious spathaceous bases partly sheathing the base of the stem; the upper sparser and gradually reduced to linear bracts: head large and broad: involucre woolly, its linear-attenuate scales numerous in at least 3 series, loose : rays 50 to 60 , yellow: pappus of very broad and short strongly fimbriate-lacerate scales. - Proc. Am. Acad. vi. 547.

High Sierra Nevada, on rocks, \&c., at and above 10,000 feet; Mount Dana and Wood's Peak, Brewer, Bolander. Mount Lyell, J. Muir. Above Sierra Valley, Lemmon. Lowest leaves 3 to 6 inches long, a quarter to half an inch wide. Heads almost an inch high, with rays half an inch long. Akenes 3 lines long: pappus not longer than the hairs of the akene, the seales sometimes concreted. Plant, according to Dr. Bolander, "very odoriferous with the copious balsamic secretion."

* * Stems depressed or largely subterranean (in volcanic scoria), leafy at summit, terminated by a solitary head: peduncle sometimes scape-like.

5. H. nana, Gray. Glandular-pubescent: leaves pinnatifid or incised, and with a rather long margined petiole: peduncle an inch or two long: scales of the 
involucre ohlong-lanceolate, in 2 series: rays 20 or 30 , yellow : seales of the pappus fimbriate-lacerate. - Pacif. R. Rep. vi. $76, t .12$.

Var. Larseni, with tufted sterns leafy almost to the head.

Crater Pass, Oregon, lat. $44^{\circ}$, Newberry. The variety on Lassen's Peak, Bolander and Larsen.

6. H. vestita, (iray. White-woully when young; the seapes soon naked and glandular: leaves obovate or spatulate, tapering into a short petiole, entire or nearly so: scales of the involucre linear or lanceolate, in 2 or 3 series: rays 20 to 30 , yellow: scales of the very silvery and conspicuous pappus erose-toothed, the two longer ones oblong and equalling the proper tube of the corolla, the alternate ones shorter as well as broader and truncate. - Proc. Am. Acad. vi. 547.

On a volcanic hill south of Mono Lake, at the height of 9,000 feet, Brcwer. Leaves an inch or so long, very white with the floceose wool, which may be deciduous. Head an inch high at maturity. Rays barely 3 lines long.

\section{RIGIOPAPPUS, Gray.}

Head rather many-flowered, with 5 to 12 pistillate rays; all the flowers fertile. Involucre a single or somewhat double series of rather rigid herbaceous subulatelinear erect seales, similar to the uppermost leaves, at length concave and half embracing akenes. Receptacle flat and naked. Rays not exceeding the disk, the oblong entire or 2-toothed ligule not longer than its tube: disk-corollas slender and with 3 to 5 short erect teeth. Style-branches of the disk-flowers with short and fat linear stigmatic portion, tipped with a longer slender-subulate hispid appendage. Akenes linear, slender, compressed, minutely rugose, sparsely hirsute, those of the disk more or less 4-angled. Pappus of 4 or 5 rigid and wholly opaque subulate awn-shaped scales, as long as or surpassing the corollas, or in the ray one or two much shorter. - A single species.

1. R. leptocladus, firity. Slenter annual, a span to a fout high or more, minutely hairy and roughish, with narrow linear alternate entire leaves, and corymbose or paniculate filiform branches, inclined to be loug and naked, terminated by small heads of inconspicuous flesh-colored or purplish flowers. - Proc. Am. Acad. vi. $5 \pm 8$; Benth. \& Hook. Gen. Pl. ii. 406.

Dry ground in the foot-hills, both of the Coast Range ( $\mathrm{Yapa} \mathrm{Co}, \mathrm{gc}$.$) and of the Sierra Nevada;$ extending into Oregon (where it was first collectod by Dr. Lycall) and Nevada.

\section{PALAFOXIA, Lagasca.}

Head 10-30-flowered; the flowers all perfect and tubular (but the marginal

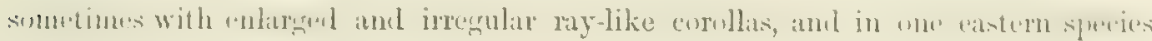
with pistillate 3 -cleft rays). Involucre campanulate or turbinate; the scales nembranaceous or herbaceous, in one or two series. Receptacle flat and naked. Corollin various; the lobes usually long and narrow. Style-branches filiform, minutely glandular-hirsute. Akenes 4-5-angled, linear or elongated-obpyramidal. Pappus of 4 to 12 hyaline claffy scales traversed by a strong midrib, commonly shorter and blunter in the ontermost flowers (rarely nearly wanting). - Herbs, or some-

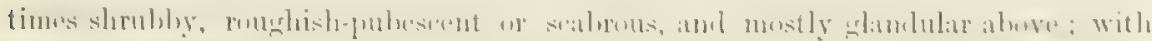

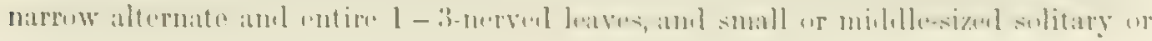
loosely corymboso heads of rose-colored or flesh-colored flowers.

A small genus confined to the southern borders of the United States and to Mexico, polymorphous as to the corollas, which in all the enstern North-Aineriesn species huve a canpunuulate 
limb very deeply cleft or parted into narrow linear lobes. One of the following species accurs on the southeastern borclers of the State; the other only further south, but it is here included for comparison.

1. P. linearis, Lagasca. Herbaceous, cinereous-scabrous, a foot to three feet in height: leaves linear or linear-lanceolate, mostly acute: heads narrow, loosely corymbose and slender peduncled: scales of the involucre narrow linear in a single series: flowers all perfect and alike or nearly so : the pale purple corollas with lobes shorter than the elongated nearly cylindrical throat: pappus of 4 to 8 linear scales, which are more or less pointed or short awned by the projection of the tapering tip of the very stout midrib, nearly equalling the corolla, or in the outer flowers sometimes very short and blunt. - Hook. Bot. Mag. t. 2132. Ageratum lineare, Cav. Ic. iii. t. 205 .

Along the Colorado, at Fort Yuma, Mohave, sce., Coulter, Sehott, Newberry, Cooper. Extends through the adjacent parts of Arizona to Mexico. Heads an inch or less in length. This is the species on which the genus was founded.

2. P. leucophylla, Gray. Shrubby, 6 to 10 feet high: leaves linear, obtuse, thickish, whitened with a close and dense silky-hirsute pubescence: pappus of 4 linear-oblong blunt and emarginate-scales, considerably shorter than the fleshcolored corolla and the 4 alternate shorter ones, which are spatulate-oblong, with midrib vanishing at the middle; some of the outer akenes with a short corneous crown instead of the scales: otherwise nearly as in the preceding. - Proc. Am. Acad. viii. 291.

Carmen Island, in the Gulf of California, Dr. Palmer.

\section{CH塈NACTIS, DC.}

Head homogamous; the flowers all perfect and tubular, but an outer series almost always more or less enlarged, usually forming a sort of ray. Involucre campanulate or hemispherical; its scales narrow, more or less herbaceous, equal, in one or two series, usually becoming concave and inclined to embrace subtended akenes. Receptacle flat, foreolate and naked, in one species with bristle-shaped rigid chaff subtending most of the flowers! Corollas tubular inclining to funnelform, and with 5 short obtuse lobes, or the marginal ones either slightly or conspicuously enlarged above, with the dilated limb 5-cleft, sometimes irregularly or obliquely so, approaching to palmate; their nerves deeply intramarginal. Anthers linear. Style-branches narrow, tapering into a slender-subulate or occasionally obtuse minutely hirsute appendage. Akenes slender, linear, tapering to the base, more or less 4-angled, commonly pubescent. Pappus of 4 to 12 awnless and nearly or quite nerveless hyaline chaffy scales (in the marginal flowers mostly shorter), in one anomalous species wanting. - Herbs, chiefly of humble stature, annuals or biennials (or some possibly perennial), all of the Californian region; with alternate 1-3-pinnately dissected leaves, and middle-sized or large pedunculate heads of yellow, white, or flesh-colored flowers terminating the loose or corymbose branches. - Gray, Proc. Am. Acad. x. 73 .

Macrocarphus, Nutt., hardly forms a primary section, and $C$. carphoclinia, with its anomaly of chaff to the receptacle, is otherwise just like the related species. In one or two species the receptacle might perhaps be said to be chaffy next the margin, there being two ranks of involucral scales subtending flowers.

\section{§ 1. Pappus present. - True Chenactis.}

$\therefore$ Corollas yellow, the outermost ones obviously enlarged at the summit, and their limb more or less irregularly 5-lobed, forming a sort of ray. 
+ Pappus of 4 or sometimes 5 about equal mostly aldong-lanerolate arutish sales, ar in the marginal flowers irregular and unequal as well as shorter.

1. C. lanosa, DC. Whitish with flocese but deciduous wool, the older leaves becoraing glabrous, a span or more high, branched and leafy only at the base: the simple naked peduucles therefore long and scape-like, bearing solitary heads: leaves with few narrowly linear divisions, or the uppermost entire: enlarged marginal corollas with short ovate lobes, hardly surpassing those of the disk.

Sandy hills, from Monterey to near San Diego. Heads barely half an inch high, on peduncles 3 to 6 inches long.

2. C. glabriuscula, DC. Lightly flocese-woully, at length somewhat glathrus, branching throughout, a foot or so high: leaves with several rather short thickish obtuse linear divisions: heads on stout rather long peduncles: scales of the involucre rather broadly linear and obtuse : marginal corollas with conspicuously enlarged and radiating palmate limb, the lobes oval or oblong. - Var. megacepluak, Gray in Pacif. R. Rep. iv. 104, is merely a stouter form, with mostly larger beads and Howers; so is $C$. denudata, Nutt. Pl. Gamb. 177.

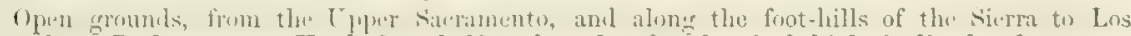
Angeles. Rather stont. Heads from half to three fourths of an inch high, inclined to be corymabose, on peduncles from 2 to 7 inches long.

3. C. tenuifolia, Nutt. Slightly and iclicately wolly when youns, lecuming nearly glabrous, a span to a foot or more high, leafy and branching to the top: leaves once or somewhat twice pinnately parted into very narrow or filiform lobes: heads somewhat corymbose, on short peduncles: scales of the hemispherical involuere narrowly linear and very numerous: enlarged marginal corollas with short somewhat irregular lobes and not surpassing those of the disk. - C. filifolia, Gray, Pl. Fendl. 98 .

Vicinity of San Diego. Heads barely 4 or 5 lines high, broad in proportion, on peduncles of an inch or less in length. Involucro rather short. Akenes much shorter than in the preceding species. The C. filfolic, described from a single specimen belonging to the Dublin University herbarium, is probably a form of this rather than of tho preceding species.

\section{++ Pappus, at least of the disk-flowers, double, of 4 ordinary and of 1 to 4 very much smaller alternating scules.}

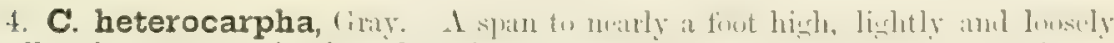
woolly when young, simple or branching above, leafy: leaves pinnately parted into 4 to 9 narrowly linear unequal divisions: seales of the involucre broadly linear: enlarged marginal corollas with oblong lobes mostly surmassing the disk. - Pl. Fendil. 98.

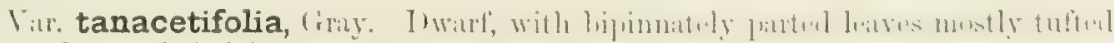
at the base; their lobes numerous, very short, croweled, often oblong or oval: root biennial. - C. tanacetifnlin, Gray, Proc. $\Lambda$ m. Acad. vi. 545.

On the Sacramento and its tributaries, Ukiah, \&c., Fremone, Harluerg, Bnlander. The Fariety, Lake Co., near (lear Lake, Bolender. Hends about half an inch high; the preduncle an inch or two long. Pappus of the outermost llowers sometimes as in the inner, or irregular and shorter, sometimes much shorter and the small outer scules wanting.

$$
\text { * Corollas white or fleslt-cnlored, }
$$

+ The marginal ones obvionsly enlarged and somewhat obliquely 5-lobed, but not surpassing the disk: pappus of only 4 or sometimes 5 usually equal scales: scales of the inulucre numerous and narrom-linear. Merbage wilh minute unolliness which early distppents, then glabrons, minuty granular or glandulur above.

5. C. brachypappa, Cray. Corrmbosely branched, a foot high: lenves twico pinuately parted into short-linear and rather rigid disaricate lohes: peduncles short: scales of the mappus truneate and almost square or slightly cuncate, one fourth of the length of the akene. - Proc. Am. Acal. viii. 390. 
Southeastern Nevada, Miss Searls; may be looked for on the Colorado : added to complete the account of the genus.

6. C. stevioides, Hook. \& Arn. Corymbosely branched, a span or more high: leaves once or somewhat twice pinnately parted into narrow linear lobes, the upper mostly entire: scales of the pappus lanceolate or narrowly oblong, acute, not much shorter than the akene.

Sand-hills on the Colorado, near the Mohave, \&c., and through Nevada north to Pyramid Lake and east to Utah and New Mexico. Heads rather small, on peduncles from half an inch to an inch and a half in length.

+ + The marginal corollas little or not at all enlarged, regular or nearly so.

+ Scales of the involucre tapering into a filiform or setaceous-subulate tip : pappus of 4 equal scales: pubescence minute and glandular, no woolliness.

7. C. carphoclinia, Gray. Corymbosely branched, slender, rigid, a span high : leaves once or twice pinnately parted into nearly filiform lobes : involucre campanulate; its scales with rather abrupt and short setaceous or subulate tips (sometimes sparsely hispid as well as glandular-viscid) : receptacle furnished with 5 to 10 slender and rigid persistent awns subtending flowers and almost equalling them in length: scales of the pappus ovate-lanceolate, acuminate, mearly as long as the akene, more than half the length of the corolla, or in a few of the outermost flowers short and truncate. - Bot. Mex. Bound. 94.

Southeastern borders of the State; at Fort Yuma (Thomas); on the Gila and Colorado Desert (Schott, A. B. Groy) to S. Utah, Parry. Also Northwestern Nevada near the borders of California, Lemmon. Remarkable for the pateoe (rather than fimbritloe) of the receptacle in the form of awns, subtending some or most of the disk-flowers.

8. C. attenuata, Gray. Resembles the preceding; but leaves apparently less divided and more tiliform: heads smaller (5 lines long), much narrower and fewerflowered : scales of the involucre narrow and more concave or involute : receptacle naked, as in the genus generally: scales of the pappus broadly obovate-cuneate and truncate, many times shorter than the corolla or the akene, little exceeding the hirsute hairs of the latter. - Proc. An. Acad. x. 73.

Ehrenberg, Arizona, A.E. Janvier, from W. M. Canby; possibly on the borders of California also : added to complete the genus.

+++ Scales of the involucre obtuse and pointless: pappus double, $i$. e. of 4 long and 4 very short and differently-shaped scales: leaves once or somewhat twice pinnatifid or the uppermost entire: woolliness thin and soon deciduous.

9. C. Xantiana, Gray. A span to a foot or more high, rather stout; the stem or branches terminated by a solitary large head on a thickish peduncle: leaves pinnately parted into 3 to 7 narrowly linear and distant lobes, the terninal one elongated: scales of the involucre narrowly linear, rather loose: anthers at length mainly exserted: pappus of 4 lanceolate scales almost equalling the corolla, and 4 exterior ones which are obovate or obcordate and several times shorter. - Proc. Am. Acad. v. 545 .

Var. integrifolia, Gray, 1. c. A slender simple-stemmed form, with most of the narrow linear elongated leaves entire, rarely a lobe or two, and the head narrower and fewer-flowered.

Near Fort Tejon, Xantus. Owens Valley, Dr. Horn (the variety). Western borders of Nevada, Anderson, Lemmon. Head an inch or less high, on a mostly fistulous peduncle of an inch or two in length ; one or two of the uppermost simple leaves passing into involucral bracts. Corollas a quarter of an inch long; the short lobes of those of the disk sparsely bearded externally; those of the margin twice or thrice as large. Akenes fully 3 lines long.

10. C. macrantha, D. C. Eaton. A span high: leaves pinnately or somewhat twice pinnately parted into broadly linear or oblong lobes: scales of the involucre linear: anthers included: pappus of 4 linear-oblong scales about half the length of 
the corolla and 4 cuneate-oblong ones three or furr times shorter. - Bot. King Exp. 171, t. 18.

Western borders of Nevada (Nevolerry, Watson, Lemmon); therefore probably within the State : extends east to S. Utah, Cupt. Bishop, Parry. Heads from half to three fourths of an inch long, on short slender peduacles. Corollas flesh-colored, some of the marginal with more or less enlarged limb.

+++ Scales of the involucre obtuse or pointless: pappus of 8 to 12 similar oblonglinear scales, little shorter than the flesh-colored corolla: leaves commonly twice pinnatifid into fine and short very obtuse lobes. (II acrocarphus, Nutt.)

11. C. Douglasii, Honk. \& Arn. I span to 2 feet hinh, from an annual or biennial root, white-tomentose or glabrate: leaves narrow-oblong in outline; the loles very many and crusted: heaks cerymbere, rarely sulitary (half to two thinds of an inch high). - C. Douglasii \& C. ackillecefolia, Hook. \& Arn. ; Torr. in Stansbury Rep. t. 6. Hymenopappus Douglasii, Hook. Fl. i. 316.

Through the Sierra Nevada, thence through Oregon and east to Wyoming and Colorado.

12. C. Nevadensis, (irat. Less than a span high, depresed, in a freminial tuft: leaves with ovate or cuneate general outline and much fewer lobes, white wmily: heads sulitary, on peduncles a little surpiassing the crowded leares. - Ilymenopappus Nevadensis, Kellogg in Proc. Calif. Acad. v.

Alpine region of the Sierra Nevada; Lassen's Peak (Breucer, Lemmon); above Summit (Kellogg); MLono Co., Muir.

\section{\$2. Pappus wanting: scales of the involucre acute. - ACARPEsA, Gray.}

13. C. artemisizfolia, Cray. Sumewhat viscicl-pulesent. a fout on two high:

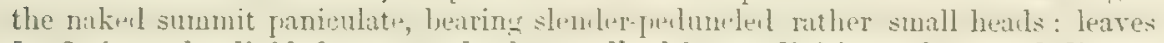
1-3-pinnately divided or parted, the small ultimate divisions short and linear:

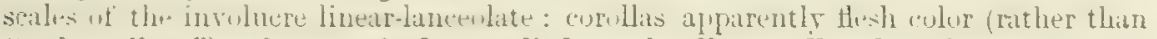
"pale yellow"); the marginal ones little or hardly at ail enlarged. - Acarphou artemisicefolia, Gray, Pl. Fendl. 98 ; Bot. Mex. Bound. 95, t. 32.

Near San Diego, Coulter, Parry, Cleveland.

78. GAILLARDIA, Fougeroux

Head many-flowered, with sevcral neutral rays. Scales of the involncre in 2 or 3 series; the outer larger, foliaceous and taper-pointed, spreading or at length re-

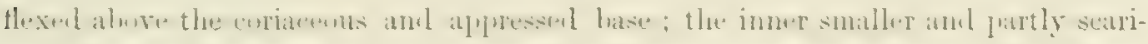

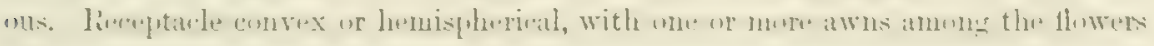
which may be taken to represent chaff. Rays cuneate, palmately 3-cleft at the

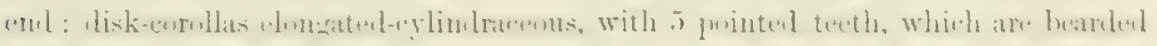

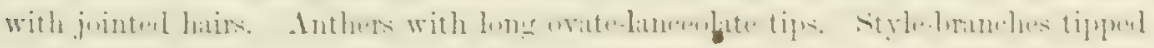
with a bristly tuft, and extended beyond it into a filiform hispid appendage.

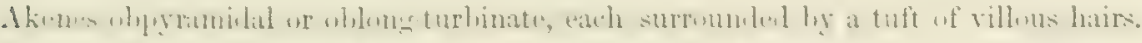

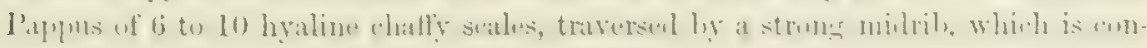
tinued into a naked awn of about the length of the corolla, or in the sterile rass the scales awnless. - Scabious-like herbs, all North American, pubescent with

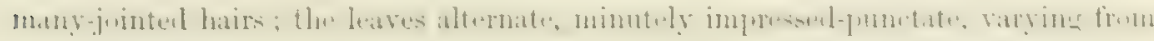
entire to incised or even pinnatifil ; heads solitary and long-peduncled, large ancl

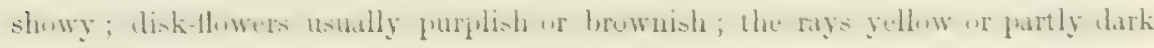
purple. 
G. PINNATIFIDA, Tort, of Colorado and New Mexico, may approach California by way of Arizona. The following Western species is almost sure to be found along the northern borders of the State, and is therefore admitted. It is the only truly perennial species, except the rare and remarkable G. acuulis, Gray, in Am. Naturalist, ix. 273, recently discovered by Dr. Parry in Southern Utah.

1. G. aristata, Pursh. Perennial, a span to a foot or more high : lowest leaves spatulate or oblanceolate, sometimes pinnatifid, tapering into petioles; the upper sessile and often entire: bristles on the receptacle slender, much longer than the akenes, sometimes almost as long as the corolla: rays 10 to 18 , an inch or more in length, yellow, sometimes tinged with purple at the very base. - Lindl. Bot. Reg. t. 1186 ; Hook. Bot. Mag. t. 2940.

Plains and open ground, common through Oregon, extending to the Saskatchewan region.

\section{HELENIUM, Linn. SNEEZE-WEED.}

Head many-flowered, with numerous or several pistillate (rarely infertile or neutral) rays: disk-flowers small and very numerous, all fertile. Involucre of one or two series of mostly small scales; the outer ones foliaceous or herbaceous, narrow and unequal; innermost shorter and more membranaceous; all spreading and at length reflexed. Receptacle mostly globular or hemispherical, naked. Rays nearly or quite destitute of tube, mostly cuneate, palmately 3-5-lobed, usually drooping: disk-corollas cylindraceous above the usually very short and narrow proper tube; the 5 or sometimes 4 teeth short and obtuse, glandular. Style-branches with capitate-truncate tips. Akenes turbinate, striate-ribbed, hairy on the ribs. Pappus of 5 to 12 thin or hyaline chaffy scales, with or without a midrib, and either blunt, apiculate, or awn-pointed. - Erect simple or branching herbs (N. American and Mexican); with all the leaves alternate and all but the lower sessile, often decurrent into wings on the striate stem; heads small or large, on naked peduncles terminating the stem or branches; flowers yellow, or those of the disk at tip turning brownish or purplish (the rays in some eastern species in part brown-purple). Foliage minutely impressed-punctate, or dotted with resinous globules, puberulent or nearly glabrous. — Gray, Proc. Am. Acad. ix. 202.

* Heads large, the disk an inch in diameter and the rays about an inch long: root perennial: stems, \&c., somewhat woolly-pubescent when young.

1. H. Hoopesii, Gray. Stem stout, a foot or two high, leafy to the top, bearing 1 to 6 heads on rather slender peduncles: leaves pale, glabrous or becoming so, thickish, entire, oblong-lanceolate, or the lowest spatulate with a long tapering base: rays cuneate-linear and moderately $2-3$-toothed at tip, these and the involucre tardily reflexed: scales of the pappus lanceolate, gradually tapering into a subulate or awn-like point, a little shorter than the disk-corolla. - Proc. Acad. Philad. 1863,65 .

Sierтa Nevada at Sonora Pass (Brewer, Bolander); thence to the Rocky Mountains in Colorado. Leaves 2 to 4, or the lowest 8 to 10 , inches long, half an inch to an inch and a half wide. Diskcorolla with a rather long tube. Akenes rather slender.

2. H. Bolanderi, Gray. Stem stout, a foot or two high, simple or sparingly branched, leafy below: heads on mostly long and naked very thick peduncles enlarging at the summit: leaves obovate or ovate-lanceolate, entire: rays cuneate, 3-lobed, deffexed (in the nusual manner of the genus): scales of the pappus lanceolate or subulate, commonly beset with 3 or 4 almost setiform teeth, and tapering into a slender awn which almost equals the disk-corolla. - Proc. Am. Acad. vii. 358. 
Meadows and swamps near the sea, in Mendocino and Humboldt Counties, Bolander. A most striking large-flowered species. Rays an inch long when well developed. Disk at lirst depressedhemispherical, becoming globular in fruit : the summit of the peduucle thickened under it.

* Heads rather large, the globose dish half an inch or more wide, and the rays half to three fourths of an inch long: root perennial: herbage glabrous or minutely pubescent.

3. H. autumnale, Linn. Stem leafy to the corymbose summit, is fout to:? or 4 feet high: leaves broadly lanceolate ( 2 to 4 inches long), often serrate: heads mostly several on slender rather short peduncles: seales of the pappus ovate or ovate-lanceolate and awn-pointed, from half to two thirds the length of the corolla.

Probably along the northern borders of the State, being common in Oregon (the var. grandiflorum, Torr. \& Gray), also in Nevada; thenco to the Atlantic States.

4. H. Bigelovii, (iray. stem from one to three feet high, commonly simpl.: leaves lanceolate or elongated-oblong varying to linear, entire ( 3 to 6 inches long, 3 to 6 lines or rarely over an inch wide): head on a slender peduncle from 3 to 18 inches long: rays numerous, half an inch or more in length : disk depressed-globose, from half to two thirds of an inch in diameter: scales of the pappus ovate-lanceolate or subulate, tapering into an awn considerably shorter than the corolla. - Pacif. $R$. Rep. iv. 107.

Wet ground, Sierra to Tosemite Valley, \&c., and westward to Lake Co. A very branching specimen, with much shorter rays, collected by Prof. Brewer, (near Monterey ?) may be au extreme forma of this rather than of the lollowing species.

* * Heads middle-sized or small; the rays shorter than the globose disk, about a quarter of an inch or less long: root annual or biennial: stems loosely branching.

5. H. puberulum, I) . Two to four feet high, panioulately much brunchul, minutely cinereous-puberulent : branches terminating in long slender peduucles: leaves lanceolate and entire, or the lower oblong and rarely incisely toothed, nearly all much decurrent : involucre mostly short and inconspicuous, as also the reflexed rays: scales of the pappus ovate, with a short mucronate tip or awn, one third or one fourth the length of the corolla.

Common along water-courses and shores through the western portion of the State, from San Francisco Bay southwarl. Disk half an inch or less in diameter. Rays 2 or at most 3 lines long, usually few, H. Mexicanum, so called, in the Botany of Whipple's Expedition, from Bolinas Bay, appears to be a form of $\Pi$. puberulum, to which may also helong Coulter's No. 357, although it has more slender rays and blunt pappus-seales. The materials of both are insullivient.

6. H. laciniatum, Gray. A span or two high, branched from the base,

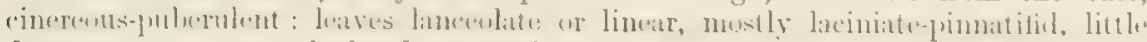
decurrent, one or two inches long: scales of the involucre mostly longer than the

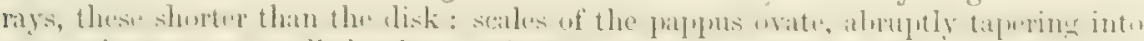

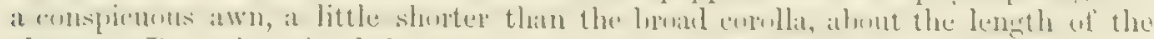
akene. - I'roc. Am. Acad. ix. 203.

"California," probably on the southenstern borders, Coulter (No. 356, 358). Taqui River, Sonora, Dr. Pelmer. Peduncles about 3 inches long. Ilead with yellow disk 4 to 6 lines in diameter; the rays 2 or 3 lines long. Disk-corollas a line long, their proper tube extrenaely short.

\section{ACTINEI,LA, Nutt.}

ILead many-flowered, with 8 to 12 pistillato rays; all the flowers fertilo. Involucro hemispherical; its scales in 2 or 3 series, nearly equal, ovato or lanceolate, rigid or coriaceous (or the inner with maryins mombranaceous), appressed. Receptralo conical or strongly convex, nakel, sometimes villous. Rays conspicuons, 3-toothed or 3-lubed at the truncate extremity; disk-corollas elongated-cyliudru- 
ceous, with 5 erect short (often glandular-bearded) teeth. Style-branches of the perfect flowers with dilated-truncate minutely penicillate tip. Akenes short, turbinate, silky-hirsute. Pappus of 5 to 12 hyaline 1-nerved or nerveless chaffy scales; the nerve when conspicuous sometimes projecting into an awn. - Chiefly perennials (of W. North America), low or acaulescent, disposed to be woolly at base of the stem; the leaves alternate, pinnately parted or entire, usually resinous-impressedpuuctate: heads peduncled, terminating the stem, scape, or branches, sometimes loosely corymbose : flowers yellow.

The acaulescent species inhabit the Rocky Mountains and the plains eastward. Those in and near California have leafy and branching rigid stems, in tufts from persistent somewhat woody rootstocks.

1. A. Richardsonii, Nutt, A span to a foot and a half high, varying from hoary with short woolliness to nearly glabrous, leafy to the top: leaves rigid, petioled, 3-7-parted into linear or almost filiform divisions, or some of them entire: heads mostly numerous and corymbose: scales of the involucre oblong-ovate, the outer series united at base: receptacle conical, glabrous or minutely pubescent when young: scales of the pappus 5 to 7 , ovate-lanceolate, subulate-acuminate, either slightly or considerably shorter than the disk-corollas, mid-nerve hardly any. Picradenia Richardsonii, Hook. Fl. i. 317, t. 108.

Var. canescens, D. C. Eaton. A hoary form, barely a span high, with fewer and larger heads, and shorter ovate and merely acute scales of the pappus. - Bot. King Exp. 175.

Collected on the northern borders of the State in the Wilkes Expedition : common in the interior of Oregon and in Nevada, extending to and beyond the Rocky Mountains. Sierra Valley, Lemmon. The latter a form with large heads (about 5 lines high), in this respect, and somewhat in the pappus, approaching the remarkable var. canescens, which was found only on one of the Eastern Humboldt Mountains.

2. A. Cooperi, Gray. Two feet high, with loose and more simple virgate branches terminated by single heads, minutely puberulent: lower leaves unknown; upper ones 3-parted into narrow linear divisions : receptacle convex, densely villous: rays elongated, acutely 3-cleft at the summit: scales of the pappus 5 , broadly ovate and obtuse or slightly pointed, traversed by an obscure midnerve, not half the length of the disk-corollas. - Proc. Am. Acad. vii. 359.

Southeastern border of the State, on Providence Mountains, at the altitude of 5,000 feet, Dr. Cooper. Head as large as in the variety of the preceding; the rays longer.

\section{SYNTRICHOPAPPUS, Gray.}

Head many-flowered, with 5 pistillate rays; all the flowers fertile. Involucre cylindraceous, of 5 equal and oblong carinate-concave scales, which partly enclose the ray-akenes. Receptacle flat, naked. Rays oval, obtusely $2-3$-toothed at the apex: disk-corollas nearly funnelform, glabrous and naked, 5-lobed; the lobes ovateoblong. Anthers tipped with a long lanceolate appendage. Style-branches linear, surmounted by an ovate-lanceolate flat appendage. Akenes linear-turbinate, with 5 strong and obtuse hirsute-villous ribs, truncate at summit, the terminal areola large. Pappus of numerous barbellate white bristles in a single series, shorter than the disk-corolla, united at base in a ring (and some of them higher up), and deciduous together. - A low diffuse white-woolly aunual, with alternate 3-lobed leaves, and wholly the aspect of Actinolepis, to which it is clearly related. - Gray in Pacif. R. Rep. iv. 106, t. 15 . 
1. S. Fremontii, fray. Two or three inches high, much resembling dmin, lepis Wallreci: leaves spatulate or narrow cuneate, 3-lobed at the apex, or sometimes nearly eatire : earliest head slender-peduncled, the others clustered : flowers golden yellow.

In the desert region of the southeastern borders of the State (Soda Lake, Dr. Cooper), and in S. Nevada and Utah (Frenont, Newberry, Capt. Bishop, Palmer). Heads 3 lines, rays barely 2 lines long.

\section{TRICHOPTILIUM, Gray.}

Head many-flowered; the flowers all perfect and tubular. Involucre hemispherical, of about 10 orite-lanceolate thin-herbaceous almost equal scales, somewhat in two series. Receptacle flat and naked. Corolla cylindraceous, with 5 short and spreading orate lobes: filaments inserted just above its base. Style-branches with dilated and very ubtuse or truncate tips, but no proper appendage. Akenes oblon:turbinate, hirsute. Pappus of 5 bruad hyaline or at length firmer nerreless chatty scales, which are dissected into slender but rather rigid bristles, the middle ones little shorter than the corolla. - $\mathbf{A}$ single species.

1. T. incisum, Gray. I small and depressed winter-annual, diffusely brunchal from the root, a span or less in height, clothed throughout with long and loose or somewhat deciduous white wool, under which it is somewhat hirsute or glandular: leaves alternate or the lower opposite, oblong-cuneate or spatulate, coarsely and sharply toothed or cut-lobed: heads (about 4 lines long) solitary on slender peduncles, the earlier ones scape-like: corolla "yellow." - Bot. Mex. Bound. 97 ; Torr. Pacif. R. Rep. v., t. 5.

Gravelly hills, of the Colojado desert region near Fort Yuma, Mohave, \&cc., Fremont, Thurber, Lieut. Du Barry, Cooper. The latter, who found it in ravines of the Caldo Valley, states that the flowers are yellow. Akenes membranaceous, slightly 5-6-nerved, somewhat angular : pappus-seales (ineluding the bristles, of which the outer are regularly shorter) about the length of the akene.

\section{BLENNOSPERMA, Less.}

Head many-flowered, with 5 to 12 pistillate rays, and sometimes as many apetalous pistillate flowers; the disk-flowers numerous, all sterile. Scales of the hemi-

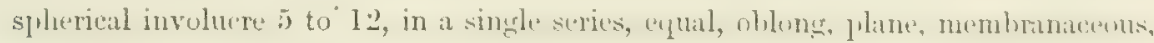
somewhat united at base. Receptacle flattish, naked. Rays an elliptical or oblong entire ligule sessile on the ovary, without a tube. Corollas of the disk-flowers with narrow tuhe abruptly expanded inte the broully campanulate 4 -5-lolma limh.

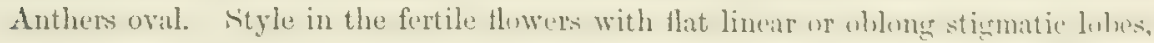
in the staminate fhwers unlivided aml capitate or disk-shapred at summit: these

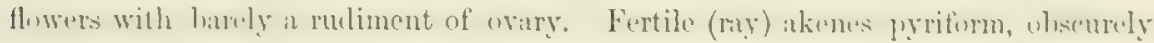

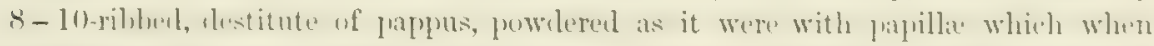

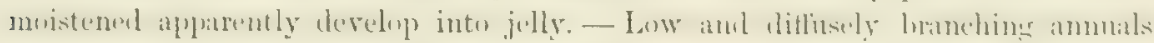

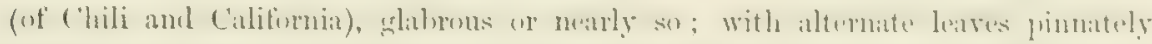

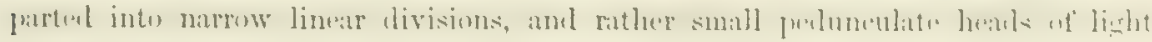
yellow llowers, terminating the branches. - Torr. \& Gray, Fl. ii. 272 ; Grny, Proc. Am. Acad. ix. 200.

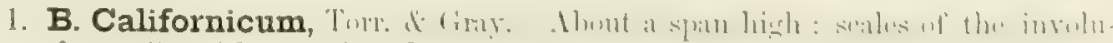
cre and rays 7 to 12 : a serjes of pistillate flowers within and alternating with the rays: style-branches of the fertile flowers oval or oblong, flat.-Coniothele Culifornica, DC. 
Moist ground, from San Francisco Bay to San Diego. Scales of the involucre sometimes tipped with purple. linys 2 or 3 lines long. The minute papille on the akene, as seen under the microscope, swell up when wetted, open at the extremity or split into two valves, and emit two long filaments of extreme tenuity, the whole apparently forming a gelatimous mass enveloping the akene: just as oceur's in Crucidizm and in some species of Senecio, \&e. From this peculiarity it took its generic zame, which means "mucilaginous seed."

Crocidum mulicaule, Hook., is a small plant resembling Blennosperma, but with a fugacious capillary pappus. It is common along the coast of Oregon, but has not been detected in California; the specimen so named in the Botany of the Mexican Boundary, collected by Dr. Stillman, proving to be Blennosperma. See Proc. Am. Acad. ix. 206.

\section{PERITYLE, Benth.}

Head many-flowered, with pistillate rays or occasionally none; the flowers all fertile. Involucre campanulate, of nearly equal scales, slightly carinate on the back, in a single or double series. Receptacle flattish or conical, naked. Rays 3toothed: disk-corollas 4-toothed; the tube glandular. Style-branches tipped with (or insensibly changing into) a short and obtuse or more commonly subulate or filiform, hairy appendage. Akenes oblong, flat (laterally compressed), dark-colored, bordered by a cartilaginous mostly ciliate-bearded margin. Pappus a series of hyaline or setiform scales, usually more or less united into a cup or crown, and commonly a slender awn from one or both margins. - Low annuals or perennials, of the southern part of California and adjacent regions; with petioled usually palmately-lobed or incised and membranaceous leaves, at least the lower ones opposite, and pedunculate rather small heads terminating corymbose or paniculate branches (rarely in a corymbose cyme). Rays white (or sometimes yellow?): diskflowers yellow. - Benth. Bot. Sulph. 23, t. 15, \& Gen. Pl. ii. 398 ; Gray, Proc. Am. Acad. ix. 194.

In our view, as stated in the paper above cited, the crown of pappus furnishes a better character than the style-apnentages, or anything in the involuere, to distinguish this genus from Lay hemiu, one sprecies of which also has short and blunt style-apuendages. Luphomit nearly takes the place of Perityle eastward, and one species of it inhabits the southern part of Nevada.

P. INCANA, Gray, Proc. Am. Acad. ined., recently discovered on Guadalupe Island, Lower California, is an anomalous species, stout and somewhat frutescent, as white-woolly as Seneeio Cincrario, and with numerous rayless heads in a crowded and naked pedunculate corymb.

1. P. Californica, Benth. Pubescent or glabrate: leaves roostly opposite, broadly ovate or deltoid, incisely toothed or somewhat lobed: rays oblong, perhaps yellow: style-appendages short and obtuse: akenes hispid-ciliate: the ontermost obovate and with much thickened corky-cartilaginous margins, the inner obovateoblong and with nerve-like margins, narrowed at the top : awns of the pappus onc or two, scabrous.

Probably only in Lower California; Bay of Magdalena, Hinds; Cape San Lucas, Xantus. Heads 3 or 4 lines long. Throat, i. e. the expanded upper part, of the disk-corolla, rather shorter than its tube. Receptacle almost flat.

2. P. plumigera, Gray. Glandular-pubertlent above, the base of stem unknown: leaves of the branches ovate or oblong, small, toothed: heads smaller than in the foregoing: rays oblong, apparently white: style-appendages short and obtuse: akenes oblong, not contracted at the apex, very densely villous-ciliate: awn of the pappus only one, nearly equalling the corolla, sparsely hispid-plumose above. - Pl. Fendl. 77.

California, Couzter. Probably from the southeastern borders of the State or adjacent portion of Arizona. Reeeptacle strongly convex.

3. P. Acmella, Gray, I. c. Puberulent and somewhat glandular : lower leaves opposite, ovate and deeply 3-cleft; the upper alternate and somewhat hastately 
3-lobed: heals small: rays brrally cuneate-oluhng: strle-appendiges short and acutish : akenes oblong, densely hispid-ciliate : awns of the pappus 2, much shorter than the corolla, scabrous. - Spilanthes Pseudo-Acmella, Hook. \& Am. Bot. Beechey, 150. Boltonia § Dichetophora, sp., Benth. \& Hook. Gen. Pl. ii. 269.

Monterey Bay, Lay \& Collic. Southern part of the State, Coulter. Receptacle merely convex. Jleads 2 lines high. Throat and limb of the disk-corollas longer than the tube.

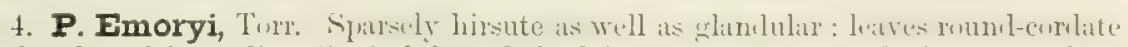
or fan-shaped in outline, 5-9-cleft and the lobes copiously incised, the upper alternate and less lobed: scales of the involucre rather broad: rays short, white, broadly oval: style-appendages oblong and obtuse: akenes nartowly oblong, hispid-ciliate: awn of the pappus only one, very slender, sparsely barbellate above, or in

Var. nuda, Gray, with no awn. - P. nuda, Torr. in Pacif. R. Rep. iv. 100.

Desert region, along the Rio Colorado on both sides, near Fort Yuma, \&ze, and on the Gila. Heads rather large for the genus, 3 or 4 lines high : receptacle broad, nearly flat. Rays said in the Botany of the Mexican Boundary, p. 82, to be "plainly yellow" ; but the ticket of Dr. Cooper's specimens from the same district states that they are white. So they are in Palmer's Guadalupe plant. Throat or expanded part of the disk-corolla shorter than the tube. Styleappendages certainly short and obtuse in the original specimens. Yet in one, seerningly of the same species (var. mudu), but with larger rays, collected in 1870 on Carmen Island, Lower California, by Dr. E. Polmer, these appendages are somewhat longer and subulate-acute! So, also, in specimens recently collected by him on Guadalupe Island. This is evidently a winterannusl; and so apparently are all the foregoing.

5. P. leptoglossa, (irity. ('increous-puberulent: leave's (of hinches) small and alternate, ovate and somewhat cordate, slenter-petioled, consely or doubly toothed: scales of the involucre narrow: rays linear, rather long: style-appendages filiform and acute: akenes linear-oblong, hispid-ciliolate: awn of the pappus ouly one, very slender, barely scabrous. - Pl. Fendl. 77.

California, Coulter. Knowa only from his collection. Heads large for the genus, 5 lines long; receptaclo merely convex. Rays 4 to 6 lines long: disk-corollas with slender tube and a remarkably long and narrow cylindrical throat.

P. Parry, P. Aglossa, and P. Coronorifolia, Gray, the latter with distinctly white rnys, belong to a region further eastward.

\section{DYSODIA, Cav,}

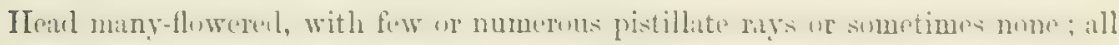
the flowers fertile. Involucre cylindraceous or campanulate, of rather rigid equal scales in a single series, often united below, commonly subtender by a row of bracts. Iieceptacle flattish, anked, often alveolate, fimbrillate, or hirsute. Rays entire or 2-3-toothed at the apex: disk-corollas narrow, 5-toothed. Style-branches of the

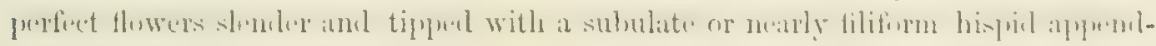
age. Akenes linear or linear-cuneate, 4-5-angled or many-nerved. Pappus single,

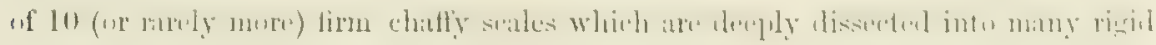
scabrous bristles, about equalling the corolla. - Herbs (all Mexican and N. Ameri-

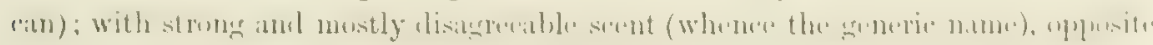
or alternate leaves, and peduncled heads of yellow, orange, or reddish flowers: scattered vil-glands rather conspicuous in the foliage and involucre.

D. curysantukmorns, Lagasea, common along the waters of the Mississippi and thence to Mexico, may appronch Californis by way of Arizona.

D. spresiss, Gray, a striking and apparently shrubly species, with rounded temate leuflets and large hends, was discovered at Cape San Lucas in Lower Californin, far beyond our limits. Tho following havo been fomul in the state.

1. D. porophylloides, Griy. Loosely much brincherl, ahont 2 feet high,

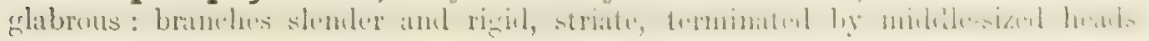


leaves alternate, small, mostly 3-5-parted into linear-lanceolate or subulate divisions, which are seldom gland-bearing; all the upper reduced to subulate bracts; those subtending the involucre very short and simple: scales of the involucre linear, abruptly acute, beset with oblong oil-glands, coalescent: rays few and inconspicuous: "flowers yellow": scales of the pappus deeply parted into about 9 bristles. Pl. Thurb. 322.

Southeastern borders of the State at San Felipe (Thurber), and Fort Mohave, Dr. Cooper. Also collected at Camp Grant, S. Arizona, by Dr. Palmer, with more developed leaflets. Head half to three quarters of an inch long. Rays linear, not longer than the disk, hardly surpassing the style.

2. D. Cooperi, Gray. Scabrous-puberulent, " 2 feet high," stouter than the preceding and with head fully an inch long: leaves (of branch) lanceolate, rigid, coarsely and spinulosely few-toothed, and parted near the sessile base so as to form a pair of subulate stipule-like lateral lobes : bracts of the involucre and scales linearsubulate and attenuate-acuminate, gradually passing into each other, carinate with strong midrib : rays somewhat exserted, "purple": pappus as in the preceding. Proc. Am. Acad. ix. 201.

Southeastern borders of the State, eastern side of Providence Mountains, Dr. Cooper. The lower leaves are probably more divided.

\section{NICOLLETIA, Gray.}

Head many-flowered, with a series of pistillate rays; all the flowers fertile. Involucre cylindraceous, of 8 to 12 equal oblong scales, calyculate with one or two small exterior scales. Receptacle convex, naked. Rays oblong, minutely 2-3-toothed: disk-corollas slender, 5-toothed. Style-branches of the disk-flowers slender, continued into filiform acute hispid appendages. Akenes linear, slender, terete, tapering to the base, pubescent. Pappus double; the outer a series of capillary bristles like those of Porophyllum; the inner of 5 thin chaffy scales with midrib produced into a bristle or awn, nearly equalling the disk-corolla. - Low and branching glabrous annuals; with alternate leaves, pinnately divided into a few narrowly linear or subulate lobes, and short-peduncled rather large heads terminating the branches. Oil-glands in the foliage and involucre few and large. Rays pink or purple, the disk-flowers (always?) yellow. - Torr. Frem. Rep. 2d Exp. 315 ; Pl. Wright. i. 119, t. 8 ; Bot. Mex. Bound. 93.

There are two species, both rare; one found near the southwestern borders of Texas, the other near the southeastern borders of California. The genus was dedicated to the memory of the distinguished geographical explorer and astronomer, J. N. Nicollet, under whom Fremont initiated his work.

1. N. occidentalis, Gray, 1. c. A span or more high : leaves thickish and with short lobes, the uppermost close to the head: scales of the pappus lanceolatesubulate, tapering into a short slender awn.

Sandy banks of the Mohave River, Fremont, Dr. Cooper. The latter found it at Camp Cady, and has recorded that the rays are purple, the disk yellow.

\section{POROPHYLLUM, Vaillant.}

Head several - many-flowered, with all the flowers perfect. Involucre cylindrical or cylindraceous, of 5 to 10 oblong or linear equal scales in a single series. Receptacle small, naked. Corollas with a slender or filiform tube, and a narrow 5-cleft limb. Style-branches slender, tipped with a subulate-filiform hispid appendage. Akenes long and slender, nearly terete, striate or angled. Pappus of copious rather 
rigid scabrous capillary bristles, ahout the length of the corolla. - Herbs, sometimes with lignens bisis, glabruns and often glancons; with slender branches terminated

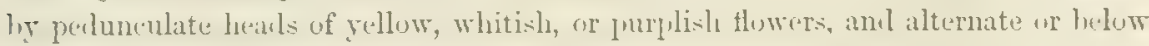
"lymsite leaves; these and the scales of the involucre maked by scattered immersed oil-glands, in the manner of Tagetes, \&c., therefore strong-scented.

Species all American, chiefly of Mexico and farther south, a few along the borders of the United States, two in Lowel California, but only the following within the State.

1. P. gracile, Lenth. Slender, loosely muth hencherl from a rather worly base, a foot or two high: lower leaves linear with tapering base, the upper nearly filiform or slender-subulate: scales of the involucre 4 to 6 , oblong-linear, obtuse, with narrow scarious margins: head 5-15-flowered: akenes scabrous-puberulent, narrowed at the summit. - Bot. Sulph. 29. P. Greggii, var. minor, Gray.

Gravelly banks, Fort Mohave and southward (Dr. Cooper, \&c..), Sin Diego, Cleveland. Heads three quarters of an inch long: flowers "puple" or "dirty white." Herbage with a strong fragrant or fennel-like odor. According to Mr. Johnson, who collected it on the Colorado River, it is there called "Poison-flower."

\section{PECTIS, Linn.}

IIead several-nuny-flowerect, with pistillate rays; the flowers all fertile. Involucre rylimbical or campanulite, of a few equal and mostly cariuate-coneare seales in a single

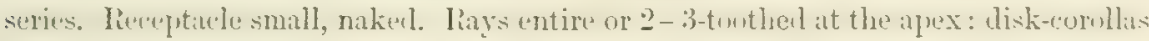

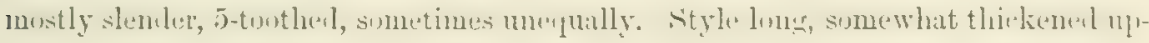
wards and minutely hispid; the branches very short and obtuse or truncate. Akenes linear or filiform, many-striate. Pappus of few or rather numerous bristles, or sometimes of a few awns, with or without some small chaffy scales, sometimes in some or all the flowers of little scales only, these united into a crown. - Low odorous herbs (all American); with opposite narrow and chiefly entire leaves, their margins beset with some long bristles, at least toward the base, in their substance as in that

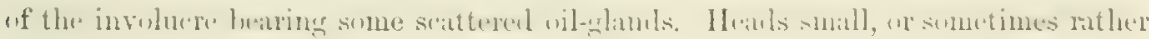
ample for the size of the plant, snattered : flowers yellow.

P. Poxctats, Jner. (Peclidium, DC.), with its paplus of 3 or 4 very rigid smooth awns, and P. Multisfis, Benth., with § pappus of 2 or 3 bristles or nono in the disk, and leaves conspicususly bristle fringed, grow in Lower California P. ProstratA, Civ, with broudish lenves and sess le hea s, comes into Arizona; as does P. IMbFans, Gray, a tall species remarkable for the want of bristles to tho lenves. The following are attributed to California solely on the authority of Coulter's collection, from which they were first deseribed; and they may all have been col. lected enst of the Rio Colomilo.

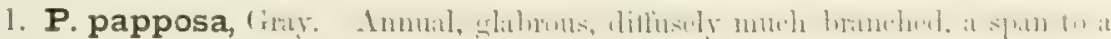
foot high, "lemon-scented": leaves elongated-linear (2) or 3 inches long, less than a line wille), furnished with very few bristles at base: heads slender-peduncle.l, senttered or corymbose, about 20-flowered: scales of the involucre 6 to 8 , linear: mys dongated, linear-oblong: pappns in the ray a scaly erown, in the disk of 15 to 20 capillary and very unequal barbellate bristles. - PI. Fentl. 62.

Californin, Conller, No. 331. Common in the Gila, Valley and through Arizonn, Selnel, Pnlmer, Wright, \&e. Akenes slender, minutely hirsute with glandular-tipgesl anul sometimes hookerl hairs. Sules of the involucro nearly infulding the ray-akenes, as in all our species.

2. P. Coulteri, Gruy, 1. c. Annun, puberulent, diffuse, 2 or 3 inches hich: leaves narrowly linear (ahout half an iuch long), spursely bristle-fringed: theads on peduncles mostly longer than the lenves: scales of the involuere and exserted rays ahout 5, both oblung: pappus in my and disk neurly alike, of 2 to 4 short and stuut awns which are retrursely bristly-barbed. 
California, Coutter, No. 330 . Arizona, Dr. Palmer. Involucre 2 or 3 lines long; the whole head 4 or 5 lines long, rather few-flowered.

3. P. filipes, Gray, 1. c. Annual, slender and diffuse, glabrous: leaves narrowly linear (an inch or more long, seldom a line wide), sparingly bristle-fringed at base: peduncles capillary, one or two inches long: scales of the involucre 5, rather broadly linear, obtuse : rays exserted, oblong : disk-flowers about 5 : akenes slender : pappus of abont 2 ( 1 to 3 ) slender awns which are gradually slightly dilated at base and minutely scabrous towards the apex, in the disk sometimes a minute crown with a solitary awn.

California, Coulter, No. 329. New Mexico, Thurber, Bigelow, Henry. Janos, Chihnahua, Schott. Involuere narrow, 2 to $2 \frac{1}{2}$ lines long. Only Coulter's plant shows the short crown of the disk-pappus. There is no trace of it, and the awns are 2 or 3 , in the other specimens, which are from a district farther east than that probably traversed by Coulter. Bentham thinks it likely to be $P$. Taliscana, Hook. \& Am. ; but it does not accord with the character of that species. Probably it has not been collected within California.

\section{TRIBE VII. ANTHEMIDEÆ.}

Distinguished from Helenioidece by the drier more scariously margined or tipped and imbricated scales of the involucre; from Asteroidece by the same and by the truncate tips of the style in the perfect flowers, never continued into an appendage; the pappus none or a mere crown. Belonging mainly to the Old World, very few in Westem North Awerica, except of Artemisia.

\section{ACHILLEA, Linn. Yarrow.}

Head many-flowered, with few or several pistillate rays; all the flowers fertile. Scales of the narrow involucre imbricated in few series, appressed, mostly with scarious margins. Receptacle from flattish to conical, with thin chaff subtending the flowers. Rays mostly short or broad. Akenes oblong or obovate, obcompressed, surrounded by a narrow and cartilaginous margin, destitute of pappus. - Perennial herbs (numerous in the Old World, but very few in the New), rather strong-scented; with alternate either serrate or pinnately dissected leaves, and small corymbose heads of yellow or white or sometimes rose-colored flowers.

1. A. Millefolium, Linn. A foot or two high, or lower on mountains, villouswoolly at least when young: leaves lanceolate or linear in general outline, twice pinnately parted into fine linear acute and 3-5-cleft lobes: heads small, crowded in a compound corymb-like cyme: rays 4 or 5 , obovate, white, rarely rose-color (occasionally becoming tubular) : akenes slightly margined.

Common in the Sierra Nevada up to 11,000 feet, extending through all the mountains northward and eastward; not rare in the western part of the State at the level of the sea; there perhaps introduced from the old World; but clearly indigenous all round the northern hemisphere.

\section{ANTHEMIS, Linn. Chamomile.}

Head many-flowered, with numerous pistillate or sometimes neutral rays; the disk-flowers fertile. Involucre hemispherical ; the scales very numerous, imbricated and appressed, scarions-margined, with a more rigid centre. Receptacle from convex to oblong-conical, chaffy with slender or thin scales or awns, subtending the flowers, at least the central ones. Rays commonly conspicuous. Akenes obovoid or oblong, 4-5-angled, 8-10-ribbed, or many-striate, truncate at the apex. Pappus 
none or a short chaffy crown - Herbs, of numerous species in the Old World, a very few have become roadside weeds in the United States. The ouly common one is the May-weed, which has reached California, viz.,

1. A. Cotula, Linn. A much branched, somewhat pubescent, strong-scented and acrid annual, a foot or less high: the alternate leaves thrice pinnately divided into small linear-subulate lobes: heads rather small terminating the branches, somewhat corymbose : rays soon reflexed, white, sterile, having an imperfect style or none: disk-flowers yellow: receptacle conical, naked toward the margin, but with almost bristle-shaped chaff near the centre: pappus none. - Maruta Cotula, Cass. : differing from true Anthemis in the sterile rays, \&c.

Sparingly found along roadsides : introduced, but not yet common.

\section{CHRYSANTHEMUM, Linn.}

Head man-flowerel, with numerous pistillate rays; the disk-Howers usually all fertile. Involncre hemispherical or flatter; the more or less scarious short and appressed scales imbricated in several series. Receptacle flat or convex, naked.

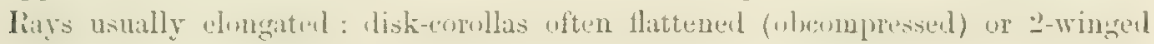
below, 4-5-toothed. Akenes short, nearly terete, several-ribbed or angled, truncate at the tip, mostly (in ours) destitute of pappus.

$\Lambda$ large and diversified genus in the Old World (especially when it includes Leucanthemum and Pyrelhrim), but not indigenous to North $A$ merica except in the arctic regions. Only one spacies is much naturalized in the Enited States, viz.

1. C. Leucanthemum, Liun. I prennial wet, sprealing from short running rootstocks, nearly glabrous, a foot or two high: stems simple or sparingly branched, the naked summit bearing a large head: leaves incisely pinnatifid or toothed; the lower spatulate; the upper becoming linear and smaller: scales of the involucre with somewhat rusty tips: rays white (over half an inch long): disk yellow: akenes many-ribbed. - Lencanthemun vulgare, Lam.

In fields at Santa Cruz; probably in some other places: introduced from the Old World. Not yet, perhaps may not become, in California the troublesome weed that it is in the Atlantie States, where it takes possession of meadows, and is known as Ox-eye Daisy, Whilc Daisy, and Whileveetl.

\section{MATRICARIA, Linn.}

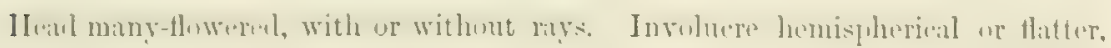
of numerous and more or less scarions appressed scales in few series. Receptacle conical or ovate, uaked. Corollas, akenes, \&c., as in the preceling genus. Pappus none or a minute crown. - A mather large genus of the Old World; only the following on the Pacific coast, where it is apparently indigenons.

1. M. discoidea, DC. Annual, a span or two high, branching, glabrous, leafy: leaves twice or thrice pinnately dissected into numerous short and narrow linear divisions: heads small, short-peduncled : involucro of broally oval seales with white-scarious margins: rays none: disk greenish-yellow, much elevated: receptacle high conical: akenes with an obscure coroniform murgin in place of pappus. - M. trnacetoides, Fischer id Meyer. Santolina suaveolens, Pursh. Tanacetum matricarioudes, Less. T. suaveolens, Hook. T. paucittorum, DC. Artemisia matricarioides, Less. Cotula matricarioides, Bongard. Lepridotheca (in errata) or Lepidanthus suaveolens, Nutt. in Trans. Amer. Phil. Soc.

Wiste grounds, through the whole length of the State, and north to ["nalaska. It has migmted to and beyond the Mississippi us a weed, as nlso to some places in the nowth of Finmpe. Sain to be used in C'alifornin as a domestie remudy for anges and bowel-complaints. Heads a quarter of an inch, or in fruit half an inch in le'lngth, greenish-yellow. 


\section{TANACETUM, Linn. TANST.}

Head many-flowered, heterogamous, with the flowers all tubular, the outermost series pistillate, or rarely these wanting when the flowers are all perfect, mostly all fertile. Involucre of numerous dry more or less scarious and brownish imbricated and appressed scales. Receptacle flat or convex, naked. Corollas of the pistillate flowers equally or obliquely 2-5-toothed; of the perfect flowers 5-toothed. Akenes generally about 5-ribbed or angled, or the marginal ones 3-sided; the broad truncate summit bearing a short and scarious coroniform pappus, or none. - Strongscented herbs; with alternate mostly compound or lobed leaves, and corymbose or rarely solitary erect heads of yellow flowers.

A moderately large genus in the Old World, widely represented by $T$. vulgare, Linn., the common Tansy, which, so far as we know, is not at all naturalized in California; but there is a stouter indigenous species on the coast related to it. 'Ihen, in the interior dry region there are three or four peculiar species (section Sphoeromeria of Nuttall) related to certain others in Asia ; the one found in California much approaches Artemisic. Ours are perennials.

* Pappus evident: leaves very much dissected into innumerable divisions.

1. T. Huronense, Nutt. Soft-hairy, usually much so when young: stems stout, a foot or two high, very leafy: leaves twice or thrice pinnately dissected; the very small and numerous lobes oblong or linear and much crowded: heads large, half an inch in diameter, on stout peduneles: corollas of the pistillate flowers rather conspicuous and somewhat ray-like, 3-5-lobed, the tube flattened, slightly winged at base: akenes very obscurely ribbed: pappus toothed.- - T. camphoratum, Less. T. Douglasii, DC. T. elegans, Decaisne, Fl. Serres, t. 1191. Omalanthus camphoratus, Less. Omalotes camphorata, DC.

Sandhills, along the coast, from San Franciseo to Puget Sound. Also on the Upper Great Iakes, and from Hudson's Bay to the northern borders of Maine.

\section{* Pappus none: leaves once or twice pinnately dissected into rather few divisions.}

2. T. potentilloides, Gray. Silvery-silky : stems numerous from a stout root, diffuse or ascending, a span to a foot long, sparsely leafy : radical leaves twice pinnately divided and petioled, the cauline mostly sessile and once divided into hinear entire lobes; uppermost reduced to nearly simple bracts: heads 3 to 6 in a loose corymb (sometimes rather panicled), hemispherical, about 3 lines broad: scales of the involucre about 10, broadly obovate, silky-tomentose: receptacle flattish, very hirsute: flowers all fertile; the pistillate ones with a small and slender 2-3toothed corolla: akenes obovate-turbinate, 3-5-angular, thin and vesicular, with truncate broad summit. - Proc. Am. Acad. ix. 204. Artemisia potentilloides, Gray, Proc. Am. Acad. vi. 551.

Eastern part of the Sierra Nevada, in Sierra Valley (Lemmon), and Carson City, Nevada, Anderson. The corymbose heads as well as the broad and abrupt top of the akene refer this to Tranacetum. The akene is thin and utricular, forming a loose investment to the seed: when soaked it swells up and becomes jelly-like; and its cells under the microscope show spiral threads.

\section{ARTEMISIA, Linn. Wormwood. SAGe-BusH.}

Head several - many-flowered, heterogamous, with the flowers all tubular and the outermost series pistillate, or homogamous by the absence of these; the more numerous perfect flowers either fertile or sterile. Scales of the involucre dry and more or less scarious-margined, imbricated in few series, appressed. Receptacle flattish, convex, or hemispherical, naked, sometimes hairy. Corollas of the pistillate flowers slender and small, 2-3-toothed; of the perfect flowers enlarged above, 
5-toothed. Anthers usually with narruw tips. Akenes ohoroid or oblung, mostly

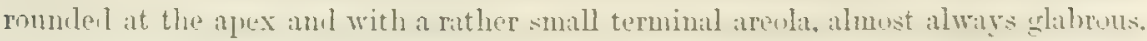
Pappus none, or in one species a vestige - Herbs or undershrubs, bitter and odorous; with alternate leaves most commonly dissected, and the numerous snall hemls of yellow or yellowish fluwers ustally nenling, and racemuse or paniclect, sometimes paniculate-spicate.

An immense genus mainly of the northern hemisphere, its headquarters in Northern Asia ; not many species in California, and fewer still in the Atlantic States; but abounding through the interior arid region, where the Suge-bneshes forn a characteristic feature. Our species are all perennials, $A$. bienris, Willd, not having been found so far west. To facilitate the determination of the species an artiticial key is appended.

Herbaceous, or hardly woody at the base ;

Green and nearly glabrous : leaves linear, entire,

Green, beeoning glabrous : leaves twice pinnately parted,

White-cottony underneath the leaves; upper face green.

Lobes of the leaves lanceolate, acute,

Lobes of the leares narrowly linear,

White-cottony throughout,

Silky villous all over,

Shrubby and spiny : heads few and scattered,

Shrubby, unarmed. (See also No. 7.)

Grayish-puberulent : pinnate leaves with long filiform divisions,

White-pubescent: leaves palmately cleft or toothed, sometimes entire. One to 6 feet high : leaves about 3-toothel,

A span or two high : leaves deeply cleft or some entire :

Their 3 lobes linear,

Their 3 to 5 lobes obovate or spatulate,

6. A. DRACUNCULMIDES.

2. A. Norvegtca.

3. A. vulgaris.

4. A. DISCOLOR.

5. A. Ledoviciaxd.

7. A. PTCNOCFipHat.

8. A. SPINESCExs.

1. A. Califormica.

9. A. TRIDENTATA.

10. A. TRIFIDA.

11. A. ARBUSCULA,

\$1. Fluuers hetroganons (sime of the murnimal unes nistillute only), but all firtile: receptacle not villous. - Abrotandu, Besser.

* Shmbby: lobes of the cinereous-puberulent leaves filiform-linear.

1. A. Californica, Less. Hout $t$ fert high, with a derileilly womly hase. very leafy: leaves all pinnately $3-7$-parted into almost filiform divisions, or some of the uppermost entire: heads small and numerous in narrow racemose panicles: seales of the involucre broad, nearly glabrous: akenes somewhat turbinate and 3-5-ribbed, utricular, with a very broad and somewhat toothed summit. $-A$. Fischeriana, Besser. A. foliosa \& A. abrotanoides, Nutt.

Dry hanks, from below Santa Barbara to San Francisco. Heats roundish, about 2 lines in diameter. Receptacle hemispherical, naked, not hairy, as said by Nuttall.

$$
\begin{aligned}
& \text { * Herbuceons: leaves on their lobes linear-lunceolate or broader. } \\
& \text { + Not white-cottony: corolla sparsely hairy. }
\end{aligned}
$$

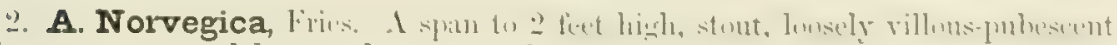
when young, or glibrous: leaves mostly bipinnately parted or cleft into linearlanceolate or broader acute lobes, or the uppermost reduced to trifid or simple bracts: heads larye, in a simple naked panicle or loose raceme: scales of the involuere oblong, brownish : akenes oblong, about 5-angled. - Novit. Stec. ed. I (1817), 56. A. rupestris, Fl. Dan. t. 801. A. arctica, Less. (1831). A. Chamissoniona, liesser, in Houk. Fl.

North side of Wood's Peak in tho Siern Nevadn, at 9,000 feot, Brencer. Also in the Rocky nnd other high mountains to Alnska, Aretic Ameriea, E. Siberia, aud the Norwegin Alps. Ileads globular, about 4 lines in diameter.

++ Leaves while-collony-tomentose underneath or on both sides: corolla glabrous.

3. A. vulgaris, Linn. A foot or two high; branching: leaves green and ghltbrous or soon hecoming so above, cottony-tomentose beneath, laciniatoly once or twice pimatifid, or some of tho upper sparingly lobal or touthed; the lothes lanceo- 
late, tapering and acute: heads numerous, spicately elustered in a leafy panicle, ovoid or globular, loosely woolly-canescent or becoming glabrous. - The typical forms are common throughout the northern portion of the Old World, especially in Asia.

Var. Californica, Besser. Stems commonly simple and tall: leaves sparingly pinnatifid, 3-5-parted, and the upper merely toothed or entire. - A. heterophylla, Nutt., \&c.

Dry soil, not rare near the coast from San Franciseo northward (a very large form at Shelter Cove, Humboldt Co., Bolander) : also in the Sierra Nevada. A very widely spread and most variable species, into which both the following appear to pass by transitions,

4. A. discolor, Dougl. Low and slender, a foot high: leaves green and glabrous above, finely cottony-tomentose beneath, nearly all once or twice pinnately parted into narrow linear lobes: heads smaller, spicately clustered in a narrow and rather naked raceme-like panicle, globular, nearly glabrous.

Sierra Nevada at Ebbett's Pass, \&c., Brewer. Thence northward and eastward to the Cascade and the Roeky Mountains. Exactly the $A$. discolor has not been met with in California. The specimens are between it and some forms of the preceding, and, with the Nevada plant of King's Expedition, varying to $A$. incompto, Nutt.

5. A. Ludoviciana, Nutt. From one to three feet high, cottony-tomentose throughout: leaves oblong, lanceolate, or linear-lanceolate, entire, sparingly toothed, or some of the lower occasionally 3-5-cleft, the upper surfaces ometimes losing its wool; heads very numerous and spicately clustered in a narrow and usually dense panicle, ovoid or globular, small.

Dry open grounds, Monterey and elsewhere in the western part of the State (with broad and entire leaves, Hartweg, Ratten, \&c.): more common, in narrow-leaved forms, on the eastern slope of the Sierra Nevada, thence abundant to and much beyond the Rocky Mountains.

\$ 2. Flowers heterogamous, as in the preceding section, but only the pistillate flowers at the margin fertile; the ovary of the otherwise perfect flowers abortive, their style mostly undivided and tufted at the apex. - Dracunculus, Besser.

+ Fertile akenes and corollas glabrous: stems herbaceous or barely woody at base.

6. A. dracunculoides, Pursh. Green and glabrous, or a little pubescent when young, branching, 2 to 4 feet high, in tufts: leaves linear, entire, some of the lower rarely 3 -cleft: heads small and very numerous in an ample compound leafy panicle, mostly pedicelled.

Common in the Sierra Nevada, also found westward (banks of San Leandro Creek, Bolander; Fort Tejon, Dr. Horn) ; and through Nevada and Oregon to beyond the Mississippi. Heads only a line or so in diameter, glabrous. The herbage is destitute of the sharp odor and taste of A. Dracunerelus.

7. A. pycnocephala, DC. Densely silky-villous all over : stems mostly simple, a foot or two high, somewhat woody at base: leaves once to thrice pinnately parted into rather few and crowded chiefly linear lobes: heads numerous, spicately clustered in a dense virgate panicle. - Also A. pachystachya, DC.

Sand bills along the coast from Monterey to Humboldt Co. WHeads fully 2 lines in diameter: involucre very villous.

++ Fertile akenes and the corollas villous with long crisped hairs: stems woody. (Picrothamnus, Nutt.)

8. A. spinescens, D. C. Eaton. A span to a foot or so high, with stout and spreading rigid branches, bearing sharp spines, villous-tomentose: leaves small, petioled, pedately once or twice parted into linear-spatulate or oblong lobes: heads rather few and loosely racemose or spicate on a persistent spinescent rhachis: scales of the involucre few ( 5 or 6 ), round-obovate, herbaceous with scarious margins. Bot. King Exp. 180, t. 19. Picrothamnus desertorum, Nutt. 
Through the interior lesert, from the Rocky Mountains to the eastern base of the Sierra Nevada; probably within the borders of the State. Well referred by Prof. Eaton to Artemisia; but the habit and the woolly akenes are peculiar.

\section{\$3. Flowers in the head all perfect and fertile. - Seriphididu, Besser.}

The N. American species of this section are the true Sage-bushcs or Sage-brushcs of the interior arid region. Their heads are always few-flowered, generally narrow, and the scales of the involucre little scarious.

A. CAxA, Pursh, the Wild Sage of Lewis and Clarke, or what Pursh took to represent it, is the more northern species, with linear entire leaves, and probably does not nearly approach the borders of California.

9. A. tridentata, Nutt. shrubby, a foot to 5 or 6 lieet hish, bushy-hnancher, canescent: leaves crowded, cuneate varying to linear-cuneate, obtusely 3 -toothed at the truncate apex, or the upperinust entire: heals spicate-clustered on the branches of the compound narrow panicle, obovoid or oblong, 5-6-flowered.

Eastern slope of the Sicria Nevada, from Sonora and Mono Passes, through Nevada and the Rocky Mountains, in immense abundance. The larger stems attain the diameter of 5 or 6 inches in favorable situations. Heads about 2 lines long.

10. A. trifida, Nutt. Shrubby, a span or two high, in tufts, canescent: leaves linear and entire, or many of them linear-cuneate and deeply cleft into 3 linear lobes: heads more simply spicate, 3-8-flowered.

Ebbett's Pass and Mount Dana (Brewer, Bolander); and through Northern Nevada to the Rocky Mountains; often accompanying the foregoing.

11. A. arbuscula, Nutt. Shrubby in dense tufts, barely a span high, very canescent: leaves cuneate, deeply 3-cleft, or the side divisions again 3-lobed; the

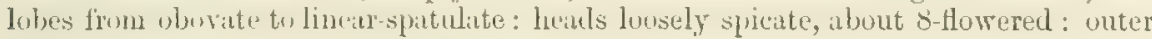
scales of the involucre more herbaceous and rigid.

High Sierra Nevada, near Summit Station, E. L. Greene. Thence eastward to the Rocky Mountains.

\section{COTULA, Linn.}

Head many-flowerel, heterogamons; one or more rows of marrinal flowers pistillate and apetaluns, mustly pelicellate; the proper lisk-flowers perfert and rither fertile or sterile. Involucre of about two ranks of nearly equal somewhat scariousmargined scales. Receptacle comroonly flat or convex, naked, papillose. Diskcorollas short, 4-toothed. Akenes obcompressed, mostly with thick or spongy

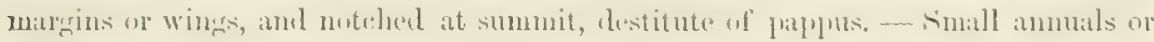
solne perennials, strong-scented when bruised; with alternate leaves, and solitary

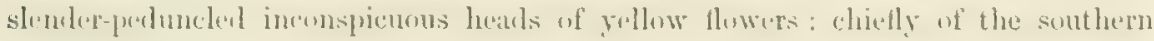
hemisphere, whence two species have reached California.

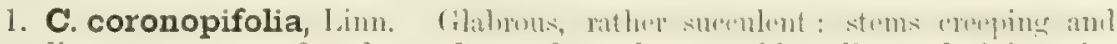
ascending, a span to a foot long: leaves lanceolate or oblong-linear, laciniate-pin-

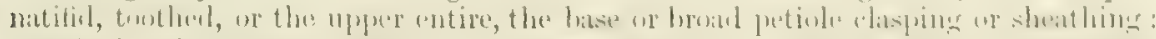

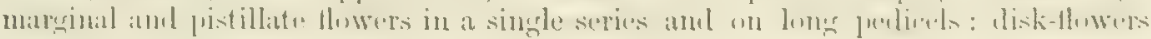
on shorter pedicels.

Wet places around San Francisco Bay : doubtless introduced. Now widely liffused over the work, minly in the southern hemisphere. Head half an inch in diameter or less.

2. C. australis, IInok. f. Somewhat hairy: stems slender, diffisely much branched, a span high: leaves usually twice pinnately parted into linear divisions: heads very small: marginal pistillate flowers in two or three ranks, pedicelled; the disk-flowers hamlly so。 - Fl. N. \%eal. i. 128.

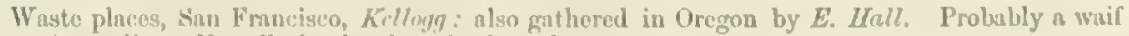
from Australia or Now Zestland, where it nbounds. 
96. SOLIVA, Ruiz \& Pavon.

Head many-flowered, heterogamous, of many pistillate and apetalous flowers, and a few perfect but mostly sterile flowers in the centre. Scales of the involucre 5 to 10, nearly equal, in one or two series, scarious-margined. Receptacle flat, naked. Disk-flowers tubular, thickish, 2-6-toothed; their style often undivided. Akenes obcompressed, with rigid wings or callous margins, the summit of which is usually pointed, and the apex armed by the indurated persistent style, destitute of pappns. - Small and depressed herbs of S. America (one naturalized on the shores of the Atlantic United States, and one seemingly indigenous to California): leaves petioled and pinnately divided into small and narrow segments: heads sessile, in fruit globose : flowers greenish or yellowish.

1. S. daucifolia, Nutt. Annual, diffuse or creeping, about a span high, softhairy: leaves once or twice pinnately dissected into rather few linear acute divisions: heads small ( 2 or 3 lines broad), sessile in the forks: scales of the involucre ovate, acuminate: akenes minutely hairy, obovate, with the broad or narrow and thin wings entire, each terminating upwards in an incurved tooth or point. - Torr. \& Gray, Fl. ii. 425.

Moist grounds near the coast, from Santa Barbara to Mendocino Co. Much like S. sessitis of Chili ; the wings of the akenes very variable in breadth, broad and thin in some well-developed specimens, often wanting towarcls the base of the akene, or rarely developed there into separate teeth or lobes.

\section{Tribe VIII. SENECIONIDEA.}

Distinguished generally by the involucre of one or two series of more or less herbaceous equal scales, or calyculate with some shorter ones at base; the pappus of soft and fine capillary bristles, generally more delicate than in any of the preceding tribes; and the receptacle not chaffy. Anthers often sagittate at base, but without tails. Style-branches of perfect flowers various, but commonly truncate or somewhat capitate at tip, rarely prolonged into an appendage. Flowers almost always yellow.

Crocidium MUlticatrie, Hook., found on the banks of the Columbia River, a delicate little plant with the aspect of Senecio, is likely to occur on the northwestern borders of the State.

\section{PETASITES, Tourn.}

Head many-flowered, heterogamous, more or less diœcious; the numerous pistillate flowers in the margin either with filiform or (in ours) with distinctly ligulate rays. Involucre campanulate or cylindraceous; its scales nearly in. a single series, and usually with some small and loose subulate bracts at base. Receptacle flat. Flowers in the sterile plant very numerous in the disk and rather few in the ray; in the fertile very few perfect or infertile ones at the centre, the rest pistillate. Corolla of the hermaphrodite flowers with a 5-cleft limb; their style entire or barely 2-lobed at the club-shaped puberulent summit. Akenes glabrous, 5-10-ribbed. Pappus of copious long and soft capillary bristles, fewer in the sterile flowers. Herbs of northern regions; with creeping rootstocks, sending up large radical palmately veined leaves on long petioles, and stont scapes in spring, beset with scaly or imperfectly folitceous clasping bracts, and terminated by a racemose or cymose cluster of rather small heads : flowers purplish or white.-Petasites \& Nardosmia, DC. 
The American species are of the Nardosmia section, with more corymbose heads and decided rays. The few species of the group are very nearly related : the most southern one, and the only one found in California, is the following. But P. sagillata (Nardosmia, Hook.), of the Rocky Mountains, may possibly occur.

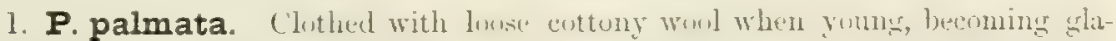

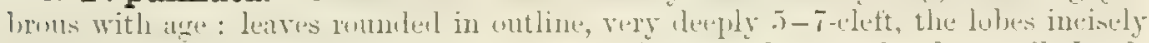
toothed or lobed: Howers dull white, deliciously scented: rays in the sterile heads oblong and conspicuous, in the fertile ones narrow and shorter than their style. Tussilago palmata, Ait. Kew. ed. 1., iii. 188, t. 2. Nardosmia palmata, Hook.

Damp woodlands, from San Francisco northward. Also in Oregon and sparingly to New England and Labrador.

\section{TETRADYMIA, DC.}

Head 4-9-(rarely 18-) flowered, homogamous; the flowers all tubular and perfect. Involucre cyliudrical or rarely campanulate; its scales 4,5 , or sometimes

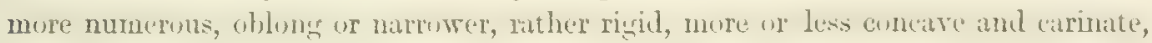
nearly equal, in one or two series, and rarely with short external ones at the base. Receptacle small, flat or nearly so. Corolla with a slender tube, abruptly dilated into a 5-parted limb; the lobes linear or lanceolate, traversed by a more or less evident mid-nerve. Anthers exserted, linear, mucronately sagittate, the auricles connate. Style-branches with minutely penicillate apex tipped with a very short and obtuse or sometimes more conspicuous and acute cone. Akenes terete, oblong or somewhat fusiform, obscurely 5-nerved, long-villous or glabrous. Pappus of copious fine and soft capillary scabrous bristles. — Low and much branched shrubs (of the interior arid region, mainly between the Sierra and the Rocky Mountains); with alternate linear or subulate entire leaves, and corymbose or racemose clusters of middle-sized heads: corollas yellow. - DC. Prodr. vi. 240; Gray, Proc. Am. Acad. ix. 207.

In the paper above cited, the genus is extended so as to include an ambiguous species, constituting the third section.

\$1. White-rvoolly, except the small terete fascicled leaves in the axils of the mimary leaves converted into spines: involucre of 5 or 6 scales, 5-9-Howered: bristles of the pappus in a single series, atmost equalled and concealed by the finer but similar pappus-like long white hairs which densely clothe the akene! - Lagothamves, Tort. \& Gray. (Lagothamnus, Nutt.)

1. T. spinosa, Hook. \& Arn. From 2 to 4 feet hish, with rigil divaricate hranches, clothed with dense white wool and armed with sharp slender spines: leaves crowded in the fuscicles, succulent, linear or terete, glabrous (ahout 3 lines long), mostly shorter than the spines: heads raceunose or scattered along the branches (half an inch long), short-peduncled. - Lagothamnes microphyllus \& L. ambiguns, Nitit.

Rastern borders of the State; San Bernadino Co., on Providence Mountains (Cooper), and through the Nevada desert to Idalio.

\$2. White-wonlly, or sometimes almost glabrate: involucre of 4 or 5 concave scales containing finur flomers: bristles of the proppus very copious: alenes eilher

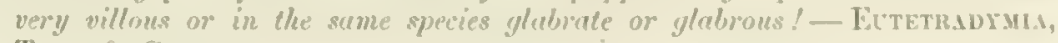
Torr. \& Gray.

2. T. canescens, T) A font or two high, unarmod, silvery-tomentose: leaves narrowly linear, varying to linenr-lanceolate or somewhat spatulate (and from nn 
inch to barely half an inch long), the wool persistent : heads corymbosely clustered. - Deless. Ic. iv, t. 60.

Dry hills and plains; from Mono Lake, \&c. (Brewer) through Nevada to the interior of Oregon and Idaho, and, in the var. inermis ( $T$. inermis, Nutt., which has shorter leaves and heads) eastward to New Mexico, Colorado, and Wyoming. Heads in the larger-leaved form about three quarters of an inch long; in the other sometimes only half an inch. Lobes of the corolla nearly linear, the mid-nerve or axis commonly carinate-thickened from the apex downward. Tips of the style-branches usually nearly as figured in the plate cited, or the base of the cone distinctly hispid, but occasionally the cone is more prominent, acute, and hispid with a few stiff bristles. In such specimens, and also in some others, the ovaries are perfectly glabrous; in others, the akenes become glabrous.

3. T. glabrata, Torr. \& Gray. A foot or two high, unarmed, cottony-tomentose with very white but more deciduous wool: leaves rather fleshy, becoming glabrous in age; the primary ones linear-subulate and conspicuously mucronate (half an inch long), erect or appressed on the branches of the season; those of the fascicles shorter and obtuse: heads corymbose. — Pacif. R. Rep. ii. 122, t. 5 ; Eaton in Bot. King Exp. 193.

Eastern side of the Sierra Nevada on the borders of the State, Beckwith, Anderson, Lemmon. Thence through the desert to Salt Lake. Heads and flowers nearly as in the preceding. Stylebranches tipped with a very short and obtuse cone. Akenes seemingly always densely villous.

T. NurTallir, Torr. \& Gray, the spiny species of this section, apparently has not been met with west of Utah or Idaho.

\section{\$3. Early glabrate, unarmed: leaves all reduced to subulate green scales; those at the summit of the branchlets passing into the scales of the 15-18-flowered campanulate involucre, which thus becomes imbricated! - Lepidosparton, Gray.}

4. T. squamata, Gray. Paniculately branched, 3 or 4 feet high: branches slender: leaves reduced to very small thick and rigid-pointed scales: heads racemose or paniculate: involucre glabrous, of 8 to 12 inmer scales in 2 or more series and subtended by several or numerous shorter bracts: lobes of the corolla linearlanceolate: style-branches with acute and minutely hairy tips: akenes rather short, completely glabrous. - Proc. Am. Acar. ix. 207. Linosyris squamata, Gra.y, 1. с. viii. 290 .

Var. Breweri, Gray, 1. c. Branches slender and rush-like, minutely and remotely scaly: involucre subtended by few bracts. - Carphephorus junceus, Durand, Pl. Heerm. in Pacif. R. Rep. v. 8, not of Benth.

Low hills and cañons, Sierra Santa Monica, towards the sea, Brewer. Tejon Pass, Heermann. The above is the var. Breweri. The var. Palmeri is of the Colorado desert in Arizona (Dr. Palmer) : it has more rigid branchlets, rather closely beset with thickish green seales, those of the pedicels thinner, imbricated and passing into those of the involucre, which thus appears to be many-ranked; and the pappus is very copious. Head in both forms about 4 lines long. Although quite glabrous, the vestiges of wool in the axils, at least in var. Palnueri, show that the plant may have been white-cottony at first.

\section{LUINA, Benth.}

Head about 10-flowered, homogamous; the flowers all tubular and perfect. Involucre campanulate, of 10 or 12 linear-lanceolate dry and rather rigid carinate-onenerved equal scales, shorter than the flowers. Receptacle flat. Corollas with a slender tube and a tubular-funnelform 5-lobed limb; its lobes ovate-lanceolate, spreading, with mid-nerves more or less evident and extending down the throat. Anthers soon exserted, linear, minutely and mucronately sagittate at base. Stylebranches linear-semiterete, minutely papillose-puberulent extermally, very obtuse, totally destitute of appendage. Akenes terete, obscurely 10-striate, glabrous, or with a few scattered fine hairs. Pappus of copious soft and white scabrous capillary bristles. - A cottony-woolly low herb; with simple stems from a stout woody 
rootstock or caulex, alternate sessile and entire leares, and small curvuhnse heats of light yellow flowers. - Benth. in Hook. Ic. Pl. t. 1139, \& Gen. Pl. ii. 438.

1. I. hypoleuca, Benth. A foot high, equally leafy to the tup : leaves ovateoblong or elliptical, obtuse, an inch long, reticulate-veiny, very white beneath, becoming green and glabrous above with age: heads half an inch long, on rather slemler peduncles, 3 to 9 in an open cluster: corcllib-lubes almost half the length of the funnelform throat.

Var. Californica, Gray. More densely wolly : unper surfice of the leaves harlly becuning maked : lubes of the corulla only a third or funth of the length uf the throat. - Proc. Am. Acad. ix. 206.

The species was collected by Dr. Lyall only in the Caseade Mountains, on the frontiers of British Columbia. Var. Califorivica, on Chimney Rock, Mendocino Co., and on the coast mountains back of Santa Cruz, California, Kellogg.

\section{PSATHYROTES, Gray.}

Head rather many-flowered, homogamous; the flowers all tubular and perfect. Involucre campanulate, of one or two series of nearly equal somewhat herbaceous seales, or the inner more scarious. Receptacle flat or barely convex, naked. Corollas narrow, with proper tube usually very short, 5-toothed; the teeth short and ultuse, externally glamlular or viscid-bearled. Anthers ninutely signttite-auriched at base. Style-branches obtuse or somewhat truncate, destitute of any distinct appendage. Akenes turbinate or oblong with narrow base, villous or hisute.

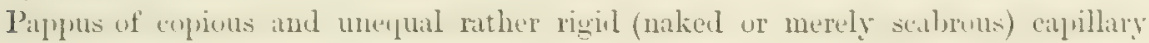
bristles, shorter than the corolla, generally rusty or brownish. - Low and more or

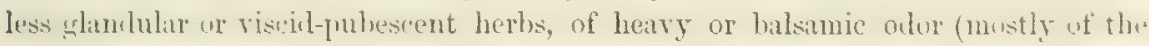
interior desert region); with alternate leaves, aml rather small or midhle sized heads of light yellow or yellowish flowers. - Pl. Wright. ii. 100, t. 13, \& Proc. An. Acad. vii. $363, \&$ ix. 206.

\$ 1. Very lnw or prostrate and diffusely much branched annuals: leaves rounded and toothed or angled, on long petioles: heads shmrt-petioled in the forks, nodding after flowering: ahenes turbinate, very villous: bristles of the pappus rigid and almost in a single series.

1. P. annua, Gray, 1. c. Scurfy-pubescent or mealy-hoary: leaves coarsely an-

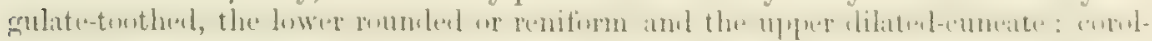
las yellowish. - Bulbostylis (Psnthyrotes) annue, Nutt. Pl. Gumb. 179.

In salino desert soil, Mono Lake (Brewer), western part of Nevada (Torrey, W"atson), and probably Arizona (not Now Mexico); first collected by Dr. Gambcl. A span high : leares nbout half an inch long and broad: heads 3 or 4 lines high. The berbage much resembles some species of Atriplex of the Obione section. Style-branches of this and the following capitellate-truncate with a slight penicillation, of the Senecionoid or Helenioid type.

2. P. ramosissima, Gray, 1.c. Resembles the foregoing, but truly woolly: leaves cremately few-toothed: corollas bright yellow: akenes short-turbinate. Tetradymia (Polydymia) ramosissima, Torr. in Emory Rep. 18.8, 145.

Gravelly hills of the southeastern borlers of the State, near Fort Mrohave (Couper): and in Arizona on the Gila, Enory, Fremont, Thurber, Parry.

\$2. Evect, rigid, and secmingly rather woody at base: leaves sessile and filiform:

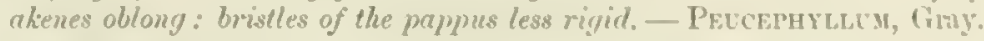

3. P. Schottii, Gray, 1. c. A span to a foot high, with ascenling branches, leafy to the solitary erect heal, nearly or quite glabrous, but somewhat glutinous: 
leaves rigid, almost acerose but pointless, impressed-punctate: head 10-16-flowered, fully half an inch long; scales of the involucre about 12 in a single series; with tips resembling the leaves, and the thinner base somewhat dilated: akenes (or rather ovaries) oblong. - Peucephyllum Schottii, Gray, Bot. Mex. Bound. 74.

Colorado bottom in Sonora (Mexico), Schott, Feb. 3, 1855. A flowerless specimen collected by Dr. Newberry on the "Colorado of California, January 15," may be this ; but is more glutinous, and is perhaps a Bigelovia or Aplopappus. Leaves an inch or less in length, punctate in the manuer of Aptopappus and of many Eupatoriacea. The flowers were said to be yellow, but they seem to have been only yellowish. The style-branches are like those of Luina, or more obtuse, and wholly destitute of any appendage or tip.

\section{SENECIO, Linn. GrodNDSEL。}

Head many-flowered, with pistillate rays, or occasionally homogamous by the want of the rays; the flowers all fertile. Scales of the involucre herbaceous, mostly narrow, equal in a single series, or calyculate with a few short scales at the base. Receptacle flat or merely convex, naked. Disk-corollas usually narrow, 5-toothed or 5-lobed. Style-appendages of the disk-flowers mostly capitate-truncate, the apex minutely tufted or hispid, rarely with a little cusp. Akenes terete or somewhat angled, usually 5-10-xibbed. Pappus of very numerous and mostly white fine and soft capillary and merely scabrous bristles. - Herbs or shrubby plants; with alternate leaves, and usually corymbose or solitary heads of yellow flowers (at least in all the American species): akenes commonly glabrous, or beset with some short hairs or papillæ, which become turgid when wetted, open at the apex, and emit one or two uncoiling spiral threads.

This is counted as the largest genus of Phænogamous plants (of little under 1,000 species), and is very widely spread over the world, the species of each great region for the most part peculiar. But North America is by no means rich in species, the central regions, however, more so than either the Atlantic States or the Pacific slope.

S. Cinetaria, DC., of the Mediterranean region, a common house-plant (known in cultivation as the Dusty Miller, from its whiteness), is in Kellogg and Harford's distributed collection, said to have been gathered on the shore of the Bay of San Francisco, near Alameda. It is doubtless a waif from cultivation.

S.? FLOCCIFERUS, DC., is Malacothrix saxatilis.

* Root annual: rays none or minute: weeds introduced from Europe into waste or cultivated grounds.

1. S. vulgaris, Linn. A span to a foot high, branching, leafy to the top: leaves clasping at base, pinnatifid; the oblong lobes and the spaces between them sharply toothed: scales at the base of the involucre conspicuous and blackishtipped: rays none.

Near San Francisco, \&c.: the common Groundsel of Europe.

2. S. sylvaticus, Linn. More slender: leaves less clasping and with narrower lobes: heads smaller: scales at the base of the involucre few, minute, not blackish: rays present but minute, hardly longer than the disk-flowers.

Introduced from Europe: San Luis Obispo (Brewer), and San Diego, Cooper. Mare Island, Greene.

* Root annual: rays conspicuous : indigenous species.

3. S. Californicus, DC. A foot or two high, with slender rather simple stem, glabrous or with some scattered hairs: leaves lanceolate, linear, or the lowest oblong, varying from sparsely denticulate to pinnatifid; the cauline with mostly clasping base; their lobes oblong or broadly linear: heads corymbose: rays elongated: akenes canescent. - $S$. Coronopus, Nutt., a form of this with the leaves deeply or even doubly pinnatifid. 
Low grounds, common from Santa Barbara to San Diego, and in all the soullern part of the State. Heads barely or less than half an inch in length.

$$
\text { * * Root perennial. }
$$

Leaves or the lobes of pinnately parted leaves all linear and entire: stems often more or less woody at base.

4. S. Douglasii, DC. White with cuttuny wul, or becoming nearly glabrous : stems in tufts, 2 to 6 or 7 feet high, the lower portion or base persistent and even shrubby, leafy to the top: leaves linear, entire and acute ( 2 to 4 inches long and less than 2 lines wide), or pinnately parted into 3 to 9 similar lohes: leeads corymbuse or sometimes nearly sulitary teminating the branches, rather liange (half to two thirds of an inch long): involucre calyculate with loose slender subulate bracts, some of them little shorter than the acute or acuminate proper scales of the involucre : rays elongated : akenes minutely canescent.

Gravelly or rocky banks of streams, \&ce, from Lake Co. southward through the State, and into Alizona and Nerada. S. longilobus, Benth., of MIexico, to which belongs S'. filifolius, S. spartioides, and probably S. Riddelliz, Torr. \& Gray, with mostly smaller heads, more herbaceous involucre, and shorter and few calyculate bracts, represents this in and eastward of the Rocky Mountains, and apparently passes into it. S. Regiomontanus, DC. Prodr. vi. 429, is probably another synonym, and the "Real del Monte" of Hrenke is Monterey, Califormia.

++ Leaves broader, all ar some of them pinnately parted or pinnate: rays numerous $r^{*}$ several and conspicuous: akenes glabrous.

5. S. Bolanderi, Gruy. Early chlahrous : stem slender, a span to a foot or more high from a slender creeping rootstock, sparsely leaved : radical and lower eaulino leaves petioled and pinnately divided, thin and membranaceous; leaflets 3 to $\overline{7}$, roundish or cuneate, incisely and obtusely lobed, the terminal leaftet larger and sometimes slightly cordate, the lower on the radical leaves often small or minute and entire, on the cauline leaves stipule-like: heads few or several and corymbose: involucre nearly destitute of bracts at the base : rays 4 to 6 . - Proc. Am. Acad. vii. 362.

Sandstone bluffs, Mendocino Co., Bolander. Cascade Mountains, Oregon, Herford and Dumn.

6. S. eurycephalus, Torr. \& Gray. Floccose-woolly or early glibrous : stem rather stout, 2 feet or more high: leaves pinnately parted or livided, somewhat lyrate; lobes or leafluts 7 to 15 , cuneate and acutely incised or cleft, or in the upper leaves becoming linear: heads mostly numerous in an ample corymb and large: involucre broadly campanulate, with very few and inconspicuous calyculate bracts: rays 10 to 12 , elongated. - Pl. Fendl. 109.

Low grounds, from Sonoma Co. and the Sacramento, along the Contra Costa Range, \&c. A very large and coarse-leaved form (var, major, Gray, in Pacif. R. Rep. iv. 111) in (alaverns Co., near Murphy's, Bigeloro. A variable species, both in foliage and the size of the heads. These, in the larger, two thirds of an inch long and fully half an inch broad, and bearing rays half an inch in length: in specimens from Monte Diablo, in Fellogg and Harford's collection. of only about half that size, not largor than thoso of $S$, aurcus.

7. S. aureus, Linn. Very loosely floccose-woolly when young, soon nakel, or even glabrous frum the first, a foot or two high, or alpine forms smaller: radical leaves or some of them entire or merely servate, from round-corlate to oblong or spatulate, slender-petioled ; the others mostly lyrately pinnatificl or lyrate, or only incisely toothed; upper sessile or partly clasping, spatulate or lanceolate: heals few or numerous, corymbose ( 3 to 5 lines high): involucre scarcely calyeulate: mys 8 to 12 , occasionally wanting. - An exceedingly variable species; the typical form with thinuish and soon glabrous leaves, the ralical ones cordate or roundish and toothed, and the lowest cauline ant to be lymate.

Var. multilobatus, Grmy (or S. multilobutus, Torr. \& Groy, Pl. Fendl., and \&. Fendleri, Laton in Bot. King Exp. in part), if perennial, is a form with thickish leaves, nearly all lyrately or otherwise pinnately parted, and the heruls munerous. 
Var. Balsamitre, Torr. \& Gray, has thinner leaves, even the radical ones lanceolate or elongated-oblong, the cauline pinnately-parted.

Var. borealis, Torr. \& Gray, is a low form, a span to a foot or more high, soon glabrous, with thick and firm small leaves; the radical obovate or spatulate and merely toothed, sometimes only at the apex; cauline ones usually few: heads one or two, or several. Alpine forms of this pass into the next species.

Moist or wet ground, chiefly in the Sierra Nevada: the ordinary form from near Mount Dana (Brewor), thence eastward and northward to the Atlantic. The var. multilobatus hardly in California (as the original is from Nevada or Utah, and Coulter's plant very likely is of the foregoing species), but occurs as near as the Pah-Ute Mountains in Nevada. Var. Balsamitce has been collected no nearer than Oregon. Var. borealis at Carson, Summit, \&ce, and an alpine form connecting it with $S$. canus from high peaks, Mount Dana, \&c. The most polymorphous species of the genus.

+++ Leaves lanceolate or broader, entire, serrate, or rarely some of them laciniate: akenes glabrous.

+ Low, small-leaved: heads few or solitary.

8. S. canus, Hook. A span or two high, white with a dense close wool which is mostly permanent: leaves entire or rarely few-toothed; the radical and lowest oblong, oval, or spatulate (an inch or less in length and with rather slender petioles); the upper occasionally sinuate-pinnatifid : heads few : involuere nearly naked at base: rays 8 to 12, oblong, yellow, occasionally wanting. - Hook. Fl. i. 333, t. 116 .

Highest portions of the Sierra Nevada, Mount Dana to Silver Mountain, \&c., at 9,000 to 12,000 feet (Erewer, Bolander); also on the Humboldt and Rocky Mountains, and thence far northward. On the higher peaks of the Sierra apparently passing into an alpine state of S. aureus. Heads 4 to 6 lines high: rays 3 or 4 lines long.

9. S. Fremontii, Torr. \& Gray. A span or two in height, diffusely much branched from the root, glabrous, leafy: leaves thickish and rather succulent, an inch long or less, from round-obovate to spatulate, obtusely and irregularly toothed, tapering into a narrow-cuneate base or short winged petiole: heads on short and bracted peduncles terminating the stems or short branches: involucre sparingly calyculate at base: rays 8 to 12, yellow. - Fl. ii. 445; Gray in Proc. Acad. Philad. 1863, 67 ; Eaton in Bot. King Exp. 192.

On Lassen's Peak, Lemmon. A rather small form. A species of the Rocky Mountains, before found as far west as those of Utah.

10. S. Greenei, Gray. Less than a foot high, lightly clothed with loose cobwebby wool when young, inclined to be glabrous with age: leaves chiefly radical, oval or roundish and mostly with a cuneate base, coarsely crenate-serrate (an inch or more in length) rather long-petioled; the cauline smaller and nearly sessile, sometimes reduced to subulate bracts: heads mostly solitary, sometimes 3, large: involucre (half an inch or more long) campanulate, wholly naked at base : rays 9 to 14, oblonglinear, deep orange or flame color; disk-corollas also orange at the tips: stylebranches bristly-fringed round the base of the obtusely conical tip, which is pointed with a central cusp. - Proc. Am. Acad. x. 75.

Woods near the Geysers, Napa Co., E. L. Greene. Rays fully half an inch long. Akenes glabrous. A showy species.

$\div++$ Taller, a foot or two, sometimes a yard or more high, naked at summit, the upper

leaves decreasing to bracts, commonly with loose woolliness when young, but green and glabrous or nearly so with age.

$=$ Heads pretty large and broad; the campanulate or hemispherical involucre 4 to 6 lines long, loosely calyculate with some slender-subulate bracts.

11. S. Clarkianus, Gray. Nearly glabrous, apparently from the first: stem strict, 3 or 4 feet high, striate-angled, leafy almost to the top, bearing several or 
numerous corrmbose heads: canline leaves lanceulate, elongated ( $t$ to 8 inches lon: $)$, tapering to both ends and the lower into petioles, laciniately dentate or even pinnatifid into narrow and acute salient teeth or lobes: bracts subtending the involucre almost tiliform, some of them nearly equalling the numerous and narrow acute proper scales: rays 10 to 15 , elongated. - Proc. Am. Acad. vii. 362.

Mariposa Co., in the natural meadow at Clark's Ranch (named for the proprietor, Galen Clurk,

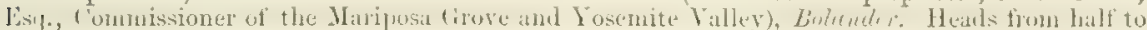
two thirds of an inch long. Teeth or lobes of the leaves horizontal, sometimes half an inch long and subulate-lanceolate, sometimes very short. Kern Co.,Rothrock.

12. S. Mendocinensis, Gray, 1. c. Beset or clothed with some loose wool when youmg, alunst glibrus with age: stem stout, 2 or 3 feet high, striate, naked at summit, bearing several corymbose heads: leaves somewhat succulent, repandtoothed or denticulate; the ralical and lower cauline varying from oval to lanceolate ( 3 to 5 inches long), mostly narrowed into margined petioles; the upper much smaller, narrowly lanceolate and sessile, and above reduced to subulate bracts:

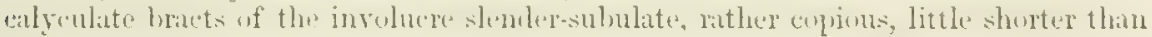
the numerous lanceolate very acuminate proper scales: rays 12 to 15 , oblong, rather short: akenes prismatic.

Near the coast of Mendocino and Humboldt Counties, Bolander, Harford. Also collected in Oregon by Kellorg. Heads two thirds of an inch or more in length, broad and very manyflowered, with thickened turbinate base or summit of peduncle, which is doubtless fleshy in the manner of the allied S. inceyerrimus. Akenes prismatic and strongly striate-angled, nearly 3 lines long. It is this species rather than $S$. lugens that is to be compared with the East Asian forms of S. pretensis (var. polyccplucelus, Regel; S. Picrotii, Miluuel, \&c.), which have heads of about the same size, but the involucre not calyculate.

S. INTEgenrtuts, Nutt., of the mourntains of Utah, Colorado, and Wyoming, perhaps also in

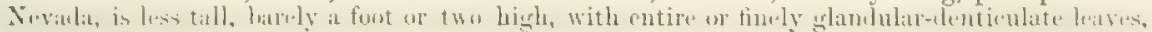
and smaller heads similarly fleshy-thickened at base. The seales of the involucre are brouder and rather obtuse, and the calyculate bracts mueh fewer and mostly short: akenes more striate.

\section{$==$ Heads smaller and narrower: involucre not over 3 or sometimes 4 lines long, obscurely and spuringly calyculate.}

13. S. lugens, Richards. Clothed with a thin and loose floccose wool when young, early or later glabrate, sometimes appearing as if wholly glabrous: stem from

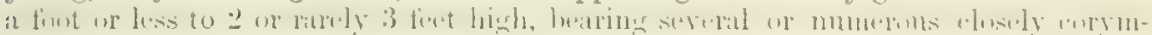
bose heads: radical and lower leaves obovate-oblong and oblanceolate or rarely wvate, glandular-denticulate, rarely more toothed (2 to 5 inches long), tapering into short margined petioles; the upper cauline mostly reduced to lanceolate or subu-

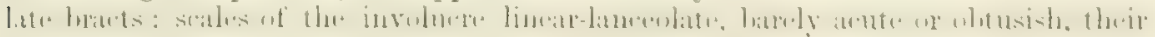

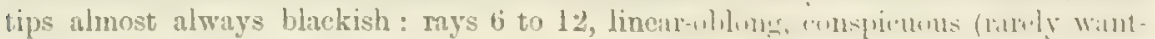
ing) : akenes angled. - Hook. Fi. i. 332, t. 114.

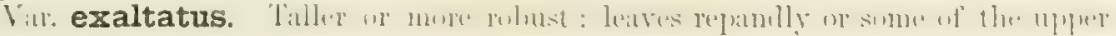
oven laciniately toothed; the ralical slender-petioled. $-S$. exaltatus of $S$. cordatus, Nutt.

Low grounds, not mare in the Sicrra Nevadn, at the altitude of 8,000 to 10,000 feet; enstward to

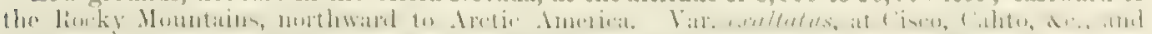

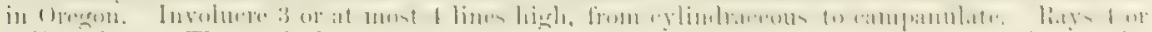
5 lines long. The typieal $S$. leenens is green or early glalnous, rather narrow-lenved, nind the upper or even almost all the enuline lenves mneh reduced in size, so that the stem, which sehom eveeds a foot or two in height, is often naked for most of its length. The var. cxultutus (as understood from Nuttall's eharncter rather thun from some specimens named by him) is as conrser form, wholly of the Pacifie side, with leaves inclined to be toathed or even laciniate, the radiual rather longr-petioled : inded, with the rays and involucre of this species along with the folinge of the next.

Yar. Folosese, Gray (S. hegrns, var. exrllentus, Eaton, in Bot. King Exp.), of the Rocky Mountains in Colorado nnd "tuh, but not yet met with in Californin, is huary with the white wool up to thu flowering stnte, and the stem conspicuously leafy almost to the top. 
14. S. aronicoides, DC. Loosely and somewhat hirsntely woolly when young, glabrous when old: stem stout, a foot to a yard high, bearing numerous small heads in dense compound cymose clusters: leaves oblong, varying to ovate or lanceolate (3 to 5 inches long), irregularly and often coarsely toothed, or the lower cauline sometimes laciniate-pinnatifid, the uppermost reduced to bracts: scales of the involucre lanceolate, acuminate, not black-tipped: rays none, or occasionally one or two short ones: disk-flowers 10 to 20.-S. exaltatus var. uniflosculosus, Gray in Pacif. R. Rep. iv. 111.

Low grounds, common about the Bay of San Francisco, the Geysers, \&c. A dwarf and nearly entire-leaved variety, around Lassen's Peak, Lemmon. Involucre a lines long.

15. S. hydrophilus, Nutt. Very glabrous apparently from the first, pale or even glaucous: stem stout, 2 to 4 feet high, many-leaved and bearing numerous paniculate-corymbose small heads : leaves thickish, entire or occasionally denticulate or repand, mostly lanceolate, with broad and strong midrib; the lower 5 to 9 inches long and tapering into a stout petiole; the upper successively shorter and sessile: scales of the narrow involucre oblong-linear, rather obtuse, mostly brownish-tipped: rays 2 to 6 and linear, or sometimes wanting: disk-flowers 8 to 20. - Torr. \& Gray, Fl, ii. 440.

Wet grounds, Lake Co. and Shasta Co. (Brewcr); salt marsh at Vallejo (Greene); in the Sierra at Mono Pass (Boldazder); near Carson (Anderson); and thenee to the Rocky Mountains. A peculiar species. Involuere 3 lines long, in specimens from Vallejo 4 lines long and rayless.

$+++\div+\div$ Tall, 2 to 5 feet high, equably leafy to the top, glabrous throughout or nearly so, not woolly when young: involucre cylindraceous, subtended by a few loose and nearly setaceous bracts: akenes glabrous.

16. S. Andinus, Nutt. Stems extremely leafy, often branching: leaves lanceolate or linear-lanceolate (or the lower oblong), tapering to both ends, either sharply and elosely denticulate or entire; the cauline nearly sessile : heads small, very numerous, corymbose-paniculate: rays 6 to 8 .

Near Carson City, Nevada (Anderson), and therefore probably within the limits of the State: not rare northward and eastward to the Rocky Mountains, along streams. Heads variable in size and in number of the flowers, from 4 to 6 lines high.

17. S. triangularis, Hook, Stems mostly simple: leaves all but the uppermost petioled and deltoid or triangular-lanceolate, or even hastate, acuminate, thickly dentate (either coarsely or sometimes finely) with sharp salient teeth : heads rather numerous, corymbose: rays 6 to 12. - Hook. Fl. ii. 332, t. 115.

Low or wooded moist grounds of the Sierra Nevada; Mariposa Grove, \&ce. (Brewer, Bolunder), Donmer Lake (Torrey), Sierra Valley (Lommon); through Nevada to the Rocky Mountains, and north to British Columbia. Heads varying from 4 to 7 lines high.

\section{ARNICA, Linn.}

Head many-flowered; with pistillate rays, or sometimes homogamous by the absence of the rays; the flowers all fertile. Involucre usually broadly campanulate, naked at base; the scales thin-herbaceous, lanceolate or linear, equal, in one or two series. Receptacle flat, naked. Rays elongated: disk-corollas with distinct and usually elongated tube and funnelform or cylindraceous 5-lobed limb. Style-appendages obtuse, pubescent. Akenes linear, 5-angled or 5-10-ribbed, somewhat hirsute or nearly glabrous. Pappus a single series of rather rigid strongly scabrous or barbellate capillary bristles. - Perennial herbs; with mostly simple stems from creeping rootstocks, bearing solitary or few usually long-peduncled and rather large heads of yellow flowers; the leaves opposite (!) or in one or two Californian species occasionally alternate, simple, entire or merely toothed. 
A genus of few species, of difficult discrimination. One, the officinal Amica montana, is paculiar to Europe ; another, found in high northern regions all round the world, but sparingly in Liurope, extends southwarl along the mountains of the western yart of our continent as far as California; the others are indigenous to similar regions in this country, except that one is conlined to the somewhat Southem Atlantic Stutes.

* Rudical and lower cauline lecres cordate or truncate at base and long-petioled.

- Some or most of the leaves alternate: heads several in a nakerl panicle, rayless.

1. A. parviflora, Gray. A foot or so in height: leaves mainly at or near the base of the slender stem, deltoid-lanceolate or ovate-lanceolate, seldom cordate at base, unequally dentate; the upper ones small; all petioled and commonly alternate: heads small (only half an inch long): akenes not pubescent but minutely glandular. - Proc. Am. Acad. vii. 363.

Chaparral, Humboldt Co., Bolander. Leaves an inch or two long, on petioles of at least equal length.

2. A. discoidea, Benth. About two feet high, stouter and more hairy : leaves ovate or oblong, coarsely and irregularly dentate, either cordate or truncate or rarely somewhat cuneate at base; the upper small and sessile, often alternate: heads 7 to 9 lines long: involucre villous and glandular: akenes sparsely pubescent, beconning glabrate, not glandular. - Pl. Hartw. 319.

In woods, not rare from Monterey northward. Lower leaves 2 or 3 inches long, on petioles of equal length.

\section{+ + Leaves all opposite: heads solitary or fere, usually with long rays.}

3. A. cordifolia, Hook. A foot or two (or in alpine forms a span or so) high, sparsely unure or less hairy: lower leaves ovate or roundish and deeply corclate, mostly coarsely toothed, commonly only 2 pairs on the stem; the upper pair sessile or nearly so, small, and often narrowed at base: head an inch long : akenes hirsute: rays usually about 12 and an inch long, rarely wanting.

Sierra Nevada, near Sierma Valley (Lenmon) and Carson (Andcrson); thence enst to the Rocky Mountains and northward tbrough Oregon. Mt. Hamilton in the Contra Costa Range, Brewcr: a rayless form ; the same collected also in Sierra Valley by Lenmon, along with an ordinary form.

* * Radical leaves rounded or somewhat cordate at base and slender-petioled; the cauline mostly closely sessile by a broad base.

4. A. latifolia, Bongard. A foot or so high, sparsely pubescent or almost glabrous, benving solitary or fow heads: cauline leaves 2 to 4 pairs, ovate or deltoidovate, sharply and usually coarsely serrate, all alike, or the uppermost smaller and narrower : head half to three fourths of an inch long: akenes slightly pubescent or at length glabrons. - A. Menziesii, Huok. Fl. t. 111.

Sierra Nevaln, from Novada Co. (Lemmon, Grecnc); thence north through Oregon to Alaska, and east to the locky Mountains.

* * Rarlical and lower cauline leaves never cordate or truncate at base, but nften tupering into petioles, the lowermost pairs of petioles commonly sheathing at base.

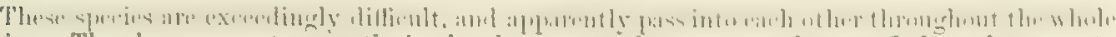
series. Tho akenes vary too greatly in tho character and amount or absenee of the pulnescence to furnish distimetions.

5. A. mollis, IIook. A foot or two high, somewhat hairy with either soft or alightly hash pubescence, leafy to the top, bearing solitary or 3 rather largo brond heads : leaves thin, oblong or the upper and closely sessile ones ovate-lanceolate with a broal base, mostly serrate or denticulate: rays pretty large, deep yellow : pappus 30 densely and strongly barbellate as to be aluost plumose.

Yosenite Valley or near it, and nenr Mount Dana (Brerer): north to Britisls Columbin ant eastward to Lake Superior, the White Mountuins of Now Hampshire, sec. Leaves 3 to 5 iuches 
long, an inch or so wide; the cauline 2 to 4 pairs. Peduncles 2 or 3 inches long. An ambiguous and reduced alpine form in the high ranges east of the Yosemite Valley, Brewer.

6. A. Chamissonis, Less. Differs from the last in its narrower (commonly oblong-lanceolate) acuminate or acute leaves, all but the uppermost with tapering base, the cauline 4 or 5 pairs; and the pappus barbellate with fine and rather sparse denticulations as in noost of the species. - DC. Prodr. vi. 317.

On the Truckee Rirer in Nevada (according to Bot. King Exp.), therefore doubtless also in California, as it is a species of wooded districts: thence northward to Alaska, \&c. The plants of the Rocky Mountains, se., referred to this in the Flora of North America, and later, mainly belong to the next.

7. A. foliosa, Nutt. A foot or two high, commonly strict, from running rootstocks, tomentose-pubescent, leafy to the top, bearing 3 to 7 corymbose rather small and shortish-peduncled heads: leaves lanceolate, mostly callous-denticulate, and with about 5 parallel nerves or ribs: rays rather short, usually pale yellow. Nutt. in Trans. Am. Phil. Soc. n. ser. vii. 407, excl. var. nana. A. Chamissonis, Torr. \& Gray, FI, in part. A. montana, Hook., in part.

Var. incana, Gray. White with floccose dense wool, which is deciduous with age.

Wet meadows, in the Sierra Nevada, from Kern Co. (Rothrock) to Oregon ; extending eastward to the Rocky Mountains and Saskatchewan. In California more commonly the var. incence Lake Tahoe (Brewer): Lake Washoe (Torrey): Sierra Valley, "in deep water," Bolander. Leaves from 2 or 3 to 5 or 6 inches long, from 4 lines to an inch in width, mostly obtuse ; the upper closely sessile, the lower with tapering bases or petioles elasping at the insertion. Involucre half an inch high, somewhat viscid-glandular under the deciduons pubescence, as is the herbage generally, not at all hirsute or hispir. Rays 4 or 5 lines long. Akenes minutely hairy or glandular, or nearly glabrous. The white-woolly form is very striking; but it passes insensibly into Nuttall's A. foliosa; of which A. longifotia, Eaton in Bot. King Exp., may be also a form.

8. A. alpina, Murr., Lestad. A span to a foot and a half high, more or less hirsute-pubescent, bearing solitary or sometimes 3 long-peduncled mostly large heads: leaves entire or sparingly denticulate; the cauline in one to 3 pairs, lanceolate or linear-lanceolate, the upper ones small; radical ones spatulate, oblong, or oval, about 3-nerved: rays large, deep yellow. - A. angustifolia, Vahl in FI. Dan. t. 1524 ; Torr. \& Gray, 1. c. A. fulgens \& A. plantaginea, Pursh.

In the Sierra Nevada (in meadows of Sierra Valley, Lemmon, \&c.) ; thence northward through Oregon to the Arctic regions, and east to the Rocky Mountains and plains of the Missouri ; also Greenland and high northern Eurne and Asia. "Exceedingly variable. The Californian specimens are large and rather broad-leaved forms. Rays three quarters of an inch long. $A$. alpina is the more appropriate name, and is conceded to be the older; but we cannot find it in "Murr. Syst. Veg. 1774," as cited by Fries.

103. RAILLARDELLA, Gray.

Head several-many-flowered, homogamous; the flowers all fertile. Involucre cylindraceous, naked at base; the scales 7 to 14 in a single series, linear, equal, lightly united into a tube or cup to or above the middle. Receptacle flat or barely convex, naked. Corollas like those of the disk in Arnica. Style-branches elongated, hirsute, and produced beyond the long stigmatic lines into an acuminate tip. Akenes linear, flattish, striate-nerved, hirsute. Pappus a single series of (20 to 25) rather stout and rigid strongly ciliate-plumose bristles, about the length of the corolla, bright white. - Acaulescent herbs (of the Sierra Nevada); with stout creeping rootstocks, bearing tufts of linear or oblancenlate entire radical leaves, and a simple naked viscid-glandular scape, terminated by a rather large head of yellow flowers. Benth. \& Hook. Gen. Pl. ii. 442. Raillardia, Sect. Raillardella, Gray, Proc. Am. Acad. vi. 550.

This interesting genus, along with the Hawailan Raillardia, seems rather to belong to the Helenioidece, next to Dubautia; but the technical characters would cause it to be looked for here, 
where Bentham has placel these genera, although the bristles of the nappus are somewhat too stout and flattish.

1. R. scaposa, firly. thmewhat hirsute as well as flumelular : seape a span to a foot high, sometines with a leaf or two towards the base : involucre 20 - 30-flowered (an inch or less long).

Sierra Nevada, in the Fosemite and Mono districts, at the elevation of 8,000 to 10,000 feet, Brewer, Bolender, Gray.

2. R. argentea, Gray. Leaves shorter, only one or two inches long, silverysilky: scape one to four inches high: involucre narrower, 7 -15-flowered (half an inch or more long).

Higher Sierra Nevada, at 8,000 to 11,000 feet; Mnunt Dana to Sonora Pass (Brever, Bolander), above Donner Lake ( $\boldsymbol{E}$. L. Greenc), and on Lassen's Peak, Lemmon.

\section{Tribe IX. CYNARODEE.}

The only Californian representatives of the tribe are Thistles, of well-known appearance, and a Centaurea or two, of the Mediterranean region, sparingly naturalizel in ficlds and arnund harbors. Even Burdocks are unknown.

Cxxard Scolymes, Linn., the Artichohe of the Old World, - remurkable for the thick fleshiness of the receptacle and scales of the involucre, which are edible, - is occasionally spontaneous, probably eseaped from cultivation.

\section{CNICUS, Linn. "ThistuE.}

Heal many-flowered; the flowers all perfect and fertile, with tubular corollas deeply (often more or less unequally) 5-cleft into narrow lobes. Involucre globular, ovoid, or at maturity sometimes campanulate; the mostly narrow scales imbricated in many series, more commonly tipped with a spine or cuspidate point. Receptacle flat, fleshy, densely clothed with bristles. Filaments commonly papillosehairy, distinct : anthers sagittate at base, the auricles frequently extended into tails. Style filiform, sometimes thickened or with a pubeseent ring or nodle at the base of the minutely puberulent stigmatic portion; which in our species is almost always slender, consisting of two filiform branches which are more or less firmly united by their inner faces up uearly or quito to the tip. Akenes glabrous and smooth, thickwalled, obovate or oblong, moro or less compressed, attached by their very buse. Pappus of copious and rather rigid long and plumose bristles in a single series, connected at the very base into a ring, so that they remain united after letaching. Not rarely the bristles of some of the outermost flowers are slightly or not at all plumose. - Stout herbs, more commnnly biennials, with alternato and usually prickly leaves, and largo or middle-sized heads; the flowers purple, red, pale yellow, or white. - Benth. \& Hook. Gen. Pl. ï. 468; Gray, Proc. Am. Acad. x. 39. Cirsium, Tunru, DC. P'roulr., dic.

A large genns, willely dispersel over the northern hemisphere, most numernus in the Ohl World. It seems necessury to follow Br.nthan in resturing the Linnsenn mane of C'nieus, inchul-

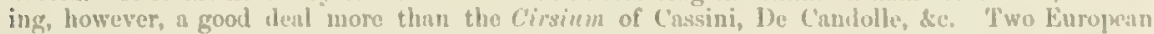
speries, which are commou and troublesome in the Atlantic Stites, seen not to have readieat Californin, viz. -

C. LAsCEnlates, the common Finh Thistle, which is well narkel by the leaves being decurrent on the stem, and their upuner surfate very harsh or almost prickly.

C. Anvissis, the Camaln Thistle (hut not indigenous to Cannda), witl numerous small heads which imcline to be diexeious. 
\$ 1. Scales of the involucre appressed and closely imbricated (except in the last species); the outer scales successively shorter, not appendaged nor margined, tipped with a mostly spreading prickle or point; the innermost rarely with a small scarious tip.

* Low species, with simple stem and green or greenish leaves, at least when old, although more or less cobwebby when young: heads proportionally large: anther-tips sharp-pointed.

1. C. Drummondii, var. acaulescens, Gray, 1. c. The larcer forms of the species (which occur in the Rocky Mountains; and from Oregon to Saskatchewan and the Arctic region) have a stem from a span to a foot or even 3 or 4 feet high, and large heads: the variety, which reaches California, has the more or less smaller heads sessile or almost so in the centre of the tuft of radical leaves; these lightly woolly when young, at least beneath, lanceolate, not deeply pinnatifid, with short and broad-margined petiole: scales of the involuere thin and proportionally large; the outer ovate-lanceolate passing into lanceolate, tapering into a weak and short or slender prickle: corollas mostly reddish purple; the lobes shorter than the throat. - Cirsium acaule, var. Americanum, Gray in Proc. Acad. Philad. 1863.

Open ground along the Sierra Nevada, chiefly ou the eastern side. Corollas an inch or more in length. The heads when several in a close cluster are smaller and narrower, when single occasionally 2 inches long.

2. C. quercetorum, Gray. Lightly woolly when young, and somewhat hairy: stem a foot or less high, occasionally branching, leafy: leaves rather rigid, pinnately or sometimes even almost bipinnately parted, more prickly: heads large and broad (about two inches high): scales of the involucre very numerous, closely appressed, all but the inner ones firm-coriaceous, from oblong-ovate to lanceolate, and rather abruptly tipped with a short rigid cusp or prickle: corollas apparently purple, four of the lobes much higher united, the other longer than the throat. - Proc. Am. Acad. x. 40 .

Hills at Oakland and elsewhere near San Francisco, Bolander, Kellogg. In Bolander's specimens the heads are naked-peduncled; the outer scales very rigid, with thinnish and erose-ciliolate margins, the outermost very short and almost ovate, all merely mucrouate or cuspidate-tipped. Dr. Kellogg's specimens, probably from less exposed ground, have less rigid foliage, and involucrescales more like those of $C$. Drummondii, less abruptly tipped with a short rigid prickle.

* $*$ Taller species, with permanently and densely white-woolly leaves, at least underneath, sometimes becoming green and naked above.

+ Involucre globular, of firm or thick-coriaceous closely appressed scales, tipped with an abrupt spreading prickle: flowers purple, sometimes cream-color or white.

3. C. Breweri, Gray, 1. c. Tall (4 to 10 feet high), branching, white-woolly: leaves elongated and pinnatifid: heads numerous and panicled, rather small (an inch or less long) : involucre at first cobwebby; the outer scales short and broadish, the back marked with a greenish or purplish thickened and somewhat glutinous or glandular spot at the blunt tip, which bears a weak prickle: lobes of the corolla shorter than the throat: anther-tips almost obtuse.

In a canon near San Juan, Monterey Co. (Brewer) : and in swamps and moist grounds of Strawberry Valley near Mt. Shasta (Brewer), also in Mendocino and Humboldt Counties (Bolan. der, Kellogg and Harford): near Carson City, Nevada, Anderson. The tall growth and the deltoid almost blunt tip to the anther-appendages mark this species.

4. C. undulatus, Gray, 1. c. Rather low (a foot or two high), white-woolly: leaves rarely becoming naked above: heads solitary or few (from 1 to 2 inches long): involucre nearly as in the last or sooner naked, with or without the viscid or greenish spot or elevated line at the tip: lobes of the corolla as long as the throat: anther-tips very sharp-pointed. - Cirsium undulatum (Spreng.), C. Douglasii (DC.), and C. Brevifolium, Nutt. 
Var. ochrocentrus, Gray. Leaves deeply pinnatifid and exceelingly armerl with slender yellowish prickles: scales of the involuere broaler and Hatter, dest it ute of glutinous spot or ridge, and armed with a long and rigid prickle. - Cirsium ochrocentrum, Gray, Pl. Fendl. 110.

Open grounds, from the upper Mississippi and from Texas to the coast of Oregon, from which the ordinary form probably extends into the northern part of California. Var. ochrocculvess, a

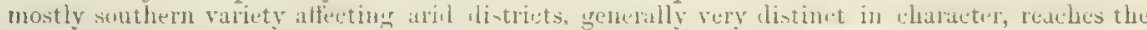

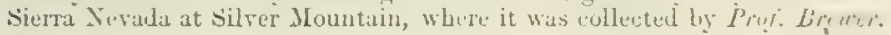

$+\div$ Invalucre narrower, becoming campanulate or cylindraceons; its scales fewer and less closely imbricated, thinner and chartaceuss, gradually longer, more tapering into the mickle or prickly point: flowers carmine or purple-red: anther-tips mertly acute.

5. C. Arizonicus, Gray, l. c. White-woully, leafy to the to 1,2 to + feet high, branching and bearing several short-peduncled or sessile heads : leaves lanceolate, pectinately toothed or pinnatifid, slender-spiny : outer scales of the involucre ovateoblong, the next lanceolate and rather abruptly narrowed into a prickly-tipped armmination: lobes of the corolla fully twice the length of the throat : stirnuatic tip of the style short.

Common in Arizona and S. Utah; most likely inhabiting the southeastern borders of our State. Heads $1 \frac{1}{2}$ to 2 inches long, apparently oblong or cylindraceous before expansion, the involucre becoming campanulate. "Flowers bright carmine" or "bright red-purple." Filaments spar-

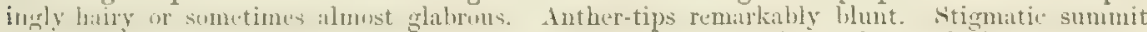
of the style only half a line or in age a line long abovo the manifest node, much shorter than in any other of our indigenous North American species.

6. C. Andersonii, Gray, 1. c. Slender, 2 or 3 feet high, sparsely leaved, the white wool rather cobwebby and deciduous: leaves mostly pinnatifid and muder-

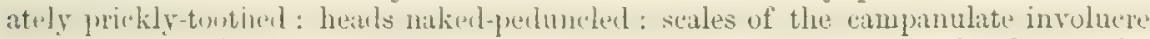
less unequal and in fewer series than in any of the foregoing, somewhat loose; the

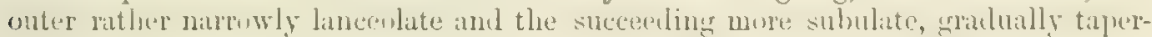
ing into a short prickly point; the innermost very long and slender: lobes of the corolla not longer than the throat.

Sierra Nevada, from Tulare Co, to Carson City and Donner Lake, Anderson, Torrey, Bo. lander. Head 2 inches long. Flowers erimsun-red. Tips of the appendages of the anthers trian gular, either acute or acutish. Stigmatic tip to the style filiform and moderately elongated; node obsolete.

\$2. Scules of the involucre of almost equal or moderately unequal length, all but the innermost tapering gradually into a long marginless and mostly greenish and spreading or ascending usuelly spiny-tipped acumination.

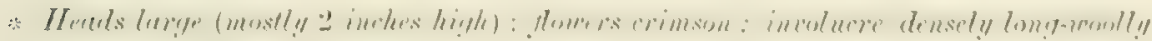
when young; the scales tapering graduully from a short coriaceous appressed base into long and slender but rigid spreading spinescent tips.

7. C. occidentalis, Gray, 1 c. Very white with long and dense wool, 2 to 5

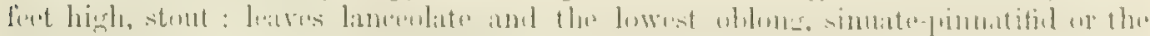
upper merely tootherl, rather weak-prickly, the upper surface often becoming naked with age: involucre globose; its scales with very long and slender rigil mostly subulate or almost needle-shaped and merely prickly-pointed tips, the lowermost usually wilely spreading: corollas brisht erimson or purple-red, veczularly 5-eleft ; the lobes one aud a half to twice the length of the throat : tips of the anther-appendages triangular-acuminate. - Carduns occidentalis, Nutt. l. c., with erronenus character. Cirsium Coulteri, Gray, Pl. Wright. ii. 110 ; Liton in Bot. King Exp. 195.

Open grounds, not rare apprently throughout the State, and within the horlers of Nevuln. A striking species, with its white cottony wool, and large and broul hemb of brigh: red flowers.

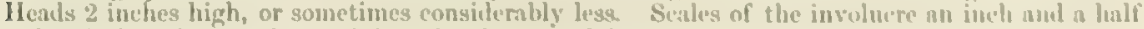
or less in length, mostly retaining the dense and long cobwobby wool. Flowers an inch and a 
half long in the larger heads. Stigmatic tip of the style naked and rather short. This proves to be Nuttall's Cardures occidentalis, and this specific name may well be used in the changes of nomenclature rendered necessary by the adoption of the generic name Cnicus. As in several species of the genus, some of the outermost pappus wants the plumes, but in the rest it is as conspicuous and the bristles as stout and numerous as in most Thistles.

* Heads smaller (not over an inch and a half high): flowers white, crean-color, or in one species purple: herbage and involucre less densely white-woolly, or naked with age.

+ Scales of the involucre rather rigid, with broadish appressed coriaceous base, tapering into pungently spiny-pointed tips; the outer somewhat shorter and spreading.

8. C. Andrewsii, Gray, 1. c. At length green, the thin and loose cobwebby wool being deciduous, apparently tall and paniculately branched: cauline leaves lanceolate and laciniate-pinnatifid : involucre very cobwebby: lobes of the equallycleft (apparently white or whitish) corolla about twice the length of the throat: anther-tips triangular-acute.

Founded on a single specimen, collected by $D r$. Andrews, probably not far from San Francisco or Sacramento; differing from the following in the length of the corolla-lobes ( 3 or 4 lines) compared with the throat (1 $\frac{1}{2}$ to 2 lines); the whole corolla hardly an inch long.

9. C. Californicus, Gray, 1. e. Rather loosely white-woolly, at least when young, 2 to 5 feet high: leaves either sinuately or deeply pinnatifid: involucre more or less cobwebby, or at length almost naked: lobes of the white or creamcolored corolla shorter (the four more united often much shorter) than the throat. - Cirsium Californicum, Gray in Pacif. R. Rep. iv. 112.

Dry open ground, from the Stanislaus River (Bigelow) to Santa Clara Co. (Brewer), and near San Diego (Cooper, Cleveland) : apparently in other parts of the State and the borders of Nevada, in varying forms.

\section{$+\div$ Scales of the involucre thinner and less rigid, looser and more slender from the} base; the outer only weakly prickly-pointed.

10. C. edulis, Gray, 1. c. Loosely cobwebby when young, soon green : stem 3 to 8 feet high, rather succulent and tender, leafy to the top, bearing rather few more or less panicled or clustered heads: leaves thin, mostly only sinuate-pinnatifid and obtuse: involucre very cobwebby when young, mostly innocuous : corolla purple (perhaps sometimes whitish), slender, equally or somewhat unequally 5-cleft; the lobes becoming nearly filiform with a thickened tip, considerably shorter than the throat. - Cirsium edule, Nutt. 1. c.

Wet or shady places, especially in Redwoods, from San Francisco Bay northward through Oregon to British Columbia. The stems, stripped of bark and leaves, are said to be eaten raw by the Oregon Indians; whence the name of the species.

11. C. remotifolius, Gray, 1. c. Tall (3 to 8 feet high), sparsely-leaved, especially towards the naked panicle, scarcely or lightly woolly, except the under side of the leaves, which also is commonly white but sometimes naked with age: leaves mostly pinnately parted into lanceolate or linear prickly-tipped and spinuloseedged divisions: involucre lightly cobwebby when young, at length nearly naked; its scales all slender and thinnish, linear-attenuate and mostly equal in length, loosely ascending, slightly and weakly prickly-pointed: corolla yellowish-white; three or four of the lobes united higher up, shorter than the throat. - Carduus remotifolius, Hook. Cirsium remotifolium, DC. C. stenolepidum, Nutt. 1. c.

Low grounds along streams, in Oregon, and south to Humboldt Co., California, Kellogg and Harford. A well-marked species, although the name is not always appropriate.

\$3. Scales of the globular involucre, or most of them, with a dilated and exosely lacerate or cut-fringed scarious appendage. (Echinais, Cass., DC.)

12. C. carlinoides, Schrank, var. Americanus, Gray. A foot or two high, branching: leaves sinuately or sometimes deeply pinnatifid, more or less prickly, 


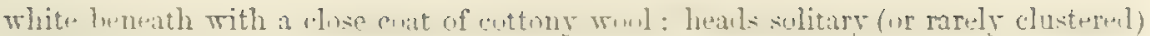
at the summit of the branches, at tirst nodding (about an inch high): scales of the involuce nearly glabrous (or slightly woolly when young, but wholly destitute of

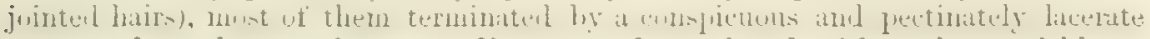
ovate or lanceolate scarious spreading appendage, tipped with a short prickle or

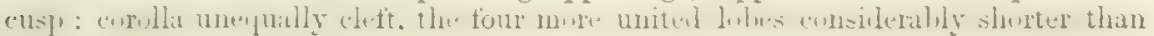
the throat: anther-tails laciniate. $-C$. scariosum, Nutt. 1. c.

Marin and Mendocino Counties, Samucls, Bolander, Kellogg, de. Also in the Rocky Mountains of Colorado. Apparently not distinct from the Caucasian aml Siberian C. carlinoides, Schrank, Ilort. Slonac. t. 11 (Echinais carlinoides \& E. nutans, ('ass., DC. Hort. Genev. t. 22), although the outer scales of the involucre are not spinosely fringed, nor so prickly-pointed, and sometimes are not at all appendaged. If distinct, Nuttall's name of scariosis could be used. His description seems best to accord with Hall and Harbour's No. 559, which looks very much like a hybrid between $C$. carlinoides and $C$. remolifolius.

C. Parrit, Gray, l. c., of the Colorado Rocky Mountains, is another species of this section verging to the preceding.

\section{SILYBUM, Gærta. Mrzk-Tuistle.}

Ifend many-floweret, with leafy-loractul spinuse inwluere; the flumers all perfect and fertile. Filaments smooth and monadelphous. Pappus of stitf and almost

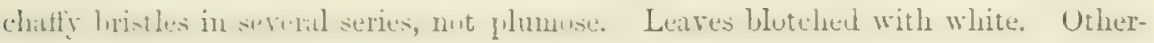
wise as in common Thistles.

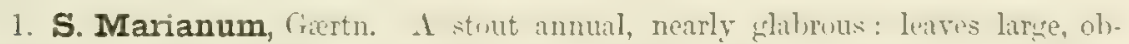

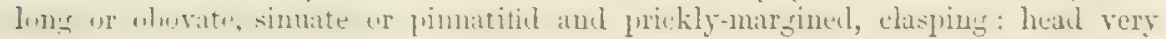
large, solitary: flowers pink-purple or red.

San Luis Obispo, on rocky hills, and probably elsewhere : a native of the Mediterranean region, introduced, probably through cultivation.

\section{CENTAUREA, Linn. Star-Tuistle.}

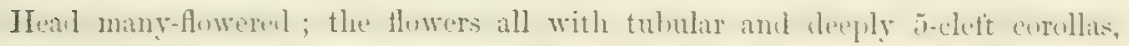

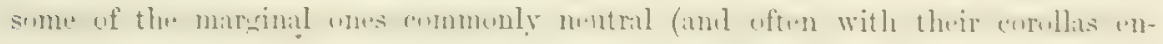
larged); the others perfect and fertile. Involucre globular; the scales tipped or margined with spines or a scariuus appendage. Tieceptacle very bristly. Akenes

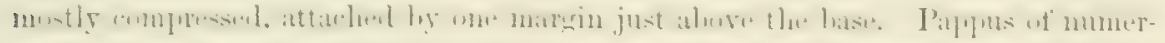

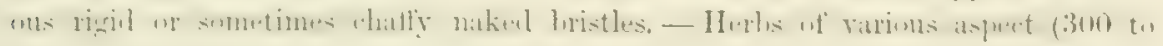
400 species), nearly all of the Old World, whence two have reached California as weeds of cultivation; both species destitute of the "false-rays," i. e. their marginal noutral flowers not enlarged and conspicuous.

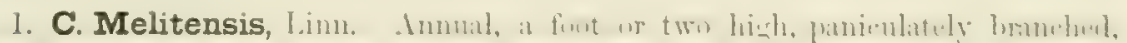

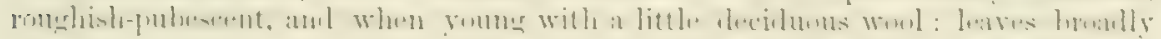
linear; the radical pinnatifid; cauline barely toother or entire, decurrent: heads rather small: most of the scales of the involuere tipped with a spine which is fringed at base with a few prickles: corollas yellow, not enlarged.

olil fielis sul waste grounds; common on the western borders of the State: introduced from Southera kurope.

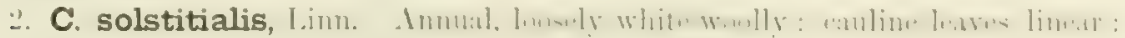
heads larger than in the foregoing: outer scales of the involucre with 3 to 5 palmate small prickles at the tip; the midllle ones with a long and stout spine in aldition: corullins more conspicuous, yellow.

Fields, Oaklaml (Bolander), San Diego (Palmer), and probubly elsewliere nen the const: " weed of cultivation ; introducel from Southern Europe. 


\section{TrIBE X. MUTISIACE. E.}

These are Bilabiatiflora, i. e. have their corollas bilabiate, one lip mostly 3 toothed, the other 2-lobed or cleft, the lobes or lips revolute. As the flowers are more commonly all perfect, and the style similar, they may be confounded with the Thistle-tribe, in which the corolla is often more or less two-lipped or irregular. But the lobes of the latter become revolute in the present tribe, and the receptacle is never clothed with a coat of bristles. - The tribe is most largely represented in South America; only one genus reaches California.

\section{PEREZIA, Lagasca.}

Head several-many-flowered; the flowers all perfect. Involncre turbinate or campanulate; its scales imbricated, lanceolate or oblong, mostly chartaceous. Receptacle flat and naked. Corolla with slender tube and bilabiate limb; the outer lip mostly longer and 3-toothed; the inner 2-toothed or 2-cleft. Anthers with long naked tails at base, and a lanceolate terminal appendage. Akenes elongated-oblong, terete or slightly angled, often obscurely narrowed at apex, commonly glandular. Pappus of copious scabrous capillary bristles. - Herbs; with alternate and mostly rigid leaves, and solitary or usually paniculate heads of purple or white flowers. Gray, Pl. Fendl. \& Pl. Wright, ; Benth. \& Hook. Gen. Pl. ii. 500.

A genus of 40 or 50 species, South American and Mexican, and a few within the borders of the United States.

1. P. microcephala, Gray, 1. c. Two or three feet high, branched and glandular-puberulent above, leafy to the top: leaves thin, oblong and the upper ovate, all cordate-clasping, with the sinus shallow, minutely glandular-scabrous, coarsely reticulate-veiny, closely spinulose-denticulate: heads copions, corymbose at the summit of the paniculate branches: scales of the involucre all abruptly very acute, puberulent-glandular; the innermost a little shorter than the 10 to 15 rose-purple flowers. - Acourtia mierocephala, DC. Prodr. vii. 66.

Near Monterey (Douglas), Santa Barbara (Torrey), and San Diego Co., D. Cleveland, Palmer. Involucre 3 or 4 or at length 5 lines high: pappus at maturity half au inch long. In the specimens of Douglas, described by De Candolle, the flowers are immature.

2. P. Arizonica, Gray. A foot or two high, almost glabrous: leaves more deeply cordately or sagittately clasping: heads fewer and rather smaller, in cymose corymbs: scales of the involucre obtuse, pubescent on the enges, otherwise glabrous and not glandular; the innermost only half the length of the 8 to 12 white or flesh-colored flowers, - $P$. microcephala, Gray in coll. Parry, No. 141, Am. Nat. ix. 273.

Arizona, Dr. Palmer. S. Jtah, Dr. Parry. Probably also No. 293 of California collection, Coulter. "Palmer's plant is said to exhale "an agreeable aroma."

\section{TRIBE XI. CICHORIACE E:}

Completely marked by the ligulate and perfect flowers throughout the head: the ligules almost always 5-toothed at the apex. Herbs, with a bitter milky juice.

Lettuce, Endive (a variety of the Cichory), and Salsify (Tragopogon porrifolizes, which is apt to run wild around cultivated grounds), are the common cultivated esculent plants of the tribe, all of the Old World. The tribe consists of 50 or 60 genera, even as consolidated by Bentham in the new Genera Plantarum, and is failly well represented in California. It is so strictly natural that it is difficult to divide it into well-limited natural subtribes or into genera. 
108. PHALACROSERIS, Gray.

Hearl mather many-fowered. Involuce campraulite, of 12 to 16 eyual lanceolate and somewhat herbaceous scales, in one or two scries, their barely united bases hecoming somewhit dilated and concare in fruit, occisimally a luose and linear subtending bractlet. Receptacle convex, naked. Ligules linear, rather short. Akenes short-ublon: becoming slightly incurvel, ohscurely 4 -.j-angled or nerverl, truncate at both ends, snooth and even, destitute of pappus. - A single species.

1. P. Bolanderi, Gray. Perennial, habons: leaves linear-lancentate or ollancenlate, entire, in a tuft from the slurt and thickish dirk-culored routsturk: scapes perfectly simple amd naked, a span to a fint hish: Huwers oratue-relluw. - I'ruse. Am. Acad. vii. 364; Benth. \& Hook. Gen. Pl. ii. 507.

Wet mearlows (Westfall's, \&c.) of the Sierra Nevada, alt. 7,000 to 8,000 feet, south of the Yosemite Valley, Bolander, Torrey, A. Gray. Head not nodding before expansion; involuere barely half an inch high. Flowers open in sunshine.

\section{MICROSERIS, Don.}

Head several-many-flowered. Involucre cylindraceous or campanulate; the

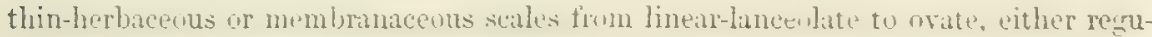
larly imbricated or mainly in a domble series, the unter short and calyoulate. Feceptacle flat, naked. Corollas mostly with a hairy tube. Akenes terete or rarely somewhat angled, 8-10- (sometimes 12-14-) ribbed, truncate at the apex, oceasionally narrowent ahove into at sort of neck or beak, furnished with a hatsal callosity which is more or less hollowed at the insertion; the outermost frequently pubescent. Pappus of few or several (mostly $5^{\circ}$ to 10 , sometimes 12 to 24) awn-bearing, chaffy scales, or slender awns or bristles with more or less paleaceous dilated base, either naked or sometimes plumose, rarely by ahortion wanting. - Annuals, bien-

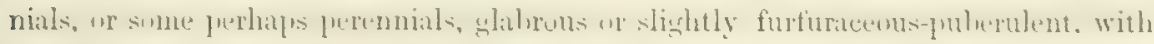

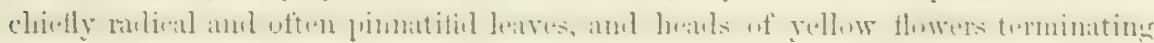

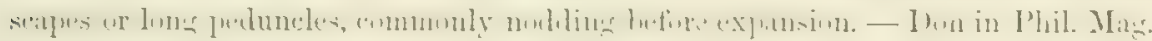
xi. 388 (1832); Gray, Proc. Am. Acad. ix. 207. Bellardia, Colla (1835). Lepi-

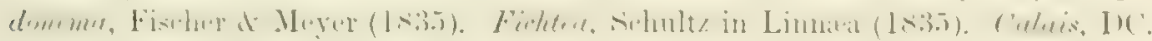
(1838); Groy in Pacif. R. Rep. iv. 121. Phyllopappus, Walp. in Linutea (1840). Uropappus \& Scorzonelle, Nutt. (18t0). Mirroseris \& Scorzonella, Benth. \& Hook. Gen. Pl. ii. 506, 533.

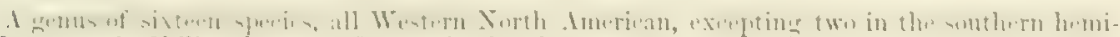
sphere (one in Chili and one in $\mathbb{N}$ ew Zcaland and Australia). De Candolle's name of Calcis, under which our species have become familiar, has to give way to the much older and less happily chosen one of Micraseris, to include also Scorronella, contrary to Mr. Benthau's opinion. The hollowed callus at the insertion of the akene is about the same in all, and the imbrication of the involucre passes by degrees into the simpler calyculate mode. The fusiform roots of the so-called perennial syecies seem to be only bienninl.

\$1. Pappus plumose and white: akenes slender, terete, not ultenuate either tourds apex or base: stems more or less branching, from a fusiform (probably bienniul) simple or fascicled root. - PTILOpHom, Gray.

1. M. nutans, Gray. Slender, a foot or so high, mostly at length loosely branched: leaves entire or laciniate-pinuatifiel into lincar lubes, varying from filiform-linear to spatulate, or the rulical even oval: hends $8-20$-tlowered, on slender peduncles: involuere cylimlraceons, of 8 to 10 linear-lanceolate griulually acumiuate principal scales and a few short and loose calyulate unes: papprus of 12 to 20 
oblong small scales tipped with a several times. longer white and soft plumose awn. - Gray in Proc. Am. Acad. ix. 208. Scorzonella nutans (Geyer), Hook. in Lond. Jour. Bot. vi. 253. Ptilophora nutans, Gray, Pl. Fendl. 113. Calais (Ptilophora) nutans, Gray in Pacif. R. Rep. iv. 112. Stephanomeria intermedia, Kellogg in Proc. Calif. Acad. v. 39.

Low or moist grounds, throughout the Sierra Nevada, from Mariposa Co. north to Washington Territory and thence east to Montana. Heads in flower half an inch high, narrow; the goldenyellow flowers open through the day. Akenes 3 lines and pappus about 4 lines long. The root is said to be eaten raw by the Indians.

2. M. major, var. laciniata, Gray, 1. c. Mostly stouter and more branched from the base, and the leaves in this variety generally pinnately parted into slender linear divisions: involucre of lanceolate and more acuminate scales, which are imbricated in three lengths, the outermost shortest: bristles of the pappus not quite so plumose as in M. nutans. - Calais (Ptilophora) major, var. laciniata, Gray, Pl. Fendl. 113. C. gracililoba, Kellogg, l. c. 48.

Long Valley, Mendocino Co. (Kellogg), and Idaho, on Clear Water, spalding.

\$2. Pappus of 5 to 10 very long-awned scales, either almost plumose or naked: akenes not attenuate towards the apex and hardly towards the base: involucre regularly imbricated, the outer scales gradually shorter: stems simple or mostly branching: root fusiform and probably biennial. - Sconzonella, Gray. (Scorzonella, Nutt., Benth. Calais § Scorzonella, Gray.)

* Akenes slender, as in the first section: awns or bristles of the pappus barbellate or almost plumose, rusty-colored.

3. M. sylvatica, Gray, 1. c. Stem a foot or so high, rather stout, commonly simple and scape-like, rarely leafy to the middle: leaves laciniate-pinnatifid or toothed: head many-flowered: involucre carnpanulate; the scales all acuminate, the outer from an ovate or ovate-lanceolate base: ligules rather long: scales of the pappus 6 to 10 (mostly 10), oblong-lanceolate, considerably shorter than the slender awn. - Scorzonella sylvatica, Benth. Pl. Hartw. 320. Calais (Anacalais) sylvatica, Gray in Pacif. R. Rep. iv. 113.

Var. Stillmani, Gray, 1. c. Differs in the narrower scales of the involucre, which are lanceolate and gradually tapering from the base, and the awns of the pappus (sometimes at least) less strongly barbellate.

In woods or low grounds, on the Sacramento and its tributaries, Hartweg, Bigelow, \&c. The var. collected by Stillman, Samuels, and on Mark West (reek by Bigelow. Peduncle or scape 6 to 12 inches long. Head an inch high. Akenes (seen in the mature state only in the variety) 3 lines long, glabrous or minutely scabrous.

* Akenes mostly shorter (terete, or in one species sometimes more or less 4-5-angled): awns of the pappus only denticulate or scabrous.

+ Scales of the involucre all long-acuminate: pappus of 8 or 10 short and small entire scales tipped with a very long capillary awn: stems more or less branching and leafy below: ligules elongated.

4. M. laciniata, Gray, 1. c. A foot or two high, commonly stont: leaves from narrowly to very broadly lanceolate in outline ( 4 to 16 inches long), commonly laciniate-pinnatifid and the lobes long and slender : heads large: scales of the involucre all broad, the outer ovate and abruptly acuminate: scales of the pappus ovate or ovate-lanceolate, only a third or fourth the length of the (sometimes prismatic) akene. - Hymenonema? laciniatum, Hook. Fl. i. 301. Scorzonella laciniata, Nutt. in Trans. Am. Phil. Soc. n. ser. vii. 426. Calais (Scorzonella) laciniata, Gray in Pacif. R. Rep. 1. c. - Passes into

Var. procera, Gray, 1. c. Stem stonter and more leafy, 2 or 3 feet high: leaves broadly lanceolate or oblong ( 1 to 21 inches wide), merely denticulate, occasionally laciniate: scales of the pappus mostly rather narrower or more tapering into the 
awn, occasionalls almost ohsolete. - IIymenoueme? glaucum, Houk., seems to be a small form of this. Calais glauca, var. procera, Gray, Proc. Am. Acad. vii. 36t.

Along streams, common in Oregon torards the coast: Ukiah (Kellogg) ; with laciniate-pinnatifid leaves, but with nartòwer paypus-scales. The var. procera, on hills, Sonoma Co. to Mendocino Co., \&c. (Bolander, Torrcy, Kcllogg) and to Klamath Co., Oregon, Cronkhile. Peduncles often a foot long. Head three quarters of an inch to an inch long, especially in the variety, which has it broad in proportion, and the outer scales of the involucre from 3 to 5 lines wide. Corollas bright sulphur-yellow. Akenes 2 to nearly $2 \frac{1}{2}$ lines long when mature.

5. M. leptosepala, Gray, 1. c. Mostly more slender than the preceding : leaves similarly either entire or laciniate-pinnatifid: head smaller: scales of the

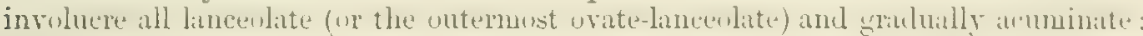
pappus-scales about one tifth of the length of the more slender akene. - Scorzonella leptosepala, Nutt., 1. c. Calais Bolanderi, Gray, Proc. Am. Acad. vii. 365. C. laciniata, Gray, 1. c. viii. 392, coll. Hall, No. 313.

Swamps, Mendocino and Humboldt Counties (Bolander, Kellogg): also in Oregon. Involucre half an inch or more high, narrower than in the last, as well as the seales narrow and more tapering; but the outermost are sometimes rather broad.

++ Scales of the involucre all rather obtuse: pappus of 5 two-cleft scales, with a proportionally shorter awn in the sinus: acaulescent: ligules short.

6. M. Parryi, Gray, l. c. Scapes a span or two high, simple: leaves linearlanceolate, laciniate-pinuatifid or entire: scales of the involucre ovate or oblong, in about 3 series: awns of the pappus rather strongly denticulate, extending to only twice or thrice the length of the 2-cleft scale. - Calais Parryi, Gray in Pacif. $h$. Rep. iv. 122, \& Bot. Mex. Bound. 104.

Near San Diego, Prrry. Head barely half an inch high. Akenes not formed in the specimen. The species was referred to the Calocalais section on account of the pappus; but the involucre refers it to Scorzonella.

\$3. Pappus of 5 (or rarely fewer) scales or awns, not plumose nor barbellate, sordid: akenes tapering more or less from below the trincate apex to the base: involucre of mostly equal principal scales and a few short calyculate ones at base: annuals, acaulescent, with simple scapes and small or mediocre heads. Proper. scales of the involucre lanceolate, and leaves either laciniate-pinnatifid or entire, in all the species. - Evcalars. (Calais \$ Eucalais, DC.)

* Awns of the pappus slender, naked and fragile, and with the scale at base nearly obsolete, sometimes deciduous or wanting.

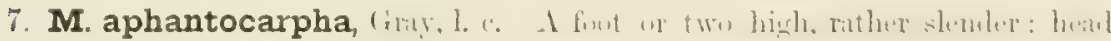
half an inch high, many-flowered: ligules short: capillary awns of the pappus

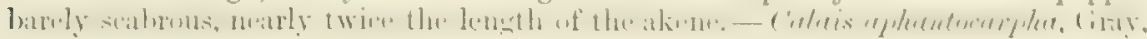
Proc, Am. Acid. vi. 552.

Var. tenella, Gray, L. c. Slender, a span high, with smaller and fewer-flowered heads: akenes inclining to clavate, the summit being nostly a little contracted: awns of tho pappus 2 to 5 , with a distinct chaffy-diliated base, deciduous or very fragile, sometimes apparently wanting. - Calais (Aphanocalcis) tenella, Gmy in Pacif. R. Rep. iv. 114, t. 17 .

llills of the Contm Costr Range near Monte Dinhlo (Brever), and in the sume part of the State, Strmuels. The var. lenella, Napa Valley, in grassy places (Bigulore), and on the Sacramento, Fitch. Akenes scabrous on the strong ribs, tapering towards the base, nud the summit nlso slightly contructed, but with no neek: the outermost pubescent, fully 2 lines long in the lurger form. The variety is most probably only a depauperate form of the larger.

* Scales of the mapmes conspicuous,

+ From obleng-lanceolate to oblong-ovate and acute, mure or less tepering into the aum.

8. M. Bigelovii, Crmy, l. c. Serapes a span to a foot or more high: leaves generilly pinmately parted into uumerous divisions: calyculate seales of tho invo- 
lucre rather numerous and of two lengths: akenes short and not at all narrowed at the summit: scales of the pappus naked or minutely scabrous externally, varying from ovate-lanceolate to oblong-lanceolate, and tapering gradually into a slender longer awn. - Caluis Bigeluzii, Gray in Pacif. R. Rep. iv. 113, t. 17. C. Donglasii, Gray, 1. c. \& Bot. Mex. Bound. 164, not of DC.

Moist places, common especially about the Bay of San Francisco. Head half an inch high.

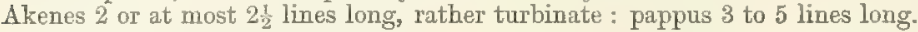

9. M. Douglasii, Gray, 1. c. Between the last and the next: akenes more slender, fusiform, tapering toward the summit almost as much as toward the base: scales of the pappus silky-villous externally, of firmer texture, ovate-oblong and wore or less tapering into a rather stout long awn. - Calais Douglasii, DC. Prodr. vii. 85; Hook. \& Arn. Bot. Beechey, 361.

California, probably near Monterey, Dougtas. As yet known only from his specimens. Akenes 3 to 31 lines long, in shape most like those of the section Calocalais. Pappus including the awn fully 5 lines long; its scales resembling those of the next species in texture, but narrower and acute : the akenes very different from those of the next or of the preceding species. But the plant is too little known.

++ Pappus-scales orbicular or very broadly ovate, and obtuse or retuse at the apex, abruptly awned: akenes thick, slightly or not at all constricted under the broad apex.

10. M. cyclocarpha, Gray, I. c. Like larger forms of M. Bigelovii: awns of the pappus slender, twice or thrice the length of the ample and (in the typical form) mostly glabrous and smooth scales. - Calais cyclocarpha, Gray in Pacif. R. Rep. iv. 115, t. 18.

Var. eriocarpha, Gray, 1. c. Awns of the pappus rather shorter, and its scales conspicuously silky-villous externally. - C. eriocarpha, Gray, Proc. Am. Acad. vi. 552.

Grazsy plains and hillsides, Napa Valley (Bigelow), and Humboldt Co. (Kellogg); the latter showing a few long loose hairs on the back of the pappus-scales, which suggest the union of the Tar. erincerphert: this collected at Xipoma (Brewer) and on Monte Diablo, Blowmer. The larger heads three quarters of an inch high. Akenes $2 \frac{1}{2}$ to 3 lines long; and the pappus-seales sometimes nearly 2 lines in length, slightly erose-denticulate at the broad summit, noore or less invoIute when dry.

11. M. platycarpha, Gray, 1. c. Resembles the preceding: awns of the pappus only about one third of the length of the broad round scale: young akenes not contracted under the stmmit. - Calais platycarpha, Gray, 1. c.

San Luis Rey, on clay hills, Parry. Known only in a single specimen, without full-grown akenes. Seales of the pappus nearly smooth, almost 3 lines long and fully 2 lines broad.

\$ 4. Pappus not plumose, of 5 or rarely more awned chaffy scales: akenes long and slender, fusiform, tapering gradually upvards into a narrow neck or even beak: involucre cylindraceous or campanulate, of lanceolate scales, the few exterior ones unequal and less distinctly calyculate: stem very short, branching and leafy at the base, and sending up simple scape-like peduncles: corollas very short, apparently transiently expanded, at evening or morning (?). Calocalats, Gray. (Calais § Calocalais, DC.)

* Scales of the pappus only 5, lancealate or oblong, abruptly awned from a notch caused by the early splitting of the apex of the scale: leaves linear, mostly narrow, either laciniate-pinnatifid or entire: root annual, slender.

12. M. Lindleyi, Gray, 1. c. A span or two high: pappus rusty-brownish; its scales about the length of the beakless but somewhat contracted akene, scabrouspuberulent extemally, oblong-lanceolate, their midrib continued beyond the (at first shallow) notch into a rather stout scabrous awn of nearly its own length. - Calais Lindleyi, DC., 1. c. 
Apparently not uncommon through the western part of the State, down to San Diego (Cleveland); mixed with the next in collections, and generally confounded with it.

13. M. linearifolia, frity, l. c. A strum or two high, either slemler or the long scape-like peduncle thickening upwards: leaves when young sometimes lightly pubescent or villous-ciliate: pappus bright white ; its scales equalling or shorter than the more or less beaked akene, linear-lanceolate, smooth, bearing a very slender short awn from the deep notch. - Calais linearifolia, DC. 1. c., excl. syn. Uropappus linearifolius \& U. grandiflorus, Nutti. l. c.

Plains and low grounds, common, extending eastward to Nevada and New Nexico. Varying much in size and in the number of flowers in the head: this from half an inch (in depauperate plants) to fully an inch long. Akenes 4 or 5 lines long, slender, some of them merely much tapering upwards, some very distinctly beaked. Delicate awn of the pappus from one fourth to less than half the length of the silvery-white scale.

14. M. macrochata, (iray, l. c. A fut or so high : pappus probululy white: its scales oblong, much shorter than the beaked akene and the very" slender awn which rises from a deep notch. - Calais macrochata, Gray, Pl. Fendl. 112, \& Pacif. R. Rep. iv. 113.

Near San Francisco, Birelow. Known only from Bigelow's immature specimens, and from the original ones collected on the northeastern borders of Oregon by Mr. Spraldiny : also a poor specimen ticketed by Nuttall "Uropappus grandiflorus, San Diego," given by him to Mr. burand.

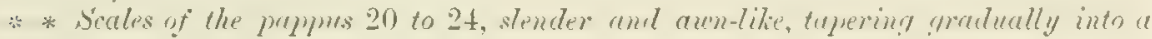
true awn: root apparently perennial, or perhaps biennial.

15. M. troximoides, Gluy. Yearly acaulescent: leaves narruwly linear, entire, thickish: scape about a foot high: pappus white, longer than the akene, which is fusiform, smooth, gradually tapering toward the summit, but not beaked. - Proc. Am. Acad. ix, 211.

California, No. 600 of Kellogg and Harford's distribution: probahly from Humboldt Co. A remarkable plant, between Microseris and Troximon. Also in Idaho (Spalding) and Montana. Heal in fruit an inch long, narrow : corollas not seen. Akenes 4 lines long. Pappus two or more series of awn-shaped seales, a quarter of a line wide at base and to the midule, thence tapering into the merely scabrous rather rigid awn.

\section{STEPHANOMERIA, Nutt.}

Head 3-12-flowered. Involucre cylindrical or rarely campanulate, of a series of linear equal scales and some short calyculate ones at base, rarely with some intermediate ones so as to be more or less imbricate. Receptacle flat, naked (in one anomalous species alveolate). Akenes oblong or short-linear, mostly columnar and

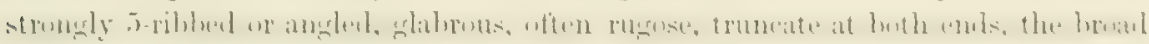
base hollowed at the insertion, the apex mrely somewhat narrowed into a neck.

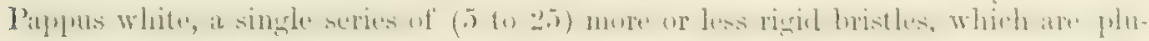

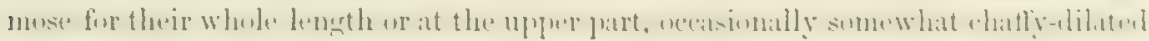

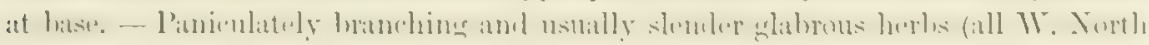
American); with narrow leaves (the upper diminished to scales or bracts), and small herels of pink or flesh-colored flowers, open in the early morning. - Nutt. in Truns. Amor. Phil. Soc. 1. c. ; Benth. \& Hook. Gen. Pl. ii. 533, excl. Rerinesquia.

$\$ 1$. Ileads small: papmes of 5 to 15 rigid bristles with more or less scaledike dilated bnse, or even scale-like throughout, plumuse tounards the summil. -

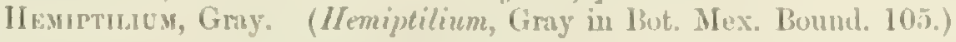

1. S. Schottii, Gray. Resembles the next, and with similar fiflowered hemls:

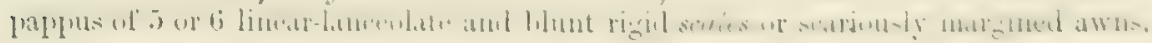


which are rather shorter than the minutely scabrous akenes, naked below, and sparingly barbellate-plumose towards the summit. - Hemiptilium Schottii, Gray, in Bot. Mex. Bound. 105.

On the Gila, Schott, therefore beyond the limits of California, but likely to occur on the Colorado.

2. S. pentachata, Eaton. A foot high, probably annual, excessively branched, paniculate: lower leaves linear and sometimes runcinate-toothed; upper reduced to minute scale-like bracts: heads 3 or 4 lines long, 5 -flowered: involucre of about 5 principal scales: akenes oblong-linear, columnar, truncate at both ends, slightly narrowed only at base, rugose-tubercled between the angles: pappus of 5 slender rigid bristles, longer than the akene, sparingly pectinate at the somewhat dilated base, thence naked to the middle, above rather copiously plumose. — Bot. King Exp. 199, t. 20.

Truckee and Humboldt Valleys, Nevada (Watson): probably reaching the borders of the State. Perhaps a form of the next, with a diminished number of bristles to the pappus.

3. S. exigua, Nutt. A foot or two high, paniculately and diffusely much branched from an annual root: radical and lower leaves linear or narrowly lanceolate, runcinate-pinnatifid or toothed; the upper slender and mostly entire except at the partly clasping base; those of the branchlets reduced to minute and obtuse bracts: heads 3 to 5 lines long, 3-9-flowered: akenes and pappus as in the preceding, but the latter of more numerous bristles, "usually 3 from each angle of the akene, and with their slightly dilated bases commonly united." - Eaton, 1. e. 198, t. 20, fig. 6, 7. Hemiptilium Bigelovii, Gray, 1. c.

Near Fort Mohave (Cooper), to Sierra Co. (Lemmon), and Carson City (Anderson, \&c.); thence through Nevada and New Mexico to the borders of Texas.

§ 2. Heads mostly small: bristles of the pappus 12 to 25, slender and plumose throughout: receptacle completely naked. - STEPHANOMERIA proper.

* Involucre narrow, 3-8-flowered, most commonly 5-flowered, its outer scales all short and calyculate: branches striate, slender and naked; their leaves usually reduced to small bracts: lower leaves linear; the radical ones generally runcinatepinnatific.

4. S. paniculata, Nutt. Stem erect from an annual root, $1 \frac{1}{2}$ to 3 feet high, with rather simple ascending virgate branches, along which the short-pedicelled heads are commonly racemose-panicled: involucre 3 or 4 lines long: akenes more or less rugose or tuberculate between the narrow ribs. - Eaton, l. c. fig. 5. S. virgata, Benth. Bot. Sulph. 32.

Hills and plains; common through the State and in Nevada. There are two forms as to the akenes; one shorter and thicker, with narrowed base, and usually strong and numerous rugosities between the distant ribs, as figured by Prof. Eaton in the Botany of King's exploration : this is S. virgata, Benth.y and is the common Californian form, with the heads disposed to be spicateracemose along the rather rigid virgate (sometimes somewhat pubescent) branches. The other form has narrower akenes, like those of $S$. exigua, with slight distinct tubercles in place of the strong rugosities; and the heads are more panicled. Apparently these characters do not always coincide or hold out.

5. S. minor, Nutt. Low: stems paniculately and loosely much branched from a perennial root, a span to a foot or more high; the slender and somewhat rush-like branches terminated by the heads: involucre 4 to 6 lines long: akenes with broad and strong (at length minutely scabrous) ribs having narrow grooves between, columnar or slightly narrowed at the surnmit. $-S$. minor, heterophylla, \& runcinata, Nutt. 1. c. Prenanthes (?) tenuifolia, Torr. Lygodesmia minor, Hook. Fl. i. 205, t. 103. Jamesia pauciflora, Nees in Neu-wied, Trav.

Dry plains, along the eastern slope of the Sierra Nevada (Bolcander, Torrey) to Oregon and to the eastern base of the Rocky Mountains. A New Mexican form of the species has narrower, almost smooth, and noore tapering akenes. 
S. MrroclaDA, Eaton, 1. c. t. 20, of Northwestern Utah, is a more slender perennial species, with smaller 3 -flowered heads; and

S. Thсів:Beri, Gray, Pl. Thurb., a larger-flowered annual or biennial of drizona and New Mexico. These are the only recognized species, besides those here described.

* Involucre broader, about 10-flowered, and with some outer scales of intermediate length: stems leafy to the top; the short peduncles mostly naked.

6. S. lactucina, Gray. Stems a span or two high from a perennial root, corymbosely branched: leaves linear or-lanceolate, runcinate-denticulate or entire, elongated: involucre half an inch long, of 6 to 9 inner seales, a few looser calyculate ones, and one or two of intermediate length and character: akenes oblonglinear, terete, very smooth, the ribs slender. - Proc. Am. Acad. vi. 552.

Wooded region of the Sierra Nevada, at about 5,000 and 6,000 feet, in and near the Mariposa Sequoia grove (Brcuer, Bolander); also in the northern part of the State, at MeCunber's (Ackebrry), and pine woods of Jount Shasta, Brewer. Leaves 2 to 4 inches long, 2 to 4 lines wide. Flowers delicate rose-color.

\$3. Heads larger, about 12-flowered: scales of the campanulate involucre, more numerous and imbricated in about 3 series, the outer successively shorter: receptacle alveolate, and the margins of the alveoli fimbriolate-hirsute: bristles of the prippus 15 to 20, short-plumose for their whole length. - Alcoseris, Gray.

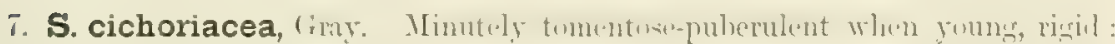
stem 2 feet or more high, leafy below, and with virgate branches naked above: leaves coriaceous, lanceolate, runcinately toothed, the teeth rigid: heads somewhat racemose or panicled, short-peduncled: scales of the involucre rather loose and rigid, lanceolate: young akenes short and smooth : pappus sordid or dull white. Proc. Am. Aciul. vi. 552.

Near Fort Tejon, Dr. Hom. Leaves 4 or 5 inches long (the lower unknown), not unlike those of Cichory, but rigil. Involuere fully half an inch high. Corollas probably rose-color. An ambiguous plant, both on account of the involucre, to which, however, the preceding species lends up, and especially on account of the alveolate receptacle, the short-plumose pappus, and its dull hue.

Custafipha Wieeleri, Gray, Proc. Am. Acad. ix. 218, discovered in Southern Nevala on the borders of Arizonh, has been recently detected in N. IV. Nevala, by Lemmon and Cose, so near the border of the State that it may be expected within. The plant has the aspect of a S/ephanomeria, or of a Lygodesmia, but the akenes of the five flowers are severally partly encloser in the carinate base of the subtenling scales of the involucre, and the papyus consists of five rigid awnlike naked scales, having a few shorter bristles alnate to their base, 3 to 5 on each side. The root is perenuial.

\section{RAFINESQUIA, Nutt.}

Ifead many- (15-30.) Howered. Involucre conical-cylindmceous, of 7 to 15 equal linear acuminate principal scales, and a few loose and shorter calyculate ones. Receptacle naked, flat. Akenes terete, slender, obscurely ǰ-ribbed or angled (nearly smooth and glabrous, or tho outermost pubescent), gradually attenuated into a slenIlor beak; tho broal baso hollowerl at the insertion, but destitute of a distinet callosity. Pappus white or whitish, of 10 to 15 caplillary bristles which are softly longplumose from the base to below the tip. - Lenfy-stommed and branching glabrous annuals; with pinnatifid leaves partly clasping at base, and mather largo hearls torminating tho paniculate branches; cornllas white or flesh-color. - Nutt. in Trans. Im. Phil. Soc. n. ser. vii. 429 ; Cray, Pl. Wright. ii. 103.

A well-marked genus (althongh joined to Slephanomerin by Benthans), of two known species, hoth Californinn, and one exelusively so. The akenes are excuvated at the broml insertion in the manner of Siorsonere and . Virraseris, but wholly wunt the callons appendage. In tho first species the flowers aro only trussiently expanded accorling to Nuttall, and the appunase of all the specimens conforms to this. But Dr. Bulander has found them open sluring tho whole dny. 
1. R. Californica, Nutt. Rather stout and much branching, 2 or 3 feet high: lower leaves pretty large, oblong; upper gradually reduced to small bracts: invoIucre becoming thick at base and more or less conical; its rather numerous calyculate scales subulate and spreading; the proper scales 12 to 15 : ligules short, white: akenes tapering into a very slender beak as long as the body: pappus dull white, the bristles fine and soft. - Torr. Bot. Mex. Bound. 106, t. 34.

Thickets and shady grounds, from San Francisco Bay to San Diego ; sometimes in grain-fields in the eastern part of the State : flowering in spring. Heads about two thirds of an inch high.

2. R. Neo-Mexicana, Gray. About a foot high, more simple: leaves lanceolate: head narrower, 15-18-tlowered: proper scales of the involucre 7 or 8 , the calyculate ones short and rather few: ligules rather large and conspicuous, fleshcolor or nearly white: akenes tapering gradually into a firmer beak which is mostly shorter than the body: pappus bright white, of 10 or 12 more rigid and arachnoidplumose bristles. - PI. Wright. ii. 103.

Sand-hills near Fort Mohave (Cooper) ; thence through S. Utah (Mrs. Thompson, Capt. Bishop) to the Rio Grande near El Paso, $C$. Wright. Head an inch long, exclusive of the corollas, which are two thirds of an inch long.

112. HY POCH ÆERIS, Linn.

Head several-many-flowered. Involucre oblong or campanulate: the scales imbricated, lanceolate, appressed, the outer ones successivel shorter. Receptacle flat, furmished with thin and narrow scarious chaff subtending the flowers. Akenes glabrous or merely scabrous, 10-ribbed, oblong or fusiform, at least the inner ones tapering upwards commonly into a beak. Pappus a series of fine plumose bristles, and often with some shorter and outer naked bristles. - Herbs with either leafy or naked stems, bearing solitary or somewhat corymbose long-peduncled heads of yellow flowers; the leaves toothed or pinnatifid. - Benth. \& Hook. Gen. ii. 519.

A rather large genus of the mountains and temperate regions of the Old World and of Sonth America (now made to include Achyrophoris, Adanson); none indigenous to North America, but the following is sparingly naturalized in California, as it is in various other parts of the world.

1. H. glabra, Linn. A span to a foot or more high from an anuual root, glabrous or nearly so: leaves all or mostly in a radical tuft, oblong-spatulate or oblanceolate, obtuse, coarsely sinuate-toothed: scape commonly branched: outermost akenes truncate at the summit, the others tapering into a long and slender beak: pappus of capillary bristles, which are intricately plumose below but nearly naked toward the apex, and of some fine and shorter naked outer bristles.

In fields, near San Francisco and Santa Cruz (Kellogg, Anderson); doubtless introduced from Europe. Heads a little over half an inch in length.

113. ANISOCOMA, Torr. \& Gray.

Head rather many-flowered. Involucre cylindraceous, imbricated; the scales all obtuse, thin-herbaceous, with broad whitish-scarious margins; the inner broadly linear and equal ; the others comparatively short and broad, oval, or the outermost nearly orbicular. Receptacle flat, furnished with long and bristleform chaff subtending the flowers. Ligules conspicuous. Akenes linear-turbinate, terete, 10-nerved, silky-pubescent, attenuate to a sharp point at base, the truncate summit crowned with a narrow cup-like border or ring. Pappus very white, of 10 or more rather rigid bristles; the about 5 longer ones (equalling the involucre) long-plumose above 
the millle; the others much shorter and less plunose or often quite naked. -1 single species.

1. A. acaule, Torr. \& Gray. A low, but shorry, stemless winter-annual, gla-

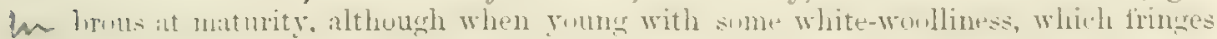
the edres of the short and rosulate-tufted runcinate radical leaves: scapes a span or less high, naked: head proportionally large (an inch or more long): corollas yellow. - Torr. \& Gray in Jour. Bost. Nat. Hist. Soc. v. 111, t. 13 ; Eaton in Bot. King Exp. 197. Pterostephanus runcinatus, Kellogg in Proc. Calif. Acad. iii. 20, fig. 4, badly characterized.

Dry plains and hills, from Fort Tejon to the Colorado, and from Sierra Valley through Western Nevada. First collected by Fremont. No doubt this is Dr. Kellogg's Pleroslephanus, but it has no such akenes as are described and rudely depicted.

\section{GLYPTOPLEURA, D. C. Eaton.}

Head 8-18-flowered. Involucre cylindraceous, of 7 to 12 lanceolate thin-herbaremis and somewhat searions-marined eyual seales, which are mited at base into a

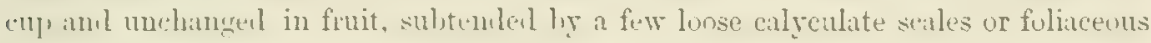

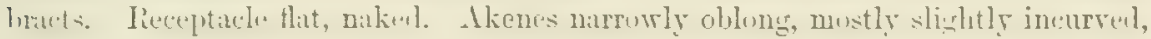
terete, not contracted at base nor bollowed at the insertion, with 5 thick and roumled ribs or angles, which are obscurely rugose, but on their sides elegantly cancellate-sculptured, so as to present a row of pores in the narrow intervals; above a cup-shaped shoulder surrounds the base of a short and thick 5-ribbed beak or neck, which is dilated at the apex into a pappus-bearing disk and hollow, at least at the top. Pappus bright white, calucous, of very numerous and equal fine and hardly scabrous eapillary bristles in several series; the outermost falling separately, the inner slightly cohering in a ring at base. - Small and depressed winter-anmuals or hiemials (uf the interior lesert), Glabrus, many-stemmed, forming that tufts why an inch or two high; the stems or simple branches terminated by sessile rather large heads of rose-purple or white flowers; the leaves runcinate and mostly with margined petioles, thickish. - Eaton, Bot. King Exp. 207, t. 20; Benth. \& Hook. Gen. Pl. ii. 523 ; Gray, Proc. Am. Acad. ix. 209.

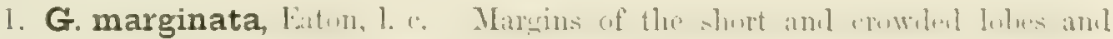
teeth of the leaves, or the whole of the obtuse teeth, white-scarions; the uppermost and the subtending spatulate bracts (which mostly equal the 15-18-flowered heads) pectinately scarions-fringed: rays (always?) small : akenes minutely cinerenus, the beak rather deeply cupped.

Truckes Pass of the Virginia Mountains and elsewhere on the western horders of Nernda (Witson, Lemmont); therefore probnbly within the line of the State. A eurious and most interesting little plunt. Heads rather over haif an inch long, hardly rising above the rallical leaves: involucre of about 12 scales. Akene 2 lines long, besiles its lenk of fully half a line in length.

G. SETulosa, Gmy, of Ctah (Pulmer), has fewer flowers and seales, larger rays (nppanently whito turning to pink), and smaller sultending braets much shorter than the unrrow head; these and the lenves want the searious margins and slender friuges, which are represented, however, hy a slight callons edge and a few bristles on the lobes; the akenes are quite glabrous, and their inesk tubular to the base.

\section{CALYCOSERIS, Gray.}

Head many-flowered. Involucre double, viz of one or two series of equal lanceulate principal scales, and several short and loose calyculate onter ones, all scariousmargined. Receptaclo flat: a persistent capillary bristle subteuding anch flower 
and equalling the akenes in length. "Ligules elongated. Akenes somewhat fusiform, 5-10-ribbed, tapering into a beak, the apex of which is crowned with a scarious persistent eup denticulate at the margin. Proper pappus of numerous fine and capillary white bristles, which are united at the base and separate in a ring. Low glabrous annuals (New Mexican and Californian), branching from the base, and bearing middle-sized pedunculate heads; the leaves pinnately parted into linear divisions, or the smaller and scattered upper ones almost entire: peduncles and involucre sparsely beset with stout-stalked tack-shaped glands. - Pl. Wright. ii. 104, t. 14, \& Bot. Mex. Bound. 106.

1. C. Parryi, Gray. Flowers yellow: akenes smooth, slender, with 5 acute and intermediate obtuse ribs, the beak slender. - Bot. Mex. Bound. 1. c.

Mountains east of Monterey, June, Parry. A fragmentary specimen, the only one known, wanting the base of the stem and the lower leaves.

C. WrighirI, Gray, 1. c., the other and better known species, inhabits the eastern part of New Mexico : it has rose-colored flowers, and stouter akenes, with thick, very obtuse, tuberculateroughened ribs and thickish beak. Dr. Palmer collected specimens in Utah with akenes somewhat intermediate in character; and Dr. Newberry found others, in W. New Mexico (without fruit), which show hardly any of the curious glands.

\section{MALACOTHRIX, DC., Torr. \& Gray.}

Head many-flowered. Involucre campanulate or cylindraceous; the scales either Ionsely imbricated, or mainly equal, and calyculate with a few short ones at base. Receptacle flat, naked, or sometimes with delicate and fragile or deciduous capillary bristles interposed between the flowers. Akenes short, oblong or columnar, glabrous, terete and 8-15-striate-ribbed, or 4-5-angled by the stronger or primary ribs, little if at all contracted at base; the broad truncate apex furnished with a crownlike entire or denticulate border or sharp edge, sometimes evidently representing an outer pappus: the ordinary pappus bright white, consisting of a single series of soft and scabrous or toward the base minutely barbellate capillary bristles, which are caducous more or less in a ring, and commonly of a few ( 1 to 8) outer and stronger as well as smoother more persistent bristles : in an anomalous species, all the pappus is wanting. - Herbs (peculiar to the western parts of North America); with somewhat leafy or scape-like and mostly branching stems, middle-sized or small pedunculate heads, commonly nodding before expansion, and pinnatifid or occasionally entire leaves. - Torr. \& Gray, Fl. il. 485; Gray, Pl. Fendl. 113 ; Benth. \& Hook. Gen. Pl. ii. 518; Gray, Proc. Am. Acad. ix. 213. Leptoseris, Leucoseris, \& Malacomeris, Nutt.

$\$ 1$. Involucre of numerous broad and blunt silvery-scarious scales, with only a green midrib or centre, regularly imbricated in several series, the outer successively shorter and rounder: receptacle beset with slender persistent bristles: corollas white or at first cream-color, changing to pink or purple in drying or fading.

1. M. Coulteri, Gray. Annual, a foot or two high, glabrous and somewhat glaucous, rather leafy: leaves laciniate-pinnatifid or toothed; the radical and lower cauline oblong or spatulate, sessile; upper auriculate-clasping and ovate-lanceolate, gradually reduced to bracts: heads terminating the loose branches: akenes acutely about 15-ribbed and 4-5-angled, the summit more or less denticulate by the projection of the ribs: one or two stouter bristles of the pappus nearly persistent. - Pl. Fendl. 113. 
First collected by Coulter, probably in the southern part of the State. Sitgreaves Pass (Nevoberry); Nacimiento River and San Luis Obispo, Brever. Apparently on the Sacramento or San Joaguin, Filch, Kellogg. Involuere over half an inch in diameter, not unlike that of a $X$ eranthemum. Structure in other respects wholly that of Malacothrix.

\$2. Involucre of narrow and acute or acuminate scales, slightly if at all scarious, in 2 or 3 series. (Puppus present.) - Malacothrix proper.

* Annuals: flowers light yellow, often turning purple. (Leptoseris, Nutt.) + Head large, solitary, terminating mostly simple naked scapes.

2. M. Californica, DC. Lousely long-worlly when youn, sometimes nearly glabrous with age: leaves mostly all in a radical tuft, laciniately pimately parted into very narrowly linear divisions: scapes ascending, a span to a foot high: scales of the broad involucre linear-subulate, loosely imbricated : akenes narrow, minutely and obtusely striate-ribbed (acutish and with is minute eallus at the base): outer pappus of '2 persistent lisistles, between the bisiss of which are several very minute pointed teeth.

Tir. glabrata, Eaton in But. King Exp., 201, is a form aprarently destitute of wool, even when young.

Open grounds, mather common from the Bay of San Francisco to San Diego, and east to the borders of Nevada and S. Utah, where the smooth variety was collected by Alnelcrson, Walson, Parry, \&ce. Head as large as that of a Danilelion, on a seape which is usually naked to the base, rarely with a leaf or two, and witl a tendency to bear lateral heads.

+ + Heads smaller and paniculate on brancling stems or scapes: involucre of equal scales and a fevo sloort calyculate ones at base.

+ Pappus with one or more somewhat persistent stouter and naked bristles.

3. M. Toneyi, fray. A span to a fout and a half light, rather leafy, warly

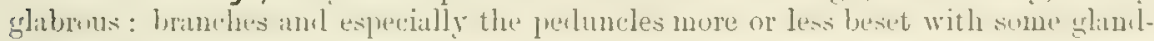
tipped bristles: heads rather large: involucre campanulate and many-flowered: akenes linear-oblong, very strongly ribbed; the 5 principal ribs almost wing-like, the pair in each interval much less prominent: outer pappus of 4 to 8 (usuilly 5 ) stont persistent bristles, between the thickish bases of which are minute teeth. - Proc. Am. Acad. ix. 213. M. sonchoides, Torr. in Stansbury Rep. 392; Gray, Pl. Wright. ii. 105, in part; Eaton in Bot. King Exp. 201, not of Torr. \& Gray.

Eastern side of the Sierra Nevada, on the borders of the State (Anderson, Watsmi, Lemunon); thence enst to Salt Lake and the southem part of U tah. Involucre sometimes half an inch high, generally smaller.

4. M. Zanti, Gray, 1. c. Slender, glabrous or slightly woolly when young: stem scape-like and loosely panicled, a foot or more high: leaves mostly radical, runcinate-pinnatifid, thin; the cauline ones small nad with almost filiform lolses: heads small: involucre cylindraceous, rather few-flowered: akenes linear-oblong, obtusely 15-ribbed, with 5 ribs moclerately stronger, the cup-like apex obtusely 5 toothed : outer pappus of 3 to 5 very slender and partly persisteut bristles. M. perviftora (i), Gray, Proc. Am. Acnd. v. 163, not of Benth.

Capo Sus Lucas, Lower Californin (X Xentus). It may occur in the southern part of the State.

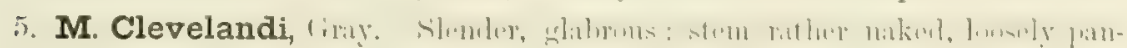
icled, a foot or more high, bearing numerons heads: leaves thin, all limenr, sparingly laciniate-pinnatific: involuere emmpanulate, rather many-flowereil; tho scales green with bruwnish or purplish tips: young akenes cylindraceous, equably and lightly striate-nerved: onter pappus of one stout bristle anu a crown of may conspicuous thin and whito teoth; soft bristles of tho imer pappus disposed to fall separately. - Proc. Am. Acad. ined.

Near Snn Diego, D. Clecreland. Also Gundulupe Island, Iower Californin, Dr. F. Palmar. Leavey a liue or two wide, even the radienl ones soldon over 2 or 3 lines brond, from 1 to 3 inches 
long. Involucre barely 4 lines high. The conspicuous many-toothed crown to the akene is here evidently pappus, and of the series to which the stout bristle belongs.

M. Fendleri, Gray, Pl. Wright, of New Mexico, is known by its rather large heads, and dark-colored cylindical and equally 15 -ribbed akenes, with the cup-like apex entire, and a single persistent bristle; in aspect it resembles $M$. Torreyi.

+++ All the bristles of the pappus deciduous in a ring: the border of the akene naked or merely denticulate.

6. M. obtusa, Benth. A span to a foot or more in height, glabrous, except some woolliness when young: stems loosely paniculately branched, scape-like or few-leaved below: leaves runcinate-pinnatifid, their lobes and teeth obtuse and rounded: heads small : involucre narrow-campanulate (3 or 4 lines long, containing rather numerous or sometimes few flowers): akenes obovate-oblong, obtusely angled by the 5 stronger ribs, the small intermediate ribs either obscure or evident, the slightly narrowed apex with a narrow entire border. $-M$. obtusa \& $M$. parviflora, Benth. Pl. Hartw. 321, the latter apparently no more than a slender and small-flowered form.

Open ground, rather common from Monterey to Humboldt Co., and Sierra Valley. In this species the capillary bristles of the receptacle are often manifest, and about twice the length of the akenes, but fragile or desiduous; sometimes only traces of them are to be found.

7. M. sonchoides, Torr. \& Gray. A span high, diffusely spreading, nearly glabrous, stouter: radical leaves runcinate-pinnatifid with teeth or lobes somewhat spinulose-pointed : heads larger: akenes linear-prismatic, five of the 15 ribs being stronger than the rest; the summit hardly contracted, bearing a crown-like minutely 15-denticulate white border. $-M$. obtusa, Eaton, Bot. King Exp. 202, in part. Leptoseris sonchoides, Nutt. in Trans. Am. Phil. Soe. n. ser. vii. 438.

N. W. Nevada, Lemmon, 1875. Ttah to Nebreska. The most eastern species; but now detected so near to California that it probably will be found within it.

* Perennials or sometimes probably biennials, with a firm or somewhat woody base: no outer pappus of bristles. (Malacomeris \& Leucoseris, Nutt.)

+ Flowers yellow: plant white-woolly.

8. M. incana, Torr. \& Gray. Low, white with cottony wool: leaves mostly crowded on a (biennial?) crown or on short stout stems, pinnatifid: flowering stems scape-like, a few inches high, bearing one or two rather large heads. - Malacomeris incana, Nutt. 1, c.

San Diego, on an island in the bay. Collected only by Nuttall, whose specimens are imperfect.

++ Flowers white (changing to rose-color?) : stems leafy, paniculately branched, a foot or two high, apparently from a perennial root.

9. M. saxatilis, Torr. \& Gray. Minutely and lightly tomentose, or nearly glabrous: leaves lanceolate or the lower somewhat spatulate, or those of the branches linear, entire, laciniate-toothed, or sparingly pinnatifid: involucre eampanulate or hemispherical, about half an inch high; the short ealyculate scales numerous and passing into loose subulate bracts: akenes linear-oblong, 10-ribbed, crowned with an obvious 10-denticulate border. - Gray, I. c. M. saxatilis \& $M$. commutata, Torr. \& Gray. Leucoseris saxatilis \& L. Californica, Nutt. 1. c. Hieracium? Californicum, DC. Senecio flocciferus, DC.

On the coast at Santa Barbara and southward. Seems to pass into the next, unless the akenes furnish a character.

10. M. tenuifolia, Torr. \& Gray. Glabrous or nearly so, with slender paniculate peduncles: leaves narrowly linear or the upper filiform, mostly pinnately parted into few divisions: akenes obovate and with an obscure nearly entire border. Leucoseris tenuifolir, Nutt. 1. c.? 
Santa Barbara ( Nuttall), and in the southern part of the State (Cmuller), to the valley of the Gila, Scholt. There are no persistent bristles to the pappus, as is wrongly stated in the Botany of the Mexican Boundary.

\$ 3. Pappus wholly wating: atherwise as in Julacothix proper: flowers white and purple. - Avatrarix, Gray.

11. M. platyphylla, (iray, l. c. Annulal, glabrous or nearly so, somewhat glaucous: leaves all radical, dilated-cuneiform and nearly sessile, almost truncate, acutely and unequally dentate or denticulate: scape naked, a foot or two high, lowsely corymberse at the summit and bearing numerens small heads : involucre of oblong equal scales and a few very short calyculate ones.

Gravelly soil near Fort Mohave, Dr. Cooper. Involucre campanulate, about 3 lines high: ligules of nearly twice that length. Leaves 2 or 3 inches long, thin, veiny. The fruit is as yet unknown.

\section{CREPIS, Linn.}

Hear several-many-fluwered. Involuce cylindraceons or campanulate, usually donble; viz. the principal scales equal, with some short calyculate ones at base, rarely more inluriated, in finit often becoming carinate or buat-shaped towals the hase ly the thickening and induration of the midrib. Receptacle flat, naked, sometimes alveolate. Akenes oblong; linear, or fusiform, nearly terete or obtusely angled, 10 - 2(1-rib) ked, generally sumewhliat contracted at hase and more tipering at summit, sometimes even beaked. Pappus simple, of copious and white capillary merely seabrous bristles, which are either persistent or singly deciduous. - Herbs, of various habit and wide distribution (mainly of the northern temperate regions of the (M) Workl), commonly with miklle-sized heals of yellow llowers. - Torr. \& Gray, Fl. ii. 487 ; Benth. \& Hook. Gen. Pl. ii. 511.

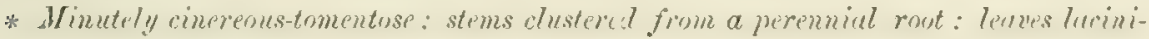
ately pinnatifid into narrow lobes or teeth: involucre of equal linear principal scales and a few short calyculate ones: ahenes fusiform, not beaked, smooth, 10-striateribbed, as long as the pappus.

1. C. occidentalis, Nutt. Dwarf or stout: stem a span to a foot or so high,

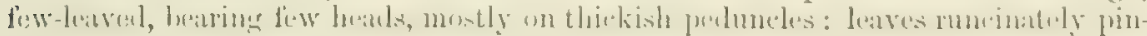
natifid or pinnately parted, broadly lanceolate in outline, with the apex acute or rurely prolunged : involucre 12-30-fluwered, furfuraceous-tomentose, occasionally beset with scattered and brownish bristles; the priucipal seales 8 to 15 : akene's with tapering summit, striate with 10 even and strong narrow ribs. - Psilochenin occidentalis, Nutt, in 'Truns. Am. Phil. Soc. n. ser. vii. 437.

Var. Nevadensis, Kellogg, in Proc. Calif. Acad. v. 50, is a dwarf form, with fincly somewhat twico pinnatuly parted leaves; and var. subacaulis, Kellogg, is a much-realucerl state of the sume.

Var. costata, dwarf or stout, with many-flowered heals, has the akenes very

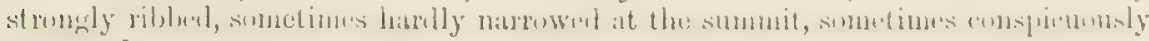
nurrowed.

Var. crinita, from Washington Territory, is shagegy with long brownish or yellowish hairs on the peduncles and involucre; the bristly hais in somewhat similar Californian specimens glandular.

Dry hills, from Mendocino Co, and throughout northeastern portions of the Sicrm Novaln to Washington Territory, Nontsum, and C'olomilo. The var. Necrelensis oueurs at Summit, Nevadu

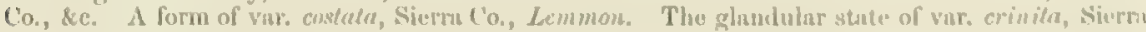

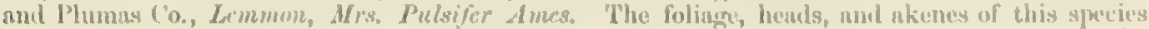
are not a little vuriable. Nuttall could have seun no woll-formed fruit, for ho deseribes tho akcnos ay not striate. 
2. C. acuminata, Nutt. Less tomentose: stem slender, I to 3 feet high, bearing an open cyme of numerous and slender-peduncled narrow heads: leaves runcinately pinnatifid into lanceolate or linear lobes below, and the apex prolonged into an entire tail-like acumination: involucre 5-15-flowered, either tomentulose or glabrous, narrow-cylindrical, 5 to 7 lines high; the principal scales 5 to 8 : akenes 10-striate, with a tapering summit. - Torr. in Stansbury Rep. 392, t. 8 (the akene too tapering at summit). C. occidentalis, var. gracilis, Eaton in Bot. King Exp. 203, slender forms.

Dry ground, from near Clear Lake (Newberry, Torrey, \&c.) and Yosemite and Sierra Valleys (Bolander, \&c.), to Oregon and the Rocky Mountains. Akenes generally rather longer than the pappus.

* Glabrous or slightly hairy: stems or mostly naked scapes and a crown of radical leaves from a solitary and thick probably biennial root, bearing a few long-peduncled heads.

3. C. glauca, Torr. \& Gray. Glabrous, except a slight pubescence on the young heads: leaves all radical, glaucous, oblong or oblanceolate, runcinate-pinnatifid or denticulate, thickish, bardly petioled: heads small: involucre 15-20-flowered, of about 12 narrow and equal scales and 3 or 4 small accessory ones: akenes oblong, incurved, slightly narrowed at both ends, 10-ribbed, shorter than the rather scanty deciduous pappus. - Crepidium glaucum, Nutt. k. c.

Low grounds in saline soil, Western Nevada (Watson) to the Platte: not yet found on the borders of California, but it may be expected. Involuere 3 to 5 lines long. Akenes only 2 lines long.

4. C. Andersonii, Graj. Glabrous, or with some woolly pubescence when young: leaves mainly radical, oblong-obovate or lanceolate, laciniately-toothed or rarely runcinate-pinnatifid, nearly sessile : heads rather large : involucre many-flowered, mostly glandular-pubescent when young; the scales imbricated in about 3 series, linearlanceolate or oblong-linear: akenes fusiform, many-striate, smooth, tapering gradually into a short but rather distinct beak. - Proc. Am. Acad. vi. 553; Eaton in Bot. King Exp. 203.

Low grounds, near Carson City (Anderson), and a caulescent form in uplands (which may be Crepidium caulescens, Nutt.), and Sierra Valley (Lemmon) : extending into Nevada, Watson. Heads half to two thirds of an inch long. Akenes 3 lines long, including the beak : pappus rather deciduous.

Crepis RunCtNata, Torr. \& Gray, is most like $C$. glauca; but has a hispidly glandular and pubescent involucre, narrower akenes, and the thinner leaves not glaueous. It belongs to the Rocky Mountain district, and probably does not approach California.

C. COoperi, Gray, is the IIalccothrix crepoides. Gray in Pacif. R. Rep. xii. 49, a small-flowered species with the aspect of Malacothrix obtusa, but not the characters of that genus. It is in E. Hall's collection from near Portland, Oregon, and may perhaps be expected in the northern part of California.

* * Glabrous or nearly so, dwarf, perennial: heads from the crown among the radical leaves, or on scapes hardly exceeding them.

5. C. nana, Richardson. Leaves in a depressed cluster, rather glaucous, oblong or spatulate and lyrate or lyrately toothed, or sometimes roundish and small, the lateral divisions being wanting, commonly long-petioled: heads elustered at the crown, or several on a scape or stem an inch or two high: involucre cylindraceous, $10-14$-flowered, of 6 to 8 linear obtuse glabrous scales, and a few short calyeulate ones at base: flowers yellow turning pink: akenes slender, linear and obscurely fusiform, not beaked, finely striate. - Hook. in Parry's 2d Voy. 397, t. 1; Torr. \& Gray, l. c.

High Sierra Nevada, at Sonora Pass (a single and somewhat ambiguous specimen), Brewer. Also in the northern Rocky Mountains, extending to the Arctic coast, and in Siberia. The narrow heads nearly half an inch long. 


\section{TROXIMON, Nutt.}

Head many-flowered. Inwhluere cunpanulate or cylindraceons; the scales motity

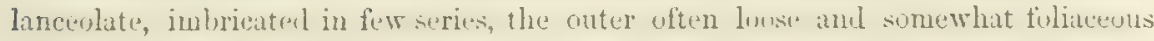
or bract-like. Receptacle flat, naked, sometimes foveolate, in one species occasionally (and ahmormally) with a few ehatty siales among the flowers. Akenes ublung or linear, terete, 10-ribbed; the apex contracted into somewhat of a neck, or prolonged into a beak; the broad base or a basilar callus to a narrower base more or less hollowed at the insertion. I'appus of enpious loright white "r whitish capillary

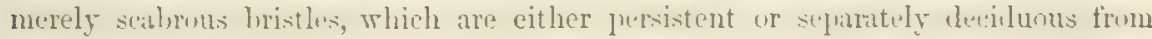
the dilated terminal areola - Acaulescent perennials or annuals; with clustered ratical leaves, ami simples seapes, bearing solitary litge or midhle-sized heals of yellow or rarely orange or purplish flowers. - Benth. \& Hook. Gen. Pl. ii. 522.

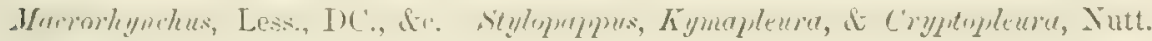
in Trans. Am. Phil. Soc. n. Ser. vii. $430-433$.

A genus of several species, natives of North America west of the Mississippi and two or three in South America, being now extented, by JIr. Bentham, to embrace Macrorhynclucs. The latter, with liliform beak to the akene, seens abundantly distinct from the eastern beakless $T$. cuspidatum, which ought to be regarded as the type of the genus. But $T$. glancum and $T$. auruntiacum connect them. See Proc. Am. Acad. ix. 215.

\$ 1. Akenes fusiform, glabrous, tapering gradually into a short or rather stout nerved beak: pappus persistent and rather rigid: root perennial. - NoтнотRохıо.

1. T. glaucum, Nutt. When young hirsute-pubescent, or nearly glabrous: leaves varying from linear to lanceolate or oblanceolate and with entire or undulate margius, rarely laciniate-pinnatifid : scapes a span to a foot high: scales of the involucre all or all but the outermost and shorter ones acuminate: mature akeue tapering into a stout beak of not more than half the length of its bocly. - Bot. Mag. t. 3462. Macrorhynchers gleucus, Eaton in Bot. King Exp. 204.

Var. taraxacifolium, Gray. Large: leaves 7 to 10 inches long and sometimes an inch and a half wide, from lauceolate to obovate-oblong, entire, toothed, or sometimes pinnatifid: scape a font or two high: involncre an inch high; its scales all acute or acuminate. - T. taraxacifolium, Nutt. in Truns. Am. Phil. Soc. 1. c.

Var. laciniatum, Gray. A dwarf or small form, with seapes 2 to 6 inehes high: leaves laciniately and runcinately pinnatitid, or occasionally entire and linear. - Macrorhynchus glaucus, var. laciniatus, Eaton, 1. c. Troximon parviflorum, Nutt. 1. c., is an entire-leaved form.

Fistern borders of the Sicrma Nevaln, from Carson City to Siem Talley, in the above two varieties (the var. lacininlum on Dount Dana and Carson Pass, at 8,000 to i1, 000 feet, Brewer, and Summit, Boleneler) ; north to Oregon, and enst to beyond the Rocky Mountains, mostly in low grounds. Corollas yellow, sometimes turning purple in age. The var. dasycrphalum, with hairy and larger somewhat foliaceous outer scales to the involucre, occasionally has chatfy stales on the receptacle.

2. T. aurantiacum, Hook. Mrore slender, a span to a foot or more high, moro glabrous: leaves thinner, inclined to oblancoolato or spatulate, often denticulate, sometimes laciniate-pinnatifid: involnere ( 6 to 9 lines high) mostly of two series of less acute scales, the outur about as long as the inner and broader: mature akenes tanering into a slender lusik of nearly or fully the length of the borly. - Hook. kl. i. 300, t. 104. T. pmemilum, Nutt. 1. c., a suall form. Macrorhynchus troximorides, Turr. \& (iray, lil. ii. 491 .

Hesulows or low grounts : sune monge nas the list, and forms of the two often confommlat. The

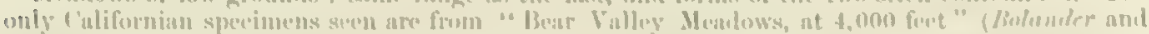
hillogg), and with pinnatifirl leaves, but no fruit. Rige akenes distinguish the speries from the preceding: the pappus also is less persistent. The corollas are orunge, olten turning to purple. 
\$ 2. Akenes oblong or fusiform, mostly acute or narrowed at base, and somewhat obliquely inserted by a small distinct callus (outermost occasionally pubescent), the apex produced into a long (usually very long) and filiform or capillary nerveless beak: pappus fine and soft, tardily deciduous. - MACrorHYNCHUS. (Macrorlynchus, Less., DC.)

* Root perennial: akenes either gradually or abruptly tapering into the slender and filiform beak.

3. T. apargioides, Less. A span to a foot or so high from a long and often large fusiform root, hirsute or glabrous: leaves variously pinnatifid or laciniate: scapes slender, ascending: head middle-sized or rather small: akenes linear-fusiform, acutely or the inner ones lightly ribbed, nearly equalling or a little shorter than the beak. - Linnæa, vi. 501. 'Barkhausia Lessingii \& Macrorhynchus Lessingii, Hook. \& Arn. Bot. Beechey, 145, 361. M. humilis, Benth. Pl. Hartw. 320. M. Harfordiz, Kellogg.

Sandy or marshy grounds; common along the coast, from Monterey to Oregon. This species is well described in the remark that it resembles Apargia autumnalis (i. e. Leontodon autromnale), and also, in its smaller form, Krigia Virginica. Like these the foliage is very variable. Involuere from 6 to 9 lines high; the outer scales sometimes more foliaceous. Akenes 2 lines and the beak 2 or 3 lines long.

4. T. Nuttallii, Gray. About a foot high: leaves glabrous, varying from oblong-spatulate and laciniate-pinnatifid to linear and entire: scapes rather stout and head rather large: scales of the involucre narrow: akenes fusiform-linear, slender, tinely and closely ribbed, equalling the beak in length. - Proc. Am. Acad. ix. 216. Stylopappus elatus, Nutt. 1. c. Macrorhynchus elatus, Torr. \& Gray, 1. c.

Meadows, from the Yosemite Valley (Bolander) to Oregon, Nuttall, Hall, Nevius, \&e. Head about an inch high. Akenes 4 lines and the beak 3 or 4 lines long.

5. T. grandiflorum, Gray. Hirsutely pubescent or almost glabrous: leaves lanceolate or oblanceolate, mostly laciniate-pinnatifid, the lobes ascending or spreading: scape one to $2 \frac{1}{2}$ feet high: head large (an inch high): outer scales of the involuere commonly loose and foliaceous, varying from ovate to lanceolate: akenes short-fusiform or oblong, abruptly tapering into the capillary beak of several times its length. - Proc. Am. Acad. ix. 216. Stylopappus grandiflorus, Nutt. 1. c. Macrorkynchus grandiflorus, Torr. \& Gray, l. c.

Var. tenuifolium, Gray. More slender, and heads somewhat smaller: leaves pinnately parted into narrow linear divisions. - Stylopappus laciniatus, var. longifolius, Nutt. 1. c.

Var. laciniatum, Gray. More slender and heads much smaller: outer scales of the involncre not dilated: leaves lanceolate or linear and variously laciniate. Stylopappus laciniatus, Nutt. 1. c.?

Meadows and hillsides, from Monterey Co. along the coast range to Oregon. The var. temuifolin has been collected only in Oregon and Washington Territory. The species is well marked when in fruit by the short and smali akenes (only 2 lines long), with very long and capillary beak, 6 or 8 lines long.

* Ront perennial: akenes abruptly beaked from a truncate apex.

6. T. retrorsum, Gray, 1. c. Almost woolly when young with soft loose hairs, or glabrate: leaves runcinately and deeply pinnatifid, the linear-lanceolate lobes all turned downwards, the apex usnally prolonged and entire, all tipped with a callous gland: scapes about a foot high : hearl large ( $1 \frac{1}{2}$ inches long in fruit) but narrow: outer scales of the involucre short and lanceolate, the inner long and linear: alrenes short-linear, closely 10-ribbed, their callous or slightly broadened summit very obtuse or truncate at maturity; the capillary beak very long. - Macrorhynchus retrorsus, Benth. Pl. Hartw. 320; Gray in Bot. Wilkes Exp. 373. 1I. anyustifolius, Kellogg in Proc. Calif. Acad. v. 47, a small form of the species. 
Tuolumne to Mendoeino Counties (Hartzery, Bigelono, Bolander), also Cisco (Kellogg); thence to the southern borders of Oregon (Pickering and Brackenridye), in open pine woods, se. Remarkable for the narrow retrorse lobes of the leaves, and the abrupt summit to the akenes. These are nearly 3 lines long, while the well-formed beak attains the length of nearly an inch.

* * Root annual: plants mostly low and small, occasionally subcaulescent.

7. T. Chilense, Gray, 1. c. More or less pubescent or hairy: leaves varying

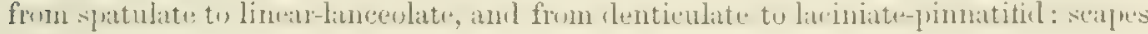
slender, a span or sometimes nearly a foot high: involucre 6 to 9 lines high; the scales in about 2 series: akenes varying from short-ablong to fusilorm and with acute or wing-like ribs, or the outer sometimes 10-wingred, usually one half or one third the length of the filiform beak. - Macrorhynchus C'hilensis, Less. Syn. 139; Hook. Lond. Jour. Bot. vi. 256. M. heterophyllus (Nutt.) \& M. Californicus, Torr. \& Gray, Fl. ii. 493. Kymapleura heterophylla, Nutt. 1. c.; the state with the outer akenes mustly undulate-winged at maturity. Cryptopleura Californica, Nutt. 1. e. ;

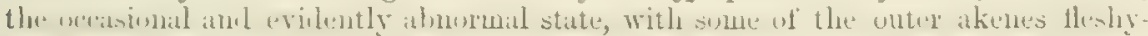
thickened and the ribs obsolete.

Open grounds; common throughout California and Oregon, extending through the interior to Utah. Flowers deep yellow, expanding but once at midklay. A most variable species, especially as to the akenes; in some of the forms agreeing wholly with Chilian specimens. More commonly the akenes are rather shorter and their beak longer. The state of the akenes on which Nuttall founded his Cryptopleurce has been only once or twice met with. The rugose-winged state is not uncommon, and in various degrees, or affecting merely some of the outer akenes.

\section{TARAXACUM, Haller. DAYDELYON.}

Ifeal many-flowerel. Involutre oblonesempandate, of thin and narrow sontewhat membranaceuss scales in two sets ; the inner equal and ereet in a single series ; the outer short and calyculate, commonly loose. Receptacle flat, naked. Akenes ohlung or fusifnm, angled, abont lo-ribberl, attenuate at hase, mostly muricate on the ribs towards the apex, which lengthens into a long filiform beak. Pappus of copious and white capillary scabrous bristles, nearly persistent. - Acaulescent

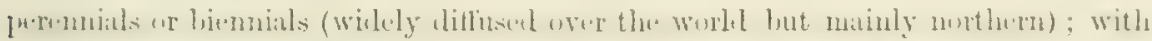

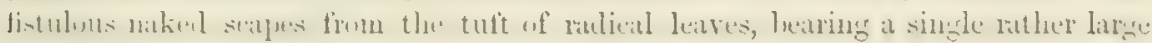
head of yellow flowers, open through the morning.

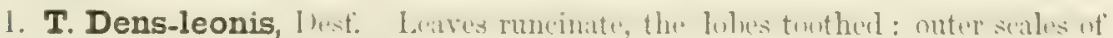
the involucre loose or reflexed, the inner destitute of a callous horn at the tip. Lenutorlon Turaxacum, Linn.

There are some indications of the Dandcliom as an introduced plant ; but it is as yet very local.

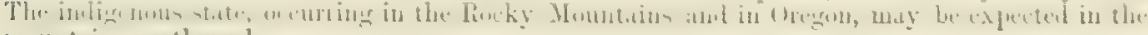
mountaius nortliward.

\section{APARGIDIUM, Torr. \& Gmy.}

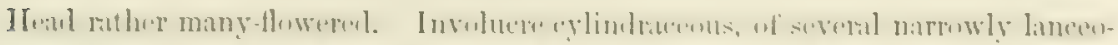

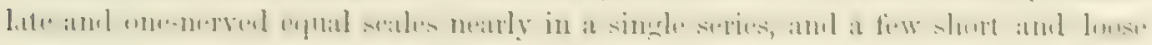

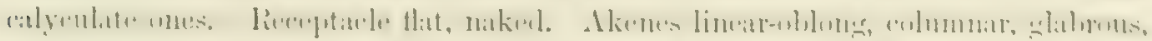

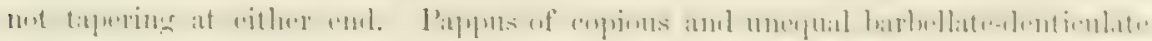

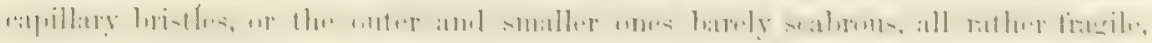
hrownish. - $\Lambda$ single species.

1. A. boreale, Torr \& firy. Stemless perenuial, ghahous: leaves linear-lancenlate, elonginted, obscurely and remouly denticulate or ontire: scapo slemer, a span to a foot high, bearing a single middle-sized head, mostling hefore openimg : Howers 
light yellow. - Fl. N. Am. ii. 474. Apargia borealis, Bongard. Leontodon boreale, DC. Microseris borealis, Schultz Bip., ex Herder, Bot. Radde, iii. (4), 28.

In bogs, Mendocino and Humboldt Counties, Bolander, Kcllogg. Oregon to Alaska. Referred to Leontodon by Bentham and Hooker : but none of the bristles of the pappus are either chaffydilated at base or plumose; nor is there any true Leontodon indigenous to America, with which to associate it.

\section{HIERACIUM, Tourn. HAWKWEED.}

Head many-flowered, or sometimes only 10-20-flowered. Involucre campanulate or cylindraceous; the scales herbaceous and narrow, the inner ones equal, the onter either gradually shorter or only short and calyculate, not altered in age. Receptacle flat, naked, sometimes more or less fimbrillate-toothed. Akenes oblong or columnar, terete or 4-5-angled, mostly 10-ribbed or striate, glabrous and smooth, the apex truncate. Pappus of one or two series of capillary rather rigid and persistent but often fragile scabrous bristles, brownish or sordid in hue. - Perennial herbs; with merely toothed or entire leaves, often coarsely or bristly hairy or glandular; the paniculate or rarely solitary heads middle-sized or small ; corollas yellow or sometimes white. - Torr. \& Gray, Fl. ii. 474.

A very large and difficult genus in Europe, moderately represented by peculiar species in North Ameriea, and with a few andine species in South America. The species of the western side of the continent are peculiar, except that $H$. Canadense, which nearly approaches or passes into $H$. umbellatum of the Old World, erosses the northern Rocky Mountains into Washington Territory and Oregon. All the Californian species have small heads and a nearly simple calyculate involucre.

* Heads only 10 - 15-flowered: akenes tapering upwards.

1. H. Bolanderi, Gray. Small : leaves mostly radical in a tnft, sessile, oblongspatulate, nearly entire, glabrous except for the long spreading bristles which fringe the margin and at first beset the upper surface: scape slender, a span high: slender peduncles and cylindrical involucre naked and glabrous or nearly so: corollas yellow : akenes fully as long as the pappus. — Proc. Am. Acad. vii. 365.

On Red Mountain, Mendocino Co., Bolander. Heads 2 to 4 lines, and involucre 4 or 5 lines long; the latter of 7 to 9 principal scales and one or two short ones, all obtuse. Akenes terete, moderately fusiform, 2 lines long, lightly striate.

* Heads 20-40-(rarely $10-15$-) flowered: akenes short, not tapering upwards.

2. H. Breweri, Gray. Low : stems 3 to 9 inches high, leafy to the top, branching, densely clothed (at least below), as are the spatulate-lanceolate or linear-oblong leaves, with very long and soft villous hairs: heads numerous, paniculate-corymbose, $10-20$-flowered : involucre of linear-lanceolate acute scales, somewhat glandular-hirsute and occasionally shaggy with long bristles: corollas yellow. - Proc. Am. Acad. vi. 553.

Sierra Nevada in Mariposa and Tuolumne Counties, in open places, at from 7,000 to 11,000 feet of elevation. Involucre about 3 lines long; the akenes a line and a half.

3. H. Scouleri, Hook. Usually a foot or two high and rather stout: stem leafy, bearing loosely paniculate $20-40$-flowered heads, beset, as also the mostly laneeolate and entire leaves, with very long and spreading villous-hispid bristles, oftener from a papillose base : pedicels and involucre glandular-hispid or sometimes only glandular-puberulent: corollas yellow. - Hook. Fl. i. 298.

Sierra Valley in the Sierra Nevada, Lemmon. Common near the coast from British Columbia to the southern part of Oregon, and east to the Rocky Mountains; doubtless in all the adjacent parts of California.

4. H. albiflorum, Hook. 1. c. Usually 2 feet or more high: stem leafy below, simple or paniculately branched and bearing several or numerous small heads on 
slender glabrous peduncles: leares oblong or chlong-spatulate, often lenticulate "r

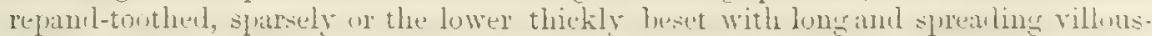
hispid bristles, as is the base of the stem: involucre narrow, about 20-Howered, smorth and glabrous or beset with some scattered long bristles, not glandular: corollas white. - $\boldsymbol{H}$. argutum, Nutt. l. c. (?), from Sta. Barbara.

Open woods; common through the State from San Diego Co. northward, and in the foothills of the Sierra Nevada; extendiug to British Columbia and eastward to the Rocky Mountanıs. Involuere 3 to 5 lines long. Akenes it line and a half long, evenly and strongly striateIilinint.

5. H. triste, Willd., var. gracile, Gray. Slender, a span or two high : stern 1-2-leaved or sometimes nearly leafless, bearing few heads, tomentose-puberulent or almost glabrous below : the summit or peduncles and involucre villous or hirsute with long and blackish hairs: leaves oblong-spatulate, entire or denticulate, tapering into a sloniler petiole: corollas yellow. \& Epicrisis Hierac.

Var. detonsum, Gray. A form destitute or mearly so of the dark soft hairs even on the involucre, or with scattered and more bristly and sometimes glandular ones in their place; the heads rather smaller.

Ebbett's Pass, Sierra Nevada, at 8,000 feet (Brencer), the var. detonsum; also in the Rocky Mountains and in Oregon, accompanied by and passing into the black-headed form of the northern locky and C'aseade Mountains, H. gracile, Hook. This in turn clearly passes into the Alnskian H. triste; which has very long and dense dark gray hairs to the heads, shorter stems, and hirsute upper leaves.

\section{LYGODESMIA, Don.}

Head few-flowered. Involucre cylindrical or cylindraceous, of 4 to 8 narrow membranaceous scales in a single series, with a few short calyculate ones at base, or rarely more unequal and imbricated. Receptacle flat, naked. Akenes linear, terete, 5 -striate or ribbed (the ribs mostly broad and low, separated by narrow grooves), often tapering at summit, but not truly beaked, the callus at base hollowed at the insertion. Pappus of copious barely scabrous capillary bristles, either rather soft or rigid, dull white or sordiu, persistent. - Low perennials (rarely annuals or biennials), pale and ghabrous; with slender and rather rigid either rush-like or divari-

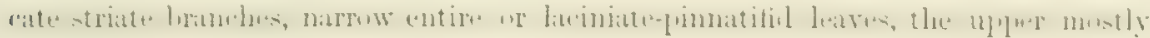
reduced to subulate scales or bracts, and small or middle-sized beads of rose-colored flowers. - Benth. \& Hook. Gen. Pl. ii. 530; Gray, Proc. Am. Acad. ix. 217.

A genus of fivo or six species, natives of the dry interior region, except that one species inhabits Texas and Florida ; in the flowers and general aspect resembling s'cphlenomeria, but with a simple scabrous pappus. One species has been collected just within the borders of the State: another approaches so nearly that it may claim admission.

1. L. juncea, Don. Perennial, copiously and corymbosely branched from the hase, abunt a loot high, rigid: lower leaves linear-subulate, an inch or two in length, entire, the upper all reduced to little scales or bractlets: heads 5 -Howerm, half an inch long, erect at the summit of the simple branchlets: ligules oblong: pappus fine anl soft.

Unionville Valley, Nevada (Wralson), thenco eastwarl to the Mfissouri River. Inroluere of equal seales and a fow calyeulnte ones at base, as in all the species except the next.

2. L. spinosa, Yutt. Perennial, or possibly bienuial, the root or emwn surmomnted by a dense tuft of wool: stems divergently and often tortuonsily much branched, rigitl, nuel the branches spinesent: lower leaves linear, entire or slightly

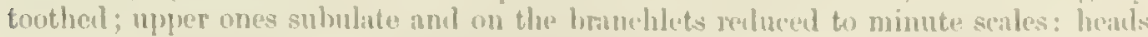
3-5-flowered, small, on shurt lateral peluncles or spurs: involucte of few unequal 
and imbricated scales, the lowest ovate, the upper successively longer and oblonglanceolate: pappus of rather rigid light-brownish bristles.

Gravelly hills, or in sand, Mono Lake (Bolander), and through the western part of Nevada, near the northern borders of which it was first collected by Nutiall.

\section{LACTUCA, Tourn. LetTuCe.}

Head few-many-flowered. Involucre cylindraceous or sometimes campanulate, seldom thickened at base; the scales thinnish, in two or few series, the outer shorter. Receptacle flat, naked. Akenes flat, from broadly oval to lanceolate, the sides fewseveral-ribbed, the apex contracted and commonly prolonged into a beak, its summit abruptly dilated into a disk which bears the (usually bright white) copious pappus of very soft and fine uniform and merely denticulate capillary bristles, falling separately. — Leafy-stemmed herbs, glabrous, or with some bristly hairs, with paniculate middle-sized heads of yellow or blue flowers. - Benth. \& Hook. Gen. Pl. ii. 524. Lactuca \& Mulgedium, Cass., DC., Torr. \& Gray, FI. ii. 495, 497.

A large genus in the Old World, represented by a few species in North America; but no genuine Lactuca (with broad and flat akenes and long filiform beak) is known on the Pacific side of the continent. The only Californian species being intermediate between true Lactuca and Mrulgedizm, it is the more expedient to follow Bentham in suppressing the latter genus.

1. I. pulchella, DC. A foot or two high, wholly glabrous: stem commonly simple, leafy, bearing a loose and naked panicle of several or numerous rather large heads: leaves pale, from oblong-lanceolate to linear, either entire, runcinately fewtoothed, or sparingly pinnatifid: pedicels scaly-bracteolate : involucre cylindraceous, 20-30-flowered, the onter scales suceessively shorter: corollas blue: akenes oblonglanceolate, rather thick-edged, several-ribbed on each face, minutely scabrous, tapering into a rather long stont beak, the upper part of which is pale and less firm in texture. - L. integrifolia, Nutt. Gen. Sonchus pulchellus, Pursh. S. Sibiricus, Richardson, not of Linn. Mulgedium pulchellum \& heterophyllum, Nutt.

Eastern part of the Sierra Nevada, north to Oregon, and east nearly to the Mississippi. Heads three fourths of an inch long. The root is apparently biennial or annual.

L. LEUCOPHEA (Sonchus 7cucophous, Willd., and Mulgedrum leucophocunn, DC.) extends across the continent from New England to the coast of Oregon, and may oceur in northern California. It is a tall and coarse species, known by its runcinate leaves, ample panicle of rather small heads of pale blue or whitish flowers, rusty-colored pappus, and beakless akenes having only a short neck.

\section{SONCHUS, Linn. Sow-ThISTLE.}

Head many-flowered. Involucre fleshy-thickened at base, ovoid, conical, or campanulate; its scales more or less imbricated, the outer shorter. Receptacle flat, naked. Akenes compressed, oval or oblong, several-many-ribbed or nerved, destitute of a beak or neck and of a dilated pappus-bearing disk. Pappus of copious very fine and soft white capillary bristles, most of them somewhat united at base so as to be deciduous together, a few separate and stronger ones sometimes less deciduous. - Leafy-stemmed and mostly glabrous herbs, generally of coarse aspect, with somewhat corymbose or panicrlate heads of yellow flowers. Probably none of them indigenous to this country, but the first and second species, the common annual Son-Thistles, are weeds almost all over the world.

1. S. oleraceus, Linn. Two or three feet high : leaves runcinate-pinnatifid or rarely undivided, beset with short and soft spiny teeth, clasping by a heart-shaped base with acute auricles: akenes nimutely rugose-scabrous.

Waste grounds around dwellings; but no Californian specimens yet seen. 
2. S. asper, Villaw. Tike the preceling or taller : leaves mure strunty and

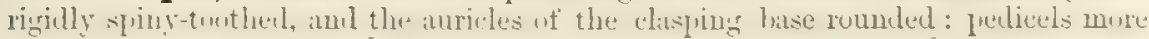
commonly glandular-bristly: akenes sharp-elged, smooth.

Waste zlaces, not only around towns but also far in the interior.

3. S. tenerrimus, Linn. Silenter: lalves pimately parted, mainly into linear

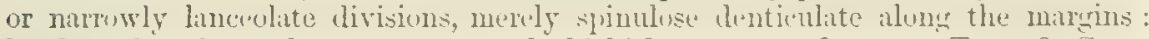
heads rather few: akenes narrow and thickish, rugose-scabrous. - Torr. \& Gray, Fl. ii. 500. S. tenuifoline, Nutt, in Trans. Am. Phil. Soc. n. ser. vii. 438.

Around San Diego, Nuthall. Doubtless introduced from the south of Europe. Apparently not since collected.

\section{ORDER LII. LOBELIACE两.}

Iferhs, mostly with milky juice, alturnate simple leaves, and seatterent or meemose flowers, the calyx adnate to the whole or the lower half of the ovary, and

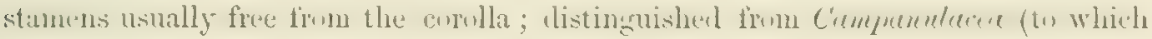
the order is now commonly reduced) by the irregnlar corolla and both monadelphous and (usually) syngenesious stamens, - Flowers perfect. Limb of the calyx divided down to the ovary into 5 lobes. Corolla inserted just where the calyx separates from the ovary, variously lobed or cleft; the lobes valvate or lightly imbricated in the bud, two of them usually different from the others in size or shape and union, sis that the limb appears bilathiate. Sitame 5 , alternite with the lobes of the corolla : filaments united into a tube above the base and commonly to

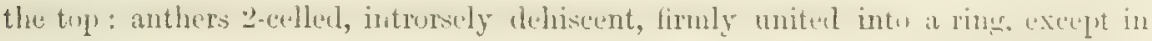
the anomalous Nemacladus. Ovary 2-celled with axile, or 1-celled with parietal placente: ovules numerous, anatropous: style entire: stigna commonly 2-lobect and girt with a ring of hairs. Fruit in ours a many-seeded capsule. Embryo small in the axis of fleshy albumen. Juice more or less acrid.

The large and willely distributed genus Lobclia (of about 200 species) is strangely ahsent from Califormia and the whole Pacific North Americau coast; but it is sparingly represented by onc Luerentia, which diffors in not having the tube of the corolla split down one (the apjurently "1pper) side - See Appondix.

TrIBE I. LOBELIEE. Anthers as well as filaments united around the style. Corolla as it were 2-lipped, two of the lobes smaller and more separated from the other united three, ereet or divergent.

1. Laurentia Corolla with a rather long cntire tube. Capsule 2-ralved across the top.

2. Downingia Corolla with very short entire tubo. Capsule linear and clongrted, opening down the sides by one to three long fissures, one-celled.

Ture II. CYPHIEE. Anthers separate, and filnments partly so.

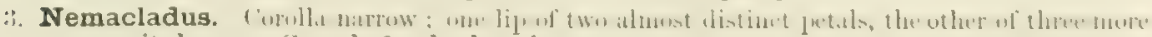
united ones. Capsule 2-valved at the top.

\section{LA URENTIA, Micheli.}

Calyx-tubo and alnato ovary top-shaped or oblong; the 5 lubes narrow. Corulla with tube as long as the limb, not split down; its lamger and 3-cleft lip wilely spreading; the smaller of 2 more erect or diverging divisions. Filunents and anthers completely united; two of the latter minutely bristle-tufterl at tho apex, nearly included. Stigma unore or less 2-lubed. Cipsule 2-valved across the projecting freo apex, 2-celled. Seeds oblung or almest fusiform. - Luw and dilluse or 
creeping small herbs, resembling Lobelias, with axillary blue flowers. - Benth. \& Hook. Gen. Pl. ii. 549.

1. I. carnosula, Benth. A glabrous diffusely branched or spreading annual, somewhat succulent, 2 to 5 inches high : leaves sessile, oblong-linear or lanceolate, entire, a quarter to half an inch long: peduncles filiform, even the lower much longer than the leaves, the upper becoming corymbose or racemose: lobes of the calyx linear, foliaceous, about the length of the obconical tube and fully equalling that of the corolla : larger lip of the latter deeply 3-cleft into roundish-obovate lobes, bright blue, with the 2-ridged palate yellow or whitish; the smaller lip of 2 lanceolate lobes. - Lobelia camosula, Hook. \& Arn. Bot. Beechey, 362, where the undivided corolla-tube is unnoticed. Porterella carnulosa (by misspelling), Torr. in Cat. Pl. Hayden Rep. 1872, 488; Parry in Am. Nat. viii. 177.

Low and muddy places, in Sierra and Indian Valleys (Lemmon) ; thence northeastward to Wyoming Territory. A pretty little plant, in aspect and flower resembling the next genus, and the corolla in vigorous specimens not much smaller; known at once by the short and broad capsule opening at the top. The late Dr. Torrey dedicated it to Prof. Thomas C. Porter, one of the authors of the Flora of Colorado Territory; but it proves to belong to a very old genus, chiefly of the Mediterranean region and Southern Africa.

\section{DOWNINGIA, Torr.}

Calyx-tube and adnate ovary very long and slender, stalk-like, 3-sided, usually twisted; its limb divided down to the ovary into 5 lanceolate or linear foliaceons lobes. Corolla with a very short but entire tube, and a bilabiate limb; the smaller lip of two narrow recurved or spreading divisions, the other very broad and 3-lobed. Filaments and anthers both united into a somewhat curved tube: two of the latter bristle-tipped. Capsule very long and slender, early becoming 1-celled, with two parietal filiform placentæ, remaining closed at the apex, but the sides dehiscent by two or three long fissures. Seeds as in the foregoing genus. - Low and spreading glabrous annuals (of Oregon and California, and a third species in Chili), rather succulent or tender; with sessile and narrow entire leaves, the upper ones reduced to bracts, and axillary sessile flowers; the corolla deep blue with a white or yellowish centre. - Torr. in Pacif. R. Rep. iv. 116; Benth. \& Hook. I. c. Clintonia, Dougl., not of Raf.

Under the name of Clintomio our two species have come into cultivation as ornamental annuals, but are rather difficult to manage. A new name being required, Dr. Torrey dedicated the genus to the memory of his friend, the late Andrew Jackson Downing, of New York, whose treatise upon landscape gardening and other horticultural and arboricultural writings are still of sterling value.

1. D. elegans, Torr. Leaves acute, varying from ovate to lanceolate: smaller lip of the corolla of two lanceolate divisions, the broad lip moderately 3-lobed, its centre a broad white spot. - Clintonia elegans, Lindl. Bot. Reg. t. 1241.

Northern part of California, and through Oregon. C. corymbosa, A. DC. Prodr. vii. 347, is a stouter and more leafy-stemmed variety, the ovary little longer than the subtending leaf. Ordinarily the slender and stalk-like ovary or capsule is over an inch in length, and the upper floral leaves so small that the inflorescence is like a raceme.

2. D. pulchella, Torr. Very like the foregoing, but the leaves mostly narrower and obtuse: the two divisions of the smaller lip ovate-lanceolate or oblong, the larger lip much dilated and deeply 3-lobed, intensely azure-blue with a large white or yellowish centre. - Clintonia pulchella, Lindl. Bot. Reg. t. 1909 ; Sweet, Brit. Fl. Gard. ser. 2, t. 412.

Valley of the Sacramento to Oregon and Nevada. Plant 3 to 6 inches high, rather moore fleshy, weak. Both species inhabit moist or wet places. 


\section{NEMACLADUS, Nutt.}

Calyx-tube short, obconical, adnate to the lower half of the ovary; its limb parted into 5 unequal lobes. Corolla short, 5-parted, or the two petals forming the lower lip often distinct to the base, and longer than the three which form the 3-parted or 3-lobed upper lip. Filaments monalelphous above the middle: anthers distinct, surrounding the stigna, oval, glabrous. Style slender, its apex incurved, a little shorter than the anthers: stigrua capitate, 2-luberl, sulutemuled ly an obsulete maked ring. Ovary 2-celled : ovules $10-18$ in each cell. Capsule about two thirls superior, ovoid, loculicidal from the top. Seeds oval. - Nutt. in Trans. Am. Phil. Soc. n. ser. viii. 254; Torr. Bot. Mex. Bound. 108, t. 35; Gray in Jour. Linn. Soc. xiv. 28, where the relationship to Cyplia (of S. Africa) is indicated. - A single species.

1. N. ramosissimus, Nutt. 1. c. Slender annual, about a span high, "lactescent," widely and at length excessively branching: branches filiform, zi zzag: radical leaves oval and toothed, tufted; cauline ones all minute, linear or subulate, subtending the branchlets and the racemose capillary naked peduncles : flowers minute (a line or two long): corolla flesh-color, the two longer divisions spatulate-oblong, the three others rather broader: seeds oval.

Sanily ol gravelly open places; common through the Sierra Nevada and its foot-hills; thenee east to New Mexico.

\section{Order LIII. CAMPANULACEA.}

Herbs, with milky juice, alternate leaves without stipules, and regular flowers, having the calyx alnate to the oviry, distinct stanens (5 or rarely $t$ ) inserted with but hardly upon the corolla, alternate with its lobes, these valvate in the bud; the fruit a many-seeded 2-5-celled capsule. - Calyx persistent. Stamens earlier than the stigmas; the 2-celled introrse anthers opening in the bud before the corolla expands. Style single, its upper portion beset with collecting hairs upon which the pollen is largely deposited; its summit $2-5$-lobed or cleft; the stigmas being the papillose inner face of these lobes, which connive until some time after the corolla expands. Ovary 2-5-celled (rarely imperfectly so), with the placentre in the axis. Ovules numerous, anatropous. Capsule usually openiug by valvas or holes at or near the top. Seeds small, with a straight embryo in Heshy albumen. - Flowers

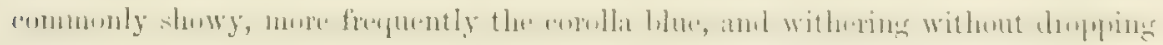
off : influrescence for the most part centrifugal, the terminal flowers opening fist.

There are a fow foreign genera with baceate fruit, and one with connate anthers. A rnther small fumily, mainly of temperate regions, sparingly represented in North America, and as indi-

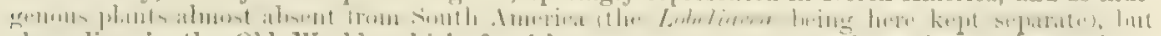
abounding in the Ohl World, which furnishes numerous ornamental species to the gardeus. Utherwisu the order is without ecoumical importance or known netive qualities.

- Ovary and capsulo long and uarrow, or at lenst oblong.

1. Githopsig. Capsule opening at the top by a hole left by the filling away of the base of the style, between the long and leafy calyx-lobes.

2. Specularia. Cupsule opening on the sides by 2 or 3 little valves which leave suall round perforations.

- Ovary and capsule short nud broad or gluhulur.

3. Heterocodon. Thin walls of the copsule bursting indefinituly between the ribs. Calyxlohes very livond.

4. Campanula. Capsule opening on the sides by 3 to 5 smull valves leaving delinite romul perforations. C'alyx-lobes nartow. 


\section{GITHOPSIS, Nutt.}

Flowers all alike. Calyx with a clavate 10-ribbed tube, and 5 long and narrow foliaceous lobes. Corolla tubular-campanulate, 5-lobed. Filaments short, dilated at the base. Ovary 3-celled: stigmas 3. Capsule clavate, of firm texture, strongly ribbed, crowned with the rigid calyx-lobes of its own length or longer, opening between them by a round hole left by the falling away of the base of the style. Seeds very numerous, between oblong and fusiform, smooth. - The calyx with its long leafy lobes resembles that of Lychnis Githago, whence the generic name. A single, but variable species, published by Nuttall in Trans. Am. Phil. Soc. n. ser. viii. 258.

1. G. specularioides, Nutt. Low, annual, an inch to a span high, either almost glabrous or more commonly (the var. hirsuta, Nutt.) the stems or the whole herbage beset with short spreading hairs: leaves lanceolate-oblong or linear, sessile, coarsely toothed: flowers terminating the stem and few branches, slightly peduncled, erect: corolla deep blue, usually with a white centre, either shorter or moderately longer than the narrowly linear and rigidly 1 -nerved (rarely few-toothed) calyx-lobes; its lobes ovate: capsule rigid, either sessile or tapering gradually into a thick and rigid peduncle. - G. calycina, Benth. Pl. Hartw. 321, a form with short corolla and long calyx-lobes. G. pulchella, Vatké, in Linnæa, xxxvii. 714, the form with longer corolla.

Open and low grounds, common through the western portion of the State, extending east to the foot-hills and north to Oregon.

\section{SPECULARIA, Heister.}

Flowers all alike, or in the American species dimorphous; i. e. some of the earlier ones smaller and with merely rudimentary corolla which never opens, close-fertilized in the bud; these with calyx-lobes mostly only 3 or 4 . Later are flowers with fully developed corolla, \&c. Calyx-tube prismatic or elongated-obconical; the lobes 5, narrow. Corolla short and broad, wheelshaped when fully expanded, 5-lobed. Filaments short. Ovary 3-celled, or sometimes 2-celled: stigmas as many. Capsule more or less elongated, opening by 2 or 3 small lateral valves which leave a round or oval perforation, usually over a partition. Seeds numerous, ovoid, or rounded and flattish, smooth. - Annuals; with sessile or clasping cauline leaves, and terminal and axillary blue or purple flowers. (Dysmicodon and Campylocera, Nutt. 1. c.)

1. S. biflora, Gray. Stems slender: leaves closely sessile, ovate or oblong, somewhat crenately toothed, the upper gradually reduced to lanceolate bracts, which are at length shorter than the flowers they subtend: flowers one or two in each axil, nearly sessile; the lower ones mostly with a calyx of 3 or 4 ovate or subulate short lobes and no developed petals; the upper and later ones with 5 longer lanceolate-subulate calyx-lobes, which are shorter than the developed corolla: capsule oblong-cylindraceous or obscurely prismatic, inconspicuously ribbed, the valvular openings just below the summit: seeds lenticular.-Campanula biflora, Ruiz \& Pav. Fl. Per. ii. 55, t. 200, f. 6. C. Montevidensis, Spreng.? C. Ludoviciana, Torr. Dysmicodon Californicum \& ovatum, Nutt. in Trans. Am. Phil. Soc. n. ser. viii. 257.

Open grounds, near towns and settlements along the coast : perhaps introduced, both here and in the Southern Atlantic States, from S. America. A span to a foot or more in height, simple or with few branches, glabrous, except usually a line of minute and stout bristles turned backwards which roughen the angles of the stem and sometimes of the calyx-tube, also on the margins and yeins of the leaves. The principal stem-leaves only half an inch long. Fully 
developed corolla half an inch broad. Capsules about 4 lines long. Intermediate in appearance between S. falcala, A. DC., of the Old World, and S. perfolinta, with which Alph. De Candolle and others have confounded it; but quite distinct from both. The name is not a happy one: but there are frequently two flowers in each axil, one later than the other:

2. S. perfoliata, A. DC. Stouter, a span to two feet high, simple or with sim-

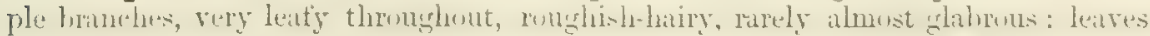
clasping, round-cordate, crenate: Howers sessile in the axils, often clustered, of two kinds, as in the preceding species: capsule oblong or slightly clavate; the valvular openings as low as the middle.

Open grounds, Plumas Co. (Lemmon) to Oregon, and common through the Atlantic States; also in Mlexico.

\section{HETEROCODON, Nutt.}

Flowers of two sorts; the lower and earlier ones with merely madimentary corolla and fertilized in the bud. Calyx with obovate or inversely pyramidal tube much shorter than the foliaceous lobes; these are broally ovate, sharply toothed, veiny, 3 or 4 in the earlier, 5 in the later flowers. Corolla short-campanulate, 5-lobed. Stamens and style as in Campanula. Capsule 3-celled, 3-angled, very thin and membmnaceons, the delicate walls bursting indefinitely on the sides. Seeds numerous, oblong, olssenrely triangular. - Nutt. 1. c. viii. 255. A single species.

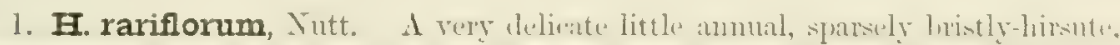

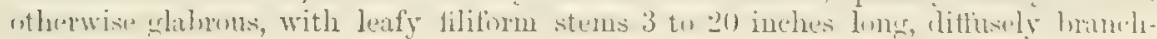
ing: lenves rounded and with cordate base, partly clasping, acutely and coarsely many-toothed, thin, 3 to 6 lines wide: flowers terminal becoming lateral, also axillary, solitary, sessile: calyx-lobes foliaceous, 1 to 3 lines long, rather shorter than the well-developed pale blue corolla, mostly longer than the capsule, the sides of which give way vaguely in age, but not by halves.

Shady and grassy places, from Napa Co. and Mariposa Co. (at 4,000 feet) to Oregon : also collected in the mountains of Nevada. Reduced by Benthan and Hooker to Campenula, but better kept up.

\section{CAMPANULA, Tourn. BellFlowerm}

Flowers all alike. Calyx-lobes narrow. Corolla campanulate or near it, 5-lobed or 5-cleft. Stamens 5: filaments dilated at base. Capsule short, 3-5-celled, opening on the sides or near the base by 3 to 5 small uplifted valves leaving round per-

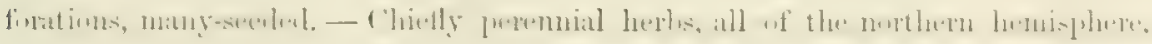
many with showy flowers; the infloreseence centrifugal or irregular.

The fow Californinn (indeed all the North American) species are blue-flowered, destitnte of any appendages between the calyx-lobes, and the stigmas and cells of the capsulo only three.

\section{* Stem-leaves all linear or lanceolate and entire.}

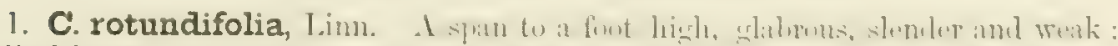

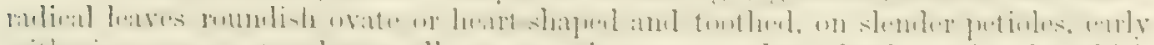

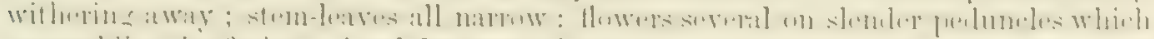

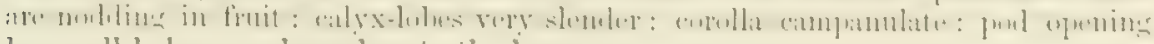
hy small hules or valves close to the base.

This, the common species round tho northern hemisplhere, oceurs near the borlers of the State north aud enst, and doubtless within the limits, growing in erevices of rocks, in shaty places. Tho corolln varies from hatf an inch to an inch in length.

* * Stem-lenves ounte or oblong-lanceolate, tonthed: copsules apparently not itrooping in fruit, and oprening by holes above the base. Species peculiur to Culifomia, except the first, which extends northuards. 
2. C. Scouleri, Hook. A foot or so high, glabrous or slightly pubescent : stems slender, Jranching, spreading, praniculately several-flowered: leaves generally all sharply serrate and acumiuate, mostly tapering below into a petiole, the lower ovate and sometimes almost entire, the upper ovate-lanceolate, or the uppermost narrower : flowers long-pedicelled: calyx-lobes slender-subulate, a little shorter than the open carnpanulate 5-cleft corolla, the lobes of which are ovate-oblong: style exserted. - Hook. Fl. t. 125.

Indian Valley, Plumas Co. (Lemmon) to Oregon and British Columbia. A broad-leaved form. Corolla 4 lines long, cleft to rather below the middle, the bud oblong.

3. C. prenanthoides, Durand. A foot or two high, roughish-pubescent or glabrous: stems clustered, rather simple, racemosely or paniculately several-flowered: leaves very sharply and mostly coarsely serrate, ovate-oblong or lanceolate, acute; those of the stem mostly sessile, or the lower short-petioled: pedicels shorter than the flower: calyx-lobes slender-subulate, usually much shorter than the corolla, the narrowly lanceolate wiclely spreading lobes of which are 2 to 4 times the length of the tube: style long-exserted. - Pl. Pratten. in Jour. Acad. Philad. n. ser. (185.5) ii. 93; Grar, Proc. Am. Acad. vii. 366. C. filffora, Kellogg, Proc. Calif. Acad. ii. 5. C. Roezli, Regel, Animad. Pl. Hort. Petrop. 1872, 6.

In redwoods, from Santa Cruz to Mendocino Co., and through the foot-hills up to Sierra Valley. Corolla 5 to 8 lines long, narrow, cylindrical before expansion. Capsule with broad and retuse base and 5 salient ribs.

4. C. linnzeifolia, Gray, l. c. Glabrous, but margins of leaves and angles of stem retrorsely hispid-scabrous: stems weak, a span or two high, simple, or corymbose at summit, single- or few-flowered: leaves oval or ovate-oblong, mostly obtuse, erenate, all but the lowest sessile: peduncle as long as the flower: calyx-lobes broadly lanceolate, acute, about half the length of the bell-shaped corolla, the lobes of which about equal the tube and are commonly retrorsely hispid-ciliate: style included. - Wahlenbergia Califonnica, Kellogg, Proc. Calif. Acad. ii. 158, f. 49, judging from the figure.

In swamps at Noyo, Mendocino Co., Bolander. Leaves 4 to 9 lines long. Corolla half an inch long. A delicate and peculiar species.

C. UxIFLonA, Linn., a very low one-flowered species, with narrow leaves, extends from the arctic regions along the higher Rocky Mlountains to Colurado, and to those of Utah at 11,000 feet: it may occur on the higher summits of the Sierra Nevada.

\section{ORDER LIV. FRICACE丑.}

Woody plants, or in the later suborders perennial herbs, with symmetrical and mostly regular flowers; the stamens as many or twice as many as the petals or lobes of the corolla, and inserted with, but hardly ever upon it; the anthers 2-celled, and the cells opening by a terminal pore or chink; the pollen of 4 united grains (except in Monotropece); the ovary with as many cells as the divisions of the corolla or calyx; the seeds small, and with small or minute embryo in copious albumen. Corolla generally gamopetalous, sometimes of distinct petals, imbricated or rarely convolute or valvate in the bud, the insertion and that of the stamens hypogynous, or when the calyx is adnate epigynous, around an annular disk. Style single: stigma not rarely girt with a naked ring. Ovary with as many cells as the petals or rarely one or two fewer : the placenta in the axis, with one exception. Ovules anatropous. Leaves simple, commonly alternate, in some opposite, rarely in whorls, articulated with the stem, destitute of stipules.

A large and important order, of wide distribution, wery sparingly represented in California, but it claims several of the most striking shrubs. Although generally inert, and the fruit when 
baccate esculent, or at least innocent, yet the leaves of some (such as Bearberry) are used in medicine, and others are reputed poisonous to eattle; while the honey made from the blossons of Rhododcudron and Azalea has from early times a bad reputation. Very many are prized in cultivation for their showy lowers.

\section{Scborder I. VACCLTIE.E.}

Corolla and stamens epigynous, i. e. raised to or near the summit of the ovary, the calyx-tulue being aduate. Fruit a berry, crowned with the vestiges of the calyxteeth. - Slirulby plints, with scaly leaf-buds. To this heloner the Huckleberries of the Atlantic States, the Llueberries, Lilberries, and Cranberries, all of the genus,

1. Vaccinium. Calyx 4-5-toothed on the summit of the ovary. Stamens 8 or 10. Berry many-seeded.

\section{SUBORDER II. ERICITEE.}

Corrolla gamopetalons, or rarely of distinct petals, and with the stamens hypogrnous, the calyx bing free. Anthers introrse in the bud. - Shrubloy plants or small trees.

* Fruit fleshy, a berry or a berry-like drupe : corolla 5 -toothed, deciduous.

2. Arbutus. Ovary 5-celled, many-ovuled. Berry many-seeded.

3. Arctostaphylos. Ovary 5-10-celled, with a single ovule in ench eell. Drupe 5-10. seeded or by abortion fewer.

* * Fruit a capsule enclosed within a fleshy calyx, seening like a berry.

4. Gaultheria. Corolla 5-toothed or 5-lobed. Ovary 5-celled, 5-lobed.

* * * Fruit a naked capsule, the calyx remaining dry underneath. Corolla deciduous.

+ Anthers with points or awns : eapsule loculicidal.

5. Leucothoe. Corolla with a narrowed 5-toothed orifice. Leaves petioled.

6. Cassiope. Corolla open-campanulate, 5-lobed. Leaves scale-like or Heath-like, sessile, imbricated.

+ + Anthers lestitute of points, awns, or other appendages : capsule septicidal.

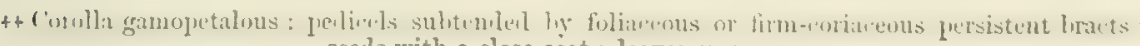
seeds with a close coat : leaves evergieen.

7. Bryanthus. Leaves Heath-like. Corolla without pouches.

8. Kalmia. Leaves broad. Corolla with 10 pouches lolding tho anthers.

+++ Corolla gamopetalous: pedicels subtended by thin scarious bracts, forming a scaly bud, these deciduous when the flowers develop: seed-cont loose.

9. Menziesia. Corolla globular-campanulate, 4-toothed. Leaves deciduous.

10. Rhododendron. Corolla funuelform or campanulate, 5-lobed.

$++4+$ Corolla 5-petalous: seed-coat loose.

11. Ledum. Leares brond. Flowers in an umbel: scaly bracts deciduous.

\section{Suborder III. PYROLEE.}

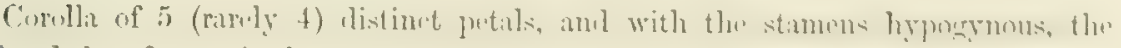
calyx being free. Anthers extrorse in the bud, the pores downward, introrse in

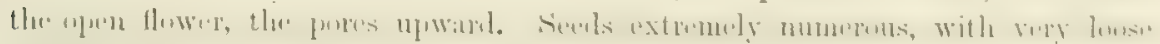

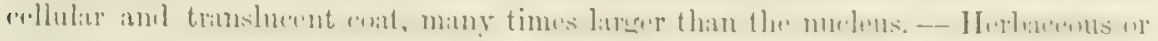
nearly herbaceons and broad-leaved low perennials, one species lenfless.

12. Chimaphila. Flowers in a corymb or unbel on a leafy stem. Potals widely spreading. Stylo vory short, top-shaped: stigma hroad and orhieuliur, peltate.

13. Moneses. Flower solitary on a scalne. Petals widely sprending. Stylo straight: stignn 5-rived.

14. Pyrola. Flowers in a racomo on a scrpe. Putals not widely spreading. Stylo long : stignu villiults. 


\section{SUBORDER IV. MONOTPOPEE.}

Corolla and stamens hypogynous. Pollen-grains simple. Capsule loculicidal. Root-parasitic scaly-bracted herbs, wholly destitute of green foliage, rather various in structure, by some of the genera intimately connected with Ericinece and Pyrolece; the last-enumerated genera anomalous in placentation. (Order Monotropece, Benth. \& Hook. Gen. Pl.)

* Ovary and capsule 4-5-celled, with placentæ in the axis adnate to a thick central column. $\div$ Corolla wanting.

15. Allotropa. Calyz of 5 sepals. Anthers extrorse in the bud, introrse in the developed flower, in the manner of Pyrola: the cells opening down to the middle.

* + Corolla gamopetalous : calyx complete, of 5 sepals : anthers not reversed.

16. Pterospora. Flowers racemose. Corolla globular-ovate, the short lobes recurved. Anthers 2-awned on the back in the manner of many Ericinece.

17. Sarcodes. Flowers in a thick scaly spike. Corolla campanulate, the lobes erect. Anthers not appendaged.

+ ++ Corolla $4-5$-petalons, and calyx incomplete or bract-like, both deciduous : anthers horizontal or peltate, opening transversely : disk 8 -10-tootled.

18. Monotropa. Flowers solitary or racemose, nodding, the fruit upright.

* * Opary and capsule 1-celled, or spuriously 4-5-celled by the meeting of parietal placentre: no central column : anthers ereet, unappendaged ; the cells opening lengthwise into 2 valves.

19. Pleuricospora. Flowers spicate. Sepals and petals each 4 or 5, fimbriolate-lacerate. Anthex's linear. Ovary and eapsule 1 -celled, with 4 or 5 bilamellate placentæ. Seeds ovoid, with a close and thin shiming coat.

20. Newberrya. Flowers capitate. Sepals 2, bract-like. Corolla gamopetalons, tubular-urnshaped, $4-5$-lobed. Anthers oblong. Ovary with 4 or 5 two-parted placentæ uniting more or less around the open centre.

\section{VACCiNiUM, Linn. Cranberry, Bilberry, \&c.}

Corolla epigynous, various in shape. Anthers with the two cells separate, tapering upwards into a tube and opening by a hole at the apex. Style long: stigma simple or more or less capitate, without a ring. Fruit a many-seeded berry crowned with the vestiges of the 4 or 5 small teeth of the calyx. - Gray, Chlor. Bor. Am. 52, \& Man. Bot. Northern U. S.

The species abound in the eastern and more northern parts of North America, but are few indeed in California (none of the eastern Blucberry type), and all except one rare. Yet the following eastern species may perchance be found along the northern borders of the State or at great elevations.

V. Oxrcoccos, Linn., Small Cranberry, which is found round the world farther north, may occur in the higher northern parts of the Sierra Nevada; but we have seen no specimens from even so far south as Puget Sound.

T. Macrocarpon, Ait., Large Cranberry, of the Atlantic side of the continent; said in Hooker's Flora to be "plentiful in swampy grounds near the confluence of the Columbia with the Pacific, where its berries are boiled and eaten by the natives under the name of Soolabich, Douglas." Attention is called to this, as no one has since met with this or any other Cranberry in Oregon.

V. CÆঙSPITOSUM, Michx., a very dwarf species, with deciduous obovate leaves, and blue berries, oceurring on the mountains in the northeastern part of Nevada and in Oregon and northward, extending to Labrador.

* Leaves deciduous: anthers with a pair of long awn-like appendages on the back: corolla short, white or flesh-color.

+ Flowers solitary in the axils on a recurved peduncle.

1. V. parvifolium, Smith. Shrub much branched, 1 to 6 feet high, glabrous: branches and branchlets sharply angled: leaves oval or oblong, very obtuse at both 
ends, nearly entire, dull, very short-pretidenl, pale beneath : caly 5 -lubed : corrllit globular, 5-toothed: stamens 10 : berries pale red, insipid. - Hook. Fl. ii. 33, t. $12 \mathrm{~s}$.

Redwoods, \&c., Mendocino Co., Bolander. Common from Oregon to Sitka Leaves from a third to a full inch long.

2. V. ovalifolium, swith. I more strughling shruh, with terete hrunches, larger and more veiny leaves, ovoid corolla, and large edible blue berries. - Huok. l. c. t. 127 .

Coinmon in Oregon, and extending to Lake Superior; commonly associated with $V$. parvifolium, and therefore probably reaching the northern part of the State on the const.

3. V. Myrtillus, Limo. Low unlershruh, flabrus, with sharply angled gresen branchlets: leaves ovate or oval, bright green and usually shining, veiny, serrate, very short-petioled: border of the calyx almost entire: corolla between globular and campanulate, 5-toothed, sometimes 4 -toothed: stamens 10 or 8 : berries blueblack when ripe. - Our plant is wholly the

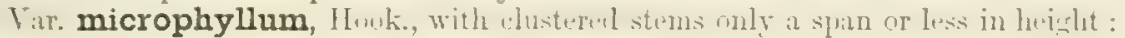
leaves from the sixth to barely half an inch long: flowers only about 2 lines long: berries accordiag to Watson (Bot. King Exp. 210) light red. But in the Rocky Mountains and in Oregron the berries are dark-eolored, and the parts all larger, yet not equalling the European Bilberry in size of foliage, fruit, \&e.

Wet places in the Sierra Nevada, at 7,000 feet (JIariposa Co., Gray), thence northward, and castward at high elevations.

\section{++ Flowers 2 or 3 or solitary from a separate scaly bud, short-peduncled.}

t. V. occidentale, Gray. Low shrub, glabruus: leaves thinnish, dull and pale buth sicles, from oval to obovate-oblong or oblanceolate, entire, acutish or

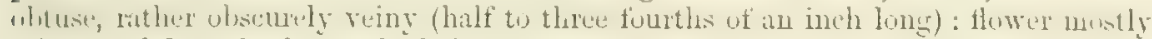
solitary : lobes of calyx and of the oblong-ovate corolla 4 : berry small, 2 or 3 lines in diameter, blue with a bloom, sweetish.

Sierra Nevada at 6,000 or 7,000 feet, from Mariposa to Sierra Co., Bolender, Anderson, Lemmon, \&:c. Mountains of Utalh, Watson.

V. ULigisustim, Linn., the Biberry of Europe, \&c., from Oregon northward, has rounder leaves couspicuously reticulated beneath, shorter and broader corolla, and berries much larger.

* * Leaves evergreen and coriaceous: parts of flower in fives and the stamens 10 : anthers not awned on the back.

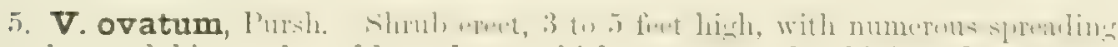
branches and hisute branchlets: leaves thick, very smooth, shining above, ovatu varying to oblongr-lanceolato, acute, serrato with rigid small teeth, sbort-petioled: flowers crowled in very short and numerons axillary and terminal meemes: corollit campanulate, pink: calyx-teeth as long as the 5-celled ovary: berries dark purplo turning black, without a bloom. - Linll. Bot. Reg. t. 135t. V. lanceolatum, DC., only a narrow-leaved form.

Along tho const range, \&c., especially in redwoods, from Monterey to Oregon. Berries edible.

\section{ARBUTUS, Tourn. ManRoNo.}

Calyx small, 5-lobed. Corolla ovato, globular, or urn-shaped, 5-toothed; tho teeth recurved. Stamens 10 , included : anthers flattened, furnishod with a pair of reflexed awns on the back below the summit; the cells opening by a terminal pore. Ovary raised on a hypogynous disk, 5-celled : avules numerous on a fleshy placenta projecting from the inmer angle of ench cell. Style mither long: stigna obtuse. Berry with a rough or gramular surfuce, maturing several seculs in each cell. Small trees or shrubs, with cvergreen and coriaceous alternate leaves, and whito or 
flesh-colored flowers in a terminal panicle or cluster of racemes. - Genus of a few species in the warm-temperate portions of the Old World, among them the Straw berry-tree, the fruit of which is eatable, two or three in Mexico, and our well-known Madroño, viz.

1. A. Menziesii, Pursh. A handsome tree, or southwards a shrub, with very hard wood, and close and smooth bark turning brownish red (the older exfoliating): leaves oval or oblong, either entire or serrulate, pale beneath, bright green above: racemes dense, minutely tomentose : corolla almost globular, white: berries dry, orange-colored (hardly eatable), with surface granulate. - Nutt. Sylv. iii. 42, t. 95 . A. procera, Dongl. in Lindl. Bot. Reg. t. 1753. A. laurifolia, Lindl. Bot. Reg. xxv. t. 67, a smaller-leaved Mexican form.

Along the coast ranges and sparingly on the foot-hills, extending north to Puget Sound, and southeastward into Mexico and Texas. In the northern coast ranges this is sometimes a magnificent tree, 80 or 100 feet high, with trunk from one to three feet in diameter. Indeed, a tree in Marin Co, north of Tamalpais, measured 23 feet in eircumference at the smallest part of the trunk below the branches, and some of the main branches were 2 or 3 feet in diameter. South of San Francisco Bay it is usually a small spreading tree or a large shrub.

\section{ARCTOSTAPHYLOS, Adanson, MaNzanita.}

Flowers like those of Arbutus (but occasionally 4-merous and 8-androus), except that the 5 to 10 cells of the ovary contain each a single suspended ovule, and the berry-like fruit a circle of 5 to 10 separate or separable bony seed-like stones, or else these cohere more or less, sometimes completely into a solid several-celled or by abortion occasionally l-celled stone. - Shrubs or small trees; with the alternate leaves coriaceous and persistent (in all but an arctic-alpine species), either entire or with a few irregular teeth; the white or rose-colored flowers in terminal often clustered racemes. —Gray in Pacif. R. Rep. iv. 116, note; Benth. \& Hook. Gen. Pl. ii. 581. Comarostaphylis, Znec. Xerobotrys \& Xylacoccus, Nutt. Daphnidostaphylis, Klotzsch.

The greater part of the species are Californian (including the Uva-ursi, which extends round the world) : their discrimination is difficult. As to the genera proposed by Zuccarini, Nuttall, and Klotzsch, mainly upon the concretion of the stones of the fruit, this sometimes takes place even in A. Uvo-ursi, and is variable in our other species. A. pungens and A. glauca, otherwise hardly distinguishable, differ greatly in this respect.

\section{§1. Drupe not warty; the flesh at maturity mealy; the stones commonly separate or separable, at least some of them, not rarely some of them united or 2-celled and 2-seeded: bracts firm and persistent.}

* Ovary and depressed-globose fruit more or less pubescent: branchlets often hispid.

1. A. Andersonii, Gray. Erect, 6 or 10 feet high : branchlets minutely tomentose when young, hispid with long and white bristly hairs: leaves thin-coriaceous, sreen and glabrous, except the bristles on the midrib beneath, lanceolate-oblong or ovate-lanceolate with a strongly sagittate-cordate base, sessile or nearly so, mucronate-pointed, mostly spinulose-serrulate (2 or 3 inches long) : fruiting pedicels about equalling the bracts: drupes reddish, much depressed, 4 or 5 lines in diameter, densely clothed with exceedingly viscid bristles. - Proc. Am. Acad. xi. 83.

In the mountains behind Santa Cruz, among redwoods (Big-tree Grove), Dr. Anderson. Filaments somewhat hirsute. Bark paler than in the Manzanitas.

2. A. tomentosa, Dougl. Erect, 2 to 6 feet high, tomentose when young, hispid with long spreading hairs on the branchlets, petioles, \&c., but these sometimes nearly wanting : leaves thick and very rigid-coriaceous, varying from oblonglanceolate to ovate and even cordate, entire, rarely serrulate, often cuspidate-mucronate, usually becoming vertical (one or two inches long): flowers in very short 
clusterul racemes (white or rose-colur), on pelicels shorter than the linets: orary hirsule: fruit red, minutely puberulent or becoming glabrous, not viscid. - But. Reg. t. 1791 ; Hook. Fl. ii. t. 130, \& Bot. Mag. t. 3220. A. cordifolia, Lindl. 1. c., a form with cordate leaves and few or no bristles. Andromeda bracteosa, DC. Xerobotrys tomentosus, argutus, \& cordifoline, Nutt. 1. c.

Dry hills, from Santa Barbara Co. northward to Puget Sound. This is a common Manzanila through the western part of the State, running into many forms as to foliage, bristles, \&ce. Fruit used for a cooling subacid drink.

3. A. nummularia, Gray. Erect, a foot or two high, nearly oliahrous, excepting long bristly hairs on the branches: leaves oval (half to two thirds of an inch long), rounded at both ends, sometimes obscurely cordate, very short-petioled, mostly entire, thick and rigid, bright green, the upper surface shining: racemes short and clustered: bracts shorter than the pedicels: ovary minutely tomentose. - Proc. Am. Acad. vii. 366.

Plains around Mendocino City, Bolunder. Very leafy: leaves like those of the Dwarf Box. Flowers small, white. Fruit unknown.

$$
\text { * * Ovary glabrous: no hispid hairs on the branches and petioles. }
$$

4. A. Uva-ursi, spreng. Prustrattr, trailinger or somewhat creeping, almust glitbrous: leaves spatulate or oblong-obovate, obtuse or retuse: flowers in small and short racemose clusters: filaments bearded: fruit red.

Doubtless in the State on the borders of Oregon and northern Nevada; thence not mre northward and matwarl, extemling rounl the world. The medicinal lece-urst, or Luerbery, amd the Kinnikinick of the Western Indians.

5. A. pumila, Nutt, Erect, dwarf, tufted, minutely tomentose-pubescent: leaves obovate-oval or oblong-obovate, obtuse, or some of them more or less mucronate-tipped, pale: flowers as in the preceding but smaller: filaments sparingly bearded or nearly naked. - A. pumila \& A. acuto, Nutt. 1. c. Daphoidostaphylis pumila, Klotzsch.

Around Monterey, Nuthall, Rich. Much resembles A. Urvo-ursi; but it is an erect shrub, about half a foot high, branching from the base and forming tufts. Leaves from half to two thirds of an inch long.

6. A. pungens, MBK. Erect or at ligh dirations procumbent, minutely cinereous-tomentose when young, or glibrous: smooth close bark brownish-red (mahogany-color): leaves commonly becoming vertical by a twist of the distinet or pretty long petiole, very rigid, often glaucous or pale, entire or occasionally denticuate with a few sharp teeth, varying from oblong-lanceolate to oval, most of them pungently mucronate-acuminate or cuspidate: flowers crowded in very short ra-

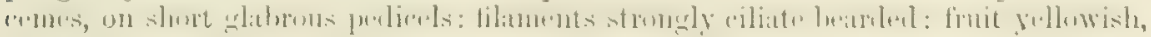
turning dull red. - HBK. Nov. Gen. \& Sp. iii.t. 259 ; Torr. in Emory Rep. t. 7. Arbutus pungens, Hook. \& Am. Bot. Beechey, 144. Anlromeda. (i) venulosa, DC. Prutr. vii. 607. Arctostaphylos IInokeri, Don. A. glauca, Watson, Bot. King Exp. 210. Xerobotrys venulasus, Nutt. 1. c.; Bunth. Pl. Hartw. 321. Daphnidostaphylis pungens \& D. Ilookeri, Klotzsch.

Dry and barren ridges everywhere, both on the const and at grent elevations, extending north

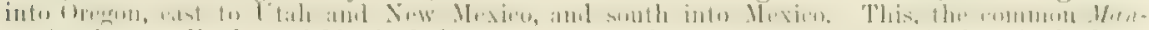
wenilu, is exceelingly variable, incluling, ns it must, the Small Manzmila, which st high olevations is proumbent, rising only a few inclses in height, and larger forms, with erect stens, tortuous brunches, se., rising to eight or ton feet in hoight; the short trunk sornetimes a foot in dismeter at hase, but lividerl nesr the ground. Some of thrse fortas, esprecinlly in the foot-hills und Siurra, with branehes nenrly or yuite ghbrous, and with brost and larger, pale or glaucous und oval or ovate lenvers, commonly destitute of the pungent tip, ne usually reforred to $A$.

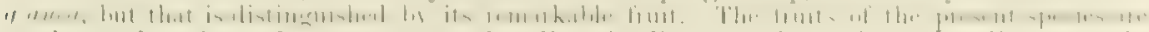

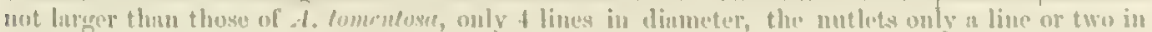

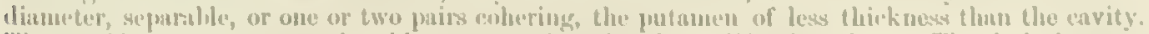

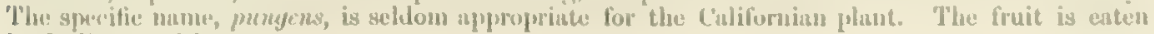
by Indius and bears. 
\$ 2. Drupe smooth and glabrous, with a solid woody or bony 1-5-celled and 1-5seeded stone in a thin pulp. - XYLococcus. (Xylococcus, Nutt.)

7. A. glauca, Lindl. Erect, 8 to 20 feet high, much branched (from a trunk sometimes a foot in diameter at the base), completely glabrous, glaucous: leaves rigid, varying from oblong to round-ovate and slightly cordate, vertical by a twist of the petiole, with or without a small mucronate tip : racemes panicled : bracts, \&c., as in the preceding: pedicels slender and minutely hirsute-glandular: filaments somewhat ciliate at base : fruit red, large; the 5-celled stone half an inch in diameter. - Lindl. Bot. Reg., a brief character in a note under t. 1791.

Dry hills, from Monterey (Douglas) to San Diego (Cleveland, \&c.). This Great-berried Manatnito is hardly to be distinguished in flower from the large and glaucesent form of the preceding, except by the glandular pedicels. But the fruit is far larger, oftener three fourths of an inch in diameter; the nutlets completely consolidated into a globose woody stone, of great thickness and solidity; the five cells all towards the centre, each with a fertile seed. While very like the preceding in aspect, it is associated with the next by the fruit.

8. A. bicolor, Gray. Erect, 3 or 4 feet high, leafy only at the end of the branches: leaves ovate-oblong or oval, thinnish-coriaceous, entire, pinnately veined, soon glabrous above and shining, whitish-tomentose beneath, as also the branchlets and the ovate chartaceous bracts of the short spicate raceme: calyx of 5 nearly distinct round-ovate imbricated sepals, somewhat colored : corolla urceolate, rose-color or tinged with red: filaments scarcely dilated at base: style long : stigma capitate. - Xylococcus bicolor, Nutt, in Trans. Am. Phil. Soc. n. ser. viii. 258.

"Near Monterey," Nuttall. Near San Diego, Dr. Cooper, D. Cleveland. Flowers in March and April. Leaves an inch or two long. Sealy spike or dense raceme barely an inch long. Fruit the size of a pea, yellow turning red, the solid stone maturiug 4 or 5 seeds, or by abortion only one.

\section{\$ 3. Drupe with a gramulate or warty surface, as in Arbutus; the cells cohering into a several-celled stone. - CoMAROSTAPHYLIS. (Comarostaphylis, Zuec.)}

9. A. polifolia, HBK. Erect, 5 to 8 feet high, glabrous: leaves linear-lanceoIate, cuspidate, pale beneath: raceme elongated; the lower bracts foliaceous, the upper becoming subulate and shorter than the slender bracteolate pedicels: calyxlobes triangular: corolla reddish: fruit dark purple, minutely warty, its stone 5-celled. - Nov. Gen. \& Sp. iii. 277, t. 258; Torr. Bot. Mex. Bound. 108.

Below San Diego, near the boundary, and in Mexico. Leaves 2 or 3 inches long, willow-like.

\section{GaUttheria, Linn. Wintergreen. Salat.}

Calyx 5-cleft, generally colored like the corolla. Corolla urceolate or campanulate, 5-toothed or 5-lobed. Stamens 10, included : anther-cells opening by a hole at the apex, each usually 2-awned or 2-pointed. Capsule 5-celled, 5-lobed, depressed and umbilicate, many-seeded, enclosed at maturity in the calyx, which enlarges and becomes fleshy after the corolla falls, and imitates a globular berry: this is eatable and aromatic-flavored. Shrubby or almost herbaceous plants; with broad evergreen leaves, and white or sometimes rose-colored flowers, mostly axillary or in axillary racemes, from scaly buds.

A rather wide-spread genus, mostly Ameriean and Asiatic, none European, of temperate regions or on mountains. The original species, confined to Atlantic North America, is the well-known Aromatic Wintergreen, G. procumbens.

1. G. Myrsinites, Hook. Very low, spreading over the ground in tufts : the slender stems and branches decidedly woody: leaves ovate or rotund (half to an inch long), the margins beset with minute more or less bristle-pointed teeth : flowers solitary in the axils of the leaves, on short 3-4-bracteolate pedicels : corolla rather 


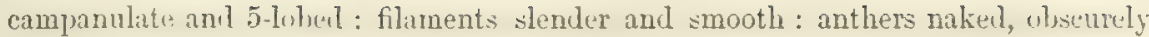
4-pointed. - Hook. Fl. ii. 35, t. 129.

In forests, near the northern borders of the State (Dr. Newberry); without much doubt also within its limits, thence through Oregon and the Rocky Mountains. The fruit scarlet, aromatic, said to be delicious.

2. G. Shallon, Pursh. Shrubby stems sprealing or ascending a fisut or tro in heidht: leates uvite or slightly corlate, acuminate (2) to 4 inches long), finely serrate (the teeth when young bristle-tipped), shining: Howers in terminal and axillary commonly panicled or compound glandular-viscid racemes: bracts scaly : pedicels recurved and 1-2-bracteolate below the middle: corolla ovate, the narrow orifice 5-toothed: filaments broad: anthers with a pair of awn-like appendages on the summit of each cell : fruit purple, becoming black. - Pursh, Fl. 284, t. 12; Hook. Bot. Mag. t. 2843 ; Lindl. Bot. Reg. t. 1411.

In redwoods, \&ce, from the Bay of Monterey to Oregon and northward. Fruit a much-esteemed article of food of the Oregon Indians, called by them Shallon according to Lewis and Clark, or at present Salcel.

\section{LEUCOTHOE, Don.}

Calyx of 5 nearly separate sepals, more or less imbricated in the bud, or very early open, not enlarging or becoming fleshy in fruit. Corolla cylindraceous or ovite, with contracted mouth and 5 short spreading teeth. Stamens 10 : filiments subulate: anthers naked, or the cells 1-2-pointed or awned at the apex, which opens by a large pore. Capsule depressed, more or less 5-lobed, 5-celled, loculicidally 5-valved, many-seeded. - Shrubs; with petioled and commonly serrulate veiny leaves, racenose influrescence, and abunlanee of white fluwers; the bracts and hractlets mostly seale-like; aml the flowers articulated with the peclicel, or this with the rhachis. - Gray, Man. Bot. 293.

Genus still somewhat uncertain in extent; the original species in the Atlantic United States; the recently-discovered Californian one a true Lencothoc, although differing in sone particulars.

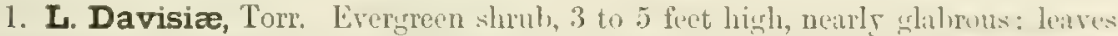

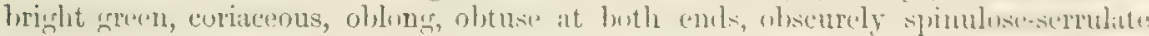
(an inch or two long): racemes slender, erect, terminal and from the upper axils, forming a cluster: flowers pendulous: bracts and bractlets at the base of the

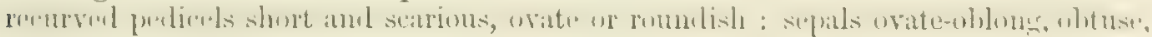
whitish: anther-cells distinct to the middle, 2-puinted at the apex. - Gray, Proc. Aro. Acarl. vii. 400.

In the Sierra Novada; near Eurcka, Nevada Co., discovered by Mriss $N$. J. Davis. Plumas Ca, Mrs. Pulsifer Ames, Lemmon. A benutiful shrub : flowers abundant : corolla 3 lines long. Fruit unknown.

\section{CASSIOPE, Don.}

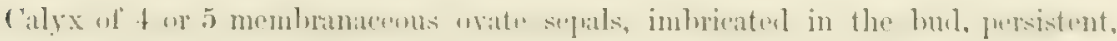
bractless. Corolla broadly campanulate, 4-5-lobed. Stamens 8 or 10, included: filaments subulate: anthers short, fixed near their apex, furnished with a pair of recurved awns at the insertion; the turgid ovoid cells opening by a large terminal pore. Stylo tapering upwards. Capsule globular, 4-5-celled, loculicidally 4-5-valvel; the valves soon 2-cleft; the large placente pentulous. Seels numerous with a close cont. - Small aretic or alpino suffrutescent everyreens, with the crowidel or imbricated fuliugo and aspect of ILenths or Club-MIsses; the white or rose-culored flowers solitury and nodiling on the anex of slender and erect naked perduncles; these surrousded by scaly bracts at their base. 
A peculiar genus of ten species, of the northern frigid regions, extending southward only along high mountains, mainly American and Asiatic, two reaching high northern Europe, five North American.

1. C. Mertensiana, Don. Branches ascending, in tufts, 6 to 12 inches high, covered throughout with the leaves, which are appressed and closely imbricated in four ranks, thick, smooth, not over 2 lines long, ovate-oblong, keeled on the back: peduncles lateral : corolla moderately 5-lobed : style rather slender. - Andromeda Mertensiana, Bongard, Veg. Sitch. t. 5. A. cupressina, Hook. Fl. ii. 38.

In the Sierra Nevada, at or above 10,000 feet, from Mount Dana to Lassen's Peak (Brewer, Bolander, \&c.); thence to Alaska, Corolla 3 lines high and 4 broad.

C. Terragona, Don, which reaches Oregon and the Rocky Mountains, is very similar, except that there is a deep groove down the back of the leaf, and the flower is rather smaller.

\section{BRYANTHUS, Steller, Gray. (Incl. Phyllodoce, Salisb.)}

Calyx of 5 or rarely 4 sepals, imbricated in the bud. Corolla campanulate and more or less deeply lobed, or ovate, and barely 5-toothed; the lobes or teeth widely spreading or recurved. Stamens 10 or 8 (rarely fewer) : filaments filiform : anthers opening by terminal oblique chinks. Style slender: stigma 5-4-lobed, or nearly entire. Capsule globular, septicidally 5 - 4-valved from the summit. - Dwarf evergreens; with woody stems thickly beset with linear obtuse Heath-like leaves; the flowers in a short raceme or umbel-like cluster from the summit of shoots of the preceding year, each pedicel from the axil of a firm foliaceous bract. - Gray, Proc. Am. Acad. vii. 367.

Consists of several arctic-alpine species. Dr. Maximowicz, perhaps with sufficient reason, would retain Phyllodoce and Bryanthus, notwithstanding our B. Brexceri, on account of the 4-merous flowers, deeply parted corolla, and naked exserted common peduncle of B. Gmelini. But the new Californian species differs about as much from the true Phyllodoces as from the original Bryanthus, agreeing with the latter conspicuously in its deeply cleft corollia and longexserted stamens.

On the other hand, Bentham and Hooker's Genera Plantarum proposes to solve the difficulty by cutting the knot, and the series, in the middle, referring to Bryanthres all the species with open-eampanulate corolla, and only these : under this view both of the species known in California would belong to Bryanthres, - to an intermediate section, which may be named Parabrixanthus: corolla open-campanulate, more or less 5-cleft or lobed : no common peduncle.

1. B. Breweri, Gray, 1. c. Stems rigid, ascending, a span to a foot high: leaves smooth or nearly so ( 3 to 7 lines long), narrowly linear, obtuse; the margins strongly revolute: flowers at first as if umbellate, at length rather racemose: foliaceous bracts ovate or lanceolate: 'pedicels glandular, soon longer than the flowers: sepals glabrous: corolla rose-purple, almost saucer-shaped, 5-cleft fully to the middle: stamens (7. to 10) and style much exserted.

High and rocky summits in the Sierra Nevada, at 10,000 feet and upwards, from Mariposa to Sierra Co., Brewer, Torrey, Bolander, \&c. The handsomest species of the genus.

2. B. empetriformis, Gray, l. c. A span or so in height, more branched than the preceding : umbellate flowers much smaller: corolla (hardly over 2 lines long) rose-color, campanulate; its lobes much shorter than the tube: stamens included: style sometimes exserted. - Menziesia empetriformis, Smith; Graham in Bot. Mag. t. 3176. M. Grahami, Hook. Fl. ii. 40. Phyllodoce empetriformis, Don.

Rocks on Mount Shasta, at 8,000 feet and higher, Brewer. Also high northward and in the Rocky Mountains.

\section{KALMIA, Linn. AMERICAN LAUREL.}

Calyx of 5 nearly distinct sepals imbricated in the bud. Corolla wheel-shaped or saucer-shaped, with 5 short lobes, and beneath these 10 small pouches, in which the 
anthers are severally lodert. Stamens 10: filaments filiform: intlers opening $7 y$ a terminal hole or chink. Style slender: stigma depressed. Capsule globular,

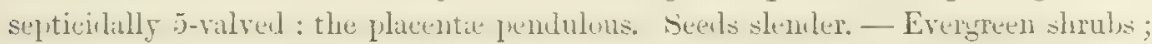
with entire coriaceuds leares, either oppesite or alternate, and showy fluwers mustly in an unbel or curymb; the pedicels sultended by curiaceuns and yersistent bratets.

The Kalmias are all American and of the eastern side of the continent, excepting the following, which ranges northward from Newfoundland to Alaska, and southward on high mountains.

1. K. glauca, Lim. Slirul, spreading, from a span to 2 feet high, very glalirous, with flat ascending branches: leaves opposite or sometimes whorled in threes, nearly sessile, narrowly oblong or appearing linear when the margins are revolute, white and glaucous beneath : corymb terminal, of several or few flowers, the lower bracts resembling the leaves: pedicels filiform: corolla lilac or chocolate-purple, half an inch in diameter. - Ait. Kew. ii. t. 8; Bot. Mag. t. 177.

Sierra Nevada; on Mount Dana, at and above 11,000 feet, in marshy places, Brevoer. Also Webber Peak, Lemmon. Only the var. microphylla, Hook, i. e. a depauperate state, rising little above the ground. Mr. Watson found it on similar high mountains in Nevada. It extends to the subaretic regions, and south to lat. $41^{\circ}$ in the Atlantic States.

\section{MENZIESIA, Smith.}

Calyx small or minute, mostly 4-parted or toothed, glandular-ciliate. Corolla from globular-urnshaped to campanulate, obtusely lobed. Stamens mostly 8 , incluichl: filuments flat : anthers rather short, naked: the cells opening at top by an whlique pore or chink. Style slender: stigma capitate-truncate. Cilpule gluhular or ovoid, mostly 4-celled and 4-valved, septicidal. Seeds numerous, scobiform (like time sawilust), the cont being very louse. - Dericluons-leared shrubs (unequilly diviled between Jalpan and $\mathrm{N}$. America); the fuliage resembling that of Azallets; the small flowers in terminal umbels (sumetines becuming litteml), leveloper simultaneously with the leaves, from separate scaly buds; their thin-scarious scales or bracts early decidtous.

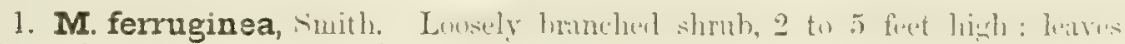
disposed to be erowded at the end of the branches, thin, short-petioled, oblongobovate, entire, acute and with a callous gland-like mucronate tip, more or less hir-

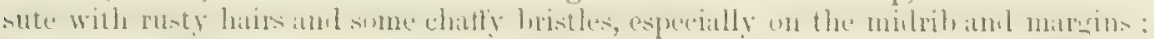

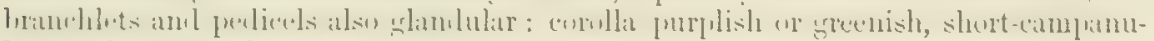
late with at first the mouth contricted. - Ic. Ined. t. 36.

Woods of Oregon and northward: doubtless in the northwestern part of California, but not yet seen : extends eastwart nearly to the Upper Great Lakes, and a variety of it iulabits the Alleghinnies. The ouly American species. Japan has several.

\section{RHODODENDRON, Linn., including AZALEA.}

Calyx very small in our species. Corolla large, varying from funnelform to campanulate, 5-lobed, often slightly irregular. Stamens 5 to 10 : filaments filiform,

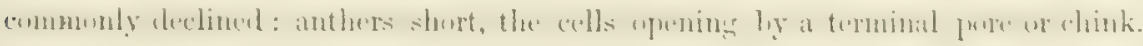
Style long, commonly declined or incurved: stigma truncate or capitate. Capsule woody, septicidally 5-valved from the summit. Seels very numerous and small, scobiform, i. o. with a loose chaff-like coat. - Ornamental shrubs; with alternate and entire leaves, usually crowled on the flowering branches; the showy flowers in terminal urabels or corymbs from ample scaly buls, the thin scales or bracts decidu- 
ous when the flowers develop. - Maximowicz, Rhodod. Asiæ Or. 13; Benth. \& Hook. Gen. Pl. ii. 599.

Rhododendrons and Azaleas, although different enough as to our common species, are quite undistinguishable when the whole are taken into view.

R. ALBIFLORUM, Hook, of the woods of Oregon and northward, which may occur within the limits of the State, is a species with lateral flowers and 10 stamens, but deciduons leaves.

\section{\$ 1. Flowers from a large and special scaly terminal bud: stamens 10 : leaves coria- ceous and evergreen. - EURHODODENDron, Maxim.}

1. R. Californicum, Hook. Shrub 3 to 8 feet high, glabrous: leaves oblong, with a short acute point, bright green above, pale beneath: umbel many-flowered: calyx minute, slightly 5-lobed : corolla rose-purple, broadly campanulate; the broad lobes undulate, upper ones yellowish and spotted within: stamens shorter than the corolla : filaments incurved at the apex : ovary silky-hairy : capsule oblong. - Bot. Mag. t. 4863.

Forests of the northern part of the State (Mendocino Co., \&cc.) extending to Oregon (E. Hall). Shrub 3 to 8 feet high, resembling $R$. Catawbiense of the Alleghanies, but with more showy flowers of about the same size. Leaves 4 to 6 inches long: corolla 2 inches or more in diameter. This solitary Californian true Rhododendron or Rose Bay is well deserving of cultivation.

\$2. Flowers from a large and special scaly terminal bud, close below which are separate leafbuds from which the shoots of the season proceed: stamens commonly 5 and exserted: leaves deciduous. - Azalea, Planchon, \&c. (Azalea, Linn., mainly.)

2. R. occidentale, Gray. Shrub 2 to 6 feet high, with shoots glabrous or minutely pubescent when young, not bristly: leaves obovate-oblong, sometimes approaching lanceolate, bright-green and shining above, minutely pubescent, glabrate, the margins minutely hispid-ciliate: scales of the flower-bud somewhat canescent: flowers appearing after the leaves: sepals distinct, oblong or oval, conspicuous : corolla minutely viscid-pubescent outside, white, with the upper lobe yellow inside; the narrow funnelform tube equalling the deeply 5-cleft slightly irregular limb; the lobes ovate: stamens and style much exserted, moderately curved: capsule oblong. - Azalea occidentalis, Torr. \& Gray, Pacif. R. Rep. iv. 116 ; Hook. Bot. Mag. t. 5005 ; Torr. Bot. Wilkes Exp. 381. A. calendulacea, var., Benth. Pl. Hartw. 321. Rhododendron calendulaceum, Hook. \& Arn. Bot. Beechey, 362.

In wooded districts along streams, almost throughout the State, extending to the mountains east of San Diego, but common northward. Leaves $1 \frac{1}{2}$ to 4 inches long, becoming of a rather firm texture. Flowers $2 \frac{1}{2}$ to 3 inches long, fragrant. This charming Califomicn Azalea, the great ornament of the wooded districts, belongs rather to the group of the eastern $R$. viscosum than to that of $R$. calendulaceum, the flowers appearing in summer or late spring, after the leaves have developed. The bright green foliage makes a fine setting for the large and copious white or sometimes slightly rosy flowers, variegated by a pale yellow band. The fragrance is unlike that of the eastern species, and not so delicious.

\section{LEDUM, Linn. Labrador Tea.}

Calyx small, 5-cleft. Corolla of 5 distinct and spreading oval or oblong petals. Stamens 4 to 10 : filaments filiform: cells of the anthers opening by a terminal pore. Style filiform, persistent. Capsule oval or oblong, septicidally 5-valved from the base upwards: placentæ pendulous. Seeds slender, with a loose coat. - Low and more or less evergreen shrubs; with broad alternate entire leaves, their margins disposed to be revolute, and the lower surface either resinous-dotted or rusty-woolly; the flowers small and white in a terminal umbel-like corymb, which is developed from a large scaly bud, its thin scales or bracts deciduous when the flowers are developed. 
L. PALUSTRE, Linn., which grows round the world far north, and L. LATtFolitr, Ait, which extends from Newfoundland to Oregon (the only other species), are not met with in California, which has a peculiar species, viz.

1. I. glandulosum, Nutt. Shruh 2 to 6 feet high, erect, glabrous or nearly so: leaves obloug or oval, pale and dotted with resinous scaly dots beneath, and when young somewhat resinous above, slender-petioled: corymbs terminal and sometimes axillary, often compound: stamens 4 to 10 : capsule oval. - Trans. Am. Phil. Soc. n. ser. viii. 270 (subgen. Ledodendron); Watson, Bot. King Exp. 211.

Mendocino Co., along the coast range, to Oregon, and through the Sierra Nevada, at and above 4,000 feet : also in the Nevada and Rocky Mountains. Leaves an inch or two long, the margins little or not at all revolute, the lower surface destitute of the wool of the other species. Flowers resembling those of $L$. latifolizm.

\section{CHIMAPHiLA, Pursh. Pirsissewa.}

Corolla of 5 rotately spreading orbicular and concave petals. Stamens 10: filaments enlarged and hairy in the midlle: anthers extrorse in the bud, introrse in the flower, opening by a round hole at the tapering summit of each cell. Style very short, inversely conical, nearly immersed in the dejressed umbilicate summit of the ovary : stigma broad, orbicular, its border somewhat 5-crenate. Capsule depressedgluluse, 5-lubed, 5-celled, loculicidally dehiscent from the apex lownwards, the edges of the valves glabrous. - Low, nearly herbaceous, evergreen perennials: with long underground shoots, ascenting stems bearing thick and smooth shining sharyly serrulate leaves in irregular whorls or pairs, or scattered, and a terminal naked peduncle supporting a few fragrant flowers in a corymb or umbel. Bracts scaly. Petals white or flesh-color, waxy: anthers violet or purple.

A small North American genus, extending into Mexico, the commonest species also in Europo and Japan : in the latter also a peculiar species very like one of ours. All grow in dry woods, especially on hillsides and in the shade of coniferous trees.

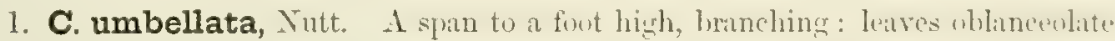
or wedge-shaped, entire towards the tapering base, bright green, not spotted : peduncle 4-7-flowered: bracts narrow, deciduous: filaments hairy on the mamgins only. - Barton, Veg. Mat. Med. t. 1. C. corymbosa, Pursh. Pyrola umbellata, Linn.; Bigel. Med. Bot. t. 21.

This, the common Pipsissewa or Prince's Pine of the Eastem States, Oregon, \&c., also found both on the eastern and western sides of the Old World and in Mexico, apperrs to be rme in Califomia and only in the north. Mount Shasta (Brewer); Mendocino Co. (Bolander); Sierra Valley, Lominon.

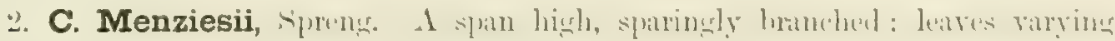
from ovate to oblong-lanceolate, acute at both ends, small ( $\frac{1}{2}$ to $1 \frac{1}{2}$ inches long , $_{\text {, }}$ purplish beneath, sometimes variegated with white above: peiluncle $1-3$-Howered: bracts ovate or roundish: filaraents villous on the dilated midulle portion. - Hook. Fil. ii. 49, t. 138. Pyrala Menziesii, Don.

Pino woods, in the Sierra Nevadn, and from Mendocino Co, northward, tlirough Oregon. Most resembles tho enstom $C$. maculate and the recently discovered C. Japonick.

\section{MONESES, Salisb.}

Corolla as in Chimaphila. Stamens 10: filaments not enlarged in the midelle. subulate, naked : anthers as in Chimaphila, but the cells contracted into a distinct short tube at the extremity. Stylo exserted, straight: stigma large, peltate, and with 5 short radiating lobes. Capsule as in Chimaphila. Parts of the flower occasionally in fours insteal of fives. -- A single species known, viz. 
1. M. uniflora, Gray. A small and low peremnial, with a cluster of round or obovate short-petioled crenulate leaves, and a scape 2 to 4 inches high, terminated by a handsome white or flesh-colored flower two thirds of an inch in diameter. Pyrola uniflora, Linn. Moneses grandiflora, Salisb.

In cold bogs round the northern hemisphere; doubtless within the limits of the State at high elevations, as it occurs north and east of thema.

\section{Pyrola, Tourn. Wintergreen.}

Corolla of 5 concave and more or less converging petals. Stamens 10 : filaments ascending or straight, subulate, naked: anthers as in the preceding genera, either with or without a tubular prolongation of the extremity of the cells, which open by a round hole. Style generally long: stigma 5-lobed or 5-rayed. Capsule depressedglobose, 5-lobed, 5-celled, loculicidally 5-valved from the base upward : edges of the valves commonly cobwebby when opening. - Low and smooth perennial herbs; with running subterranean shoots, broad and petioled leaves close to the ground, and a more or less scaly-bracted scape bearing a simple raceme of white, greenish, or rose-colored nodding flowers.

The genus, and several of the 12 to 14 species, extend round the world in the cooler parts of the northern temperate zone. Some divide it into three genera, but on characters of small account.

\section{\$1. Corolla and stamens regular: petals with two tubercles at base inside: style} straight: stigma large, depressed, at length obtusely 5-lobed.

1. P. secunda, Linn. Leaves clustered or somewhat scattered on ascending shoots, thin, ovate, serrulate, on naked petioles: scape 3 to 5 inches high, bearing several or numerous flowers in a close one-sided racene : petals oval-oblong, greenish-white, not at all spreading, shorter than the slender style: anthers blunt.

Woods in the higher Sierra Nevada, at Donner Pass, \&c. ; thence northward and eastward round the world.

\section{\$ 2. Corolla somewhat irregularly spreading: stamens more or less declined and curved towards the upper side of the flower: style long, turned downward and more or less curved: stigma narrower than the apex of the style, surrounded by a ring or collar, from which the 5 lobes (more or less concreted into one, and at first almost included) at length conspicuously project.}

2. P. rotundifolia, Linn. Leaves coriaceous, shining above, orbicular, varying to ovate, round-obovate, or round-reniform, on slender naked petioles : scape with the loosely many-flowered raceme 6 to 14 inches high, scaly-bracted: bracts lanceolate or ovate-lanceolate: lobes of the calyx mostly lanceolate or triangular-lanceolate and about half the length of the broadly obovate (white, greenish-white, or rose-purple) petals : cells of the anther slightly contracted into an obscure neck under the orifice. - The Californian specimens as yet seen all belong to the

Var. bracteata, Gray. A large form: leaves 2 or 3 inches long, often serrulate: scape a foot or mоге high, usually conspicuously but remotely scaly-bracted : anthers prominently mueronate at base. $-P$. bracteata, Hook. P. elata, Nutt. Thelaia bracteata, Alefeld in Linnæa, xxviii. 57.

In coniferous woods, Mendocino to Sierra Co, and north to British Columbia. The var. uliginosa, Gray, common on the northern borders of the Atlantic States, occurs on the mountains in Nevada, and a form near it at Carson City. It has smaller pink flowers with red-purple anthers, and shorter triangular-ovate calyx-lobes.

3. P. picta, Smith. Leaves thick, coriaceous, pale (at least beneath, sometimes purplish), and above commonly variegated or blotched with white, ovate varying to obovate and oblong-spatulate or lanceolate-oblong, on short or else margined petioles: 
scape with the mostly short maceme 4 to 8 inches high: bracts small: lobes of the calyx ovate, short, not half the length of the roundish greenish-white petals : cells of the anther contracted into a neck or short tubular prolongation below the orifice. - $P$. dentata, Snith, a form with the narrower leaves more or less serrate. Thelaia spatulata, Alefeld, l. c.

Open woods, from the Mariposa Grove along the Sierra, and from Mendocino Co. to British Columbia. Leaves an inch or two long, in the narrower forms tapering into the petiole, which is from a quarter to a full inch in length. Rootstocks ereet, branching, rigid. Peculiar to the Pacific side of the continent.

4. P. chlorantha, swartz. Lenves coriaceous, not shining, orbicular or approaching it, often retuse, small, commonly much shorter than the petiole: scape and fewflowered raceme 4 to 8 inches high: bracts inconspicuous: lobes of the calyx broadly ovate or roundish, very short, appressed to the base of the oval-obovate white and little-sinerealing petals : cells of the anther distinctly contracted beluw the orifice into a short tube.

Hills near Downieville, Yuba River, Bigelow, according to Torrey. Apparently rare on the Pacific side of the continent; common northward on the Atlantic side, and aljo in northern Europe. Leaves balf an inch to an inch, sometimes even an inch and a half long.

5. P. aphylla, Smith. Scapes leafless, 7 to 12 inches high from a long and deep scaly-bructed and doubtless parasitic rootstock: raceme loosely many-fluwered: lobes of the calyx ovate, acute, very much shorter than the obovate white petals: cells of the anther contracted into a short tube below the orifice. - Hook. Fl. ii. 48, t. 137.

Fir woods, along the Sierra Nevada from San Diego Co. to Shasta Co. and to British Columbia. Suare reddish. Flowers about as large as those of $P$. rotundifolin: sntures of the capsule not cobweblyy in dehiscence. A peculiarly interesting plant, on account of its living the parasitic life of the Hionotropece.

\section{ALLOTROPA, Torr. \& Gray.}

Calyx of 5 roundish sepals, persistent. Corolla none. Stamens 10, glabrous: anthers short, z-lobed, extrorse in the but, soon becoming introrsely pendulous on the slender filament; the cells opening by a chink reaching to near the middle. Ovary globose, 5-celled : style at first very short, at lengh longer: stigma large, peltate-capitate. Seeds very numerous on the thick placente in the axis, linear with a small central nucleus. - (Bot. Wilkes Exp. 385, 1874.) Gru in Pacif. $R$. Tiep. vi. 81, \& Proc. Am. Acad. vii. 368. - Single species.

1. A. virgata, Torr. \& Gray, 1. c. A reddish or whitish herb, a span to a foot high, glabrous, rather fleshy, with a thicker base, beset with ovate-oblong or lanceolate scales, continued into a virgate many-flowered spike: flowers crowded, very short-peclicelled, 2-bracteolate, a quarter of an inch long; the upper ones about equalled by the bracts: sepals shorter than the filiform filaments, whitish.

Mendocino Ca, near Bear Harbor (Bolander, Kcllogg), generally under Qucrcus densiflora;

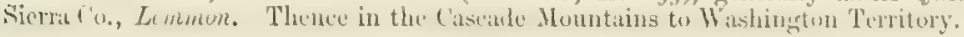

\section{PTEROSPORA, Nutto PIXEDRops.}

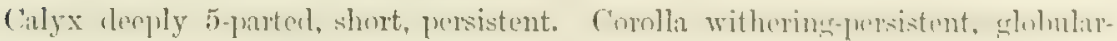
ovate, with contracted mouth; the 5 very short lobes recurved, almost convoluto in the bud. Stamens 10, included: filaments subulate: anthers short, erect in the bud (or just before anthesis horizontal); each cell bearing a dellexed awn on the back near the base, opening lengthwise. Style short: stigma 5-lohed. Capsule

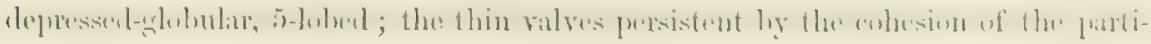


tions with the central axis, from which the placentæ are pendulous. Seeds very numerous, ovoid, with a thin nearly close coat, apiculate at base, and at apex bearing a broad hyaline and reticulated wing-like appendage, many times larger than the seed itself. - Nutt. Gen. i. 386 ; Lindl. Collect. t. 5. - Single species.

1. P. andromedea, Nutt. A stout, purplish-brown or chestnut-colored and clammy-pubescent herb, 1 to 3 feet high: the lanceolate scales or bracts small, crowded at the base, scattered above: raceme long, virgate, many-flowered; the spreading and recurved pedicels slender, as long as the linear scarious bracts: corolla white, a quarter of an inch long, somewhat viscid: capsule a third of an inch in diameter.

In dry soil, under pines or other coniferous trees and oaks, from Monterey northward, extending to British Columbia and through the Northern Atlantic States.

\section{SARCODES, Torr: SNOW-PLANT.}

Calyx of 5 oblong erect sepals, shorter than the corolla, persistent. Corolla cylindraceous-campanulate, moderately 5-lobed, the lobes little spreading, persistent. Stamens 10, included, glabrous: filaments slender: anthers linear-oblong, attached by the outside a little above the base, not appendaged, the 2 cells united throughout and with a very narrow counective, opening by the whole obliquely truncate apex. Ovary 5-lobed, 5-celled: style columnar: stigma capitate, slightly 5-lobed. Capsule fleshy; the thick placentæ adnate to the axis for their whole length. Seeds very numerous, oval; the coat cellular-reticulated, but closely fitted to the nuclens, except a conical protuberance at the apex. - Torr. Pl. Fremont. in Smithsonian Contrib. 17, t. 10 .

1. S. sanguinea, Torr. 1. c. A stout fleshy herb, a span or two in height, of a bright red color, more or less glandular-pubescent, thickly clothed, at least up to the raceme, with firm fleshy scales; the lower ones ovate and closely imbricated, the upper gradually more scattered, narrower, and passing into the linear bracts, which mostly exceed the flowers, their maryins glandular-ciliate : pedicels erect, at least the upper ones short: corolla half an inch long, rather fleshy, glabrous.

In coniferous forests, especially those of Scquoia and Abies, through the Sierra Nevada from 4,000 to 9,000 feet, shooting forth and flowering as soon as the snow melts away.

\section{MONOTROPA, Linn. Indian Pipe. Pine-Sap.}

Calyx of 2 to 5 lanceolate often loose and dissimilar bract-like scales, deciduous. Corolla of 4 or 5 erect spatulate or oblong seale-like petals, which are gibbous or saccate at base, tardily deciduous. Stamens twice as many as the petals : filaments filiform-subulate: anthers more or less reniform, transverse upon the apex of the filament; the cells more or less confluent into one, opening across the top. Style columnar, tubular, more or less dilated at the apex into the disk-like or somewhat funnelform obscurely 4-5-crenate stigma. Disk confluent with the base of the ovary, bearing 8 or 10 deflexed teeth. Capsule ovoid, 4-5-celled: the thick placentre covered with innumerable minute loose-coated seeds. - Low fleshy-scaly herbs, white or reddish, turning brownish; the clustered and loosely scaly stems rising from a ball of matted fibrous roots; the flowering summit at first nodding, becoming erect in age. - Two or three species, of two well-marked subgenera, by many received as genera; but the differences are rather unimportant. 
§.1. Flowers solitary, terminal: anthers opening equally by 2 chinks.

1. M. uniflora, Linn. Ilant white (rarely ruse-culur), inodorous, a span hich, glabrous : calyx represented by 2 to 4 bracts or sepals, the uppermost larger : petals 5 and stamens 10 (rarely more) : stigma naked.

In damp woods : not yet seen in California; but occurs in Oregon, though perhaps less commonly than in the Atlantic States; extends on the one hand into South Ameriea, on the ather into Japan and to the Himalayas.

\$2. Flowers several in a spike or close raceme, with more regular sepals, and the petals more saccate at base, the terminal flower mostly with 5 petals and 10 stamens; the others respectively 4 and 8 (or rarely fewer) : anthers more reniform; the cells completely confluent into one, which opens by 2 unequal valves, one broad and spreading, the other remaining erect and contracted: margin of the stigma glandular or hairy. - HrpopiTYs. (Hypopitys, Dill.)

2. M. fimbriata, Gray. Near a foot high, glabrous, except a minute pubescence of the spike-like raceme: the obovate-cuneate bracts and the spatulate sepals erosely or laciniately fimbriate: some flowers with only 3 petals and 6 stamens. Proc. Am. Acad. viii. 629.

In the southern Cascade Mountains, Oregon, E. Hall. It may be expected in Northern California.

M. Hrpopitys, Linn, or some form or near relative of this, the common Pine-sap, extending round the world in the temperate zone, occurs in the northern part of Oregon. It is pubescent or rarely glabrous, and the seales and bracts nearly entire.

\section{PLEURICOSPORA, Gray.}

Calyx of 4 or 5 ollong-lanceolate scalc-like sepals, with laciniately fimbriate margins. Corolla of as many nearly similar oblong petals, shorter than the calyx. Stamens 8 or 10, glabrous, included: anthers linear, erect upon the apex of the filiform flattish filament and hardly wider than it, apiculate at the retuse apex; the cells united throughout, opening lengthwise from the base to the apex. Ovary

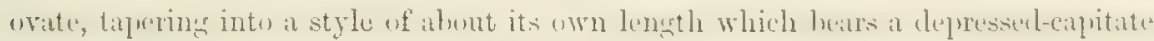
stigma, one-celled, with 4 or 5 bilamellate parietal placente, which are ovuliferous

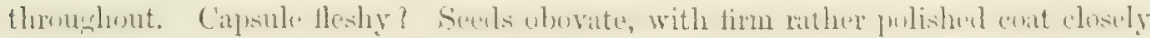
fitted to the nuclens. - Plants light brown or whitish, with the aspect of Monntropa, sect. Hypopitys, but stouter; the stem crowded or at first imbricated with the scales; flowers in a close erect spike. - Gray, Proc. Am. Acad. vii. 369.

1. P. fimbriolata, Gray, 1. c. A span or more hich, glabrons or nearly so: scales of the stem ovate-lanceolate, the lower with orose edges, the upper and bracts with scarious whitish and fimbriate margins.

In tho Mariposa Grove, Bolender. There are indications of a Mexican species.

\section{NEWBERRYA, Torr.}

Calyx of 2 scalc-like sopals, resembling bractlots. Corolla oblong, somewhat

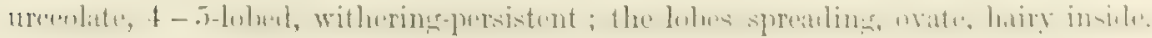
Stamons 8 or 10, somewhat included: filaments filiform, above tho midille hearded with long hairs: anthers oblong, erect; the cells opening lengthwise, from top to bottom, into two unequal valves. Ovary ovato: style elongated, hairy above: stigma depressed-eapitate, entire, umbilicate and pervious : placentre 4, anch 2-parted, the two broal plates covered with ovules on both sides, and their edges meetingr or 
cohering, leaving a central cell (if correctly understood). Inflorescence capitate. A single imperfectly known species.

1. N. congesta, Torr. Glabrous, brownish : simple stems a span high, clothed with loosely imbricated oval or oblong and obscurely erose scales; the uppermost forming large bracts to the capitate-erowded flowers. - Ann. Lye. New York, viii. 55 ; Benth. \& Hook. Gen. Pl. ii. 606. Henitomes congestum, Gray in Pacif. R. Rep. vi. 81, t. 12 : description and figure faulty, and name inapplicable, therefore changed.

Southern part of Oregon, upper part of Des Chutes Valley, Newberry. Near California, and probably occurring within its limits. It is very desirable to rediscover this little-known plant.

\section{ORDER LV. LENNOACE出。}

Root-parasitic fleshy herbs, scaly, destitute of green herbage, with the aspect of Monotropece and Orobanchacea, but nearer the former; remarkable for having the . parts of the flower almost always more than five and the cells of the ovary at least doubled, these one-ovuled, the stamens adnate up to the very throat of the tubular corolla (anthers on very short filaments, 2-celled and opening lengthwise), and the fruit drupaceous. - Comprises three genera and not more than four species, of Mexico and California.-Torr. in Ann. Lyc. New York, viii. 51; Solms-Laubach in Abhaudl. Nat. Halle, xi., \& DC. Prodr. xvii. 37 ; Benth. \& Hook. Gen. Pl. ii. 621.

1. Pholisma. Flowers spicate. Sepals and short lobes of the corolla 6 , rarely 5 : stamens as many in a sincle series.

2. Ammobroma. Flowers covering the upper surface of a dilated concave receptacle. Sepals about 10 , filiform and plumose. Lobes of the corolla and stamens 6 to 10 .

LENNOA, Llav. \& Lex. (Corollophyllum, HBK.), has the parts of the flower in eight, and the stamens in two series below the throat of the curved corolla.

\section{PHOLISMA, Nutt.}

Calyx of 6 (or rarely 5) linear sepals, shorter than the corolla, naked. Corolla tubular, obscurely funnelform, withering-persistent; the lobes as many as the sepals, short and broad, undulate and plaited-imbricated in the bud. Stamens as many as the lobes of the corolla and alternate with them, borne in the throat in a single rank. Ovary and drupaceous (?) fruit 12-20-celled, depressed-globose. Style long: stigma 6-10-crenate-lobed. + A single species.

1. P. arenarium, Nutt. Brownish fleshy herb, of simple sterns, a span high, puberulent, thick, clothed with small erect scales: spike at first capitate, at length oblong, dense: flowers sessile, rather longer than the linear bracts (about 4 lines long), purplish. - Hook. Ic. Pl. t. 626.

Sandy soil and at the base of hills, near Monterey and San Diego, Douglas, Nuttall, \&c. Parasitic on the roots of oaks?

\section{AMMOBROMA, Torr.}

Calyx of mostly 10 filiform plumose-hairy sepals, equalling the usually 6-lobed corolla; this and the stamens and pistil nearly as in Pholisma.

1. A. Sonore, Torr. Ront of thick tortuous fibres: stems simple, elongated, beset with lanceolate acute mostly appressed scales, the summit dilated into a funnelform receptacle, with recurved or spreading margins; the whole cavity densely lined with short-pedicelled flowers : corolla about 4 lines long: ovary about 20 -celled. - Ann. Lyc. New York, viii. 51, t. 1. 
Sandhills of the desert bordering the head of the Gulf of California, around Adair Bay, in the Mexican State of Sonora; "very abundant in the hills, the whole plant except the top buried in the sand, apparently attached to some other root or sulustance," Col. A. B. Gray. Eaten by the Papago Indians, after roasting or drying in the sun; the fresh plant "when cooked luscious, resembling the sweet potato in taste, only more delicate," according to the discoverer. The locality is not far below the borders of the State.

\section{ORder LVI, PLUMBAGINACE正。}

Chiefly maritime herbs, with the lase of the alternate leaves clasping the stem at their insertion, regular flowers with the parts in tive throughout, the stamens opposite the petals, and the ovary one-celled with a solitary ovule rising from its base. Flowers perfect. Calyx tubular or funnelform, 5-plaited, 5-toothed, persistent. Corolla hypogynous; in Plumbago gamopetalous and salverform; in our genera 5-petalous, with long claws barely united into a ring at base, commonly convolute in the bud. Stamens 5, opposite the petals, adnate to their base: anthers 2-celled, introrse, opening lengthwise. Ovary jansted at summit, containing an anatropus ovule hanging from the apex of a long funiculus which rises from the base of the single cell: styles 5, distinct or united into one. Fruit utricular or akene-like, in the huttm of the persistent calyx. Seed with a straight embry in mealy albumen. Cotyledons flat: radicle short. - Leaves mostly entire : stipules none.

A small and unimportant order, of no active qualities except that the roots are astringent; chiefly indigenous to the Old World; the genus Plumbago, of warm climates, with gamopetalous corolla, furnishing some ormamental species for cultivation, is partly shrubby : the native North Ameriean species are merely one Thrift, and one Marsh-Rosemary.

1. Armeria. Flowers in a globose head, on a simple seape.

2. Statice. Flowers paniculate or corymbose on a branching stem or scape.

\section{ARMERIA, Willd. Thrift.}

Thowrs in a single grlubuse hear (emmposed of numerons glomerate spikelets each subtended by a scarious bract), which is raised on a scape. Calyx scarious, fumnelform. Corolla of 5 nearly distinct long-clawed petals, each with a stamen attached to its base. Styles 5, filiform, united only at the very base, delicately plumose

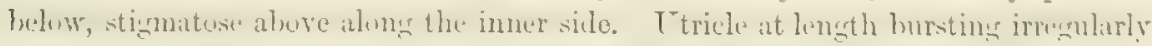

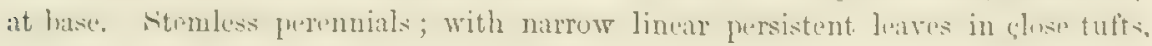
the naked scape with a reversed sheath under the head: flowers rose-color.

1. A. Vulgaris, Willd. Leaves flat, 1-nerved: bracts very obtuse, the outermost often mucronate: lobes of the calyx abruptly mueronate-pointed. - Statice Armeria, Linn.

On hills and bearhes, along the coast : a tall form, with scapes a foot or two high, and mather rigid leaves (A. andina, var. Californica, Boissier in DC. Prodr. xii. 682), apparently most like a Chilian form of a widely diffused and considembly variable species, common in the Olel World; by some earefully discriminated into several species.

\section{STATICE, Limn, Willd. MLARI-Rosemary.}

Flowers in swall spikes or clusters crowded at the extremities of a branching scape; their structure nearly as in Armeria. Styles glabrous, distinct: introrse stigmas shorter, sometimes terminal. V'tricle indehiscent. - Leaves commonly with a broal coriaceous blade tapering below into a petiole. 
1. S. Limonium, Linn, Rootstock thick, very astringent: leaves obovateoblong, thickish, fleshy-coriaceous, pale, tapering into a petiole : scape a foot or two high, much-branched, corymbose-panicled, bearing the numerous 2-3-flowered spikelets on one side of its divisions: outer bract ovate, herbaceous on the back, much smaller than the broadly scarious innermost bract: calyx-tube more or less hairy on the angles.

Salt marshes on the coast; the var. CALIForNiCa (S. Californica, Boiss. in DC.), with denser and more corymbose inflorescence than the Atlantic coast plant (var. Caroliniana), but closely Iesembling the S. Limonium of Europe.

\section{ORDER LVII. PRIMULACE开。}

Herbs, with perfect regular flowers, well marked by having the stamens as many as the lobes of the corolla and opposite them, inserted on its tube (only in Glaux the corolla is wanting and the stamens on the calyx alternate with its lobes), a single entire style and stigma, a one-celled ovary, with the ovules borne on a free central placenta, and a capsular fruit. Calyx 4-8-cleft, commonly 5-cleft, hypogynous, except in Samolus. Anthers 2-celled, opening lengthwise. Ovules several or numerous, on a globular central placenta, - amphitropous (except in Hottonia, which we have not). Embryo small, in fleshy or horny albumen. - Leaves simple, mainly entire: stipules none.

An order of about 20 genera and twelve times that number of species, widely distributed over the world, but mainly in the temperate and frigid portions of the northern hemisphere, of no marked aetive properties and small economical importance, except to the florist; not largely American, and very scanty in California, where only Dodecatheon is conspicuous.

* No sterile filaments : calyx wholly free from the ovary.

+ Flowers umbellate or sometimes solitary, on a naked scape : corolla imbricated in the bud.

1. Dodecatheon. Corolla 5-parted; its divisions reflexed. Stamens projecting: filaments monadelphous, shorter than the connivent sagittate or lanceolate anthers.

2. Primula. Corolla salverform, or fumnelform with a flat limb, the tube rather long. Anthers obtuse, included.

3. Androsace. Corolla short-salverform or funnelform, small, with tube hardly exceeding the limb. Anthers obtuse, included.

$+\div$ Flowers axillary on leafy stems : corolla convolute in the bud, or none in No. 7 .

4. Trientalis. Corolla 7- (5-9-) parted rotate. Capsule opening lengthwise.

5. Anagallis. Corolla 5-parted, longer than the calyx, rotate. Capsule circunscissile,

6. Centunculus. Corolla 4-5-cleft, shorter than the calyx. Capsule cincumscissile.

7. Glaux. Corolla none. Calyx colored. Capsule opening at the top by valves.

* Sterile filaments alternate with the lohes of the corolla: calyx-tube partly adnate.

8. Samolus. Corolla campanulate, 5-cleft; the lobes imbricated in the bud. Flowers racemose.

Lxsmachia. It is remarkable that no species of this rather large genus is known in California. But L. CILIATA occurs in Oregon, and may reach the northern part of the State. It belongs to a section (Steironema) which has the lobes of the corolla involute severally around the stamens. The genus is most like Trientalis, but the parts of the flower five, and the stems equably leafy throughout.

\section{DODECATHEON, Linn.}

Calyx deeply 5-cleft, the divisions reflexed in flower, afterwards erect over the capsule. Corolla with extremely short tube, a dilated and thickened throat, and an abruptly reflexed 5 -parted limb; its divisions long and narrow, entire. Stamens inserted on the throat of the corolla: filaments short, monadelphous (but separable 
ahore in are): anthers lanceulate or linear (yellow or violet), introrse, more or lis connivent around the filiform exserted style. Stigma small. Capsule ovoid or oblong, splitting from the apex into 5 or more teeth or valves: placenta columnar, many seeded. - Perennial snaoth lerbs, acaulescent; with a tuft of membranaceous leaves, and below fibrous roots springing from a short erect crown, sending up a naked simple seape, which is terminated by an umbel of few or many (rurely even solitary) handsome flowers: these at first gracefinly pendulous on the recurvel summit of the pedicels: after flowering the pedicels are erect. Involucre of a few slemler bracts. Corolla Imrple, pink, or sumetimes white. The Howers vecasionally vary with all their parts in fours.

1. D. Meadia, Linn. Leares varying from uborite to lincenlite, entire ur more or less tuothed: scape 3 to 15 inches high: umbel 2-20-flowered. - So far as we can make out, only one species occurs, which extends across the continent,

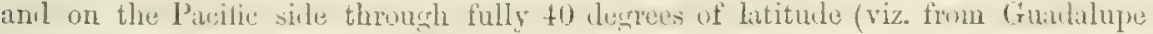
Island, Lower ('alifornil, to those within behrins straits), varying immensely aud inextricably. The Pacific forms (which usually have rather shorter or blunter anthers that the Itlantic) may, as to their leading features, be wainly but louscly arranged under the following varieties.

Far, brevifolium: common through the warmer parts of the state: leawes

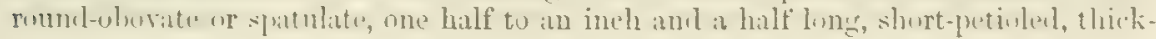
ish : scape a span to near a foot high, few-many-flowered : capsule ovoid, harlly exceeding the minutely glandular calyx. - D. ellipticum, Nutt. ex Durand, Pl. Pratt. in Jour. Acad. Philad. n. ser. ii. 95. D. integrifolium, Benth. Pl. Hartw. 322 , not of Michx.

Tar. lancifolium: common in wet mountain mealows, flowering in summer:

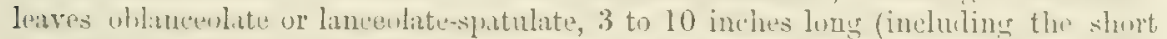

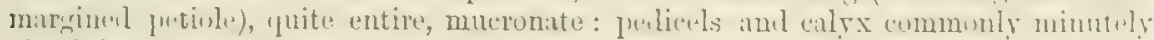

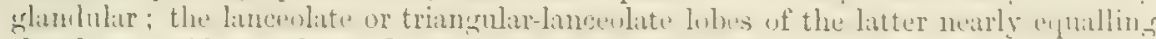
the short-ovoid capsule. - D. Jaffrayi of the gardens.

Vill. alpinum: a liminutive state of the fimenine on the hirher momntain: at 9,500 to 12,000 feot: the narrow leaves an inch or two, the 1 - 3 -flowered scaps 2 to 4 inches high: pedicels and calyx quito glabrous.

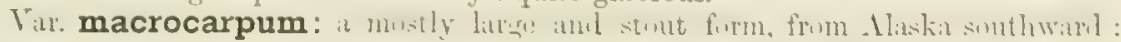

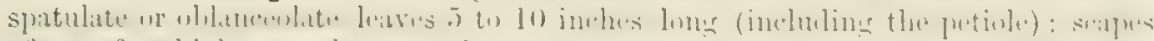

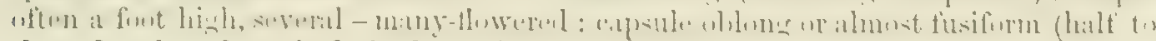
three fourths of an inch in length), about twice the leugth of the narrow calyxlobes, - A form which may be referred here, with laciniately-toothed spatulate leares, was collected on the mountains of Ventura Co., Brever.

Var. frigidum, Hook. Bot. May. t. 5871, \& S. Watson, Bot. King Exp。: includes various forms, ranging from tho high Sierm northward to the islands within Bohring Straits: leaves obovate or oblong, very obtuse, mostly entire, with either short or slender potiolo: scape a span or more high, few-several-flowered : calyxlobes longer than the tube, varying from broally to ovate-linceolate, shorter thim

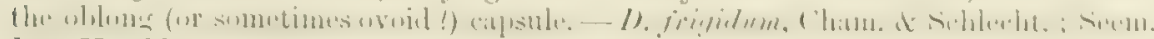
liot. Herill. t. 9.

Var. latilobum: leaves thin, oval, undulate-toothed, 1 to $2 \frac{1}{\text { inches }}$ long, abruptly contracted into a petiole of nearly twice the length: scapo a span to a fout high, 1 - sevoral-flowered: calyx-lobes ovate or triangular-ovate, not longres than the tube, about half the length of the narrowly oblong capsule. - D. Meadia, var. frigiclum, Watson, 1. c., in part. (East side of Cascado Mts., Wishington Territory, Ly yall. Wahsateh Nits., Utuh, W'atson.)

Stations and geographical rango sufliciently specified above. 


\section{PRIMULA, Linn. Primrose.}

Calyx 5-cleft. Corolla commonly salverform, enlarging more or less just above the insertion of the stamens ; the limb 5-parted; lobes obovate, or obcordate. Stamens included, distinct. Stigma capitate, depressed. Capsule ovoid, 5-valved at summit, the valves again usually 2 -cleft. Seeds very numerous on the large central placenta. - Perennial herbs; with clustered leaves at the root or rootstock, and simple scapes bearing solitary or usually an umbel of several handsome flowers.

Primroses, Cowsitips, and Auriculas of the gardens are Old World representatives of this genus. In California only one indigenous species has been detected, but that is a new and charming accession to the genus, viz.,

1. P. suffrutescens, Gray. Glabrous: leaves thick and rather coriaceous, cuneate-spatulate, coarsely toothed at the apex, persistent and crowded on firm and rather fleshy-ligneous creeping and densely matted rootstocks: scape $3-7$-flowered : involucre of a few short and subulate bracts: calyx campanulate, minutely glandular-puberulent, deeply 5-cleft : corolla deep maroon-purple with a yellowish eye; its tube longer than the calyx, but hardly longer than the obovate-emarginate or obcordate lobes. - Proc. Am. Acad. vii. 371.

On exposed rocks of the Sierra Nevada, at the elevation of 9,000 to 11,000 feet; above the Yosemite Valley, Bridges (who first discovered it), Muir, \&c. Silver Mountain, Brewer. Mt. Stanford, Bolander, Kellogg. The thick matted rootstocks fill the crevices of rocks, and are more creeping than in any other species. Leaves an inch long, or rather more. Scape 3 or 4 inches high. Corolla fully two thirds of an inch in diameter.

\section{ANDROSACE, Tourn.}

Calyx 5-cleft. Corolla short-salver-shaped or almost rotate; the tube shorter than the calyx; throat commonly constricted; the small limb 5-parted. Stamens and short style included. Capsule 5-valved, few-many-seeded. - Very small or delicate berbs; with clustered leaves, and small umbellate or sometimes solitary flowers, usually on a scape : corolla white or nearly so.

Mainly an alpine or subalpine genus, chiefly of the Old World ; no species yet detected in California or on its immediate borders ; but the two following may be expected at the north.

A. SEPTENTRIONALIS, Linn.: a harely puberulent annual or biennial, with an open tuft of lanceolate or oblong radical leaves, from which are sent up numerous filiform seapes, an inch to a span high, bearing a loose umbel of several flowers, on long filiform pedicels : calyx-lobes ovatesubulate, green, equalling the very small corolla. - Mountains of Nevada and northward to the arctic regions, and in the old World.

A. FILIForMIs, Retz, is similar, but glabrous, with broader leaves, and ovate and bluntish more membranaceous calyx-lobes shorter than the corolla; this, as in the preceding, only a line or so in diameter. - Occurs in the mountains of the southwestern part of Oregon, as well as in the Rocky Mountains; also Northern Asia.

\section{TRIENTALIS, Linn. STAR-FLOWER.}

Calyx and wheel-shaped corolla 7-parted, sometimes 6 -9-parted, widely spreading from the very base. Filaments slender, spreading, united in a ring at the base: anthers oblong, revolute after discharging the pollen. Style filiform : stigma small. Capsule at length splitting into 5 valves, few-seeded.-Low and glabrous perennials; with filiform tuberiferous rootstocks, sending up simple stems, which bear alteruate scales or sometimes small leaves below, and a whorl of fully developed leaves at the summit, in their axils slender peduncles supporting a star-shaped white flower.

The Atlantic States have a peculiar species, T. Americana, Pursh, with long lanceolate leaves tapering to both ends, and gradually acuminate divisions to the corolla. The Pacific States have only forms of the Old World species. 
1. T. Europza, Linn, vin: latifolia, Turr. Stems \pm to 8 inches high, sprinsing from a well-formed little tuber, nearly leafless: leaves 4 to 6 , obovate or oblongoval: corolla often tinged with purple; its divisions oblong and abruptly sharppointed. - T. latifolia, Hook. Fl. ii. 121.

Woods, chiclly along the Coast Ranges, from Monterey north to Oregon, \&c. Mature leaves in the Californian plant often 4 inches long.

Var. Anctica ( $T$. areticu, Fischer), which has very much smaller and obtuser leaves, more or less scattered along the stem, occurs in Oregon and northward.

\section{ANAGALLIS, Tourn. PMPERELL}

Calyx and rotate corolla 5-parted; the divisions of the latter broad. Filaments slender, bearded : anthers ovate. Style slender: stigma small. Capsule globose,

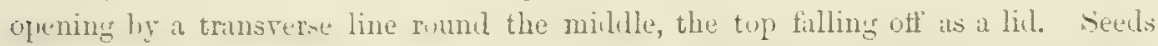

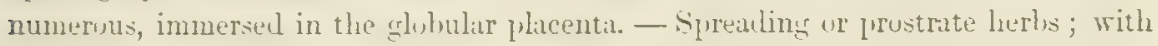

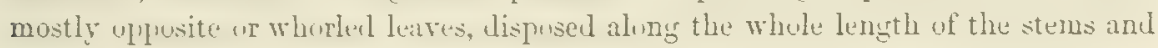
branches, anl Howers on axillary peduncles. Xaturilized aloner buth coasts, but not indigenous to North America.

1. A. arvensis, Linn. Annual: leaves ovate, sessile, shorter than the peduncles, commonly opposite, sometimes in threes: flowers opening only in sunshine, st:arlet or purple, sometimes blue or white: petals cubtuse, fringed with minute tecth or stalked glands.

Common in waste and cultivated grounds near the coast : introduced from Europe.

\section{CENTUNCULUS, Linn.}

Calyx 4-5-parted; the lobes narrow. Corolla very small, shorter than the calyx, 4-5-cleft; the tube globular; the lobes acute. Filaments short: anthers cordateovate. Capsule as in Anagallis. Seeds minute. - Small and low annuals, with mostly sessile entire leaves, and minute flowers in the axils: the inconspicuous corolla white.

1. C. minimus, Linn. An inch to a span high, simple or diffusely branched, glabrous: leaves alternate, obovate, 2 or 3 lines long, narrowed at base: flowers almost sessile, tho parts in fours: calyx-lobes slender-subulate. $-C$. lanceolatus, Michx. Fl. i. 93.

Low grounds : not yet seen in the State; but occurs in Oregon, and in South America, as well as in the Atlantic States, and in Europe.

\section{GLAUX, Linn. SEA-MILEWORT.}

Calyx campanulate, 5-cleft ; the lobes ovate and petal-like. Corolla wanting. Stamens 5, borne on the base of the calyx alternate with its lobes. Filaments rather shorter than the calyx: anthers cordate-avate. Style filiform: stigma capitate. Capsule globular, 5-valved, few-seeded. - A single species, nearly confined to salline soil.

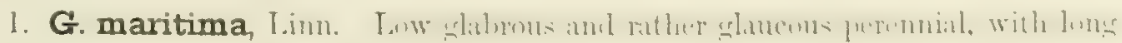
and sleuder rootstocks and roots: branching stems 3 to 9 inches long, leafy to the top: leaves opposite or oceasionally alternate, fleshy, oblong, varying either to linear or to ovate, half an inch or less long, minutely dotted: flowers axillary, almost sessile, white or purplish.

On the sea-shoro, and in more or less snlino soil in the interior. Occurs also on the Atlanti: coast, and all round the northern heraisphere. 


\section{SAMOLUS, Linn. BROOKWEED.}

Calyx 5-cleft, its base coherent with the lower part of the ovary. Corolla campanulate, 5-cleft: a slender tooth answering to a sterile filament borne at each sinus. True stamens 5, short and included, inserted on the tube of the corolla. Capsule globular, 5-valved at the summit, many-seeded. - Glabrous low herbs; with alternate entire leaves, and small white flowers in loose racemes. Most of the several species are of the southern hemisphere; one is cosmopolitan, viz.,

1. S. Valerandi, Linu., var. Americanus, Gray. Stems branching and spreading, 6 to 15 inches long, slender, leafy: leaves obovate : racemes often panicled: bracts none at the base of the slender pedicels, but minute bractlets on them near the middle: lobes of the calyx ovate, shorter than the corolla.

Along brooks, \& c., scarce in California, but found north of it, and as far south as the mountains behind San Diego.

\section{ORDER LVIII. STYRACACE无.}

Shrubs or trees, with alternate simple leaves, no stipules, regular perfect flowers, a calyx adherent at least to the base of the ovary, stamens mostly at least twice the number of the petals or lobes of the corolla, and more or less united with each other and to the base of the corolla; the seeds few, with a slender embryo in fleshy or horny albumen. - A single species of the typical genus, and that rare, represents this family (of seven genera and over 200 species) on the Pacific side of N. America.

\section{STYRAX, Tourn. StoraX.}

Calyx persistent, truncate, campanulate, the border merely denticulate or irregularly toothed, in the $\mathrm{N}$. American species coherent at its base with that of the 3-celled many-ovuled ovary. Corolla of 5 or sometimes 4 to 8 soft-downy petals, which are united at base into a very short tube, deciduous. Stamens 10 : filaments flat, monadelphous at base into a short tube which is coherent with the base of the corolla: anthers linear, 2-celled, fixed by the base, introrse; the cells opening lengthwise. Style filiform. Fruit globular, its base girt by the persistent calyx, at first rather fleshy, at maturity dry, commonly splitting into 3 valves, I-celled, filled with a single large globular seed, which resembles a small nut; the seed-coat being thick and crustaceous. Embryo nearly the length of the fleshy albumen: cotyledons broad and flat: radicle slender.-An Asiatic and American genus, warmtemperate or tropical, with scurfy or stellate-downy herbage, and mostly handsome flowers.

1. S. Californica, Torr. Shrub 5 to 8 feet high: leaves ovate or oval ( 1 to 21 inches long), obtuse at both ends, entire, minutely stellately pubescent, at least when young, and even hoary beneath: flowers few in a cluster or corymbose raceme, on a short terminal peduucle: pedicels clubshaped: divisions of the white softdowny corolla 5 to 8 , spatulate-lanceolate (half an inch or more in length), imbricated in the bud: filaments monadelphous nearly to the middle: bony seed half an inch in diameter. - Swithsonian Contrib. vi, 4, \& Pacif. R. Rep. iv. 118.

Foot-hills, from Calaveras Co. to the Upper Sacramento, first collected by Fremont. A handsome species, with flowers much larger than in any of those of the Atlantic States, except the Texan S. platanifolia, Engelm. 


\section{ORDER LIX, OLEACE无。}

Trees or shrubs, rarely herbaceous or nearly so; with mostly opposite leaves, without stipules; the flowers hypogynous and diandrous, rarely triandrous, while the parts of the regular calyx and corolla are four or more, but one or both of these are sometimes wanting, or the petals distinct, or rarely reduced to two. - Anthers 2-celled, opening lengthwise. Ovary 2-celled; the cells alturnate with the stamens, mostly only a pair of ovules in each: style one or none: stigma usually 2-lobed. Fruit various. Embryo straight and large, mostly in albumen.

A family of about 20 genera and nearly 300 species, of wide distribution, sparingly represented in North America, especially so in California, being represented only by a couple of Ashes, and by Menodorc (of the Jessamine-tribe) on the southeastern border.

Olea Europea, Linn., the Olive-tree, - the type of the order, - with complete flowers and the lobes of the corolla valvate in the bud, was early introduced from Europe, by the Missionaries, and its fruit is still an important product of the southern part of the State, for olives and oil.

Hesperelea Palmeri, Gray in Proc. Am. Acad. ined., is a tree, of a new genus, with distinct spatulate petals aud evidently drupaceous fruit, recently discovered by $D r$. $E$. Palmer ou Guadalupe Island, Lower California.

Menodora. Flowers perfect. Corolla campanulate or funnelform. Capsule 2-parted, membranaccous. Almost herbaceous: leaves often alternate.

Fraxinus. Flowers polygamous or dicecious. Petals 2 to 4 or none. Fruit a one-seeded samara, Trees: leaves opposite, pinnate.

\section{MENODORA; Humb. \& Bompl.}

Calyx with a short and turbinate tube, and 5 to 14 narrow lobes from its truncate border. Corolla campanulate, funnelform or almost rotate, mostly 5-lobed; the lobes imbricated in the bud. Stamens 2, sometimes 3, on the tube of the corolla: anthers oblong or linear. Style slender: stigma obtuse or somewhat 2-lobed. Capsule didymous, mostly 2-parted, membranaceous at maturity, circumscissile, the upper part of each lobe falling as a lid, leaving the scarious membranaceous base. Seeds 2 (or rarely fewer) in each cell, ascending, large, and with a fleshy or when dry a spongry outer coat, destitute of albumen. - Low and undershrubby or nearly herbaceous plants; with sessile leaves, not rarely alternate, and terminal mostly somewhat cymose flowers, which are rather showy. - Grny in Am. Jour. Sci. ser. 2, xiv. 41. Bolivaria, Cham. \& Sehlecht.

$\Lambda$ genus allied to Jasminum, of a dozen or more species, most of them on the U. S. and Mexican frontiers, ono in extra-tropical South America, one in South Africa. Two species reach our borklers.

1. M. spinescens, firy. Shrubly, two to four fout hish, with rigid aml divaricate spinescent branches, obscurely puberulent: leaves reduced to minute and

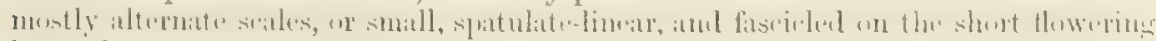
brunchlets : flowers short-peduncled or nearly sessile in the fascicles of leaves: lobes of the deeply parted calyx 5 or marely 6 , a littlo shorter than the funuelform light yellow corolla : filaments shorter than the anthers: divisions of the capsule almost distinct, divaricate, obovoid. - Proc, Am. Acar. vii. 388.

Providence Mourtains, in tho southenstern part of tho Strte, Dr: Conper. Also S. E. Nevadh, Dr. Anderson. Apparently for the most part lenfless; thr lenves in the flowering branchlets an line or two long. Corolla 3 lines long, its lobes a line long. Carpels 3 lines long, very tarlily vireumscissile.

2. M. scoparia, Enerelm. MLs. Shrubly at hase, 2 or 3 feet high, panieudately hranched, glabrous and smooth or nearly so: leaves of the herluecons floworing shoots very conmonly alteruate, linear or lanceolite, entire; the mpermost reduced 
to small subulate bracts; the lower oblong or obovate and short-petioled: calyxlobes 5 or 6 (rarely with intermediate ones, making 8 to 10 ), about the length of the tube of the almost rotate yellow corolla: divisions of the capsule globose. M. scabra, var. glabrescens, Gray in Watson, Cat. Pl. Wheeler, 15.

Southeastern borders of the State, Dr. Cooper, Dr. Palmer. Arizona, Dr. Palmzer, Dr. Smurt, Lierct. Wheeler. Saltillo, Mexico, Gregg; on whose specimens Dr. Engelmann indicated the species. It probably passes into $M$. scabra, Gray, of Arizona, New Mexico, and Colorado. Lobes of the corolla 3 or 4 lines long, exceeding the tube.

\section{FRAXINUS, Tourn. AsH.}

Flowers polygamous or dioecious. Calyx small and 4-cleft, or merely toothed, or obsolete. Petals of 4 or sometimes only 2 petals, either distinct or united at base. Stamens 2, rarely 3 or 4, hypogynous: anthers proportionally large. Ovary 2-celled; a pair of anatropous ovules pendulous from near the summit of each cell. Fruit a samara, winged from the summit, usually only 1-celled and 1-seeded. Embryo with flat cotyledons, in fleshy albumen. - Trees; with tough and straight-grained wood, petioled and pinnate opposite leaves, and numerous small flowers in crowded panicles, developed with or before the leaves, from separate buds.

A genus of about 20 species, of the northern temperate zone; represented in California by two species; one of them of the Omus or petaliferous section.

1. F. dipetala, Hook. \& Arn. Small tree, glabrons: leaflets 5 to 9 , or rarely 3 , oval or oblong, serrate, mostly petiolulate, when old rather coriaceous, an inch or two long : panicles effuse : calyx usually 4 -toothed, sometimes alnost entire: petals only 2, obovate-oblong with a short claw, white, 2 lines long, equalling the linear anthers : fruit narrowly spatulate-oblong, mostly retuse, an inch long, and the base merely sharp-edged; or in one form almost obovate, wing-margined to the base and much shorter. - Bot. Beechey, 362, t. 87; Torr. Bot. Mex. Bound. 167, var. (?) trifoliolata. Chionanthus fraxinifolius, Kellogg, Proc. Cal. Acad. v. 18.

Not uncommon through the western part of the State.

2. F. Oregana, Nutt. A fine tree: leaves tomentose, or becoming naked when old: leaflets 5 to 7 , from oval to oblong-lanceolate, entire, sessile, 2 to 4 inches long: male panicles dense, with oblong anthers; fertile panicles ample: flowers all with a minute calyx and no petals: fruit marginless at base, gradually margined upwards and produced into an oblanceolate or spatulate retuse wing, the whole 1 to $1 \frac{1}{2}$ inches long. - N. Am. Sylv, iii. 59, t. 99. F. pubescens, var., Hook. Fl. ii. 51. F. grandifolia, Benth. Bot. Sulph. 33.

In ravines and along streams, from the Sierra Nevada in Fresno Co., and from the vicinity of San Francisco northward to Oregon, where it is common and forms a large timber-tree. In foliage it resembles the Black Ash, but the wood is light colored and nuch like that of the White Ash of the Atlantic States, is used for the same purposes, and appears to be equally valuable. It is known as Oregon Ash.

\section{ORDER LX. APOCYNACE互。}

Shrubs, trees, or (ours) herbs, with acrid milky juice, opposite entire leaves, destitute of stipules, regular. flowers with all the parts in five, except that there are only 2 carpels, and these usually distinct as to the ovary, while the styles or stigmas are united: stamens borne on the corolla alternate with its lobes, which are convolute and sometimes also twisted in the bud: the anthers disposed to cohere with the stigma: and the pollen of the ordinary powdery grains. Calyx free, or in Apocymum adnate to the very base of the ovaries. Seeds anatropous or amphitropous, 
often bearing a tuft of down (a coma). Embryo large and straight, in sparing albumen.

$\Delta$ large family in the warmer regions, sparingly represented in the temperate zones, only two small genera reaching California, one of them peculiar to it.

1. Apocynum. Stamens on the base of the campanulate corolla: little scales of the latter opposite the lobes. Glands of disk 5.

2. Cycladenia. Stamens on the tube of the short-funnelform corolla, which bears minute appendages alternate with the lobes. Disk a. ring or cup.

\section{APOCYNUM, Tourn, DOgBATE INDIAN HEMP.}

Calyx 5-parted; its short tube coherent by the disk with the base of the ovaries. Corolla campanulate, 5-cleft, toward the base hearing a triangular scale-like appendage opposite each lobe. Stamens borne on the base of the corolla : filaments very short: anthers of firm texture, sagittate, conniving around the solid stigma, to a ring of which the broad summit of the connective adheres. Proper style none. Cvaries 2, ovoid, in fruit forming a pair of long and stemler follicles. Cilimes is around the base of the ovaries. Seeds numerous, bearing a long tuft of silky down. - Perennial herbs ( $\mathrm{N}$. American, and one in the Old World); with branching stems, an extremely tough fibrous bark (used by the Indians for cordage), mucronate-tipped leaves, and small white or rose-colored flowers in terminal and axillary snall cymes: flowering in summer.

1. A. androszmifolium, Linn. Erect, with diverent brunches, slatorus, in one form solt-tonnentuse, at least when young : leaves wrate or roumlish, an inch ur

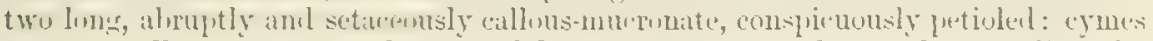
open: corolla open-campanulate; its lobes recurved; its tube much exceeding the calyx. - Bot. Mag. t. 280 ; Bigelow, Med. Bot. t. 36.

Wooded districts, Sierra Nevada to Mt. Shasta; thence north to British Columbia and east to the Atlantic.

2. A. cannabinum, Linn. Teret re asentine, with less spremlinis hranches,

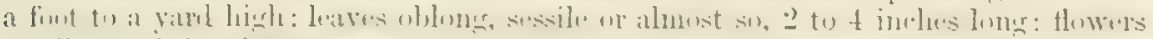

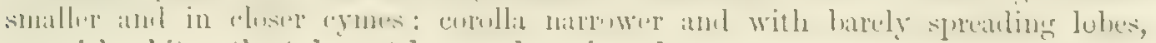
greenish-white; the tube not longer than the calyx.

Along streams, from the southern borders of the State and from near San Frnncisco to Oregon,

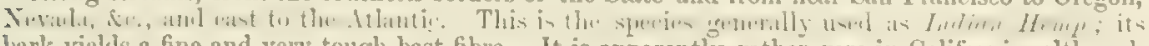
bark yields a fine and very tough bast-fibre. It is apparently mather are in California, although occurring through a wide range.

\section{CYCLADENIA, Benth.}

Calyx 5-parted, hypogynous, naked; the lobes narrow lanceolato or linear.

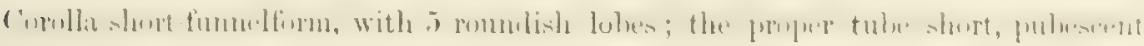

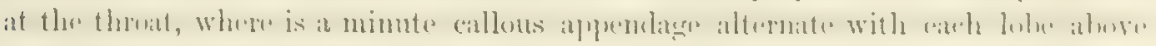

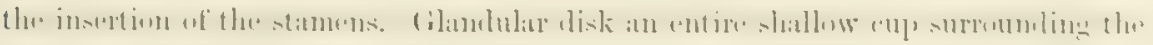
base of the ovaries. Filaments inserterl on the tube, short: anthers sagittnte, both tip and basal lobes slemier-euspiclate; otherwise as Apocymum. Stylo long and filiform: a conspicuous 5-lobed membranous ring unler the capitate 5-angled and truncate stigma. Follicles lanceolate, smooth, many-seeded. Seeds ovate, namowed at the apex, which hears a long and copions tuft of down. - Depressed perennial herbs (peculiar to California); with fleshy branching rootstorks, low and simple or sparingly branched stems bearing 2 to 4 pairs of leaves; these ample, thickish, 
ovate, several-ribbed from or near the base and with a stronger midrib, the base contracted into a conspicuous margined petiole: peduncles terminal, becoming lateral, scape-like, cymosely or corymbosely few-flowered; the bracts alternate: pedicels filiform, much twisted after flowering: corolla rose-color or purple. - $\mathrm{Pl}$. Hartw. 322, \& Gen. Pl. ii. 728.

1. C. humilis, Benth. 1. c. Glabrous throughout and green, or with minute hoariness when young: leaves ovate or sometimes obovate, thickish, 1 to 3 inches long.

"Mountains of the Saeramento" (Hartweg), of Shasta Co. (Brewer), and of Plumas Co., Lemmon, \&xc. Corolla three fourths and the lobes one fourth of an inch in length, inserted on a thin flat disk at the bottom of the calyx, surrounding the nearly entire saucer-shaped nectary which characterizes the genus.

2. C. tomentosa, Gray. Tomentose-hirsute throughout: leaves ovate and oblong-ovate ( 2 or 3 inches long, besides the petiole): calyx hirsute.

Plumas Co., between Big Meadows and Indian Valley, with the preceding (of which it may be only a variety), Lemmon.

\section{ORDER LXI. ASCLEPIADACE丑.}

Herbs (as to temperate regions), with milky juice, no stipules, and regular flowers with the parts in five, except that there are two carpels with distinct ovaries, but a common stigma; the stamens surrounding and attached to this; the pollen in solid masses, in ours all the pollen of each anther-cell in one waxy mass. Leaves entire, generally opposite, sometimes whorled, rarely alternate. Calyx and corolla in ours almost valvate. Flowers usually in simple umbels. Fruit a pair of follicles. Seeds almost always with a coma of silky down.

A large order, nearly related only to the preceding, from which the peculiarities of the stamens, mentioned above, readily distinguish it, widely distributed over the temperate and warmer parts of the world, but very scanty in Europe, and feebly represented on the Pacific side of North America. The sensible properties nearly those of Apocynacea, the juice more or less acrid and containing caoutchouc, and the inner bark (especially in Asclepias) abounding with very tough bast-fibre.

* Erect herbs : a hooded appendage (nectary) behind each anther.

1. Asclepias. An incurved horn or projecting crest from the cavity of each hooded appendage.

2. Gomphocarpus. No horn to the appendages.

$$
\text { * * Twining herbs. }
$$

3. Sarcostemma. Crown a ring in the throat of the rotate corolla: pollen-masses vertical.

4. Lachnostoma. Crown as in Asclepias: pollen-masses horizontal. - See Appendix.

1. AsClepias, Linn. Milkweed. Siliweed.

Calyx and corolla both deeply 5-parted; the divisions small and reflexed. Filaments inserted on the very base of the corolla, monadelphous, short, 'often very short, crowned behind each anther with a conspicuous hood-like appendage, from the cavity of which rises a subulate and usually falcate horn: anthers conniving around and adherent to the solid stigma, their thin and broad scarious tips inflexed over its truncate summit, the wing-like cartilaginous edges meeting and more or less projecting between the hoods: wax-like pollen-mass of each cell pear-shaped, tapering above into a stalk by which it is suspended, along with a pollen-mass from an adjacent anther, to a black gland affixed to the upper edge of the stigma alter- 
nate with the anthers; the 10 pollen-masses, therefore, hanging in pairs from the five glands, extricated from the cells only by the agency of insects, being carrieil away alonir with the glands (enenerally by their less). Ovaries with short styles, the tips of which readily separate from the massive common stigma (to the under side of which the pollen-tubes are directed). Fullicles ovate or linceolate. Sumls numerous, flat, downardly imbricated all over the linge and suon detached ylitcenta ; the upper end with a long tuft of down (coma). Embryu large, with hruml flat cotylerlons in thin albumen. - Perennial (Ameriean) herbs; with copiuus milky juice and tough bark, and numerous flowers in umbels, the freluncle genenally between the opposite leaves: involuero a whorl of small usually subulate bracts. Fluwering in summer. (Compratively few species west of the liocky MIountains, very few west of the Sierra Nevada.)

* Hoods erect, broadenin! upumd, trice the length of the stamens and stigma, the horn short from near its summit.

1. A. subulata, Decaisne (?). Glahrous, pale or glaucous: branches ritril anul rush-like, leafless, or with a few terete subulate or tiliform leaves abuve: umbels racemose, short-preduncled: perlicels and ovate sepals cinereous-puhescent when young: lobes of the greenish-white corolla oblong-ovate, a third of an inch long: hoouls a little elevated on the column of united filaments, purplish, 3 or 4 lines long, undulate and somewhat 3-toothed at the apex, crested through the middle, the crest terminating near the sunmit in a short and subulate nearly incluted horn: fullicles lanceolate, smooth. - Torr. Bot. Mex. Bound. 164.

Below San Diego along the Lower Californian boundary line, Parry, Clcveland. Ravines on the lower Rio Colorado, Scholl, Cooper, Palmer. The peduncles are not reflexed: otherwise the specimens accord with Decaisue's brief character, taken from a plant in Pavon's collection.

* * Itoots spreading, tapering upward, more than twice the length of stumens and stigna, the horn projecting from near its base.

2. A. speciosa, Torr. Suft-tumentuse, or smother when ollt: stem stunt, 2 te 4 feet hich, leafy to the top: leaves opposite, ovate or obloncr-ovate, almost sessile, acute or pointed, 4 to 6 inches long: pedtuncle longer than the numerous woolly

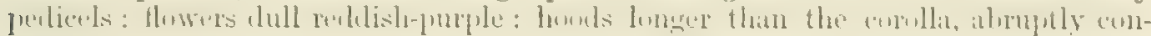
tracted above the short involnte base or body into the long and nearly flat lanceo-

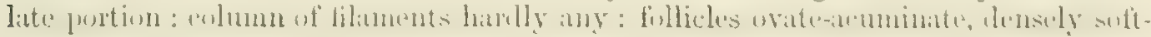
spiny and wonlly. - Ann. Lye. N. York, i. 218. A. Douglasii, Hook. Fl. ii. 53, t. $142, \&$ Bot. Mag. t. 4413 .

In the Sierra Nevada (Yosemito Valloy, Bolander, to Plumns Co., Mrs. Pulsifor Amss, \&c.): common through Oregon, and eastward to the plains east of the Rocky Mountains. Hoorls at length half an inch long. Pods 4 inches long, resembling those of $A$. Cornuti, the comnou Bilkweed of the Atlantic States.

* * Hoods erect or ascending, not exceeding the stamens and stigma,

+ Ovate, obluse, entire, comparatively small; the exserted horn rising from below its midlle: flowers small and numerous: leaves narrow.

3. A. fascicularis, Decaisne. Glabrous, slender, 3 to 5 feet high: lenves in whorls of 3 to 5 , or the lower and uppermost opposite, sometimes also with finscicles in the axils, linear and linear-lnncenlate, slightly petioled (2 to 5 inches long, 1 to 6 lines wille): perluncles slender, often in whorls : pedicels and calyx commonly puberulent: fluwers white or whitish: lobes of the curolla oblong (2) liness long): column of filaments half as lomg as the anthers: horns longer than the hood, subulato, and conspicunsly incurved over the summit of the stigmu: folliches 
slender-fusiform, smooth. - DC. Prodr. viii. 569; Watson, Bot. King Exp. 282. A. macrophylla, Nutt. PI. Gamb. 180.

Hillsides, \&c., throughout the State, extending northward and eastward into Oregon and Nevada.

++ Hoods broad and ventricose or saccate, truncate or notched at the broad summit, mostly including the strongly incurved-uncinate horn, which rises from near the summit: leaves broad and proportionally large: flowers rather large: corolla greenishor yellowish-white: the hoods usually flesh-colored.

+ Glabrous throughout, low: leaves 3 or 4 pairs: hoods saccate, open only at top.

4. A. cryptoceras, S. Watson. Stems decumbent, a span to a foot high, simple: leaves opposite, broadly ovate or orbicular, an inch or two long, very short petioled: unbels nearly sessile, few-flowered: lobes of the corolla oblong-ovate, nearly half an inch long: saccate hoods sessile (a quarter of an inch long), 2-cleft at the summit, each lobe anteriorly alıruptly subulate-pointed, the slender sickle-shaped horn included. - Bot. King Exp. 283, t. 28. Acerates latifolia, Torr. in Fremont Rep. 317.

Mountains near Humboldt Lake, Nevada, Watson. May therefore be expected on the eastern borders of California. Extends to Utah and Idaho, Nuttall, Fremont.

++++ White-woolly, even to the ontside of the corolla in bud, but the wool sometimes deciduous with age, leafy: lobes of the corolla oblong-ovate, about 3 lines, and the hoods 2 lines long, the latter open down the inner side: ovaries glabrous, but the young follicles tomentose.

5. A. vestita, Hook. \& Arn. Stem a span to 2 feet high, stout, simple: leaves opposite, ovate-lanceolate or oblong-lanceolate, almost sessile (3 to 6 inches long), all but the lower gradually acuminate, the base of the upper often cordate: umbels almost sessile, many-flowered : hoods slightly raised on the short filament-sheath, obliquely truncate, so as to be broadly rhombic when outspread and the lateral angles acute, a broadly triangular or vomer-shaped ascending crest rather than horn attached to nearly the whole length of the hood and not exceeding it. - Bot. Beechey, 363 (not Hook. Bot. Mag. t. 4106); Engelm. in Am. Nat. ix. 349. A. eriocarpa, Torr. in Pacif. R. Rep. iv. 128, not of Benth.

From near San Francisco and Monterey to the foot-hills of the Sierra Nevada. In one or two of the hoods the crest or horn has been found nearly wanting. Follicles ovate, minutely tomentose-pubescent.

6. A. eriocarpa, Benth. Stem 2 or 3 feet high, often sharply angled: leaves not rarely 3 ог 4 in a whorl, and the upper occasionally alternate, oblong-lanceolate or oblong, acute ( 4 to 7 inches long): peduncles of the many-flowered umbels an inch or two long, equalling or exceeding the pedicels: hoods rather conspicuously elevated, broader than high, ventricose, the truncate upper portion emarginate at the back, much extended inward horizontally, and enclosing the horizontally produced vomer-shaped crest rather than horu. - Pl. Hartw. 323 ; Engelm. 1. c.

Dry hills, from Monterey (Hartweg) to Owen's Valley (Dr. Horn), and behind San Diego, Cleveland, Palmer. Flowers commonly larger than in the foregoing : the horizontal crest twice longer than high, conformed in shape to the upper part of the hood, which merely eacloses it.

7. A. leucophylla, Engelm. Stem 2 to 4 feet high: leaves as in $A$. vestita, but closely sessile: peduncles of the many-flowered unbels longer than the pedicels, as in $A$. eriocarpa: hoods erect, much narrower, oblong (or when ontspread obovate) with rounded entire summit; the falcate or claw-shaped horn attached below the middle, ascending and incurving over the stigma, longer than the hood. - An. Nat. ix. 349.

Southeastern borders of the State; Providence Mountains ( $D r$. Cooper) and southward ( $D r$. Palmer); thence to S. Utah, Parry. 'Woolliness fine and white, but deciduous, as in A. vestita. Dr. Palmer's specimens are green and glabrate. Corolla greenish; the hoods yellowish. 


\section{GOMPHOCARPUS, R. Brown.}

No horn to the hoods of the stamens: otherwise as Asclepias; equally diverse in the form of the hoods, \&c. - Benth. \& Hook. Gen. Pl. ii. 753.

Accralcs, Ell., and Anantherix, Nutt., are regarded as sections of this genus, which represents Asclepias in the Old World, mainly in Africa. If the few North American species only were concerned, they were better reunited to Asclcpias. Our first section is peculiar.

$\S 1$. Honds saccate, pointless, more or less depending, lower than the anthers, open wholly or partly down the back, as if 2-valved. - ScHizoxotos, Gray.

1. G. tomentosus, Gray. White-tumentuse, even to the outside of the gremish-

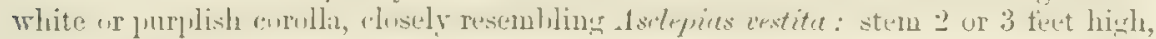
acutely angled: leaves opposite, ovate or oblong, acutely acuminate (about 4 inches long): umbels nearly sessile, rather few-flowered: filament-sheath manifest under the crown; the hoods almost orbicular in outline, laterally compressed, centrally attached, reaching to near the midlle of the anthers, 2 -valved fully half-way round, i. e. from the upper edge of the insertion to the middle of the back. - Acerales tomentosa, Torr. Bot. Mex. Bound. 160, t. 44.

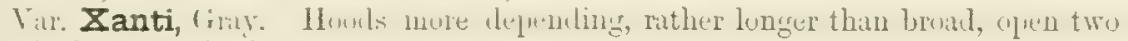
thirds down the back.

Dry hills, from behind San Diego northward (Purry, Thurber, Filch, Pcckham), and on the north side of Monte Diablo (Brever, Bolander): the variety near Fort Tejon (Xantus) and Ojai (Pecklam); and some of the specimens from Monte Diablo approach it. Sepals linear-lanceolate. Lobes of the corolla ablong-ovate, about $t$ lines long. Hoods $2 \frac{1}{2}$ or 3 lines long : summit of the filament-sheath obtusely callous-toothed between the hoods on each side of the salient-angled base of the wings of the anthers: anther-tips very large and broad.

2. G. purpurascens, (imy. Canescently puluerulent: stems ascrutinis, a span to a foot high: leaves ovate and more or less cordate, obtuse, thickish (an inch or two long), short-petioled: flowers small, numerous in a compact umbel: peduncle longer than the pedicels: lobes of the red-purple corolla oblong : hoods white, oval, wholly below the short greenish anthers, adnate by their whole length to nearly the

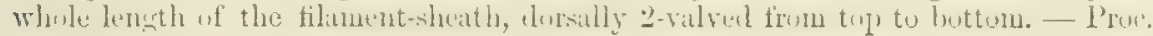
Am. Acad. x. 76 .

Lake Co, on tho exposed summit of a mountain near the Geysers, E. L. Greene. Lobes of the corolla fully 2 lines and hools one line long. Wings of the anthers lunate, not truneate and angled at base.

\section{\$2. Iloods cucullate, erect, open down the front, someroluat surpassing the anthers.}

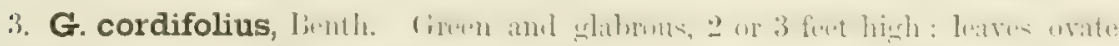

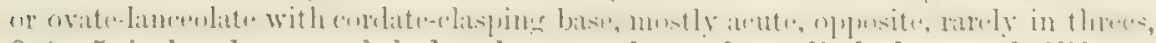
2 to 5 inches long: umbels loosely many-llowered: pedicels long and filiform: calyx hairy ; its lobes lanceolate : corolla dark red-purple; the lobes oval : filament-

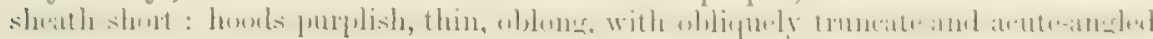
summit, attached at and near the base, the fissure down the front narrow : follicles ovate-lanceolate, smooth and glabrous. - Acerates cordifolia, Benth. Pl. Hartw. 323. A. atropurpurea, Kellogg, Proc. Calif. Acad. i. 65. Asclepias ecornutum, Kellogg, l. c. 55 .

Common in the Valley of the Sacmmento and through the foot-hills, up to Indian Valley and tho Yosemite. Peluncles either short or up to 2 inches in length : pedicels an incls or less long. Lobes of tho corolla 3 or 4 lines, and hoods 2 lines long : a prair of linear-subulate teeth alternate with the hoods, one each side of the suliont nngulate-truncate base of the anther-wings

\section{SARCOSTEMMA, R. Brown.}

Calyx 5-parted. Corolla rotato, deeply 5-cleft, an entire or cnenate ring forming a crown in its throat. Short sheath or ring of monadelphous filaments bearing 
behind each anther a fleshy and flattish appendage. Anthers, fruit, \&c., nearly as Asclepias. - Twining herbs or partly shrubby plants (of the warm regions); with opposite leaves and umbellate flowers.

1. S. heterophyllum, Engelm. Puberulent or almost glabrous: twining stems filiform: leaves linear or narrowly linear-lanceolate, acute, some of them cordate or hastate at base, a few tapering into the petiole: umbels several-flowered, longpeduncled: corolla dull purple or whitish, almost 5-parted; the lobes ovate, with scarious-white more or less ciliate margins, cinereous-pubescent outside, nearly smooth within, thrice the length of the linear-lanceolate hairy calyx-lobes: appendages of the stamens roundish, rather longer than the anthers: follieles lanceolate and slender-pointed, puberulent. - Torr. in Pacif. R. Rep. v. 363, \& Bot. Mex. Bound. 161.

Var. hirtellum. Erect, but inclined to twine, two feet high, slender, minutely but densely pubescent all over with short spreading hairs: leaves all linear and tapering at base: flowers one half smaller, "whitish-yellow, fragrant."

Climbing over bushes in the southern part of the State, Parry, Cooper, Cleveland. Extends into Mexico and Texas. Corolla about half an inch in diameter, except in the variety. The latter near Fort Mohave, Dr. Cooper.

\section{ORdER LXII. GENTIANACE巴.}

Glabrous herbs, with colorless and bitter juice, entire opposite and sessile leaves (except in Menyanthes and sometimes in Swertia), no stipules, perfect and regular flowers, stamens as many as the lobes of the corolla and alternate with them, inserted on the tube, the anthers free from the stigma; ovary one-celled with two parietal placentæ, becoming a septicidal capsule; style one or none; the stigmas commonly two; seeds numerous and sometimes innumerable, rarely few; and the embryo small or minute in copious albumen. Calyx persistent. Corolla mostly convolute in the bud, rarely valvate with the edges turned inward, usually withering-persistent. Seeds anatropous or amphitropous. - An order of about 40 genera.

\section{SUBORDER I. GENTIANEAE.}

Lobes of the (withering-persistent) corolla convolute in the bud. Seeds sometimes covering the whole walls of the capsule, the coat usually thin. Leaves opposite or whorled (or alternate in Swertia), entire; the cauline sessile.

The following genera, not yet known to occur within or very near the borders of California, may be expected in the northernmost parts of the State :

Pleurogrne (rotata, Grisebach), like an anuual Gentian, but with rotate corolla.

HALENIA (DEFLEXA, Grisebach), known by the spurs, one under each lobe of the corolla.

Swertia (Perennis, Linn.), most like one of the smaller species of Frasera; the leaves alternate! or only the upper ones opposite.

Eustoma, a genus with showy sky-blue flowers, and a filiform style, belongs to the region east of the southern borders of the State. - See Appendix.

1. Erythraea. Corolla salverform, red. Anthers spirally twisted after shedding the pollen. Style slender, at length decidnous. Calyx 5-parted.

2. Microcala. Corolla short-salverform, yellow. Anthers short, not twisting. Style in ours persistent: calyx merely 4-toothed.

3. Gentiana. Corolla from campanulate or funnelform to salverform. Style none or hardly any : stigmas 2, thin and Hat, persistent. Seeds very numerous and small.

4. Frasera. Corolla rotate, 4 -parted, each lobe bearing one or two fringed glands in the form of shallow pits. Style distinct, persistent: stigna small, entire or 2-lobed. Seeds few or several, large. 


\section{Suborder II. MENYANTHIDEE.}

Lobes of the corolla induphicate in the hul. Seerls rather fer and with a thick harl and close coat. Ayuatic or low plants, with alturnate leares, sometimes of 3 leaflets; the petioles sheathing at base. - Represented only by

5. Menyanthes. Curulla deciluous, 5-cheft ; the lubes within white-bearded : flowers racemose.

\section{ERYTHR 开A, Pers. Carchalagua.}

Calyx 5-parted, or occasimally 4-parted; the divisions slender. Corolla salverform, withering-persistent on the capsule; the lubes convolute in the bucl. Stamens inserted on the thruat of the corolla : filaments slemler: anthers ublong or linear, twisting spirally (in 2 to 4 turns) after shethling the pollen. Style filiform, at length deciluous: stigmas, in vurs wedge-shaped or fin-shaped, before expansion cornmonly appearing as if united and connjessed-capitate. Capsule frum ublongovate to lanceolate-cylindraceous; the sutures little or considerably introflexed. Seeds very numerous, globular or oblong, with a close reticulate-pitted coat. Lrw herhs (both of the Old and New World, in warm-temperate regions), wainly annuals; with litter ruots, cymose inflorescence, and usually pink or rose-red flowers (whence the generic name).

Like the Gentians, these plants are bitter tonics ; and, in Califomia as well as in Chili, are in medicinal repute, under the name of Canchalagica. Dr. Engelmann points out a character in the stigmas; i. e. that in the European species, excepting the peculiar $E$. maritina, they are broadly ovate or with rounded summit, while in the American they are either cuneate or flabelliform, the summit truncate, or in $E$. Chilensis emarginate.

E. (Gyrandra) chirosioldes (not of Tort.) and E. speciosa (Gyrandra, Grisebach, and Benth. Bot. Sulph. t. 45) - large-flowered species, which hardly differ except in the shorter filaments of the latter - are Mexican only, and are sectionally distinguished by having the apparently pale and broad corolla-lobes rather longer than the tube at the time of opening, and the eapsule oval. In all the following the capsule is from elongated-oblong to fusiform.

* Corolla large; its limb at first almost as long as the tube: seeds globular: inflorescence corymbosely cymose: peduncles as long as the calyx.

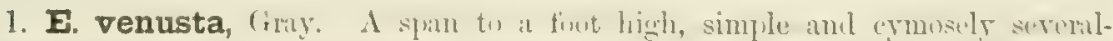

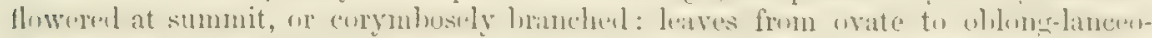

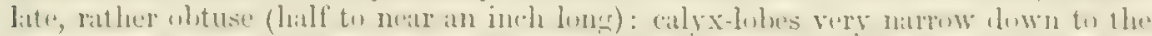

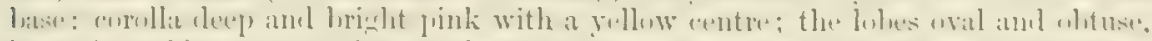

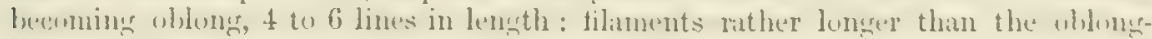
linear anthers, $-E$. chironivides, Torr. Bot. Mex. Bound. 156, t. 42, excl. syn. E. tricantha, Durand in Pacif. R. liep. v. t. 9, not Griseb.

Common through all the southern part of the State, and extending (mostly in a smaller forma) along the Sierra Nevada to Sierra Co, up to about 4,000 feet. The name givea in Coulter's collee-

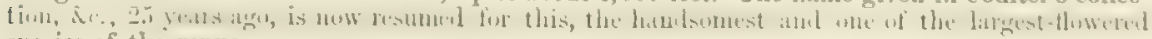
species of the genus.

* Corolla with lobes shorter than the tube: seeds oblong: inflorescence cymoseclustered; the crowded flowers sessile or nearly so in the forks, and the lateral ones with a pair of bracts wner the calyx: stigmes small.

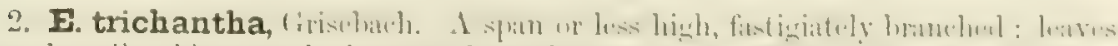

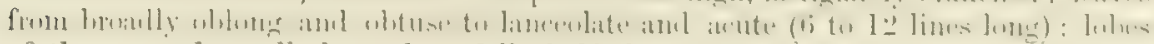
of the rose-red corolla lanceolate, fully half the length of the tube at the time of expansion ( 3 or 4 lines long), becoming narrow and by involution acuminato with ago: calyx-lobes filiform-triquetrous : anthers linear. - Gent. 146, \& DC. Prodr. ix. 60, excl. var. angustifulia.

Comnon nem the coast from Lake Co. and the Valley of the Lower Sacramento to Monterey. 
3. E. floribunda, Benth. More slender and inflorescence more open: lobes of the light rose-colored corolla oblong, becoming lanceolate in age, hardly 2 lines long, only a third or one fourth the length of the tube: anthers oblong: calyxlobes more subulate and less carirate than in the preceding. - Pl. Hartw. 322.

Valley of the Sacramento, Hartweg. Also, in a dwarf and fewer-Howered form, Sierra Valley, Lernmon.

* * Corolla-lobes ( $1 \frac{1}{2}$ to 3 lines.long) much shorter than the tube: seeds globular: anthers oblong: flowers sparsely paniculate or solitary, peduncled.

4. E. Muhlenbergii, Grisehach. Two inches to a span high, simple or branched from the base: leaves mostly oblong, obtuse, and about half an inch long: peduncles mostly shorter (sometimes much shorter) than the flowers: lobes of the rose-red corolla oval, very obtuse, becoming oblong (often 3 lines in length). - E. Muñlenbergii, Grisebach, l. c. as to Californian plant only; Benth. Pl. Hartw. 322.

Hills, Monterey to San Francisco Bay, not uncommon. The Pennsylvanian plant, on which Grisebach mainly founded his E. Munlenbergii, is E. ramosissima, introduced from Europe; but the name may be kept up for the Californian species, although meaningless, as Muhlenberg had nothing to do with it.

5. E. Douglasii, Gray. Mostly slender, from 2 to 12 inches high, loosely paniculate: leaves lanceolate or linear-lanceolate and acute, or the lower ones narrowly oblong (from half an inch to nearly an inch in length): peduncles long and filiform, commonly strict and the earlier or central ones an inch long or more: lobes of the pink corolla oblong (barely 2 lines in length): seeds globular, hardly a quarter of a line long. - Cicendia exaltata (wrongly characterized), Grisebach in Hook. Fl. ii. 69, t. 157, A. Erythroea Nuttallii, Watson, Bot. King Exp. 276 , in part.

Along the eastern borders of the State from Fort Mohave northward, and sparingly on the western : also in Oregon, Idaho, and Northern Utah. Neither of Nuttall's unpublished names ( $E$. tenella for a dwarf state, and $E$. elata for a taller one) seems appropriate : so we have imposed the name of the first collector, Douglas.

E. NutTaluit, Watson (Bot. King Exp. 276, t. 29 mainly), is distinguished from E. Douglasii by the acutish lobes of the commonly larger eorolla, and the oblong seeds, which are fewer and much larger, a third of a line long. It occurs in Nevada, as near as Ruby Valley, and in adjacent parts of Idaho and Utah, Nuttall, $H$. Engelmann. Although two of the three of Nuttall's unpublished names, cited by Watson under $E$. Nuttalliri, belong to the plant now distinguished as $E$. Douglasit, yet Mr. Watson's figure and description relate mostly to the species for which the name is here retained.

\section{MICROCALA, Link.}

Calyx 4-toothed, 4-8-ribbed. Corolla short-salverform, withering persistent on the ovoid capsule. Stamens short, inserted in the throat: anthers round-cordate. Style filiform, in ours persistent or tardily deciduous: stigma peltate-dilated, at length separating or separable into 2 broad plates. Seeds, \&c., as Erythrcea. Little annuals, one in the Old World, and one or two in South America, whence the following may have reached California.

1. M. quadrangularis, Grisebach. An inch or two high, filiform, simple and one-flowered, or branched at base, with one to three pairs of minute oval or oblong leaves below : peduncle strict and naked, quadrangular: calyx short, strongly quadrangular, and as it were truncate at bottom and top, at least when in fruit; the teeth distant and very short: corolla saffron-yellow, barely twice the length of the calyx, open only in bright sunshine, closing in the afternoon. - DC. Prodr. ix. 63 ; Progel in Fl. Bras. vi. 213, t. 58, f. 3. Exacum quadrangulare, Willd. E. inflatum, Hook. \& Arn. Cicendia quadrangularis, Grisebach, Gent. 157.

Hillsides and moist meadows abont San Francisco, Martinez, and Vallejo, where it may readily have been introduced; but also on the coast' near Mendocino (Bolander), under Pinus contorta; so that it may be indigenous. 


\section{GENTIANA, Linn. GeNTiar.}

Calyx 4-5-cleft or toothed. Corolla 4-5-lobed, funnelform, campanulate, or sometimes salvertirm, often with haited aud touther firhls in the sinuses, witheringpersistent. Stamens included: anthers sometimes cohering in a ring or tube. Style none or very short: stigmas 2, thin and flat, persistent. Capsule septicidal. Sceds very numerous and small, sometimes lining the whole wall of the capsule; the coat usually but not always loose. - Herbs; with bitter roots, opposite leaves, and terminal or clustered flowers, watlly showy, appearing in summer or antum.

The typical and the largest genus of the family, comprising 150 species, widely distributed over the cooler regions of the work, moderately represented in Oregon and the Rocky Mountains, as well as in the Atlantic States; but few reach California, and those are scarce and confined to the Sierra Nevada or to the northem part of the State.

\$1. No plaited folds in the sinuses of the corolla: anthers versatile: root in ours annual, or rarely biennial. - Gentunella.

* Flowers small: corolla nearly salvershaped, crowoned with a fringe of bristles on the base of the lobes within.

1. G. Amarella, Limn, vir. acuta, Enselm. From a span to a font ur more in height, slender, simple or paniculately branching: leaves thin; the larger an iuch long and oblong-lanceolate; the lowest obovate or spatulate; uppermost ovate-lanceolate : flowers in axillary and terminal clusters, or rarely solitary, forming a narrow panicle: corolla light blue, a quarter to half an inch long; its 5 short lobes from ovate to oblong-lanceolate, obtuse or becoming acute. $-G$. acuta, Michx, \&c.

In the Sierra Nevada, from Mariposa Co. northward, at 5,000 feet and over; thence far northward and eastward, rumning into various forms.

* * Flowers lavge for the size of the plant; the parts usually in fours : corolla destitute of fringe across the base of the lobes, but their edyes sometimes fringed: a rono of glands between the bases of the filaments: capsule stipitate.

2. G. simplex, Gray. Stem 2 to 10 inches high from a small and slender anmul root, simple, bearing 2 to 4 pairs of lanceolate or linear-oblong leaves ( $t$ to 9 lines long) and a single slenter-pelunculate flower: corolla blue, 1 to 1 in inches long; the oblong-spatulate lobes entire or erose-toothed, or marely with a few bristly teeth low down on the sides: sceds smooth but longitulinally striate, narrow, wingless when mature, but somewhat cellular-appendaged at each end. - Pacif. R. Rep. v. $87, \mathrm{t}, 16$.

Higher parts of the Siem Nevada, in wet ground, from Placer Co, at 8,000 feet (Breacer), ahove

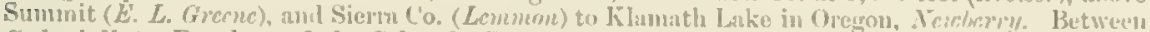
G. barbellater, Engelm., of the Coloralo Rocky Mountains (which is perennial), and depaupernto forms of the next; but the seeds very different, when mature not wingerl, however, ns representerl in the figure ahove cited: they are laneenlate in outline, the nurelens consely striate, produced into a thiekish cellulur bas?, and at the other end into a moro subulate cupty tip.

3. G. serrata, Cumner. Stem 3 to 18 inches high from a slender anmul ront, simple or the lamer plants brunched from tho base, bearing few or soveral pairs of lancenlate or linear leaves, all narrow at base or the lowest oblancenlate, and terminated by a long and naked one-flowered petuncle: cornlla light blue, mostly an inch and a half long; tho oblong or spatulate-obovate lohes commonly erosely toothed around tho summit and often fringed down the sides: seeds oval, wincrless, the close cuat rough with minute projecting seales - (FI. Dan. t. 317) Fl. Norvers. 101, t. 2, fig. 3-5 (1766); Fries, Simm. Sand. 190. G. detomsa, Rott. Art. Ilatn. x. 25t, t. 1, fig. 3 ; Grisebach, Gont. \& in IIook. Fl. ii. 6t, \&c. G. brarkypetala, Thungo, Consp. Gent. 225, t. 11, fig. 3.

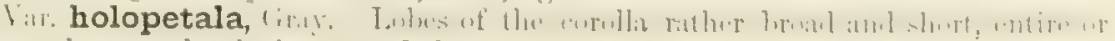
obscurcly crosedenticulate round the summit: secds as in tho fringed forn. 
Wet ground, in the higher regions of the Sierra Nevada: Soda Springs of the Tuolumne, at 8,600 feet (a pygmy form, only 2 to 5 inches high, with leaves merely 4 or 5 lines long and crowded towards the base), to Mariposa Co. above the Yosemite (much larger, a span high or more), Bolander. Both of the variety, which accords with the Scandinavian plant, except in the entireness of the corolla lobes, which also occurs in European specimens. The larger form, G. detonsa, var. barbata, Frolich and Grisebach, which is common eastward of the Rocky Mountains, where it too closely approaches $G$. crinita (the common Fringed Gentian of the Atlantic States), is unkuown in California and Oregon. It is singular that, while only entire petals are known of this species in California, the $G$. simplex, described with entire petals, has them sparingly fringed in most of the specimens now known.

\$2. Plaited folds at the sinuses of the short-funnelform or campanulate 5-lobed (in ours blue or bluish) corolla:" anthers erect and fixed: root perennial. Pnemonaythe.

* Plaits extended between the lobes into conspicuous cleft or lacerate appendages.

+ Low, with decumbent one-flowered stems: leaves with conspicuously connate-sheathing base, the uppermost becoming bracts to the flower.

4. G. Newberryi, Gray. Dwarf (2 to 4 inches high): flowering stems 1 to 4 , ascending from around a short central axis which bears a rosette of obovate or spatulate leaves, of about an inch in length: cauline leaves 2 to 4 pairs. (half an inch long); the lowest obovate, the uppermost oblanceolate: calyx-lobes oblong or lanceolate, nearly as long as the tube: corolla broadly funnelform (over an inch long), pale blue, within white, and greenish-dotted; its lobes ovate, mucronate, longer than the slender-subulate tips of the 2-cleft or laciniate interposed appendages: seeds oval, broadly winged.-Proc. Am. Acad. xi. 84. G.calycosa (?), Gray in Pacif. R. Rep. vi. 86, not of Grisebach.

Sierra. Nevada, at 5,000 to 8,000 feet; Crater Pass in Oregon, lat. 44 (Nexberry), Lassen's Peak (Brever), and Mariposa Co. south of the Yosemite, Bolander. Somewhat related to $G$. frigida, which inhabits the alpine region of the Rocky Mountains.

5. G. setigera, Gray. Stems stout, but diffusely spreading from a thick caudex, a foot or less long, bearing 7 to 10 pairs of thick very obtuse leaves: lower leaves roumd-oval; upper oblong; two uppermost pairs involucrate around the flower (all an inch long, or the lower shorter): calyx-lobes oval, about the length of the tube: corolla oblong-campanulate, apparently with dull purplish tube and the ovate lobes blue: appendages in the sinuses small and short, but extended into 2 or 3 capillary bristles which almost equal the lobes. - Proc. Am. Acad. xi. 84.

Red Mountain, Mendocino Co., in damp soil, Bolander. Corolla an inch and a half long, Tather broad; the lobes nearly half an inch long. Sheaths of the leaves mostly a quarter of an inch long. Forming seeds orbicular and winged.

++ Mostly erect and taller, 1 - several-flowered, leafy: leaves not conspicuously connate-sheathing at base, except the lower pairs.

6. G. calycosa, Grisebach. A span to a foot in height: leaves ovate (an inch to half an inch long); the lower decreasing in size, the one or two uppermost pairs involucrate around the one to three sessile flowers: calyx-lobes ovate or ovate-lanceolate, equalling or rather shorter than the short tube: corolla oblong-campanulate, blue (over an inch long); appendages in the sinuses laciniate, shorter than the broadly ovate lobes: seeds lanceolate, wingless. - Gent. 292, \& in Hook. Fl. i. 58, t. 146.

Sierra Nevada at 8,800 feet in Placer Co. (Brewer); Calaveras Co., near Murphy's (Lemmon); also collected at some unknown station by Bridges. Occurs in the northern Rocky Mountains and those of the interior of Oregon. Rarely 2 or 3 flowers from the axils.

G. PArRYI, Engelm., of the Colorado Rocky Mountains, collected by Watson in the northeastern part of Nevada, differs principally in the much smaller calyx-lobes, and the leaves are sometimes narrower.

7. G. affinis, Grisebach. A foot or two or sometimes only a span high : leaves from ovate-oblong to linear-lanceolate (an inch or so in length), the uppermost 
narrower: flowers mostly 5 to 20 and racemose or spicate, forming a leafy thyrsus (rarely solitary in depauperate plants): calyx lobes narrow and unequal, mostly linear and the longest sborter than the tube: corolla short-funnelform, blue (an inch or more in length); appendages triangular, acute, mostly 2-cleft or 2-4-cuspidate, shorter than the round-ovate lobes: seeds ovate or oblong, flat, wing-margined.

Var. ovata, Gray: a form with ovate or oblong leaves, and fewer commonly larger flowers, the calyx-lobes lanceolate and as long as the tube; the lobes of the corolla commonly rounder.

Northeastern portions of the Sierra Nevada, at 5,000 feet, \&c.; thence north to British Columbia, and eastirard to the Rocky Mountains from New Mexico to Rupert's Land. The var. from near San Francisco (Bolander) to Klamath Valley in Oregon (Cronklite) and the borders of British Columbia (Lyrll), appearing to be different, and with the aspect of the next, but passing into ordinary forms of the species.

* * Appendages of the plaits in the sinuses hardly any, or short and broadly truncate, naked: seeds wingless: only the lowest pairs of leaves with sheathing base.

8. G. sceptrum, Grisebach. Erect, 2 to 4 feet high, leafy: leaves from ovate to oblong-lanceolate (an inch or two long): flowers several and racemosely or spicately clustered, sometimes almost solitary: corolla campanulate, an inch and a half long; its lobes broad and rhombic-rounded: seeds somewhat fusiform, narrowed into a cellular appendage at both ends. - Hook. Fl, ii. 57, t. 145.

Var. humilis, Engelm. ined. Much smaller: stems slender and weaker, a foot or two long, one-few-flowered: corolla an inch and a quarter in length; the sinuses sumetimes 2-3-crenate. - G. Menziesii, Grisebach, l. c. G. affinis, Gray in coll. E. Hall, No. 426, \& Proc. Am. Acad. viii. 398.

The ordinary form is eommon in Oregon, and it may confidently be expected in the northeastern part of the State. The var. Inmilis, on Mendocino Plains, Bolander"; Oregon, E. Holl; also Mcnzics, this being without much doubt $G$. Mcnziesii. At first view it seems abundantly distinct from $G$. sceptrion. Calyx-lohes variable, as in all these species, commonly louger than the tube, and unequal, lanceolate or oblong-linear.

\section{FRASERA, Walter.}

Calyx deeply 4-parted, slightly imbricated in the bud. Corolla rotate, 4-parted, per'sistent; the divisions convolute in the bud; their inner face furnished with a large depressed gland or pair of glands, which are bordered by a fringe, sometimes a crown of bristles or scales at their base. Stamens inserted on the very base of the corolla : filaments subulate, distinct or obscurely monadelphous at base. Orary ovate, taperiug into a conspicuous and persistent style: stigmn small, 2-lobed or entire. Capsule coriaceous, commonly flattened, strictly one-celled, few - 30-seeded. Seeds comparatively large, flat, sometimes margined. - Gharous anl commonly stout herbs, or one slemler species puberulent, all North American, and all but one far-western; with a thick and purely bitter biennial root, an erect leafy stem, hoaring opposite or whorled leaves (which when broad are nervose, and in most species cartilaginous-raargined), and abundant rather large flowers in cymose clusters; the corolla dull white, yellowisb, or bluish, and commonly dark-dotted. Parts of the fluwer sometimes in fives?

'The root of the $\Lambda$ thantiv: specieg, $F$. Carolinmsis, has heen used in medicino as a hitter tonic. This (with (appsule strongly flattened pamblel with the valves) and

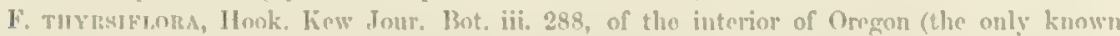

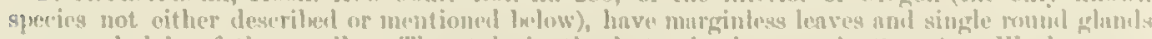

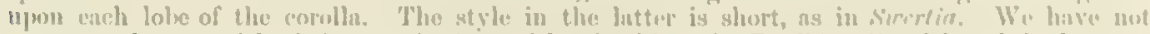

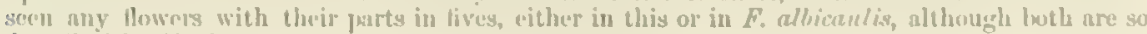
cleserituel by Hooker. 
\$ 1. A pair of glands on each division of the corolla: divisions of the calyx linear: flowers in a narrow leafy thyrsus: capsule much flattened contrary to the deep boat-shaped or almost conduplicate valves.

1. F. speciosa, Dougl. Stout, 2 to 5 feet high, very leafy : leaves nervose, in whorls of four to six, not white-margined; the radical and lowest cauline obovate or oblong, 6 to 10 inches long, above lanceolate and becoming linear: flowers on slender at length strict pedicels in umbel-like pedunculate cymes (or some fascicled in the axils), forming a long virgate thyrsus: corolla greenish-white or barely tinged bluish, conspicuously dark-dotted, not longer than the sepals; its divisions oraloblong, bearing a pair of oblong and strongly fringed glands about the middle, crowned at base by a friuge of 8 to 10 long setaceous filaments. - Grisebach in Hook. Fl, ii. 66, t. 153. Tessaranthium radiatum, Kellogg, Proc. Calif. Acad. ii. 142, fig. 41.

Along the eastern parts of the Sierra Nevada (from Tuolumme Co. Brewer); thence northward to the interior of 'Washington Territory, and east to Wyoming and New Mexico. Divisions of the corolla two thirds of an inch long; the fringe-like crown adnate to their base, and wholly separate from the base of the quite distinct stamens. Style not longer than the ovary: seeds 30 or more.

F. Pantodtata, Torr. in Pacif. R. Rep. iv. 126, is a New Mexican species of this section, imperfectly known.

\section{§2. A single gland with $\alpha$ notched summit on each division of the thickish corolla: divisions of the calyx ovate-lanceolate or broader: flowers loosely and effusely cymose-panicled. (Mature capsule unknown.)}

2. F. Parryi, Torr. Stout, 2 or 3 feet high: leaves opposite and in threes, lanceolate, with cartilaginous white margins; the floral and bracts oblong and ovate: divisions of the whitish and dark-dotted corolla ovate, commonly acute, half an inch long; the fringed gland below its middle, lunately obcordate and with rounded naked base. - Bot. Mex. Bound. 156.

Southern part of the State, east of San Diego and Los Angeles, Coulter, Wallace, Parry. Ovary apparently flattish parallel with the carpels : ovules rather few.

F. Albomarginata, Watson, Bot. King Exp. 280, of Southem Utah and Nevada, and to be looked for on the southeastern borders of California, is of this section. It is a small species, narrow leaved ; the divisions of the corolla conspicuously cuspidate ; and the fringed obcordate dark gland on the middle of the petal runs into an adnate scale-like appendage, fixed by its back quite down to the base, the free margins fringed, and united across the base by a small laciniate portion, forming a sornewhat hooded base, as in the next.

\$ 3. A single oblong or linear and entire gland reaching from near the base to near the middle of each division of the thinnish (pale blue or lavender-colored) corolla: divisions of the calyx subulate-lanceolate: flowers thrysoid-glomerate: capsule flattened parallel with the valves, few-seeded.

3. F. nitida, Benth. Glabrous throughout (not ninutely and closely puberulent as in $F$. albicaulis), a foot or more high, slender: leaves only 3 to 5 pairs, linear (2 to 4 inches long, 2 or 3 lines wide, the radical longer and gramineous), whitemargined: flowers glomerate in 3 or 4 pairs of short-pedincled or subsessile dense cymes or glomerules, forming a naked and interrupted spicate thyrsus : lobes of the corolla ovate-oblong; becoming lanceolate ( 3 or 4 lines long); the gland with a short inflexed fringe all round, which is longer and more laciniate at the hooded base: crown stamineal, consisting of linear or oblong laciniate or nearly entire scales alternate and partly comnate with the bases of the filaments. - Pl. Hartw. 322 ; Torr. in Pacif. R. Rep. iv. 126.

Foot-hills of the Sierra Nevada (Hartweg, Bigelow, \&c.), and Sierra Valley (Lcmmon, \&c.), to Oregon, Lyatl, Nevius. Probably this may be only a variety of F. albicautis of Oregon (Hook. F1. t. 154), extending as it does into the range of that species. The crown appears to be different, but its characters are variable. 


\section{MENYANTHES, Toun. BUCKBEAN.}

Calyx 5-parted. Corolla nearly campanulate, the lobes valvate in the bud with the margins turned inward, the upper surface densely white-bearded, deciduous. sityle slender, persistent: stigna o-luhed. Capsule whoular, rather Heshy, inclined to burst irregularly. Seels not very numerous, but large in proportion: the seedcoat hard, smooth and shining. - A single genuine species, flowering in spring.

1. M. trifoliata, Linn. Low and smonth perennial, with lons and stout creeping rootstock, bearing alternate leaves, with long petioles sheathing at base, and 3 oblong leatlets: scape naked, elongated, terminated by a short raceme of white or pinkish flowers : anthers dark brown, sagittate: in some Howers the style, in others the filaments are long-exserted.

In shallow water or wet ground, near San Francisco (Bigelow), and Sierra Valley (Mrs. Pulsifer $A m c s)$; extending round the world in the northern portion of the temperate zone.

ORDER LOGANIACEAs. There is a Buddleio in Coulter's Californian Collection, No. 625, which we do not possess. As none has been deteeted since, it is more probable that Coulter's specimen was gathered on the route to California, is far south and east at least as Arizona.

\section{ORder LXIII. POLEMONIACE开.}

Chiefly herbs, with bland and colorless juice, simple or divided leaves, and no stipules; readily distinguished from related orders by having all the parts of the regular Hower five, except the pistil, which has a 3-celled ovary and a 3-lobed style; the fruit a loculicidal 3-many-seeded capsule, with placenta in the axis. Calyx imbricated in the bud, persistent. Corolla convolute in the bud, not plaited, rarely a little irregular. Stamens on the corolla alternate with its lobes, distinet : anthers introrse, opening lengthwise. Stigmas occupying the inner side of the narrow or

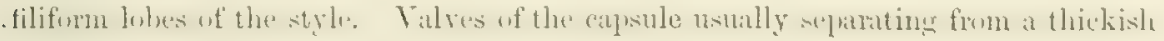
triangular axis, which bears the seeds: these amphitropous or nearly anatropous, small, with a thin or soft coat, commonly dereloping mucilage when wetted. Embryo rather large, straight, in the axis of fleshy albumen. - $\mathrm{A}$ few have suftrutescent or more woody stems. In Gilin, $\S 6$, the cells of the ovary and the stigmas are occasionally reduced to two. - Gray, Proc. Am. Acad. viii. 247.

Mfaiuly an American and especially a North American and Mexican ovler, of fer genern, but many species, increasing in number westward, most abundantly represented in California; of no marked sensible qualities or economical uses, oxcepting ornamental cultivation.

COBNA SCAXDENS, Cav., of Mexico, a well-known cultivated climber, is an outlying member of this ordor, its pinnate leaves tendril-benring, and a large lleshy disk oncircling the buse of the ovaly.

- Corolla quito regular: secds wingless.

1. Phlox Stamens unequally inserted and included within the narrow tube of the salvershaped corolls. Seed-cont unchanged in water. Leaves opposite, ontiro.

2. Collomia. Stamens unequally insorted in or below the thront of the funnelform or salvershaped corolla: filaments slender, often exserted. Secds copiously mucilaginous when wet. Leaves all or mostly alternate, sometimes divided.

8. Gilia. Stamens eyually inserted on the thront or tube of the corolla : filaments not ileclined. Sirels almost always mucilaginous when wet. Leaves various.

4. Polemonium. Filments moro or lrss declined. Utherwise nearly as Giline Laves all pimnate and alterunte, and sorolla short.

* - Corolla with limb somewhat irregularly cleft : seeds wing-margined.

5. Laselia. Stamens more or less exserted. Upper sinnses of the corollu more deeply eleft thon the others. 


\section{PHLOX, Linn.}

Calyx narrow, 5-cleft. Corolla salverform, with a narrow orifice and broad or rounded lobes. Stamens included, very unequally inserted on the upper part of the tube: filaments usually very short. Ovules and seeds solitary in each cell (or the former sometimes 2 or 3). Capsule small, ovoid. Seed with a simple and elose coat, neither mucilaginous nor developing spiral threads when wet. - Herbaceous or suffruticose plants (ours all perennial), with simple and entire opposite leaves, or the uppermost alternate, and rather showy terminal or cymose flowers; the corolla white, purple, \&c., in all the Californian white or light rose-color.

A genus of nearly 30 species, all North American and one Siberian, several of them familiar in ormamental cultivation. The Pacific species are few, and different from those of the Atlantic States.

* Loose; with flowering branches mainly herbaceous from a woody base: leaves linear or lanceulate, spreading, mostly an inch or two long: flowers peduncled and loosely cymose-clustered.

1. P. speciosa, Pursh. Viscid-puberulent above or nearly glabrous: flowering stems a foot to a yard high, diffusely ascending from a branching woody base: leaves lanceolate or linear, one or two inches long, the upper broader at the base: flowers corymbose, showy: lobes of the corolla obcordate or sometimes merely emarginate, a third to half an inch long; the tube little exceeding the calyx: style not longer than the ovary nor the stigmas. - Gray, Proc. Am. Acad. viii. 256. P. Sabini, Dougl., a northern form with almost entire corolla-lobes. P. occidentalis, Durand in Pacif. R. Rep. iv. 125. P. divaricata, Durand, Pl. Pratten, in Jour. Acad. Philad. n. ser. ii. 97 .

In the Sierra Nevada and its foat-hills, Placer to Plumas Co., and northward to the borders of British Columbia; chiefly the larger and broader-leaved forma.

2. P. longifolia, Nutt. Somewhat viscid-pubescent or glabrous: tufted stems about a span high from a woody base: leaves narrowly linear and an inch or two long in the typical forms: flowers smaller: lobes of the corolla obovate or oblongcuneate, entire or retuse, a fourth to a third of an inch long; the tube considerably longer than the angled calyx: style long and slender.-Jour. Acad. Philad. vii. 41; Gray, 1. c. P. humilis, Dougl. in DC. Prodr. ix. 306.

Var. Stansburyi, Gray, 1. c. A rather dwarf and rigid form, more pubescent, with lanceolate or ovate-lanceolate leaves, sometimes of about half an inch in length; appearing very distinct, but it passes into the genuine form. - $P$. speciosa, var. Stansburyi, Torr. Bot. Mex. Bound. 145.

Eastern part of the Sierra Nevada, from near Carson City and Sierra Valley (Anderson, Lemmon, \&c.), thence far eastward and northward through the interior regions to and beyond the Rocky MLountains.

* Cespitose and depressed, forming broad or dense matted tufts: flowers sessile, terminating the densely leafy branches.

+ Leaves acerose or subulate, rigid or loose, green, destitute of cobwebby hairs.

3. P. Douglasii, Hook. Forming broad but rather open tufts, glabrous or a little pubescent : leaves acerose, commonly spreading, half an inch or less in length, and with fascicled shorter ones crowded in the axils, their margins naked or nearly so: tube of the corolla longer than the calyx; the lobes obovate and entire, about 3 lines long. - Fl. ii. 73 , t. 158.

Var. diffusa, Gray, l. c. : a form of moister or more shaded stations, with procumbent stems, and laxer less rigid leaves. $-P$. diffusa, Benth. Pl. Hartw. 325.

Var. longifolia, Gray, l. c. : a form with more slender and rigid leaves, from half to two thirds of an inch in length. 
Sierra Nevada, from Mariposa Co, to Sbasta, at 5,000 to 10,000 feet, thence far northward and eastward; on the westward slope mainly the var. diffusa. A variable species.

4. P. cæespitosa, Nutt. Forming dense and cushionlike tufts 3 or 4 inches high: leaves short ( 2 to 5 lines long), from acerose-subulate to oblong-linear, rigid, erect or ascending and ustally imbricated, completely covering the short stems, their elges ciliate with short bristly hairs, otherwise glabrous: flowers as in the preceding but smaller. - Jour. Acad. Philad. vii. t. 6.

Higher Sierra Nevada : on Silver Mountain at 11,000 feet (Brever), the var. condensata; ; a very compact, small-leaved and small-flowered form, which has been confounded with $P$. Hoodii. The species, in several forms, extends enstward to the Rocky Mountains.

$$
++ \text { Leaves hoary with soft pubescence or cobwebby woot: flowers white. }
$$

5. P. canescens, Torr. \& Gray. Forming broad and mostly compact mats, a few inches high, gray or whitened by the woolly pubescence: leaves acerose or slender-subulate, ascending or somewhat spreading, rather rigid, 3 to 5 lines long: tube of the corolla longer than the calyx; the lobes obovate, entire or emarginate. Pacif. R. Rep. ii. 8, t. 6.

Eastern side of the Sierra Nevada on the bonlers of the State (Bloomer, Watson), and through the interior country to Utah and Wyoming.

P. Muscomes and P. Bnyoldes, Nutt, are smaller species, in dense moss-like tufts, with the downy leaves compactly imbricated in four ranks, natives of the interior and Rocky Mountains.

\section{COLLOMIA, Nutt.}

Calyx 5-eleft. Corolla salverform or tubular-funnelform; the throat commonly enlarged. Stamens usually more or less exserted, with slender filuments, unequally inserted in or beneath the throat of the corolla. Ovules and seeds solitary or several in each cell. Seed-coat simple, when wetted producing copious mucilage (whence the generic name), which is usually filled with long uncoiling spiral threads. Chiefly annuals (North American, and one or two extra-tropical South American), mostly glandular-viseid; with alternate leaves, or the lower opposite, either entire, incised, or pinnately compound : flowers cymose-clustered or panicled, or scattered.

\$1. Corolla salverform, or with the throat or upper part of the tube somerohat enlargerl: seeds solitary in each cell, or 3 or 3 in the last species.

* Leaves simple and sessile, entire, or the lower occasionally fero-toothed or incised. + Calyx-tube abcomical or top-shaped: leaves all but the lorest alternate.

1. C. grandiflora, Dougl. Erect, a font or two high, rather stout: lenves linear, oblong-lanceolate, or the uppermost almost ovato ( 2 or 3 inches longr) : flowers capitate-crowderl at the summit and in the upper axils : calyx-lobes obtuse : corollia luffi or salmon-color (an inch long and the oblong lobes 4 lines long), showy. Iindl, But. Reg. t. 1174 : Hook. Bot. Mag. t. 2894.

Sierra Nevada and higher foot-hills, from San Diego Co. northward; thence to Oregon and the liocky Mountains.

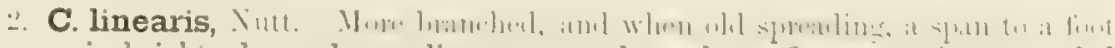
or more in lecinth: lower leaves linenr, upper lanceolate: flowers capitate-crowdend as in tho foregroing, but smaller: culyx-lobes triangular-lanceolate and very acute: corollin yellowish-white or brownish-purple, slenter, half an inch long or less; the wral holies abunt a line long. — Cien. i. 126; Limll. But. Reg., t. 1166 ; Honk. Bot. Jit. t. 289.3.

Tat. subulata, Cimy. Diffusely much hameherl, a spun or so in height, mome viscill leaves acute: flowers fower in the clusters, und some scathered or nearly 
solitary in the lower forks: calyx-lobes more subulate from a broad base. - Proc. Am. Acad. viii. 259. C. tinctoria, Kellogg in Proc. Calif. Acad. iii. 17, t. 2.

Sierra Nevada, mainly in the eastern portion; thence to British Columbia and the northern regions east of the Rocky Mountains. The var. subulata, which is peculiar in aspect, and may be distinct, on the eastern borders of the State, from Nevada Co. to Oregon, and in Nevada.

3. C. tenella, Gray. Diffusely branched, slender, 3 to 5 inches high: leaves narrowly linear, with a tapering base (sometimes an inch and a half long) : flowers scattered, solitary in all the forks, almost sessile: calyx-lobes broadly triangular and acute, shorter than the tube: corolla narrow, purplish, 3 or 4 lines long. - Proc. Am. Acad. viii. 259.

Sierra Nevada; south of Yosemite Valley, at 8,000 feet (Gray); Nevada and Utah, Watson.

++ Calyx-tube rounded at base and very short: many lower leaves opposite.

4. C. gracilis, Dougl. A span or two in height, in age corymbosely much branched: the flowers at length somewhat scattered: leaves lanceolate or linear, or the lowest oval or obovate (an inch or less long): corolla rose-purple, turning bluish, less than half an inch long, narrow; the tube hardly exceeding the linear calyxlobes; the oval lobes less than a line long. - Gilia gracilis, Hook. Bot. Mag. t. 2924 .

Hills, not rare through the State; extending to British Columbia and to the Roeky Mountains; also in Chili. The seeds are mucilaginous, but want the spiral threads of all the other species.

* Leaves deeply cleft or compound, the lower petioled: stems loosely branched.

5. C. gilioides, Benth. A span to 3 feet high : lower leaves simply pinnately parted into few or several linear lateral lobes, or the larger terminal lobe oblong and toothed: upper leaves 3-5-divided : flowers scattered or somewhat clustered: lubes of the nearly 5-parted calyx linear-subulate, its base rounded: corolla pink or purplish, its slender tube about half an inch long, twice or thrice the length of the calyx: stamens moderately unequal in insertion: capsule globular, 3-seeded. C. glutinosa, Benth. in DC., a more viscid form. Gilia divaricata, Nutt. Pl. Gamb. 155.

Moist ground, common through the western part of the State, and extending to the Sierra Nevada : variable.

6. C. heterophylla, Hook. A span or two in height, diffuse: leaves mostly pimnately parted or the upper pinnatifid, and the lobes incised or cleft; the uppermost often entire and broader, subtending the capitate-clustered flowers (or these rarely somewhat scattered): lobes of the merely 5-cleft calyx ovate-lanceolate or triangular, acute; base of the tube in fruit acute : corolla purplish, half an inch long: stamens very unequally inserted : capsule oval; the cells $1-3$-seeded. - Bot. Mag. t. 2895 ; Bot. Reg. t. 1347. Courtoisia bipinnatifida, Reichenbach, Ic. Exot. t. 208. Navarretia heterophylla, Benth. in DC.

Moist ground, Monterey to British Columbia. Stamens sometimes short, sometimes longer.

\section{\$ 2. Corolla funnelform: seeds or at least the ovules several in each cell.}

7. C. leptalea, Gray. Slender, with diffuse and filiform branches, 2 to 18 inches high, minutely glandular: leaves narrowly linear, entire, or some of the lowest occasionally with 2 or 3 small lobes: flowers effusely panicled, on naked filiform peduncles: calyx small, its lobes subulate: corolla pink-red, 5 to 10 lines long, with slender tube longer than the calyx, and rather abruptly expanded into a wide-funnelform throat abont the length of the oval spreading lobes. - Proc. Am. Acad. viii. 261 ; Watson, Bot. King Exp. 262, t. 65. Gitia capillaris, Kellogg in Proe. Calif. Acad. v. 46.

Conmon on moist or wet bauks, and more depauperate in drier soil, in the Sierra Nevada, at 4,000 to 9,000 feet. Unlike any of tlee foregoing in habit. 
3. GILIA, Ruiz \& Pav.

Corolla funnelform, salverform, or sometimes short-campanulate or rotate, regular. Stamens equally inserted in the tube or throat of the corolla; the mostly slender filaments sometimes unequal in length, not declined. Ovules and seeds several or fow or rarely solitary in each cell. Seecl-coat, with few exceptions, mucilaginous when wetted, and in many with uncoiling spiral threads. - Herbs or suffrutescent plants; with either opposite or alternate and simple or compound leaves, many. species with showy flowers.

A somewhat polymorphous genus, of nearly 70 species, belonging to the United States west of the Mississippi, excepting one species to the east of it and two or three in extra-tropical South

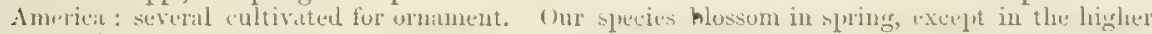
mountains.

I. All or most of the leaves opposite at least on the main stens, sessile und palmately parted or rarely entire. (Seeds more or less mucilaginous in water, but with no spiral threads.)

\$1. Corolla from short-funnelform to almost rotate; the lobes obovate: filaments slender: anthers oval: onules many or sometimes few in each cell: low or slender loosely and mostly small-flowered annuals: the leaves with divisions filiform or setaceous, appearing as if whorled, or in the last species entire. Dictylophylud, Benth. (\$Dactylophyllum \& Dianthoides, Benth.)

* Flowers short-pedicelled or almost sessile in the forks of the stem: corolla campanulate, its lobes entire: leaves 3-parted.

1. G. demissa, Gray. Diffusely much branched, rather rigid, barely a span high, profusely-tlowered: lobes of the leaves acerose, half an iuch long: lobes of the 5-parted calyx subulate, scariously margined below, unequal, the longer equalling the white 5-lobed corolla: stamens included: ovules f'ew in each cell. - Proc. Am. Acad. viii. 263.

Southeastern borders of the State, near Fort Mohave, Dr. Cooper. Also Southern Utah, Irrs. Thompson, Parry. Upper lenves often alteruate.

* Flowers on capillary or filiform pedicels, loosely paniculate: corolla from rotate to short-funnelform, its lobes entire: leaves 3-7-purted, those of the branches frequently alternate.

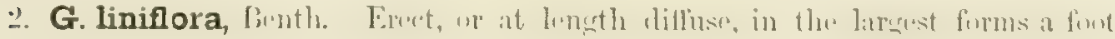
and a half high, almost glabrous: divisions of the leaves nearly tiliform, Spurteylike, about an inch long: flowers loosely pauicled: corolla white, rotate when fully open, from 10 to 6 lines in diameter, twice or thrice the length of the calyx, 5-parted lown to the very short tubo: filaments pubescent at base: ovules 6 or 8 in each cell. - But. Mag. t. 5895.

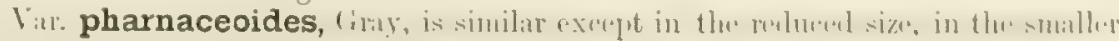

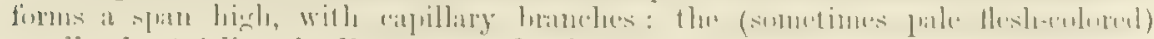
corolla about 4 lines in diamoter. - G. pharmaceoudes, Hook. Fl. ii. 74, t. 161.

Not raro through the western part of tho State, in both forms: the small variety extenling to Orengon and Utah.

3. G. pusilla, Benth. Small, 2 to 6 inches high, at length diffuse, often scabrous-puberulent: divisions of the lenves filiform-subulate or acernse, less than half an inch long, shorter (mostly much shorter) than the seattered capillary perlicels: corolla nearly white, or purplish with yelluw throat, between rotate and shortfunnelform; its lobes broally ubovate : tilments nearly uhabrens at base : orules 3 to 5 in each coll. - Corolla lis to 2 lines long aud lithlo oxceeding tho calys, in the form answering to the Chilian species. 
Var. Californica, Gray, 1. c., has corolla 3 lines long, twice the length of the calyx, and throat often brownish: peduncles frequently an inch long. - G. filipes, Benth. Pl. Hartw. 325.

Not uncommon in the western part of the State; and in Nevada and Utah (Watson), both the smaller and the larger flowered forms; the latter predominating.

4. G. Bolanderi, Gray, 1. c. Very like the preceding: but the tube of the blue or purple-tinged corolla longer and narrower, about equalling the narrow 'and cylindraceous calyx-tube, and rather longer than the limb (consisting of the oblong lobes and a very short slightly dilated throat) : filaments inserted just below the sinuses: ovules 2 to 5 in each cell.

Dry hitls, Sonoma Co. (Bolander') to Plumas Co., Mrs. Pulsifer Ames. Corolla 3 or 4 lines long: peduncles 4 to 12 lines long.

5. G. aurea, Nutt. Diffuse, 2 to 4 inches high: divisions of the roughish hispidulous leaves narrowly linear, a quarter of an inch long: peduncles shorter or little longer than the flower, corymbose: corolla ustally yellow, open and shortfunnelform, half an inch or less in diameter; the roundish-obovate lobes about the length of the obconical throat and the short proper tube: filaments inserted just beneath the sinuses, glabrous: ovules about 10 in each cell. - Pl. Gamb. 155, t. 22.

Var. decora, Gray, 1. c. : corolla white or pale violet, with or without brownpurple in the throat: peduncles sometimes elongated.

Santa Barbara to the Mohave, and thence to New Mexice. The variety on Monte Diablo (Brewer), and in the southern part of the State, Frenont, \&e.

* * * Flowers mostly short-peduncled terminating the branches: corolla with fringedtoothed lobes: leaves all. opposite and entire.

6. G. dianthoides, Endl. An inch to a span high, minutely pubescent or almost glabrous, the stronger plants fastigiately or diffusely branched from the base: leaves filiform-linear, obtuse: corolla lilac or pale purple with darker or yellowish throat; the ample lobes cuneate-obovate, fimbriately or erosely toothed round the broad summit, longer than the short-funnelform tube : ovules 10 to $20 \mathrm{in}$ each cell. - Atakt. Bot. t. 29 ; Benth. in DC. Prodr. x. 314 ; Hook. Bot. Mag. t. 4876. Fenzlia dianthiflora, Benth. in Bot. Reg. F. speciosa \& F. concinna, Nutt. Pl. Gamb. 157.

Conmon from Santa Barbara to San Diego, and on Catalina Island. A charming little plant, with abundance of comparatively large blossoms; the corolla less than an inch long.

\$ 2. Corolla salverform, but the tube shorter than the calyx; the broad cuneate-obovate lobes slightly crenulate, strongly convolute in astivation: stamens inserted low on the tube of the corolla and included in it: ovules many in each cell: capsule. narrowly oblong: erect and very glabrous annuals: leaves opposite and entire or 3-5-divided and seemingly whorled. - LinantuUs, Endl.

7. G. dichotoma, Benth. I. c. Erect, a span to a foot high, remotely leaved: leaves ог their divisions filiform: flowers nearly sessile in the forks or terminating the branches: calyx. with cylindrical tube (5 lines long) wholly white-scarious except the 5 filiform green ribs, which are continued into acerose-linear lobes: corolla white, large and showy (the lobes from half to nearly a full inch long): anthers linear: seeds globular, with a loose cellular outer coat, unchanged when wet! - Linanthus dichotomus, Benth., formerly.

Dry or moist ground, nearly throughout the western part of the State. Tube of the corolla sometimes purplish.

G. BigecoviI, Gray, 1. c. (Watson, Bot. King Exp. t. 25), which occurs from Arizona and Utah to the borders of Texas, is distinguished by its much smaller flowers, the lobes of the corolla only 2 lines long and hardly exceeting the calyx, and the oval or oblong seeds have a close coat, developing mucilage when wetted. 


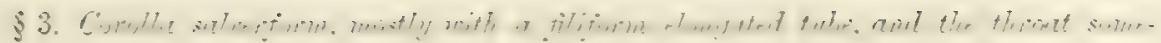
times abruptly dilated: stamens inserted in the throat or orifice: anthers short: orules numerous: erect annuals, with leaves as in the preceding, and handsome but sometimes smull flowers crouted in a terminal capitate cluster. - Leptosiphos, Enull. (Leptosiphon, Benth., formerly.)

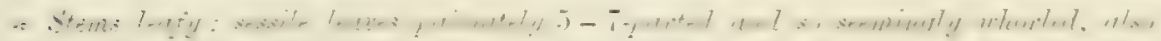
faseicled in the axils; their divisions linear-filiform: filaments slender, more or less exserted (their length and that of the style different in different individuals, $i$. e. dimorphous).

- Corolla comparatively large and its tube short.

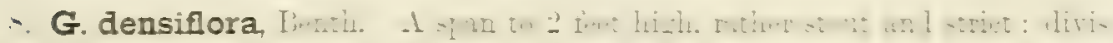
ions of the leaves numerous, fliform, rather rigid, in somewhat distant apparent

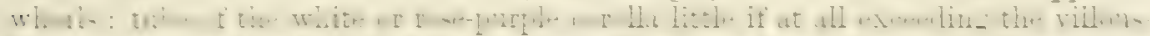

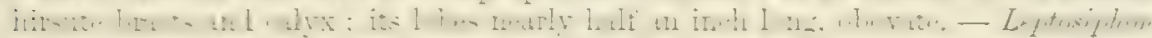
densiflorus, Benth. in Hort. Trans. 183t, t. 18, \& Bot. Reg. t. 1725 ; Bot. Mag.

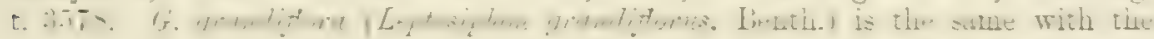
tube of the corolla a little longer than usual.

Sandy soil, through the westem part of the State from San Francisco Bay southward.

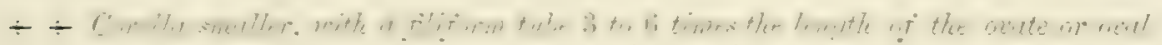
lobes; the latter from $1 \frac{1}{2}$ to $t$ lines long.

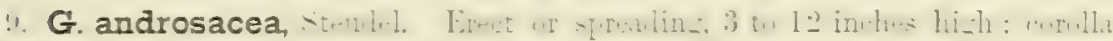
lilac, rose-pink, or almost white, with a yellow or lark throat; its tube (abuut an

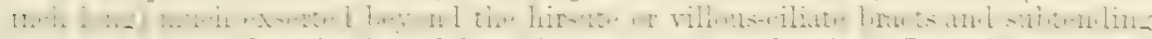
leaves, thrice the length of the lobes (these 3 or $t$ lines long). - Leptasiphon androsareus, Benth. L. c. t. 1S, \& Bot. Reg. t. 1710 ; Hook. Bot. Mag. t. $3 \pm 91$.

Var. detonsa, Gray, l c. : a slender and almost glabrous form, the bracts and leares merely hispidulous-ciliate.

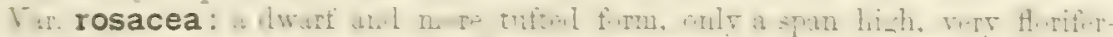

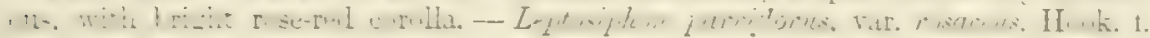
But. Mag. t. 5863.

Hillsiles, throughout the western part of the State and up to the higher foot-hills of the Sierra Besala Var. defonen, in the mountains of Monterey Co. (Brencer); also collected by Bridtges. An intermeiliate form near Carson City, dnderson. War. rosween, near San Franciseo, Relloyy, \&5. A benutiful species in cultivation.

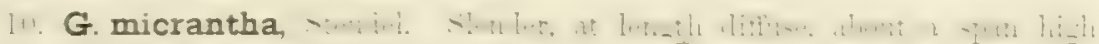
tuhe of the corolla extremely slender (three fourths to an inch and a half Inng), 4 to 6 times lunger than the lobes; these 2 or 3 lines long, from yelluw to cream-coln and pale purple or whitish: pubescence of the bracts and upper leaves short and sift. - G. Lutea, Steuclel., Benth. Leptosiphon parviforns \& $L$. Luteus, Benth. in Bot. Reg. G. micranthn, var. auren, \& G. longiluba, Benth. Pl. Hartw. 324, 3:5.

Hillsides, throngh the western part of the State. Passes by larger-flowered formas (G. Tongiubur, Benth.) into var. rowara of the preceling.

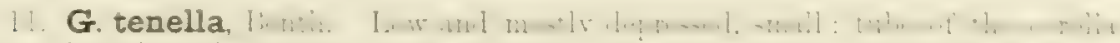
bi to 9 lines long, less slenuler in proportion to the size of the limb (the latter nose color or piak with a yellow throat); the lubes barely a line and a half long: hrocts and leaves hispillulous-ciliate. - Pl. Hartw. 325. Leptosiphon biculor, Sutt. Pl. Fraub. 156, chiefly.

Dry hillsiles, Suntu Parhnm to Puget Sound.

12. G. ciliata, Bernth. 1. c. More rivil and hirsute, a span to n font high : tulwe

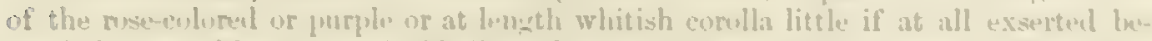
vont the very hirsute or hispinl-eiliate hracts and suldemling leaves, hall to throe quarters of an iucb long, the lubes only a line and is half long: calyx-lubes anceruse. 
Hillsides, Mariposa to Sierra and Mendocino Counties, and along the western borders of Nevada. Grayish with short pubescence on the stems, and with long hairs, both soft and rigid, on the upper leaves.

* Stems leafless below: leaves entire: anthers sessile in the throat of the corolla.

13. G. nudicaulis, Gray. An inch to a span high, wholly glabrous, simple or branched from the base : leaves several and densely crowded, forming an involucre around a terminal capitate cluster of flowers, linear to ovate-lanceolate, obtuse, rather fleshy, half an inch long; the small ovate cotyledons usually persisting below: corolla white, pinkish, or pale yellow; its lobes cuneate, with repand or 1-3-toothed summit, 2 or 3 lines long, shorter than the slender tube. - Proc. Am. Acad. viii. 266. Collomia nudicaulis, Hook. \& Arn. Bot. Beechey, 369.

Moist sandy ground, along the eastern borders of the State (Carson City, Anderson, \&c.) to Utah and Colorado.

\$ 4. Flowers as in $\$ 3$; but tube of the corolla not exceeding the calyx, the throat more funnelform, and ovules only 2 to 4 in each cell: filaments and anthers short: peremials, more or less woody at base: leaves opposite and 3-7-parted, so appearing to be whorled. - SipHoneLLA, Gray.

14. G. Nuttallii, Gray. A span to a foot high, many-stemmed from the woody subterranean base : divisions of the leaves narrowly linear, rigid (half to three fourths of an inch long), mucronate, hispidulous-scabrous, the lower shorter than the internodes: flowers in a capitate terminal cluster : calyx rigid, cylindraceous, soon 5-parted, not scarious, the lobes lanceolate-subulate: ovules a pair in each cell. - Proc. Am. Acad. viii. 267; Watson, Bot. King Exp. 265, t. 26, fig. 8.

Eastern borders of the 'Sierra Nevada (near Carson City and on Silver Mountain, Anderson, Brewer); thence to Utah and Arizona.

15. G. floribunda, Gray, 1. c. Taller, more slender and bushy, corymbose at summit: divisions of the leaves acerose (half to a full inch long), and nearly smooth: flowers cymose-clustered (delicate-scented), some of them rather slenderpedicelled: ovules 4 in each cell.

Near the southern borders of the State, Coulter, E. W. Morse, Cleveland. Also Arizona, Palnuer.

II. All the leaves alternate (in our species) and palmately parted, crouded on the woody stems. (Seeds unaltered in water, developing neither mucilage nor spiral threads.)

\$5. Corolla salverform, with tube more or less exceeding the calyx: fllaments short, inserted in or below the throat: anthers short, included: ovules numerows in each cell: seed-coat close, as in Phlox, developing neither spiral threads nor mucilage when wetted: woody based perennials or undershrubs, Phlox-like, very leafy: leaves alternate, except in one species, and much fascicled in the axils, palmately 3-7-parted; the divisions acerose or subulate, rigid and pungent: flowers showy, sessile, solitary or few in a cluster at the end of short branches or branchlets. - LeProdactrLon, Benth. (Leptodactylon, Hook. \& Arn.)

G. WATSONI, Gray, of Utah, is remarkable for its opposite leaves, and nearly herbaceous flowering-stems. - The following are decidedly shrubby.

16. G. Californica, Benth. in DC. Two or three feet high, with spreading rigid branches, villous or soft-pubescent when young: leaves widely spreading: corolla rose-color or lilac; the ample limb an inch and a half in diameter, and the broadly cuneate-obovate lobes often erose on the margins: anthers linear-oblong, included in the upper part of the tube: ovules 20 or more in each cell. - Leptodactylon Californicum, Hook. \& Arw. Bot. Beechey, 349, t. 89; Bot. Mag. t. 4872.

Dry hills, throughout the southern part of the State, and north at least to Monterey. A handsome species. 
17. G. pungens, Lenth. 1. c. A span to a fout or so in height, hushy : more or less viscid-pubescent, or nearly glabrous : rigid leaves little spreading or erect: corolla white or rose-color; the lobes narrower and only half as large as in the preceding: anthers borne in the throat, oblong: ovules 8 or 10 in each cell. - Gray, 1. c. 268. G. pungens \& G. Hookeri, Benth. in DC. Cantua pungens, '́orr. Ann. Lyc. N. X. ii. 221. Phlox Hookerr, Dougl. in Hook. Fl. t. 159.

Var. squarrosa, Gray, 1. c.: subulate divisions of the leaves stouter and soon spreading or squarrose-recurved.

High and dry parts of the Sierra Nevada (common above the Yosemite Valley), and through the interior of Oregon, to the Rocky Mountains; the var. squarrosa, from the western borders of Nevada, through the dry interior. Probably Douglas mistook in assigning yellow flowers to this species.

III. All or all but the lowest leaves alternate and more or less pinnately compound, cleft, or tonthed, or rarely quite entire. (Seed-coat when wetted usically developing spiral threads as well as mucilage.)

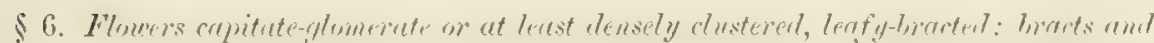
calyx-lobes often laciniate, rigil-acerose or spinulose-tipped. Corolla slender, tubutar-funnelform or almost salverform, and with small oblong lobes: filtements inserted in or below the throat: anthers short: cells of the ovary and stigmas sometimes only 2: annuals, mostly viscul-pubescent or glandular, never white-woolly, with once or twice pinnatifid or incised leaves, their lobes commonly pungent: the bracts sometimes palmately rather than pinnately cleft. Navarretu, Gray. (Navarretia, Ruiz \& Pav.)

* Stumens included in the throat of the corolla: ovules 8 to 12 in each cell.

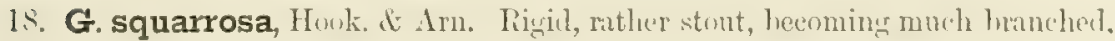
very glandular-viscid, fetid: leaves twice pinnatifid, or pinnately parted and the divisions either parted or incised: upper leaves and bracts spinescent : cornlla blue, marely whitish, 4 or 5 lines long, rather shorter than the usually entire calyx-lobes: stamens unequal in length and slightly so in insertion. - G. pungens, Hook. Bot. Mag. t. 2977. Hoitzia squarrosa, Eschsch. in Mem. Acad. Petrop. 1826, 283. Navarretia squarrosa, Hook. \& Arn. Bot. Beechey, 368 ; Benth. in DC. Prodr. l. c. N. pungens, Hook. Fl. ii. 75 .

(1)wn grwml, common throngh the western part of the State and in the foot-hills, extendime to Oregon.

* * Stamens more or less exserted: corolla slender, 3 to 5 lines long.

+ Leaves twice pinnatifid, at least the lower ones: ovules 1 to 4 in each cell.

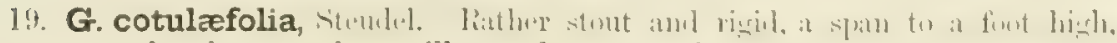
tomentose-puberulent, or abovo villous-pubescent and minutely glandular: most of the leaves twice pinnately divided or parted into slemler-subulate divisions; the upper and the braets spinescent : tube of the violet or whitish corolla hardly longer than tho sparsely villous calyx: ovules 1 or 2 in ench cell: capsulo usually only 1-secrled. - Nevarretia pubescens \& N. cotulufolia, Benth.

I)ry hillsiles, common throngh the western part of the Stute and in the foot-hills of the Sierm Nevudn. Exhules the oulor of Anthemis Cotula.

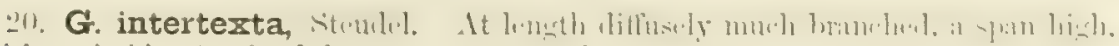
neither viscil nor glandular: stems retrorsely pubescent: leaves nminly glnbrous; their divaricato acerose and spinescent divisions either sparingly divideal or simple: fluwers densely glomemte: base of the bracts and tube of the calyx densely whitevilluus with long sprealing hairs: comlln white, littlo exceenling the ealyx: orules and seeds 3 or $t$ in each cell. - Navarretia intertexta, 1Inok. Fl. ii. 75.

Dry hills, from near San Frauciseo to Sierra Co, and nortls to Washingtou Tervitory. 
G. MrNima, Gray, a dwarf and tufted nearly glabrous white-flowered species, related to this and the next, inhabits the interior dry region, but has not been found west of Utah.

21. G. Breweri, Gray. A span high, or less, at length much branched and diffusely tufted, miuntely glandular-puberulent throughout: divisions of the leaves acerose and mostly entire: flowers in less dense leafy heads : corolla yellow, hardly longer than the slender-subulate ealyx-lobes; the tube of the latter very short: ovules and seeds mostly solitary. - Proc. Am. Acad. viii. 269.

Dry ground, in the Sierra Nevada, from Placer Co. to Sierra Co. at 6,000 to 8,000 feet (Brewer, Bolander), and through Nevada to Wyoming Territory.

22. G. leucocephala, Gray, l. c. A span high, rather slender, loosely branched, not glaudular, glabrons, except a little woolliness at summit and on the thin calyxtube: leaves soft, with commonly simple linear-filiform divisions; those of the bracts hardly pungent: heads dense: corolla white, longer than the calyx : ovules 2 in each cell. - Navarretia leucocephala, Benth. Pl. Hartw. 324.

Damp or low grounds, around San Francisco Bay to the Sacramento and Mendocino Co.

++ Leaves only once pinnatifid or incised, or many of them entire,

$\rightarrow$ All slender and filiform, except the bracts of the small heads, which are more or less palmately 3-5-cleft: coralla small (3 or 4 lines long), rather slender.

23. G. divaricata, Torr. Diffusely branched, slender, a span or more in height, somewhat pubescent, hardly at all glandular, the bracts and calyx more or less woolly-pubescent: filiform branches proliferous: divisions of the uppermost leaves and the similar bracts acerose: corolla purple or (apparently) yellowish: ovules 5 to 7 in each cell. - Gray, Proc. Am. Acad. 1. c.

Lake Co. to Mariposa Co. up to 8,000 feet.

24. G. filicaulis, Torr. A span or two high, moderately or at length widely branched, slender, viscid-glandular, especially above; branches naked : иррег leaves filiform or setaceous and entire; bracts somewhat cuneate and the lobes pungent, the inner ones shorter than the violet corolla: ovules mostly solitary in each cell. Gray, Proc. Am. Acad. 1. c.

Mariposa Co. to Butte Co., Jeffray, Torrey, Mrs. Pulsifer Ames.

$\div+\div$ Leaves broader, rigid, linear or lanceolate, and with spinulose lobes: stems stout:

flowers densely glomerate: corolla violet or purple, barely half an inch long; about twice the length of the pungent calyx-lobes.

25. G. viscidula, Gray, l. c. A span high, or less, at length much branched, viscid-pubescent: cauline leaves mostly slender and laciniate-pinnatifid; the ascending lobes acerose or subulate; floral ones broader and more spinescent; bracts more dilated at base and palmately cleft: ovules 1 to 4 in each cell. - Navarretia viscidula, Benth. Pl. Hartw. 325, a small form.

Dry hills, Santa Barbara to San Franciseo, \&c., and to the Sierra Nevada.

26. G. atractyloides, Steudel. A span high, simple or much branched, viscidpubescent, very rigid, especially the foliage: cauline leaves lanceolate, the upper becoming broader and the floral ovate, all pinnatifid, with widely spreading subulate spine-like lobes : leafy heads rather few-flowered : ovules 6 or 7 in each cell.

Open dry ground, from San Diego to Santa Cruz. Leaves, at least the floral ones, almost cartilaginous.

$+\div \div$ Leaves dilated towards the apex, at least the upper ones: stems depressed: flowers proportionally large, less crowded.

27. G. setosissima, Gray, I. c. An inch or two high, at length forming a depressed tuft, cinereous-pubescent or glabrate: lower leaves linear and slightly toothed, the upper becoming oblanceolate, spatulate, or with a euneate 3-lobed 


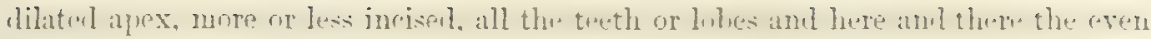
margins beset with very long white bristles, many of the lower in pairs: calyx-lobes similarly setose-tipped : corolla purple or purplish, 6 to 9 lines long : ovules several or rarely few in each cell. - Navcerretia setosissima, Torr. \& Gray, in Ives Colorado Exp. 22. N. Schottii, Torr. Bot. Mex. Bound. 1Ł5̆, a small form.

Gravelly plains, on the Rio Colorado and the Mohave, and Providence Mountains (Coutler, Newobry, Cooper, \&c.), extending to Southern Utah.

\$7. Flnwers, inflorescence, dec., nearly as in the foregoing section; but the anthers longer and always exserted: corolla (salverform) more conspicuous : plants all white with floccose wool, at least when young, and neither glandular nor viscid. - Hugelia (Hugelia, Benth. in Bot. Reg. Gilia \$ Hugelia \& Pseudocollomia, Benth. in DC.).

* Root perennial: stems woody at the base: anthers linear-sagittate : oviles several.

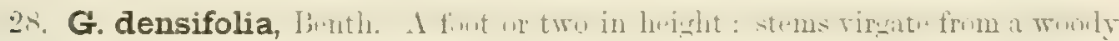
base, leafy to the top: leaves rigid, linear, laciniate-pinnatifid or incised; the short lobes few or several, subulate: Howers numerous in a compact head: corolla over half an inch in length, violet-blue, two or three times the length of the calyx (the lobes 3 lines long): anthers linear. - Hugelia densifolia (a short stout form) and H. elongata, Benth.

Dry hills, from Santa Clara Co. to the Mohave, and in Southern Nevada.

* * Root annual: stems slender, at length loosely branched, a foot or less in height: leaves and their few (if any) divisions filiform: flowers rather few in the small clusters.

29. G. virgata, strurlel. It first striet and simple-stemmel, at leneth lowncherl from the base or throughout, sometimes glabrate: tube of the blue corolla longer than the calyx: anthers (when dry) linear, deeply sagittate, a line long: ovules 2 to 5 in each cell. - Hugelia virgata, Benth.; Hook. Ic. Pl. t. 200.

Var. floribunda, Gray, 1. c. Low and rather stout: even the upper leaves pinnately $3-7$-parted: the numerous heads and flowers fully as large as those of G. densifolia.

Dry lills, Monterey to San Diego and east to the Rio Colorado. The remarkable variety from Santa Clara Co. (Brewor) to Tejon, W'allace.

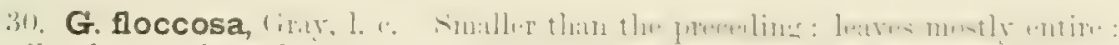
corolla about 4 lines long, blue or becoming white (probably never "yellow") : anthers linear-oblong (barely half a line in length): ovules 1 to $t$ in each cell. Unegelia lutea, Benth. in Bot. Reg. Gilia lutescens, Steulel; Benth. in DC. (But the flowers were doubtless bluish, facled to dull white.)

Eastern borlers of the State, from the Mohave to the Truckee, \&ce, and east to Utal. Also near Monterey.

31. G. filifolia, Nutt. Like the preceding, but more rigid: leaves mostly 3-partul: corolla bluo or bluish, little if at all exserted: anthers oval, very small: ovules 4 to 6 in each cell. - Pl. Granb. 156 ; Gris, l. c.

Near Santa Burbara (Nullall), and San Isabel (Thurber), to the Mohave (Comper), Arizona, and lievada. This and the preceding probably run together, and all these annual species are luarl to distingnish.

\$ 8. Flowers capitate-crouded or somewhat looser, bracteate: corolla while or purplish, salverform, mostly with a short tube: stamens shorter than the lwhes of the comolla, inserted in or near the sinuses: anthers short: lobes of the cally.s and of the lenews tipped with an aton-like but not pungent cusp: lore biennials, arnuals, or short-lived perennials, waully viscill-pubescont with many-jointerl hairs, and with simply pinnatiful or entire leaves. - Elaphocens, Sitt. 


\section{* Perennial, densely-flowered.}

32. G. congesta, Hook. Woolly-pubescent, becoming glabrate, tufted, 3 to 12 inches ligh: leaves petioled, much crowded on the short sterile shoots, scattered on the erect flowering stem, thickish, mostly pinnately parted into 3 to 7 short-linear or oblanceolate divisions, which are not rarely so crowded as to appear palmate or pedate: flowers numerous in solitary or a few corymbose naked and dense heads: corolla white; its tube hardly longer than the calyx and the oval lobes (these a line or two long): exserted filaments as long as the anthers: ovules 2 to 4 in each cell. -Fl. ii. 75, \& Ic. Pl. t. 235.

Sierra Nevada at 10,000 feet and upwards, in Placer and Nevada Counties (Brewer, Bolander, E. L. Greene), and on the northern border of the State (Ncwberry): thence to Oregon and the Rocky Mountains. The var. crebrifolia, Gray (G. crebrifolia, Nutt.), with entire and more glabrous leaves, occurs in the northenstern part of Nevada.

* Annual, low and spreading, loosely branched: flowers fewer, more leafy-bracted, in less dense clusters: lobes of the calyx and leaves conspicuously cuspidate-tipped.

33. G. pumila, Nutt. Slightly woolly-pubescent: leaves narrowly linear, entire or with 2 to 4 narrow lobes: tube of the corolla ( 3 or 4 lines long) about twice the length of its lobes and of the calyx-lobes: filaments shorter than the lobes of the corolla: ovules 5 or 6 in each cell. - Pl. Gamb. 156. G. trifida, Benth. in Kew Jour. Bot. iii. 291.

Foot-hills of the Truckee Mountains, Northwestern Nevada, Watson. Thence east to New Mexico and Wyoming.

34. G. polycladon, Torr. Puberulent or sparsely pubescent, with elongated branches leafless below: leaves short, spatulate or oblong in outline, incisely pinnatifid into several small and irregular lobes; those of the branches mainly clustered around the flowers (half an inch long): corolla barely 2 lines long, its tube hardly exceeding the calyx-lobes: anthers almost sessile in the throat: ovules only a pair in each cell. - Bot. Mex. Bound. 147; Watson, Bot. King Exp. 268.

Mountains on the western borders of Nevada, Watson. Thence east to Utah and the borders of Texas. This and the preceding will doubtless be detected within the State.

\$ 9. Flowers thyrsoid-panicled, hardly bracteate: corolla (red) salverform with a long and stightly funnelform tube, very much surpassing the calyx: stamens inserted in or below the throat of the corolla, not longer than its lobes: anthers short: ovules numerous in each cell: biennials, merely pubescent, with simple virgate stem and large showy blossoms. - Ipomorsis, Benth.

35. G. aggregata, Spreng, A foot to a yard high : leaves thickish, pinnately parted into 7 to 13 linear mucronulate divisions, or in the upper leaves fewer: flowers in small clusters, disposed in a simple or sometimes branching virgate naked panicle : calyx commonly glandular; its lobes subulate: corolla scarlet (varying to pink or rarely white); its tube an inch long, 2 to 4 times the length of the ovatelanceolate or oblong-lanceolate acute soon recurved-spreading lobes: filaments slender. - Don, Brit. Fl. Gard. ser. 2, t. 218 (Cantua aggregata, Pursh). G. pulchella, Dougl, in Hook. Fl. ii. 74. Ipomopsis elegans, Lindl. Bot. Reg. t. 1281. - Runs into various forms, of which the most marked is

Var. Bridgesii, Gray, 1. c. : a rather low form, loosely somewhat few-flowered: corolla said to be purple: calyx-lobes short and broadly triangular-subulate or ovatedeltoid: lobes of the leaves very obtuse, seldom mucronulate.

Rocky ravines, \&c., Sierra Nerada, throughout its length, to Oregon and Idaho, and east to the Rocky Mountains. 'The rariety eollected only by Bridycs, - station in Califormia unknown various specimens of the Sierra Nevada approach it. Flowers "very fragrant," even more showy than those of the related $G$. coronopifolin of the Southern Atlantic States. Stamens in some individuals included, in others conspicuonsly exserted; these with style equally or even more exserted. 
36. G. subnuda, Torr. A span to a ficht higli, glimdular-puluerulent : leaves chiefly at the lasie, spatulate or whlons, incisely touthed or slingtly few-lobed; thase of the naked stem small and entire, and above reduced to minute bracts: flowers somewhat elustered at the summit of the branches of the naked panicle: calyr-lobes broadly subulate: corolla orange or scarlet; the tube half an inch long, thrice the length of the ovate obtuse lobes. - Gray, Proc. Am. Acad. viii. 276.

Western part of Nevada (R. H. Strelch), and Arizona (Neuberry, Pulmer) : may be expected on the eastern borders of California. In the specimens, the anthers are included, on short filaments.

\$10. Flowers capitate-glomerate or panicled, or scattered, usually bractless: corolla (blue, purple, or white) from funnelform to campanulate or almost rotate: stamens included or not surpassing the corolla-lobes: filaments slender: leaves mostly pinnately incised or twice or thrice pinnately dissected. - EugILIs, Benth. mainly.

\section{* Dwarf perennial, few-flowered among the leaves: ouncles salitary.}

37. G. Larseni, Gray. Depressed, rising an inch or two out of ground from filiforn subterranean running shoots, soft-puboscent: leaves nuch crowded at the summit (but alternate), somewhat pedately $5-7$-parted or the upper 3 -cleft; the lobes 2 to 4 lines long, linear-oblong, or the larger more dilated and 2-3-cleft: flowers almost sessile, little exceeding the leaves: corolla funnelform, violet-purple, nearly half an inch long, fully twice the length of the calyx; the lobes broadly oval. - Proc. An. Acad. xi. 84.

On Lassen's Peak, in loose soil of voleanic ashes, Lemmon and John Larsen. This singular little species niight be thought to belong to the Navarrclia section; but the lobes of the leaves and of the calyx are not rigid, nor even so much as mucrouate, and the flowers are not eapitateerowded. In sorne flowers two or three of the stamens are abortive and very short, but all are inserted at the same height, low down in the throat of the corolla. It is only in the solitary ovules that this species accords with the section Microgilice.

* * Annuals: ovules and seeds fewo or numerous in each cell.

- Flonvers numerous in dense headlike clusters on long naked peduncles: stems erect, a foot or two high: stamens inserted in the very sinuses of the short and broal coralla, as long as their lobes: leaves twice or thrice pinnately dissected into very narrow linear divisions.

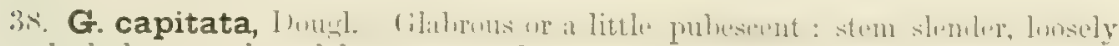
branched above : calyx glabrous or nearly so: lobes of the light blue (rarely white)

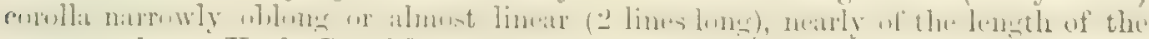
narrow tube. - Hook. But. Mag. t. 2698 ; Lindl. Bot. Reg. t. 1170.

Low grounds, not rare, from the Bay of San Francisco to Oregon.

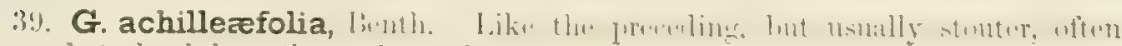
somewhat glandular: the capitate clusters and flowers larger or less compact : calyx more or less woolly, its lohes with short recurved tips: lobes of the corolla obovate or broally oblong (2 or 3 lines long), the throat abruptly much dilated. - Hook. Mot. Mag, t. 5939.

Hills and sandy ground, common through tho western part of the State.

++ Flowers in small and rather lonse clusters, or else scattered in the opnen panicle.

+ Leaves muinly twice or thrice pinnately divided into fine and narror segments:

corollu funnelform, from one to heo thirds of an inch long: herbarje somenthat viscidpubescent or glandular, or glabrate: stems erect or at lenglh diffisely spresuling.

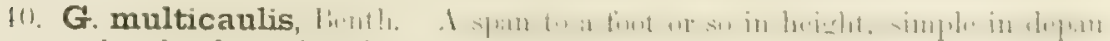
perate and carly plants, loosely bramed in larger and later: flowers few or several (rarly solitary) in a cluster terminating the slender naked perduncles, short-pedicelled or almost sessile; corolla (a thirl of an inch long) violet, with proper tube 
shorter than the viseid calyx, and the obovate lobes not longer than the funnelform throat: capsule ovoid.-G. achilleafolia, Lindl. Bot. Reg. t. 1682; Hook. Bot. Mag. t. 3440, not of Benth. G. millefoliata, Fischer \& Meyer; a diffuse cultivated form.

Var. tenera, Gray, 1. c.: a slender, depauperate, few-flowered state, with the peduncles, or at least some of them, one-flowered. - G. stricta, Liebmann, Ind. Sem. Hort. Hafin. 1853.

In dry ground, common throughout the western part of the State. Slender depauperate forms abound in poor soil.

41. G. tricolor, Benth. A span to a foot or two in height, in age diffusely branched: flowers few in the loosely paniculate and rather short-peduncled clusters: pedicels shorter than the viscid-puberulent or rarely glabrous calyx: corolla (one third to half an inch long) with very short proper tube and ample campanulatefunnelform throat, which is pale yellow or orange below, dark purple above; and the lilac or violet roundish lobes longer than the stamens. - Hort. Trans. viii. t. 18; Lindl. Bot. Reg. t. 1704; Bot. Mag. t. 3463.

Common through the western part of the State and the foot-hills; familiar in cultivation.

42. G. tenuiflora, Benth. Commonly a foot high, slender: radical and lower cauline leaves with shorter lobes than in the two preceding species: upper leaves few, small, and simpler: flowers mostly slender-pedicelled in the loose panicle: corolla purple or rose-color, funnelform with slender tube, 4 or 5 times the length of the calyx ( 7 to 9 lines long); its lobes broadly obovate and longer than the stamens. - Lindl. Bot. Reg. t. 1888.

Var. latiflora, Gray, 1. c. : a form with shorter tube to the corolla, more abruptly dilated throat, and broader limb: radical leaves sometimes simply pinnatifid.

Dry ground, Monterey to San Diego, \&c. The variety, Los Angeles, \&c., Fremont, Wallace.

++ Leaves once or sometimes twice pinnatifid, or merely incised or toothed: flowers loosely panicled.

= Corolla funnelform, from less than a quarter to half an inch long: seeds many.

43. G. inconspicua, Dougl. A span to a foot high, at length loosely much branched, somewhat viscid or glandular, when young usually a slight woolliness upon the foliage: radical and lower leaves pinnately parted into numerous short oblong or lanceolate and commonly few-toothed or incisely-lobed divisions; the upper with simple and fewer mostly linear divisions: pedicels some slender and some short or mearly wanting: corolla violet-purple or bluish, twice or thrice the length of the calyx. - Hook. Bot. Mag. t. 2833. Ipomopsis inconspicua, Smith, Exot. Bot. t. 14. Cantua parvifora, Pursh. This is the smaller-flowered form, with tube of the corolla at first shorter than the calyx, and lobes only a line long. It passes by gradation into

Var. sinuata, Gray, 1. c., with tube of corolla more slender and exserted, and lobes often 2 lines long: lobes of the radical leaves commonly narrow and entire. G. sinuata, Dougl. ex Benth. in DC. Prodr. ix. 313. G. arenaria, Benth., appears to be a form of this, from the sea-beach at Monterey, with short ovate lobes to the radical leaves, and a slender corolla-tube, seemingly passing into $G$. tenuiflora.

Dry or gravelly ground, common nearly throughout the State and in Oregon, and east through the Rocky Mountain region.

44. G. leptomeria, Gray. A span high, minutely glandular or viscid : leaves mainly in a radical tuft, narrowly oblong (about an inch long), pinnatifid with very short lobes or merely incised; the cauline small, linear, entire, mostly reduced to hracts of the ample and effuse cymose panicle: pedicels some filiform, some shorter than the calyx: corolla nearly white, $1 \frac{1}{2}$ to 3 lines long, slender, approaching salverform, twice or thrice the length of the calyx, the lobes ovate, sometimes repandly 
2-3-toothed and acnte, haif a line long: seeds not mucilaginous when wetted! Proc. Am. Acad. viii. 278; Watson, Bot. King Exp. 270, t. 26, fig. 6, 7.

Northwestern Nevada, on the borders of California (Watson, Lemmon); east to Utah.

$$
==\text { Corolla campanulate, white or nearly so: seeds fero. }
$$

45. G. micromeria, Gray. Diffuse, 2 or 3 inches high, very slender, almost glabrous: radical and lower leaves pimnatifid, with linear-oblong very obtuse lobes; those of the branches linear and entire, gradually reduced to bracts: flowers sparse, mainly opposite the leaves, on long filiform at length somewhat refiacted pedicels: corulla barely a line long, little exceeding the calyx : capsule globular, longer than the style. - Proc. Am. Acad. viii. 279; Watson, 1. c. t. 26, tig. 12 - 16.

Northwestern Nevada, Truckee Valley to the East Humboldt Mountains, W Wuson. Probably reaches California.

46. G. campanulata, Gray, 1. c. Diffuse, 2 or 3 inches high, somewhat pubescent and viscid: lower leaves lanceolate, sparingly toothed or incised (half an inch long); those of the slender janiculate branches similar, or narrower and entire:

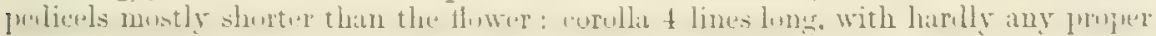
tube, moderately 5-lobed, about twice the length of the lanceolate-subulate lobes of the deeply parted calyx; these scariously margined toward the base: stameus inserted low down : ovules 6 or 7 in each cell. - Watson, 1. c. t. 26, fig. 16-18.

Banks of the Truckee River, Nevada, Walson. Perhaps extending to California Flower not unlike that of the first species here described, viz., G. deinissa.

G. FILfFormis, Parry, a newly discovered species of Southern Utah, related to the last, has smaller and cream-colored flowers on filiform at length refracted pedicels, and almost filiform entire leaves.

G. MrsutiflonA, Benth., of a peculiar section, - with very small flowers, 5-toothed calyx, salverform corolla, and solitary ovules, - has been attributed to California, but is known only from the interior of Oregon and eastward.

\section{POLemoniUM, Toum. Greek Valerian.}

Flowers as in Gilia § Eugilia, but the corolla short and broad, the stamens

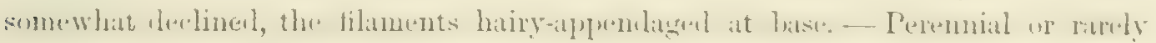

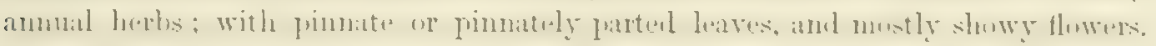
Calyx herbaceous; its divisions and those of the leaves pointless. Corolla more commonly blue, varying to white.

The few species are all North American, either northern or of elerated districts; two of them also of the Uld World. The genus, sufficiently well marked as to the original species, is much invalidated by the annual $P$. micranthum on the one hand, and one or more with funnelform corollu on the other.

\section{\$ 1. Annual, diffuse: rotate corolla shorter than the calyx: flowers scattered.}

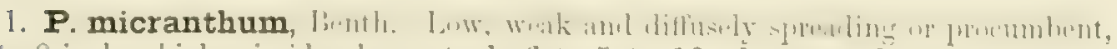
3 to 8 inches high, viscirl-pubescent: leaflets 5 to 13 , obovate or lanceolato (2 to 4

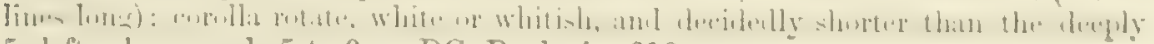
5-eleft calyx: seeds 5 to 9. - DC. Prodr. ix. 318.

Moist grounds, Sierm Co. (Lemmon), and adjacent borders of Nernda (Anderson, Walson), north to British Columbia.

\section{\$2. Perenninl: corolla rotate-campanulute from a very short somewhat abennienl. lube; limb surpassing the calyx: inflorescence cymose or thyrsoid-prenicled.}

2. P. humile, Willt. A span high, commonly in tufts finm mor slenter rootstucks, minutely viscial-pubeseent or almost glabrous: leaflets 11 tn 21 , from oblonis-lanceolate to oval, and from 2 to 7 lines long, either scattered or crowiled, entiro: cymes corymbose, few-fluwered, Innse: callyx decply 5-cheft: corolla (blue, 
lavender, or sometimes nearly white) half an inch or more in diameter: seeds one or two in each cell. - P. pulchellum, Bunge; Ledeb. Fl. Alt. Ic. t. 20; Lindl. Bot. Reg. t. 1304. P. Richardsoni, Graham in Bot. Mag. t. 2800. P. capitatum, Benth. in DC, not of Eschscholtz. P. pulcherrimum, Hook. Bot. Mag. t. 2979.

High Sierra Nevada, at and above 8,000 feet, from Mariposa Co. (Brewer) to Lassen's Peak (Lommon); east to the higher Rocky Mountains, north to the Arctic regions, Siberia, Spitzbergen, \&c. A polynorphous species.

3. P. cæruleum, Linn. Glabrous or viscid-pubescent, 2 or 3 feet (or in arcticalpine forms a span or two) in height, leafy, usually bearing numerous flowers in an interrupted narrow thyrsoid panicle or in loose corymbose cymes: leaflets 11 to 21 , from linear-lanceolate to ovate-oblong ( $\frac{1}{2}$ to $1 \frac{1}{2}$ inches long): calyx cleft to or beyond the middle: corolla an inch or more in diameter (bright blue, varying to white), shorter than the stamens or at least than the style: seeds several in each cell, in ours acutely angled.

Low grounds, not rare from San Franciseo to the high Sierra Nevada. Extends north to the Aretic coast, and east to the northern Atlantic States (sparingly), and through the north of Asia and Europe. A striking form, var. foliosissimum, Gray, approaching $P$. Ifecicanum, oecurs in the Rocky Mquntains and those of Utah.

\section{\$3. Perennial: corolla with truly funnelform tube longer than the calyx: inflores- cence capitate or spicate: leaflets mostly palmately divided.}

4. P. confertum, Gray. A span or more high from stout and branching or tufted rootstucks, on the summits of which the radical leaves are densely crowded, glandular-viscid and musk-scented: leaves narrowly linear in general outline, erect; leaflets very numerous and crowded, sometimes even imbricated, sessile, most of them 3-5-parted and seemingly whorled; the divisions from round-oval to linearoblong, and from a line to a quarter of an inch or more in length: flowers in a single dense capitate cluster, or in age spicate, honey-scented: corolla (blue, and a white variety) with narrow funnelform tube (half an inch long) twice or thrice the length of the rounded lobes: ovules 3 in each cell. - Proc. Acad. Philad. 1863, 73, \& Proc. Am. Acad, viii. 280.

Among rocks on high peaks of the Sierra Nevada, at 12,000 to 13,300 feet; Mount Goddard and Mount Dana (Brewer), Mount Lyell ( $J$. Muir); and on the higher mountains of Nevada and Colorado. Ours are of the condensed and small-leaved form.

P. viscosum, Nutt. Pl. Gamb. 154 (mainly, Nuttall having mixed the two), is between the above and $P$. humite, and is known only in the more northern Rocky Mountains.

\section{LGESELIA, Linn.}

Flowers nearly as in Gitia' \& Ipomopsis, except that the tubular-funnelform corolla is irregular, as it were bilabiate $\left(\frac{1}{4}\right)$, one of the cuneate or oblong lobes being separated by deeper sinuses. Stamens declined. Seeds few in each cell, ovoid, mucilaginous when wetted. - Rigid herbs or undershrubs (natives of Mexico); with alternate and simple and entire or sharply serrate leaves, and showy red or blue flowers in terminal or lateral clusters, with or without scarions dilated bracts.

1. L. tenuifolia, Gray. Nearly glabrous: stems woody at base, slender: leaves very narrow, spinulose-mueronate; the lower pinnately parted into a few subulate short lobes; the upper entire and filiform (about an inch long): branches loosely few-flowered at the summit : calyx bractless: corolla scarlet, nearly salverform; its oblong lobes truncately 3-toothed at the apex, about one third the length of the narrow tube: eapillary filaments inserted low down and much exserted : ovules 8 or 10 in each cell. - Proc. Am. Acad. xi. 86.

Tantillas Mountains, below San Diego, within the borders of Lower California, Mr. Dunn, Dr. Palmer. Probably also within the southern line of the State. Corolla an inch long: calyx 3 lines long. See Appendix. 


\section{ORDER LYIV. HYDROPHYLLACEÆ.}

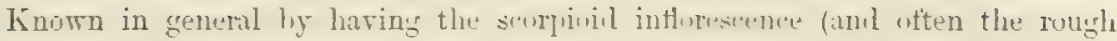
hairiness) of the Borraginacea, along with an undivided 1-2-celled 4-manyovuled ovary, and the two styles distinct at the apex if not to the base, the flowers regular and 5-androus, and the fruit a capsule, with the two placentre parietal or borne upon the half-partitions. - Flowers perfect. Calyx mostly 5-parted or of 5

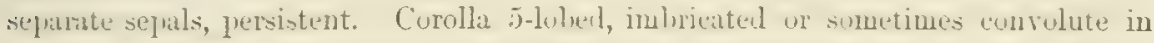
the hul. Stamens horne on the tube of the corolla, alteruate with its lubes. Stinmis terminal, small and simple or more or less capitate. Only in Romanzoria are the stigmas as well as styles completely united into one. Ovary commonly hispid or hirsute, at least at the tol. Caprule in all ours loculicinlal. Seets amplitronums or anatropous, with a close and commonly reticulated or pitted coat, and a horny or

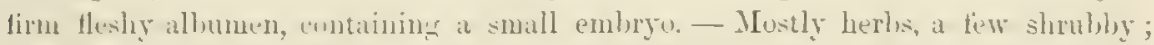
with altermate or rarely ulpusite leaves, no stipules, and an insipid colndess juice. Flwwes sometimes in fuefect ermes, or solitary aul teruinal and becomins lateral by the forking or the unilateral continuation of the stem, or more commonly re"lneerl tw either geminite or single sronpioid and bractless fillse spikes or rucemes, which are in the following descriptions simply called spities or racemes. - Benth. Hylrophyll. in Linn. Traus. xvii. 272; A. DC. Prodr. ix. 287; Gray; Proc. Am. Acad. x. 312.

A family of about 120 species, in over a dozen genera, all American, except a few outlying species of Hylrolia, mostly North American, and increasing in number and variety from the Stlantic const westward, very fully represented in California Wholly inert plants, of no eco. nomical importance; but several of the Californian species are familiar ornamental annuals in general cultivation.

TRIBE I. HYDROPHYLLE. Ovary and capsule one-celled; the cell lined with the placentre in the form of a rather fleshy or when dry membranous sac, attached prinarily tor the walls by two parietal lines, enclosing 4 to 20 amplitropous ovules and (often by ahortion fewer) seeds. Style 2-cleft. Corolla almost always couvolute in the bud. Seeds spherical or roundish-oval, with cartilaginous albumen. Herbs.

* Flovers in crowded or capitate clusters: stamens and style longor than the corolla. Ours perennials, with calyx not appendaged nor much enlarged after flowering.

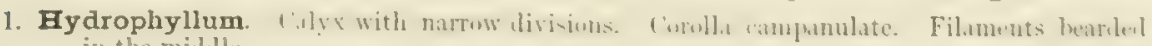
in the micklle.

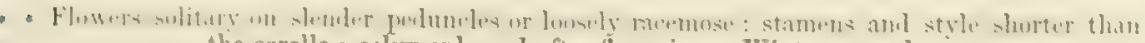
the corolla : calyx enlarged after flowering. Winter annuals.

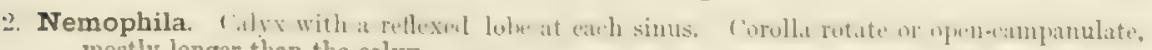
mostly longor than the calyx.

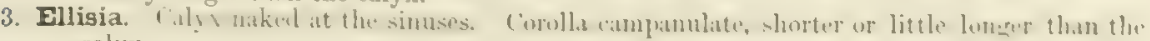
calyx.

Tring II. PHACELIEE. Ovary 1-celled, or 2-celled by the meeting of the two narrow or little dilated placentse in the axis. Style 2-cleft (in Romanzofive entire). Capsule loculicillal, separating tho placente, which usually remain borne on the milhlle of the 2 valves, cither directly or on the half-partition. Corolla imbriented in the but. Caly naked at the sinuses. Seeds between amphitropous and anatropous, with cartilaginous or firm lleshy albumen. Herhs.

- Leaves all opposite and entire.

4. Draperia. Corolln tubular-fuunelform, destitute of internal appendages. Stamens unequal and uneyually inserted. Ovary and capsule 2-celled, s-seeded. Flowers in a terumal scorpioid cyme. 
* Leaves all or all but the lower alternate : flowers in cymes, scorpioid spikes, or racemes, or rarely in the forks of the stem.

* Style from 2-cleft at the apex to 2-parted.

5. Phacelia. Calyx of 5 similar or slightly dissimilar mostly narrow divisions. Corolla deciduous, not yellow. Stamens equally inserted low down. Flowers clustered, spiked, or racemed.

6. Emmenanthe. Corolla yellow or cream-color and scarious-persistent. Otherwise as the preceding genus.

7. Conanthus. Calyx of very narrow and similar divisions. Corolla deciduous, tubular-funnelform: the unequal stamens unequally inserted on its tube. Flowers solitary in the leafy forks and terminal.

8. Tricardia. Calyx of 3 outer much enlarging cordate sepals and 2 inner linear ones.

$$
\text { + }+ \text { Style and even stigma entire. }
$$

9. Romanzoffia. Calyx of similar divisions. Corolla destitute of appendages. Leaves roundreniform and crenate-lobed. Flowers racemed.

*** Leaves (alternate) all radical : peduncles in their axils 1-flowered : style 2-cleft at apex.

10. Hesperochiron. Corolla campanulate or nearly rotate, deciduous.

Tribe III. NAMEA. Otary (more or less completely 2-celled), eapsule, dehiscence, \&c., nearly of Phaceliece. Styles 2, distinct to the base, their tips thickened or stigmas capitate. Herbs or shrubs.

11. Nama. Corolla funnelform. Capsule membranaceous, 2-valved; valves undivided. Low herbs or suffrutescent : leaves entire.

12. Eriodictyon. Corolla funnelform or almost campanulate. Capsule crustaceous, splitting into 4 equal half-valves. Shrubs: leaves toothed.

\section{HYDROPHYLLUM, Tourn. WATERLEAF.}

Calyx 5-parted into narrow divisions, nearly unchanged after flowering; the sinuses in our species entirely without appendages. Corolla campanulate, 5-lobed; the lobes oval, convolute in the bud, in the tube a nectariferous grooved appendage opposite each lobe. Filaments and style filiform and exserted beyond the lobes of the corolla: the former bearded with some long hairs near the middle: anthers linear or oblong, inflexed in the bud. Ovary hispid with stiff straight hairs, 4ovuled. Capsule tardily 2-valved, 1-4-seeded. - Perennials (an annual species in the Atlantic States); with erect and sparingly branching stems from clustered horizontal rootstocks, mostly pinnately parted long-petioled leaves, and white or violet flowers in close or capitate pedunculate cymes.

A wholly North American genus, of six species, growing mostly in wooded or shaded places; two of them peeuliar to the Rocky Mountain and Pacific regions and found in California; a third, riz.

H. VIRGINicUM, Linn., is common to the Atlantic States and Oregon, and may be looked for on our northem borders. This may readily be known by being eomparatively smooth, and with only 3 to 5 divisions to the cauline leaves, which are of ovate general outline.

1. H. capitatum, Dongl. Only a span or so high, in tufts, with rather small rootstocks and coarse fleshy-fibrous roots : leaves soft-hirsute or pubescent, and with blade shorter than the petiole, ovate or roundish in general outline, 2 or 3 inches long, pinnately parted or at base divided into 5 or 7 crowded 2 -3-lobed leaflets or divisions; the lobes oblong, obtuse, mucronate: flowers in a close capitate cluster on a very short pedunele: calyx very hispid : corolla bluish or violet: anthers oblong. - Benth. in Linn. Trans. xviii. 273. - In California we have only

Var. alpinum, Watson. Almost stemless, the comparatively open cymes and the petioles of the leaves rising directly out of the ground; the calyx more white-hairy and less hispid. - Bot. King Exp. 249.

Sierra Nevada (Plumas Co., Mrs. Pulsifer Ames) to Humboldt Mts., Nevada, Watson, \&c. The ordinary form of the species from Utah to Washington Territory. 
2. H. occidentale, (irily. I foot or two high, hirsutely pubescent or alore sonewhat hispid: leaves elongated-oblong in general outline, parted or below divided into 7 to 15 oblong and mostly incised divisions: peduncles longer than the petishes and generully surpassing the leares ( 4 to 9 inches loug), hearing wine ar two rather small and capitate clusters of bluish flowers : calyx very hispid or hispidciliate, deeply parted into lanceolate rather obtuse divisions : anthers linear. - Proc. Am. Acal, x. 314. H. cupitatum, Torr. Pacif. R. Rep. iv. 125, not of Dougl.

Var. Watsoni, Gray, l. c. Commonly lower, sounetimes ouly a span or so high and almust stemless, rather soft-pubescent, especially the lower side of the leaves, which, as well as the calyx, is often pale and whitish or canescent: cyme rather open. - U. macrophyllum, var. occidentale, Watson, Bot. King Exp. 248, mainly.

In woods, Duffield's Ranch in the Sierta Nevada (Bigclow'), Mendocino Co. (Ke/logg), and in Oregon. Var. Watsoni, Sierra Nevada, Bolander, Aaderson, Ilrs. Ames; thence to mountains of Utah, Watson, Parry. The larger and more birsute form, with corolla 4 lines long and pale or white, and hirsute pubescence, approaches the eastern $H$. macrophylhum, which is larger and with a different calyx. The var. Watsoni has rather smaller and blue flowers, the calyx less hispid, but variable.

\section{NEMOPHILA, Nutt.}

Calyx 5-parted and with a supplementary reflexed lobe at each simus, enlarging more or less in fruit. Corolla rotate, or inclined to campanulate, deeply 5-lobed; the lobes convolute in the bul; the throat aprendaged more or less with 10 internal scales or plaits. Stamens and mostly the style shorter than the corolla: filaments naked : anthers linear or oblong and sagittate. Ovary, capsule, \&c., nearly as in Hydrophyllum. Ovules 4 (i. e. a pair on each placenta) or considerably more numerous, ripening from 1 to 16 seeds. - North American annuals, the greater muber C'alifurnian, ferminating in autumn and flowering the following spring; witl tender herbage, diffuse or at length procumbent stems, and pinnately lobed or divided leaves, all more or less hirsute : peduncles termimal or lateral, one-flowered, slender: corolla blue, violet, or rarely nearly white. MIost of the species are well known in the gardens as ornamental aunuals.

* Leaves mostly alternate: stems long and weak, beset with sparse and stiff reflexed bristles by which the plant is disposed to climb: later flovers unaccompanied by leaves and therefore loosely racemose: onules only 4.

1. N. aurita, Lindl. Stems 1 to 3 feet long: leaves all with an auriculate. dilated and clasping base or winged petiole, above deeply pinnatifid into 5 to 9 oblong or lanceolate and mostly retrorse lubes: calyx-appendages small: corolla violet, nearly an inch in diameter, its internal appendages broad, partly free, in pairs at the base of each stamen: seeds globose, reticulated and the spaces deeply sunken. - Bot. Reg. t. 1601 ; Brit. Fl. Gard. ser. 2, t. 338 ; A. DC. Prodr. ix. 290.

Low shady grounds, from the Sacramonto Valley to San Diego.

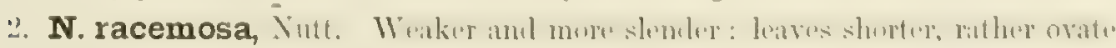
in outline, with fuwer divisions, and a naked petiolo not auricled at base: flowers one half smaller, the upper ones decidedly racemose. - Gray, Proc. 1. c. 315.

San Diego, Nuttall. Catnlina Island, Dall \& Balicr.

* * Leaves all opposite, not auricled at base, commonly surpassed by the slenter pertuncles: ovules 7 to 24 , ripening about 4 to 16 sects; these usnally wille a sort of caruncle.

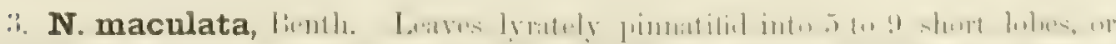

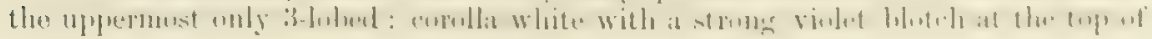


each lobe; its very broad internal scales hirsute on the free edge: seeds globular, nearly smooth, with a very prominent aipple-like caruncle. - Lindl, in Jour. Hort. Soc. iii. 319, \& fig.; Paxt. Mag. xvi. t. 6 ; Fl. Serres, v. t. 431.

Common through the western and middle portions of the State. Corolla over an inch, but less than 2 inches in diameter.

4. N. insignis, Dougl. Leaves pinnately parted into 7 to 9 oblong and sometimes 2-3-lobed small divisions: corolla bright clear blue; its internal scales short and roundish, partly free, hirsute with short hairs : seeds oval, somewhat corrngated or tubereulate. - Benth. Hydrophyll. in Linn. Trans. xvii. 275 ; Bot. Reg. t. 1713 ; Bot. Mag. t. 3485. N. Menziesii, var., Hook. \& Arn. Bot. Beechey, 372.

Common in low or damp grounds, displaying its bright blue flowers from the earliest spring. Corolla from over an inch down to little over half that diameter.

5. IN. Menziesii, Hook. \& Arn. Smaller than the preceding, and the leaves less divided : corolla from light blue to nearly white, and sprinkled with dark dots or spots, at least towards the centre, or (in cultivation) the spots confluent into a brownish purple eye; its scales narrow and wholly adherent by one edge, the other edge densely ciliate: seeds oval or oblong, either even or more or less tuberculate when ripe. - Bot. Beechey, 152 \& 372 (excl. var. $\beta$ ). N. liniflora, Fischer \& Meyer, Sert. Petrop. t. 8. N. pedunculata, Benth. 1. c.; sinall-flowered form. N. atomaria, Fischer \& Mejer, 1. c. ; Bot. Reg. t. 1940 ; Bot. Mag. t. 3774. N. discoidalis, Fl. Serres, ii. t. 75, a cultivated form with large dark eye to the corolla.

Low or shady grounds, not uncommon. Corolla from half an inch to near an inch in diameter.

* * Upper leaves often alternate and the lower opposite, mostly longer than the peduncles, and slender-petioled: flowers small: ovules only 4: seeds from 1 to 4: caruncle mostly deciduous or evanescent.

6. N. parviflora, Dougl. Slender and weak, or procumbent: leaves pinnately 5-9-parted or cleft, or sometimes many only 3-5-lobed; the divisions obovate or oblong, obtuse : corolla light blue or whitish, 3 to 5 lines in diameter, somewhat campanulate, but the lobes longer than the tube, its internal appendages oblong, wholly adherent by one edge, glabrous or nearly so. - Benth. l. c. $N$. parviflora $\& N$. pedunculata (not of Benth.), Hook. Fl. ii. 79. N. heteropluylla, Fischer \& Meyer, 1. c:, a rather large-flowered form.

Low and shady grounds throughout the State, and north to British Columbia: very variable in size and foliage. Forms with larger and less lobed leaves, all the upper ones alternate, have been mistaken for $N$. microcalyx, of the southern Atlantic States; which has minute calyx-appendages, and the smaller corolla destitute of scales within, its lobes shorter than the tube.

N. Breviflora, Gray (N. parviftora, Watson, Bot. King Exp., as to his specimens), collected in the mountains of Northern Utah by Watson, and in the adjacent Snake Country by Tolmie, nlay reach the northeastern borders of the State. It is distinguished from $N$. parvifora by the oblong-lanceolate acute and entire divisions of the 3-5-parted leaves, a much larger calyx in fruit ( 3 lines long), and from all by the broadly campanulate corolla being decidedly shorter than the calyx, in the manner of Ellisia. The calyx-appendages are conspicuous. In Watson's specimens the leaves are all alternate, in Tolmie's all that are developed are opposite.

\section{ELLISIA, Linn.}

Calyx 5-parted, stellately enlarging and more foliaceous under the fruit, the sinuses destitute of appendages. Corolla either narrowly or broadly campanulate, mostly short in proportion to the calyx; the internal appendages at base minute or obsolete; the lobes in the Californian species usually one outside and one inside in the bud. Stamens and style shorter than the corolla: filaments naked: anthers oval or cordate. Ovary, capsule, \&c., nearly as in the preceding. - North American annuals, ours commonly germinating in autumn and flowering from early spring, 
more or less hirsute; the lraves oppwite or the upuermost alternate, once tu thrive

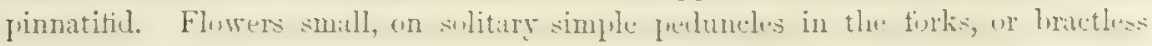
and loosely racemose at the summit of the branches: corolla white or whitish. (The following are all the species known, excepting the Eastern and original E. Nyctelea, Limn.)

\$ 1. Leaves once pinnately parted: oveles only 4 and all enclosed in the dilated investing placentoe in the manner of the tribe: seeds globose, reticulated. - ELLISIs proper.

1. $\boldsymbol{E}$. membranacea, Benth. Sprarsely heset with some shuit and rigid histly hairs, otherwise ulabrous: stems a foot or so in length, weak, soon prostrate: leaves pinnately divided into 3 to 9 linear very obtuse and mostly entire divisions; the petiole wing-margined: flowers mainly racemose on a terminal peduncle: calyx-lobes oblong or at length obovate, very obtuse, rather shorter than the open campanulate corolla, not exceeding the $1-2$-seeded capsule.

Shady and damp places, from the lower part of the valley of the Sacramento to San Diego. Corolla only 4 lines in diameter. Ovary bearing only a few scattered and very stout subulate bristles.

\$2. Leaves mainly twice or thrice pinuatifid: ovules 8, viz. a pair on the back as well as on the front of each placenta: seeds oblong-oval, dissimilar, usually two remaining concealed after dehiscence. - EucrYPTs. (Eucrypta, Nutt.)

2. E. chrysanthemifolia, I) nth. Simewhat lirsute and fulenent : stem at font or two high, erect, paniculately branched: Ieaves Tausy-like, dissected into very many small and short divisions: flowers all loosely racemose: calyx-lobes ob-

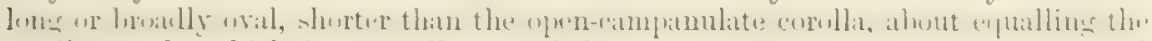
small capsule, which is generally 6-seeded : the mostly 4 ordinary seeds enclosen between the placente rugose-tuberculate and free in lehiscence; while between each placenta and the valve (which it exactly lines and is conformed to) is concenlerl a single meniscoidal and smooth seed:- whence Nuttall's name. - Eucrypta paniculuta \& E. foliosa, Nutt. Pl. Gamb. 159. Phacelia micrantha, var. (?) bipinnatifida, Turr. in Bot. Ives Colorado Exped. 21.

Sharly grounds, not uncommon from Bay of San Francisco to San Diego. Corolla and the stellate-sfreading fruiting calyx about 3 lines in diameter, sometimes smaller. There are two forms, one with obtuse lobes to the lenves, broader calyx-lobes obovate in fruit, and corolla barely exceeding the calyx; the other with acutish lobes to the leaves, and oblong calyx-lobes considerably shorter than the corolln. But they run together, and do not severally accord with the characters of Nuttall's two species.

\section{DRAPERIA, TorT.}

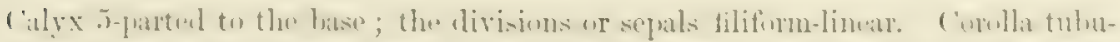

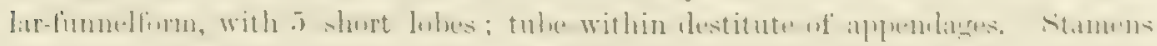

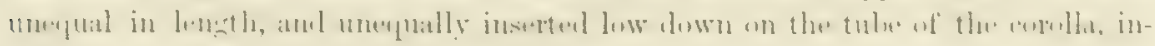
cluded. Ovary strictly 2-celled, with a pair of orules pendulous from near the summit of each cell. Stylo long and filiform, 2-cleft at apex. Capsulo globose,

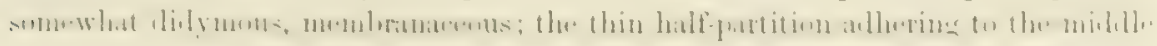
of each valve, mustly without the thin placental portion, which soparates with the 4 seeds. These are oval, anglecl, and with a smoothish close coat. - A single species, peruliar to California.

1. D. systyla, Torr. A luw, diffusely sprealing, grayish silky-hisute, pereu-

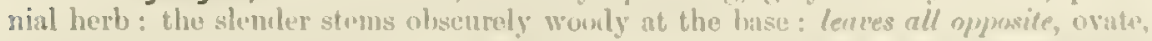
entire, slenter-petioled: fluwers crowiled in the scorpioid spikes of a pedunculat 
once or twice 2-forked or 2-4-rayed cyme, short-pedicelled : corolla purplish. Gray, Proc. Am. Acad. vii. 401, \& x. 316. Nama systyla, Gray, l. c. vi. 37.

Not rare in shaded and wooded ravines in the Sierra Nevada, at the elevation of 4,000 to 5,000 feet, from the Yosemite to Placer Co: Corolla less than half an inch long. This interesting genus was dedieated by Dr. Torrey to the distinguished Professor Draper of New York.

\section{PHACELIA, Juss.}

Calyx deeply 5-parted; the divisions usually narrow and similar. Corolla from almost rotate to narrow-funnelform, deciduous, commonly with appendages upon the inside of the tube in the form of 10 vertical plates or lamellæ approximate in pairs between the bases of the filaments, or else adnate more or less to their base one on each side. Stamens equally inserted low down or at the base of the corolla. Ovules and seeds from 4 (a pair to each placenta) to very numerous. - Herbs, mostly branched from the base; with simple or compound alternate leaves, or the lower opposite, and more or less scorpioid spicate or racemose cymose inflorescence. Corolla blue, violet, purple, or white, never yellow, except sometimes the tube or throat.

As now received (see Proc. Am. Acad. X. 316), this genus comprises nearly half the order, viz. alout $50 \mathrm{~N}$. American species and two or three of Mexico and Chili. One, the earliest-described species, is common to the two continents and ranges almost throughout their length. The genus is mainly western, and is largely represented in California and along its borders.

§ 1. Ovules and seeds only 4, a pair to each placenta. - Euphacelis, Gray.

* Lower leaves opposite: spikes or branches of the cyme hardly at all coiling (or scorpioid), destitute of hispid or hirsute hairs: corolla-appendages. at base of filament short.

1. P. namatoides, Gray. Anmual, barely a span high, with opposite ascending branches, glabrous and glaucous below, glandular-pubescent above: leaves narrowly lanceolate, entire, tapering into an obscure petiole, opposite or nearly so; the uppermost only altemate, equalling or surpassing the rather loose cyme or its spikelike divisions: corolla narrow-campanulate, blue, a little longer than the calyx: stamens and at length deeply 2-parted style included.-Proc. Am. Acad. x. 316. Nama racemosa, Kellogg, Proc. Acad. Calif. v. 51.

Wooded region of the Sierra Nevada, from Calaveras grove to Summit Station, Bolander, Kellogg. Corolla and globular capsule each only a line or so long. Seeds alveolate-reticulated. A genuine Phacelia in structure, with the aspect of Nama.

* * Leaves all but the very earliest alternate (as in the genus generally) : pubescence or some of it hispid or hirsute, especially the inflorescence of spikes conspicuously coited in the bud, and mostly in pairs or cymose-clustered: internal appendages of the corolla manifest, and more or less united with the base of the fllaments.

+ Leaves either simple and entire, $r$ with a pair or two of similar and smaller leaflets or lobes: capsule ovate, acute.

2. P. circinata, Jacq. f. A span to 2 feet high from a perennial or biennial stont root, hispid, and the foliage strigose, either green, grayish, or canescent with a softish pubescence: leaves varying from lanceolate to ovate, acute, obliquely and simply straight-veined; the lower tapering into a petiole and some of them more commonly bearing one or two pairs of lateral leaflets: inflorescence hispid; the dense spikes thyrsoid and crowded: corolla whitish or bluish, moderately 5-lobed, longer than the linear or oblong-lanceolate calyx-lobes: filaments much exserted, sparingly bearded. - Eclog. i. 135, t. 91; A. DC. Prodr. ix. 298. P. heterophylla, Pursh. P. Californica, Cham. 
Var. calycosa, Cray, 1. c. Invisions of the calyx limer and more fuliacents, at length with narrowed base, obovate-spatulate or oblong, when old reticulated.

Very common in dry open grounds, extending north to British Columbia, enst to and beyond the Rocky Mountains, southward into Mexico, and even to Patagonia. A very variable species; the more dwarf states sometimes with mearly lealless and seape-like stem. The variety may be common in California ; but thus far seen only in a cultivated specimen raised by $E$. Hall, and wild from Borax Lake (Torrey), and foot-hills, Mariposa Co., A. Gray; also, a form with large and green entire and ovate leaves, collected on the Mission hills, San Francisco, by Kellogg.

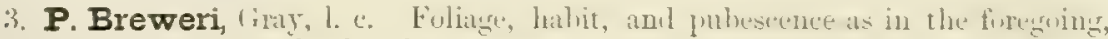
but smaller and more slender, from an annual root: leaves seldom an inch long,

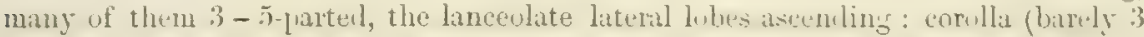
lines lons) more hrually campanulate, blue or viulet, nearly twice the lenerth of the linear calyx-lobes: tilaments glabrous, a little shorter than the corolla.

On Monte Diablo, on dry and soft sandstone, Brewer. In character this approaches the Chilian P. brachynutha, Benth.; but that has softer pubescence, broader and almost all entire leates, longer calyx, narrower corolla, and still shorter stamens.

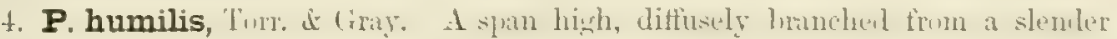
annual root, pubescent, or the inflorescence hirsute: leaves spatulate-oblong or oblanceolate, rather obtuse, all entire, or rarely some of the lower with 1 to 3 lateral

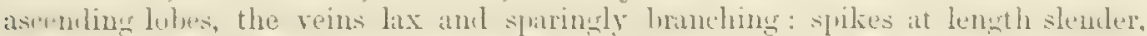

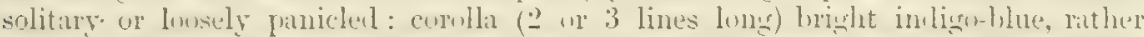

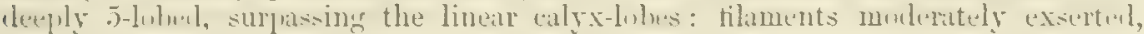
glabrous or bearded with very few hairs. - Pacif. R. Rep. ii. 122, t. 7; Watson, Bot. King Exp. 250.

Var. calycosa, iray, l. c. A les-branched and more slemele furm, with corullit appratently jale, anl the calyx-lubes dilated-spatulite, as in the inalugus variety of $P$. circinata.

Noftheastern part of the State; Sierra and Nevada Counties, at 5,000 to 6,000 feet (Beclurith, Bolunder, Lommon): also in the adjacent parts of Nerada, Anderson, Wutson, \&c. The rar. calycosa, from near Mono Lake, Bolander. Only in Bolander's specimens have any divided leaves been seen.

\section{$\div+$ Leaves simple, rounded and cordate, incisely lobed and serrate.}

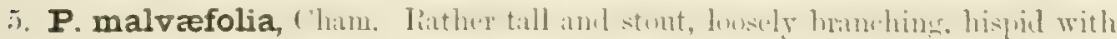
spreading or reflexed stinging hairs, and the folinge more or less pubescent: root unknown: leaves green, membranaceous, all petioled, somewhat palnately 5-9lobed, acutely toothed ( 2 inches or more in diameter): spikes solitary or in pairs:

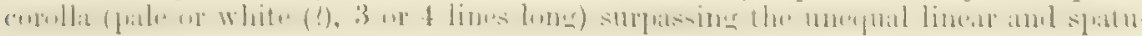
late calyx-loles: stamens much exserted : seeds alveolate-scabrous.

Bay of San Francisco, Chrtmisso (Linnea, iv. 494); not since detected, until lately collected by Dr. Kellogg, at Potrero. The bristles appear to sting like those of a Lonsa.

+++ Leuves once to thrice pinnatifid or pinnately compound, oblong ar narrouner in general outline: style 2-parted: corolla light violet or blue, varying to white: calys (excepting the first species) bristly-lispid, its lobes not ravely dissimilur. Annuals, the species difficult to discriminate.

6. P. crenulata, Torr. A span or a foot high, viscid-pubescent and very glandular, and the calyx hirsute but not hispid: leaves oblong or linear-oblong in outline, crenatuly lobed or pinnatifid, or at base lymately divided; the lobes short and rounded, the larger ones oblong and sometimes crenately incised: spikes clus. tered: corulla rotatro-campanulate, bright violet : stamens and style much exserted : calyx-lobes oblong-linear or somewhat spatulate, eyualling the gplobular capsule: sceds with corky-thickenel and transversely corrugated inflexed margins and central rillge. - Watsun, But. King Exp. 251.

Sinar the horder of the state in Wushe Co, Nevala, Lemmon. The deply pinnatifid form ncrus through Neveda to Arizona und Sew Mexico. 
7. P. tanacetifolia, Benth. Erect, 1 to 3 feet high, roughish-hirsute or hispid: leaves 9-17-divided into linear or oblong-linear once or twice pinnately-parted or cleft divisions, all sessile or nearly so; the lobes small and mostly linear-oblong: spikes cymosely clustered, at length elongated; the very short pedicels ascending or erect: corolla light violet or bluish : stamens and style usually very much exserted: calyx-lobes linear or linear-spatulate, not twice the length of the oval or oblong-oval capsule — Bot. Reg. t. 1696 ; Brit. Fl. Gard. ser. 2, t. 360 ; Hook. Bot. Mag. t. 3703 .

Sandy or gravelly banks of streams, \&e, throughout the western part of the State. Generally well marked by its much dissected Tansy-like foliage, which gives the specific name: this is particularly afylicable to the forn called by Thurber var, temuifolic (Bot. Mex. Bound. 143), a very fine-leaved state.

8. P. ramosissima, Dougl. Divergently branched or straggling, beluw merely pubescent or hispid, above hispid and commonly glandular-viscid: leaves pinnately $5-7$-divided or parted into oblong or even linear pinnatifid-incised divisions : spikes clustered and elongating little in age, the short pedicels soon horizontal : starnens and style moderately exserted: calyx-lobes from linear or spatulate to obovate, more than twice the length of the almost globular capsule. - Benth. in Linn. Trans. xvii. 280 ; Hook. Fl. i.. 80. P. tanacetifolia, var. latifolia, Thurber in Bot. Mex. Bound. 143.

Var. hispida, Gray, 1. c. Conspicuonsly bearded with long and white spreading bristles, like Borrage, especially the spikes, which are more open and racemose in fruit, sometimes elongated: calyx-lobes from narrow spatulate-linear to more broadly spatulate, in fruit sometimes half an inch long.

Dry ground, apparently from San Francisco Bay to the southern limits of the State, and in all the dry regions east of the crests of the Sierra Nevalla, whence it ranges fir uorthward and southward, passing into the foregoing. The var, hispida, a striking and less known form, if not distinct species, occurs from Santa Barbara southward, Nuttall, Xantus, Torrey, Cleveland.

9. P. ciliata, Benth. 1. c. A span or two high, resembles depanperate or low forms of the two preceding with less dissecter foliage : leaves rarely divicled but much incised or cleft and toothed: spikes simple or in pairs, at length loosely-flowered, the short pedicels ascending in fruit: stamens and commonly the style not surpassing the more open or almost rotate corolla: calyx-lobes from linear-lanceolate to ovate, thin, bristly only or chiefly along their edges (whence the specific name).

Near the coast, from San Francisco Bay and the Sacramento southward. The included stamens, if constant, should mark this species.

P. PHYLLOManica, Gray, is a remarkable new species of this subdivision, most peculiar in having all or a part of the sepals pinnatifid or trifid and foliaceous; and the pubescence is very soft. It was discovered on Guadalupe Island, Lower California, by Dr. E. Palmer.

§ 2. Ovules and seeds several or numerous to each placenta, the latter not transversely corrugated: tube of the corolla appendaged with 10 internal vertical plates or lamello in pairs. - Eutoca, Gray. (Eutoca, R. Brown.)

* Stamens and style capillary and much longer than the open-campanulate corolla.

+ Perennial, silky-pubescent or canescent: leaves once to thrice pinnatifid.

10. P. sericea; Gray. A span or two high: stems simple, rather leafy: leaves with numerous narrow and mostly linear lobes: flowers much crowded in a narrow spike-like cluster: corolla violet-blue or sometimes whitish, cleft to the middle, persistent in fruit around the base of the capsule (as in no other species); the internal appendages oblong and free from the stamens: style 2-cleft at the apex only: seeds 12 to 18, ribbed and reticulated. - Amer. Jour. Science (1862), xxxiv. 254 ; Watson, Bot. King Exp. 252. Eutoca sericea, Graham; Bot. Mag. t. 3003.

In the higher mountains of Nevada (as well as in the Rocky Mountains), also in the southeastern lorders of Oregon, and thence northward; therefore probably in the northern sierras of California. 
++ Perennials, with soft and not bristly pubescence: corolla short-campanulate, with very large and broad internal appendages uniled in pairs to or across the base of the filament: leaves ull petioled: stems nearly simple: flowers cymose-clustered.

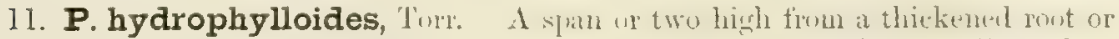
rootstock, canescently pubescent, above hirsute and glandular: Jeaves silky-pubescent both sides, ovate or rhombic (an inch or two long), obtuse, incisely few-toothed or lobed, or the lowest lyrate, haviug one or two nearly separate small basal lobes:

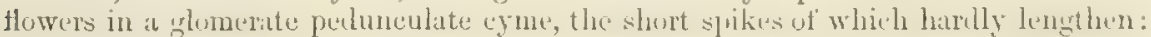
corolla violet or whitish : anthers short-linear : style almost 2-parted : capsule about the length of the slightly hispid calyx, short-pointed, 6-8-seeded. - Gray, Proc. Am. Acad. vii. $400, \&$ x. 323.

Dry sandy or gravelly soil, in the higher sierras, from Mariposa to Sierta Counties, Breveer, Bolcunder, Lommon, \&c. Has the aspect of a Hydrophyllum, whence the name,

12. P. procera, Gray, 1. c. Several feet high, minutely soft-pubescent, glandular at summit: loaves green and membranaceous, 2 to 5 inches long, ovatelanceolate and ovate, acnte, mostly incised-pinuatifid or cleft; the lobes 2 to 4 pairs and acute: spikes in a 2-parted ur crowded eyme, somewhat lengthened when old: corolla white or bluish: anthers oblong: style cleft hardly to the middle: calyx not at all hispid : capsule nearly blunt, 10 -18-seeded.

Mountain meadows of the Sierra Nevala, at 4,000 to 5,000 feet, in Nevada and Sierra Counties, Bolander, Lemmon.

$$
+++ \text { Amual, bristly hispid, branching. }
$$

13. P. loasafolia, Torr. I fout high, rery hispiel with lone and sprealing bristly hairs (as in $P$. malvafolia, which it resembles), also viscid-pubescent: leaves ovate or oblong, or the lower almost cordate, more or less pinnatifid and the lobes incisely toothed: spikes rather crowded: corolla whitish, a little longer than the calyx-lobes; the semi-cordate broad internal appendages auriculate-inflexed at the base, where they are united with the base of the filament, free and pointed at the apex: ovules 12 to 18. - Eutoca loascefolia, Benth. 1. c.

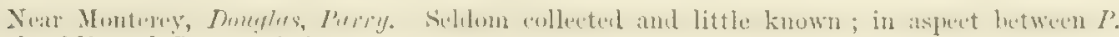
malvoefolia and $P$. ramosissima.

* Stamens equalling or slightly exceeding the rotate-campanulate corolla.

- Appendages of the corolla large, semi-obovate, the pairs united at base before the base of the filament: root peremial?

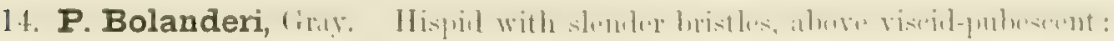
stem stout, a funt or two high, lonsely branched: lower and ralical leaves lyrato and oblong in outline, at base usually with one or two pairs of small and incised lateral divisions; the terminal division and the short-petioled upper leaves ovate or oval ( 2 or 3 inches long), conrsely lobed or tonthed, truncate or sulucomdate at hase: cymes once to thrice forked, the divisions raemose: corollit large (almost an inch in dimeter), white; its internal appendages almost as brond as long: anthers oblong: style cleft to near the milille: ovules 40 or 50 on each dilisted placentis: capsule ovate, acute, matny-seelerl. - Proc. Am. Acad. x. 32 ?.

Mendacino Co., on Cottonuby Creck, 20 miles north of Noyo, Bolander. A striking ant pe-

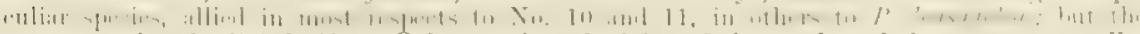
stamens and style slightly if nt and longer than the lobes of the ample and ahuost rotate corolla. It is uncurtain if the root is perenninl.

++ Appendarpes of the corolle Ining and narronn, fiee from the filuments: calyx-lobes linear: style decteft at apex: anmurals, a span to a foot hish.

15. P. Franklinii, fray. Softhirsuto or pulhescent: stem simple or corymbose sit summit: leaves once or twice pimately divided or parted into numerous short 
oblong or linear lobes; the lower petioled; the upper sessile and less divided: Howers cymose-clustered: corolla pale blue or nearly white: capsule about the length of the calyx: ovules 40 or more: seeds minutely alveolate in vertical lines. - Eutoca Franklinii, R. Brown in Frankl. Jour. App. t. 27 ; Bot. Mag. t. 2985.

Southwestern borders of Idaho, and therefore likely to occur in the northeastern borders of California : extends northeastward to Lake Superior and Bear Lake.

16. P. Menziesii, Torr. Cinereous-pubescent, and above mostly roughish-hirsute or even hispid, at length paniculately branched: leaves usually sessile, linear or lanceolate and entire, or some of them cleft into 2 to 5 linear or lanceolate entire divisions or lobes: inflorescence thyrsoid-paniculate, the spikes or spike-like racemes at length elongated and strict: corolla bright violet, varying to white: capsule shorter than the ealyx: ovules 12 to 16 : seeds oblong, reticulate-pitted. - Hydrophyllum lineare, Pursh., Fl. i. 134. Eutoca Menziesii, R. Brown, 1. c.; Hook. Bot. Mag. t. 3762. E. multiflora, Dongl, ; LindI. Bot. Reg. t. 1180.

Common in open ground through the northern part of the Sierra Nevada, thence to Utah, British Columbia, \&c. It is very; floriferous and handsome; the corolla usually deep violet, half to three fourths of an inch in diameter.

* * Stamens shorter than the corolla (in No. 20, 21, sometimes equalling it): inflarescence spiciform or racemose.

+ Leaves pinnatifid, elongated-oblong or spatulate; the lobes short and obtuse : appendages of the corolla narrow and nearly free from the filaments.

+ Flowers (small) in at length elongated spikes.

17. P. brachyloba, Gray. A foot or two high, erect, roughish-pubescent, above viscid-glandular: leaves short-petioled; the 7 to 15 lobes entire or obtusely fewtoothed: spikes solitary or in pairs, slender : flowers very short-pedicelled : lobes of the campanulate nearly white corolla about half the length of the tube: style 2-cleft above the middle: capsule oblong-oval, very obtuse, thin, shorter than the calyx: seeds 6 or fewer to each placenta. - Proc. Am. Acad. x. 324. Eutoca brachyloba, Benth. l. c.

Near Monterey and Santa Barbara, in open ground, Douglas, Brewer, Torrey.

$++\div+$ Flowers loosely racemose and long-pedicelled: stems low or diffuse, a span or less high: leaves mainly at or near the base.

18. P. Douglasii, Torr. Pubescent and hirsute with mostly spreading hairs: leaves elongated-oblong or linear in outline, pinnatifid or pinnately parted into several or numerous pairs of lobes; the terminal lobe hardly larger than the others and not parallel-veined: calyx-lobes spattulate: corolla open-campanulate, rather large: ovules 12 to 14 on each dilated placenta: capsule ovate, mucronate. Eutoca Donglasi, Benth. 1. c.

Open grounds, rather common from Monterey southward. In aspect considerably resembling Nemophilu insignis. Pedicels an inch or less in length, spreading. Corolla half an inch high, and proportionally broad when expanded.

19. P. Davidsonii, Gray, 1. c. Low and depressed: hoary with appressed hirsute hairs and a minute close pubescence : leaves deeply pinnatifid into one or two pairs of triangular entire lateral lobes, and a much larger oblong or lanceolate terminal one, the conspicuous veins of which are nearly parallel, or some upper leaves entire: racemes few-flowered: calyx-lobes oblanceolate or linear: corolla small (3 lines long), violet-colored: ovules 8 or 10 to each placenta.

Kern Co., California, Prof. Davidson. In aspect resembling the species of the next section and $P$. humitis, but with the long pedicels of the preceding; the flowers much smaller.

+ + Leaves entire, or the lower rarely 1-2-lobed, not cordate, the veins parallel or converging as in $P$. circinata: no glandular pubescence: calyx hirsute or hispid. 
with long spreading hairs. appendages of corolla united to the buse of the filaments.

20. P. circinatiformis, Griy. Erect, a span high, hispid and puberulent: leaves ovate and ublong-lanceolate, conspicuously parallel-veined, somewhat strigose : racemes or spikes dense: corulla narrow, almost funnelform, little longer than the calyx, apparently pale or white, much surpassing the stamens: ovules about 4 to each placenta. - Proc. Am. Acad. x. 325. Eutoca phacelioides, Benth. 1. c.

Califormia, Douglas; only known in his collection, probably from Monterey. Has the aspect of a snall form of $P$. circinata.

21. P. curvipes, Torr. Diffuse, 3 or 4 inches high, hirsute and puberulent: leaves oval or lanceulate, inostly shorter than the slender petiole: racemes simple, soon loose; the lower pedicels as long as the calyx: corolta open-campanulate, violet or blue: style 2-cleft to the middle: ovules 8 or 10 to each placenta. - Watson, Bot. King Exp. 252.

Eastern foot-hills of the Sierra Nevada (Watson), extending to Owens Valley, Dr. Horn. Resembles $P$. humilis. Pedicels a quarter to half an inch long, even the lowest not commonly deflexed and then upturned; so that the name is seldom applicable. Corolla 3 lines long: the hispid calyx in fruit 4 or 5 lines long.

22. P. divaricata, Gray, 1. c. Diffusely spreading, a span high, more or -less hirsute and pubescent: leaves ovate or oblong, mostly longer than the petiole, occasionally $1-2$-toothed or lobed at base, the veins curving upwards : spikes or racemes at length loose : the pedicels usually much shorter than the calyx: style 2-cleft at the apex : corolla open-campanulate, pretty large (three fourths of an inch in diameter when expanded), violet: ovules 12 to 20 on each placenta. - Eutoca divaricata, Benth.; Lindl. Bot. Reg. t. 1784; Hook. Bot. Mag. t. 3706. E. Wrangeliana, lischer \& Meyer; Don, Brit. Fl. Gard. ser. 2, t. 362, a form with leaves inclined to he 1 -2-lobed or toothed.

Common about San Franciseo Bay, \&c. : a showy species in cultivation.

+++ Leaves entire or crenate-lobed, roundish; the veins divergent, mostly obscure: pubescence glandular, not at all hispid: appendages of the narrou-campanulate white corolla nearly free from the unequal filaments: flowers small (only about 2 lines long) in a loose raceme.

23. P. pusilla, Torr. 1. c. Only 2 or 3 inches high, slender: leaves roundishoval or oblong, cntire, seldom half an inch long: flowers few on filiform pedicels: capsule narrow-oblong, obtuse and slightly pointed, 18-24-seeded.

Under sage-brush and junipers, east of the Sierra Nevada, extending to the borders of California, Hitson.

24. P. rotundifolia, Torr. 1. c. Diffusely branched, slender, 2 to 4 inches high : leaves thin, round-cordate, crenately 7 -13-toothed or somewhat lohed, much shorter than tho petiole: flowers on pediccls shorter than the calyx-lobes: style obscurely 2-cleft at the apex: capsule oval-oblong, abruptly pointed, 60-100seerdert.

Southenstem borders of Califomia (on the Mohave, \&c. Cooper) to Southern Utwh. Leaves half an inch or less in dinmoter, nearly palmately veinet.

\$3. Seeds (several or numerous) transversely corrugated: otherwise as in § 2. Low annuals: stamens unequal and shorter thun the cornlla: style 2-clejt only at the tip. - Michogenerrs, Gray. (Microgenetes, A. DC.)

"Corolla almost rotate, the tube being shorter than the lobes: the internal appendages 10 transverse callous ridges just betow the throat, remote from the stemens.

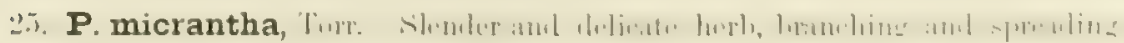
or procumbent, slightly hirsute and glandular: leaves thin, pinnately parted intu 
5 to 9 obovate or oblong mostly entire divisions; the upper with dilated and sometimes auricled and partly clasping base; the lower with margined petiole: racemes geminate or panicled, very loose: pedicels as long as calyx: corolla blue with yellowish tube (barely 2 lines broad), little surpassing the spatulate enlarging calyxlobes: capsule globular, $20-24$-seeded : seeds cylindraceous, incurved, very deeply rugose transversely and tuberculate. - Bot. Mex. Bound. 144; Gray, Proc. Am. Acad. х. 327.

Along the Rio Colorado (Parry, Bigelow), and eastward through S. Arizona to the Rio Grande.

* Corolla funnelform or cylindraceous; the internal appendages vertical, long and narrow, united more or less extensively to the base of the filaments: style more or less hairy below: leaves pinnatifid and with naked petioles: seeds finely reticulated. as well as coarsely rugose. (Phacelia § Euglypta, Watson.)

\section{+ Corolla white or pale purple, little longer than the calyx.}

26. P. Ivesiana, Torr. A span high, diffusely branched from the base, hirsute-pubescent and glandular: leaves pinnately parted into 7 to 15 linear or oblong divisions, rarely twice pinnatifid : racemes loose, 6-20-flowered : appendages of the corolla almost free from the filament: calyx-lobes linear : capsule oblong, 16 - 24-seeded. - Bot. Ives Colorado Exp. 21.

Arizona from the borders of California (Ives), Southern Nevada, and Utah.

\section{++ Corolla conspicuously longer than the calyx; the limb mostly bright purple or violet-blue; the throat and tube whitish or yellowish.}

27. P. Fremontii, Torr. 1. c. A span to a foot high, much branched from the base, viscid-puberulent: leaves simply pinnatifid into 7 to 15 obovate or shortoblong mostly entire lobes: flowers short-pedicelled, crowded in an elongating spike: funnelform corolla ( 3 to 5 lines long) fully twice the length of the spatulate calyx-lobes; the appendages united below to the filament: capsule oblong, 20-30seeded.

From Kern County through Western Arizona and Southern Nevada to Southern Utah.

28. P. bicolor, Torr. Diffusely branched from the base, barely a span high, viscid-pubescent: leaves twice pinnately parted or merely pinnatifid into small short-linear or oblong lobes: racemes or spikes loosely 10-20-flowered : funnelform corolla (5 to 7 lines long) about thrice the length of the almost linear calyx-lobes; the long and narrow appendages united for more than half their length with the filament, forming a narrow tubular cavity behind it: capsule oval-oblong, about 16-seeded. - Watson, Bot. King Exp. 255.

Eastern portion of the Sierra Nevada (Sierra.Co., Lemmon, \&c.), and adjacent parts of Nevada, first collected by $D r$. Anderson. The largest-flowered of these species; the rather showy corolla purple, with a yellowish tube and eye.

29. P. gymnoclada, Torr. 1. c. Branched from the base, low, somewhat viscidpubescent; the primary branches decumbent, long and naked below: leaves obovate, oval, or oblong, obtusely toothed or almost pinnatifid, mostly shorter than the petiole: spikes several-flowered: the short-funnelform corolla (3 or 4 lines long) not twice the length of the obseurely spatulate and hirsute calyx-lobes (its appendages as in the preceding) : capsule oval, or oblong, 5-16-seeded.

Truckee Pass and Winnemueca, $W$ atson, Lemmon. Therefore probably within the eastern border of California. Lemmon's specimens are better develoned than Watson's, without sucl long naked branches from the root; the ovules about 12 , only 4 or 5 ripening into pretty large seeds : the capsule oval or elliptical.

30. P. crassifolia, Torr. 1. c. Diffusely branched, 3 or 4 inches high, viscidpubescent: leaves thickish and rather fleshy, roughish, half an inch or less long, oblong-ovate, tapering into a short petiole, the lower with some short blunt teeth, 
the upper entire: racemes lnosely fiuw-llowerm ; short peticels spreading: fumnelform corolla ( 3 or 4 lines long) fully twice the lencth of the linear calyx-lobes; the appendages small and obscure : capsule ovoid, 6-8-seeded. - Watson, 1. c.

Reese River Valley, Nevada, Watson. Not unlikely to be also Californian.

\$4. Like \$2, but no appendages within the rolate-campanulate corolla or on the base of the filaments: ovules and seeds very numerous on the dilated placenta, the latter pitted: very glandular annuals. - GrмnовттеUs, Gray.

31. P. viscida, Torr. A foot or two high, branching and hirsute at base, very glandular-viscid above: leaves ovate or obscurcly cordate, doubly and irregularly toothed or incised, an inch or two long: fluwers in loose racemes: corolla deep blue with purple or pale centre (sometimes white), from 6 to 10 lines broad, about the

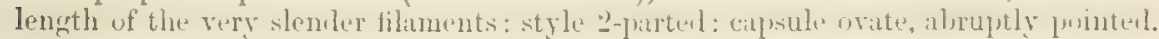
- Bot. Mex. Bound. 143; Gray, 1. c. Eutoca viscida, Benth. in Bot. Rey. t. 180s; Bot. Mag. t. 3572. Cosmanthus (Gymnobythus) viscidus, A. DC. Prodr. ix. 296.

Var. albiflora, (iraty (Eutwere clliglore, Nutt.), is a white-fluweded form, utherwise similar.

Open grounds near the coast, from Santa Barbarn southward.

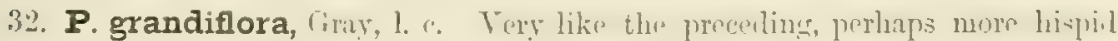
at the base of the stem; but the light blue or white almust rotate corolla abuut double the size. - Entoca grandiflora, Benth. 1. c. E. speciosa, Nutt. Pl. Gamb. 158, Cosmanthus (Gymnobythus) grandiftorus, A. DC. 1. c.

Santa Barbara to San Diego, Douglas, Nuttall, Peckham, Cleveland, \&c.

\$ 5. Like \$ 4, but with a small truncate or emarginate scale adnate to the inner base of each capillary exserted filanent: style 2-cleft above the middle: cornlla either oblong-campanulate or open-campanulate: glandular annuals. - WIITLAVIA, Gray.

* Coralla open-campanulate: ovules and seeds not very numerous.

33. P. Parryi, Torr. 1. c. A span or two high, hirsute or even hispid as well as glantular-viscid: leaves ovate, irregularly doubly toothed or laciniate, or tho lowest pinnately parted, the upper cauline longer than their petioles: racemes very loose, at length elongated: pedicels widely spreading, slencler (from half to a full inch long): corolla cleft beyond the midlle, deep violet with a yellowish or whit: 5-rayed eye, half an inch long, about twice the length of the narrow calyx-lubes: filuments bearled, a little exserted: ovules 20 or 30 to each placenta.

Near San Diego and Los Angeles, Perry, Cooper, \&c.

34. P. longipes, Torr. Apparently low, slender, loosely branched, glundular and slightly lispid (buse of the stem unknown): cauline lenves ronnel-oval or corlate, coarsely and obtusely 5-8-toothed (half an inch long), shorter than their petioles: racemes very loose: corolla hardly half an inch long, apparently whitu, 5-cleft to the michlle, nearly twice the leneth of the spatulate-linear sparsely lisplis calyx-lohes: style rather decply 2-eleft: ovules only 8 or 10 to each placenta: seeds fuw. - Gray, 1. d. 322 .

Santa Barbara Co., Torrcy. No one else hns yet met with it.

* Corollu oblong-campanulate, the tube cylindraceous-mentricose: ovules and seeds very numerous on the dilated placente. - (Whithvia, Iisrvey.)

35. P. Whitlavia, Gray. About a foot high, loosely branching, hirsule amil ghamlular: leaves ovato or deltoid, obtusely and incisely toothed, longer than thro petiole: xaceme lonso and elongating: tube of the violet (or mrely white) corulla an inch or so long, twice or thrice the length of the rounded luhes and of the narmw calyx-lubes: stamens conspicunnsly exsorted. - Whilluria grandiflura, Harv, in 
Lond. Jour. Bot. v. 312, t. 11 ; Hook. Bot. Mag. t. 4813. W. minor, Harvey, 1. c., a depauperate form.

Los Angeles to San Bernardino, Coulter, Wallace, Antisell, \&ic. Prized in cultivation, as are several of the foregoing species.

\section{FMMENANTHE, Benth.}

Calyx deeply 5-parted, the divisions similar. Corolla campanulate, yellow or cream-colored, persistent. Otherwise as in Phacelia § Eutoca \& Microgenetes. Low Californian annuals. - Gray, Proc. 1. c. x. 328. Emmenanthe \& Miltitzia, A. DC.

\$ 1. Resembling Phacelia \$ Microgenetes: seeds more or less rugose transversely: flowers small: calyx-lobes broader upwards. - Mrltitzia, Gray. (Miltitzia, A. DC.)

* Corolla bright yellow, merely 5-lobed, exceeding or at least equalling the calyx both in flower and in fruit, withering-persistent and enclosing the capsule; the tube within mostly with 10 narrow appendages: style persistent: herbage pubescent.

1. E. parviflora, Gray. Low and depressed, rather densely pubescent, viscid: leaves deeply pinnatitid: flowers spicate-erowded, very short-pedicelled: corolla not longer than the almost linear sepals: style hardly longer than the 20 -40-ovuled ovary. - Pacif. R. Rep. vi. 85, t. 15, \& Proc. Am. Acad. x. 328.

Shore of Lake Klamath, Oregon, Newborry. Therefore probably extending into the northern borders of California.

2. E. Iutea, Gray, 1. c. Diffuse, minutely pubescent, somewhat viscid but slightly if at all glandular: leaves oblong or obovate, incisely few-toothed or pinnatifid : flowers rather crowded in short racemes : corolla (3 lines long) surpassing the spatulate-linear calyx-lobes: style filiform, much longer than the about 12ovuled ovary. - E. parviflora, Watson, Bot. King Exp. 257, not of Gray. Eutoca lutea, Hook. \& Arn. Bot. Beechey, \& Ic. Pl. t. 354. Miltitzia lutea, A. DC.

Northeastern part of the Sierra Nevada (Anderson, Watson, \&ce.), and through Nevada to the borders of Idaho.

3. E. glandulifera, Torr. More slender, 3 to 5 inches hirh, diffuse, glandular as well as viscid: leaves small (half an inch or less in length), oblong or spatulate, incisely few-toothed, or the upper entire: flowers numerous in slender spikes or racemes: corolla narrowly campanulate, exceeding the linear calyx-lobes: style filiform: ovules 6 to 12. - Watson, Bot. King Exp. 257.

Eastern side of the Sierra Nevada, at Carson City, on the borders of California, Anderson, Watson. Corolla 2 lines long; no appendages detected. Perhaps only a variety of the preceding.

* * Corolla apparently nearly white, 5-cleft, usually shorter than the calyx and capsule; internal appendages not manifest: leaves rather fleshy and entire, tapering into a petiole: capsule 8-10-seeded.

4. E. glaberrima, Torr. 1. c. Wholly glabrous and glandless, stout and somewhat succulent, a span or less high, diffusely decumbent: leaves oblong-spatulate or obovate (half an inch or more long), some of the lower occasionally 2-4-toothed: flowers few or several in short or at length elongated spikes or strict racemes; pedicels short and appressed: corolla not exceeding the thick spatulate or oblong calyxlobes, hardly surpassing the glabrous ovary, rather shorter than the firm-coriaceous capsule, which is pointed with the indurated base of the style. - Watson, Bot. King Exp. 257 ; Gray, 1. c.

Low saline ground, Humboldt Sink and Reese Valley, Nevada, Watson, on whose authority it is said to be the "Eutoca aretioides" of the Botany of the Ives Colorado Expedition. Not yet found within California, but may be expected. Fruiting calyx and capsule $2 \frac{1}{2}$ lines long, thick, tardily dehiscent. 
5. E. pusilla, Ciray. Soft-puhescent, an inch or two high, erect, at length branched from the base: leaves oblong-lanceolate or spatulate, 2 to 5 lines long and with slender petiole of equal length: flowers 3 to 7 , scattered in a filiform loose raceme, the primary one scapiform; pedicels spreading: corolla about half the length of the linear and obscurely spatulate calyx-lobes and also of the ovoid very obtuse and pointless capsule: style very short and deciduous. - Proc. Am. Acad. xi. 87 .

Northwestern Nevada, Watson (young specimens, taken for a state of Pluacclia musitle), also Lenumon. Calyx in blossom one line, in finit 2 lines long. Corolla apparently white, persistent, investing the base of the capsule. Seeds strongly corrugated.

\$2. Larger, with loose panicled racemes: seeds coarsely pitted: calyx-lobes broader downward: style deciduous: corolla cream-colored, with short rounded lobes, destitute of appendages. - EMMENANTHE proper.

6. E. penduliflora, lienth. A span to a funt ligh, villous-pubesecnt, smmewhat viscid: leaves pinnatifid; the lobes numerous, short, somewhat toothed or incised: pedicels filiform, at base sometimes bracted, as long as the at length nodding flowers: filaments almost free from the broally campanulate unwithering corolla: ovules about 16.

Open ground, not rare from Lake Co. to San Diego, extending east to Southern Utah. Flowers handsome : corolla almost half an inch long. Seeds a line long.

7. CONANTHUS, S. Watson.

Calyx deeply 5-parted, the lobes very narrow and similar. Corolla funnelform, not appendaged, deciduous. Stamens unequally inserted more or less high on the tube of the corolla: filaments slender. Style 2-cleft at apex, sometimes nearly entire: stigmas capitellate. Ovary and capsule 2-celled, 10-20-seeded. Seeds with a thin and translucent coat, nearly smooth, the sides obscurely rugose or excavated when mature. - Watson, Bot. King Exp. 256; Gray, Proc. Am. Acack. x. 329. Eutoca (1) sect. Conanthus, A. DC.

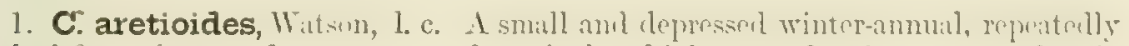
forked from the very base, two or threo inches high, soon forming a matted tuft, hirsute-hispid, flowering copiously a long time: leaves spatulate-linear (an ineh or less long): flowers sessile in the forks, half an inch long: corolla with a narrow tube and rather ample limb, purple. - Eutoca aretioides, Hook. \& Arn. Bot. Beechey, 374; Hook. Ic. Pl. t. 355.

Dry eastern side of the Sierm Nevada, and adjacent portions of the interior region, from Oremon to Arizona. Plant with mostly the characters of Nama, except the united styles. Stumens and style varying in length and height of insertion, appurently from dimorphism.

\section{TRICARDIA, Tort.}

Calyx-lobes or sepals very dissimilar, three outer ample and round-cordate, thinherhaceous, enlarging and becoming senrious and reticulated with age; the two inner small and linear. Corolla broadly eanpanuate, deciduous; internal appendages 10 narrow plaits, free and rather distant from the unequal filaments. Stylo 2-cleft. Ovary glabrous, incompletely 2-celled: ovules 4 to ench placenta. Flowers meemose, rather few : corolla purplish. - S. Watson, Bot. King Exp. 258, t. 24.

1. T. Watsoni, Torr. in Bot. King, 1. c. A low perennial, hruncheal from the haso, a spun high, cottony-puhescent, but nearly ghlabrous whon old: lenves nll altersnate, entiro; the rulical und lower canline spatulatolaneeolate fono or two inches long) amb tapering into a margined petiole; the upper much smaller and more 
oblong, short-petioled or sessile: pedicels recurved in fruit: the enlarged heartshaped sepals much longer than the ovate pointed 8-seeded capsule: stamens and style included.

Truckee Pass, \&c., Nevada, Watson. Probably extending to the California line.

\section{ROMANZOFFIA, Cham.}

Calyx deeply 5-parted, the lobes similar. Corolla more or less funnelform, not appendaged within, deciduous. Stamens inserted on the base of the tube of the corolla, unequal. Style undivided, filiform: stigma small, entire. Ovary and the retuse capsule 2-celled or nearly so. Ovules and pitted-reticulated seeds numerous, on narrow-linear placentæ. - Low and delicate perennial herbs, with the aspect of Saxifrages: the leaves mainly radical, all alternate, round-cordate or reniform, crenately 7 -11-lobed, long-petioled: the scapes or flowering stems racemosely or pamiculately and loosely several-flowered. Corolla pink or purple, varying to white, delicately veiny.

A genus of two species, the original one, $R$. Unalaschkensis of Chamisso, found only on Unalaska and adjacent islands.

1. R. Sitchensis, Bongard. Slender filiform rootstocks bearing small grain-like tubers: scapes weak, a span long: pedicels spreading and longer than the flowers: calyx-lobes glabrous, oblong-linear or lanceolate, much shorter than the corolla, a little shorter than the capsule: style long and slender. - Veg. Sitka, 41, t. 4: Hook. f. Bot. Mag. t. 6109.

In shady woods along the Coast Range, especially in redwoods, from Santa Cruz northward; extending to Alaska.

\section{HESPEROCHIRON, S. Watson.}

Calyx 5-parted, rarely 6-7-parted, and the lanceolate or linear lobes sometimes unequal. Corolla campanulate or rotate, 5-cleft, rarely 6-7-cleft, deciduous. Stamens inserted on the base of the tube of the corolla, unequal, included: filaments subulate. Ovary partly one-celled, tapering into a short style, which is barely 2-cleft at the tip: stigmas minute. Ovules numerous, on dilated placentæ, borne on incomplete semi-dissepiments. Capsule loculicidal, 15-20-seeded. - Dwarf and stemless perennials or possibly biennials, soft-pubescent; with spatulate or oblong entire leaves on margined petioles, and from their axils naked one-flowered scapes, of about the same length, bearing a solitary purplish or nearly white flower. Base of the calyx obscurely adnate to the broad base of the conical-ovate ovary: seeds rather large, and with a somewhat fleshy minutely reticulated coat. - Bot. King Exp. 281, t. 30 ; Gray, 1. c. 330.

An anomalous genus, but probably of this order, peculiar to California, Oregon, and the adjacent interior region. Only one species has been found in California, and it is doubtful if the second is distinct.

1. H. Californicus, Watson, 1, c. Leaves copious in a rosulate tuft (an inch or two long, besides the petiole into which the blade abruptly contracts or gradually tapers): corolla oblong-campanulate; its lobes shorter than the tube. - Ourisia Californica, Benth. Pl. Hartw. 327. H. latifolius, Kellogg in Proc. Calif. Acad. จ. 44, a large state.

Hills and meadows of the Sierra Nevada, from the Yosemite northward to Washington Territory, and east to Nevada and Utah. Corolla from 5 to 8 or 9 lines long: the lobes oblong. 
H. PUMilus, Porter (Villarsia memila, Dougl.; Griseb. in Hook. Fl. ii. 70, t. 157), has fewer leaves from a more slender rootstock, and a nearly rotate corolla with lobes longer than the tube, this densely bearded within. It grows in springy or marshy ground, in the Rocky Mountains of Idaho and Northera Utah (near Ogden, Hayden), \&c.

\section{NAMA, Linn.}

Calyx ieeply 4-parted. Corolla fundelorm or somewhat salverform; the tube destitute of internal appenditges. Stamens often umeyual, and munully iuserted, included. Styles 2, distinct to the base: stigmas somerwat capitate. Capsule thin, completely or incompletely 2-celled by the weeting or alluximation in the axis of the two thin and dilated placentre, 2-valved; the valves entire. Seerls usu-

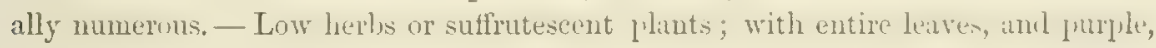
bluish, or white flowers. - Gray, Proc. Am. Acad. v. 337, viii. 282, \& x. 330.

The species aro all American, excepting one in the Sandwich Islands, most numerous near and in Hexico. Of the seven known within the United States four inhabit California ; and a fifth, $N$. stenocarpum, Gray, common on the southern border of Arizona (and well marked by its almost linear capsule) may yet be found near the southeastern frontiers of our State.

\$ 1. Annuals, pubescent or hirsute: flowers terminal and lateral or in the forks, shortpeduncled or sessile: seeds with a thin and translucent close coat.

1. N. hispidum, firty. 1 sman to a fort high, repeateily forketh, hirsute or hispid: leaves linear-spatulate, most of the upper ones sessilo: flowers lateral and solitary, or 3 to 5 in terminal and one-sided nearly bractless clusters: sepals narrowlinear, harlly if at all broadened upward, shorter than the purple corolla : capsule narrowly oblong, $30-40$-seeded : seeds nearly smooth.

Along the Rio Colorado (mostly a low form, with soft pubescence, and occasionally 3 or 4 styles and placentre!), thence east to Texas.

2. N. demissum, Glay. Dwart and depressed, commonly 2 or 3 inches high,

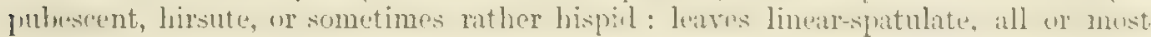
of them tapering into a petiolo: flowers subsessile in the forks : sepals very narrowlinear, not at all broader upward, usually much shorter than the bright purple or "crimson" corolla: capsule short-obloug, 10-16-seeded.

Interior desert region, from the Rio Colorado and the Mohave, through W. Arizona, Nevada, and Utah, to Washington Territory. Flowers showy, ay in Conanthes, which it much resembles (but that has the styles united into one) : corolla 4 or 5 or even 6 lines long : flaments very unequally inserted, somewhat subulate. Seeds much larger and fewer than in the preceding.

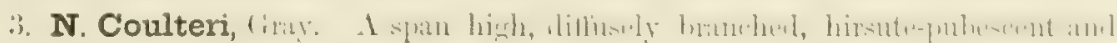
somewhat viscid: leaves short, oblong-spatulate, the lower tapering into a petiole:

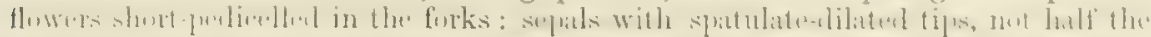

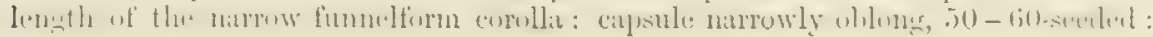
seeds obscurely wrinkled or pitted.

No. 463 of the Californian collection of Couller; not since found; perlings really collected in Arizona or Mexico,

\section{\$ 2. Suffuticose, silky-moolly: flowers clustered: ovary and styles hirsute.}

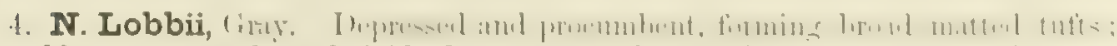
the older stems woody and rigid: leaves marrowly spatulate or linear, tapering to a nearly sessile base, an inch or two long; the younger ones white with the soft villous wool; the older becoming naked and their margins revolute, moro or less nersistent: Howers clustered in the upper axils and at the summit: sepuls very slender, more than half the length of the fumelform purple corolla (this half an imbl loug).

On rocks, dec, not mre in tho northorn part of the Sierra Nevada, first collecterl by Lobb. Fruit not yet se'en. 


\section{ERIODICTYON, Benth.}

Calys deeply 5-parted, the lobes or sepals not broader upwards. Corolla funnelform or approaching campanulate or salverform. Stamens more or less included. Styles 2, distinct to the base; their tips or the stigmas clavate-capitate. Capsule crustaceous, small, globose-ovate and pointed, 2-celled and with dilated placentæ, 4-valved, i. e. at first loculicidal in the manner of the tribe, then septicidal, thus splitting into four hard and thick half-valves, closed by a portion of the partition on one side and partly open on the other. Ovules rather numerous, but seeds few. - Low shrubs (Californian, \&c.); the leaves alternate, of rigid coriaceous texture, pinnately veined and with finely reticulated veinlets conspicuous on a fine woolly ground (whence the generic name), at least underneath, their margins beset with rigid teeth, the base tapering into more or less of a petiole. Flowers in scorpioid cymes collected in a terminal panicle: corolla violet or purple, varying to white. Filaments variably adnate to the tube of the corolla, sometimes almost up to the throat. - Benth. Bot. Sulph. 35.

1. E. tomentosum, Benth. White or in age rusty-colored with a dense coat of short villous down, 6 to 10 feet high; branches leafy to the top : leaves oblong or oval, very rigid, obtuse ( 2 to 4 inches long): calyx and corolla villous, the latter somewhat salverform and about twice the length of the former. - Torr. Bot. Mex. Bound. 148. E. crassifolium \& E. tomentosum, Benth. 1. c.

San Gabriel and Fort Tejon to San Diego, \&c. Corolla hardly half an inch long.

2. E. glutinosum, Benth. Smoothish, glutinous with a resinous exudation, 3 to 5 feet high: leaves ( 3 to 6 inches long) lanceolate, irregularly serrate or nearly entire, whitened beneath between the reticulations by a minute close woolliness, glabrous above: cymes in a long naked panicle: corolla tubular-funnelform, thrice the length of the sparsely and slightly hairy calyx. - Wigandia Californica, Hook. \& Arn. Bot. Beechey, 364, t. 88.

Dry hills ; common through the western and southern portion of the State. Corolla half an inch long. Infusion of the balsamic-resiniferous leaves in spirit used as a tonic.

E. ANGUStifolium, Nutt. Pl. Gamb. (E. glutinosum, var. angustifolium, Torr.), is found only in the interior, from $\mathbf{S}$. Nevada and Utah to the adjacent borders of New Mexico. It is barely distinguished from $E$. glutinosum by its linear leaves with revolute margins, and almost campanulate corolla only 2 or 3 lines long.

\section{ORDER LXV. BORRAGINACE正.}

Mostly roughish-pubescent herbs, with colorless and inert juice, alternate entire leaves without stipules, scorpioid inflorescence, and perfect regular 5-androus flowers; the ovary of 4 lobes or divisions around a central style, ripening into seed-like nutlets, or when undivided 4-celled and 4-ovuled and splitting into nutlets (if drupaceous containing seed-like stones). Calyx free, 5-parted or 5-cleft, persistent. Corolla with a 5-lobed limb, commonly imbricated in the bud. Stamens distinct, inserted in the tube or throat of the corolla alternate with the lobes: anthers 2-celled, opening lengthwise. Ovules solitary, anatropous, amphitropous, or almost orthotropous; the orifice and the radicle of the straight embryo (mostly without albumen) always superior or when the nutlets are horizontal centripetal, or in one anomalous genus inferior in an erect nutlet. Lower leaves not rarely opposite. 
The one-sirter and coiler apparent spikes or racemes straighten as the hilswinus develop: these sometimes scattered: bracts frequently wanting. Echium, an Old World genus with irregular corolla and stamens, has not reached California (although the common species is naturalized in the ("uited sitates): mor are there any of the tirst and second tribes with Heshy or herry-like lruparents fruit; these belonging mainly to tropical regions. - Gray, Proc. Am. Acad. x. 48.

A rather large order, of wide distribution, comprising between 60 and 70 genera, of no economical importance, except that the roots of several yield a red dye, and those of Confrey were of repute in popular medicine as a demulcent, while some, such as Heliotropes and Forget-me-nots, are cultivated for ornament. Although the Calitornian genera are hardly more numerous than those of the Atlantic States, the species are twice as many.

As in the foregoing order, the scorpioid Hower-clusters are termed spikes or racemes, although the flowers are not in the axils of the bracts, when these are present.

Echidocarya Anizosica, Gray, a new genus of a single species from the middle of Arizona, is doubtless wholly out of our range. The aspect of the plunt is wholly that of an Eritrichinem: but the nutlets are as it were stipitate and inflexel over the short free style, with the thick and cartilaginous elongated bases or stalks united in pairs, the whole bearing some likeness to four viper-heads.

THBE I. CORDIEE. Style termiual, once or twice forked; the branches tipped with a simple stigma. Ovary laterally 4 -lobed or entire. Generally woody, ours herlaceous.

1. Coldenia Corolln-lobes imbricated or partly convolute in the bud. Style simply and deeply 2-cleft. Fruit separating into 4 (or by abortion fewer) one-seeded dry nutlets.

TRIBE II. HELIOTROPIE.E. Style terminal, sometimes very short or uone, entire: stigma a fleshy ring or the margin of a disk, which is mostly sumnounted by a conical appeudage.

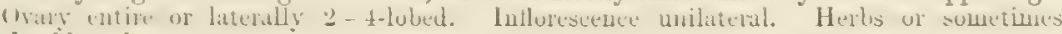
shrubby plants.

2. Heliotropium. (orwlla imluriater in the hud, with the sinuses plaited. Fruit splitting into 4 one-seeded or 2 two-celled and two-seeded nutlets.

Tribe III. BORRAGEA. Style central, entire or nearly so, terminated by a single stigma or pair of stigmas destitute of any appendage, its base surrounded by the divisions of the deeply 4-parted ovary, which in fruit are scparate dry nutlets. Inflorescence mostly unj-

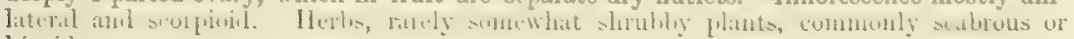
lispid.

* Nutlets naked in the base of the equal and unchanged calyx.

+ Nutlets fixed by their very base to a flat receptacle, erect; the sear flat and rather small.

3. Lithospermum. Nutlets bony. Flowers leafy-bracterl. Corolla-lobes imbricated in the bud, as in all the following but No. 4.

4. Myosotis. Nutlets thin-crustaceous, smooth. Inflorescence bractless. Corolla-lobes convolute in the bud.

++ Nutlets fixed by somo part of the inner angle or face, eitler next the bnse or ligher up, to a couical, low-pyramidal, or more elevated receptacle (gynobase),

++ Unarmed and except ono species unappendaged, erect.

5. Mertensia. Flowers violet or blue. Nutlets rather fleshy, becoming coriaccous. Smooth or soft-pubescent perennials.

6. Amsinckia. Flowers bright yellow. Nutlets coriaceous or crustnceous, fixed above the hase. Cotyletlons 4, that is each of tho pair 2-parted! Bristly-hispiel mmuals.

7. Eritsichium. Flowers in ours white. Nutlets coriaceous or cartiluginous, ovate or triangular. Hirsute or hispid, mostly amuals.

t+ + Glochilliate or otherwise armed or prickly nutlets, hecoming burs (sticking in the flece or bnir of slicep and cattle) : calya opven or spreading in fruit: corolla blue or white.

8. Echinospermum. Nintets erect: the nurgin surrounderl by harbed-tipned prickles. Flow. ers small, in partly lmoneted racemes or spikes. Ambuals or liemuials.

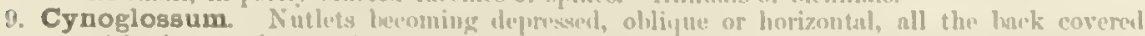
with short and stout harhed-tipyed lristles or prickles, at mafurity sepamating from the receptaclo frons the hase upwarnls and lonuging awhile from tho siyle. Flowers larger, in bractless panicled meemes. Ours pereunial. 
10. Pectocarya. Nutlets divergent and horizontal in pairs, oblong, somewhat boat-shaped by a wing-like toothed or pectinate border, which bears more or less hook-tipped bristles. Flowers very small, white, scattered along leafy branches.

* Fertile nutlet invested by two united and cornute-appendaged divisions of the very unequal calyx; the others sterile : seed erect and radicle inferior !

11. Harpagonella. Fructiferous portion of the calyx bur-like, about 7 -horned, the horns or processes armed with hooked bristles. Flowers very small, scattered along the leafy stem and branehes.

\section{COLDENIA, Linn.}

Calyx 5-parted or deeply 5-cleft (or in one species 4-parted). Corolla shortfunnelform or salverform; the lobes rounded and usually between convolute and imbricated in the bud (one lobe wholly exterior). Anthers oval. Style 2-eleft or 2-parted: stigmas small, capitate. Ovary more or less 4-lobed, in fruit forning 4 or fewer one-seeded nutlets. Seeds destitute of albumen : cotyledons thick. Low herbs or suffrutescent plants, with mostly white small flowers in sessile terminal and lateral chusters. - DC. Prodr. ix. 558; Gray, Proc. Am. Acad. v. 340, viii. 292, \& x. 48. Tiquilia, Pers. Galapagoa, Hook. f. Stegnocarpus, Ptilocalyx \& Eddya, Tort. \& Gray, Pacif. R. Rep. ii. 169.

The original species is East Indian and also widely dispersed over the warmer parts of the world; the sections Stegnocarpus and Ptilocalya, and also Eddya, inhabit the southern borders of the United States from Arizona or New Mexico eastward (one of them C. hispidissima, which has narrow and excessively hispid leaves, \&c., may approach the eastern borders of our State); the section Tiquilia consists of two Westerm South American species; and finally ours form the section Tiquitiopsis, characterized by scales or plaits at the base of the corollatube, and cotyledons either horseshoe-shaped and surrounding or else entire and incumbent on the radicle.

1. C. Nuttallii, Hook. Annual, prostrate and many times forked, hoary-pubescent and sparingly hispid: leaves ovate or roundish, about 2 lines long and on petioles of equal or greater length, marked with 2 or 3 strong veins on each side of the midrib: flowers densely clustered in the forks of the stem: lobes of the 5-parted calyx linear, sparsely hispid, equalling the tube of the pinkish or white corolla: filaments shorter than the anthers, inserted high up on the corolla-tube, at the base of which within are 5 very short adnate scales: style almost 2-parted: nutlets oblong-ovate, smooth and shining, rather thin, marked with a linear ventral scar: embryo straight: cotyledons elongated horseshoe-form, the 4 long basal lobes almost enclosing the long radicle. - Benth. in Kew Jour. Bot. iii. 296; Watson, Bot. King Exp. 248. Tiquilia brevifolia, Nutt. in herb.; Tors. Bot. Mex. Bound. 136, \& Bot. Wilkes Exp. xvii. 411, t. 12 A.

Arid plains, along the eastern borders of the State (Anderson, Torrey, \& the arid interior district from Washington Territory to Arizona, and eastward to Wyoming 'Territory.

2. C. Palmeri, Gray. Perhaps perennial and slightly woody at base, whitened with a fine and close pubescence, not hispid: branches ascending: leaves obovate or ovate, 2 to 4 lines long and with shorter petioles, strongly marked or lineate by about 6 pairs of straight veins: lobes of the 5-cleft calyx lanceolate, about half the length of the tube of the (bluish) corolla, which bears 5 salient plaits extending upwards quite to the base of the slender filaments: nutlets only one or two ripening, these globular and with a round scar: cotyledons entire and thick, incumbent on the radicle!-Proc. Am. Acad. vii. 292, \& x. 49 ; Watson, Bot. King Exp. 247. Tiquilia brevifolia, var. plicata, Torr. Bot. Mex. Bound. 136.

Sand-hills, along the Rio Colorado and the lower part of the Mohave, and adjacent parts of Arizona, Cooper, Emory, Schott, Palmer. Mr. Watson found evident albumen; but in mature seeds there is merely a trace. 


\section{HELIOTROPIUM, Toura, Heltotrote, Tursolf}

Calyx 5-parted. Corolla funnelform or salverform, imbricated and the sinuses plaited in the bud. Stamens included: filaments mostly short or none: anthers conmivent and sometimes cuhtring ly their usually acuminate or mucronate tips. Style entire or none: stigma a fleshy ring or the edge of a peltate or umbrellashaped disk, which is surmounted by a conical, calpitate, or sulublate often :-cleft

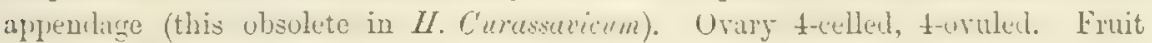

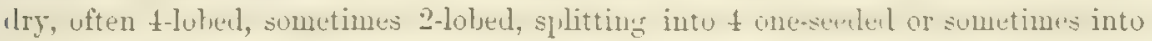
2 two-seeded nutlets. Embryo either straight or curvect, commonly surmumbel by some albumen. - Herbs or low shrubly plants, with the nstally snill humers more conmonly spiked and bractless, sumetimes accompanied hy leafy luacts; the sucalled "spikes" une-sideul and coiled at the ajex, straichtening as the blussoms open. - Gray, Proc. Am. Acad. x. 49.

A large genus, widely dispersed over the warmer parts of the world, represented in the United States by fully a dozen species, only three of which occur in California, and two of these are of great range. The Sweet Heliotrope of cultivation is Peruvian (H. Peruvianum, Linn.). H. Indieum, Linn., the common representative of the section Tiarilium, Lehm., or Heliophylum, DC. (by these and other authors regarded as a distinct genus), although a common weed of waste grounds in warm-temperate and tropical countries, appears not to have run wild in ('alifornia. The two following are true Heliotropes, with fruit of 4 one-seeded nutlets, distinct stamens, flowers in bractless spikes, \&c.

\section{\$1. Fruit 4-lobed, splitting into 4 one-seeded mutlets. - True HeLiotropivM.}

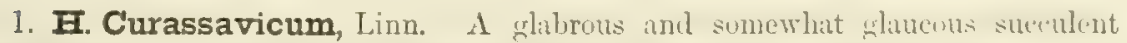

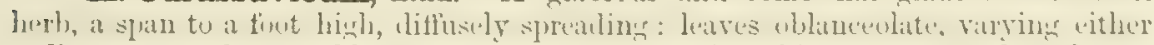
to linear or to obovate-oblong (an inch or two in length) : spikes mostly either in pairs or twice forked, forming a kind of eyme: flowers cromled, pure white, ratture litrye for the genus: stigma sessile, umbrellat-shajed, nearly Hat-tullned, as bruath ats the glabrous ovary.

Sants of the sea-shore, also in damp saline soil in the interior; widely spread over the world. Specimens from 'frejon (liollrock) apparently have blue flowers!

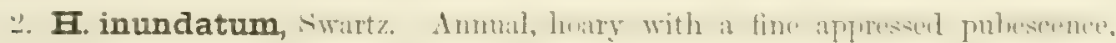
a foot or two high: leaves spatulate-oblong or sometimes oblanceolate, tapering nt baso into a slender petiole: spikes 2 to 4 in a cluster, filiform: flowers very small and close : corolla only a liue long, white: stigma sessile, thick, surmuunted by a short blunt cone.

California, Coulter (probably on the Rio Colorado) : thence to Texas; also West Indies, Tropical America, \&c.

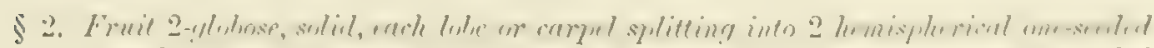
nutlets: corolla pretty large: style long: trincate cone of the stigma beurded with a tuft of strong bristles. - Euplocs, Gray. (Euploca, Niutt.)

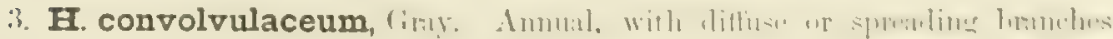
from the base (a span to a foot long), hoary or strignse-hispid: leaves oblung-lancoolate or ovato, petioled: Howers seattered, short-pedicelled, generally opposito the leaves, sweet-sceuted, opening towarls evening: corolla white, with the upper part of the hairy tube sonewhat enlarged and the orifice narrowed, and a rotato scarrily lubed but plaited border: anthers with slightly cohering tips. - Mem. Am. Acul. vi. 403; Proc. Am. Acad. v. 340, x. 50. Euploca convolvulacea, Nutt. in Traus. Am. Phil. Soc. n. ser. v. 189 ; Torr. in Marcy, Rep. t. 15.

In whito sand near "Sodu Lake," Dr. Cooper. Otherwise known ouly enst of the Rocky Mountains, on sundy plains, from Nebraska to Texas. 


\section{LITHOSPERMUM, Tourn. Gromwelt. Puccoon.}

Calyx 5-parted. Corolla salverform or funnelform; its lobes rounded, imbricated in the bud. Filaments short. Style slender: stigma capitate-2-lobed or sometimes truncate. Ovary of 4 distinet lobes. Nutlets 4 , or by abortion fewer, ovate, bony, naked, usually white and smooth, erect, attached to the flat receptacle by the base; the scar flat, rather small. - Herbs, usually with red or violet-colored roots which contain coloring-matter, pubescent or hairy; the flowers in or near the axils of the upper leaves, or leafy-spiked.

A genus of a considerable number of species in the Old World, several in North America, of which the most striking are the Puccoons. One of these, $L$. canvescens, reaches Arizona, and a species much like it has been sparingly found in California, viz. :

1. I. Californicum, Gray. Perennial, a foot or two high, soft-hirsute throughout: leaves lanceolate or oblong (about 2 inches long) : corolla apparently bright light yellow, hardly an inch loug; its narrow tube almost twice the length of the soft-hirsute calyx; the open and enlarged throat nearly naked; lobes very short. L. canescens, var., Torr. Pacif. R. Rep. iv. 124.

Grass Valley, Nevada Co., Bigelow. Plumas Co., Lemmon. The former in flower, the latter in fruit: fruiting branches not elongated.

2. I. pilosum, Nutt. Perennial, pale or hoary with a soft hirsute pubescence: stems numerous from a stout root, a foot high, very leafy : leaves narrowly lanceolate (2 to 4 inches long), mostly tapering from base to apex: flowers crowded in a leafy cluster: corolla dull greenish-yellow, hardly half an inch long, silky outside, the open throat naked or nearly so: nutlets broadly ovate, acute, smooth and polished. - Jour. Acad. Philad. viii. 43 ; Watson, Bot. King Exp. 238. L. ruderale, Dougl, in Hook. Fl, ii. 89.

Hills and cañons of the Sierra Nevada (Sierra Valley, Carson, \&cc.), and through the interior to British Columbia, and east to Dakota.

\section{MYOSOTIS, Linn. SCORPTON-GRASS. FORGET-ME-NOT.}

Calyx 5-parted or 5-cleft. Corolla between salverform and rotate; the tube rarely surpassing the calyx; throat with small and blunt crests at base of the rounded lobes; these convolute in the bud. Stamens, pistil, \&c., as in Lithospermum. Nutlets smooth, somewhat compressed, thin-crustacęous in texture, attached to the flat receptacle by the very base; the scar minute. - Low herbs, mostly softhairy; with small flowers in so-called spikes or racemes, bractless, but sometimes there is a leaf or two at base of the inflorescence. Corolla blue, varying to purple or white.

Species rather numerous in the cooler parts of the old World, very few in the New. None have yet been detected in California ; but the following are not unlikely to occur, and are therefore briefly characterized. Both are of the section in which the calyx is closed or with lobes erect in fruit, and some of its loose hairs or bristles minutely hooked at tip.

1. M. verna, Nutt. Anuual or biennial, at first erect, a span to a foot high, roughish-hirsute: leaves spatulate-oblong: racemes strict, often leafy at base: pedicels in fruit equalling or shorter than the rather unequally 5-cleft hispid calyx, the lower part erect, the upper spreading: corolla white, very small. $-M$. versicolon \& M. flaccida in part, Hook. Fl. (?). Lycopsis Virginica, Linn.

Coast of Oregon; a large and loose form, with nutlets unusually large (var. macrosperma, Chapman); rather common through the Atlantic States.

2. M. sylvatica, Hoffuann, var. alpestris, Koch. Perennial, in loose tufts, pubescent or barely hirsute, a span or so in height: leaves oblong-linear or lance- 
rlate; racemes ruther dense: pedicels short am mostly sprealing: corolla with bright blue or at first purple limb about 3 lines in diameter.

Mountains of Oregon and northward (to be sought in the high Sierra Nevada or on the northwestern borders of the State) : extenling to the Asctic regions, and in Asia and Europe.

\section{MERTENSIA, Roth.}

Calyx 5-parted or 5-cleft, herbaceous. Corolla salverfurm or somewhat funnelform, with rounded lobes, the open throat naked or with mostly inconspicuous crests. Filaments in our species broader than the authers. Sityle filiturm: stifma minutely capitate. Nutlets ovate or somewhat triangular, hetwern fleshy aud coriaceous, dull, commonly somewhat wrinkled when dry, sometimes smooth and vesicular, fixed, usually by a projection of the ventral angle towards or above the

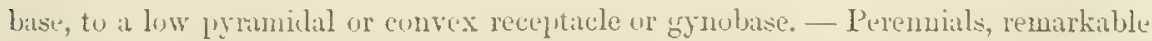
in this order for their smouthness; with broad leaves, and racemose or [raniculateclustered flowers, which are usmally noddiner or inclined on rather slenter pedicels, only the lowest leafy-bracted : flowers blue, violet-purple, or rarely white. - DC. 1. c.; Gray in Am. Jour. Sci. ser. 2, xxxiv. 339 \& Proc. Am. Acad. x. 52.

A genus of a dozen or more species, divided between North Americn and Northern Asia, one species, the handsomest and largest-flowered, peculiar to the Atlantic States, and one smallflowered maritime species (M. marilima) on all the northern shores. On the Pacific const this is not known to occur south of Puget Sound. Besides the following, Mr. paniculata, Don, and M. celpina, Don, both common in the higher Rocky Mountains, are likely to be found also in the Sierra Nevada.

1. M. Sibirica, Don. Smooth and slabrons or nearly so, a fout or more high, rather succulent, leafy: leaves pale, ovate-lanceolate or oblong, acute, 2 to 5 inches long, or the lowest larger and broader, minutely ciliate: flowers at first clustered: corolla half an inch or less long, much longer than the oblong obtuse divisions of the calyx; the 5-cleft limb about half the length of the tube: stamens protruding out of the throat, and the capillary stylo early projecting beyond the lobes. Gray, 1. c.; Watson, Bot. King Exp. 239. Pulmonaria Sibirica, Linn. Mertensia denticulata \& ciliata, DC.

Along mountain strenms, in the Sierra Nevada, Bolander, Lemmon. Also in the mountains castward, and in N. E. Asia. Flowers handsome, violet-blue.

\section{AMSINCKIA, Lehm.}

Calyx 5-parterl, persistent. Corolla salvertim, or at the thruat sumewht funmel-

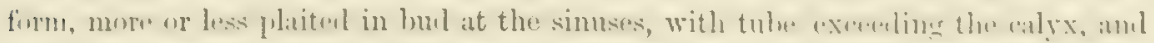

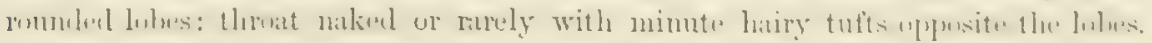

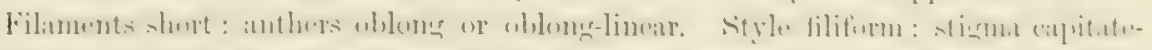

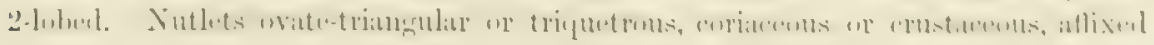
above the base to an oblong-pyramidal gynohase; the scar ovate or oblong. Coty-

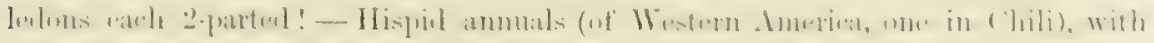

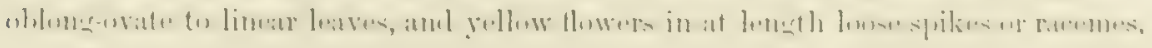
without bracts, except sometimes to the lowest. Bristles mostly from a conspicnous pustulate hase. Flowers, at lenst in some species, dimorphous as to insertion of stamens and length of atyle. - Fischer \& Meyer, Ind. Sem. Hurt. Putrop. 1835, 26 ; DC. Protr. x. 117 ; (1)ay, 1'roc. Am. Acad. x. 54.

The apecies are difficult to chancterize, except the last, which has a peculiar fruit. 
§ 1. Nutlets broadly ovate-triangular, somewhat incurved, narrowed at the apex, convex and somewhat ridged on the back, dull, roughened-granulate, rugose, or muricate; ventral angle acute and prominent down to the rather broad scar.

* Nutlets beset with slender prickly projections.

1. A. echinata, Gray, 1. c. Erect, 3 feet high: leaves lanceolate or broadly linear : corolla slender, apparently light yellow, 3 or 4 lines long, not broadened at the throat, twice the length of the yellowish-hispid calyx: anthers borne in the throat, oval-oblong: nutlets thickly armed with long and narrow rather soft spiny projections, and between these sharp granulate points, not rugose.

Sandy plains, west of Fort Mohave, Cooper. The nutlets are peculiar; otherwise the species resembles some forms of the next.

* * Nutlets granulate-roughened or rugose, the muricate points very short if any, the back convex or at length keeled or ridged.

2. A. spectabilis, Fischer \& Meyer, l. c. Erect, slender, a span (when depauperate) to a foot high : leaves mostly linear : tube of the bright orange-yellow corolla twice or thrice the length of the linear lobes of the rusty or reddish-yellow-bispid calyx, nearly half an inch long; the throat enlarging, and the expanded limb a third to half an inch in diameter : anthers oblong-linear, when high protruding from the throat: nutlets granulate-rugose, roundish on the back. - A. Douglasiana, A. DC. Prodr. x. 118.

Open ground, throughout the southern and western part of the State, and as far northeast as Plumas $\mathrm{Co}_{\text {. }}$ The corolla has 5 minute bearded tufts in place of erests in the throat, when the stamens are inserted low down the tube; these not found when the anthers are borne in the throat, which is more plaited than in the other species.

3. A. intermedia, Fischer \& Meyer, I. c. Erect, usually a foot or two high: the bristles even of the calyx whitish or merely yellowish : leaves linear or only the lower lanceolate : corolla bright yellow, 3 or 4 lines long; its tube a little surpassing the narrow-linear calyx-lobes; the limb barely 2 or 3 lines in diameter: anthers oblong, high or sometimes low on the tube: nutlets not half the length of the narrow calyx-lobes. - A. lycopsoides, partly, of authors, \& Proc. Am. Acad. 1. c.

Dry open grounds, on the eastern borders of the State (Carson City, Anderson) and common in the interior country to Utah, Idaho, and Oregon. Also near the coast in Sonoma Co., \&c. ; on the sea-shore perhaps passing into the next species.

4. A. lycopsoides, Lelım. More branching and diffuse in age : leaves mostly lanceolate, or even oblong, greener, and the sparse bristles with conspicuous pustulate base: lower part of the at length lax spikes commonly leafy-bracted: corolla light yellow, 3 lines long or less; the tube equalling or hardly surpassing the lanceolate calyx-lobes, which are hardly twice the length of the nutlets: anthers short. -Del. Sem. Hort. Hamb. 1831, 7 ; Gray, 1. c. in part. Lithospermum lycopsoides, Lehm. Pug. Pl. ii. 28, \& Hook. Fl. ii. 89.

On the coast, San Francisco Bay to Puget Sound. Limb of the corolla a line or two broad.

$$
\text { * * * Nutlets nearly flat on the back, not keeled, coarsely granulate. }
$$

5. A. tessellata, Gray. About a foot high, rather stout, coarsely hispid, the bristles of the calyx rusty-reddish or paler: corolla orange-yellow, 3 or 4 lines long; the throat plaited; the tube rather longer than the lanceolate obtuse calyx-lobes: anthers oblong: nutlets broadly ovate, obscurely ridged on the flattened back, thickly covered with truncate warty granulations, which are compacted in more or less wavy transverse lines (so as to appear rugose), closely fitting like the blocks of a parement. - Proc. Am. Acad. x. 54.

Dry or arid grounds, fram Tejon (Xantus), and the mountains north of Monte Diablo (Brewer), to the eastern side of the Sierra Nevada (Anderson, Lemnon), and through Nevada (Watson, \&c.) to Southern Utah, Parry. 


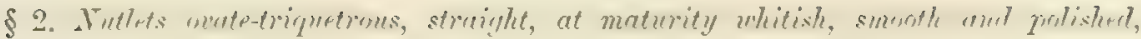
attached by the lower part of the sharp inner angle, the scar narrow, all three fuces flat or nearly so.

6. A. vernicosa, Mnk. ot Am. spurely hritly, simple or lunsely hranchet, a foot or two Ligh: leaves from linear to ovate-lanceolate: corolla light yellow, 4 or 5 lines long, and the limb 2 lines in diameter; the tube longer than the linear-lanceolate calyx-lobes: nutlets shaped like a grain of buckwheat.

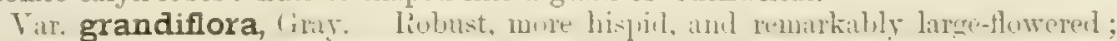

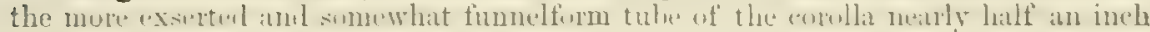
long, and the ample limb broader: calyx-lobes often combined, so as to appear as 3 or 4 : nutlets broader, and rather concave on the back. - A. grandiftora, Kleeberger, ined. (Stamens low on the tube, and style very long, in the specimen; while in those known of $A$. vernicosa the stamens are borne in the throat.)

Western part of the State, probably near Monterey, Couller, Douglas. The remarkable variety, which may be quite distinet, at Antioch, Kellogg.

\section{ERITRICHIUM, Schrader.}

Calyx 5-parted and persistent (one species excepted), erect or closed in fruit. Corolla salverform with tube mostly short and not exceeding the calyx, with or without arching crests in the throat; the rounded lobes imbricated in the bud. Filaments short. Sityle short or sometimes lones stisma minutely capitate. Oyary of 4 lobes. Nutlets 4 , or sometimes by abortion fewer, usually ovate and more or

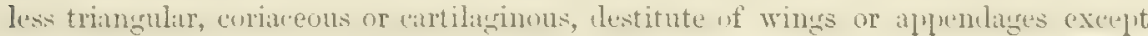
in one sinecies, attareded by the insille of the hase or some part of the rentral fice or angle to a convex, pyramidal, or more elevated and even subulate receptacle (gynobase), which when slender is usually called the base of the style. - Mostly hispid or hairy herbs, mainly annuals, with usually small or minute and either

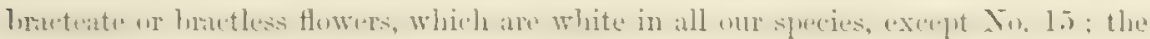
leaves narrow. - Gray, Proc. Anı. Acad. x. 55. Eritrichium, Plagiobothrys, \& Krynitzia, Fischer \& Neyer; A. DC. Prodr. Piptocalyx, Torr.

A rather large genus, of N. America, N. Asia, \&c., one extending into the Alps of Europe, a few South American. The greater part of our species inlabit tle region stretching from liupert's Land to Texis and westward.

\$1. Nutlets attached by the inside of the base only to a slightly elevated receptacle: small or low and diffuse or spreading annuals, more or less hirsute, with linear leaves, the lower ones ofitener opposite: flowers with or withoul bracts: fruiting calyx rather open, except in No. 2.

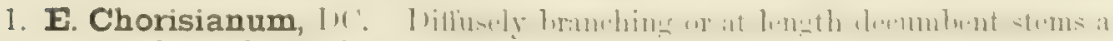
span or two long: leaves broadly or narrowly linenr (1 to 3 inehes long, 1 to 4 lines wile): flowers lonsely racemose, on spreading peilicels which are generally 3 to 5 times longer than the calyx, both yellowish-hirsute when young: corolla with lobes longer than its tube and much surpassing the calyx; the limh 2 to 4 lines in diumeter; yellow crests in the thront conspienus: nutlets romphish, somewhat keded down the back, - Myosolis Chorisiana, Cham. \& Sehlecht. Eritrichium connulifolium, Kellogg, Proc. Calif. Acad. ii. 103, fig. 51.

Wot ground, slsores of San Francisco Bay nud sonth to Monterey. Known hy the peylivels, of which tho enrlier nut longer aro usually half an inch long, but the later ones much shomer.

2. E. Scouleri, A. DC. Slenler, genemlly upright, a span to a foot high: lenvos nurruw: lluwers mather crowded in naken spikes (these often in pairs), the lowest leufy-bracted, tho rest bractless: pedicels vory short and neirly erect, 
only half the length of the fruiting calyx (half a line to a line long) : corolla smaller than in the preceding: nutlets smaller and smoother, but rugose, broadly ovate. Myosotis Scouleri, Hook. \& Am. Eritrichium plebeium, Torr. in Pacif. R. Rep. iv. 124, not of DG., which is an Alaskan species more like the preceding.

Moist or rather dry soil, San Franciseo Bay to Oregon, \&c. Between the last and the next.

3. E. Californicum, DC. Slender, spreading, 2 to 10 inches high: leaves mainly alternate, small, narrowly linear: flowers very small, almost sessile, in fruit scattered, chiefly accompanied by a leaf or bract: corolla hardly surpassing the calyx, its limb only a line or less in diameter and shorter than its tube; the crests in the throat smooth and inconspicuous: nutlets ovate or oblong, more or less rugoseroughened. - Myosotis Californica, Fischer \& Meyer.

Var. subglochidiatum, Gray. Somewhat succulent: nutlets when young more or less hirsute or hispid (especially on the crests of the rugosities), some of the bristles at length stouter and glochidiate under a lens; the roundish carunculate scar almost strictly basal.

Springy or wet places, rather common, extending through Oregon and Nerada to and beyond the Rocky Mountains. The remarkable variety (which passes into the accompanying ordinary form), Placer to Sierra Co. (Kellogg, Lemmon), Nevada (Watson), \&c.

\$2. Nutlets attached by the middle of the somewhat concave inner face by a large and roundish protuberant scar to a hemispherical or globular receptacle, broadly ovate-triangular and somewhat incurved, rugose on the back: low, mostly villous-hirsute annuals, with small flowers like those of the preceding section. Plagiobothrys, Gray, Proc. Am. Acad. x. 57.

* Nutlets not vitreous-shining, the wrinkles elevated narrow meshes.

4. E. fulvum, A. DC. An inch or so to a foot high, slender: leaves linear or the lowest rather spatulate: spike naked, at first dense, in fruit elongating: calyx densely clothed with rusty-yellow or reddish hairs: corolla 2 or 3 lines in diameter : nutlets (a line long) dull, rugose with elevated narrow meshes bounding minutely granulated-ronghened or at length smooth surfaces, an indistinct ridge down the back. - Myosotis fulva, Hook. \& Arn. Plagiobothrys rufescens, Fischer \& Meyer, \&c.

Common through the State, in open grounds, extending through Oregon, \&c. Also in Chili.

5. E. canescens, Gray, 1. c. Generally larger than the foregoing, villous-hirsute with white or whitish hairs: nutlets larger ( $1 \frac{1}{2}$ lines long), less dull, with longer transverse but otherwise similar meshes and a more distinct dorsal ridge, the surface either granulate with some projecting points or smoothish. - Plagiobothrys canescens, Benth. PI. Hartw. 336.

Open grounds, common through the State, mainly towards the coast, and Washington Terr.

* Nutlets vitreous-shining or porcelain-like, the wrinkles narrow and impressed transverse lines mostly running unbroken from the low and narrow dorsal ridge to the margin of the broad posterior face.

6. E. tenellum, Gray, l. c. Seldom a span high, hirsute with rather soft hairs, those of the calyx only fulvous or yellowish: stems erect and slender from the rosulate tuft of radical leaves: these broadly linear or spatulate-lanceolate (one third to an inch long), the cauline shorter or smaller: seldom any bracts among the rather few flowers of the spike: corolla a line or two in diameter: nutlets (a line long) broadly ovate and obscurely cruciform from the abrupt contraction of base and apex, cartilaginous, the broad and low transverse ridges separated by very narrow impressed lines and conspicuously muricate. - Myosotis tenella, Nutt. in Kew Jour. Bot. v. 295. Eritrichium fulvum, Watson, Bot. King Exp. 243, not of DC.

Sierra Nevada and foot-hills, especially northward, to British Columbia and through Nevada, Idaho, \&c. The fruit is very characteristic. 
7. E. Torreyi, rimy, 1. c. Diffuse or decumbent, rough-lirsute or eren hispil, the hairs even of the calyx not yellowish: stems branching and uniformly leafy: leaves oblong (half an inch or less in length); the uppermost forming similar bracts to the lax leafy and intermpted spikes: corolla apparently as in the preceding species: nutlets broadly ovate and only the apex contracted, the broad transverse riliges serarated by narrow sunken lines, very smooth, or olscurely tuberculate along the sides.

Sierra Nevada : Yosemite Valley and Mountains, Torrey (a rather slender and upright form, with bracts hardly surpassing the flowers). Sierra Valley, Lemmon: a dilliusely spreading torm, with copious bracteal leaves, like those below, accompanying and much exceecling the flowers.

\section{\$ 3. Calyx only 5-cleft, at maturity separating about the middle of the short tube by a transverse division, the membranaceous base persisting under the fruit, while the rest falls away: othemoise as in the next section. - PIPTOCALYX, Gray, 1. c. (Piptocalyx, Torr.)}

8. E. circumscissum, firay, 1. c. Very low and diflusely much-hranched annual, an inch to a span high, whitish-hispid throughout: narrow linear leaves (half an inch or less long) and minute tlowers crowded on the branches, forming leafy spikes: corolla without crests in the throat, bearing the stamens on the middle of the tube: nutlets (less than a line long) oblong-ovate, very smooth, attached by almost the whole leugth of the narrow-grooved inner angle to the narrow almost subulate receptacle (gynobase) which bears the short style. - Lithospermum circumscissum, Hook. \& Arn. Bot. Beechey, 370. Piptocalyx circumscissus, Torr. Bot. Wilkes Exp. 414, t. 12 B; Watson, I. c. 240.

Southwestern borders of the State and along the enstern side of the Sierra Nevada ; also throughout the interior arid region to Utah, Washington Territory, and Wyoming.

\$ 4. Calyx (as in the genus generally) deeply 5-parted, persistent, or sometimes at maturity falling off whole with the fruit enclosed: nutlets attached by the ventral face or angle, either from base to near the middle or for almost the volole length, to a high pyramidal or subulate receptacle (qynobase), which when slender is commonly called the base of the style: the scar either a narrow groove or broculer. - KRYsitzkis, Gray, l. c.

There are several species besides the following in the interior region, some extending to the plains east of the locky Mountains and to Texas.

* Nutlets rounded (or at least not margined or acute-angled) at the sides, attached to a slender mostly subulate gynobase by a narrow (or in No. 12 downwarlly widening) sear or groove, occupying nearly its whole length: calyx very hispial, much disposed to full off when ripe as a sort of bur : style short: corolla small or minute: annuals, mostly low and slender: flowers in at length elongated bractess spikes. (Krynitzkia, Fischer \& Meyer.)

$$
+ \text { Nutlets very smooth and shining. }
$$

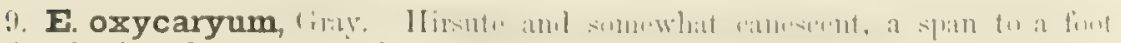
ligh, slender: leaves narowly linear: spikes rather densely flowered, at length strict: corulla nakerl in the thront: bristles of fruiting calyx rigid, partly reflexed, inclined to have hookel tips: only one nutlet maturing, that lanceolate-ovate (a line and a half long), sauch longer than the gynohase, to which it is attached only by the lower part of the slender ventml groove, - Proc, Am. Acal. I. c.

Open grounds from Trjon to Oregon, also Arizonn Corolla only about 2 lines wide.

10. E. leiocarpum, Watson, 1. c. Rongh-hispicl and loosely brunched : lenvers linear: spikus often hecoming loosely-fluwerer below: corolla (2 or 3 lines witu) with crests in the throat: calyx very bristly: nutlets all 4 maturing, ovatus or oblong-ovate (barely a line long), attached by the greater jart of the slemiter grueve 
to the subulate gynobase. - Echinospermum leiocarpum, and afterwards Krynitzkia leiocarpa, Fischer \& Meyer. Myosotis flaccida, Dougl, at least in part.

Common in open grounds, extending to British Columbia and across the Rocky Mountains. Variable in size and appearance.

\section{++ Nutlets granulate-roughened.}

11. E. muriculatum, A. DC. (?); Torr. Resembles the foregoing; but the nutlets are mostly larger and broader, the grooved scar when ripe wider and deeper at base, and the rounded back either sparsely or densely granulate-roughened. - Torr. Bot. Wilkes Exp. 416, t. 13 A. E. angustifolium, Watson, Bot. King Exp. 241, not the true one of Torrey.

Nearly the same range as the last, and not uncommon.

12. E. angustifolium, Torr. Hispid with very stiff spreading hristles, often accompanied by softer hairs, low, diffusely branched: leaves narrowly linear : calyx very closely sessile and mostly persistent in the densely flowered spikes, its lobes almost filiform in fruit (less than 2 lines long, not longer indeed than their rigid divaricate bristles) : corolla minute, but its crests prominent: nutlets minute (barely half a line long), oblong-ovate, minutely and densely granulate, the scar gradually broadening from apex to base, affixed by its whole length to the conical-subulate gynobase. - Pacif. R. Rep. v. 363.

Southeastern borders of California (Coulter, Thomas, Thurber, \&c.) and adjacent parts of Arizona; also Lower California.

* * Nutlets roundish at the sides, somewhat incurved at maturity, attached to a pyramidal gynobase by a shorter narrow salient scar : calyx less hispid, not separating at maturity: style short: corolla larger (limb 3 or 4 lines in diameter). (Intermediate between this section and $\S$ Plagiobothrys.)

13. E. Kingii, Watson. Apparently biennial, villous-hirsute and somewhat hispid: stems ereet or spreading, a spau high, rather stout: leaves from spatulate or the upper oblong to oblong-linear: flowers very short-pedicelled, crowded in short spikes or clusters, which are sometimes leafy at base: calyx-Iobes lanceolate: tube of the corolla not longer than its lobes, the crests conspicuous: nutlets triangularovate, with the summit at maturity incurved, roughish-rugose on the flattish back; the scar linear-lanceolate in outline and somewhat salient, extending from above the broad rounded base to beyond the middle. - Bot. King Exp. 243, t. 23; Gray, 1. c. 60 .

Eastern portion of the Sierra Nevada ; Truckee Pass, Sierra Valley, and adjacent parts of Nevada, Watson, Lemmon. Mature fruit of an apparently decumbent form was collected by Mr. Lemmon, in 1874 and 1875 .

* * Nutlets three-sided and with acute lateral angles, attached by the lower part of the ventral angle to a subulate or narrow-columzar gynobase; style mostly long: anthers linear-oblong: coralla rather large and the crests in its throat very promiatent and arching: stout biennials or perennials, with thyrsiform leafy-bracteate inflorescence: the calyx and pedicels persistent in fruit.

14. F. glomeratum, DC. Root biennial, or in the mountain form perhaps perennial, a span to a foot high, grayish-hirsute and hispid: leaves spatulate and linear-spatulate: tuhe of the corolla not surpassing the linear-lanceolate lobes of the very bristly hispid (sometimes yellowish) calyx, and hardly longer than its lobes, the limb 3 to 5 lines in diameter: nutlets tuberculate-rugose on the back. Cynoglossum glomeratum, Pursh. Myosotis glomerata, Nutt.; Hook. Fl. ii. 82, t. 162.

High Sierra Nevada, from Mariposa to Sierra counties, thence eastward and northward to British Columbia and the plains east of the Rocky Mountains : only the low and less hispid form (var. humile, Gray) in California. - The two following species, not yet actually found within the State, may be expected. 
15. E. fulvocanescens, (:ivy. 1. c. I)illers from the preceding in the peren-

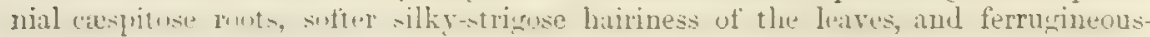
yellow hairs of the calyx: tube of corolla longer than the calyx, twice or thrice the length of its own lobes (limb 3 or 4 lines in diameter): nutlets granulate-roughened. - E. glomeratum, var. (?) fulvocanescens, Watson, l. c.

High mountains of Nevada, to New Mexico and Wyoming. Intermediate in aspect between the last and the next.

16. E. leucophzum, 1. DC. Porennial, and almost womly at biste a span tin a foot high in tufts, silvery-canescent and somewhat strigose: leaves lanceolate and linear, acute: spicate-glomerate inflorescence and calyx hirsute and hispid with whitish or yellowish hairs and slender bristles: tube of the (cream-colored or yellow!) corolla exceeding the calyx and twice or thrice the length of its lobes: style

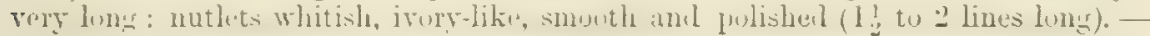
Myosotis lencophaea, Dougl. in Hook. 1. c. t. 163.

Dry and barren interior region, from British Columbia to Southern Utah, reaching the borders of California near Mono Lake, Brewer.

* * * * Nutlets narrowly ovate, affixed by their whole length to the subulate gynobase by a very narrow groove having a more or less woidened base, one of them without lateral angles (as in 9 \& 10), the other three with their lateral angles extended into a continuous broad and somewhat crenate or pectinate wing, rarely all four winged.

17. E. pterocaryum, Torr. Slemler anmal, hirsute, lumily lundhin: loaves linear or the lowest spatulate: flowers in naked and mostly bractless geminate or cymosely clustered spikes: calyx-lobes oblong or in fruit ovate, enclosing the nutlets : corolla minute, barely a line long. - Bot. Wilkes Exp. 415, t. 13 B; Watson, liot. King Exp. 245.

Eastern side of the Sierra Nevada (Anderson, Watson, Lemmon), and through the dry interior region, from the borders of British Columbia to New Mexico and the borders of Texas. Nutlets a line and a half long; the wing on either side as wide as the body, usually merely toothed, in var. pectinatum cut half-way down into narrow and crowded linear-oblong lobes.

\section{ECHINOSPERMUM, Swartz. STICKSEED.}

Calyx 5-parted, persistent, spreading or reflexed in fruit. Corolla short-salverform and with conspicuous arching crests at the throat. Short filaments, style, ovary, \&c., as in Eritrichium. Nutlets 4, erect, attached by their ventral angle for most of their length to a subulate or broadly pyramidal gynobase, the sides surrounded by one or more rows of rigid prickles with backwardly barbel (glochiliate) tips, either distinct or confluent into a borler or wing, the back unarmed or sometimes similarly prickly, - forming a bur, which is carried in the wool and hair of animals. - DC. 1. c.

A genus of about 30 species, mostly rinther conrse and small- (blue- or rarely white-) flowered weedy plants, nbounling through Northern Asin, a few reaching Europe, one of which, E. Jap. pula, is a nuturalized weed throughout the Atluntic Lnited States. W $\mathbb{W}^{2}$ have also two or three imligenous species.

1. E. Redowskii, Lohm. Annual, roughish hisute, a span to a foot or two high, much branchod: lenves linear, lanceolnte, or the lower somowhat spuatulate, oltuse; the upper becoming brats of the looso lesfy spikes: pelicels erect or merely spreuling, stunt, shorter than the narrow and at length uneyual lohn's of the calyx, which mostly exeed the fruit: corolla small, a line or two long, hluo: nutlets bordered by a single row of subulate barbect prickles, their bases often brondened and more or less confluent; the hack und siles thickly beset with irrugular sharp pwints or tubercles; sear and gynobase slender. $-E$. Redomskii, var. occiden- 
tale, Watson, Bot. King Exp. 246, t. 23, fig. 9 to 12. E. patulum, Lehm. in Hook. Fl.; Torr. Bot. Wilkes Exp. 418, not of Lehm. Asper, E. Lappula, Hook. \& Arn. Bot. Beechey, not of Lehm.

Var. cupulatum, Gray. Prickles of the fruit with broadened bases united into a coriaceous wing, which sometimes forms a deep cup on the back of the nutlet, its margins incurved and thickened. - $E$. strictum, Nees in Neu-Wied, Trav., not of Ledeb. E. Redowskii, var. strictum, Watson, l. c.

Dry plains, along the eastern side of the Sierra Nevada (Watson, \&c.), and through the whole interior region, eastward to Minnesota and Texas (also in N. Asia). The variety with the other form, and passing into it by gradations; sometimes one of the four nutlets bordered with distinct prickles, while the other three are deeply cupped by their union up to near their barbed tips. The E. patulum of Siberia has the little tubercles on the back and sides of the nutlets fewer and arranged in regular rows, as indicated by Mr. Watson.

2. E. deflexum, Lehm., var. floribundum, Watson. Biennial, hoary-pubescent or hirsute: stem erect, from a foot to 4 feet high, with erect paniculate branches: leaves lanceolate or oblong-lanceolate, 2 to 5 inches long: racemes panicled, at length slender; the lower bract rather leafy, the upper ones minute or wanting: pedicels slender, a line or two long, much longer than the calyx, deflexed in fruit: corolla sky-blue (rarely white), conspicuous, the limb a quarter to fully half an inch in diameter: nutlets bordered by a single row of numerous subulate barbed prickles with bases more or less confluent; the flattish back minutely roughgranulate or rarely smooth; the scar short and broad: gynobase broadly conicalpyramidal. - E. floribundum, Lehm. ; Hook. 1. c. t. 164.

Open woods, not rare through the State, and eastward to and beyond the Rocky Mountains; northward, on the borders of British Columbia, passing into the smaller-flowered and greener form which well represents the European and Siberian E. deflexum. On Mount Shasta, Prof. Brewer collected an ambiguous form, tall and stout, with upper cauline leaves ovate-lanceolate and partly clasping, and fruit large, the nutlets equally prickly all over the back; perhaps a distinet species, possibly $E$. diffusum, Lehm.

\section{CYNOGLOSSUM, Tourn. HOUND'S-TONGUE.}

Calyx 5-parted, persistent, open in fruit. Corolla short-salverform or funnelform, with conspicuous arching crests at the throat. Stamens and style included. Nutlets 4, clothed over the whole back with short and stout prickles having minutely barbed (glochidiate) tips, or sometimes merely muricate, oblique or horizontal (although the lobes of the ovary are erect or ascending, and with an ascending anatropous ovule), the inner angle being carried upwards by the growth of the pyramidal gynobase to which the nutlets are affixed by a large scar, separating at maturity from below upwards, hanging for some time by a process which at length peels off from the style. - Coarse and broad-leaved herbs, with lower leaves large and long-petioled, and middle-sized flowers in bractless panicled racemes; the nutlets forming "burs."

C. officinale, Linn., the common Hound's-tongue, is a coarse biennial weed of the Old World, abundantly naturalized in the northern Atlantic States. It has not reached California, apparently. The plant so named in the Botany of Beechey's Voyage doubtless belongs to the following species.

1. C. grande, Dougl. A thick-rooted perennial, about 2 feet high, pubescent when young with mostly soft slender hairs, or the stem and the upper face of the leaves glabrous : radical and lower cauline leaves ovate-oblong, usually rounded or cordate at base, long-petioled; the upper ones similar, but smaller and with tapering base or short margined petiole: panicled racemes or cyme small, on a long naked peduncle terminating the stem: corolla blne or violet, its tube longer than the calyx, but hardly longer than the ample roundish lobes. 
Woods, from Monterey to Washington Territory. An unusually smooth form from Plumas Co, Mfrs. Pulsifer. Ames. Nutlets not seen; the moderately enlarging lobes of the ovary only sparsely and minutely muricate on the back.

2. C. occidentale, (iray. Alunt a fimet high, leafy to the top or nearly, roughish-hirsute: leaves oblong or lanceolate, mostly obtuse and with a small point;

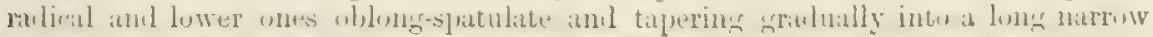

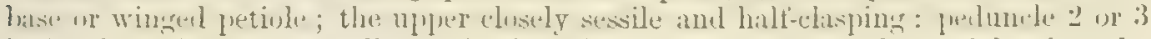
inches long, bearing a small mostly forked cyme: corolla purple or violet, its tube twice or thrice the length of the short and roundish lobes: nutlets borizontal at maturity, very convex and tumid as in the Eastern $C$. Virginicum. - Proc. Am Acad. X. 58.

Sierra Co. and northrard, Lemmon (in fruit), Rcv. R. Burgess (in flower).

\section{PECTOCARYA, DC.}

Calyx 5-parterl, persistent, sprealing. Corulla very small, salverform or fumelform, with erests in the throat. Stamens and very short style includecl. Nutlets

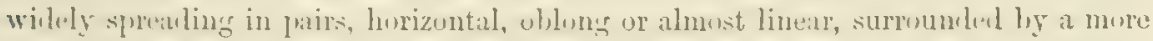

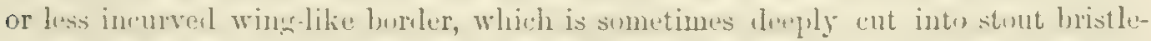
besting teeth, or is more or less heset with stitt bristles or slemer priekles, the tipes of which are simply hooked. Gynobase very short. Radicle of the embryo centripetal, i. e. pointing to the gynobase. - Low and insignificant slender annuals, diffusely branching; with hoary strigose-hirsute pubescence, narrow linear leaves

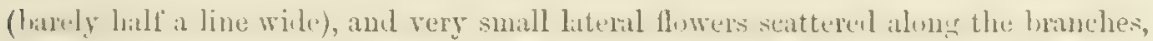
on very short peduncles: corolla white.-DC. Prodr.x. 120 ; Gray, Proc. Am. Acad. x. 61.

A genus of probably only two variable species, and perhaps of only one, inhabiting the western const of America from Chili to California, perhaps diffused since the introduction of sheep and cattle, the nutlots being bur-like.

1. P. lateriflora, DC. Nutlets about 2 lines long, surrounded by a mither broad and thick expanded wing, which is deeply cut or parted into abont 9 to 15 triangrular-subulate tecth, more or less tipped with hook-bristly points. $-C y n n g l o s-$ sum lateriflom, Lam. C. pilosum, liniz \& Pav. Pectocarya laterifora, linearis, \& (a slenter form) Chilensis, DC. 1. C. P. Chilensis, var. Californica, Torr. in Pacif. R. Rep. iv. 124, where the character in the Prodromus as to the position of the radical is currected.

Dry sandy or gravelly soil, Los Angeles to Arizona and Southern Utah (Parry, Bigcloro, \&c.). Also coast of P'erru and Clitil.

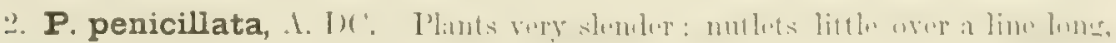
with narrow and entire or rarely fow-tonthed wing, the apex thickly besot with hooked bristles, the silus more or less incurved and naked or sometimes bearing a fow scattered bristles, - C'ynoglossum penicillatum, Hook. \& Arn.

Common in sandy or gravelly soil along and near the const. Also in N. W. Nerada, between Long Iake and Soda Lake Valleys, Lommon. Probably passes into the preceding.

\section{HARPAGONELLA, Giny.}

Calyx imegular; threo of the sepals distinct nearly to tho base, two uniterl to near the suidille. Comblla almost rotate, harlly surpassing the calyx; the throat with obtuse crests; the rounlish lohes imbrieated in the bud. Style short: stigm: somewhat cupitate. Divisions of the ovary globular, attacherl by the base to a nearly flat receptacle, two of them apparently always abortive. Ovulu nearly erect, 
anatropous, the orifice inferior. Nutlets mostly 2, collateral, oblong, coriaceous, perfectly smooth, obliquely fixed by the base; one of them naked, ascending, and usually if not always infertile; the other larger and completely invested by the two united lobes of the now very oblique calyx, in the form of a bur (somewhat resembling that of a small Franseria), being sparsely beset with 7 to 9 long and diverging soft spines, which are armed with short hook-tipped bristles. Radicle inferior or centripetal. - A little herb with the aspect of Pectocarya. - Proc. Am. Acad. xi. 88.

1. F. Palmeri, Gray, 1. c. Diffuse and slender annual, a span high, minutely strigose-hirsute: leaves linear-lanceolate: flowers very small, lateral at all the nodes, on short at length deflexed peduncles: corolla white, minute: spines of the fruiting calyx as long as the bur-like body; the 3 free calyx-lobes small and rather remote.

Guadalupe Island, Lower California, Dr. E. Palmer. Although from a station two hundred miles below the line of the State, this curious little plant is not unlikely to occur along the borders, in company with Pectocarya, with which it is associated on Guadalupe Island.

\section{Order LXVI. CONVOLVULACE开.}

Herbs, or some sbrubs in warm climates, more commonly twining or trailing, many with milky juice; all with alternate leaves (or scales) and regular perfect flowers; the stamens as many as the lobes or angles of the corolla and alternate with them (5, rarely 4$)$; the free persistent calyx of mostly distinct nuch-imbricated sepals; ovary $2-3$-celled, with a pair of erect or ascending ovules in each cell, the cells occasionally divided, so as to form 4 one-ovuled half-cells; capsule generally globular; seeds 1 to 4, proportionally large, with a large embryo and a little mucilaginous albumen. Inflorescence axillary: peduncles 1-flowered or cymosely several-flowered. Flowers oftener large and showy, and opening only once.

An order of nearly 30 genera and numerous species, widely spread over the world, but most abundant in warm countries, moderately well represented in the Atlantic United States, at least in the Southern, but there are wonderfully few on the Pacific side. Lower California has several, all of the tropical types and quite beyond our reach. The order yields purgative medicines, such as Jalap and Scammony, and one important article of food, Sweet-Potato, the root of Ipomaea Batatas; also some ornamental flowers.

Evolvulus, Linn., a genus of low and slender plants, not twining, small-flowered, and remarkable for having two styles each 2-cleft, is represented by two or three species reaching as near as Lower California and Arizona.

Dichondra, Forster, a genus of two small creeping herbs, - one of them most widely diffused throughout the warm-temperate and tropical regions of the world, the other Mexican extending into Arizona, \&c., - appears to be wholly absent from California. The genus is known by the anomaly of two distinct ovaries as well as styles.

Tribe I. CONVOLULEE. Plants with ordinary green herbage. Embryo with broad and thin foliaceous cotyledons, folded and crumpled in the seed.

1. Convolvulus. Corolla plaited and usually convolute in the bud; the limb mostly entire or 5 -angled. Style single: stigmas 2, linear, or oblong. (IPOMEA will bo known by its capitate or 2-3-capitate stigma.)

2. Cressa. Corolla not plaited, 5-cleft. Styles 2, distinct, each with a capitate stigma.

TRIBE II. CUSCUTINE无. Twining parasites, whitish or yellowish, wholly destitnte of green foliage. Embryo filiform and spiral, destitute of cotyledons.

3. Cuscuta. The only genus. Corolla not plaited, 4-5-lobed. Styles in ours 2, and stigmas capitate. 


\section{CONVOLVULUS, Linn. BISDWEED.}

Corolla campanulate or short and open-funnelform, with more or less 5-angulate or obscurely 5-lobed border, deeply plaited down the sinuses in the bud; the plaits convolute, commonly straight, snuetines contorted (either in the sanne lirection ats the plaits overlap or in the opposite). Stamens included. Style filiform: stigmas 2, subulate, or in ours flat, and from narrowly linear to oval. Capsule globose, 2-celled (sometimes imperfectly so) : cells 2-ovuled and commonly 2-seeded : dehiscence when perfect septifragal, $i$. e. the valves separating from the partition. Embryo with broad and foliaceous cotyledons, folded and crumpled in the seed. Stems twining, trailing, or in some erect and bushy. Peduncles solitary in the axils, in ours one-flowered, or occasionally 2-flowered. Ours are all perenuial herbs.

A mother large genus in the Old World, sparingly represented in the New.

I ponga (Pharbitis) pUtrurea, and I. Nil, the common species of annual Morning-Glory of cultivation and occasional naturalization in the Atlantie States, natives of Mexico, \&c, might be expected to occur, either indigenous or adventive, in the southern part of the State; but we have not met with them.

Calystegra, $\mathbf{R}$. Brown, in viow of the Californian species, is not even a well-marked section. All the following species would belong to it except the last, and the next to the last, which is ambiguous.

* A pair of thin membranacen-foliaceous bracts close to the calyx, and enveloping it or partly so. - (Calystegia, R. Brown.)

+ Herbage rather fleshy: stigmas nvate or oval.

1. C. Soldanella, Linn. Maritime, low, glabrous: stems a foot or less in length, trailing, rarely attempting to climb: leaves kidney-shaped, entire or obscurely angulate-lobed, an inch or two broad, long-petioled: bracts ovate-cordate, not longer than the sepals: corolla pink or purplish, an inch or more in length: capsule becoming one-celled. - Calystegia Soldanella \& $C$. reniformis, $\mathrm{R}$. Brown.

Saudy sea-shore, San Diego and northward to Puget Sound. Widely distributed over the Pacific and Europenn consts.

$$
++ \text { Not fleshy: stigmas linear, or at most oblong-linear. }
$$

2. C. occidentalis, Gray. Glabrous or minutely pubescent: stems twining, several feet high: leaves from broally ovate-triangular with a deep and natrow basal sinus to harrowly lanceolate-hastate; the posterior lohes often 1 -2-toothed: perluncle elongated, not rarely 2 -tlowered within the bracts; these ovate or rarely oblung, commonly surpassing and enclosing the calyx: corolla white or pinkish, 1 to $1 \frac{1}{2}$ inches long, and the expanded limb as wide. - Proc. Am. Acad. xi. 89.

Dry hills, through the western part of the State, from near San Francisco (Dr. Gibhons, with smaller ovate-lanceolate and not enveloping bracts, and a second flower from the axil of one of theniu) to San Dingo (Conper, Cleveland) : var. anguslissimus, an extreme form, with 2-flowered peduncles and very narrow linear-lanceolnte sngittate leaves, Santa Barbara, Nivitall. The opno=

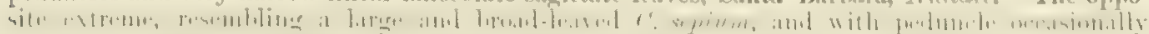
3-flowered, is from (fuadaluno Island, off Lower California, Dr. Palmer. The stigmas are linear: the style in nge inclines to split in two.

C. SEPIT, Linn, whith oecurs northenst of Californin, and extends ronnel the worlh, is distinguished by its ovate or oblong stigmas, and only one-flowered peduneles have heen observed.

3. C. Californicus, Choisy. Mimutrly and mother densely puheseent, or somewhat glabrate, a span or less high and subeaulescent, or prulucing truiling stems a span to a font long: lenves mostly olutuse, from ovate or obovato and olselurely has-

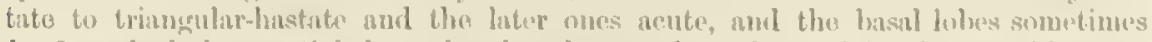
1-2-toothed, longepetioled: perduncles shorter than the petiole: brats oblung or oval, not unlike the outer sepals and equalling them, or mither shorter: corolla 
white, cream-color, or flesh-color, $1 \frac{1}{2}$ to 2 inches long. - DC. Prodr. ix. 405. Calystegia subacaulis, Hook. \& Arn. Bot. Beechey, 363.

Hills and banks, Marin Co. to San Luis Obispo. Blade of the leaf from half an inch to an inch or more in length : peduncles 1 to 3 inches long.

4. C. villosus, Gray. Densely and softly white-tomentose throughout: stems a span to 2 feet long, trailing or feebly twining: leaves from reniform-hastate to sagittate, the upper acuminate, mostly longer than the petiole; the basal lobes often angulate-1-2-toothed : peduncles mostly shorter than the petiole: bracts oval or ovate, as long as the calyx : corolla cream-color, an inch long. - Proc. Am. Acad. 1. c. Convolvulus (n. sp. ?), Torr. in Pacif. R. Rep. iv. 127. Calystegia villosa, Kellogg, Proc. Calif. Acad. v. 17.

Dry hills, from the Upper Salinas River, Monterey Co., and Tejon, to Plumas and Sierra counties. The silky-villous wool very soft and velvety.

* * No calyx-like bracts, sometimes a pair of leaves close under the flower or a pair of bracts at some distance below it.

5. C. luteolus, Gray. Glabrous or pubescent: stems at length 2 or 3 feet long and twining: leaves triangular-hastate or sagittate, the basal lobes sometimes 2-lubed: pedumcles commonly as long as the leaves, bearing a pair of linear or lanceolate entire foliaceous bracts a little below the flower; a second flower occasionally from the axil of one of them : sepals mostly broad and roundish : corolla pale yellow, an inch or more in length. - Proc. Am. Acad. l. c. Ipomoea sagittifolia, Hook. \& Arn. Bot. Beechey, 151 (?), but the stigmas are linear.

Var. fulcratus, Gray, l. c. More pubescent : a pair of hastate or sagittate small leaves for bracts either below or close to the flower. $-C$. Californicus, Torr. Pacif. R. Rep. iv. 127, not of Choisy.

Hillsides from Lake and Colusa to Alameda connties. Variable in foliage, generally glabrous; the bracts from 1 to 4 lines long. and about the same distance below the calyx. Var. fulcratus, which in aspect sometimes much resembles the less downy forms of the preceding species, comes from the foot-hills of the Sierra Nevada (Sonora, Bigelow) to Fort Tejon (Wallace, Horn), and Cajon Pass (Cooper) : its bracteal leaves commonly half an inch long.

6. C. longipes, Watson. Glabrous throughout, erect and much branched, the filiform branches sometimes twining: leaves small and sparse, rather short-petioled, or the upper sessile, entire, or most of the lower hastate by a pair of oblong or linear divaricate basal lobes: peduncles 1-flowered, 2 to 6 inches long, naked, or with one or two distant small leaves remote from the bractless calyx: corolla yellowish, over an inch long. - Am. Nat, vii. 302.

Owen's Valley or near Fort Tejon, Dr. Horn. Southern Nevada, Lieut. Wiceler.

2. CRESSA, Linn.

Corolla deeply 5-cleft, not plaited; the oblong or ovate lobes more than half the length of the somewhat campanulate tube, lightly convolute in the bud, or with one lobe external. Stamens and the two distinct entire styles exserted. Stigmas capitate. Capsule 2-valved, by abortion commonly one-seeded. - A single species.

1. C. Cretica, Linn. Perennial herb, a span or two high, erect or diffuse, exceedingly branched, silky-villons and hoary : leaves very numerous, small (2 to 4 lines long), almost sessile, mostly ovate-lanceolate or oblong: flowers sessile or shurt-peduncled in the upper axils: corolla 2 or 3 lines long, white, silky-pubescent outside, a little longer than the calyx. - C. Truxillensis, HBK., a name for the American form, which does not much differ from that of Australia (C. australis, $\mathrm{R}$. Brown), but is more silky than that of Europe.

Saline soil, along the whole length of the coast. Also in alkaline soil in valleys of the Monte Diablo Range, Brewor. Extends to Arizona, \&e., and coast of S. America round to S. Brazil. 


\section{CUSCUTA, Tourn. DoDDER.}

(By Dr. George Exgezuaris.)

Calyx 5- (sometimes 4-) cleft or parted. Corolla campanulate or short-tubular, the sprealing limb 5 - t-parted, between convolute and inbricated in the bud, not

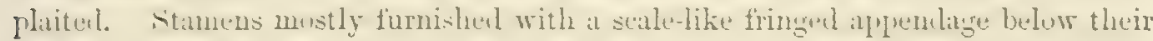

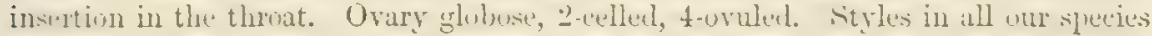

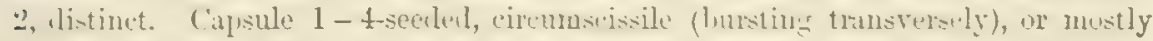
barate. Embryo tiliform, spirilly coileal in the (when ilry) harblteshy albumen, destitute of cotyledons, sometimes furnished at the upper part with a few alternate sales (helenging to the plumule). greminating in the suil, hut mot renting

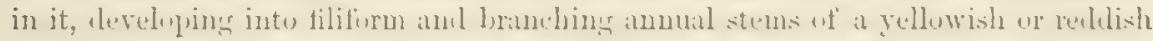
hue, which become parasitic on the bark of herlos or small shrubs, being attached by means of suckers at the whole surface of contact (the base soon dying away), twining extensively, bearing occasional small scales in the place of leaves. Flowers small, cymose or densely clustered, white or whitish, usually produced late in the season. - Engrelm. in Amer. Jour. Sci. 18t2, \& Trans. St. Louis Acad. Sci. (1859) i. 453 .

A wilely distributed genus of nearly 80 species, divided into three subgenera; the first, Eucuseun (with distinct styles and elongated stigmas, and circumscissile capsule), inligenous exclu-

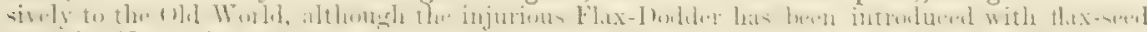

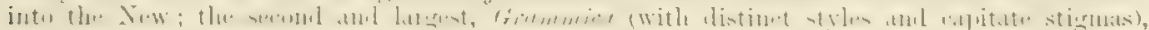
belonging principally to the New; the third and smallest, Monognnce (witls styles united into one), seattered over the whole globe. The Californian sjecies are all of the section Clistogrammica, having capitate stigmas and a baccate or indehiscent capsule. The following species, natives of Arizona or Utah, are not unlikely to reach California :-

C. TExurf Lora, Engelm. and C. oBTUsiflora, HBK., both with closed or baccate capsule :

C. applaxata, Engelm., C. odoxtolepis, Engelm., and C. unbeliata, HBK., with capsule opening regularly round the base.

\section{* Capsule degressed-globose.}

1. C. arvensis, Beyrich. Stems capillary: flowers small (about a line long), in small umbel-like cymes, pechicellate : tube of the broad-campanulate corolla included in tho broally lobed calyx, as lung as or rather shorter than its ovatelanceolate inflexed-pointed lobes: seales large, broally oval, deeply fringed: styles shorter than the largo depressed ovary: capsulo depressed-globose, girt at the bise by the persistent corolla : seeds 4. - Engelm. in Gray, Man. ed. 2, 336, \& ed. 5,378 .

Long Palley, Mendocino Co., Ecllogg. Not rare from the Midhlle Atlantic States to Texis, but thits far found only once in Califormia.

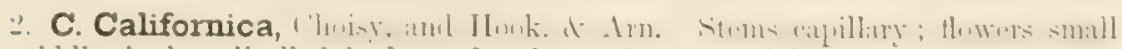
or midlle-sized, predicelled in loose few-flowered cymes: lobes of the enlyx acuto: lubes of the corolla lanceolate-subulate, as long as or longer than the shallow campanulate tubo: filaments mostly as long as the linenr-oblong anthers: scales none, or sometimes indicated by rulimentary inverted arches near the base of the tube: ovary small, mostly tepressed, with slender styles; capsule depressed. - DC: Produ. ix. 457. - The extreme forms are:

Var. breviflora, Engrelm. Flowers scarcely more than a line long: calyx-lohes acuminate, eyualling or surpassing the tube of the corolla: filaments aml anthers short: style's as long as the ovary : corolla withering at base of or around the $2-4$ -

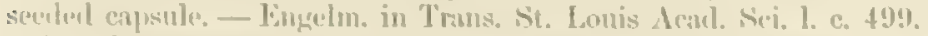

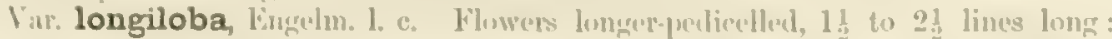
calyx-lobes short, or sometimes long and acumimote and even recurved at tip: lobes 
of the corolla slender, longer than the tube or even twice as Iong: filaments and anthers more slender: styles much longer than the ovary : capsule mostly 1 -seeded and enveloped by the corolla.

Not rare through the western part of the State. The shorter-flowered variety from the coast at Monterey (Hartweg) to Clear Lake (Torrey), and to the Tuolumne in the Sierra Nevada (Bolander): a low plant, often only a few inches high. The var. longiloba, principally near the coast in the southern part of the State, Santa Barbara to San Diego and into Arizona, in arid localities, on Eriogonum, \&c. These extreme and the numerous intermediate forms are easily recognized by the delicate white sharply-lobed flowers destitute of the substamineal scales: lobes of calyx and corolla never overlapping.

\section{* Capsule more or less conical or pointed.}

3. C. salina, 1l. sp. Engelm. Stems slender : flowers ( $1 \frac{1}{2}$ to $2 \frac{1}{2}$ lines long) pedicelled in loose cymes, shorter and wider than in the next: lobes of the calyx ovate-lanceolate, acute, as long as the similar but mostly broader and overlapping denticulate lobes and as the shallow campanulate tube of the corolla: filaments about as long as the oval anthers: fringed scales mostly shorter than the tube, sometimes incomplete: styles as long as or shorter than the pointed ovary; capsule conical, surrounded (not covered) by the withered corolla, mostly I-seeded.-C C. subinclusa, var. abbreviata, \& C. Californica, var. (?) squamigera, Engelm. 1. c. 499, 500.

Saline marshes, on various Chenopodiaceous plants, especially Salicornia: Bay of San Francisco, C. Wright, Bolander, Kellogg. Also extending to British Columbia (Lyalll), and in the interior to Arizona and Southern Utah. In many respects intermediate between the preeeding and the following species; but distinguished from the former by the presence of infrastamineal scales and the larger flowers; from the latter by the less erowded flowers, with shorter more delicate and open corolla.

4. C. subinclusa, Durand \& Hilgard. Stems rather coarse: flowers sessile or short-pedicelled, at length in large (half-inch or inch thick) clusters, $2 \frac{1}{2}$ to $3 \frac{1}{2}$ or 4 lines long: calyx-lobes ovate-lanceolate, acutish, overlapping, much shorter than the cylindrical at last urn-shaped tube of the corolla: lobes of the corolla much shorter than tube, ovate-lanceolate, acute, minutely crenulate or papillose: anthers oval, nearly sessile: scales narrow, fringed, reaching only to the middle of the tube: slender styles longer than the pointed ovary : capsule conical, capped by the withered corolla: seeds mostly solitary.

The most common Californian species, on shrubs or coarse herbs throughout the State, mostly in the mountains, the coast ranges as well as the Sierra Nevada, but also along the coast. The long and nartow tube of the corolla, only partially covered by the thick and fleshy and usually reddish calyx, readily distinguishes this species.

5. C. decora, Choisy, Engelm. Stems coarse : flowers ( $1 \frac{1}{2}$ to $2 \frac{1}{2}$ lines long) pedicelled in loose clusters: lobes of the fleshy calyx acute, as long as the broadly campanulate tube of the corolla: lobes of the latter as long as its tube, ovate-lanceolate, minutely papillose-crenate, spreading and with acute inflexed tips: scales large, broadly oval, deeply fringed: capsule pointed, enveloped by the remains of the corolla: seeds about 4.

Near Clear Lake, Bolander; on a Senecio. A variable species of the southern Atlantic States, extending through a large part of America, apparently rare in California. The only specimen seen belongs to the large-flowered form, which often has deep purple anthers and stigmas. Texture of the corolla fleshy, granular-papillose.

6. C. denticulata, Engelm. Stems capillary: flowers small (about a line long), short-pedicelled in small umbel-like clusters: tube of the broadly campanulate corolla included in the rounded-lobed and denticulate calyx, and as long as its round-ovate spreading lobes: anthers oval, on very short filaments: scales reaching to the base of the stamens, denticulate at the rounded tip: styles as long as the pointed ovary: stigmas very small and hardly capitate: capsule covered by the withered corolla, 1-2-seeded. - Parry in Am. Nat. ix. 348.

Southwestern Utah, Parry. To be looked for in adjacent parts of California. 


\section{ORDER LXVII. SOLANACE画.}

Herhs or shruhs (commonly rank-sented), with culurless juice, alternate leaves and no stipules, regular 5 -merous J-antrus thwers on bractless pedicels, the corollit valvate or sumetimes imbricated and usually llaited in the bud, a single style, and a (normally) 2-celled ovary ; the fruit a mant-seceld berry or cansule; the embryo

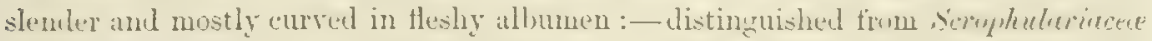
by the recrulan 5 -androus llowers; from the greceding unlers with free calyx and

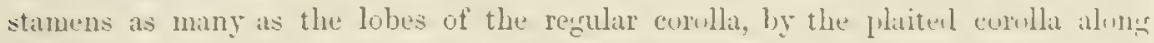
with a single style, plincente jn the axis, numerous seeds, curved embryo, de. Seets campylotropous or amphitropous. Calyx usually persistent. Flowers solitary or cymose, mostly unaccompanied by bracts, and the cymes or their branches oftener secund or scorpioid and imitating racemes, in the manner of Borraginacea, \&c. Loitves commmly uneynally geminate, and peduncle distant from the nearest leat:.

A large and widely diffused order, mainly affecting the warmer parts of the world, but most sparingly represented in ('alifornia. Narcotic and poisonous properties prevail in it, as exemplified by the Deadly Nightshade of Europe (Atrope Belledonna), Henbane (Hyoselyamass), Tobacco, \&ic. Nevertheless it furnishes important esculents, such as the Tomato and Egg-plant, condiments, such as Capsicum, and one staple article of farinaceous food, the Potato.

The five natural tribes which the order comprises being 1ather difficult to characterize, and the

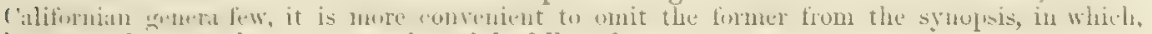
however, the natural armagement is mainly followed.

Nicasdra Physalordes, Grertner, sometimes called Apple of Peru, a widely dispersed weel of waste grounds and gardens, is very likely to be introduced, but has not yet been met with. It is like a tall Physalis, but larger-flowered, very smooth, and with a five-celled berry, which dries as it ripens and bursts irregularly like a capsule.

1. Fruit a berry, from an ovary of 2 or rarely (except in cultivated plants) of 3 or more cells : embryo coiled or curved.

* Corolla rotate or barely campanulate, valvate and mostly induplicate or plaited in the bud.

1. Lycopersicum. Anthers united into a cone; the cells opening lengthwise down the inside: filaments very short. Leaves pinnately compound, the leaflets stalked. Berry naked.

2. Solanum. Anthers distinct, but generally conniving, longer than the filaments; their cells opening at the apex by a hole or slit, but often also longitudinally.

3. Capsicum. Anthers distinct, short, not longer than the lilament, the cells opening length. wise, without a terminal hole. Calyx herbaceous, girting only the base of the berry, and with little or no border or lobes.

4. Chamzsaracha. Anthers distinet und not connivent, short, on slender filuments, opening lengthwise. Calyx enlarging closo around but not completely enclosing the berry, not reticulate-veiny.

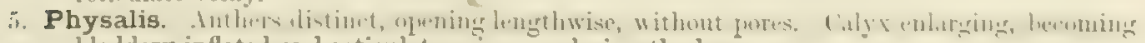
bladdery-inflated and reticulate-veiny, enclosing the berry.

- Corolla tubular or funnelform, imhricated or indupliente-plaited in the bud.

6. Oryctes. Herbaceous. Calyx 5-parted. Corolla 5-toothed.

7. Lycium. Diffusely branched shrubs, commonly spiny, with entire leaves. Calyx 3-5. twothed or eleft. Corolla 4-5-lobed. Berry minutely stalked in the calyx.

1I. Fruit a capsule, but sometimes a fleshy one : corolla plaited in the bud.

- Calyx deciduous, lesving a short base under the fruit : seeds largo: embryo curved.

8. Datura. Capsule dry, or somewhat succulent but at length bursting, prickly, 2-celled, and

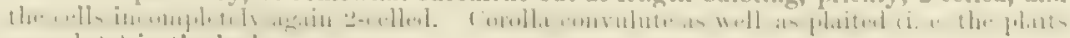
convoluter in the bud.

- C'alyx persistent : secls small : embryo shorter, straightish.

9. Nicotiana. Capsule smonth, with 2 (mely more) simple sells, splitting at the npex into as many valves, and these 2 -cleft, mostly enclosed in the tulne of tho toothed or lober calyx.

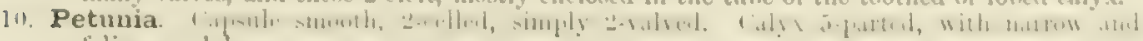
folisceous lobe's, 


\section{LYCOPERSICUM, Tourn. TOMATO.}

Flowers as in Solonum, except that the anthers (on very short filaments) are united by their contiguous edges into a cone, and their cells open longitudinally down the whole length of the inner face, not by a hole at the apex. - Herbs of the warmer part of America, one species widely dispersed in cultivation; the small racemose flowers on peduncles which soon become lateral or opposite a leaf : pedicels articnlated and reflexed in fruit.

1. I. esculentum, Mill. (Томато.) Annual, widely spreading, rank-scented, hirsute and glandular, at least the branches: leaves interruptedly once or twice pinnate; the larger leaflets cut and toothed, the interposed small oues rounder and often entire: corolla yellow : berry edible. - Solanum Lycopersicum, Linn.

The common Tomato probably has run wild in cultivated and waste grounds in the southern part of the State. Var. CErasiforme (Cherry Tomato) is seemingly native along the southern borders of the United States as far west as Arizona, probably reaching California. The parts of the flower, normally five, and two in the ovary, are often increased in the cultivated plant, and very commonly two or more flowers are blended into one.

\section{SOLANUM, Tourn. Nightshade. Potato.}

Calyx and rotate corolla 5-parted or eleft (or sometimes 4-10-parted or lobed); the lobes. of the latter valvate in the bud, with margins usually turned inwards more or less, or the sinuses plaited. Filaments short: anthers distinct, although often conniving; the cells with a hole or chink at the apex, in many species also opening lengthwise. Style elongated : stigma mostly entire. Ovary with 2 cells, or rarely more, becoming a berry. Seeds many, flat. - Herbs, or sometimes shrubby plants, of various aspect and foliage.

One of the largest genera known, chiefly indigenous to warm climates, a moderate number in temperate regions, but exceedingly few in the Pacific United States. S. Tuberustam is the common Potato. S. Melongena, the Aubergine or Egg-plant. S. Hetcrodoxum, Dumal, and S. Rostratum, Dunal, peculiar species extending from Mexico well into the United States east of the Rocky Mountains (and remarkable for prickliness, for somewhat irregular corolla, one anther much larger and longer than the rest, and the beury completely and closely invested by the prickly calyx), might be expected to reach California by way of Arizona; but they have not been met with here.

* Never prickly : anthers not tapering upward, disposed to dehisce from top to bottom.

+ Corolla (mostly white) deeply 5-cleft or 5-parted, small.

1. S. nigrum, Linn. Annual, or sometimes becoming woody at base and more enduring, widely branching, green and almost glabrous: leaves more or less ovate and sinttate-toothed, sometimes merely repand or nearly entire, acute or acuminate: flowers in small and pedunculate lateral umbellate clusters: berries small, black when ripe, or rarely reddish. (The common Black Nightshade.)

Var. Douglasii, Gray, Varying from almost glabrous to hoary-puberulent, and from one to several feet high: leaves apt to be coarsely toothed, and the flowers larger (sometimes half an inch or more in diameter) : fruiting calyx erect. - $S$. Douglasii, Dunal in DC. Prodr. xiii. 49 .

Waste and cultivated grounds and along streams towards the coast; mainly or wholly the var. Douglasiz, which is seemingly indigenous, sometimes very large, and "shrubby at base." S. umbelliferum, var. trachycladon, Torr. in Pacif. R. Rep. vii. 12, from Santa Iñez, is of this form. Southward it runs into the val. nodiforum, which inclines to have entire leaves and glabrous filaments, and the fruiting calyx reflexed. In multifarions forms this weed occurs in almost every country. At least fifty of the species admitted by Dunal in De Candolle's Prodromus are by other author's reduced to this. The berries have the reputation of being poisonous, but in some parts of the world they are safely eaten. 
2. S. triquetrum, rav. Peremial and more or less wondy at base, glahrous: the slender and triangular branches disposed to clinub or to be flexuous: leares deltoid-cordate or hastate, sometimes 3-5-lobed, the margins entire; the middle lobe varying to lanceolate or even linear: umbellate pedunculate clusters rather fewflowered; berry red. Cav. Ic. iii. 30, t. 259. S. Lindheimerianum, Scheele in Linnæa, xxi. 766.

From Texas westward along the southern frontier; given on the authority of a sterile specimen said to be Californian, but more likely from Arizona.

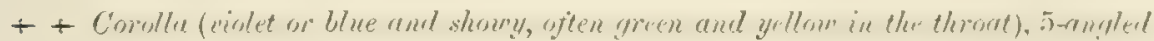
or very moderately 5-lobed, very flat: peduncles short, terminal or becoming lateral, bearing an open forking or umbellate cyme; a nodose or cupshaped enlurgement under the articulation at the base of each slender pedicel: berries purple, the base covered by the somewhat enlarged calyx.

3. S. Xanti, (iray. Perennial, nearly herbacenus except the hatse, fuhlesecut

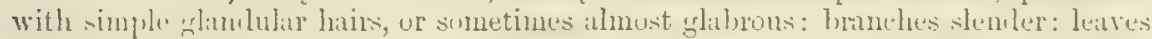
thimish, ovate or ovate-oblong, entire or repand, or rarely auriculate-lobed at the usually obtuse or rounded or subcordate base: corolla from three fourths to a full inch in dimeter. - Proc. Am. Acad. xi. 90.

Var. Wallacei, Gray, 1. c. Leaves and flowers much larger; the former 3 or 4 inches long and the corolla fully an inch and a lialf in diameter: inflorescence and branches villous with long and viscid many-jointed hairs.

Common through the southern part of the State, and north to Santa Barbara; also on the borders of Nerada, and in Sierra Co. Has heen confounded with the following, and is almost as polymorphous; is known by the pubescence of simple and jointed hairs, conmouly tipped with a gland. Named for Xanlus de Vesey, one of the first to collect it. Var. Wallacei, Catalina Islind, a striking form.

4. S. umbelliferum, Eschscholtz. Perennial from a shruhby hase, minutely

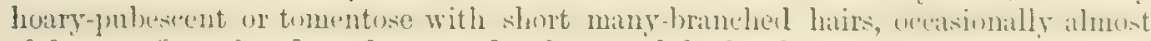
glabrous: flowering branches mostly short and leafy: lenves obovate and oblong and commonly obtuse, sometimes ovate and acute, entire (half an inch to an inch or two in length); the upper acute or narrowed, the lower and larger ones rounded at base: flowers few or several in unbel-like clusters: corolla about three fourths of an inch in diameter. - S. Culifornicum \& $S$. genistoides, Dunal in DC. ; the latter a starved and twiggry form with snall leaves.

Common from the foot-hills of the Sierm Nevada to the const, and south to San Diego Co. A very polymorphous species, prolucing through the season its handsome vinlet-blue (or rarely white) llowers.

* Sometimes prickly: anthers longer, tapering upwards, opening omly at the tip.

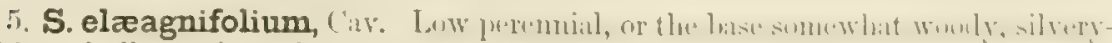
whitened all over by a denso and rather scurfy pubescence conposed of many-myed stellate hairs: prickles straight and small on the branches and midrihs, but sometimes wanting: leaves lanceolate or oblong, sinuate or entire: perluncles at first terminal, few-flowered: calyx 5-angled and with slender Jobes: corulla violet, moderately 5-lobed, an inch or less in diameter: ovary tumentuse : berry yellowish, at length nearly black.

A Alexican and extra-tropieal South Ameriean species, extending from Texas to Arizonn, and in a shumbly form (S. Jindsinnum, Benth.) to Lower ('alifurnin: probubly in the souchesstern part of the state.

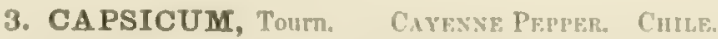

Calyx short, minutely textherl or truncate, little enlarging, firting the luse of tho acrid and sometimes juinhes berry. Corulla 5-6-0let. Anthers shorter or not longer than the filament, whlung, blunt; the cells onnening lengthwise. Other- 
wise as Solanum. - Herbs or shrubs, natives of the warm parts of America, green and mostly glabrous; with many-times forking stems, ovate and entire or barely repand thinnish leaves, and small flowers on solitary or cymose-clustered pedicels. Corolla mostly white and the anthers bluish.

Capsicem Annoum, Linn., is the Cayenne Pepper, or Chile Colorado of the Mexicans, with large and long pod-like fruit, of very warm and opungent acridity.

1. C. baccatum, Linn. Shrubby, a foot or two high, with slender diverging branches: leaves ovate, slender-petioled: berry globular, as large as a pea, on a slender erect peduncle.

Wild along the Mexican frontier, and in Arizona, probably within the borders of the State, the form called C. microphyllum by Dunal in DC. Prodr.

\section{CHAM ÆSARACHA, Gray.}

Calyx 5-lobed, enlarging after flowering, but remaining rather herbaceous, not reticulated, incompletely investing the rather dry-globose berry. Corolla rotate, 5-angulate. Anthers short, on slender (not at all counivent) filaments; the cells opening lengthwise throughout. - Low perennial (Texano-Californian) herbs; with the corolla of Saracha and a calyx between that of Solanum and Physalis, with rather narrow leaves tapering into margined petioles, and in their axils filiform solitary or sometimes geminate pedicels, which are mostly refracted or recurved in fruit. Corolla white, yellowish, or tinged with violet. - Benth. \& Hook. Gen. PI. ii. 891. Saracha § Chamaesaracha, Gray, Proc. Am. Acad. x. 62.

1. C. Coronopus, Gray. Diffusely much branched, green, almust glabrous, or beset with some short and roughish hairs, a span high; leaves lanceolate or linear with cuneate-attenuate base, varying from almost entire to laciniate-pinnatifid: calyx somewhat scurfy-hirsute with 2-forked hairs: corolla yellowish, half an inch or less in diameter: berry nearly white: seeds thickish, rugose and favose. - Solanum Coronopus, Dunal in DC. Prodr. xiii. 64. Withania (?) Coronopus, Torr. Bot. Mex. Bound. 155. Saracha (Chamasaracha) Coronopus, Gray, 1. c. Saracha acutifolia, Miers in Ann. \& Mag. Nat. Hist. 1849? (but the flowers too small).

Arizona (Palmer) and S. Utah (Capt. Bishop) to Texas and Colorado. Not met with in California, unless it be Saracha acutifolia of Miers, and it is probable Coulter's specimen on which that was founded came from Arizona. The more eastern and broader-leaved specimens are near to $C$. sordida, which is pubescent and glandular.

2. C. nana, Gray. Many-stemmed from slender creeping rootstocks, barely a span high, cinereous-puberulent, comparatively large-leaved: leaves crowded, oblong-ovate and ovate-lanceolate, entire or undulate (the blade an inch or two long, and at base contracted into a petiole of equal length): peduncles mostly shorter than the petiole: corolla white or bluish, 7 to 9 lines in diameter: fruiting calyx hemispherical and with distant subulate teeth: seeds flat, smoothish. - Saracha nana, Gray, 1. c.

Eastern part of the Sierra Nevada in Nevada and Sierra counties, Kellogy or Bolander, Lemmon. Connects with Physalis through $P$. grandiflora.

\section{PHYSALIS, Linn. Ground Cherry.}

Calyx 5-lobed, enlarging after flowering and becoming membranaceous and veiny, forming a loose bladdery envelope enclosing the 2-celled juicy berry. Corolla rotate or commonly with an open-campanulate base, 5-angulate or obscurely lobed. Anthers oblong or linear, not conmivent, on short or slender filaments; the cells opening lengthwise throughout. - Herbs, widely distributed over the world, mainly in 


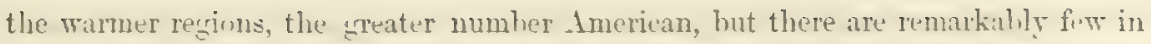
Oremon and ('alifimia, and thuse only on the horders. The fruit of several slecies is edible when cooked, but of little importance.

\$1. Corolla violet or purple, open-rotate: seeds thickish and obscurely tuberculaterugose: calyx, pedicels, and all the young parts scurfy-granuliferous or mealy, oitherwise wholly glabrous. - ChavepHrsalis, Gray, Proc. Am. Acad. $x, 62$.

1. P. lobata, Torr. Low, diffusely branched or at length spreading and decumbent from a thickish perennial root: leaves oblong-spatulate or obovate, vary-

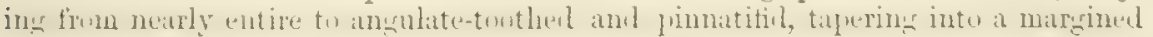
petiole: pedicels usually in pairs, longer than the Hower: corolla from half to two thirds of an inch wide: fruiting calyx globular-inflated, about half an inch long.Torr. in Ann. Lyc. Y. Y. ii. 226. Solanum luteoliftorem, Dunal in DC. 1. c. Saracha acutifolia, Miers?

Dry plains, from Texas to Arizona; probably reaching the southeastern border of California.

\$2. Corolla white, greenish, or yellow, mostly rotate-campanulate: seeds smootlt and even, minutely punctate: no scurf or mealiness, and leaves never truly pinnatifid. - True Prysalis.

* Root perennial suthers yellow: corolla not spotted or dark in the centre: leaves thickish.

2. P. crassifolia, Iunth. Iale ur minutely hearr with an extremely short and

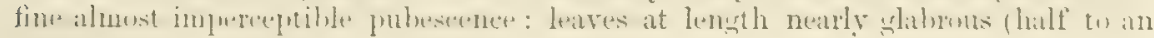
inch and a half long), ovate or round-cordate, repandly few-toothed or almost entire: pedicels long and sleuder : corolla apparently crean-color, half an inch in diameter: fruiting calyx an inch long, 5-angled. - Bot. Sulph. 40. P. cardiophylla, Torr. Bot. Mex. Bound. 153, a form with mostly round-cordate leaves.

Along the Rio (Colorado (Bigelow, \&c.), east of San Bernardino (Parry), and in Lower California.

P. rlabra, Benth. 1. c., is a diffuse and small-leaved species, ns yet known only in Lower Califomia, well marked by being perfectly glabrons, even to the calyx, the leaves ovate-lanceolato and approaching hastate; otherwise nearly like P. crassifolia.

* * Root annual: anthers tinged with blue or violet: corolla greenish-yellow with a dark centre: leaves thin or soft.

3. P. aquata, Jacq. Green and almost glabrous, a foot or two high, widely sprealing: leaves ovate or oblong, sinuate-toothed or repand: pedicels very short:

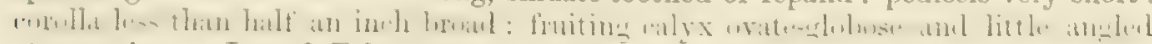
at maturity. - Jace. f. Eclog. 2, t. 137 ; Gray, 1. c.

This is in Coulfer's Californian collection, probably from the most sonthern part of the State, as it is a dexiern species.

4. P. pubescens, Linn. A foot or two high, widcly spreading, villous or

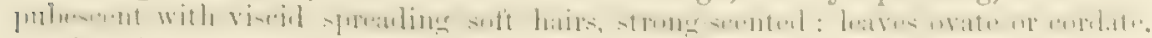
varying frow entire to angulate-tonthed, mther tender, ahout 2 inches long: pedi-

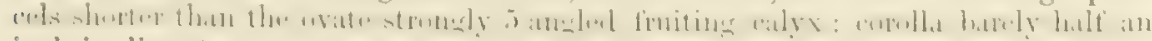
inch in liameter.

Fort Yuma, on the Rio Colomdo (Thomas, \&e.), thence eastward to the Atlantic States, where it is common.

\section{ORYCTES, Wratson.}

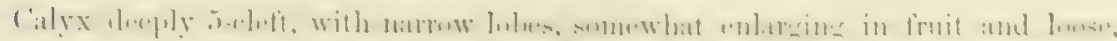

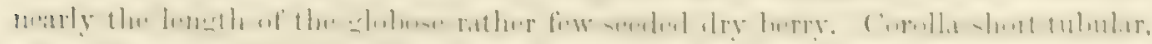

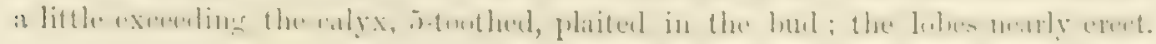


Stamens somewhat unequal in length: filaments slender, included: anthers very short. Seeds, habit, \&c., of Physalis and the related genera. - A single species.

1. O. Nevadensis, Watson, Annual herb, a span high, with some rather scurfy viscid pubescence: leaves ovate, oblong, or lanceolate, with undulate margins, the base tapering into a petiole: pedicels 2 to 4 in an axillary sessile umbel: corolla blue or purplish, 3 lines long. - Bot. King Exp. 274, t. 18, fig. 5-10.

Eastern foot-hills of the Virginia Mountains, Nevada, in stony barren soil under Artemisic bushes, near the Big Bend of the Truekee, Watson. Not again met with as yet. Mature fruit is desired. Evidently the seed figured was immature and the embryo not fully grown.

\section{LYCIUM, Lim.}

Calyx 4-5-toothed or more deeply cleft, persistent at the base of the berry. Corolla varying from short-funnelform to tubular, the 4 or 5 lobes commonly imbricated in the bud, the sinuses often plaited. Filaments filiform, included or exserted: anthers short, fixed by the middle; the cells opening lengthwise. Ovary 2-celled, slightly stalked in the calyx: style filiform: stigma capitate. Berry manyseeded. Seeds roundish : embryo coiled or curved, slender. - Shrubs, mostly spiny, diffusely much branched; with entire alternate leaves, commonly fascicled in the axils or on short axillary spurs, in our species small and spatulate or sornewhat linear, nearly veinless. Pedicels solitary or fascicled, mostly from the leafy fascicles. Flowers white or purplish. Berries small, usually red, sometimes white.

A large genus, dispersed over the warm-temperate and subtropical zones, one species, native of the Levant, \&ce, commonly planted for ornament in the Atlantic United States (under the name of Matrimony Vine), but it is by no means showy ; several are indigenous to the Mexican frontier and its vicinity. Of these L. PALLIDUM, Miers, the largest flowered of all, with corolla nearly an inch long, L. Patmeri, Gray, from W. Sonora, Mexico, with long callyx-lobes, L. PAPVIFLORUM, Gray, from S. Arizona, with corolla only one sixth of an inch long, and two littleknown species of Lower California, viz. L. BREvipes, Benth., with 5-merous slender flowers and acicular spines, and L. RichII, Gray, may hereafter be found within the State. But the following are all that are now known within or near its borders. For an account of the North American species, see Proc. Am. Acad. vi. 45, vii. 49, \& viii. 292.

\section{* Lobes of the calyx foliaceous, as long as the tube.}

1. I. Cooperi, Gray. Minutely pubescent, with stout branches and some very short spines: leaves spatulate, apparently somewhat viscid, half an inch or more long: pedicels about the length of the cylindraceous or when old campanulate calyx, both somewhat hirsute; lobes of the latter oblong and not longer than the tube: corolla apparently white, narrow-funnelform, half an inch long, its ovate lobes short : filaments hairy at base: anthers oval, mucronulate - Proc. Am. Acad. vii. 388 .

San Bernardino Co, on the eastern slope of Providence Motnntains, Cooper.

2. I. macrodon, Gray. Puberulent, becoming glabrate: leaves spatulate-oblanceolate, only 2 to 4 lines long: pedicels very short: calyx minutely viscid; its lobes narrowly linear and twice the length of the short campanulate tube, half the length of the narrow corolla: filaments slightly hairy at base: anthers ovaloblong. - Proc. 1. c. vi. 46.

California or Nevada, Fremont (coll. 1849 ; not otherwise known).

* Calyx with 4 or 5 short teeth, or sometimes irregularly 2-3-cleft.

* Corolla very small and short.

3. I. Californicum, Nutt. in herb. Glabrous, very much branched, 2 to 4 feet high: branchlets spinescent: leaves thick and fleshy, very small, in the fascicles 
a line or two long, from oval or obovate to oblong or spatulate, or on vigorous shoots 3 lines long and almost linear: flowers nearly sessile or on pedicels of one or two lines in length: tube of the white corolla included in the campanulate 4 -toothed calyx, its 4 oval rotately spreading lobes hardly a line long.

Near San Diego, on clay-hill slopes, Nullall (without flowers), Cooper, Clercland. The flowers barely 2 lines long, on slender short pedicels in Dr. Cooper's specimen, but nently sessile in those of Mr. Cleveland; the plants otherwise similar. Foliuge apparently as tleshy as in $L$. Carolinienum.

\section{++ Corolla a third to half an inch in length.}

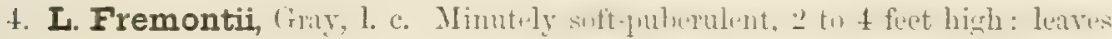
spatulate, 4 to 9 lines long: pedicels not longer than the oblong-campanulate or cylindraceous ealyx: corolla white with some purplish, tubular, 4 to 6 lines long, 5-lobed, the lobes ovate and very short: filaments nearly naked.

California or Nevada? Fremont, $18 \pm 9$ (the station unknown). There is a var. (?) Bigelovii, Gray, with shorter flowers, in Arizona.

5. L. Torreyi, Gray, 1. c. Glabrous, 3 to 8 feet high: leaves nearly spatulate or oblanceolate, 6 to 14 lines long: pedicels usually as long as the c:lyx (2 lines long): corolla white or tinged with purple, 5 or 6 lines long, tubular-funnelform grailually eularging from base to summit, with 4 or 5 short and broad sprealing lobes, the edges of these minutely tomentose: filaments woolly at base: berries red, "not edible." - Parry in Am. Nat. ix. 348.

Southeastern borders of the State, lower part of the Rio Colorado to S. Utah, on low saline flats, Thomas, Cooper, Purry, sec. Extends eastward to the borders of Texas.

6. I. Andersonii, Gray. Resembles the preceding; but is lower, 2 to 4 fect high, smaller-leaved, very abundantly flowered; the white corolla narrower and more tubular, 5 lines long, its limb only 2 or 3 lines wide, and its short rounded lobes with naked edges: pedicels and ealyx only a line long: berries bright rel, or amber-colored, "ripening a month earlier than those of the preceding, edible." Proc. Am. Acad. vii. 388 ; Watson, Bot. King Exp. 275 ; Parry, 1. c.

Rocky hills in the desert region, borders of S. Nevada (Auderson) to Utah (Wrtson, Parry); not certuinly known within the limits of the State. - Var. Wrightii, Gray, is a more leafy and sparsely flowered form, with smaller flowers, collected by C. Wright and E. Palmer in Arizona, and perhaps to bo found on the Kio Colorado.

\section{DATURA, Linn. Stramoxium. Thoræ-Apple.}

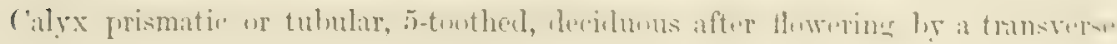
separation near the base, which persists as a circular plate under the fruit. Corollin funnelform, with an ample expanded border which is strongly 5-plaited and the plaits convolute in the bud. Stamens mostly included : filaments long and filiform: anthers opening lengthwise. Style long: stigma 2-lipped. Capsule thickish, prickly or muricate all over, with 2 proper cells, each diviled more or less by a firlse partition which bears the two brond transverse placentae acmss its midille. Seeds very numerous, rather lnrge, reniform. Embryo sleniler and coiled. Plants (our species coarso herbs), of rank odor and narcotic-poisonnns qualities; with ovate petioled leaves, and solitary mostly large flowers in the forks of thro stem, on short peduncles, produced through the season. Corolla commonly white or tinged with violet, sometimes fingrant.

('hiefly natives of tropienl Amerien, but now wiklely diffused over the world. There is $n$ seetion, Bunpmasia, consisting of soft-wooled arharescent or shrubly plants, with penelulms flowers of

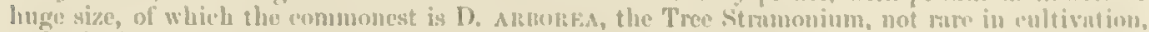
ant which may stuml the winter withont protection in tho southern part of the State, - Onr wild or spontancous species are herbs, with the flower eret. 
\$ 1. Calyx-tube prismatic, acutely 5-angled: border of the corolla with 5 acute teeth: capsule dry and of firm texture, 4-valved from the top: seeds with a thick and rough dark-colored coat: root annual.

$$
\text { * Capsule erect as well as the flower. }
$$

1. D. Stramonium, Linn. (Common Stramonium.) Smooth, green, 2 or 3 feet high: leaves sinuately and laciniately angled and toothed: corolla white, about 3 inches long: capsule thickly beset with short and stout prickles, the lower ones commonly shorter than the upper.

Waste grounds, especially near towns, sparingly naturalized, probably originally from Asia.

2. D. Tatula, Linn. Like the preceding, except that the stem is reduishpurple, the corolla pale violet, and the prickles on the fruit about equal.

Not yet recorded from California, but probably introduced in some places, from Tropical America.

3. D. quercifolia, HBK. Green, and the young herbage commonly a little pubescent: leaves sparingly but deeply sinnate-pinuatifid: corolla nearly as in the foregoing: capsule armed with unequal and flattened prickles, some of them large and strong, even an inch long.

Along the Rio Colorado, especially in Arizona; perhaps indigenous, as it is a Mexican species.

$$
\text { * Capsule nodding on a recurved peduncle. }
$$

4. D. discolor, Bernh. Rather low, pubescent: leaves laciniately or sinuately toothed: corolla 2 or 3 inches long, white with a purple tinge: capsule globose, pubescent, armed with stout large prickles. - Gray, Proc. An. Acad. v. 165. D. Thomasii, Torr. in Pacif. R. Rep. v. 362, \& Bot. Mex. Bound. 155.

- Along the Rio Colorado, at Fort Yuma, \&e.; thence into Mexico, from which it is likely to have been introduced : yet it may be indigenous.

\$2. Calyx tubular and nearly cylindrical: capsule nodding on the recurved short peduncle, globose, succulent, bursting from the apex somewhat irregularly at maturity: seeds flatter, with a softer and pale smoothish coat.

5. D. meteloides, DC. Perennial, pale, being coated with a very minute and soft whitish pubescence, from one to 4 feet high: leaves mostly only repand or entire: calyx 3 and corolla 7 or 8 inches long; the latter white or suffused with violet, the widely expanded border with 5 (not 10) slender-subulate conspicuons teeth: capsule 2 inches in diameter, thickly beset with short and weak equal prickles: seeds bordered by a narrow and uniform cord-like margin. - Dun. in DC. Prodr. xiii. 544 (with erroneous deser.); Gray in Bot. Mex. Bound. 154. D. Metel, var. quinquecuspida, Torr. in Pacif. R. Rep. vii. 18. D. Wrightii of the gardens, \& Regel, Gartenfl. viii. t. 260.

Southern part of the State, extending northward as far as to Santa Barbara on the sea-shore, and eastward to Texas, and in adjacent parts of Mexico. Now common and very ornamental in cultivation.

\section{NICOTIANA, Toum. Tовассо.}

Calyx campanulate or oblong, 5-toothed or moderately lobed, persistent, closely investing the capsule. Corolla various, but commonly funnelform or salverform; the limb plaited and the plaits поте or less convolute in the bud. Stamens mostly included: anthers short, opening lengthwise. Style long: stigna capitate or depressed, somewhat 2-lobed. Capsule smooth, with 2 (rarely more) cells, and very numerous seeds on broad placentæ borne in the axis, 2-valved from the top, and the valves themselves soon 2-cleft, thus becoming as it were 4 -valved. Seeds very numerous and small, oval or roundish, somewhat pitted. Embryo straightish. - 
Herhs (or one nr two snft-woody plants), nenrly all of American origin, hearyscented, viscil-pubesent, nareotic-peisonous, with mostly entire leaves and pauiculate or racemose flowers, some of them rather showy. Our species all annuals.

\$ 1. Flowers pink-red (sometimes in cultivation white), open through the day: capsule septicillal, dividing the two placentee as well as the partition. - TABscuM.

1. N. Tabacum, Linn, (Comsox Tobsccu.) Tall, lirge-leaved, with a panite of short-penticelled Howers: curullia 2 inches lons, funnelform with a wide or intlated throat, and spreading acute or acuminate lobes.

Vir. undulata, semltner. Leaves very ling and narrumly lincerlate, umlulate helow the milille, grawlually and much tapering to the slender apex: curulla-lubes also much acuminate. $-N$. caudata, Nutt. Pl. Gamb. 181?

The common Tobacco, of Central or South American origin, is merely cultivated in Califoruin. This may have been the case also with Nuttall's $N$. caudala, from Mlonterey; which appears to be the same as the Yaqui Tobacco, found in a cultivated state in Arizona or Sonora, by Dr. Palmer. It is probably the $N$. lancifolia, Willd., and. $N$. Ybarrensis, HBK.

\$2. Flowers white, greenish, or yellowish: capsule septifragal, leaving the thin partition with the undivided placental column in the centre.

* Corolla more or less constricted at the orifice, dull-colored, open through the day; the labes short and rounded.

2. N. rustica, Linn. Rather stout, a foot or two high : leaves petioled, ovate, or the lower sumewliat cordate, these oftener a foot long: panicle thyrsiform: calyx broad, and with short and broad teeth, shorter than the globular at first only 2-valved capsule: corolla short and broad, less than an inch long, harlly thrice the length of the calyx, oblong-inflated from the short narrow base; the bruad lubes reticulate-veiny.

Waste grounds, in California, as well as eastward and northward, probably escaped from aboriginal cultivation: the native country uncertain.

3. N. trigonophylla, Dunal. Thather hencher, one to three feet high: liars sessile, oblong, 2 to 4 inches long, or the upper smaller; the lower obovate, with narrow tapering auriculate and partly clasping, the upper with bruader aud more clasping base : raceme at length loose and virgate, with bracts small or sometimes wanting; perlicels rather unilateral: calyx with subulate-lanceolate teeth, about equalling the ovate 4-valved capsule: curolla greenish-white, less than an inch long,

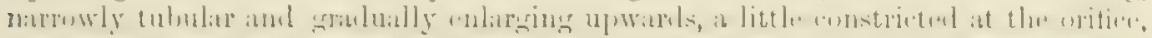

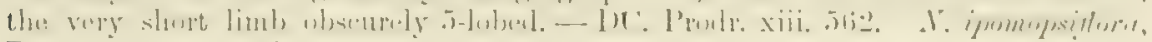
Dunnl, 1. c. 559 (Mogino \& Sesse, Ic. Mex. Ined. t. 909); Gray, Proc. Am. A caul. v. 166. N. multiftore, Torr. in Pacif. R. Rep. v. 302.

Sonthern purt of the State; "Monterey" (Couller, but probahly from farther south), and on

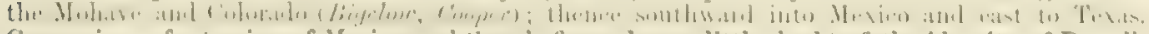
Comparison of a tracing of MIowino and sesse's figure leaves little doubt of the identity of Dunal's two species : but the name here adopted was founted on specimens, the other upon a figure only.

* * Corolla with open more or less diluted orifice to the long tube, white, somelimes with a greenish or bluish tinge, expanding at sunset, closed by day except in very cloudy weather.

4. N. attenuata, Torr. A foot or two high: lenves all petioled; the malical oval or oblong; the lower cauline ovate-lanceolate or narrower; the upluer muruwly lanceulate or linear and long-tapering to the point: flowers loosely paniched, shortpelicelled: upper bracts minnte or none: calyx with triangular-laneeclate teeth much shorter than the tube aml mather shorter than the 4-valved capsule: comollit fully an inch long, narrow-salverform, with obtusely 5-lobed border a third to half an inch in diameter. - Watson, Bot. King Exp. 276, t. 27. 
Dry plains and hills, Monterey Co. to the Mohave, and along the eastern borders of the State iu Nevada ; east to Colorado.

5. N. Bigelovii, Watson. Larger and stouter than the preceding: leaves oblong or oblong-lanceolate ( 4 to 6 inches long, or the nppermost smaller), only the lower ones petioled; some of the upper often with broader and partly clasping base: Howers scattered: teeth of the calyx linear-lanceolate and surpassing the ovate 4-valved capsule: corolla nearly salverform, with tube an inch and a half long, and a 5-cleft border of an inch or more in diameter, its lobes triangular and acute. Bot. King Exp. 1. c. t. 27. N. plumbaginifolia, var. (?) Bigelovii, Torr. in Pacif. R. Rep. iv. 27.

Not uneommon, from Lake Co. to San Diego, and east to the borders of Nevada. Very riscid and stinking: this and the preceding much used by the Indians.

N. Quadrivalvis, Pursh, and its variety multivalvis ( $N$. multivalvis, Lindl. Bot. Reg. t. 1057), may be expected in the northern part of the State, being not uncommon in Oregon. It may be distinguished from $N$. Bigeloviz by its lower and stouter habit, corolla with proportionally shorter tube, broader obtusely 5-7-lobed border, and globose at length thin-walled capsule of four cells, in the var. multivalvis of several cells; - an anomaly in the genus. No certain iudigenous habitat is known: the plant was cultivated by the aborigines from the Missouri River to the Pacific, and greatly prized for its tobacco. $N$. Bigelovii is perhaps the original of it.

\section{PETUNIA, Juss.}

Calyz 5-parted, persistent; the divisions narrow and foliaceous. Corolla funnelform or somewhat salverform; the 5-lobed limb plaited in the bud. Stamens unequal, included: filaments and tip of the style more or less incurved. Stigma dilated-capitate and 2-lobed. Capsule simply 2-valved (the valves entire), leaving the placenta in the axis. Seeds numerous, small, scrobiculate. Embryo straightish. - Viscid-pubescent herbs, with entire leaves and lateral or at first terminal flowers.

The common Petumias of the gardens are mixtures of two shory species from Buenos Ayres. Very different in appearance is the following.

1. P. parviflora, Juss. A small and insignificant annual, much branched, spreading or nearly prostrate, pubescent: leaves narrow-spatulate, hardly half an inch long, almost sessile: flowers small (about a third of an inch long), very short peduncled: calyx-lobes resembling the leaves: corolla purple with a yellowish tube, its short retuse lobes slightly unequal: capsule ovoid. - Ann. Mus. Par. ii. 216, t. 47. Salpiglossis prostrata, Hook. \& Arn. Bot. Beechey, 123, 376.

Common on the sea-shore from the Bay of Monterey south: also in Texas, and S. America.

\section{ORDER LXVIII. SCROPHULARIACE夿.}

Known by the irregular (more or less bilabiate) corolla with lobes imbricated in the bud, didynamous or diandrous stamens, single style, 2-celled many-few-seeded capsule with the placentre in the axis, and seeds with a small embryo in copious albumen. The exceptions do not concern the Californian flora, except an introduced Mullein, which has 5 perfect stamens. - Flowers perfect. Calyx of 5 or sometimes 4 distinct or variously united sepals. Corolla 4-5-lobed or cleft, commonly bilabiate ( $\frac{2}{3}$, i. e. two lobes forming the upper and three the lower lip), imbricated in the bud, not plaited. Stamens borne on the tube of the corolla, 4 and didynamous or only 2, the fifth and upper stamen and sometimes the two lateral or anterior ones either absent or reduced to sterile filaments or vestiges, rarely (in Terbascum, \&c.) all five present and fertile. Stigma entire, or with two (upper and 
lower) lohes. Ovary 2-cellerl, the plicenta being firmly united in the axis (or in Mimulus § Diplacus little if at all so): ovules very numerous or occasionally few; anatropous or amphitropous. Seeds mostly small. - Herbs, or sometimes shrubs, very rarely trees, destitute of colored juice, with the general inflorescence indeternimate in all genuine members of the order, but when compound the partial inflorescence determinate, $i$. e. the axillary clusters are cymes: in Veronica, dic., indeterminate, i. e. racemes or spikes.

A large and wide-spread family, of over 150 genera, numerously represented in California. Generally bitterish, many inert, some mareotic-poisonous, the common Foxglove (Digitalis) of Europe useful in medicine and ornamental in cultivation, as are species of Pentstemon, Collinsia, Minulus, and others.

I. Upper lip of the corolla covering the lower in the bud.

* Stamens all five present and anther-bearing.

1. Verbascum. Corolla wheel-shaped. Filaments woolly. Leaves alternate.

* * Stamens two pairs with anthers, or one pair in No. 4 : capsule opening by holes or chinks near the apex: corolla personate, gibbous or spurred at base auteriorly : peduncles I-floweréd.

2. Linaria. Corolla strongly bilabiate, spurred at base.

3. Antirrhinum. Corolla only saccate or gibbous at base. Stamens 4.

4. Mohavea. Corolla merely gibbous at base. Fertile stamens 2: anthers confluently 1-celled.

* * * Stamens two pairs with anthers: capsule opening from top to bottom by valves: leaves all opposite or whorled.

+ Stigma small and entire or minutely 2-eleft : calyx 5-parted.

5. Scrophularia. Corolla ereet, short and ventricose, with 5 short lobes; the anterior one reflexed, the others erect: a seale in the throat on the upper side answers to the fifth stamen. Pedineles cymosely several-flowered.

6. Collinsia. Corolla declined, with ventricose tube gibbous posteriorly, bilabiate, the middle lobe of the lower lip folded lengthwise into a sac which encloses the stamens and style : a gland on the base of the corolli answers to the fifth stamen. Peduncles 1-flowered.

7. Tonella. Corolla obscurely if at all bilabiate; the lobes rotntely spreadiug, flat : otherwiso nearly as Collinsice

8. Pentstemon. Corolla more or less bilabiate, open. Sterile filament of the fifth (posterior) stamen long and conspicuous.

++ Stigma dilated, 2-lipped, or a broad disk : peituneles all 1-flowered.

9. Mimulus. Calyx 5-toothed or barely 5-eleft, 5-angled. Cells of the anther contiguous.

10. Stemodia. Calyx deeply 5-parted. Cells of the anther separated, as if stalked.

* * * Stamens only a single pair with anthers : the anterior pair reduced to sterile filaments or somctimes wanting altogether : capsule opening from top to bottom by valves : stigna of 2 1hat lobes: calyx 5-parted: leaves all opposite: peduncles I-flowered.

11. Gratiola. Sterile filaments simple or none. Capsule 4-valved,

12. Hysanthes. Sterile filaments unequanlly 2 -forked, borne high on the throat of the corolla.

II. Lower lip of the corolla covering the upper in the bud.

- Corolla rotato or short-eampanulnte, not evidently bilaluate.

13. Limosella. Culyx (5-toothed) anil corolln (5-eleft) campnulate, nearly negular. Stamons 4, nearly equal : anthers confluently 1-celled. Peeluneles seape-like, i-flowored.

14. Synthyris. Calyx 4 -parted. Corolla 4 -lohecl, campanulate. Stanens 2 : anthers 2 -celled. Flowers racenud. labes alternate.

15. Veronica. Colyx 4-parted. Corolla rotate, 4-lohed; the lower lobe narrower. Stnunens 2: cells of the anther confluent at their tips. Flowers mostly macemed and lenves opprosite.

- Corolla tubular; tho upper lip (galea) erect or incurved, Interally compressed ; the lowel varinus: stamens nscending under or enclosed in the upper lip : capsule loculichdal : llowers spicate or rarely racemet.

$$
\text { + Anthers unequnlly 2-relled or sometimes 1-ecllest. }
$$

16. Castilleia. Corolln murrow, with lower lip very short, or small in propertion to tho upper. Calyx tulular, eleft unteriorly or posteriorly or buth. Mestly peremings. 
17. Orthocarpus. Corolla with saccate lower lip large in proportion to the upper. Calyx tubular or campanulate, 4-cleft. All but one annuals.

18. Cordylanthus. Lips of the corolla both short, of nearly equal length; the lower merely 3-crenulate. Calyx spathaceous, 2-leaved, anterior and posterior, or the anterior division wanting. Anzuals.

$$
\text { + + Anthers equally 2-celled. }
$$

19. Pedicularis. Calyx irregular. Corolla various; lower lip 3-lobed. Perennials.

\section{VERBASCUM, Linn. MULleIN.}

Calyx 5-parted. Corolla rotate, more or less irregularly 5-lobed, the lobes broad and rounded. Stamens 5, all with anthers, but more or less dissimilar : all the filaments or the three upper woolly : anthers transverse. Style flattened and enlarged at the tip, entire. Capsule globular, many-seeded. - Flowers in racemes or spikes.

The Mulleins all belong to the Old World: some are introduced rreeds in the New. But even the common one, $V$. Thapsus, is yet unknown on the Preific coast, althongh a Moth Mullein, different from that found in the Atlantic States, is sparingly spontaneous.

1. V. virgatum, Withering. Annual or bienuial, 3 or 4 feet high : leaves oblong, crenate-toothed, nearly glabrous: raceme loose and virgate, somewhat hairy and glandular: pedicels not longer than the broadish calyx-lobes, some of them clustered : corolla yellow or sometimes white : filaments all violet-bearded.

Waste grounds, naturalized in a few places, from Southern Europe, probably by way of Mexico.

\section{IINARIA, Tourn." TOAD-FLaX.}

Calyx 5-parted. Corolla strongly bilabiate, personate, i. e. with a prominent palate to the lower lip nearly closing the throat, the base at the front continued into a dependent spur. Stamens 4 : anthers 2-celled. Stigma nearly entire. Capsule opening by an irregular hole near the top of each cell, many-seeded.

While the old World abounds in species, only one or two are indigenous to the New. Even the conmon Toad-flax of Europe, $L$. vulgaris, which is a pernicious although handsome weed in the Atlantic States, is happily yet monkown in California.

1. I. Canadensis, Dum. A slender and nearly glabrous annual or biennial, a span to 2 feet high, with linear alternate leaves on the erect flowering stems, but the smaller and broader ones crowded on procumbent radical shoots oftener opposite or whorled: flowers small, blue, in a terminal raceme, on erect pedicels not longer than the slender eurved spur.

Sandy ground, less common than in the Atlantic States, extending far into South America.

\section{ANTIRRHINUM, Tourn. SNAPDRAgON.}

Like Linaria, except that the corolla has merely a sac-like protuberance or gibbosity at base in front, instead of a spur. Sometimes the cells of the capsule open by two holes. - For N. American species, see Gray, Proc. Am. Acad. vii. 372.

A genus of several Old World species and of as many Californian ones, none in the Atlantic States, except that the cultivated Snapdragon, $A$. majus, and the insignificant $A$. Orontizm, are disposed to escape from gardens.

A. cyathiferum, Benth. Bot. Sulph., is described from Lower California, an annual, with cupshaped seeds. Nothing like it has been detected in the State or on its borders.

§ 1. Herbs, with entire leaves short-petioled or sessile, all but the lowest alternate: corolla with very protuberant palate closing the throat or nearly so: seeds not cupshaped nor margined, but rugose-pitted or tuberculate: capsule oblique, the persistent style or its base bent forwards. (Ours are all annuals, so far as the root is known; the upper lip of the corolla spreading, and the lobes of the lower deflexed.) - Antirnhivastrum, Chavannes. 
* Erect, 3 to 5 jeet high, destitute of prehensile branchlets: flowers crowded in a spilies or raceme, mostly rose-colored.

1. A. virga, Gray, 1. c. Glabrous : stem strict and simple (its base unknown):

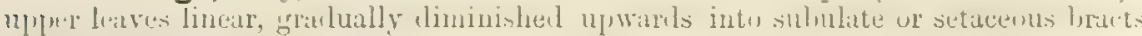
of the long and naked spike-like raceme: flowers mostly secund, soon horizontal: corolla with narrow tube (half an inch long) fully twice the length of the lips: dilated tip of the longer filaments broader than the anther.

Known ouly in a collection made by the late Thomas Bridges, the station unknown.

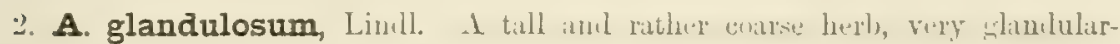
pubescent and viscill throushout, branching and leafy: leaves lanceolate, mostly sessile, gradually passing into bracts of the dense spike or raceme: sepals unequal:

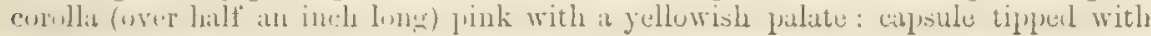
a long persistent style. - Bot. Reg. t. 1893.

Gravelly beds of streams, from Santa Cruz southwards.

* * Erect, a span or two high, destitute of prehensile or tortile branchlets: flowers small, yellowish or dull-colored, sessile or nearly so in the axils of the almost uniform leaves, beginning nearly at the base of the stem: sepals equal, linear: whole style indurated and persistent.

3. A. cornutum, Inuth. Villens and viscid, simply branchet : leaves linearoblong or lanceolate (an inch long), the lower tapering into a short petiole: filaments all dilated at tip: style rather longer than the capsule: seeds echinate and pitted. - Pl. Hartw. 328.

Valley of the Sacramento, Hartweg. No one else has yet found it. Corolla less than half an inch long; the lips nearly as long as the tube; the sac at base prominent.

4. A. leptaleum, (iru, l. c. Slenter, viscil-pulnsent, matly simple-stemuen: lower leaves aluost linear (less than an inch long); the upper and swaller spatulate-

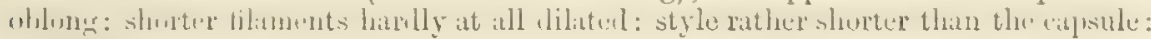
steds rugrose-pitted. - A. cormutum, Duramd, Pacif. R. Rep. v. t. 10, not Benth.

Banks of strems, Muriposa to Keru counties, Bolunder, \&c. Corolla a quarter of an inch long. * * Erect or spreading, branching, slender, producing filiform and at length tortile axillary branchets, by which the plant is disposed to climb: calyx unequal: corollu (small) short, both lips spreading, the lover lurger and as long as the tube.

+ Flowers in a naked spike or dense raceme: bructs minute.

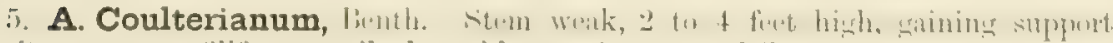
by its numerous filifion tortile branchlets acting as tendrils, glabrous below, as are the linear or narruw-oblong and distant leaves: spike villous-pubescent and viscid, vimate, 2 to 10 inches long: pedicels usually shorter than the linear or lanceolate whtuse sepals, which are shorter than the ovate-oblong capsule: style short. I) C. P'roils. x. 593.

Santa Barhara Co. to San Diego, Coulter, Wallace, Cleveland, dec, Corolln cither violet-purplo

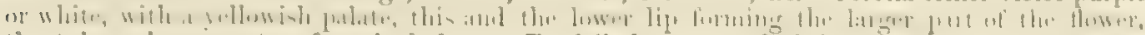
the tuho only a quarter of an ine:hl long. Tendril-shoots mostly bolow the intloresconce, sometimes from the lower part of it.

+ + Flowers (purple or blue, rarely anlite) scattered along the slender diffuse branches, in the axils of leaves or leaftlike bracts, some of them often accompanied by tortile prehensile branchlets: upyer sepal conspicnously lurger than the others: leaves short, from linere to owate.

+ Peduncles mostly shorter then the calyy, sometimes havilly any: tube of the corollu mulher longer then the ligus: seedls tulneroulute.

6. A vagans, Giny, I. c. Very difluse, spuringly bristly, often glamlular, 
varying to glabrous: leaves lanceolate to oblong-ovate: flowers comparatively large (half-inch long): sepals or at least the oblong upper one equalling the tube of the corolla, the others linear: saccate base of the corolla broad: style slender, as long as the capsule. - A. Coulterianum, var. appendiculatum, Durand, 1. c. 11, t. 11.

Var. Bolanderi, Gray, l. e, a form growing in the shade of Redwoods, has broader and thinner leaves, those on tortile branchlets orbicular, and an unusually large posterior sepal. - A. Breweri, var. (?) ovalifolium, Gray, 1. c., may be a form of this with shorter calyx.

Wooded places, apparently common throughout the western part of the State; the variety, Marin Co., Bolandes".

7. A. Breweri, Gray, I. c. Slender, paniculately branched, more or less viscidpubescent or puberulent, at first erect and with few tortile branchlets: leaves from oblong-linear to oval (half an inch long): tube of the corolla ( 3 lines long) considerably longer than the moderately unequal sepals, narrowly saccate at the base: style subulate, glandular, at length strongly deflexed, and rather shorter than the capsule.

Lake to Mendoeino and Plumas counties, rather common.

$+\div$ Peduncles mostly slender, many of them longer than the flower: tube of the corolla rather shorter than the spreading lips: capsule tipped with the nearly straight style or its persistent base.

8. A. Nuttallianum, Benth. Viscidly soft-pubescent, or below glabrous, at length a foot or two high and diffusely much-branched; the tortile branchlets few or more leaf-bearing than in the preceding: leaves ovate or the lowest slightly cordate (an inch long), those of the branchlets gradually much diminished and nearly sessile: some of the lower peduncles longer than the flowers, often tortile: sepals ovate or oblong, shorter than (or the broader upper one almost equalling) the tube of the corolla; this 2 or 3 lines long, merely gibbous at base: capsule oblong: seeds sharply and strongly ribbed.

Common in the southern part of the State, about Los Angeles, San Diego, \&ce.

9. A. Kingii, Watson. Glabrous, slender, a span to 2 or 3 feet high, loosely branching, at length producing more or less tortile branchlets: leaves linear or the lower lanceolate, tapering more or less into a petiole: peduncles as long as the calyx, sometimes fully as long as the flower: sepals linear-oblong, slightly glandular; the upper one as long as the corolla ( 2 or 3 lines long and obtuse); the others about the length of its tnbe, which is merely gibbous at base: capsule globose: seeds pitted and tuberculate. - Bot. King Exp. 215, t. 21.

Dry valleys, along the western borders of Nevada ( $W$ utson, Lemmon), and east to Salt Lake.

§ 2. Herbs, with entive or lobed leaves and no prehensile branchlets, mostly climbing by tortile filiform petioles or peduncles, or by both, mainly glabrous: corolla with the prominent palate wholly or partly closing the throat: capsule and calyx equal-sided or nearly so: seeds as in the preceding: all but the lower leaves alternate. - MAURANDELLA, Gray.

* Annuals, with narrow and short-petioled leaves, but long and filiform prehensile peduncles: calyx rather shorter than the globose capsule.

10. A. strictum, Gray, l. c. Erect, nearly simple, a font or two high, somewhat pubescent below: lower leaves lanceolate, the upper linear, and the upper floral ones filiform; the latter much shorter than the tortnous racemose peduncles: corolla violet-purple, half an inch long, gibbous at base; the palate hairy : capsule crustaceous, tipped with a straight style of equal length. - Maurandia stricta, Hook. \& Arn. Bot. Beechey, 375.

Mountains behind Santa Barbara, Douglas, Brewer. 
11. A. Cooperi, Gray, 1. e. Climbing (2 or 3 feet) by the long filifurm peduncles: stens very sleuder, at length much branched: lowest leaves ovate or oblong, the others linear, and the upper floral minute: corolla bright yellow (half an inch long), conspicuously saccate at base; the palate hairy: style deciluous frum the thin-walled capsule: seeds rough-rugose and with 3 or 4 corky ribs.

Ravines on the Mohave, Cooper, Alinendinger. Also Southern Utah, Parry.

12. A. filipes, Gray. More delieate than the preceding, with broader and thinner leaves, very capillary tortile peduncles, and very small flowers: corolla "white," little exceeding the calyx. - Bot. Ives Colorado Exp. 19.

Desert arroyos on the Arizona side of the Colorado. Perhaps a depauperate form of $A$. Cooperi, with imperfectly developed corolla.

* Perennial, clinnling by the slender tortile petioles and axillary peduncles: leaves lobed or cordate: calyx longer than the globular capsule.

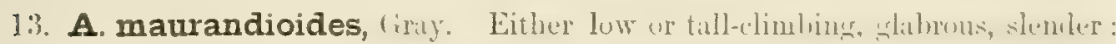
leaves triangular-hastate or more cordate, the lobes at base often with a posterior tooth: corolla (purple or sometimes white, 6 to 12 lines long); its palate nearly closing the throat: sepals lanceolate, very acute : style sleuder: seeds corky-ribbed. - Proc. 1. c. vii. 374. Usteria antirminifora, Poir. Maurandia antirninifora, Willd. Hort. Berol. t. 83 ; Bot. Magr. t. $16+3$.

A Mexican and Texan species, common in cultivation, extending westward through Arizona to or near the Colorado.

\$ 3. Shrubby and erect : leaves mostly opposite or in threes, evergreen, entire: carolla tubular with short lips: the smooth palate prominent, but not closing the throat: capsule globose, not oblique: style stmight, slender: seeds as of the preceding sections. - Gamberia, Gray. (G'ambelia, Nutt.)

14. A. speciosum, Gray, 1. c. A much-branched shrub, 3 or 4 feet high; the young parts soft-pubescent, the older glabrous, at least the oval or oblong thickish and firn leaves (theso an inch or two long and lnalf to an inch wido): flowers in short terminal racemes and in the axils of the upper leaves: perlicels like the leaves or bracts usually verticillate: corolla scarlet, hardly an inch long; the tube cylindrical excopt the gibbous base, twice or thrice the length of the marrowly linceolate sejals, 3 or 4 times the length of the short lips: stigma entire or emarginate: capsule pubescent, opening by a chink on each sile of the slender straight style: seeds oblong, truncate, strougly rugose-ribbed. - Gambelia speciosa, Nutt. PI. Gamb. 149, t. 22.

Island of Catalina, Gumbel. Also Gundalupe Island, off Inower Californin, in flower and fruit, Pilmer. A showy shrub, with bright red flowers; these pubescent outside: the folinge not unlike thut of cistrum diurnum.

15. A. junceum, Gray, 1. c. Perhaps shrublyy, glabrous, 2 fect high: leaves small, oblung-linear: tube of the corolla 8 lines long. - M. juncea, Benth. But. Sulpl. 41.

From Sun Dirgn to Bay of Magdalena in Lower California, Hinds. Not since seen; perhaps same as the preceling.

Sacrolania Veatenir, Kellogg, Proe. Calif. Acad., from Cerros Island, off Lower Californin, Which has been conjectured to be a liussellin, is probuluy a form of Galvesir Limusise, a shrubby phaut of tho l'acific const, near the last section of Anirrhinum.

\section{MOHAVEA, fimy.}

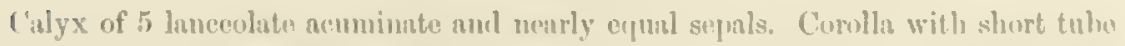

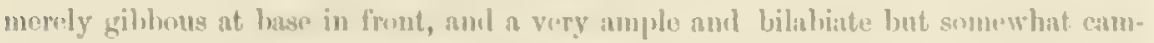

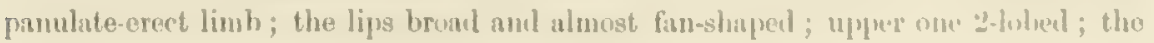


lower 3-lobed and bearing a prominent but comparatively small palate, bearded down its middle; all the lobes broad, erose-denticulate and abruptly short-acuminate. Fertile stamens 2, with anthers one-celled by confluence: the other pair reduced to rudimentary sterile filaments. Stigma depressed-capitate. Capsule globular, thin-walled, tipped with the persistent style, the nearly equal cells opening near the top by a transverse chink. Seeds numerous, oblong, smooth on the back, cupshaped and with thickened corky sides on the inner face. A single species. - Gray in Pacif. R. Rep. iv. 122, Bot. Ives Colorado Exp. 19, \& Proc. Am. Acad. vii. 377.

1. M. viscida, Gray, 1. c. An erect annual, a span to 2 feet high, corymbosely branched, pubescent and very viscid: leaves lanceolate, entire (2 inches long), tapering into more or less of a petiole; the lower opposite, the upper alternate: Howers in the axils of the npper leaves and corymbose or at length racemose at the summit, short-pedicelled : corolla sulphur-colored and somewhat purple-dotted (an inch and a half long). - Antirrhinum confertiflorum, Benth. in DC.

Gravelly banks, from Fort Mohave to Fort Yuma on the Colorado, and adjacent parts of Arizona, first found by Coulter and Fremont.

\section{SCROPHULARIA, Tourn: FIGWORT.}

Calyx deeply 5-cleft, the lobes usually broad and rounded. Corolla short, with a ventricose globular or oblong tube, mequally 5-lobed; 4 of the lobes erect (the two npper longer), the fifth or lower one recurved or spreading. Stamens 4 in two pairs, inserted low down on the corolla, shorter than the lobes: anthers transverse and by confluence one-celled: a rudiment of the fifth stamen conspicuous in the form of a scale borne on the upper side of the throat of the corolla. Stigma entire or emarginate. Capsule ovate, septicidal, many-seeded. Seeds tuberculate-rugose. - Chiefly perennial herbs, of homely aspect; with opposite leaves, and loose cymes of small flowers in a narrow terminal panicle or thyrsus.

1. S. Californica, Cham. Nearly smooth perennial, 2 to 5 feet high : peduncles and pedicels of the open panicle minutely glandular: leaves oblong-ovate with a truncate or cordate base, or narrowly deltoid, coarsely doubly toothed or incised, sometimes laciniate; the lower ones occasionally with a pair of detached lobelets near the summit of the petiole: rudiment of the sterile stamen spatulate or narrowly cuneiform, either rounded or somewhat pointed at the apex. - Linnæa, ii. 585. S. nodosa, var., Benth. Pl. Hartw., \&c.

Moist grounds, from San Diego to San Francisco, \&c., and east to Nevada. Variable in the foliage and size of flowers and capsules. Corolla 3 to 5 lines long, dull or lurid purple.

S. Nonosa, Linn., of the Atlantic States and Europe, extends west to Utah and apparently to Oregon. It may therefore oecur in the northern part of the State. It is distinguished by the larger and orbicular sterile stamen-rudiment, and the leaves are merely serrate, rarely at all incised.

\section{COLLINSIA, Nutt.}

Calyx deeply 5-cleft, somewhat campanulate. Corolla with tube more or less ventricose and gibbous or saccate on the uppex side, more commonly declined, conspicuously bilabiate; the upper lip 2-cleft, and its lobes more or less recurving; the lower 3-lobed and larger, its lateral lobes pendulous-spreading, the middle one conduplicate into a keel-shaped sac and including the declined stamens and style. Stamens 4 in two pairs, with long filaments; the lower or anterior pair inserted 
higher on the corolla than the other: anthers round-reniform, their two cells confluent at the apex into one. A gland at the base of the corolla on the upper side answers to the fifth stamen. Style filiform: stigma small, entire or minutely 2-cleft. Capsule ovate or globose, at first septicidal, but the valves soon 2-cleft. Seeds few or several in each cell, amphitropous and peltate; the face concave. Winter anjuals (all North Anericin and mainly western); with simple ollusite sessile leaves, or the lowest petioled and the unger whorled, and usully hambume llowers in their uper axils: pedieels solitary or eymorsely unbellate-chostered, or in whorls; the upper tiers commonly naked by the diminution of the later leaves into small bracts. Corolla blue, purple, or white, sometimes yellowish, commonly twocolored. The plants mostly spring from seed in autumn and flower early the next season. In garden cultivation the Californian species flower directly as annuals. The stamens and style not rarely rise out of the sac of the corolla into a more erect position before all the pollen is shed.-Gray, Proe. Am. Acad. xi. 91.

The short base of the corolla below the bulging we will call the tube, and the whole inflated and bulging portion up to the eleft, the throat. The little organ which stands in place of the fifth stamen, we call simply the gland.

* Flowers short-pedicelled or neavly sessile, mostly 6 or more in each close and whortlike or head-like cluster, only the lowest clusters subtended by leaves, the other's by small bracts.

+ Corolla strongly declined; the much inflated and saccate gibbous throat fully as broad as long and forming an obtuse or right angle with the very short proper tube: gland short and small, sessile: upper pair of filaments more or less bearded towards the buse.

1. C. bicolor, Benth. A foot or so high, from nearly glithrotis to hirsute ami

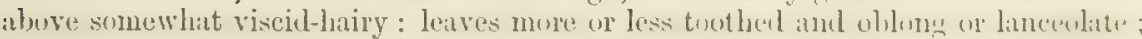
the upper usually ovate-lauceolate and sessile by a broad often subeordate and nervose-veined base: pedicels shorter than the acute lobes of the calyx: corolla party-olored (the lower lip vinlet or mase-purple and the uprer paler or nearly white). occasionally all white; the saccate throat very oblique to the tube; the recurvectspreading upper lip a little shorter than the lower. - Bot. Reg. t. 1734; Brit. Fl. Gard. ser. 2, t. 307 ; Bot. Mag. t. 3488 . C. heteroplyylla, Graham in Bot. Mag. t. 3695 , a form with 3-cleft lower leaves, which is rare.

Moist hillsides, \&c. ; nbounding through all the western part of the State. A pure whiteflowered form (var. candickt) is in cultivation, and also (we believe) widd. The most showy species, with corolla three fourths of an inch long.

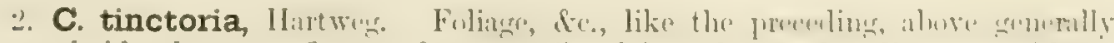
more viscill-pubescent: flowers almost sessile: lobes of the calyx linear or oblonglinear, mostly obtuse: corolla yellowish, cream-color, or white, usually with some purple lots or lines; the axis of the strongly saccate-ventricose throat at right angles with that of the tuhe; the upper lip and its lobes very short. - Benth. PI. IIartw. 328 (1849). C. barbata, Bosse in Verhand. Gartenb. Prenss. 1853, \& But. Zeit. xii. 905. C. seguemnervia, Kellogg, Proc. Calif. Acad. ii. 224, tig. 69.

Moist grounds and banks of streams, along tho western slopes of the Sierra Nevmln and

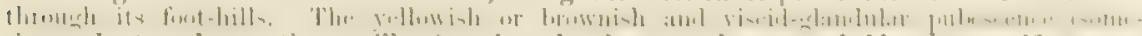
times short and sometimes villons) stains the fingers, whence jrolully the sperific name. Tho upver face of the lateral lohes of the lower lip of the corollat is sparsely beartenl, and the murgins of the lenves are senbrous.

++ Corolla less declined or curved; the gibbous but not sacrate throat much longer

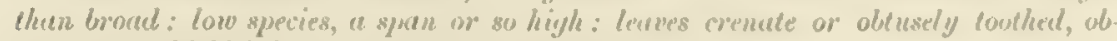
tuse, often thichish in lexture", seldeme over an inch long. 
$+\div$ Filaments and interior of the throat of the corolla somewhat bearded: upper lip of the latter crestless: calyx-lobes broadish, obtuse.

3. C. bartsizfolia, Benth. Puberulent and somewhat glandular, rarely hairy above: stem strict and simple or loosely branched: leaves from ovate-oblong to linear: flower-whorls 2 to 5, rarely only one: calyx either naked or villous: upper lip of the corolla about the length of the curved gibbous throat; the lower narrow at the base, its lateral lobes emarginate or obcordate: gland sessile and elongated, porrect. - DC. Prodr. x. 318. C. bicolor, var., Benth. Pl. Hartw. 328, no. 1884. C. hirsuta, Kellogg, l. c. 110, fig. 34, hairy form.

Common thronghout the central and western parts of the State to the foot-hills of the Sierra Nevada, mostly in sandy soil. Corolla from half to two thirds of an inch long, purplish, pale violet, or whitish : upper lip with a low transverse callosity at the origin of the limb, bordering a small hooded depression.

4. C. corymbosa, Herder. Minutely puberulent or nearly glabrous, branched from the base and dilfuse or decumbent, tufted: leaves oblong or oval, very obtrise, rather fleshy: flowers mainly in a single terminal and leafy-bracted capitate cluster: upper lip of the straightish corolla very short, its limb (spreading above the transverse callosity) almost obsolete; lobes of the elongated lower lip entire: gland small, oblong, flattish, short-stipitate. - Ind. Sem. Petersb. 1867, \& Gartenfl. 1868, 35, t. 568 ; Gray, Proc. Am. Acad. vii. 378.

Coast of the northern part of the State ; on the beach at Fort Bragg, Humboldt Co., Bolander. Described from cultivated specimens, the seed said to come from Mexico, which is most unlikely. Corolla three fourths of an inch long; lower lip white or somewhat creano-colored, the very short upper one blue or bluish.

+++ Filaments and interior of the corolla glabrous: upper lip of the latter prominently crested.

5. C. Greenei, Gray. Small and slender, glandular-puberulent: leaves oblonglinear and tapering to the base, rather coarsely and sparsely dentate: flowers few ( 2 to 6$)$ in the clusters, on pedicels sometimes as long as the calyx: lobes of the latter acutish : upper lip of the violet purple corolla much shorter than the oblong throat, about half the length of the lower, crested above the gorge and under the origin of the linb with a pair of conspicuous callous teeth on each side, which are connected by a less elevated transverse ridge; the lateral lobes of the lower lip small : gland small and sessile.-Proc. Am. Acad. x. 75 .

Crevices of rocks, Lake Co., E. L. Grcene. Corolla 5 lines long: the callosity of the upper lip, which is obvious in some other species, is in this developed into a projecting 2-toothed crest.

* * Flowers slender-pedicelled, solitary or umbellate-whorled.

+ Glabrous or minutely more or less puberulent: at least the lowest leaves broadish or roundish and more or less toothed: lobes of the calyx acute, longer than the capsule.

6. C. grandiflora, Dougl. A span to a foot or so in height: upper leaves from spatulate-oblong to linear-lanceolate; the floral mostly in whorls of 3 to 7 : pedicels at least as many in the whorls, not longer than the flowers: calyx-lobes tapering from a broad base to a slender subulate point: corolla strongly declined; the very saccate throat broader than long, and with its axis almost transverse with that of the tube, about the length of the pale or white upper lip; the larger lower lip deep bright blue or violet: filaments glabrous: gland sessile and capitate. — Lindl. Bot. Reg, t. 1107.

Shady hillsides, Mendocino Co. (Bolander, Kellogy); thence north to Washington Territory. Corolla about half an inch long; the lobes a little undulate or merely emarginate : a pair of strong and hood-Jike callosities on the upper lip. Nearest $C$. violaced of Arkansas, which has obcordate-cleft lateral lobes to the corolla and much less acute calyx-lobes. Notwithstanding the name, this is by no means the largest-flowered species, but the blossoms are numerous and showy. 
7. C. sparsiflora, Fischer it MLeyer. Slemilet, difluse or erect, a span to a funt high: upper leaves linear-oblong or linear-lanceolate, seldum tapering at base, merely opjusite, or the minute upper floral ones in threes: pedicels solitary, in pairs, or sone of the upper in whorls of three, longer or shorter than the flower: calyx-lobes from ovate to deltuid-lanceolate: corolla (mostly violet) strongly declined; the inflated saccate throat very oblique on the tube, about the length of the upper lip : filaments hairy below: gland sessile and projecting forwarls, cyliudricalsubulate. - Ind. Sem. Petersb. (1835) ii. 33. C. parviftora, var. spursiftora, Benth. in DC. C. solitaria, Kellogg, 1. c. ii. 10.

Shaded hillsides, \&ce, from near San Francisco northward. Corolla 4 to 6 lines long: the upper lip and the middle lobe of the lower commonly yellowish and purple-dotted, or paler than the innple and violet lateral lobes. Calyx-tube commonly tinged with purple.

8. C. parviflora, Dougl. Low, at length difluse, a span high: leaves mostly oblong or lanceulate; the upper narrowed at base and entire; the flom often in threes or fours or even fives: pedicels 1 to 5 , mostly longer than the small flowers: calyx-lobes lanceolate, a little shorter than the blue moderately obligue corollat the oblong gibbous-saccate throat of which is longer than the lips: filiments all glabrous: gland small and capitate, short-stipitate: stigrma 2-cleft. - Lindl. Bot. Rieg. t. 1802; Hook. Fl. ii. 94, by misprint as C. pauciflora. C. minima, Nutt. in Jour. Acad. Philad. vii. 47.

Shady moist grounds, from the coast north of San Franciseo to the Sierra Nevada; thence northward to Washington T'erritory and Lake Superior. Corolla 2 to 4 lines long, mather narrow. Nuttall's $C$. minima is a depauperate form, early flowering from the seed, with corolla ( 3 or 4 lines long) fully twice the leugth of the shortish calyx.

\section{++ Glandular: leaves entire, narrow: lobes of the calyx obtuse, shorter than the capsule,}

9. C. Torreyi, Gray. Slender, erect, a span or so high, divergently branched: leares thickish; the lowest narrowly spatulate; the others linear with a tapering base, mainly opposite, or the floml in threes or fours; all the uppermost of these reduced to minute bracts: pedicels 2 to 7 in a whorl, rather longer than the flowers: corolla deep violet-blue, almost thrice the length of the calyx, moderately declinel, the gibbous throat with the tube about the length of the lower lip: filaments glitbrous : gland sessile, subulate. - Proc. Am. Acad. vii. 378.

Common in the higher parts of the Sierna Nevala, from Mariposa Co. to Nevada Co., Torrey, Bolander, Wielson, \&c. Somewhat viscid, beset with minute dark glames. Corolla 3 or 4 lines long; the plaits foming the margins of the sae of the lower lip terminating below in a spur-like projection. Seeds oblong, more terete than usual, and large for the sizo of the capsule, a line long.

TONELLA, Nutt.

Corolla obscurely bilabiato; the 5 more or less unequal lobes somerrhat rotately

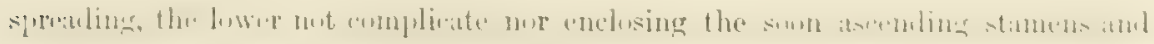
style; the tube slightly gibbous posteriorly. Ovules and seeds from one to four in each cell. Cauline leaves mainly ternately divided or 3-parted. Otherwise as in Callinsia. - Nutt. ex Benth. in DC. Prodr. x. 593 ; Gray, Proc. Am. Acad. vii. $378, \&$ xi. 92.

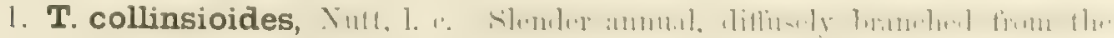
base, nearly glabrous: brunches filiform, a span to a font leng: ratienal and lowest cauline lenves ovate or roumlish, somewhat lobed, crenate or entire (a y ularter to half an inch long), on sleneler potioles; the others shorter-petiuled or sessile, 3-parterl or divided into ublong or lincendate divisions or leallets: the flumal ones sometimes in whorls of three, and the uppermost simple, and shorter than the slemer liliform perlicels; these solitary, or in fairs, or sometimes 3 in a whorl: fluwers mimate, at 
most a line and a half long: corolla a little longer than the calyx; its 5 lobes of equal length, but the anterior one transversely oval or roundish, very much larger than the lateral and posterior oblong ones, and separated from them by deeper sinuses: ovules solitary in each cell : capsule considerably exceeding the calyx. Collinsia tenella, Benth. in DC. Prodr. l. c.

Mendocino Co., near Ukiah, in shady ground (Kellogg, Bolander); also in Oregon, where it was first collected by Nuttall and later by E. Hall.

T. FLoribunda, Gray, the other species, has been collected only in Idaho, on the Kooskooskie River, by Spalding, Geyer, \&ce. It is much larger, a foot or two high ; the stems terminating in a rather crowded racenne of whorls, each of 3 to 6 comparatively showy flowers; the open (purple) corolla over a quarter of an inch in diameter and thrice the length of the calyx; the three lobes answering to the lower lip obovate and nearly alike, smaller than those of the 2-cleft upper lip; the ovules and seeds 3 or 4 in each cell.

\section{PENTSTEMON, Mitchell.}

Calyx 5-parted. Corolla with a conspicuous and mostly elongated or ventricose tube; the throat gibbous on the lower if on either side; the limb more or less bilabiate; upper lip 2-lobed; the lower 3-cleft, recurved or spreading. Stamens 4, declined at base, ascending above; the fifth (posterior) stamen represented by a conspicuous sterile filament: anthers with their cells mostly united or confluent at the summit. Style long: stigma entire. Capsule ovate, septicidal, many-seeded. Seeds angled, wingless. - Perennial berbs, or a few shrubby; with opposite (rarely verticillate) leaves, the upper sessile or partly clasping, the floral gradually or abruptly reduced to bracts. Flowers (appearing in summer) commonly showy and racemose-panicled, the peduncle from the axil of the floral leaves or bracts generally 2-bracteolate when single-flowered, oftener cymosely few-several-flowered. Corolla red, blue, purple, or white, rarely yellow. - Gray, Proc. Am. Acad. vi. 56 ; Watson, Bot. King Exp. 456.

A well-marked gents of nearly 70 speeies, all North American with a few Mexican, much more numerous in the Pacific than the Atlantic States, most so in the intermediate region. Several are common in ornamental cultivation. In a few instances the rudimentary stamen has been found to be antheriferous.

Chetone Nemorosa, Dougl, a native of the woods of Oregon, has been met with in the Cascarle Mountains about 200 miles north of the California line. It would be taken for a Pentstemon except for the seeds, which are broadly winged.

\$1. Anthers with cells at length diverging or divaricate, so as to become transverse, and opening for their whole length.

* Anthers long-woolly: stems suffrutescent.

1. P. Menziesii, Hook. Branching and tufted at the woody base, a span to a foot high, nearly glabrous; the flowering shoots erect: leaves coriaceous, oval or oblong, mostly beset with some small rigid teeth, an inch or less in length : peduncles almost always 1-flowered, and forming a short somewhat glandular raceme: corolla about an inch loug, pink-red; the narrow but gradually expanding tube and throat much longer than the lips. - Gerardia fruticosa, Pursh, Fl. ii. 423, t. 18. P. Newberryi, Gray, in Pacif. R. Rep. vi. 82, t. 14, the var. Newberryi, Gray, Proc. 1. c.

On rocks, through the Sierra Nevada at 5,000 to 12,000 feet; thence north to British Columbia and the northern locky Mountains. Showy in blossom, running into several varieties; the Californian form apparently always with pink or rose-red corollas.

* Anthers glabrous, or sometimes with a few scattered beard-like hairs.

+ Stems woody, at least the base: leaves somewhat coriaceous or chartaceous, small, mostly very short-petioled: filaments all bearded at base. 
+ Corolla red, long and narrow-tubular (an inch or more in length); the upper lip erect; lover more or less spreading: inflorescence somewhat glandular, paniculate or cymose: sterile filament bearded down one side.

2. P. cordifolius, Denth. seranhling wer hulus by lung samentuse linnches to several feet in height, scabrous-puberulent, very leafy: leaves somewhat cordate, or some ovate with a truncate base, mostly acute and serrate or denticulate with sharp salient teeth: the veins impressed on the upper and prominent on the lower face: flowers in a somewhat leafy panicle: peduncles divaricate: calyx-lobes ovatelanceolate: corolla scarlet (an inch and a half long, the upper lip over half an inch).

Towards the coast, from Los Angeles to Santa Barbara. Sterile filament densely yellowishbearded from the apex for some distance downward.

3. P. corymbosus, Ihenth. Lower than the forming a fout or two hish, softpubescent or nearly glabrous, leafy to the tip : leaves oblong or oval, obtuse, acute or acutish at hase, sliehtly and sparsely denticulate (half an inch to nealy 2 inches long), the veins disposed to be parallel: flowers few or rather numerous in a clnse corymbiform terminal cyme: calyx-lobes linear-lanceolate: corolla scarlet (an inch long). - Torr. Bot. Wilkes Exp. 395 .

Shasta Co. to Santa Cruz; first collected by Coullor (small branches or depauperate speciniens), but the station unknown. Nearly related to the preceding; the sterile filament about equally bearded above and sparsely so lower down.

4. P. ternatus, Torr. Glabrous, the long virgate shoots glaucous, 2 to 4 feet

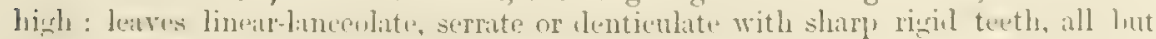
the uppermost in whorls of three: flowers in a more naked long and narrow virgate

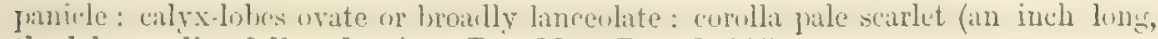
the lobes or lips 3 lines long). - Bot. Mex. Bound. 115.

Mountains east of San Diego (Parry, Clevcland), and Fort Tejon, Xantus.

+++ Corolla more or less yellow or tinged with purple (half to two thirds of an incth long), the tube much shorter than the widely gaping lips, of which the upper is arching and merely notched, and the lower pendulous-recurved.

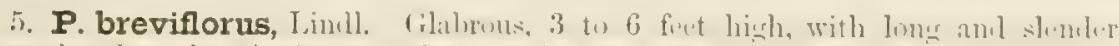

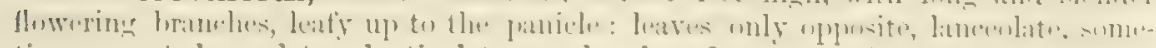
times ovate-lanceolate, denticulate: peduncles few - several-flowered, meemosepanicled: calyx-lobes ovate-lanceolate and acuminate: corolla yellowish or flesh-

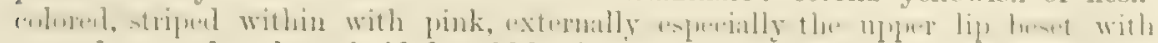
some long and rather viscid beard-like bairs; these sometimes on the calyx also: sterile flament naked. - Bot. Peg. t. 1946.

Dry hills and hanks, throughout the foot-hills of the Sierm Nevada and the Const Range.

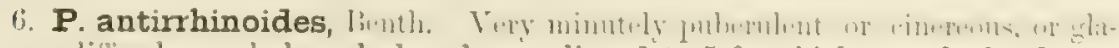
brous, diffinsely much branched and spreading, 1 to 5 feet high, very leafy : leaves

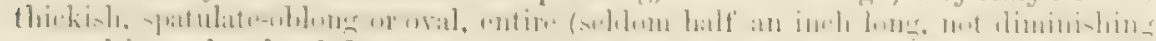
upwards): peduncles 1-flowered, terminating leafy paniculato branches and in the upper axils: calyx-lobes roundish-ovato: corolla very broad for its length, pure lemon-yellow: short sterile filament very densely hearileil on one sille. - Ifouk. Bot. Mag. t. 6157. P. Loblie, of the garclens, Illust. IIort. 1862, t. 315.

Southem part of the State, not mare about San Diego and San Pascual. Peculiar for its clear yellow flowers.

+++++ Corolla flesh-color or purplish (half an inch inny): the tube and throat Ionger
than the short spreading lips.

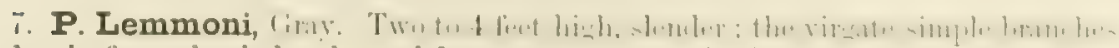
rither leafy, and wholo plant ghorous up to the pedicels: leaves ovate-lanceolate. 
sharply and sparsely denticulate (about an inch or less long), shorter than the internodes: panicle virgate and racemose, loose: peduncles longer than the subtending floral leaves, cymosely 2-7-flowered: very short pedicels and calyx glandular: sterile filament strongly yellow-bearded on one side of the curved apex.

Long Valley, Mendocino Co. (Kellogg, 1869); Plumas Co. (Lemmon, 1874). Resembles $P$. breviftorus in habit and foliage; but the leaves proportionally broader and the flowers fewer; the form of the corolla nearly that of the succeeding species. Divisions of the calyx ovate-lanceolate and gradually much acuminate, rather dry. Corolla in Dr. Kellogg's specimeus "flesh-colored, inclining to pink veins, with red-purple throat," externally somewhat glandular, not bearded, the general form campanulate, the lips about 2 lines long; npper 2-lobed, the lower 3-lobed. Main peduncles an inch or more long.

\section{Stems herbaceous, generally simple.}

+- Corolla at least an inch long, showy, never red; the short tube abruptly ditated into an ample and wide ventricose throat; the broad and roundish lobes spreading: plants glabrous: leaves lanceolate or ovate: panicle nalced and elongated.

$=$ Leaves all entire and distinct at the base: panicle strict and raceme-like or spicate; the peduncles and pedicels both short.

8. P. glaber, Pursh. Very smooth throughout, a foot or two high: leaves mostly lauceolate or the lowest oblong or spatulate, the upper closely sessile: panicle very narrow, a span to a foot long: corolla blue or violet, or varying to purple, ventricose-oblong or between campanulate and funnelform above the narrow tube: anthers either glabrous or with some scattered short hairs; the cells not dehiscent quite to the tip, so that they never open widely: sterile filament either naked or a little bearded on one side at the apex. - P. glabra, Pursh, Fl. ii. 738; Bot. Mag. t. 1672. P. Erianthera, Nutt. in Fraser Cat. P. speciosus, Dougl.; Lindl. Bot. Reg. t. 1720. P. Gordoni, Hook. Bot. Mag. t. 4319.

In the Sierra Nevada from Nevada Co. northward to Oregon (mainly the western form with narrow leaves and wholly naked sterile filament and anthers, the $P$. speciosus of Douglas); thence eastward to and much beyond the Rocky Mountains.

$==$ Leaves or some of them beset with rigid sharp teeth; the upper connate-perfolinte: panicle lmg and open, most of the peduncles and pedicels of the severalflowered cymes being slender.

9. P. Palmeri, Gray. Glancous, 2 or 3 feet high: leaves ovate, or the lower oblong-lanceolate, the upper pairs broadly united: panicle and calyx commonly puberuleut and a little glandular: corolla white or cream-color partly suffused with pink or rose, very abruptly dilated and broad-campanulate above the narrow short tube, the limb an inch broad: sterile filament densely yellow-bearded above. Proc. 1. c. vii. $378, \&$ viii. 291 ; Hook. f. Bot. Mag. t. 6064.

Native of Arizona, Utah, and Nevada, in the latter fornd on the foot-hills of Trinity Mountains (Wotson) so near the eastern line of California that it doubtless occurs within it.

10. P. spectabilis, Thurber. Smooth throughout, inclined to be glancous, 2 to 4 feet high: leaves ovate or oblong, the upper pairs united into a roundish or oblong: disk with acuminate ends: panicle often 2 feet long, loosely many-flowered: corolla abruptly oblong-campanulate beyond the narrow tube, purple and the lobes often blne: sterile filament naked. - Gray in Pacif. R. Rep. iv. 119, \& Bot. Mex. Bound. 113; Hook. Bot. Mag. t. 5260.

Dry plains and hills, Ventura Co. to San Diego (first collected by $W . A$. Wallace), thence to the northern part- of Arizona. One of the handsomest species.

+++ Corolla two thirds or three fourths of an inch long, not scarlet-red; the tube gradually and moderately enlarged above; the roundish lobes short and spreading: plants glabrous throughout and glaucous: leaves thickish, closely sessile. 


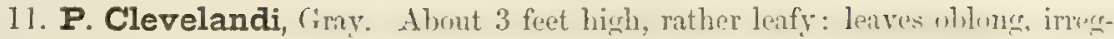
ularly and sharply toothed ( 2 inches long); the floral merely small ovate-subulate bracts of the loose and naked virgate panicle: few-flowered peduncles and pedicels slender: calyx herbaceous; the lobes ovate: curnlla crimson (three fourths of an inch long), tubular-funnelform, distinctly bilabiate; the lobes barely one quarter of the length of the tube including the throat: sterile filument moderately bearded at and below the dilated tip. - Proc. Am. Acad. xi. 94.

Cañon Tantillas, in Lower California, about 25 miles below the State boundary (Clceelend, P(almer) ; cast of San Bernardino, Purry.

12. P. acuminatus, Dougl. A foot or so high, leafy: leaves from ovate to ohlong-lanceolate (am inch or two long), entire; the upjer and the floral ones inclined to be cordate-clasping: flowers numerous in a long and mostly interrupted virgate spike-like panicle, the base of which is usually leafy, mostly several-in the Horiferous axils: pedicels and especially the peduncles short: lobes of the calyx narrow or acuminate: corolla lilac-purple or violet, with open throat and widely spreading lobes: sterile filament strongly bearded at the dilated tip (rarely naked) : capsule firm-coriaceons and acuminate. - Lindl. Bot. Reg. t. 1285. P. nililus, Dougl. P. Fenuleri, Gray in Pacif. R. Rep. ii. 168, t. 5 .

Near Humboldt Lake, Nevada, Watson. Therofore not improbably reaching the borders of the State. A neat species, widely diflused northward and eastward through the interior region to and beyond the Rocky Mountains.

$$
\begin{gathered}
++++ \text { Corolla half an inch or less in length, blue, purplish, or whitish, moderately } \\
\text { enlarging above; the roundish lobes spreading. } \\
=\text { Leaves serrate or toothed. }
\end{gathered}
$$

13. P. deustus, Dougl. A span to a foot high, in tufts from an almost woody branching base, glabrous: leaves all sessile, from ovate to linear-oblong, seldon over an inch long, sharply serrate with many or rarely few narrow teeth (occasionally some of them entire): narrow and virgate or spike-like panicle mostly lenfy below; the clusters several-many-flowered, close: peduncles and pedicels short : corollit eream-color or buff, sometimes with a tinge of rose : sterile filament naked. - Lindl. Bot. Reg. t. 1318. P. heterander, Torr. \& Gray, in Pacif. R. Rep. ii. 123, t. 8.

Dry rocks and banks, castern side of the Siem Nevala (Sierra Valley, Lemmon, \&c.), to the interior borders of British (columbia and Wyoming Terr. Varies much in the folinge and more or less dense or interrupted inflorescence; also in the sepals, which are commonly laneealate and rather long, sometimes shorter, rarely almost ovate. $P$. helerander is a narrow-leaved and strict form, from Beckwith's. P'ass, in which the sterile filament was found to be antheriferous; but this ocensionally happens in cultivated plants of other species, and has not been found a second timo in this.

P. ovarus, Dongl. Bot. Mag, t. 2903, a native of the woods of Oregon, mny rench Californin : it is a foot or two high, minutely pubescent, has thinnish and bight green orate or somewhat cordate and acutely serrate leaves, and a rather open naked paniclo of blue tlowers.

$$
==\text { Leaves quite entive. }
$$

14. P. Gairdneri, Hook. $\Lambda$ span high, in tufts from a somewhat woody base, minutely cinereus-puberulent throughout: leaves all linear or the radical linearspatulate, seldom an inch long, the marnins soon revolute: flowers fow and almost simply racemoso: calyx somewhat glandular: sterilo filament bearded down one sido, - Benth, in DC. Prodr. x. 321.

Virginin City, Nevada (Bloomer), doubtless also within the State line: also in the dry interior of Oregon.

P. LAmetFot.rTs, Hook. \& Arn., a still dwarfer species, wholly glnhrons, with simple stems and leaves almost filiform, sparingly inlabits the same interior region, and may reach the northo mastern borders of the state.

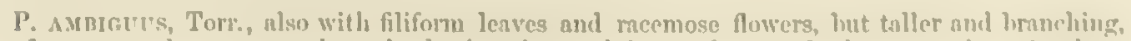
is of more southurn range through the interior, and is not known farther west thun southern I'tuh. 
15. P. confertus, Dongl. A span to a foot or more high, wholly glabrous: stem strict and simple: leaves lanceolate or oblong-lancenlate, or the lower spatulateoblong, an inch or two long: the upper pairs often distant: flowers numerous and crowded in short-peduncled or sessile clusters and very short-pedicelled, forming an interrupted spike of 2 to 5 apparent whorls, or sometimes a solitary terminal head: edges of the calyx-lobes usually scarious and lacerate: corolla (a third to half an inch long), either yellowish cream-color, violet or blue, the short lower lip bearded inside: sterile filament bearded at the tip. - Bot. Reg. t. 1260. P. procerus, Dougl. ; Bot. Mag, t. 2954 ; the var. cceruleo-purpureus, Gray, I. c.

Moist grounds, common in the higher portions of the Sierra Nevada; thence north to Washington Territory and east to the Rocky Mountains. Only violet- or blue-flowered forms yet found in California, but some are pale.

$++\div++$ Coralla deep and bright red, tubular, fully an inch long: the short lobes

or lips less spreading, hardly longer than the diameter of the throat: perfectly glabrous plants: leaves thickish, all but the lowest closely sessile by a broadish base, the upper pairs more or less cordate-clasping: stamens included: slender sterile filament naked.

16. P. centranthifolius, Benth. Glaucous, strict and vircate, very leafy, 1 to 3 feet high: leaves ovate-lanceolate or the lower lanceolate-oblong or narrower: panicle narrow, commonly a foot or two long: pedicels slender: corolla very narrowtubular and obscurely bilabiate; the short-oblong lobes alike except that the posterior are united higher: anthers opening widely (in the usual way). - Hook. Bot. Mag. t. 5142.

Open and dry grounds, from Monterey? and Santa Barbara southward. A showy species; the narrow corolla bright vermilion-colored. The name comes from the resemblance of the foliage to that of Centranthres ruber.

17. P. Eatoni, Gray. Hardly if at all glaucous, a foot or two high: leaves from lanceolate to nearly ovate: panicle narrow and racemose, a span to a foot long: corolla gradually a little broadening upwards; the roundish-oval lobes nearly alike except that the two of the upper lip are united higher, all nearly erect: cells of the anther diverging from the first or divaricate, never spreading open, the line of dehiscence stopping short of the apex. - Proc. Am. Acad. viii. 395. $P$. centranthifolius, Watson, Bot. King Exp. 219.

Open dry ground, from the southern part of the State (W Wallace) to Utah. Also a very showy species, with broader corollas than the last, in color less verging to scarlet. It belongs to the same group as $P$. barbatus (which is common in cultivation) and $P$. imberbis, natives of the southern Rocky Mountains and Northern Mexico.

P. PUNTCEUS, Gray, is another red-flowered species in Arizona, but it has not been found very near California.

\$2. Anthers horseshoe-shaped, reniform, or sagittate; the cells opening from the confluent apex down only to or below the middle, leaving the bases saccate (the edges of the chink usually denticulate or bristly-cilicte).

* Leaves entire: corolla scarlet, tubular.

18. P. Bridgesii, Gray. A foot or two high, up to the inflorescence glibrous: leaves pale or glaucous, thickish, spatulate-lanceolate or linear, or the lowest oblong-spatulate; the upper not broadened at base (as in the two preceding): flowers in a loose virgate naked panicle or raceme; the clusters 1 -5-flowered: short peduncles and pedicels as well as calyx somewhat glandular-pubescent: corolla slightly and gradually enlarging upwards, an inch long; the short lips 3 or 4 lines long, upper one erect and 2-lobed at apex, the lower 3-parted and its oblong lobes recurved: anthers deeply sagittate. - Proc. An. Acad. vii. 379.

Rocky hanks, Yosemite Valley, \&c. (Bridges, Bolnnder), to Kern Co. (Rothrock); and eastward to Bill Williams Mountaiu, in N. Arizona (Palmer), and S. W. Colorado, Brandegee. 
* Leaves entire: corolla purple or blue.

+ Corolla rather slender, half an inch or so long: stevile filament commonly a little bearded down one side.

19. P. gracilentus, Gray. A foot or more high, up to the inflorescence glabrous: stems slender, few-leaved and with long internodes above, terminating in a loose mostly naked and short panicle: leaves lanceolate, or the upper ones linear and the lowest oblong : slender 2-5-flowered peduncles and short pedicels as well as the calyx glandular-pubescent: corolla bright violet-blue, tubular and gradually broadening upwards; the lips (2 lines lung) molerately spreading. - Pacif. $\mathrm{R}$. Rep. vi. 82, \& Proc. Am. Acad. vi. 75.

Shaded ground or banks, through the northern portion of the Sierra Nevada (Nevobcrry, An derson, \&:c.), and on Mit. Shasta above 8,000 feet, Brever.

+ + Corolla larger and ventricose-dilated above; the broad lips widely spreading: sterile filament glabrous: flowers racemuse-panicled, showy.

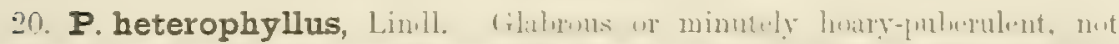

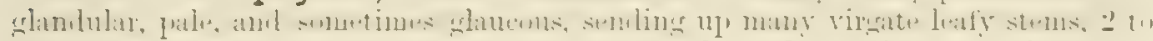
5 feet high from a persistent woody base : leaves lauceolite or linear, or the lowest oblong-lanceolate, the floral diminishing into narrow subulate bracts: peduncles 1-3-flowered, mostly short and erect: corolla pink or rose-purple, or with shades of violet, fully an inch long, ventricose-funnelform above the narrow rather slender base. - But. Reg. t. 1899 ; Bot. Mag. t. 3853.

Dry banks of streams, through the western part of the State, from San Diego to Jendocino Co. The anthers, as in all the following, are ciliate with short and stiff bristles along the line of opening, and otherwise either glabrous or sparsely hirsute underneath. All these are slowy species; and they seem to run into one another. The calyx is variable.

21. P. azureus, Benth. Glabrous and glaucous, 1 to 3 feet ligh: leaves as in the preceding, or inclined to be more lanceotate or with a broaler base: corolla similar, but azure-blue or approaching violet, sometimes with red-purple tube, mostly rather broarler and larger. - Pl. Hartw. 327 ; Gray, Proc. 1. c. vi. 75.

Var. Jaffrayanus, Gray. A foot high: leaves broaler; the lower spatulateoblong, the upper from oblong-lanceolate to orate. - P. glancifulius, Gray in Pacif: R. Rep. vi. 82. P.Jufirayanus, Hook. Bot. Mag. t. 5045. P. helerophyllus, var. lutifolius, Watson, Bot. King Exp. 222.

Common through the interior, from the Sacramento Valley enstward : the variety in the Sierrn Nevada; also in the Wahsatch Jountains of Ltah.

22. P. laetus, Gray. Cinereous-puberulent or pubescent and abore glandular. a foot high: leares from lanceolate to linear or below to spatulate: panicle more? open; the peduncles and pedicels often spreading: corolla as of the preceding or smaller, an inch long, blue. - Jour. Bost. Nat. Hist. Soc. vii. 147, \& Proc. Am. Acal. vi. 76.

Near Los Angeles (Wallace) and Tejon (Xrulus) to the Sierra abovo the Yosenito Talley, \&c.

23. P. Roezli, Rexpel. Smaller, a span to a foot or so high, below glalions or minutely puberulent, above (at least the inflorescence) glandular-puhescent: leares all lanceolate or linear (an inch or more long) : panicle open amel often compouncl; the few-flowered or loosely several-flowered peduncles and the pelicels contuonly diverging : corolla from lualf to two thirds of an inch long, bluish or pale? viulet. Regel in Proc. St. l'etersb. Bot. Gard. ii. 326. P. helerophlyllus, var. (1), Torr. \& Gray in Pacif. R. Rep., ii. 122.

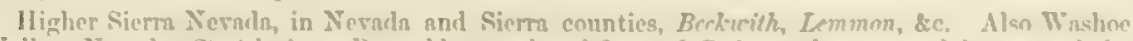

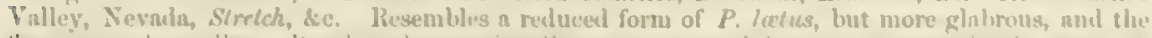

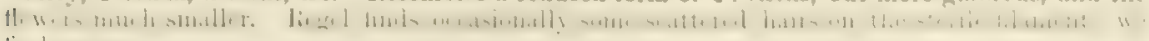
lint nome. 
* * * Leaves all or some of them sharply serrate or laciniate: corolla purple or mostly violet, with ample ventricose-inflated throat; the upper lip somewhat and the lower more widely spreading; the lobes short and roundish.

24. P. triphyllus, Dougl. A foot or two high, nearly glabrous: stems slender, paniculately branched, leafy: leaves lanceolate or linear, sharply toothed or laciniatepinnatilid, about an inch loug, many of the middle ones in whorls of three or four, and of the uppermost alternate: peduncles $1-3$-flowered in a simple or compound loose and sometimes leafy panicle: corolla fully half an inch long, less enlarged in the throat than the following : sterile filament densely bearded at the tip. - Lindl. Bot. Reg. t. 1245.

Not rare in Oregon and Washington Territory; said in the Botanical Register to have been found by Douglas in Northern California also.

25. P. Richardsonii, Dougl. Like the preceding, but more branched and diffuse, 2 feet or more high: leaves ovate-lanceolate or narrow, acute, laciniatetoothed or pinnatifid, an inch or two long, opposite or on the branchlets alternate : panicle loose and irregular, glandular: corolla an inch long, much enlarged at the throat, violet: sterile tilament slightly bearded at the tip. - Lindl. Bot. Reg. t. 1121 ; Hook. Bot. Mag. t. 3391.

Northern part of the State, Kellogg \& Earford. Thence through Oregon to Washington Terr. - The three following Oregon species have not been detected in California, but are so likely to occur that their names and main distinctions are appended.

P. DIfFursus, Dougl. Glabrous or merely puberulent above, 2 or 3 feet high; the ascending stems simple or branching at the summit : leaves ovate or ovate-lanceolate, coarsely or finely serrate, the upper slightly cordate and clasping at base : panicle rather leafy; peduncles and pedicels rather short : corolla over half an inch long, light purple : sterile filament bearded at the tip. Lindl. Bot. Reg. t. 1132 ; Hook. Bot. Mag. t. 3645 . In aspect most like $P$. ovalus.

P. venustus, Dougl. Glabrons throughout: stems strict and simple, erect, very leafy: leaves narrower than in $P$. diffusus, of firmer texture, mostly oblong-lanceolate, beset with close sharp teeth : panicle narrow or thyrsiform, usually naked : corolla usually more than an inch long, violet-purple; the lobes ciliate. — Lindl. Bot. Reg. t. 1309.

P. Glandulosus, Dougl., is a rather large-leaved and large-flowered species, probably growing in shade, clothed with a short and soft-downy more or less glandular pubescence: leaves thin, ovate or ovate-lanceolate, moderately serrate; the upper cordate-clasping; acuminate, often nearly entire; the floral ones mostly longer than the short peduncles in their axils: pedicels very short: corolla pale violet, fully an inch long, much broadened above : sterile filament glabrous.

P. Canosa-Barbatum, Kellogg in Proc. Calif. Acad. ii. 15, - described from a specimen collected in the Sierra Nevada by Mr. Hutchings, said to have "scarlet or red" peduncles, a "colored" corolla with "Iower lip slightly 2-notched, carinate, densely bearded below, mostly at the extremity, with white or long transparent frosted hairs," - is a complete puzzle. As the tube of the corolla is said to be "short, like that of $P$. brevifor"us," it may belong to that species.

P. RostRiftortm, Kellogg, 1. c., from the same source, - said to have linear-lanceolate leaves, narrow creamy-yellow corolle, with linear and acute lobes to the lower lip, - is wholly confounding in its characters.

\section{MIMULUS, Linn. MONEEY-FLOWER.}

Calyx tubular-prismatic or campanulate, mostly plicately 5-angled, 5-toothed, rarely 5-cleft, often oblique. Corolla funnelform, with included or rarely prolonged and exserted tube, bilabiately 5-lobed; the upper lip 2- and the lower 3-lobed or parted; the lobes plane or roundish, more or less spreading or those of the upper lip turned back; a pair of palatine ridges (either bearded or naked, and more or less intruded) running down the lower side of the throat. Stamens 4 : the anthers oftener approximate in pairs, their cells divergent. Style filiform: stigma bilamellar, with the lips or lobes commonly petaloid-dilated, or more or less entire and peltatefunnelform. Capsule loculicidally 2-valved, the placentre either remaining united in 
the axis, or separatiug and lume ly the half-partitions on the midale of the valves. Seeds very numerous, small, oval or oblong, mostly with a close smooth coat, often apiculate at each end. - Herbs, or one peculiar species shrubby; with opposite

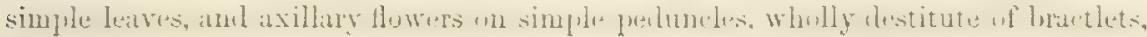
sometimes becoming racemose by the diminution of the upper leaves to bracts; the flowers various in color, commonly handsome, usually appearing in long succession. -Gruy, Proc. Am. Acad. xi. 95. Mimulus, Diplarus (Nutt.), \& Eunanus (Beuth.), with Herpestis § Mimuloides, Benth. in DC. Prodr. x. 368.

A genus, as here maintained, of 40 or 50 species, far the greater number Pacific-North Ameriean, a few extending to extra-tropical South America, one or two Asiatic, Australian, or even South African. Several species, chiefly indigenous to California, are prized in orumental cultivation.

In this and related genera, the lips of the stigma close with a quick morement upon receiving pollen or being otherwise touched.

\$ 1. Corolla with a long filiform tube, very much exserted beyond the narrow prismatic oblique calyx: stamens strongly didynamous; the anthers approximule in pairs, forming crosses: style pubescent above: stigma variable: capsule cartilaginous, filling the calyx or its lower part, giblous at bose, sulcate at the septiferous sutures, very tardily dehiscent; the valves bearing the placentur: dwarf Califormian annuals, in the earlier stage the (purple or variegated) corolla much longer than all the rest of the plant: leaves entive or abscurely fero-tonthed. - Wivo, Gray.

M. I.ATIFolites, Gray in Proc. Am. Acad. 1. c., a species recently discovered by Dr. Palmer ou Guadalupe Island, Lower California, accords with this section except in having a shorter and barely exserted tube to the corolla (which otherwise is netrly that of 3 . Doreglasii): so that this section might as well be merged in Eunanus, to which Bentham referrel it; but the very long and slender tube of the corolla in the two following species is very characteristic.

1. M. Douglasii, Gray. Leaves orate or oblong, 3-5-nervel at base, mostly contracted abruptly into a short petiole: calyx soon very gibbous at base on the upper side: Iower lip of the corolla very much shorter than the amplo erect ujper one, sometimes almost wanting: capsulo linear or linear-oblong, nearly tereto but strongly 4-sulcate, gilubous or somewhat inflexed at the very base: seeds oval, apiculate at both ends. - M. namus, var. subuniflomes, Hook. \& drn. Bot. Beechey, 378. Eunanus Douglasii, Benth. in DC. Prodr. x. 374.

Gravelly hills and banks, rather common through nearly the whole length of the State. Stems at first flowering half an inch or less, soon rising to a span in height. Inter flowers distinetly peduncled. Calyx about half an inch long; its orifiee very oblinge and the teetly short ani obtuse. Corolla with tulne an inch to an inch and a half long; the funnelform dilated thront about 3 lines long, deeper pink or purple or spotted, with some yellnw below; the broad and 2-cleft upper lip as long as the throat. Stigm in some specinenis with a long and laneeolate upper lip and a very short and obtuse lower one, or with two trond and unequal connate lips, or eccentrically disk-shupen, or sometimes with very broad and equal connate lips and appearing sancer-shnyed or centrally peltate when expanded, in the manuer of the next section: the differences unacconnxunied lyg other distinctions. Capsule 3 to 5 lines long. Seculs harally latf $a$ line long.

2. M. tricolor, Lindl. Leaves from oblong to linenr, with marrowel base sessile or nearly so, ubscurely nerved: calyx havlly gilhous at base, ampler toward the very oblinto orifico, and the teeth longer: lower lip of the comolla ahout the length of the upper; the 5 lohes somewhat similur: capsule somewhat compressed, shortoval or ovate, very obtuse, the anterior and posterior edges acute: seeels choviate. oblique, - Jour. Hort. Soc, iv. 222, June, 1849. Eunanus Coulteri, Gruy ex Dienth. Pl. Hartw, 32!), Auy, 1849 .

Var. angustatus, (rimy. Leaves small and narmw: tube of corolla (2 inches long) very slender, - Eunamus Coulteri, var, angustulus, Ciray, Proc. Am. Ariul. vii. 381. 
Valley of the Sacramento to Plumas and Mendocino connties. The slender var. in Long Valley, Plumas Co., Bolander. Much like the preceding, except in the points noted. Tube of the corolla from 1 to 2 inches long; the limb oblique, but the roundish lobes of the two lips nearly equal, "pink with a deep crimson spot upon the base of each lobe, and a bright vellow stain along the lower lip " (Lindley; hence the name). Stigma of two broad and rounded and mostly equal lips, which are united so as to form when expanded a saucer-shaped disk. Capsule almost bony, only 2 or 3 lines long, and about 2 lines wide, furnished with a groove at the septiferous suture on the sides. Seeds double the size of those of M. Douglasii. - It is well that Lindley's appropriate name is the earlier; as there was a mistake in supposing this species to have been in Coulter's collection.

\$2. Corolla from tubular-funnelform to nearly campanulate; its lobes about equal in length: calyx campanulate or barely oblong, angled in the manner of Mimulus proper: style glandular-pubescent above: stigma a peltate-funnelform and entire or obscurely 2-lobed dilated disk: capsule between membranaceous and coriaceous; the valves in dehiscence bearing the placenta: dwarf or low annuals, viscid-pubescent or glandular. - Eunanus, Gray. (Ennanus, Benth. in part.) Closely connects the preceding section with true Mimulus.

* Small-and slender-flowered: corolla 3 to 6 lines long: calyx-teeth nearly equal.

3. M. leptaleus, Gray. At length much branched, 1 to 3 inches high : leaves from spatulate-oblong to lanceolate-linear (half an inch or less long): teeth of the campanulate calyx ovate or triangular, a quarter or one third the length of the tube, a little shorter than the oblong-ovate obtuse capsule: corolla crimson-red, slender, with filiform tube, little enlarged throat, and oblique limb ( $1 \frac{1}{2}$ to 3 lines wide). Proc. Am. Acad, xi. 96.

Sierra Nevada, in gravelly soil, above the Yosemite, at about 6,000 feet (Miss Dix, Gray), and Sierra Co., Lemmon. Capsule 2 lines long.

* Large-flowered for the size of the plant (an inch to a span high) : corolla 7 to 11 lines long, funnelform, with widely spreading limb; the proper tube not much if at all longer than the calyx: calyx hardly at all oblique, the teeth almost equal. (Species seemingly too nearly related.)

4. M. Bigelovii, Gray. An inch to a span high: leaves oblong and the upper ovate, acute or acuminate: teeth of the calyx subulate (about 2 lines long when well developed), half the length of the broadly campanulate tube; the lower ones shorter: corolla with cylindraceous or narrow throat and ample rotate-spreading limb: capsule oblong-lanceolate, acute or acutish, a little exceeding the calyx, the valves membranaceons. - Eunanus Bigelovii, Gray in Pacif. R. Rep. iv. 121.

Gravelly hills and ravines, on the Molhave and Colorado (Bigelow, Cooper), and Tejon (Xantus), to Western Nevada (Bloomer, Torroy), and Southern Utah, Parry. Corolla crimson or purple, with yellow centre.

5. M. nanus, Hook. \& Arn. From an inch to at length a span in height: leaves from oblong or the lowest obovate to lanceolate : teeth of the calyx broadly lanceolate or triangular, acute (a line long, fully one fourth the length of the tube): corolla (either deep crimson-purple or yellow) with narrow tube rather longer than the calyx, and a gradually dilated funnelform throat: capsule with tapering apex rather exceeding the calyx; valves chartaceous. - Bot. Beechey, 378 (var. plnriflorus). Eunanus Tolmicei, Benth. I. c. E. Fremonti, Watson, Bot. King Exp. 226.

Var. (?) bicolor, Gray: a doubtful form, with throat of the corolla abruptly much dilated and "dark purple, the limb yellow." - Eunanus bicolor, Gray, Proc. Am. Acad. vii. 381.

Hillsides and banks, throughout the Sierra Nevada, extending more or less into the westem part of the State, and into Nevada, the eastern borders of Oregon, and to Wyoming. The greater part of Hooker and Arnott's description of $M$. namus relates to var, subuniflorus, i. e. to $M I$. Douglasiz. The var. bicolor, from the higher parts of the Sierra Nevarla in Fresno Co. (Brewcr), is known only from scanty young specimens, and may be quite distinct. 
6. M. Fremonti, Gray. Two to four inches high : leaves narrowly oblong, or the lowest spatulate, obtuse: teeth of the calyx (less than a line long) ovate, obtuse or acutish, less than a quarter of the length of the tube, surpassing the proper tube of the crimson corolla: throat of the latter gradually dilated, funnelfurm. Eunauus Fremonti, Benth. 1. c.

Southern part of the State, Conller, Fremont (his specimens probably from the San Joaquin Valley or farther south), Wallace, \&c.

* * * Ample-flowered: calyx with manifestly oblique orifice and unequal teeth, the upper larger; moper tube of the corolla short and included.

7. M. Parryi, Gray. Less than a span high, slightly glandular: leaves oblong or oblanceolate, eutire (half an inch long): teeth of the campanulate oblique calyx acute; the upper and larger one ovate; the others subulate from a broad base, a third or a fourth the length of the campanulate tube: corolla yellow or sometimes pink, funnelform, two thirds of an inch long: capsule oblong-lanceolate, not longer than the calyx. - Proc. Am. Acad. xi. 97.

Gravelly hills, near St. George, Southern Utah, Party (No. 147). Beginning to flower at the first or second pair of leaves.

8. M. Torreyi, Gray, I. c. A span to a foot high, simple or loosely branching, viscid-pubescent: leaves oblong or almost lanceolate, entire (half to a full inch long): teeth of the moderately oblinue calyx all very broad and obtuse, the upper and larger one barely a line long: corolla funuelform, from half to three fourths of an inch long, pink-purple: capsule lanceolate-oblong, chartaceous. - Eunanus Fremonti, Gray in Pacif. R. Rep. vi. 83, not of Benth.

Through the Sierra Nevada, in moist grounds, at 4,000 feet and upwards, from Mariposa Co. northwards : first collected by Neuborry in Plumas $C_{0}$, and next by Torroy and others. Calyx tecth fully as broad as long. Capsule 3 or 4 lines long.

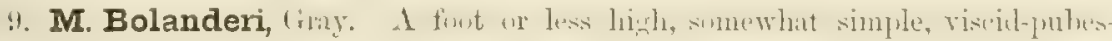
cent: leaves oblong, entire or sharply denticulate (one or two inches long), tho lower exceeding the flowers: teeth of the very oblique calyx lanceolate; the upper and longer one 3 lines long, half the length of the oblong calyx: corolla purple, about an inch long, with short wholly included tube and ample throat: capsule fusiform-subulate, somewhat coriaceous. - Proc. Am. Acad. vii. 380. M. brevipes, Gray in Pacif. R. Rep. iv. 120, not of Benth., a large form.

Foot-lills and lower part of the Sierm Nevaln, Bridges, Bolunder (at Clark's), Bigeloro (at Knight's Ferry on the Stanislaus). Lobes of the corolla rather short. Stigma sometimes unequally bilamellate or very obliquely peltate.

10. M. brevipes, Benth. A foot or two high, viscil-pubescent: stem mostly simple: lenves lanceulate or linear, or the lowest sumewhat oblong, entire or sharply denticulate with salient teeth (from 1 to $t$ inches long): teeth of the calyx very unecunl, acuminate, the upper one fully half the length of the broadly campanulate tube: corolla yellow, with very short included tube, campanulate-ventricose throat, and ample rounded lobes, when expanded an inch and a half in diameter: cajsule ovate, acuminate, firm-coriaceous. - DC. Proll. x. 369; Gray, Bot. Mex. Bound. 116.

Millside's, San Diego to Santa Barharn, A very large-flowered species, quite unlike the rest of the section, but connected with it through the inmedintely preceding speries.

\$ 3. Corolla funnelform, with the proper tube litle or not at all exceeding the long amd narrow prismatic calyx: slyle glundular: stiyme almost equally 2-lipped: placentue meeting but not cohering in the axis, in dehispence borne me the linear firm-coriaceons valves: shrubly plonts, with glutinons erndention and thickish firm leares. - Iniplacus, Giry. (Diplaces, Xutt.)

11. M. glutinosus, Wendland. Two to six foet high, nearly glithrous or minutely pubesceut: lenves from marrowly oblong to lincar-lanceulate, ami from minutely 
dentate to nearly entire ( 1 to 4 inches long), the margins inclined to be revolute: peduncles in the axils of the leaves, either a little or much shorter than the narrow prismatic calyx: corolla $1 \frac{1}{2}$ to 2 inches loug, in the typical form buff or salmoncolor; the lobes either exose-toothed or emarginate. - Jacq. Hort. Schonb. iii. 364. M. aurantiacus, Curt. Bot. Mag. t. 354. Diplacus glutinosus \& latifolius, Nutt. in Ann. \& Mag. Nat. Hist. i. 137. D. stellatus, Kellogg, Proc. Calif. Acad. ii. 18. A common and very polymorphous species, which runs into the following principal but indefinite varieties.

Var. puniceus, with red or scarlet flowers on mostly slender peduncles: lobes of the corolla simply obcordate or emarginate, or sometimes irregularly toothed: calyx glabrous. - Diplacus puniceus, Nutt. 1. c.; Hook. Bot. Mag. t. 3655. D. glutinosus, var. puriceus, Benth. in DC.

Var. linearis, with red-brown or salmon-colored flowers on very short peduncles: calyx commonly pubescent: leaves linear and with nearly entire soon revolute margins, more rigid. - M. linearis, Benth. Scroph. Ind. 27. Diplacus leptanthus, Nutt. 1. c.

Var. brachypus, with salmon-colored flowers of pretty large size (fully 2 inches long), on very short peduncles: calyx viscid-pubescent or villous: leaves linearlaneeolate, entire or nearly so. - Diplacus longiflorus, Nutt. 1. c.

Dry and rocky banks, \&ce, common from San Diego to San Francisco Bay ; common and very ornamental in cultivation, especially is a green-house plant: flowering almost through the year. Even in the wild state it exhibits a great diversity of colors; but it seems impossible to distinguish the forms as species. The last variety collected by Coutter (No. 639), near Santa Barbara by $N$ uttall, and a form of it, connecting with ordinary $M$. glutinosis, in San Luis Obispo Co., by Brewer.

\$ 4. Corolla with short and included proper tube: calyx with plaited-carinate salient angles, 5-toothed, the strong nerve traversing the teeth: style glabrous: stigmn 2-lipped, the lips ovate or roundish and equal: placento remaining united in the axis of the capsule, or dividing merely at top (in $M$. rubellus sometimes completely); the thin and often membranaceous valves tardily separating from the axis: annual or perennial herbs. - Mivulus proper.

* Large-flowered: corolla $1 \frac{1}{2}$ to 2 inches long, red or rose-color, with cylindrical tube and throat longer than the limb: calyx oblong-prismatic; the short teeth nearly equal: anthers hairy or nearly glabrous in the same species: peduncles elongated: seeds with a loose dull epidermis wrinkled lengthwise: leaves several-nerved from the base: root perennial.

12. M. cardinalis, Dougl. Villous with viscid hairs: leaves ovate and the upper often connate, the lower' commonly obovate-lanceolate, all erosely dentate : corolla scarlet, with tube hardly exceeding the calyx; the limb remarkably oblique, the upper lip nearly erect with the lobes turned back, the lower reflexed: stamens projecting. - Lindl. in Hort. Trans. ii. 70, t. 3 ; Brit. Fl. Gard. ser. 2, t. 358 ; Hook. Bot. Mag. t. 3560.

Common along water-courses throughout the State and in Oregon; much prized in cultivation. Capsule oblong, thin-chartaceous when dry; the valves tardily separating from the placentabearing axis.

13. M. Lewisii, Pursh. More slender than the foregoing, greener, minutely somewhat viscid-pubescent: leaves from oblong-ovate to lanceolate, merely denticulate : corolla rose-red or paler (the throat spotted with yellow); its tube longer than the calyx; the roundish lobes all spreading: stamens included. - Pursh, Fl. ii. 427, t. 20. M. roseus, Dougl. in Bot. Pieg. t. 1591; Hook. Bot. Mag. t. 3353 ; Brit. Fl. Gard. ser. 2, t. 210.

Shady or damp places and along streams, throughout the Sierra Nevada and in the northern part of the State, extending through Oregon and to the Rocky Mountains. Capsule as in the preceding. 


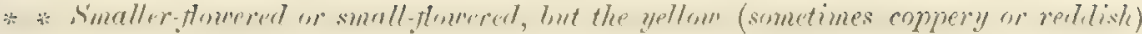
corolla often a full inch or more long in $\boldsymbol{M}$. luteus: seeds, except in the first species, with smooth and thin polished coat.

+ Leafy-stemmed, glubrous, or merely pubescent or glandular.

+ Calyx oblique at the orifice, especially in fruit; the upper tooth largest: leaves mostly broad and thin, at least the lower very distinctly or abruptly petioled, all 3 - several-nerved at base.

14. M. Iuteus, Linn. Erect or diffuse, from a fibrous annual root, and commonly perennial by short stoluns, glabrous or merely puberulent; the ordinary erect form a foot or two or even 3 or 4 feet high: leaves ovate, oval or roundish, sometimes cordate, several-nerved from base and near it, sharply and irregularly dentate, of the lower occasionally lyrate-laciniate; the upper sessile; the floml becoming small and bract-like, often connate: peduncles becoming racemose, equalling or shorter than the flower: calyx becoming ovate-iuflated in fruit and the upper tooth couspicuously largest: corolla from $1 \frac{1}{4}$ to $\frac{3}{4}$ of an inch long, yellow, often dotted within and sometimes blotched with brown-red or purple. — Bot. Mag. t. 1501, 3363; Bot. Reg. t. 1030, 1796; Andr. Bot. Rep.t.661. M. guttatis, DC. Hook. Fl. ii. 99. M. variegatus, Lord. Bot. Cab. t. 1575. M. rivularis, Lodil. Bot. Cab. t. 1525 ; Nutt. in Jour. Acarl. Philad. vii. 47. M. lyratus, Benth. Scroph. Ind. 1. c, a state with lower leaves lyratcly laciniate at base. M. Scouleri, Hook. 1. c., a nalrow-leaved form. M. glabrulus, HLK. (?) M. Roezli, Regel. - Runs through numerous and very various forms. The following aro dwarf or depauperato valieties.

Tar. alpinus, Gray. A span or less high, equably leafy to the top : leaves half an inch to an inch long, ovate or oval, denticulate or some of them entire : stems 1 -4flowerert: corolla proportionally large (an inch or less long). - Proe. Acad. Philad. 1863, 71; Watson, Bot. King Exp. 224. M. Tilingii, Regel, Gartenfl. 1869, t. 631 , - the same plants the second year developing into the ordinary condition of the species, and figured by Regrel, 1. c. 1870,290 , t. 665 . M. cupreus, Teitch, in Gard. Chron. 1864, 2 ; Recrel, 1. c. 1864 , t. 422 (M. luteus, var. cuprea, Hook. f. Bot. Mag, t. 5478), - a form with the corolla turning orange or coprer-red.

Var, depauperatus, Gruy. Slender, mostly smooth, and with shaply-tootheil or laciniate leaves (from a fourth to half an inch long), slender petioles, and filitorm. peluncles twice or thrice the length of the small llowers: corolln only a thirl or hulf an inch long: some forms much approaching $M$. alsinoides; but the calyx is that of $M$. luteus, except in size. - M. micropleyllus, Benth. in DC. 1. c. M. tenellus, Nutt. herb., not of Bunge.

Moist or wet groumds, very common, extending north to the Alnskan Islames, east to the Rocky Mountains, and south along tho Andes to the extremity of ('lili. The var. alpinus in the Sierra Nevada, sc. The var. depauperatus consists of reduced forms, fowering as tiny or slender annuals, in Oregon and California.

M. Drstatus, Nutt., from the woods of Oregon, if a Fariety of this species is a peculiar one,

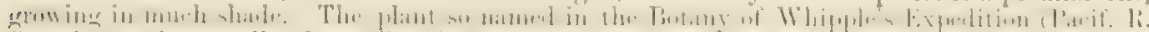
Rep. iv. 64) is a smaller-flowered anel depauperate form of $\dot{H}$. lueves.

M. ALsisord Fs, Dougl., of Orrgon nud British Columbia, resembles the last verioty of M. Iuteus, but is known by the narrower calyx, in fruit ohlong ( 3 or 4 lines long), and the tewh very short : also by the liliform at length divariente peeduncles, of nu inch or more in lengh, and nemply of them honger than the ovate or roumbish leaves, these ull petioled. The larigest forms are a font high, ane diffusely much branched, with narrow corolln half un inch long: The smallest (vas: minimes, Benth.) are minute, with corolla only à lines long.

15. M. laciniatus, (imy. Annual, glabruss, small and very slemeler, a span or less in height, diffue : cauline leaves ublong or sputulate, mestly laciniatuly fewtoothed or lobed, sometimes hastate, 1-nervini, a yutrter to half an ineh loner and with filiform petiole of equal or greater lesgth: pechucles about the length of the 
leaf: flowers very small : calyx short, ovate in fruit, the upper tooth prominently largest : corolla yellow, barely 2 lines long. - Proc. Am. Acad. xi. 98.

Mariposa Co, on the south fork of the Merced, at Clark's Ranch, Groy. A peculiar little species.

\section{+++ Calyx not oblique or searcely so, the teeth all equal: erect and small annuals. $=$ Leaves all distinctly petioled.}

16. M. Pulsiferze, Gray. Puberulent-glandular throughout and viscid, branched from the base, barely a span high: leaves ovate-oblong or ovate-lanceolate, or the radical roundish, sparingly denticulate or entire, 3-nerved at the acute or cuneate base, about half' an inch long (on petioles of 2 to 4 lines), about the length of the peduncles: calyx with very short ovate-triangular teeth, the tube oblong in fruit ( 3 or 4 lines long) : corolla yellow ( 5 lines long), barely twice the length of the calyx. - Proc. Am. Acad. l. e.

Sierra and Indian Valleys in the Sierra Nevada, Bolander, Mrs. Pulsifer Ames.

$$
==\text { Leaves all but the lowest sessile. }
$$

17. M. inconspicuus, Gray. Glabrous throughout, 2 inches to a span high, simple or branched from the base: leaves ovate or oblong-ovate, entire, more or less 3-5-nerved, all but the lowest elosely sessile by a broad base (a quarter to half an inch long), equalling or shorter than the peduncles: calyx with minute teeth, in fruit oval and appearing truncate ( 4 or 5 lines long): corulla about 5 lines long, yellow or rose-color. - Pacif. R. Rep. iv. 120.

Damp hillsides, from Los Angeles to the Sacramento River, Bigclow, Bridges, Rattan. An ambiguous form with more evident calyx-teeth, Contra Costa Mountains, southwest of Monte Diablo, Erewer.

18. M. bicolor, Benth. Viscid-pubescent, from 2 inches to a span or more high, simple or branched from the base: leaves linear-oblong or lanceolate with tapering base, denticulate or toothed, very obscurely 3-nerved at base, seldom an inch long; the lower tapering into somewhat of a margined petiole; the upper shorter than the peduncles: teeth of the calyx conspicuous, triangular (about a line long); the tube oblong, 4 lines long in fruit: corolla more than twice the length of the calyx; the limb comparatively ample, yellow, or the lower lip ustally white. - Pl. Hartw. 328. M. Pratteni, Durand in Jour. Acad. Philad. n. ser. ii. 98 (1855).

Moist banks, not uncommon in the foot-hills of the Sierra Nevada, and through the central part of the State. Calyx commonly dotted with purple. Corolla two thirds to three fourths of an inch long.

19. M. rubellus, Gray. Viscid-puberulent or even pubescent, varying to glabrous with some viscidity, 1 to 6 inches high, branched from the base: leaves from spatulate-oblong to linear, narrowed at base, entire (rarely with one or two denticulations, a quarter to two thirds of an inch long); the lowest often ubovate or roundish, and tapering into somewhat of a petiole; the nerves obseure and the texture rather fleshy : peduncles about the length of the flower : calyx oblong (mostly 3 lines long in fruit); the teeth short and usually roundish: corolla either little or else double the length of the calyx, yellow, red or crimson-purple. - Bot. Mex. Bound. 116; Watson, Bot. King Exp. 225. M. montioides, Gray, Proc. Am. Acad. vii. 380, in part.

Var. latiflorus, Watson, 1. c. A low and large-flowered form, blossoming almost from the ground, nearly glabrous: corolla much surpassing the calyx, often half an inch long, with narrow exserted tube rather abruptly expanded into an ample limb, deep yellow with purple spots. - M. montioides, Gray, l. c., mainly.

Common through the Sierra Nevada and its foot-hills, and through the dry interior to the Rocky Mountains and New Mexico. The variety near Carson, and in the high southern Sierras. A polymorphous little species, the size of the flower varying wonderfully. There is also a form 
with calyx-teeth as long in proportion as those of $M$. bicolor. In the dehiscence of the membranaceous capsule the placenta sometimes splits into two portions adnate to the valves, but as conmonly is barely 2-cleft at the sumrait. The whole plaut is often purplish.

+ + Leafy-stemmed, viscilly villous on pilose: leaves all petioled, thin and broad, toothed, more or less pinnately veined: corolla yellow: calys slightly if at all oblique.

20. M. floribundus, Dougl. Annual, erect or with numerous ascending branches, a span or two high, flowering from the base: leaves ovate (half to a full inch long), the lower slightly cordate: upper peduncles longer than the leaves: calyx short-campanulate, becoming ovate in fruit (barely is quarter of an incli long); the teeth short, equal, broadly triangular : corolla barely half an inch long: capsule globose-ovate, obtuse. - Lindl. Bot. Reg. t. 1125.

Moist ground, throughout the Sierra Nevada region (Bigelow, Lcmmon, Rothrock); thence to Oregon and the Rocky Mountains.

21. M. moschatus, Dougl. Annual, or perenuial hy the ereeping stems, diffure and decumbent, beset with very soft long hairs, strongly musk-scented : leaves ovate or oblong, short-petioled (an inch or two long), mostly exceeding the pedumcles: calyx short-prismatic, oblong-campanulate in fruit (a third of an inch long); the teeth somewhat unequal, rather long, acuminate : corolla two thirds to a full inch long : capsule ovate, acute. - Lindl. Bot. Reg. t. 1118.

Wet and muldy ground; common in the mountains, especially northward, extending to British Columbia, and eastward to Utah. The Californian specimens of this, the Mrusk-plane of the gardens, incline to have a longer corolla, fully thrice the length of the calyx, and twice the size of that of the plant in common cultivation.

$$
+\div+ \text { Scapose. }
$$

2.2. M. primuloides, Benth. Perennial by stulons, llwarf: lonvess spsile, from broadly obovate to linear-oblong, entire or toothed, 3-5-nerved, obtuse (a quarter to a full inch long), all crowded in a radical tuft at the base of the filiform ( 1 to 3 inches loug) scape, or, in large and vigorous plants, in several approximate pairs on a stem which is as long as the one or two peluncles ( 1 to 4 inches): calyx narrow (in fruit oblong and at most 3 lines long), with short and equal teeth, less thin half tho length of the funnelform golien yellow corolla. - Regel, Gartentl. 1872, t. 739 .

Wet meadows in the Sierm Nevada, from Mount Whitney northward to Oregon, and in Nevarla; only at considerable elevations, Leaves at first villous with long and soft jointerl huirs: peduncles and calyx ghlahrous. Curolla varying from 3 to 8 lines in lengtle.

\section{\$ 5. Corolla, dec., of Mimulues proper: calyx short and 5-cleft, not prismatic nor with carinate angles or lobes: capsule and divided placente as of the section Eunanus: low annual. - Mrmerordes, Benth. under Herpestis.}

23. M. pilosus, Watson. Annual, a span or more hich, much brancher from the base, leafy, villous throughont with long and soft white and somewhat viscid hairs, flowering from alnost all the axils: leaves lnnceulate or almost oblong, entire, sessile, the later ones about the length of the peduncles: culyx oblique, the iz!n' touth longest and about tho longth of the tube, all oblong or ovate : corolla yellow, 3 or 4 lines long, little exceeding tho calyx; the lins short and with equal lobes, a mir of brown-purple spots on the lower: capsule ubleng-nvate, neute. - Bot. King lixp. 225. Verpestis (Wimulnides) pilose, Benth. in Comp. Bot. Mag. ii. 57, d: DC. 1. c. 394. Mimulus exilis, Dursud, in Pacif. R. liep. v. 12, t. 12.

firavelly banks of strenus; very common, extemling into the horders of Nevaln. Lohes of

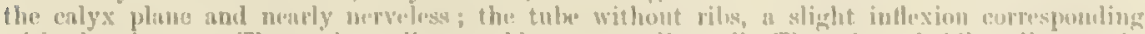
with the sinuses. "The nuther-cells sre oblong, not "lineas." The stignu is bilanellate, us in the genus, not "entire." 
10. STEMODIA, Linn.

Calyx deeply 5-parted; the divisions narrow and nearly equal. Corolla short; the upper lip 2-lobed; the lower 3-parted. Stamens 4, included: cells of the anthers separated and even short-stalked. Stigma 2-lobed. Capsule short, septicidal and the valves at length 2-parted: the placenta left in the axis. Seeds numerous. - Viscid-pubescent herbs, chiefly tropical, with opposite or whorled leaves, and solitary flowers in their axils; these sometimes becoming spicate or racemose at the summit of the stems: a pair of bractlets at the base of the calyx.

1. S. durantifolia, Swartz. Erect, a span to a foot high: leaves lanceolate, sharply serrate, mostly narrowed below and then with a dilated partly clasping base: flowers sessile : corolla purplish, a quarter of an inch long. — S. verticillaris, Link; Reichenb. Ic. Exot. ii. t. 149.

Wet grounds: southern borders of the State, Coutter, Palmer. Extends to S. America.

\section{GRATIOLA, Limn. HFDGe-Hyssop.}

Calyx 5-parted; the divisions narrow and hardly unequal. Corolla with upper lip entire or 2-lobed; lower one 3-cleft. Stamens included, only 2 fertile; their anthers with 2 transverse cells on a broad connective; the anterior pair reduced to simple sterile filaments or wanting. Style commonly bent at the tip : stigma of 2 flat lobes or lips. Capsule many-seeded, 4-valved, leaving the thick placenta in the axis. - Low and branching herbs; with opposite sessile leaves, and small solitary flowers on simple naked peduncles in their axils, with or without a pair of bractlets under the calyx : flowering in summer; the corolla in ours whitish and yellowish.

A genus of about 20 species, widely distributed over the world, mainly in temperate climates, inhabiting wet places.

I. G. Virginiana, Linn. Minutely viscid-puberulent, a span high, diffuse: leaves lanceolate, sparingly serrate, mostly narrower below: peduncles equalling or surpassing the leaves: a pair of conspicuous bractlets at the base of the calyx: corolla (4 lines long) twice the length of the calyx: capsule ovate.

In the Sierra Nevada, Plumas Co., \&c. (Lemmon); thence through Oregon to the Atlantic States.

2. G. ebracteata, Benth. Lower and more erect, glabrous, obscurely viscid: leaves lanceolate, acute, oftener entire: no bractlets to the calyx, which about equals the small corolla: calyx globose, - DC. Prodr. x. 595.

Northern part of the State (Ukiah, Botander), and in Oregon. Root annual.

12. ILYSANTHES, Raf.

Calyx 5-parted; the divisions narrow and nearly equal. Corolla with a short and erect 2-lobed upper lip; the larger lower one 3 -cleft and spreading. Stamens only 2 fertile, included, with 2-celled anthers; the anterior pair sterile, inserted high up on the throat of the corolla, consisting each of an unequally 2-lobed filament; the shorter lobe smooth and tooth-like, the longer one glandular. Style straight: stigma of two small flat lobes or lips. Capsule small, many-seeded, 2-valved; the edges of the valves separating from the partition, which is left with the undivided placenta. - Small and low annuals, glabrous; with opposite sessile leaves, and solitary 1-flowered filiform and naked peduncles in their axils, the upper becoming racemose by the reduction of the subtending leaves to bracts. Flowering all summer.

A genus of several species, distributed over the world in the manner of Gratiola. 
1. I. gratioloides, Benth. Diffusely branching, about a span hish: leaves ovate or ublong, sparingly toothed or entire: peduncles mostly twice the length of the leaves, divergent in fruit: corolla violet or purple, 3 or 4 lines long.-Capraria gratioloides, Linn.

Wet places, in the Sierra Nevada (Lemmon): thence to Oregon and through the Atlantic States : also in S. America. Occurs on the coast of France, but probably a casual introduction.

\section{LIMOSELLA, Ling. MUDWORT:}

Calyx campanulate, 5-touthed. Corulla letween rotate and campanulate, 5-cleft, nearly regular. Stamens 4 , mearly equal: anthers contluently l-cellech. sityle short,

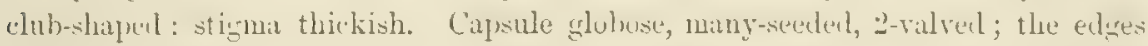

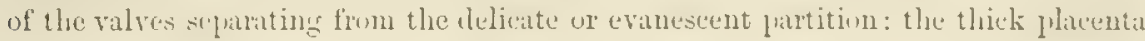
left in the axis. - Diminutive and glabrous annuals, rooting and creeping in mud, especially when saline; with narrow entire fleshy leaves, in clusters around the simple 1-flowered peduucles or scapes, and at the end of the runners, or when scattered alternate. Flowers small : corolla white or purplish.

1. I. aquatica, Linn. An inck to a span high: petioles longer and in water much lumger than the linear or spatulate-oblong or wral blate, and longer than the peduncles.

Along the sea-shore, also in and beyond the Sierra Nevada, in brackish mud or sand, or in apparently fresh water; thence to the Rocky Mountains. Common in the Old World. In our broadest-leaved form (Sierra Valley, Lemmon), the blade is two thirds of an inch long and one third wide, in the narrower and smaller less than a line wide. L. tenuifolia, Nutt, which takes its place in the Atlantic States and in the southern hemisphere, has fleshy petioles with no distinct blade.

\section{SYNTHYRIS, Benth.}

Calyx 4-parted. Corolla campanulate, with 4 slightly spreading more or less unewpual lobes, or sometimes divided irresulary, sumetimes wholly wanting. Stamens 2 , inserted on the upper side of the throat (rarely a lower pair inserted neal the base of the corolla on the lower side): anthers 2-celled; the cells parallel and distinct. Style slender: stigma small, undivided. Capsule Hattened, obtuse or emarginate, loculicidal; the valves cohering below by the partition to the central many-seeded placenta. - Perennial herbs (all North American, and chiefly west-

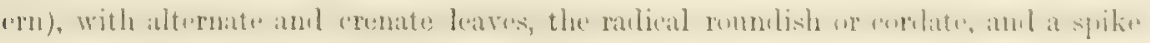

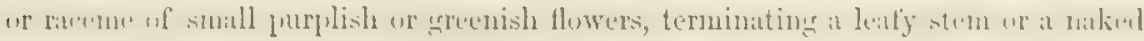
serape.

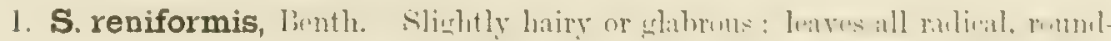
reniform, thin : scape when in blossom hardly surpassing the leaves ( 3 to 8 inches high), bearing a short and loose raceme of several flowers: corolla "blue," about twice the length of the calys. - DC. Prodr. x. 454. Wulfenia reniformis, Benth. Scroph. Inil.; Hook. Fl. ii. t. 171.

Var. cordata: a form with mther coriacens and smaller lenves; the blude an inch long and ovatc-cordate: probably growing in a more exposed situation.

The species oecurs in the woods of Oregon. This variety, on gravelly hillsides, Red Mountain, Menilocino Co, Kellowy.

S. IBuma, Benth. 1. c. (nfymnendra rubra, Ifook. 1. c. 103, t. 172), belongs to Oremon, but may inhahit the northern jurt of the State. It is steuter and conrser, Inbescent when young. has ovate or oblong thickish lenves, those of the flowering stem several and sessile, the flowers in a dense spike and destitute of corollit. The other species are more enstern. 


\section{VERONICA, Lim. SPEEDWÉLl, BrookLIME.}

Calyx 4-parted. Corolla rotate, 4-parted; the lower lobe and sometimes the lateral ones narrower than the others. Stamens 2, inserted on the throat of the corolla, one each side of its upper lobe, exserted: cells of the auther confluent at the apex. Style tipped with a somewhat capitate stigma. Capsule compressed, few-many-seeded; the dehiscence generally loculicidal. - Leaves opposite or sometimes in whorls, or in one species mostly alternate. Flowers small, in racemes or spikes, or sometimes solitary in the axils, blue, purplish, or white.

A genus of about 150 species, distributed almost throughout the world, mainly in temperate and trigid regions, not Iargely represented in North America, and scanty in California. In high latitudes of the southern hemisphere several are shrubs or trees: one or two of these are in ornamental cultivation.

\section{* Low perennials, with opposite leaves.}

+ Racemes axillary: plants glabrous, decumbent or ascending, rooting at base.

1. $\mathbf{V}$. Americana, Schweinitz. Stems a span to 2 feet long: leaves ovate or mostly oblong, serrate, rather succulent, short-petioled, the base slightly cordate or truncate: racemes opposite, slender-peduncled, many-flowered: pedicels slender, diverging : corolla bluish with purple stripes : capsule turgid, many-seeded.

In brooks and ditches, not uncommon : extending north to Alaska and east to the Atlautic. Formerly confounded with the $V$. Beccabunga of Europe.

V. ANAgallis, Linn., like the preceding but with sessile and mostly clasping acute leaves, occurs both north and east of Califfornia.

V. scuteliata, Linn., growing in cold swamps northward, is also in Oregon. It is well marked by its linear sessile leaves, loose racemes from alternate axils, filiform divaricate pedicels, and very flat few-seeded deeply notched capsules.

++ Raceme terminal, leafy below: pedicels short, erect: capsule flat, several-seeded.

2. V. alpina, Linn. Pubescent, or becoming glabrous below: simple stems erect from a somewhat creeping base, a span or more high : leaves oval, oblong, or the lowest roundish, somewhat toothed or entire, sessile : raceme spike-like, fewflowered: corolla blue : capsule obovate or oblong, slightly notehed. - The Greenland and American form, var. Wormskioldii, Hook. Bot. Mag. t. 2795. V. Wormskioldii, Romer \& Schultes.

High portions of the Sierra Nevada, at 8,500 to 10,000 feet (Brewer, Bolander): also in the alpine region of the Rocky Mountains, of the White Mountains in New Hampshire, and through the arctic regions.

3. V. serpyllifolia, Linn. Minutely pubescent or glabrous, branching and creeping at base, leafy : flowering shoots about a span high: leaves round-ovate or oblong, obseurely crenate, thickish, barely half an inch long; the lower shortpetioled; the upper gradually diminished into lanceolate or oblong bracts: raceme strict: corolla whitish or bluish with deeper stripes: capsule strongly notched, broader than long.

Not yet received from the State, but doubtless in the Sierra Nevada, as it occurs northward and eastward, extending through the cooler parts of the northern hemisphẹre.

$$
\text { * Low annual: all the upper leaves alternate. }
$$

4. V. peregrina, Linn. Minutely pubescent or glabrous, a span or more high, erect, branching: leaves rather succulent, mostly linear-oblong, obtuse; the lower commonly toothed; the upper entire and narrower, gradually diminishing, but all longer than the very short-pedicelled flowers in their axils: corolla inconspicuous : capsule rounded-obcordate, many-seeded.

Waste and cultivated grounds, especially near habitations, everywhere appearing like an introduced weed, but doubtless of American origin. 


\section{CASTILIEIA, Linn, f. PAINTED-CeP.}

Calyx tubular, more or less cleft either in front or behind, or both; the lobes 2 and lateral, or 4. Corolla tubular, more or less laterally compressed, especially the Inng and conduplicate or carinate-concave upper lip (galea); the lower lip short or minute, always small in comparison with the upper, 3-toothed, 3-carinate or somewhat saccate below the short teeth; the tube usually enclosed in the calyx. Stamens 4, enclosed in the upper lip: anthers 2-celled; the cells oblong or almost linear, unequal, the outer one tixed by its middle, the inner one smaller and pendulous. Style long: stigma capitate, sometimes 2-lobed. Capsule loculicidally 2 valved, the valves bearing the placenta on their middle. Seeds numerous, with a

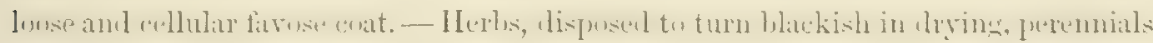
and sometimes a little woody at base, or a few annula ; most of the leaves alternate, all sessile, the floral ones or their tips, as well as the calyx-lobes, commonly petaloidcolored (red, sometimes whitish or yellowish). Flowers in terminal and simple spikes, without bractlets. - Gray in Am. Jour. Sci. xxxiv. 335; Watson, Bot. King Exp. 456.

A genus of 30 or more species, all American, except one in Northern Asia, the greater prart North American west of the Jississippi and in the Andes. The brightly colored floral leaves or bracts of most of them are more showy than the flowers, the corolla being commonly yellowish or greenish.

\$1. Annual: leaves all entire and linear-lanceolate; or the upper floral sometimes a little dilated and incised: calyx narrozw, as deeply clejt behind as bejore and usually more 80 : all the lower flowers pedicelled.

1. C. affinis, Hook. \& Arn. Pubescent : stem strict and mostly simple, a foot to a yard high: flowers scattered or the upper crowded in the leafy spike, curving: calyx and the upper bracts tinged with red: corolla an inch or more long, yellowish, or the tip reddish, surpassing the calyx; lower lip very short but protuberant, its

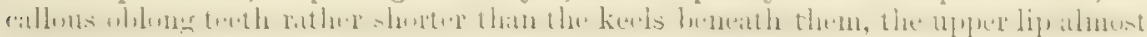
as long as the tube. - Bot. Buechey, 154.

Moist grounds or along streams, from San Diego to the Sacramento. The plant fignred nuder this name by the late C. A. Meyer, in the Sertum Petrop. ii., is apparently a common largeflowered fonm of C. parviflora, i. e. C. Douglesii, Benth.

2. C. minor, Gray. More slender, a foot or two high, simple or paniculately hranching, the pubescence somewhat viscid: flowers at length senttered in a virmate leafy apike, straight: upper bruets red-tipped, slender: corolla little exceeling the green calyx, 6 to 9 lines long, yellowish; its lower lip extremely short and not protuberant, its teeth thin and rounded; tho upper lip rather broad and not half the length of the tube. $-C$. affinis, var. minor, Gray in Ibot. Mex. Bond. 119, \& Am. Jutur. Sici. 1. c.

Not yet found within the limits of the State, but near hy, in Nevnda, at Carson City (Anderson) and Truckee Valley (II'relson); also in Arizonn, and enst to New Mexico and Nelonska.

\section{\$2. Perennial: leaves all narrow: calyx narron, deeply cleft before, thothes behind; the teeth subulate.}

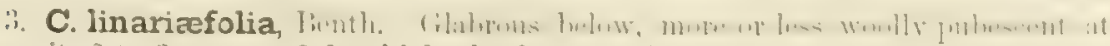
stmmit, 2 to 3 ur even 6 feet high, slender, sometimes paniculately hranched alwive: leaves not brialened at base, linear, eutire, or some of the mpere and flumal 3-cleft : spike dense, or beluw loose : flowers soon eurved, the lower short-pedirelled: comiln an inch or two long, narrow, scirlet or red, as are also the cnlyx nul the lobes of the bracts; the falcate upper lip commouly yellow or yellowish, as long as the tulu, 
wholly exserted; the lower lip extremely short, callous and protuberant. $-C$. candens, Durand in Pacif. R. Rep. v. 12.

Sides of rocky hills, near Fort Tejon and in the Sierra Nevada, chiefly in the eastern ranges and at about 8,000 feet; thence along the mountains to New Mexico, Colorado, and Wyoming.

\$ 3. Perennial: calyx cleft more or less behind as well as before; the lobes therefore right and left, two and entire or notched, or else 2-parted, making 4, variable in this respect.

\section{* White-woolly, rather shrubby at base.}

4. C. foliolosa, Hook. \& Arn. A foot or two high, clothed with a matted white wool (consisting of intricately branched hairs), which becomes loose with age: leaves rather short and very numerous, being often in fascicles in the axils, linear and entire, or with a pair of linear divaricate lobes; the upper floral cleft and their Iobes with more or less dilated yellowish or red tips: the 2 calyx-lobes broad, retuse or merely notched, nearly equalling the corolla, the lower lip of which is very small. - Bot. Beechey, 154 ; Gray in Bot. Mex. Bound. 118.

Hillsides, Mendocino Co. to San Diego, must common southward. Seeds elongated-oblong, somewhat club-shaped.

* * Pubescent or villous-hirsute with simple hairs, or below glabrous, herbaceous.

- Leaves short and small, broad and obtuse.

5. C. latifolia, Hook. \& Aru. 1. c. A foot or two high, diffusely branched from the base, the copious soft-hirsute pubescence viscid: leares from round-obovate to oval, half an inch to an inch long, sometimes 3-5-lobed, especially the dilated floral ones, the uppermost red; the 2 calyx-lobes broad and notched or 2-lobed at the summit, longer than the tube of the corolla; the lower lip of which is very short, callous, and the teeth inflexed.

Along and near the coast, Mendocino Co. to Monterey. Corolla about two thirds of an inch long; the narrow upper lip rather longer than the tube.

++ Leaves or their lobes from lanceolate-oblong to narrowly linear. (The species variable and difficult.)

+ Upper lip of the corolla elongated, as long as or longer than the tube, many times longer than the very short lower lip: floral leaves or their lobes dilated and petaloid, scarlet or crimson, rarely yellowish or whitish: calyx mostly tinged with the same color: corolla yellowish often tinged with green, sometimes with red.

6. C. parviflora, Bongard. From villous-pubescent to hirsute, especially above, a span or two to a foot or two high: leaves laciniate-cleft or incised, sometimes entire: corolla an inch to half an inch in length; the lower lip not callous-saccate and protuberant. - Veg. Sitcha, 157; Gray in Am. Jour. Sci. 1. c. C. Toluccensis, Cham. \& Schlecht. in Linnæa ii. 579 (?), not of HBK. C. coccinea, Lindl. Bot. Reg. t. 1136, not of Spreng. C. hispida, Benth. in Hook. Fl. ii. 105. C. Douglasi, Benth. in DC. Prodr. X. 530. Euchroma angustifolia \& E. Bradburie, Nutt. in Jour. Acad. Philad. vii. 46 ; small forms.

Open grounds, from the mountains behind San Diego northward throughout the State, extending to Sitka, and through the mountains to Dakotah, \&e. The earlier name is the least appropriate and is even misleading; the flowers when well developed being as large as in the eastern C. coceinea, or even larger, except in some dwarfed mountain forms. Sac below the teeth of the lower lip thin and little projecting, longer than deep, 3-carinate; the teeth (at first involute and always small), remarkably variable, sometimes lanceolate and acute and as long as the saceate portion, or the middle one shorter or obsolete; sometimes all short and ovate or deltoid; occasionally all three truncate and extremely short.

7. C. miniata, Dougl. Glabrous below, more or less pubescent above, commonly 2 feet high, strict, often slender : leaves lanceolate or linear-lanceolate, almost always entire; the broader floral ones or bracts of the close spike at most incised or 3-cleft, 
shorter than the flowers: corolla more than an inch long, narrow; the linear-lanceolate upper lip couspicuously long and exserted; the lower very protuberant, as deep as long, callous and mammeform, with the ovate short teetl involute. Hook. Fl. ii. 106. C. pallida, var. miniata, Gray in Amer. Jour. Sci. l. e.

In the Sicrm Nevada and other mountainous districts, extending northward and eastward through the same range as the preceding.

++ Upper lip of the corolla considerably shorter than the tube, barely twice or thrice the length of the comparatively conspicuous lower lip.

8. C. pallida, Kunth. A foot or so high, above commonly villous with long and weak cobwebby hairs, especially the dense leafy-bracted spike: leaves all or mainly entire, membranaceous; the lower linear ; the upper from narrowly to ovatelanceolate; the floral or bracts often sparingly laciniate or cleft, colored usually with white or yellowish, equalling the flowers (these commouly an inch long): lower lip of the corolla only one third or half shorter than the upper. $-C$. Sibirica, Lindl. Bartsia pallida, Limn. This is Siberian and Arctic X. W. American.

Var. septentrionalis. Commonly less pubescent, often almost glabruus, a span to two feet ligh: bracts not rarely tinged with purple: corolla two thirds to three fourths of an inch long; its lower lip less large, from one third to half the length of the upper, - C. septentrionalis, Lindl. Bot. Rer. t. 925 (I825). C. acuminata, Spreng. Syst. ii. 775 (1825, Bartsia acuminata, Pursh, unless this be $C$. miniata, a slender pale form of which comes from Sitka, \&c.).

Var. occidentalis. Barely a span high, tufted: leaves rather rigid, narrow; the upper cauline as well as the sparingly colored (pale) bracts often 3-cleft : corolla a third to half an inch long; its lower lip about half the length of the upper. $C$. occidentalis, Torr. in Ann. Lyc. N. Y. ii. 230.

Even the var, scptcutrionalis, which abounds on the higher mountains north and east of California, and extends across the continent high northward to Labrador, has not been met with in the State. Var. occidenlalis (belonging to the higher alpine region of the Rocky MLountains), on the higher parts of the Sierra Nevada, from Tulare Co. to Sierna Co., Brewer, Bolander, Lemmon.

\section{ORTHOCARPUS, Nutt.}

Calyx short-tubular or oblong-caupanulate, 4-cleft, or sometimes cleft before and behind, and the two lateral divisions 2-cleft or parted. Corolla tubular; the upper lip (galea) little or not at all longer than the lower, like that of Castilleia but shorter, small in comparison with the inflated $1-3$-sacente lower one. Starnens as in Casilleia, or the lower and smaller anther-cell sometimes wanting. Style, capsule, \&c., similar. - Low annuals, with two exceptions (of the Californian region and one South American), more or less resembling Castilleia in foliage and intlores-

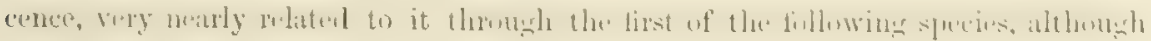
the later ones are conspicuously different.

\$1. Lower lip of the corolla simply or somewhat triply saccate, and bearing 3 conspicuous mostly erect teeth or lobes; the upper lip broalish or narrow: stigma onpitute: anthers all 2-celled: seed-coat very lonse, cellular-finose and arilliform: bracts with more or less of colored tips. - CAsTILLEloIdes, Girny.

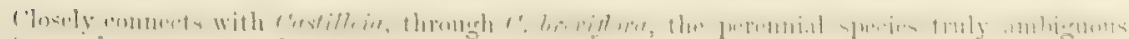
letween the two genern, but retained here on account of the size of the lower lip, which nearly

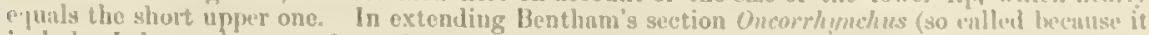
include's Lehmann's genus Oncorrhmehus), the sectional namo is changerd on necount of its inapproprateness : for the galea is not hooked in the original South American species, nor in any other, except in the anomulous 0. purpuresecons. 
* Root perennial! : lips of the short and yellowish corolla somewhat equal, the upper being broadish and blunt (straight) and the lower rather obscurely saccate: filaments glabrous.

1. O. pilosus, Watson. A span or two high, many-stemmed from the firm root, either suft-villous or hirsute, very leafy : leaves rather rigid, at least when old; the lowest linear and entire; the others 3-5-parted into narrowly linear diverging lobes; the lower floral similar, the upper ones with more or less dilated and sparingly colored (white or yellowish) tips: spike dense, rather short: calyx somewhat equally 4-cleft into narrow linear lobes which nearly equal the corolla, or these united at base in pairs: lower lip of the corolla at first equalling, at length a little shorter than the upper; its lobes ovate, shorter than the slightly saccate portion beneath. - O. pallescens, Gray in Am. Jour. Sci. xxxiv. 339, \& Proc. Am. Acad. vii. 384, except as to Nuttall's plant. O. pallescens (the more rigid form) \& 0 . pilosus (the softer villous form), Watson, Bot. King Exp. 231, 459.

Higher parts of the Sierra Nevada, from Tulare Co. to Sierra Co, and on Mount Shasta, at 5,000 to 9,000 feet (Brewer, Torrey, Kellogg, Lemmon, \&c.); and in the interior of Oregon and Idaho. Corolla 6 to 8 lines long; the lips only 2 lines long; lower with the slightly ventricose portion rather longer than the lobes, obseurely callous below the base of these, within more or less plaited-trisaceate. Stigma large, strongly capitate.

0. PALlescens, Gray, 1. c., as to Nuttall's Euchroma pallescens only (and which may best retain the name, since one is provided for the species confounded with it), proves to be identical with O. Parryi, Gray in Amer. Nat. viii. 214, from the Rocky Mountains in Western Wyoming. It is distinguished by a minute and somewhat hoary pubescence (even the inforeseence destitute of villous or hirsute hairs), less leafy stems, looser spike, and the pair of ealyx-lobes broader and united high up, lower lip of the corolla rather more ventricose, and the floral leaves or bracts nearly if not absoiutely without colored tips.

$$
\text { * * Root anmual, as in all the following species. }
$$

+ Filaments glabrous: upper lip of the corolla straight or nearly so, naked, narrow, lanceolate-triangular or broadly subulate; the lover moderately ventricose, and within somewhat plaited-trisaccate for its whole length; its teeth on lobes erect and. conspicusous, oblong-linear : capsule oblong or oval.

2. O. attenuatus, Gray. Slender, strict, a span or two high, mostly simple, above hirsute-pubescent: leaves linear-attenuate with a few setaceous lobes, or the lower entire: spike virgate, loosely-flowered below, in small specimens with few and rather scattered flowers: bracts with their slender divisions barely white-tipped: corolla narrow throughout, only half an inch long, white or whitish, with one or two purple spots on the lower lip, the narrow teeth of which nearly equal the upper. - Pacif. R. Rep. iv. 121.

Borders of San Francisco Bay, \&c. Also Oregon (E. Hall) to Puget Sound, Lyall. Resembles a slender form of $O$. hispidus, but in character more like a depauperate $O$. densiftorus, into which it may pass.

3. O. densiflorus, Benth. Erect or diffusely branched from the base, a span to a foot high, above soft-pubescent: leaves linear or linear-lanceolate and gradually attenuate, with a few slender lobes, or the lower entire: spike dense, many-flowered, at length cylindrical, or the lower flowers somewhat scattered: bracts 3-cleft, about equalling the flowers; the linear lobes with purplish and white tips: corolla from two thirds to near an inch long, purple and white (the lips or their tips usually purple), the teeth of the moderately dilated lower lip shorter than the upper. Scroph. Ind. \& in DC. Prodr. x. 536.

Low grounds along the coast, from San Luis Obispo to Sonoma Co. The stem is commonly erect, rather than "diffuse"; and the var. latifolizus, Benth., with few or no lobes to the cauline leaves, is the commoner form. Seeds small, short-oval, the mature nucleus very loose in the cellular coat.

4. O. castilleioides, Benth. At length diffusely much branched, a span or 
two high, somewhat pulwescent or in the mostly lense shurt spikes smmetimes villous-hirsute: leaves from narrowly lanceolate to oblong, entire or laciniate-incised into rather short and blunt lobes; the upper and the bracts more cumeate-dilated, equalling the flowers, herbaceous, the blunt tips whitish or yellowish : corolla near

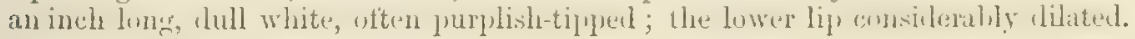

Pine woorls and low grounds near the sea-shore, Monterey to Humbollt Co., and along the coast to Washington Territory. Seeds oblong, twice or thrice larger than those of the preceding, to which the species is much more nearly related than to the next.

++ Filaments pubescent: upper lip of the corolla long and almost linear, obtuse and hooked at the apex, densely red-bearded; lower lip with three very small and somezohat didymons little sacs at its broad apex, directly under and not larger than the short and rounded recumbent teeth or lobes: stigma very large, depressed-capitate: capsule ovate.

5. O. purpurascens, Benth. Erect, at leneth diffusely mule hranched at the base, rather stout, a span to a foot high, hirsute: leaves above the lanceolate or linear base laciniately once or twice pimately parted into narrow linear or filiform divisions: spike dense and thick, oblong, at length cylindrical: bracts about the length of the flowers; their laciniate-lobed divisions or their tips and those of the calyx-lobes crimson-purple and rose-color: corolla about an inch long, the tube yellowish or whitish, the summit crimson or red.

Common along the hills and mountains of the coast, from MIonterey to Humboldt Co., so abundant as to give the ground a purple hue for miles in some places: occasionally, with duller or only pallid color, in salt marshes. The reddish soft and copious beard of the narrow and hooked upper lip, which marks this species, is composed of many-and close-jointed hairs. Sceds - oval ; the loose arilliform coat deeply favose.

\$2. Lower lip of the coralla simply saccate or nearly so, its 3 teeth very shost and inconspicuous or absolete; the upper lip moderately smaller, short, ovate-triangular; the tube hardly if at all surpassing the calyx: stigma small and entive: anthers all 2-celled: sceds with a very loose costate-reticulated coat: bracts all herbaceous. - True OrTHocarpos. (Orhocarpus, Nutt.)

6. O. luteus, Nutt. A span to a foot high, with strict simple or virgately branched stem, minutely pubescent and more coarsely hirsute: flowers leafy-spicate: leaves linear-lanceolate, entire or 3-cleft; the floral ones similar or often broader: calyx-teeth lanceolate, acute: corolla golden yellow (half an inch long), not exceeding the floral leaves or brets; the lips of equal length and not very ditierent in size - O. strictus, Benth.; Hook. Fl. ii. t. 172.

Dry banks and plains, along the northenstem borders of the State (Carson and Lake Washoe, Nevadn, Anderson, Torrey); thence northward and enstward to British (olumbia and to the Upper Mississippi.

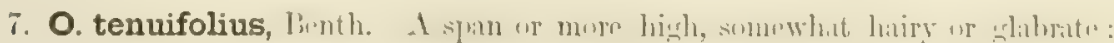
flowers in a dense thick spike: leaves or at least the upper ones hispid-eiliate; the lower linear and mustly $3-5$-cleft, with the divisions linear-filiform; the Horl or bracts broadly ovate, incisely 2 - 3-cleft or tonthed, or often entire, becoming thin and reticulated in age, usually imbricated over the flowers or fruit: calyx-tecth subulate: corolla purplish; the upper lip becoming longer, slightly hooked at the tip. - Bartsia tennifulia, Pursh. O. imbricatus, Watson, Hot. King Exp. 458.

Dry rilges, Sierra Nevadn, near Summit ( $E$. L. Orene), and Lassen's P'enk (Lrmum): thence to British Columbia and Montana. Sprikes from 1 to at length 3 or 4 inches long; the brom imbricated bracts strikingly and abruptly different from the leaves below. The ('uliforniam specinens are of the smoother form, very nearly that described its 0 . imbricalns.

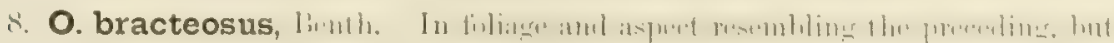
the bracts deeply 3-cleft and with triangular-lanceolate lobes (their pulsesener mather hisute), shorter than the bright rose-purple corolla : lower lip of this ampler and more saceato; the upper with narrower and more deeidedly hooked tip. 
Plumas Co., Lemmon. Thence north to British Columbia. Corolla over half an inch long, slightly or decidedly pubescent.

O. ToLmiex, Hook., is a smoothish and loosely branching species of this section, with attenuate and mostly entire leaves, flowers in short and at length loose spikes, and smooth yellow corolla seldom half an inch long. It inhabits Utah and the interior of Oregon.

O. PURPUREO-Albus, Gray (Watson, Bot. King Exp. 458), the only remaining species of this section, is a native of New Mexico and Southern Utah. It is known by its attenuated and uniform leaves, slender loose spike, and especially by the more exserted and slender tube of the (purple and white) corolla, the galea also rather narrower; so that it counects with the next section, with some species of which it agrees in having the loose seed-coat coarsely reticulated, but not costate nor with the areolations in longitudinal rows.

§ 3. Lower lip of the corolla conspicuously 3-saccate, and very much larger than the slender upper one; its teeth small or minute; the tube filiform or slender: stigma capitate, sometimes 2-lobed: bracts all herbaceous and like the leaves, or their tips somewhat colored in O: gracilis and the last species. - TRIPHYSARIA, Benth. (Triphysaria, Fischer \& Meyer.)

* Anthers one-celled: lower lip of corolla saccately 3-lobed from the end: seed-coat close, conformed to the 1-2-apiculate nucleus.

+ Stamens soon free from the less involute oblong-lanceolate upper lip of the corolla.

9. O. pusillus, Benth. Weak and diffuse, branched from the base, 2 to 6 inches high, somewhat hirsute: leaves 1-2-pinnatifid or floral ones 3-5-parted into filiform or almost setaceous divisions, exceeding the scattered and inconspicuous flowers: corolla purplish, glabrous, 2 or 3 lines long; the tube not exceeding the calyx and little longer than the lips; the upper lip considerably longer than the moderately 3-lobed lower one, a little surpassing the longer stamens: capsule globular. - Scroph. Ind. 12, \& DC. Prodr. x. 535.

Low ground, around San Franciseo Bay, and in Oregon. Lower lip rather open and with beardless throat; the sacs short.

10. O. floribundus, Benth. 1. c. Slender and erect, a span to a foct high, almost glabrous, fastigiately branched: npper part of the leaves pinnately parted into linear-filiform divisions, some of them incised: spike many-flowered, dense above: bracts of the upper flowers not exceeding the calyx: stamens about the length of the soon open upper lip of the corolla; the lower lip with 3 diverging oval sacs; their scarious teeth lanceolate and exect.

Hillsides, common around San Francisco Bay. Corolla white or cream-color, half an inch long, glabrous or the tube slightly pubescent; this twice the length of the calyx; two longitudinal villous lines on the inside of the lower lip corresponding to the sinuses between the saes.

+ + Stamens more strictly enclosed in the acute involute-subulate upper lip: lower lip of 3 obovate or globular-inflated sacs, tomentose-puberulent underneath or glabrous, not more than a quarter of the length of the filiform and mostly densely pubescent tube; the two folds within separating the sacs villous-bearded: flowers numerous in a rather dense spike: upper bracts not exceeding the calyx; the lower and the cauline leaves above the broader entire base pinnately parted into slender setaceous or filiform divisions.

11. O. erianthus, Benth. 1. c. Erect, fastigiately much branched from near the base, soft-pubescent, a span or two high: corolla sulphur-color, with the very slender and acute slightly falcate upper lip (and sometimes the throat) dark purple; the tube thrice the length of the calyx (half to two thirds of an inch long).

Var. roseus, with rose-colored corolla (or white turning rose-purple?) ; the tube shorter. - Triphysaria versicolor, Fischer \& Meyer, Ind. Sem. Petersb. ii. 52?

Moist grounds, common from Monterey Bay northward. The variety in sandy fields, Noyo, Mendocino Co, Bolander. Fischer and Meyer describe their plant above eited (which must have come from north of San Francisco) as having a white corolla changiug to rose-color, and the tube twice the length of the calyx. The beard within the lower lip is denser in this than in the next. 
12. O. faucibarbatus, Fray. Tearly glahrons, or the bracts, \&ce, with some short hirsute pulneicence, ratler stout, anil the branches fewer: leares rather coarser: corolla apparently white and with smaller sics: the heard within less conspicuous; the strainht upper lip harsly tinged with purple: utherwise nearly as $O$. eriunthus. - Pacif. R. Rep. iv. 121 ; Watson, Bot. King Exp. 457.

Moist grounds, around San Francisco bay and northward to Hendocino Co., apparently not rare.

* * Anthers 2-celled; the lower cell mostly small and imperfect in the first two species: seed with an outer loose and arilliform coarsely reticulated coat.

+ Lower lip of the corolla very broad; the sacs deeper (horizontally) than long,

+Comparatively small: narrow upper lip iruncate at the lip): capsule oblung, abtuse.

13. O. gracilis, Tenth. Minutely pubescent, or below glabrous, brancher from the base; the slender branches a span or more high: leaves 3-parted into linearfilifurm divisious, or sume of the lower nearly entire: nyper bracts shorter than the rather closely spieate llowers, the tips of their lobes purplish-tinged : corollat puhescont, purplish; its slemler tube twien the leneth of thr calyx; luwer lip decidenly shorter than the upper; its sacs small but deep, sornewhat conical.

California (near Monterey?), Douglas, Nuttall. We have only specimens from Douglas. Corolla 7 lines long; the upper lip 2 lines; lower one a line deep. Seeds broadly oval, in a very loose and lace-like arilliform coat.

++ Sacs ample: upper lip subulate: capsule ovate: stem simple or few-branched: spike thickish and commonly dense, at least above.

14. O. campestris, Benth. Cilabrons or noirly so below, above (the calyx and base of bracts) birsute or hispid, 2 to 4 inches bigh: leaves and bracts narrow-linear and entire, rarely with a lobe or two: calyx-lobes lanceolate, often united in pairs: corolla white; the erect and scarious teeth of the lower lip slender and rather conspicuous. - Pl. Hartw. 329.

Fields in the valley of the Sacramento, Hartweg. Plumas Co., Mrs. Pulsifer Ames. Corolla about three fourths of an inch long: lower lip 2 lines deep.

1.) O. lithospermoides, Benth. Hirsute abure, puhesent below, ahunt a foot high, strict and simple or with some erect branches, very leafy : leaves lanceolate or lanceolate-linear and all but the lower with few or several slencler lobes; the floral with a dilated base and somewhat palmate lobes almost equalling the crowded flowers: calyx-lobes linear: corolla cream-color, "often turning pale

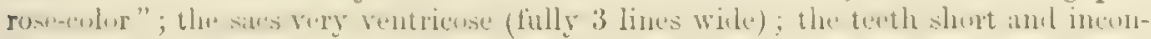
spicuous.

Hillsides, and moist meadows ; common through the western part of the State from San Francisco Bay and the Sacramento northward. Corolla an inch long or rather less.

++ Lower lip of the corolla less antple, surpassed by the subulate upper one; the sacs not deeper than long: hirsute, strict and simple, or the larger plants branching, with leaves and lobes linear and mostly attenuated: spikes leafy: calyx-lobes slender.

16. O. lacerus, linth. A span to a fout high, rather soft-himute and abure

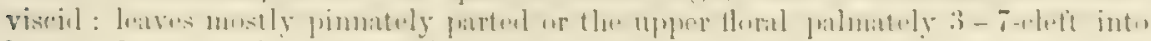
long and narrow divisions or lobes: leafy spikes at first dense, at length loose: calyx-lobes shorter than the tube: corolla yellow, its sacs about as deep as long. Pl. Hartw. 329. O. hispidus, Watson, Bot. King Exp. 230, in part, \&c.

Open grounds, from the valley of the Sacramento (Huremeg) and through the Sierm Nerath, whero it abounds from Mariposs Co. to Sierra Valley. Corollis two thinds or half an inch long: the tube little or considembly longer than the caly'x. Related on mo hand to O. Tillinequemardes in its larger forms, in the smaller ones to $O$. hispidus, with which it las been confounded. 
17. O. hispidus, Benth. Strict, mostly slender and little branched, hirsute: leaves with few slender divisions, or the lower entire: leafy spike virgate: calyxlobes much shorter than the tube: corolla whitish or pale yellow, its sacs rather narrow and longer than deep.

Common in Oregon, as far south as Klamath Valley (Cronkhite) ; therefore probably in California. Corolla half an inch long; the lower lip much smaller than in the preceding.

18. O. linearilobus, Benth. A foot high, above with hirsute or somewhat hispid pubescence : leaves with few or several long and slender divisions ; floral ones equalling the densely spicate flowers, the tips of their divisions commonly tinged with purple: calyx-lobes much longer than the tube and equalling that of the (purplish?) corolla: sacs of the latter narrow, tapering gradually downward, much longer than deep; the ovate-subulate teeth thickish and short. - Pl. Hartw. 350.

Mountain pastures of the Sacramento district, Hartweg. In grain-fields, Anderson Valley, Mendocino Co., Bolander. Corolla three fourths of an inch long.

\section{CORDYLANTHUS, Nutt}

Calyx spathaceous, of an anterior and a posterior leaf-like division, or the anterior one wanting. Corolla tubular, a little enlarging upward, bilabiate; the lips short and nearly of equal length; the lower very obtusely and crenulately 3 -toothed; the npper straight and compressed, with the apex more or less uncinately incurved. Stamens as in Orthocarpus: cells of the anthers either ciliate, or minutely bearded at base and apex. Style mostly hooked at the tip, and more or less thickened under the entire terminal stigma. Capsule compressed, loculicidal. Seeds several or rather numerous, with a loose coat, tipped with a point. - Branching annuals; with alternate narrow leaves, either entire or 3-5-parted, the floral ones or bracts not brightly colored. Flowers one to each bract, not showy, yellow or purplish, capitately or spicately crowded, or sometimes loosely paniculate. - Gray, Proc. Am. Acad. vii. 381 ; Watson, Bot. King Exp. 231, 459.

The species are all Californian and of the interior region eastward, one extending to the western frontiers of Texas. The genus was first named Adenostegia, by Bentham; but as this name was only partially applicable, the author himself adopted Nuttall's name, Cordylanthus.

\$ 1. Calyx 2-leaved: flowers short-pedicelled or almost sessite, subtended by 2 to 4 bractlets: floral leaves and bracts with the truncate retuse or 2-3-toothed apex tipped with a callous gland. - Adenostegia, Gray.

* Stamens 2: anthers 1-celled: flaments nearly glabrous: posterior division of the calyx 2-nerved and 2-cleft.

1. C. capitatus, Nutt. A foot or two high, paniculately much branched, finely soft-pubescent, rather hoary: leaves very narrowly linear, or the floral broader and 3-5-cleft : flowers few or several in a capitate cluster at the end of the branchlets : corolla purplish, half an inch long: capsule 8-seeded. - Benth. in DC. Prodr. х. 597 ; Watson, 1. c.

"California, Nuttall"; but more probably collected by him in the interior region. Rediscovered by Watson in the Clover Mountains in the northeastern part of Nevada, not far south of Nuttall's route in crossing the continent.

* Stamens 4 : anthers 2-celled: filaments villous : both calyx-leaves 5-6-nerved.

2. C. ramosus, Nutt. A span or two high, diffusely branched from the base, hoary-puberulent: leaves mostly 3-7-parted into filiform divisions, which are hardly at all glandular or dilated at the apex : flowers few in a terminal fascicle or in the upper axils : corolla yellow : capsule 20-seeded. - Watson, 1. c. 
Humboldt Mountains, Nevada (Torrey/, \&c.); probably reaching the adjacent borders of California : not rare through the interior region to the borders of Wyoming.

3. C. filifolius, Nutt. Paniculately branched, a foot or two high, puberulent and somewhat viseid, or sometimes nearly glabrous, sumetimes sparsely hispid: leaves filiform or linear-filiform; the lower entire, the upper 3-5-parted, the floral with cuneate base and bristly-ciliate margins; the divisions with dilated and retuse or notched gland-bearing tip: flowers rather numerous in terminal heads: corolla purplish, 6 to 9 lines long. - Nutt. ex Benth. in DC. 1. c. Adenostegia rigida, Benth. in Lindl. Syst. Nat. \& DC. 1. c. 537.

San Diego Co, to San Francisco, \&ce, aud east to Mariposa Co.

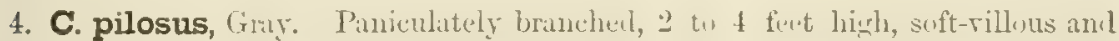
more or less hoary: leaves very narrowly linear, entire; the upper and floral ones usually broader and notched or 3-toothed at the tip : flowers crowded two or three torether at the summit of the hranches or becoming stattered or faniculate : corolla yellowish with some purple, less than an inch long. - Proc. Am. Acad. vii. 383.

Var. Bolanderi, Gray, 1. c. Little or not at all villous, glandular-pubescent: flowers more panicled or scattered.

Open grounds, Santa Clara Co., to the Sacramento and to Mendocino Co., Brever, Bolander, Kellogg, \&c.

5. C. tenuis, Gray, 1. c. Diffusely branched from the base, a foot or two high, from very minutely pubersent to nuarly flabrons: branches filiform: leaves entire, filiform or very narrowly linear; the upper sometimes dilated or tridenticulate at the tip; the floral sometimes 3-parted: flowers more or less seattered: corolla purplish and yellowish, 6 or 7 lines long.

Dry sandy soil, in the Sierra Nevada from Mariposa to Plumas Co., and adjacent frontiers of Nevala: also Red Mountain, Mendocino Co., Kellogg or Bolender.

\$2. Calyx one-leaved (the anterior division wanting): flowers destitute of bractlets, each one sessile in the axil of a clasping bract: herbage not glandular but sometimes viscid-pubescent: no callous gland at the tips of the leaves. Hemistegla, Gray.

* Stamens 4, all with villous filaments and 2-celled anthers; their cells bearded at base and apex: leaves mostly 3-cleft.

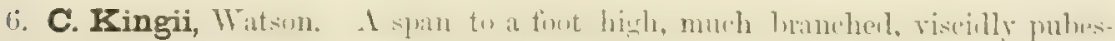
cent: divisions of the leaves linear-filiform: brats $3-5$-cleft : flowers croirded at

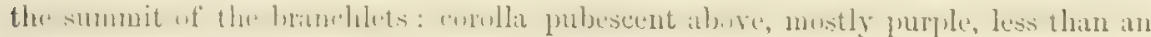
inch long. - Bot. King Fxp. 1. c. t. 22.

Monitor Valley, Novada (Watson), and Southern Utah : not yot known in California.

* * Stamens 4, with glabrous filaments: anthers of the longer stamens 2-celled, of the shorter with a small lower cell only; merely the base of the anther-cells ciliolate or bearded: leaves all entire.

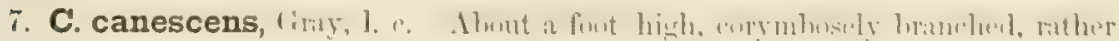
stout, hoary-pubescent : leaves linear-lanceolate, acute, rather erect: bracts lanceolate: flowers fow in a close capitate cluster : corolla purplish.

Washoe Co., Nerada (Anderson, Torrey, \&c.), near the California line, and doubtless also within it.

8. C. maritimus, Nutt. 1. c. A foot or less high, corymbosely brnnehed from the base, pale, less hoary-pubescent than the preceding, which it resembles: the leaves and bracts similar : inflorescence similar or more spicate: corolla dull purplish: filaments in very unequal pairs.

Sandy salt-marshes along the coast, from San Francisco Bay to San Diego. 
* * Stamens only 2, with glabrous filaments: anthers unequally 2-celled: upper leaves and bracts incisely pinnatifid or toothed.

9. C. mollis, Gray, 1. c. Barely a foot high, with numerous branches, villoushirsute: leaves oblong-linear; the lower entire and obtuse; the upper and the bracts with 2 to 4 pairs of laciniate obtuse teeth or lobes: flowers in short thickish spikes: corolla whitish or yellowish, with some dull purple.

Salt-marshes of San Franciseo Bay, at Mare Island and Vallejo, C. Wright, E. L. Greene. Corolla three fourths of an inch long. Seeds somewhat reniform, with a loose and thick cellularreticulated coat.

\section{PEDICULARIS, Tourn. LOUSEWort.}

Calyx 2-5-toothed, irregular. Corolla strongly bilabiate; the upper lip (galea) arched and laterally compressed, sometimes beaked; the lower erect at base, 2 -crested above, 3-lobed. Stamens 4, enclosed in the upper lip: anthers transverse, equally 2-celled, all ог in pairs closely approximate. Style filiform: stigma small, entire. Capsule ovate or lanceolate, oblique, compressed, more or less loculicidal. Seeds several or numerous, comparatively large, ovoid. - Perennial herbs; with alternate or sometimes opposite or whorled leaves, these mostly pinnately divided or lobed, the floral ones commonly reduced to bracts; the flowers commonly spicate, sometimes racemose, of various colors. - The leaves in ours all or mostly alternate.

A genus of nearly 150 species, widely distributed, but chiefly in the northern hemisphere and in cool temperate or arctic regions, more numerous from Oregon northward and in the Rocky Mountains than in California, which, however, has two or three peculiar species.

* Leaves undivided, merely serrate: flowers racemose: corolla beaked.

1. P. racemosa, Dongl. Glabrous or nearly so: stems numerous in a cluster, a foot or two high, very leafy: leaves lanceolate, with narrowed base more or less petioled, closely and often doubly crenate-serrate; the upper floral or bracts linear and entire and shorter than the flowers, but the raceme leafy below: calyx split down the front, 2-toothed posteriorly : corolla white or purplish, with tube hardly exceeding the calyx; the upper lip strongly incurving and tapering into a subulate beak which touches the broad lower lip: anthers pointed at base. - Hook. Fl. ii. 108.

Mountain woods, Sierra and Bear Valleys, Lemmon, Bolander. Also Utah and Colorado in the higher mountains, and north to British Columbia.

\section{* * Leaves at least once pinnatifid.}

+ Upper lip of the corolla tipped with a long and slender proboscis; its base with a tooth on each side: anthers very blunt: stem and virgate spike strict, together from a span to 2 feet high.

2. P. Grœnlandica, Retz. Glabrous: leaves lanceolate in outline, pinnately parted ; the divisions linear-lanceolate, sharply and sometimes incisely serrate: calyx campanulate; the 5 teeth short: corolla rose-colored, short, barely half the length of the filiform deflexed and then ascending or recurved beak, this nearly half an inch long. - Fl. Dan. t. 1166, poor. P. incarnata, Retz, Obs. iv. 27, t. 1. P. surrecta, Benth. in Hook. Fl. ii. 107, \& Prodr. x. 566 ; the larger-flowered form, which prevails.

Higher parts of the Sierra Nevada from Placer Co. (Torrey) east to the Rocky Mountains, and north to British Columbia, Labrador, and Greenland?

3. P. attollens, Gray. Glabrons below: the dense spike rather woolly : leaves lanceolate or linear in outline, pinnately parted, with linear or somewhat oblong divisions, some of the lowest leaves nearly bipinnatifid; the upper scattered, gradu- 
ally smaller and simpler; the libes sharply serrate : calyx unequally 5-tunthed; the teeth almost as long as the tuhe : condli purple; the urper lip little exserted out of the calyx, much shorter than the broad lower one, and only about half the length of its abrupt upturned or retrocurved filiform beak, this 2 or 3 lines long. - Proc. Am. Acad. vii. 384 .

Moist meadows in the Sierra Nevada at 5,000 to 10,000 feet, from Mariposa to Placer Co., Bridges, Brower, Bolander, Torrey.

++ Coper lip of the corolla blunt and beakless: radical leares ample, nearly equalling or exceeding the spike or dense raceme.

4. P. densiflora, Eentl. Pubescent when rounc, or nearly ulabrous, stout, a span to a foot or more high: leaves oblong-lanceolate or broader in general outline, twice pinnatilit or pinnately parter, and the divisions irregularly and sharph incised and toothed; the upper simpler and reduced to foliaceons bracts of the dense or in age more lengtheued and looser spike or raceme: calyx-teeth 5, lanceolate or subulate: corolla red or scarlet, striticht and narrum, slightly clavate, an inch or more long; the lower lip very small, inconspicuous, only a quarter of the length of the upper: anther-cells with tapering or acute base. $-P$. densiflora \& $P$. attenuata, Benth. in DC. 1. c. 574 .

Common throughout the western and middle portions of the State. Spike at first 2 or 3 inches, in age often a foot or more in length: pedicels shorter than the calyx, sometimes very short. Tube of the corolla either littlo or considerably exserted.

5. P. semibarbata, (init. Sumewhat puhescent, or at length glabrate, almost stemless: leaves crowded next the ground, slender-petioled, much exceeding the short and nearly sessile spiken, twice pinntely parted into small amel short mostly few-toothed or incised lobes: calyx unequally 5-toothed: corolla yellowish, externally pubesent, two thirds of an inch long, moderately enlar ring upwarl, straight; the short obtuse upper lip a little incurved, slightly longer than the almost erect lower one: the two longer filaments villous above the middle; the others nearly naked: anther-cells abruptly pointed at the base. - Proc. Am. Acad. vii. 385.

Open woods through the Sierra Nevada, at 5,000 to 10,000 feet, from Mariposa to Placer Co. (Brewer, Bolunder, Gray); also found near Carson City by Anderson.

P. cestraxtulara, Gray in Bot. Mex. Bound. 120, is a somewhat similar, but more peculiar, nearly stemless species, with once pinnatifid leaves, longer and purple corolla, and anned anthers. It was discovered in New Mexico, hut has recently been detected in the southwestern part of Utah, so that it may reach the borders of California.

\section{ORDER LXIX. OROBANCHACE再.}

Rout-parasitic herhs, clestitute of fuliago and preen colur, with irresular clicely bilabiate corolla, lidynamous stamens, amd nne-celled orary and eapsule with two or more parietal many-senled placente, - by the latter charaeter only distingrushed

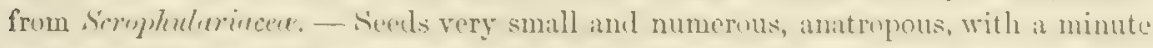

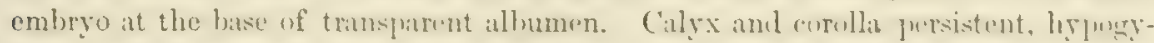
nous. Stamens on the tube of the corolla : anthers 2-celled. Style long: stigma 2-lobed or nearly entire. Capsule 2-valved: each valve bearing one placenta or a pair. Dry or fleshy scales, in place of leaves, alternate,

A small order mainly of the northern temperate zone, of 11 genera and about 150 species, all except a dozen belonging to the Old World, only two genera represented in or near California.

1. Aphyllon. Stamens included: celly of the anthers pointed at hase. Calyx 5-cleft.

2. Boschniakia. Stanens protruded: anther-cells closely parallel and blunt at base. Calyx truncate posteriorly, the teeth anterior and lateral. 
1. A PHYLLON, Mitchell. CANCER-ROOT.

Calyx 5-cleft or 5-parted, regular or nearly so. Corolla more or less tubular and curved, either almost regular or bilabiate. Stamens included: cells of the anther deeply separated from below upward, mucronate at base. Style long: stigma diskshaped and peltate, or more or less bilamellar ; the lobes anterior and posterior. A double placenta or a pair of contiguous placentæe on the middle of each valve of the capsule. Low and commonly viscid-pubescent or glandular, pale or brownish in hue, some with slender naked scapes or peduncles, others with spicate flowers: corolla purplish or yellowish. - Gray, Man. Bot. ed. 1, 290, ed. 5, 323 ; Benth. \& Fook. Gen. Pl. ii. 983. Anoplanthus § Euanoplon, Endl., Reuter in DC. Prodr. xi. 41, with species of Phelipoea.

A North American genus, to which must be added two or three species which had been referred to Phelipeed as that genus had been understood. The original Phelipoed, on the other hand, is more like the original Aphyllon in habit.

\$1. Scapes or peduncles naked, long and slender, from a loosely scaly rootstock or short ascending stem, and no bractlets at the base of the 5-lobed calyx: corolla with an almost regular and equally spreading 5-lobed border. - True APHYLLON.

1. A. uniflorum, Gray, 1. c. Scapes few and barely a span high from a nearly subterranean short rootstock: lobes of the calyx longer than its tube, subulate: corolla (about an inch long) bluish-purple or purplish. - Pacif. R. Rep. iv. 118. Orobanche uniftora, Linn.

Parasitic on roots of various plants, not rare in California, and north to British Columbia, east to the Atlantic. Flowers verual, with the odor of violets.

2. A. fasciculatum, Gray, 1. c. More pubescent and glandular : scaly stem rising out of ground 2 or 3 inclies, bearing numerous fascicled peduncles of about the same length: lobes of the calyx not longer than its tube, broader and shorter than in the preceding: corolla purplish or sometimes sulphur-yellow.-Orobanche fasciculata, Nutt.; Hook. Fl. il. 93, t. 170.

Sandy ground: commoner than the other, extending eastward to the Mississippi and the upper Great Lakes.

\$2. Stems rising above the ground: flowers racemose, panicled, or spicate, mostly with one or two bractlets close to or rarely below the calyx: corolla plainly bilabiate; upper lip 2-lobed or notched; lower 3-parted. - NothapHYllon, Gray.

* Flowers racemose, distinctly jedicelled, pretty large (an inch or more long): the lobes of the corolla more or less spreading: calyx 5-parted into long and slender lobes.

3. A. comosum, Gray. Low, branching at or near the surface of the ground: flowers on slender and mostly naked pedicels in a corymb or short raceme: bractlets at the calyx often wanting, when present very slender: corolla rose-colored or purple, with oblong spreading lobes. - Orobanche comosa, Hook. 1. c. t. 169.

Dry hills; parasitic on Artemisia and other plants; on the Coast Range back of Monterey (Brerer) to Washington Territory. Pedicels sometimes nearly an inch long. Calyx half the length of the corolla, which is not rarely $1 \frac{x}{2}$ inches long and broad at the throat. Anthers woolly.

4. A. Californicum, Gray. Stem stout, a span or more high, simple or branching: flowers crowded in an at length elongated and dense spike-like raceme: pedicels shorter than the calyx, which is commonly 2-bracteolate and its slender divisions almost as long as the yellowish or purplish corolla, the lobes of which are rather shorter and less spreading than in the preceding. - Orobanche Californica, Cham. \& Sichlecht. Phelipere Californica, Don; lienter in DC. Prodr. xi. 11. P. erianthera, Watson, Bot. King Exp. 225, not of Engelm.

Dry hills, from near the coast to Nevada. Anthers naked or slightly hairy. 
* Flowers mainly sessile, crowded in a simple or branching spike: lobes of the corolla short and less spreading: calyx deeply 5-cleft into linear-lanceolate divisions, 2-bracteolate.

5. A. Ludovicianum, (rmy. Nore puheseent, a spran to a fext hish : enlyx

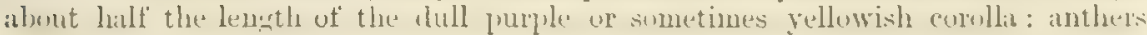
(before opening) glabrous or slightly woolly. - Orobanche Lauloviciana, Nutt. Gen. ii. 58. Phelipaea Ludoviciana, Thalp.; Reuter, 1. c.

Nenr Fort Mohave, Cooper. Thence through New Mexico to Texas, Illinois, and Minnesota. "Rootstock bitter, but eaten by the Mohaves." Corolla barely three fourths of an inch long: upper lip occasionally entire : calyx often rather irregular.

A. Meltiflores, Gray (Orobanche multiflora, Nutt. Pl. Gamb. 179, \& Plwlipace eriantherc,

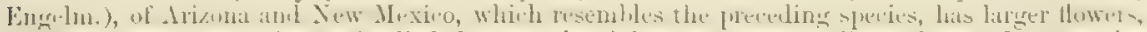

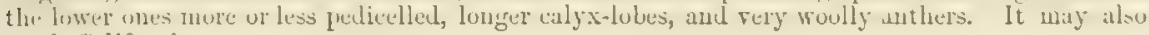
reach California.

* * * Flowers mainly sessile, in a panicle or thyrsoid cluster, small, at most half an inch long: calyx 2-bracteolate; its lobes rather short: corolla with short and hardly sprealing lobes: anthers glabrous or nearly so: stems from a thick and firm tuberous base.

6. A. tuberosum, Crar. Minutely puberulent, low and stout, the thickenerd base with firm imbricated scales: flowers in a compact cluster: calyx unequally cleft, a little shorter than the yellowish corolla. - Phelipcea tuberosa, Gray, Proc. Am. Acad. vii. 371.

Sandy soil on dry ridges, Gavilan Mountains east of Monterey, Brewer. Specimens mainly in fruit.

A. PINETORUM, Gray (Phelipae pinetorum, Gray, 1. c., and Orobanche pinctorn, Geyer in Hook. Kew Jour. Bot. ii. 297), of the Columbia River region, another species of this seetion, has more tapering stems and a looser panicle, often a foot high, and equal calyx-lobes rather shorter than its tube.

\section{BOSCHNIAKIA, C. A. Meyer.}

Calyx short and cupshaped, oblique, or the upper side truncate, the lorrer sido with about 3 distant teeth: no bractlets at its base. Corolla ventricose; the upper lip erect or somewhat arched and entire; the lower 3-parted, sometimes very short. Stamens somewhat protruded : anthers blunt at base. Seeds with a thin and reticulated coat. - Short and stout simple stems from a tuberous base, thickly beset

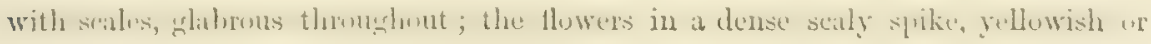
brownish. - Bongard, Veg. Sitcha, 158.

B. GLABRA, C. A. Meyer, the original species (which is figured in Hooker's Flora Bor.-Am.),

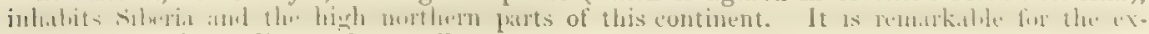
tremely short lower lip to the corolla.

B. Hookeri, Walp. (figured by Hooker as Orobanche tuberosa), known only by a specinen collected by Jenzies on the N. W. Coast, must be near the following, but has short and blunt calyx-tecth and narrow bracts to the spike.

1. B. strobilacea, Gray. A span high, thick and stout, with broad and roumled dark-bruwn senles overlying one another, so as to resemble al surtce-cone, floriferulus from near the hase: calyx truncate-entire on the posterior sicle, on the anteriur with 3 linear-subulate teeth longer than the tube: lower lip of the corolla as long as the upper, of 3 oblong spreading lobes: filaments strongly bearled at baso: placentro 4, equiclistant. - Pacif. R. Rep. iv. 118.

On dry steep lills of the South Yuka, Bigrlow. Stn. Lucin Mountains, parasitic on roots of Mnnzanita, Breucr. "Scales brownish-red with light margins: corolla striped with white and brownish-red." 


\section{ORDER LXX. LENTIBULARIE更。}

Aquatic or marsh herbs, with bilabiate calyx and corolla, the latter personate and spurred or saccate on the lower side, only 2 stamens, their anthers confluently 1-celled, and the free ovary 1-celled, with a free central placenta. Ovules numerous, anatropous. Capsule many-seeded, bursting irregularly. Seeds destitute of albumen : the embryo thick, almost entire, a mere notch for the cotyledons. Flowers perfect, on a scape or scape-like peduncle.

The principal genera are Pinguicula or Butterwort, inhabiting wet roeks, one species in Oregon, and the rather large genus, -

\section{UTRICULARIA, LIIn. BLADDERWORT.}

Calyx persistent, its lips entire. Corolla with very short tube and ample lips; the lower larger, 3-lobed, bearing a prominent and usually bearded palate, deciduous. Stamens borue in the base of the corolla, connivent: anthers approximate. Style short: stigma 1-2-lipped. - The commoner species are immersed in still or slow-flowing water, have branching stems, and capillary dissected leaves, and on some of them bladders with a valvular opening, in which minute aquatic animals are caught and retained.

A genus of numerous species, widely distributed over the world, several in the Atlantic United States, but only the following known in California, both ranging round the world.

1. U. vulgaris, Linn. Stems 1 to 3 feet long, swimming free under water, beset with twice or thrice pinnately-parted capillary leaves bearing many bladders: peduncles rising out of the water 6 to 12 inches high: flowers 5 to 12 in a raceme, ( $\frac{3}{4}$ inch broad); the conical curved spur rather shorter than the lower lip of the corolla: pedicels nodding after flowering.

Lakes and pools, in the Sierra Nevada and in the northwestern counties; the var. Americana, Gray, having a narrower and less blunt spur than in the European plant.

2. U. minor, Linn. Stems a few inches long, slender, swimming free, branching, beset with short and 2 to 4 times forked leaves having linear-filiform divisions: peduncle slender, rising out of the water, and bearing 3 to 8 flowers in a raceme: corolla 3 lines long, with very short and blunt spur or sac: pedicels nodding after flowering.

Big Spring in Indian Valley, Lemmon. Collected by Watson in Nevada and Utah, but only sterile.

\section{ORdER LXXI. BIGNONIACE开.}

Woody plants, erect or climbing, with more or less bilabiate corolla, didynamous .or by abortion diandrous stamens, a free ovary with two parietal placentæ but very commonly 2-celled by a false partition, and numerous seeds with a flat embryo and no albumen. Leaves various, but commonly opposite. Flowers usually large and showy, perfect. Corolla 5-lobed, imbricated in the bud, the three lobes of the lower lip covering the others. Stamens borne on the tube of the corolla alternate with the lobes; the anterior pair always fertile and rudiments of the 3 others present, or 4 fertile, the uppermost rudimentary or wanting: anthers 2-celled. A fleshy annular disk around the base of the ovary. Style single: stigma of 2 broad lips. Ovules anatropous or amphitropous. Fruit mostly a capsule, opening by 2 
valves which fall aray from the placentiferous partition or replum. Seeds large, winged or appendaged; the kernel consisting of the flat embryo : cotyleduns bruad and foliaceous : radicle short.

A large order in the tropies, and with a few representatives in the temperate zones, especially in America, such as the Trumpet-Creeper (Tecoma radicans) and the Catalpa-tree in the Atlantic States. There are some true Bignonincece in the southern part of Iower California ; but in our State only one, and that barely along the southeastern frontiers.

Martynia (Unicorn-plant) is represented by a species or two in Lower California and Arizona, but none is known along or near our boundary. They are viscid and rauk-scented herbs, with a sort of drupaceous imperfectly 2-5-celled fruit, and thick-conted wingless seeds, M. YROBOSCIDEA, Linn., the common Unicorn-plant, sometimes cultivated in gardens, is not unlikely to occur in California as an introduced plant. These plants, with Sesamum and some other genera, constitute the order or suborder PEDALINE.E.

\section{CHILOPSIS, Don, Desert-Wrllow.}

Calyx membrantceous, ovate in the bud, irregularly bilabiate, often split decper on one side. Corolla funnelform, ventricose above, with an ample bilabiately 5-lobed spreading limb; the rounled lobes crose and undulite. Stamens 4 and a sterile filament: cells of the anther naked amd diverging. Capsule long and linear, terete, resembling that of Catalya, 2-celled with the at length louse narrow partition contrary to the valves. Seeds oblong, thin, with the wing at each end dissected into a wonlly or tine bristly tuft. Cutyledons 2-lohed. - Don in Edinb. Phil. Juur. ix. 261 ; DC. Prodr. ix. 227. - A single species.

1. C. saligna, Don, l. c. Shrub or tree, 10 to 20 feet high, with hard wood, willow-like, puluescent when young, soon glalnous, with slender hranches hearing numerous leaves: these linear or linear-lanceolate, 4 to 6 inches long, opposite, whorlet, or mostly irregularly alternate, entire, slinhtly whtinous when old: flowers in a short terminal meeme: corolla one or two inches lune white and purplish : arpsule 6 to 10 inches long. -C. linearis, DC. 1. c. Bignonia (?) linearis, Cav. Ic. iii. t. 269.

Along water-courses, San Bernardino and San Diego counties, and through the arid interior region to the borders of Texas and the northern part of Mfexico.

\section{ORDER LIXII. ACANTHACEA.}

Like Sirophularincere in ceneral chanceter, cxeept in the capsule and seeds. Flowers perfect, mostly with bractlets at the hase of the calyx. (Bwary a-eclled, with placenta in the axis, hearing few or definite anatupuns urules in each cell. Capsule 2-rellal, few-steded. Seeds borne on hook-like or rardy cupshaped proce'sses uf the flimentil (retinacula), destitute of albumen. ('otyleduns bruad and flat. Corolla with lobes either imbricated or convolute in the bud.

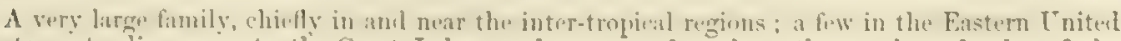
States extending even to the Great Lakes; a larger number along the southern border of the United States; one or two only known to occur within the borders of the State of Californim but severnl not far distant. Ono or two species of Thumbergia commonly represent the order iu cultivation. The herbage is bland or slightly bitter, and destitute of active properties.

* Stamens 4 : corolla harlly or only slightly bilabiate.

1. Ruellia. Anthers 2-celled. Corolla convolute in the bud. Capsule several-seculed.

2. Berginia. Anthers 1-celled. Corolla imbricated in the bud. Capsule 1 -seelled.

- Stamens only 2 : anthers 2-celled : corolla strongly bilabiate : capsule 4-seciled.

3. Beloperone. Anthers with lower coll spurred or pointed at hase. Flowers 1-bmeted.

4. Dicliptera. Anther-cells pointless. Flowers 1 to 3 between a pair of valvate bracts. 


\section{RUELLIA, Linn.}

Calyx 5-parted into narrow and nearly equal divisions. Corolla broadly funnelform, almost regularly 5-lobed; the lobes broad and flat, convolute in the bud. Stamens 4, didyuamous, included: filaments united at the base in pairs: anthers sagittate, 2-celled; the cells nearly parallel and equal. Capsule oblong or clubshaped, nearly terete, 8-16-seeded. Seeds flat, rounded or somewhat heart-shaped. - Perennials and chiefly herbs; with oval or oblong and petioled leaves, and rather large blue or purple flowers; many of the most fertile ones never unfolding, being close-fecundated in the bud.

1. R. tuberosa, Linn. Pubescent, 2 or 3 feet high: leaves oval or ovate: flowers in a nearly naked terminal panicle: corolla ( 1 to 2 inches long) with a slender tube suddenly expanded into an ample throat : stigma single (the other fork wanting) : capsule 12-16-seeded. - Cryphiacanthus Barbadensis, Nees.

California, Coutter. But his plant (No. 556) very likely collected in Arizona, whence this species extends to Texas, and is common in Mexico, W. Indies, \&c.

\section{BERGINIA, Harvey.}

Calyx 5-parted into narrow chartaceous and striate nearly equal divisions. Corolla with tube about equalling the calyx and the irregular rather bilabiate limb; upper lip nearly erect, 2-parted, the lobes oblong, interior in the bud; lower longer and spreading, 3-parted or cleft; the lobes somewhat obovate, the middle one with a bearded patch at and below its base. Stamens 4, inserted in the throat: filaments subulate, the anterior pair bearded inside next the anther : anthers ovate-lanceolate, the acute tips at first lightly cohering by a minute beard. Style thickened at apex: stigma naked, truncate and a little cupped. Capsule not at all stalk-like or narrowed at base, ovate, apparently thin-walled and not compressed, 4-seeded from near the base. - A single species.

1. B. virgata, Harvey, in herb. Appareutly a low and somewhat shrubby plant, minutely puberulent, with slender branches: leaves linear-oblong, entire, sessile or nearly so, scabrous (half an inch or so in length), with midrib prominent underneath; the upper reduced to ovate-lanceolate bracts of the loose interrupted spike, barely equalling the 2-bracteolate calyx: corolla apparently white, less than half an inch long. - Benth. \& Hook. Gen. Pl. ii. 1096.

California, No. 603, Coulter. Not since met with; more probably collected in Arizona or within the borders of Mexico.

\section{BELOPERONE, Nees.}

Calyx equally 5-parted, subtended by a pair of small bractlets. Corolla tubular, bilabiate; the upper lip interior in the bud, concave, erect or arching, entire or emarginate; the lower spreading and 3-lobed. Stamens 2: anthers 2-celled; the cells disjoined, one higher than the other, the lower one with a short spur at base. Style filiform: stigma mostly entire. Capsule clavate, having a long empty stalklike base; the short cells each 2-seeded. - Mostly shrubs, of Tropical America; with flowers in spikes or racemes; the bracts and bractlets small and narrow. Benth. \& Hook. Gen. Pl. ii. 1110.

1. B. Californica, Benth. Tomentose or hoary: stems shrubby, slender, often becoming leafless: leaves ovate, round-oval, or somewhat cordate, nearly entire, 
slender-petioled : racemes short and loose: bracts and bractlets deciluens: calyxlobes subulate: corolla dull red, narrow, an inch long; the lips truncate: cells of the anther nearly equal in size, the lower with a short blunt spur: capsule tomentose, club-shaped, the stalk-like empty base longer than the seed-bearing portion. Bot. Sulph. 38. Jacabinia Californica, Nees in DC. Prodr. xi. 729. Sericographis Californica, Gray in Bot. Mex. Bound. 125.

Along the southeastern borders of the State (Fremont, Newbermy, Parry, \&c.), in Arizona, and through Lower California. Capillary style rather persistent, at length separating by a joint above the base.

\section{DICLIPTERA, Juss.}

Bracts a pair, valvately enclosing 1 to 3 flower-buds. Corolla tubular, bilabiate; the upper lip interior in the bud, flat or concave, emarginate or entire; the lower spreading, 3-toothed or lobed. Stanens 2 : anthers with 2 cells, one higher than the other, buth frintlis.s. (aljule shurt, flattenul contray to the partition, 1 -seded, the base seedless and stalk-like: the strong processes that bear the sieds curving upward and becoming hook-like at dehiscence. Seeds flat. - Mostly herbs; with 6anglerl steme, broulish and juetioles leaves, and either scattered or clustered fluwers: mainly tropical, two or three species reaching the United States.

1. D. resupinata, Juss, Tearly glabruls: stems slender, loosely loranching: leaves oblong or lanceulate, slender-petioled : peduncles seattered, bearing a pair of cordate or rounded foliaceous bracts, and between them a single flower or rarely a pair : corolla purplish, half an inch loug. - Torr. Bot. Mex. Bound. 125. D. thiaspioides, Nees in DC. 1. c. 474.

California, No. 557, Coulter : but perhaps only in Arizona, where it abounds, as also in Lower California, in the form of $D$. thlaspioides; so called becanse the flattened pair of bracts ( 3 to 5 lines in diameter), terminating a peduncle of ahout the same length, may be likened to the silicle of a Thlaspi. In most species, when the flowers are in clusters, many of the corollas appear to be reversed (resupinate), the 3-lobed lip seemingly the upper one as respects the main axis.

\section{ORDER LXXIII. LABIAT出。}

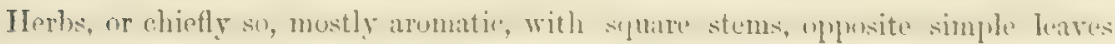

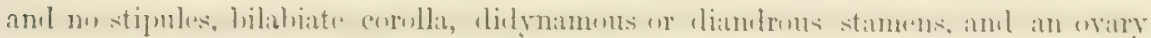

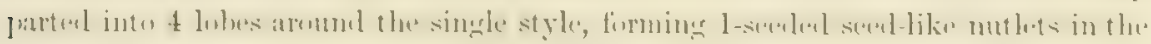
bottom of the persistent calyx. - Flowers perfect. Calyx 3-5-toothed or cleft, or bilabiate. Upper lip of the corulla 2-lobed or entire; the lower 3-cleft or parted (or in the first tribe as if 4 in the upper and one in the lower lip). Stamens on the

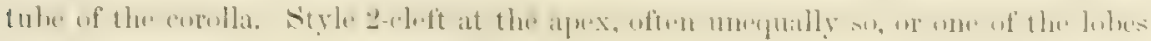
obsolete: stigmas minute. Seed erect from the base of the nutlet, mostly without

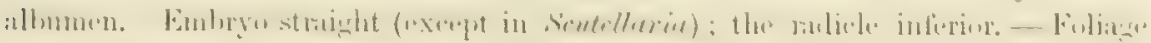

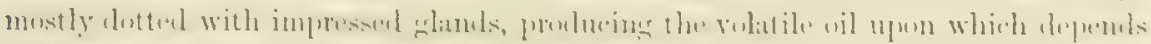

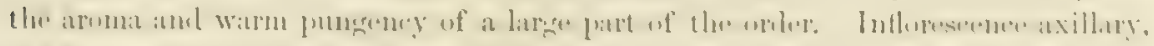

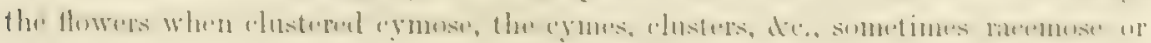
spicate at the upper portion of the stem or branches.

A largo order, found in all countries, but most ahundunt in warn-temperate regions. All the plants innocent, but some aromatic-pungent; severnl used in medicine or for condiments; others, with brillinut hossoms, surh as Mfexican and Brazilinn Sages, cultivateul for olvument. Many 1)ld-World species, such as Marjorm, Savory, Thyme, sevent Mints, (at-. Iint, Motherwort, de., are naturalized in the Stlantic stutes, but havo not been net with on the Califurnian site. 
Hyssopus offrcinalis, Linn, the Hyssop of the old World, which has sparingly escaped from gardens to roadsides at the East, has once been received from Plumas Co., California; but probably it is not there naturalized.

Nepera Cataria, Linn., the Catnip, and perhaps N. Glechoma, Benth., the Ground Iry, also Galeopsts Tetrahit, Linn,, the Hemp-Nettle, Leonurus Cardiaca \& L. Sibiricus, Linn., Motherwort, and Lamium AMplexicaule, Linn., \&c., Dead-Nettle, -weeds from the Old World, - are to be expected in California, but apparently have not yet found their way thither.

I. Nutlets not reticulated, quite distinct and attached at the very base : corolla not more deeply cleft down the upper side.

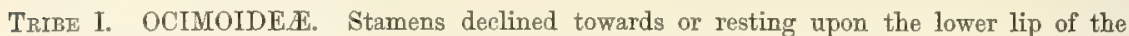
corolla, all four fertile. Corolla declined, the 4 somewhat equal lobes forming the upper lip, and the fifth dissimilar one the lower. (Ocimum Basilicum, Linn., the Sweet Basil, cultivated as a sweet herb, is the type of this tribe.)

1. Hyptis. Calyx 5-toothed. Lower lobe of the corolla saccate, abruptly deflexed at the base.

TRIBE II. SATUREIEE. Stamens erect or ascending; the posterior pair shorter or wanting: anthers 2-celled, and the short cells never far separated, sometimes partly confluent but not blended. Upper lip of the corolla never hooded : all the lobes flat or flattish.

* Corolla (small and short) about equally 4-lobed and calyx 4-5-toothed : tube uaked within.

2. Mentha Stamens 4, nearly equal, erect, straight and distant.

3. Lycopus. Stamens 2 with anthers : the posterior pair sterile or wanting.

* * Corolla with border bilabiate, and no hairy ring within the base of the tube.

+ Calyx about equally 5-toother and 13-nerved: style beardless.

4. Pycnanthemum. Flowers glomerate-capitate. Stamens 4, straight, distant and divergent : antiner-cells parallel. Corolla-lips and lobes short.

5. Monardella. Flowers glomerate-capitate. Stamens 4, straight, exserted : anther-cells at length divergent. Corolla-lobes narrow.

6. Micromeria. Flowers solitary or loosely clustered in the axils. Stamens 4 , curving and ascending, shorter than corolla.

$$
\text { * * Calyx distinctly bilabiate : style beardless. }
$$

7. Calamintha. Flowers scattered or loosely clustered. Stamens 4, the shorter pair sometimes sterile, conniving in pairs or ascending parallel.

* + + Calyx unequally and deeply 5-cleft, mostly 15-nerved: style bearded above.

8. Pogogyne. Stamens 4, sometimes the upper pair sterile, ascending.

* * Corolla not manifestly bilabiate : a hairy ring at the base of the tube witbin.

9. Sphacele. Calyx campanulate, deeply and nearly equally 5-toothed, membranaceous and enlarging in fruit, only 10-nerved, reticulated. Stamens 4, distant. Corolla with 5 roundish lobes, the lower longest.

TrIBE III. MONARDEE. Stamens only 2 fertile, the upper pair rudimentary or wanting : anthers apparently or really of a single linear-oblong cell, or of 2 cells very widely separated upon the two ends of a flament-like connective.

10. SaIvia. Connective longer than the filament itself, which it strides, a narrow anther-cell at its upper end, a smaller one or a long process at the lower.

11. Audibertia. Connective much shorter than the filiform filament and continuous or barely articulated with its apex, or apparently none : anther 1-celled, no rudiment of the second cell below.

TRIBE IV. NEPETEE. Stamens all four with good anthers, ascending or divergent; the posterior pair surpassing the anterior. Corolla distinctly bilabiate : calyx 15-nerved. (NEPETA, the type of this tribe, would be expected to give two European weeds, the Catnip and Ground Iry; but they have not yet been seen in collections.)

12. Lophanthus. Calyx 15-nerved, 5-toothed. Stamens divergent, the pairs crossing : anthercells parallel.

Tribe V. STACHYDE $\approx$. Stamens all 4 with good anthers, ascending and parallel under the concave or galeate upper lip of the corolla. Calyx 5-10-nerved. Herbage much less aromatic than in the preceding tribes, the glandular dots or oil-glands scanty.

* Anthers of the longer pair of stamens with one cell abortive or wanting, as also is the upper fork of the style: embryo curved; the short radicle resting against one of the cotyledons : 
lateral lobes of the corolla commonly united rather to the upper than to the lower : calyx with short entire lips.

13. Scutellaria. Culyx with a strong projection on the upper side, becoming casque-shaped, finally splitting and the upper part usually falling.

14. Salazaria. Calyx with no projection on the back, enlarged and bladdery-inflated in fruit.

* Anthers all alike 2-celled. Embryo straight, as in the order generally.

15. Brunella. Calyx reticulate-veiny, strongly bilabiate; upper lip truncate-3-toothed, lower 2-eleft. Filaments 2-forked at apex, one fork bearing the anther.

16. Marrubium. Calyx 5-10-nerved, 10-toothed. Stamens enclosed in the short tube of the corolla.

17. Stachys. Calyx 5-10-nerved, 5-toothed. Stamens rising out of the throat and under the upper lip of the corolla.

II. Nutlets rugose-reticulated, somewhat united at base or obliquely fixed : corolla most deeply cleft between the two upper lobes.

Tribe VI. AJUGOIDEE. Stamens ascending parallel, and protruded from the eleft on the upper side of the corolla, which thus divides completely the upper lip : the anterior longer than the posterior pair.

18. Trichostema. Calyx campanulate, 5-cleft. Corolla with 5 somewhat similar oblong lobes; the limb oblique in the bud and containing the spirally coiled stamens.

\section{HYPTIS, Jacq.}

Calyx somewhat equally 5-toothed. Corolla short; the lower lobe saccate, abruptly deflexed at the contracted and callous-margined base; the other 4 lobes nearly equal and flat. Stamens 4, declined, included in the sac of the lower lobe. - Herbs or low shrubs, of very many Sonth American and Mexican species, a few reaching the United States.

1. H. Emoryi, Torr. Minutely scurfy-tomentose and canescent, shrulliy, $t$ or 5 feet high, with slender branches: leaves ovate or oval, obscurely crenate, an inch

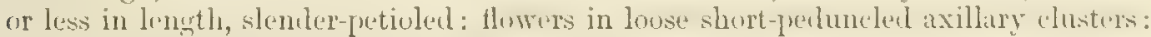
pedicels about the length of the somewhat turbinate calyx, both densely scurfy. Bot. Ives Colorado Exp. 20. E. lanata, Torr. Bot. Mex. Bound. 129, a slip for II. laniflora, excl. syn.

Gravelly ravines of the Mohave (Frcmont, Conper) and eastward, Einory, Newberry, \&c. Canon Tantillas, within the borders of Lower California, Pulmer. "Fragrant." Corolla 2 or 3 lines long, apparently purplish.

H. ALBIDA, HBK., a related Mexican species, sparingly occurs in Arizona, but no nearer than Camp Grant, Palmer.

H. LAviflom, Benth., and H. TEPHrodes, Gray, are known only from the southern part of Lower C'alifornia.

H. PoLYstAcuYs, HBK., which is probably only H. spicala, Poiteru, an annual species, of Mexico, dic., is doubtfully enumerated in Bot Beechey's vayage; but nothing like it is known from California.

\section{MENTHA, Linn. MINT.}

Calyx about equally 5-toothed. Corolla with a short included tube, and a cam-

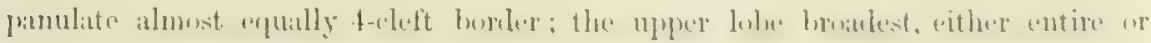

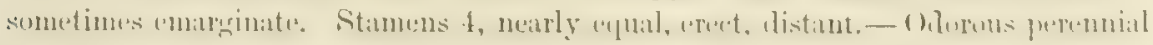

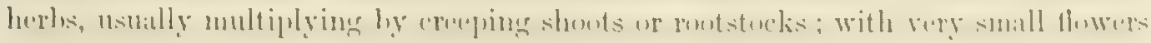
in dense clusters, the two opposite ones forming an apparent whorl, either in the axils or else spicate at the top of the branches: corolla whitish or purplish.

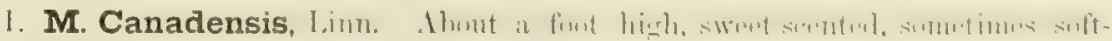
pubesecat, sometimes almost glabrous: leaves from oblong-orate to nlmost lanceulate, sharply serrate, acute, short-petioled: flowers all in short axillary clusters, the summit of the stem being sterile: calyx hairy, its teeth short. 
Border of streams and springs, San Francisco Bay and eastward to Nevada, \&c. Extends northward to Puget Sound, and east to the Atlantic.

M. Piperita, Linn., the Peppermint, which is glabrous, the leaves petioled, and the flowers crowded in a terminal spike, is probably in cultivation, and therefore likely to be naturalized.

M. vrrmis, Linn., the Spearmint, like the last, but with veiny less smooth and sessile leaves, probably in large demand for juleps, is sure to be naturalized before long.

\section{LYCOPUS, Toun. WATER HoREHOUND.}

Like Mentha, but the posterior pair of stamens wanting or sterile. Calyx in the same species either 5-toothed or 4-toothed. Corolla apparently regular, being about equally 4-lobed. Nutlets with thickened margins at the top. Flowers white or nearly so, in close sessile whorl-like clusters in the axils of the leaves. - A genus of few species, widely dispersed. - Gray, Proc. Am. Acad. viii. 285.

1. I. sinuatus, Ell. Not stoloniferous nor tuberiferous, but with rootstocks more or less creeping, glabrous or minutely roughish-pubescent, a foot or two high, loosely branching: leaves oblong or lanceolate, acuminate, laciniate-pinnatifid or irregularly incised, or merely sinuate, petioled: outer bracts barely equalling the flowers: calyx-teeth triangular-subulate and cuspidate, rigid, nearly equalling the corolla, in fruit surpassing the nutlets: rudiments of sterile stamens slender and with a thickened tip.

Wet grounds; rare in the northern part of the State, not uncommon in Oregon, extending througli the Atlantic States.

2. I. lucidus, Turez, var. Americanus, Gray, 1. c. Somewhat stoloniferous from the base of the stem, and with stouter subterranean runuers producing large tubers, nearly glabrous, or usually puberulent-hirsute: stem stout and strictly erect, 2 or 3 feet high, very leafy, acutely angled towards the summit: leaves lanceolate (2 to 4 inches long), acute or acuminate, sharply and coarsely serrate with ascending teeth, sessile or nearly so: subulate outermost bracts as Iong as the flowers: calyx-teeth slender-subulate, equalling the corolla, not exceeding the nutlets: rudiments of sterile stamens slender and with a thickened tip.

Low grounds near San Francisco (Kellogg, \&c.): also from Arizona and New Mexico to Saskatchewan. Foliage not at all lucid as in the Siberian plant.

L. Virginicts, Linn., in a large-leaved form ( $L$. macrophyllus, Benth.) occurs in Oregon and eastward. It may be known by the abundance of filiform runners produced during the summer, and the pointless calyx-teeth, which are mostly 4 , while 5 largely prevails in the other species. An unusual bitterness gave this plant a certain repute in medicine, but it is of no account.

\section{PYCNANTHEMUM, Michx.}

Calyx ovate-oblong or short-tubular, ours with 5 short equal teeth; the throat naked within. Corolla short, with tube hardly exceeding the calyx, and a distinctly 2-lipped border; both lips nearly flat; the upper entire or nearly so and rather erect; the lower spreading and 3-cleft into short and obtuse lobes. Stamens 4, straight, distant and divergent; the anterior pair slightly longer: anther-cells close and parallel. - Perennial erect herbs, with densely-crowded flowers (whence the name); consisting of 16 species of the Atlantic United States, and one in California.

1. P. Californicum, Torr. About 2 feet high, corymbosely branched, sweetodorous, whitened with a fine and soft elose pubescence, or in age sometimes smoothish and greener: leaves from ovate to ovate-lanceolate, closely sessile by a roundish or slightly cordate base, sparingly denticulate or entire ( 1 to 3 inches long): heads of flowers very dense at summit and in 2 or 3 upper pairs of axils, compacted with slender bracts, white-villous: flowers whitish. - Pacif. R. Rep. iv. 122 . 
Dry and open ground; common nearly throughout the State to the southern boundary and the

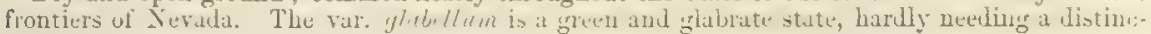
tive name.

\section{MONARDELLA, Benth.}

Calyx tubular, narrow or elongated, 10-13-nerved, 5-toothed; the teeth short, straight, and nearly equal; the throat naked within. Corolla with the tube either

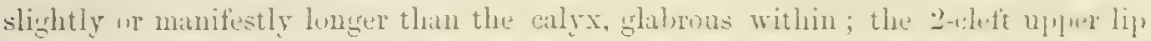
and the lobes of the 3-parted lower one all tlat and linear or oblong. Stamens 4, exserted, either strongly or moderately unequal: anther-cells often divergent or divaricate. - Annual or perennial sweet-odorous herbs (all Californian, one or two

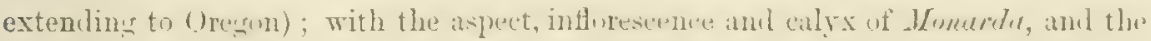

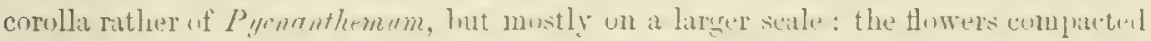
in terminal heads involucrate with bracts, rose-color, purple, or white. Leaves entire or obscurely toothed. - Lab. 331, \& DC. Prodr. xii. 190.

\$1. Flowers comparatively fero and loose in the head, large: corolla mostly with long-

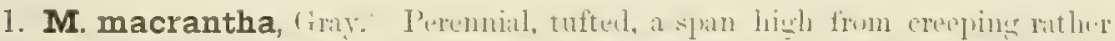

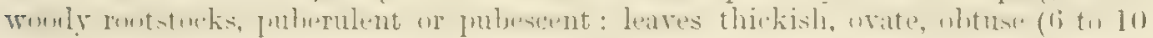
lines long), glabrate, slender-petioled: bracts of the $10-20$-flowered head ovate or

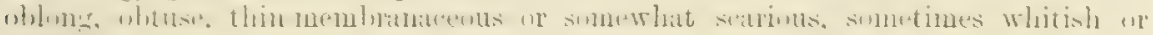
purplish-tinged, externally like the calyx villous-pubescent: teeth of the latter lanceolate, merely acute: corolla about an inch and a half long, glabrous, orange-red; its tube fully twice the length of the salyx; the lobes lanceolate. - Proc. Am. Acad. xi. 100 ,

Criamaca Mountains and near Julian City, northeast of San Diego, Clcreland, Palmer. Calyx

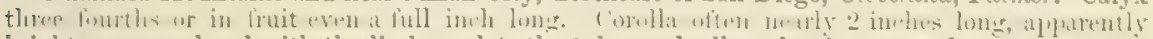
bright orange-colored with the limb scarlet, the tube gradually enlarging upward.

2. M. nana, Gray, 1. c. Resembles the preceding, with somewhat hirsute mbescence: Howers smaller: corolla not twice the length of the calrx. white or tingerl with rose-color; the slender tuhe pubescent: bracts whitish and rose-color.

Mountains behind San Diego, Cleveland. Specimens barily suffeient. Calyx barely two thirls of an inch long: tube of the pale corolla sometimes hardly exceeding its lanceolate teeth, sometimes 2 lines louger.

\section{\$2. Flowers numerous and densely capitate: calyx from a fourth to a third of an} inch long: anther-cells shorter and less divaricate.

* Perennial, in tufis from a procumbent and almost voouly base, or from somernhat

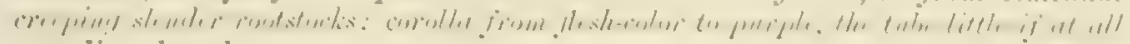
exceeding the calyx.

3. M. villosa, Benth. Soft-pulhescent or villons, a foot or two hich : lenves

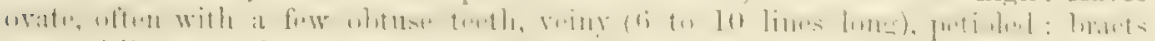

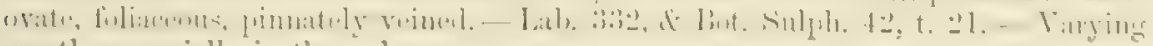
greatly, especially in the pubescence.

Var. leptosiphon, Torr. a less pubescent form, with thimer and almost entire leaves, on slemiler peticles, and slemiler more exserted tube to the corolla. - Ibot. Mex. 13แund, $1 \geq 9$

Var. glabella, fray: a form with nearly oblong leaves, somntimes almust ses

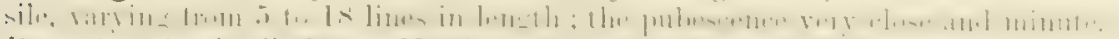

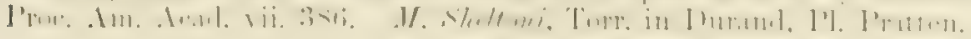

Dry and mostly wooded grounds, rommon through the Shate; the more villons form, whith suggisted the specitic name, chiclly southward. 
4. I. odoratissima, Benth. Pale and nearly glabrous, or canescently-tomentulose, a span to a foot high: leaves oblong-lanceolate, mostly entire ( 4 to 15 lines long), and short-petioled; the veins not prominent: bracts thin-membranaceous and colored (whitish or pinkish), inclining to parallel-veined, eiliate or villous: calyx-teeth short, triangular-lanceolate, hirsute without and within.

Dry hills along the Sierra Nevada at 5,000 to 10,000 feet, and through the interior of Oregon to Washimgton Territory. Plant with a strong scent of Pennyroyal : in California it is hardly if at all pubescent, except the head.

5. M. linoides, Gray. Minutely canescent, but the pubescence imperceptible: stems more erect and rigid, a foot high, slender: leaves small (about half an inch long), lanceolate, or the upper linear and sessile and the lowest oblong-spatulate, obtuse, the veins very obscure: bracts nearly as in the preceding but barely ciliate: calyx-teeth narrowly lanceolate, mereIy pubescent. - Proc. Am. Acad. xi. 101.

Mountains east of San Diego, near the Oroflamme mine, Palmer. Redolent of Bergamot.

$$
\text { * Annual, less leafy: leaves entire or merely undulate. }
$$

+ Coralla (from flesh-color to rose or purple) with tube slightly or moderately exserted from the calyx: the lobes linear or elongated-oblong.

$\div$ Bracts pointless, parallel-veined or chiefly so: calyx-teeth rather broad and blunt.

6. M. undulata, Benth. A span to a foot or more high: leaves from oblongspatulate to nearly linear with a narrowed base, obtnse, undulate-margined (commonly an inch long), tapering into a petiole, minutely pubescent or glabrous: braxts and calyx villous; the latter broadly ovate, mostly obtuse, thin-membranaceous or scarious, destitute of cross-veinlets between the nerves: corolla rose-color.

Not uncommon in the western part of the State, from near San Francisco to its southern borders. "Exhales a strong odor of Peppermint."

7. M. lanceolata, Gray. A foot or so high, brachiately branched, green and almost glabrous, or the stem puberulent: leaves lanceolate or oblong-lanceolate (an inch or two long), tapering below into slender petioles; the upper acute; all with entire and even margins: bracts foliaceous or nearly so, ovate or oblong, mostly acute, copiously reticulated between the ascending or parallel ribs or primary veins by cross veinlets: calyx inconspicuously nerved; the short teeth densely hirsute within, sparsely if at all so withont: corolla bright rose-color or purple, sometimes spotted with darker dots. - Proc. Am. Acad. 1. c. 102.

Dry ground, common aloug the foot-hills of the Sierra Nevada, from Plumas Co. to Tejon and San Diego Co. It has been confounded both with $M$. undulata and $M$. canclicans. Apparently much handsomer than either.

8. M. candicans, Benth. A foot or so in height, at length loosely branched, canescently soft-puberulent, at least above: leaves oblong or lanceolate (about an iuch long), commonly obtuse, rather abruptly contracted at the base into a slender petiole, the margins even: bracts thin-membranaceous or almost scarious, ovate, obtuse, reticulated by some cross-veinlets between the parallel ribs: calyx evidently nerved; the teeth very villous both within and without: corolla pale or white, the tube not exserted. - Pl. Hartw. 330.

Foot-hills on the Sacramento, Stanislaus, Cosumnes, \&c.

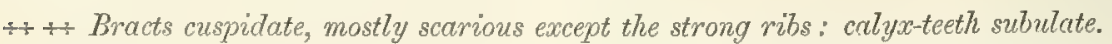

9. M. Breweri, Gray. A span or more high, puberulent: leaves oblong or ovate, abruptly petioled, pinnately veined (the larger an inch long): bracts broadly ovate, abruptly acuminate-cuspidate, whitish-scarious, the outer pinnately and the inner nervosely 7-9-ribbed, most of the ribs converging into the point: corolla rose-purple, the tube surpassing the calyx. - Proc. Am. Acad. vii. 386,

Corral Hollow, Contra Costa Co., south of Monte Diablo, on a very dry sandy hill, Brewer. The plant lias the aspect of a small Monarda fistulosa. 


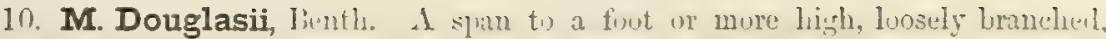

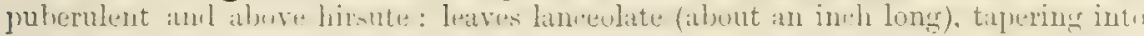
the petiole, the veins inconspicuous and ascending: bracts ovate and ovate-lanceolate, gradually acuminate to a cuspidate point, wholly or mainly trausparent-

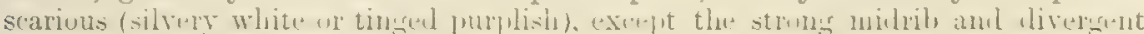
pinnate veins which all run into a marginal false vein of equal strength, forming is rigid framework: corolla deep rose-color, the tube little exserted beyoud the sharppointed calyx-teeth. - Lab. 332, \& DC. Prodr. L. c. M. candicans, var. venosa, Torr. Pacif. R. Rep. iv. 123.

Hills and plains, around San Francisco Bay and nortl to Yuba Co. Plant strong-scented. The very thin and transparent veinless substance of the bracts set as in frames formed of the ribs and simple veins.

++ Cornlla (white?) small, with whally included tube and short oxate-oldims hobes.

11. M. leucocephala, Gray. Is sian or two hiph, mimtely cinerems-puluescent: leaves oblong or lanceolate, entire, short-petioled: bracts orbicular-ovate, pointless, thin-scarious, bright white, $\mathbf{i}$-9-nerved, and with a few indistinct veinlets: calyx hirsute, finely and closely nerved; the teeth subulate and whitish.Proc. Am. Acrd. vii. 385.

Plains near Merced, Brever. Bracts 4 or 5 lines long, the veins minutely hispid underneath. Calyx 21 lines long. Corolla probably more conspicuous in other specimens. The species is it very peculiar one.

\section{MICROMERIA, Benth.}

Calyx oblong or tubular, about 13-striate, terete, not gibbous nor declined, about

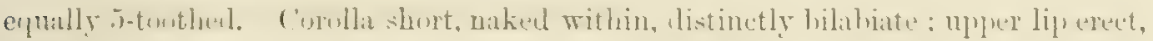
flattish, entire or emarginate; lower sprealing, 3-parted. Stamens 4: filaments arcuate-ascending; the anterior pair longer: anthers 2-celled. Style glabrous. Low plants, sweet-odorous, various in habit, with small flowers in the axils of the leaves.

A genus of numerous old World and several South American species, one of which (of the peculiar section, Hesperuturavs) reaches the Southern Atlantic States, and has a relative on the Parific Const.

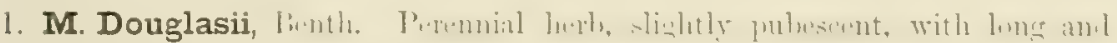
slender creping and trailing stems: leaves round-ovate, thim, sparingly toothed (an inch or less in diameter) short-petioled : flowers mostly solitary in the axils, on it long and filiform 2-bracteolute peduncle: calyx-teeth sululate: corolla purplish, 4 lines long, twice the length of the enlyx, the tube exserten. - Lab. 372. Thymus Douglasiz \& Chamissonis, Benth, in Limiea, vi. 82. Micromeria barbnta, Fischer \& Meyer, Ind. Sem. Petrop. viii. 67.

Woods of tho Coast Ranges, mostly in sandy soil, from Santa Rarban Co. northwarl to Washington Territory. A sweet-scented herb, the well-known Yerba Buena.

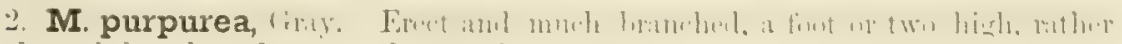
finely and loosely pubescent: leaves short-petioled, lanceolate, acuminate, sparsely sermito with sharp appressed teeth (an inch long): fowers numerous in umbul-like? sessile or short-peduncled fuscicles in the axils of the leaves: calyx ohloni-campannlate, about the length of the pedicels, naked in the throat; the slemler-sulmlate teeth one third the length of the tube: corolla " purple-blue," 2 lines long, little excecting the calyx. - IIedeoma purpurea, Kelloger in Proc. Calif. Acal. v. 52.

Webb's Landing, on an istand in the San onmunin River, Kollemp. Plant with "the strong

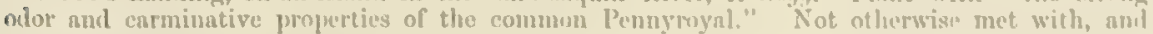
mether obseurs. It is in no respect a Hedrona: in unexpunded flower-buts all four libments thar fertile and similar anthers. 


\section{CaLamintha, Monch. Calaminth.}

Calyx oblong or tubular, often gibbous, about 13-striate, bilabiate; the upper lip 3-toothed or 3-cleft; lower 3-parted; the throat either naked or bearded. Corolla with a straight tube mostly exceeding the calyx, an enlarging throat, and a distinctly bilabiate limb; upper lip erect, flattish or concave, entire or emarginate, the lower spreading, 3-lobed or parted. Stamens 4 ; the upper pair sometimes smaller and sterile: filaments ascending parallel under or beyond the upper lip, or comniving in pairs: anthers 2-celled, with or withont a thickened connective. - Herbs or somewhat suffruticose plants, of various habit, forming four or five very distinct sections ; the species dispersed around the northern hemisphere.

C. Palmeri, Gray, is a new species of the Acinos section, a low and small-flowered annual, with wholly the aspect of a Hedeoma. It was recently discovered on Guadalupe Island off Lower California, by Dr. E. Palmer.

1. C. mimuloides, Benth. Erect, 2 feet high, somewhat viscidly villous: leaves ovate, thin, coarsely serrate, an inch or two in length, slender-petioled: flowers nearly solitary in the axils; their slender peduncle leafy-bracteate at the base: calyx tubular, two thirds of an inch long, nearly naked in the throat, barely bilabiate, the three teeth of the upper lip united higher than the two lower, all cuspidate from a broadly triangular base: corolla orange, an inch and a half long, its cylindrical tube twice the length of the calyx. - Pl. Hartw. 331.

Shady places, Carmel River, Monterey Co., Hartweg.

2. C. (?) ilicifolia, Gray. Annual, branched from the base, 3 to 6 inches high, rigid, puberulent or glabrate: leaves coriaceous, ovate-spatulate or cuneate, coarsely few-toothed, about half an inch long and with a petiole of equal length: bracts nearly as large as the leaves, but closely sessile, rigid-coriaceous, broadly ovate or roundish, callous-margined; the stout midrib and 3 or 4 pairs of pinnate divaricate veins projecting into long prickles: flowers several and sessile in each axillary cluster, each pair of clusters (making a false whorl) involucrate by 4 bracts : calyx oblong, villous-pubescent, moderately bilabiate; the teeth spinulose-subulate from a broad base: corolla apparently purplish or white (half an inch long); the tube twice the length of the calyx ; upper lip erect, oblong and concave, entire; the lower broad and spreading, 3-lobed; the lobes short and rounded; middle one deeply and the lateral ones slightly emarginate: stamens inserted high in the enlarged throat; the pairs very unequal; anterior pair with stout filaments and divaricate almost confluent anthers; posterior pair with slender filaments and much smaller or abortive anthers. - Proc. Am. Acad. viii. 368.

California, Major Rich, in herb. Torrey. Near San Diego, D. Cleveland. Described as constituting a peculiar section, Agaxthomixtha. Additional specimens, from Mr. Cleveland, show abortive anthers to the upper pair of stamens (and no villosity to the fertile stamens, as deseribed from Rich's specimen in the Torreyan herbarium); and the upper lip is so concave that, taking the singular braets and the habit into view, the plant may with reason be ranked as a genus.

\section{POGOGYNE, Benth.}

Calyx unequally and deeply 5-cleft; the lanceolate teeth longer than the campanulate or turbinate mostly 15-nerved tube, the two lower longer; throat naked. Corolla straight, tubular-funnelform, with short lips; the erect and entire upper lip and the three lobes of the spreading lower one oval and somewhat alike. Stamens 4 with anthers, or the upper and shorter pair sterile, ascending, and above more or less approximate in pairs : anthers 2-celled; the cells parallel and pointless. Style somewhat exserted, bearded above with hirsute hairs. - Low annuals (all Californian), 
sweet-arumatip; with ohlons or ohlanceolate mosty entire Inaves, narrowel inte a

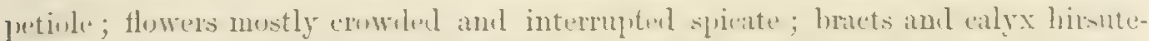

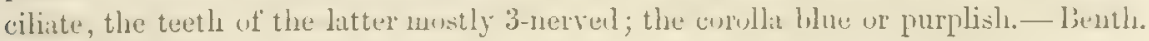
Lab. 414 .

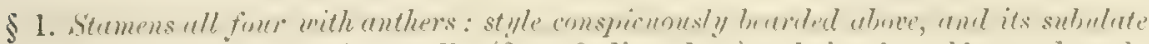
lobes almost equal: corolla ( 6 to 9 lines loing) tubular-funnelform, the tube surpassing the calyx (calyx-feeth variuble).

* Flower-clusters densely crowded into an oblong or cylindrical spike, which is conspicuously white-hirsute with the long and stiff ciliate hairs of the bracts and calyx.

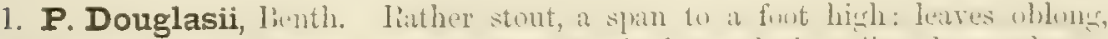

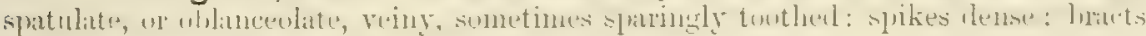
linear, acute: lower divisions of the calyx twice or thrice the length of the tube and much longer and narrower than the others: corolla half to three fourths of an inch long, blue, or sometimes purplish.-Hook. Bot. Mig. t. 5886. P. multiflora, Lenth. Lab. \&c., a smaller form with rather shorter bracts.

Open and shady grounds, throughout the western part of the State and into the foot-hills of the Sierra Nevada,

2. P. parviflora, Benth. More slender, 5 to 8 inches high: leaves narrower: spike shorter: bracts mostly obtuse: divisious of the calyx rather broad, the lower harlly longer and the upper shorter than its tube: corolla barely half an inclu long.

San Franciseo Bay to Mendocino Co., Douglas, Bolander, \&e.

* Whorl-like flower-clusters more or less distant: bracts and calyx sparsely and rather slightly hirsute-ciliate.

3. P. nudiuscula, Gray. A span to a foot high, with slender puberulent branches: leaves spatulate or linear-spatulate, obtuse (an inch or less in length), glabrous: bracts linear-subulate and cuspidate : corolla half an inch long, twice the length of the calyx : anthers of the posterior stamens usually smaller than the others, but polliniferous.

Near San Diego, D. Cleveland. Calyx-lobes lanceolate-subulnte or linear-suhulate, in the later flowers all twice or thrice the length of the tube, but in some of the earlier ones little longer than the tube.

\$2. Upper stamens sterile: style sparingly hairy, its lobes very unequal: flowers small. - Hedeomordes, Gray.

* Tube of the corolla slender and manifestly exceeding the calyx, 4 or 5 lines long: inflarescence capitate.

4. P. tenuiflora, Gray. $\Lambda$ span or less in height, puberulent or at the summit pubescent, corymbusely branched or simple: leaves spatulate or obovate, their petioles and the narrow bracts slightly and sparsely and sometimes not at all bristlyciliate: calyx-lohes unequal, linear-lanceolate, about half the length of the filiform tube of the corolla: sterile filments tipped with a small capitate gland. - Proc. Am. Acul. xi. 100.

Guudalupe Island, Lower Californin, Dr. Palmar. Added to complete the account of the genus. * * Corolla at most 2 lines long, little if at all surpassing the calyx.

5. P. ziziphoroides, lienth. Stems 2 to 6 inches high: leaves ovate or oval, thickish; the thoml with the righil marrow hracts and the calyx hirsute-ciliate with strong whito hairs: inthoresence capitate or spieate, sometimes intermplent, of with a few solitary fluwers in the lower axils: calyx-luhes slightly unound, loroully lancoolate, very acute, harily twice the length of the tube, the lunger equalling the 
corolla : posterior filaments not reduced in size, but bearing only abortive anthers. Pl. Hartw. 330.

Valley of the Sacramento, Hartweg, Andrews, Bolander.

6. P. serpylloides, Gray. Stems slender, diffuse, 3 to 6 inches high: leaves obovate-oval or spatulate : lower flowers remote and often solitary in the axils, leafybracted; the upper usually interruptedly spicate: calyx-lobes unequal and with the bracts more minutely and sparsely ciliate, all much longer than the tube, the larger fully equalling the violet or bluish corolla : sterile filaments of the posterior stamens tipped with minute rudiments of anthers: style bearded above with very few and coarse hairs. - Proc. Am. Acad. vii. 386. Hedeoma (?) serpylloides, Torr. Pacif. R. Rep. iv. 123.

Monterey to Mendocino Co. : apparently common. Leaves 2 or 3 lines long, besides the petiole. Corolla inconspicuous.

\section{SPHACELE, Benth.}

Calyx campanulate, nearly equally 5-cleft, thin-membranaceous and reticulated, especially when enlarged in fiuit, irregularly about 10-nerved, naked within. Corolla cylindraceous or oblong-campanulate, with 5 broad and roundish rather erect lobes, the lower one longest: a hairy ring at the base of the tube within. Stamens 4, distant, somewhat ascending: filaments naked; the posterior pair shorter: anthercells diverging. — Somewhat shrubby, veiny-leaved, and rather large-flowered. All Sorth American and Mexican, excepting one in the Sandwich Islands and the following.

1. S. calycina, Benth. Shrubby only at the base, 2 to 5 feet high, villouspubescent or tomentose, leafy: leaves 2 to 4 inches long, ovate or oblong, mostly obtuse, crenate or serrate, sometimes almost entire, thinnish, either roundish, cuneate, or occasionally obscurely cordate at base, usually petioled; the floral ovate-lanceolate and sessile : flowers an inch long, mostly solitary in the upper axils, forming a short leafy raceme; calyx a little shorter than the purplish or lead-colored corolla, soon inflated; the lobes triangular-lanceolate. - Lab. 568, \& in DC. Prodr. xii. 255.

Var. glabella, Gray : a form with pubescence minute or hardly any, the veinlets sometimes inconspicuous, sometimes more prominently reticulated.

Var. Wallacei, Gray : loosely villous : lower leaves with truncate or sometimes - hastate-subcordate base: lobes of the calyx attenuately linear-lanceolate from a broader base.

Not uncommon on hillsides, from San Francisco Bay southward: the var. glabella collected by Bridges and S. F. Peckham (Santa Barbara Co.): var. Wallacei only by Wallace, near Los Angeles?

\section{SALVIA, Limn. Sage. Chia.}

Calyx bilabiate; its upper lip (2-) 3-toothed or entire, lower 2-cleft. Corolla deeply 2-lipped; the upper lip erect, straight or falcate, entire or emarginate, or rarely 2-lobed; the lower spreading or drooping, its middle lobe sometimes notched or obcordate, commonly large. Stamens 2, inserted in the throat of the corolla: filaments short, sometimes very short, apparently forked, i. e. a slender connective attached by the middle to its apex, its posterior portion ascending and bearing a linear anther-cell; its anterior or descending end bearing a smaller and deformed anther-cell or a mere rudiment. Posterior stamens mere vestiges or none. Nutlets when wetted mostly developing abundant mucilage and long spiral threads. - Her- 
baccous or suffruticuse plant, aromatic and bitterish, of varions aspect, many with showy flowers.

A genus of about 450 species, found in all parts of the world, but mainly in warm temperate and subtropical regions. There are about two dozen species in the United States, but ouly two, and of a peculiar section, have yet been met with in the State of C'aliforuia.

\$ 1. Throat of the calyx villous or naked; its upper lip much longer than the lower, more or less incurved, 3-2-toothed; the lonoer 2-parted; the teeth all spinulase-awned: corolla ringent, blue or purple; its tube with a hairy ring inside, and the upper lip 2-lobed: stamens distant from the upper lip, unconnected; the lower fork of the long filiform connective bearing a polliniferous anthercell: root annual or perhaps biennial: leaves pimnatifid: Howers in solitary or 2 to 4 proliferous dense capitate clusters, which are involucrate with persistent bract-like floral leaves. - EcHivospince. (\$ Echinosphace \& Pycnosphace, Benth.)

1. S. carduacea, Penth. Whitr-woully with lax coluwhly hairs : stem stout, simple, a foot or two high, nearly naked, at base surromded by a cluster of oblong

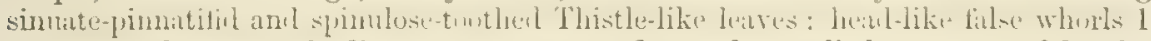
to 4 , an inch or more in diameter, very many-flowered, equalled or surpassel by the involucrate lanceolate or ovate-lanceolate and spinescently pectinate-touthed bricts: calyx long-woolly, many-nerved; its ample upper lip strongly 3 -toothed, the middlo tooth much the larger, the lateral ones distant; the throat villous: tube of the corolla slightly exserted; its upper lip erose-denticulate and 2-cleft; the lower with small lateral lobes and a larger flabelliform and fimbriately many-cleft midule one: proper filaments harilly any: anther-cells hairy. - Hook. Bot. Mag, t. 487 t. S. gossypina, Benth. Pl. Hartw. 330.

Sandy soil, not uncommon throughout the western and middle parts of the State to San Diego. Corolla an inch long.

2. S. Columbarize, In'nth. Minutely tomentose or suft-pubesent : stem commonly slender, brunching, and lenfy below, a span to a foot or two high from an annual ront, naked and peluncle-like below, terminated by a solitary or two proliferous head-like false whorls: leaves deeply once or twice piunatifid or parted into oblon: and crenately-toothed or incised divisions, pointless, rugose: involucrate flural leaves bract-liko and short, ovate, entiro: bracts similar but membranaceous, sometimes purplish, abruptly acuminate-awned : flowers small : calyx naked within; its large upper lip arched, hispid at base outside, tipped with a pair of comivent and partly connate short-awned teeth, much exceeding the two small and porrected tecth of the lower lip: corolla (blue) hardly exceeding the calyx; its upper lipi merely notched; the lower with small laterial lobes; the middle one much larger, trausversely oval, on a short claw, 2-lobed, and otherwiso nearly entire: filaments slender.

Common through the State, Newadn, and Arizonn, especially southward. Corolln 3 or 4 lines long. Calyx with middle tooth of the upjer lip always wanting. This is the "Chice" of the aborigines: the seed-like nutlets, infused un water, form a plensnit mucilaginous drink, which is largely used.

\section{\$2. Throat of the calyx nakerl: anthers with only one polliniferons cell; the lnuer fork of the connective naked, deflexed into the throat of the coralla, linenr or oblong; the pair more or less united lengthwise or at the tip. (None indigenous.)}

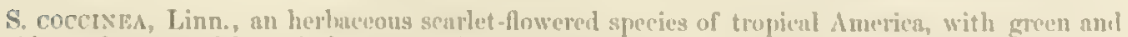
deeiduous bracts and loose infloreseence, is not unlikely to be spontuneous in the sonthem part of the state, $11 \mathrm{~s}$ it is in the (iulf situtes.

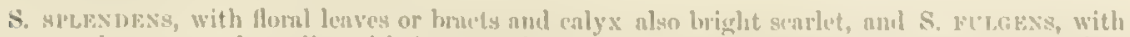
these nearly green and corolla red-hairy, are the common Searlet siges of eultivation : but they seem not to huve becume spontuncous. 
S. Platrcinerla, Gray, Proc. Am. Acad. viii. 292, a shrubby and hoary bluish-flowered species, the funnelform dilated calyx with ovate lips, was discovered by Dr. Palmer, at Carmen Island, Lower California, lat. 26\%. It is relatel to S. BALlotercora, Benth., of New Mexico and Texas.

\section{AUDIBERTIA, Benth.}

Calyx nearly as in Salvia, or more cleft on the lower side, as if spathaceous. Corolla with the upper lip spreading, 2-lobed or emarginate; the lower spreading and 3-lobed, the broad middle lobe emarginate. Stamens 2 : filaments slender, exserted, apparently simple and bearing a linear one-celled anther, or with an articulation, showing that the portion above it answers to a filiform connective, the lower end of which sometimes projects into a subulate point, but never shows any trace of a second anther-cell. Vestiges of the posterior stamens often present. Perennial aromatic herbs or undershrubs (all Californian extending into the regions adjacent), hoary; with rugose-veiny mostly crenulate leaves, resembling those of Sage, and capitate-glomerate or sometimes a more open and paniculate inflorescence: the flowers prized for bees.

\section{§1. Flowers densely capitate-glomerate: bracts crowded and conspicuous.}

* Large: corolla an inch and a half long, crimson-purple; its upper lip rather erect and short: lower leaves cordate or hastate at base.

1. A. grandiflora, Benth. Stem villous and glandular, stout, 1 to 3 feet high from a scarcely woody base: leaves very rugose, sinuately erenate, white-tumentose beneath; the lower hastate-lanceolate and obtuse, 3 to 8 inches long, on margined petioles; the upper oblong and sessile; floral ones and bracts broadly ovate, membranaceous, villous, cuspidate-tipped: heads large, interruptedly spicate: stamens much exserted: a conspicuous slender tooth representing the lower fork of the connective. - Torr. Bot. Mex. Bound. 132, t. 38, the sterile filaments incorrectly represented.

On the Coast Ranges, from San Mateo Co. southward. A showy plant.

* Smaller-flowered: corolla from half to three fourths of an inch long, violet or bluish-purple: leaves not cordate.

+ Bracts, most of the floral leaves, and the bilabiate calyx scarious-membranaceous, reticulated, more or less colored; the tip obtuse, pointless, or at most mucronate: dense heads interrupted-spicate or rarely solitary: corolla not over half an inch long: low species of the interior arid region.

2. A. incana, Benth. Shrubby, a foot or so in height, finely tomentose-canescent, leafy: leaves spatulate or obovate, obtuse or retuse, entire, not rugose, glandular-dotted, seldom an inch long, all but the uppermost tapering into a petiole: bracts and upper floral leaves obovate or oval, the innermost spatulate, pubescent and ciliate, tinged with rose or purple: calyx turbinate, its ovate or oblong anterior teeth nearly equalling the very broad truncate and emarginate upper lip: stamens much exserted. - Lindl. Bot. Reg. t. 1469.

From San Diego Co. along the eastern borders of the State, and from S. Utah northward to the Upper Columbia River.

3. A. capitata, Gray. Cinerenus-pubescent: leaves oblong, acntish, very rugose, crenulate, somewhat abruptly petioled: flowers usually in a single terminal head: bracts and floral leaves apparently whitish, ovate or oval, minutely glandular: otherwise resembling the preceding. - Proc. Am. Acad. vii. 387.

Summit of Providence Mountains, San Bernadino Co., Cooper. 
++ Bracts more or less herbaceous: leaves minutely rugose and crenulate. + + Corolla half an inch or less in length: all the calyx-teeth and the bracts subulate or aun-pointed.

4. A. humilis, lienth. I span high, tumentulesecantescent, cespituse : thwering stem seape-like: leaves mainly radical, oblanceolate or spatulate-oblong, very obtuse, tapering into a slender petiole: spike of 3 or 4 small and closely sessile hearl-like clusters: bracts lanceolate or ovate, villous-hirsute, their tips and the calyx-teeth subulate, not rigid: stamens and style long-exserted.

Near San Francisco or Monterey, Douglas. Hillsides near Nevada, Bigcloro. Mountains of San Diego C'o., Palmer,

5. A. stachyoides, Bentlo. Decidenlly shrubby, 3 to is foet high, rickil, with lerbaceous flowering branchlets, leafy, cinereous-tomentulose, becoming greener and glabrate : leaves oblong-lanceolate, tapering into more or less of a petiole, obviously crenate, the upper surface glabrous with age: bracts of the 3 to 5 dense sessile and

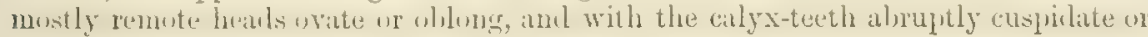
awned : style and especially the stamens little exserted.

Common from the Contra Costa Mountaing to the southern borders of tho State.

+++ Corolla two thirds to three fourths of an inch long, its tube much exceeding the calyx and the short bracts: upper lip of the calyx barely 1-3-mucranate, the teeth of the lower more pointed: stamens and style moderately exserted: stems 4 to 8 feet high, with paniculate and virgate herbaceous remotely-leaved flowering branches; the stem below woody.

6. A. Palmeri, firay. Minutuly tomentuluseraneseent: leaves ublone-Ieneerlate, acute (the larger 2 or 3 inches long) : head-like clusters of flowers 5 to 8 , remote in the elongated virgate naked spike : bracts oblong or lanceolate, acuminate into a slender cuspidate tip: lower calyx-teeth subulate-setaceous.

Near Tighes Runch in the mountains northenst of San Diego. "Corolla a delicate blue." In some respects intermediate between the foregoing and the following. The virgate much interrupted spikes often a foot or more in length ; the whorl-like capitate clusters from 3 incles to half an inch apart.

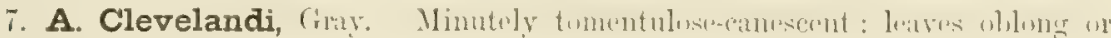
the upper lanceulate-oblong, all obtuse (an inch or two long): head-like clusters one or two (rarely 3) and rather distant, or single terminating peduncle-like branchlets: bracts ovate or oblong, merely mucronate or abruptly short-pointed, viscidpubescent, as is the calyx: upper lip of the latter short and subulate. - Proc. Am. Acad. x. 76 .

Mountains northeast of San Diego, at about 2,200 feot, Clevcland, Palmer. The latter found it growing in or near tho habitat of tho preceding and closely related species.

++++++ Corolla barely half an inch long, its tube hardly exceeding the herbaceons blunt and pointless bracts and calyx.

8. A. mivea, Benth. Shrubby, 3 or 4 feet high, leafy, mealy-tomentose, and very white: leaves oblong-lanceolate, obtuse, very short-petioled, the upper truncate at baso: bracts ovate or oblong, much imbricated: calyx splitting down the front and at length notched posteriorly" corolla "light purple"; the tube hardly longer than the lips: stmmens and style conspicuously exserted.

Dry hillsides from Sunta Barbarn southward. Full-grown cepitato flower-clusters an ineh broad (nutluer larger than in the two preceding species), from 2 to 4 in the interrupted spike.

\$2. Flowers thyrsoid-paniculate: the fornd leates and the fere bracts of the smull and numerous clusters lumcerdute or subulate.

9. A. polystachya, Benth. Shrubliy, 3 to 10 fiet high, closely and finely tomontose-canescent: herlacceus flowering branches virgate: leaves lanceulate or 
the lower oblong, minutely rugose, tapering into a petiole; the floral small and bract-like; the uppermost minute: open thyrsoid-virgate inflorescence a foot or so in length, naked: flowers nearly sessile: the broad upper lip of the calyx entire or obsoletely 3-tuothed, double the length of the triangular-subulate teeth of the lower lip : corolla apparently white or pale, with very short tube and ample lower lip: stamens and style long-exserted.

Dry hills and banks, Santa Barbara to San Diego and eastward, where it is one of the various shrubs called Grease-wood. Corolla half an inch or more in length. The open inflorescence of this species gives it a peculiar aspect.

\section{LOPHANTHUS, Benth.}

Calyx tubular-campanulate, 15-nerved, rather oblique, 5-toothed. Corolla with tube not surpassing the calyx: upper lip nearly erect, 2-lobed; the lower somewhat spreading and 3-cleft, its broad middle lobe crenate. Stamens 4, exserted, straight; the upper pair declined and the lower and shorter pair ascending, so that the pairs cross: anthers short, 2-celled, the cells nearly parallel. - Tall perennial herbs, mostly coarse; with ovate and serrate petioled-leaves, and small, purplish, violet, or whitish flowers, crowded into terminal spikes.

A small genus, of two N. E. Asiatic, three Eastern North American species, and one in Oregon and California. L. anisatus, Benth., the sweet-scented species of the Upper Mississippi region, is in Bolander's published list of plants growing in the vicinity of San Francisco; but the following was doubtless intended.

1. L. urticifolius, Benth. Glabrous or nearly so, 4 to 6 feet high : leaves ovate and cordate, coarsely or crenately toothed (2 to 4 inches long, pleasantly scented), rather short-petioled: flower-clusters compacted in a close oblong or cylindrical pedunculate spike: calyx-teeth lanceolate, subulate-acuminate, membranaceous, whitish and purplish : corolla light violet-purple.

Through the wooded region of the Sierra Nevada, from Mariposa Co. northward, extending to Oregon and to the Rocky Mountains.

\section{SCUTELLARIA, Linn. SKULL-CAP.}

Calyx in flower campanulate, with two entire lips and a gibbous projection on the back, closed and with the dorsal projection enlarged after flowering, becoming casque-shaped, at length splitting to the base, and the upper or casque-shaped portion usually falling away. Corolla with an elongated and curved ascending tube, a dilated throat, naked within, an erect arched or galeate upper lip (entire or barely notched), with which the lateral lobes belonging to the lower lip appear to be more or less connected; the anterior lobe (convex or with the sides recurved and apex notched) appearing to form the whole lower lip. Stamens 4, ascending under the upper lip of the corolla; the lower or antexior pair longer and with one-celled (or half-) anthers; the posterior pair with 2-celled cordate anthers: these in all ours ciliate or bearded. Upper fork of the style very small or abortive. Nutlets granulate or tuberculate. Embryo curved! - Bitterish herbs, not aromatic, chiefly perennial; with single flowers in the axils of the leaves or bracts; the corolla more commonly blue or bluish.

A genus of almost 100 species, widely distributed over the world, most largely in temperate regions, well represented in the Atlantic United States, but few in California, none of them with racemose or spicate inflorescence.

S. LATERIFLORA, Linn., well characterized by its small flowers in axillary one-sided racemes, extends northwardly across the continent to Oregon, and may therefore reach the northern por- 
tion of California. - The following all bear single and short-peduncled flowers in the arils of ordinary cauline leaves, but the uppermost leaves are sometimes a little reduced, giving a tendency to racemose intlorescence.

* Leaves all broad and somerohat cordate or tmuncate at base: stems very leafy: propagating by filiform subterranean shoots: tubers none or hardly any.

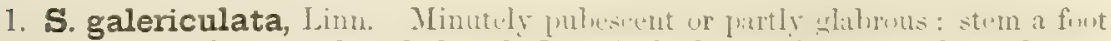
or two high, simple or at length loosely branched: leaves thin, ovate-lanceolate or the upper lanceolate, an inch or two long, acute, pinately veiny, all but the uppermost serrate : corolla pubescent, light blue (about two thirds or three fourths of an inch loner), with somler tube and enlareme thruat ; the lewer lip nearly ereet and larger than the upper.

Wet grounds in the Sierra Nevada (Plumas Co, Lcmmon): extending north to British Columbia and east to the Atlantic. The only species common to America and the Old World.

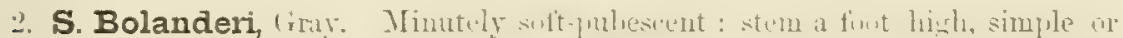
branched from the base, equally very leafy to the sumnit: leares thimnish, oval, obtuse, with subcordate base, closely sessile, an inch long or less, entire, or the lower sparingly somewhat crenately toothed, a pair of veins from the base on each side: corolla whitish or crean-colored, two thirds of an inch long, much eularged above from a short tube; the lower lip ample. - Proc. Am. Acad. vii. 387.

Wooded portion of the Sierra Nevada : at Clark's, Jariposa Co., Bolander. Also Indian Valley, Plumas Co., Lemmon. Leaves 18 to 22 pairs, mostly longer than the internodes. Neither tubers nor tiliform subterranean shouts have been seen.

* Leaves, at least the upper ones, narrowed or merely abtuse at base,

- From oblong to linear, entire or nearly so: stems erect: filiform subtemanean shoots abundant, but slighly if at all tuberiferous.

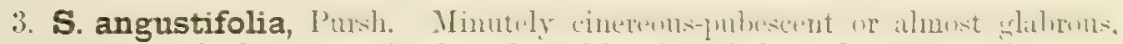
a span to a toot high: stems simple or branching from below: leaves from linear to narrowly ublong (about an inch long), all but the lower acute at the sessile base or tapering into a slight petiole; the radical lenves often roundish or even cordate am sometimes toothed: pedicels as long as the calyx: corolla blue or violet, an inch long, with slender tube and moderately enlarged throat; lower lobo villons inside.

Var. canescens, Gray : a form with soft-hoary pubescence, and the tube of the corolla often with recurving base, and above this erect or thrown somewhat backward. - S. siphocampyloides, Vatke in Bot. Zeit. xxx. 717.

Sierm Sevala and foot-hills, from Placer Co. northward, extending to British Columbia. The var. canescens alung the mount:ins frou Monterey Co. to Lake C'o.

4. S. antirrbinoides, lituth. I span to a fint am a half hish, ristmbles the

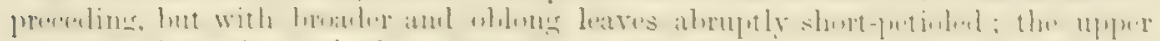

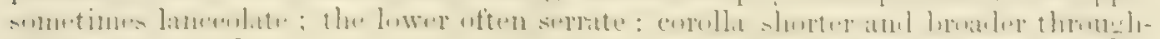
out, from half to three fourths of an inch long, apparently paler. — Gray, Proc. Am. Acal, viii, 396. So resinosa, Watson, Bot. King Exp. in part.

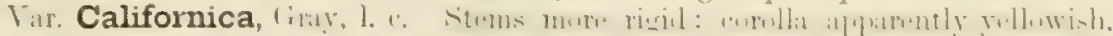
more ventricose, its tuhe more enlurning immediately above the calyx. - S. angustifolia, Benth. Pl. Hartw. 331 (No. 1918), is a narrow-leaved form of this.

Along streams, Alameda to Mendocino Co. Also in Oregon and the mountsins of Nevadu.

++ Leaves oute, petioled: stems low or diffuse: propagating by filiform subcerranean shonts terminated by moniliform tubers.

5. S. tuberosa, Benth. Soft-villous or pubescent, an inch or two lighth, or at length with difluse or trailing stems a foot long, slemer: lenves thin, from cordateovate to olovate or the upper cuneate-ublone, slemerepetinled, coarsely mone or less towthed: corolla pulessent, blue or viulet, over hath an inch long, and with rather slemilex tuthe. 
Plains and hillsides, rather common from Monterey Co. northward ; beginning to blossom in February. Varying greatly in size. Upper flowers in vernal specimens sometimes much exceeding the leaves, on the longer trailing stems much exceeded by them.

6. S. nana, Gray. Depressed, cinereous-puberulent throughout: stems tufted on the filiform subterranean shoots, 2 or 3 inches high: leaves thickish, obovate or ovate, very obtuse, entire, half an inch long, tapering into a short petiole, equalling the flowers : pedicels very short: corclla "white," half an inch long, rather broad, and with short equal lips. - Proc. Am. Acad. xi. 100.

On a clay ridge, Winnemucca Valley, near Pyramid Lake, N. W. Nevada, Lemmon. Tubers copious, moniliform, an inch or two long. Corolla appearing purplish in the dried specimens, said to be white.

\section{SALAZARIA, Torr.}

Calyx at first campanulate or oblong, with two entire lips and no gibbous projection on the back, in fruit much enlarged and globose-inflated, thin and bladdery, reticulated, closed. Corolla, stamens, \&c., as in Scutellaria. Upper fork of the style wanting. - A single species.

1. S. Mexicana, Torr. Shrubby, 2 or 3 feet high, with slender and divaricate straggling branches, somewhat sarmentose, canescent: leaves becoming green and glabrate, ovate-lanceolate or oblong, mostly entire, an inch or less in length, on short slender petioles; those of the flowering branches reduced to bracts of the loose raceme or spike: corolla purple or whitish, nearly au inch long, pubescent: scarious fruiting calyx over half an inch in diameter : nutlets depressed, minutely muricate. Bot. Mex. Bound. 133, t. 39.

S. E. borders of the State, on the Mohave, \&c., to S. Utah, and south to the adjacent part of Mexico, Fremont, Parry, Cooper, \&c. Named in honor of Signor Salazar, Mexican Boundary Commissioner.

\section{BRUNELLA, Tourn. SELF-HEAL.}

Calyx oblong, about 10 -nerved and reticulate-veiny, bilabiate; the lips flattened and closed in fruit; the upper dilated, truncate and 3-toothed, its teeth yery broad and short; lower 2-cleft, the teeth lanceolate. Corolla with ascending tube, open lips, and slightly contracted orifice: upper lip arched and entire; lower 3-lobed, its middle lobe drooping, rounded, concave, denticulate. Stamens 4, ascending under the lower lip : filaments 2-toothed at the apex, the lower tooth bearing the 2-celled anther, the cells of which are divergent. Nutlets smooth. - Low perennials, of two or three very similar species: the flowers crowded in a terminal oblong or cylindraceous head ox spike.

1. B. vulgaris, Linn. A span to a foot high, roughish-pubescent or almost glabrous: leaves ovate or oblong, slender-petioled, entire or toothed : corolla violet, purple, or rarely white, not twice the length of the purplish calyx.

Open grounds or borders of woods, near San Franciseo and near the Yosemite, probably indigenous, as it certainly is in Oregon, British Columbia, and eastward: extending round the northern hemisphere.

\section{MARRUBIUM, Linn. HoReHoUnd.}

Calyx cylindraceous, 5-10-nerved, of firm texture, 10-toothed; the alternate (accessory) teeth shorter, spiny-tipped and recurved at maturity. Corolla short, its tube included in the calyx; the upper lip erect and concave, narrow, 2-lobed at the tip; the lower spreading and 3-cleft. Stamens 4, included in the tube of the corolla: anthers 2-celled, but the cells confluent. — Bitter-aromatic whitish-woolly 
perennials, lorancherl from the base: leaves mgnse: forwers small, much comrled in axillary false whorls or heads. - An Old World genus, a single species naturalized in the New, used in popular medicine.

1. M. vulgare, Linn. A font or two high, hoary-woolly: leaves roundish, crenate: Howers crowded in the upper axils: corolla swall, white: calyx-teeth and bracts hooked at the tip.

Waste and dry grounds near the coast: naturalized from Europe.

\section{STACHYS, Linn. HEDGE-NETTLE.}

Calyx tubular-ampanulate or turbinate, 5-10-nervel, nearly equally 5-toothed; the teeth sometimes rigid or spiny-pointed. Corolla with cylindrical tulbe, not dilated at the throat; the upper lip erect and concave or arched, entire or merely emarginate; the lower spreading and 3-lobed, its middle lohe larger. Stamens 4, ascending under the upper lip: filaments naked: anthers approximate in pairs, 2-celled; the cells either parallel or divergent. Nutlets obtuse, not truncate. Herbs (or a few undershrubs), not aromatic; with flower's clustered, capitate, or scattered, often spicate or racemose at the summit of the stem or branches: ours all perennials, and the flowers sessile or nearly so.

$$
\text { * Tube of the corolla little if at all longer than the calyx. }
$$

Cornlla white or whitish; the upper lip bearded or woolly on the back: herbage tomentose or soft-hairy.

1. S. ajugoides, Benth. I span tis a font high, villous or silly-hirsute with whitish hairs: leaves oblong, very obtuse, crenately toothed ( 1 to 3 inches long), the base either obtuse or tapering into the petiole; the upper sessile: flowers about 3 in the axils of the distant upper ordinary leaves, and loosely leafy-spicate at the summit, mostly surpassed by the floral Jeares: calyx short-campanulate, very hairy; its teeth ovate and merely mucronate-acuminate. - Prodr. xii. 474.

Moist grounds, common from Mronterey to Lake Co.

2. S. albens, Gray. Tall (3 to 5 feet ligh) and rather strict, soft-tomentose throughout with white or whitish wool, leafy: leaves oblong or ovate and mostly cordate, obtuse, crenate ( 2 or 3 inches long), the lower short-petioled, the upper nearly sessile: flowers several or numerous in the eapitate clusters, which mostly exceed the floral leaves and form an intermpted at length elongated virgate spike (from 3 to 9 inches long): calyx turbinate-eampanulate, its teeth triangular and awn-pointed: corolla white with purple dots on the lower lip, glabrous except the villous beard on the back of the upper lip. - Proc. Am. Acal, vii. 387.

Moist and rich soil, on the mountains and foot-hills of the Sicrra Nevada, from Fort Tejon to Santa r'lara and Tuolumne Co.

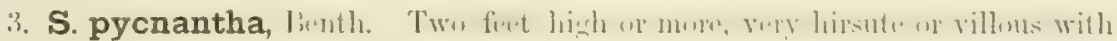
long and mostly soft spreading hairs, not white: leaves oblong-ovate and somewhat cordate, obtuse, crenate ( 2 to 4 inches long), all but the floral ones mather long potiolal: flowers in a dense cyliminceous nuked spike (an inch or two loug), exceeding the small bractiko floral leaves excent in the lowest ant somotimes rather distant clusters: cnlyx-teeth triangular and slightly mucronate : corolla apparently white or cream colur with purple on the lower lip, the upper lip strongly bearded on tho lack. - 1'l. Hartw. 331 .

Mouterey Co. (IIarlurey) to near San Francisco, Kcllogg.

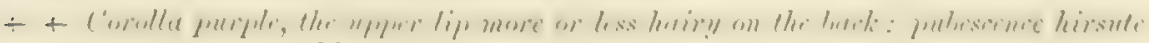
or hispid, at least on the stem; no tomentum. 
4. S. bullata, Benth. Stem retrorsely hispid or hirsute especially on the angles, a foot or two high: leaves ovate or ovate-oblong, at least the lower more or less cordate, coarsely crenate, obtuse, veiny, sonetimes rugose, nearly all petioled (an inch or two long), most of the floral much reduced and shorter than the calyx : flowers usually 6 in the false whorls, these rather distant, forming a narrow much interrupted spike: calyx turbinate-campanulate, mostly hirsute or villous with widely spreading hairs; the teeth triangular-ovate and subulate-cuspidate, rigid: lower lip of the corolla fully as long as the tube, much larger than the upper. S. bullata, \& S. Californica, Benth. in DC. S. Nuttallii, var. leptostachya, Benth. PI. Hartw. 331.

Mendocino Co. to San Diego and Fort Mohave; apparently a very comınon as well as widespread and variable species; the pubescence of the leaves often soft. Lower lip of the corolla 4 or 5 lines long, the upper 2 or 3 .

S. PALUSTRIs, Linn., in some of its forms occurs in Oregon, and may reach the northern borders of California.

* Tube of the red corolla much surpassing the calyx, over half to three fourths of an inch long: flowers mostly 6 in the false whorls.

5. S. Chamissonis, Benth. Stem 2 to 5 feet high, stout, mostly rough-hispid with rigid retrorse bristles, at least on the angles: leaves ( 2 to 5 inches long) oblongovate and mostly a little cordate, crenately serrate, usually villous or hirsute above and villous-tomentose beneath, nearly all petioled; all but the lowest floral ones shorter than the loosely interrupted spicate flowers: calyx tubular-campanulate; its triangular-ovate teeth cuspidate-tipped: corolla rose-red; its tube twice the length of the calyx ; the lips pubescent outside.

Wet grounds; common around San Francisco Bay.

S. cillata, Dougl., a smoother and thinuer-leaved species of this section, with the lower flowers in the axils of ordinary leaves, belongs to the coast of Oregon and northward, perhaps also in the northern part of California.

S. CoccrNeA, Jacq., a handsome Mexican species, with a tubular scarlet corolla, occurs in Arizona and nay perhaps reach the lower borders of California.

\section{TRICHOSTEMA, Linn, BLUE-CURLS.}

Calyx campanulate, in ours little oblique and almost equally 5-cleft. Corolla with short or rather slender tube and almost equally 5-parted limb, which is gibbous or oblique in bud; the lobes oblong and similar. Stamens 4 : filaments long and capillary, spirally coiled in the bud, long-exserted from the upper side of the corolla, sometimes monadelphous at base: anther-cells divergent or ilivaricate, and soon confluent. Nutlets coarsely rugose-reticulated. - Sweet-aromatic herbs or suffrutescent plants (all North American); with entire leaves, and blue or purple corolla and stamens. - The two species of the Atlantic United States have scattered and pedunculate flowers, with a very oblique and unequally 2-lipped calyx; the intermediate $T$. Arizonicum has the loose inflorescence of the foregoing with the almost regular calyx of the western species, all which have very short axillary peduncles, bearing several or numerous flowers in dense and mostly unilateral cymose clusters.

$$
\text { * Corolla hardly if at all surpassing the calyx. }
$$

1. T. oblongum, Benth. Annual, soft-villous: stem a span or two high, diffusely branching, equally leafy to the top: leaves oval-oblong, thin, contracted at base into a short petiole, much exceeding the small and dense cluster of nearly sessile flowers: calyx very villons, deeply 5-parted, the lobes lanceolate-subulate. Lab. 659 \& in DC. Prodr. xii. 573. 
Wooded portion of the Sierra Nevada, from Mariposa to Shasta Co, and in Oregon. Plant with a pungent and very pleasant aroma. Leaves barcly an inch long; the pinnate veius ascending. Corolla barely 3 limes long, and the stamens 2 limes longer.

* Corolla with slender tube exceeding the calyx: cymose flower-chusters disposed to fork and to become raceme-like in age.

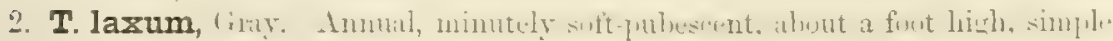
or loosely branched from the base: leaves rather distant, lanceolate and oblumglanceolate, acute or acuminate, rather obscurely pinnately veined (an inch or two long), tapering at the base mostly into a slencer petiole: axillary cymose clusters

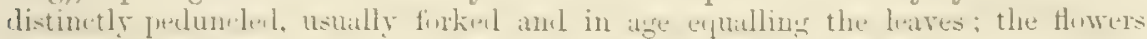
pedicelled: calyx-lobes ovate-triangular and equalling the tube: corolla almost glabrous, 3 or 4 lines long, and the stamens half an inch longer. - Proc. Am. Acad. vii. 387.

Dry ground, from Marin Co. to Humboldt Co. ; apparently a rather common species. Flowers indigo-blue.

3. T. lanceolatum, Benth. Annual, cinereons-pubescent or villous, a span to a foot or more in height, with virgate stem or branches very leafy: leaves much longer than the internodes, lanceolate or ovate-lanceolate, sessile by a broul base, grailually acuminate, traversed by 3 to 5 strong and almost parallel nervose veins or ribs (an inch or less long): cymose axillary clusters uearly sessile, short, ome-

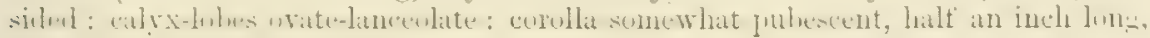
the tube almost filiform.

Dry ground, chiefly in the western part of the State, rather common from Los Angeles Co. northward and in Oregon.

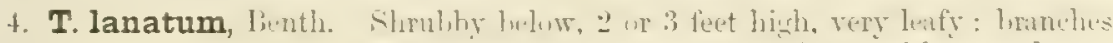
and foliage canescently puberulent or tomentulose and glabrate with age: leaves very narrowly linear, obtuse, l-nerved and with revolute margins, Rosemary-like, many fascicled in the axils; the floral ones mostly small and bract-like: flower-

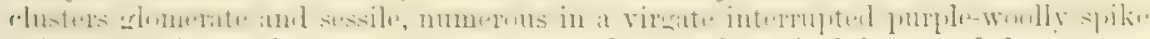
(of a fuot or less in length): corolla very woolly, nearly an inch long, and the stamens and style an inch or two longer. - Torr. Bot. Mex. Bound. t. 40.

Rocky leiges, Monterey? or Santa Burhara to San Diego Co. Flowers violet. Very striking for the purple-woolly spike and long capillary stamens and style.

\section{ORDER LXXIV. VERBENACE无.}

Herbs or shrubs, differing from Labialce mainly in the ovary and fruit, which is undivided and 2-4-eelled, at maturity either dry and splitting into as many 1-seeded nutlets, or drupaceous containing as many little stones. - Calyx persistent.

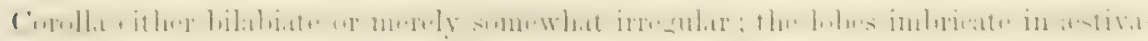
lion. Stamens 4, didynamous. Style single: stigna entire or 2-lobed. Solitary ovule erect or ascending and anatropous. Seed with a straight embryo, its ralicle inferior, and no albumen. Leaves opposite or whorled, very rarely alternate, with-

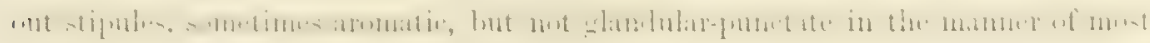
Labiate. Fluwers perfect: inflorescence variuus.

An order of molemte extent in tropical and warm-tenpente regions, a few, chiefly weets, in the cool-teniprate, of no striking sensille properties or economiral imprortance, exirpting the Ameriwan Verluens so conmon in ornamental cultivation, and a few species of Lentuna. r'lus rillifurnian representation of the onder is feuble.

1. Verbena. Fruit of 4 unitud nutlets. Calyx tubulur or prismatic.

2. Lippia, Fruit of 2 united uutlets. Calyx 2-cleft. 


\section{VERBENA, Limu. VervatN.}

Calyx tubular or plicately prisnatic, 5 -toothed, one tooth often shorter. Corolla salverform; the tube sometimes curved; the limb more or less unequally 5-cleft. Stamens 4, included; the upper pair sometimes sterile. Stigma of two dissimilar lobes, one of them smaller and mostly abortive. Ovary 4-celled, in fruit splitting into 4 one-seeded little nutlets. - Herbs (or a few South American species shrubby); with the flowers in single or panicled spikes or heads, small, or in some showy. The commoner species are apt to hybridize naturally, and the hybrids are not rarely fertile.

Chiefly an American genus, mainly South American; the few Californian representatives weeds or weedy, and only two or three truly indigenous.

\$1. Flowers small in proportion to the spike: anthers glandless.

* Stem erect: spikes filiform and with the flowers or fruits at length more or less scattering: bracts usually shorter than the fruiting calyx.

+ Annual, or the base becoming ligneous and of longer duration: stems a span to 2 feet high, slender: some of the leaves pinnatifid, tapering at base, the lower into a margined petiole.

1. V. canescens, HBK. Hoary-hirsute : leaves oblong-lanceolate and cuneateobovate, rigid, sharply incised or pinnatifid: sjukes mostly solitary, terminating the branches; some of the bracts exceeding the flowers: corolla bluish, the limb a line or so in diameter. - Nov. Gen. \& Sp. ii. 274, t. 136. V. remota, Benth. Pl. Hartw., from Mexico, is a simple-stemmed form.

Cañon Tantillas, south of San Diego Co., Palmer. Probably extends within the State, as it does eastward to Texas and Mexico.

2. $\mathbf{V}$. officinalis, Linn. Minutely roughish-pubescent, loosely branched: leaves obovate or oblong, or the upper lanceolate, some merely incised, others once or twice pinnatifid or 3-5-cleft: bracts all shorter than the calyx: corolla purplish or lilac, the limb 2 lines in diameter, sometimes more.

Dry waste grounds through the western part of the State, probably naturalized, but the species occurs round the world. A stouter form, and with limb of corolla 3 or more lines in diameter, answering to $V$. sororia, Don, was sent from San Diego by $D r$. Hitch.cock.

$$
++ \text { Perennial, } 2 \text { to } 5 \text { feet high: leaves serrate or merely incised. }
$$

3. V. polystachya, HBK. Scabrous with very short partly hispid pubescence, green, paniculately branched: leaves from oblong to lanceolate (mostly about 2 inches long), sessile by a narrowed base, or the lower short-petioled, coarsely serrate or sparingly incised : spikes loosely panicled or sometimes solitary : corolla purplish or nearly white, the limb about a line in diameter. $-V$. polystachya, V. biserrata, \& (according to Schaner) $V$. veronicaefolia, HBK. l. c. $V$. Carolinensis, \&c., Dill. Hort. Elth. 407, t. 301. V. Caralina, Linn., but it is a Mexican, not a Carolinian species. V. Caroliniana, Spreng.; Hook. \& Arn. Bot. Beechey, 156 ; Schauex in DC. Prodr. xi. 546.

Monterey or San Franciseo, according to Hooker \& Arnott in the Botany of Beechey's Voyage. Los Angeles, Wallace?

V. vrTrcifoliA, Linn. Green, minutely rouglish-pubescent: leaves ovate and ovate-lanceolate, mostly acute or acuminate, simply or doubly serrate, all but the uppermost with rounded base and a slender petiole, the larger 4 or 5 inches long : panicled spikes very slender : corolla mostly white.

A common weed in the Atlantic States, extending into Mexico, \&e. ; very likely to reach California : the specimen sent by $W$ allace, mentioned under the preceding, is too incomplete to determine whether it belongs to that or the present species. 
* * Stem erect: spities slender-cylindrical, densely-flowered; the flowers and fruit overlapping: bracts short.

4. V. hastata, Linn. Perennial, minutely pubescent: stem stouter, 3 to 6 feet high: leaves oblong-lanceolate, gradually acuminate, coarsely or incisely serrate, petioled, some of the lower ones commonly hastate-3-lobed: spikes numerous in a terminal panicle, 2 to 4 inches long: corolla blue, 2 lines long, and the limb as broad. - V. paniculata, Lam., the name given to the form, not uncommon, which has no lobes to the leaves.

Marshes on the Lower Sacramento, according to Torrey, Bot. Wilkes Exp. 403. Probably elsewhere in the State.

$$
\text { * * Stems spreading or merely ascending: spikes not fliform. }
$$

5. V. prostrata, R. Brown. Soft-hirsute or villous: stems at first erect or ascending, a foot high, at length widely branched and diffuse, rarely prostrate:

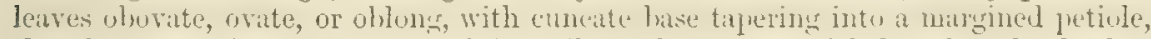
sharply serrate, incised, or 3-5-cleft : spikes solitary or panicled, rather slender but dense when in flower, becoming 4 to 10 inches long, hirsute or villous: bracts subulate, not longer than the calyx: corolla violet or blue, 2 lines long. - Ait. Hort. Kew. ed. 2, iv. 41. V. lasiostachys, Link; Hook. \& Arn. Bot. Beechey, 156.

Common in dry ground through the western parts of the State. Root probably perenuial. Plant very variable. From Jamuel Valley, below San Diego, Dr. Palmer sends a more upright and thickish-spiked plant, which might be a cross between this and $V$. stricta, if the latter wero Californian; or perhaps it has some $V$. haslate in it.

6. V. bracteosa, Michx. Perennial, hirsute, a span to a foot high, at length diffusely much branched: leaves cuneate-oblong or obovate, pinnately incised or 3 -cleft and coarsely toothed; the lower narrowed into a short margined petiole; the uppermost passing into bracts: spikes terminating the branches, thickish, rather

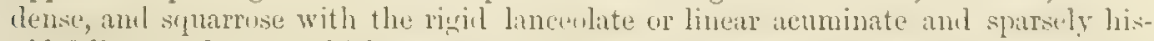
pid follitceous bracts, which surplats the Howers: corolla purplish or blue, small and slender. - Hook. Bot. Mag. t. 2910.

Near Monterey, in alkalino soil, Bolander: a peculiar and rigid form, with bracts or bract-like leaves far down the stem. The ordinary form occurs in Oregon, and extends to the Atlantic States.

\section{\$2. Howers more showy: spike at first short and capitate: connective of the anthers of the longer stamens tipped with a gland.}

7. V. ciliata, Irenth. Low and diffuse, appurenty annual, villons-hirsute: or the

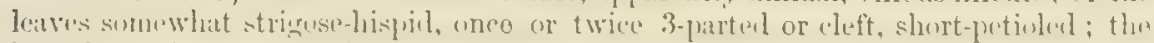
lateral divisions commonly 2-lobed and the midrlle one 3-5-lobed or incised: bracts lanceolate-subulate, shorter than the calyx: tube of the latter oblong; the tecth rather short-subulate, nemly equal: corolla "blue," or purple; the tube hardly twice the length of the calyx. - Pl. Hartw. 21; Schauer in DC. Prodr. xi. 553.

Tautillas Mountains on the southern borlers of the State (Pnlmer), a form with rather coarsely cleft leaves : extends through Arizona (Pilmer, Licul. Whecler, de.), to W. Texas and Mexico.

V. mipinnatifida, Schauer (Glandularia bipinnatifida, Nutt.), from Colorndo to Texas, is certainly perennial, and has much longer and sleniler bracts and calyx-tecth, the latter very unequal.

\section{LIPPIA, Linn.}

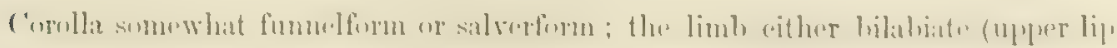
entire or 2-lobed, lower 3-parted), or 4-cleft and merely oblique. Stumens 4, included. Stigma crpitate or oblique. Ovary 2-celled, in fruit forming 2 one-seeded nutlets. - Hurbs or shrubs, of varius aspect: tho folinge sometimes aromatic, as in $L$. citrialora, the sweet Verbena-shrub of the gardens, native of S. America, to which most of the species belong. 
1. L. Iycioides, Steudel. Shrubby, 4 to 10 feet high, minutely puberulent: branches long and slender; branchlets sometimes spinescent: leaves lanceolateoblong, obtuse (a quarter to a full inch long), narrowed at base into a slight petiole, 1-nerved, nearly veinless, roughish above, on flowering stems commonly entire: flowers small, vanilla-scented, in slender naked spikes : calyx very hirsute, 4-cleft: corolla barely 2 lines long, white or bluish, 4-lobed.

No. 548 in the Californian collection of Conlter. More likely collected in the Mexican province of Sonora, where it was found by Dr. Palmer, whence it extends eastward to Texas. Also a native of Buenos Ayres, \&c.

2. L. nodiflora, Michx. Perennial ? herb, creeping extensively, minutely cinereous-pubescent or nearly glabrous: leaves cuneate-spatulate or oblanceolate, sessile or nearly so, obscurely veined or veinless, the tapering base entire, from the middle to the apex sharply serrate: peduncles erect from the rooting joints, 1 to 4 inches long, much exceeding the leaves: flowers in a globular or at length cylindraceous head, a quarter of an inch thick: bracts closely imbricated: calyx compressed fore and aft, 2-cleft, 2-carinate, the lobes conduplicate, linear-lanceolate, lateral: corolla purplish or white, bilabiate: fruit corky, not readily separating into the 2 nutlets. - Zapania nodiftora, Lam. Lippia lanceolata, Torr. Bot. Wilkes Exp., 403, not of Michx.

Banks of the Lower Sacramento and San Joaquin to the Rio Colorado: east to Texas and Florida; and widely dispersed over the warm regions of the world. Includes several nominal species.

\section{ORder LXXV. PLANTAGINACE无.}

Stemless herbs with flowers in spikes, the 4-cleft regular corollas dry and scarious, consisting almost wholly of the genus,

\section{Pidantago, linn. Plantain. Ribgrass.}

Flowers perfect, or sometimes more or less dicecious, in a spike or head, each subtended by a bract. Calyx of 4 persistent imbricated sepals, free from the ovary. Corolla hypogynous, of scarious texture, veinless, withering-persistent, short salverform; its limb 4-parted, imbricated in the bud. Stamens 2 to 4, inserted on the corolla altemate with its lobes: filaments commonly long and flaccid in anthesis: anthers versatile, 2-celled, opening lengthwise. Ovary 2-celled, or by a false partition in some 3-4-celled, with one or more amphitropous ovules in each cell: style filiform, all the upper part pubescent or bearded and stigmatic. Fruit a membranaceous or coriaceous capsule, circumscissile towards the base, the upper part falling away as a lid, carrying with it the loose partition, which bears one or more peltate seeds on each face. Seed-coat mucilaginous when wet. Embryo straight, about the length of the fleshy albumen. - Mostly stemless herbs, with nerved or ribbed radical leaves, and naked scapes of small mostly greenish flowers.

A large genus, widely distributed over the world, mainly in the temperate zones, in Europe accompanied by a monocious genus, Littorella, but otherwise having no obvious near relationship. The North American species are few.

\$1. Flowers all alike and perfect, with the 4 stamens and long style both much exserted, but at different periods, i. e. the latter while the stamens are still in the unopened corolla, these protruded by the elongation of the slender filaments a day or two later, after the stigma has begun to wither: lobes of the corolla not closed after flowering. 


\section{* Leaves 3-7-ribbed, not fleshy: root perennial.}

1. P. major, Linn. Gilaturs ur sumetimes jullescent : leaves orate or lroadly oblong, large, abruptly contracted into a channelled petiole, 5-7-ribbed: spike long and slender: capsule 7-16-seeded.

San Diego to Oregon; apparently sparingly naturalized in California. This Wayside Plantain, probably indigenous only to the Old World, is reported to spring up in North Ameriea "wherever the white man bas set his foot."

2. P. lanceolata, Linn. Mrstly hairy : leaves lanceolite ur clongitecl-obloner, 3-5-ribbed: scape deeply grooved and angled, slender, at length much surpassing the leaves (a foot or two long), bearing a head which commonly lengthens into a dense thick spike: bracts and sepals scarious, two of the latter commonly united into one: capsule 2-seeded: seeds hollowed on the inner face.

Dry fields, near San Francisco. The Ribgrass, Ripplegrass, or English Plantain ; introduced from Europe; apparently not widely established.

\section{* Leaves ribless or nearly so, fleshy and narrow.}

3. P. maritima, Linn. Perennial or biennial : the thick crown more or less woolly among the bases of the leaves, which are linenr, usually much fleshy-thickened, entire or with a few scattered sharp teeth: scapes a span or less in height, hearing a dense many-flowered oblong or cylindrical spike: sepals scarious-membranaceous with a thickish green centre, which in the posterior ones is crested: capsule often more or less 3-4-celled, a single seed in each cell.

Along the sen-shore, on rocks, in sand, or in salt-marshes. Widely dispersed over tho world, and varying in form.

\$2. Flowers of two kinds on different individuals, both with 4 stamens, one sort with long exserted filaments, the other with shori included filaments and small anthers.

4. P. Patagonica, Jilc1. Anmul, silky-wolly, or sumetimes muly jubscent: leaves varying from narrowly linear-lanceolate to nearly filiform, entire or sparingly denticulate, 1-3-nerved: scape slender, 2 to 6 inches high, bearing a dense cylindrical or oblong spike, in depanpernte specimens frequently reduced to a head: flowers all perfect: sepals very obtuse, scarious except a thick central portivn: lobes of the corolla round-ovate and cordate, remaining expanded after anthesis: capsule 2-seeded: seeds large, deeply hollowed on the face or boat-shaped. - Gray, Man. ed. 5, 312, \& in Pacif. R. Rep. iv. 117.

Open grounds, common in the western part of the State, chicfly in a small form. Extends sonthwarl almost to the extremity of the American continent, and on the eastern side, uniler sevoral forms, from Texas through the Valley of the Mississippi and the grent plains to the Saskatthawan district.

5. P. Virginica, Linn, vir. maxima. Annull or himnial, pulesent or hirsute with many-jointed hairs, becoming woolly at tho crown: leaves from oblanceolate to olblong and oval or obovate, 3 to 10 inches long, obtuse, sparingly clenticulate, 3-7-ribbed, tapering into a narrowed base or wing-marmined petiole: scape a span to a foot or une long, bearing a clense spike: bracts not longer than the calyx: lobes of the rather small corolln ovate and slightly corlate; in the long-stamened and sterilo form remaning open or reflexel; in the much commoner amb fully fruitful form with small or incluted stamens, clnsing permanently over the ovary and cnpstele and somewhat indurating in the form of a slender-conical beak, crowning the summit of the orate obtuse $2-3$-sected capsule: seels nearly flat on the

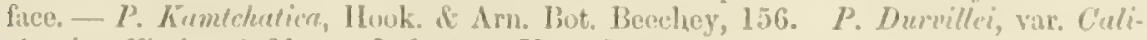
fornicen, Fischer \& Meyor, Int. Sem. TLort. Petrop.

Along the const, San Francisco lany to Afonterey. The assoriation of this rolust plunt with

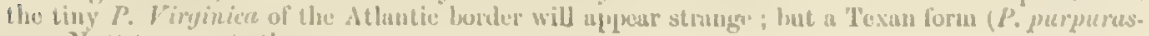
cons, Nutt.) cunneets (hem. 


\section{§ 3. Flowers perfect (and perhaps of two kinds): stamens 2.}

6. P. Bigelovii, Gray. Anmual, small and slender, a span or less in height, slightly hirsute: leaves linear, obtuse, entire, a line or two wide, the broader ones obseurely 3-nerved, shorter than the scape : spike oblong or linear, densely few many-flowered: bracts carinate, about the length of the calyx: lobes of the corolla ovate, remaining open : stamens and style a little exserted: capsule ovoid-oblong, somewhat exceeding the calyx, 2-celled, 4-seeded: seeds oblong, not hollowed on the face. - Pacif. R. Rep. iv. 117.

Salt-marshes, San Pablo Bay, at Benicia and Vallejo, Bigclow, E. L. Grcene. Re-described from good specimens collected by Mr: Greene. Flowers twice the size of those of the eastern $P$. pusilla, which extends westward to Utah, and was mistaken for this in the Botany of King's Expedition.

P. ERIOPODA, Torr., of the Rocky Mountains, which reaches Northeastern Nevada, also

P. MACrocarpa, Cham. \& Schlecht., of the northern Pacific coast, are the only other Western species; both with thickish spikes and rather large flowers and capsules. 


\section{ADDITIONS AND CORRECTIONS.}

Page 43.

17. NASTURTIUM.

3․ N. obtusum, Nutt. Annual or biennial, glibrous or nearly so : stems much branched, elecumbut or proeumlsent, a span lone or le'ss: leares pinnitely parterl or divided; the segments mostly oblong, sinuately toothed: flowers minute: pods ovate- to linear-oblong, 2 or 3 lines long, very obtuse or acutish, beaked by the short style: pedicels about a line long. - Torr. \& Gruy, Fl. i. 74.

On the headwaters of Kern River (Rothrock); Northern Nevada (Watson); fre: luent eastward from Colorado and New Mexico to the Mississippi.

Page 300.

3. BRICKELLIA.

2. B. grandiflora, Nutt, var, minor, Gray, Proc. Lear. Philad. MLarch, 1863, 67. A form deciledly smaller in all its parts; collected on a peak near Luke Tahoe, Lemmon.

Page 313.

16. APLOPAPPUS.

8a. A. Palmeri, fray. Slurub 4 feet hirh, paniculately much branched, sone. what resinous; brunches often virgate, very leafy: leaves filiform, about an inch long, with shorter ones fascicled in the axils, obscurely punetate: heads paniculate, 4 lines loug : involucre turbinate; the scales oblongr-linear, very obtuse, chartaceous,

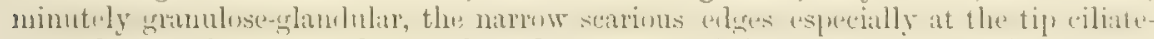
fringed : rays 3 or 4, not longer than the 11 to 15 disk-flowers: akenes short-linear, villous-pubescent. - Proe. Am. Acad. xi. 74.

Tecate Mountains, in Lower California, 20 miles or more below the State boundary (Pa7mer); San Bernardino Co., Parry. One of the Ericancria section, related to A. pinifolius, A. ericoides, and the New Mexican A. laricifolius.

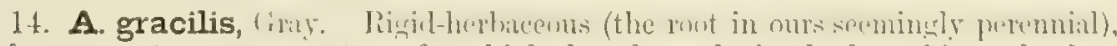
pubescent: stems a span to a foot high, loosely and simply branching, slender: leaves linear or the lowest somewhat spatulate, pinnately 5-7-eleft or incised, the lobes short and tipped with a rigil bristle; upper leaves gralually reduced to linear and entire small and appressed bracts (3 to 2 lines long), which pass into the

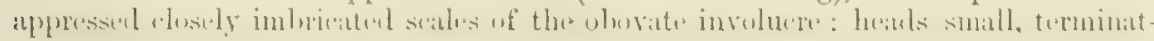
ing the virgate branches: rays 12 to 18 , short: akenes silky-hairy: pappus dirty

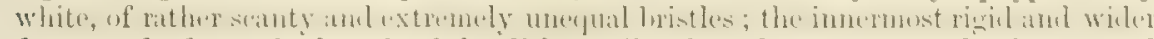
downward, about the length of the disk-corolla, the others successively shorter and finer: style-appendages linear, as long as the stigmatic portion. - Pl. Fendl. 76.

Southoastern part of the Stato; San Diego and Sun Bernardino counties (Cooper, Clerelend, Pintiner); thence east to Now Mexico. Heal a quarter of an inch high: senles of the involuere linenr, rigil, mostly bristle-tipped, in the plunt of Arizona and California minutely grumulatephantular. Belongs to the Blepharodun section, along with $A$. arenarius and $A$. spinuelosis, refurred to on p. 314 .

Page 314.

\section{BIGELOVIA.}

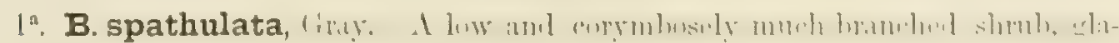
brous, hamlly at all glutinons: branchlets loafy to the summit: leaves (half an inch 
long) cuneate-obovate, entire, mostly retuse, thick-coriaceous, veinless and with midrib indistinct, obscurely if at all punctate: heads in small corymbose terminal clusters, 4 or 5 lines long, about 16-flowered: scales of the turbinate involucre numerous and regularly imbricated; all of the inner ones broadly linear, coriaceous, rather obtuse, destitute of green tips; the outer shorter, greenish, and gradnally passing into roundish rigid scale-like bractlets: appendages of the style-branches slender-subulate, as long as the stigmatic portion and narrower: akenes silky-hairy. - Proc. Am. Acad. xi. 74.

Tantilias Mountains, near the entrance of the Great Cañon, below the southern boundary of the State, Palmer. Too closely resembles Aplopappres cuneatus, p. 312 ; but not balsamic-resinous; leaves almost dotless; heads smaller, fewer-flowered, and rayless; akene shorter and with silky pubeseence, and slender bristles of the pappus not thickened toward the tips.

2. B. arborescens, Gray. Foot-hills of the Sierra Nevada in Calaveras Co., Lemmon, 1875.

3a. B. brachylepis, Gray. Resembles B. Cooperi: heads larger and broader, 4 or 5 lines long, 8-12-flowered, corymbose or thyrsoid, or terminating short-leaved branchlets: scales of the campanulate involucre all obtuse, many with resinousglandular thickened midrib, the innermost not exceeding the linear akenes: styleappendages slender-subulate, obtusish.

Larkens' Station, 80 miles east by north of San Diego, Dr. Palner. Shrub 4 to 6 feet high, fastigiately branched. Also resembles $B$. teretifolia in foliage and in traces of glands to the involucre.

8. B. paniculata, Gray. San Bernardino County, Parry. Also Southern Utah, Palmer.

9. B. graveolens, Gray, has been found as far west as Kern Co., Rothrock.

10. B. Douglasii, Gray. To the varieties must be added a most distinct and. remarkable one,

Var. stenophylla, Gray. Leaves all from very narrowly linear to filiform, smooth: heads narrower, oftener only 4-flowered.

N. W. Nevada (Watson, Lemmon, \&c.) to borders of Lower California, Palmer. Perhaps a distinct species.

Page 324.

\section{ASTER.}

10. A. zstivus, Ait. (?) . Minutely pubescent or nearly glabrous: leaves narrower and heads more paniculate than in $A$. Douglasii: scales of the involucre narrower, the outer all linear, mainly green. - A. laxifolius, Nees. A. Douglasï, DC. in part.

Moist grounds, mountains of San Diego Co. (Cleveland); Southern Sierra Nevada, Tulare Co., \&e., Rothrock. Not uneommon far eastward and northward.

16. A. spinosus, Benth. Glabrous, 2 or 3 feet high, with slender virgate or rush-like branches, terminated by single naked heads, bearing also some soft-spinescent branchlets below : leaves small and linear, or reduced to minute subulate scales, at length deciduous: heads 3 lines long: scales of the involucre subulate: rays rather short, whitish : akenes glabrous. - Pl. Hartw. 20; Torr. \& Gray, Fl. ii. 165.

Interior of San Diego Co., Palmer. Extends through Arizona to Texas and into Mexico.

Page 333.

25. BACCHARIS.

8. B. brachyphylla, Gray. Minutely roughish-puberulent: slender and diffuse branches 2 or 3 feet long from a woody base, beset with small linear or lanceolate subulate leaves (the lower half an inch long, the upper reduced to scale-like bracts less than a line long), bearing loosely paniculate heads: involucre 2 lines high; the 
scales broully laneenlitu, ante, puberulent and erreenish on the back, aud with scarious margins : pappus short, fulvous. $-\mathrm{Pl}$. Wright. ii. 83.

Eastern part of San Diego and San Bernardino counties (Palmer, Parry); enstward to New Mexico.

Page 343.

37^. DICORIA, Tort. \& Gray.

Hearl heterosinnus, disenil; ane or two marrinal flowers pistillate and fertile, apetalous, consisting of an ovary and a 2-parted style; the other flowers 6 to 12 , staminate and sterile, with olwonical so-tonther corrilit, comfletely monalelphons filanents, slightly chlerent anthers, and unlivided style destitute of stigma and appendages. Involucre of about 5 short and oval herbaceous scales, and of either one or two much larger and flat accrescent scarious ones, each of the latter subtend-

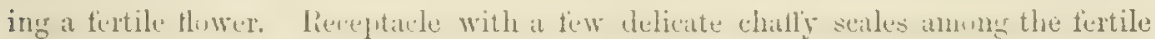
flowers. Akenes obcompressed, oblong, sumrounded by a toothed border or wing, much exceeding the outer involucre. - Annual or biennial herbs, whitened with nppressed hirsute pubescence; with entire or serrate petioled leaves, the lowest

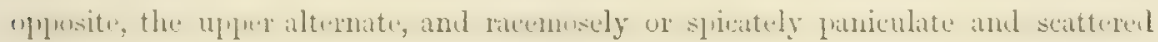
small heads, nodding in fruit; the flowers greenish yellow. - Emory Rep. 143, \& Bot. Mex. Bound. 86, t. 30 ; Gray, Proc. Am. Acad. xi. 76.

1. D. canescens, Tors. \& Gray, l. c. A foot to a yard hish: leaves from oblong-lanceulate to ovate: internal and greenish-yellow scales of the involuere a

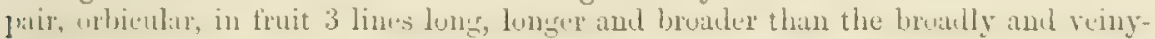
winged akenes they subtend.

Desert washes in San Bernardino Co. (Parry), and eastrard in S. Utah and Arizona.

D. Brasnegri, Gray, 1. c., of S. E. Colorado, has narrow leaves, and a single fertile flower, the akene of which has a callous-toothed border in place of wing, and much exceeds the relatively smaller subtending seale.

Page 343.

38. IVA.

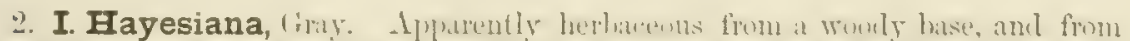

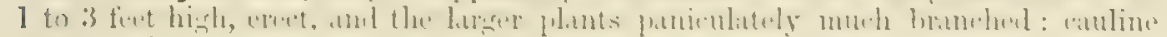
leaves opposite, spatulate-oblong and very obtuse, an inch or two long, the base nar-

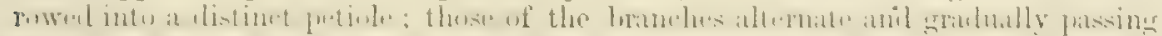

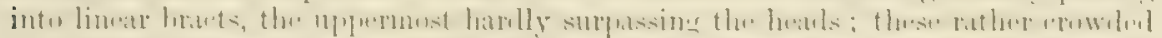

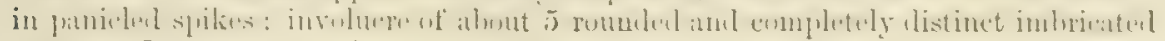
scales, - Proc. Am. Acad. xi. T8.

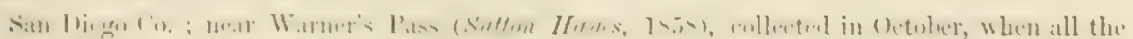
flowers hud fullen; Jumucl Valley, south of San Diego, Dr. Palmor, 1875.

\section{Prge 344 .}

41. FRANSERIA.

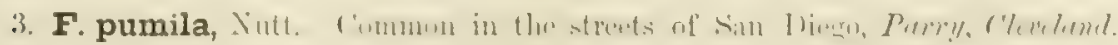
The fruit is small, and much of it one-celled and spincless, and therefore that of an Ambrosin. 'The species needs to bo compared with $A$. eenuifolia, Spreng., aul $A$. fruticost, I) $\mathrm{U}$, var. canescens.

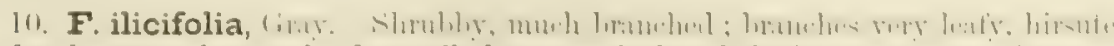
and pubescont : leaves closely sessilo by an auriculate half-elnsping hase, coriacents, prouinently veiny and reliculated, ovato or oblong (less than 2 inches long), scahrous and pubeseent, coursely serate; the teeth and especially tho nemunate apex spiny-tiplued: fortile involuere slubuse, thickly armed with houk-tipused prickles, 
which are as long as the somewhat stouter beaks, 2-celled, 2-seeded. - Proc..Am. Acad. xi. 77.

In the Tantillas Cañon, northern part of Lower California, Palmer. A remarkable species, with Holly-like leaves. Sterile-involucres unknown. Full-grown bur half an inch in diameter including the prickles.

Page 349.

45. WY ETHIA.

3a. W. coriacea, Gray. (In character between * and **) Barely a foot high, villuus-pubescent : stem stout, few-leaved : leaves long-petioled, firm-coriaceous, much reticulated, ovate, or sometimes roundish, or the upper oblong, 3 to 5 inches long; the base either truncate or inclining to cordate, or oblique, or sometimes narrowed into the petiole: heads few, rather narrow: scales of the involncre 5 or 6 , foliaceous, oblong or lanceolate, an inch to an inch and a half long, equalling or exceeding the 5 to 8 rays, also 2 or 3 smaller rather chaffy ones within: akenes glabrous; those of the ray oblong and obcompressed, of the disk 4-5-angled and narrower: pappus 4 to 6 small and stout rather unequal blunt teeth, a little united at base, rarely one of them longer and subulate. - Proc. Am. Acad. xi. 77.

On the Mesa Grande, 70 miles northeast of San Diego, Dr. Palmer.

Page 352.

\section{ENCELIA.}

5. E. viscida, Gray. Apparently a foot or two high and herbaceous, branching, viscid-glandular throughout: stem and branches (as well as sparingly the leaves) hirsute with long and slender many-jointed widely spreading hairs: leaves alternate, ovate or oblong, sessile, mostly with auriculate or cordate half-clasping base, sparingly serrate, an inch or two long (the lower not seen): heads terminating short leafy branches: scales of the involucre broadly linear, obtuse, a little unequal, all shorter than the disk; the outer greenish and viscid, thin-membranaceous; the innermost like the chaff of the receptacle thin-scarious: rays none: disk-corollas light yellow: akenes narrowly cuneate, with callous margins and summit, strongly white-villous, especially the margins, these extended into strong pubescent awns. Proc. Am. Acad. xi. 78 .

Southern part of San Diego Co., at Larkens' Station, 80 miles enst of San Diego, Dr. Palmer. A remarkable species, with the aspect and foliago of a IInTsco. Heads three fourths of an inch long. Akenes 4 or 5 lines long; and the subulate awns 2 or 3 lines.

Page 353.

49. HELIANTHUS.

6. H. gracilentus, Gray. Perennial (but base not seen), apparently 3 feet or more high: slender branches nearly smooth and glabrous: leaves lanceolate, rather short, entire, pale and minutely hispid-scabrous both sides, obscurely triplinerved; the lower opposite and abruptly contracted into a short petiole; the upper scattered and gradually reduced to an inch or less in length: peduncles few or solitary and slender: involucre shorter than the brownish-yellow disk; its scales regularly imhricated, acute, destitute of tips, densely and rather hirsutely puberulent: rays 12 to 16, an inch or less long: akenes flat and broad, smooth, only half the length of the slender bayonet-shaped scales of the pappus, which are fully three fourths the length of the disk-corolla. - Proc. Am. Acad. xi. 77.

Mountains 45 miles northeast of San Diego, Dr. Palmer.

Page 362.

57. HEMIZONIA.

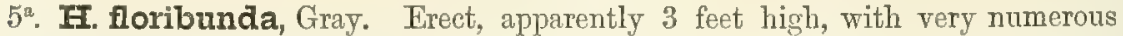
and leafy branches, minutely glandular-pubescent: lower leaves not seen ; the upper linear, obtuse, entire, a half to a quarter of an inch long: heads terminating the branchlets, 3 or 4 lines broad and high, mnny-flowered: scales of the involucre 
oblong-lanceclate, shorter thin the lisk, mather olutnes, extremely glamlular: rily: 20 or more, forming two series, with cuneate 3-lubed deep orange-yellow ligules: disk-flowers about as many, most of them fertile: chaff of the flattish receptacle only between the ray and disk flowers, of linear and nearly distinct seales : pappus of the disk-akenes of 5 to 8 ovate or roundish blunt and entire scales, which are hairy on the back and margin. - Proc. Ain. Acad. xi. 79.

On the Fort Yuma road, at Larkens, 80 miles east of San Diego, Palner. A striking species of the Hartmannia section, in some respects resembling $H$. frulscens, to be inserted in the subdivision (with some emendation) which includes $H$. anguslifolice and $H$. comymbosa.

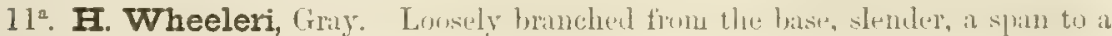
foot high, somewhat hirsute, bardly at all glandular: leatves all linear and entire, scattered (the lower an inch or two long): heads scattered, short-peduncled: seales of the involucre lanceolate, lerbaceous, rather short: rays only 5 or 6 , bright yellow: disk-flowers numerous (yellow), with abortive ovary and no pappus: outer chaff of the receptacle of distiuct thin scales; inner mostly winting : fertile akenes triangular.

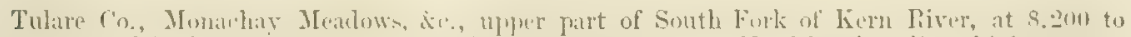

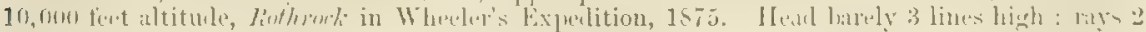

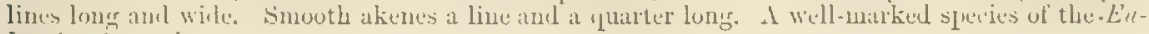
han izomia section.

Page 391.

77. HYMENOPAPPUS, L'Her.

Head homogamous; the rather numerous flowers all alike, perfect and tubular. Scales of the involucre 6 to 12, more or less imbricated, obovate or oval, flat, thin, often partly scarious or colored (whitish, rarely purplish). Receptacle small, naked. Corolla with a narrow and glandular tube, abruptly dilated into a campanulate throat, and with 5 revolute lobes. Style-branches rather broad and obtuse. Akenes turbinate or inversely pyramictal, with a short stalk-like base. Pappus of 8 or 10 short and blunt silvery-scarious scales, nearly or quite uerveless. - Biennial or rarely perennial herbs (all N. American), whitened with a rather deciduous wool; the stems with a solitary or corymbose head of whitish or yellow flowers.

1. H. luteus, Nutt. A span to a foot high: leaves mainly in a tuft at the root, twice pinnately diviled; the lobes narrowly linear. with revolute margins or nearly filifurm : stem scape-like, bearing few or rarely solitary long-peduncled heads of licht yellow flowers; akenes very villous, at least on the angles: pappus nearly as long as the tube of the corolla. - Torr. \& Gray, Fl. ii. 373.

Tantillns Mountnins, nenr the State line, in Lower California, Dr. Palmer. Extends eastwarl to the Rocky Mountains.

Page 499.

88. PECTIS.

1. P. papposa, fimy, wr. epapposa. I l, collected by Dr: Palmer, abont half-way between San Diego and Fort Yuma (also

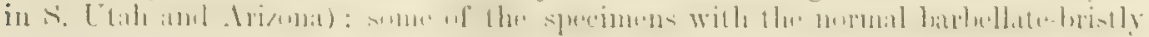
pappus to the disk-flowers, the others with a mero vestige or none.

Pago 102.

93. TANACETUM.

* * Puppres none: lecues only 3-cleft or entire. (Sphceromeria, Nutt.)

3. T. canum, D. C. Faton. A spun high or more, in tufts from a woolly hnse, silvery-canescent : flowering stems simple, terminated by one ol two or several corymbose-crowded heals: lenves half an inch or moro long, sessile, somo cuncate aud 
3-cleft into narrow-entire lobes, others linear or lanceolate and entire: involucre 2 lines high, of about 12 obovate scales: flowers yellowish; a few of the outer ones pistillate; the rest perfect. - Bot. King Exp. 180, t. 19.

Olanche Mountain, Tulare Co., at 10,000 feet, Rothrock in Wheeler's Exped., 1875. Elsewhere found only in the E. Humboldt Mountains, Nevada, Watson.

Page 405.

94. ARTEMISIA.

12. A. Rothrockii, Gray. Shrubby, a foot or less high, bushy, cinereous with a minute appressed pubescence, but green or greenish, and sometimes almost glabrous, or slightly viscid : leaves from cuneate and 3-4-cleft above into oblong lobes to cuneate-linear or spatulate and (especially on flowering shoots) entire, or some of the upper linear-oblong: heads crowded, spicate-panicled, greenish, $2 \frac{1}{2}$ to 3 lines long, 10-12-flowered: scales of the campanulate involucre concave, rather firm; the outer ovate and largely herbaceous; the inner oblong : flowers all perfect and fertile.

Sierras of Tulare Co., Olanche Mountains and Monachay Meadows, at 8,000 to 9,300 feet, Rothrock in Wheeler's Exped., 1875. The Sage-brush of the region. Heads even thicker than those of $A$. cant.

13. A. Palmeri, Gray. Apparently wholly herbaceous and at least 3 feet high, cinereous-puberulent: leaves narrowly linear and the lower 3-5-parted (the divisions an inch or two long and a line or more wicle), with revolute margins, the lower surface minutely white-woolly: heads greenish, very numerous in an ample open panicle: scales of the involucre ovate, thin: flowers all perfect, most of them subtended by chaff similar to the inner scales of the involucre (or the innermost much smaller), - an anomaly in the genus. - Proc. Am. Acad. xi. 79.

Jamuel Valley, 20 miles east of south of San Diego, Patmer.

Page 412.

101. SENECIO.

9. S. Fremontii, Torr. \& Gray. A very well-marked form of this species is

Var. occidentalis, Gray. Much more slender, a span to a foot high: leaves from ovate-orbicular and repand to obovate or spatulate and incised, thimner, most of them on rather long and wing-margined petioles: heads smaller (4 lines high), fewer-flowered, and slender-peduncled.

Sierra Nevada, on Mount Whitney at 12,000 feet, and S. Fork of Kern River down to 9,800 feet, Rothrock in Wheeler's Exped., 1875. Lemmon's plant from Lassen's Peak is between this and Watson's and Parry's specimens from the mountains of Utah and Wyoming.

Page 417.

103. RAILLARDELLA.

A part of the generic character to be modified, and a portion of it thrown into a $\S 1$, to contrast with the following:-

§2. Scales of the involucre distinct to the base, the margins below at length more or less involute: central flowers (always?) sterile, both anthers and ovary imperfect: stem leafy.

3. R. Muirii, Gray. A span or two high, slender, hirsute, and with some stalked glands above: leaves (about an inch long) linear, with somewhat revolute margins, acute: heads terminal and short-peduncled, and also 2 or 3 lateral ones: involucre campanulate: bristles of the pappus 10 to 12 , stouter, fully equalling the corolla in length.

In the Sierra Nevada (the station unknown), $J_{0}$ Muir. Head little over half an inch long. Stem slender, very leafy below, sparsely so above. In habit unlike the genuine species of Raillardella, but the floral characters accord. The mature akenes are terete, but so they may be when ripe in the original species. 
Page 441.

122. LYGODESMIA.

2. I. spinosa, var. cladopappa, (riny; il state with many of the stiff bristles of the pappus bearing a few slender branches toward the base.

Carson Valley, Lcmmon, 1875. Specimens by other collectors from the same neighhorhoou do not show this peculiarity of the pappus, in which, as well as in the rigidity, there is an approach to Chacladelpha.

Page 442.

123. IACTUCA.

IaActuca Cananexsis, tinn., was collected in a grain-field in Siena Valley, in the summer of 1875. Being otherwise unknown west of the Rocky Mountains, it was probably a waif or chancecomer.

Page 443.

\section{ORDER LI. LOBELIACE正.}

Tieplace the key to the genera unler the Tribe LoIELIE. b hy the following.

* Capsule short, 2-celled, 2-valved at the top.

1. Lobelia. Corolla with the more or less clongated tube split from top to bottom on the apparently upper side. Stamens freo from the corolla.

2. Palmerella. Corolla with a long tube, which is entire at the summit; the stamens aduate to its upper part.

3. Laurentia. Corolla with a rather long entire tube ; the stamens free from it, except perhaps at the very baso.

* * Capsule and ovary long and linear, one-celled, opening down the sides.

4. Downingia. Corolla with a very short and entire tube.

Prefix no. 5 to Nemacladus.

\section{LOBEIIA, Linn.}

Calyx 5-cleft, and with a short tube. Corolla with a straight tube split down to

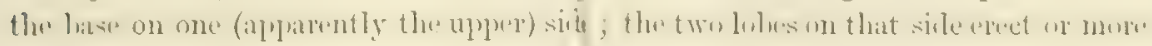
separated from the three more united orls; all the petals sometimes inclined to separate at the base. Anthers and all the/ pper part of the filaments united around the style: these inserted with the corollaf Stigna 2-lobed. Capsule 2-valved at the top. Scels very numerous and smal-Chiefly herbs, of wide geographical distribution; with racemose or spicate flowers, produced in summer.

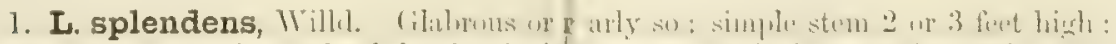

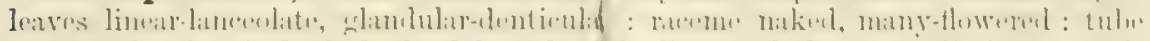
of the calyx hemispherical; its lobes slentigly linear-subulate: corolli inteuse red,

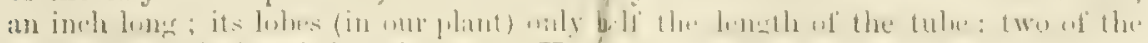
anthers strongly bearled at the tip. - Hord Berol. t. 86.

Mountains northeast of San Diego, Clevelend, Jther. Extends through Arizona to Texns and Mexico, prohnbly only in shuded ind moist or wefolnces. Murh resembles the eastern $L_{0 .}$ cardimulis or Canlinal-flower. Lobes of the corollis me smaller than in the cultivated and some of the wild Mexican specimens.

\section{PALMERELA, Gmy.}

Calyx 5-parterk down to tho turbinato tuld which is wholly adnato to the ovary: tho lohes slenderly linear-subulate. Corolla vith its lhng and stmight narow-eylinirieal tulbe, entire (at least the uppere part), lit at all dilated at the throat ; the short lobes abruptly sprealing; two smaller disdict, spatulate-linesr amt turnet hack- 
wards; the other three oblong, united at the very base. Filaments (more or less) adnate to near the throat or the npper part of the tube of the corolla, then free or further adnate to one side, and monadelphous: anthers oblong, united, three of them naked, two tipped with a small tuft of very unequal rigid bristles. Stigma, ovary, and apparently capsule of Lobelia, of which the plant has the habit, except in the remarkably long tube of the corolla. - Name in acknowledgment of the services to North American Botany rendered by the discoverer, Dr. Edward Palmer, who more than any one else has explored the botany of the region to which it belongs, viz. Arizona, the southern frontiers of the State of California, and Lower California. - Proc. Am. Acad. xi. 80.

1. P. debilis, Gray. Herb a foot or two high, probably from a perennial root, smooth and glabrous except the inside of the corolla; stem weak and slender, simple or at length loosely branched: leaves thin (the lowest not seen): the cauline ones linear-lanceolate, 2 or 3 inches ling, entire or rarely a little denticulate, sessile, alternate, above gradually diminishert into slender bracts of the several-flowered leafy raceme: limb of the corolla bright blue; the tube whitish, half or three fourths of an inch long, hairy inside.

Var. serrata, Gray. Minutely puberulent, at least toward the summit and the trube of the corolla: leaves almost all acutely serrate, or the upper merely denticulate; the lower spatulate or obovate (one or two inches long, sometimes an inch broad) : flowers rather few and crowded.

Great Cañon of the Tantillas Mountains, in Lower California, Sept. 1875, Dr. E. Palmer. The variety, on wet sandstone rocks in the valley of Ojai Creek, Ventura Co., July, 1875, Dr. Rothrock in Wheeler's Exped. The base of the corolla-tube inclines to kreak up in age as it were into claws of the five component petals, as in Lobelia splendens, \&c. Then the adnate filaments become free below, remaining coalescent above.

Page 476.

\section{ASCLEPIAS.}

7. A. leucophylla, Engelm, var. obtusa, Gray. Wool deciduous, hardly any on the outside of the corolla : leaves oblong, all the lower very obtuse or truncate: hoods rather broader and truncate.

Bartlett's Cañon, near Santa-Barbara, Rothrock in Wheeler's Exped., 1875. The hoods in this species and in A. eriocarpa have a lamelliform fold or duplication on each side below near the interior maryin.

\section{Page 478.}

4. LACHNOSTOMA, HBK.

Calyx, corolla, fruit, \&c., nearly as in Sarcostemma. Crown (in the following species) consisting of a hood-like appenonge behind each anther, not unlike that of Asclepias. Anthers short, and the polleh-masses horizontal, otherwise nearly as in Asclepias. - A tropical and subtropical American genus of the Gonolobus tribe, chiefly of twiners; mostly with opposite cordate and petioled leaves, and small dull-colored flowers. - Benth. \& Hook. Gen. ii. 767.

1. L. hastulatum, Gray. A slender twining plant, herbaceous or nearly so, ntathnd with a fine and dense soft pubsence : leaves hastate, 2 or 3 lines long, on a slender petiole: flowers solitary and scattered, nearly sessile, whitish: calyx 5-parted, the divisions linear : corolla 5-parted, the divisions oblong-linear, almost glabrous inside: hoods behind the anthers oblong-obovate, white, acutely 3-toothed at the apex, and with a short triangulur-subulate internal horn: follicles fusiform, beset with a few small and soft procesies, - Proc. Am. Acad. xi. 87.

Tautillas Cañon, within the borders of Lover California, Dr. E. Palmer. 
Page 483.

4. EUSTOMA, Salisb.

Calyx 5-6-parted; the divisions slender-subulate, carinate. Corolla campan-

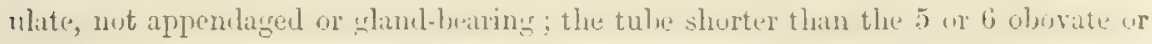
oblong ample lobes. Filaments filiform, borne in the throat. Anthers oblong, not twisted. Style filiform, "persistent: stigma of 2 broad plates. Capsule ovoid, manyseeded. - Glaucous annuals or bienuials; with oblong partly clasping leaves, and

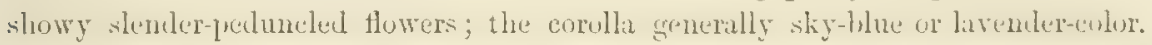
Of the two publishel species, one, E. liusselienum, very ornamental in cultivation, belongs to Texas and adjacent districts. E. gracile, Engelm. ined., of Northern Mexico, is perhaps a slender variety of it. The remaining less showy species is -

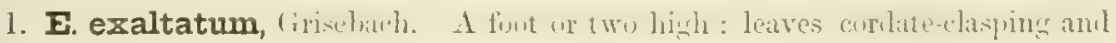
often connate, 1 to 3 inches long: corolla about au inch long; its lobes nearly

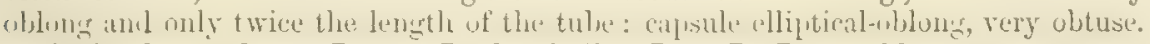
- Lisianthus exaltatus, Lam. L. glancifolius, Jacq. Ic. Rar. t. 33.

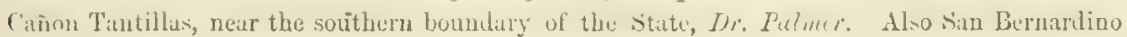
Co., Parmy.

Page 500.

\section{LEESELIA.}

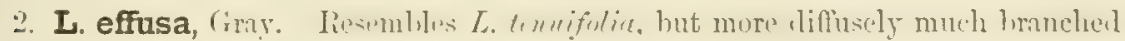
from an annual root: leaves apparently all entire, short-filiform, from half to a fourth of an inch long (but the lowest are wanting): flowers loosely panicled: calyxteeth very short, pointed from a broad base: corolla barely half an inch long, "pink" or purple; the euncate and truneate obscurely 3-toothed lobes as long as

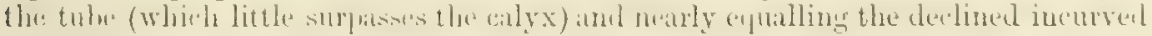
capillary filaments and style. - Proc. Am. Acad. xi. 86, whero a section, GiLropsis, is proposed for this very Gilia-like species and $L$. tenuifolia.

Tantillas Mountains, within the borders of Lower Californin, Dr. Palmer.

\section{Page 517.}

\section{NAMA.}

To the character of the gonus add: leaves sometimes toothed.

\section{\$3. Perennials, sometimes woody beloro; the pubescence hispid or lirisute: flowers densely chestered: leaves with undulate or sinuate-toothed margins, sessile.}

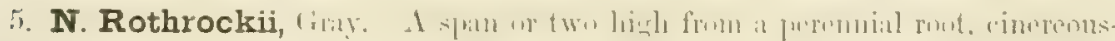
pubescent or minutely hirsute and slightly viscid: the stem, caly $\mathrm{x}$, \&c., hispid with

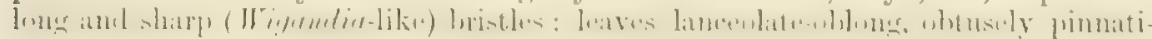
ficl-toothed: flowers numerous in a terminal and sessile capitate cluster: sepals hardly at all dilated upward, half an inch long, nearly equalling the corolla : seeds rather few, large (almost a line long), oval, closely reticulate-pitted.

Meadows on S. Kern River, at 5,000 fect, Rolhrock, in Wheeler's Rxped., 1875. Ieaves an inch or more long ; the rather prominent pinnate veins ruming to the sinuses between the strong teeth, and there forking. Corolln whitish or purplish. Ovary and 2-celled capsule somewhat birsute. Most remarkible in the genus for the toothing of the leaves and for tho nlmost stinging

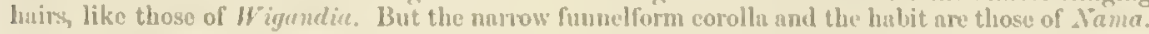

6. N. Parryii, Gray. Six feet high! from a woody stunt baso: leaves linear, villous-hirsute thronghout, numerously pinmately veined ind somewhat hullate, tho matrins revolute and undulate or repaind: flowers unilatemal and at length densely spieato on the few bromehes of the compract scorpind evmes sepals neirly filiform, little surpussing the oval rapsulo: seels oval, half a line long, minutely marked with nurow transverse reticulations. 
On the Mobave slope of the San Bernardino Mountains, Parry, Dec. 1875, in fruit only. Leaves on new shoots 2 or 3 inches long and only 2 or 3 lines wide. Cymes apparently pedunculate. Capsule and calyx only 2 lines or so in length. Stem $W$ igandia-like, over half an inch in diameter at base, decidedly woody, but with a large pith.

Page 550.

3. ANTIRRHINUM.

8. A. Nuttallianum, var. effusum, Gray. Climbing over bushes, 5 feet high : flowering branches paniculate: pedicels all filiform and longer than the flowers: ribs of the seeds less wing-like : calyx-lobes rather less unequal.

Jamuel Valley, southeast of San Diego, Dr. Palmer.

Page 556.

\section{PENTSTEMON.}

14. P. Fremonti, Torr. \& Gray. A span or more high, pruinose-puberulent or below glabrous : leaves lanceolate or oblong-lanceolate, and the lowest spatulate or oval, an inch or two long: flowers racemose-thyrsoid, rather crowded and numerous : pedicels and mostly the peduncles short and glandular-pubescent : corolla purple or whitish, half an inch or more in length, tubular-funnelform: anthers not opening widely: sterile filament dilated and bearded at the tip. - Proc. Am. Acad. vi. 60; Watson, Bot. King. Exp. 218.

Sierra Nevada, on a high mountain near Donner Pass (Torrey); Utah, Fremont. A smoother and taller variety (Parryi), Nevada, Watson, Wheeler, \&c.

After no. 17, add a fifth subdivision, as follows :-

$+\div+\div+\div+\div$ Corolla scarlet, tubular; its upper lip erect and 2-toothed; the lower reflexed and 3-parted.

$17^{\text {a }}$ P. barbatus, Nutt., var. labrosus, Gray. Entirely glabrous, somewhat glancous: stems virgate, 2 feet high or more: lowest leaves oblanceolate; the upper narrowly linear: panicle slender and raceme-like: sepals ovate, short: corolla an inch and a half long; its lips half an inch or more; the upper oblong and concave, barely 2-lobed at the tip; the lower 3-parted into linear divisions; these and the throat glabrous, as also the stamens and style: anther-cells divaricate, never spreading open, the inner portion of the line of dehiscence remaining closed.

On Mount Pinos, sonth of Tejon, at 7,000 feet, Rothrock in Wheeler's Exped., 1875. A remarkable form, seemingly, of $P$. barbahus, agreeing with the var. Torreyi of New Mexico and Colorado in the want of beard; but the lobes of the lower lip remarkably long and narrow. The tube of the corolla appears to have been yellowish, the lips scarlet.

Page 575.

17. ORTHOCARPUS.

Chloropyron palustre, Behr in Proc. Calif. Acad. i. 62, 66, is some one of the species of this genus, with reduced anther-cells; perhaps 0 . faucibarbatus or 0 . floribundus.

Page 581.

18. CORDYLANTHUS.

3. C. filifolius, Nutt. The ripe seeds are ovate or oval; the coat close, and in the dry state lineate-reticulated under a lens with innumerable slender wavy lines or wrinkles: embryo little shorter than the nucleus, the cotyledons orbicular. The ovules are slender, tapering to the apex, which is coiled into a helix.

Var. brevibracteatus, Gray. Tall and stouter, glabrous up to the floral leaves; these hirsute-ciliate and all shorter than the flowers, more dilated, and not glandtipped: cauline leaves not seen.

Near Soda Spring on Kern River, at 8,500 feet, Rothrock in Wheeler's Exped., 1875. A rather smooth form collected by D. Cleveland near San Diego approaches this. 


\section{N D E}

Names of Orders and SUborders in small capitals, of Genera and Sections in Roman lower case, and Synonymy in Italies.

\begin{tabular}{|c|c|c|c|}
\hline 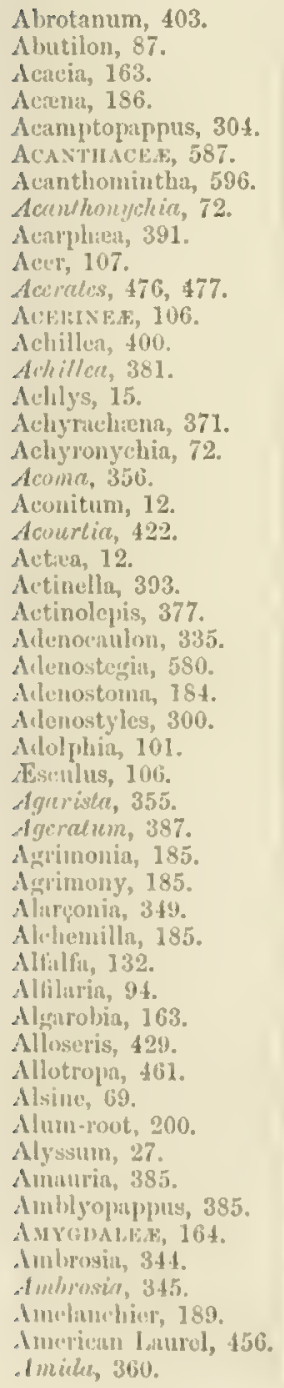 & $\begin{array}{l}109 . \\
337 . \\
456 . \\
\\
4 . \\
548 . \\
8,62 . \\
2 . \\
6 . \\
05 .\end{array}$ & 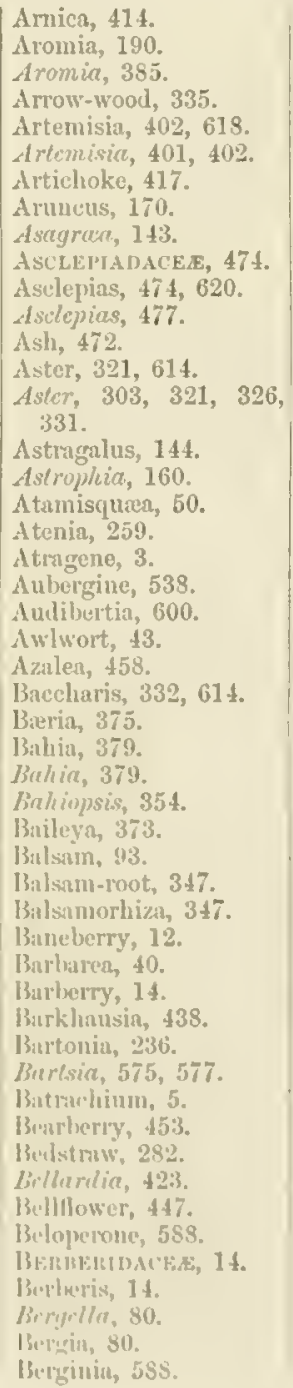 & 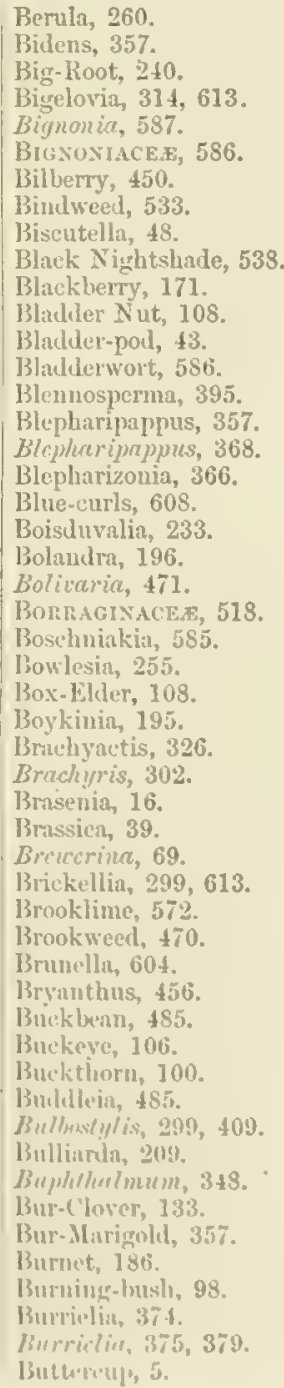 \\
\hline
\end{tabular}


Butterwort, 586 .

Button-bush, 281.

Button Snakeroot, 255.

Cacalia, 301.

Cactacen, 242

Cænotus, 331.

Cesalpinem, 113.

Calabazilla, 240.

Calais, 423

Calaminth, 596.

Calamintha, 596.

Calandrinia, 74.

Calf's-Head, 18.

California Lilac, 102.

Calliachypis, 370 .

Callichroa, 369.

Calliglossa, 370.

Callirrhoe, 83.

Callitriche, 215.

Calocalais, 426 .

Caltha, 9.

Calycadenia, 464.

CalyganthaCeds, 190.

Calycanthus, 191.

Calycoseris, 431.

Calyptridium, 78 .

Calystegia, 533.

Camarostaphylis, 454 .

Campanula, 447.

Companula, 446.

Campanulacere, 445.

Campion, 62.

Campylocera, 446.

Cancer-root, 584.

Canchalagua, 479.

Candlewood, 79.

Canotia, 190

Cantua, 493, 496, 498.

Capnorchis, 24.

CAPPARIDACE西, 49.

Capraria, 571.

CAPRIFOLIACF, 277.

Caprifolium, 280.

Capsella, 44.

Capsicum, 539.

Cardamine, 30.

Cardiospermum, 106.

Carduus, 419,420 .

Carpenteria, 203

Carpetweed, 252.

Carphephorus, 301.

Carphephorus, 408.

Carrot, 272.

Carroway, 259.

Carum, 259.

Caryophyllace $x, 61$.

Cassia, 161.

Cassione, 455.

Castilleia, 573.

Catehfly, 62.

C'atrip, 590.

Caucalis, 272

Caulanthus, 36.

Cayenne Pepper, 539.

Ceanothus, 102.

Celastrace五, 98

Celastrus, 98

Celery, 258.
Centaurea, 421.

Centunculus, 469.

Cephalanthus, 281.

Cerastes, 104.

Cerastium, 66.

Cerasus, 167.

Ceratophyllum, 215.

Cercidirmn, 162.

C'ercis, 160.

Cercocarpus, 174.

Cereus, 246.

Chænactis, 388.

Charophyllum, 263.

Chrtadelpha, 429.

Chamæbatia, 178.

Chamrbatiaria, 170.

Chamæphysalis, 541 .

Chamæsaracha, 540.

Chamiso, 184.

Chamonile, 400.

Charlock, 40.

Cheiranthodendron, 88 .

Cheiranthus, 35.

Chelone, 556.

Cherry, 166.

Cherry Tomato, 538.

Chia, 598.

Chicalote, 21.

Chickweed, 66, 67.

Chile, 539.

Chile Colorado, 540.

Chili Cojote, 240.

Chilopsis, 587.

Chimaphila, 459.

Chionanthus, 472.

Chloropyron, 622.

Choke Cherry, 167.

Chrysanthemum, 401.

Chrysobotrua, 207.

Chrysocapnos, 24.

Chrysocoma, 317.

Chrysopsis, 309.

Chrysopsis, 329.

Chrysothamnus, 314.

Chylismia, 227

Cicendia, 480.

Cicuta, 260.

Circæa, 234.

Cüsium, 417.

Cistace 54.

Clarkia, 231.

Clavigera, 299.

Claytonia, 75 .

Cleavers, 282.

Clematis, 2.

Cleome, 51.

Cleomella, 51.

Cliff-Rose, 175.

Clintonia, 444.

Clotbur, 346.

Clover, 125.

Cneoridium, 97.

Cnicus, 417.

Cobra, 485.

Cocklebur, 346.

Coinognne, 372

Coldenia, 520.

Coleogyne, 174.
Collinsia," 552.

Collinsia, 556.

Collomia, 487.

Collomia, 492.

Columbine, 9.

Comarum, 180.

CoMPosit $\not$ 电 488.

Conanthus, 515.

Cone-flower, 347.

Coniothele, 395

Conium, 258.

Dead-Nettle, 590

Convolvulus, 533. Dendromecon, 22.

Conyza, 332.

Dentaria, 29.

Cordylanthus, 580, 622. Dentarice, 31.

Coreocarpus, $356 . \quad$ Desert-Willow, 587.

Coreopsis, 355.

Corethrogyne, 320.

Corn Poppy, 19.

Corn-Spurrey, 70.

CORNACEE, 274.

Comel, 274.

Cornus, 274.

Corollophyllum, 464.

Corydalis, 24.

Cosmanthus, 513.

Cotton-plant, 82.

Cotula, 405.

Cotula, 401.

Cotyledon, 210.

Courtoisia, 488.

Cow Parsnip, $2 \pi 1$.

Cowamia, 175

Crab-Apple, 188

Cranberry, 450.

Cranestoill, 93.

CrassulaCere, 208.

Cratregus, 189.

Cratoegus, 188.

Cream Cups, 20.

Creosote-bush, 92

Crepidium, 436.

Crepis, 435 .

Cressa, 534.

Crinitaria, 317.

Crocidium, 396, 406.

Crossosorna, 13.

Crossostigma, 220.

Crowfoot, 5.

Cructere正, 25.

Cryphiacanthus, 588.

Cryptopleura, 439

Cryptostemma, 298.

Cucrumis, 239.

Cucurbita, 239.

Cucurbitacex, 238.

Cudweed, 341.

Currant, 204.

Cuscuta, 535.

Cycladenia, 473.

Cylindropuntia, 249.

Cymopterus, 266.

Cynapium, 264.

Cynapium, 271.

Cynara, 417.

Cynoglossum, 530.

Cynogrossum, 528, 531.

Dactylophyllum, 489. Emmenanthe, 514.
Dicentra, 23.

Dichrta, 376.

Dichondra, 532

Dicliptera, 589.

Dicoria, 615.

Dieteria, 322

Diplacus, 565.

Diplopappus, 321, 322 329.

DIPSACEE, 287.

Dipsacus, 287.

Dithyrea, 48.

Dodder, 535 .

Dodecatheon, 466.

Dogbane, 473.

Dogwood, 274.

Downingia, 444.

Draba, 27.

Dracunculus, 288.

Draperia, 505.

Drosera, 213.

DROSTRACE 212

Drymaria, 62 .

Dusty Miller, 410.

Dutch Clover, 129.

Dyer's Weed, 53.

Dysmicodon, 446.

Dysodia, 397.

Eatonella, 379.

Echeveria, 210.

Echidocarya, 519.

Echinais, 420.

Echinella, 8.

Echinocactus, 244.

Echinocereus, 246.

Echinocystis, 241.

Echinopanax, 273.

Echinospermum, 529

Echinospermum, 528.

Echinosphace, 599.

Edosmia, 259.

Eddya, 520

Eggnlant, 538.

Elaphocera, 495.

ELATINAGE 80.

Elatine, 80.

Elatine, 80 .

Elder, 277.

el7ionico, 54 
Emplectocladus, 168. Encelia, 351, 616.

Encelia, 354.

Enchanter's Nightshade, 234.

Enclive, 422.

Exilobium, 218.

Elrimedium, 15.

Eremiastrum, 306.

ERJCACE, 448.

Ericameria, 313, 314.

Erigenn, 326.

Erigeron, 325, 332.

Eriolictyon, 518 .

Eriogymia, 171.

Eriopappus, 368.

Eriophyllum, 380 .

Eritrichium, 525.

-Erodium, 94.

Eryngium, 255.

Erysimum, 38.

Erysimum, 36, 41.

Erythrea, 479.

Eschscholtzia, 22.

Fspeletia, 348.

Eucalyptus, 191.

Euchardium, 232.

Euchronne, 576.

Eucnide, 512.

Eucryptr, 505.

Eulohus, 221.

Eunanus, 564 .

Eumanus, 563.

Euonymus, 98.

Eupatorium, 299.

Euryptera, 269.

Eustoma, 621.

Euthamia, 318.

Eutoca, 508.

Éuloca, 513, 514, 515.

Evax, 337.

Evening Primrose, 223.

Everlasting, 340, 341 .

Evolvulus, 532 .

Exacuin, 480.

Fagonia, 92.

Fallugia, 175 .

Fatsia, 273.

Fenstio, 490.

Ferula, 547 .

Ficoldes, 250.

Fichtex, 423.

Fig. Marygold, 251.

Figwort, 552 .

Filago, 338.

Five-finger, 177.

Filax, 89.

Flnx-1)odkter, 535.

Fleabune, 326.

Flurken, 95.

Flarkece, 95.

Forget-me-not, 522.

Founuiera, 79 .

Fragari̊, 176.

Frangula, 101.

Frankenin, 60.

Prankiniage, 60.

Franseria, 344, 815 .
Frasern, 483.

Fraxinus, 472.

Fremontib, 88.

Fringe-pod, 49.

Fuchsia, 216.

Fumaria, 24.

Fumariace $2,23$.

Fullers' Teasel, 287.

Gaillardia, 391.

Galapagor, 520.

Galeopsis, 590 .

Galium, 282.

Galvesia, 551.

Gambelia, 551.

Gamochreta, 342.

Gartya, 275.

Citultheria, 454.

Gaura, 233.

Gaura, 234

Gayophytum, 221.

Geyophytum, 233.

Gentiana, 481.

Genthasace.e, 478.

Gentianella, 481.

Geren, 351.

Geraniacere, 92.

Geranium, 93.

Iercurdia, 556.

Geum, 176.

Gilia, 489.

Gilia, 488.

Giliopsis, 621.

Githopsis, 446.

Glandularia, 609.

Glaux, 469.

Glossopetalon, 108.

Glycosma, 262.

Glyeyrrhiza, 143.

Glyptopleura, 431.

Gnaphalium, 341.

Giuphalium, 338, 339, $3+1$.

Gobernadora, 92.

Godetia, 228.

Gomphocarpus, 477.

Gooscberry, 480 .

Grossypium, 82.

(irape, 105.

Grass-of-Purnassus, 201.

Gratiola, 570.

Greek Valerian, 499.

Grindelia, 303.

Gromwell, 522.

Grossularia, 204.

Ground Cherry, 540.

Ground Ivy, 590.

Groumdsel, 410 .

Gum-plant, 303.

Guticrrezin, 302.

Gymzкudra, 571.

Gymnobythus, 513.

Hulenio, 478 .

HALORAGRA, 214.

IIтрлесатрия, 360.

Jin rumearyms, 361 .

Hupragonella, 5\$1.

Hartuanni⿱ 361.

Hartmannia, 370.
Hawkweed, 440.

Hedeoma, 595, 598.

Hedge-Hyssop, 570.

Hedge-Mustard, 40.

Hedge-Nettle, 605.

Helenium, 392.

Helenium, 381.

Helianthella, 352 .

Helianthemum, 54 .

Helianthus, 352, 616.

Helianthus, 350, 354 .

Heliopsis, 348.

Heliotrope, 521.

Heliotropium, 521.

Helogyne, 249.

Helosciadium, 259, 260.

Hemiptilium, 427.

Hemistegia, 581.

Hemilomes, 464.

Hemizonella, 360.

Hemizonia, 361, 616.

Hсmizomia, 360, 361, 367.

Hemp-Nettle, 590.

Heracleum, 271.

Herpest is, 569.

Hesperastrum, 322.

Hesperelax, 471.

Hcsperis, 35.

Hesperochiron, 516.

Hesperoliuon, 89.

Heterocodon, $\mathbf{4} 7$.

Heterogaura, 234.

Heteromeles, 188.

Heterospermum, 357.

Heterotheea, 308.

Heuchera, 200.

Henchera, 197, 199.

Hibiscus, 87.

Hideondo, 92.

Hicracium, 440.

Hicracium, 434.

Hippuris, 215.

Hofmeisteria, 298.

Joilzill, 493 .

Hologymne, 384.

Homalobus, 153.

IIonzopreppise, 312.

Honey Mesquit, 163.

Honeysuckle, 280.

Hop-tree, 97.

Horchound, 604.

Horkelin, 181.

Jorkrtia, 183.

Horse-chestnut, 106.

Horsemulish, 43.

Ilosackin, 133.

Hound's-tongue, 530.

Hugelia, 495.

Hulser, 385 .

Hulchinsia, 42

JYMIUNGIEN, 192.

Hyilrocotyle, 254 .

II'MtOPHYLLACE, 5i11.

Hyirophyllum, 502.

Hifl rophyllum, 510 .

Hymenoclen, $9 \$ 3$.
Hymenoneme, 424, 425.

Hymenoparyus, 617.

Himucnopapjus, 391.

Hymenoxys, 378.

HYPEIICACE \&, 80.

Hypericum, 80.

Hypocheris, 330.4

Hypopitys, 463.

Hyptis, 591.

Hyssop, 590.

Hyssopus, 590 .

Ice-Plant, 251.

Idria, 79 .

Ilex, 99.

ILLECEBRACE $E, 72$.

Ilysanthes, 570 .

Impatiens, 93.

Indian Hemp, 473.

Indian Pipe, 462.

In farlea, 385 .

1 pon oea, 533.

Ipomaea, 534.

Ipomopsis, 496.

Ipomopsis, 498.

Jronwood, 157.

Isomeris, 50.

Isopyrum, 9.

Iva, 343,615 .

Ivesia, 182.

Iresia, 182.

Jucobinia, 589.

Jemesia, 428.

Jaumer, 371.

Jewel-weed, 93.

Judas-tree, 160 .

Juneberry, 189.

Jussiea, 217.

Kalliactis, 347.

Kallstromia, 91.

Kinlmia, 456 .

Karwinskia, 100.

Kellogria, 282.

Kentrophyta, 156.

Kinnikinick, 453 .

Krameria, 59.

Krynitzkin, 527.

Kuhnioides, 301.

Kismapleurn, 439.

LABIAT\&, 589.

Labralor Tea, 458.

Lace-pod, 49.

Lachnostomn, 620 .

Lactuen, 442, 619 .

Iady's Mantle, 185.

Lagophylla, 367.

Lagothamuแs, 407.

Laphamia, 396.

Latkspur, 10.

Iarreu, 92.

Listhenia, 384.

Desthenia, 382.

Lathyr'us, 158.

Laturel, 356 .

Iaturentia, 43 .

Laturocerasus, 168.

Iavatera, 82.

Layia, 368.

Leilum, 458. 
LEgUMINos $\not 111$.

Leña amarilla, 15 .

Lennoa, 464.

LENNOACFA, 464.

LENTIBULARIEA, 586.

Leontodon, 439, 440.

Leonurus, 590.

Lepidanthus, 401.

Iseyidimm, 45.

Lepidoneme, 423.

Lepilosparton, 408.

Lepilostephonus, 371.

Lepidotheca, 401.

Lepigonum, 71.

Leptarrhena, 469.

Leptodactylon, 492.

Leptoseris, 433 .

Ieptosiphon, 491.

Leptosyne, 355.

Leptotenia, 271, 272.

Lessingia, 306 .

Lettuce, $422,442$.

Leucanthemum, 401.

Leucoseris, 434 .

Lettcothoe, 455.

Lewisia, 78.

Ligusticum, 264.

Lilac, 102

Limnanthes, 95.

Limosella, 571.

LINACEA, 88.

Linanthus, 490.

Linaria, 548.

Linnrea, 278.

Linosyris, 314, 408.

Limum, 89.

Limum, 54.

Lippia, 609.

Liquorice, 143.

Lisianthus, 621.

Lithophragma, 197.

Lithospermum, 522.

Lithospermum, 524,527.

Lithriea, 111.

LOASACE 235.

Lobadinm, 110.

Lobelia, 619.

Lobetia, 444.

LOBELIACE $\approx, 443,619$.

Loeflingia, 71 .

Løselia, 500, 621.

IJOGANIACE 485.

Lonicera, 280.

Loosestrife, 214.

Lophanthus, 602.

Lotus, 135, 137.

Lousewort, 582.

Lucerne, 132.

Ludwigia, 217.

Ltiina, 408.

Lupine, 115.

Lupinellus, 125.

Lupinus, 115.

Lutkea, 171.

Lychnis, 64.

Lycium, 542.

Lycopersicum, 538.

Lycopsis, 522.
Lycopus, 592.

Lyyodesmia, 428.

Lyroearpa, 44.

Lysimachia, 466.

LYTHRACE $2,213$.

Lythrum, 214.

Machæranthera, 322.

Mucrocarphus, 391.

Locronema, 313, 314.

Macropodium, 38.

Macrorhynchus, 438.

Madaria, 358.

Madaroglossa, 368.

Matia, 358.

Madorella, 359.

Madroño, 451.

Mahonia, 14.

Malacomeris, 434.

Malus, 188.

Malacoth'ix, 432.

Solacothrix, 436 .

Mallow, 83.

Malva, 83.

Malva, 84-87.

Malvace $8,82$.

Malvastrum, 84.

Malvastrum, 86 .

Mamilaria, 243.

Manzanita, 452.

Mapple, 107.

Marah, 241

Mare's Tail, 215.

Marrubium, 604.

Marsh Pennywort, 254.

Marsh Rosemary, 465.

Martynia, 587.

1.arieta, 401.

Matricaria, 401.

Maurandella, 550.

Marrandia, 550, 551.

May-Apple, 16.

May-Weed, 401

Meadow-Sweet, 169.

Meconella, 20.

Meconopsis, 21.

Medicago, 132 .

Megalastrum, 323.

Megarrhiza, 240.

Melendryum, 64.

Melilotus, 132

Melothria, 240.

Menodora, 471

Mentha, 591.

Mentzelia, 235.

Mentzelia, 237.

Menyanthes, 485 .

Menziesia, 457 .

Menziesia, 456 .

Merimea, 80.

Mertensia, 523.

Mesembryanthemum, 251.

Mesquit, 162

Miciocala, 480.

Microgenetes, 511.

Microlotus, 137.

Hicromeria, 595 .
Micropus, 335.

Micropus, 336.

Microrhamnus, 99.

Microseris, 423.

Wicroseris, 440 .

Mignonette, 53.

Milk Thistle, 421.

Milkweed, 474

Miltitzia, 514.

MIMOSE E, 113.

Mimulus, 562.

Nint, 591.

Mitella, 199.

Mitclla, 197.

Nitre-wort, 199.

Mock Orange, 202.

Moehringia, 70.

Mohavea, 551.

Mollugo, 252.

Monardella, 593.

Moneses, 459 .

Monkey-flower, 562.

Monkshood, 12.

Monolopia, 383.

Monolopia, 384.

Monoptilon, 306.

Monotropa, 462 .

Montia, 77.

Mountain Ash, 189.

Mountain Mahogany, 174

Mouse-ear Chickweed, 66.

Mouse-tail, 4.

Mudwort, 571.

Mulgedium, 442.

Mullein, 548.

Mustard, 39.

Mygrinda, 99.

Myosotis, 522 .

MIyosotis, 525, 526, 528, 529.

Myosurus, 4.

Myriophyllum, 215.

Myrrhis, 262.

Mrrtacen, 191.

Nama, 517, 621 .

Nxma, 506.

Nardosmia, 407.

Nasturtium, 42, 93, 613

Navarretia, 493.

Navarretia, 489.

Negundo, 108.

Neillia, 171.

Nemacladus, 445.

Nemophila, 503.

Nepeta, 590.

Newberrya, 463.

Nicandra, 537.

Nicolletia, 398.

Nicotiana, 544.

Nightshade, 538.

Nine-bark, 171.

Nothophyllon, 584.

Nothotroximon, 437.

Nuphar, 17.

Nuttallia, 168.

Nrmph正ACE正, 16.
Ocinum, 590.

(Enanthe, 263.

OEnoe, 568.

Enothera, 222.

Enothera, 228, 229, 230, 231, 233.

Olea, 471.

OLEACEe, 471.

Oligomeris, 53.

Olive-tree, 471.

Olneya, 157.

Omalanthus, 402.

Omalotes, 402.

ONAGRACEXE, 216.

Opsicunthes; 232.

Opuntia, 247.

Oregon-Ash, 472

Oregon Crab-Apple, 188.

Mregon Grape, 15.

Oreophila, 99.

OROBANCHACE正, 583 .

Orobanche, 584, 585 .

Orobus, 160.

Orthocarpus, 575, 622 .

Oryctes, 541 .

Osmadenia, 365.

Osmorxhiza, 261.

Oso Berry, 168.

Ourisia, 516.

Ox-eye Daisy, 401.

Oxalis, 96.

oxypceppus, 378.

Oxystylis, 53 .

Oxytenia, 343.

Oxytripolium, 325.

Oxytropis, 144.

Oxyura, 370.

Pachypodium, 37.

Pachystima, 98.

Padus, 167.

Pæonia, 13.

Painted-Cup, 573.

Palafoxia, 387.

Palmerella, 619.

Papaver, 19.

Papayeraces, 18.

Parabryanthus, 456 .

Parkinsonia, 161.

Parnassia, 201.

Paronychia, 72.

Parsley, 258.

Pear, 188.

Pearlwort, 70 .

Peavine, 158.

Pectis, 499, 617.

Pectocarya, 531.

Pedicularis, 582.

Pelargoninm, 93.

Pentacæna, 72.

Pentachæta, 305.

Pentstemon, 556, 622.

Pepper-grass, 45.

Peppermint, 592.

Perezia, 422.

Perityle, 396.

Petalonyx, 237.

Petalostemon, 141.

Petasites, 406. 
Petrophytum, 170.

Petunis, 5\$6.

Peucedanum, 267.

Peucephyllum, 409.

Phaca, 146, 148-151, 155

Phacelia, 506.

Phacelia, 505, 515.

Phatostomn, 232.

Phalacroloma, 331.

Phalacroseris, 423 .

Phelipere, 584, 585.

Plellendrinem, 264.

Philadelphus, 202.

Phlox, 486.

Ph7ox, 493.

Phonicaulis, 35.

Pholisma, 46t.

Photinia, 188.

Phyllodoce, 456.

Phyllonionnes, 423.

Physalis, 540 .

Pliysaria, 47.

Pickeringia, 114.

Picradenia, 394.

Picrothamules, 404.

Pilocereus, 247.

Pimpermel, 469.

Pimpinelli, 259.

Pin-clover, 95.

Pin-grass, 95.

Jine-sap, 462.

Pineltrops, 461.

Pinguicula, 586.

Pipsissewa, 459.

Piptocalyx, 527.

P'irus, 188.

Pistreia, 109.

Pilevia, 98.

Plagiobothrys, 526.

Puancaginacede, 610 .

Plantago, 610.

Plantain, 610.

Platopuntin, 248 .

Platycarnos, 124

Platyspermum, 27.

Platystomon, 19.

Platystioma, 20.

Pleutritis, 287.

Plcuricospora, 163.

Pleurogyno, 478.

Pluther, 33.t.

Plum, 166.

P'UUMBAGNACR: 465.

l'noumonanthe, 181 .

Porloscislium, 263.

Pogogyne, 596.

Poison Hemlock, 258.

Poison Oak, 110

Polınisin, 50 .

Putr.moniacke, 485.

Polenonium, 499.

Polyesmon, 71.

Polyogla, 58.

Ponychaducen, 58.

Pullpmipures, 334.

Povitis? 161\%.

Pout-lily, 17.
Porophvllum, 398.

Porterciler, 44.

Portulaca, 73.

Purtulacaces, 73.

Potato, 558.

Potentilla, 177.

Potcntilla, 181, 184.

Potevidium, 156.

Poterium, 186.

Pronanthes, 428.

Primrose, 468.

Primula, 468.

Primulacese, 466.

Prince's Pine, 459.

Prosopis, 162

Prumus, 166.

Psathyrotes, 409.

Psilocarphus, 336.

Psilocringhus, 337.

Psilochenia, 435.

Psoralea, 139.

Ptelea, 97.

Pterospora, 461.

Plerostephanass, 431.

Plilocalyx, 520.

Ptilomeris, 378.

Ptilophora, 423.

Puccoon, 522.

Pugiopapnus, 354.

Pulmonaria, 523.

Pulsatilla, 3.

Purshia, 173.

Purslane, 73.

Pycnanthemum, 592.

Pyrola, 460.

Pyrola, 459, 460.

Pirrocoma, 311, 312 , 315.

Radish, 49.

Rafinesquia, 429.

Ragreed, 344.

Raillardella, 416, 618.

Rasuneuhaces 2 .

Ranunculus, 5 .

Raphanus, 49.

Risuberry, 171.

Rattleweed, 144 .

Red-bud, 160.

IRell Clover, 128.

Ruelwood, 104.

Relbunium, 283.

Reseda, 53 .

RIISFDACIRE, 53.

RHAMNCWF, 99

Rhamuus, 100.

Rhodolendron, 457.

Rhus, 109.

Pluyneholcmis, 435.

Riliesia, 206.

Rilues, 204.

Rilugrnss, 610 .

Ridldelin, 372 .

Rigiols

Rohsonin, 204.

Roเมแบ\%oflia, 516.

liomuneys, 20.

Rusa, 157.

Rosdek.F, 16.4.
Rose, 187.

liose Bay, 458.

Rosinweed, 361.

RCBLACEA, 281.

Rubus, 171.

Rudbeckia, 347.

Ruellia, 588.

RuTACEx, 96.

Rutosina, 97.

Saccularia, 551.

Singe, 598.

Sage-bush, 402.

Sagina, 70.

St. John's-wort, 80.

Salal, $45 t$.

Salnzaria, 604 .

Salmon-berry, 171.

Sulpiglossis, 546.

Salsify, 422.

Salvia, 598.

Sambucus, 277.

Samolus, 470.

Sand-Spurrey, 71.

Sandwort, 68.

Sanrreisorba, 186.

Sanicle, 255.

Sanicula, 255.

Srentolina, 401.

SAPINDACr. E, 105.

Saracha, 510, 541.

Sarcodes, $46^{\circ} 2$

Sareostemma, 477.

SARRACENICEA, 17.

Suxifraga, 192.

Soxifriga, 196.

Saxifragace $x, 192$.

Saxifrage, 192.

Schinus, 109.

Schizocarya, 234.

Schizonotus, 477.

Sclerocermus, 360.

Scorpion-Gruss, 522.

Scorzondla, 424 .

Serew-bean, 162

Sclew-pod Mesquite, 163.

Scrophularia, 552.

Scirophluartack. $5 \pm 6$.

Scutellaria, 602.

Sen-Milkwort, 469.

Sen-Purslnue, 251.

Siclum, 209.

Sedum, 211; 212.

Solf-heal, 604.

Selinum, 264.

Sclimum, 260 .

Semnorvivum, 208.

Sienelicra, 48.

Sunecio, 410, 618 .

Srnecio, 431.

Sertna, 161

Serricocarpus, $31 \mathrm{~s}$.

Siricouruph is, 489 .

Seviplinlium, 405.

Sirvice-lerry, 189.

sisti, 268

sesuviurm, 251.
Shepherd's Purse, 44.

stwrtiue 378.

situbaldia, 180.

Sida, 86.

S'idu, 83, 84, 87.

Siulalcea, 83.

Sieversia, 176.

silene, 62.

silybun, 421.

silkweed, 474.

Simsin, 351 .

Sinnpis, 39.

Siphocalyx, 207.

siphonella, 492 .

sisymbrium, 40 .

Sium, 261.

Sium, 260.

sikullcap, 602.

Small Manzanita, 453.

smelowskia, 42.

Sincloroskia, 41.

Snapdmgon, $5 \pm 8$.

Snewze-weed, 392.

Snow-Plant, 462.

Snowberry, 279.

snowbusl, 103.

SOLANACE.F, 537.

Solanum, 538.

Solcmem, 538.

Solidago, 318.

Solideryo, 314.

Suliva, 406.

Sonchus, 442 .

Sonchus, 442.

Sophora, 114.

Sorbus, 189.

Sow-Thistle, 442 .

Spanish Needles, 357.

spearmint, 592.

Specularia, 442.

Speedwell, 572.

Spergula, 70 .

Spcryula, 70.

Sperguelaria, 71 .

Fiphucele, 598.

Siphanusciadium, 265.

spharaleen, 86.

Spharalce, 87.

Spheromeria, 617.

Sphrerostigna, 225.

sinikenaru, 273.

Sprilunthes, 397.

spindle-treo, 98.

Snirnea, 169.

Spirea, 171.

Spramien, 77.

Stachys, 605.

Stanleyn, 38.

Staphylen, 108.

Star-flower, 168.

Star-Thistle, 421 .

Statice, 465.

Slative 465.

Siremocrimus, 520.

Stellarin, 67.

Stemolin.5\%

Syenat is, :330, 331.

slemolus, 311. 
Stephanomeria, 427. Stephanomeria, 424. STERCUliacex, 88. Stickseed, 529.

Stone-crop, 209. Storax, 470.

Stramonium, 543.

Strawberry, 176.

Streptanthus, 33.

Streptanthus, 36-38.

Strombocarpa, 163.

Stylocline, 336.

Stylopappus, 438.

STYRACACE $\mathbb{x}, 470$.

Styrax, 470.

Styphonia, 110.

Subularía, 43.

Sundew, 213.

Sunflower, 352.

Sweet Alyssum, 27.

Sweet Basil, 590.

Sweet Cicely, 261.

Sweet Clover, 132.

Sweet Mignonette, 53.

Sweet-scented Shrub, 191.

Swertia, 478 .

Symphoricarpus, 279.

Synthyris, 571 .

Syntrichopappus, 394.

Syringa, 202.

Syrmatium, 137.

Tabacum, 545 .

Talinum, 74.

Talinum, 74, 75 .

Tamariscinede, 79

Tanacetum, 402, 617.

Tanacetum, 401.

Tansy, 402.

Taraxia, 224

Taraxicum, 439.

Tare, 157.

Tarweed, 358, 361.

Teasel, 287.

Tellima, 197.
Tessuranthinm, 484. Tessaria, 334.

Tetradymia, 407.

Tetradymia, 409.

Thalictrum, 4.

Thamnosma, 97.

Thelaia, 460, 461 .

Thelypodium, 37.

Thermopsis, 113.

Thistle, 417.

Thlaspi, 45 .

Thom, 189.

Thorn-Apple, 543.

Thrift, 465.

Thymus, 595.

Thysanocarpus, 48.

Tiarella, 199.

Tiarella, 197.

Tidy-tips, 370.

Tillæa, 208.

Tiquilia, 520.

Toad-Hax, 548.

Tobacco, 544 .

Tollon, 188.

Tolmiea, 196.

Tomato, 538.

Tonella, 555.

Tornilla, 163.

Toxicodendron, 110.

Toyon, 188.

Trachyphytum, 235.

Tragopogon, 422.

Tree Mallow, 82.

Tree Stramonium, 543.

Tribulus, 91.

Tricardia, 515.

Tricerastes, 242.

Trichophyllum, 381.

Trichoptilium, 395.

Trichosterna, 606 .

Trientalis, 468.

Trifolium, 125.

Triphysaria, 578 .

Tripolium, 325, 326.

Tropæolum, 93.
Tropidocarpum, 44.

Troximon, 437.

'l'uckermannia, 356.

Turnip, 39.

Turnsole, 521.

Turritis, 41.

Tussilago, 407.

Twin-flower, 278.

UMBELLIFER.E， 252.

Unicorn-plant, 587.

Uropappus, 427.

Usteria, 551.

Utricularia, 586.

Uva-ursi, 453.

Vaccininm, 450.

Valerian, 286.

Valeriana, 286.

VALERIANACE.E, 286.

Vanconveria, 15

Venegasia, 372.

Verbascum, 548 .

Verbena, 608.

Verbena-shrub, 609.

VERBENACF. 6 , 607.

Verbesina, 350.

Veronica, 572.

Vervain, 608.

Vesicaria, 43.

Vesicuria, 47.

Vetch, 157.

Viburnum, 278.

Vicia, 157

Viguiera, 354.

Villarsia, 517.

Vine-Maple, 107.

Viola, 55.

VIOLACEA, 54.

Violet, 55 .

Virgaurea, 318.

Vitaces, 105.

Vitis, 105.

Wahlenbergia, 448 .

Water-Cress, 43.

Water Hemlock, 260.

Water Horehound, 592. ZYGopHYLLACE, 91.
Water Milfoil, 215.

(Water Parsnip, 216.

Water-Shield, 16.

Waterleaf, 502 .

Weld, 53.

Western Mountain Ash, 189.

Whipplea, 203.

White Clover, 129.

White Daisy, 401.

White-weed, 401.

Whitlavia, 513.

Whitneya, 374.

Wigandia, 518.

Wild Mock C'herry, 167.

Wild Cabbage, 36.

Wild Cherry, 167.

Wild Plum, 167.

Wild Padish, 49.

Willow-Herb, 218

Winter Cress, 40.

Wintergreen, 454, 460.

Wislizenia, 52 .

Withania, 540.

Wood-Anemone, 4.

Wood-Solrel, 96

Woodbine, 280.

Woodvillea, 331.

Wormwood, 402.

Wulfenia, 571

Wyethia, 348, 616 .

Xanthium, 346.

Xerobotrys, 453.

$X$ imenesia, 350.

Xylococeus, 454 .

Xylodalea, 142.

Xylosteum, 280.

Yarrow, 400.

Yeara, 110.

Yellow Pond-Lily, 17.

Yerba Buena, 595.

Zapania, 610.

Zauschneria, 217.

Zizyphus, 99

END OF VOL. I. 







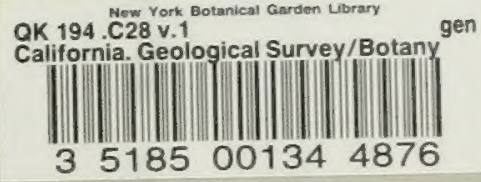


